Frederico Celestino Barbosa

Administração: caminhos para o desenvolvimento sustentável

1 a ed.

Piracanjuba-GO

Editora Conhecimento Livre

2020 
$1^{\mathrm{a}}$ ed.

\section{Dados Internacionais de Catalogação na Publicação (CIP)}

Barbosa, Frederico Celestino

B238a Administração: caminhos para o desenvolvimento sustentável.

/Frederico Celestino Barbosa - Piracanjuba-GO

Editora Conhecimento Livre, 2020

823 f.: il

DOI: $\quad 10.37423 / 2020 . \mathrm{a} 12$

ISBN: 978-65-86072-16-7

Modo de acesso: World Wide Web

Inclui bibliografia

1. Administração 2. Sustentabilidade. 3. Custos. I. Barbosa, Frederico Celestino. I. Título 


\section{EDITORA}

\section{CONHECIMENTO LIVRE}

\section{Corpo Editorial}

MSc. Frederico Celestino Barbosa

MSc. Carlos Eduardo de Oliveira Gontijo

MSc. Plínio Ferreira Pires

Editora Conhecimento Livre

Piracanjuba-GO

$\underline{2020}$ 


\section{Administração: caminhos para o desenvolvimento sustentável}

\section{Sumário}

CAPÍTULO 1

IGUALDADE DE GÊNERO NO MERCADO DE TRABALHO: ESTUDO COMPARATIVO ENTRE PONTA GROSSA-PR E SUCREBO

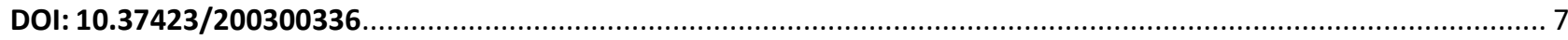

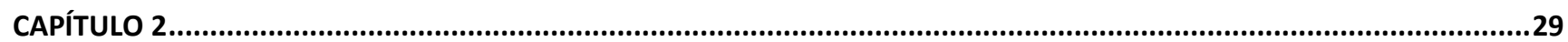

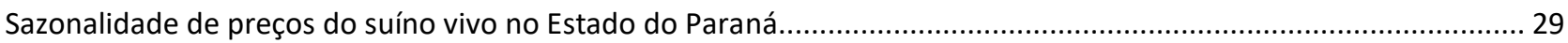

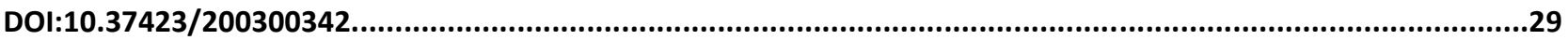

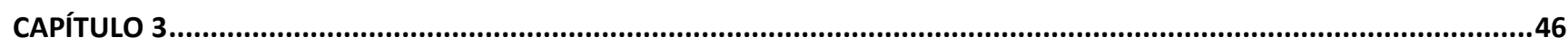

APLICAÇÃO DE JOGO FINANCEIRO PARA INTEGRAÇÃO DE CONCEITOS EM ADMINISTRAÇÃO..........................................46

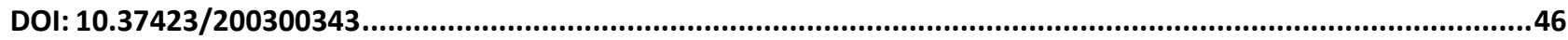

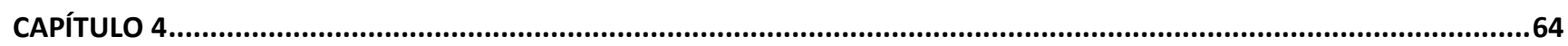

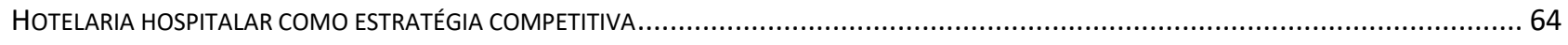

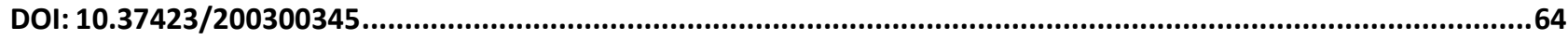

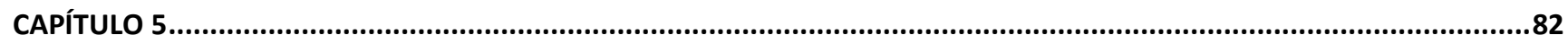

TRANSFORMAÇÃO DIGITAL E A QUARTA REVOLUÇÃO INDUSTRIAL: TEORIA DA INOVAÇÃO DISRUPTIVA................................................ 82

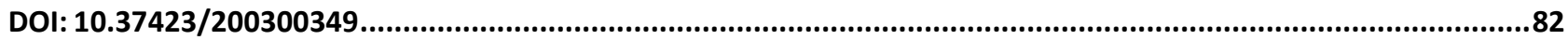

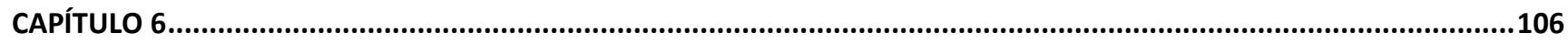

AS EMPRESAS DO RAMO ELETROELETRÔNICO DO POLO INDUSTRIAL DE MANAUS SOB O OLHAR CONCEITUAL DOS CLUSTERS 106

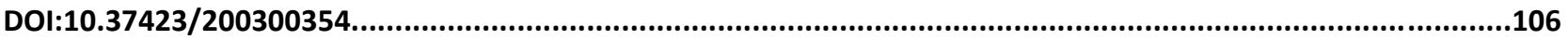

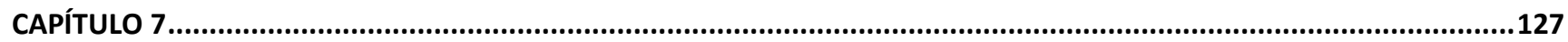

INFRAESTRUTURA DE ACESSO: FATOR CRÍTICO DE SUCESSO PARA IMPLANTAÇÃO DE EMPREENDIMENTOS DE TURISMO RURAL. ................... 127

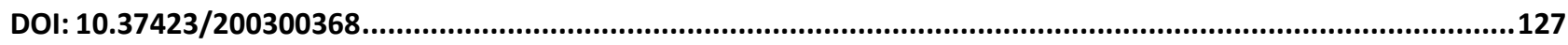

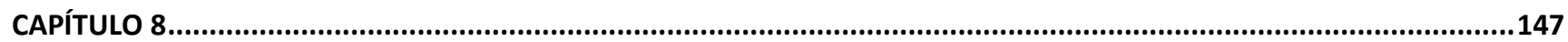

Sistemas de Informações Gerenciais no Auxílio à Tomada de Decisão nas Micro e Pequenas Empresas de Vestuário........147 


\section{Administração: caminhos para o desenvolvimento sustentável}

DOI: $10.37423 / 200300369$

CAPÍTULO 9.

O SIMBOLISMO ORGANIZACIONAL PELA TEORIA DAS PRÁTICAS NOS ESTUDOS SOBRE AS PRÁTICAS DA AGRICULTURA FAMILIAR BRASILEIRA

DOI: $10.37423 / 200300372$ 163

CAPÍTULO 10 177

Desenvolvimento sustentável: interfaces com o planejamento e controle da produção em redes de empresas.

DOI: $10.37423 / 200300381$

CAPÍTULO 11

RESPONSABILIDADE SOCIAL EMPRESARIAL: UM ESTUDO DE CASO EM PEQUENAS E MICRO EMPRESAS DO RAMO METAL-MECÂNICO INSTALADAS NO DISTRITO INDUSTRIAL DA CIDADE DE PANAMBI/RS E ASSOCIADAS AO SEBRAE/RS 192 DOI: $10.37423 / 200300382$ 192

CAPÍTULO 12 209

O MICROCRÉDITO E O DESENVOLVIMENTO ECONÔMICO-FINANCEIRO DOS EMPREENDIMENTOS BENEFICIADOS PELO PROGRAMA BANCO SOCIAL.

DOI: $10.37423 / 200300385$ 209

CAPÍTULO 13

ASPECTOS HISTÓRICOS E PEDAGÓGICOS DOS 10 ANOS DE IMPLEMENTAÇÃO DO PROGRAMA DE DESENVOLVIMENTO EDUCACIONAL NO ESTADO DO PARANÁ 230

DOI: $10.37423 / 200300387$ 230

CAPÍTULO 14 247

QUALIDADE DE VIDA DO TRABALHO DOCENTE: UM ESTUDO DE CASO COM OS DOCENTES DE UMA ESCOLA MUNICIPAL.

DOI: $10.37423 / 200300390$

CAPÍTULO 15

ESTUDO DA GOVERNANÇA CORPORATIVA EM INCUBADORAS DE BASE TECNOLÓGICA 362

DOI: $10.37423 / 200300392$

CAPÍTULO 16

TESSITURAS SOBRE O MARKETING RELIGIOSO EM BOM JESUS DA LAPA, BAHIA.

DOI: $10.37423 / 200300396$ 


\section{Administração: caminhos para o desenvolvimento sustentável}

DOI: $10.37423 / 200300398$

CAPÍTULO 18

Aplicação de conceitos da logística e de produção na realização de eventos: estudo de caso de um casamento.

DOI: $10.37423 / 200300401$ 311

CAPÍTULO 19 328

A VISÃO ESTRATÉGICA NAS ORGANIZAÇÕES DE PRODUTORES: A MATRIZ SWOT COMO INSTRUMENTO PARA A ELABORAÇÃO DAS ESTRATÉGIAS DA AMIGA EM IGARAPÉ-AÇU/PA 328 DOI: $10.37423 / 200300402$ 328

CAPÍTULO 20 343

INTRAEMPREENDEDORISMO: PERSPECTIVAS E DESAFIOS NA ADMINISTRAÇÃO PÚBLICA 343 DOI: $10.37423 / 200300402$ 343

CAPÍTULO 21 354

CAPITAL HUMANO: UMA ABORDAGEM CONTEMPORÂNEA 354

DOI: $10.37423 / 200300408$ 354

CAPÍTULO 22 367

O OUTRO LADO DA CIDADE SERRANA: INOVAÇÕES SUSTENTÁVEIS E EMPREENDEDORISMO NO LICOR DE GUAVIRA PRODUZIDO EM - BODOQUENA -MS 367

DOI: $10.37423 / 200300416$ 367

CAPÍTULO 23 388

A importância das lições aprendidas como ferramenta da gestão do conhecimento no segmento industrial offshore 388

DOI: $10.37423 / 200300420$ 388

CAPÍTULO 24 406

Comportamento de compra do consumidor no varejo supermercadista de mato grosso. .406

DOI:10.37423/200300421 406

\section{CAPÍTULO 25}

UTILIZAÇÃO DO MINICONTRATO DE DÓLAR FUTURO COMO FERRAMENTA PARA PROTEÇÃO DAS FLUTUAÇÕES CAMBIAIS EM EMPRESAS DE PEQUENO PORTE. 


\section{Administração: caminhos para o desenvolvimento sustentável}

CAPÍTULO 26

EDUCAÇÃO AMBIENTAL E COLETA SELETIVA: PERCEPÇÃO E CONSCIENTIZAÇÃO DOS DISCENTES DO CURSO DE ADMINISTRAÇÃO DA UNIVERSIDADE FEDERAL DO PIAUÍ - CAMPUS MINISTRO REIS VELLOSO.....

DOI: $10.37423 / 200300426$ 448

CAPÍTULO 27 463

ESTRATÉGIAS DE MARKETING DIGITAL INFLUENCIAM OS CONSUMIDORES DA GERAÇÃO Z? UM ESTUDO COM ALUNOS DO IF FARROUPILHA CAMPUS SANTO AUGUSTO/RS 463 DOI: $10.37423 / 200300429$ 463

CAPÍTULO 28 483

IMPLANTAÇÃO DA ESTRATÉGIA CRM EM PEQUENAS EMPRESAS 483

DOI: $10.37423 / 200300430$ 483

CAPÍTULO 29. 495

A IMPORTÂNCIA DA TERCEIRIZAÇÃO EM USINA HIDRELÉTRICA: ESTUDO DE CASO SOBRE A GESTÃO DA MANUTENÇÃO... 495

DOI: $10.37423 / 200300431$ 495

CAPÍTULO 30 514

ABORDAGEM VIVENCIAL E COOPERATIVA DOS JOGOS DE EMPRESA. 514

DOI: $10.37423 / 200300432$ 514

CAPÍTULO 31

ANÁLISE DA VIABILIDADE ECONÔMICA E AMBIENTAL DO PLANTIO DE TECA (TECTONA GRANDIS LINN F.) NO MUNICÍPIO DE

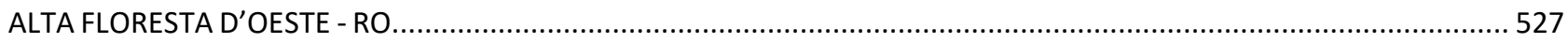

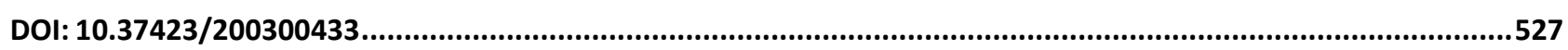

CAPÍTULO 32

MULTICOLINEARIDADE EM ANÁLISE DE REGRESSÃO. 547

DOI: $10.37423 / 200300435$

CAPÍTULO 33 565

REDES COLABORATIVAS INTRAORGANIZACIONAIS: ESTUDO DAS RELAÇÕES INTERNAS EM UMA PREFEITURA MUNICIPAL 565

DOI: $10.37423 / 200300437$ .565

CAPÍTULO 34 .582

LIDERANÇA: SUA IMPORTÂNCIA NA GESTÃO DE PESSOAS 582 


\section{Administração: caminhos para o desenvolvimento sustentável}

CAPÍTULO 35

EXPECTATIVAS dOS ACADÊMICOS DE CIÊNCIAS CONTÁBEIS AO INICIAR O CURSO: A PERCEPÇÃO DOS CALOUROS INGRESSANTES EM 2008 NA

UEPG.

DOI: $10.37423 / 200300445$..

CAPÍTULO 36

GESTÃO DE DOCUMENTOS E O GERENCIAMENTO DA INFORMAÇÃO DOCUMENTAL: ESPECIFICAÇÃO DE UMA SOLUÇÃO PARA UMA UNIDADE ADMINISTRATIVA DE UMA UNIVERSIDADE PÚBLICA.

DOI: $10.37423 / 200300446$ 611

CAPÍTULO 37 .630

NOVAS PRÁTICAS SOBRE A DEPRECIAÇÃO DO ATIVO IMOBILIZADO, CONFORME AS NORMAS BRASILEIRAS DE CONTABILIDADE APLICADAS AO SETOR PÚBLICO (NBCASP).

DOI: $10.37423 / 200300447$ 630

CAPÍTULO 38. 646

Análise do processo da criação do conhecimento organizacional em uma indústria do vestuário: um estudo de caso........ .646

DOI: $10.37423 / 200300454$ 646

CAPÍTULO 39. 658

ÉTICA PROFISSIONAL: A PERCEPÇÃO DOS EGRESSOS DO CURSO DE CIÊNCIAS CONTÁBEIS DA UFMS 658

DOI: $10.37423 / 200300456$ 658

CAPÍTULO 40. .676

Planejamento Estratégico, Balanced SCORECARd (BSC) e VisÃo Sistêmica: Um Processo de Gestão EstratéGica 676

DOI: $10.37423 / 200300457$ 676

CAPÍTULO 41 .685

ECOEFICIÊNCIA: OS BENÉFICIOS DA EMPRESA CENTROFLORA SER ECOEFICIENTE NA CIDADE DE PARNAÍBA-PI 685 DOI: $10.37423 / 200300464$ 685

CAPÍTULO 42 697

COOPERATIVISMO: UMA ALTERNATIVA EMPREENDEDORA SUSTENTÁVEL. 697

DOI: $10.37423 / 200300471$ 697

CAPÍTULO 43 715

INOVAÇÃO E PEQUENAS EMPRESAS: ANÁLISE NO ARRANJO PRODUTIVO LOCAL DO BREJO PARAIBANO 715 DOI: $10.37423 / 200300473$ 


\section{Administração: caminhos para o desenvolvimento sustentável}

POLÍTICAS PÚBLICAS E AGRICULTURA FAMILIAR: UMA ANÁLISE DOS AGRICULTORES QUE BUSCAM FINANCIAMENTO NO PRONAF 738

DOI: 10.37423/200300475 .738

CAPÍTULO 45 .751

DISCUSSÃO SOBRE O USO DA CONTROLADORIA NO APOIO AO PLANEJAMENTO OPERACIONAL 751 DOI: $10.37423 / 200300475$ .751

CAPÍTULO 46 769

A FormaÇão de COMPETÊNCIAS GERENCIAIS NO MOdELO QUINN: UM ESTUdO dE CASO DA CONTRIBUIÇÃO dO CURSO DE AdMINISTRAÇÃO 769

DOI: $10.37423 / 200300514$.. .769

CAPÍTULO 47 782

UMA ANÁLISE SOBRE O ENVELHECIMENTO: A PERCEPÇÃO DOS GESTORES E DOS SUJEITOS DA TERCEIRA IDADE. 782 DOI: $10.37423 / 200300516$ 782

CAPÍTULO 48. .805

CAdeia TÊxtil e a Manufatura do VestuÁRio de Moda - Uma Estratégia de Negócios ..... 805

DOI: $10.37423 / 200300536$ .805 


\section{Capítulo 1}

\section{IGUALDADE DE GÊNERO NO MERCADO DE TRABALHO: ESTUDO COMPARATIVO ENTRE PONTA GROSSA-PR E SUCRE-BO}

DOI: $10.37423 / 200300336$

Eliane de Fátima Rauski (UEPG, Brasil, efrauski@ead.uepg.br

Ernani Barbosa Lepka (UEPG, Brasil). ernaniblepka@gmail.com

Ivan Marcelo Povedavelasco (UMRPSFXCH, Bolívia).marcelo.poveda@gmail.com

Natali Nicole Vildozo Rojas (UMRPSFXCH, Bolívia). natalivildosorojas1998@gmail.com

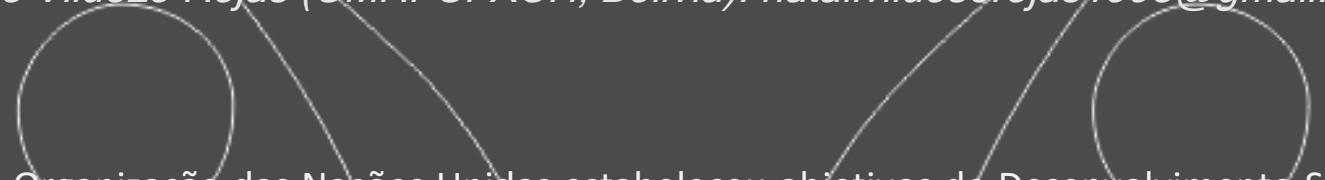

Resumo: A Organização das Nações Unidas estabeleceu objetivos de Desenvolvimento Sustentável para diminuir as desigualdades no mundo e que tem comp premissa o equilíbrio baseado no-tripé da sustentabilidade: éconômico, social e ambiẹntal. Com relação às pessoas, o objetivo no 5 foi estabelecido com vistas à dìminuição das desigualdades de gênero no mercado de trabalho até o ano de 2030. Assim, a finalidade deste estudo é analisar os dados estatísticos disponíveis nos órgãos oficiais, no sentido do alcance da meta de reduçầo das desigualdades de gênero no mercado formal de trabalho na cidade de Ponta Grossa-PR,Brasil e na cidade de Sucre, Bolívia. O estudo se caracteriza como exp/oratório, qualitativo e quantitativo, com utilização de análise de conteúdo e medidas estatísticas para análise dos dados secundários. Os resyltados apontam melhoria no que se refere à igualdade de gênero no trabalho formal da mulher ha cidade de Ponta Grossa-PR; na cidade de Sucre, Bolívia, embora ainda frágeis estes nutmeros.

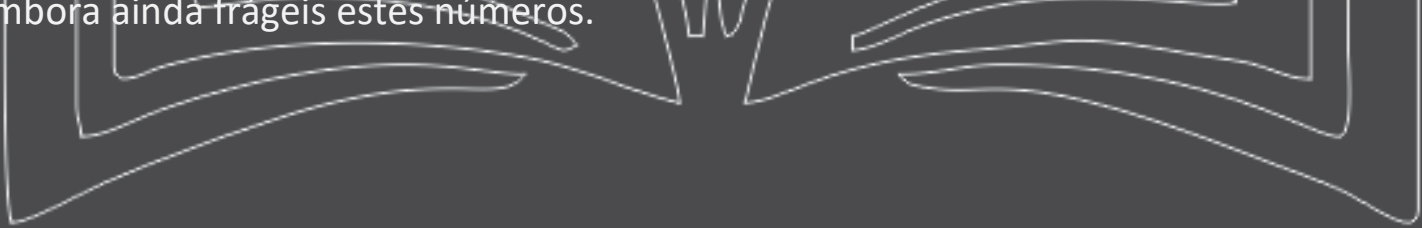




\section{Administração: caminhos para o desenvolvimento sustentável}

Nestas cidades, os setores que mais empregam mulheres são Comércio e Serviços, porém, nenhum dos setores da economia se destaca no quesito igualdade com relação à remuneração das mulheres em comparação com a remuneração dos homens, apontando um caminho longo de mudança cultural e necessidade de definição de políticas organizacionais para que a desigualdade de gênero seja vencida e os talentos sejam compensados e evidenciados de forma justa. Quebrar a barreira do gênero e estabelecer como critério a competência e a qualificação se faz urgente.

Palavras Chave: Mercado de trabalho; Desigualdade de gênero; Trabalho formal. 


\section{Administração: caminhos para o desenvolvimento sustentável}

\section{INTRODUÇÃO}

Em setembro de 2015 a Organização das Nações Unidas-ONU através dos chefes de Estado e de Governo, reunidos em Nova York, decidiram criar um conjunto de objetivos e metas universais para acabar com a pobreza e a fome em todos os lugares; combater as desigualdades dentro e entre os países; construir sociedades pacíficas, justas e inclusivas; proteger os direitos humanos e promover a igualdade de gênero e o empoderamento das mulheres e meninas; assegurar a proteção duradoura do planeta e seus recursos naturais e criar condições para um crescimento sustentável, inclusivo e economicamente sustentado, prosperidade compartilhada e trabalho decente para todos, tendo em conta os diferentes níveis de desenvolvimento e capacidades nacionais. (ONU, 2015) Este conjunto de objetivos e metas foi denominado AGENDA 2030, ano planejado para seu alcance, porém, as ações específicas dependem de diferentes setores da sociedade para sua efetivação, de onde vem a inquietação com relação ao que já está sendo feito e o quanto das propostas serão alcançadas até 2030, prazo exíguo de 15 anos para acabar com uma desigualdade secular em nossa sociedade. Os dezessete Objetivos de Desenvolvimento Sustentável (ODS) nasceram na Conferência das Nações Unidas sobre desenvolvimento sustentável no Rio de Janeiro em 2012 e substituem os Objetivos de Desenvolvimento do Milênio (ODM), que começou um esforço global em 2000 para combater a indignidade da pobreza. Desses objetivos estabelecidos para um avanço das sociedades no que tange a desigualdade, nos desperta interesse o objetivo no 5 que estabelece o alcance da igualdade de gênero e empoderamento de todas as mulheres e meninas, cujas estratégias estão diretamente relacionadas com a área de gestão de pessoas das organizações. Desta forma, estudar o mercado de trabalho da mulher em Ponta Grossa-PR e em Sucre-Bolívia, com vistas a identificar o estado da arte dos objetivos de sustentabilidade da ONU nestas duas cidades da América do Sul é de interesse da academia em visualizar no nível micro as nuances pensadas para o macro. Além disso, visa fornecer elementos que contribuam na preparação dos gestores de pessoas que atuam nas organizações e que também devem pensar a questão da desigualdade de gênero em termos de cargos e salários, Recrutamento e Seleção. Existe um estreitamento de laços entre a Universidade Estadual de Ponta Grossa-PR (UEPG) e a Universidade San Francisco Xavier na Bolívia (USFX) face o termo de parceria assinado pela cúpula destas Instituições, além do vínculo criado entre o Departamento de Administração da UEPG e o Setor de Controladoria da USFX para envolver alunos e docentes em estudos que sejam de interesse de ambas as instituições, tendo estas ponderações nos direcionado para o trabalho em questão. 


\section{Administração: caminhos para o desenvolvimento sustentável}

A cidade de Ponta Grossa se localiza no Estado do Paraná, região Sul do Brasil, com uma população formada, basicamente, por imigrantes e tornou-se um município em 1855. A população estimada pelo IPARDES para 2018 é de 348.043 habitantes, sendo que o censo de 2010 apontou 311.611 habitantes, dos quais 151.362 são homens e 160.249 mulheres e o total de 245.119 habitantes se declararam de raça branca (78,66\%). (BRASIL, 2019)

O censo de 2010 também apontou que 304.733 habitantes moram na área urbana e 6.878 habitantes na área rural e que a população ocupada, segundo as atividades econômicas era de 139.096 habitantes, cerca de $44,63 \%$ da população total.

Quanto desta população economicamente ativa são homens ou mulheres, que atividades formais exercem e o salário percebido devem ser questões extremamente relevantes para sofrerem acompanhamento no período 2015/2030 com a finalidade de se observar o quanto dos objetivos propostos pela ONU foram alcançados ao final do período.

Sucre se situa no Departamento de Chuquisaca - Bolívia, sendo a cidade em que ocorreu o primeiro grito de liberdade das Américas, em 25 de maio de 1809, e onde de firmou a Ata da Independência do domínio espanhol, em 06 de agosto de 1825. Anos mais tarde é designada Capital da Bolívia. Possui a quinta maior população do país com 261.201 habitantes (2007), dos quais 124.667 ou 47,73\% são homens e 136.534 ou $52,27 \%$ são mulheres. Por quatro censos consecutivos o comportamento é o mesmo, maior proporção de homens na população infantil e adolescente e predomínio da população feminina na população adulta. No censo de 2012 a população feminina era de 50,1\% e a masculina era de $49,9 \%$. (CEPAL, 2012)

Setores como a construção civil e a indústria cimenteira se beneficiaram de um maior fluxo de dinheiro na economia, mas atualmente atravessam um período de recessão.

Assim como ocorre com outros Departamentos do país, Chuquisaca sente falta de diversificação produtiva e econômica, o que afeta, diretamente, o trabalho formal neste Departamento e em Sucre. Considerando os diversos pontos elencados, o objetivo geral é a discussão do trabalho formal, com vínculo empregatício, assalariado da mulher e emprego nos diferentes setores da economia na cidade de Ponta Grossa, Paraná, Brasil e na Cidade de Sucre, Departamento de Chuquisaca, Bolívia, com vistas ao acompanhamento da evolução das ações para o atingimento do ODS no 5 da ONU. 


\section{Administração: caminhos para o desenvolvimento sustentável}

\section{A PROPOSTA DA ONU - 17 OBJETIVOS DE SUSTENTABILIDADE}

Os 17 Objetivos de Desenvolvimento Sustentável (ODS) foram elaborados com base no legado dos Objetivos do Desenvolvimento do Milênio (ODM) com vistas a concluir o que os ODM não alcançaram.

Os ODS têm o objetivo de garantir os direitos humanos e alcançar a igualdade de gênero e o empoderamento das mulheres e meninas no mundo todo, de forma integrada, até o ano de 2030, sendo indivisíveis e tendo como premissa o equilíbrio baseado no tripé da sustentabilidade: econômico, social e ambiental (ONU Brasil, 2015).

Os ODS tem objetivo de estimular a ação até 2030, em 5 áreas temáticas que são de fundamental importância para o planeta e para os seres humanos, assim definidos pelos Chefes de Estado, de Governo e altos representantes reunidos na sede da ONU, em Nova York, 2015:

- Pessoas: objetiva acabar com a pobreza e a fome, além de garantir que todos os seres humanos possam desenvolver seus potenciais com igualdade e dignidade, em um ambiente saudável.

- Planeta: tem como objetivos principais proteger o planeta da degradação, principalmente através da produção e uso sustentável dos recursos naturais, buscando tomar medidas para frear o aquecimento global e as mudanças climáticas. Tais objetivos são importantes para que o planeta possa suportar as necessidades das gerações presentes e futuras.

- Prosperidade: busca garantir a todos os seres humanos uma vida próspera e com desenvolvimento pessoal juntamente com o desenvolvimento da tecnologia, da economia e da sociedade em harmonia com a natureza.

- Paz: promoção de sociedades pacíficas, inclusivas e justas, livres do medo e da violência. Não há desenvolvimento sem paz e não há paz sem desenvolvimento.

- Parceria: visa a implementação de uma Parceria Global para o Desenvolvimento Sustentável, baseada em uma solidariedade global, com foco nos mais pobres e vulneráveis buscando a participação de todos os países.

Os ODS e as metas são acompanhados e revisados com base em um grupo de indicadores elaborados pelo Grupo Interagencial de Peritos sobre os Indicadores dos ODS (Inter-Agency Expert Group on SDG Indicators - IAEG-SDG), que foram analisados e validados pela ONU através da sua Comissão de Estatística. 


\section{Administração: caminhos para o desenvolvimento sustentável}

Os indicadores e as metas globais são de fundamental importância para o monitoramento, a comparação e a coordenação dos progressos dos países no alcance dos ODS, por parte da ONU, permitindo que a instituição identifique os países e áreas temáticas que precisam de maior assistência dos organismos internacionais e de maior cooperação para o desenvolvimento (IPEA, 2018).

Através do Encontro do Alto Fórum Político dos Objetivos de Desenvolvimento Sustentável (High-Level Political Forum on Sustainable Development Goal - HLPF), realizado anualmente pela ONU, o monitoramento global é realizado. Nesse encontro são apresentados relatórios voluntários de progresso por parte dos países participantes, possibilitando a realização da comparação em âmbito global. Sendo assim, o HLPF é a principal plataforma de acompanhamento e revisão do cumprimento dos ODS (IPEA, 2018).

\section{DIVISÃO SEXUAL DO TRABALHO NO BRASIL E NA BOLÍVIA}

Segundo dados da Pesquisa Nacional por Amostra de Domicílios - PNAD de 2018, a população ocupada de 25 a 49 anos no Brasil, totalizava 56,4 milhões de pessoas, sendo 54,7\% homens e 45,3\% mulheres.

O valor médio do rendimento por hora trabalhada em 2018 foi de $R \$ 13,00$ para mulheres e $R \$ 14,20$ para homens, representando que as mulheres ganhavam $91,5 \%$ do valor recebido pelos homens. Ao analisar o valor do rendimento médio total, se percebe maior discrepância, visto que homens recebiam $R \$ 2.579,00$ e mulheres $R \$ 2.050,00$ com o salário feminino representando $79,5 \%$ do salário masculino (PNAD, 2018).

Os grupos de ocupações nos quais as mulheres eram maioria são: ocupações elementares (55,3\%); trabalhadores dos serviços, vendedores dos comércios e mercados (59,0\%); profissionais das ciências e intelectuais $(63,0 \%)$ e trabalhadoras de apoio administrativo $(64,5 \%)$. Já os grupos em que os homens eram maioria são: membros das forças armadas, policiais e bombeiros militares (86,8\%); operadores de instalações e máquinas e montadores (86,2\%); trabalhadores qualificados, operários e artesãos $(83,8 \%)$ e os trabalhadores qualificados da agropecuária, florestais, da caça e da pesca (78,9\%) (PNAD, 2018).

Na Bolívia, segundo informações da Organização Internacional do Trabalho (OIT, 2017), 68,6\% da população total encontra-se ocupada. Porém há diferenças entre a população ocupada de mulheres e de homens, visto que a taxa de participação masculina é de $78,4 \%$ do total de homens e a feminina é de $59,4 \%$ do total de mulheres, diferença esta bastante acentuada se for considerado que a população feminina é de $50,1 \%$ e a masculina é de $49,9 \%$, conforme dados da CEPAL, 2012. Nos médios e altos 


\section{Administração: caminhos para o desenvolvimento sustentável}

postos de direção e gerência, apenas $26,8 \%$ destes cargos são ocupados por mulheres. A diferença salarial entre os sexos é de cerca de 6,2\%, sendo maior para os homens (OIT, 2014).

A porcentagem da população urbana sem renda própria é de 30,1\% para as mulheres e 7,3\% para os homens (CEPAL, 2017).

Segundo o diretor da OIT para países Andinos, Philippe Vanhuynegem (2016), na Bolívia os homens recebem cerca de $47 \%$ a mais de renda que as mulheres, fazendo o mesmo trabalho, independentemente de terem o mesmo treinamento.

\section{MERCADO FORMAL DE TRABALHO NO BRASIL, NO PARANÁ E PONTA GROSSA}

O mercado formal de trabalho compreende os empregados assalariados que possuem carteira de trabalho assinada incluindo domésticos e não domésticos e os funcionários públicos e estatutários (MACIEL, OLIVEIRA, 2018).

Já o trabalho informal origina-se como consequência do excedente da força de trabalho que não participa do setor de trabalho formal.

Como apontam Maciel e Oliveira (2018), a literatura nacional brasileira define que a diferença entre o trabalho formal e informal é a posse ou não de carteira assinada e/ou pela posição de trabalho por conta própria, além de trabalhadores familiares auxiliares, bem como empregadores e trabalhadores por conta-própria que não contribuem para a previdência social (BRASIL, 2018).

Para fins deste estudo, serão considerados os dados apenas com relação ao mercado formal de trabalho.

Entre 2008 e 2018 o mercado de trabalho formal no Brasil registrou um aumento de 31,9\% no número de mulheres e $16 \%$ no número de homens. Nesse mesmo período o emprego feminino variou positivamente em todas as faixas etárias e o emprego masculino teve retração nas faixas mais jovens, de até 29 anos. (BRASIL, 2018).

A população ocupada de 25 a 49 anos totalizava 56,4 milhões de pessoas no Brasil em 2018. Esse contingente era composto por $54,7 \%$ de homens e $45,3 \%$ de mulheres. Essas estimativas não apresentaram variações importantes desde 2012, mostrando o predomínio da participação masculina no contingente de ocupados. (PNAD, 2019)

Segundo este mesmo relatório especial sobre o mercado de trabalho da mulher, em 2018, no Brasil, a mulher ocupada de 25 a 29 anos de idade recebia $86,9 \%$ do rendimento médio do homem; a de 30 a 


\section{Administração: caminhos para o desenvolvimento sustentável}

39 anos chegava a $81,6 \%$ e a de 40 a 49 anos baixava para $74,9 \%$. Nesse último grupo, o rendimento médio da mulher era de $\mathrm{R} \$ 2.199$ e o do homem, $\mathrm{R} \$ 2.935$; já no primeiro ( 25 a 29 anos de idade) os valores eram de $\mathrm{R} \$ 1.604$ e $\mathrm{R} \$ 1.846$, respectivamente, mulheres e homens. (PNAD, 2019)

Algumas particularidades foram apontadas pelo Ministério do Trabalho e Emprego-MTe (2018) com relação a este período:

- aumento no desemprego tanto para homens quanto para mulheres de 2012 a 2017;

- aumento de $28,9 \%$ de mulheres empregadoras;

- de 2007 a 2016 o número de mulheres que ocupavam cargos de direção aumentou 55\%.

Destoam destes dados os registros para a Região Sul e para o Estado do Paraná, onde observamos uma variação entre homens $(0,60 \%)$ e mulheres $(0,38 \%)$ do ano de 2016 em comparação com o ano de 2017, sendo que para o ano de 2018 os dados ainda não foram disponibilizados pelo MTe

\begin{tabular}{|c|c|c|c|c|c|c|c|c|c|}
\hline \multirow{2}{*}{ UF } & \multicolumn{3}{|c|}{206} & \multicolumn{3}{|c|}{2017} & \multicolumn{3}{|c|}{ Variação Relativa (\%) } \\
\hline & M a sculino & Fem inino & Total & M a sculino & Feminino & Total & Masc. & Fem. & Total \\
\hline Norte & 1.455 .188 & 1.123 .847 & 2.579 .035 & 1.488 .601 & 1.53 .022 & 2.641 .623 & 2,30 & 2,60 & 2,43 \\
\hline $\begin{array}{l}\text { Nordest } \\
\mathrm{e}\end{array}$ & 4.744 .216 & 3.691987 & 8.436 .203 & 4.795 .407 & 3.748 .244 & 8.543 .651 & 1,08 & 1,52 & 1,27 \\
\hline Sudeste & 12.784 .495 & 10.066 .680 & 22.851 .175 & 12.738 .166 & 10.019 .924 & 22.758 .090 & $-0,36$ & $-0,46$ & $-0,41$ \\
\hline Sul & 4.386 .971 & 3.704 .940 & 8.091 .911 & 4.45 .776 & 3.719 .527 & 8.136 .303 & 0,68 & 0.39 & 0,55 \\
\hline $\begin{array}{l}41 \text { - } \\
\text { Paraná }\end{array}$ & 1.648 .999 & 1.364 .106 & 3.013 .105 & 1.658 .910 & 1.369 .282 & 3.028 .192 & 0.60 & 0.38 & 0,50 \\
\hline $\begin{array}{l}\text { Centro- } \\
\text { Oeste }\end{array}$ & 2.426715 & 1675.159 & 4.01 .874 & 2.473 .285 & 1728.638 & 4.201923 & 1,92 & 3.19 & 2,44 \\
\hline Total & 25.797 .585 & 20.262613 & 46.060 .98 & 25.92 .235 & 20.369 .355 & 48.281 .590 & 0,44 & 0,53 & 0,48 \\
\hline
\end{tabular}

\section{Fonte: Rais-Dec.76.900/75}

Quadro 1 - Brasil - Número de Empregos Formais por Região Natural e Unidade da Federação segundo Sexo do Trabalhador (BRASIL, 2018)

Apesar desse aumento do número de mulheres no mercado de trabalho e o fato de que as mulheres têm mais anos de estudo que os homens, seus salários são menores, independente do grau de instrução, inclusive dentro do mesmo grupo de ocupação, ficando evidenciado que a redução das desigualdades ainda está longe de ser alcançada.

Entre os anos de 2012 a 2014, a remuneração da mulher com instrução maior era superior a remuneração dos homens, mas entre 2017 e 2018 esta proporção se inverteu apresentando rendimento inferior para as mulheres, mesmo com instrução superior aos homens. 


\section{Administração: caminhos para o desenvolvimento sustentável}

Um maior número de mulheres possui ensino superior completo $(28,7 \%)$, comparado com os homens (15,7\%). Em 2016 a maior parte das mulheres no mercado formal de trabalho possuía o ensino médio completo $(47,4 \%)$, sendo bastante semelhante aos homens $(47,7 \%)$. Nesse mesmo ano, as mulheres ganhavam na média, $84 \%$ da remuneração masculina e em cargos de direção a diferença salarial é ainda maior, visto que ganhavam cerca de $67,6 \%$ da remuneração masculina (BRASIL, 2018).

Segundo o IBGE existem diversos aspectos estruturais do mercado de trabalho que permitem compreender as diferenças de rendimento entre homens e mulheres, entre eles a idade, horas trabalhadas, raça ou cor, nível de instrução e tipo de ocupação que a pessoa exerce e também, aprofundando a análise, o tempo de trabalho na ocupação exercida também influencia a evolução profissional ou planejamento de carreira (IBGE, 2018)

No mesmo sentido, para Giuberti e Filho (2005) as características médias dos grupos de homens e mulheres, tais como idade, setor de trabalho, experiência e educação poderiam ser as explicações para a diferença de rendimentos. Afirmam os autores, que essas características explicam apenas uma parte das diferenças, sendo o restante atribuído a um componente residual relacionado à discriminação. Outro fator de relevância é a ocupação dos indivíduos que também influencia no valor do salário recebido e a concentração de mulheres em ocupações de salários menores poderia explicar parte das diferenças salariais.

Para o IBGE, as possíveis interrupções e/ou rotatividade no mercado de trabalho muitas vezes tem consequências como reinserção em novos trabalhos com menor remuneração, fator que pode ser de maior relevância para mulheres, os diferentes tipos de arranjos familiares também influenciam no tipo de inserção no mercado de trabalho, especialmente para mulheres com filhos menores, que não raras as vezes, destinam boa parte de seu tempo para cuidar de pessoas e afazeres domésticos (IBGE, 2018). 


\section{Administração: caminhos para o desenvolvimento sustentável}

No gráfico 1, se pode visualizar a evolução da remuneração média real em dezembro, por sexo, dos anos de 2002 a 2017. (BRASIL,2018)

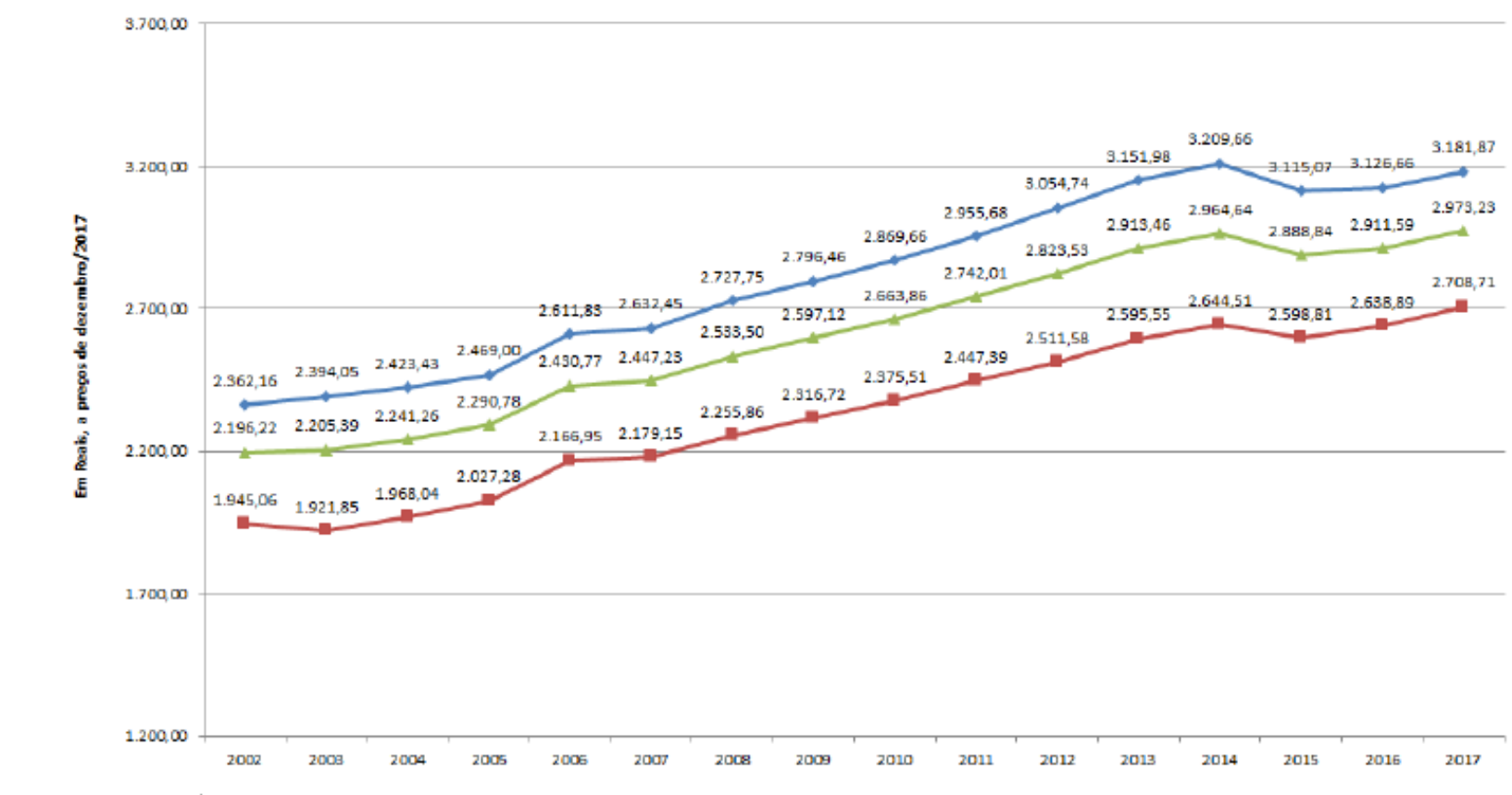

(*)-denacionado péo INPC/BGE

Gráfico 1: Brasil - Remuneração Média Real em Dezembro por sexo - 2002 a 2017

É possível verificar que em 2015 houve uma queda geral da Remuneração média que voltou a crescer em 2016 e 2017, porém, com clara diferença entre homens e mulheres.

Em 2015, ano em que os Objetivos de Desenvolvimento Sustentável-ODS da Organização das Nações Unidas-ONU foram lançados, a remuneração das mulheres era 19,9\% menor que a remuneração dos homens, em 2016 esta diferença diminuiu para 18,5\% e em 2018 ficou na casa dos 17,40\%, demonstrando uma melhora gradativa nestes indicadores.

Conforme observa-se na Tabela 1, em Ponta Grossa-PR, entre 2014, ano anterior a fixação dos ODS pela ONU e 2017, seguiu a tendência nacional de queda geral da Remuneração média, com uma diferença de 14,23\% a menos na média salarial das mulheres em 2017, em comparação com a média salarial dos homens. Em 2014 esta diferença era de 17,99\%, portanto, houve uma melhoria de 3,76\%. No comércio e prestação de serviços que mais empregam mulheres, esta diferença salarial é bastante acentuada, na casa de $19,72 \%$ no comércio e $15,62 \%$ no setor de serviços contra $30,20 \%$ na indústria e 17,04\% no setor agropecuário. Devemos ressaltar que a indústria e a agropecuária são os setores 


\section{Administração: caminhos para o desenvolvimento sustentável}

que movimentam a região dos Campos Gerais, portanto, esta região está bastante distante da média nacional.

\begin{tabular}{|l|r|r|r|r|r|r|}
\hline \multicolumn{7}{|c|}{ MÉDLA SALARIAL EM SALARIO MINIMO } \\
\hline GÊNERO/TOTAIS & $\mathbf{1}$ - Indústria & $\begin{array}{l}\mathbf{2} \text { - Construção } \\
\text { Civil }\end{array}$ & $\mathbf{3}$ - Comércio & 4 - Serviços & $\begin{array}{l}\text { Agropecuá } \\
\text { ria }\end{array}$ & Total \\
\hline TOTAL 2017 & $\mathbf{2 , 9 8}$ & $\mathbf{2 , 2 9}$ & $\mathbf{1 , 9 9}$ & $\mathbf{2 , 9 2}$ & $\mathbf{2 , 1 5}$ & $\mathbf{2 , 6 4}$ \\
\hline Masculino 2017 & 3,14 & 2,30 & 2,18 & 3,20 & 2,23 & 2,81 \\
\hline Feminino 2017 & 2,38 & 2,20 & 1,75 & 2,70 & 1,85 & 2,41 \\
\hline TOTAL 2014 & $\mathbf{3 , 0 6}$ & $\mathbf{2 , 2 9}$ & $\mathbf{2 , 0 6}$ & $\mathbf{2 , 9 8}$ & $\mathbf{2 , 2 3}$ & $\mathbf{2 , 6 7}$ \\
\hline Masculino 2014 & 3,24 & 2,30 & 2,31 & 3,31 & 2,30 & 2,89 \\
\hline Feminino 2014 & 2,39 & 2,11 & 1,76 & 2,70 & 1,91 & 2,37 \\
\hline
\end{tabular}

Tabela 1 - Média Salarial (SM) em Ponta Grossa-PR

Na tabela 2 podemos perceber esta diferença da média salarial, com base no salário mínimo real do IPEADATA, já deflacionado. (IPEA, 2019)

\begin{tabular}{|c|c|c|c|c|c|c|}
\hline \multicolumn{7}{|c|}{ MÉDIA SALARIAL EM REAIS (DEFLACIONADO) PONTA GROSSA-PR } \\
\hline GÊNERO/TOTAIS & $\begin{array}{l}1 \text { - } \\
\text { Indústria }\end{array}$ & $\begin{array}{l}2 \text { - } \\
\text { Construção } \\
\text { Civil }\end{array}$ & $\begin{array}{l}3 \text { - } \\
\text { Comércio }\end{array}$ & $\begin{array}{l}4 \text { - } \\
\text { Serviços }\end{array}$ & $\begin{array}{l}5- \\
\text { Agropecuá } \\
\text { ria }\end{array}$ & Total \\
\hline TOTAL 2017 & 2949,51 & 2269,41 & 1968,45 & 2890,91 & 2127,02 & 2614,46 \\
\hline Masculino 2017 & 3103,74 & 2274,89 & 2155,07 & 3164,66 & 2204,87 & 2786,77 \\
\hline Feminino 2017 & 2358,64 & 2178,87 & 1735,46 & 2672,57 & 1833,93 & 2381,03 \\
\hline TOTAL 2014 & 2879,85 & 2151,76 & 1934,70 & 2799,32 & 2092,60 & 2511,40 \\
\hline Masculino 2014 & 3043,69 & 2163,29 & 2166,77 & 3115,19 & 2164,08 & 2713,42 \\
\hline Feminino 2014 & 2247,20 & 1978,85 & 1656,25 & 2539,17 & 1799,84 & 2225,55 \\
\hline
\end{tabular}

Tabela 2 - Média Salarial em Reais (R\$) em Ponta Grossa-Pr

\section{MERCADO FORMAL DE TRABALHO EM SUCRE}

O Androcentrismo é a visão do mundo que situa o homem como o centro de todas as coisas. Esta concepção da realidade parte da ideia que o olhar masculino é a única e universal possibilidade de compreensão das coisas, negando a possibilidade do olhar feminino.

El androcentrismo es una visión parcial del mundo, que considera que lo que han hecho los hombres es lo que ha hecho la humanidad o, al revés, que todo lo que ha realizado el género humano lo han realizado sólo los hombres. Implica pensar que lo que es bueno para los hombres es bueno para la humanidad, y creer que la experiencia masculina incluye y es la medida de las experiencias humanas. En definitiva, el androcentrismo valora sólo lo que han hecho los 


\section{Administração: caminhos para o desenvolvimento sustentável}

hombres. Entendemos por patriarcado una forma de organización política, económica, religiosa y social basada en la idea de autoridad y liderazgo del varón, en la que se da el predominio de los hombres sobre las mujeres. De este modo, la masculinidad tradicional se fundamenta en una visión androcéntrica del mundo dentro de un sistema social y cultural patriarcal basado en la idea de autoridad y liderazgo del varón" (BERGARA Ander, 2008, pág. 27).

A cidade de Sucre vive esta realidade já que se caracteriza por um comportamento patriarcal que dirige as relações entre os gêneros, com uma estrutura de domínio do homem, então, também as atividades laborais são afetadas por práticas machistas, pelo privilégio de decisão do homem no ambiente de trabalho, principalmente em níveis hierárquicos que uma mulher possa assumir um cargo, análise esta reforçada por pesquisa realizada pelo Centro Juana Azurduy em 2016, onde 92\% das mulheres entrevistadas afirmam haver sofrido violência por parceiros nos últimos 12 meses. (LAMBERTIN \& SÁNCHEZ, 2008) Não existem dados estatísticos oficiais sobre o mercado formal de trabalho da mulher e nível de renda na cidade de Sucre, porém existem organizações que trabalham com grupos femininos, dentre as quais o Centro Juana Azurduy (ONG) é o mais representativo e um dos que mais se relaciona com o Município através da emissão de resoluções municipais e outras atividades. Entre seus objetivos figuram o fortalecimento das organizações de mulheres em torno de reivindicações específicas de gênero, capacitando-as tecnicamente para o trabalho e ainda com o oferecimento de serviços de saúde, jurídicos e informações especializadas, orientando na solução de conflitos sociais, familiares e de trabalho que enfrentam no cotidiano. (LAMBERTIN \& SÁNCHEZ, 2008, p. 21). A comunidade internacional tem financiado projetos que envolvem a igualdade de gênero em Sucre. A Suíça em 2016, encampou o Projeto de formação técnica Profissional que teve como âmbito de ação, no Departamento de Chuquisaca, os municípios de Sucre, Yotala, Presto, Zudáñez e Villa Mojocoya e foi executado pela Fundação Educação para o Desenvolvimento - (MINA, 2016, p. 2)

Algumas questões com relação ao tema gênero e o mercado foral de trabalho são preocupações constantes na Bolívia, para o enfrentamento das desigualdades.

Até que ponto foram implantadas estratégias e políticas de emprego orientadas para as mulheres e como se criam empregos para os setores mais vulneráveis em uma economia é outra pergunta que precisa de respostas para que se cumpra o ODS 5.

A Constituição Política do Estado da Bolívia (CPE) em seu texto atribui ao Estado a responsabilidade de promover a incorporação das mulheres ao mercado de trabalho e também a garantia de remuneração equivalente, independentemente de gênero: 


\section{Administração: caminhos para o desenvolvimento sustentável}

El Estado promoverá la incorporación de las mujeres al trabajo y garantizará la misma remuneración que a los hombres por un trabajo de igual valor,...las mujeres no podrán ser discriminadas o despedidas por su estado civil, situación de embarazo, edad, rasgos físicos o número de hijas o hijos. Se garantiza una inamovilidad laboral de las mujeres en estado de embarazo y de los progenitores, hasta que la hija o hijo cumpla un año de edad." (CPE, 2009)

A nova constituição política do estado promulgada em 2009 estabelece de forma clara o compromisso do Estado na redução das desigualdades de gênero no mercado de trabalho assegurando que as mulheres entrem no mercado de trabalho em igualdade de oportunidades e remuneração com os homens, por trabalho de igual valor.

Outro ponto importante da política nacional de enfrentamento das desigualdades de gênero é a inclusão do direito a ter e cuidar de uma família, tanto para homens quanto para mulheres, o que representa, sem dúvida, uma das mais importantes características deste compromisso por parte do Estado já que reconhece que o enfrentamento das desigualdades de gênero no mercado de trabalho passa, necessariamente, por mudanças das percepções da sociedade que ainda credita tais obrigações exclusivamente para as mulheres. Estudos sobre emprego e desemprego na Bolívia tem mostrado que o desemprego é e tem sido sempre maior entre as mulheres, confirmando que para as mulheres as necessidades de emprego são maiores que para os homens.

Qualquer que seja a forma de identificar a participação das mulheres no mercado de trabalho formal chegam ao mesmo resultado de baixa representatividade das mesmas nos indicadores. Isto não se aplica no mercado informal de trabalho ou emprego "por conta própria", onde abundam os empreendimentos familiares em que as mulheres estão bem representadas. Quando se estabelece o subemprego como categoria de análise, se observa também que uma grande maioria das mulheres aparecem nas estatísticas como "ocupadas", quando na verdade se encontram trabalhando menor quantidade de horas do que querem trabalhar em empregos precários que, dificilmente satisfazem suas necessidades básicas.

Na realidade, as tendências do emprego e do desemprego na Bolívia refletem três características fundamentais presentes nas desigualdades de gênero no mercado de trabalho: (1) as mulheres possuem menores oportunidades de emprego formal, estável, protegido e associado a maiores remunerações, (2) para muitas mulheres o emprego precário e por conta própria é a única forma de poder conciliar o cuidado da família com a necessidade de gerar renda e (3) que a efetiva redução de desigualdades no mercado de trabalho vai além das ações desenvolvidas exclusivamente no mercado 


\section{Administração: caminhos para o desenvolvimento sustentável}

de trabalho para incluir a mudança na forma de assumir as responsabilidades familiares dentro e fora de casa.

Na Bolívia, a partir dos anos de 1980, tem-se desenvolvido políticas e programas de emprego. Alguns sofreram mudanças e outras estão em pleno funcionamento. Na prática existem dois tipos de programas: (1) os orientados para facilitar o melhor funcionamento do mercado de trabalho a exemplo da bolsa de emprego e capacitação para o trabalho, conhecidos como políticas ativas de emprego e (2) os que tem por objetivo reduzir os impactos de uma perda da remuneração ao longo dos anos (esquemas de emprego intensivo) que são parte das chamadas políticas passivas de emprego. Em resumo, os programas das políticas ativas de emprego que se desenvolveram nos últimos 10 anos na Bolívia possuem duas características muito importantes. Primeiro seu limitado alcance em termos do número de pessoas que participam destes programas e, portanto, seu limitado impacto ao longo do tempo e segundo, o foco desses programas que são os grupos sociais em estado de vulnerabilidade (jovens e mulheres de baixa renda) que mesmo atingindo um pequeno número de pessoas pode gerar um impacto significativo.

\section{DESIGUALDADE DE GÊNERO}

Segundo o World Economic Forum (WEF, 2017), a perspectiva para atingir a igualdade de gênero no local de trabalho (ODS 5) é o ano de 2186, uma meta para além da nossa existência, mas que precisa ser trabalhada por todas as organizações e com definição de políticas apropriadas de gestão de pessoas, para o que a própria ONU propõe algumas estratégias: (1) Desenvolvimento e treinamento de liderança para mulheres; (2) Definição de metas e acompanhamento do progresso; (3) promoção do equilíbrio entre vida pessoal e profissional; (3) Apoio à integração da mulher na cadeia de valor; (4) trajetórias de carreiras e estruturas salariais transparentes; (5) Apoio/oferecimento de trabalho flexível; (6) benefícios gerenciais equivalentes e (7) demonstrar compromisso de liderança. (WEF, 2016)

Quando analisamos este gap por regiões, a previsão para a América Latina e Caribe fecharem o gap é de 61 anos, precedida apenas pela Europa Ocidental em que a previsão é de 47 anos. 


\section{Administração: caminhos para o desenvolvimento sustentável}

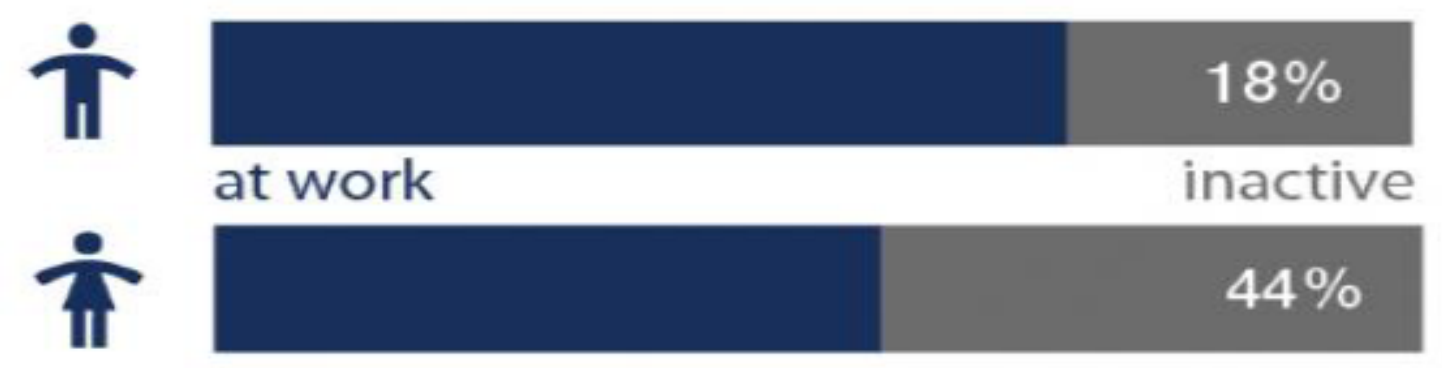

Figura 1- Força de trabalho - comparativo homens e mulheres (WEF,2017)

Os países mais bem colocados no ranking na América Latina são Nicarágua (10), Bolívia (23) e Costa Rica (32), com o Brasil ocupando o 70ㅇ lugar no ranking.

Este mesmo relatório de 2018 aponta que o desempenho do mercado de trabalho também continua sendo um dos maiores desafios para o Brasil. A pontuação do pilar 8 caiu de 52,8 (99ㅇ) em 2017 para 51,0 (114으) em 2018, indicando que as reformas aprovadas em 2017 com o objetivo de aumentar a flexibilidade do mercado de trabalho ainda não produziram os efeitos desejados (WEF, 2018).

A reunião de Genebra, Suíça, em 2016 concluiu que o mundo está enfrentando um mal uso agudo de talento ao não agir mais rápido para enfrentar a desigualdade de gênero e que embora as mulheres possuam as mesmas qualificações que os homens, elas obtêm resultados diferentes, aliado ao fato de que $81 \%$ da população mundial feminina ainda é inativa. (WEF, 2017)

Em 2017, a proporção da percentagem de mulheres entre os 15 e os 64 anos que participam na força de trabalho, enquanto trabalhadores assalariados, e a percentagem de homens com idades entre 15 e 64 anos que participam na força de trabalho como trabalhadores assalariados no Brasil é de 0,82, ocupando a 49a Colocação e da Bolívia é de 0,76, ocupando a 62a Colocação, com base nos dados de novembro de 2017.

Com base no relatório WEF (2018) que aponta o ranking mundial de igualdade entre homens e mulheres, o Brasil vem sendo superado pela Bolívia, conforme se observa na Tabela 3. A Bolívia ocupa em 2018 o 25 lugar no ranking de 149 países enquanto o Brasil ocupa a 95a posição.

O Brasil é superior à média mundial no quesito educação e participação econômica e oportunidades, está na média no quesito saúde, porém está muito aquém da média mundial no quesito políticas de empoderamento das mulheres com pontuação de 0,101, ocupando o 112ㅇ lugar dos 149 países em observação pelo WEF. 


\section{Administração: caminhos para o desenvolvimento sustentável}

A Bolívia supera em muito a média mundial nas políticas de empoderamento das mulheres com pontuação de 0,408 e ocupando a 14a posição entre os 149 países observados pelo WEF, supera a média mundial na participação econômica e se mantem na média mundial nos quesitos educação e saúde.

\begin{tabular}{|c|c|c|c|c|}
\multirow{2}{*}{ ANO } & \multicolumn{2}{|c|}{ BOLIVIA } & \multicolumn{2}{c|}{ BRASIL } \\
\cline { 2 - 5 } & $\boldsymbol{R A N K}$ & SCORE & RANK & SCORE \\
\hline \multirow{2}{*}{$\mathbf{2 0 0 6}$} & 87 & 0,634 & 67 & 0,654 \\
\cline { 2 - 5 } & 25 & 0,748 & 95 & 0,681 \\
\hline
\end{tabular}

Tabela 3 - Score Global da diferença de gênero

A figura 2 demonstra que, mundialmente, as mulheres dividem os postos de trabalho com os homens nos setores primários e secundários da economia, prevalecendo a ocupação por homens nos empregos formais do setor terciário e quando o assunto é a ocupação de homens e mulheres, exercício de funções mais qualificadas e funções de liderança, há predominância da presença masculina no mercado de trabalho (WEF,2017).
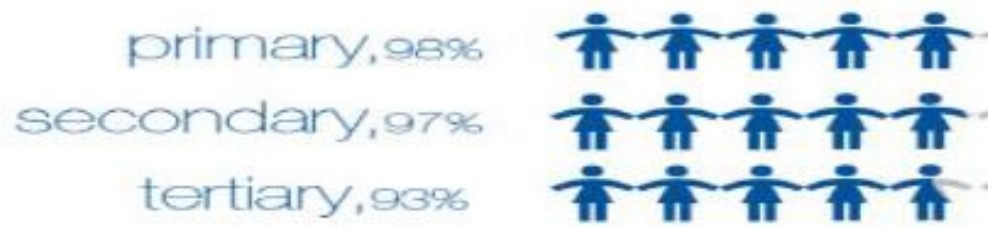

at work,66\%

skilled roles, s6\% leaderstip roles, 36\%

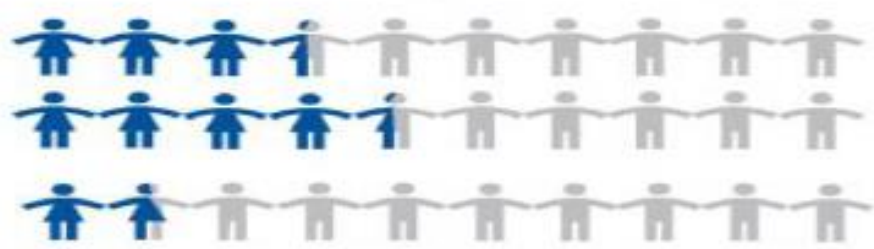

Figura 2: Setores Produtivos $x$ Trabalho da mulher

Os dados encontrados nos órgãos oficiais expressam que a desigualdade de gênero ainda se faz presente mundialmente e que a estimativa do WEF para fechamento do gap para a América Latina e Caribe é bastante otimista.

\section{METODOLOGIA}

O estudo se caracteriza como exploratório, qualitativo e quantitativo, com utilização de dados secundários obtidos junto aos órgãos Governamentais do Brasil, da Bolívia, ONU e WEF, que foram 


\section{Administração: caminhos para o desenvolvimento sustentável}

analisados mediante a técnica de análise de conteúdo e também com utilização de medidas estatísticas simples (média, percentual) e pesquisa bibliográfica prévia sobre o tema no Portal Scielo, buscando pelos termos "Genero" and "Mercado de trabalho" e "Gender" and "Market Work"sendo que a busca resultou em 172 estudos, aplicando os filtros para Revistas específicas da área de Ciências Sociais Aplicadas("Revista Brasileira de Estudos de População" OR "Nova Economia" OR "Sociedad y Economía" OR "Economia Aplicada" OR "Revista Brasileira de Ciências Sociais" OR "Revista de Economia Contemporânea" OR "Trabalho, Educação e Saúde" OR "Estudos Econômicos (São Paulo)" OR "RAM. Revista de Administração Mackenzie" OR "Revista de Administração Contemporânea" OR "Revista de Estudios Sociales" OR "Economia e Sociedade" OR "Revista Crítica de Ciências Sociais"), no período 2014 a 2018, restaram 35 artigos que foram consultados e dos quais foi selecionado 01 artigo para este estudo por se enquadrar no recorte temporal que está sendo aplicado. Nenhum dos artigos tratava especificamente do ODS5.

\section{CONCLUSÃO}

Sendo o Objetivo no 5 um objetivo mundial, com mensurações específicas elaboradas pelo Fórum Econômico Mundial que prevê o alcance desta meta até o ano de 2030, considerando que o WEF fez uma estimativa em 2016, de mais 61 anos para seu completo atingimento na américa latina, ou seja, até o ano de 2077, buscamos verificar o status de sua implementação em Ponta Grossa-PR e Sucre, BO.

Em termos mundiais, o relatório WEF de 2018, aponta o Brasil ocupando a 49a posição e a Bolívia ocupando a 62a posição no ranking de participação feminina no mercado de trabalho formal, porém, a Bolivia vem superando a média mundial de politicas de empoderamento feminino, ocupando o 14으 lugar mundial no ranking de 149 países.

A reunião de Genebra, Suíça, em 2016 concluiu que o mundo está enfrentando um mal uso agudo de talento ao não agir mais rápido para enfrentar a desigualdade de gênero e que embora as mulheres possuam as mesmas qualificações que os homens, elas obtêm resultados diferentes, aliado ao fato de que $81 \%$ da população mundial feminina ainda é inativa.

Considerando que o Brasil supera a média mundial no quesito educação das mulheres, podemos fazer uma análise do mau uso do talento feminino que pode ser atribuído a falta de políticas de empoderamento das mulheres, como estratégia de ação. 


\section{Administração: caminhos para o desenvolvimento sustentável}

Neste quesito, em Sucre-BO, não há dados estatísticos oficiais sobre o mercado formal de trabalho da mulher e nível de renda mas, as informações das ONGs que atuam na cidade afirmam que Sucre se caracteriza por um comportamento patriarcal que dirige as relações entre os gêneros, com uma estrutura de domínio do homem, então, também as atividades laborais são afetadas por práticas machistas, pelo privilégio de decisão do homem no ambiente de trabalho, principalmente em níveis hierárquicos que uma mulher possa assumir um cargo.

Estudos sobre emprego e desemprego na Bolívia tem mostrado que o desemprego é e tem sido sempre maior entre as mulheres, o que confirma que para as mulheres as necessidades de emprego são maiores que para os homens. Qualquer que seja a forma de identificar a participação das mulheres no mercado de trabalho formal chegam ao mesmo resultado de baixa representatividade das mesmas nos indicadores.

Na Bolívia refletem três características fundamentais presentes nas desigualdades de gênero no mercado de trabalho: (1) as mulheres possuem menores oportunidades de emprego formal, estável, protegido e associado a maiores remunerações, (2) para muitas mulheres o emprego precário e por conta própria é a única forma de poder conciliar o cuidado da família com a necessidade de gerar renda e (3) que a efetiva redução de desigualdades no mercado de trabalho vai além das ações desenvolvidas exclusivamente no mercado de trabalho para incluir a mudança na forma de assumir as responsabilidades familiares dentro e fora de casa.

Na cidade de Sucre há mais limitações para que as mulheres desfrutem do direito a um trabalho digno. O trabalho feminino está mais direcionado aos trabalhos domésticos como limpeza e cuidado das crianças. A maior quantidade de trabalhos formais estão dirigidos aos homens e quando as mulheres têm acesso a eles, são trabalhos de menor importância e menor nível hierárquico, muito embora a população seja formada por maior quantidade de mulheres que homens.

Em todos os setores de trabalho se dá preferência ao homem, criando insuficientes oportunidades de trabalho formal para o gênero feminino. A legislação vigente na Bolívia estabelece normas que garantem a igualdade de homens e mulheres e que as contratações aconteçam com base nas competências para o trabalho, porém, mesmo em situação de equivalência nas competências profissionais, na prática, os homens têm a preferência. Igualmente, as diferenças salariais entre os gêneros acontece em todos os setores, com prevalência da maior remuneração entre os homens, em detrimento das mulheres, sendo este o processo de cognição enraizado na sociedade. Os avanços requerem a mudança de mentalidade e, mesmo que as normas legais avancem, não conseguem 


\section{Administração: caminhos para o desenvolvimento sustentável}

superar o paradigma machista. Conforme observa-se na Tabela 2, em Ponta Grossa-PR, entre 2014, ano anterior a fixação dos ODS pela ONU e 2017, seguiu a tendência nacional de queda geral da Remuneração média, com uma diferença de 14,23\% a menor na média salarial das mulheres em 2017, em comparação com a média salarial dos homens. Em 2014 esta diferença era de 17,99\%, portanto, houve uma melhoria de $3,76 \%$.

No comércio e prestação de serviços, setores que mais empregam mulheres, esta diferença salarial é bastante acentuada, na casa de $19,72 \%$ no comércio e $15,62 \%$ no setor de serviços contra $30,20 \%$ na indústria e $17,04 \%$ no setor agropecuário.

Devemos ressaltar que a indústria e a agropecuária são os setores que movimentam a região dos Campos Gerais, portanto, esta região está bastante distante da média nacional. Com relação a análise feita pelo WEF identificando quatro grandes grupos mundiais no enfrentamento desta problemática, a saber: o primeiro grupo (1) abrange os países cujos investimentos na saúde e na educação femininas estão dando frutos na forma de uma maior participação econômica e política; no segundo grupo (2), estão os países que estão investindo nestas áreas mas não aproveitam esta reserva adicional de talento por causa das barreiras sociais e institucionais ainda existentes; o terceiro grupo (3), inclui os países onde desigualdades significativas na educação e na saúde não permitem a realização plena do potencial das mulheres, embora as mesmas desempenhem um papel importante na força de trabalho, geralmente em empregos que requerem pouca qualificação e o quarto grupo (4) reúne os países com importantes desigualdades em educação, economia e política, cabe pesquisa futura para identificar a forma de enfrentamento e os resultados obtidos pelos diferentes países uma vez que os dados do relatório WEF (2018) apontam que as políticas de empoderamento das mulheres tem levado a Bolívia a um destaque no cenário mundial.

Assim, concluímos este estudo no sentido de que muito pouco é feito em termos de políticas institucionais e organizacionais no Brasil e em Ponta Grossa-PR para desenvolver uma visão diferente do capital humano - inclusive na maneira como impulsionam as mulheres para os postos de líderes pois as mulheres ainda são preteridas na disputa por uma vaga no mercado formal, mesmo apresentando superior perfil de competências.

Os diferentes posicionamentos encontrados são no sentido de que uma revolução mental e prática não é uma meta para o futuro, mas sim um imperativo para hoje, com investimento na educação de mulheres, que compete tanto às organizações, associações, governo quanto às escolas e Universidades que preparam profissionais para atuarem na área de Gestão de Pessoas. Quebrar a 


\section{Administração: caminhos para o desenvolvimento sustentável}

barreira do gênero e estabelecer como critério a competência e a qualificação se faz urgente em nossas sociedades.

Podemos afirmar que houve melhoria no que se refere a igualdade de gênero no trabalho formal da mulher na cidade de Ponta Grossa-PR entre os anos de 2014 e 2017 e que houve melhoria no que se refere a igualdade de gênero no trabalho formal da mulher na cidade de Sucre, Bolívia, embora ainda frágeis estes números.

Nestas duas cidades, o setor que mais emprega mulheres é o setor de Comércio e Serviços, porém, em nenhum dos setores da economia (primário, secundário ou terciário) se destaca no quesito igualdade com relação a remuneração das mulheres em comparação com a remuneração dos homens, apontando para um caminho longo de mudança cultural e de definição de políticas organizacionais claras.

A área de Recursos Humanos, Gestão de Talentos, Gestão de Pessoas seja qual for a nomenclatura que se adote, deve ter uma posição mais clara e uma atuação mais forte para que a desigualdade de gênero seja vencida e que, realmente, os talentos sejam compensados e evidenciados.

\section{REFERÊNCIAS}

BERGARA, A. Los hombres, la igualdad y la nueva masculinidad. Edita y realiza: EMAKUNDE Instituto Vasco de la Mujer, 2008.

BOLIVIA. Constituição do Estado da Bolivia. La Paz, 2009

BRASIL. IPARDES. Ministério da Economia. CADERNO ESTATí́STICO: MUNIIPIO DE PONTA GROSSA. 2019. Disponível

em: <http://www.ipardes.gov.br/cadernos/MontaCadPdf1.php?Municipio=84000\&btOk=ok>. Acesso em: 05 jun. 2019.

BRASIL. Observatório Nacional do Mercado de Trabalho. Ministério do Trabalho e Emprego (Org.). PARTICIPAÇÃO FEMININA NO MERCADO DE TRABALHO. Brasília, 2018. 13 p. (BOLETIM ESPECIAL DO OBSERVATÓRIO). Disponível

em:<http://obtrabalho.mte.gov.br/images/artigos/Boletim\%20Especial\%20Participa\%C3\%A7\%C3\%A 30\%20feminina\%20no\%20mercado\%20de\%20trabalho.pdf>. Acesso em: 11 jun. 2019.

BRASIL. PDET Programa de Disseminação das Estatísticas do Trabalho Estatisticas. Ministério do Trabalho. RAIS 2017.2018. Disponível em: <http://pdet.mte.gov.br/index.php/rais>. Acesso em: 22 abr. 2019.

CEPAL. Observatório de Igualdade Gênero da América Latina e do Caribe. Bolívia - Perfil do País. 2017. Disponível em: <https://oig.cepal.org/pt/paises/6/profile>. Acesso em: 24 jun. 2019. 


\section{Administração: caminhos para o desenvolvimento sustentável}

MINA, M.E.C. Experiências de incorporación del enfoque de gênero en procesos de formación técnica. FAUTAPO: 2016.

GIUBERTI, Ana Carolina; MENEZES-FILHO, Naércio. DISCRIMINAÇÃO DE RENDIMENTOS POR GÊNERO: UMA COMPARAÇÃO ENTRE O BRASIL E OS ESTADOS UNIDOS. Revista de Economia Aplicada, Ribeirão Preto-sp, v. 9, n. 2, p.369-383, 2005. Anual. Disponível

em: <http://www.scielo.br/pdf/ecoa/v9n3/v9n3a02.pdf>. Acesso em: 11 jun. 2019.

IBGE- Instituto Brasileiro de Geografia e Estatística. Ministério da Economia (Org.). Mulheres no Mercado de Trabalho. Brasília, 2018. 15 p. Disponível

em: $\quad$ https://www.ibge.gov.br/estatisticas/sociais/educacao/9171-pesquisa-nacional-por-amostrade-domicilios-continua-mensal.html?=\&t=estudos-especiais>. Acesso em: 11 jun. 2019.

IPEA - Instituto de Pesquisa Econômica Aplicada. Ministério do Planejamento, Desenvolvimento e Gestão (Org.). ODS - Metas Nacionais dos Objetivos de Desenvolvimento Sustentável. Brasília, 2018. Disponível

em:<http://www.ipea.gov.br/portal/images/stories/PDFs/livros/livros/180801_ods_metas_nac_dos _obj_de_desenv_susten_propos_de_adequa.pdf>. Acesso em: 17 maio 2019.

IPEA-Instituto de Pesquisa Econômica Aplicada. SOCIAL. 2019. Disponível

em: <http://www.ipeadata.gov.br/Default.aspx>. Acesso em: 14 jun. 2019

LAMBERTIN, G; SANCHEZ, J.P. Narrativas y políticas de Identidad en los valles de Cochabamba, Chuquisaca y Tarija.. Ed.UNIR. La Paz Bolivia, 2008.

OIT - Organização Internacional do Trabalho. Bolívia. 2014. Disponível

em: <https://www.ilo.org/lima/paises/bolivia/lang--es/index.htm>. Acesso em: 24 jun. 2019.

OIT - Organização Internacional do Trabalho. Representantes de trabajadores de Bolivia destacan el rol de la mujer en el ámbito sindical. 2016. Disponível em: <https://www.ilo.org/lima/sala-deprensa/WCMS_525110/lang--es/index.htm>. Acesso em: 24 jun. 2019.

OIT - Organização Internacional do Trabalho. Bolívia. 2017. Disponível em: <https://www.ilo.org/lima/paises/bolivia/lang--es/index.htm>. Acesso em: 24 jun. 2019.

ONU (Brasil). Transformando Nosso Mundo: A Agenda 2030 para o Desenvolvimento Sustentável. 2015. Disponível em: <https://nacoesunidas.org/pos2015/agenda2030/>. Acesso em: 05 abr. 2019.

PARANÁ. Ipardes. Secretaria de Estado do Planejamento e Coordenação Geral - Sepl. Cadernos municipais: Ponta Grossa-PR. 2017. Disponível

em: <http://www.ipardes.gov.br/cadernos/MontaCadPdf1.php?Municipio=84000\&btOk=ok>. Acesso em: 22 abr. 2019.

PNAD - Pesquisa Nacional por Amostra de Domicílios Contínua (IBGE). Divulgação Especial. Mulheres no Mercado de Trabalho. Publicado em: 08 março 2019. Disponível 


\section{Administração: caminhos para o desenvolvimento sustentável}

em: <https://www.ibge.gov.br/estatisticas/sociais/educacao/9171- pesquisa-nacional-por-amostrade-domicilios-continua-mensal.html?=\&t=estudos-especiais>. Acesso em: 31 maio 2019

MACIEL, Francieli Tonet; OLIVEIRA, Ana Maria Hermeto C. de. INFORMALIDADE E SEGMENTAÇÃO DO MERCADO DE TRABALHO BRASILEIRO NOS ANOS 2000: UMA DECOMPOSIÇÃO QUANTÍLICA DE DIFERENCIAIS DE RENDIMENTOS. Revista de Economia Contemporânea, Rio de Janeiro, v. 2, n. 22, p.137, 27 abr. 2018. Disponível em: <http://www.scielo.br/pdf/rec/v22n2/1415-9848-rec-22-02e182223.pdf>. Acesso em: 07 maio 2019.

NAÇÕES UNIDAS, BRASIL. Transformando nosso mundo: a Agenda 20130 para O desenvolvimento Sustentável. 13 de outubro de 2015. Disponível

em: <https://nacoesunidas.org/pos2015/agenda2030/>. Acesso em: 12 maio 2019.WEF. The Global Competitiveness Report 2010-2011. Disponível em: http://www.weforum.org. Acesso em 22.04.2019

WEF. The Global Competitiveness Report 2013. Disponível

em http://www3.weforum.org/docs/WEF_NR_GGGR_LatinAmerica_Report_2013_PT.pdf . Acesso em 22.04.2019.

WEF. The Global Competitiveness Report 2018. Disponível em http://reports.weforum.org/globalcompetitiveness-report-2018/competitiveness-rankings/\#series=FMLWGEDWRKRT. Acesso em 10.06.2019.

WEF (Genebra). Além de nossa existência: perspectivas para atingir a igualdade de gênero no local de trabalho atingem o ano 2186. 2017. Disponível

em: <http://www3.weforum.org/docs/Media/GGGR16/GGGR16_PTBR.pdf>. Acesso em: 05 jun. 2019.

WEF. GLOBAL GENDER GAP REPORT 2016. 2016. Disponível em: <http://reports.weforum.org/globalgender-gap-report-2016/infographics/>. Acesso em: 05 jun. 2019. 


\section{Capítulo 2}

\section{SAZONALIDADE DE PREÇOS DO SUÍNO VIVO NO ESTADO DO PARANÁ}

DOI: $10.37423 / 200300342$

Germano de Paula (UNIOESTE-PR) germano5043@hotmail.com José Matheus Yalenti Perosa (FCA-UNESP-Botucatu-SP) dede@fca.unesp.br Osmar de Carvalho Bueno (FCA-UNESP-Botucatu-SP) osmar@fca.unesp.br Vanessa Bottonidos Santos (Faculdade Mater Dei-PR) vanessabottoni@gmail.com Edison LuizLeismann (ONIOESTE-PR) elleismann@gmail.com

Resumo: A suinocultura paranaense é uma das mais importantes/fornecedoras de proteína animal aos consumidores do ẹstado, dọ Brasil e do munqb. Faz usø de alto padrão tecnológico, sento_ainda relevante fonte-de emprego e renda, notadamente-a-agricultura familiar, solo a forma de parceira ou integração às cooperativas e/ou agroindústrias, além de gerar divisas ao país. Diante disso, dada a importância deste segmento, esta pesquirsa objetivou analisar a sazonalidade de preços do suोino vivo no estado do Paraná enøuanto produto ofertado, por produtores da agricultura familiar o estudo abrangeu of período de janeiro de 2000 a dezembro de 2009 e fez uso da metodologia da média geométrica móvel centralizada de 12 mesés. Constatou-se que os índices sażphais abaixo gu/igual a 100 incidiram em metade dos meses do ano, indicando épocas de major oferta/do animal. Os índices acima de 100 , ocorreram, em sua maioria, nos meses de queda na oferta do produto. Quianto a maior diferença entre os limites infertor-superion Ldos/indices, verificou-se que a mesma ocorre entre os meses-de indices-mais baixos. Desse-mode, infere-se que opreço do suino vivg mostra uma sazonatiđade de preços moderada.

Palavras chave: Preços, Suíno Vivo, Agropecuária. 


\section{Administração: caminhos para o desenvolvimento sustentável}

\section{INTRODUÇÃO}

O Brasil é um dos líderes mundiais na produção, consumo e exportação de produtos oriundos da agropecuária, que supre grande parte dos alimentos consumidos pela população brasileira. Ainda é um dos setores que mais emprega mão-de-obra, particularmente da agricultura familiar, gera renda, volume de divisas ao país, e foi um dos precursores de pesquisas na busca da autonomia energética.

A sedimentação da base técnica da agricultura brasileira, imposta pelas mudanças na política urbanoindustrial acentuou a mercantilização da área rural e sua especialização, com propósito primordial de gerar crescimento de produtividade física e o aumento de rentabilidade econômica (SORJ, 1980). Desse modo, no processo de acumulação capitalista, coube ao setor rural brasileiro produzir produtos complementares ao setor industrial e suprir de alimentos baratos o setor urbano.

A modernização da agricultura brasileira impactou também a região Sul, onde o agricultor familiar integrou-se à produção capitalista enquanto consumidor de insumos e fornecedor de matérias primas, ao processo de produção agroindustrial, especialmente no setor de carnes.

Importante fonte de proteína animal, a carne suína tem destaque mundial e faz parte da alimentação de populações de diferentes níveis de renda em todos os continentes. Segundo perspectivas da Organização das Nações Unidas para Agricultura e Alimentação (FAO), de 2012 até 2030, o mundo terá de aumentar a produção per capita de carne em $20 \%$. As carnes com perspectivas de maiores crescimentos serão carne de aves $(40,4 \%)$, suína (20\%), peixe (19\%) e carne bovina $(12,7 \%)$.

Em 2007, a China foi o maior produtor de carne suína, seguido pelos 27 países da União Européia, EUA e Brasil. Em termos de consumo per capita (kg/pessoa/ano), destacam-se a China $(33,3)$, Canadá $(29,5)$ e Rússia 19,8. O Brasil aumentou o consumo, de 1999 a 2007, passando de 10,4 para 12,3 $\mathrm{kg} /$ habitante/ano, respectivamente (ANUALPEC, 2008).

Os maiores importadores da carne suína brasileira foram a Rússia, China( Hong Kong), Ucrânia, Cingapura e Argentina (ABIPECS 2007).

Para Roppa (2006), a suinocultura brasileira apresentou os menores custos entre os países produtores e exportadores de carne suína, além de ter disponibilidade de grãos, a incorporação de tecnologias de abate e processamento, de produção pecuária com avanços em genética, nutrição e medicamentos e de organização e coordenação da cadeia produtiva suinícola. No entanto, segundo o mesmo autor, há 


\section{Administração: caminhos para o desenvolvimento sustentável}

ainda grande parcela de matrizes não tecnificadas, notadamente no sistema de produção dos produtores independentes.

O segmento da agropecuária brasileira tem importante papel a ocupar na economia brasileira, em especial, a cadeia produtiva de suínos, que é uma das mais dinâmicas do país em função dos benefícios não somente aos produtores, mas também às cadeias da soja, do milho, bem como dos setores como agroindústrias, cooperativas, transportes, serviços, dentre outros. Assim, conforme Roppa (2006), o valor da cadeia produtiva suinícola brasileira gerou US\$ 1,8 bilhão, e 700 mil pessoas dependiam de forma direta da mesma.

A produção suinícola nacional, conforme o Censo Agropecuário de 2006, contabilizou 31,9 milhões de cabeças, e essa atividade cresceu 14,75\% no período de 1996 a 2006 (IBGE, 2009). É uma atividade presente nas macrorregiões brasileiras, com destaques para os estados de Santa Catarina, Rio Grande do Sul, Paraná, Minas Gerais, Goiás e Mato Grosso.

Os principais estados em abate de suínos inspecionados foram Santa Catarina, Rio Grande do Sul e Paraná, no 3 trimestre de 2007. Isso exigiu maiores ofertas de matérias-primas e insumos para suportar tais incrementos. Assim, segundo a União Brasileira de Avicultura (2007), a suinocultura brasileira consumiu $27 \%$ das rações produzidas, equivalente a 13,1 milhões de toneladas, com 8,5 e 3,5 milhões de toneladas, de milho e farelo de soja, respectivamente.

A suinocultura industrial, de acordo com Miele e Waquil (2007), é formada pelos produtores tecnificados, que incorporam os avanços tecnológicos em genética, sanidade e demais aspectos produtivos. Essa suinocultura é formada por produtores integrados e independentes, que exploram ganhos de escala e, na maior parte, adota uma estratégia de especialização crescente. Desse modo, no Brasil, para os mesmos autores, a suinocultura industrial, em 2005 , detinha $60 \%$ no alojamento de matrizes e também mais de $80 \%$ dos abates e da produção de carne suína concentravam-se nos estados da região Sul.

A integração, conceito usado na cadeia produtiva suinícola, abrange um grande número de opções, que vão desde transações formalizadas por contrato, típico da suinocultura industrial, até transações sem contrato, mas amparadas no cooperativismo e em programas de fomento pecuário.

Para Miele (2006), no Brasil, em 2005, a região Sul tinha 92\% das propriedade sob o sistema de integração, a Sudeste (75\%), a Norte e Nordeste, com 70\% e a Centro Oeste (53\%). 


\section{Administração: caminhos para o desenvolvimento sustentável}

A suinocultura é atividade de grande impacto ambiental, que requer grande volume de água de água e pelos dejetos produzidos, que são altamente tóxicos, oriundos do processo produtivo nas suas diversas fases de produção e lançamento

A importância da participação da agricultura familiar na economia brasileira denota relevância pela produção de alimentos e pela ocupação em imóveis rurais, dentre outros. Assim, segundo dados do Ministério do Desenvolvimento Agrário (MDA) (BRASIL, 2003), a participação da agricultura familiar representavam mais de $84 \%$ dos imóveis rurais do país, com 4,1 milhões de estabelecimentos no meio rural. Dos 80,25 milhões de hectares da agricultura familiar, 45\% eram destinados a pastagens, $28 \%$ a florestas e $22 \%$ a lavouras.

Para o IBGE (2009), os estabelecimentos ligados à agricultura familiar são responsáveis cerca de $40 \%$ do valor bruto da produção agropecuária e 80 \% das ocupações produtivas agropecuárias. $\mathrm{Na}$ produção de alimentos, a produção da agricultura familiar responde por $70 \%$ do feijão, $84 \%$ da mandioca, $59 \%$ dos suínos, $54 \%$ do bovino leiteiro, $49 \%$ do milho e $40 \%$ das aves. Em termos de valor médio da produção anual obtido pela agricultura familiar, que foi de $\mathrm{R} \$ 13.990$, os empreendimentos que se dedicaram à criação de aves tiveram o menor valor ( $R$ \$ 1.560) e aqueles voltados à produção de flores, tiveram o maior valor ( $\mathrm{R} \$ 17.560)$.

Fontana (1976) e Machado (1991) diagnosticaram os principais problemas estruturais que afetam a suinocultura no Brasil: a atomização da produção, que dificulta o ganho de escala; estacionalidade dos abates (presença de produtores safristas); baixo nível de consumo; localizações das lavouras de milho e soja e excessivo grau de industrialização da carne suína.

Um grande problema que os suinocultores enfrentam é a sazonalidade da produção, que afeta os preços desse animal e geram instabilidade no fluxo de renda dos mesmos.

A produção agropecuária está sujeita às oscilações da oferta e da procura pela natureza de ser um produto agropecuário (HOFFMANN, 1998). Assim, apesar do sistema de integração ser apontado como uma forma de amenizar o risco para o produtor familiar, essa atividade está sujeita à dependência de milho e soja, lavouras também sujeitas a riscos climáticos e com produções sazonais. Vários fatores afetam a capacidade de gerir o negócio em períodos de preços baixos, daí necessita-se buscar a sustentabilidade do negócio, tanto em aspectos econômicos, mas também sociais e ambientais. 


\section{Administração: caminhos para o desenvolvimento sustentável}

Outro problema enfrentado pelos suinocultores é a sazonalidade da produção de suínos, que afeta os preços desse animal e geram instabilidade no fluxo de renda dos mesmos.

Estudos realizados por Besen et al (2002) constataram que os suinocultores não integrados por atuarem independentemente das processadoras (agroindústrias), correm o risco de ofertar mais suínos que a programação de abate. Desse modo, tais agentes podem gerar um excesso de oferta no mercado e queda dos preços, que geram impactos negativos sobre a margem de lucro da suinocultura em geral.

Conforme Carvalho et al (1995), os preços recebidos pelos produtores de suíno para abate têm pico em dezembro e menor índice em abril. Segundo os mesmos autores, quanto aos preços de ração para suínos, também há sazonalidade, com menor índice em julho e maior em novembro.

A cadeia produtiva da suinocultura do Paraná destaca-se no Brasil, por apresentar grande parte da produção tecnificada, produzida em grande parte por produtores da agricultura familiar e forte vínculo entre produtores e agroindústrias.

Em 2001 os suinocultores brasileiros tiveram cenário positivo, em função de queda do custo de produção, aumento das exportações e expansão da produção nas regiões tradicionais (Sul) e não tradicionais (Centro Oeste).

Porém, em meados de 2002, os produtores tiveram problemas sanitários, queda de preços e da rentabilidade além da crise cambial, que elevou as taxas de juros, com reflexos nos custos de produção da atividade.

Em 2004, os focos de Febre Aftosa fizeram com que a Rússia proibisse importações das carnes de aves, bovina e suína do Brasil. Com a descoberta de novos focos da doença (nos estados do MS e PR), em outubro e em dezembro de 2005, respectivamente, reforçou o embargo da Rússia, do Chile, Inglaterra, União Européia, dentre outros.

Em parte do ano de 2006, o mercado de suíno vivo registrou preços baixos ainda como reflexos do embargo russo, dentre outros problemas, devido às condições sanitárias do rebanho brasileiro. Com excesso de produção no mercado interno, houve aumento da demanda da carne e seus derivados, mas com prejuízo na rentabilidade dos suinocultores. 


\section{Administração: caminhos para o desenvolvimento sustentável}

Diante disso, a busca por estudos que possam fornecer informações do comportamento dos preços dos suínos é salutar, desde que as mesmas possam gerar subsídios para medir as oscilações médias nos períodos produtivos desse animal. Desse modo, a presente pesquisa tem por objetivos analisar a sazonalidade de preços do suíno vivo no estado do Paraná, de 2000 a 2009, produzidos por produtores da agricultura familiar.

\section{REFERENCIAL TEÓRICO}

\subsection{AGRICULTURA FAMILIAR E SUINOCULTURA PARANAENSE}

O Paraná é um dos maiores produtores e exportadores de carne suína e seus derivados no Brasil, fruto de um desenvolvimento histórico, econômico e social da sua agricultura. Assim, os anos 70 foram determinantes para a consolidação da agricultura dentro do modelo capitalista, surgindo o agronegócio no Paraná. Desse modo, entra em decadência a agricultura tipo colonial (produtora de café), que foi substituída pelas culturas de milho e soja (REZENDE; PARRÉ, 2003).

A modernização da agricultura brasileira impactou também a região Sul, onde o agricultor familiar integrou-se à produção capitalista enquanto consumidor de insumos e fornecedor de matérias primas, ao processo de produção agroindustrial, especialmente no setor de carnes.

Um estabelecimento tipicamente familiar é aquele em que a direção dos trabalhos é exercida pelo produtor e que o trabalho familiar sobreponha-se ao trabalho contrato, além da extensão territorial das unidades de produção, limitadas regionalmente, mas, em geral, de pequeno porte (INCRA/FAO, 2000).

Em termos de especialização e diversificação do estabelecimento agropecuário, uma das configurações existentes no Brasil é aquela onde o estabelecimento é diversificado com produção de suínos, grãos (notadamente milho para o auto consumo) e bovinos de leite. Tais propriedades têm base na agricultura familiar e se caracterizam pela pequena escala se produção. Para o mesmo autor, outra configuração é composta por estabelecimentos com especialização na suinocultura, mas sem produção de grãos, que exploram ganhos de especialização e de escala.

O rebanho de suínos do estado distribui-se em estabelecimentos diversificados: aqueles com economia de escala ( associado a maior eficiência dos fatores de produção), e outros com economia de escopo - ganhos com a produção diversificada (GONÇALVES et al, 2005). 


\section{Administração: caminhos para o desenvolvimento sustentável}

Para Sorj et al. (1982) o motivo principal da rápida difusão do sistema de produção integrada, via contratos, foi a busca de atividades econômicas alternativas que garantissem a sobrevivência dos pequenos agricultores e, em particular, da agricultura familiar. Esta busca de alternativas, no caso do suinocultor, ocorre em função das oscilações dos preços recebidos pelo produto.

Segundo Graziano da Silva (1998), no processo de produção com predomínio da integração, há necessidade constante de recursos para investimentos, pois as atividades exploradas são intensivas em insumos industriais, com auxílio de máquinas, equipamentos e instalações onerosas.

No campo teórico, a suinocultura industrial integrada ocorre não apenas via contratos, mas também por meio de acordos tácitos (MIELE; WAQUIL, 2007). A cadeia produtiva da suinocultura do Paraná destaca-se tem destaque no Brasil, com grande parte da produção tecnificada, produzida em grande parte por produtores da agricultura familiar e forte vínculo entre produtores e agroindústrias.

O PIB paranaense é o quinto maior do país $(5,8 \%)$, distribuído nos setores de serviços $(62,7 \%)$, indústrias $(29,1 \%)$ e agropecuária (8,2\%). Das 5,4 milhões de pessoas ocupadas no mercado de trabalho, $20 \%$ concentravam-se na agropecuária. A produção animal contribuiu com $30 \%$ do total de ocupados - aí incluídos a criação de bovinos de corte e de leite, aves e suínos (IBGE,2009).

O rebanho suíno do Paraná (4.736.000 de cabeças), em 2007, foi o terceiro maior do país, atrás apenas do Rio Grande do Sul e Santa Catarina. Em termos de abate de suínos inspecionados, em 2008, o Paraná participou com $16, \%$ do total. No comércio exterior, as exportações de carne suína do estado somaram 31.400 toneladas ou 5,1\% do total brasileiro (PARANÁ, 2009).

O rebanho de suínos paranaense encontra-se distribuído em estabelecimentos diversificados com economia de escala ( associado a maior eficiência dos fatores de produção) e economia de escopo ganhos com a produção diversificada (GONÇALVES et. al, 2005).

A criação de suínos é responsável, de maneira direta e indireta, por aproximadamente 217 mil empregos, distribuídos nos diversos segmentos da cadeia produtiva do suíno (PARANÁ, 2008). Para a mesma fonte, a suinocultura do estado representou $4 \%$ de receita total do estado (valor bruto da produção), incluindo tanto o abate de suínos (raça e comum) e a venda de leitões para recria. Quanto ao abate de suínos de raça, em 2007 no Paraná, os núcleos regionais de destaque foram Toledo (34,2\%), Francisco Beltrão (18,4\%), Cascavel (16,2\%) e Ponta Grossa $(12,2 \%$.). 


\section{Administração: caminhos para o desenvolvimento sustentável}

Comparando os censos agropecuários realizados em 1996 e 2006, a atividade suinícola paranaense apresentou reduções tanto no número de estabelecimentos quanto no efetivo de suínos. Desse modo, conforme dados do IBGE (2009), os estabelecimentos dedicados à produção de suínos, que em 1996 somavam 35.578 , reduziu para 25.241 , em 2006 , com queda de $29,1 \%$.

Conforme Silva Filho et al (2005), a oferta de carne suína no Paraná está condicionada a vários fatores, entre eles, destacam-se o preço da carne suína, o preço do milho (principal insumo utilizado na alimentação dos suínos), os salários pagos aos trabalhadores rurais, o volume de carne suína exportada e o consumo interno de carne suína.

\section{METODOLOGIA}

No desenvolvimento da pesquisa, foram utilizados os preços médios mensais recebidos pelos produtores de suíno vivo de raça do estado do Paraná, abrangendo o período de janeiro de 2000 a dezembro de 2009. Os dados foram obtidos Secretaria de Agricultura e Abastecimento do Estado do Paraná/ Departamento de Economia Rural (SEAB/DERAL). Os preços foram corrigidos pelo IGP-DI, da Fundação Getúlio Vargas (FGV, 2010), em valores constantes de dezembro de 2007.

O arcabouço metodológico adotado é de Hoffmann (1998), com a utilização da média geométrica móvel centrada em 12 meses. Para realização dos cálculos, definiu-se que o preço é igual ao produto de três componentes:

I. um fator $A B t$, que inclui a tendência e todas as variações no nível de preços entre anos;

II. um fator que representa as variações sazonais;

III. um fator Ut, que se refere às variações aleatórias nos preços mensais.

Empregou-se a seguinte expressão:

$$
P_{t}=P_{i j}=A B^{t} \varepsilon_{j} U_{t}
$$

Onde:

$\mathrm{P}=$ preço do produto; $\mathrm{i}$ = refere-se $\mathrm{o}$ ano; $\mathrm{j}$ = indica o mês.

Para determinar os índices sazonais, realizaram-se os seguintes cálculos:

I. média geométrica móvel centralizada (Gt), onde são eliminadas as variações sazonais e grande parte das variações aleatórias; 
II. índices estacionais de preços;

III. médias geométricas dos índices estacionais;

IV. índices sazonais para cada mês;

V. índices de irregularidades para cada mês;

VI. estabelecimento de um intervalo de dispersão dos índices sazonais, limites inferiores e superiores, que são obtidos multiplicando e dividindo o índice sazonal pelo índice de irregularidade.

O estudo a partir de médias móveis centradas (em um período $n$ ) consiste em suavizar as variações das séries por um processo de sucessivas médias. Desse modo, quanto maior o número de termos usados para a média móvel, mais suavizada será a série resultante. Devido suas características, a média móvel exclui as variações aleatórias e os movimentos sistemáticos que tem duração de tamanho $\mathrm{n}$.

Uma média móvel de um número par de termos, isto é, se $k=2 \lambda$, um valor qualquer da média móvel não corresponde exatamente a nenhum dos termos da série dada. Por exemplo, uma média móvel de 4 termos corresponde a um intervalo entre o segundo e o terceiro termo levado considerado no seu cálculo. Desse modo, para solucionar esse problema, define-se a média aritmética móvel centralizada de $k=2 \lambda$ termos correspondentes ao seu valor $t$.

O cálculo da média móvel centralizada de 12 meses para uma série de preços é feito pela seguinte equação:

$$
g_{t}=\frac{1}{12}\left(0,5 \ln P_{t-6}+\ln P_{t-5}+\ldots+\ln P_{t}+\ldots+\ln P_{t+5}+0,5 \ln P_{t+6}\right)
$$

Onde:

gt = In Gt = média geométrica móvel no mês $t ; P t=$ preço no mês $t$ e $t=$ mês em que a média é centralizada.

Os índices estacionais dos valores pesquisados (It) podem ser estimados dividindo o preço (Pt) pela respectiva média geométrica (Gt), e em seguida multiplicar por 100. 


\section{Administração: caminhos para o desenvolvimento sustentável}

Para encontrar um índice sazonal para cada um dos 12 meses do ano (It), calcula-se a média de todos os índices sazonais relativos ao mês em questão e usa-se da seguinte fórmula:

$$
\ln \bar{I}_{i}=\frac{1}{m-1} \sum_{j=2}^{m} \ln _{i j}
$$

$\mathrm{I}=$ mês (janeiro, fevereiro, $\operatorname{março}, \ldots .$. dezembro); $\mathrm{J}=$ ano e $\mathrm{m}=$ número de anos .

Para se obter os índices de irregularidade, inicialmente, faz-se o cálculo do desvio padrão (si), dos valores dos índices sazonais em torno da sua média, expressa por:

$$
s_{i}=\sqrt{\frac{1}{m-2} \sum_{j=1}^{m-1}\left(d_{i j}-\bar{d}_{i j}\right)^{2}}
$$

Onde:

$\mathrm{i}=$ mês (janeiro, fevereiro, março,...., dezembro); $\mathrm{j}=$ ano e $\mathrm{m}$ = número de anos

Multiplicando e dividindo o índice sazonal pelo índice de irregularidade, obtêm-se os limites superior e inferior do intervalo que indica a variação dos índices estacionais.

\section{RESULTADOS}

Os produtores paranaenses de suíno vivo ficaram sujeitos aos preços oscilantes que receberam pelo animal, no período de janeiro de 2000 a dezembro de 2009.

Nos anos 2001 e 2002, como mostra o Gráfico 1, a atividade suinícola registrou resultados positivos para os produtores, em funções de fatores tais quais o baixo custo de produção em 2001 e o aumento das exportações, inclusive do Paraná. Isso culminou com a expansão da produção nas regiões tradicionais (Sul) e não tradicionais (Centro Oeste). Sendo assim, em meados de 2002, os produtores defrontaram-se com queda de preços e de rentabilidade na atividade.

De setembro de 2004 a dezembro de 2005, conforme o gráfico abaixo, os produtores do estado do Paraná receberam os melhores preços pelo suíno vivo ( base dezembro de 2007), que representaram as melhores médias mensais da série estudada. Assim, de setembro a dezembro, os preços corrigidos alcançaram valores acima de $R \$ 3,00$ por quilo, atingindo a máxima cotação $(R \$ 3,12)$, em dezembro de 2004. 


\section{Administração: caminhos para o desenvolvimento sustentável}

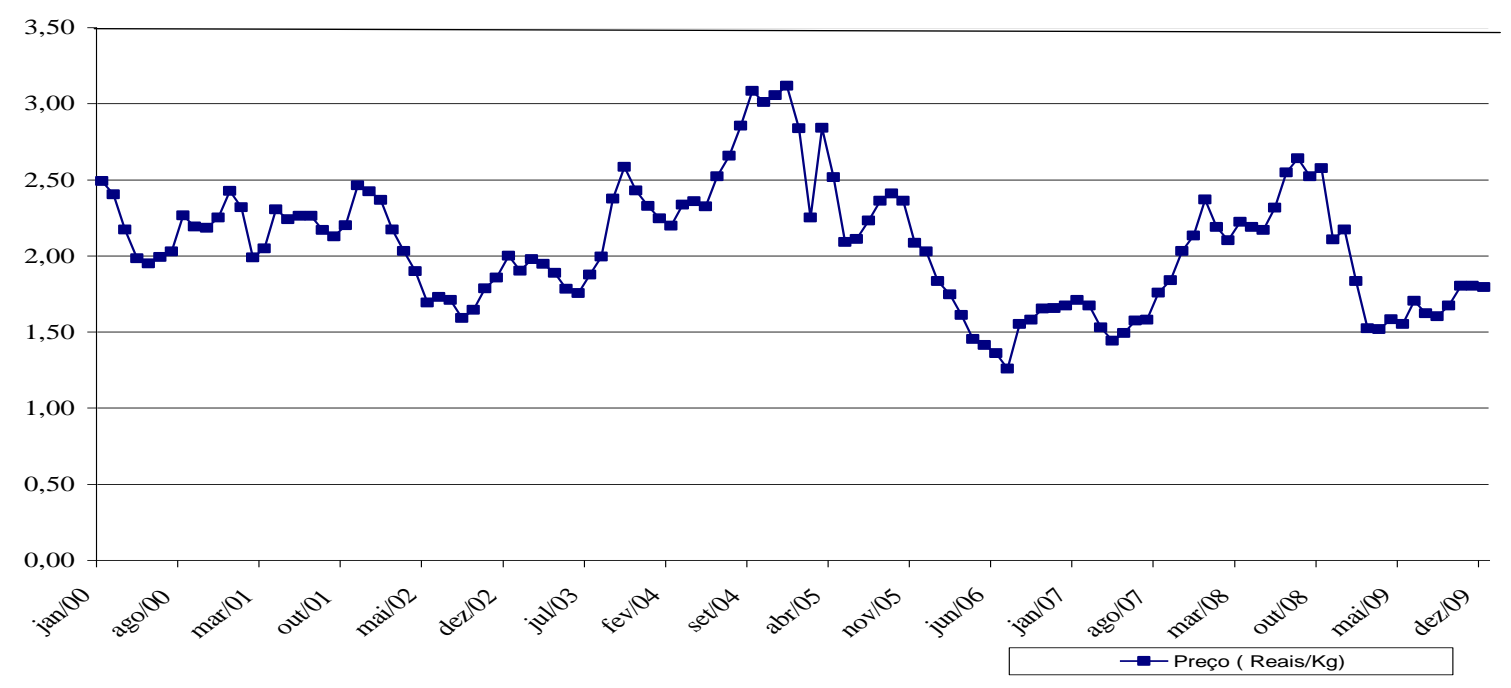

Fonte: Elaborado pelos autores com dados da SEAB/DERAL- PR

Gráfico 1. Evolução dos preços médios mensais recebidos pelos produtores de suíno vivo de raça (em kg) no estado do Paraná, no período de janeiro/2000 a dezembro/2009*

* Valores corrigidos (IGP-DI, base dez/2007)

A relação de troca de suíno pelo grão de milho, ou seja, quanto o produtor de suíno consegue adquirir da matéria-prima com o equivalente a um quilo de suíno, foi um indicador que confirmou os bons preços do suíno vivo no Paraná em 2004. De acordo com Paraná (2006), essa relação, que em maio de 2004 estava em 5,32, menor relação de troca obtida nesse ano, atingiu 11,00 em dezembro, constituindo-se como sendo a melhor relação de troca em favor do suinocultor familiar.

O diagnóstico de focos de febre aftosa (MS e PR), no terceiro trimestre de 2005, afetou intensamente a suinocultura brasileira, e, em especial, a cadeia suinícola paranaense. O Gráfico 1 acima mostra a queda dos preços do suíno vivo no referido período.

Segundo Paraná (2006), o produto (carne suína) tem passado por quedas de preços desde outubro de 2005, quando a média mensal das cotações atingiu $\mathrm{R} \$ 2,13 \mathrm{~kg}$ (preço nominal), com redução de 39\% no período. Assim, os preços aquecidos de 2004 até antes dos focos da doença, foram sendo substituídos por preços mais baixos no decorrer de 2005 e estendendo-se até o terceiro trimestre de 2006. De outubro de 2005 a setembro de 2006, os preços nominais pagos aos produtores de suínos registraram as menores cotações: em abril de 2006 ( $R \$ 1$ 1,30), maio de 2006 ( $R \$ 1$ 1,27) e, em julho de 2006, registrou a cotação mínima de $\mathrm{R} \$ 1,14$. Nos mesmos períodos, os custos de produção por quilo 


\section{Administração: caminhos para o desenvolvimento sustentável}

de suíno vivo (preços nominais) foram de $\mathrm{R} \$ 1,59$ (abril), $\mathrm{R} \$ 1,58$ (maio) e $\mathrm{R} \$ 1,57$ (julho), mostrando que os produtores estavam tendo prejuízos durante meses seguidos, mesmo que no período, os preços do milho e do farelo de soja tenham registrado quedas.

A suinocultura mundial e brasileira sofreriam outro revés, quando em outubro de 2008, a crise financeira mundial, fez o crédito externo torna-se escasso e caro, que dificultou o acesso a financiamentos externos e também a obtenção de recursos para produção e comercialização de suíno vivo. Desse modo, nos estados produtores, que passaram a ter excesso de oferta devido, a queda no preço, que iniciaram em outubro de 2008 , e só pararam de cair, em março de 2009, conforme mostra o Gráfico 1.

Estudos de mercado de Girotto (2007) constataram que o crescimento na oferta brasileira de carne suína entre $4 \%$ e $5 \%$ ao ano na suinocultura industrial e de $2 \%$ a $3 \%$ para todo o rebanho.

Em abril de 2009, com o aparecimento da Gripe Suína (H1N1), somado à escassez de créditos, dificultaram a colocação da produção de carne suína brasileira no mercado externo. Então, após a crise internacional, houve queda acentuada nas cotações internacionais do produto (cerca de 38\%), na comparação de setembro de 2008 a junho de 2009. Desse modo, os preços no mercado interno do suíno vivo reduziram de $32,6 \%$ nos mesmos meses.

No segundo semestre de 2009, com os preços baixos, para o produtor, os mesmos não vem cobrindo os custos de produção, pois o volume de carne suína produzida no Paraná nesse período vem aumentando a uma taxa de $11,75 \%$, em relação ao mesmo período de 2008 . Comparativamente, a taxa média de crescimento da produção de suíno vivo é de 7\%.\% ao ano no período de 2006 a 2008 (PARANÁ, 2009).

\subsection{ANÁLISE DOS ÍNDICES SAZONAIS DA SÉRIE PESQUISADA}

Na Tabela 1 com os índices sazonais de preços, no período de 2000 a 2009, verifica-se que atingem valores acima da média nos meses de início e final de ano.

Conforme a mesma tabela abaixo, constatou-se que nos meses de janeiro e, a partir de agosto, é que o índice sazonal supera a média. Assim, por exemplo, no mês de janeiro (índice sazonal igual 102,98), significa que, o preço do suíno vivo no Paraná, estava 2,98\% superior à média ao longo do ano. Para os demais meses (março a julho) constatou-se que este índice situa-se abaixo de 100. Ou seja, em julho, por exemplo, o preço médio do suíno vivo, no Paraná, estava 5,55\% abaixo da média ao longo do ano. 


\section{Administração: caminhos para o desenvolvimento sustentável}

Pode-se ainda perceber que ocorre uma variação moderada dos preços, dado que os índices sazonais não se distanciam muito de 100.

\begin{tabular}{lccc}
\hline \multicolumn{1}{c}{ Meses } & Índice Sazonal & Limite Inferior & Limite Superior \\
\hline Janeiro & 102,98 & 98,40 & 107,78 \\
Fevereiro & 97,52 & 89,87 & 105,82 \\
Março & 96,59 & 90,90 & 102,64 \\
Abril & 95,37 & 88,90 & 100,17 \\
Maio & 93,88 & 83,85 & 105,11 \\
Junho & 93,30 & 87,40 & 99,59 \\
Julho & 94,45 & 85,62 & 104,20 \\
Agosto & 100,71 & 93,68 & 108,27 \\
Setembro & 103,73 & 94,76 & 113,55 \\
Outubro & 108,12 & 100,41 & 116,41 \\
Novembro & 106,66 & 102,91 & 110,55 \\
Dezembro & 109,60 & 105,48 & 113,89 \\
\hline
\end{tabular}

Fonte: Dados da pesquisa

Tabela 1. Índices sazonais e limites superior e inferior relacionados com os preços médios atualizados do suíno vivo recebidos pelos produtores do estado do Paraná, no período de 2000 a 2009

O Gráfico 2 apresenta o comportamento desta variação sazonal. Nota-se no mesmo que a maior amplitude entre os limites inferior e superior dos índices ocorre entre meses de índices mais baixos. A maior amplitude é observada em maio, com 21,35 enquanto a menor ocorre em novembro $(6,94)$. No primeiro caso, na série de preços estudada. Constatou-se que foi o período em que os preços médios recebidos pelos produtores oscilam mais. No segundo caso, observou-se como sendo o período de menores oscilações de preços médios e com ganhos mais estáveis para os produtores.

No caso do Paraná, outras variáveis também interferem na oferta de suíno vivo como a oferta do suíno dos produtores não integrados ou independentes, o preço da carne suína, o volume de carne suína exportada, o consumo interno de carne suína, o preço do milho e os salários pagos aos trabalhadores. Pesquisas realizadas por Silva Filho et al (2005) de análise de oferta e demanda de carne suína no Paraná, constataram que para cada $1 \%$ de variação positiva no preço recebido pelo produtor, há um acréscimo de $0,78 \%$ na quantidade ofertada. Na mesma pesquisa, nas exportações, para cada $1 \%$ de variação positiva no preço de exportação da carne suína paranaense, há acréscimo de 0,041\% na quantidade de carne ofertada, mantido tudo o mais constante. Já para a demanda, a referida pesquisa 


\section{Administração: caminhos para o desenvolvimento sustentável}

constatou que para cada $1 \%$ de variação positiva no salário dos trabalhadores do estado do Paraná, há um aumento de $0,40 \%$ na quantidade demandada de carne suína.

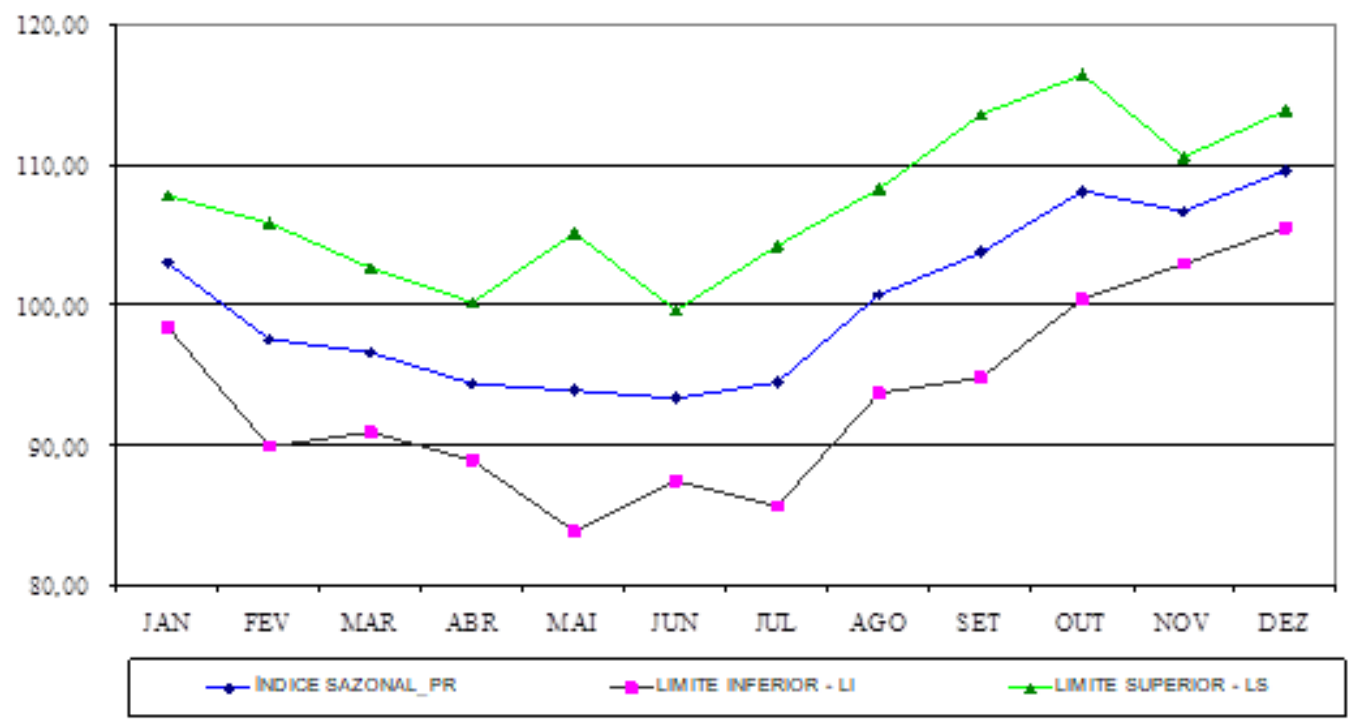

Fonte: Dados da pesquisa

Gráfico 2. Índices sazonais e limites superior e inferior relacionados com os preços médios atualizados do suíno vivo recebidos pelos produtores do estado do Paraná, no período de 2000 a 2009.

Salienta-se que outros fatores além dos citados acima podem ser responsáveis de maneira não direta nas oscilações de preços e o seu comportamento no tempo como a estrutura fundiária, complexidade da cadeia produtiva, legislação ambiental e condições climáticas, que poderiam distorcer os fundamentos da oferta e da demanda para o produto.

\section{CONSIDERAÇÕES FINAIS}

A carne suína é uma importante fonte de proteína animal que compõe o cardápio de consumidores brasileiros e é responsável pela geração emprego, renda e divisas ao país.

Os produtores inseridos na cadeia suinícola paranaense, na grande maioria, da agricultura familiar, são apenas tomadores de preço e com fraco poder de barganha.

Os preços médios do suíno vivo corrigidos refletiram o comportamento do mercado, nos períodos de safra e de entressafra do produto. 


\section{Administração: caminhos para o desenvolvimento sustentável}

Os resultados dos índices sazonais apresentaram coerência com o comportamento de mercado que os preços do suíno vivo tiveram ao longo da série de anos estudada para o Paraná.

Os dados trabalhados sinalizaram o comportamento dos preços do suíno vivo no Paraná no período de 10 anos. No entanto, outros insumos e matérias-primas empregados na produção do mesmo devem ser objeto de futuras pesquisas, com uso e adaptação da metodologia empregada, que vai gerar mais informações, para dar maior segurança na tomada de decisões que envolvam a atividade.

Com os resultados da pesquisa, espera-se que a mesma sirva de referência para orientar os produtores dos possíveis patamares dos preços do suíno nos períodos sazonais. E ainda, tanto eles quanto outros agentes da cadeia produtiva possam planejar melhor a produção, com estratégias que tragam lucratividade até mesmo nos períodos de crises da atividade.

\section{REFERÊNCIAS}

ABIPECS. Associação Brasileira da Indústria Produtora e Exportadora de Carne Suína. Relatório 2007. Disponível em: <http://www.abipecs.org.br/relatório/ABIPECS_relatório>. Acesso em: 10 fev.2010.

ANUALPEC 2008: Anuário da Pecuária Brasileira. São Paulo: Instituto FNP, 2007. 380 p. Anual.

BESEN, G.M.V. et al. Análise da competitividade da cadeia agroindustrial de carne suína no Estado do Paraná. Curitiba: IPARDES, 2002.

BRASIL. Ministério do Desenvolvimento Agrário. Programa de agroindustrialização da produção dos agricultores familiares 2003/2006: Documento Referencial. Brasília, 2003.

CARVALHO, F.C de; VEGRO,C.L.R.; ZIRLIS, A. E.F. Produção e preços de rações e de alimentos de origem animal, Brasil, 1985-94. Revista Informações Econômicas, São Paulo, v. 25, n. 6, jun. 1995.

FONTANA, V. Produção de Suínos: Indústria de Suínos. In: SIMPÓSIO NACIONAL DE SUINOCULTURA E FRUTICULTURA, 1., 29-31 mar. 1976, Florianópolis. Anais... Florianópolis, SC: Federação da Agricultura do Estado de Santa Catarina, 1976.

FUNDAÇÃO GETÚLIO VARGAS. Preços agropecuários. Disponível em:<http://www.fgvdados.fgv.br/>. Acesso em: 10 jan. 2010.

GONÇALVES, W.M. et al. O gerenciamento da demanda em função da economia de escala, escopo e do composto de marketing em diferentes organizações do setor de lácteos, no Rio Grande do Sul: um estudo multicaso. In: CONGRESSO BRASILEIRO DE ECONOMIA E SOCIOLOGIA RURAL, 43., $24-27$ jul. 2005, Ribeirão Preto (SP). Anais... Brasília, DF: SOBER, 2005. 1 CD-ROM.

GRZYBOWSKI, N. A suinocultura e o mecanismo de desenvolvimento limpo. Disponível em: < http://74.220.207.63/ agrosoft/pdf.php/?node=22671 >. Acesso em: 05 fev. 2009.

HOFFMANN, R. Estatística para economistas. 3 ed. São Paulo: Pioneira, 1998. 


\section{Administração: caminhos para o desenvolvimento sustentável}

INCRA/FAO. Retrato da agricultura familiar: o Brasil redescoberto. Brasília: INCRA/FAO, 2000.

INSTITUTO BRASILEIRO DE GEOGRAFIA E ESTATÍ́sTICA. Censo Agropecuário 2006 - Resultados preliminares. Disponível em: <http:// www.ibge.gov.br>. Acesso em: 10 fev. 2009.

MACHADO, J.S. Suínos: estrutura de mercado e tendências da produção. Caderno de Economia Agrícola, Florianópolis, n.7, p. 1-29, 1991.

MIELE, M. Cadeia produtiva da carne suína no Brasil. Concórdia: EMBRAPA -CNPSA, 2006.

MIELE, M.; GIROTTO, A.F. A Suinocultura Brasileira em 2007 e Cenários para 2008. Disponível em:<www.cnpsa.embrapa.br/sgc/sgc_artigos/artigos_q7b85o6v.pdf > Acesso em: 01 dez. 2009.

MIELE, M.; WAQUIL, P. D. Cadeia produtiva da carne suína. Revista de Política Agrícola, Brasília (DF), v. 16, n. 1, p. 75, 2007.

MIELE, M.; WAQUIL, P. D. Estrutura e dinâmica dos contratos na suinocultura de Santa Catarina: um estudo de casos múltiplos. Est. Econ., São Paulo, v. 37, n. 4, p. 817-847, out.-dez. 2007.

PARANÁ (Estado). Secretaria de Agricultura e Abastecimento do Estado do Paraná. Departamento de Economia Rural. Dados sobre a produção de suínos: 2006 . Disponível em : <http://www.pr.gov/seab/deral>. Acesso em: 10 dez. 2009.

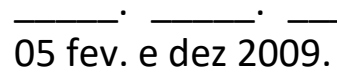

. Suínos: 2006. Disponível em: <http://www.pr.gov/seab/deral>. Acesso em:

Números da Pecuária Paranaense. Curitiba, 2008. Disponível em: <http://www.pr.gov.br/seab/deral/nppr.pdf>. Acesso em: 05 fev. 2009.

Suinocultura Paranaense: evolução dos últimos 54 meses (janeiro de 2005 a junho de 2009). Curitiba, 2009. Disponível em: <http://www.pr.gov.br/seab/deral/nppr.pdf>. Acesso em: 20 jan. 2010.

<http://www.pr.gov.br/seab/deral/nppr.pdf>. Acesso em: 05 fev. 2010.

REZENDE, L.P.; PARRÉ, J.L. O desenvolvimento agrícola dos municípios paranaenses. In: ENCONTRO DE ECONOMIA PARANAENSE, 2., 2003, Maringá. Anais... Maringá, 2003.

ROPPA, L. Perspectivas da produção mundial de carnes, 2006 a 2030. Revista Suinocultura Industrial, Itu (SP), n. 34, p. 16-27. 2006.

SANTINI, G.A.; SOUZA FILHO, H.M. Carnes: relatório setorial final do projeto de pesquisa Diretório da pesquisa privada no Brasil. Brasília: FINEP, 2004.

SILVA FILHO, L.et al. O mercado de carne suína no Paraná: análise de oferta e demanda. In: CONGRESSO BRASILEIRO DE ECONOMIA E SOCIOLOGIA RURAL, 43., 24-27 jul. 2008, Ribeirão Preto (SP). Anais... Brasília, DF: SOBER, 2005. 1 CD-ROM.

SILVA, J.G. da. A nova dinâmica da agricultura brasileira. 2 ed. rev. Campinas: Instituto de Economia, UNICAMP, 1998. 


\section{Administração: caminhos para o desenvolvimento sustentável}

SORJ, B. Estado e classes sociais na agricultura brasileira. Rio de Janeiro: Zahar, 1980.

SORJ, B.; POMPERMAIER, M. J.; CORADINI, O. L. Camponeses e Agroindústria: transformação social e representação política na avicultura brasileira. Rio de Janeiro: Zahar Editores, 1982

UBA. União Brasileira de Avicultura. Relatório Anual 2006-2007. São Paulo (SP), 2008. 


\section{Capítulo 3}

\section{APLICAÇÃO DE JOGO FINANCEIRO PARA INTEGRAÇÃO DE CONCEITOS EM ADMINISTRAÇÃO}

DOI: $10.37423 / 200300343$

Edison Luiz Leismann (Professor Associado C do CCSA-UNIOESTE-Universidade Estadual do Oeste do Paraná. Grupo de Pesquisa em Sustentabilidade-GPSA-. Doutor em Economia Aplicada pela UFV-MG. Pós-Doutorado em Administraçẫ) Finanças no PROPAD /DCA / UFPE-PE). elleismann@hotmail.com

Kadidja F. dos Santos (Professora Assistente da Universidade Federal da ParaíbaUFPB). kadidja@gmaileom<smiles>C1CC1</smiles>
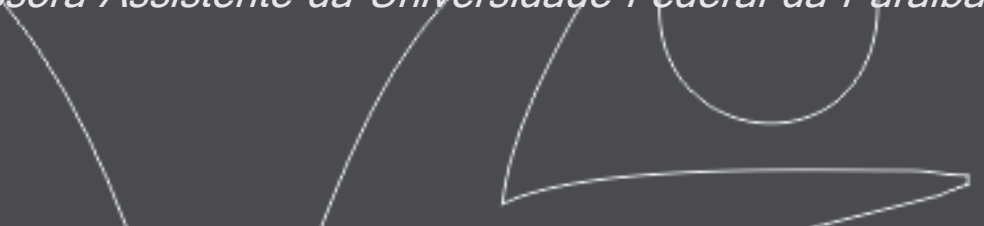

Charles Ulises de Montreuil Carmona YProfessor Associado do PROPADADCA/UFPE. Doutor em Engenharia de Produção pella PUC-RJ e Pós-Doutorado na University of Illinois at Urbana-Champaign, USA). carmona@ufpe.br

Liana Fátima Fuga (Professora Assistente da UNIQESTE-Universidade Estadual do Oeste do Paraná-, Campus de Cascavel). lianaffuga@gmail.com

RESUMO: 0 ensino_de finanças no curso de administração é um grande desafio. É preciso integrar os conceitos das finanças de mercadpleom/ financas-corporativas. Nas duas áreas, mas principalmente em finanças corporativas, conceitos vindos de outras disciplinas como contabilidađe, economia, estatística, custos, matemática financeira, produção e màteriais, são imprescindíveis. 


\section{Administração: caminhos para o desenvolvimento sustentável}

Este trabalho visa demonstrar como essa integração pode ser feita a partir de um jogo didático, com foco em finanças. A aplicação do jogo em cursos de graduação e pós graduação tem demonstrado que a atividade melhora o aprendizado. Outros efeitos verificados são o dinamismo das aulas e a empolgação gerada nos alunos pela disputa no decorrer da atividade. Entre os aspectos que dificultam a aplicação está a necessidade de sala com pelo menos 7 computadores e de pelo menos 4 horas-aula para aplicar o jogo por 4 períodos. Por outro lado, por ser desenvolvido em planilha eletrônica com macros, facilita a utilização e controle por parte do professor. O jogo está disponível no site http://sites.google.com/site/jogosfinanceiros/.

PALAVRAS-CHAVE: Jogos Financeiros- Aprendizado Financeiro - Integração de Conhecimentos. 


\section{Administração: caminhos para o desenvolvimento sustentável}

\section{1- INTRODUÇÃO}

Tradicionalmente, o ensino de determinada área é subdividido em compartimentos, que serão integrados nos momentos finais dos cursos e, em muitos casos, por ocasião da elaboração de monografias ou estágios. Na área de Administração não é diferente; porém, durante o curso, muitas vezes os alunos não conseguem, ao estudarem diferentes disciplinas, visualizar a integração das diversas áreas no contexto da empresa ou do mercado. Na área de finanças, isso ocorre com frequência. Assim, o ensino de finanças no curso de administração é um grande desafio; é preciso integrar os conceitos das finanças de mercado com finanças corporativas. Nas duas subáreas, mas principalmente em finanças corporativas, conceitos vindos de outras disciplinas como contabilidade, economia, custos, matemática financeira, produção e materiais, são imprescindíveis.

Essa falta de compreensão ocorre em função da dificuldade de perceber a visão sistêmica da empresa. Os alunos têm acesso a conhecimentos de diversas áreas e muitas vezes não conseguem ver os efeitos decorrentes de decisões tomadas em determinada área em outras da empresa. Assim, os jogos de empresa, quando aplicados ainda durante o curso, mesmo quando os alunos ainda não tiveram contato com algumas disciplinas específicas da área empresarial, melhoram o aprendizado e se realça a importância da interconexão existente entre as áreas/departamentos da empresa.

Outro aspecto importante é o espírito de disputa que se estabelece durante a aplicação do jogo empresarial, em que os alunos deixam a cômoda posição de ouvintes e passam a tomar decisões simuladas, com resultados demonstrados em forma de balanços patrimoniais e demonstrações de resultados, o que lhes permite comparar os seus resultados com os dos demais grupos.

\section{PROBLEMA DA PESQUISA E OBJETIVOS}

Considerando a dificuldade de integração de conceitos por parte dos alunos, aludida anteriormente, verifica-se a necessidade de se buscar inovadoras maneiras para apresentação do conteúdo em sala de aula, de forma a estimular um maior envolvimento dos alunos, bem como a facilitar a apreensão dos conteúdos de forma sistêmica pelos mesmos.

Deste modo, considerando o atendimento da necessidade apresentada, isto é, a exposição de conceitos de forma integrada por meio de métodos diferenciados, acredita-se que os jogos de empresas mostram-se como alternativa inovadora viável. Estes, além de serem uma ferramenta didática inovadora, no caso da aplicação na área de administração, propiciam um contato mais 


\section{Administração: caminhos para o desenvolvimento sustentável}

aproximado com a realidade empresarial, podendo, inclusive, despertar habilidades empreendedoras dos alunos.

Assim, o objetivo deste trabalho é apresentar e demonstrar a importância de um jogo de empresa, focado na área de finanças, que tem por finalidade melhorar a visão sistêmica e facilitar o aprendizado de conceitos da área financeira corporativa.

Desta forma, o texto está assim formatado: após a introdução e objetivos, apresenta-se um breve referencial teórico sobre jogos de empresas (item 3). No item 4, apresentam-se os conceitos utilizados na formulação do jogo; no item 5 ressaltam-se os conceitos desenvolvidos; no item 6 apresenta-se a metodologia utilizada; no item 7 , os resultados da experiência prática; finalmente, no item 8 estão apresentadas as conclusões.

\section{REVISÃO BIBLIOGRÁFICA}

\subsection{ASPECTOS GERAIS DOS JOGOS DE EMPRESAS}

Os jogos de empresas, utilizados como recurso didático para exposição e assimilação de conteúdos em sala de aula, são uma modalidade de simulação que consiste de um modelo operacional e dinâmico de certo recorte da realidade (SANTOS e LOVATO, 2007).

Em termos de instrumentos facilitadores da aprendizagem, e baseando-se na teoria de Piaget, podese supor que esses jogos desencadeiam o processo de equilibração responsável pela estruturação cognitiva naqueles indivíduos que apresentam dificuldades na aprendizagem, visto que a situaçãoproblema apresentada (o jogo) se constitui num desafio ao pensamento, isto é, uma perturbação que ao ser compensada resulta em progresso no desenvolvimento do pensamento (COELHO, 2007).

Como se percebe, os jogos de empresas podem ser um aliado poderoso do professor quando da ministração de aulas, especialmente nas áreas que requerem maior ligação com a prática, como é o caso de boa parte das disciplinas do curso de Administração.

As vantagens e desvantagens de sua utilização têm sido estudadas por vários autores. Dentre as vantagens pode-se citar a facilitação do processo de aprendizagem, por meio da contribuição para melhoria do entendimento do assunto abordado, possibilita a prática reflexiva e a construção colaborativa de conhecimentos através das interações sociais (FREITAS E SANTOS, 2005 apud SANTOS e LOVATO, 2007). 


\section{Administração: caminhos para o desenvolvimento sustentável}

Sauaia (2006) referenciado por Santos e Lovato (2007) destacam que os jogos submetem os participantes às forças competitivas, econômicas, legais, sociais e políticas. Além disso, os jogos estimulam o pensamento sistêmico, treina o processo decisório, estimula habilidade de trabalho em equipe, treina lideranças e fornece conhecimentos administrativos básicos (PROTIL, 2005 apud SANTOS E LOVATO, 2007).

Quanto às desvantagens, destacam-se o tempo exigido para aplicação dos jogos, a dificuldade de avaliar os alunos participantes, a dificuldade em encontrar professores ou aplicadores de jogos e o alto custo de aquisição do software (ROSA e AZUAYA, 2006 apud SANTOS e LOVATO, 2007). Bernard (2006) também citado por Santos e Lovato (2007), ainda aponta que a simulação é uma simplificação do funcionamento da empresa e que não dispõe de todas as variáveis, como as qualitativas. Além disso, há que se destacar a deficiente infra-estrutura de muitas instituições de ensino superior no Brasil, que por vezes não permite a utilização deste recurso.

Gallego (2007), citando Motokane (s/d), aponta que os jogos podem ser classificados em três tipos:

a) Jogos de treinamento, que são utilizados quanto o professor percebe a necessidade de reforçar determinado conteúdo e deseja substituir as listas de exercícios. Neste caso, quase sempre o fator sorte exerce papel preponderante e interfere nos resultados finais;

b) Jogos estratégicos, no qual são trabalhadas as habilidades que compõem o raciocínio lógico. Neste caso, os alunos lêem as regras e buscam caminhos para alcançarem o objetivo final, utilizando-se de procedimentos estratégicos para tal;

c) Jogos geométricos, que apresentam como objetivo desenvolver a habilidade de observação e o pensamento lógico. Com eles, é possível trabalhar figuras geométricas, semelhança de figuras, ângulos e polígonos.

Dentre os tipos citados, os que se enquadram mais no perfil dos cursos de ciências sociais e, especificamente, no curso de administração, são os jogos de treinamento e estratégico. Com eles, os alunos encontram a oportunidade de exercitarem os conteúdos abordados em sala de aula por meio dos processos de tomada de decisão requeridos pelos jogos. A perspectiva é de que a prática proporcionada pela simulação permita aos alunos uma vivência próxima à exigida pelo mercado de trabalho. 


\section{Administração: caminhos para o desenvolvimento sustentável}

Conforme Santos e Lovato (2007), percebe-se uma tendência de aumento no uso dos jogos de empresas em sala de aula, sendo isto uma decorrência da familiaridade dos alunos e professores com as tecnologias computacionais, que são cada vez mais modernas e de fácil utilização.

\subsection{VISÃO SISTÊMICA}

Um dos principais objetivos da utilização de jogos empresariais em sala de aula é repassar ao aluno uma visão sistêmica do ambiente industrial e comercial.

A visão sistêmica tornou-se um conceito abrangente no momento em que humanidade precisou resolver problemas que não podiam ser entendidos isoladamente, devido a sua complexidade, tendo, portanto, uma extensão para a complexidade das organizações, procurando entender a influência das partes em si e não somente cada uma isoladamente; tem como característica então, tentar estudar as partes levando em conta o seu papel na estrutura do todo. Assim, entende-se por visão sistêmica a compreensão dos subsistemas de uma organização, bem como a visão de um grande sistema de informações.

Conforme afirma Carmona (2009, p. 14), ao comentar sobre as competências do profissional da área de finanças corporativas: "Competências fundamentais são a visão sistêmica, flexibilidade, a capacidade de trabalhar sob pressão, planejamento, habilidade negocial, criatividade, ética e excelente competência técnica no campo das finanças". Sob esse aspecto, o jogo apresentado procura simular o ambiente real e demonstrar a necessidade de entender detalhadamente cada parte, envolvendo os conceitos básicos de finanças, sem perder a perspectiva do todo. Esse é, evidentemente, o grande desafio.

Há muito a humanidade tenta entender os subsistemas isoladamente, não levando em conta as interações com o todo. A visão sistêmica veio como uma evolução natural, possibilitando uma maior aproximação da realidade da ciência que estuda os sistemas.

Com o passar do tempo, se observa a necessidade de desenvolver nossa visão do todo. Tomar decisões sem analisar a situação no âmbito geral, pode trazer problemas à organização, gerando assim, decisões unilaterais, isoladas, inconsistentes, sem credibilidade e com prejuízo. De fato, a visão sistêmica nada mais é do que perceber o movimento integrado entre o ambiente, nossas decisões e o futuro. 


\section{Administração: caminhos para o desenvolvimento sustentável}

A visão sistêmica consiste na capacidade de entender, implementar e demonstrar o comportamento na compreensão do todo a partir de uma análise global das partes e da interação entre elas. Várias forças atuam num sistema em funcionamento, sejam estas internas ou externas. Usando adequadamente esse importante conceito, pode-se minimizar diversos danos futuros e ter um diferencial competitivo.

Assim, os alunos passam de uma visão inicial de uma organização que funciona de maneira independente, para a percepção de que esta faz parte de um macroambiente e se interrelaciona com as demais num mercado regido por regras.

Na divisão de tarefas que se torna necessária na organização do jogo, logo fica evidente que se trata de uma organização que necessita da especialização, mas que o objetivo maior é a obtenção de resultados da empresa como um todo, refletida nos lucros acumulados. Assim, a visão sistêmica desse processo se torna o fator primordial para o sucesso da empresa.

A constatação de que a visão sistêmica melhora em jogos simulados foi identificada em pesquisa realizada por Oliveria \& Sauaia $(2008$, p. 9) com grupo de professores submetidos a um estudo sobre jogos de empresas, em que afirmam que:

Pode-se perceber que do grupo gerencial o aspecto mais mencionado como potencialidade foi a visão sistêmica e estratégia (25\%), seguido das habilidades gerenciais e de tomada de decisão (21\%) e a análise quantitativa e financeira (17\%), entretanto para os participantes estes aspectos também representaram fraquezas com 18 e 36\% respectivamente, neste último tratou-se mais de uma limitação do que força, demonstrando que para o grupo pesquisado, a atividade exigiu noções de raciocínio quantitativo e fundamentos financeiros. A integração dos conhecimentos em gestão (8\%) foi outro aspecto que desafiou os participantes.

\section{CONCEITOS UTILIZADOS NO JOGO}

Antes de discorrer sobre os conceitos utilizados, através de uma breve descrição, apresenta-se, no item 4.1, o "Jogo Financeiro da Cerveja".

\subsection{JOGO FINANCEIRO DA CERVEJA}

O jogo financeiro apresentado neste trabalho é denominado "Jogo Financeiro da Cerveja". É aplicado a partir de quatro fábricas de cerveja, que disputam o jogo entre si, e três supermercados, que também 


\section{Administração: caminhos para o desenvolvimento sustentável}

são concorrentes, no mercado e no jogo. Todas as sete empresas começam com a mesma estrutura de capital e mesmos ativos. $O$ jogo pode ser aplicado entre uma e 12 rodadas (meses) e ganha o jogo, em cada uma das duas categorias (fábricas e supermercados), a empresa que terminar com maior Patrimônio Líquido. Outra forma de ganhar o jogo é obter um Capital Circulante Líquido (CCL) positivo. Inicialmente todas as empresas começam com CCL negativo em $\mathrm{R} \$ 1.330 .000,00$.

A disputa se dá em períodos de tempo definidos pelo professor para as atividades de planejamento e vendas no mercado; nesses períodos, ocorrem as negociações efetivas, com termo de assinatura da compra realizada.

No caso das fábricas, nas atividades de planejamento, tomando-se por base uma estrutura de custos fixos totais mensais e variáveis unitários predefinida, a equipe precisa planejar os investimentos em propaganda, definir quantidade a ser produzida e o preço planejado.

No caso dos supermercados, de forma similar, ocorrem as atividades de planejamento. Para o caso dos supermercados, o custo variável unitário efetivo depende do preço médio ponderado de compra, livremente negociado com as fábricas. Os demais itens são definidos inicialmente com o planejamento e, a partir da definição do preço de venda, após as compras, estes não podem ser mudados. A quantidade vendida é definida a partir de uma quantidade fixa por empresa, somada a uma quantidade em função da propaganda e o restante dependerá da curva de demanda.

A curva de demanda é influenciada pela propaganda coletiva das sete empresas. Também, a demanda individual dos supermercados é influenciada pela propaganda feita pelas fábricas das quais cada supermercado efetuou as compras, assim como de seus próprios investimentos nesta área e de um efeito residual da propaganda feita pelos concorrentes. Além disso, venderá o produto em primeiro lugar o supermercado que estipular o menor preço. Havendo demanda residual, o segundo supermercado vende no limite da demanda residual e se ainda restar demanda, o supermercado com preços mais altos também vende até atender toda a demanda. Caso algum supermercado ou fábrica não consiga vender o que comprou ou produziu, carregará o estoque para o mês seguinte. A demanda do mês não atendida não se acumula para o mês seguinte.

Assim, para que o jogo ocorra, os alunos devem conhecer os seguintes conceitos: a) Curvas de demanda, oferta e equilíbrio de mercado; b) Efeitos da propaganda sobre as vendas; c) Custeio Variável, Pontos de equilíbrio contábil, econômico e financeiro; d) Alavancagens Operacional e 


\section{Administração: caminhos para o desenvolvimento sustentável}

Financeira; e) Tributação; f) Estrutura das Demonstrações Financeiras; g) Outros fatores: Risco de Inadimplência e Capital Circulante Líquido (CCL).

\subsection{DESCRIÇÕES SIMPLIFICADAS DOS CONCEITOS UTILIZADOS NO JOGO DA CERVEJA}

Antes de adentrarmos nos conceitos abordados no jogo, é importante salientar que nos dados da demanda não estão sendo considerados os aspectos de sazonalidade. Todavia, a equação de demanda pode ser alterada para considerar esse aspecto, acrescentando demanda independente adicional nos períodos de verão, elevando a complexidade do jogo.

\subsubsection{CURVAS DE DEMANDA, OFERTA E EQUILÍBRIO DE MERCADO}

De acordo com a teoria microeconômica, ceteres paribus, quanto maiores os preços, menor será a demanda. Por outro lado, quanto maiores os preços, maior será a oferta. Assim, a curva de demanda é negativamente inclinada e a curva de oferta é positivamente inclinada, de forma que, as duas curvas se cruzam, gerando uma quantidade e um preço de equilíbrio.

No caso deste jogo, a parte da demanda segue inicialmente os dados do Quadro 01.

Como pode ser observado no Quadro 01, a curva de demanda tem como base um determinado número de consumidores, com dada renda mensal e que gastam $10 \%$ da mesma com cerveja.

Como pode ser observado no Quadro 01, a curva de demanda tem como base um determinado número de consumidores, com dada renda mensal e que gastam $10 \%$ da mesma com cerveja. A elasticidade renda da demanda considerada é de 1,5 e a elasticidade preço da demanda é -1. Assim, sem propaganda, a demanda é de $\mathrm{R} \$ 300$ mil. A curva de demanda é calculada tomando-se por base um preço de $\mathrm{R} \$ \mathbf{8 0 , 0 0}$ por caixa. Desta forma, os $\mathrm{R} \$ 300$ mil permitirão o consumo de 3.750 caixas. $A$ demanda para preços mais altos ou mais baixos leva em consideração a Elasticidade-Preço da demanda de cerveja. 


\section{Administração: caminhos para o desenvolvimento sustentável}

Quadro 01 -Dados iniciais da demanda do jogo da cerveja

\begin{tabular}{|c|c|}
\hline Quantidade de Consumidores: & 2,000 \\
\hline Renda média dos Consumidores MES anterior & $1,500,00$ \\
\hline Renda média dos Consumidores MÊS ATUAL & $1,500,00$ \\
\hline Elasticidade Renda da Dem anda: & 1,5 \\
\hline$\%$ da renda gasta com CERVE JA mês anterior & $10,0 \%$ \\
\hline$\%$ de variação em função da mudança na renda & $0,0 \%$ \\
\hline Valor/mês anterior gasto com CERVEJAs/ propaganda: & RS150,00 \\
\hline Valor/mês atual gasto com CERVEJA s/ propaganda: & $\mathrm{RS} 150,00$ \\
\hline$\%$ da renda gasta com CERVE JA mês atual: & $10,00 \%$ \\
\hline Demanda por CERVEJA (normal, sem propaganda) & RS $300,000,00$ \\
\hline + Demanda por Propaganda=Multiplicador $x$ Investim ento & RS 0,00 \\
\hline Total do Valor m ensal gasto com CERVEJA: & RS300,000,00 \\
\hline Elasticidade-Preço da demanda de CERVEJA: & $(1,0)$ \\
\hline
\end{tabular}

Fonte: Desenvolvido pelos autores.

A elasticidade renda da demanda considerada é de 1,5 e a elasticidade preço da demanda é -1. Assim, sem propaganda, a demanda é de $\mathrm{R} \$ 300$ mil por mês. A curva de demanda é calculada tomando-se por base um preço de $\mathrm{R} \$ 80,00$ por caixa. Desta forma, os $\mathrm{R} \$ 300$ mil permitirão o consumo de 3.750 caixas. A demanda para preços mais altos ou mais baixos leva em consideração a Elasticidade-Preço da demanda de cerveja.

Da mesma forma, como pode ser visto no Quadro 01, o total do valor mensal gasto com cerveja pode aumentar de acordo com a propaganda. O efeito da propaganda inicial considerado é de 2,5 vezes o valor investido. Todavia, tanto o multiplicador da propaganda, quanto a elasticidade renda da demanda e elasticidade preço da demanda podem ser alterados pelo professor. Da mesma forma, isso pode ser feito com a quantidade de consumidores e a renda ou o percentual da renda gasto com cerveja. Isso permite flexibilidade na condução do jogo, podendo aumentar ou diminuir o grau de dificuldade do mesmo. A sugestão é que eventuais alterações ocorram somente após um certo número de rodadas na situação original.

\subsubsection{EFEITOS DA PROPAGANDA SOBRE AS VENDAS}

Os efeitos da propaganda sobre as vendas normalmente se estendem por vários períodos. Todavia, devido às dificuldades de controle, os efeitos da propaganda neste jogo ocorrem apenas na rodada em questão. Cada fábrica ou supermercado decide no mês (rodada) quanto vai investir em propaganda e os efeitos ocorrem somente no período. 


\section{Administração: caminhos para o desenvolvimento sustentável}

Outro aspecto sobre os efeitos da propaganda é quanto à distribuição dos benefícios. Embora sejam, evidentemente, absorvidos em grande parte pela empresa que faz os investimentos, isso não ocorre na totalidade. Assim, no caso das fábricas, se considera que apenas $70 \%$ da propaganda seja absorvida pela empresa que faz os investimentos. Os outros $30 \%$ são distribuídos proporcionalmente entre as outras três empresas, com $10 \%$ cada uma. Isso ocorre de maneira recíproca. De forma que, se todas investirem a mesma quantia em propaganda, o efeito para cada empresa será o seu próprio investimento vezes o multiplicador estabelecido (inicialmente 2,5 ).

Todavia, se uma empresa não fizer propaganda, se beneficia da propaganda feita pelas demais. Em síntese, os consumidores, ao serem "atingidos" pela propaganda de cerveja, decidem comprar cerveja, não necessariamente da marca que anunciou.

Os investimentos feitos em propaganda pelas fábricas é um forte argumento na negociação de venda aos supermercados, tendo em vista que estes são diretamente beneficiados pela propaganda feita pelas fábricas das quais compram a cerveja. De forma similar, a propaganda feita por cada supermercado, é absorvida somente em $80 \%$ do valor despendido, sendo os outros $20 \%$ distribuídos proporcionalmente entre os dois outros supermercados ( $10 \%$ para cada um). Novamente, se todos fizerem os mesmos investimentos, cada um se beneficiará do valor correspondente aos seus próprios investimentos nesta área.

Assim, aliada a uma venda fixa mínima de 300 caixas por período, são somadas as vendas garantidas pela propaganda, podendo esta ser zero, caso não ocorram, ou em valor muito pequeno, caso o supermercado compre de fábricas que não investiram em propaganda e ele próprio não tenha feito investimentos nesta área. O benefício seria apenas dos efeitos residuais dos investimentos de outras fábricas e supermercados.

\subsubsection{CUSTEIO VARIÁVEL E PONTOS DE EQUILÍBRIO CONTÁBIL, ECONÔMICO E FINANCEIRO}

Para simplificar o processo de tomada de decisões de precificação, optou-se por trabalhar com o método de custeio variável. Por este método, os custos são divididos em fixos e variáveis. Os custos fixos são apresentados por período (mês) e são inicialmente idênticos para todas as empresas. Entre esses custos fixos, constam as Despesas Financeiras Líquidas.

No caso das fábricas, o custo variável correspondente à matéria prima é de $\mathrm{R} \$ \mathbf{8 , 0 0}$ por caixa e os demais custos variáveis dependem do preço que será praticado, sendo em grande parte referente a 


\section{Administração: caminhos para o desenvolvimento sustentável}

tributos sobre as vendas, sob o sistema de substituição tributária. No caso dos supermercados, o custo variável corresponde principalmente ao preço médio ponderado de aquisição do produto, mais um adicional de impostos sobre vendas, em pequena proporção (PIS e COFINS) e os tributos sobre lucro, se houver, em 15\% de Imposto de Renda Pessoa Jurídica (IRPJ) e 9\% da Contribuição Social sobre Lucro Líquido (CSLL) até o limite de R\$ 20 mil por mês e 10\% de adicional de IRPJ para lucro acima de R\$ 20 mil por mês.

Assim, tomando-se por base o custo fixo mensal de $\mathrm{R} \$ 52.033,33$ inicial para cada empresa, seus custos variáveis para diferentes níveis de preços, o aluno deve calcular a quantidade que deve vender para atingir os diferentes pontos de equilíbrio.

O ponto de equilíbrio contábil mostra a quantidade que se deve vender para que o lucro contábil seja zero e é obtido a partir da equação 01.

$$
\text { Ponto de Equilíbrio Contábil }=\frac{\text { Custos Fixos Totais }}{(\text { Preço-Custo Variável Unitário })}
$$

O ponto de equilíbrio econômico acrescenta aos custos fixos o custo de oportunidade do capital próprio. Como cada empresa inicia com um Patrimônio Líquido de R\$ 1 milhão, aplica-se uma taxa de $1 \%$ sobre esse valor, inicialmente $\mathrm{R} \$ 10$ mil. Após a primeira rodada o patrimônio líquido se altera e, por conseqüência, o valor do custo de oportunidade. Esse percentual de 1\% também poder ser alterado pelo professor ao aplicar o jogo. Esse ponto de equilíbrio nos informa a quantidade que precisa ser vendida para que se tenha lucro econômico igual a zero. Ele pode ser obtido por meio da equação 02.

$$
\text { Ponto de Equilíbrio Econômico }=\frac{\text { Custos Fixos Totais }+ \text { Custo de Oportunidade }}{(\text { Preço-Custo Variável Unitário })}
$$

O ponto de equilíbrio financeiro nos informa a quantidade que precisa ser vendida no período que permita à empresa manter seus pagamentos em dia, sem recorrer a novos empréstimos. São deduzidos dos custos fixos totais os custos e despesas não desembolsáveis (depreciação) e acrescentados os valores referentes à amortização de empréstimos. Neste jogo, todas as empresas

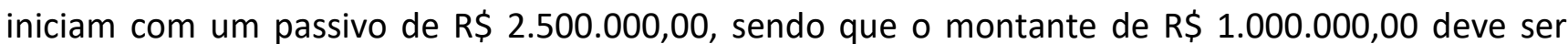




\section{Administração: caminhos para o desenvolvimento sustentável}

amortizado em 24 meses. O ponto de equilíbrio financeiro pode ser calculado por meio da equação 03.

$$
\text { Ponto de Equilíbrio Financeiro }=\frac{\text { Custos Fixos Totais-Depreciação+Amortizações }}{(\text { Preço-Custo Variável Unitário })}
$$

\subsubsection{ALAVANCAGENS OPERACIONAL E FINANCEIRA}

Os cálculos disponibilizados de Alavancagem Operacional e Financeira direcionam os alunos para acompanhar esses indicadores no decorrer do jogo.

$\mathrm{Na}$ alavancagem operacional, através do Grau de Alavancagem Operacional (GAO), verifica-se quanto pode aumentar ou diminuir o lucro operacional, a partir de variações no nível de vendas. $\mathrm{O}$ indicador permite aos alunos planejarem e projetarem alternativas.

No caso da alavancagem financeira, se evidencia os ganhos para os acionistas, a partir de custos inferiores da estrutura financeira, em relação ao verdadeiro custo da dívida, considerando os custos dos empréstimos e os benefícios fiscais da tributação.

\subsubsection{TRIBUTAÇÃO}

De acordo com a Tabela do Imposto sobre Produtos Industrializados (TIPI) em vigor no Brasil em maio/2009, o código 2203.00.00-Cerveja de malte, paga alíquota de 40\%. O ICMS da Cerveja considerado é de 17\%, em regime de Substituição Tributária. Assim, um produto com vendido por R\$ 10,00, paga $R \$ 4,00$ de IPI (como o valor total pago pelo cliente neste caso é de $R \$ 14,00$ e sendo $R \$$ 4,00 de IPI, o percentual deste sobre o valor de vendas é de $28,57 \%$ ) e mais $\mathrm{R} \$ 1,70$ de ICMS, totalizando $\mathrm{R} \$ 5,70$ de imposto. No caso do PIS, a alíquota considerada é de 1,65\% sobre o Valor Agregado e no caso da COFINS, de 7,60\% também sobre o valor agregado. Os valores expostos referem-se às fábricas. Para os supermercados, como já ocorreu a substituição tributária para o ICMS e como o IPI só é pago pela indústria, considera-se apenas o PIS e a COFINS sobre o valor agregado, além do Imposto de Renda Pessoa Jurídica (IRPJ) e a Contribuição Social sobre o Lucro Líquido (CSLL), aplicável a todas empresas, de acordo com a existência ou não de lucro e o seu montante.

\subsubsection{ESTRUTURA DAS DEMONSTRAÇÕES FINANCEIRAS}

O Quadro 2 mostra a estrutura inicial para as sete empresas. O Capital Circulante Líquido negativo em $\mathrm{R} \$ 1.330 .000,00$ é um item de acompanhamento constante, pois a empresa que conseguir torná-lo 


\section{Administração: caminhos para o desenvolvimento sustentável}

positivo, ganha o jogo antecipadamente. ATIVOPASSIVOAtivo Circulante (AC) $=930,000,00$ Passivo Circulante $(P C)=R \$ 2,260,000,00$ Passivo Não Circulante $=R \$ 240,000,00$ Ativo Não Circulante $=$ $2,500,000,00$ Patrimônio Líquido $=\mathrm{R} \$ 1,000,000,00$ Total $=3,430,000,00$ Total $=3,430,000,00$ Capital Circulante Líquido: CCL:(1,330,000,00)

Quadro 02 - Balanço Patrimonial (idêntico para as sete empresas) (em R\$̦)

\begin{tabular}{|c|c|c|c|}
\hline ATIVO & & \multicolumn{2}{|l|}{ PASSIVO } \\
\hline \multirow{4}{*}{$\begin{array}{r}\text { Ativ o Circulante }(\mathrm{AC})= \\
\text { Realizável a Longo Prazo }= \\
\text { Ativo Permanente }= \\
\text { TOTAL }=\end{array}$} & $930,000,00$ & \multirow{5}{*}{$\begin{array}{r}\text { Passivo Circulante: } \\
\text { Exigí el a Longo Prazo: } \\
\text { Patrim ôn io Líq uid o: } \\
\text { TOTAL= }\end{array}$} & $\mathrm{R} \$ 2,260,000,00$ \\
\hline & $70,000,00$ & & R\$240,000,00 \\
\hline & $2,500,000,00$ & & $\mathrm{R} \$ 1,000,000,00$ \\
\hline & $3,500,000,00$ & & $\mathrm{R} \$ 3,500,000,00$ \\
\hline Capital Circulante Líquido:CCL & $(1,330,000,00)$ & & \\
\hline
\end{tabular}

Fonte: Desenvolvido pelos autores.

O Quadro 3 mostra a Demonstração de Resultados (DRE) sintética, comum para as 7 empresas. A estrutura analítica também é disponibilizada aos alunos para controle. Observa-se que, neste quadro, além dos valores em Reais, também é informado o percentual sobre as vendas, exceto no item Impostos/IR e CSLL, cujo percentual refere-se à proporção do LAIR que é pago em Imposto de Renda e Contribuição Social (CSLL).

Os dados do Quadro 03 ocorreram no período anterior ao início do jogo, de forma que o lucro de R\$ 14.931,47 já foi incorporado ao patrimônio líquido.

VENDAS 100,0\% R\$160,000,00 Margem de Contribuição 51,7\% R\$82,680,00 CUSTOS FIXOS(Exceto CF) 26,9\% R\$43,033,33 Lucro Operacional/LAJIR 24,8\% R\$39,646,67 Custo Financeiro 12,5\% R\$20,000,00 LAIR 12,3\% R\$19,646,67 Impostos / IR e CSLL= 24,0\% R\$4,715,20 LUCRO LÍQUIDO= 9,3\% R\$14,931,47

Quadro 03 - DRE (idêntico para as sete empresas) (em R\$)

\begin{tabular}{|l|r|r|}
\hline VENDAS & $100,0 \%$ & RS160,000,00 \\
\hline Margem de Contribuição & $51,7 \%$ & RS\$2,680,00 \\
\hline CUSTOS FIXOS(Exceto CF) & $26,9 \%$ & RS43,033,33 \\
\hline Lucro Operacional/LAJIR & $24,8 \%$ & RS39,646,67 \\
\hline Custo Financeiro & $12,5 \%$ & RS20,000,00 \\
\hline LAIR & $12,3 \%$ & RS19,646,67 \\
\hline Impostos / IR e CSLL $=$ & $24,0 \%$ & RS4,715,20 \\
\hline LUCRO LÍQUIDO $=$ & $\mathbf{9 , 3} \%$ & R $\$ 14,931,47$ \\
\hline
\end{tabular}

Fonte: Desenvolvido pelos autores. 


\section{Administração: caminhos para o desenvolvimento sustentável}

\subsubsection{OUTROS ASPECTOS CONSIDERADOS}

\subsubsection{A RISCO DE INADIMPLÊNCIA (INCOBRÁVEIS)}

Um aspecto considerado no jogo é o risco de incobráveis, estabelecido a cada rodada como uma variação aleatória entre 0 e 5\% do faturamento, influindo diretamente nos resultados obtidos.

Relativamente à concessão de crédito, o risco pode ser considerado como a possibilidade de não recebimento dos valores acordados na transação das vendas, dentro do prazo estabelecido. A expressão "risco de crédito" é usada para caracterizar os diversos fatores que podem contribuir para que aquele que concedeu o crédito não receba do devedor o pagamento na época acordada (ESTRELA, 2002).

Caouette et al (1999, p.11) afirmam que "sempre há um elemento de risco quando uma pessoa adquire um produto ou serviço sem pagar imediatamente por ele".

No jogo em questão, o risco é um processo aleatório e serve para gerar maiores cuidados na precificação, por parte dos tomadores de decisão, na fase de negociação de preços no caso das indústrias e definição de preços, no caso dos supermercados.

\subsubsection{B CAPITAL CIRCULANTE LÍQUIDO (CCL)}

É um importante indicador de risco de liquidez da empresa. Existe um tradeoff entre risco de liquidez e retorno, na medida em que utilizar fontes de curto prazo implica, normalmente, custos menores, sob o risco de ter dificuldades financeiras. Assim, como todas as empresas começam numa situação de baixa liquidez, a equipe que conseguir zerar o Capital Circulante Líquido, ganha o jogo. Assim, os alunos acompanham esse indicador de risco de liquidez.

\section{CONTROLE, OPERACIONALIZAÇÃO E CONCEITOS RESSALTADOS}

Este jogo tem por objetivo envolver os alunos numa disputa simulada de mercado, em que se exige planejamento, cálculos de custos, definição de preços, propaganda e negociação.

Montam-se quatro equipes de Fábricas de Cerveja e três equipes de Supermercados. As fábricas disputam entre si e o mesmo ocorre com os supermercados.

Os objetivos são: a) Compreender alguns fundamentos da teoria microeconômica (Teoria do Consumidor e Teoria da Firma); b) Compreender aspectos básicos da Administração Financeira: Balanços, Demonstrativos de Resultados, Retorno sobre o Investimento, Alavancagem Financeira e 


\section{Administração: caminhos para o desenvolvimento sustentável}

Alavancagem Operacional, Custo da Estrutura Financeira e Custo de Capital; Formação do Preço de Venda ; Planejamento e Negociação.

\section{METODOLOGIA}

Considerando-se os objetivos propostos e com base na taxionomia adotada por Gil (2007), que classifica as pesquisas, quanto ao nível, em exploratórias, descritivas e explicativas, este estudo classifica-se como exploratório, tendo em vista que, conforme o referido autor, este tipo de estudo apresenta como finalidade esclarecer conceitos e idéias, além de serem desenvolvidos com o objetivo de proporcionar uma visão geral, de tipo aproximativo, sobre determinado fato.

No que se refere ao delineamento da pesquisa, ainda de acordo com Gil (2007), este estudo adotou, inicialmente, a pesquisa bibliográfica sobre os conceitos utilizados no jogo, bem como sobre a importância didática deste no processo de ensino-aprendizagem; a coleta de dados foi realizada através de consultas a livros, trabalhos acadêmicos e artigos divulgados na Internet. Finalmente realizou-se a construção e aplicação do jogo, por meio da utilização de planilhas eletrônicas do Microsoft Excel com o uso de macros. Este jogo vem sendo aplicado a vários anos e este artigo tem por objetivo apresentar essa experiência prática.

\section{ANÁLISE DOS RESULTADOS DA EXPERIÊNCIA DE APLICAÇÃO}

O jogo vem sendo aplicado há nove anos em cursos de graduação e pós-graduação em Administração. No início, a proposta era identificar os cálculos de ponto de equilíbrio contábil e reforçar a importância do planejamento financeiro. Com o passar do tempo e das aplicações desenvolvidas, novos elementos foram sendo incorporados ao jogo. Destaca-se a incorporação dos investimentos em propaganda feitos pelas empresas participantes e o estabelecimento de uma curva de demanda incorporando os aspectos relacionados à elasticidade-preço da demanda.

Um aspecto importante se dá a partir das negociações entre as equipes e o espírito de disputa, gerando tensão, interesse e aprendizado. O dinamismo observado ao longo das atividades desenvolvidas, e a rapidez com que passam períodos de quatro aulas seguidas, normalmente sem intervalo por sugestão dos alunos, criam um ambiente de trabalho desafiador.

Os seguintes aspectos podem ser destacados na aplicação do jogo, quanto aos alunos: compreendem os conceitos com maior facilidade; interagem com os colegas, estabelecendo-se líderes naturais, que coordenam as atividades do grupo; gostam das aulas, cobrando maior número de rodadas; participam 


\section{Administração: caminhos para o desenvolvimento sustentável}

dos debates de avaliação, fazendo considerações sobre os conceitos ligados às tomadas de decisões do grupo, consolidando o entendimento dos conceitos.

Quanto à aula em si, destacam-se os seguintes aspectos: torna-se dinâmica; exige controle por parte do professor; permite trabalhar de forma integrada diversos conceitos. Todavia, como a avaliação é em equipe, isso não implica abrir mão de uma prova individual para verificação dos conceitos aprendidos.

Apesar destes benefícios, não se pode perder de vista os objetivos da técnica, que não são um fim em si e sim um meio para atingir o melhor aprendizado. Este, obtido em um ambiente em que o aluno não é apenas um ouvinte e sim participante do processo de tomada de decisão e dos resultados decorrentes, mostra-se consolidado, podendo ser verificado em semanas seguintes por meio de avaliações; os resultados mostram que realmente eles aprendem. Aprendem fazendo.

\section{CONCLUSÕES}

Procurou-se através desse texto demonstrar um dos jogos desenvolvidos para fins educacionais, chamado Jogo Financeiro da Cerveja, seus detalhes, suas dificuldades, cuidados e efeitos sobre o aprendizado dos alunos.

Talvez o grande diferencial neste modelo de ensino/aprendizagem em relação às outras tradicionais formas de aprendizado, como aulas expositivas, resida no fato de ser fundamental a interação entre os integrantes das equipes, onde o aprendizado é facilitado pelo fato dos alunos tornarem-se agentes ativos do processo. Esta é uma característica típica da abordagem vivencial, na qual o método está baseado.

Procura-se, através da adoção desse método, passar aos acadêmicos que a empresa, quer seja a simulada ou não, não pode prescindir da visão sistêmica do processo. Além disso, as áreas pelas quais são responsáveis não subsistem por si só; é preciso, antes de tudo, saber conviver em equipe, formando um time; quanto mais entrosado estiver o time, maiores e melhores serão os resultados.As aplicações práticas evidenciaram que os conceitos utilizados no jogo são melhor compreendidos pois estão contextualizados, num caso real. Além disso, observou-se maior interação entre os alunos, maior estímulo para freqüência nas aulas, bem como maior participação nos debates.

No que se refere à aula propriamente dita, verificou-se aumento no dinamismo, bem como e talvez mais importante, a interconexão entre vários conceitos oriundos de diversas áreas. Finalmente, ainda nesta mesma linha, considera-se relevante, na aplicação dos jogos de empresa na área financeira, uma 


\section{Administração: caminhos para o desenvolvimento sustentável}

maior interação entre os professores ligados às áreas citadas. Isto permitiria aulas conjuntas. É um aspecto a ser explorado.

\section{REFERÊNCIAS}

CARMONA, C. U. M; NEVES FILHO, G. P.; LUCENA, P. Finanças Corporativas e Mercados. São Paulo: Atlas, 2009.

CAOUETTE, J. B. et al. Gestão do Risco de Crédito: o próximo grande desafio financeiro. Trad. Allan Hastings. Rev. tec. João Carlos Douat. Rio de Janeiro: Qualitymark, 1999.

COELHO, C. G. Os Jogos de Regras e o Aprendizado da Matemática. Universidade Cândido Mendes. Instituto A vez do Mestre. Monografia (Pós-graduação em Psicopedagogia). Rio de Janeiro: UCM, 2007. Disponível

em:<http://www.vezdomestre.com.br/monopdf/6/CAROLINA\%20GOULART\%20COELHO.pdf>. Acesso em: 24 Jun. 2009.

ESTRELA, L. V. F. O setor bancário, a internacionalização da economia, as instituições financeiras e os novos critérios de provisões para créditos de liquidação duvidosa. 2002. Projeto de pesquisa (graduação em economia). João Pessoa: UFPB, 2002.

GALLEGO, J. P. A utilização dos jogos como recurso didático no ensino-aprendizagem da matemática. Universidade Estadual Paulista "Júlio de Mesquita Filho". Monografia (Graduação em Pedagogia). Bauru: UNESP, 2007. Disponível

em:<http://www.fc.unesp.br/upload/pedagogia/TCC\%20Julia\%20Perruchetti\%20-\%20Final.pdf)>. Acesso em: 24 Jun. 2009.

GIL, A. C. Métodos e Técnicas de Pesquisa Social. 5. ed. 8. reimp. São Paulo: Atlas, 2007.

LEISMANN, Edison Luiz. Jogos Financeiros. Unioeste, 2007. Disponível

em: <http://sites.google.com/site/jogosfinanceiros/>.

OLIVEIRA, M. A.; SAUAIA, A. C. A. Prontidão Docente para Aprendizagem Vivencial: uma mudança de filosofia Educacional por meio do Jogo de Empresas. XXI SemeAD- 28 e 29 de agosto/2008, Área Temática: Jogos de Empresas. FEA-USP, São Paulo, 2008.

RECEITA FEDERAL DO BRASIL. Tabela do Imposto de Renda (TIPI). Disponível em: <http://www.receita.fazenda.gov.br/Aliquotas/DownloadArqTIPI.htm>.

SANTOS, M. R. G. F.; LOVATO, S. Os Jogos de Empresas como Recurso Didático na formação de Administradores. Revista Novas Tecnologias na Educação. V. 5, $n^{\circ} 2$, dezembro de 2007. Disponível em: <http://www.cinted.ufrgs.br/ciclo10/artigos/2aMagda.pdf>. Acesso em: 24 Jun. 2009. 


\section{Capítulo 4}

\section{HOTELARIA HOSPITALAR COMO ESTRATÉGIA COMPETITIVA}

DOI: $10.37423 / 200300345$

José Alberto Yemal (Universidade Paulista - UNIP)

yemal@bignet.com.br

Mirian Mazini Rodrigues (Universidade Paulista - UNIP) mirianmazini@ig.com.br

Alexandre Varella de Andrade (Universidade Paulista - UNIP) alexandre-varella@hotmajl.com

DaniêtFernandes Pastorello (Universidade Paulista - UNIP) df_pastorello@yahoo.com.br

RESUMO: Este trabalho apresenta um estudo baseado na necessidade de se implantar um setor de Hotelaria Hospitalar emùm hospital priyado, comø diferencial competitivo que esta nova tendência proporcionará para a prganização de saude, vendo este conceito como uma novą visăo de negócio.

O conceito de Hotelaria Hospitalar é recehte no Brasil, tem pouco menos de uma década. Proqura-se oferecer conforto, segurança e bern-estar ao paciente, seus familiares e amigos, de forma diferenciada. Tememsua essência o propósito-de mudaroestereótipo do hospital de lugar frio-e de sofrimento, tornando o ambiente mais agradável. 


\section{Administração: caminhos para o desenvolvimento sustentável}

Este novo serviço pode agregar valor ao atendimento e pode ser visto como um novo negócio promissor, de modo a atrair novos clientes e, consequentemente, aumentar a receita. É uma área pouco explorada pelos hospitais, porém mostra-se como uma tendência devido ao novo perfil do cliente, hoje mais informado e exigente.

Fui desenvolvido um estudo de caso através de uma pesquisa de campo utilizando um instrumental de pesquisa embasado em um referencial teórico, aplicado junto aos clientes e colaboradores de um hospital privado na cidade de Santos/SP, além de uma entrevista exclusiva com o Diretor Administrativo da organização.

Palavras chave: Hotelaria, Hospital, Negócio, Estratégia. 


\section{Administração: caminhos para o desenvolvimento sustentável}

\section{INTRODUÇÃO}

Atualmente a procura pela qualidade é o objetivo de todas as empresas, sejam elas de produtos ou de serviços. O cliente, ou melhor, o paciente começou a questionar e exigir que lhe ofereçam não só o tratamento, a cura, mas também segurança, conforto e bem-estar. Devido à era da informação as pessoas estão mais esclarecidas, pois as informações e inovações são compartilhadas em tempo real, fazendo com que as organizações estejam sempre acompanhando esta evolução. Com os hospitais não é diferente, são obrigados a mudar o perfil de atendimento, para garantir a sobrevivência e o grau de competitividade.

O paciente hoje não se vê como um ser passivo, mas sim como um cliente que busca um serviço diferenciado tanto de diagnóstico quanto de atendimento e principalmente de acomodações. É imprescindível dispor de serviços especializados, instalações e acomodações em conformidade com as novas exigências dos futuros clientes em potencial, de modo a não deixar de atender às expectativas dos clientes, para que os mesmos migrem para outras regiões. Fazer com que os hospitais sejam cada vez mais procurados e ao mesmo tempo eficientes, inovadores e lucrativos, é um grande desafio.

O conceito de Hotelaria Hospitalar é recente no Brasil, tem menos de dez anos, porém é cada vez mais disseminado nos hospitais em diversas regiões. Antigamente os hospitais preocupavam-se apenas com a tecnologia e dispor de um corpo clínico de ponta, não levando muito em consideração o conforto, a hospitalidade e a humanização, e também o bem-estar de familiares e amigos. Diversos fatores foram cruciais para esta nova tendência, principalmente o paciente, ou como será visto no decorrer da pesquisa "cliente saúde", que começou a exigir muito mais além da cura e do tratamento. É uma área pouco explorada pelos hospitais, mas de grande potencial, podendo ser visto pelas organizações de saúde como um novo negócio e um diferencial competitivo, de forma a impactar positivamente na receita do hospital.

Com base em todo este cenário é imprescindível a implantação de um setor específico que reúna todos os serviços de apoio juntamente com os serviços específicos a fim de oferecer melhor qualidade no atendimento aos clientes internos e externos, e consequentemente, encantar os mesmos. Nesta pesquisa serão apresentados conceitos como hospitalidade, humanização, fidelização de clientes, competitividade, estratégia competitiva, bem como o conceito de Hotelaria Hospitalar. A coleta de dados foi dividida em três esferas abrangendo os clientes do hospital, os colaboradores e o Diretor Administrativo da organização. O objetivo deste estudo foi demonstrar, a partir de um estudo de caso, 


\section{Administração: caminhos para o desenvolvimento sustentável}

que a hotelaria hospitalar é um diferencial competitivo e uma estratégia inteligente para visão de negócio no setor de saúde na rede particular de hospitais na cidade de Santos.

\section{REVISÃO BIBLIOGRÁFICA}

Para Castelli (2001), o hotel pode ser definido como sendo uma construção que, mediante o pagamento de diárias, recebe clientes diversificados e oferece alojamento. A definição oficial brasileira de hotel é um estabelecimento comercial de hospedagem, que oferece ocupação temporária, com banheiro, aposentos e serviço de alimentação, além dos demais serviços de relativos à atividade hoteleira (CASTELLI, 2001).

Fiuza (2010) comenta que os hotéis são caracterizados por locar dependências mobiliadas de modo a atender as necessidades de descanso e higiene de determinados usuários, cujas necessidades se dão por diversas razões. Deste modo a definição de hotéis estará ligada ao segmento de mercado e localização que um determinado hotel se propõe a atender. Assim, hotel é caracterizado por receber uma clientela de passagem ou em permanência, que se caracteriza por um aluguel, de modo que não constitua um domicílio.

A palavra hospital "vem do latim hospitalis, adjetivo derivado de hospes (hóspede, estrangeiro, viajante, conviva) significando também o que dá agasalho, que hospeda" (MIRSHAWKA, 1994). Existem autores que afirmam que os hospitais surgiram no quinto século antes da era cristã. Antigamente, eram hospedarias especiais que se chamavam hospium e, ao longo dos anos, foram evoluindo, sempre mantendo o papel principal de cuidar dos doentes. Essas hospedarias eram destinadas a receber doentes e acidentados.

O autor ainda explica que a assistência hospitalar no Brasil teve início logo após o seu descobrimento. Ele ainda relata que com o passar dos tempos grandes números de estabelecimentos hospitalares foram disseminados pelo país afora, somente após a terceira década do século XX é que a administração hospitalar começou a apresentar sinais de presença. A nova era hospitalar foi marcada por dois grandes projetos: a construção e organização do novo Hospital da Irmandade Santa casa de Misericórdia de Santos e do Hospital das Clínicas da Universidade de São Paulo.

Segundo Mac Earchem Apud Zanon (2001) o hospital é a representação do direito inalienável que o homem tem de gozar de saúde, e o reconhecimento formal, pela comunidade, da obrigação de prover meios para mate-los vivo ou restaurar-Ihe a saúde perdida. Para Watanabe (2010) a origem da palavra hospital se deriva do termo hospitalidade, que significa acolhimento, presente ao longo da história da 


\section{Administração: caminhos para o desenvolvimento sustentável}

humanidade nas organizações sociais das mais diversas. De acordo Taraboulsi (2003) o hospital também oferece alojamento mediante pagamento, mas a uma clientela específica, que está necessitando de cuidados com a saúde. Ao contrário da organização hoteleira, o hospital não está voltado ao lazer, mas ao atendimento ao cliente em um momento de grande sensibilidade, fraqueza e carência, quando necessita de cuidados com a sua saúde. Se no hotel todos os serviços prestados estão á disposição dos clientes, no hospital essa disponibilidade é ainda mais importante, pois a vida do cliente pode depender da presteza com que for atendido (TARABOULSI, 2003).

De acordo com Trigo (2005) a Comissão de Peritos em Assistência Médica da Organização Mundial da Saúde - OMS, em reunião realizada em Genebra em junho de 1956 definiu hospital como:

Uma parte integral de uma organização médica e social, cuja função é prover completa assistência de saúde à população - curativa e preventiva e cujos serviços de ambulatório atingem até a família em seu meio ambiente, é também um centro destinado ao treinamento de pessoal de saúde bem como à pesquisa biossocial (TRIGO, 2005:808).

Para Trigo (2005) o hospital deve ser encarado sob a forma de uma instituição dotada de planta física, equipamentos e organização adequados para receber pacientes, tratá-los e devolvê-los à comunidade em condições satisfatórias de saúde. O hospital é parte organização médica social, e sob tal designação, independentemente sua denominação, esta todo estabelecimento dedicado à atenção médica, ambulatorial ou por meio de internação, não importando se é público ou privado, seu nível de complexidade, se declara de fins lucrativos ou não, se está aberta a toda comunidade ou circunscrito a um setor dela (ZOBOLI, 2003).

O hospital deve possuir uma orientação para serviços, tratando o usuário como alguém a quem se deve servir e satisfazer às necessidades básicas, relacionada à cura, e específicas, relacionada a personalização. Com isso buscar a satisfação do cliente e manter a fidelidade do mesmo.

Para Watanabe (2010), a hospitalidade é um conceito que dentro da teoria da administração de serviços, faz parte de um grupo de atividades chamadas de suplementares que agrega valor ao tratamento dispensado aos clientes, que devem ser recebidos como hóspedes, em qualquer empresa. A autora ressalta que sobre o conceito de hospitalidade e sua aplicação, pode melhorar o modelo de gestão em saúde, uma vez que considera aspectos mais amplos, que envolvem o receber humano, inclusive, completar e superar as atuais práticas de qualidade nos serviços de saúde com fins lucrativos, abrindo possibilidades de ser utilizado até em organizações sem finalidade lucrativa e hospitais públicos. Já para Boeger (2003) o conceito de hospitalidade não é restrito somente em hotéis e restaurantes, clubes, cruzeiros, universidades, mas sim em hospitais também. Mullins apud Trigo 


\section{Administração: caminhos para o desenvolvimento sustentável}

(2005) informa que a hospitalidade é um processo que inclui a chegada, a acomodação confortável, o atendimento dos desejos do hóspede e sua partida ao final da estada. No entanto, é necessário lembrar que a gestão hoteleira dentro de um hospital deve respeitar as regras hospitalares, de modo que as funções hoteleiras aplicadas sejam traduzidas como qualidade na prestação de serviço de atendimento e acolhimento, sendo implantado e executado por todo o corpo hospitalar (BOEGER, 2003).

Cada vez mais este conceito é aplicado e valorizado tanto pelos clientes de saúde quanto as organizações de saúde também. Conforme Taraboulsi (2003), o triunfo da hotelaria está na humanização do ambiente hospitalar: serviços eficientes que encantam, cores suaves, plantas e jardins bem cuidados e, principalmente, pessoas entusiasmadas interagindo com os clientes de saúde, revelando de tal forma o segredo desta nova proposta que é o sorriso sincero e permanente, marca registrada da satisfação e do amor pelo trabalho realizado.

Para que efetivamente a humanização tenha êxito, faz se necessário que a educação continuada norteie as ações para a prática do atendimento humanizado e que as mesmas partam da direção da instituição e possam atingir toda a equipe, os quais as aplicará ao paciente/cliente (SAEKI et al., 2002). Taraboulsi (2003) comenta que os clientes de saúde (enfermos, familiares, acompanhantes, visitantes) sentem-se confiantes e motivados quando a solidariedade apresenta-se estampada nos semblantes de todos os envolvidos em seu atendimento. É a humanização, através da hotelaria, mudando condutas e comportamentos, tornando o hospital um espaço digno para os momentos difíceis de nossos clientes de saúde.

A humanização é um dos pilares da hotelaria hospitalar, juntamente com a hospitalidade formam a base do diferencial no atendimento. Cliente é aquele que usa os serviços ou consome os produtos de determinada empresa ou de determinado profissional (MIRSHAWKA, 1994). Juran (1997) cita cliente como qualquer pessoa que seja impactada pelo produto ou processo, pode-se afirmar que o cliente é qualquer pessoa que participe do processo, desde a sua concepção até o seu consumo. Os clientes podem ser internos e externos. No caso de cliente interno incluem todos os departamentos e indivíduos que fornecem serviços para outros. Já os clientes externos, incluem, entre outros, os pacientes, os médicos, as famílias e os amigos, e terceiros que pagam as contas como as empresas e a própria comunidade (MIRSHAWKA, 1994). Cliente é a pessoa que toma uma decisão de compra, porém o conceito mais abrangente de cliente refere-se àquelas organizações e pessoas que recebem 


\section{Administração: caminhos para o desenvolvimento sustentável}

os produtos oferecidos por outra organização. Consumidor, usuário final, beneficiário e comprador são exemplos de outras denominações para clientes (FNQ, 2008).

Conforme os autores acima, cliente é aquele que recebe um produto ou serviço de uma organização, no caso de clientes de um hospital, procuram um atendimento ou outro tipo de serviço. Taraboulsi (2003) diz que ao reconhecer que a expressão cliente de saúde é a mais adequada dentro do contexto hospitalar e abrange, além da pessoa enferma, os familiares, amigos e visitantes, torna-se mais fácil adotar estratégias e implementar ações, inclusive as de hotelaria, que possam garantir a humanização e a qualidade e inteligência, conhecer bem o cliente para que todas as pessoas envolvidas no atendimento possam ter a noção de sua importância para a instituição de saúde.

Para Ferreira (1985), qualidade é propriedade, atributo ou condição das coisas ou das pessoas, capazes de distingui-las das outras e de lhes determinar a natureza numa escala de valores. De acordo com a definição encontrada em medicina, qualidade é um pressuposto, é uma obrigação, é compromisso permanente de todos que trabalham no hospital, é um paciente bem atendido, por médico qualificado, especialista reconhecido, com acompanhamento constante, com diagnóstico certo e terapêutica adequada, executando com perícia e precisão os procedimentos médicos de cirurgia e anestesia (FERNANDES, 2002).

De acordo com Godoi (2004) quando se trata de investir em qualidade na saúde, investe-se na verdade na vida. A qualidade nos serviços de saúde envolve uma correta adequação de todos os serviços prestados às necessidades que o paciente apresenta, superando suas expectativas. Envolve basicamente a satisfação das necessidades do paciente, sendo algo intangível de difícil percepção por outrem. O autor acrescenta que a qualidade não deveria ser um adjetivo, mas sim estar intrinsecamente embutida em todos os produtos e serviços disponibilizados ao uso e consumo. Embora essa esteja sendo a realidade do mercado, nem sempre foi assim. Durante muito tempo anunciar a qualidade de um produto ou de um serviço era um atrativo a mais nele, algo que acrescentava valor ao produto e que o destacava dos demais no seu segmento.

Atualmente, as empresas de maior sucesso são aquelas que estão fazendo tudo para manter seus clientes. Para Bogmann (2000), cliente fiel é aquele que sempre volta à organização por ocasião de uma nova compra ou transação, por estar satisfeito com o produto ou com o serviço. Para Kotler \& Keller (2006) fidelizar o cliente significa vender o maior número de produtos a um único cliente por maior tempo possível, mantendo-o satisfeito. É conquistá-lo de tal forma que o impeça de migrar para a concorrência. Conforme Kotler \& Armstrong (2000) manter os clientes custa de 5 a 7 vezes mais do 


\section{Administração: caminhos para o desenvolvimento sustentável}

que reter os clientes considerados como fiéis, portanto a retenção dos clientes pode ser considerada um investimento, pois aumentará as vendas e diminuirá as despesas.

No entendimento de Brown (2001:53), "a fidelidade do cliente é o resultado real de uma organização criando benefícios para um cliente, para que ele mantenha ou aumente suas compras junto à organização. A fidelidade do cliente é criada, quando ele se torna um defensor da organização, sem incentivo pra tal". Stone \& Woodcoc (1998) comentam que existem graus de fidelidade. Dessa forma alguns são mais fiéis que outros. A fidelidade é desenvolvida através de abordagens que causam um impacto mental positivo, onde o objetivo não é tornar todos os clientes fiéis, mas sim aumentar o grau de fidelidade daqueles que são propensos a expressarem certo tipo de reação. Percebe-se assim que para fidelizar o cliente é necessário não somente a qualidade de produtos ou serviços, mas sim desenvolver estratégias para conquistar a confiança dos clientes, de modo que ele possa ser um colaborador para o melhoramento dos processos na empresa e também para a sobrevivência da organização.

Para Dias (2005) toda empresa, seja ela pública ou privada, tem como finalidade se manter viva no mercado e sendo assim, deve obter lucro e ser competitiva, e a competitividade entre hospitais não são diferentes. Há dez anos os hospitais só se preocupavam aperfeiçoar na qualidade no atendimento e com novas tecnologias como diferencial competitivo, desta forma os hospitais que possuíssem estes equipamentos de última geração de grande avanço tecnológico encontravam-se à frente dos demais hospitais (DIAS, 2005). Barbosa (1999) complementa que "uma empresa é competitiva quando ela é capaz de oferecer produtos e serviços de qualidade maior, custos menores, e tornar os consumidores mais satisfeitos do que quando servidos por rivais". Na visão de Campos (1992) ser competitivo é possuir entre os concorrentes a maior produtividade. A garantia da competitividade da empresa é sua sobrevivência, porém a sobrevivência decorre da competitividade, a competitividade vem da produtividade e esta da qualidade, representada pelo valor agregado.

As empresas têm como obrigação de aperfeiçoar suas capacidades e de gerenciar seus conhecimentos de forma estratégica. Entende-se que a estratégia tem como finalidade constituir para a empresa um diferencial competitivo diante a concorrência visando o crescimento no mercado e amento dos lucros. Porter (1986) define que o desenvolvimento de uma estratégia competitiva é, em essência, o desenvolvimento de uma fórmula ampla para o modo como uma empresa irá competir, quais deveriam ser as suas metas e quais as políticas necessárias para se levar a cabo estas metas. Desta 


\section{Administração: caminhos para o desenvolvimento sustentável}

forma, para o autor, a estratégia competitiva é uma combinação dos fins (metas) que a empresa busca e dos meios (políticas) pelos quais ela está buscando chegar lá.

Não se compreende vantagem competitiva visando à empresa de forma única, como se a empresa não possuísse as mais diversas e diferentes atividades pra se realizar sua cadeia de valor, o autor cita ainda que a empresa seja um conjunto de processo que são efetuadas para projetar, produzir, comercializar, entregar e apoiar seu produto e ou serviço, estas atividades são fontes de vantagem competitiva (PORTER, 1989). Carletto et al. (2005) afirmam que a busca por maior competitividade no mercado, face à globalização da economia tem forçado as organizações investirem em novas metodologias, sistemas e técnicas de gestão, sendo assim um fator determinante para garantir a sobrevivência da empresa.

O conceito de Hotelaria Hospitalar, que no Brasil nasceu há pouco menos de uma década, é cada vez mais difundido pelos hospitais em todas as regiões. Foi criado devido á necessidade emergente de vários fatores (BOEGER, 2003). Taraboulsi (2003) explica que a hotelaria hospitalar é uma tendência que veio para livrar os hospitais da "cara de hospital" e que traz em sua essência uma proposta de adaptação à nova realidade do mercado, modificando e introduzindo novos processos, serviços e condutas. Para Boeger (2003:24) "uma das definições mais objetivas para hotelaria hospitalar é a seguinte: Hotelaria Hospitalar é a reunião de todos os serviços de apoio, que, associados aos serviços específicos, oferecem aos clientes internos e externos conforto, segurança e bem-estar durante seu período de internação". Dias (2005) comenta que a hotelaria hospitalar não fazia parte do contexto do hospital brasileiro. Desde que o médico fosse competente e o hospital aparentemente limpo, nada mais importava para o paciente. O cliente-paciente, como tem sido mencionado por alguns autores, vai a procura de solução para os seus problemas e gosta de ser bem atendido.

Conforme o autor explica, antigamente o paciente ao entrar no hospital deixava de ter seus direitos de cidadão, de ter suas vontades, tinha apenas que fazer o tratamento. Esse tempo passou. Agora quem busca o hospital não é mais paciente, mas um cidadão que sabe dos seus direitos e suas responsabilidades. Mcgibony apud Trigo (2005:65) comenta "O sucesso do hospital está baseado numa tríade: 'Bom planejamento comunitário, bom projeto de construção e boa administração'. Em termos de cuidado aos pacientes, eficiência administrativa e serviços comunitários, a falta de um item desta combinação gera um hospital medíocre". Pela sua preocupação com o bem-estar, a hotelaria hospitalar visa, permanentemente, à busca de excelência, alinhando os objetivos do hospital com ato 


\section{Administração: caminhos para o desenvolvimento sustentável}

de hospedar, sem esquecer o tipo diferenciado de seus clientes, pois a hospitalidade hoje é uma ferramenta de gestão nas instituições de Saúde.

Com a alta tecnologia e a rápida troca de informações os clientes estão mais sabedores dos seus direitos e também mais exigentes quanto a qualidade. De acordo com Boeger (2003) essa situação não foge dos hospitais, que estão sendo obrigados a mudar o perfil do atendimento em todos os sentidos, para garantir a sobrevivência da empresa em um mercado cada vez mais competitivo. Taraboulsi (2003) comenta que várias instituições de saúde investiram na modernização, na pesquisa científica e na diversificação de processos de trabalho e serviços, tronando-se hospitais de primeiro mundo quanto aos aspectos tecnológico e científico. E esqueceram-se do cliente de saúde (pessoas enfermas, familiares, acompanhantes, visitantes) como um ser circunstancialmente fragilizado, constituído de emoções e sentimentos que exigem atenção e carinho. Watanabe (2010) diz que as medidas comumente adotadas como a introdução da tecnologia e a adoção de modelos de gestão como terceirização, parcerias e franquias, são evidências no aprimoramento das organizações. Isso demonstra a necessidade de implantação de um departamento específico da área hoteleira nos hospitais para um resultado melhor nos serviços prestados, ou uma comissão que cuide dos serviços que compõem a hotelaria (BOEGER, 2003).

Watanabe (2010) comenta que hospitais têm se adaptado à realidade de mercado, em que a competitividade, aliada às exigências cada vez maiores dos clientes, aumenta a busca pela qualidade na prestação dos serviços. A introdução de novas abordagens de gestão, portanto, tornou-se necessária para explorar as possibilidades que um hospital pode dispensar aos pacientes (físicoestruturais e humanas). Para Boeger (2003) a hotelaria hospitalar acabou tornando-se uma tendência irreversível em qualquer instituição de saúde, pois não se trata mais de uma opção da empresa, mas de uma exigência do público que frequenta hospitais e que começa a habituar-se aos serviços de hotelaria existentes. Trigo (2005) diz que a hotelaria é uma ferramenta que o hospital pode utilizar para melhorar o atendimento e o serviço. Porém, é necessário estar atento a atividade em que ela está inserida, para melhor servir e atingir os objetivos propostos com sua implantação. Segundo Boeger (2003) administrar o processo de criação, mudança ou ampliação de um hospital exige profundo conhecimento sobre as metas a serem alcançadas, relacionadas com o planejamento em todos os aspectos, dos processos de reestruturação e expansão da rede de saúde.

Dias (2005) afirma ainda que "Hoje, grande parte dos hospitais tem acesso às novas tecnologias, tornando-se indispensável à busca de um diferencial competitivo". A hotelaria hospitalar surgiu no 


\section{Administração: caminhos para o desenvolvimento sustentável}

Brasil há pouco mais de dez anos, é implantada nos hospitais com o intuito de ser um diferencial competitivo tornando o ambiente um lugar mais agradável suprindo as exigências dos usuários. Boeger (2003) comenta que a hotelaria em hospitais, hoje, é um conceito sólido, irreversível e necessário. Não é apenas mais um termo mercadológico, utilizado para demonstrar preocupação com o bem-estar dos clientes. O que era apenas um assunto se transformou em um departamento ou, então, é de responsabilidade de alguma diretoria, despontando entre os vários temas de importância na pauta de reuniões dos administradores, diretores e médicos.

Conforme ABIFICC (2010) é necessário entender que a Hotelaria Hospitalar também traz recursos, ou seja, ela também gera lucro e é um centro de negócios. Primeiramente, é necessário encontrar o equilíbrio, estabilizar o setor, mantendo controle efetivo das despesas e custos. Isto parece lógico, mas como muitos hospitais acreditam que isto não é possível ou não veem este serviço como um centro de negócios, então não buscam este equilíbrio e daí através do prejuízo buscam justificar o não investimento.

\section{ESTUDO DE CASO}

O Hospital Ana Costa S/A foi fundado em 12 de novembro de 1966, na Rua Pedro Américo, 60, com o intuito de complementar e melhorar o serviço que até então era prestado pelo Pronto-Socorro Ana Costa (primeiro pronto-socorro particular da cidade), o qual foi criado em 1957, pelos médicos João de Azevedo Lage e Jorge Armando de Oliveira, localizado na Avenida Dona Ana Costa, no 468, motivo pelo qual recebe o nome de Pronto-Socorro Ana Costa. No ano de 1970 a direção do Hospital Ana Costa cria um plano de saúde para atender inicialmente apenas planos empresariais, denominado Plano de Saúde Ana Costa. Em 1982, este plano passa a oferecer planos familiares e individuais.

Atualmente conta com unidades nas cidades do Guarujá, em São Vicente e na Praia Grande. Com unidades de fisioterapia, cardiologia, clínica geral, pediatria, traumatologia e oftalmologia. É uma empresa de grande porte formada por Sociedade Anônima de capital fechado. Composto por aproximadamente 1721 colaboradores, 1000 médicos em seu corpo clínico, além de prestadores de serviços (lavanderia, higienização, lanchonete, entre outros).

O HAC acredita ter como vantagem o fato de contar com a residência médica e convênio com as faculdades de medicina, mostrando sua preocupação com o ensino e atualização médica. Aliados a isso, o treinamento de seus funcionários, o investimento em tecnologia e a busca constante na 


\section{Administração: caminhos para o desenvolvimento sustentável}

melhoria do atendimento o diferencia dos demais concorrentes. Estruturado com 253 leitos para internação, distribuídos da seguinte forma:

- Apartamento: 83 Leitos;

- Enfermaria: 117 Leitos;

- Berçário: 02 Leitos;

- Unidade de Terapia Intensiva Geral: 26 Leitos;

- Unidade de Terapia Intensiva Cardiológica: 12 Leitos;

- Unidade de Terapia Intensiva Neonatal: 08 Leitos;

- Unidade de Terapia Intensiva Infantil: 05 leitos.

\section{PESQUISA}

O instrumental de pesquisa direcionado aos clientes foi aplicado nas dependências do hospital, com apoio do setor de Atendimento ao Cliente. Foram entrevistados 55 pacientes, abrangendo os quartos de enfermaria e particulares.

1) Por que escolheu este hospital? Do total de entrevistados $43 \%$ responderam que seu convênio só atende neste hospital.

2) Por quantos dias estiveram internado (a)? A maioria dos entrevistados, representados por $36 \%$ permaneceram internados entre quatro e seis dias.

3) Em que unidade você permaneceu durante o período que esteve no hospital? Das unidades acima mencionadas, $38 \%$ caracterizam-se por outros tipos de atendimentos, como exames, RX, etc.

4) Recepção? A maioria dos entrevistados representados por $49 \%$ avaliaram o hospital como possuidor de um bom serviço de recepção.

5) Instalações? Do total de entrevistados $47 \%$ classificaram as instalações do hospital como regular. Logo abaixo com $46 \%$ as instalações foram classificadas como bom seguido de ótimo com $7 \%$.

6) Alimentação? A maior parte dos entrevistados avaliou a alimentação como bom, representado por $55 \%$. 


\section{Administração: caminhos para o desenvolvimento sustentável}

7) Higienização? A grande maioria dos entrevistados representados por $89 \%$ classificam como boa a higiene do hospital.

8) Enxoval? Do total de entrevistados $47 \%$ avaliaram a parte de enxoval do hospital como bom. Muito próximo com 42\% Regular. Não souberam opinar representaram 5\%, avaliaram como ótimo $4 \%$ e apenas $2 \%$ classificaram o como ruim.

9) Médicos / Enfermagem? A maior parte dos entrevistados representados por $60 \%$ avaliam como bom o serviço dos médicos e de enfermagem.

O instrumental de pesquisa direcionado aos colaboradores foi aplicado nas dependências do hospital, localizado no prédio central. Foi entrevistada uma amostra de 61 colaboradores, aproximadamente $10 \%$ do total desta unidade. A pesquisa abrangeu os setores administrativos e parte da área técnica.

1) Treinamento? A grande maioria dos entrevistados representados por $65 \%$ responderam já ter recebido algum tipo de treinamento.

2) Comunicação interna? Do total de entrevistados $54 \%$ classificam como boa a comunicação entre os setores.

3) Conhecimento sobre hotelaria hospitalar? Do total de entrevistados $36 \%$ responderam ter baixo conhecimento sobre o serviço de Hotelaria Hospitalar na empresa.

4) Canais de comunicação? Dos entrevistados 34\% informaram ter conhecimento do setor de Hotelaria Hospitalar através da chefia, já 30\% disseram tomar conhecimento por meio do Jornal Interno da empresa.

5) A importância de o hospital dispor do serviço de hotelaria? A grande maioria representada por $51 \%$ responderam que o serviço de hotelaria agrega valor ao atendimento.

6) Mudanças após a implantação do setor de hotelaria hospitalar? Do total de colaboradores entrevistados $31 \%$ não souberam opinar sobre mudanças após a implantação da Hotelaria Hospitalar, já $24 \%$ avaliam como uma oportunidade de crescimento a empresa dispor de hotelaria.

7) Nível de satisfação? A grande maioria dos colaboradores representados por $46 \%$ classificam como médio o nível de satisfação dos pacientes com relação à implantação do setor de Hotelaria Hospitalar. 


\section{Administração: caminhos para o desenvolvimento sustentável}

8) Informação para o desempenho da função? A maior parte dos entrevistados representados por $75 \%$ avaliam como satisfeitos sobre a informação recebida da empresa para o desempenho de suas funções.

\section{ENTREVISTA COM O DIRETOR DA ORGANIZAÇÃO}

Foi realizada uma entrevista aberta e estruturada com o Diretor Administrativo da organização no dia 03 de setembro de 2009, em seu escritório. A entrevista teve duração de aproximadamente 30 minutos. O Diretor Marcio Assis, graduado em TI, tem experiência na gestão de alguns hospitais em São Paulo, entre eles Albert Einstein e São Camilo. O Sr. Marcio vem desenvolvendo vários projetos dentro do hospital, entre eles a implantação do setor de Hotelaria Hospitalar. A seguir relatório da entrevista:

Em entrevista, foi abordado sobre o motivo da implantação de um setor de Hotelaria Hospitalar, bem como os benefícios em relação ao tratamento e bem estar, não se esquecendo de mencionar a parte financeira do negócio. Conforme o Sr. Marcio existe uma barreira de modo geral que se aplica a todos os hospitais, o fato de tratar os pacientes como doentes tendo apenas a finalidade de obter a cura, porém durante o período de tratamento, se o doente estiver bem amparado, com conforto e tendo uma hospitalidade diferenciada, a recuperação desse paciente poderá ser mais rápida, com isso haverá ganho de tempo e uma melhor eficiência no tratamento do paciente.

Outro ponto mencionado pelo diretor foram algumas barreiras quanto à parte técnica, ou seja, a estrutura de um hospital não é igual a de um hotel. Toda a parte de mobiliário e higiene tem que passar por um estudo, uma análise de risco. Já na parte de higiene todo e qualquer enxoval antes de ser comprado tem que ser analisado pelo setor de Controle de Infecção Hospitalar, além de todo o acompanhamento do processo junto a área de enfermagem. Com relação a colocação de mobiliário não é diferente, tudo deve ser monitorado e aprovado pelo setor de Segurança do Trabalho, visando não colocar nenhum móvel que apresente um possível risco ao paciente.

Quando questionado sobre a mão de obra, o Diretor foi claro ao dizer que teve que mudar o quadro de pessoal dessa área, a implantação deste novo setor exigiu um profissional com uma olhar mais técnico, vindo da área de hotel e não com uma formação de enfermagem. Acrescentou que se não tivesse feito esta mudança, todo o projeto, bem como o trabalho em cima da implantação do novo setor estaria perdido. É importante que as áreas de enfermagem e de hotel estejam alinhadas, para que se tenha uma visão geral, tanto de um lado como do outro. 


\section{Administração: caminhos para o desenvolvimento sustentável}

O diretor foi enfático ao responder que a Hotelaria Hospitalar é um diferencial competitivo frente aos outros hospitais, no caso do HAC este novo segmento é uma maneira de aumentar a receita, pois a capacidade de ocupação está no limite, com isso o diferencial no atendimento e prestação de serviço difere a organização das outras. Explicou que a Hotelaria Hospitalar é uma nova visão de negócio, porém, advertiu que este novo negócio não é fácil de ser implantado, mas é algo que as organizações deste setor tendem a implantar. A valorização da infraestrutura e do tipo de atendimento prestado será cada vez mais um indicador de escolha do cliente.

\section{DISCUSSÃO DOS RESULTADOS}

A análise das informações obtidas com o questionário e a entrevista mostra que o serviço de atendimento no hospital se enquadra de forma satisfatória, pois grande parte dos entrevistados escolheu os serviços da organização pela fidelidade existente entre as partes. Este raciocínio vai de encontro a que Brown (2001) menciona, a fidelidade do cliente como algo que crie benefícios para o mesmo, fazendo com que ele mantenha e aumente suas compras junto à organização.

Dessa forma, de uma maneira geral o hospital vem proporcionando um bom atendimento aos seus usuários, o que torna o setor de Hotelaria Hospitalar peça chave neste processo, como propõe Boeger (2003), que a Hotelaria Hospitalar é a junção dos serviços de apoio, associados aos serviços específicos, oferecem conforto, segurança e bem-estar aos clientes internos e externos, durante o período de internação. Ressaltando a importância dos clientes internos dentro de uma organização, é importante mencionar que os clientes internos do HAC mostraram um conhecimento sobre a Hotelaria Hospitalar classificado como médio, com isso a organização deixa de contar com uma ferramenta importantíssima de divulgação, pois uma empresa prestadora de serviços mantém um relacionamento constante com clientes externos.

Em contrapartida, dos colaboradores entrevistados mais da metade veem a hotelaria Hospitalar como uma forma de agregar valor ao atendimento, o que vai de encontro com o que diz Taraboulsi (2003), que destaca que a Hotelaria Hospitalar traz em sua essência uma adaptação à nova realidade do mercado. Assim, o HAC tem colaboradores que entendem que dispor de um novo serviço traz um diferencial, portanto o aprimoramento dos mesmos faria com que a organização obtivesse uma força de divulgação e esclarecimento ainda maiores.

Analisando o parecer da alta direção quanto às barreiras existentes na implantação deste novo setor, vale ressaltar o que Boeger (2003) comenta em relação a administrar o processo de criação, mudança 


\section{Administração: caminhos para o desenvolvimento sustentável}

ou ampliação de um hospital exige profundo conhecimento sobre as metas a serem alcançadas, relacionadas com o planejamento em todos os aspectos. Neste sentido, dificuldades existem em qualquer organização, visto que organizações são sistemas abertos e em constantes mudanças, o que as tornam diferentes é a forma que a organização se prepara para enfrentá-las. O HAC vem trabalhando para que estas barreiras sejam superadas.

Sobre o fato da mudança no quadro de pessoal mencionado pelo Diretor Administrativo, vai de encontro com o que propõe Boeger (2003), da necessidade de implantação de um departamento específico da área hoteleira nos hospitais para um melhor resultado nos serviços prestados. O HAC segue essa linha de raciocínio mostrando que está embasado em fundamentos para tais mudanças.

O Diretor Administrativo declarou que a organização aposta na hotelaria hospitalar como um diferencial competitivo e uma maneira de aumentar a receita do hospital, pelo fato de operar com a capacidade máxima de ocupação. Confirma o que Boeger (2003) cita em relação ao fato da hotelaria hospitalar ter se tornado uma tendência irreversível em qualquer instituição de saúde, da exigência do público que frequenta hospitais e que começa a habituar-se a estes tipos de serviços de hotelaria.

Finalizando com o que o Diretor comentou sobre o fato da empresa ver a hotelaria como uma nova visão de negócio cruza principalmente com a citação da ABIFICC (2010), que entende a hotelaria hospitalar como um gerador de recursos, de modo a trazer lucro para a organização e também ser visto como um centro de negócios.

\section{CONCLUSÃO}

Este trabalho teve como objetivo identificar a Hotelaria Hospitalar como uma nova visão de negócio, de modo que a partir disto se tenha um diferencial competitivo frente aos concorrentes. $\mathrm{O}$ estudo de caso foi realizado num hospital privado de grande porte da cidade de Santos. Onde se teve a oportunidade de aplicar instrumentais de pesquisa, com total liberdade de acesso as áreas envolvidas diretamente na implantação e administração deste novo serviço.

Durante o desenvolvimento do trabalho procurou-se demonstrar que este novo serviço nos hospitais é algo a ser visto como uma nova visão de negócio, um diferencial competitivo, na visão de um administrador. O cliente hoje necessita de algo mais além do tratamento convencional de um hospital, ele necessita de um tipo de tratamento diferenciado e que faça com que a organização tenha uma visibilidade positiva, de modo a chamar sempre a atenção do cliente, familiares e amigos. Possuir um corpo clínico de ponta e tecnologia não é suficiente para os clientes cada vez mais exigentes e 


\section{Administração: caminhos para o desenvolvimento sustentável}

sabedores dos seus direitos. Algo importante a ser ressaltado são as mais diversas barreiras existentes na implantação de um novo setor como o de hotelaria onde estão relacionados à parte técnica, estrutural e de mão de obra especializada.

A pesquisa pode mostrar e visualizar o universo que abrange uma instituição de saúde dispor de um setor de hotelaria hospitalar. O Diretor Administrativo, em entrevista, informou que a organização aposta na hotelaria hospitalar como um diferencial competitivo e também uma maneira de aumentar a receita do hospital, pelo fato de operar com a capacidade máxima de ocupação. Além de ser um gerador de recursos, traz lucro para a organização e também pode ser visto como um centro de negócios. A diferença no atendimento prestado e na infraestrutura pode influenciar a escolha do cliente. Portanto a Hotelaria Hospitalar oferece a organização não só um atendimento mais hospitaleiro e humanizado, mas principalmente uma nova forma de adquirir receita para a instituição. Além de ser visto pela alta direção como um diferencial competitivo e uma nova visão de negócio, visto que este serviço ainda é pouco explorado na área da saúde.

\section{REFERÊNCIAS}

ABIFICC. Hotelaria hospitalar: investir para sobreviver [Online] // ABIFICC - Associação Brasileira de Instituições Filantrópicas de Combate ao Câncer. 2010 - Disponível

em: http://www.abifcc.org.br/oldnews/noti10012006.html. Acesso em 28 de abril de 2010.

BARBOSA, F. V. Competitividade: conceitos gerais. In: Competitividade, alianças estratégicas e gerência internacional. RODRIGUES, S. B. - São Paulo: Atlas, 1999.

BOEGER, M. A. Gestão em hotelaria hospitalar. São Paulo: Atlas, 2003.

BOGMANN, I. M. Marketing de relacionamento - estratégias de fidelização e suas implicações financeiras. São Paulo: Nobel, 2000.

BROWN, S. A. CRM - Customer Relationship Management. São Paulo: Makron Book, 2001.

CAMPOS, V. F. TQC: Controle da qualidade total (no estilo japonês). 2a ed. - Belo Horizonte: Bloch, 1992.

CARLETTO, B.; FRANCISCO A. C. de; PILATTI, L. A. Impactos do Sistema de Gestão da Qualidade para a competitividade da empresa: Caso lapó. ADM2005 - Congresso de Administração e 4ㅇ COMEXSUL Congresso Sul Brasileiro de Comércio Exterior. - Ponta Grossa: 2005.

CASTELLI, G. Administração hoteleira. 9ạ ed. Caxias do Sul: Educs, 2001.

DIAS, M. A. de A. Hotelaria hospitalar, uma tendência ou um modismo? Revista Hospitais Brasil. jan/fev de 2005. - n. 11: Vol. 3. - pp. 62-64. 


\section{Administração: caminhos para o desenvolvimento sustentável}

FERNANDES, A. Um hospital particular no Brasil. Santos: Cromosete, 2002.

FERREIRA, A. B. de H. Dicionário Aurélio. Rio de Janeiro: Nova Fronteira, 1985.

FIUZA, D. Definição de Hotel [Online] // Ambiente Verde. 2010 - Disponível em: http://ambienteverde.blogspot.com/2006/10/definio-de-hotel.html. Acesso em 02 de maio de 2010.

FNQ. Cadernos Compromisso com a Excelência: Clientes. Série Cadernos Compromisso com a Excelência / Fundação Nacional da Qualidade - São Paulo: Fundação Nacional da Qualidade, 2008.

GODOI, A. F. de Hotelaria hospitalar e humanização no atendimento em hospitais: pensando e fazendo. São Paulo: Ícone, 2004.

JURAN, J. A qualidade desde o projeto. 3a ed. São Paulo: Thomson Pioneira, 1997.

KOTLER, P.; ARMSTRONG, G. Administração de marketing: análise, planejamento, implementação e controle. 5ạ ed. São Paulo: Atlas, 2000.

KOTLER, P.; KELLER, K. L. Administração de marketing. 12a ed. São Paulo: Atlas, 2006.

MIRSHAWKA, V. Hospital: fui bem atendido, a vez do Brasil. São Paulo: Makron Books, 1994.

PORTER, M. E. Estratégia competitiva: técnicas para análise de indústrias e da concorrência. 7ạ ed. Rio de Janeiro: Elsevier Campus, 1986.

PORTER, M. E. Vantagem Competitiva - Criando e Sustentando um desempenho superior. Rio de Janeiro: Elsevier Campus, 1989.

SAEKI, T. J.; CORRÊA, A. K.; SOUZA, M. C. B. de M.; LANETTI, M. L. O psicodrama pedagógico: estratégia para a humanização das relações de trabalho. Rev. Bras. Enfermagem. - jan/fev de 2002. - n. 1: Vol. 55. - pp. 89-96.

STONE, M.; WOODCOC, K. N. Marketing de Relacionamento. São Paulo: Literatura Mundi, 1998.

TARABOULSI, F. A. Administração de hotelaria hospitalar. 2a ed. São Paulo: Atlas, 2003.

TRIGO, L. G. G. Análises regionais e globais do turismo brasileiro. São Paulo: Roca, 2005.

WATANABE, S. Hospitalidade: uma abordagem para melhoria da qualidade [Online] // Hospitalar. 2010. Disponível em: http://www.hospitalar.com/opiniao/opiniao_1176.html. Acesso em 09 de maio de 2010.

ZANON, U. Qualidade da assistência médico-hospitalar. Rio de Janeiro: Medsi, 2001.

ZOBOLI, E. L. C. P. Ética e administração hospitalar. São Paulo: Loyola, 2003. 


\section{Capítulo 5}

\section{TRANSFORMAÇÃO DIGITAL E A QUARTA REVOLUÇÃO INDUSTRIAL: TEORIA DA INOVAÇÃO DISRUPTIVA}

DOI: $10.37423 / 200300349$

Norberto Almeida De Andrade - norbertofatecsp@hotmail.com

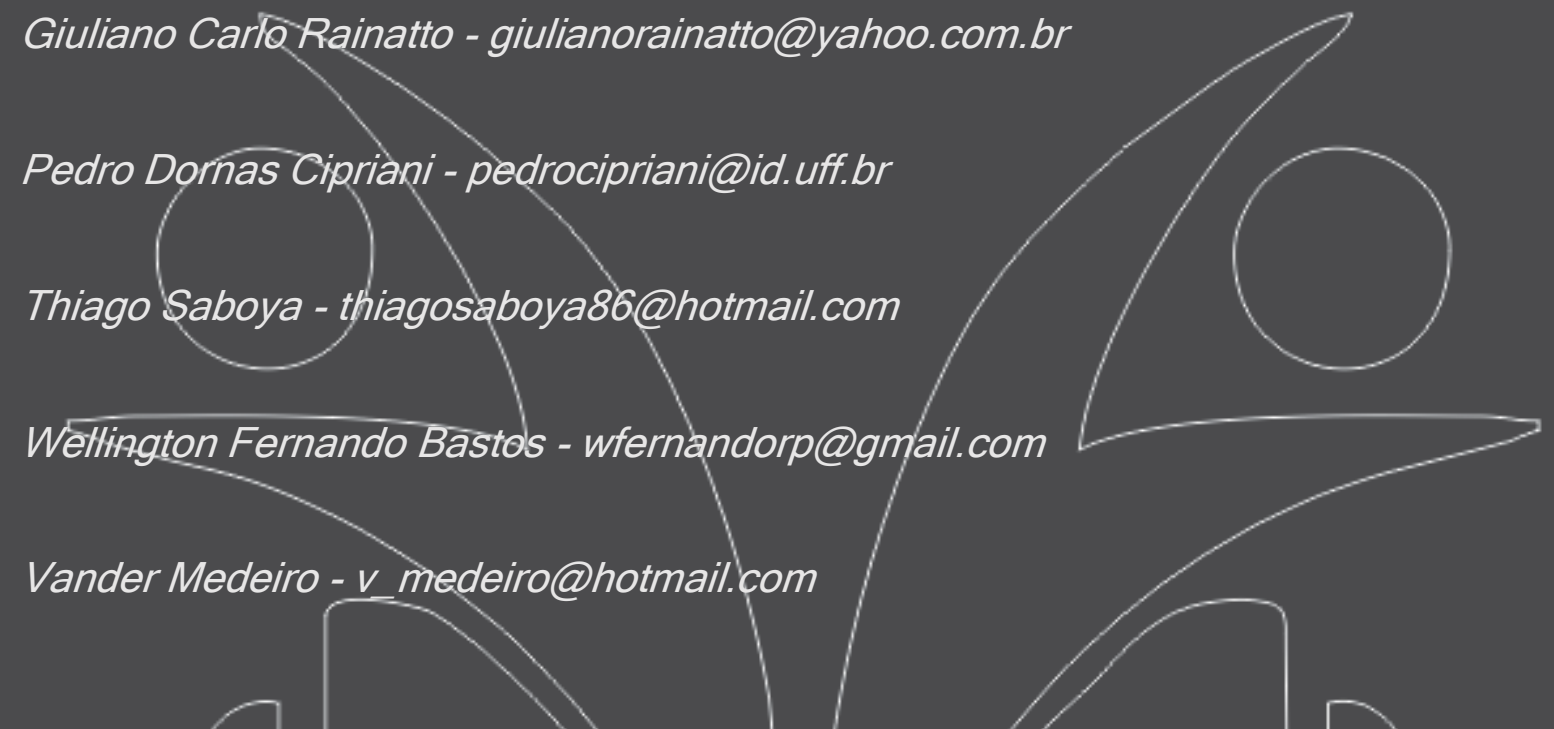

RESUMO: A Transformação Digital afeta indivídylos, empresás e a sociedade como um todo. Em particular, a rápida disseminaçẩo das tecnologias digitais estabelece uma enorme mudança de movimento. É essencial que as economias invistam contihuamente no desenvolvimento de infraestruturas digitąis para atehder à demanda existente e futura. Elas fornecem a base para muitos novos serviçds, aplicativos e modelos-de negócios. Também são cruciais para apoiar e viabilizà as inbvaçóes digitais que-estão transformando a proquçãe inclusive no contexto da Transformação Digital, Indústria 4.0 e Inovação Disruptiva. Tdealmente, esses planos devem abordar as principais barreiras à implañtação de redes e serviços de alta velocidade e incluir metas mensuráveis para enfrentar os desafios políticos associados à garantia de concorrência e investimento. 


\section{Administração: caminhos para o desenvolvimento sustentável}

Também é importante que esses planos incluam metas associadas aos importantes facilitadores técnicos, como acesso a pontos de troca e espectro da Internet, entre outros. Este artigo promove a reflexão sobre o desenvolvimento social, econômico e da administração intergeracional e uma visão para desenvolver, difundir e governar tecnologias de maneira a promover uma base mais colaborativa e sustentável em torno de todas estas transformações.

Palavras-chave: Transformação digital; Quarta revolução industrial; Inovação Disruptiva. 


\section{Administração: caminhos para o desenvolvimento sustentável}

\section{INTRODUÇÃO}

Na teoria dos negócios, uma inovação disruptiva é uma inovação que cria um novo mercado e uma rede de valor e, eventualmente, interrompe um mercado e uma rede de valores existentes, substituindo empresas, produtos e alianças estratégicas e líderes de mercado estabelecidos (Berman, 2012).

Nem todas as inovações são perturbadoras, mesmo que sejam revolucionárias. Por exemplo, os primeiros automóveis no final do século 19 não foram uma inovação disruptiva, porque os automóveis antigos eram itens de luxo caros que não perturbavam o mercado de veículos puxados por cavalos. 0 mercado de transporte permaneceu praticamente intacto até a estreia do Ford Modelo $\mathrm{T}$, de preço mais baixo, em 1908. O automóvel produzido em massa foi uma inovação disruptiva, porque mudou o mercado de transporte, enquanto os primeiros trinta anos de automóvel não mudaram (Maynard, 2015).

Inovações disruptivas tendem a ser produzidas por pessoas de fora e empresários em startups, em vez de empresas líderes de mercado existentes. O ambiente de negócios dos líderes de mercado não lhes permite buscar inovações disruptivas quando surgem pela primeira vez, porque não são rentáveis o suficiente no início e porque seu desenvolvimento pode afastar recursos escassos da sustentação de inovações (necessárias para competir contra a concorrência atual), (Peters, 2017).

Um processo disruptivo pode levar mais tempo para se desenvolver do que pela abordagem convencional e o risco associado a ele é maior do que as outras formas de inovação mais incrementais ou evolutivas, mas, uma vez implantado no mercado, atinge uma penetração muito mais rápida e um maior grau de impacto nos mercados estabelecidos. Além dos negócios e da economia, inovações disruptivas também podem ser consideradas como perturbadoras de sistemas complexos, incluindo aspectos econômicos e relacionados aos negócios (Schwab, 2017).

Em relação a esse processo em evolução da tecnologia, West (2018) retrata o que é e o que (não é) uma inovação disruptiva:

- A interrupção é um processo, não um produto ou serviço, que ocorre da periferia ao mainstream.

- Originam-se em bases de baixo custo (clientes menos exigentes) ou em novos mercados (onde não existiam). 


\section{Administração: caminhos para o desenvolvimento sustentável}

○ Novas empresas não atendem aos clientes tradicionais até que a qualidade atenda aos seus padrões.

- O sucesso não é um requisito e alguns negócios podem ser perturbadores, mas fracassam.

○ O modelo de negócios da nova empresa difere significativamente do atual.

As mudanças tecnológicas que prejudicam as empresas estabelecidas geralmente não são radicalmente novas ou difíceis do ponto de vista tecnológico. No entanto, eles têm duas características importantes: Primeiro, eles geralmente apresentam um pacote diferente de atributos de desempenho - que, pelo menos no início, não são valorizados pelos clientes existentes. Segundo, os atributos de desempenho que os clientes existentes valorizam melhoram a um ritmo tão rápido que a nova tecnologia pode invadir posteriormente os mercados estabelecidos (Schwab \& Davis, 2018).

Em 1979, o futurista Alvin Toffler popularizou o conceito de uma nova era da informação, sustentada por várias ideias-chave, incluindo a desmassificação da mídia, o fim da massa produção e consumo em massa, produtos personalizados serviços, descentralização, interatividade e total, mas emprego hiperflexível.

As tecnologias da informação e comunicação (TICs) passaram a representar de maneira abrangente imagens e expectativas do futuro. Esperanças de progresso contínuo, crescimento econômico, aprimoramento de habilidades e possivelmente também a democratização esteja ligada às novas TICs bem como temores de controle totalitário, alienação, perda de emprego e insegurança (Matt, Hess \& Benlian, 2015).

Atualmente, com os termos Indústria 4.0. e Quarta Revolução Industrial (QRI), referem-se à transformação incipiente da produção de bens e serviços resultantes da aplicação de um novo onda de inovações tecnológicas (Hirschi, 2018).

O elemento essencial dessa transformação é considerado o cruzamento entre produção, processamento processos e fluxos de informações on-line como, por exemplo: Internet das Coisas (IoT), Cloud, Big Data e dispositivos (sensores, chips) que comunicam-se independentemente entre si ao longo do cadeia de valor inteira. As empresas estabeleceriam redes globais incorporam suas 


\section{Administração: caminhos para o desenvolvimento sustentável}

máquinas, sistemas de armazenagem e instalações de produção na forma de sistemas ciber-físicos (SCF), (Chung \& Kim, 2016).

O Relatório do Fórum Econômico Mundial sobre O Futuro do Trabalho (2018) retrata a natureza mutável do trabalho e examina como a tecnologia molda a demanda relativa por certas habilidades nos mercados de trabalho e expande o alcance das empresas, robótica e tecnologias digitais, por exemplo, permitem que as empresas automatizem, substituindo o trabalho por máquinas para se tornar mais eficiente e inovar, expandindo o número de tarefas e produtos.

Ransome (2019) explica o processo de como a tecnologia disruptiva, através de sua rede de suporte necessária, transforma drasticamente uma determinada indústria. Quando surge a tecnologia que tem o potencial de revolucionar um setor, as empresas estabelecidas costumam vê-lo como pouco atraente: não é algo que seus principais clientes desejam e suas margens de lucro projetadas não são suficientes para cobrir a estrutura de custos das grandes empresas.

Como resultado, a nova tecnologia tende a ser ignorada em favor do que é atualmente popular entre os melhores clientes. Mas então outra empresa entra para trazer a inovação para um novo mercado. Depois que a tecnologia disruptiva é estabelecida lá, a inovação em menor escala aumenta rapidamente o desempenho da tecnologia em atributos que agregam valor aos clientes (Westerman, Bonnet \& McAfee, 2014).

A implementação de alta tecnologia é frequentemente resistida. Essa resistência é bem compreendida por parte dos participantes ativos. O carro elétrico será resistido por operadores de postos de gasolina da mesma maneira que caixas eletrônicos (ATM) foram resistidos por caixas bancárias e automóveis por fabricantes de cavalos (Willcocks \& Lacity, 2016).

De acordo com as principais representações da Indústria 4.0. instituições privadas e públicas, esperase que seus efeitos ser principalmente positivo, no que diz respeito à produtividade, às oportunidades econômicas e ao futuro do trabalho (Ustundag \& Cevikcan, 2017).

De acordo com a Comissão Europeia em Anais da Mesa Redonda Aberta sobre o Futuro do Trabalho (2018), a "Quarta Revolução Industrial" tem o potencial de aumentar os níveis de renda global e melhorar a qualidade de vida das populações em todo o mundo.

Os trabalhadores serão grandemente beneficiados por isso. $\mathrm{Na}$ luz da escassez iminente de trabalhadores qualificados, os trabalhadores mais velhos poderiam prolongar sua vida profissional. A organização flexível do trabalho permitiria que os trabalhadores combinassem seu trabalho e vidas 


\section{Administração: caminhos para o desenvolvimento sustentável}

privadas para continuar o desenvolvimento profissional mais promovendo um melhor equilíbrio entre vida profissional e pessoal (Colombo et al., 2017).

As consequências sociais da revolução da "Indústria 4.0 ", como o problema do desemprego e a composição mercado de trabalho em termos de qualificações profissionais, são mantidas em segundo plano (Chung \& Kim, 2016).

Os processos, mecanismos, oportunidades e ameaças que a literatura tem atribuído nos últimos anos as TICS, economia digital e "economia do conhecimento" - e em geral, às consequências das tecnologias digitais no trabalho e na produção - agora se tornam ainda mais radicais nas representações atuais da Indústria 4.0. por instituições públicas e privadas (Bloem et al., 2014).

Opiniões críticas sobre essas narrativas institucionais apontam principalmente duas questões problemáticas. Primeiro, o determinismo tecnológico é questionado. As tecnologias não são exógenas às estruturas sociais, mas elas estão incorporadas relações sociais e de poder, e eles não são neutros, mas aberto a certas opções sociais e fechado a outras. Segundo, efeitos da tecnologia sobre desemprego, condições de trabalho e organização do trabalho.não previsível (Morrar, Arman \& Mousa, 2017).

Tais mudanças no desempenho dos trabalhadores serviriam para garantir aumentos significativos produtividade e organizar processos onde as forças motrizes são habilidades rápidas de resolução de problemas, criatividade, habilidades cognitivas, linguísticas e sociais dos trabalhadores, bem como seu envolvimento total no processo de trabalho (Ustundag \& Cevikcan, 2017).

Estruturas excessivamente hierárquicas e excessivamente rígidas o controle do trabalho, de acordo com essas visões, impede produção e disseminação de conhecimento e informação. Essas mudanças no desempenho e na organização do trabalho considerariam o trabalho manual e não manual, setor industrial e de serviços, pois todos estão em diferentes maneiras afetadas pela atual centralidade de informação, conhecimento, comunicação e dados dentro processos de produção (West, 2018).

Os potenciais positivos agora atribuídos ao novo ciclo inovação evocam e expandem os atribuídos à ondas anteriores de inovação ligadas às TICS, e, mesmo antes, à transição do fordismo para o pósfordismo (Schwab, 2017).

As teorias sobre TICs enquadraram principalmente a nova fase de capitalismo como economia baseada no conhecimento considerando que as tecnologias digitais e as transformações organizacionais no capitalismo estejam na origem de uma sociedade societária geral mudança, definida alternadamente 


\section{Administração: caminhos para o desenvolvimento sustentável}

como sociedade baseada no conhecimento, sociedade virtual, sociedade da Internet, sociedade em rede, ciber- sociedade e capitalismo informacional ou digital (Berman, 2012).

Essas definições se referem à ideia que os processos de produção relacionados ao ITC determinem uma descontinuidade decisiva entre a sociedade moderna e a sociedade contemporânea (Matt, Hess \& Benlian, 2015).

As tecnologias da informação e comunicação (TICs) são provavelmente o setor que é mais emblemático do progresso e da inovação em toda a sociedade, tecnologicamente e economicamente. De fato, práticas de uso da tecnologia, emprego e trabalho organização do setor é pioneira em desenvolvimentos em outros setores (Morrar, Arman \& Mousa, 2017).

A razão óbvia é que esse setor desenvolve uma grande proporção das tecnologias que visivelmente mudar o trabalho e a vida em todas as sociedades e economias. Ele constrói suas práticas nas autoaplicações de suas próprias invenções. Simultaneamente, esses se difundem em outros setores e esferas de sociedade, mudando esses contextos e sendo adaptado a eles (Schwab \& Davis, 2018).

Nas representações atuais da Indústria 4.0. o nexo entre inovação tecnológica e tomada de decisão horizontal, difusão de responsabilidades e aumento de autonomia, criatividade e habilidade entre os trabalhadores, é estendido ainda mais.

Conforme Kine (2019) os funcionários serão apoiados em seu trabalho por sistemas de assistência multimodal e fácil de usar interfaces de usuário. Além de treinamento abrangente e organização e desenho do trabalho, modelos serão fundamentais para permitir uma transição bem-sucedida que é bem-vindo pela força de trabalho (Maynard, 2015).

Esses modelos deve combinar um alto grau de auto-regulação autonomia com abordagens descentralizadas de liderança e gestão. Os funcionários devem ter maior liberdade para tomar suas decisões, se tornam mais ativamente envolvidos e regular sua carga de trabalho (Cherry, 2015).

De acordo com a maioria da literatura sobre economia baseada no conhecimento, capitalismo digital e narrativas tecno-otimistas sobre a quarta revolução industrial, a humanidade ficará amplamente livre do ônus do trabalho manual duro e da autonomia e criatividade dos trabalhadores serão desagregados (Bloem et al., 2014).

A QRI criará um conjunto de escravos tecnológicos, ou seja, máquinas e robôs capazes de responder a comandos vocais ou comportamento não planejado, orientado para uma função finalidade. Assim, a capacidade de manipular símbolos, especificamente de um tipo lógico-matemático, tornaria-se o 


\section{Administração: caminhos para o desenvolvimento sustentável}

valor norteador dos novos laboratórios especializados. Trabalhadores do conhecimento, aqueles que organizarão e administrarão o processos de trabalho e constituirá a nova elite, baseada em mérito e não nas classes sociais ou no controle do capital (Schwab \& Davis, 2018).

Essas representações, no cenário atual, correspondem a fenômenos reais? Esta é a questão no cerne deste trabalho, que visa analisar o impacto atual e potencial - de inovação tecnológica no trabalho. Primeiro, será feita uma revisão das representações institucionais Indústria 4.0, com base nos relatórios oficiais produzidos por instituições públicas e privadas (Peters, 2017).

Segundo, o estado da arte sobre "trabalho digital" será analisada, com base nas literatura e evidência. Sendo o processo da Indústria 4.0. ainda incipiente e seu impacto no trabalho ainda imprevisível, uma análise de suas possíveis conseqüências só pode foco no cenário atual, ou seja, nas tendências em andamento e as consequências já observáveis das tecnologias digitais no trabalho (Ransome, 2019).

A análise será concentrada na relação entre retórica acadêmica e institucional sobre Indústria 4.0. capitalismo digital - que, como temos já visto, evoca rigorosamente e expande a retórica anterior sobre a economia baseada no conhecimento pós-fordismo e a evidência empírica no trabalho digital (Morrar, Arman \& Mousa, 2017).

\section{NARRATIVAS INSTITUCIONAIS E CORPORATIVAS NA INDÚSTRIA 4.0}

Indústria 4.0. é considerada parte integrante da ampla economia. Segundo Colombo et al., (2017), grande parte dos esboços emergentes da literatura sobre economia digital, como a chegada das informações e conhecimentos há muito anunciada, mas recentemente passaram por uma reinterpretação, enquanto outros foram debatidos no corpo substancial da literatura publicada sobre a nova economia ou economia digital por volta da primeira década do novo século.

Conforme Ransome (2019) esses esboços podem ser resumidos da seguinte forma:

1. A informação digital tornou-se um recurso estratégico, e a rede se tornou a principal organizadora princípio da economia e da sociedade como um todo.

2. A economia digital segue os princípios de crescimento retornos (externalidades positivas da rede) e zero ou custos marginais quase zero. Críticas foram feitas a esse princípio. Primeiro concentra-se exclusivamente em externalidades positivas da rede e ignora 
externalidades negativas, em particular preocupações ambientais, como o consumo de eletricidade e recursos minerais escassos e as produção de lixo eletrônico. Além disso, os ganhos eficiência e rentabilidade geradas pelo investimento tecnológico em qualquer sistema técnico são inicialmente muito alto, mas depois declina e se torna cada vez mais incremental à medida que a inovação se generaliza. A longo prazo, esse "esgotamento" tecnológico significa que inovações geram retornos decrescentes até a sistemas técnicos são regenerados por inovações radicais.

3. Novos modelos de negócios estão surgindo para tirar proveito dos mercados frente e verso e da plataforma economia, particularmente as que envolvem colaboração ou compartilhamento e nova dinâmica competitiva - dominada pelo modelo "o vencedor leva tudo" - está se apoderando mercados de bens e serviços digitais. A plataforma em si é, portanto, o local primário de valor criação para ambos os lados. O valor de um serviço para o atores de um lado do mercado se correlaciona com a número e qualidade dos atores, por outro. Exemplos de plataformas que correspondem a este A descrição inclui Google, Booking, Uber, Amazon e muitos outros. O recém-desenvolvido sistema baseado em plataforma modelo de negócios reescreveu as regras da concorrência nos setores de mercado em que essas plataformas operam promovendo uma abordagem de "o vencedor leva tudo".

4. Indústria 4.0. envolve pequenas tiragens de bens personalizados em massa, a fragmentação global do valor cadeias, a criação de redes de capacidades produtivas e o embaçamento das fronteiras entre produtores, vendedores e consumidores, por um lado, e a indústria e os setor de serviços, por outro.

5. A ligação de causa e efeito entre inovação tecnológica e ganhos de produtividade ainda não foi diretamente estabelecida e a relação entre tecnologia e a produtividade ainda é fortemente ditada pela sociedade 


\section{Administração: caminhos para o desenvolvimento sustentável}

aceitação de inovações e mudanças organizacionais dentro das empresas.

Vamos nos concentrar no ponto de maior interesse deste artigo, a Indústria 4.0., resumindo as principais perspectivas incluídas nos relatórios institucionais, narrativas institucionais e corporativas na indústria 4.0.

O processo de inovação definido como Indústria 4.0. ou a Quarta Revolução Industrial é baseada em uma nova onda de inovações tecnológicas: robôs colaborativos interconectados; machine learning; inteligência artificial; impressoras 3D; simulação de máquinas interconectadas; integração do fluxo de informações ao longo do cadeia de valor, do fornecedor ao consumidor; comunicação multidirecional entre processos de fabricação e produtos (internet das coisas); gestão de grandes quantidades de dados em sistemas abertos (computação em nuvem); e análise de grandes bancos de dados para otimizar produtos e processos (Big Data e Analytics), (Schwab \& Davis, 2018). objetivo final da Indústria 4.0 é alcançar um novo nível de automação baseado em peças descentralizadas e inteligentes da cadeia produtiva, capazes de reagir autonomamente a estímulos externos. O objetivo dessa concepção é gerenciar as crescentes demandas de flexibilidade dos mercados finais, individualização crescente de produtos, ciclos de vida cada vez menores, bem como a crescente complexidade de cadeias de processo e os próprios produtos (Ustundag \& Cevikcan, 2017). Em outras palavras, o existente limites tecnológicos e econômicos da automação devem ser quebrado e estendido precisamente em resposta ao novo demandas colocadas pela flexibilidade. Indústria 4.0. é, portanto, um projeto de integração da produção em toda a cadeia de valor. O fluxo apertado é possível através da conexão digital de diferentes partes da linha de produção, não apenas aquela interno da empresa, mas de toda a cadeia de suprimentos; a conexão não seria apenas entre máquinas, mas entre máquinas e homens (Hirschi, 2018).

De acordo com as principais descrições sobre os possíveis cenários, no ambiente de fabricação, os sistemas cyber-físicos compreenderão máquinas inteligentes, armazenamento sistemas e instalações de produção capazes de autonomamente troca de informações, desencadeamento de ações e controle um ao outro de forma independente (Kane et al., 2015). Mais em geral, computacional design, fabricação aditiva, engenharia de materiais e a biologia sintética será combinada para abrir caminho para uma simbiose entre micro-organismos, nossos corpos, produtos que consumimos e até edifícios que habitamos (Matt, Hess \& Benlian, 2015). 


\section{Administração: caminhos para o desenvolvimento sustentável}

De acordo com Chung \& Kim (2016), uma quarta revolução industrial está se construindo na terceira, a revolução digital que vem ocorrendo desde meados do século passado. É caracterizada por um fusão de tecnologias que está borrando as linhas entre as esferas física, digital e biológica.

Há três razões pelas quais as transformações de hoje representam não apenas um prolongamento da Terceira Revolução Industrial, mas sim a chegada de um Quarto e distinto: velocidade, escopo e sistemas impacto. A velocidade dos avanços atuais não tem precedente histórico (Matt, Hess \& Benlian, 2015).

Quando comparado com as anteriores revoluções industriais, a Quarta está evoluindo a um exponencial e não linear. Além disso, está interrompendo quase todos os setores em todos os países. E a amplitude e profundidade dessas mudanças anunciam a transformação de sistemas inteiros de produção, gestão e governança (Willcocks \& Lacity, 2016).

Fabricantes adotando robôs, permitindo mais mercadorias produzidos enquanto empregam menos trabalhadores na algumas instalações. Inteligência Artificial em suas muitas manifestações também promete promessa de transformar a base da economia crescimento para países em todo o mundo; um recente análise de 12 economias desenvolvidas (incluindo Estados Unidos) descobriram que a IA tem potencial para taxas de crescimento econômico anual dobradas nos países analisados até 2035, (Ransome, 2019).

No geral, de acordo com essas visões, os efeitos que a Quarta Revolução Industrial pode ter nos negócios considera quatro domínios principais: (a) expectativas dos clientes; (b) aprimoramento do produto; (c) inovação colaborativa; (d) formas organizacionais (Morrar, Arman \& Mousa, 2017).

Produtos físicos e serviços agora podem ser aprimorados com recursos digitais que aumentam seu valor. Novas tecnologias tornam ativos durável e resistente, enquanto os dados e análises são transformando como eles são mantidos. Enquanto isso, um mundo de experiências do cliente, serviços baseados em dados e desempenho de ativos por meio de análises requer novos formulários colaboração, particularmente dada a velocidade com que inovação e interrupção estão ocorrendo. E o surgimento de plataformas globais e outros novos negócios modelos, finalmente, significa que talento, cultura e formas organizacionais terão que ser repensados (Maynard, 2015).

Indústria 4.0. implicaria um duplo processo de e integração vertical. Nos campos da engenharia de produção e automação e TI, a integração horizontal refere-se à integração dos vários sistemas de TI usados nas diferentes etapas do processos de fabricação e planejamento de negócios, que envolvem 


\section{Administração: caminhos para o desenvolvimento sustentável}

uma troca de materiais, energia e informação dentro de uma empresa (por exemplo, logística de entrada, produção, logística de saída, marketing) e entre várias empresas diferentes redes de valor (Peters, 2017).

O objetivo dessa integração é fornecer uma solução de ponta a ponta. Nos campos de engenharia de produção e automação e TI, vertical integração refere-se à integração dos vários sistemas de TI nos diferentes níveis hierárquicos (por exemplo, o atuador e sensor, controle, gerenciamento de produção, fabricação e execução e níveis de planejamento corporativo) em ordem, mais uma vez, para fornecer uma solução de ponta a ponta (Morrar, Arman \& Mousa, 2017).

Schwab \& Davis (2018) afirmam que a indústria 4.0. tem estes potenciais: (a) atender aos requisitos individuais do cliente. O setor 4.0 permitiria indivíduos específicos do cliente critérios a serem incluídos nas fases de projeto, configuração, pedido, planejamento, fabricação e operação e permite que alterações de última hora sejam incorporadas (Hirschi, 2018); (b) flexibilidade, a rede adhoc permite a configuração dinâmica de diferentes aspectos dos processos de negócios. Isto significa que os processos de engenharia podem ser mais ágeis, processos de fabricação podem ser alterados, temporários escassez (por exemplo, devido a problemas de fornecimento) pode ser compensada e enormes aumentos na produção podem ser alcançados em um curto espaço de tempo espaço de tempo (Colombo et al., 2017); (c) Tomada de decisão otimizada. Indústria 4.0 fornece transparência de ponta a ponta em tempo real, permitindo verificação antecipada das decisões de projeto na esfera de engenharia e respostas mais flexíveis à interrupção e otimização global em todos os sites de uma empresa em a esfera da produção (Chung \& Kim, 2016); (d) Produtividade de recursos e eficiência. 0 CPS permite que os processos de fabricação sejam otimizado caso a caso em todo o valor rede. Além disso, ao invés de ter que parar a produção, sistemas podem ser continuamente otimizados durante a produção em termos de recursos e consumo de energia ou reduzindo suas emissões (Kane et al., 2015); (e) Criando oportunidades de valor através de novos serviços. Indústria 4.0 abre novas formas de criação de valor e novas formas de emprego, por exemplo através de serviços a jusante. Algoritmos inteligentes podem ser aplicados a grandes quantidades de dados diversos (big data) gravado por dispositivos inteligentes para fornecer serviços inovadores. Existem oportunidades particularmente significativas para as PMEs e startups para desenvolver serviços B2B (business to business) para a Indústria 4.0 (Schwab, 2017); (f) Resposta a dados demográficos mudança no local de trabalho. Em conjunto com o trabalho iniciativas de organização e desenvolvimento de competências, a colaboração interativa entre seres humanos e sistemas tecnológicos fornecerá às empresas novas 


\section{Administração: caminhos para o desenvolvimento sustentável}

maneiras de transformar as mudanças demográficas em seu proveito. No face à escassez de mão de obra qualificada e à crescente diversidade da força de trabalho (em termos de idade, gênero e cultural), a Indústria 4.0 possibilitará diversas e planos de carreira flexíveis que permitirão que as pessoas continuem trabalhando e permaneça produtivo por mais tempo (Ustundag \& Cevikcan, 2017); (g) Equilíbrio trabalho-vida pessoal. Os modelos mais flexíveis de organização do trabalho das empresas que usam sistemas cyber-físicos significa que estão bem posicionados para atender à necessidade crescente de funcionários para encontrar um melhor equilíbrio entre o trabalho e a vida privada e também entre desenvolvimento pessoal e desenvolvimento profissional contínuo (Schwab \& Davis, 2018).

De acordo com Ransome (2019) a transformação digital é constituída pela Internet das Coisas: Ela descentralizará a produção, permitindo flexibilidade, formas de fabricação programáveis e incorporadas.

Comunicação máquina a máquina em tempo real oferecidos pela loT sincronizarão sistemas de produção complexos e avançados, criando cadeias de valor altamente inovadoras que abrangem os setores tradicionais e domínios. Formas avançadas de fabricação serão impulsionar o design de novos materiais, desfocando a linha entre fabricação e montagem (Hirschi, 2018).

A indústria dará um grande impulso ao gerenciamento e reciclagem do ciclo de vida. Com base no próximo passo na digitalização, um foco de negócio poderia ser o uso de informações como uma nova fonte de criação de valor, uma vez que os sensores e a abordagem centrada na rede levarão a uma quantidade de dados (Bloem et al., 2014). Esta informação pode ser usada para alinhar ainda mais as atividades da cadeia de valor e melhorar a comunicação entre as organizações. Também pode ser usado para aumentar as qualidades do produto com novos Serviços. Com a ajuda de sensores inteligentes e $\mathrm{Tl}$, o fabricante pode prever a necessidade de manutenção e pode ajudar clientes em todo o mundo com TI atualizações (Cherry, 2015).

A coleta de todos os tipos de dados (por exemplo sobre o ambiente) pode ser traduzido em grupos de novos e inesperados serviços intersetoriais. De acordo com a Comunidade Europeia (p. 74, 2018) "No futuro, as tecnologias inovação também levará a um milagre do lado da oferta, com ganhos a longo prazo em eficiência e produtividade. Os custos de transporte e comunicação cairão, logística e cadeias de suprimentos globais se tornarão mais eficazes, e as o custo do comércio diminuirá, e todos abrirão novos mercados e impulsionar o crescimento econômico". 


\section{Administração: caminhos para o desenvolvimento sustentável}

De acordo com Peters (2017) sobre inteligência artificial e economia da automação: "A automação orientada por IA pode ajudar impulsionar o crescimento total da produtividade dos fatores e criar novas potencial para melhorar a vida das pessoas em geral ".

No que diz respeito ao trabalho, de acordo com esses relatórios, a implementação da visão da Indústria 4.0 permitir que os funcionários controlem, regulem e configurem redes de recursos de fabricação e etapas de fabricação com base em alvos sensíveis à situação e ao contexto (Maynard, 2015).

Os funcionários ficarão livres de ter que realizar tarefas de rotina tarefas, permitindo que eles se concentrem em atividades criativas, com valor agregado. Assim, eles manterão um papel fundamental, particularmente termos de garantia de qualidade. Ao mesmo tempo, flexibilidade condições de trabalho permitirão maior compatibilidade entre o trabalho e a vida (Westerman, Bonnet \& McAfee, 2014).

Organização do trabalho e modelos de design pode ser a chave para permitir uma transição bemsucedida que seja bem-vinda pela força de trabalho. Esses modelos devem combinar uma alta grau de autonomia autorregulada com descentralização abordagens de liderança e gestão (Willcocks \& Lacity, 2016).

Os funcionários devem ter maior liberdade para tomar suas próprias decisões, tornar-se ativamente envolvidos e regulam sua própria carga de trabalho. Temos, portanto, uma confirmação adicional de que, do ponto de vista visão do trabalho, a retórica sobre a Indústria 4.0. são os mesmo que aqueles relacionados ao pós-fordismo, a economia baseada em conhecimentos e a digitalização(Morrar, Arman \& Mousa, 2017).

Chung \& Kim (2016) retratam também um ponto crucial de análise relativo à questão do desemprego. Isto é o único ponto em que as previsões otimistas de público e instituições privadas no novo ciclo de inovação mostram algumas incerteza, embora em um contexto que busque destacar oportunidades mais do que riscos.

A Organização para Cooperação e Desenvolvimento Econômico, destaca que a automação tem como alvo tarefas e não ocupações. Muitas ocupações provavelmente mudarão, já que algumas suas tarefas associadas se tornam automatizáveis, de modo que a OCDE $A$ análise conclui que relativamente poucos serão inteiramente automatizado, estimando que nos EUA apenas $9 \%$ dos empregos são em risco de ser completamente deslocado. Se essas estimativas de empregos ameaçados se traduzem em 


\section{Administração: caminhos para o desenvolvimento sustentável}

deslocamento de emprego, milhões de Os americanos terão seus meios de subsistência significativamente alterados (Ransome, 2019).

O relatório do governo dos EUA identificou quatro categorias de empregos que podem sofrer diretos de IA crescimento no futuro. Emprego em áreas onde os seres humanos interajam com as tecnologias existentes de IA, desenvolva novas tecnologias, supervisionar as tecnologias de IA na prática e facilitar as mudanças sociais que acompanham as novas tecnologias de IA provavelmente crescerá. Limites atuais de destreza manual de robôs e restrições à inteligência generativa e à criatividade das tecnologias de IA provavelmente significam que o emprego exigindo destreza manual, criatividade, interações sociais e inteligência, e o conhecimento geral prosperará (Schwab \& Davis, 2018).

O estudo do Fórum Econômico Mundial (2018) prevê que 5 milhões de empregos serão perdidos antes de 2020, como inteligência artificial, robótica, nanotecnologia e outras tecnologias socioeconômicas e outras tecnologias que substituem a necessidade de trabalhadores humanos.

De acordo com este estudo, esses mesmos avanços tecnológicos também criar 2,1 milhões de novos empregos. Mas é improvável que trabalhadores que se encontrem desempregados possuam as habilidades necessárias para competir pelos novos papéis.

A maioria novos empregos estarão em áreas mais especializadas, como computação, matemática, arquitetura e engenharia. Habilidades como compartilhar e negociar serão cruciais. O futuro local de trabalho, onde as pessoas se deslocam entre diferentes papéis e projetos, assemelhar-se-á às salas de aula pré-escolares, onde aprender habilidades sociais como empatia e cooperação.

Segundo Hirschi (2018), nos últimos anos, muitos empregos requerendo apenas habilidades matemáticas foram automatizadas. Caixas bancários e funcionários estatísticos sofreram. Funções que exigem habilidades predominantemente sociais trabalhadores, por exemplo) tendem a ser mal pagos porque de trabalhadores em potencial é muito grande. Portanto, trabalhadores que combinar com sucesso habilidades matemáticas e interpessoais nas economias baseadas no conhecimento do futuro muitas oportunidades gratificantes e lucrativas. Este tipo de trabalhador parece um robô empático.

O estudo da European Trade Union Institute - ETUI (2018) estima que os trabalhadores menos instruídos têm maior probabilidade de substituídos pela automação do que os altamente qualificados. De fato, os autores do estudo da OCDE estimam que 44\% dos americanos trabalhadores com menos de um diploma de segundo grau mantêm empregos tarefas altamente automatizáveis, enquanto 1\% das pessoas com o diploma de bacharel ou superior detém esse emprego. Para o grau que educação 


\section{Administração: caminhos para o desenvolvimento sustentável}

e salários estão correlacionados com habilidades, implica um grande declínio na demanda por trabalhadores menos qualificados e pouco declínio na demanda por trabalhadores mais qualificados.

Essas estimativas sugerem uma continuação do viés de habilidade mudança técnica no curto prazo. Isso dará origem a uma mercado de trabalho cada vez mais segregado nos segmentos " baixa qualificação / baixo pagamento " e " alta qualificação / alta remuneração ", que por sua vez levará a um aumento das tensões sociais (Ransome, 2019).

A tecnologia é uma das principais razões pelas quais a renda estagnaram, ou até diminuíram, para a maioria da população em países de alta renda: a demanda por trabalhadores altamente qualificados aumentou enquanto a demanda por trabalhadores com menos escolaridade e menor qualificação diminuíram (Schwab \& Davis, 2018).

O resultado é um mercado de trabalho com uma forte demanda nas altas e extremidades baixas, mas um esvaziamento no meio. Isso também ajuda a explicar por que as classes médias de todo o mundo são experimentando cada vez mais um sentimento generalizado de insatisfação e injustiça (Matt, Hess \& Benlian, 2015).

Uma economia de "Vencedor leva tudo" que oferece apenas acesso limitado à classe média é uma receita para mal-estar democrático e abandono. A pesquisa, de acordo com esses estudos institucionais, constata consistentemente que os trabalhos ameaçados pela automação estão altamente concentrados entre os que têm salários mais baixos, os menos qualificados, e trabalhadores menos instruídos. Isso significaria que a automação continuará pressionando a demanda por grupo, pressionando os salários para cima e para baixa pressão sobre a desigualdade (Colombo et al., 2017).

No longo prazo, pode haver efeitos diferentes ou maiores. Uma possibilidade é preconceituosa com uma estrela mudança tecnológica, onde os benefícios da tecnologia acumular para uma parcela ainda menor da sociedade do que apenas altamente trabalhadores qualificados. A natureza da informação que mais leva o vencedor mercados de tecnologia significa que apenas alguns podem chegar a dominar mercados (Peters, 2017).

De acordo com o Fórum Econômico Mundial (2018), se o trabalho os aumentos de produtividade não se traduzem em aumentos salariais, então os grandes ganhos econômicos trazidos pela IA, aprendendo máquinas e outras tecnologias podem resultar em poucos. Em vez de uma prosperidade amplamente compartilhada entre trabalhadores e consumidores, isso pode levar à redução da concorrência e aumento da desigualdade de riqueza. 


\section{Administração: caminhos para o desenvolvimento sustentável}

\section{ECONOMIA DIGITAL, TRABALHO DIGITAL E SUAS AMBIVALÊNCIAS}

Vamos ver, à luz da literatura e das evidências disponíveis no cenário atual do trabalho digital, as críticas que podem ser feitas às perspectivas institucionais sobre trabalhar na época da "Quarta Revolução Industrial" e principais premissas incluídas no processo institucional. Uma primeira questão diz respeito ao determinismo tecnológico. Relatórios institucionais e literatura mainstream fazem processo, inovações organizacionais e de produtos e a reestruturação do ciclo de negócios, direta e imediatamente derivam da própria natureza das tecnologias, como se estas eram autônomos das relações sociais existentes entre as forças produtivas (Schwab \& Davis, 2018). Pelo contrário, os efeitos das tecnologias em empregos e organizações devem ser consideradas socialmente moldadas (Peters, 2017).

De acordo com Matt, Hess \& Benlian (2015) é a política e não as características imanentes das tecnologias que decidirão como as novas máquinas são projetadas. A tecnologia é frequentemente usada como pretexto ou oportunidade de promover processos de reestruturação industrial motivados principalmente pela rentabilidade financeira, redução de custos salariais ou considerações de concorrência internacional. Além disso, as inovações tecnológicas não preveem consequência prescrita sobre empregos e organização em si. Hirschi (2018) identifica três dimensões: (1) efeitos pretendidos ou não intencionais. Algumas tecnologias são introduzido com fins claros à vista. Em outros casos, efeitos resultam da interação entre forças de produção e processos sociais. (2) efeitos diretos ou indiretos. Muitas tecnologias têm efeitos indiretos em dois sentidos. Primeiro, eles afetam trabalhadores que não são eles próprios sujeitos à tecnologia, por exemplo, onde uma linha de montagem é acompanhada de alterações no trabalho de pessoas em operações auxiliares. Segundo, os efeitos podem contribuir para uma maior organização arranjos. Quanto mais houver tais efeitos, mais complexa a questão de como responder será. Esta ideia abraça a abrangência de uma tecnologia em termos de impacto geral no sistema econômico. Algumas tecnologias aplicações específicas, enquanto outras, como as TIC, são extremamente difundido. (3) O grau em que uma tecnologia é reconstituído em uso. Não é a tecnologia em si, mas o extensão do seu uso que se altera.

Conforme Ustundag \& Cevikcan (2017) o investimento em tecnologias ITC registra aumento da produtividade, mas esses investimentos determinam apenas os efeitos da microeconomia, porque esses ganhos custam às empresas investidoras menos eficientes. Segundo, existe uma diferença entre o crescimento exponencial do desempenho tecnológico, por um lado, e a taxa mais lenta em que inovações são adotadas e apropriadas pelas empresas e outras organizações, por outro (West, 2018). 


\section{Administração: caminhos para o desenvolvimento sustentável}

Uma tecnologia precisa "Em qualquer lugar" antes que seu impacto na produtividade possa ser avaliado. Terceiro, os ganhos de produtividade são um corolário da mudanças organizacionais facilitadas por inovações tecnológicas e não pelas próprias tecnologias, e serão alcançados apenas por empresas que adotam novas formas de organização do trabalho ao mesmo tempo que as novas tecnologias (Westerman, Bonnet \& McAfee, 2014).

No que diz respeito à organização do trabalho, uma interpretação amplamente compartilhada pela maioria das perspectivas sobre novas tecnologias e trabalho baseado em conhecimento, estabelece um estreito vínculo entre os atuais ciclo de inovação e formação de um novo tipo de organização de negócios (Cherry, 2015).

A metáfora usada com mais frequência é o da "empresa de rede": nas empresas autogerenciadas unidades de processo, equipes de projeto, organizações temporárias que produzir e gerenciar processos de inovação e resolução de problemas (Bloem et al., 2014).

As grandes corporações são mesmo denominadas "organizações baseadas em projetos" ou "ambientes de múltiplos projetos". Projetos são configurações temporárias de recursos (humanos) situado dentro de uma organização "permanente" maior, onde indivíduos têm outras "casas" antes, durante e depois estar envolvido nesta organização temporária. Funcionários e freelancers - devido às tecnologias ITC - podem participar de vários projetos simultaneamente, para uma ou mais empresas, potencialmente assumindo papéis e responsabilidades diferentes em cada um (Berman, 2012).

Isso individualiza as relações de trabalho e pode ajudar os trabalhadores a se tornarem mais autônomos respeito às empresas. Informação e conhecimento como insumos e resultados do processo de trabalho, de acordo com essas visões, resistir a processos formalizados e rígidos, enquanto funcional para seu desenvolvimento é a presença de "comunidades" dentro a organização que cria um senso de identidade e o compartilhamento de valores e propósitos, parcialmente autogerenciados processos de cooperação, modos de circulação do conhecimento e compartilhamento e intensificação de ações internas e externas de comunicação (Schwab, 2017).

Competências linguísticas, éticas tendências e aspectos da subjetividade tornam-se meios de produção e resultados do processo, e essa 'imaterialidade' dos atores e os meios de produção dificultar a subjugação do trabalho vivo ao capital, porque o trabalho está cada vez mais conectado a faculdades e habilidades que pertencem aos próprios trabalhadores, bem como aos processos que exigem pelo menos autonomia parcial para executar (Colombo et al., 2017). 


\section{Administração: caminhos para o desenvolvimento sustentável}

O dualismo do mercado de trabalho mundial tem confinado uma parcela crescente da geração mais jovem empregos mal remunerados, com más condições de trabalho e altos níveis de instabilidade. Segundo, o conjunto de fenômenos denominado "trabalho em multidão" implica a participação no ciclo de produção por um número crescente de colaboradores temporários, consumidores e usuários que, em certa medida, substituem o trabalho remunerado (Chung \& Kim, 2016).

"Crowdworking" pode ser considerado como extremo e instância possivelmente superestimada do assunto básico. Empregadores à procura de novas forças de trabalho mais baratas, mais flexível, mais adequadamente qualificado e, de preferência, todas essas coisas (Morrar, Arman \& Mousa, 2017).

O trabalho em multidão, portanto, se encaixa no continuum de realocação virtualização e implementação de mercados internos e sistemas de licitação que foram observados nos últimos anos e provavelmente continuarão. Sob condições de trabalho intensificado e aumento da concorrência entre locais e trabalhadores, pode ser um esforço inerentemente contraditório. O risco seria transferido ainda mais para os trabalhadores, e as empresas escapariam dos regulamentos legais, da parceria social relações e acordos coletivos (Bloem et al., 2014).

Verificou-se que mesmo as empresas que pretendem cultivar o comprometimento dos funcionários por essas mesmas razões têm sucesso limitado com esses esforços, pois as mesmas empresas são cada vez mais impulsionados pela financeirização, desempenho de curto prazo e valor do acionista ou intervenção real do acionista (Willcocks \& Lacity, 2016).

Essas dinâmicas pressionam o emprego e condições de trabalho, redução do nível de pessoal, intensificação do trabalho, redução de custos e redução da segurança no emprego, em particular nos países com salários mais altos (West, 2018).

Os esforços de RH para cultivar comprometimento e fortes culturas organizacionais em esses contextos são percebidos como hipócritas pelo menos e em insultos. As empresas são capazes de integrar práticas, redes sociais e formas de livre cooperação no processo produtivo por construção de redes de 'produção estendida' que envolvem freelancers, usuários e consumidores (Chung \& Kim, 2016).

As soluções de modelagem de big data estão facilitando o uso quantitativo ou quantitativo padrões qualitativos de desempenho como base para perfis de benchmarking e desempenho. É para este conjunto de processos e mecanismos que a definição de Schwab (2017) de 'Taylorismo digital' pode ser aplicado. Passando para a categoria dos chamados independentes trabalhadores (freelancers, 


\section{Administração: caminhos para o desenvolvimento sustentável}

auto-empreendedores, etc.) não pode ser disse que a cooperação é sua característica distintiva (Schwab \& Davis, 2018).

Ao discutir as habilidades cognitivas exigido da nova força de trabalho, Schwab (2017) referiu-se ao "taylorismo digital": raramente o trabalho digital é verdadeiramente mais autônomo, autoorganizado, variado e criativo do que o trabalho fordista; o desempenho dos trabalhadores é organizado pelos planejadores de maneira semelhante àquela em que os engenheiros trabalho material simplificado na economia fordista. Devemos acrescentar a esses problemas a questão decisiva do desemprego tecnológico.

Robótica, digitalização e desenvolvimento Inteligência Artificial, somada à mecanização, pode levar a taxas de desemprego que, segundo Ransome (2019), podem atingir os 50\% da força de trabalho até 2040. A informatização ainda está em sua juventude e a informatização de trabalho de classe média está ocorrendo em um ritmo muito mais rápido do que a mecanização da força de trabalho manual. Em formação a tecnologia não gera empregos remunerados na mesma proporção que os elimina (Hirschi, 2018).

Se as previsões de Schwab \& Davis (2018) forem confirmadas, os efeitos sobre os profissionais do conhecimento serão os de radicalização extrema das atuais tendências negativas que evidência destaca, em relação aos níveis salariais, emprego oportunidades e condições de trabalho, e também o de um desaparecimento significativo do trabalho cognitivo.

Mas Ransome (2019) argumenta que esses processos também podem levar a conseqüências mais amplas. À medida que a classe trabalhadora encolheu através da mecanização, o capitalismo foi salvo pela ascensão da classe média. Agora o capitalismo não pode compensar a digitalização trabalho de classe média com uma criação correspondente de novos empregos.

Segundo West (2018), esses processos que levarão a uma crise sistêmica do capitalismo antes do século 21 acabaram, como o capitalismo não pode suportar as taxas de desemprego de $50 \%$ ou mais e sistemas em que o trabalho assalariado é uma minoria da força de trabalho ativa.

De acordo com o estudo sobre trabalho digital da ETUI (European Union Union Institute, 2018) uma proporção substancial dos empregos atuais serão tornados obsoletos pelas últimas geração de robôs, devido à sua capacidade de imprimir 3d objetos, tradução de documentos, elaboração de apólices de seguro, cuidando de idosos em suas casas, dizendo aos médicos o que pode estar errado com os 


\section{Administração: caminhos para o desenvolvimento sustentável}

pacientes. O próprio conceito de "Trabalho" pode ficar desatualizado e substituído por um portfólio cada vez maior de comissões e projetos atribuídos através de plataformas online.

O atual ciclo de inovação envolve também uma individualização do relacionamento entre trabalhadores e máquinas. O conjunto desses processos afetam o poder de barganha dos sindicatos e a capacidade de ação coletiva dos trabalhadores (Kane et al., 2015).

Para os trabalhadores permitirem processos de mudança disruptiva significa lidar com as perdas relacionadas fatos objetivos (risco de desemprego, saúde desconhecida riscos, uma mudança invertida no conteúdo do trabalho etc.) e/ou um sentimento de impotência em proporcionar processos além de qualquer possibilidade de controle pelo indivíduo. Ambos estes elementos, se presentes, são cruciais para dificultar a participação em sindicatos e mobilizações coletivas (Willcocks \& Lacity, 2016).

\section{CONCLUSÕES}

A atual onda de inovação tecnológica e seus relacionamentos com trabalho e produção são compostos por expressões como Indústria 4.0 e capitalismo digital. As narrativas retóricas e expectativas que acompanham essas definições das mudanças atuais no capitalismo não são novas.

Eles confirmam e ampliam a retórica e as expectativas que nas últimas décadas estavam ligadas a conceitos como pós-fordismo e economia baseada no conhecimento. Neste artigo, a escolha foi focar principalmente no implicações que as transformações atuais podem ter trabalho, tendo em vista o que ocorreu nos últimos anos e o cenário atual. Em particular, a retórica sobre digital e trabalho de conhecimento foram confrontados com os literatura e evidências sobre esse assunto.

O que surgiu é que todas as transformações frequentemente chamadas "revolução digital" até agora não alcançaram nenhum das promessas que levantou. A organização do trabalho não tem tornar-se mais horizontal, se não parcial e formal. Os trabalhadores não aumentaram seu poder de decisão ou sua autonomia.

O trabalho tornou-se mais criativo apenas para uma fração de trabalhadores altamente qualificados. Por outro lado, trabalho tornou-se mais precário e menos remunerado, e a distinção entre tempo de trabalho e tempo de vida diminuiu. Ao contrário do que é declarado pelas leituras institucionais de Indústria 4.0., até agora a inovação tecnológica não substituir empregos predominantemente menos qualificados. A criação de novos empregos referem-se principalmente ao atraso dos serviços. Até agora, inovação digital produziu predominantemente resultados que as empresas sempre perseguido na história do capitalismo: reduzir a força de trabalho, salários, garantias e direitos relacionados ao 


\section{Administração: caminhos para o desenvolvimento sustentável}

trabalho e a poder de barganha dos trabalhadores; um aumento na capacidade de monitorar e avaliar o desempenho do trabalho; dispersão de força de trabalho e concentração de capital (monopólios, "o Vencedor leva toda a economia"), propriedade e gerenciamento funções; um aumento da eficiência da produção processo e gerenciamento da cadeia de valor, devido a aumento da produção e disseminação de dados.

Atualmente, as empresas estão conseguindo fazer o segundo polo dessas dicotomias (taylorismo digital, verticalização, mercantilização, individualização) dominando o primeiro (autonomia, participação, cooperação entre pares e socialização da produção). Como sempre ocorreu em a história da relação entre capital e trabalho, a possibilidade de o processo de produção mudar de direção favorável ao trabalho depende principalmente da capacidade de coalizão e conflito e na negociação poder do último. Esses elementos se desenvolvem dentro do trabalho também graças ao apoio da dinâmica (político, cultural, organizacional) e atores que são externo ao processo de produção, como a história da movimentos dos trabalhadores demonstra. Portanto, resultados positivos da "Indústria 4.0" para os trabalhadores vão depender de conflitos sociais e políticos.

\section{REFERÊNCIAS}

Berman, S. J. (2012). Digital transformation: opportunities to create new business models. Strategy \& Leadership, 40(2), 16-24.

Bloem, J., Van Doorn, M., Duivestein, S., Excoffier, D., Maas, R., \& Van Ommeren, E. (2014). The fourth industrial revolution. Things Tighten, 8.

Cherry, M. A. (2015). Beyond misclassification: The digital transformation of work. Comp. Lab. L. \& Pol'y J., 37, 577.

Chung, M., \& Kim, J. (2016). The Internet Information and Technology Research Directions based on the Fourth Industrial Revolution. KSII Transactions on Internet \& Information Systems, 10(3).

Colombo, A. W., Karnouskos, S., Kaynak, O., Shi, Y., \& Yin, S. (2017). Industrial cyberphysical systems: A backbone of the fourth industrial revolution. IEEE Industrial Electronics Magazine, 11(1), 6-16.

European Comission (2018) Proceedings of the Open Round Table on the Future of Work. Available at: https://ec.europa.eu/info/sites/info/files/research_and_innovation/ege/ege_b5_proceedings_roun dtable-future-of-work.pdf . Accessed 15 April 2019 


\section{Administração: caminhos para o desenvolvimento sustentável}

European Trade Union Institute - ETUI (2018) Work in the digital. Available at: https://ec.europa.eu/info/sites/info/files/research_and_innovation/ege/ege_b5_proceedings_roun dtable-future-of-work.pdf . Accessed 15 April 2019

Hirschi, A. (2018). The fourth industrial revolution: Issues and implications for career research and practice. The career development quarterly, 66(3), 192-204.

Kane, G. C., Palmer, D., Phillips, A. N., Kiron, D., \& Buckley, N. (2015). Strategy, not technology, drives digital transformation. MIT Sloan Management Review and Deloitte University Press, 14(1-25).

Matt, C., Hess, T., \& Benlian, A. (2015). Digital transformation strategies. Business \& Information Systems Engineering, 57(5), 339-343.

Maynard, A. D. (2015). Navigating the fourth industrial revolution. Nature nanotechnology, 10(12), 1005.

Morrar, R., Arman, H., \& Mousa, S. (2017). The fourth industrial revolution (Industry 4.0): A social innovation perspective. Technology Innovation Management Review, 7(11), 12-20.

Peters, M. A. (2017). Technological unemployment: Educating for the fourth industrial revolution. Journal of Self-Governance and Management Economics, 5(1), 25-33.

Ransome, P. (2019). Sociology and the future of work: contemporary discourses and debates. Routledge.

Schwab, K. (2017). The fourth industrial revolution. Currency.

Schwab, K., \& Davis, N. (2018). Shaping the future of the fourth industrial revolution. Currency.

TOFFLER, A. (1979). sd O Choque do Futuro. Ed. Record, Rio de Janeiro.

Ustundag, A., \& Cevikcan, E. (2017). Industry 4.0: managing the digital transformation. Springer.

West, D. M. (2018). The future of work: robots, Al, and automation. Brookings Institution Press.

Westerman, G., Bonnet, D., \& McAfee, A. (2014). The nine elements of digital transformation. MIT Sloan Management Review, 55(3), 1-6. 


\section{Administração: caminhos para o desenvolvimento sustentável}

Willcocks, L. P., \& Lacity, M. (2016). Service automation robots and the future of work. SB Publishing.

World Economic Forum. (2018). The future of jobs report 2018. World Economic Forum, Geneva,

Switzerland. Available at: http://www3.weforum.org/docs/WEF_Future_of_Jobs_2018.pdf Accessed 15 April 2019. 


\section{Capitulo 6}

\section{AS EMPRESAS DO RAMO ELETROELETRÔNICO DO POLO INDUSTRIAL DE MANAUS SOB O OLHAR CONCEITUAL DOS CLUSTERS}

DOI: $10.37423 / 200300354$

Raphael Ribeiro Palheta,

Naira Neila Batista de Oliveira Norte,

Roseani Pereira Parente,

Almir Kimura Junior

Resump Estruturado: - Introdução: A Zona Franca de Manays (ZFM) é um modelo de desenvolvimento econômico com objętivo de integrar a região Norte ao resto do país. Esse modelo é importante para d Amazonàs, para o Bpasil e parla o mundo, pois concilia o crescimento econômico e social com a presservação da floresta. Dentre os segmentos do Polo Industrial de Manaus (P)M), o de eletroeletrônicó é o que historicamente apresenta maior faturamento. A principal contribuição deste estudo é dar um primeiro pas\$o no sentido de caracterizar as empresas do segmento eletroeletrônico do polo como integrantes de um cluster industrial.

- Problema de Pesquisa e Objetivo: Nossso problema de pesquisa consiste na ausência de estudos que relacionem o conceito de clusters com as empresas do segmento eletroeletrônico, localizadas no polo. Neste artigh, buscaremos, com base na literatura e utilizando indiees de concentração fGL L e de lodalizaça (OL), verificar se as-empresas do segmento eletroetetrônico do PIM apresentam características que às definam como integrantes de um cluster industrial. 


\section{Administração: caminhos para o desenvolvimento sustentável}

- Fundamentação Teórica: Cluster pode ser conceituado como um agrupamento geograficamente concentrado de empresas inter-relacionadas e instituições correlatas numa determinada área, as quais estão vinculadas por elementos comuns e complementares. O escopo geográfico pode variar de uma única cidade ou estado para todo um país ou rede de países vizinhos (PORTER, 1999, p.211).

As empresas participantes de um cluster precisam estar interligadas entre si e com as instituições, para que os arranjos e benefícios possam ser efetivados. (PIEKARSKI;TORKOMIAN, 2012, p.43)

- Metodologia:Para a identificação de características de cluster industrial no segmento eletroeletrônico do PIM foram percorridas etapas básicas para o mapeamento de forma quantitativa: a definição da região econômica; o cálculo das concentrações de emprego através de QL e GL e a seleção das classes CNAE.

- Análise dos Resultados :O resultado encontrado de QL foi 5,56. Um QL maior que 1 indica que há concentração da atividade econômica especificada no setor observado superior à concentração desta atividade no país.O de GL obtido foi de 0,613. Quanto mais próximo de 1 estiver o valor do GL mais concentrada estará a atividade de produção avaliada. O valor obtido atende aos critérios estabelecidos por Suzigan e Zissimos.

- Conclusão: Várias características de clusters industriais foram avaliadas, entre elas: espaço geográfico definido, através dos indicadores de localização e concentração respectivamente, (QL e GL); participação governamental em clusters através de incentivos fiscais; cooperação horizontal e vertical; concentração de mão de obra especializada; proximidade das empresas formadoras de um cluster aos seus fornecedores de insumos/consumidores finais.

Esse trabalho apresenta-se como um passo inicial para definirmos se o polo eletroeletrônico do PIM se adequa a um cluster.

Palavras-chave: Clusters, Zona Franca de Manaus, Indicadores QL e GL

- Referências Bibliográficas:

SUPERINTENDÊNCIA DA ZONA FRANCA DE MANAUS. Indicadores de desempenho do Polo industrial de Manaus.

Disponível:em:http://site.suframa.gov.br/noticias/faturamento-do-pim-supera-r-34-bilhoes-no semestre/suframa-indicadores-do-pim-marco-2017.pdf. Acessado em 15 de junho de 2017

SUZIGAN, W., FURTADO, J., GARCIA, R., \& SAMPAIO, S. E. Coeficientes de Gini locacionais-GL: aplicação à indústria de calçados do Estado de São Paulo. Nova Economia, 13(2), 2009. 


\section{Administração: caminhos para o desenvolvimento sustentável}

\section{INTRODUÇÃO}

A Zona Franca de Manaus (ZFM) é um modelo de desenvolvimento econômico com objetivo de integrar a região Norte ao resto do país. Esse modelo é importante para o Amazonas, para o Brasil e para o mundo, pois concilia o crescimento econômico e social com a preservação da floresta. Dentre os segmentos do Polo Industrial de Manaus (PIM), o de eletroeletrônico é o que historicamente apresenta maior faturamento.

Nosso problema de pesquisa consiste na ausência de estudos atualizados que relacionam o conceito de clusters com as empresas do segmento eletroeletrônico, localizadas no polo.

Neste artigo, buscaremos, com base na literatura e utilizando índices de concentração (GL) e de localização (QL), verificar se as empresas do segmento eletroeletrônico do PIM apresentam características que as definam como integrantes de um cluster industrial.

A principal contribuição deste estudo é dar um primeiro passo no sentido de caracterizar as empresas do segmento eletroeletrônico do polo como integrantes de um cluster industrial.

\section{REFERENCIAL TEÓRICO}

\subsection{DEFINIÇÃO DE CLUSTERS}

No mundo capitalista, uma das possibilidades estratégicas disponíveis para as empresas apresentarem vantagens competitivas é a cooperação mútua, o que dá margem, inclusive, para a combinação entre as expressões competição e cooperação.

A partir dessa ideia de cooperação está assentada a noção de clusters, uma vez que nessa espécie de arranjo é essencial que os participantes cooperem entre si, não apenas envolvendo a ideia de competição entre empresas.

Assim, em uma definição inicial, um cluster pode ser representado por uma concentração de várias empresas que se instalam em um mesmo local, aliado ao fato de que todas devem possuir características parecidas entre suas atividades principais, o que propicia a comunicação e cooperação entre elas.

Considerando-se a concentração setorial e espacial de empresas, é pacífico que a existência de formação de clusters pode representar uma vantagem competitiva para uma determinada região e, não raras vezes, até mesmo para uma nação inteira. E a reunião de empresas em um mesmo espaço, 


\section{Administração: caminhos para o desenvolvimento sustentável}

explorando setores industriais semelhantes e correlatos entre si pode auxiliar tais firmas a romper obstáculos relativos ao crescimento de todas elas além de possibilitar o avanço para mercados que seriam inacessíveis caso cada uma efetuasse sua atuação no mercado individualmente.

Muito antes da conceituação formal do que pode ser definido como cluster, já havia surgido a ideia e percepção na literatura de que a concentração de indústrias especializadas em certas localidades pode auxiliar essas empresas aglomeradas a obter vantagens competitivas mais evidentes do que se estivessem atuando sozinhas.

Ainda no final do século XIX, em meados dos anos 1890, surgiu a teoria clássica de Alfred Marshall, em sua obra Princípios de Economia, na qual aborda justamente a ideia de que a situação particular de indústrias aglomeradas pode redundar em vantagens competitivas geradas pela própria divisão de trabalho e cooperação entre essas indústrias localizadas em um mesmo pólo geográfico (KELLER, 2008, p. 33).

Mais tarde, Michael Porter sistematizou e difundiu a teoria e conceituação de clusters em sua obra A Vantagem Competitiva das Nações.

Na definição mais clássica, cluster pode ser conceituado como um agrupamento geograficamente concentrado de empresas inter-relacionadas e instituições correlatas numa determinada área, as quais estão vinculadas por elementos comuns e complementares. O escopo geográfico pode variar de uma única cidade ou estado para todo um país ou rede de países vizinhos (PORTER, 1999, p.211).

Ainda segundo Porter, os clusters consistem em redes densas de empresas inter-relacionadas que surgem em uma região por causa de fortes externalidades e spillovers entre firmas (e vários tipos de instituições) dentro de um cluster. Os clusters geram produtividade e inovação. As empresas que estão localizadas dentro de um cluster podem transacionar de forma mais eficiente, compartilhar tecnologias e conhecimento mais prontamente, operar com mais flexibilidade, iniciar novos negócios com mais facilidade e perceber e implementar inovações mais rapidamente (PORTER, 2009, p.5).

Também pode ser conceituado como a concentração geográfica de empresas interconectadas, provedores especializados, empresas e serviços e agentes de apoio em um âmbito determinado, em que competem porém também cooperam entre si (ESTÉVEZ, 2013, p. 19). 


\section{Administração: caminhos para o desenvolvimento sustentável}

\subsubsection{PRINCIPAIS CARACTERÍSTICAS PARA IDENTIFICAÇÃO DE UM CLUSTER}

Algumas características comuns são importantes e precisam estar presentes para identificar e caracterizar um Cluster como tal.

Em primeiro lugar, os agentes e empresas participantes devem estar localizados em espaços geográficos definidos. Isso se dá exatamente para que esteja caracterizada a aglomeração de empresas com a finalidade de propiciar o envolvimento e cooperação econômica e produtiva entre elas.

Deve haver, igualmente, a participação das instituições locais que se envolvem no sentido de garantir os benefícios necessários para a constituição e localização de um cluster em uma determinada região geográfica, e tais instituições podem ser governamentais, mistas, privadas, sindicatos de classe, entre outras.

Ainda, as empresas participantes de um cluster precisam estar interligadas entre si e com as instituições, para que os arranjos e benefícios possam ser efetivados. As empresas locais, usualmente, devem interagir por meio de relações de produção, comércio e distribuição. (PIEKARSKI;TORKOMIAN, 2012, p.43).

Também se faz necessário que haja proximidade geográfica entre os fornecedores e as empresas participantes do cluster.

Essa interligação entre as empresas, de acordo com a literatura, pode se dar através de cooperação horizontal, quando envolve, geralmente, acordos de longo prazo entre empresas do mesmo setor, que originam as denominadas alianças estratégicas, e cooperação vertical, quando envolve diferentes entidades da cadeia de fornecimento, notadamente, fornecedores, fabricantes, distribuidores e clientes.

Para caracterização de um cluster é necessária, também, a presença de economias externas relacionadas ao tamanho de mercado. Aqui, há uma percepção de que, havendo a aglomeração de empresas em um mesmo espaço geográfico, com especialização setorial, irão, possivelmente, emergir economias externas (HUMPHREY; SMITH, 1996, p. 1863).

Necessária também se faz a concentração de mão-de-obra especializada para a existência de um cluster, isto significa que os agentes que trabalham naquela formação em clustering devem ser especializados no ramo de atuação daquele agrupamento industrial. 


\section{Administração: caminhos para o desenvolvimento sustentável}

Por fim, a existência de spillovers tecnológicos, além de outros fatores que favorecem a especialização, também caracterizam um cluster (SUZIGAN et al, 2000, p.5).

\subsubsection{CLASSIFICAÇÃO E ESTUDO DAS VÁRIAS DEFINIÇÕES DE CLUSTER}

Ao se mencionar a classificação dos clusters, é possível observar na literatura que se apresentam algumas possíveis divisões, mas estas não são definitivas e nem sempre unânimes. Contudo, demonstra-se a seguir uma classificação em duas dimensões, ou seja, quanto a relação entre as entidades e, em seguida, estas analisadas nos níveis micro, médio e macro (HOEN, 2000, p.1), a qual traz um panorama de como os clusters podem se classificar.

Os clusters, analisados a partir de um ponto de vista teórico, podem se apresentar de formas variadas e, dessa maneira, podem ser classificados em duas dimensões, que são apresentadas, respectivamente, na primeira dimensão, em uma distinção de acordo com o escopo ou nível de análise e, na segunda dimensão, de acordo com a relação entre as entidades dentro de um cluster (HOEN, 2000, p.1).

Ao ser classificados de acordo com o nível de análise, podem se dividir em níveis micro, médio e macro.

O micro nível diz respeito aos clusters de empresas, enquanto que os níveis médio e macro dizem respeito aos clusters de setores. (HOEN, 2000, p.1).

Sendo analisados de acordo com a relação entre as entidades participantes do clusters, estas podem se referir a esforços voltados à inovação ou ligação para a produção (respectivamente, para difusão de inovações ou formação de produção e cadeia de valor agregado).

Dessa forma, aqueles baseados em esforços de inovação dizem respeito a firmas ou setores que cooperam entre si no processo de difusão de inovações, tais como novas tecnologias e produtos (HOEN, 2000, p.1).

Já os clusters de ligação para a produção dizem respeito a firmas ou setores que geram uma produção ou cadeia de valor agregado, de acordo com a definição de Hoen.

Essas distinções de classificação de clusters acarretam seis tipos de clusters, a partir das duas dimensões citadas.

No nível micro, em clusters de esforços para inovação, há uma difusão de tecnologia e conhecimento entre as firmas, instituições de pesquisa, entre outros. 


\section{Administração: caminhos para o desenvolvimento sustentável}

Ainda no micro nível, nos clusters de ligação para a produção, compradores e fornecedores formam uma produção ou cadeia de valor agregado.

No nível médio, em clusters de esforços para inovação, há uma difusão de tecnologia e conhecimento entre setores.

Também no nível médio, nos clusters de ligação para a produção, há ligações para trás e para a frente entre os setores, a partir de uma análise parcial.

No nível macro, nos clusters de esforços para inovação, há uma separação do sistema econômico em setores que difundem conhecimento e tecnologia.

Por fim, no nível macro, nos clusters de ligação para a produção, há uma separação do sistema econômico em setores que formam valor agregado ou cadeias de produção.

\subsubsection{O PAPEL DO GOVERNO EM CLUSTERS}

A reunião de empresas em formação de um cluster é um fator que auxilia as firmas a aumentar sua competitividade e obter vantagens que seriam mais difíceis de se conseguir se estivessem isoladas.

Entretanto, os clusters não se formam aleatoriamente e, nesse sentido, o papel do Governo na formação de clusters mostra-se fundamental.

A participação e interesse governamental em formular políticas públicas voltadas para a formação de clusters deve estar presente para a difusão desse aglomerado, especialmente quando há a intenção do poder público em incentivar o emprego e o desenvolvimento de determinada região.

Humphrey e Schmitz, citados por KELLER (2008, p. 44), ao tratar da formulação de políticas públicas para o incentivo à formação de clusters, desenvolveram a abordagem que denominaram Triplo C para a atuação governamental no apoio aos clusters.

Essa abordagem se baseia políticas públicas orientadas para o cliente, para o coletivo e para a capacidade cumulativa.

Em primeiro lugar, uma abordagem voltada para apoio aos participantes do clusters para que possam atender às necessidades dos clientes.

Na sequência, políticas públicas orientadas para o grupo de empresas participantes do cluster, que possam propiciar transações a custos mais baixos, além de permitir o desenvolvimento de relações de cooperação entre as empresas. 


\section{Administração: caminhos para o desenvolvimento sustentável}

Por fim, políticas públicas voltadas para a capacidade cumulativa dizem respeito à acumulação de melhorias que propiciem o crescimento e fortalecimento das entidades integrantes do cluster. Com a continuidade dessas melhorias há maior independência de apoio externo.

\subsection{TÉCNICAS DE MAPEAMENTO DE CLUSTERS}

Os métodos de identificação e caracterização de aglomerações industriais utilizados no Brasil envolvem, no geral, a execução de pelo menos três etapas básicas: a definição da região econômica; o cálculo das concentrações de emprego e a seleção de aglomerações preliminares. A delimitação da região econômica básica adotada varia entre o uso dos municípios e das microrregiões (agrupamento de municípios limítrofes). O cálculo das concentrações de emprego envolve a determinação do Quociente Locacional (QL) que possibilita a comparação entre uma região econômica básica com uma de referência que pode ser o Estado ou o País. Quando o QL é superior a um está indicando uma especialização relativa em uma região. Quanto maior, mais especializado. E a última etapa consiste basicamente na listagem das aglomerações que estão adequadas aos critérios estabelecidos na etapa anterior. Outros trabalhos fazem uso do coeficiente de Gini Locacional (GL) em conjunto com o QL. O GL foi inicialmente proposto por Krugman (1991), e é interpretado como um indicador do grau de concentração espacial de determinada atividade em uma base geográfica que pode ser uma região, um estado ou um país. O coeficiente varia de zero a um de modo que quanto mais espacialmente concentrada for a atividade, mais próximo da unidade estará o índice (ZISSIMOS et al, 2007; BRITTO; ALBUQUERQUE, 2002; BRITTO, 2004; PIRES et al, 2013; PUGA, 2003; SUZIGAN et al. 2003 e 2006; REZENDE; DINIZ, 2013; CROCCO et al, 2006).

Um cuidado adicional na análise dos resultados do QL (indicador de especialização) e do GL (indicador de concentração) sugere a adoção de alguns filtros de controle (critérios de densidade), tais como o volume de empregos e o número de estabelecimentos. A utilização dessas variáveis pode identificar, por exemplo, se um elevado coeficiente de especialização (QL) para uma região, não é somente decorrente da presença no local e uma ou poucas grandes empresas.

Como há divergências quanto aos critérios de análise para os resultados desses indicadores, resumimos na tabela 1 os limites estabelecidos nos trabalhos de Suzigan et al (2003), Zissimos et al (2007) e Rezende e Diniz (2013) nos quais as classes de atividades econômicas deveriam se enquadrar para serem escolhidas como potenciais possuidoras de aglomerações de empresas. 


\section{Administração: caminhos para o desenvolvimento sustentável}

Tabela 1 - Resumo dos critérios de análise para identificar localidades e/ou setores com aglomerações de empresas com maior potencial.

\begin{tabular}{c|c|c|c}
\hline Critérios & $\begin{array}{c}\text { Suzigan et al } \\
\mathbf{( 2 0 0 3 )}\end{array}$ & $\begin{array}{c}\text { Zissimos } \\
\mathbf{( 2 0 0 7 )}\end{array}$ & $\begin{array}{c}\text { Rezende e } \\
\text { Diniz (2013) }\end{array}$ \\
\hline QL & $>2$ & $>1$ & $\geq 3$ \\
GL & $>0,5$ & $>$ Mediana & Não especifica \\
Empresas & $>20$ & $>5$ & $\geq 25$ \\
Empregos & $>1 \%$ & $>1 \%$ & $\geq 500$ \\
\hline
\end{tabular}

Fonte: Zissimos et al, 2007; Rezende e Diniz, 2013.

Para Bastos e Almeida (2008) com a realização de pesquisas de campo e estudos de caso seria possível alcançar a detecção dos elementos intangíveis das aglomerações industriais, tais como a cooperação entre as empresas ou entre as empresas e instituições. Esta etapa permitiria a validação e o refinamento da seleção preliminar feita pelos três critérios acima relacionados.

\section{A ZONA FRANCA DE MANAUS}

A Zona Franca de Manaus (ZFM) é resultante de um projeto federal de cunho geopolítico, que teve como objetivo, instalar na Amazônia, um modelo de desenvolvimento econômico por meio dos polos industrial, comercial e agropecuário com fins de integração da região norte ao resto do país.

O principal órgão do governo federal que administra a ZFM é a Superintendência da Zona Franca de Manaus - SUFRAMA - tendo como uma de suas atribuições realizar o levantamento de todos os resultados do Polo Industrial de Manaus (PIM), os quais podem ser observados no relatório de indicadores de desempenho atualizados anualmente.

A ZFM, criada em 06.06.1957 através do Decreto Lei 3.173, teve sua implementação como Zona de Livre Comércio em 28.02.1967 através do Decreto Lei no 288. O modelo conforme Artigo 42 do Decreto no 288, teve sua vigência inicial por trinta (30) anos, valendo para o período de 1967 a 1997 (SUFRAMA, 2017). Após essa fase inicial a mesma já obteve quatro prorrogações, sendo a última ocorrida no dia 05/08/2014, em que o Congresso Nacional promulgou a Emenda Constitucional 83/2014, a qual prorrogou os incentivos fiscais até o ano de 2073, possibilitando expectativa de vida de no mínimo 56 anos a esse modelo.

O processo de modernização do PIM verificado entre a terceira e quarta prorrogação por meio da automação e foco em qualidade proporcionou um crescimento significativo no faturamento e na produtividade na indústria de transformação beneficiando o processo de industrialização brasileira 


\section{Administração: caminhos para o desenvolvimento sustentável}

em geral (KATZ, 2000). Vale ressaltar que o desenvolvimento da ZFM ocorreu em paralelo com a da própria industrialização brasileira desde a sua criação, no final dos anos 60. (BARBERIA; BIDERMAN, 2010; FIGUEIREDO, 2008).

Para o desenvolvimento deste trabalho foi escolhido o segmento de eletroeletrônico, dentre os segmentos do PIM, no ano de 2016 representou $28,31 \%$ do seu faturamento total visto na Figura 1, o que correspondeu a um montante de expressivos 19 bilhões de reais.

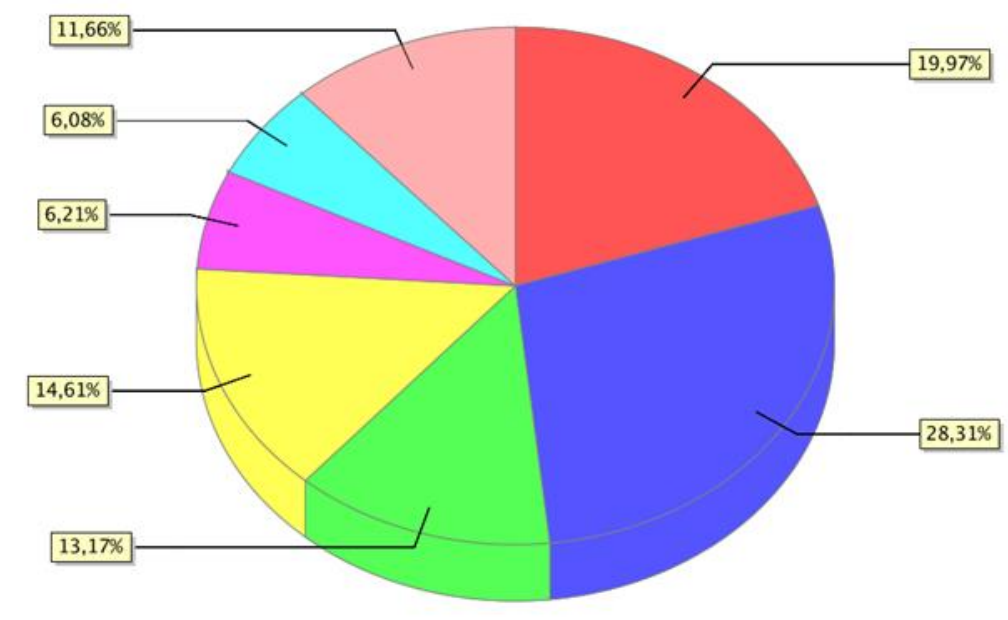

- Bens de Informática - Eletroeletrônico ๑ Outros $\bigcirc$ Duas rodas $\odot$ Termoplástico $\bigcirc$ Metalúrgico $\bigcirc$ Químico

Figura 1 - Participação dos subsetores de atividades no faturamento do PIM - Jan a Nov/2016

Fonte Suframa (2017)

\subsection{PRINCIPAIS INCENTIVOS}

Os principais incentivos fiscais federais, estaduais e municipais são, segundo a Cartilha de Incentivos Fiscais da SUFRAMA, os seguintes:

- Redução do Imposto de Renda - 75\%;

- Isenção de $100 \%$ do IPI;

- Redução de 88\% do Imposto de Importação;

- Crédito estímulo de ICMS de 55\% até 100\%;

- Isenção de PIS/COFINS nas operações internas na ZFM com produtos intermediários;

- $\quad$ Isenção de PIS/COFINS nas compras de insumos de outras regiões do país. 


\section{Administração: caminhos para o desenvolvimento sustentável}

\subsection{CARACTERIZAÇÃO DO SETOR DE ELETROELETRÔNICO NO BRASIL E NO POLO INDUSTRIAL DE MANAUS}

De acordo com o relatório “Diagnóstico e Propostas elaborados pelos Metalúrgicos da CUT" de 2012, o setor eletroeletrônico brasileiro é um aglomerado de atividades econômicas que possui itens com finalidades distintas, passando desde componentes, automação industrial, bens de consumo até equipamento médicos. Ainda de acordo com esse relatório, até a primeira metade da década de 70, as empresas existentes no Brasil eram predominantemente multinacionais, produtoras de bens de consumo em que o processo de produção se reduzia a montagem de componentes importados. Para Gutierrez e Alexandre (2002), esse cenário mudou com a aceleração do processo de abertura comercial dos anos 90, quando praticamente todos os setores foram afetados pelo aumento das importações, sendo que o setor mais afetado foi, segundo os autores, o de eletroeletrônicos.

Para Bampi (2008), os quatro subsistemas da indústria eletroeletrônica no Brasil são: componentes eletrônicos, semicondutores e material eletrônico básico, eletrônica de consumo, bens de informática e automação e bens de telecomunicação.

O mesmo autor relaciona as características essenciais e limitações significativas da indústria eletrônica no Brasil.

- Indústria essencialmente "seguidora" dos produtos mundiais, sem pioneirismo e valendo-se de um mercado aberto, sujeito a padrões internacionais.

- Produção dedicada quase que exclusivamente a atender o mercado doméstico, com baixo coeficiente de exportação.

- $\quad$ Produção de bens eletrônicos finais, sem agregação de valor no Brasil em seu design eletrônico, sem componentes locais, sem diferenciação por marca própria local;

- Inexistência de marcas nacionais expressivas em segmentos de bens de massa, com baixa taxa de inovação local em produtos e processos;

- Baixíssimo conteúdo nacional em componentes eletrônicos de maior valor agregado que são essenciais para a funcionalidade completa do bem final.

Segundo o relatório de Indicadores de Desempenho do PIM referente ao período de 2012 a 2017, o parque fabril do PIM, distante dos grandes centros produtores e consumidores do Brasil, alcançou em 2016 um faturamento de $\mathrm{R} \$$ 74,4 bilhões. Somente o setor de eletroeletrônicos atingiu um total de 


\section{Administração: caminhos para o desenvolvimento sustentável}

$\mathrm{R} \$ 19,5$ bilhões $(26,18 \%)$ com o faturamento da linha de televisores na ordem de $\mathrm{R} \$ 11,2$ bilhões (57,5\%). No ano de 2012 , o segmento eletroeletrônico representou 34,34\%, que foi o maior percentual no período de 2012 a 2015. O tamanho desse segmento permitiu um encadeamento produtivo com o estabelecimento de um subsetor termoplástico que fornece insumos não somente para o subsetor eletroeletrônico como também para o de duas rodas (motocicletas e afins) que em 2016 representou $14,14 \%$ do faturamento do PIM. Em relação à exportação o PIM teve o montante de $\mathrm{R} \$ 1,5$ bilhões em produtos no ano de 2015.

De acordo com a Suframa através do documento "Perfil das Empresas com Projetos Aprovados pela Suframa" publicado em Janeiro/2017, o setor de eletroeletrônicos é usualmente denominado de "Material Elétrico, Eletrônico e de Comunicação" e é sub classificado em três segmentos:

- Polo de "Componentes", com 43 empresas;

- Polo de "Produtos Elétricos, Eletrônicos e de Comunicação" com 74 empresas; e,

- $\quad$ Polo de “Máquinas Copiadoras e similares" com 6 empresas.

Considerando os três grupos mencionados estão cadastradas 123 empresas (25,15\%) atuando no segmento do total de 489 empresas instaladas no PIM.

\section{METODOLOGIA}

Para a identificação de características de cluster industrial no segmento eletroeletrônico do PIM foram percorridas as três etapas básicas para o mapeamento já explicitadas: a definição da região econômica; o cálculo das concentrações de emprego e a seleção de aglomerações preliminares.

A base de dados utilizada como fonte de informações foi a Relação Anual de Informações Sociais (RAIS) do Ministério do Trabalho e Emprego (MTE), utilizada pela maioria dos trabalhos voltados para análise de aglomerações de empresas no Brasil. Para Puga (2003), a vantagem do uso desta base de dados reside no nível de detalhamento espacial e setorial desejado.

Considerando que apenas um segmento será analisado, para classificar as atividades econômicas das empresas contidas no mesmo, foi empregada a Classificação Nacional de Atividades Econômicas (CNAE) 2.0 a quatro dígitos.

A literatura aponta algumas deficiências no uso da RAIS tais como a sua cobertura, considerando que a mesma inclui apenas relações contratuais formais, e o uso de um método da autoclassificação na coleta das informações primárias. Ou seja, empresas que possuem mais de uma unidade produtiva 


\section{Administração: caminhos para o desenvolvimento sustentável}

podem informar todas as unidades em uma mesma declaração, num mesmo endereço, assim como reunir todos os produtos em um único setor CNAE. Já a sua principal vantagem é a desagregação setorial e geográfica dos dados, o que possibilita a obtenção e o processamento dos dados desagregados até o nível de município (termos espaciais) e até o nível de classes de indústrias (termos setoriais) por divisão da classificação CNAE (SUZIGAN et al, 2004 e 2009; BASSO et al, 2005).

Dessa forma, o trabalho proposto utiliza os dados do número de empregos informados na RAIS 2015 pelas empresas do segmento eletroeletrônico do PIM listadas pela Suframa. Foram identificadas dezessete classificações CNAE para as quais foi calculado o Quociente Locacional.

O Quociente Locacional (QL) possibilita medir o grau de especialização industrial comparando as cotas de emprego setorial de uma região com as de uma área de referência geográfica maior como um estado ou país. Já o Gini Locacional (GL) permite identificar classes de indústrias com elevado grau de concentração geográfica da atividade econômica observada (BRITO; ALBUQUERQUE, 2002; O'DONOGHUE; GLEAVE, 2004; PIEKARSKI; TORKOMIAN, 2005; ZISSIMOS et al, 2007; SUZIGAN et al 2009; PIRES et al, 2013).

Para o cálculo do QL serão utilizados os dados referentes ao total de empregados registrados (EMP) informados na RAIS 2015 pelas indústrias do segmento eletroeletrônico do PIM por classe CNAE a 5 dígitos que chamaremos de setor de modo que teremos:

$$
Q L=\frac{\frac{E M P \text { no setor } \text { i no municipio }}{\text { EMP em todos os setores no município }}}{\frac{\text { total EMP do país no setor } i}{\text { total EMP em todos os setores do país }}}
$$

A interpretação do QL mais empregada é: valores maiores que 1 indicam que há concentração da atividade econômica especificada no setor observado superior à concentração desta atividade no país; valores iguais a 1 indicam que a concentração da atividade econômica especificada no setor observado é igual à concentração da mesma no país; e valores menores que 1 indicam que a concentração da atividade econômica especificada no setor observado é menor à concentração da mesma no país.

Para calcular o GL, os setores foram ordenados de forma crescente quanto ao valor do QL da variável base considerada (número de empregados). Em seguida deve-se construir a curva de Lorenz e a partir da mesma calcular a área sobre a linha de equalidade. O coeficiente de Gini consiste no valor 0.5 menos o valor da área calculada. De forma resumida, podemos dizer que coeficiente de Gini Locacional (GL) mostra a concentração espacial de uma atividade e pode ser obtido pela expressão sugerida por Horffman (2006): 


\section{Administração: caminhos para o desenvolvimento sustentável}

$$
G L=1-\frac{1}{n} \sum_{i=1}^{n}\left(\theta_{i-1}+\theta_{i}\right)
$$

nde: $\mathrm{n}$ é o número de classes (no presente caso, os setores CNAE); $\theta_{-}$i é a participação acumulada percentual; e, $\theta_{-}(i-1)+\theta_{-} i$ é a participação acumulada percentual mais a classe imediatamente anterior. O coeficiente varia de zero a um e, quanto mais espacialmente concentrada for a atividade econômica, mais próximo da unidade estará o índice (SUZIGAN et al 2009).

\section{RESULTADOS E DISCUSSÃO}

\subsection{RESULTADOS DO QUOCIENTE LOCACIONAL ( QL)}

Para cálculo do QL para o segmento eletroeletrônico do PIM em relação ao mesmo segmento no país foi determinado com a aplicação da expressão abaixo:

$$
Q L=\frac{\frac{\text { EMP no setor Eletroeletrônico em Manaus }}{\text { EMP em todos os setores de Manaus }}}{\frac{\text { total EMP no setor Eletroeletrônico no Brasil }}{\text { total EMP em todos os setores do Brasil }}}
$$

O resultado encontrado foi 5,56. E, conforme definido na metodologia, um QL maior que 1 indica que há concentração da atividade econômica especificada no setor observado superior à concentração desta atividade no país. Neste caso, a especialização local do polo eletroeletrônico do PIM é mais de cinco vezes em relação.

Os resultados obtidos para o QL para cada uma das classes CNAE associadas às empresas do segmento eletroeletrônico estão resumidos na Tabela 2:

\begin{tabular}{|c|c|c|c|c|}
\hline \multirow[b]{2}{*}{ Classe CNAE } & \multicolumn{2}{|c|}{ Número de Empregados } & \multicolumn{2}{|c|}{$\begin{array}{l}\text { Empregos no } \\
\text { Setor }\end{array}$} \\
\hline & $\begin{array}{c}\text { Empregados } \\
\text { no Setor em } \\
\text { Manaus } \\
\end{array}$ & $\begin{array}{l}\text { Empregados } \\
\text { no Setor no } \\
\text { Brasil } \\
\end{array}$ & QL & $\begin{array}{c}\% \\
\text { Total }\end{array}$ \\
\hline $\begin{array}{l}\text { Fabricação de aparelhos de recepção, } \\
\text { reprodução, gravação e amplificação de áudio } \\
\text { e vídeo }\end{array}$ & 6.566 & 13.244 & 46,01 & 49,6 \\
\hline Fabricação de componentes eletrônicos & 10.578 & 32.304 & 30,39 & 32,7 \\
\hline $\begin{array}{l}\text { Fabricação de equipamentos e instrumentos } \\
\text { ópticos, fotográficos e cinematográficos }\end{array}$ & 551 & 2.455 & 20,83 & 22,4 \\
\hline $\begin{array}{l}\text { Fabricação de equipamentos de informática e } \\
\text { periféricos }\end{array}$ & 4.598 & 39.586 & 10,78 & 11,6 \\
\hline Fabricação de equipamentos de comunicação & 1.975 & 19.035 & 9,63 & 10,4 \\
\hline
\end{tabular}

Tabela 2 - Quocientes Locacionais do segmento eletroeletrônico do PIM. 


\section{Administração: caminhos para o desenvolvimento sustentável}

\begin{tabular}{l|c|c|c|c}
\hline $\begin{array}{l}\text { Fabricação de aparelhos e instrumentos de } \\
\text { medida, teste e controle }\end{array}$ & 2.019 & 23.937 & 7,83 & 8,4 \\
\hline $\begin{array}{l}\text { Fabricação de pilhas, baterias e acumuladores } \\
\text { elétricos }\end{array}$ & 551 & 9.776 & 5,23 & 5,6 \\
\hline $\begin{array}{l}\text { Fabricação de equipamentos para distribuição } \\
\text { e controle de energia elétrica }\end{array}$ & 2.636 & 59.088 & 4,14 & 4,5 \\
\hline $\begin{array}{l}\text { Fabricação de equipamentos e aparelhos } \\
\text { elétricos não especificados anteriormente }\end{array}$ & 1.123 & 28.493 & 3,66 & 3,9 \\
\hline $\begin{array}{l}\text { Fabricação de geradores, transformadores e } \\
\text { motores elétricos }\end{array}$ & 1.360 & 38.376 & 3,29 & 3,5 \\
\hline $\begin{array}{l}\text { Fabricação de máquinas e equipamentos de } \\
\text { uso geral }\end{array}$ & 3.552 & 111.556 & 2,95 & 3,2 \\
\hline Fabricação de eletrodomésticos & 1.554 & 51.057 & 2,82 & 3,0 \\
\hline $\begin{array}{l}\text { Fabricação de artigos de joalheria, bijuteria e } \\
\text { semelhantes (inclui jogos eletrônicos) }\end{array}$ & 375 & 19.246 & 1,81 & 1,9 \\
\hline $\begin{array}{l}\text { Fabricação de aparelhos eletromédicos e } \\
\text { eletroterapêuticos e equipamentos de } \\
\text { irradiação }\end{array}$ & 81 & 5.509 & 1,36 & 1,5 \\
\hline $\begin{array}{l}\text { Fabricação de motores, bombas, } \\
\text { compressores e equipamentos de transmissão }\end{array}$ & 359 & 54.933 & 0,61 & 0,7 \\
\hline $\begin{array}{l}\text { Fabricação de produtos diversos } \\
\text { Fabricação de máquinas e equipamentos de } \\
\text { uso industrial específico }\end{array}$ & 513 & 52.791 & 0,53 & 1,0 \\
\hline
\end{tabular}

Fonte: Elaborado pelos autores com base nos dados da RAIS de 2015.

Aplicando os critérios de análise para identificação de aglomerações de empresas com maior potencial indicativo de cluster industrial resumidos na Tabela 2, observamos que das 17 classes CNAE listadas as primeiras 14 (82\%) apresentam um QL que atende aos requisitos definidos pelos três autores indicando um alto grau de especialização industrial.

Destacamos os resultados das cinco primeiras classes. As duas primeiras, quais sejam a de "Fabricação de aparelhos de recepção, reprodução, gravação e amplificação de áudio e vídeo" e de "Fabricação de componentes eletrônicos" obtiveram um QL igual a 46,01 e 30,39 respectivamente. Segundo os dados informados na RAIS 2015, a primeira classe reuniu 49,6\% dos empregados no setor em 26 empresas que correspondem a $22 \%$ em relação ao total de empresas no Brasil do mesmo segmento. Com relação à segunda classe, são $32,7 \%$ dos empregados no setor em 36 empresas operando no PIM, representando, $11,3 \%$ em relação à quantidade de empresas atuando no mesmo segmento no Brasil.

Já a terceira classe "Fabricação de equipamentos e instrumentos ópticos, fotográficos e cinematográficos" mostrou um QL de 20,83 e agrupa um total de 22,4\% dos empregados no setor em 4 empresas $(30,8 \%)$ de um total de 13 empresas que atuam no mesmo segmento no Brasil. 


\section{Administração: caminhos para o desenvolvimento sustentável}

Analisando a quarta e quinta classes, respectivamente, "Fabricação de equipamentos de informática e periféricos" e "Fabricação de equipamentos de comunicação" verificamos os valores de 10,78 e 9,63 para o QL respectivamente. A quarta classe reúne $11,6 \%$ do total de empregados no setor em 23 empresas que correspondem a 8,7\% em relação ao total de empresas atuando no mesmo segmento no Brasil. Já a quinta classe, reúne 10,4\% dos empregados do setor em 15 empresas (11\%) em relação ao total de empresas que atuam nesse segmento no Brasil.

As empresas enquadradas nas duas primeiras classes atendem a todos os requisitos definidos pelos três autores para os critérios de densidade resumidos na Tabela 1. As empresas da terceira classe, com relação volume de empregos atendem aos critérios de densidade definidos por todos os autores e a nenhum deles com relação ao número de empresas.

Já as empresas enquadradas na quarta e quinta classes atendem a todos os critérios com relação ao volume de empregos. Com relação ao número de empresas, as enquadradas na quarta classe atendem somente ao critério definido por Suzigan et al (2003) e as da quinta atendem somente ao critério definido por Zissimos (2007).

\section{2) RESULTADO DO GINI LOCACIONAL (GL)}

Como visto na metodologia o primeiro passo para cálculo do coeficiente de Gini consiste em ordenar os QL de forma crescente, calcular os seus valores porcentuais e acumulados de frequência (as classes foram renomeadas de $\mathrm{CO}$ a C17) como visto na Tabela 3.

Tabela 3 - Construção da Curva de Lorenz baseado no Quociente Locacional (QL)

\begin{tabular}{c|c|c|c|c|c}
\hline $\begin{array}{c}\text { Classe } \\
\text { s }\end{array}$ & $\begin{array}{c}\text { \% } \\
\text { Frequência } \\
\text { Acumulada } \\
\text { Classes }\end{array}$ & QL & $\begin{array}{c}\text { \% } \\
\mathbf{Q L}\end{array}$ & $\begin{array}{c}\text { Frequência } \\
\text { Acumulada } \\
\text { QL }\end{array}$ & $\begin{array}{c}\text { Área } \\
\text { sob } \\
\text { a curva }\end{array}$ \\
\hline C0 & 0,00 & 0,00 & 0 & 0 & 0,00000 \\
\hline C1 & 0,059 & 0,42 & $\begin{array}{c}0,00 \\
3\end{array}$ & 0,003 & 0,00008 \\
\hline C2 & 0,118 & 0,55 & $\begin{array}{c}0,00 \\
4\end{array}$ & 0,006 & 0,00027 \\
\hline C3 & 0,176 & 0,61 & $\begin{array}{c}0,00 \\
4\end{array}$ & 0,010 & 0,00049 \\
\hline C4 & 0,235 & 1,36 & $\begin{array}{c}0,00 \\
9\end{array}$ & 0,019 & 0,00087 \\
\hline C5 & 0,294 & 1,81 & $\begin{array}{c}0,01 \\
2\end{array}$ & 0,031 & 0,00149 \\
\hline C6 & 0,353 & 2,82 & 0,01 & 0,050 & 0,00238 \\
\hline
\end{tabular}




\section{Administração: caminhos para o desenvolvimento sustentável}

\begin{tabular}{c|c|c|c|c|c}
\hline $\mathrm{C} 7$ & 0,412 & 2,95 & $\begin{array}{c}0,01 \\
9\end{array}$ & 0,069 & 0,00350 \\
\hline $\mathrm{C} 8$ & 0,471 & 3,29 & $\begin{array}{c}0,02 \\
2\end{array}$ & 0,091 & 0,00470 \\
\hline $\mathrm{C} 9$ & 0,529 & 3,66 & $\begin{array}{c}0,02 \\
4\end{array}$ & 0,115 & 0,00604 \\
\hline $\mathrm{C} 10$ & 0,588 & 4,14 & $\begin{array}{c}0,02 \\
7\end{array}$ & 0,142 & 0,00755 \\
\hline $\mathrm{C} 11$ & 0,647 & 5,23 & $\begin{array}{c}0,03 \\
4\end{array}$ & 0,176 & 0,00936 \\
\hline $\mathrm{C} 12$ & 0,706 & 7,83 & $\begin{array}{c}0,05 \\
1\end{array}$ & 0,228 & 0,01188 \\
\hline $\mathrm{C} 13$ & 0,765 & 9,63 & $\begin{array}{c}0,06 \\
3\end{array}$ & 0,291 & 0,01525 \\
\hline $\mathrm{C} 14$ & 0,824 & $\begin{array}{c}10,7 \\
8\end{array}$ & $\begin{array}{c}0,07 \\
1\end{array}$ & 0,362 & 0,01919 \\
\hline $\mathrm{C} 15$ & 0,882 & $\begin{array}{c}20,8 \\
3\end{array}$ & $\begin{array}{c}0,13 \\
7\end{array}$ & 0,498 & 0,02530 \\
\hline $\mathrm{C} 16$ & 0,941 & $\begin{array}{c}30,3 \\
9\end{array}$ & $\begin{array}{c}0,20 \\
0\end{array}$ & 0,698 & 0,03519 \\
\hline $\mathrm{C} 17$ & 1,000 & $\begin{array}{c}46,0 \\
1\end{array}$ & $\begin{array}{c}0,30 \\
2\end{array}$ & 1,000 & 0,04994 \\
\hline
\end{tabular}

Com os dados encontrados, a curva de Lorenz é desenvolvida (Figura 2).

\section{Curva de Lorenz}

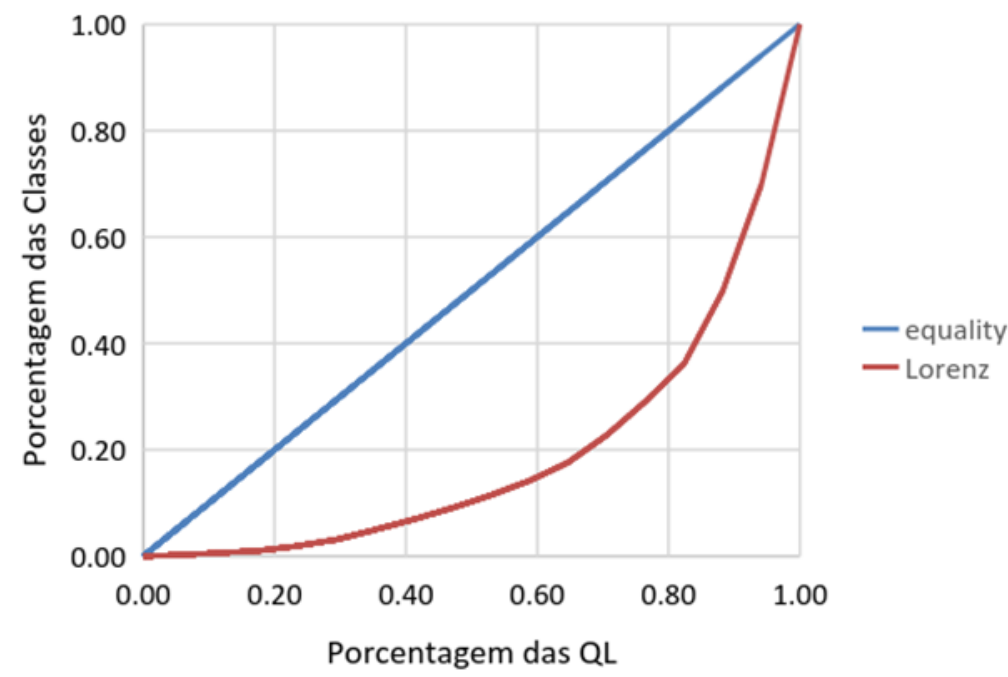

Figura 2 - Curva de Lorenz para QLs calculados

O valor da área obtida foi de 0,306 o que fornece um valor do Gini Locacional igual a 0,613. Conforme definido na metodologia, quanto mais próximo de 1 estiver o valor do GL mais concentrada estará a atividade de produção avaliada. Nesse caso, o segmento de eletroeletrônicos no PIM em relação à mesma atividade no Brasil. O valor obtido atende aos critérios estabelecidos por Suzigan e Zissimos resumidos na Tabela 1. 


\section{Administração: caminhos para o desenvolvimento sustentável}

Analisando o coeficiente de Gini em Manaus e no Brasil considerando o emprego como variável estudada e não o QL, obtivemos respectivamente os valores de 0,566 e 0,399, confirmando a concentração de empresas do setor de eletroeletrônico no PIM.

\section{6) CONCLUSÕES}

Tendo sido realizado estudo sobre o conceito e principais caraterísticas que determinam a formação e existência de um cluster, faz-se necessária uma comparação do que pode ser considerado cluster com as peculiaridades do Polo Industrial de Manaus, com a finalidade de identificar parâmetros que permitam ou não concluir se o PIM representa um cluster.

Em primeiro lugar, no que se refere à necessidade de que as empresas formadoras de um cluster estejam localizadas e aglomeradas em um espaço geográfico definido, de acordo com o que foi apurado nesta pesquisa, através dos indicadores de localização e concentração respectivamente, (QL e GL) verifica-se que o polo eletroeletrônico do PIM, possui essas características.

Em seguida, observa-se a importância da participação governamental para a criação e funcionamento de um clusters, no que se refere às políticas públicas voltadas para o desenvolvimento deste agrupamento bem como a existência de incentivos, principalmente fiscais, que possam garantir vantagens ao cluster em funcionamento naquele determinado local. Assim, o Polo eletroeletrônico de Manaus possui incentivos fiscais derivados da criação da Zona Franca de Manaus, que são suficientes para atender esse aspecto da caracterização de um cluster.

Quanto aos critérios de cooperação horizontal e vertical, em que a horizontal trata da cooperação entre as firmas e a vertical envolve diferentes entidades da cadeia de fornecimento, notadamente, fornecedores, fabricantes, distribuidores e clientes, é possível observar que, no setor de eletroeletrônicos, possui um sistema de cooperação vertical eficiente, porém não temos dados referentes a existência de cooperação horizontal entre as empresas.

Por outro lado, existe no mencionado polo eletroeletrônico do PIM efetiva concentração de mão de obra especializada, atendendo uma das características que determinam a existência de um cluster.

Por fim, no que se refere à proximidade das empresas formadoras de um cluster aos seus fornecedores de insumos/consumidores finais, a logística na região amazônica é um fator que dificulta essa proximidade. 


\section{Administração: caminhos para o desenvolvimento sustentável}

Não identificamos na literatura nenhum trabalho atualizado sobre mapeamento de clusters no polo eletroeletrônico do PIM vinculando com LQ e GL, esse trabalho contribui com o estudo nesse tema.

Considerando as análises desenvolvidas nesse trabalho sobre mapeamento de clusters industriais, podemos considerá-las como um passo inicial para definirmos se o polo eletroeletrônico do PIM se adequa a um cluster. Para uma visão conclusiva neste sentido, é necessário que se realizem novas pesquisas.

\section{REFERÊNCIAS}

A indústria de eletroeletrônica no Brasil - Diagnóstico e Propostas elaboradas pelos Metalúrgicos da CUT - Disponível

em: http://www.cnmcut.org.br/midias/arquivo/184-diagnostico-eletroeletronico.pdf . Acessado em 01 de julho de 2017

BAMPI, Sergio. Perspectivas do investimento em eletrônica. Rio de Janeiro: UFRJ, Instituto de Economia, v. 2009, p. 272, 2008.

BARBERIA, Lorena G.; BIDERMAN, Ciro. Local economic development: Theory, evidence, and implications for policy in Brazil. Geoforum 41 (2010) 951-962. Disponível em: www.elsevier.com/locate/geoforum. Acessado em 25 de fevereiro de 2017.

BASSO, D., NETO, B. S., \& STOFFEL, J. Concentração e especialização em setores industriais na região Noroeste Colonial do Rio Grande do Sul. Indicadores Econômicos FEE, 33(3), 163-174, 2005.

BRASIL. Constituição Federal - Ato das Disposições Transitórias, Art. 40.

. Emenda Constitucional 83/2014, de 05.08.2014. Prorroga o prazo de vigência das isenções tributárias previstas no Decreto-Lei $288 .$.

. Decreto-Lei 288, de 28.02.1967. Altera as disposições da Lei número 3.173 de 6 de junho de 1957 e regula a Zona Franca de Manaus.

. Lei 3.173, de 06.06.1957. Cria uma Zona Franca na cidade de Manaus.

BRITO, J., \& da MOTTA, E. Clusters industriais na economia brasileira: uma análise exploratória a partir de dados da RAIS. Estudos Econômicos (São Paulo), 32(1), 71-102, 2002.

ESTÉVEZ, Joan Martí. Clústers. Estrategias ganhadoras y trabajo en equipo. 1a. Edição. Barcelona, 2013. p. 19.

FIGUEIREDO, Paulo N. Industrial Policy Changes and Firm-Level Technological Capability Development: Evidence from Northern Brazil. World Development Vol. 36, No. 1, pp. 55-88, 2008. Disponível em www.elsevier.com/locate/worlddev.

HOFFMANN, Rodolfo. Estatística para economistas. 4ạ. Edição revisada e ampliada. São Paulo, 2006. 


\section{Administração: caminhos para o desenvolvimento sustentável}

HOEN, Alex. Three variations on identifying clusters. In: National Innovation Systems: Workshops and Meetings of the Focus Group on Clusters. Utrecht: OCDE, 2000, p.8-9.

HUMPHREY, John; SCHMITZ, Hubert. The triple c approach to local industrial policy. World Development, Oxford, v. 23, n. 1, p.149-162, 1995b.

KATZ, Jorge. Structural Change and Labor Productivity Growth in Latin American Manufacturing Industries 1970-96. World Development Vol. 28, No. 9, pp. 1583-1596, 2000. Disponível em www.elsevier.com/locate/worlddev.

KELLER, Paulo Fernandes. Clusters, distritos industriais e cooperação interfirmas: uma revisão da literatura. Economia \& Gestão, v. 8, n. 16, p. 30-47, 2008.

O'DONOGHUE, D., \& GLEAVE, B. A note on methods for measuring industrial agglomeration. Regional Studies, 38(4), 419-427, 2004.

PIRES, J. C., CRAVO, T., LODATO, S., \& PIZA, C. Industrial clusters and economic performance in Brazil (No. IDB-WP-475). IDB Working Paper Series, 2013.

PIEKARSKI, A. E. T., \& TORKOMIAN, A. L. V. (2005). Identificação de clusters industriais: uma análise de métodos quantitativos. Revista GEPROS, (1), Pag-40.

PORTER, Michael E. Clusters and Economic Policy: Aligning Public Policy with the New Economics of Competition. Harvard Business Review.ISC White Paper. November 2007, p. 2.

PORTER, Michael E. Clusters and the New Economics Competition. Harvard Business Review.ISC White Paper. November 2009, p. 5.

PORTER, Michael E. The Competitive Advantage of Nations. New York: Free Press, 1990.

SUPERINTENDÊNCIA DA ZONA FRANCA DE MANAUS. Indicadores de desempenho do Polo industrial de Manaus. Disponível em: http://site.suframa.gov.br/noticias/faturamento-do-pim-supera-r-34bilhoes-no-semestre/suframa-indicadores-do-pim-marco-2017.pdf. Acessado em 15 de junho de 2017

SUPERINTENDÊNCIA DA ZONA FRANCA DE MANAUS. Cartilha de Incentivos Fiscais. Disponível em: https://www.suframa.gov.br/noticias/arquivos/Cartilha_Incentivos_Fiscais_PORT_VF_04_10_2014.p df. Acessado em 20 de junho de 2017

SUPERINTENDÊNCIA DA ZONA FRANCA DE MANAUS. Perfil das Empresas com Projetos Aprovados pela SUFRAMA. Disponível em: http://www.suframa.gov.br/zfm_ind_perfil.cfm. Acessado em 18 de junho de 2017

BUARQUE, Cristovam Ricardo Cavalcanti. Avaliação Econômica de Projetos. 12.ed. Rio de Janeiro: Campus/Elsevier, 266 p.

SUZIGAN, W.; FURTADO J. GARCIA, \& SAMPAIO, S. Aglomerações industriais em São Paulo. Pesquisas NEIT. Campinas: Instituto de Economia/UNICAMP, 2000.

SUZIGAN, W.; FURTADO J. GARCIA, \& SAMPAIO, S. Sistemas Locais de Produção: Mapeamento, Tipologia e Sugestões de Políticas. Encontro Nacional de Economia, ANPEC, 2003. 


\section{Administração: caminhos para o desenvolvimento sustentável}

SUZIGAN, W., FURTADO, J., GARCIA, R., \& SAMPAIO, S. E. Clusters ou sistemas locais de produção: mapeamento, tipologia e sugestões de políticas. Revista de Economia Política, 24(4), 543-562, 2004.

SUZIGAN, W., FURTADO, J., GARCIA, R., \& SAMPAIO, S. E. Coeficientes de Gini locacionais-GL: aplicação à indústria de calçados do Estado de São Paulo. Nova Economia, 13(2), 2009.

SUZIGAN, W., FURTADO, J., GARCIA, R., \& SAMPAIO, S. E. Inovação e conhecimento: indicadores regionalizados e aplicação a São Paulo. Rev. econ. contemp., Rio de Janeiro, v. 10, n. 2, p. 323-356, Aug. 2006.

ZISSIMOS, I. R. M., RIBEIRO, E. P., \& HASENCLEVER, L. Configurações produtivas locais no Nordeste: Uma nova proposta de identificação. XII Encontro Regional de Economia, 2007. 


\section{Capítulo 7}

\section{INFRAESTRUTURA DE ACESSO: FATOR CRÍTICO DE SUCESSO PARA IMPLANTAÇÃO DE EMPREENDIMENTOS DE TURISMO RURAL.}

\section{DOI: $10.37423 / 200300368$}

Diogo Luders Fernandes (UNICENTRO) diggtur@yahoo.com.br

Elieti Fátima de Goveia (UNICENTRO) elietigoveia27@hotmail.com

Ronaldo Ferreira Maganhotto (UNICENTRO) ronaldomaganhotto@gmail_com

Resumo o turismo rural sùrge comq uma reação ao estresse e agressão que o meio urbano exerce sobre o ser humano, decorrentes da expansão das cidades industriais, além da busça para um locatjunto à natureza na tentativa de restabbelecer suas forças físicas-e mentais, o turismo rural ainda possui uma demanda que buscam uma nova forma de fazer turismo diferente das estruturas clássicas da atividade, so/e mar, indo a procura de aspectos simples e autênticos. A adequação do meio, das propriedades e das comunidades rurais para o desenvolvimento da atividade turistica deve ser feito de forma a proporcionar ao visitante uma experiência autentica, onde é nẹcessário assocjay os serviços de receptivo as dèmais atividades produtivas da propriedade, sem descaracterizá-la, pois do contrário o que encontraremos será novamente o turismo convencional. Sendo a infraestrutura de acesso um fator crítico-de-sucesso da-implantaçấp de tais tipos de empreendimentos Assim este estudo tem-por objetivo levantar-as condiç̧̃os de acesso-das propriedades dós-jovens do CEDEJOR - Guamiranga-PR, com o intuito de desenvolver o turismo rural em suas comunidades. A pesquisa caracteriza-se por um estudo descritivo desenvolvido por melo de questionários aplicados aos jovens do CEDEJOR. 


\section{Administração: caminhos para o desenvolvimento sustentável}

Os dados coletados foram sistematizados e analisados por meio do método DAFO, que identificou os fatores positivos e negativos quanto a implantação do turismo rural frente a realidade da infraestrutura de acesso as propriedades rurais.

Palavras chave: Turismo Rural, acesso, desenvolvimento econômico. 


\section{Administração: caminhos para o desenvolvimento sustentável}

\section{INTRODUÇÃO}

A atividade turística em áreas naturais possibilita a valorização do meio e cotidiano rural, surgindo como alternativa de complementação de renda às comunidades. Conseqüentemente, atingiu consideráveis índices de crescimento nos últimos anos. Assim, o turismo rural proporciona o contato direto do consumidor com o produtor que consegue vender serviços de hospedagem, alimentação, entretenimento, além de produtos in natura (frutas, ovos, verduras) ou beneficiados (compotas, queijos, artesanato).

A prática do associativismo, o resgate do patrimônio cultural e natural dos agricultores, o estabelecimento das parcerias institucionais, o comprometimento com a produção agropecuária de qualidade e com os processos agroecológicos, são alguns princípios e valores embutidos nesta atividade, que devem ser seguidos para um crescimento satisfatório deste segmento.

Conforme as Diretrizes Para o Desenvolvimento do Turismo Rural elaborado pelo Ministério do Turismo, são vários os benefícios gerados por este segmento. Suas contribuições podem vir a favorecer decisivamente no desenvolvimento socioeconômico e cultural das populações rurais a partir dos elementos descritos a seguir:

Diversificação da economia regional; interiorização do turismo; difusão de conhecimentos e técnicas das ciências agrárias; diminuição do êxodo rural; promoção de intercâmbio cultural; conservação dos recursos naturais; reencontro dos cidadãos com suas origens rurais e com a natureza; Geração de novas oportunidades de trabalho; melhoramento da infra-estrutura de transporte, comunicação, saneamento; integração do campo com a cidade; promoção da imagem e revigoramento do interior; resgate da auto-estima do campesino.

Deste modo este estudo tem por objetivo levantar as condições de acesso das propriedades dos jovens do CEDEJOR - Guamiranga-PR, com o intuito de desenvolver o turismo rural em suas comunidades.

O Centro de Desenvolvimento do Jovem Rural (CEDEJOR) é uma associação civil, sem fins lucrativos, fundada em 2001 e reconhecida como Organização da Sociedade Civil de Interesse Público (OSCIP). O público para o qual suas ações estão orientadas é a juventude residente no meio rural. Em geral, são jovens com idade entre 16 a 24 anos que tenham concluído, preferencialmente, o Ensino Médio e que pretendam desenvolver empreendimentos que visem o desenvolvimento sustentável e o fortalecimento do campo. (CEDEJOR, 2009). A organização tem como missão "contribuir para a 


\section{Administração: caminhos para o desenvolvimento sustentável}

formação de jovens empreendedores [...] através de iniciativas educacionais e da consolidação de parcerias interinstitucionais que promovam o desenvolvimento sustentável de territórios rurais" (CEDEJOR, 2009).

Os jovens ao longo da formação no CEDEJOR elaboram um projeto para suas Unidades Familiares de Produção, que necessitam suporte tecnológico para sua implantação. As atividades agrícolas de criação e cultivo e a não-agrícola, turismo, apresentam-se como opções viáveis, proporcionando o desenvolvimento local, geração de emprego e renda, diversificação da economia e melhor qualidade de vida.

Os municípios beneficiados com a ação do CEDEJOR e da UNICENTRO são: Fernandes Pinheiro; Guamiranga; Imbituva; Inácio Martins; Irati; Mallet; Prudentópolis; Rebouças; Rio Azul; Teixeira Soares e Ivaí. Todos estes compõe a Região Centro-Sul do Paraná.

Sendo assim a pesquisa realizou-se em três etapas, onde a primeira foi o levantamento bibliográfico e documental sobre a temática para familiarização com o tema, assim como a escolha do formulário para levantamento dos dados.

Após tais reflexões e análises a segundo etapa se caracterizou por uma pesquisa de campo, onde os pesquisadores munidos do formulário de levantamento de dados, adaptado do modelo do SENAR, foram a campo identificar os pontos fortes e fracos das propriedades na comunidade.

O questionário que serviu de base para a elaboração do formulário utilizado na pesquisa é usado pelo Sistema Nacional de Aprendizagem Rural - SENAR, em seus cursos de Turismo Rural, quanto a identificação da potencialidade turística das propriedades, abordando elementos como: Localização, infraestrutura da localidade e da propriedade, estrutura produtiva, recursos humanos disponíveis, potencialidade turística, recursos financeiros e perfil empreendedor do produtor rural. Sendo que para pesquisa foi realizada uma adaptação do mesmo onde foram levantados somente os dados quanto a localização, a infra-estrutura da localidade e das propriedades, suas potencialidades turísticas e produtivas.

A última etapa consistiu na interpretação dos dados levantados na pesquisa de campo, que se deu por meio da análise DAFO, que consiste no conjunto de análises do ambiente externo e interno, forças e fraquezas, oportunidades e ameaças. Esta análise possibilita e orienta a formulação de estratégias de modo à capitalizar as oportunidades e enfrentar as ameaças. 


\section{Administração: caminhos para o desenvolvimento sustentável}

Deste modo proporcionando uma avaliação das propriedades dos jovens que participam do CEDEDJOR, objetivando analisar as condições de acesso às propriedades doa alunos interessadas em implantar o turismo rural, que pode ser utilizado como forma de desenvolvimento alternativo para comunidade local.

\section{METODOLOGIA}

Para tanto a pesquisa de caráter quantitativa exploratória descritiva, fundamentado a partir de estudo de caso. O trabalho procedeu-se em dois momentos distintos, sendo o primeiro um levantamento bibliográfico sobre a temática, para que a base teórica estudada viesse a auxiliar na resposta do problema de pesquisa e concretização dos objetivos propostos pela pesquisa.

Após os levantamentos bibliográficos e documentais, foi elaborado um questionário composto por 11 questões que abordassem as indagações dos objetivos do trabalho. Ao todo foram respondidos 27 questionários pelos Jovens Rurais vinculados ao CEDEJOR, com objetivo central de identificar e analisar as condições de acesso das propriedades, como também, a distância da propriedade a sede do município, do município pólo da região e o trajeto turístico mais próxima a propriedade. No mesmo intuito por parte dos pesquisadores, foi levantado outras questões relevantes a propriedade dos jovens, sendo; a paisagens das propriedades, construções antigas, conservação e caracterização do espaço rural, assim como construção de valor histórico, organização social, realização de eventos permanentes, recolhimentos de lixo, instalação de empresas e problemas de empresas que polui a propriedade, assim como também atinge a comunidade.

Em posse dos dados coletados os mesmos foram tabulados e apresentados em forma de gráficos e tabelas para melhor entendimento e auxiliar na análise dos resultados encontrados, que se utilizou da análise DAFO, identificando as oportunidades e forças, debilidades e ameaças, para poder assim elaborar uma análise que venha a definir ações estratégicas para auxiliar no desenvolvimento turístico da região.

\section{TURISMO RURAL UMA OPORTUNIDADE DE DESENVOLVIMENTO RESPONSÁVEL}

O que se percebe dês da década de 70 é na realidade um aumento dos turistas por produtos ditos de turismo alternativo: A procura por lugares com qualidade ambiental e pouco saturado, por férias ativas, pelo contato com a natureza e a integração com a cultura e costumes locais tem feito com que os espaços rurais e naturais tornem-se destinos privilegiados dos fluxos turísticos desta categoria. 


\section{Administração: caminhos para o desenvolvimento sustentável}

Esta forma de turismo tem buscado espaços naturais e rurais onde ainda se encontra recurso natural e cultural ainda preservados ou não degradados que possam ser utilizados para fins turísticos, servindo assim como uma opção para o desenvolvimento local e regional. Outra característica marcante desta atividade é o fato de ser contraditória ao desenvolvimento convencional do turismo de massa, no turismo alternativo existe um planejamento específico, onde atividade é praticada em pequena escala, e possui uma preocupação com a preservação patrimonial e a promoção do bem-estar das populações locais.

O turismo alternativo surge como alternativa as novas tendências do mercado determinados por fatores que segundo Silveira (2001, p.135) são: interesse crescente da população por questões voltadas ao meio ambiente procura por experiências mais autentica e um maior contato e convívio com a cultura local, fuga do estresse do cotidiano dos grandes centros na busca de sossego e tranqüilidade que a vida no campo oferece e maior volume de oferta e marketing dos produtos turísticos no meio natural e rural.

Entre os segmentos do turismo que surge com o grupo de turismo alternativo encontramos o turismo rural, que aparece no mercado como uma reação ao estresse e agressão que o meio urbano exerce sobre o ser humano, decorrentes da expansão das cidades industriais, além da busca para um local junto à natureza na tentativa de restabelecer suas forças físicas e mentais, o turismo rural ainda possui uma demanda que buscam uma nova forma de fazer turismos diferentes das estruturas clássicas da atividade, sol e mar, indo a procura de aspectos simples e autênticos.

O turismo rural é uma atividade bastante nova no Brasil suas primeiras iniciativas oficiais datam da década de 80, para ser mais exato no ano de 1986, ocorreu no município de Lages em Santa Catarina, na fazenda Pedra Branca que oferecia uma proposta de vivencia de um dia com a vida no campo aos visitantes. Pioneiros na oferta de pernoite e participação com as atividades do campo encontramos a fazenda Barreira e Boqueirão. As iniciativas se expandiram por toda a região Sul e hoje temos dados que atividade é desenvolvida em todo o país.

O turismo rural no Brasil deve ser encaro diferente dos outros exemplos encontrados pelo mundo, pois a diversidade cultural, a dinâmica da produção rural no país ou a riqueza dos recursos naturais que integram o espaço rural brasileiro fazem com que o Brasil seja um modelo único de desenvolvimento da atividade. 


\section{Administração: caminhos para o desenvolvimento sustentável}

Isto porque em cada região do país encontraremos diversas formas de turismo rural isto devido a fatores como os ciclos econômicos brasileiros que deixaram na paisagem suas marcas e um diversificado patrimônio histórico - cultural, além da forma de ocupação do território que irá diversificar a forma como as terras estão divididas e como será o empreendimento, pois não podemos comparar uma pequena propriedade familiar de subsistência com população tradicional como uma grande propriedade contemporânea com produção de larga escala. Portanto classificar o turismo rural no país é uma atividade um tanto complexa que deve levar em conta as potencialidades e as realidades humanas e ambientais de cada localidade estudada.

Nestas colocações vemos que o espaço rural a cada momento vem apropriando se para satisfazer as necessidades de ócio e lazer da sociedade urbana potencializando assim suas aptidões turísticas. 0 resultado de tal dinâmica tem sido a apropriação do espaço rural para implantação de atividades produtivas que não tem um caráter agrário propriamente dito, sendo um deles o turismo rural.

O termo turismo rural ainda esta em formação, mas algumas definições expressam o que realmente deve ser entendido pela atividade. No Brasil a EMBRATUR apud Silveira (2001, p. 137), conceitua o Turismo com uma visão mercadológica considerando a atividade de turismo rural como sendo "um conjunto de atividades turísticas comprometidas com a produção agropecuária, agregando valor ao produto do meio rural, resgatando e promovendo o patrimônio cultural e natural das comunidades do campo".

Mas existe autores que vêem o turismo rural com uma ótica mais ligada aos aspectos culturais, como de Vaz (1999) citado por Silveira (2001, p. 137), para quem "turismo rural diz respeito ao conjunto de atividades que compõem a vida no campo, envolvendo a experiência do dia-a-dia nas fazendas, o convívio com camponeses, a montaria de cavalos, as plantações, as pastagens, o sabor dos alimentos comidos diretamente da fonte".

Outros autores citados por Silva (2000, p. 23) como, Cals, Capella e Vaque (1995) reservam a terminologia de "turismo rural para aquelas atividades que, em sua maior medida, identifique-se com as especificidades da vida rural, seu habitat, sua economia e sua cultura". Portanto uma atividade que pode possuir as atividades de outros tipos de turismo que deve estar diretamente ligada, expressar e valorizar a vida e os costumes da vida no campo tendo seu potencial nas capacidades humanas e ambientais do espaço rural. 


\section{Administração: caminhos para o desenvolvimento sustentável}

Outra característica importante do empreendimento de turismo rural é sua ligação com seu entorno, sua paisagem, sua história um terreno posteriormente comprado e equipado para receber o turista onde seu proprietário residir fora da propriedade e seus funcionários serem os responsáveis pelo mesmo onde não existe um caráter histórico cultural forte com as características rurais é simplesmente um empreendimento fora do perímetro urbano, mas com pouca ou quase nada de elementos rurais, a não ser sua localização.

Portanto o turismo rural tem um papel e uma capacidade de estimular e aproveitar o potencial das localidades rurais utilizadas turisticamente para proporcionar as comunidades receptoras desenvolvimento locais. Mas é preciso atenção, pois muitos dos produtos rotulados como turismo rural muita vezes não passa de atividades de lazer ou ócio fora das áreas urbanas, onde o meio rural serve apenas como base física para atividade. Não havendo uma maior interação no meio e no cotidiano rural. E não pode ser considerado o que entendemos por turismo rural, um turismo que respeita a sua identidade, "um turismo de zona rural em todas as suas formas".

Para tais casos como pesque pagues, propriedades rurais que foram adaptadas para receber eventos entre outros empreendimentos do gênero onde não há a pernoite do visitante, não podem ser classificado como turismo rural, pois primeiro não possui nenhuma característica que a classifique como tal, e segundo não havendo a pernoite não pode ser considerada como turismo, talvez como excursionismo, tais atividades estão muito mais voltados para o lazer das populações e de seus visitantes e nem toda atividade de lazer é turismo, portanto Rodrigues (2001, p. 107) sugere uma outra classificação denominando tais atividades de lazer periurbano e no caso quando a atividade se encaixa como uma atividade turística esta pode ser denominada como turismo periurbano.

Estas duas modalidades são atividades de lazer e turismo que ocorrem no meio rural, mas que não apresentam nenhuma característica de ruralidade que possa caracterizá-lo como uma atividade de turismo rural propriamente dita. Não é de concordância de todos, uma definição exata de turismo rural, mas o que encontramos em várias das bibliografias estuda é que esta atividade possui alguns elementos básicos, sendo este, que para Zimmermann (2000, p. 30) a atividade de "turismo rural deve estar obrigatoriamente em harmonia com os interesses da comunidade local, do turismo e do meio ambiente. A harmonização desses elementos significa garantir a sustentabilidade da atividade por meio do tripé: elementos culturais/antrópicos, ecológicos e econômicos". 


\title{
Administração: caminhos para o desenvolvimento sustentável
}

O produto de turismo rural segundo Zimmermann (2000, p.131) obedecer a princípios como "atendimento familiar e preservação das raízes, harmonia e sustentabilidade ambientais, autenticidade e manutenção da identidade, qualidade do produto e envolvimento da comunidade local".

As atividades de restaurante, pousadas, industrialização caseira e outras atividades de lazer podem se encaixar sim no âmbito do turismo rural, mas para tanto é importante conforme Silva (2000, p. 20) que tais atividades: "[...] se constituem em atividades internas à propriedade - on farm -, que geram ocupação complementares às atividades agrícolas, as quais continuam a fazer parte do cotidiano da propriedade em menor ou maior intensidade."

Pode ser mais bem explicado com a comparação entre o hotel - fazenda e a fazenda - hotel, elaborado por Silva (2000, p. 20 - 21), nestes dois equipamentos turísticos encontramos a diferença entre um turismo desenvolvido na área rural e o turismo rural.

\begin{abstract}
O hotel - fazenda pode ser entendido, antes de tudo, como um hotel similar aos outros, com a particularidade de estar localizado na zona rural (com raras exceções) e não na praia. Daí, oferecer serviços integrados ao local onde se instalou, por exemplo, passeios a cavalo e comidas típicas da zona rural onde se localiza, da mesma maneira que o hotel à beira - mar oferece passeios de jangada e moqueca de peixe. Na fazenda - hotel, a propriedade agropecuária continua com suas atividades produtivas. Além de andar a cavalo, contemplar paisagens e praticar esportes, os hóspedes podem vivenciar rotinas que vão desde as cotidianas ordenha e alimentação do gado até as práticas agrícolas sazonais, como preparo do solo e as colheitas.
\end{abstract}

Portanto o turismo rural não é simplesmente a atividade turística realizada no meio rural ele é uma atividade que busca proporcionar ao turista uma experiência autentica da vivência no campo.

O senso comum pode observar qual é a relação existente entre os transportes e o turismo, qualquer pessoa que já saiu de viagem, seja qual for sua motivação, sabe que para alcançar seu destino teve de utilizar um meio de transporte, portanto assim podemos ver que o turismo não existe sem o transporte, sendo este um dos elementos básicos da atividade turística.

No turismo os sistemas de transportes são fundamentais na realização da atividade, fornecendo a ligação necessária entre as cidades de origem dos turistas aos seus destinos desta forma para Page (2001, 15) "facilitando o movimento de pessoas em férias, viajantes a negócios, gente que visita amigos e parentes e aqueles que se dedicam ao turismo educacional e de saúde. O transporte também é um elemento-chave da "experiência turística"”". 


\section{Administração: caminhos para o desenvolvimento sustentável}

Sendo os transportes um dos fatores mais significativos no desenvolvimento do transporte internacional e doméstico, o desenvolvimento dos transportes está diretamente relacionado com o aparecimento e crescimento da atividade do turismo, as melhorias nas condições do transporte proporcionaram facilidades para o desenvolvimento do turismo como um todo.

Onde o crescimento do turismo em uma localidade ou sua expansão, baseia-se muitas vezes em uma questão de acessibilidade a áreas de seus atrativos e recursos. Onde este sistema é um elemento que apóia e sustenta o crescimento contínuo da prática do turismo.

Segundo Palhares $(2002,27)$.

Como forma de definir a atividade de transporte, mas especificamente para o caso do transporte voltado para o turismo, o mesmo pode ser tido como a atividade meio que interliga a origem de uma viagem turística a um determinado destino (e vice-versa), que interliga vários destinos turísticos entre si (primário e secundário) ou que faz com que os visitantes se desloquem dentro de um mesmo destino primário ou secundário.

Portanto os transportes têm uma importância quando a interligação entre as zonas emissivas dos turistas até suas destinações passando pelo espaço de percurso, e ainda os roteiros que interligam os atrativos e os equipamentos turísticos de uma localidade. Os elementos constituintes do transporte podem ser classificados segundo Palhares $(2002,29)$ em: vias de acesso, veículos, força motriz e terminal.

Sendo as vias de acesso um dos componentes da infraestrutura, onde Boullón (2002) ressalva que o desenvolvimento do turismo está condicionado a infraestrutura, pois não é possível investir em locais cujo acesso é inviável, permanecendo incomunicável, mesmo que lá se encontre um atrativo de grande expressão. Sem uma infraestrutura básica não tem condições de se implantar os empreendimentos turísticos e atender os turistas. Muitas vezes a causa da ausência de infraestrutura está vinculado ao seu custo que é alto e de retorno a longo prazo, mas o que os governos precisam tomar consciência, que as verbas destinas à melhoria de infraestrutura de uma localidade, não são gastos mas sim investimentos, pois através de sua implantação se torna mais fácil captar investimentos da iniciativa privada para o desenvolvimento econômico da região, assim como tais investimento do poder público vão proporcionar uma melhoria na qualidade de vida da população local. 


\section{Administração: caminhos para o desenvolvimento sustentável}

Assim o acesso é um dos elementos condicionantes do desenvolvimento do turismo sendo um fator determinante para a implantação de empreendimentos que venham a atender a demanda turística, que sem boas vias de acesso e de uma sinalização adequada, sem a acessibilidade não existe turismo, uma vez que a atividade turística está diretamente relacionada ao deslocamento de indivíduos ou grupos de indivíduos.

Assim a adequação do meio, das propriedades e das comunidades rurais para o desenvolvimento da atividade turística deve ser feito de forma a proporcionar ao visitante uma experiência autentica, onde é necessário associar os serviços de receptivo às demais atividades produtivas da propriedade, sem descaracterizá-la, pois do contrário o que encontraremos será novamente o turismo convencional.

Portanto o turismo rural possui alguns princípios básicos que devem ser elementos integrantes as atividades que visam à divulgação das características tradicionais regionais, designadamente o seu patrimônio, os itinerários temáticos, o folclore etc.

Outros elementos de destaque são a especificidade familiar, a alternativa de renda em caráter de complementaridade com outras atividades socioeconômicas. Desta forma proporcionando um aumento em particular do rendimento dos agricultores e a qualidade de vida das populações, em geral. Portanto para uma atividade turística ser considerado de turismo rural este deve possuir qualidades que o tornem verdadeiramente rural, a saber: qualidade ambiental, sossego, contatos personalizados.

Portanto uma atividade que deve respeitar o meio ambiente comprometendo-se com a conservação de seu patrimônio natural e cultural, onde as atividades devem ser baseadas nas potencialidades humanas e ambientais locais.

Mesmo com todas estas vantagens o turismo rural não pode ser encarado como a salvação ou a solução para os problemas do campo, o que esta atividade vem a oferecer são soluções parciais para tais problemas: como o estimulo a outras possibilidades de atividade rurais não agrárias voltadas à recepção e atendimento da demanda turística no campo; promove um mercado para produtos tradicionais e agrícolas que pode vir a suprir o excesso de produção das propriedades, que do contrário poderia vir a desaparecer; possibilitam novas formas de renda complementares as atividades desenvolvidas na propriedade transformando as tarefas clássicas em atividades produtivas; além de atrair investimentos externos na comunidade receptora. 


\section{Administração: caminhos para o desenvolvimento sustentável}

A atividade de turismo rural de acordo com Zimmermann (2000, p. 128) pode atuar como um agente promotor das seguintes funções: ser uma estratégia para a preservação e a recuperação ambientais do espaço rural, garantir a manutenção das atividades tradicionais e a conseqüência manutenção da família rural no campo, formular um novo conceito de produção, com a conseqüência incrementação da receita para o espaço rural.

Portanto o turismo rural deve ser desenvolvido segundo Silveira (2001, p. 138 -139) de forma, planejada buscando a sustentabilidade, de modo a, entre outras coisas, "compatibilizar a conservação e o desenvolvimento dos recursos turísticos destacando se a importância do patrimônio natural e sociocultural e o respeito à integridade desses recursos"; bem como, "promover um turismo organizado e administrado pela população rural com uma oferta de pequena escala, o que torna essa estratégia possível e permite que benefícios econômicos do turismo tenham incidência na sociedade rural".

Desta forma ao se pensar no turismo rural deve-se ir além da teoria da sustentabilidade, esta atividade deve ser formulada, organizada e executada, com uma política territorial e uma estratégia de desenvolvimento com base local baseado em um planejamento integrado e participativo. Onde a comunidade pode interagir com todos os atores locais, podendo tomar suas decisões buscando o que é melhor pra si, de modo a aproveitar seu potencial humano e natural.

Assim as políticas e planos de desenvolvimento da atividade do turismo rural devem buscar aliar a utilização turística dos recursos, à preservação ambiental e histórica cultural, na potencialidade natural e humana da localidade, na tentativa de proporcionar ao turista à experiência mais autentica possível, para que com isso haja uma geração de emprego e renda para as comunidades locais, proporcionando melhoria da qualidade de vida destas populações, incentivando desta forma a permanência dos proprietários no meio rural.

Para que os benefícios do turismo rural ocorram é necessária uma gestão integrada, participativa e democrática da atividade turística na região, que tenha como base o princípio da satisfação das necessidades locais considerando a capacidade de carga ambiental do território.

Ruschmann (2000,p. 71) alerta que "para tanto é preciso ter consciência que a proteção da originalidade desses meios dependerá do tipo de desenvolvimento proposto para área, que só será 


\section{Administração: caminhos para o desenvolvimento sustentável}

sustentável se for voltada para a valorização do homem do campo, para sua autenticidade e para a estabilidade ecológica do meio natural."

Buscar os benefícios para a população local deve ser as reais preocupações os planejadores e gestores da atividade tendo sempre em vista a manutenção da atividade agropecuária e a valorização da cultura rural, para que assim o turismo rural possa obter segundo Silva $(2000$, p. 32) efeitos indiretos como: melhoria da infraestrutura e das telecomunicações, desenvolvimento das pequenas e médias indústrias existentes no meio rural, como conseqüência do crescimento da demanda por artesanato e produtos alimentícios, melhoria indireta do setor agrícola, pela potencialização de produtos de qualidade típicos de cada zona, como é o caso do mel, dos queijos, dos embutidos.

Esta estratégia para ser bem sucedida necessita indispensavelmente do apoio da participação efetiva da comunidade local. Nenhuma política ou estratégia de desenvolvimento terá sucesso sem a sua participação, uma vez que apenas ela devidamente conscientizada tem o poder de definir a intensidade e os rumos pretendidos para a atividade.

O turismo proporciona as áreas rurais uma segunda chance uma vez que a primeira perdeu-se com a exaustão de sua potencialidade produtiva, pelo uso indiscriminado do solo e de pesticidas. O futuro e o desenvolvimento desta atividade esta diretamente relacionada a qualidade do produto oferecido, pela promoção dos valores locais e da estabilidade da autenticidade cultural e da proteção ambiental, proporcionando a comunidade rural uma melhoria nas suas condições de vida de modo a integrar os elementos econômicos, sociais, culturais e ambientais.

\section{APRESENTAÇÃO E ANÁLISE DOS RESULTADOS}

As respostas dos 27 questionários aplicados aos jovens do CEDEJOR - Guamiranga-PR, propiciaram aos pesquisadores elementos que auxiliaram a um diagnóstico quanto a potencialidade e as oportunidades de desenvolver o turismo nas propriedades rurais. Para este estudo específico decidiuse por orientar as análises quanto a infraestrutura de acesso as áreas rurais.

Uma vez que a questão de acesso é fundamental na prática do turismo, sendo o deslocamento um fator inerente na existência da prática turística, condicionando muitas vezes o desenvolvimento da atividade na localidade, Palhares (2002) deixa claro em seus estudos que a acessibilidade das localidades é um dos fatores decisivos a ser atentado pelos órgãos responsáveis pelo planejamento e gestão do turismo. 


\section{Administração: caminhos para o desenvolvimento sustentável}

Quando trabalhado o turismo rural a acessibilidade deve ter atenção diferenciada, uma vez que as estradas rurais em sua maioria não possuem pavimentação, o que dificulta sua manutenção em períodos chuvosos, tanto das vias de acesso quanto de estruturas existentes na vias (pontes, bueiros, etc.), a sinalização é outro fator crítico nas vias rurais a inexistência ou o péssimo estado de conservação das mesmas dificultam a localização das propriedades rurais, estas são realidades relatadas pelos questionários (Tabela 1) e pode ser comprovado pelas reportagens na mídia impressa e televisiva da região, impedindo o acesso aos possíveis empreendimentos de turismo rurais nos municípios.

\begin{tabular}{ccc}
\hline Condições de acesso & Pavimentação & Sinalização \\
\hline Bom & $33 \%$ & $22 \%$ \\
Ruim & $67 \%$ & $78 \%$ \\
\hline
\end{tabular}

Elaborado pelos Autores

Tabela 1 - Estado de conservação da infraestrutura de acesso.

As condições de acesso das propriedades dos 27 jovens estudadas revelaram conforme os questionados que 09 consideram que as estradas encontram-se em bom estado de conservação. Porém, 18 destes jovens apontaram nesta pesquisa que o acesso quanto à pavimentação encontra-se num estado precário e teria que ocorrer investimentos por parte do setor público para o melhoramento desta realidade e a sua utilização para o turismo, sendo necessária a revitalização das vias, de pontos e bueiros.

Pois o estado atual das vias prejudica o deslocamento de visitantes até as propriedades devido a buracos, irregularidades e má condições das estradas, muitas das vezes ocasionando prejuízos, quebras e desgastes nos automóveis dos turistas, que devido a esta má conservação optam por outro tipo de atividade. A sinalização também foi apontada pelos jovens rurais do CEDEJOR Guamiranga/PR, como crítica, o que dificulta o deslocamento de turista até as propriedades, pois não tendo placas indicativas é praticamente impossível localizar as propriedades e as comunidades no meio rural.

Quanto a sinalização, somente 5 jovens consideram bom e 21 dos respondentes, ou seja, quase a maioria das propriedades encontra-se em estado de precariedade quanto a sinalização nas vias de acesso as propriedade, necessitando também de investimentos por parte do poder público olhar mais 


\section{Administração: caminhos para o desenvolvimento sustentável}

para o interior dos municípios e seria um ponto forte para que os jovens viessem a pensar a empreender alguma atividades voltada ao turismo rural.

Sendo assim vemos que o estado de conservação das vias, assim como a sinalização são elementos que devem ser mais bem trabalhados no processo de planejamento e gestão do turismo nas propriedades estudadas, do que adianta tais localidades possuírem atrativos e estarem preparadas para receber o turista, se este não tem condições de chegar ao empreendimento, sendo assim este é um fator limitante do desenvolvimento de turismo rural nas propriedades da maioria dos jovens que responderam o questionário.

Mesmo que as propriedades estejam próximas das sedes de seus municípios como pode ser observado na tabela a seguir, as más condições das estradas muitas vezes impedem o desenvolvimento da prática da atividade do turismo.

\begin{tabular}{lcc}
\hline \multicolumn{1}{c}{ Distância de pontos referenciais } & SIM & Ñ̃O \\
\hline Menos de 20 KM da sede do município & $73 \%$ & $27 \%$ \\
Menos de 100 KM do município polo da região & $78 \%$ & $22 \%$ \\
Menos de 50 KM do trajeto turístico mais próximo & $58 \%$ & $42 \%$ \\
\hline
\end{tabular}

\section{Elaborado pelos Autores}

Tabela 2 - Proximidade das propriedades rurais as municípios.

A tabela anterior nos trás alguns dados interessantes que foram adquiridos com os questionários, um fator de sucesso da atividade turística consiste em os destinos turísticos estarem próximos as regiões emissoras dos turistas, sendo assim as propriedades que se encontram próximos aos municípios pólos regionais, possui uma vantagem competitiva frente as que se encontram mais distante, uma vez que os atrativos das áreas rurais pode se tornar um chamariz aos moradores destas cidades, que por motivos como descanso, fuga da rotina, busca de áreas de lazer em contato com a natureza e a vida no campo, podem atrair visitantes a estas propriedades.

A proximidade das propriedades com trajetos turísticos já existentes pode ser considerada um fator favorável para a implantação do turismo nas propriedades rurais, pois próximo a estas áreas já existe um fluxo de turistas que trafega pela região, podendo vir a ser uma demanda potencial para os empreendimentos de turismo rural, portanto a proximidade das propriedades a trajetos turísticos existentes, como a BR-277, ou a municípios que já vem trabalhando o turismo como é o caso de Prudentópolis, tem maiores oportunidades de implantação uma vez que estes novos 


\section{Administração: caminhos para o desenvolvimento sustentável}

empreendimentos podem vir a se tornar atrativos complementares em produtos turísticos já consolidados e com um fluxo de turista já existe, mesmo que sazonal.

Os aspectos da infraestrutura de acesso, assim como a proximidade das propriedades rurais a municípios que possuam uma demanda potencial para prática do turismo são fatores determinantes em um planejamento e na organização de atividades de turismo rural na região Centro-Sul do Paraná, portanto a seguir será apresentada os fatores que contribuem e restringem quanto a infraestrutura de acesso a implantação da atividade de turismo rural nas propriedades dos jovens do CEDEJOR Guamiranga-PR.

\begin{tabular}{|c|c|c|c|}
\hline \multicolumn{4}{|c|}{ Interno } \\
\hline & Forças (Pontos Fortes) & & Debilidades (Pontos Fracos) \\
\hline $\mathrm{F} 2$ & $\begin{array}{l}\text { Localização próxima a sede do } \\
\text { município; } \\
\text { Localização próxima dos municípios } \\
\text { pólos da região; } \\
\text { Localização próxima a trajetos e a } \\
\text { municípios turísticos; }\end{array}$ & $\begin{array}{l}\text { D1 } \\
\text { D2 }\end{array}$ & $\begin{array}{l}\text { Sinalização dos nomes e entradas das propriedades; } \\
\text { Estado de conservação das vias de acesso as } \\
\text { propriedades rurais; }\end{array}$ \\
\hline \multicolumn{4}{|c|}{ Externo } \\
\hline & Oportunidades & & Ameaças \\
\hline $\mathrm{O} 1$ & $\begin{array}{l}\text { Demanda potencial existente próximo as } \\
\text { propriedades; }\end{array}$ & A1 & $\begin{array}{l}\text { Falta de investimento em obras de melhorias das } \\
\text { condições de acesso das estradas rurais; }\end{array}$ \\
\hline $\mathrm{O} 2$ & $\begin{array}{l}\text { Estar localizada em uma região turística } \\
\text { do Estado do Paraná; }\end{array}$ & A2 & $\begin{array}{l}\text { Manutenção por parte da prefeitura com as vias } \\
\text { rurais; }\end{array}$ \\
\hline
\end{tabular}

Elaborado pelos Autores

Tabela 3 - Forças, debilidades, oportunidades e ameaças quanto ao acesso.

Por meio da tabela anterior podemos fazer uma análise da condição real que se encontra tais propriedades quanto a efetivação da implantação do turismo quanto ao fator acesso. Considerando o que foi trabalhado na fundamentação teórica deste estudo e retomando os relatos de Palhares (2002) a questão de acessibilidade a atrativos, empreendimentos e destinos turístico é um fator que resultará de sucesso ou não da atividade, uma vez que a infraestrutura de acesso é deficiente dificultando a chegada do turista, a destinação terá um fator crítico de desenvolvimento.

Assim a análise da Tabela 3, indica que seja feita algumas considerações quanto ao caso estudado, identificando elementos favoráveis e desfavoráveis quanto a implantação do turismo nas propriedades estudadas. 


\section{Administração: caminhos para o desenvolvimento sustentável}

Primeiramente a localização das áreas rurais próxima ao município sede, ao município pólo da região e a trajetos turísticos já existentes, deve ser considerada pontos fortes e favoráveis para implantação da atividade turística, uma vez que esta proximidade vem a facilitar o acesso quanto à distância, pois facilita a chegada dos turistas, o traslado quando necessário dos turistas entre a cidade e o empreendimento de turismo rural, a compra de produtos necessários para atender aos turistas minimizando custos com deslocamento, assim como a contratação de mão-de-obra se for o caso. Outro fator positivo principalmente para as propriedades próximas a trajetos turísticos já existentes é a possível colocação no mercado em um produto turístico já formatado e organizado, sendo o empreendimento rural mais uma opção de produto turístico para região.

Como conseqüências dos fatores trabalhos anteriormente têm como oportunidades para estas propriedades o fato de que suas localizações favorecem a implantação da prática turística por estarem próxima a trajetos turísticos que são freqüentados por visitantes, sendo assim já há uma demanda que trafega próximo a estas áreas, que com um pequeno investimento em publicidade como: outdoors, guias e sites. Poderiam estar atraindo estes turistas que já frequentam a região.

As proximidades com as sedes dos municípios e com os municípios pólos regionais fazem com que no entorno destas propriedades, exista uma demanda potencial que pode ser motivada por produtos turísticos de lazer e descanso junto à natureza e em contato com a vida no campo, que venha a contribuir para o descanso e a fuga da rotina dos moradores destes centros urbanos.

Em contra partida a estes pontos fortes e oportunidades trabalhos na Tabela 3 e nos parágrafos anteriores, os pontos fracos e as ameaças existentes são significativas, pois as duas estão diretamente ligadas ao problema das condições de sinalização e de estado de conservação das vias de acesso a estas propriedades.

As péssimas condições das estradas rurais que ligam a propriedade ao município sede e a falta de sinalização indicando a propriedade e as localidades rurais são elementos que além de desqualificar o possível produto turístico, dificultando a chegada e a saída dos turistas das propriedades é um fator crítico quanto ao desenvolvimento do turismo rural nas propriedades estudadas, pois como se encontram hoje estas estradas não é possível garantir o turismo uma acesso de qualidade e seguro, atendendo as necessidades dos visitantes. 


\section{Administração: caminhos para o desenvolvimento sustentável}

Estes fatores críticos muitas vezes são reflexos da falta de investimento e de manutenção das estradas rurais, isto devido as intensas chuvas deste ano, do tráfego de carga pesada nas estradas e da quantidade de estradas rurais existentes em nossos municípios que dificultam o trabalho de manutenção das mesmas, devido ao reduzido número de maquinários e mão-de-obra dos órgãos responsáveis, resultando em uma realidade que em muitos casos inviabiliza investimentos no meio rural como o turismo.

Portanto a análise dos dados coletados neste trabalho apresenta uma realidade desfavorável a implantação do turismo nas propriedades rurais, uma vez que mesmo tendo as vantagens mencionadas anteriormente conforme a Tabela 3, proximidade com a sede do município, como o município pólo regional e com trajetos turísticos já existentes, deste modo apresentando assim uma demanda real e potencial para o turismo rural, não é suficiente para qualificar o investimento, pois estas vantagens frente as restrições apresentadas pelo péssimo estado de conservação das estradas rurais e a falta de sinalização, faz com que mesmo próximo aos centros urbanos estes possíveis empreendimentos apresentem sérios problemas de acessibilidade, fato este que dificulta e muito o sucesso do turismo, pois mesmo com atrativos de qualidade as condições da infraestrutura de acesso restringiria a chegada dos turistas até os empreendimentos.

\section{CONSIDERAÇÕES FINAIS}

O turismo rural é um instrumento de desenvolvimento e alternativa de renda para propriedades rurais, uma vez que por meio da prática do turismo insere na área rural uma atividade econômica não agrícola que vem a contribuir e complementar a receita das famílias rurais.

Por suas características a atividade do turismo rural vem a contribuir em áreas rurais que possuem potencialidades para a prática turística, esta atividade visa uma experiência onde o turista terá contato com os modos e costumes da vida no campo, portanto exige das propriedades que decidam por sua implantação o desenvolvimento em conjunto das atividades tradicionais do campo em conjunto com o turismo, sendo uma complementação econômica para famílias rurais que buscam diversificar a produção de suas propriedades.

O turismo rural tem em sua essência a preservação do meio ambiente, a conservação dos costumes e da cultura do homem do campo, a melhoria da qualidade de vida das comunidades rurais e a 


\section{Administração: caminhos para o desenvolvimento sustentável}

complementação de renda das propriedades. Portanto uma atividade estratégica para a manutenção e o desenvolvimento da vida dos proprietários rurais.

Estas características incentivaram alguns jovens do CEDEJOR - Guamiranga - PR, em desenvolver projetos de implantação de turismo rural em suas propriedades, considerando a distância de suas propriedades à sede do município como gargalo para empreender alguma atividade relacionada ao Turismo. Contudo, as precárias condições de acesso e sinalização as propriedades dos jovens rurais, são fatores limitantes para que estes possam pensar em empreender atividade turística em suas propriedades.

Ficou claro que os pontos fortes e as oportunidades trabalham neste estudo não foram suficientemente satisfatórios frente às deficiências e as fraquezas que a infraestrutura de acesso às propriedades rurais apresentam, dificultando a implantação do turismo nesta áreas rurais.

A questão de acessibilidade é um fator crítico de sucesso no turismo, assim investimentos nestas áreas devem ser feitas nas estradas rurais nos municípios que tem o intuito de diversificar sua economia oportunizando a famílias rurais uma complementação de renda com uma atividade econômica não agrícola em suas propriedades. Onde o turismo rural venha a contribuir para a permanência do homem no campo, de forma a lhe oferecer uma alternativa econômica e complementar ao seu trabalho agrícola, um desenvolvimento responsável em harmônio com o meio ambiente, preservando a cultura local, buscando a melhoria de vida para as famílias rurais.

\section{REFERÊNCIAS}

CEDEJOR. Apresentação. Disponível em:

http://www.cedejor.org.br/ctms/1/1/apresentacao acesso em: 27/04/2009.

JOAQUIM, Graça. Turismo e o mundo rural: que sustentabilidade? IN. RODRIGUES, A. B. Turismo rural: prática e perspectivas. São Paulo: Contexto, 2001; pg. 35 - 46.

MINISTÉRIO DO TURISMO. Diretrizes para o desenvolvimento do turismo rural no Brasil. Secretaria de Políticas de Turismo. 2003

PAGE, Stephen. Transporte e Turismo. Porto Alegre: Bookman, 2001.

PALHARES, G. L. Transportes Turísticos. São Paulo: Edusc, 2002.

RODRIGUES, A. B. Turismo rural no Brasil - ensaio de uma tipologia. IN. RODRIGUES, A. B. Turismo rural: prática e perspectivas. São Paulo: Contexto, 2001; pg. 101 - 116. 


\section{Administração: caminhos para o desenvolvimento sustentável}

RUSCHMANN, D. V. M. O turismo rural e o desenvolvimento sustentável. IN. ALMEIDA, J. A.; FROEHLICH, J. M.; RIEDL, M. (orgs.). Turismo rural e desenvolvimento sustentável. Papirus: Campinas, 2000, pg. $63-74$.

SILVA, J. G.; VILARINHO, C.; DALE, P.J. Turismo em áreas rurais: suas possibilidades e limitações no Brasil. IN. ALMEIDA, J. A.; FROEHLICH, J. M.; RIEDL, M. (orgs.). Turismo rural e desenvolvimento sustentável. Papirus: Campinas, 2000, pg.15- 63.

SILVEIRA, M. A. T. da. Política de turismo: oportunidade ao desenvolvimento local. IN. RODRIGUES, A. B. Turismo rural: prática e perspectivas. São Paulo: Contexto, 2001; pg. $133-150$.

ZIMMERMANN, A. Planejamento e organização do turismo rural no Brasil. IN. ALMEIDA, J. A.; FROEHLICH, J. M.; RIEDL, M. (orgs.). Turismo rural e desenvolvimento sustentável. Papirus: Campinas, 2000, pg. $127-142$. 


\section{Capitulo 8}

\section{SISTEMAS DE INFORMAÇÕES GERENCIAIS NO AUXÍLIO À TOMADA DE DECISÃO NAS MICRO E PEQUENAS EMPRESAS DE VESTUÁRIO}

DOI: $10.37423 / 200300369$

Amilton Luiz Novaes (Universidade Federal da Grande Dourados - UFGD)

Elizângela Cristina Martins Fernandes (Universidade Estadual de Mato Grosso do Sul - UEMS)

José Jair Soares Viana (Universidade Federal da Grande Dourados - UFGD)

Rosemar José Hall (Universidade Federal da Grande Dourados - UFGD)

Filipe Toscano de Brito Simões Corrêa (EMBRAPA)

Resumb: A tomada de dęcisão é influenciada pelas informações/que olgestor possui à sua disposição, ò que por sua veżpode afetar o posicionamento e a estratégia dè-uma empresa. O presente artigo objetivou diagnosticar às Micro e Pequenas Empresas (MPEs) do comércio varejista de vestuàrio no município de Doùrados-M\$ no que diz respeito às suas ferramentas de auxílio no processa de tomada de decisẩo. A escolha do referido setor-se justifica por sua expressiva participação na eøonomia do município, gerando diversos postos de trabalho e contribuinđo para o desenvolvimento da região. Para a realização deste estudo, ùtilizou-se inicialmente de uma pesquisa exploratória, e em seguida de uma pesquisa descritiva transversal única. Os dados primários foram colétádos por meio de um questionârio estruturado aplicado à amostra de 40 estabeledimentos. Foi possível constatar que os gestpres das MPES pesquisadas se utilizam de/Sistemas de Informação (SIGs) de forma incipiente, não usufruindo de todos os benefficios que eles podem proporcionar.

Palavra-Chave: tomada de decisão, sistemas de informação, varejo, vestứákio 


\section{Administração: caminhos para o desenvolvimento sustentável}

\section{INTRODUÇÃO}

\section{REVISÃO DA LITERATURA}

De acordo com Laudon e Laudon (2007), toda empresa opera em um ambiente que engloba tanto elementos ligados diretamente a ela, tais como clientes, fornecedores, acionistas, concorrência e órgãos que regulamentam a atividade, quanto elementos que atuam de forma mais ampla, como aspectos políticos, econômicos, tecnológicos e acontecimentos internacionais, que de certa forma afetam a maneira como as empresas e seus sistemas operam.

Para Oliveira (2007), quanto menor se tornar a incerteza no processo decisório através do uso da informação, maior qualidade lhe será atribuída. E no que diz respeito ao valor, este é relacionado à utilização final da informação. O autor ainda acrescenta que a informação deve ser disponibilizada o quanto antes para que seja útil no processo decisório, e deve estar de acordo com as prioridades definidas no modelo de gestão da empresa.

Simon (1960) apud Laudon e Laudon (2007) considera que o processo decisório é composto por quatro fases: inteligência, concepção, seleção e implementação. Na fase de inteligência os problemas existentes na organização são identificados, juntamente com as causas, localização e efeitos. Na concepção ocorre um levantamento das maneiras de resolver o problema. A seguir, na seleção, optase por uma das soluções, que será colocada em prática na fase de implementação, controlando-se os resultados. Caso a alternativa escolhida não seja satisfatória, pode-se retornar ao estágio anterior e escolher uma outra alternativa.

O número de etapas do processo de decisão varia conforme o pesquisador. Nesse sentido, Hammond, Keeney e Raiffa (1999, p. 6-9) definem oito: (1) trabalhar sobre a correta decisão do problema; (2) especificar seus objetivos; (3) criar alternativas imaginativas; (4) entender as conseqüências; (5) lutar com suas trocas; (6) esclarecer suas dúvidas; (7) pensar muito sobre sua tolerância ao risco; e, (8) considerar decisões interligadas. Tais elementos são denominados de PrOACT, e os autores revelam que estes oferecem um quadro de enriquecimentos das possibilidades aumentando as chances de encontrar uma solução satisfatória.

Uma questão importante levantada por Laudon e Laudon (2007) diz respeito à qualidade das decisões, pois os critérios considerados para avaliá-las dependem da organização, das partes envolvidas e dos valores pessoais do tomador da decisão. Dentre os critérios analisados, podem ser citadas: precisão, abrangência, imparcialidade, velocidade, coerência e obediência a um processo. 


\section{Administração: caminhos para o desenvolvimento sustentável}

E ainda, a tomada de decisões pode ser afetada por algumas limitações, tais como a carência de informações que dentre outras estão relacionadas ao problema ou aos critérios. Tais informações possuem sua qualidade e quantidade reduzidas devido a restrições de tempo e custo. Soma-se a esse quadro a quantidade reduzida de informações retidas na memória dos decisores, além da racionalidade limitada. Ainda segundo o autor, o gestor muitas vezes se depara com situações incertas, cujas decisões são críticas e envolvem áreas importantes. Deve-se reconhecer a existência da incerteza e analisar as alternativas de forma sistemática e racional. (BAZERMAN, 2004)

Oliveira (2007) acrescenta que o decisor, durante o processo decisório, deve conhecer os fatores internos e externos da organização para que possa visualizar as alternativas possíveis e ponderar quais efeitos a seleção de uma alternativa em detrimento das outras poderá causar na empresa. Isso se torna possível através das informações que o decisor possui à sua disposição, sejam relacionadas à empresa ou ao ambiente no qual ela se encontra.

Desta forma, pode-se definir Sistema de Informações Gerenciais (SIG) como sendo "o processo de transformação de dados em informações que são utilizadas na estrutura decisória da empresa, proporcionando, ainda, a sustentação administrativa para otimizar os resultados esperados" (OLIVEIRA, 2007, p. 26). Turban, Rainer Jr. e Potter (2007) acrescentam que um SIG é um Sistema de Informação que sintetiza dados e gera relatórios, em sua maioria para gerentes intermediários, embora tais recursos possam também ser direcionados a gerentes de outros níveis.

O sistema de informações consubstancia-se no conjunto de elementos (humanos, tecnológicos, materiais e financeiros) que viabiliza a captação de dados, seu processamento e a geração e divulgação de informações. Ele é o encarregado de prover informações, em todas as etapas do processo de gestão (planejamento, execução e controle), para os diferentes níveis hierárquicos e áreas funcionais da empresa (BEUREN, 2000, p. 38-9).

Oliveira (2007) ressalta que o SIG constitui um poderoso instrumento a ser utilizado no apoio à decisão, embora o processo decisório ainda seja influenciado por diversos fatores, tais como a criatividade dos decisores e a cultura organizacional. Laudon e Laudon (2007) acrescentam a essa lista premissas, valores e métodos. Neste sentido, os sistemas de informações, conforme apontado por Bio (2008), interagem com a estrutura organizacional das empresas, principalmente em relação à coleta de dados dos processos. Como os dados fluem através da estrutura, em todas as funções envolvidas, de onde são originados, torna-se mais difícil identificar sua origem, caso seja detectada alguma alteração de sentido nos relatórios. 


\section{Administração: caminhos para o desenvolvimento sustentável}

Conforme salientado por Bio (2008), devido à dependência e influência mútuas entre os sistemas e a organização, qualquer modificação em tais relações causará efeitos na outra parte, como por exemplo a necessidade de transferir, reagrupar, eliminar, criar novos cargos ou re-analisar a autoridade/responsabilidade. $\mathrm{E}$ ainda que os problemas existentes na organização interferem no desenvolvimento dos sistemas, dentre os quais podem ser citados: união errônea de funções, ou ao criar departamentos em demasia, faz com que as informações movimentem-se na estrutura de forma demorada e desordenada; autoridade/responsabilidade indeterminadas, que torna difícil definir a quem recorrer caso haja alguma alteração de sentido; ausência de funções essenciais para atingir um objetivo, ou tais funções não possuem a importância que lhes devia ser atribuída, o que faz com que as informações geradas pelo sistema não reflitam a realidade da empresa; e funções iguais sendo executadas de maneiras diversas. Esses são apenas alguns dos problemas que podem ser encontrados em uma organização, e em determinadas situações, alguns podem não ser solucionados, entretanto, é necessário levar em consideração os impactos que tais problemas causarão no sistema e na tomada de decisão.

Beal (2004) cita dois fatores igualmente importantes que interferem no conjunto de atributos da decisão e que permitem avaliá-la: a qualidade da informação e a habilidade do decisor em extrair o sentido da informação para que possa selecionar a opção mais adequada. Nesse sentido, Beuren (2000) destaca a importância do fator humano no processo decisório, que confere utilidade à informação não apenas de acordo com a maneira com a qual o gestor toma decisões, mas também à sua conduta com relação às informações.

Para que o sistema de informações possa, de fato, contribuir na tomada de decisão, Oliveira (2007) menciona alguns pontos que merecem atenção, como a participação das pessoas no processo, sejam tomadores de decisão ou geradores de informações, bem como a importância de os gestores estarem aptos a reconhecer as necessidades de informações, a utilização do SIG na tomada de decisões, seguindo o plano-mestre, de forma a atingir os resultados definidos tanto no planejamento estratégico, que possui a natureza mais abrangente, quanto no tático e operacional, que contemplam as particularidades dos SIGs; a utilização de um sistema de controladoria, que pode dinamizar a atuação do SIG no processo; e, os custos para desenvolvimento e manutenção de um SIG, que devem ser menores do que os benefícios dele advindos.

Mason Jr. (1975 apud BEUREN, 2000), salienta que para o desenho e arquitetura de um sistema de informações gerenciais é imprescindível a análise minuciosa do processo decisório e do fluxo de 


\section{Administração: caminhos para o desenvolvimento sustentável}

informações, pois a qualidade das decisões é dependente da relação existente entre as informações fornecidas pelo sistema e quais informações os gestores, ou tomadores de decisão, necessitam. Sobre tais necessidades, Beal (2004) afirma que elas são diferentes para cada nível de usuário e, por isso não estão restritas ao conteúdo das informações, mas tambémestão relacionadas à forma como as informações são organizadas e expostas, visando a sua utilização.

De acordo com Beuren (2000), para avaliar a utilidade das informações, faz-se necessário especificar suas particularidades, como custo, valor, qualidade e validade. Para tal, a mensuração das informações é essencial. Ao mensurar, podem ser utilizados tanto métodos quantitativos quanto qualitativos, ressalvando que as limitações do método e a particularidade a ser definida determinarão a escolha de um em detrimento de outro. Para Oliveira (2007), o valor efetivo da informação decorre do impacto causado nas decisões e das vantagens por ela proporcionadas levando em consideração o tempo de uso da mesma.

Porém, como não existe uma forma de precisar o valor das informações, Horngren (1982) apud Beuren (2000) afirma que as opções de informações disponíveis devem ser analisadas considerando como critérios alguns objetivos, aceitar o fato de que a incerteza existe e, dentre as opções, selecionar a que figurar como a melhor escolha. Para avaliar as informações, pode-se utilizar o método do custobenefício, no qual é feita uma suposição com base na ligação entre o sistema de informações, a tomada de decisão, a seqüência de atuação selecionada e suas conseqüências.

Além dessas características, Beuren (2000, p. 32) cita ainda a relevância de algumas, tais como: "a precisão e significância das informações transmitidas, a rapidez com que as informações fluem dos pontos sensores aos centros de decisão, a periodicidade, tempestividade e adequação da informação gerada etc". Entretanto, segundo a autora, é complicado definir a quantidade ideal de informações a serem geradas, de modo que seu custo marginal se iguale à vantagem a ela atribuída, pois não há como prognosticar o impacto que esta informação terá, no que diz respeito à influência e à redução de incerteza na tomada de decisão. Beal (2004) acrescenta que o volume de informações não deve exceder a capacidade das pessoas em processá-las, e que para conferir-lhes utilidade, faz-se necessário selecioná-las de acordo com a conveniência, volume e qualidade.

Para planejar, os gestores necessitam tanto de informações internas, que dizem respeito ao funcionamento da empresa, quanto externas, que são relativas ao ambiente, e abrangem aspectos políticos, legais, características do governo, da sociedade, tendências econômicas e informações sobre o mercado no qual a empresa atua. Para controlar, as informações necessárias incluem as relacionadas 


\section{Administração: caminhos para o desenvolvimento sustentável}

ao que foi efetivamente realizado no plano de vendas, aspectos da produção e de finanças. E os dados externos, em virtude da dificuldade de aquisição e adequação dos mesmos às normas e procedimentos, requerem um tratamento mais cuidadoso. $(\mathrm{BIO}, 2008)$

No que diz respeito às políticas na organização, para Oliveira (2007, p. 136), "Política é definição dos níveis de delegação, faixas de valores e/ou quantidades-limite e de abrangência das estratégias e das ações para a consecução dos objetivos e das metas da empresa". Bio (2008, p. 53) atribui os seguintes conceitos: "políticas são 'decisões futuras', ou 'são orientações preestabelecidas para a tomada de decisões no sentido dos objetivos', ou, ainda, 'são guias de raciocínio planejados para a tomada de decisões repetitivas no sentido dos objetivos'”. O autor acrescenta que as políticas estratégicas, por interferir significativamente no funcionamento da organização, consequentemente afetam seus sistemas e subsistemas, inclusive nas questões ligadas às necessidades de informação. As políticas operacionais, por sua vez, estão relacionadas a um subsistema em especial. Ambas exercem influência sobre os sistemas, em maior ou menor grau, positiva ou negativamente.

Sobre a utilização de tecnologia nos sistemas de informação, Bio (2008) aponta alguns fatores que influenciam na decisão, dentre os quais podem ser citados: a quantidade de dados e informações a serem processados, a rapidez com que eles devam fluir da origem para o ponto de decisão, a relação entre o custo e as vantagens advindas da obtenção e uso da tecnologia, bem como os recursos para adquiri-la. A tecnologia escolhida, por sua vez, pode requerer alterações no arranjo da organização, sobretudo nas decisões sobre centralizar e/ou descentralizar as tarefas, de acordo com os recursos disponíveis na empresa.

A decisão de adquirir recursos de processamento eletrônico de dados possui alguns fatores preponderantes, pois o simples fato de adquiri-los não garantirá a qualidade do sistema de informações. Entretanto, os benefícios advindos da adoção de computadores permitem maximizar a qualidade dos sistemas, principalmente no que diz respeito à confiabilidade das informações, capacidade de armazenamento, classificação, retenção e recuperação das mesmas, dentre outras habilidades que, dependendo da situação, poderiam não ser realizadas, ou até mesmo executadas com restrições relacionadas a tempo, volume de trabalho, dentre outras, sem a aquisição de tais recursos. Devido a essas e outras restrições, existem algumas ocasiões diante das quais o uso do computador é recomendado, tais como: grande volume de processamento, operações repetitivas, grande quantidade de cálculos, rotinas estáveis, necessidade de informações distribuídas em tempo hábil e com exatidão (BIO, 2008). 


\section{Administração: caminhos para o desenvolvimento sustentável}

Beal (2004) afirma que a informatização torna-se uma tendência natural dos sistemas de informação manuais, à medida que a quantidade de informações e a complexidade de processamento aumentam. Em tais condições, os sistemas manuais apresentam problemas ou limitações, dos quais Bio (2008) cita dois: proliferação de arquivos de dados duplicados nos departamentos, e dificuldades por parte dos departamentos em reconhecer até que ponto o desempenho de suas atividades interfere nas atividades dos demais departamentos. Ainda de acordo com Beal (2004), a utilização de recursos computacionais não exclui a participação das pessoas no processo, pois é através dela que os sistemas de informação tornam-se úteis e funcionais.

De acordo com Turban, Rainer Jr. e Potter (2007), os três principais tipos de relatórios fornecidos por um SIG são os relatórios de rotina, os ocasionais e os de exceção. Os relatórios de rotina são produzidos periodicamente. Os relatórios ocasionais (por demanda) contêm informações que não estão contidas nos relatórios de rotina, e tais relatórios podem ser detalhados, de indicadores principais ou comparativos. Os relatórios de exceção contemplam as informações que, ao serem comparadas com os padrões, apresentam discrepâncias e indicam áreas problemáticas.

\section{METODOLOGIA}

Para atender aos objetivos, este estudo fez uso da pesquisa exploratória e da pesquisa descritiva transversal única. De acordo com Malhotra (2006), a pesquisa exploratória visa proporcionar maior entendimento sobre o problema. A pesquisa exploratória foi complementada por uma pesquisa descritiva transversal única. Ainda para o autor, o estudo transversal único é o qual se obtém as informações de uma amostra extraída da população-alvo, uma única vez. Neste estudo a coleta de dados foi feita através de questionários pessoais. Utilizou-se também dados secundários disponíveis em livros, publicações e Internet.

Foi elaborado um questionário estruturado, contemplando 2 partes, a saber: caracterização da empresa e do gestor; e, aspectos específicos relacionados a sistemas de informações gerenciais. Os questionários foram respondidos pelos gestores/proprietários dos estabelecimentos.

O universo de empresas do comércio varejista de vestuário e acessórios no município de DouradosMS, segundo consulta à Junta Comercial do Estado de Mato Grosso do Sul (JUCEMS), totalizou 717 MPEs, das quais 684 são micro e 33 são pequenas empresas, contudo, não há como determinar quantos são os estabelecimentos que comercializam apenas artigos de vestuário, e quantos ainda estão em atividade. $O$ tamanho da amostra pesquisada foi de 40 empresas, escolhidas por critério de 


\section{Administração: caminhos para o desenvolvimento sustentável}

acesso, independente do tipo de artigo de vestuário comercializado. Foram entregues 77 questionários, com o retorno de 40 questionários válidos. O pré-teste foi realizado em 6 estabelecimentos nos dias 13 e 14 de outubro de 2008. Os questionários do pré-teste foram desconsiderados do total. A pesquisa foi realizada no período de 15 a 21 de outubro de 2008 .

\section{ANÁLISE E DISCUSSÃO DOS DADOS}

As micro e pequenas empresas do comércio varejista de vestuário do município de Dourados-MS possuem em média 11 anos, sendo a mais antiga de 1970 e a mais recente de 2008. Dos estabelecimentos pesquisados, utilizando um dos critérios adotados pelo SEBRAE (2009) para classificar as empresas de acordo com o porte, que é o número de funcionários, 32 são micro e 8 são pequenas empresas. O tempo de experiência médio do administrador no segmento acima mencionado é de 12 anos. A maior parte dos pesquisados (62,5\%) é do gênero feminino, e 47,5\% dos respondentes situam-se na faixa etária de 30 a 39 anos.

A dedicação aos negócios mostrou-se ser integral para $82,5 \%$ dos gestores e, dentre os $17,5 \%$ que se dedicam parcialmente, 3 declararam-se autônomos, 3 se dedicam ao comércio em outro ramo e 1 afirmou ser fazendeiro. Em $70 \%$ dos estabelecimentos pesquisados, o proprietário administra o empreendimento. No que tange à formação, em $45 \%$ dos estabelecimentos pesquisados o gestor possui ensino superior completo, seguido por $25 \%$ que possuem ensino médio completo.

Em 82,5\% das empresas pesquisadas não havia divisão por departamentos, e das que a possuíam, percebe-se que os departamentos mais comuns são Vendas, em 31,6\%, Financeiro e Gerência, ambos em $15,8 \%$ das empresas. Independentemente da divisão por departamentos, de acordo com os gestores, Vendas é a função mais importante da empresa, com $29 \%$, seguida por Compras, com $25,5 \%$ e Finanças, com $21 \%$ das respostas.

Na maioria dos estabelecimentos pesquisados o número de peças de vestuário vendidas por mês ultrapassa 250 unidades. O número médio de funcionários é de 8 pessoas. No que diz respeito a treinamentos, $42,5 \%$ das empresas entrevistadas não investem mensalmente em treinamento de funcionários, e os 57,5\% restantes investem valores inferiores a $R \$ 50,00$ (25\%) e valores entre $R \$$ 101,00 e 150,00 (12,5\%). Em 30\% dos estabelecimentos, os gestores afirmam que os funcionários que não estão diretamente ligados à gestão participam ativamente do processo decisório, enquanto que $35 \%$ atuam parcialmente. 


\section{Administração: caminhos para o desenvolvimento sustentável}

No que diz respeito ao uso de tecnologia nos SIGs, nota-se que entre 1 e $20 \%$ das decisões tomadas pelos gestores em $32,5 \%$ dos estabelecimentos, são utilizados sistemas informatizados ou qualquer meio de processamento eletrônico na tomada de decisão, seja na geração de relatórios, refinamento de informações, etc. Os gestores que afirmaram não recorrer a recursos computacionais envolvendo o SIG representam $15 \%$ do total de pesquisados. Para $50 \%$ dos pesquisados, a forma como as informações são exibidas influencia muito na tomada de decisão, seguido pelos $40 \%$ que acreditam que a forma influencia pouco. Para 35\% dos respondentes, as decisões tomadas são influenciadas em um grau que varia entre 41 e 60\% pelas informações disponíveis na empresa, para 25\% a influência é de 61 a 80\%, e em 15\% dos estabelecimentos a influência é de 81 a 100\%, como pode ser verificado através da Tabela 1.

\begin{tabular}{|l|c|c|}
\hline \multicolumn{1}{|c|}{ Influência das informações } & Frequência & $\%$ \\
\hline $0 \%$ & 1 & 2,5 \\
\hline & & 5,0 \\
\hline a $20 \%$ & 2 & 17,5 \\
\hline 21 a $40 \%$ & 7 & 35,0 \\
\hline 41 a $60 \%$ & 14 & 25,0 \\
\hline 61 a $80 \%$ & 10 & 15,0 \\
\hline T1 a $100 \%$ & 6 & $\mathbf{1 0 0 , 0}$ \\
\hline
\end{tabular}

Tabela 1 - Influência das informações disponíveis exercida sobre as decisões

Fonte: Pesquisa de campo (2009).

A forma como as informações são trabalhadas na empresa deveria continuar como ocorre atualmente, para $52,5 \%$ dos gestores. As respostas dos gestores que acreditam que o processo deveria sofrer alterações constam na Tabela 2. A ordem de importância varia do 1 ao 3, sendo 1 a maior importância e 3 a menor importância. Para o cálculo da média ponderada, foram atribuídos pesos de 1,0 a 3,0, ordenados de forma decrescente, de acordo com a importância, sendo assim, a maior importância recebeu peso 3,0 e a menor importância recebeu peso 1,0. Dos pesquisados, 19,3\% apontaram "Reuniões entre os funcionários" como sendo a alteração mais importante, 15,8\% escolheram "Análise para detectar as informações que são realmente relevantes" e "Participação dos demais funcionários" como sendo as alterações de média importância e 13,2\% atribuíram à "Geração de relatórios" a menor importância.

Dos gestores pesquisados, 30\% afirmaram que a busca de informações externas ocorre diariamente, para $25 \%$ dos respondentes a busca é semanal e em $15 \%$ dos estabelecimentos não há essa preocupação. No que diz respeito às fontes de informações externas utilizadas na empresa, os 


\section{Administração: caminhos para o desenvolvimento sustentável}

gestores puderam escolher mais de uma alternativa. Dentre as fontes com maior número de respostas estão Clientes, Internet, Fornecedores e Funcionários, com 19,4\%, 12,6\%, 10,9\% e 10,3\%, respectivamente.

\begin{tabular}{|l|c|c|c|c|c|}
\hline \multirow{2}{*}{ Possíveis alterações } & \multicolumn{3}{|c|}{ Importância } & \multirow{2}{*}{ Média } & \% \\
\cline { 2 - 5 } & $\mathbf{1}$ & $\mathbf{2}$ & $\mathbf{3}$ & & \\
\hline Maneira como são coletadas as informações & 2 & 2 & 2 & 2,0 & 10,5 \\
\hline Geração de relatórios & 2 & 3 & 3 & 2,5 & 13,2 \\
\hline Armazenamento de informações & 1 & 1 & 0 & 0,8 & 4,4 \\
\hline Forma como são divulgadas as informações & 1 & 2 & 3 & 1,7 & 8,8 \\
\hline Participação dos demais funcionários & 3 & 3 & 3 & 3,0 & 15,8 \\
\hline Utilização de computadores & 0 & 2 & 3 & 1,2 & 6,1 \\
\hline Reuniões entre os funcionários & 5 & 2 & 3 & 3,7 & 19,3 \\
\hline Velocidade com a qual as informações são distribuídas & 1 & 2 & 0 & 1,2 & 6,1 \\
\hline Análise para detectar quais informações são realmente relevantes & 4 & 2 & 2 & 3,0 & 15,8 \\
\hline Total & $\mathbf{1 9}$ & $\mathbf{1 9}$ & $\mathbf{1 9}$ & $\mathbf{1 9 , 0}$ & $\mathbf{1 0 0 , 0}$ \\
\hline
\end{tabular}

Tabela 2 - Alterações no processo de coleta e tratamento de informações

Fonte: Pesquisa de campo (2009).

Das informações que, segundo os respondentes, são importantes à tomada de decisão, mas que não estão disponíveis na empresa, informações sobre concorrentes obtiveram maior número de respostas (17,3\%). Os gestores que necessitam de informações referentes à Marketing e funcionários representaram $14,8 \%$, percentual igual àqueles que afirmam que possuem todas as informações necessárias.

De acordo com a Tabela 3, dos relatórios gerados na empresa, os que obtiveram maiores ocorrências foram Vendas, Estoque e Financeiro, respectivamente $33,9 \%, 25,7 \%$, e $22,0 \%$. Os estabelecimentos pesquisados também apresentaram, para os mesmos relatórios, maior número de respostas no que diz respeito aos relatórios efetivamente utilizados na empresa, respectivamente $37,8 \%, 28,6 \%$ e 21,4\%. Destaca-se o fato de os relatórios de Marketing, de maneira geral, apresentaram um número de respostas bem inferior se comparados aos demais relatórios, obtendo o penúltimo lugar na lista. Isso, somado ao fato de que os relatórios de Vendas obtiveram o maior número de respostas, pode indicar uma orientação voltada às vendas nos estabelecimentos pesquisados. Nota-se ainda que o número de relatórios gerados é maior do que o número de relatórios utilizados, o que sugere que os SIGs das empresas pesquisadas geram informações que não são utilizadas. 


\section{Administração: caminhos para o desenvolvimento sustentável}

\begin{tabular}{|l|c|c|c|c|}
\hline \multirow{2}{*}{\multicolumn{1}{c|}{ Relatórios }} & \multicolumn{2}{c|}{ Gerados } & \multicolumn{2}{c|}{ Utilizados } \\
\cline { 2 - 5 } & Frequência & $\%$ & Frequência & $\%$ \\
\hline Vendas & 37 & 33,9 & 37 & 37,8 \\
\hline Estoque & 28 & 25,7 & 28 & 28,6 \\
\hline Financeiro & 24 & 22,0 & 21 & 21,4 \\
\hline Contábil & 13 & 11,9 & 9 & 9,2 \\
\hline Marketing & 4 & 3,7 & 2 & 2,0 \\
\hline Recursos Humanos & 2 & 1,8 & 1 & 1,0 \\
\hline Nenhum & 1 & 0,9 & 0 & 0,0 \\
\hline Total & $\mathbf{1 0 9}$ & $\mathbf{1 0 0 , 0}$ & $\mathbf{9 8}$ & $\mathbf{1 0 0 , 0}$ \\
\hline
\end{tabular}

Tabela 3 - Relatórios gerados e efetivamente utilizados na empresa

Fonte: Pesquisa de campo (2009).

Considerando investimento para aquisição de informações como sendo a quantia investida para obtenção de informações das fontes externas citadas anteriormente, em 32,5\% dos estabelecimentos pesquisados, o investimento mensal em informações superou $\mathrm{R} \$ 250,00$. No que diz respeito à quantia máxima que o gestor estaria disposto a investir na aquisição de informações, o número de respostas com valores superiores a $\mathrm{R} \$ 250,00$ foi reduzido, passando a representar apenas $25,0 \%$ das respostas, o que pode apontar uma tendência de redução de custos por parte das empresas.

Em 41,4\% das empresas, as informações são armazenadas em computadores, através de programas processadores de texto, planilhas ou qualquer outra forma de arquivo eletrônico armazenado em discos rígidos, excluindo dessa contagem os bancos de dados, presentes em 18,6\% dos estabelecimentos. Os gestores utilizam arquivos de documentos impressos em $21,4 \%$ das empresas. Os respondentes podiam escolher mais de uma alternativa sobre a forma de armazenamento, caso julgassem necessário.

\begin{tabular}{|l|c|c|c|c|c|}
\hline \multicolumn{1}{|c|}{ Variáveis } & CT & CP & NCND & DP & DT \\
\hline As informações chegam em tempo hábil. & 45,0 & 35,0 & 2,5 & 5,0 & 12,5 \\
\hline As informações são confiáveis. & 42,5 & 25,0 & 15,0 & 7,5 & 10,0 \\
\hline As informações chegam em quantidade adequada. & 37,5 & 37,5 & 7,5 & 5,0 & 12,5 \\
\hline $\begin{array}{l}\text { Há uma preocupação quanto ao armazenamento e descarte das } \\
\text { informações consideradas confidenciais. }\end{array}$ & 77,5 & 10,0 & 5,0 & 0,0 & 7,5 \\
\hline $\begin{array}{l}\text { Coletam-se informações junto aos clientes para identificar comportamentos } \\
\text { de compra e tendências. }\end{array}$ & 65,0 & 20,0 & 2,5 & 2,5 & 10,0 \\
\hline Os relatórios gerados contêm todas as informações necessárias. & 40,0 & 27,5 & 10,0 & 2,5 & 20,0 \\
\hline São gerados relatórios diferentes de acordo com os níveis hierárquicos. & 57,5 & 10,0 & 5,0 & 2,5 & 25,0 \\
\hline Há relatórios contendo os recursos disponíveis no caixa da empresa. & 82,5 & 7,5 & 2,5 & 0,0 & 7,5 \\
\hline $\begin{array}{l}\text { Não há relatórios internos na empresa que especifiquem as contas a receber } \\
\text { dos clientes e seus respectivos prazos de recebimento. }\end{array}$ & 5,0 & 12,5 & 0,0 & 2,5 & 80,0 \\
\hline A empresa mantém controle diário das vendas em relatórios internos. & 90,0 & 10,0 & 0,0 & 0,0 & 0,0 \\
\hline $\begin{array}{l}\text { Os custos da empresa não possuem relatórios internos de controle, sendo } \\
\text { esta uma função da contabilidade. }\end{array}$ & 30,0 & 5,0 & 2,5 & 2,5 & 60,0 \\
\hline $\begin{array}{l}\text { As informações obtidas através dos relatórios de fluxo de caixa são usadas } \\
\text { para planejar melhor as políticas de prazos da empresa. }\end{array}$ & 80,0 & 17,5 & 0,0 & 2,5 & 0,0 \\
\hline
\end{tabular}




\section{Administração: caminhos para o desenvolvimento sustentável}

\begin{tabular}{|l|l|l|l|l|l|}
\hline $\begin{array}{l}\text { As informações obtidas nos relatórios de fluxo de caixa da empresa são } \\
\text { usadas no processo de tomada de decisão. }\end{array}$ & 77,5 & 15,0 & 7,5 & 0,0 & 0,0 \\
\hline $\begin{array}{l}\text { O processo de coleta e tratamento das informações é avaliado } \\
\text { periodicamente para detectar falhas ou alterações necessárias. }\end{array}$ & 40,0 & 27,5 & 15,0 & 0,0 & 17,5 \\
\hline $\begin{array}{l}\text { Incentiva-se a colaboração dos funcionários que não estão diretamente } \\
\text { ligados às funções de gerência. }\end{array}$ & 52,5 & 20,0 & 10,0 & 5,0 & 12,5 \\
\hline $\begin{array}{l}\text { Legenda: CT: Concordo Totalmente; CP: Concordo Parcialmente; NCND: Não Concordo Nem Discordo; DP: } \\
\text { Discordo Parcialmente; DT: Discordo Totalmente. }\end{array}$ \\
\hline
\end{tabular}

Tabela 4 - Afirmações referentes ao processo de tomada de decisão (em valores percentuais)

Fonte: Pesquisa de campo (2009).

De acordo com a Tabela 4, sobre a chegada de informações em tempo hábil à tomada de decisão, em $80 \%$ dos estabelecimentos pesquisados, todas ou quase todas as informações chegam em tempo hábil e $17,5 \%$ dos respondentes afirmam que quase todas ou todas as informações não chegam a tempo. No que diz respeito à confiabilidade da informação para o processo decisório, $67,5 \%$ dos gestores afirmam que todas ou quase todas as informações são confiáveis, $15 \%$ dos pesquisados permaneceram neutros quanto a esse aspecto e em $17,5 \%$ das empresas todas ou quase todas as informações não são confiáveis.

Quanto ao volume de informações disponíveis, 75,0\% dos respondentes consideram adequado, ou adequado na maioria das vezes. Em 17,5\% dos estabelecimentos, a quantidade de informações disponíveis ao gestor é sempre ou quase sempre inadequada. Em 87,5\% dos estabelecimentos há uma preocupação com o armazenamento e descarte de todas ou quase todas as informações consideradas confidenciais, e 7,5\% dos gestores não consideram esse aspecto importante. Das empresas pesquisadas, $85 \%$ coletam informações junto aos clientes para identificar padrões de compra e tendências, ou tais informações são coletadas, mas não exatamente dessa forma e com essa finalidade. Conforme mencionado anteriormente, a utilização das informações relacionadas a Marketing é limitada, o que aponta ao menos duas possibilidades no que diz respeito às informações coletadas junto aos clientes: os gestores utilizam as informações de forma limitada, voltados apenas ao volume de vendas, negligenciando aspectos como moda e tendências; ou as informações são coletadas, mas por alguma razão elas não utilizadas.

Ainda conforme a Tabela 4, no que diz respeito a relatórios, em $67,5 \%$ dos estabelecimentos os relatórios contêm todas ou quase todas as informações necessárias à tomada de decisão, enquanto que em $22,5 \%$ das empresas os relatórios contêm algumas ou até mesmo nenhuma das informações necessárias. Em 67,5\% das empresas são gerados relatórios total ou parcialmente diferentes, de 


\section{Administração: caminhos para o desenvolvimento sustentável}

acordo com os níveis hierárquicos. Em 27,5\% dos estabelecimentos são gerados relatórios iguais ou com poucas diferenças entre os níveis.

A disponibilidade de caixa da empresa é controlada através de relatórios em $82,5 \%$ das empresas. Os relatórios contendo as contas a receber dos clientes e respectivos prazos de recebimento estão presentes em $80 \%$ dos estabelecimentos, e $90 \%$ das empresas controlam diariamente suas vendas através de relatórios internos. Os custos são controlados através de relatórios internos em $60 \%$ dos casos, enquanto $30 \%$ dos gestores controlam os custos através de informações vindas da Contabilidade. As informações obtidas através dos relatórios de fluxo de caixa são utilizadas para planejar as políticas de prazos de pagamentos e recebimentos em $80 \%$ das empresas, e $77,5 \%$ dos gestores utilizam tais informações no processo decisório.

Segundo a Tabela 4, em 67,5\% das empresas o processo de coleta e tratamento de informações passa por avaliações para detectar eventuais falhas ou alterações necessárias, seja de forma periódica ou em intervalos de tempo irregulares, e em $17,5 \%$ das empresas não há avaliações. A colaboração dos funcionários que não estão ligados diretamente às funções de gerência no processo de tomada de decisão, no sentido de levar informações relevantes aos decisores, é incentivada em $72,5 \%$ das empresas, total ou parcialmente, enquanto em $12,5 \%$ dos estabelecimentos a colaboração não é incentivada.

Os relatórios de vendas são classificados em 93,3\% das empresas, e as principais classificações são por tipo de venda e por vendedor, ambas com 35\% das respostas, e ainda há a classificação por clientes, utilizada em $23,3 \%$ dos estabelecimentos. O acompanhamento das informações e relatórios do fluxo de caixa em $67,5 \%$ das empresas pesquisadas é feito diariamente.

E, para $67,5 \%$ dos gestores, as informações possuem vida útil estimada em 29 meses. Os demais respondentes afirmaram que a vida útil de tais informações é indefinida. As informações consideradas antigas são mantidas em arquivo em $55 \%$ dos estabelecimentos, e em $30 \%$ elas são mantidas temporariamente. Não foi possível determinar o período que tais informações permanecem em arquivo. Nos estabelecimentos restantes (15\%), as informações são descartadas após o uso. A maioria dos gestores $(82,5 \%)$ afirmou que raramente se depara com informações duplicadas ou redundantes, $10 \%$ admitiram que essa ocorrência é freqüente e $7,5 \%$ responderam que nunca se depararam com tal situação. 


\section{Administração: caminhos para o desenvolvimento sustentável}

\section{CONSIDERAÇÕES FINAIS}

A presente pesquisa realizou um diagnóstico da utilização dos Sistemas de Informações Gerenciais no auxílio à tomada de decisão em Micro e Pequenas Empresas do comércio varejista de vestuário na cidade de Dourados-MS. Através dos resultados obtidos foi possível concluir que os gestores da maioria dos estabelecimentos pesquisados se utilizam dos SIGs de forma incipiente.

Grande parte dos gestores realiza suas atividades de planejamento e controle através de registros manuais e, dentre as empresas que se utilizam de tecnologia no auxílio à decisão, nota-se que o uso de tais ferramentas ainda é limitado. Deve-se considerar, no entanto, conforme apontado por Bio (2008), um dos fatores que determinam a aquisição de tecnologia a ser utilizada em Sistemas de Informação é representado pelos recursos disponíveis na empresa para adquirir tal tecnologia, o que em se tratando de MPEs, torna-se complicado devido à escassez de recursos, que lhes é característica.

O processo decisório é influenciado pelas informações internas e externas disponíveis na empresa, em um grau que poderia ser classificado como mediano. Das informações internas, nota-se uma tendência por parte dos gestores em priorizar os relatórios relacionados a Vendas em detrimento de Marketing e Recursos Humanos. Percebeu-se ainda a intenção de alguns gestores em reduzir os investimentos destinados à aquisição de informações.

Dentre as principais falhas que foram detectadas no decorrer da pesquisa, podem ser citadas a carência de informações que os gestores julgam necessárias à tomada de decisão e a geração de relatórios que não são utilizados no processo decisório. Foram constatadas algumas áreas críticas à implantação e posterior funcionamento do SIG, dentre elas podem ser citadas a filtragem de informações relevantes à tomada de decisão, reuniões entre funcionários e participação dos funcionários que não estão ligados diretamente às funções de gerência no processo decisório, como geradores e disseminadores de informações. Estes foram os fatores mais citados pelos respondentes no que diz respeito a alterações.

Conforme o que havia sido afirmado por Beal (2004), Beuren (2000) e Oliveira (2007), com posterior comprovação através dos resultados dessa pesquisa, independente do nível de utilização de tecnologia, o fator humano é de suma importância para o bom funcionamento de um SIG, pois tal sistema não seria funcional caso os decisores não fossem capazes de determinar quais informações são necessárias, ou extrair o sentido dessas informações para utilizá-las na tomada de decisão. Alterações como as que foram apontadas pelos gestores poderiam potencializar os efeitos de um 


\section{Administração: caminhos para o desenvolvimento sustentável}

Sistema de Informações Gerenciais, de forma que a empresa possa usufruir os benefícios por ele proporcionados, ressaltando que um SIG deve ser visto como um instrumento administrativo e que os resultados dependem das decisões tomadas pelos gestores com base nas informações fornecidas.

\section{REFERÊNCIAS}

BAZERMAN, Max H. Processo decisório: para cursos de Administração e Economia. Rio de Janeiro: Elsevier, 2004.

BEAL, Adriana. Gestão Estratégica da Informação: Como Transformar a Informação e a Tecnologia da Informação em Fatores de Crescimento e de Alto Desempenho nas Organizações. São Paulo: Atlas, 2004. 144 p.

BEDÊ, Marco Aurélio (coord.). Onde estão as micro e pequenas empresas no Brasil. São Paulo: SEBRAE, 2006. Disponível

em:<http://201.2.114.147/bds/BDS.nsf/6001C92ABEE055BF8325723C006739DE/\$File/NT00034016. pdf>. Acesso em 15 jul. 2008.

BEUREN, Ilse Maria. Gerenciamento da informação: um recurso estratégico no processo de gestão empresarial. São Paulo: Atlas, 2000.

BIO, Sérgio Rodrigues. Sistemas de informação: um enfoque gerencial.2 ed. São Paulo: Atlas, 2008.

HAMMOND, J. S.; KEENEY, R. L.; RAIFFA, H. Smart choices. Boston, Mass.: Harvard Business School Press, 1999.

HORNGREN, Charles T. Management Accounting: where are we? In: RAPPAPORT, Alfred. Information for decision making: readings in cost and managerial accounting. 3. ed. Englewood Cliffs, New Jersey: Prentice Hall, 1982.

LAUDON, Kenneth C.; LAUDON, Jane P. Sistemas de Informações Gerenciais. 7. ed. São Paulo: Pearson Prentice Hall, 2007.

MALHOTRA, Naresh. Pesquisa de Marketing: uma orientação aplicada. 4. ed. Porto Alegre: Bookman, 2006.

MASON JR.; Richard O. Basic concepts for designing Management Information Systems. In: RAPPAPORT, Alfred. Information for decision making: quantitative and behavioral dimensions. 2. ed. Englewood Cliffs, New Jersey: Prentice Hall, 1975.

OLIVEIRA, Djalma de Pinho Rebouças de. Sistemas de Informações Gerenciais: estratégicas, táticas, operacionais. 11. ed. São Paulo: Atlas, 2007.

RAIS - Relação Anual de Informações Sociais. Brasília: Ministério do Trabalho e Emprego, 2004. CDROM.

SEBRAE - Serviço de Apoio às Micro e Pequenas Empresas. Critérios e conceitos para classificação de empresas. 2009. Disponível 


\section{Administração: caminhos para o desenvolvimento sustentável}

em:<http://www.sebrae.com.br/customizado/estudos-e-pesquisas/integra_bia?ident_unico=97>. Acesso em 16 jul 2009.

SIMON, H. A. The new science of Management decision. New York: Harper \& Row, 1960.

TURBAN, Efraim; RAINER JR., R. Kelly; POTTER, Richard E. Introdução a Sistemas de Informação: uma abordagem gerencial. Rio de Janeiro: Elsevier, 2007. 


\section{Capítulo 9}

\section{O SIMBOLISMO ORGANIZACIONAL PELA TEORIA DAS PRÁTICAS NOS ESTUDOS SOBRE AS PRÁTICAS DA AGRICULTURA FAMILIAR BRASILEIRA}

DOI: $10.37423 / 200300372$

Thiago Chagas De Almeida (Graduado em Administração Pública pela trniversidade Estadual do Norte Fluminense Darcy Ribeiro - UENF, Mestrando em Administração pela Universidade Federal do Espírito Santo - UFES - Universidade Federal do Espírito Santot.

thiagocfalmeida@kotmail.com

Resumo: O simbolismo organizaciònal são transformações de şentido èm representações compreensíveis à organização (WOOD yUNIOR, 2001). Desse modo, associando as práticas da agricultura familiar ao conceito de organizing, o presente artigo objetivou análisar como os simbolismos organizacionais se manifestam no estudos sobre as práticas da agricultura familiar brasileira e as contribuições que a tẹoria das práticas pode dar a esses estudos. Para tanto, esse-trabalho utilizou uma metodologia qualitativa, baseada em pesquisa bibliográfica. Após a discussão, observou-se que poucos estudos associam o simbolismo organizacional às práticas agrícolas familiares e percebeu-se uma ausência de trabalĭos que fazem essa as\$ociação pela lente da prática. Como contribuições, a teoria das práticas poderia levar a um maior entendimento de como essas ações se gonstituem e se estapelecem entum processo-contínuo e situado.

PALAVRAS-EHAVE:-Simbolismo organizacional, teoria das práticas, agricultura familiar. 


\section{Administração: caminhos para o desenvolvimento sustentável}

\section{INTRODUÇÃO}

O simbolismo organizacional é um campo de estudo bastante diverso no que tange suas perspectivas teóricas. De acordo com Reckwitz (2002), diversas teorias sociais analisam os simbolismos nas organizações, como o mentalismo culturalista, o textualismo, o intersubjetivismo e a das práticas. Morgan, Frost e Pondy (1983) também analisam a diversidade de abordagens teóricas articulando o simbolismo a quatro paradigmas dos estudos organizacionais, são eles: humanismo radical, estruturalismo radical, sociologia interpretativa e sociologia funcionalista. Já Hassard e Cox (2013), fazem outra distribuição paradigmática nos estudos organizacionais. A partir de uma subdivisão entre crítico e normativo, os autores apresentam paradigmas voltados ao estruturalismo, antiestruturalismo, e pós-estruturalismo. Portanto, observa-se que é possível analisar o simbolismo organizacional por diferentes "lentes" teóricas. No entanto, este trabalho deu ênfase à teoria da prática, ao considerar que essa teoria se articula melhor ao conceito de organizing (organizar), visto seu caráter dinâmico de enxergar a organização.

Diferente do conceito de organização que exprime um sentido estático ou de estruturas fixas, o conceito de organizing, discutido por Duarte e Alcadipani (2016), representa uma organização que se estabelece e se transforma continuamente. O foco então deixa de ser a "organização dos processos" e passa a ser o "processo de organizar" (HATCH, 2011). Segundo Hatch (2011), a perspectiva do organizing permite um maior entendimento de como a cultura, estrutura e práticas são produzidas nas organizações. Portanto, a escolha de se aprofundar nessa perspectiva de organização, se deu pela sua capacidade de gerar um entendimento maior de como as práticas (objeto empírico) organizacionais são produzidas.

Nesse sentido, identificando as práticas da agricultura familiar como um processo de organização contínuo, em que seus significados se estabelecem e se moldam a partir das relações entre seus indivíduos e objetos, associou-se a agricultura familiar à concepção de organizing. Dito isso, desenvolveu-se os seguintes questionamentos: Como os simbolismos organizacionais se manifestam nos estudos sobre as práticas da agricultura familiar brasileira? Quais contribuições a teoria das práticas pode dar a esses estudos? O objetivo desse trabalho é, portanto, analisar as manifestações dos simbolismos organizacionais nos estudos sobre as práticas da agricultura familiar brasileira e as contribuições que a teoria das práticas pode oferecer a esses estudos.

Ressalta-se que as contribuições da teoria das práticas serão colocadas pela identificação do seu eixo teórico, visto que seu conceito e desdobramentos variam de acordo com entendimento de cada autor. 


\section{Administração: caminhos para o desenvolvimento sustentável}

Logo, observou-se que o foco nas relações e o dinamismo na constituição dos elementos simbólicos viriam como contribuição da teoria das práticas para compreender como as práticas dos agricultores familiares se estabelecem. O interesse por esse objeto de estudo se deu pela relevância econômica e social da agricultura familiar, tanto a nível nacional, como global e por observar uma lacuna teórica em estudos que tratam das práticas dos agricultores familiares pela teoria da prática. A metodologia utilizada baseou-se em uma abordagem qualitativa, pautada na pesquisa bibliográfica.

Em relação à estrutura, esse artigo se subdividiu nas seguintes seções: Metodologia, trazendo os materiais e métodos utilizados para o atingimento do objetivo proposto, informando como os estudos foram coletados e analisados; Simbolismo organizacional, com discussões acerca de como o simbolismo se apresenta nas organizações e sua relação com as práticas agrícolas familiares; Desenvolvimento da agricultura familiar no Brasil, que abordou o processo constitutivo da agricultura familiar no contexto brasileiro; Construções simbólicas organizacionais nos estudos sobre as práticas da agricultura familiar, que observou como os estudos de agricultura familiar abordam o simbolismo organizacional e quais contribuições a teoria das práticas poderia trazer a esse campo de estudo; e Considerações finais, com as principais observações feitas após essa pesquisa teórica.

\section{METODOLOGIA}

O presente ensaio teórico utilizou uma metodologia qualitativa. Assim sendo, para analisar a manifestação dos simbolismos organizacionais nos estudos sobre as práticas da agricultura familiar e as contribuições que a teoria das práticas pode dar a esses estudos, fez-se uma pesquisa bibliográfica. A pesquisa bibliografia é "[...] o estudo sistematizado desenvolvido com base em material publicado em livros, revistas, jornais, redes eletrônicas, isto é, material acessível ao público em geral." (VERGARA, 2009, p.43). Destarte, foram mapeados artigos, capítulos de livros e demais trabalhos acadêmicos relacionados ao objeto de estudo, nos portais de periódicos: Scielo; Spell; Scopus; e Periódicos CAPES.

Nessas plataformas de periódicos foram pesquisados os seguintes termos, por meio de uma busca em títulos, resumos e palavras-chave: "identidade agricultura"; "cultura agricultura"; "simbolismo agricultura"; e "significado agricultura". Após essa pesquisa, foram lidos os resumos dos trabalhos identificando os que tratam do simbolismo organizacional nas práticas da agricultura familiar brasileira. Ressalta-se que a correlação temática de simbolismo organizacional e práticas da agricultura familiar brasileira foi investigada para além das semelhanças terminológicas utilizadas 


\section{Administração: caminhos para o desenvolvimento sustentável}

pelos autores desses estudos. Ou seja, os textos foram associados ao simbolismo organizacional e às práticas da agricultura familiar ainda que esses termos não fossem colocados pelos autores. Associouse aos conteúdos que remetem a esses conceitos, que serão discutidos ao longo desse trabalho. Com isso, identificou-se ao todo 5 artigos que analisam a manifestação do simbolismo organizacional nas práticas da agricultura familiar brasileira.

\section{SIMBOLISMO ORGANIZACIONAL}

Ao discutir simbolismo organizacional nessa pesquisa, é necessário entender o que esse termo representa e qual é a sua relação com as práticas dos agricultores familiares. De acordo com Wood Junior (2001), os simbolismos organizacionais são transformações de sentidos inconscientes e demais significados em representações compreensíveis à organização. Esse movimento de simbolização constitui um processo irreversível, indo além das fronteiras das organizações, influenciando também o repertório simbólico da sociedade (WOOD JUNIOR, 2000). Para o autor, após a virada do século, as organizações se transformaram em "reinos mágicos", em que seus simbolismos se manifestam pelo uso de metáforas e manipulação de significados.

Já a relação do simbolismo organizacional com as práticas dos agricultores familiares se estabelece pela associação dessas práticas ao conceito de organizing. O sentido de organizing nas práticas da agricultura é colocado a partir do momento que se entende que essas práticas ocorrem em processos de organização continuamente constitutivos. Logo, entende-se que o organizing seria um processo no qual as práticas se organizam. Utiliza-se aqui, o conceito de práticas como atividades agrupadas que executam um tipo de componente de ordem social (SCHATZKI, 2002). Portanto, observa-se que há uma relação entre os simbolismos organizacionais e as práticas da agricultura familiar. Cabe nesta seção apresentar as diferentes perspectivas de simbolismos nas organizações, ressaltando a teoria das práticas.

Alguns autores, como Gherardi (2009a), Orlikowski (2000) e Schatzki (2001), analisam as manifestações simbólico-sociais através da teoria das práticas. Feldman e Orlikowski (2011) acreditam que um princípio geral da teoria da prática é que as ações humanas são consequentes na prática, ou seja, ocorrem na produção dos contornos estruturais da vida social. Para Corradi, Gherardi e Verzelloni (2010), a principal contribuição da prática para as organizações seria a constituição do seu sentido epistemológico. As autoras ressaltam a importância da prática como uma maneira de "ver" o contexto, portanto, sendo uma lente para enxergar os fenômenos. Gherardi (2009b) complementa o conceito 


\section{Administração: caminhos para o desenvolvimento sustentável}

de prática atribuindo que esse não deve ser entendido apenas como padrões criados recorrentes de ação, analisando com isso a prática somente pela lógica da produção. Segundo a autora, o conceito também deve abarcar a noção de ações socialmente sustentadas, trazendo não só efeito produtivo da prática, mas também seu efeito reprodutivo. Além das interpretações dos simbolismos organizacionais pela lente da prática, alguns autores vão articulá-los à cultura.

Reckwitz (2002) relaciona o simbolismo aos estudos de cultura organizacional. O autor observa diferentes visões teóricas de cultura - incluindo a própria teoria das práticas - e mostra que essas teorias tem em comum a associação do social ao simbolismo, apesar dessa associação ser feita distintamente. Weber e Dacin (2011) analisaram os estudos de cultura organizacional de diversos autores, desde a década de 1980. Os autores, traçando uma perspectiva dos estudos futuros, identificaram que esses seriam pautados principalmente no desenvolvimento da cultura organizacional face às relações e interações sociais. Fine e Hallet (2014), apesar de não se enquadrarem no escopo dos estudos futuros traçados por Weber e Dacin (2011), também trazem as interações sociais como um dos principais elementos influenciadores de uma cultura organizacional. Tais interações ocorreriam continuamente, moldando as culturas de grupo das organizações e com isso, por meio de negociações culturais, seriam levadas às culturas comuns da organização (FINE; HALLET, 2014). Nesse ponto, pensando na agricultura familiar como organizing, é necessário entender como essas interações sociais refletem sua cultura.

Acerca da análise de cultura organizacional e seus desdobramentos, Wasserman e Frenkel (2011) acreditam que a estética organizacional, no sentido da constituição de um espaço organizacional, pode ser utilizada como forma de controle ou regulação cultural por parte daqueles que detêm o poder decisório da organização. Nesse sentido, por meio de um olhar crítico para cultura organizacional, torna-se cada vez mais necessário se preocupar em como os espaços organizacionais são concebidos, percebidos e vividos. Segundo Fantinel, Cavedon e Fischer (2012), em um espaço organizacional, através da sociabilidade apresentada por Simmel (2006), é possível identificar diversas significações simbólicas. Essas significações podem inclusive ocorrer ao mesmo tempo, como por exemplo, a identificação de significados de consumo, lazer e cultura permeando um ambiente organizacional. Para Simmel (2006), a sociabilidade seria uma forma de "sociação", a maneira com que os indivíduos constituem uma unidade para satisfação de seus interesses, de modo que o conteúdo dessa unidade seja um compilar de experiências com elementos indissociáveis. 


\section{Administração: caminhos para o desenvolvimento sustentável}

A construção de sentidos em uma organização, também pode ser analisada à luz da teoria do sensemaking. O sensemaking envolve transformar as circunstâncias em uma situação que é explicitamente compreendida em palavras e que serve como um trampolim para ação (WEICK; SUTCLIFFE; OBSTFELD, 2005). Nota-se até aqui, que os elementos envoltos ao simbolismo organizacional podem ser percebidos por diversas perspectivas teóricas, seja pela ótica das práticas, cultura, sensemaking, etc. Portanto, para efeitos de investigação desse trabalho, foram analisados os estudos acadêmicos que articulam elementos simbólicos às práticas da agricultura familiar, identificando a manifestação dessas práticas no organizing e por isso remontando o conceito de simbolismo organizacional. Mas antes de analisar como esses simbolismos se manifestam nos estudos das práticas dos agricultores familiares, discorreu-se sobre o desenvolvimento da agricultura familiar brasileira, para que se tenha uma visão geral do objeto pesquisado.

\section{DESENVOLVIMENTO DA AGRICULTURA FAMILIAR NO BRASIL}

A agricultura familiar já na sua concepção traça significados singulares em suas práticas. De acordo com o Ministério da Agricultura, Pecuária e Abastecimento (MAPA, 2016), na agricultura familiar o trabalhador estabelece uma relação particular com a terra, sendo essa mais que um mero local de trabalho, sendo também local de moradia da família. Outra característica da agricultura familiar, é que sua produção é feita em pequenos espaços e com um cultivo multicultural de alimentos, comparado ao agronegócio (MAPA, 2016). Logo, pode-se dizer que a agricultura familiar é uma prática cultural em que se predomina a mão de obra da família para a produção agropecuária.

Segundo Assis, Priore e Franceschini (2015), o termo agricultura familiar no Brasil começou a ser discutido na década de 1990. Esse período foi marcado por forte pressão de movimentos sindicais agrários e agrícolas, que reivindicavam soluções para queda do valor dos principais produtos agrícolas exportados à época, pouca abertura comercial e falta de crédito (ASSIS; PRIORE; FRANCESCHINI, 2015). Ainda segundo as autoras, dentre os movimentos sindicais, destacava-se o Movimento dos Trabalhadores Rurais Sem Terra (MST). De acordo com Picolotto (2014), além do sindicalismo, os trabalhos acadêmicos, por repensar o lugar teórico da agricultura familiar e o Estado, por desenvolver políticas e normativas legais para a categoria, também foram responsáveis pelo processo de construção da agricultura familiar no Brasil. A agricultura familiar por muito tempo foi tida como uma mera atividade de subsistência. Entretanto, no decorrer dos anos, foi se mostrando cada vez mais importante, passando a ser a principal fornecedora de produtos básicos para alimentação humana no país, além de movimentar o mercado agropecuário interno (ASSIS et al., 2015). 


\section{Administração: caminhos para o desenvolvimento sustentável}

Segundo o MAPA (2018), a agricultura familiar produz nacionalmente $87 \%$ da mandioca, $70 \%$ do feijão, $46 \%$ do milho, $38 \%$ do café, $34 \%$ do arroz e $21 \%$ do trigo. O setor também é responsável por $60 \%$ da produção de leite, $59 \%$ dos suínos, $50 \%$ das aves e 30\% do rebanho bovino (MAPA, 2018). Apesar desses dados já serem úteis para mostrar a importância da agricultura familiar nacional, sua importância vai muito além deles. Se considerasse apenas a agricultura familiar, o país teria o 8 maior faturamento com produção de alimentos do mundo, conforme a tabela 1.

\begin{tabular}{|c|c|c|}
\hline \multicolumn{3}{|c|}{ Faturamento anual com produção de alimentos } \\
\hline Ranking & Países & Faturamento (US\$) \\
\hline 10 & China & $958,2 \mathrm{bi}$ \\
\hline 20 & Índia & $353,6 \mathrm{bi}$ \\
\hline 30 & Indonésia & $125,4 \mathrm{bi}$ \\
\hline $4 \stackrel{0}{\circ}$ & Nigéria & $84,9 \mathrm{bi}$ \\
\hline 5은 & Brasil & $84,6 \mathrm{bi}$ \\
\hline 60 & Paquistão & $64,7 \mathrm{bi}$ \\
\hline 70 & Japão & $56,9 \mathrm{bi}$ \\
\hline 8 & Agricultura familiar do Brasil & $55,2 \mathrm{bi}$ \\
\hline 90 & Rússia & $54,8 \mathrm{bi}$ \\
\hline 10 은 & Turquia & $53,4 \mathrm{bi}$ \\
\hline
\end{tabular}

Tabela 1: Faturamento anual com produção de alimento, 2018, MAPA.

Através da tabela 1 também é possível perceber que o setor representa 65,2\% do faturamento do Brasil, sendo assim, o maior responsável pelo faturamento com alimentos do país. Esses dados mostram a relevância econômica do setor, tanto a nível nacional, como global. No entanto, ao fazer essa análise de dados, questiona-se o que foi considerado produção agrícola familiar, ou seja, quais critérios de identificação foram utilizados para classificar o agricultor como "familiar". Para essa e outras aplicações, em 24 de julho de 2006 foi criada a Lei 11.326, que estabelece as diretrizes para a formulação da Política Nacional da Agricultura Familiar e Empreendimentos Familiares Rurais. Os critérios para o reconhecimento de um agricultor familiar são elencados no seguinte artigo:

Art. 3o Para os efeitos desta Lei, considera-se agricultor familiar e empreendedor familiar rural aquele que pratica atividades no meio rural, atendendo, simultaneamente, aos seguintes requisitos:

I - não detenha, a qualquer título, área maior do que 4 (quatro) módulos fiscais; II - utilize predominantemente mão-de-obra da própria família nas atividades econômicas do seu estabelecimento ou empreendimento;

III - tenha percentual mínimo da renda familiar originada de atividades econômicas do seu estabelecimento ou empreendimento, na forma definida pelo Poder Executivo; (Redação dada pela Lei no 12.512, de 2011) 


\section{Administração: caminhos para o desenvolvimento sustentável}

IV - dirija seu estabelecimento ou empreendimento com sua família. (Lei 11.326, 2006, p. 1).

Para efeitos legais, também são beneficiários das políticas que a Lei se refere, as comunidades rurais de: silvicultores, quilombolas, indígenas, pescadores artesanais, aquicultores e extrativistas. Buscando criar um instrumento que operacionalizasse essa Lei, foi instituída a Declaração de Aptidão ao Programa Nacional de Fortalecimento da Agricultura Familiar (DAP). De acordo com o MAPA (2019), a DAP é utilizada para identificar e qualificar as Unidades Familiares de Produção Agrária (UFPA), assim como suas formas de organização em pessoa jurídica. Contudo, por meio da categorização em Lei, as UFPA registram apenas a DAP principal para contabilização dos estabelecimentos rurais, o que significa que um único membro de cada estabelecimento o representa para efeitos de cálculo (MAPA, 2019).

Condizente a esses critérios, o último Censo Agropecuário do Instituto Brasileiro de Geografia e Estatística (IBGE, 2006) identificou 4,3 milhões de estabelecimentos agrícolas familiares. Esse número corresponde a $84,4 \%$ dos estabelecimentos agropecuários brasileiros, ocupando uma área de 80 milhões de hectares (IBGE, 2006). Portanto, observa-se que a agricultura familiar brasileira, em praticamente três décadas, progrediu significativamente em relação a sua relevância e identidade (no sentido de uma maior categorização).

\section{CONSTRUÇÕES SIMBÓLICO-ORGANIZACIONAIS NOS ESTUDOS SOBRE AS PRÁTICAS DA AGRICULTURA FAMILIAR}

Essa seção apresentará, previamente, os estudos brasileiros identificados que articulam elementos simbólicos à agricultura familiar. Posteriormente, será apresentado como as práticas dos agricultores familiares poderiam ser analisadas pela própria teoria das práticas, trazendo contribuições de autores que analisam as práticas de uma maneira geral, não pela agricultura familiar. Tais perspectivas da teoria das práticas, ainda que não utilizando a agricultura familiar como objeto empírico, foram consideradas por trazer contribuições amplas da prática como campo de estudo. No entanto, ressaltase a necessidade de estudos futuros que observem e aprofundem nas singularidades da agricultura familiar.

Picolotto (2014) percebeu elementos simbólicos nas práticas que vieram a esculpir a própria concepção atual de agricultura familiar brasileira. Nesse processo, como mencionado na seção anterior, o autor observou que os principais atores foram os movimentos sindicais, os trabalhos acadêmicos e o Estado. $O$ trecho a seguir mostra os benefícios que essa transformação trouxe à categoria, proporcionando à agricultura familiar um significado mais positivo: 
Por meio de uma luta simbólica movida pelo sindicalismo, por setores acadêmicos e do Estado, a agricultura familiar passou a ser associada com adjetivos considerados positivos, tais como: moderna, eficiente, sustentável, solidária e produtora de alimentos. Tais reversões de valores estão intimamente vinculadas ao processo de construção da agricultura familiar enquanto modelo de agricultura do tempo presente e do agricultor familiar como personagem político (PICOLOTTO, 2014, p. 64).

Já Dalmoro, Medeiros, Pauli e Amarante (2017), investigaram o simbolismo na agricultura familiar pelas subjetividades dos indivíduos. Tais subjetividades foram desmembradas em quatro lógicas complementares, a identitária, a cultural, a social e a de produção. Dalmoro et al. (2017) ao fazer essa investigação, concluíram que essas lógicas seriam influenciadas e influenciariam as condições de vida dos agricultores. Entretanto, os autores observam que essas condições são distintas das do agronegócio, hegemônica no que tange às características das políticas públicas agrícolas. Dito isso, notou-se que há a necessidade de desenvolver ações, via políticas púbicas, que observem e considerem as distinções simbólicas entre a agricultura familiar e o agronegócio (DALMORO et al., 2017).

Com uma conclusão próxima, Castro (2016) analisou que os valores da agricultura familiar, de acordo com suas formas de agir, extrapolam os que são assumidos como desenvolvimento agrícola pelas políticas públicas, em que se pauta a lógica capital-terra. Para o autor, a agricultura familiar tem uma cultura própria, decorrendo de uma unidade entre o operacional e cultural, em que suas práticas de trabalho são ao mesmo tempo estruturas de reprodução sociocultural, de produção e de consumo. Portanto, pela herança e compreensão de vida, regras de parentesco, dentre outros vínculos de significados, a agricultura familiar se remete a uma lógica muito mais de família-produção-trabalho (CASTRO, 2016). Percebeu-se, após essas considerações, que as políticas públicas devem corresponder aos elementos simbólicos das práticas da agricultura familiar, para que não se estabeleça um processo de distorção dos seus significados culturais.

Em uma outra associação à prática, Costa, Bastos, Lima e Silva Filho (2014) analisaram o simbolismo na agricultura familiar pela sua criação de sentido ao trabalho. Desse modo, os autores abordaram o entendimento de prazer e sofrimento no trabalho e perceberam que determinados tipos de inovações sociais, que aumentam o sentimento de pertença do produtor rural, contribuem para gerar qualidade de vida social e consequentemente prazer no trabalho.

Por fim, analisou-se o estudo de Da Silva e Silva Júnior (2010), que observaram o simbolismo na agricultura familiar pela teoria das representações sociais. Essa teoria, de modo geral, analisa o 


\section{Administração: caminhos para o desenvolvimento sustentável}

simbolismo pelo que cada ação pode representar. No caso, os autores identificaram, a partir de entrevistas com questões relacionadas às ações sustentáveis, que os agricultores familiares desenvolviam práticas predominantemente convencionais e algumas sustentáveis. Esse diagnóstico se deu - dentre outras percepções identificadas pelas representações que as respostas trouxeram pelos agricultores (de uma determinada localidade) majoritariamente justificarem que um rio estava sendo poluído por problemas externos, ignorando ou deixando em segundo plano o descaso ambiental que ocorria localmente. Em síntese, a pesquisa indicou que a concepção teórica de prática sustentável não era condizente com as representações reproduzidas pelos agricultores. Cabe agora observar como as práticas dos agricultores familiares poderiam ser analisadas pela própria teoria das práticas.

Diversos trabalhos como Whittington (1996), Seidl e Whittington (2014), Jarzabkowski e Lê (2016), analisam as práticas nos estudos organizacionais como objeto empírico. Convergente a isso, Brown e Duguid (1991) ao observar a relação entre trabalho, aprendizagem e inovação, vão trazer que a prática social é inseparável desses elementos, sendo esse processo de interação responsável por constituir uma organização continuamente. Outros autores, no entanto, enxergam a prática como uma lente. Essa ótica, apesar de também trazer um dinamismo na relação dos atores constituintes das práticas, podendo eles ser indivíduos e objetos de acordo com cada autor, se configura de maneira diferente.

O potencial crítico da lente da prática é o de questionar metodologicamente como uma prática reflexiva cria seu contexto de ser praticada e quais são os seus efeitos (GHERARDI, 2015). Orlikowski (2002), por exemplo, coloca que o processo de conhecimento é inseparável da prática, devendo esse processo ser visto não como algo fixo ou estável, mas emergido por meio das práticas contínuas e situadas. Carlile (2002), também pela lente da prática, traz a ideia de que o conhecimento deve ser envolto em um processo de transformação. Dessa forma, ao representar, aprender, negociar e alterar o conhecimento atual, os indivíduos criam novos conhecimentos para resolver as questões identificadas. Dessarte, tanto como objeto empírico quanto lente, a prática poderá proporcionar uma lógica de dinamismo na constituição dos seus elementos simbólicos.

Além do conhecimento, alguns autores como Oliveira e Cavedon (2013) e Roberts (2006), vão articular as práticas ao cotidiano, com suas concepções próprias do termo. Certeau (1998) ao também fazer essa articulação, vai indicar que as relações sociais determinam o indivíduo e a partir daí se faz necessário compreender suas práticas sociais. Acerca das relações sociais, Heller (2016) vai mostrar que o homem, enquanto "dado" relativo, pode constituir tanto uma relação com sua própria 


\section{Administração: caminhos para o desenvolvimento sustentável}

particularidade vivida, quanto com sua própria comunidade. Nota-se então, que há diversas formas de tratar do simbolismo organizacional pelas práticas, além dos diferentes usos da prática como lente teórica.

Foi possível perceber, durante a análise dos estudos, que cada um buscou contribuir para compreensão das práticas da agricultura familiar e que o simbolismo organizacional se manifestou de diferentes formas. No entanto, ao fazer a seleção dos trabalhos, notou-se que poucos estudos associam de fato o simbolismo às práticas dos agricultores familiares, ainda que indiretamente. Também se destaca a ausência de trabalhos que investigam esse fenômeno pela lente da prática. Como já ressaltado no texto, essa lente traria uma perspectiva de análise bem particular, diversa dos estudos que tratam do simbolismo organizacional na agricultura familiar. A teoria das práticas contribui principalmente para entender como as práticas dos agricultores familiares são constituídas mutuamente e se estabelecem através da produção e reprodução de significados, em processos situacionais contínuos.

\section{CONSIDERAÇÕES FINAIS}

Os estudos identificados, que relacionam o simbolismo às práticas da agricultura familiar, trouxeram contribuições importantes para o campo de pesquisa, cada qual com suas considerações. Vale destacar as diferentes abordagens teóricas desses trabalhos, e que mesmo o conceito de simbolismo organizacional não sendo adotado neles, foi apontado com tal, por eles exibirem as mesmas características teóricas abordadas na definição tratada aqui. Essa ponderação serve inclusive para o conceito geral de simbolismo e práticas, que não foram mencionados explicitamente em todos os textos.

Dentre os estudos pesquisados, observou-se que nenhum deles utilizou a prática como lente. No entanto, esse trabalho explorou os pontos de interseção entre a teoria das práticas e as práticas agrícolas familiares, que mesmo não sendo utilizadas para esse fim, suas considerações se mostraram universais e aplicáveis ao objeto de estudo. A escolha por enfatizar essa abordagem se deu pela sua articulação à perspectiva do organizing (visto seu caráter dinâmico de enxergar a organização), que de acordo com Hatch (2011), é a mais adequada quando se quer analisar como uma prática (como objeto empírico) é produzida.

Pondera-se, que a abordagem das práticas tem suas distinções internas, de acordo com a compreensão de cada autor, que cabem ser aprofundadas. Entretanto, percebeu-se um eixo teórico 


\section{Administração: caminhos para o desenvolvimento sustentável}

que serve como ponto de partida, para um então debate da teoria. Nesse sentido, considera-se que a teoria das práticas poderia ser desenvolvida nesses estudos pela sua capacidade de trazer um entendimento de como as práticas se constituem e se estabelecem, produzindo e reproduzindo significados, emergidos de maneira situada e em processos contínuos. Portanto, como sugestão para estudos futuros, indica-se a utilização da teoria das práticas para explorar as especificidades do campo empírico da agricultura familiar, para a então compreensão de como seus elementos simbólicos organizacionais podem ser constituídos.

\section{REFERÊNCIAS}

ASSIS, S. C. R.; PRIORE, S. E.; FRANCESCHINI, S. C. C. Impacto do Programa de Aquisição de Alimentos na Segurança Alimentar e Nutricional dos agricultores. Ciênc. saúde coletiva, Rio de Janeiro, v. 22, n. 2, 2017, p. 617-626.

BRASIL. Instituto Brasileiro de Geografia e Estatística. Censo Agropecuário 2006. 2006. Disponível em: <https://ww2.ibge.gov.br/home/estatistica/economia/agropecuaria/censoagro/brasil_2006/default. shtm> Acesso em: 21 set. 2019.

BRASIL. Lei $n=11.326$, de 24 de julho de 2006. Estabelece as diretrizes para a formulação da Política Nacional da Agricultura Familiar e Empreendimentos Familiares Rurais. Diário Oficial da República Federativa do Brasil, Poder Executivo, Brasília, DF, 24 jul. 2006. Disponível em: <http://www.planalto.gov.br/ccivil_03/_Ato2004-2006/2006/Lei/L11326.htm> Acesso em: 21 set. 2019.

BRASIL. Ministério da Agricultura, Pecuária e Abastecimento. Agricultura familiar do Brasil é 8a maior produtora de alimentos do mundo. Portal Eletrônico do Governo Federal, Brasília, DF, 2018. Disponível em: <http://www.mda.gov.br/sitemda/noticias/agricultura-familiar-do-brasil-\%C3\%A9-8\%C2\%AAmaior-produtora-de-alimentos-do-mundo> Acesso em: 16 set. 2019.

BRASIL. Ministério da Agricultura, Pecuária e Abastecimento. Declaração de Aptidão ao Pronaf (DAP). Portal Eletrônico do Governo Federal, Brasília, DF, 2016. Disponível

em: <http://www.mda.gov.br/sitemda/saf/dap> Acesso em: 17 set. 2019.

BRASIL. Ministério da Agricultura, Pecuária e Abastecimento. O que é a agricultura familiar. Portal Eletrônico do Governo Federal, Brasília, DF, 2016. Disponível

em: <http://www.mda.gov.br/sitemda/noticias/o-que-\%C3\%A9-agricultura-familiar> Acesso em: 20 set. 2019.

BROWN, J. S.; DUGUID, P. Organizational learning and communities-of-practice: toward a unified view of working, learning and innovating. Organization Science, v. 2, n. 1, 1991, p. 40-57.

CARLILE, P. R. A pragmatic view of knowledge and boundaries: boundary objects in new product development. Organization Science, v. 13, n. 4, 2002, p. 442-455. 


\section{Administração: caminhos para o desenvolvimento sustentável}

CASTRO, L. F. P. Agricultura familiar: perspectivas e desafios para o desenvolvimento rural sustentável. Revista Urutágua, n. 34, 2016, p. 174-189.

CERTEAU, M. de. Artes de Fazer. In: CERTEAU, M. de. A invenção do cotidiano. Artes de Fazer. Tradução de Ephraim Ferreira Alves. 3. ed. Petrópolis: Vozes, 1998, p. 33-106.

CORRADI, G.; GHERARDI, S.; VERZELLONI, L. Through the practice lens: where is the bandwagon of practice-based studies heading? Management Learning, v. 41, n. 3, 2010, p. 265-283.

COSTA, J. S. et al. Inovação social, prazer e sofrimento no trabalho: o caso do Projeto Mandalla no Ceará. Administração Pública e Gestão Social, v. 6, n. 1, 2014, p. 11-18.

DA SILVA, A. J.; SILVA JÚNIOR, M. F. Representações sociais e agricultura familiar: indícios de práticas agrícolas sustentáveis no Vale do Bananal - Salinas, Minas Gerais. Sociedade \& Natureza, v. 22, n. 3, 2011, p. 525-537.

DALMORO, M. et al. As lógicas dos produtores invisíveis: significados culturais na produção agrícola familiar. Revista Eletrônica de Administração, Porto Alegre, v. 23, n. 3, 2017, p. 92-115.

DUARTE, M. F., ALCADIPANI, R. Contribuições do organizar (organizing) para os estudos organizacionais. Organizações \& Sociedade, v. 23, n. 76, 2016, p. 057-072.

FANTINEL, L. D.; CAVEDON, N. R.; FISCHER, T. Produção de Significações do Espaço e Sociabilidade em um Café Artesanal de Salvador. Revista Interdisciplinar de Gestão Social, v. 1, 2012, p. 51-74.

FELDMAN, M. S.; ORLIKOWSKI, W. J. Theorizing Practice and Practicing Theory. Organization Science, v. 22 , n. 5,2011 , p. $1240-1253$.

FINE, G. A.; HALLETT, T. Group Cultures and the Everyday Life of Organizations: Interaction Orders and Meso-Analysis. Organization Studies, v. 35, n. 12, 2014, p. 1773-1792.

GHERARDI, S. Introduction: the critical power of the "practice lens". Management Learning, v. 40, n. 2, 2009a, p. 115-128.

GHERARDI, S. Practice? It's a Matter of Taste! Management Learning, v. 40, n. 5, 2009b, p. 535-550.

GHERARDI, S. To start practice theorizing a new: The contribution of the concepts of agencement and formativeness. Organization, 2015, p. 1-19.

HASSARD, J.; COX, J. W. Can Sociological Paradigms Still Inform Organizational Analysis? A Paradigm Model for Post-Paradigm Times. Organization Studies, v.34, 2013, p. 1701-1728.

HATCH, M. J. What is organization? In: HATCH, M. J. Organizations: A very short introduction. Oxford: Oxford University Press, 2011, p. 1-11.

HELLER, A. A estrutura da vida cotidiana. In: HELLER, A. O cotidiano e a história. 11 ed. São Paulo: Paz e Terra, 2016.

JARZABKOWSKI, P. A.; LÊ, J. K. We have to do this and that? You must be joking: Constructing and responding to paradox through humor. Organization Studies, 2016. 


\section{Administração: caminhos para o desenvolvimento sustentável}

MORGAN, G., FROST, P.; PONDY, L. Organizational symbolism. In: PONDY, L. et al. (eds.). Organizational symbolism. Connecticut: Jay Press, 1983, p. 3-35.

OLIVEIRA, J.S.; CAVEDON, N.R. Micropolíticas das Práticas Cotidianas: Etnografando uma Organização Circence. Revista de Administração de Empresas, v. 53, n. 2, 2013, p. 156-168.

ORLIKOWSKI, W. J. Knowing in practice: enacting a collective capability in distributed organizing. Organization Science, v. 13, n. 3, 2002, p. 249-273.

ORLIKOWSKI, W. J. Using Technology and Constituting Structures: A Practice Lens for Studying Technology in Organizations. Organization Science, v. 11, n. 4, 2000, p. 404-428.

PICOLOTTO, E. L. Os atores da construção da categoria agricultura familiar no Brasil. Revista de Economia e Sociologia Rural, Brasília, v. 52, supl. 1, 2014, p. 63-84.

RECKWITZ, A. Toward a theory of social practices: A development in culturalist theorizing. European Journal of Social Theory, v. 5, n. 2, 2002, p. 243-263.

ROBERTS, J. Prologue: Dangerous Memories. In: ROBERTS, J. Philosophizing the everyday revolutionary praxis and the fate of cultural theory. London: Pluto Press, 2006, p. 1-15.

SCHATZKI, T. R. Introduction: Practice Theory. In: SCHATZKI, T. R.; KNORR-CETINA, K.; VON SAVIGNY, E. (eds) The Practice Turn in Contemporary Theory. London and New York: Routledge, 2001, p. 10-23.

SCHATZKI, T. R. What Is a Social Practice? In: SCHATZKI, T. R. The site of the social: a philosophical account of the constitution of social life and change. Pennsylvania: Pennsylvania State University, 2002, p. 70-88.

SEIDL, D.; WHITTINGTON, R. Enlarging the Strategy-as-Practice Research Agenda: Towards Taller and Flatter Ontologies. Organization Studies, v. 35, n. 10, 2014, p. 1407-1421.

SIMMEL, G. A metrópole e a vida mental. In: VELHO, O. G. O Fenômeno Urbano. Rio de Janeiro: Zahar, 1973, p. 11-25.

VERGARA, S. Projetos e relatórios de pesquisa em Administração. 11. ed. São Paulo: Atlas, 2009.

WASSERMAN, V.; FRENKEL, M., Organizational Aesthetics: Caught Between Identity Regulation and Culture Jamming. Organization Science, v. 22, n. 2, 2011, p. 503-521.

WEBER, K.; DACIN, M. T. The Cultural Construction of Organizational Life: Introduction to the Special Issue. Organization Science, v. 22, n. 2, 2011, p. 287-298.

WEICK, K. E.; SUTCLIFFE, K. M.; OBSTFELD, D. Organizing and the process of sensemaking. Organization Science, v. 16, n. 4, 2005, p. 409-421.

WHITTINGTON, R. 'Strategy as Practice'. Long Range Planning, v. 29, n. 5, 1996, p. 731-735.

WOOD JUNIOR, T. Organizações Espetaculares. 1. ed. Rio de Janeiro: Editora FGV, 2001.

WOOD JUNIOR. T. Organizações de simbolismo intensivo. Revista de Administração de Empresas, v.40, n.1, 2000, p.20-28. 


\section{Capítulo 10}

\section{DESENVOLVIMENTO SUSTENTÁVEL: INTERFACES COM O PLANEJAMENTO E CONTROLE DA PRODUÇÃO EM REDES DE EMPRESAS}

DOI: $10.37423 / 200300381$

Francisco José Santos Milreu - USCS - milreu@uol.com.br José Barrozo de Souza - IFES -jbarrozo@terra.com.br José Benedito Sacomano - Unip - sacomano@terra.com.br José Paulo Alves Fusco - Unesp -jpafusco@uol.com.br Sergio LuizKyyrillos-Unip - sergiolalupe@greco.com.br

Resumb: Modelos de crescimento econômico que tenham como bașe a exploração da natureza, que demonstra sinais de esgotamento, @stão a exigir uma ñova visão das estrâtégias que objetivam competitividade e produti/vidade.

No Brasil as emprešas vêm sentindo pressões do mercado interno das organizações internacionais que aqui operam. Utilizar tecnologia adequada às manufaturas, aumentar a capacitação depessoal e imprimir uma gestão profissional aos negócios combase em uma manufatura sustentável poderá trạnformar o Brasil em um dos países mais competitivos num cenário de negócios com amplitude global. Asșín, gerir as organizações produtivas, flexíveis, ágeis e sustentáveis, lançando hạão de ferrạmentas operacionais disppníveis, tornase relevante num mercado cada vez mais competitivo e fustigado por custo\$ de produção nada desprezíveis.

Palavras-chave: Planejamento e Controlle da-Produção, Sustentabilidade, Redes de empresas.

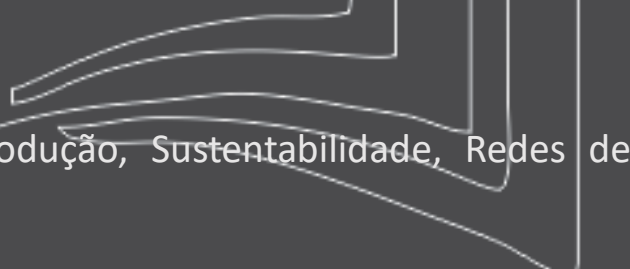




\section{Administração: caminhos para o desenvolvimento sustentável}

\section{INTRODUÇÃO}

A administração das unidades de manufatura envolve, atualmente, relações paradigmáticas vinculadas ao Planejamento e Controle da Produção (PCP).

O Planejamento de capacidade de produção é uma atividade crítica, deve ser desenvolvido junto ao planejamento de materiais e segundo Mac Carthy e Fernandes (2000) o sistema de produção industrial, entendido como "o conjunto de elementos físicos, humanos e de procedimentos gerenciais projetados de maneira inter relacionada" deve ser capaz de gerar produtos com valor superior ao total dos custos despendidos para obtê-los.

O sucesso em conceber atributos de controle, conforme Fligstein (1996) é função da habilidade desenvolvida pela gerência das organizações produtivas. Uma abordagem de manufatura que possua um maior envolvimento com a questão ambiental deverá contemplar estratégias sustentáveis, em todas suas fases. Desde o consumo de matérias primas e energia, até o controle do fluxo de efluentes.

Modelos existentes de PCP que contemplem apenas ganhos econômicos financeiros em detrimento do desenvolvimento sustentável devem sofrer modificações, que analisadas isoladamente produzam efeitos sobre as cadeias produtivas. Ao PCP, via de regra, vinculam-se quesitos de agilidade, flexibilidade, qualidade, recursos materiais, financeiros e humanos e fluxo de informações. Os países em desenvolvimento têm uma oportunidade para geração de métodos de PCP que incluam os princípios da sustentabilidade.

\section{REFERENCIAL TEÓRICO}

\subsection{PCP E REDES DE EMPRESAS}

Planejar, controlar e produzir requer a utilização de informações, além de capacidade tecnológica suficiente para determinar, em maior ou menor grau, o sucesso da administração da produção e das operações.

O ambiente globalizado, pouco a pouco, tem imposto elevada concorrência entre as empresas e as estratégias de gestão da manufatura fazem enorme diferença em um ambiente de negócios com essa dimensão.

Mudanças climáticas, tecnológicas, econômicas, além de políticas públicas são itens importantíssimos que integram uma nova pauta vinculada aos sistemas de gestão dos negócios e da produção. Olhar para os processos internos por intermédio da manutenção dos equipamentos e instalações pode 


\section{Administração: caminhos para o desenvolvimento sustentável}

auxiliar de forma decisiva na incidência das falhas, melhora na eficiência das operações e na economia dos insumos.

Evitar acidentes ambientais, contribuir para a redução da poluição do ar e das águas, do consumo de energia, dos resíduos e substâncias tóxicas são fatores determinantes para um PCP mais competitivo.

Um desenvolvimento articulado entre questões de caráter eminentemente ambiental e social e aqueles atrelados à produção e a economia servirão de base para discutir o legado que se pretende deixar para as gerações vindouras. Os rumos que apontam para o desenvolvimento sustentável. Esse desafio, aparentemente, enclausura uma era de análise de ordem econômica envolvendo lucratividade e apresenta outras dimensões mais ricas e complexas.

Novos atores, tais como a sociedade civil, estados, organizações produtivas, grandes conglomerados, articulados e críticos deverão - por meio de um debate analítico e reflexivo - apontar novas possibilidades que envolvam a questão do crescimento versus o desenvolvimento com base na sustentabilidade.

Moraes e Barone (2001) alertam que "as novas teorias do crescimento examinam apenas um conjunto limitado de fatores facilmente quantificáveis. Outros fatores - tais como os hábitos das pessoas, os seus grupos e redes sociais, a natureza das instituições e das políticas governamentais - são mais difíceis de quantificar, mas, não menos vitais para a explicação das diferenças de taxa de crescimento entre países.”

Os modelos atuais não tem conseguido dar respostas aos complexos acordos existentes entre as empresas que se organizam em redes - que vem estabelecendo relações funcionais profundas - às demandas promovidas pela sociedade organizada e às transformações que ocorrem sobre a governança corporativa nos últimos tempos.

O desenvolvimento e as questões de opulência econômica, tais como Produto Interno Bruto (PIB), Produto Nacional Bruto (PNB) e renda per capita parecem estar sucumbindo a uma questão mais significativa à qual se incluem Índices de Desenvolvimento Humano (IDH), Pegada Ecológica, Pegada Hidrológica além de Índices de Sustentabilidade Ambiental (ISA) entre os quais podemos mencionar:

a) Qualidade do Ar, da Água, dos Solos,

b) Consumo e desperdícios,

c) Pressão demográfica, 


\section{Administração: caminhos para o desenvolvimento sustentável}

d) Poluição, Saúde e Estresse ambiental,

e) Eco eficiência em Ciência \& Tecnologia e governança ambiental,

f) Responsabilidade Global e as Emissões de gases estufa,

g) Índices de Transbordamento.

Godinho Filho, (2004) ao estabelecer os Paradigmas Estratégicos de Gestão da Manufatura (PEGEMs) pondera quatro elementos, a saber, de um PEGEM para as diferentes formas de execução das manufaturas (em massa, em massa atual, ágil, enxuta, flexível, responsiva, customizada):

- Direcionadores: São as condições do mercado que possibilitam / facilitam a implantação de um PEGEM.

- Os princípios: Idéias que norteiam as empresas rumo aos PEGEMs.

- Capacitadores: Ferramentas, tecnologias e metodologias que devem ser implantadas para que um PEGEM forneça resultados de acordo com os objetivos estratégicos.

- Os objetivos de desempenho : Objetivos estratégicos da produção que a manufatura deseja priorizar. É possível de maneira similar investigar tais elementos para uma manufatura que tenha como base o meio ambiente. O conceito de redes simultâneas - Concurrent Networks - proposto por Fusco et al. (2003) propõe que uma determinada rede de operações, possa ser composta e analisada por subredes nas dimensões física, de valor e de negócios permitindo avaliar a competitividade a partir de alianças e parcerias.

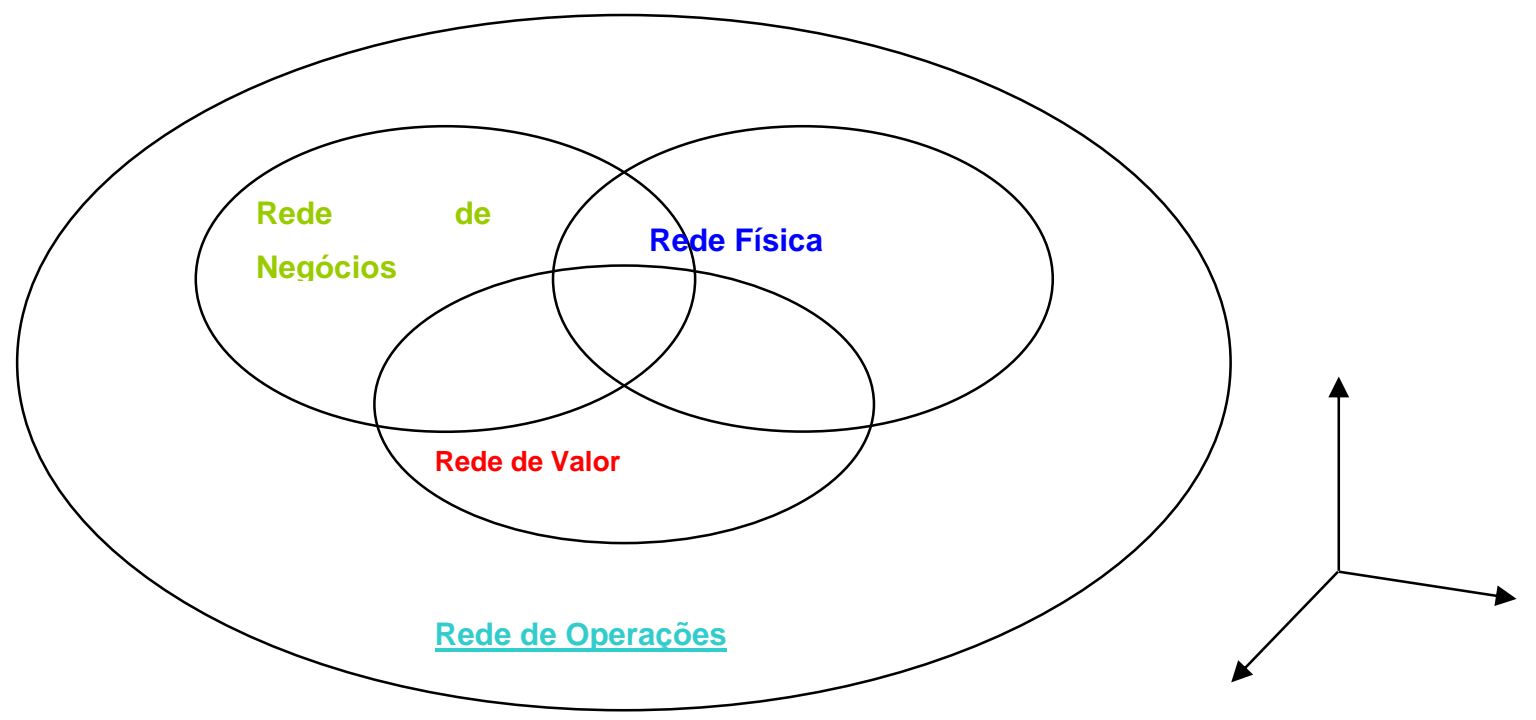




\section{Administração: caminhos para o desenvolvimento sustentável}

Figura 1 - As redes simultâneas.

Milreu (2006) em pesquisa realizada na Ford Motor do Brasil qualifica os projetos em relação às principais ações estratégicas, segundo os princípios da governança corporativa (GC) nas redes simultâneas. Seu estudo demonstra a preocupação com os princípios da sustentabilidade na unidade produtiva. A seguir é apresentado um recorte do estudo de Milreu (2006) envolvendo os projetos com suas respectivas classificações, em relação aos critérios adotados.

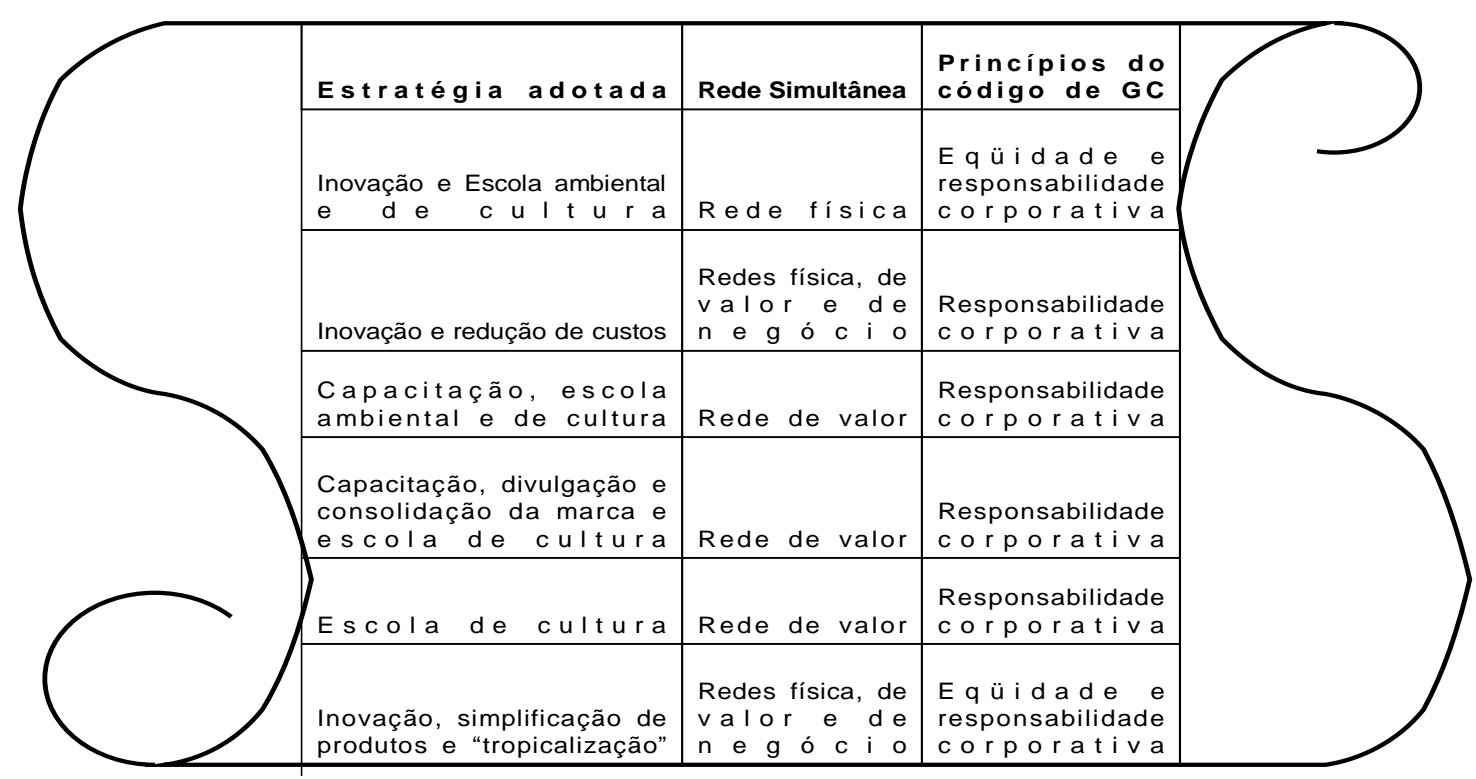

Figura 2 - Recorte dos projetos desenvolvidos e qualificados segundo princípios da governança corporativa, no âmbito das redes simultâneas. Adaptado a partir de Milreu (2006).

Sobre a dimensão custo implica a gestão dos recursos ambientais, instrumento capaz de promover aumento da competitividade por meio da redução dos gastos efetuados com energia, água e o reaproveitamento de insumos. Uma gestão dos custos ambientais, capaz de formar consciência e criar estruturas que permitam a utilização racional dos recursos naturais, permite que países em desenvolvimento avancem no rankig dos países mais sustentáveis, conforme apresentaremos adiante. 


\section{Administração: caminhos para o desenvolvimento sustentável}

\subsection{NOVOS VALORES}

A ISO 14001 define requisitos para estabelecer e operar sistemas com base na gestão ambiental, reconhece que as organizações produtivas poderão, simultaneamente, envolver-se tanto com a sua lucratividade quanto com a gestão de impactos ambientais.

Young e Lustosa (2007) em estudo realizado sobre a competitividade apresentada pela indústria brasileira e suas relações com o meio ambiente, esclarecem que um dos argumentos "usualmente apresentados como justificativa para o abrandamento de medidas de controle ambiental é o de que gastos ambientais reduzem a competitividade dos produtos nacionais frente aos originários de países onde tais controles são inexistentes".

Relatam que paises em desenvolvimento e pobres utilizam esse argumento e que "poluir seria inevitável" para garantir crescimento industrial e o desenvolvimento e que os países ricos já degradaram seu ambiente e agora usam a questão ambiental para interferir no desenvolvimento econômico dos países pobres. Trazem à baila argumentos demonstrando que a melhoria ambiental implica em ganhos de competitividade, sob uma ótica de pesquisa e desenvolvimento, além da dinâmica sobre os determinantes da competitividade. Observam que empresas inseridas no mercado em proporções globais são aquelas que mais se preocupam com a questão ambiental.

Segundo Veiga (2008) a indústria sem a organização da produção e dos processos não teria se estruturado conforme a conhecemos.

Valendo-se dessa organização da produção e do trabalho, é possível avaliar que houve geração e distribuição de riquezas. Entretanto, Veiga (2008) defende que: “O trabalho é considerado um dever moral, uma obrigação social e caminho natural da realização pessoal. Essa chamada 'ética do trabalho', que impregnou todas as sociedades modernas, tem três grandes alicerces: (a) quanto mais um indivíduo trabalha, mais ajuda a melhorar a vida da coletividade; (b) quem trabalha pouco ou não trabalha, prejudica a comunidade e não merece respeito; (c) quem trabalha direito acaba tendo sucesso e quem não o alcança é por sua própria culpa. Acontece que essa ética está envelhecida. Foise o tempo em que produzir mais significava viver melhor. Valoriza-se o ar, a água, o silêncio os contatos".

Demétrio, Giannetti e Almeida, (2009) apontam que o PIB (Produto Interno Bruto) considera apenas a dimensão econômica do desenvolvimento; outros índices, devem ser considerados. 


\section{Administração: caminhos para o desenvolvimento sustentável}

\subsection{NOVOS ÍNDICES}

O Redefining Progress Institute ONG californiana que mede a "pegada ecológica" (Ecological Footprint) - índice que mede o uso da natureza pela humanidade - aponta que a área disponibilizada para cada habitante do planeta é próxima de 2 hectares; nos Estados Unidos 9,71. Segundo o World Wildlife Fund International a capacidade biológica da terra já foi excedida em 20\%. Entre 1961 e 2001 a pegada ecológica dos países ricos saltou de 3,8 hectares por habitante (ha/hab) para 6,6 ha/hab; dos países pobres de 1,4 ha/hab para 1,5 ha/hab (VEIGA, 2008).

O índice de sustentabilidade ambiental (ESI), de 2002, apresentado no Fórum Econômico Mundial envolveu pesquisadores da Universidade de Yale e Columbia, 142 países, 68 variáveis, 20 indicadores e 5 dimensões, valores nem sempre considerados anteriormente:

1. Sistemas ambientais

2. Estresse

3. Vulnerabilidade humana

4. Capacidade Social

5. Responsabilidade Social.

Caso sejam feitas comparações entre o índice de desenvolvimento humano (IDH), de 2004, que inclui diversos indicadores sociais e o ESI-2002, mais complexo teríamos alterações dramáticas no ranking dos países com mudanças nas posições ocupadas por países considerados desenvolvidos e em desenvolvimento, sustentáveis e insustentáveis. Os EUA, por exemplo, apresentava IDH =0,939 (8ª . posição); considerando o $\mathrm{ESI}=53,2$ passa à 45a . posição sendo considerado pais insustentável. $O$ Uruguai apresentava IDH = 0,833 (46a. posição); considerando o ESI = 66,0 passa a ocupar a 6a . posição, sendo considerado pais bastante sustentável.

O IDH 2007, publicado em 2009, apresenta diferenças significativas de classificação. O Brasil que ocupava a 75á. posição no IDH 2004, considerando os países do G20, salta para a 6a . posição. $\mathrm{Na}$ seqüência, alguns dos países que integram o G20, utilizado como referência o IDH 2007, publicado em 2009.

\section{PAÍSES - G20}

1. África do Sul, 2. Alemanha, 3. Arábia Saudita, 4. Argentina, 5. Austrália, 


\section{Administração: caminhos para o desenvolvimento sustentável}

6. Brasil, 7. Canadá, 8. China.

Quadro 1 - Posição dos países do G20 considerando o IDH - 2007 publicado em 2009.

Em relação ao ESI, índice mais complexo, o Brasil apresenta um bom desempenho. No ESI-2005 o Brasil ocupa a 11aㅡ posição, à frente de países desenvolvidos, como Japão (30으), Alemanha (31ํ), Estados Unidos (45). Entre os países em desenvolvimento Uruguai (3으), Argentina (9으) posicionam-se a frente do Brasil - mais sustentáveis - enquanto Costa Rica (18ㅇ) e Chile (42ํ) estão mais vulneráveis.

\section{METODOLOGIA E PROPOSTA DE TRABALHO}

Uma nova dimensão dos sistemas de operação que permita atender às necessidades atuais sem que se comprometam possibilidades de desenvolvimento no futuro, garantindo a disponibilidade de recursos naturais, renováveis e não renováveis e que respeitem os limites da biosfera carecem de consideração. O modo convencional de planejamento dos sistemas de operações das atividades que envolvem a fabricação visa o consumo de um produto final, de modo que fins têm sido usados para justificar os meios. Isso não parece ser uma boa proposta para gestão de sistemas produtivos baseados no desenvolvimento sustentável.

- As unidades de negócios utilizam estratégias de produção bastante consolidadas. Sob essa ótica Godinho Filho (2004) relata algumas classes de sistemas de produção em função do fluxo produtivo e suas características:

A) Sistema de produção em fluxo ou em linha:

- seqüência operacional previsível com produtos bastante padronizados,

- seqüência linear,

- quando o tipo de produto processado é discreto o sistema de produção passa a ser denominado manufatura em massa ou manufatura repetitiva, quando o tipo de produto processado é contínuo, como no caso das indústrias de processo a manufatura é dita contínua (indústria química, por exemplo).

B) Sistema de produção em lotes ou bateladas:

- manufatura de lotes específicos e definidos, em caso de produção discreta, 


\section{Administração: caminhos para o desenvolvimento sustentável}

- ao término do lote de um produto, outros produtos tomam o seu lugar nas

máquinas, caracterizando assim a chamada manufatura intermitente,

- em processos contínuos temos a chamada manufatura descontínua que se caracteriza pela produção em lotes de itens considerados contínuos.

C) Sistema de produção em item único:

- são manufaturas de grandes projetos, particularizadas. Caracterizam-se por tarefas executadas em longo prazo, geralmente em manufaturas discretas e únicas.

\section{Sistemas de Produção}

A forma de organização dos sistemas de operação e suas características.

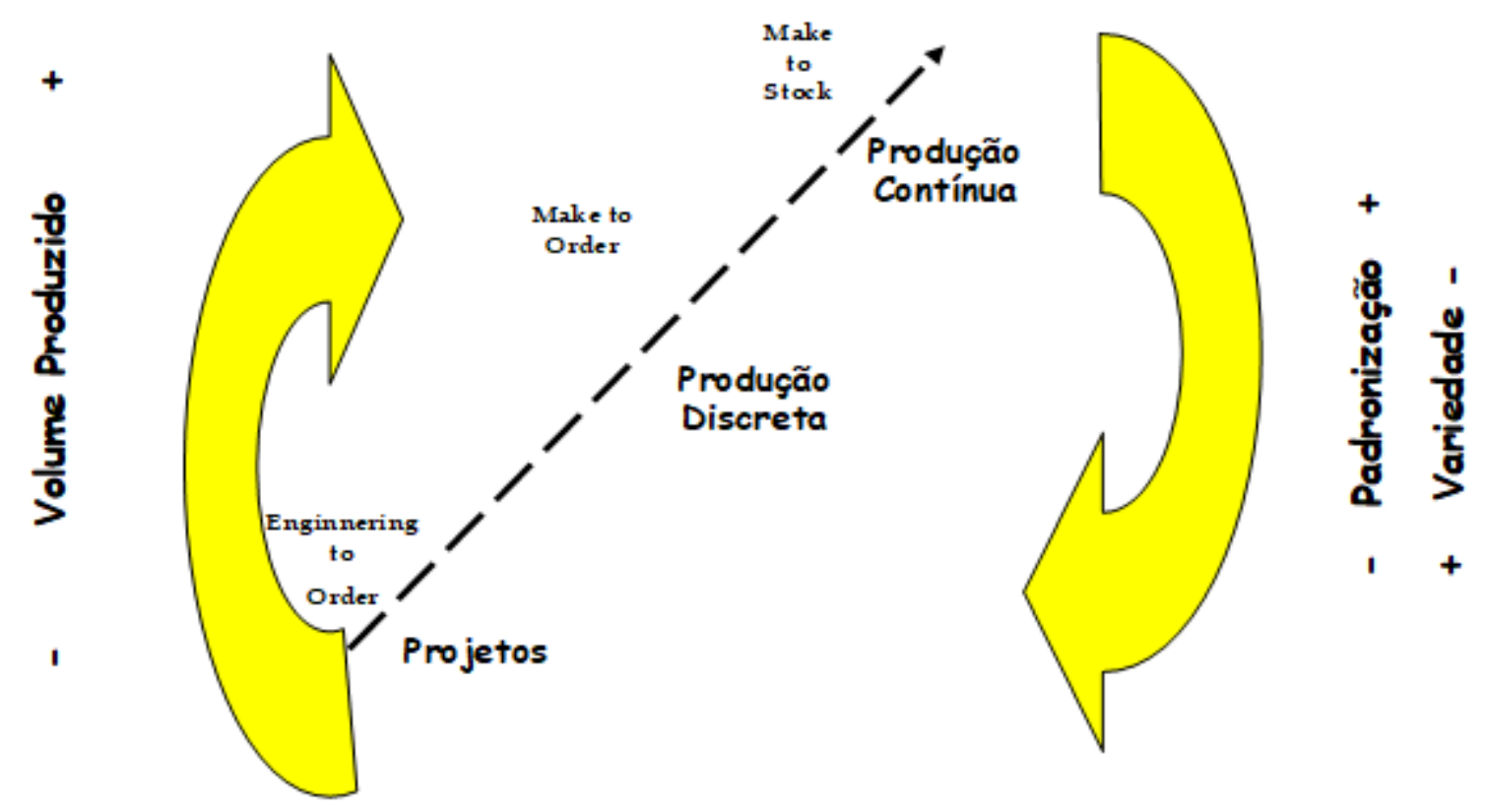

Figura 3 - Sistemas de produção. Volume, padronização e organização.

Elaborado pelos autores.

A figura 4, a seguir, apresenta as estratégias de manufatura e alguns dos objetivos que se persegue nos processos de produção. 


\section{Administração: caminhos para o desenvolvimento sustentável}

É possível afirmar que há um aumento da visão holística, à medida que se afasta da manufatura em massa, que objetiva alta produtividade e custos baixos, e se aproxima da manufatura ágil, que busca a adaptabilidade.

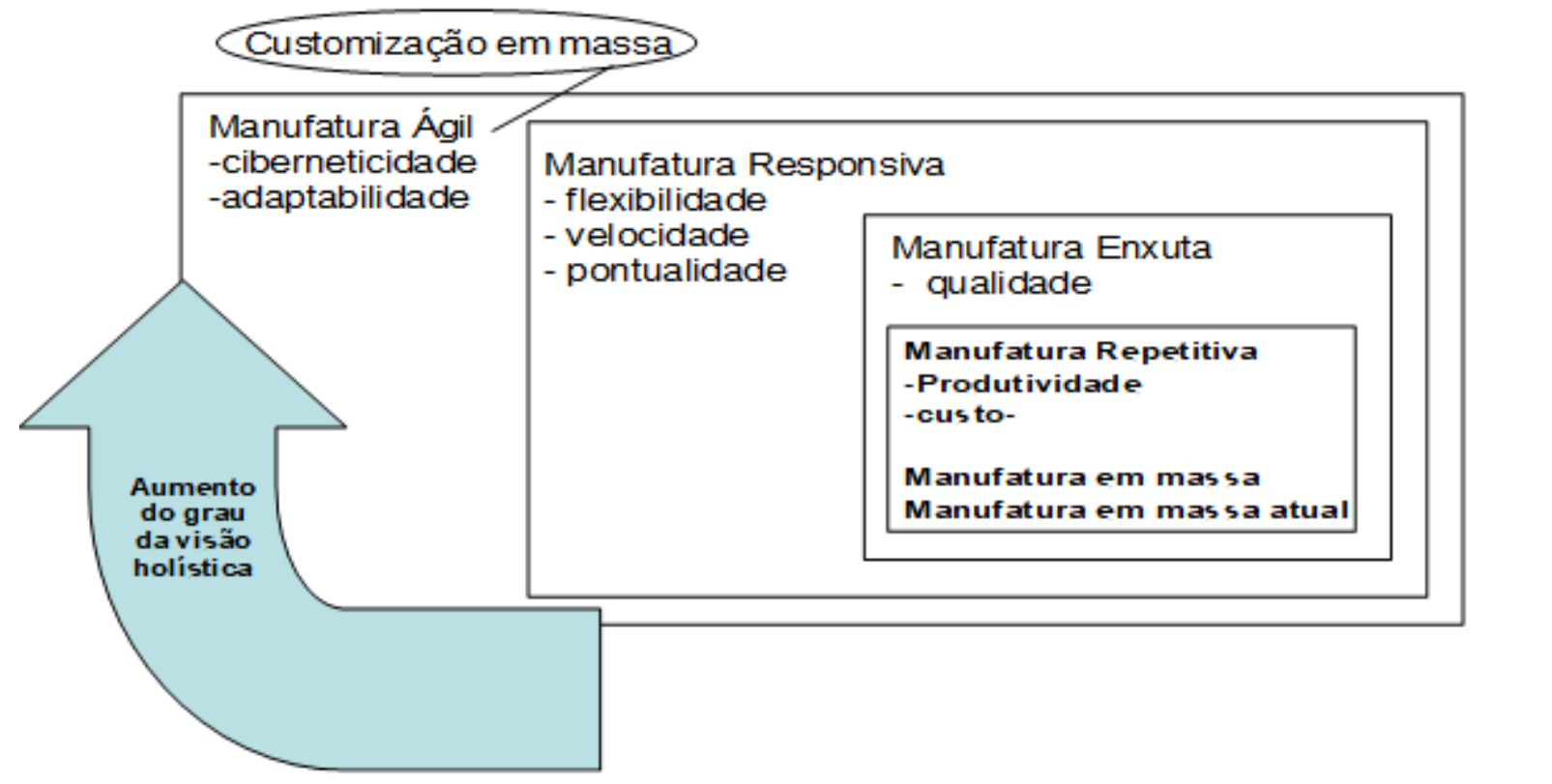

Figura 4 - Estratégias de manufatura e objetivos estratégicos da produção. Fonte: FERNANDES \& MACCARTHY (1999) - Adaptado de Godinho Filho, M. (2004)

O grupo de estudos sobre o PCP nas empresas em redes da Universidade Paulista tem ido a campo para investigar as interfaces que se apresentam, no âmbito da governança operacional das empresas em rede.

Kyrillos, Milreu e Sacomano (2009) desenvolveram - a partir do conceito de redes simultâneas proposta por Fusco, et al. (2003) - um modelo conceitual que vincula as estratégias de negócios, de produção e o PCP em redes de empresas. O modelo proposto em 2009, evoluiu para o perfil expresso pela figura 5 .

A governança das corporações, que envolve as estratégias de negócios e as estratégias de produção vincula-se à rede de negócios. 


\section{Administração: caminhos para o desenvolvimento sustentável}

\section{AS ESTRATÉGIAS DE NEGÓCIOS INFLUENCIAM A REDE DE OPERAÇÕES.}

A governança da rede vinculada à rede física interfere sobre as estratégias de manufatura e ferramentas de gestão adotadas para o PCP. Tais estratégias permitem o surgimento de arranjos produtivos, aglomerações e sistemas produtivos locais.

As estratégias de produção exercem influencias sobre a rede de atividades (ou rede física).

A rede de negócios e a rede física, por meio da rede de valor, estabelecem vínculos capazes de fortalecer o PCP nas empresas em redes.

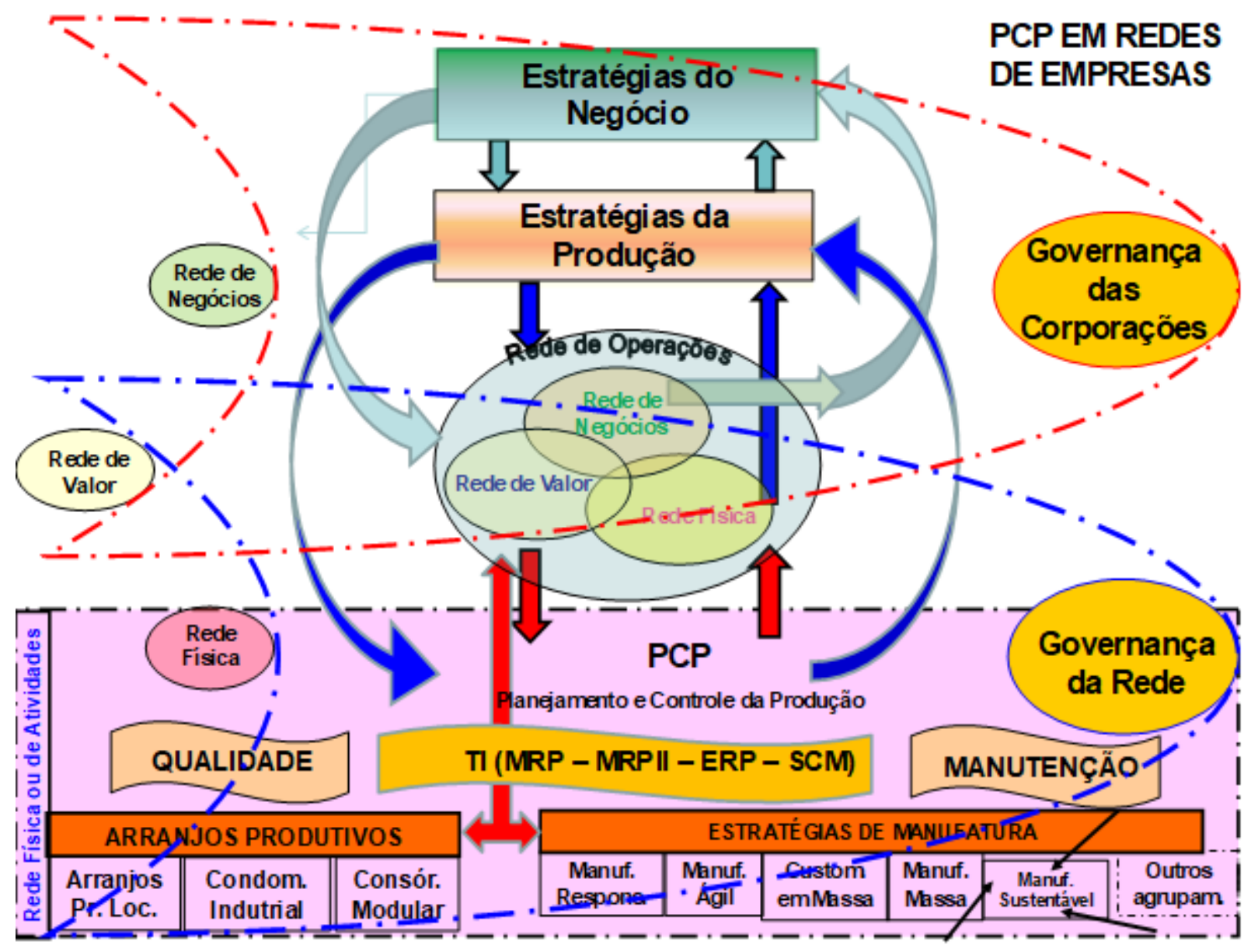

Figura 5 - Modelo conceitual para o PCP em redes de empresas

Elaborado por Milreu, Kyrillos e Sacomano, a partir do conceito de redes simultâneas proposto por Fusco, et al. (2003). 


\section{Administração: caminhos para o desenvolvimento sustentável}

\subsection{PESQUISAS}

Os fatos supra mencionados foram testados em três unidades de negócios e indicaram existir, na rede de atividades, sistemas de produção que se moldam às necessidades das organizações, criando hibridismos às estratégias de manufatura.

O primeiro caso refere-se à aplicação de princípios da manufatura ágil em uma empresa gráfica inserida em redes de empresas atuando sob os preceitos de make to order, conforme Kyrillos, et al.(2009). O segundo relaciona-se ao emprego da customização em massa sobre uma trefiladora de aços fortemente influenciada pela manufatura em massa com princípios make to stock. $\mathrm{O}$ terceiro estudo vincula-se à adaptação da produção de uma metalúrgica fabricante de artigos de cutelaria que utiliza ferramentas de gestão da manufatura em massa, da manufatura responsiva e da manufatura enxuta.

Nas unidades de negócios os mais fundamentais princípios do PCP mostraram-se presentes para que os players, envolvidos nas redes, tenham suas provisões atendidas para que se efetivem as estratégias de produção adotadas. Os PCPs adotados em redes de empresas prevêem o estabelecimento de sistemáticas capazes de examinar as atividades desenvolvidas em várias fases da cadeia e não apenas na empresa focada, de tal forma que o valor agregado à rede deva ser considerado sob um ponto de vista de estratégia do negócio. Em função do hibridismo presente nas organizações é possível afirmar que é viável, além de recomendável, a implantação de processos de produção - nos mais diferentes segmentos das manufaturas - capazes de implantar sistemas sustentáveis.

Giannetti e Almeida, (2006) relatam um exemplo de formação de eco-rede: o parque industrial de Kalundborg, na Dinamarca, que possui em seus nós, fábrica de cimento, refinaria, indústria de fertilizantes e granjas, que interagem entre si.

Piazzi Filho e Oliva, (2007) alertam que "se por um lado, as empresas apostam em prioridades e vantagens competitivas baseadas na produção, por outro lado, uma maior inter-relação entre a função produção e as outras funções da empresa são observadas" tais como fluxos de informações alinhados e capazes de suprir os materiais exigidos, na quantidade adequada e na forma desejada, no local e no momento certos ou o compartilhamento sustentado da capacidade produtiva, pela venda de bens e serviços, para outros atores da rede. 


\section{Administração: caminhos para o desenvolvimento sustentável}

\subsection{PROPOSTAS E DISCUSSÃO DOS RESULTADOS}

Quanto à viabilidade de uma manufatura que tenha como foco o desenvolvimento sustentável, poderse-ia questionar se ao reduzir o consumo de matéria prima, recursos naturais em todas as suas vertentes e energia/material energético; mesmo assim conseguiríamos manter a competitividade das organizações produtivas em níveis globais?

Seria, ainda, possível garantir estabilidade social e econômico-financeira para as organizações? Indicadores que levam em conta o perfil das organizações sustentáveis consideram as alterações requeridas pelas mudanças no ambiente e almejam a adoção de uma estratégia acertada, respondem sim às questões propostas e fatores - como os a seguir mencionados - tornam-se relevantes para viabilizá-las:

- Capacidade em proporcionar integração, permitindo que a organização torne-se uma empresa autosustentável e possua habilidade para suportar pressões de competitividade, que as obrigue a rever relações com o meio exterior sedento por atividades sustentáveis capazes de manter a qualidade do ar, da água e do solo.

- Desenvolver normas internas de trabalho; capacitando-a para empreender em mercados globais crédulos em manufaturas baseadas na sustentabilidade.

- Perfil multi abrangente que permita inserção de diferentes sistemas produtivos de criação de valor, valendo-se de energias renováveis.

- Competência para promover alterações nos conjuntos internos e nas relações externas.

- Habilidade para a flexibilização interna e externa, face às constantes mudanças do ambiente, que é dinâmico, e requer responsabilidade sócio-ambiental quando se trata da criação de valor.

- Persuasão para criar conectividade com players econômicos participantes em sistemas alternativos (sustentáveis) de criação de valor.

- Conectividades que sejam estratégicas, estáveis e confiáveis, que possuam rapidez e densidade de informação, diante das aspirações de preservação do planeta e diminuição da sua vulnerabilidade.

\section{CONCLUSÕES}

No modelo, expresso na figura 5, é possível introduzir um agrupamento que possua uma estratégia baseada em manufatura sustentável. Validar práticas de gestão com princípios e práticas do 


\section{Administração: caminhos para o desenvolvimento sustentável}

desenvolvimento sustentável é um desafio que vem sendo requisitado pela sociedade, tendo nas pessoas e na sobrevivência do planeta seu apelo.

Desenvolver um PCP que tenha os elementos propostos por Godinho Filho (2004) agrega contribuições para estratégia de produção baseada em uma manufatura sustentável, conforme disposto na tabela I.

\begin{tabular}{|c|c|c|c|}
\hline Direcionadores & Princípios & Capacitadores & Objetivos de desempenho \\
\hline $\begin{array}{c}\text { Ponderar sobre } \\
\text { a }\end{array}$ & $\begin{array}{c}\text { Responsabilidade } \\
\text { social. } \\
\text { do planeta. }\end{array}$ & $\begin{array}{c}\text { Adotar de energias } \\
\text { renováveis. }\end{array}$ & $\begin{array}{c}\text { Manter e/ou melhorar a } \\
\text { qualidade da água, do ar e } \\
\text { do solo. }\end{array}$ \\
\hline $\begin{array}{c}\text { Ponderar sobre } \\
\text { a } \\
\text { vulnerabilidade } \\
\text { do ser humano. }\end{array}$ & $\begin{array}{c}\text { Responsabilidade } \\
\text { ambiental. }\end{array}$ & $\begin{array}{c}\text { Efetivar o tratamento de } \\
\text { resíduos industriais e } \\
\text { esgotos. }\end{array}$ & $\begin{array}{c}\text { Manter a biodiversidade. } \\
\text { Evitar o } \\
\text { esgotamento } \\
\text { das reservas } \\
\text { naturais. }\end{array}$ \\
$\begin{array}{c}\text { Preservar a } \\
\text { biosfera. }\end{array}$ & Ética. & $\begin{array}{c}\text { Empregar processos de } \\
\text { produção com bases } \\
\text { tecnológicas que não } \\
\text { permitam o desperdício de } \\
\text { água. }\end{array}$ & $\begin{array}{c}\text { Impedir transbordamentos } \\
\text { de resíduos. } \\
\text { Diminuir o estresse do } \\
\text { planeta. }\end{array}$ \\
\hline
\end{tabular}

Tabela 1 - Dimensões propostas para a manufatura sustentável adotando os PEGEMs propostos por Godinho Filho, (2004).

É necessário destacar que "buscar a compreensão e o entendimento das mudanças nas organizações é extremamente instigante e não é tarefa simples. Cada organização tem um "dialeto" próprio para a manifestação de como as tarefas se realizam dentro do complexo de informações e relações que compõe a estrutura organizacional." (SACOMANO NETO e ESCRIVÃO FILHO, 2000). O Brasil vem galgando postos em escala crescente na busca pela sustentabilidade, a partir de índices como o IDH ou o ESI.

\section{REFERÊNCIAS}

DEMÉTRIO, Fernando J. C.; GIANNETTI, Biagio F.; ALMEIDA, Cecília. M. V. B.: Estudo comparativo entre a sustentabilidade e o índice de desenvolvimento humano. In: 2 nd. International Workshop Advances in Cleaner Production. Universidade Paulista, São Paulo: 2009.

FLIGSTEIN, Neil. Markets as politics: a political-cultural approach to market institutions. American Sociological Review, v.61, 650-680, 1996.

FUSCO, José Paulo A.; SACOMANO, José B.; BARBOSA, Francisco A.; AZZOLINI JÚNIOR, Walter Administração de Operações: da formulação estratégica ao controle operacional. São Paulo: Arte e Ciência, 2003. 


\section{Administração: caminhos para o desenvolvimento sustentável}

GIANNETTI, Biagio F.; ALMEIDA, Cecília M. V. B.: Ecologia Industrial: conceitos, ferramentas e aplicações. São Paulo: SP, Editora Edgard Blücher, 2006.

GODINHO FILHO, Moacir: Paradigmas estratégicos de gestão da manufatura. Tese (doutorado) PPGEP, Universidade Federal de São Carlos, São Carlos, SP: 2004

KYRILLOS, Sergio L.; MILREU, Francisco J.S.; SACOMANO, José B.: Fatores determinantes para o PCP em Redes de Empresas XVI Simpósio de Engenharia de Produção - SIMPEP, Faculdade de Engenharia de Bauru, FEB-UNESP: 2009.

KYRILLOS, Sergio L.; SACOMANO, José B.; MILREU, Francisco J.S.; FUSCO, José Paulo A.; SOUZA, José B.: Gestão da Produção com Manufatura Ágil: A Aplicação do Diagrama PERT-CPM em uma Plastificadora Inserida em Redes de Empresas. In: II Simpósio de redes empresas e cadeias de fornecimento. II Simpósio de redes empresas e cadeias de fornecimento, Universidade Paulista, SP: 2009.

MAC CARTHY, Bart L.; FERNANDES, Flávio C.F.: A multi-dimensional classification of production systems for the design and selection of production planning and control systems. Production Planning \& Control, v.11, no 5, p. 481-496, 2000.

MILREU, Francisco J.S.: Uma Análise da governança corporativa, sob o enfoque estratégico, em uma rede do setor automotivo, utilizando a abordagem das redes simultâneas. Slade, 2006.

MORAES, Antonio C. e BARONE, Radamés: O desenvolvimento sustentável e as novas articulações econômica, ambiental e social. Revista Pesquisa \& debate, SP, volume 12, n. 2(20), p. 119-140, 2001.

PIAZZI FILHO, Hélio G. e OLIVA, Eduardo C. O comportamento organizacional ante a adoção de indicadores de desempenho para a área de produção. Revista FACEF Pesquisa, v.10, n.1, p. 47-58, Universidade IMES, SP: 2007.

SACOMANO NETO, Mário; E ESCRIVÃO FILHO, Edmundo.: Estrutura organizacional e equipes de trabalho: Estudo da mudança organizacional em quatro grandes empresas industriais. Revista Gestão e Produção v.7, n.2, p. 136-145, ago. 2000.

YOUNG, Carlos Eduardo F. e LUSTOSA, Maria Cecília J.: Meio ambiente e competitividade na indústria brasileira. Grupo de Pesquisa em Economia do Meio Ambiente e Desenvolvimento Sustentável, Instituto de Economia, UFRJ. - 2007, Disponível em www.ie.ufrj.br/gema/pdfs/meioambient.pdf (Acesso em 28.03.2010).

VEIGA, José. E.: Desenvolvimento Sustentável: O desafio do século XXI, Rio de Janeiro: Garamond, 3a. ed. 2008. 


\section{Capítulo 11}

RESPONSABILIDADE SOCIAL EMPRESARIAL: UM ESTUDO DE CASO EM PEQUENAS E MICRO EMPRESAS DO RAMO METAL-MECÂNICO INSTALADAS NO DISTRITO INDUSTRIAL DA CIDADE DE PANAMBI/RS E ASSOCIADAS AO SEBRAE/RS

DOI: $10.37423 / 200300382$

Fabricio Carlos Schmidt

fabricioschmidt@gmail.com

Ana Carla Cargnin Schmidt

anacarlacgs@gmail.com

Gil Eduarơ Guìmarães

profdrgil@gmail.com

Resumo: $\theta$-presente trabalho tem como objetivo/apresentar os dados-coletados da realīzação do diagnóstico dâs ações de Responsabilidade Sociał Empresarial (RSE) praticada pelas empresas que se enquadram como micro e/pequenas empresas atuantes no ramo metal-mecânico instaladas no Distrito Induștrial de Panambi/RS e associadąs ao SEBRAE/RS. Foi realizado um estudo de caso, onde foi laplicado a 16 empresas um questionário com respostas fechadas - trata-se de uma ferramenta desenvolvida pelo Instituto Ethos em parceria com o SEBRAE, Ferramenta de Auto-Avaliação/elanejamento - Indicadores EthosSebrae de Responsabilidade Social Empresarial para Micro e Pequenas Empresas. 0 questionário classifica-se em: valores e transparêhcia, público interno, meio ambiente, fornecedores, clientes/consumidores, comuhidade, sociedade/governo. O tema desta pesquisa é a Responsabilidade SociàtEmpresarial, mais-especificamente, como delimitação do temaltem-se a-observação de como as empresas de micro e peqứeno porte do ramo metal-mecânico, instaladas no distrito industrial de Panambi/RS e cadastradas ao SEBRAE/RS, estão se posicionando quanto à Responsabilidade Social Empresarial. 


\section{Administração: caminhos para o desenvolvimento sustentável}

Sabendo-se que o município de Panambi/RS, abriga atualmente 3.474 (três mil quatrocentos e setenta e quatro) empresas, das quais cadastradas no SEBRAE totalizam 123, sendo que 53 delas atuam no ramo metal-mecânico, 16 ramo agropecuário, 6 funilarias, 9 madeireiras, 8 marcenarias, 2 marmorarias, 3 empresas de Óleos vegetais, 5 plásticos, 3 ramo alimentício, 6 diversos, 3 são cooperativas e 9, apresenta-se como questão orientadora deste estudo: Como as micro e pequenas empresas do ramo metal-mecânico instaladas no distrito industrial de Panambi/RS e cadastradas ao SEBRAE/RS estão se posicionando frente à Responsabilidade Social Empresarial.

Palavras chave: Responsabilidade social empresarial, Sustentabilidade, Metal Mecânico. 


\section{Administração: caminhos para o desenvolvimento sustentável}

\section{INTRODUÇÃO}

No mundo globalizado, competitivo e de rápidas mudanças, as empresas são obrigadas a buscar novas alternativas de gestão para adaptar-se à nova realidade. Diante deste cenário, o diferencial de uma empresa vai além da qualidade nos produtos e serviços, essa distinção está na particularidade que a empresa estabelece seu relacionamento com seus stakeholders ${ }^{1}$. Nesta perspectiva, considerando as mudanças que vem ocorrendo no mercado - desde a maior conscientização dos consumidores quanto ao produto comprado até as normas e leis mais estreitas quanto ao modo de produção e suas conseqüências para a sociedade e meio-ambiente - o conceito de Responsabilidade Social Empresarial (RSE) vem se consolidando de forma multidimensional e sistêmica perpassando todos os níveis e operações do negócio e abrangendo, inclusive, a relação com os interlocutores da empresa (OLIVEIRA, 1984; CARRIERI; BITTENCOURT, 2005; SCHMIDT, F. C, et al., 2014; SCHMIDT, F.C, ZANINI, R. R., 2014; SCHMIDT, F.C, et al., 2018; SCHMIDT, F. C. 2019).

Importa ressaltar que as práticas de responsabilidade social no Brasil ganharam força a partir dos anos 90. Ética profissional, meio ambiente, transparência na gestão empresarial, filantropia, são assuntos que, ao longo das décadas, vêm adquirindo grande espaço no âmbito acadêmico e na sociedade civil organizada. A freqüente exposição e discussão destes temas na mídia e em organismos internacionais - como a Organização Internacional do Trabalho (OIT) e Organização das Nações Unidas (ONU) - têm estimulado/impelido as empresas a adotarem uma gestão socialmente responsável e a incorporar valores ético-morais a sua atividade produtiva, ultrapassam suas obrigações legais e, deste modo, geram valor para a sociedade.

Dentro desse cenário estão inseridas micro e pequenas empresas que, segundo o diretor-executivo do Instituto $\mathrm{ETHOS}^{2}$, Paulo Itacarambi, significam 94\% das empresas brasileiras e, no Rio Grande do Sul, segundo SEBRAE/RS, representam 99\% das organizações instaladas, em Panambi/RS, segundo o Departamento de Fiscalização e Tributos da Prefeitura Municipal, essas empresas representam $68,13 \%$.

\section{APRESENTAÇÃO DO ESTUDO}

O tema desta pesquisa é a Responsabilidade Social Empresarial, mais especificamente, como delimitação do tema, tem-se a observação de como as empresas de micro e pequeno porte do ramo metal-mecânico, instaladas no distrito industrial de Panambi/RS e cadastradas ao SEBRAE/RS, estão 


\section{Administração: caminhos para o desenvolvimento sustentável}

se posicionando quanto à Responsabilidade Social Empresarial, ou seja, como estão enfrentando as novas imposições do mercado quanto ao tema escolhido.

Sabendo-se que o município de Panambi/RS, conhecido também como "Cidade das Máquinas" e 3o Pólo Metal-Mecânico do Rio Grande do Sul (devido ao seu diversificado parque industrial), abriga atualmente 3.474 (três mil quatrocentos e setenta e quatro) empresas, das quais cadastradas no SEBRAE totalizam 123, sendo que 53 delas atuam no ramo metal-mecânico, 16 ramo agropecuário, 6 funilarias, 9 madeireiras, 8 Marcenaria, 2 marmorarias, 3 empresas de Óleos vegetais, 5 plásticos, 3 ramo alimentício, 6 diversos, 3 são cooperativas e 9 tornearias (das quais segundo a Prefeitura Municipal 90 são optantes do simples nacional e 33 geral), apresenta-se como questão orientadora deste estudo:

Como as micro e pequenas empresas do ramo metal-mecânico instaladas no distrito industrial de Panambi/RS e cadastradas ao SEBRAE/RS estão se posicionando frente à Responsabilidade Social Empresarial?

\section{OBJETIVO GERAL}

Realizar um diagnóstico das ações de Responsabilidade Social Empresarial praticada pelas empresas que se enquadram como micro e pequenas empresas atuantes no ramo metal-mecânico instaladas no Distrito Industrial de Panambi/RS e cadastradas ao SEBRAE/RS.

\section{EMPRESAS COTADAS PARA A PESQUISA}

As empresas cotadas para participar do presente estudo são de micro e pequeno porte e fazem parte do setor metal-mecânico. Sendo assim, passa-se, neste momento, a caracterização destas duas classificações.

\subsection{EMPRESAS DE MICRO E PEQUENO PORTE}

Os critérios que classificam o tamanho de uma empresa constituem um importante fator de apoio às micro e pequenas empresas (MPE), permitindo que estabelecimentos dentro dos limites instituídos possam usufruir os benefícios e incentivos previstos nas legislações. No Estatuto de 1999 (SEBRAE, 2009), o critério adotado para conceituar micro e pequena empresa é a receita bruta anual. Além do critério adotado no Estatuto, o SEBRAE utiliza ainda o conceito de funcionários nas empresas. 


\section{Administração: caminhos para o desenvolvimento sustentável}

\section{CLASSIFICAÇÃO DO ESTUDO}

O presente estudo utilizou a pesquisa de campo, aplicada do ponto de vista de sua natureza, já que objetivou gerar conhecimentos para aplicação prática dirigida à solução de problemas específicos. Do ponto de vista da forma de abordagem do problema, o tipo de pesquisa quantitativa, pois traduziu, em números e conceitos informações para classificá-las e analisá-las e, também qualitativa.

Do ponto de vista de seus objetivos, a pesquisa foi exploratória, pois, assim como visou proporcionar maior familiaridade com o problema com vistas a torná-lo explícito ou a construir hipóteses (envolve levantamento bibliográfico; entrevistas com pessoas que tiveram experiências práticas com o problema pesquisado; análise de exemplos que estimulem a compreensão), também objetivou descrever as características de determinada população ou fenômeno ou o estabelecimento de relações entre variáveis (envolve o uso de técnicas padronizadas de coleta de dados: questionário e observação sistemática) (GIL, 1991).

Para participar da pesquisa privilegiaram-se empresas do ramo metal-mecânico, por ser este um dos primeiros mercados da cidade de Panambi/RS e por constituir uma grande força da economia local e, também, as empresas cadastradas ao SEBRAE/RS. As empresas estão instaladas no Distrito Industrial representam um total de 36 (trinta e seis) organizações. Para a pesquisa foram utilizada 17 (dezessete) empresas, as quais correspondem a empresas de mico e pequeno porte atuantes no ramo metalmecânico e cadastradas ao SEBRAE/RS. Das 17 (dezessete) empresas uma não respondeu ao questionário, mesmo após várias visitas e inúmeros esclarecimentos da importância do estudo do tema proposto.

\subsection{COLETA DE DADOS}

Primeiramente foi contatado o gestor da empresa, para explicar a relevância da pesquisa e garantir o anonimato das organizações participantes. Ainda foi feita a designação de quem respondeu ao instrumento de pesquisa, sendo que esta pessoa deveria ser conhecedores da realidade da empresa.

Posteriormente foi aplicado um questionário com respostas fechadas, trata-se de uma ferramenta desenvolvida pelo Instituto Ethos em parceria com o SEBRAE, Ferramenta de Auto-Avaliação e Planejamento - Indicadores Ethos-Sebrae de Responsabilidade Social Empresarial para Micro e Pequenas Empresas. O questionário aplicado é composto de nove questões iniciais (que tem por objetivo introduzir o restante do questionário) e trinta e sete questões que, por sua vez, está dividido em sete grandes temas, conforme figura 1: 


\section{Administração: caminhos para o desenvolvimento sustentável}

Figura 1 - Distribuição das questões - Ferramenta de Auto-Avaliação e Planejamento - Indicadores Ethos-Sebrae de Responsabilidade Social Empresarial para Micro e Pequenas Empresas

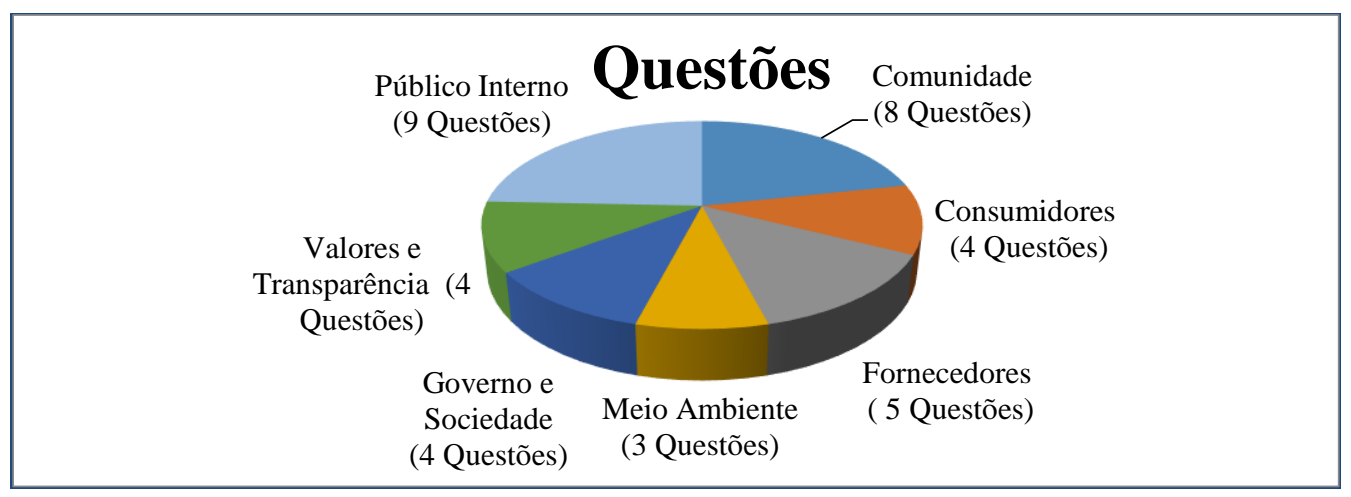

Fonte: Indicadores Ethos-Sebrae de Responsabilidade Social Empresarial para Micro e Pequenas Empresas.

Este instrumento tem como objetivo levar aos sócios e proprietários de micro e pequenas empresas o conceito de responsabilidade social e deve ser encarado como o início de um processo de autodiagnóstico que, combinado com a missão e estratégia geral da empresa, permitiu identificar a situação atual da empresa, bem como permitiu a obtenção de um parâmetro comparativos de como a responsabilidade social vem sendo praticada pelo conjunto de empresas em estudo.

Segundo o Instituo Ethos e SEBRAE trata-se de um conhecimento relevante para que se avalie a contribuição efetiva da responsabilidade social para a competitividade e produtividade das empresas. Outrossim, resta salientar que a utilização deste instrumento de pesquisa foi previamente autorizado pelas instituições que desenvolveram o questionário.

\section{ANÁLISE DOS RESULTADOS E PROPOSTAS DE MELHORIAS}

Após a aplicação dos questionários as empresas fazem-se a análise das questões que fazem parte do instrumento de pesquisa. Esse questionário é um exercício para entendermos que a Responsabilidade Social Empresarial está refletida nos vários relacionamentos da empresa, na transparência com que ela lida com suas obrigações, na forma como trata seus funcionários, ou seja, seu público interno, na forma como trata o planeta, nosso meio ambiente, no tipo de relação que tem com seus fornecedores e clientes, no tipo de relacionamento que busca ter com seus vizinhos, sua cidade, ou seja, com a comunidade à qual pertence, e, finalmente, no tipo de contribuição que oferece para organizar a sociedade e influir no governo e na sociedade. Segue abaixo resultados obtidos no estudo de caso realizado: 


\section{Administração: caminhos para o desenvolvimento sustentável}

Figura 2- Sobre a Responsabilidade Social Empresarial

1) Sobre Responsabilidade Soclal Empresarlal:

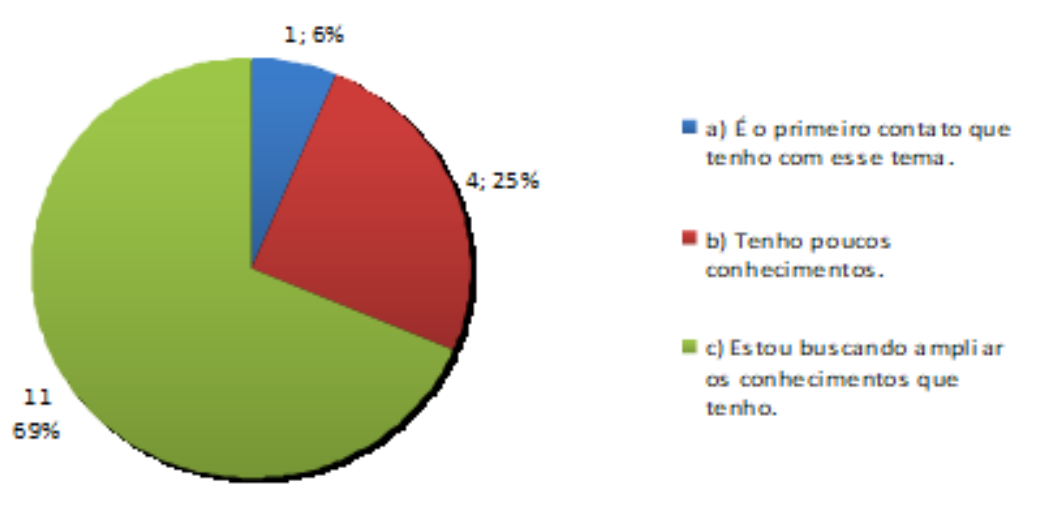

Fonte: Pesquisa de Campo, 2010.

Pode-se observar, na figura 2, que a maioria das empresas (11) já teve contato com o assunto e busca ampliar os conhecimentos existentes. Apenas uma empresa (6\%) afirma nunca ter tido contato com o tema e quatro (25\%) afirma ter pouco conhecimento.

Figura 3- Quanto a obrigações Legais

2) Quanto a obrigações legais, minha empresa:

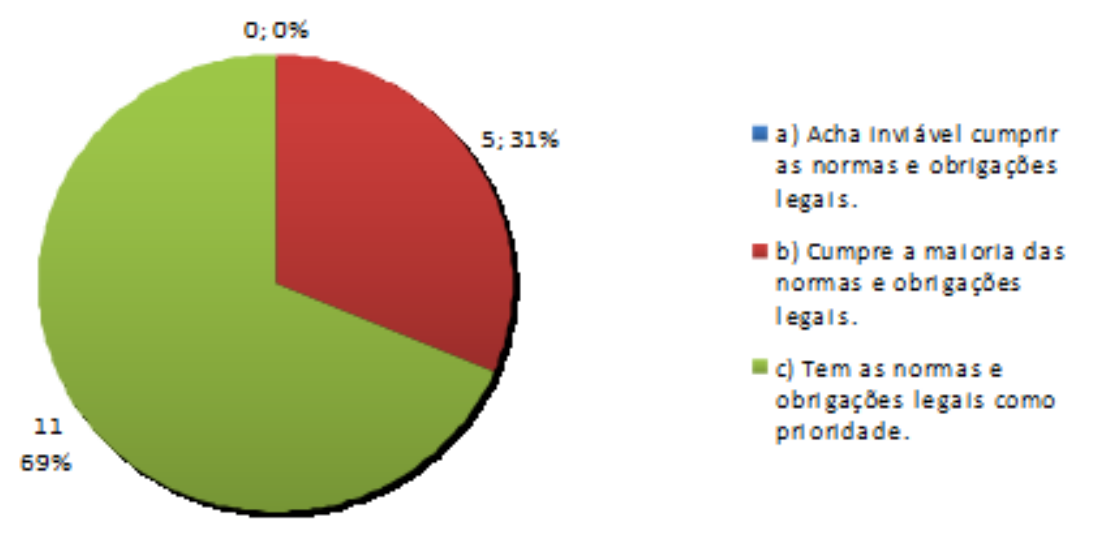

Fonte: Pesquisa de Campo, 2010.

A figura 3 mostra que $69 \%$ das empresas entrevistadas têm como prioridade em sua administração, cumprir as normas e obrigações legais, fato que evidencia a preocupação destas empresas em não infringir as leis e afiança a busca por melhorias relatada na questão anterior, bem como, é reflexo do conhecimento de que a empresa deve procurar "andar na linha" para não sofrer nenhum prejuízo advindo de multas e/ou sansões legais. Nenhuma das empresas participantes do estudo afirma que é 


\section{Administração: caminhos para o desenvolvimento sustentável}

inviável cumprir as normas e obrigações legais e, 31\% (5 empresas) garante que cumpre a maioria das normas e obrigações legais.

Figura 4 - Quanto à Ética

3) Ética, para mim, é:

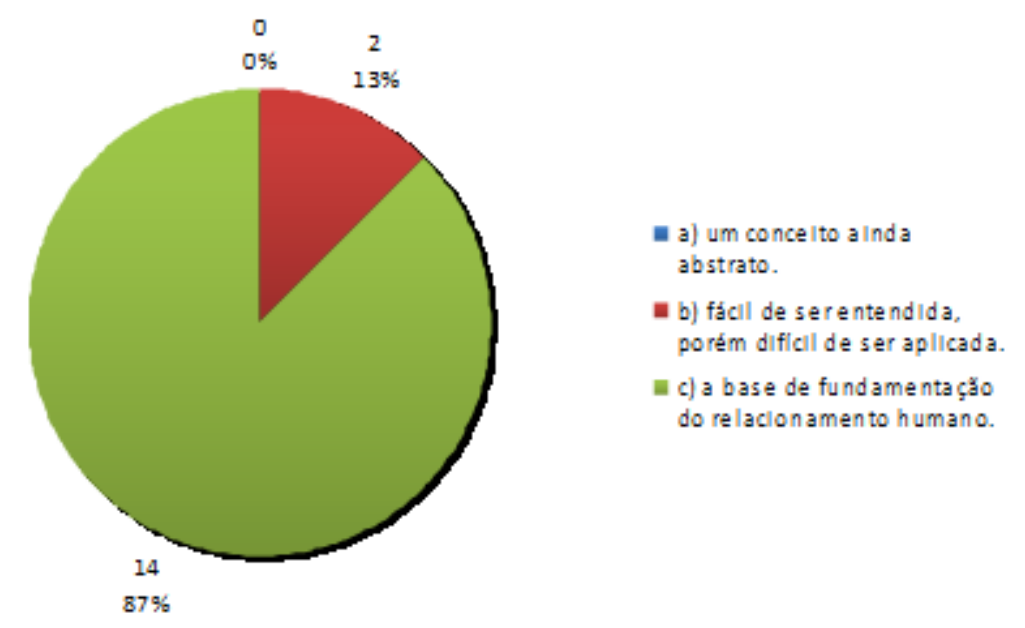

Fonte: Pesquisa de Campo, 2010.

Novamente, como mostra a figura 4, nenhuma empresa afirma o desconhecimento do conceito de Ética, porém, duas empresas participantes da pesquisa (13\%) garantem que o conceito de Ética é fácil de ser entendido, mas difícil de ser aplicado. A grande maioria das empresas entrevistadas (87\%, 14 empresas) afirma que um ambiente onde há Ética é a base de fundamentação do relacionamento humano.

Figura 5 - Quanto à forma de lidar com as pessoas

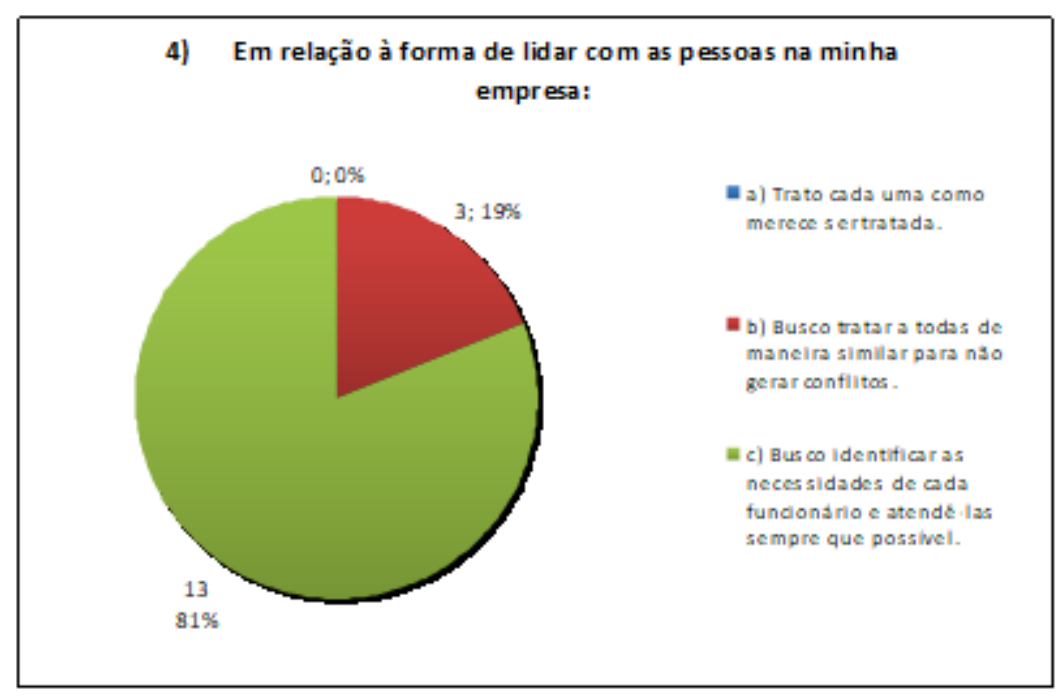

Fonte: Pesquisa de Campo, 2010. 


\section{Administração: caminhos para o desenvolvimento sustentável}

A quarta questão (figura 5) mostra que a maioria (81\%) tenta identificar as necessidades de cada funcionário e atendê-las sempre que possível, isso revela que as empresas têm a preocupação de manter seus funcionários satisfeitos com a política interna da empresa e garantir um ambiente de trabalho agradável e harmônico.

Quanto ao meio ambiente (figura 6) apenas uma empresa afirmou não fazer nada a respeito deste tema, mesmo preocupando-se. O restante (94\%) afirma que procura respeitar o meio ambiente e incentivar os colaboradores a fazerem o mesmo.

Figura 6 - Quanto ao meio ambiente

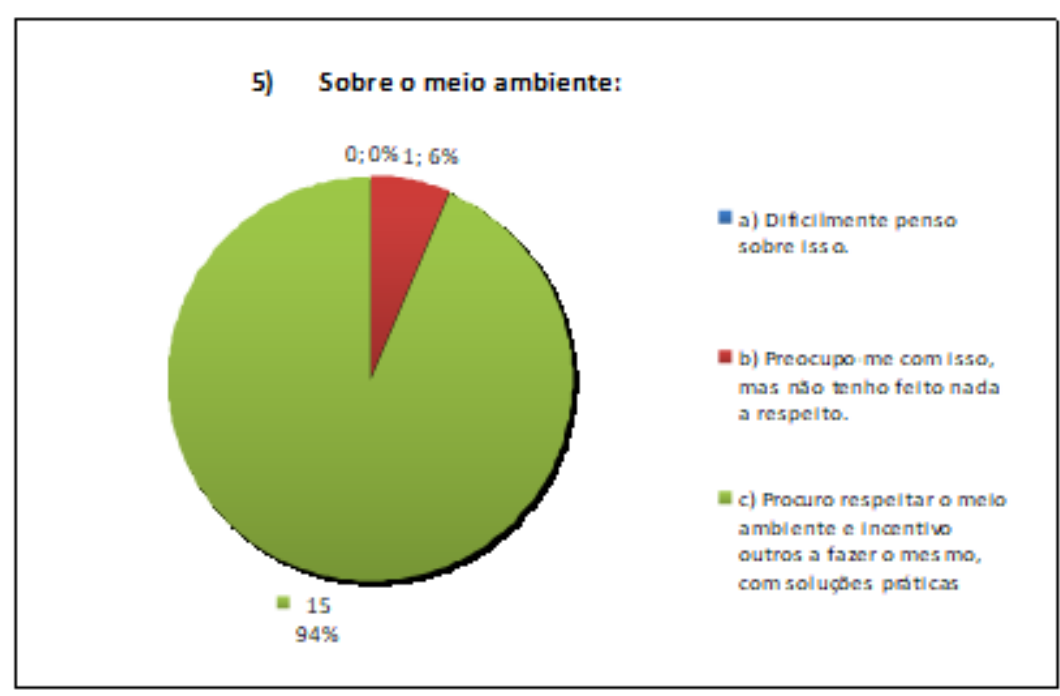

Fonte: Pesquisa de Campo, 2010.

Figura 7 - Quanto à relação com fornecedores

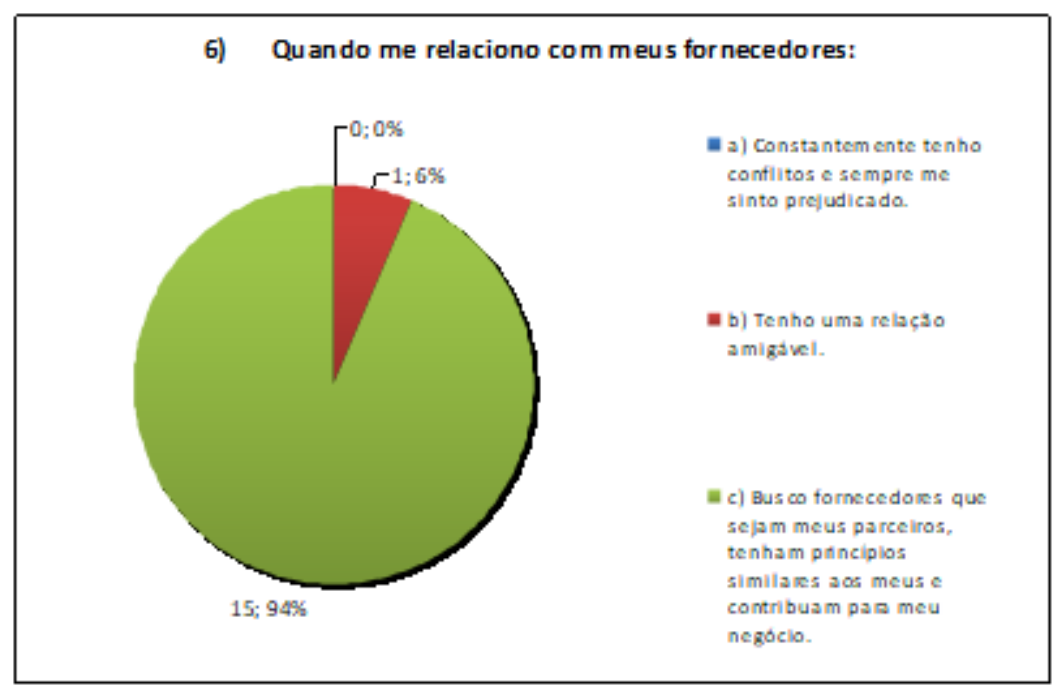

Fonte Pesquisa de Campo, 2010. 


\section{Administração: caminhos para o desenvolvimento sustentável}

A sexta questão (Figura 7) mostra que a maioria das empresas busca fornecedores que contribuam com o seu negócio de forma a alavancar uma parceria baseada em princípios comuns. Apenas uma empresa afirma ter apenas uma relação amigável com os seus fornecedores e, nenhuma empresa assinalou a alternativa que diz entrar em constante atrito com os fornecedores e sentir-se, assim, prejudicado.

A relação com fornecedores passou de meramente compra e tornou-se parceria. As empresas que buscam agir desta forma, certamente, terão retorno considerável.

Figura 8- Quanto à relação com os clientes e consumidores

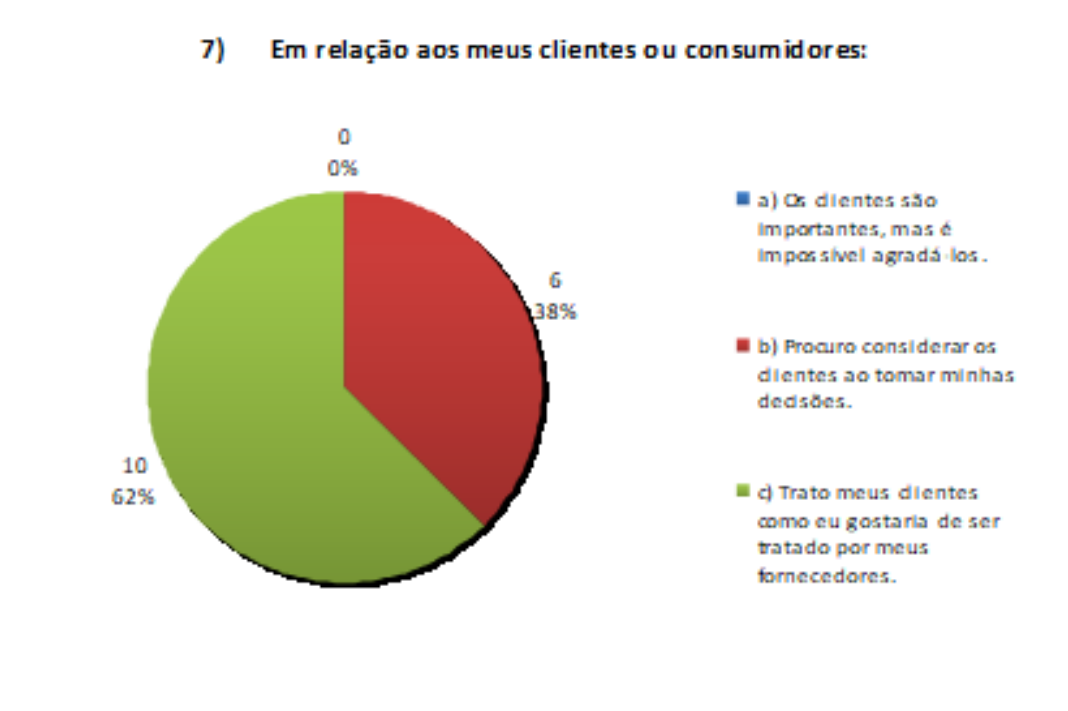

Fonte: Pesquisa de Campo, 2010.

Quando questionados sobre a relação com os consumidores/clientes, 10 empresas (62\%) afirmam que o tratamento é baseado na recíproca e, 6 empresas (38\%) consideram a clientela na tomada de decisões (Figura 8).

Na figura 9, com base em três frases, pré-estruturadas, a opinião das empresas ficou bastante diversificada. A maioria ( 9 empresas, 56\%) afirma que gostaria se uma pessoa dissesse a um funcionário que procura um emprego em sua empresa, provavelmente, neste caso, levou-se em consideração o fato de que, caso existam pessoas interessadas em trabalhar na empresa, a relação com a comunidade é de prestígio. As empresas que afirmam que gostariam de ser lembradas pelo progresso que trouxeram ao instalarem-se na cidade/comunidade, foram 4 (25\%) dos entrevistados. E, 3 empresas (19\%) afirmam que a torcida por um crescimento, mesmo que acarrete a saída da empresa do local onde está instalada (comunidade/cidade), é a melhor frase a ser ouvida. 


\section{Administração: caminhos para o desenvolvimento sustentável}

Figura 9- Quanto à relação com a comunidade

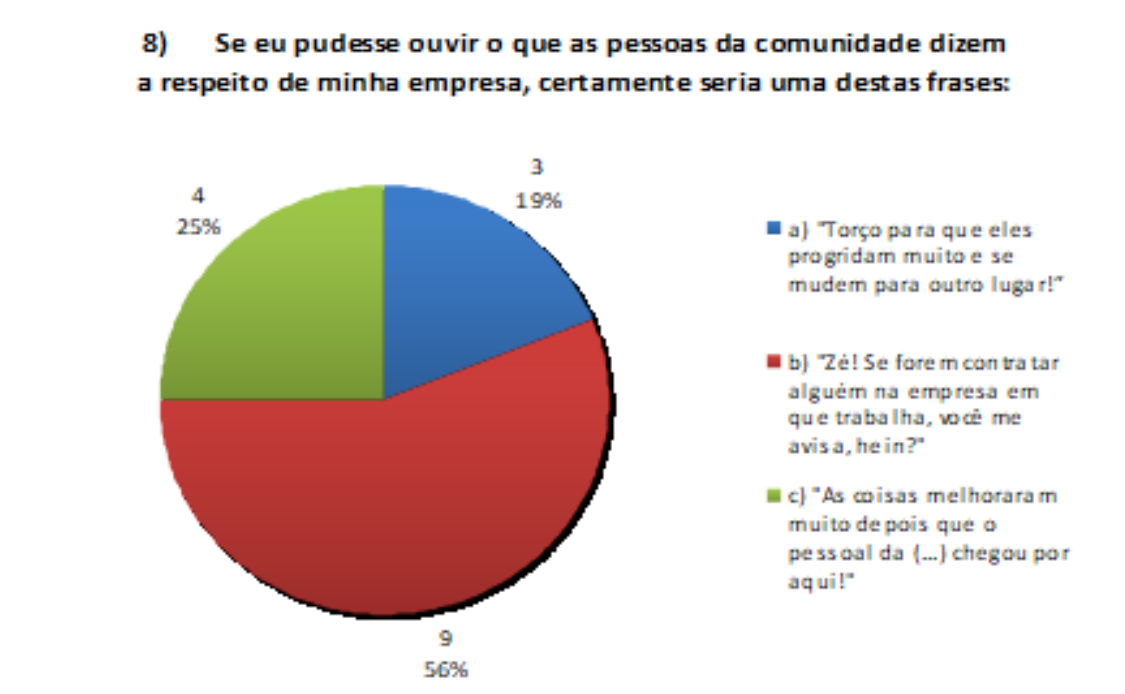

Fonte: Pesquisa de Campo, 2010.

Figura 10 - Quanto à relação com a política

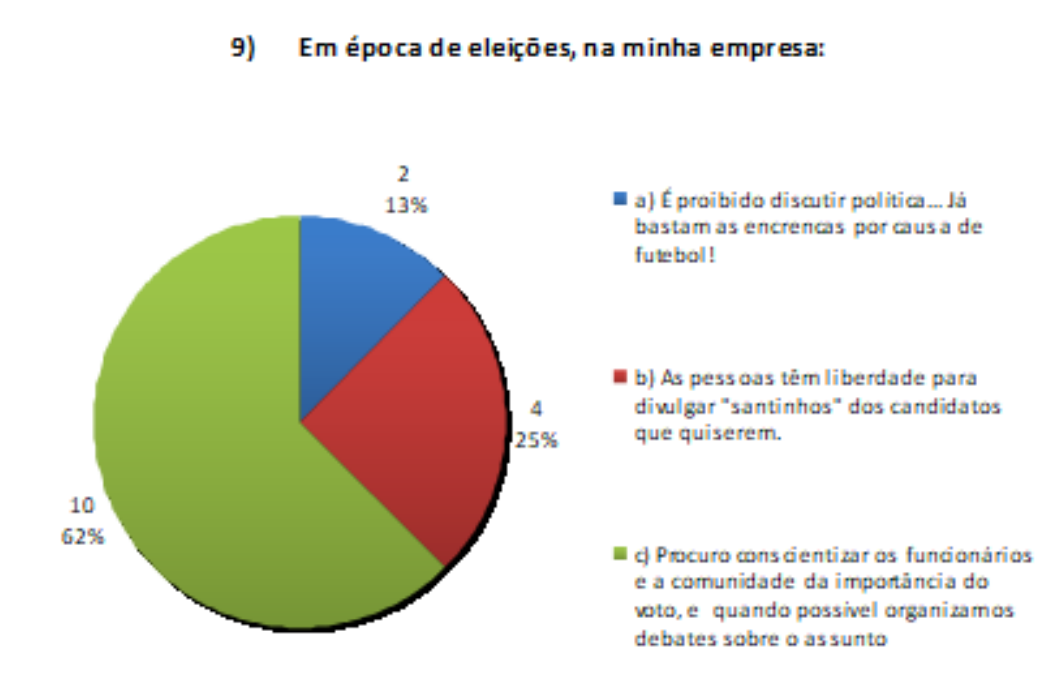

Fonte: Pesquisa de Campo, 2010.

A nona questão (Figura 10) avalia a relação das empresas com os funcionários em época de eleição, ou seja, avalia a relação da empresa com a política. A maioria das empresas entrevistadas (62\%, 10 empresas) afirma que procura conscientizar os funcionários sobre a importância de um voto pensado e, também, quando possível procura organizar debates sobre o assunto. Existem duas respostas que afirmam ser proibido discutir política em ambiente de trabalho, para evitar problemas e discussões. E, em 4 empresas (25\%) os funcionários e membros da comunidade podem distribuir livremente propagandas de seus candidatos. Numa análise global destas nove questões o que se pode observar 


\section{Administração: caminhos para o desenvolvimento sustentável}

foi que, por ter optado pelas respostas "c", a maioria das empresas já caminha bastante na trilha da Responsabilidade Social Empresarial (talvez nem percebessem). Nos casos de respostas com as letras "a" e "b", em que o administrador gostaria de ter respondido com a letra "c", é sinal de que já se está refletindo sobre a RSE. Porém, existem casos em que se acredita firmemente que a letra "a" é sempre a melhor resposta. Recomenda-se uma busca por informações sobre o novo contexto do mundo dos negócios, no qual as empresas estão inseridas, com o material publicado pelo Instituto Ethos e pelo SEBRAE.

Se a empresa já está familiarizada com o tema da Responsabilidade Social Empresarial, um olhar mais detalhado sobre as práticas que vêm sendo adotadas e um planejamento orientado para a melhoria e o aperfeiçoamento das ações empresariais poderão ajudar a evoluir mais rapidamente. Como sabemos, o planejamento aborda as decisões que devemos tomar hoje para alcançar o resultado futuro desejado e indica as ações que deverão ocorrer dentro de um período de tempo, para que se possa chegar ao objetivo. Passa-se, neste momento, para a análise e interpretação das 09 questões respondidas pelas empresas participantes deste estudo. Estas questões foram divididas em sete grandes temas: (1) Valores e transparência; (2) Público interno; (3) Meio ambiente; (4) Fornecedores; (5) Consumidores/clientes; (6) Comunidade; e, (7) Governo e sociedade.

\subsection{ANÁLISE DO DESEMPENHO GLOBAL}

Para a análise do desempenho global da empresa, deve-se considerar o TOTAL GERAL alcançado pela soma das notas dos temas na Ficha de Avaliação (máximo de 70 pontos). Essa nota posicionará a empresa quanto a sua realidade em relação à Responsabilidade Social Empresarial. Dessa forma, avaliações anuais indicarão a evolução da empresa a partir dos resultados alcançados.

De 0 a 10 pontos: A empresa guarda grandes oportunidades de melhoria, pois ainda não possui uma gestão voltada para a Responsabilidade Social Empresarial. A ferramenta utilizada vai auxiliá-la a planejar uma forma mais estruturada de aumentar a qualidade e a extensão das ações voltadas para a RSE.

De 11 a 35 pontos: A empresa já realiza ações voltadas para a Responsabilidade Social Empresarial. Fazer uma análise mais detalhada da ferramenta utilizada verificando em quais temas obteve pontuação mais alta e o que contribuiu para esse resultado.

De 36 a 60 pontos: A empresa já assimilou os conceitos da RSE e tem clareza dos compromissos necessários para uma atuação socialmente responsável. Esses compromissos devem estar trazendo 


\section{Administração: caminhos para o desenvolvimento sustentável}

aspectos positivos para o negócio, por meio de um relacionamento mais próximo e produtivo com as partes envolvidas (governo e sociedade, comunidade, público interno, clientes, fornecedores). Nessa etapa, a empresa possui maturidade para aprofundar alguns aspectos dessa atuação.

De 61 a 70 pontos: A empresa está inteirada dos temas emergentes de gestão e utiliza a Responsabilidade Social Empresarial para atingir seus objetivos. Nesse estágio, torna-se viável a busca de parcerias e de alianças intersetoriais como forma de potencializar a atuação da empresa e adquire importância a sistematização de conhecimentos como meio de colaborar com outras empresas.

Tão importante quanto coletar os dados é saber como analisá-los e interpretá-los. Os objetivos do estudo serão alcançados com a coleta, o tratamento e, posteriormente, com a interpretação dos dados. Para isso foram utilizadas as tabelas disponibilizadas no instrumento de coleta de dados. As questões apresentadas na ferramenta Indicadores Ethos-Sebrae de Responsabilidade Social Empresarial para Micro e Pequenas Empresas são auto-avaliadoras, e determina a pontuação para cada questão, variando de 0 a 3 pontos, conforme se segue:

Tabela 1 - Pontuação para cada questão

\begin{tabular}{|l|c|}
\hline \multicolumn{1}{|c|}{ Resposta } & Pontuação \\
\hline Não & 0 ponto \\
\hline Em parte & 1 ponto \\
\hline Em grande parte & 2 pontos \\
\hline Sim & 3 pontos \\
\hline
\end{tabular}

Fonte: Indicadores Ethos-Sebrae de Responsabilidade Social Empresarial para Micro e Pequenas Empresas

Cada tema pode alcançar a pontuação máxima descrita abaixo, de acordo com o número de questões do tema:

Tabela 2 - Pontuação Máxima

\begin{tabular}{|l|c|c|c|}
\hline \multicolumn{1}{|c|}{ Tema } & Pontuação & Fator de correção & Pontuação Máxima \\
\hline Valores e transparência & 12 pontos & 0,833 & 10 pontos \\
\hline Público interno & 24 pontos & 0,370 & 10 pontos \\
\hline Meio ambiente & 12 pontos & 1,110 & 10 pontos \\
\hline Fornecedores & 12 pontos & 0,677 & 10 pontos \\
\hline Clientes/Consumidores & 15 pontos & 0,833 & 10 pontos \\
\hline Comunidade & 24 pontos & 0,417 & 10 pontos \\
\hline Governo e sociedade & 12 pontos & 0,833 & 70 pontos \\
\hline Total & 111 pontos & 0,630 & . \\
\hline
\end{tabular}

Fonte: Indicadores Ethos-Sebrae de Responsabilidade Social Empresarial para Micro e Pequenas 


\section{Administração: caminhos para o desenvolvimento sustentável}

Figura 11 - Gráfico da Pontuação Geral das Empresas

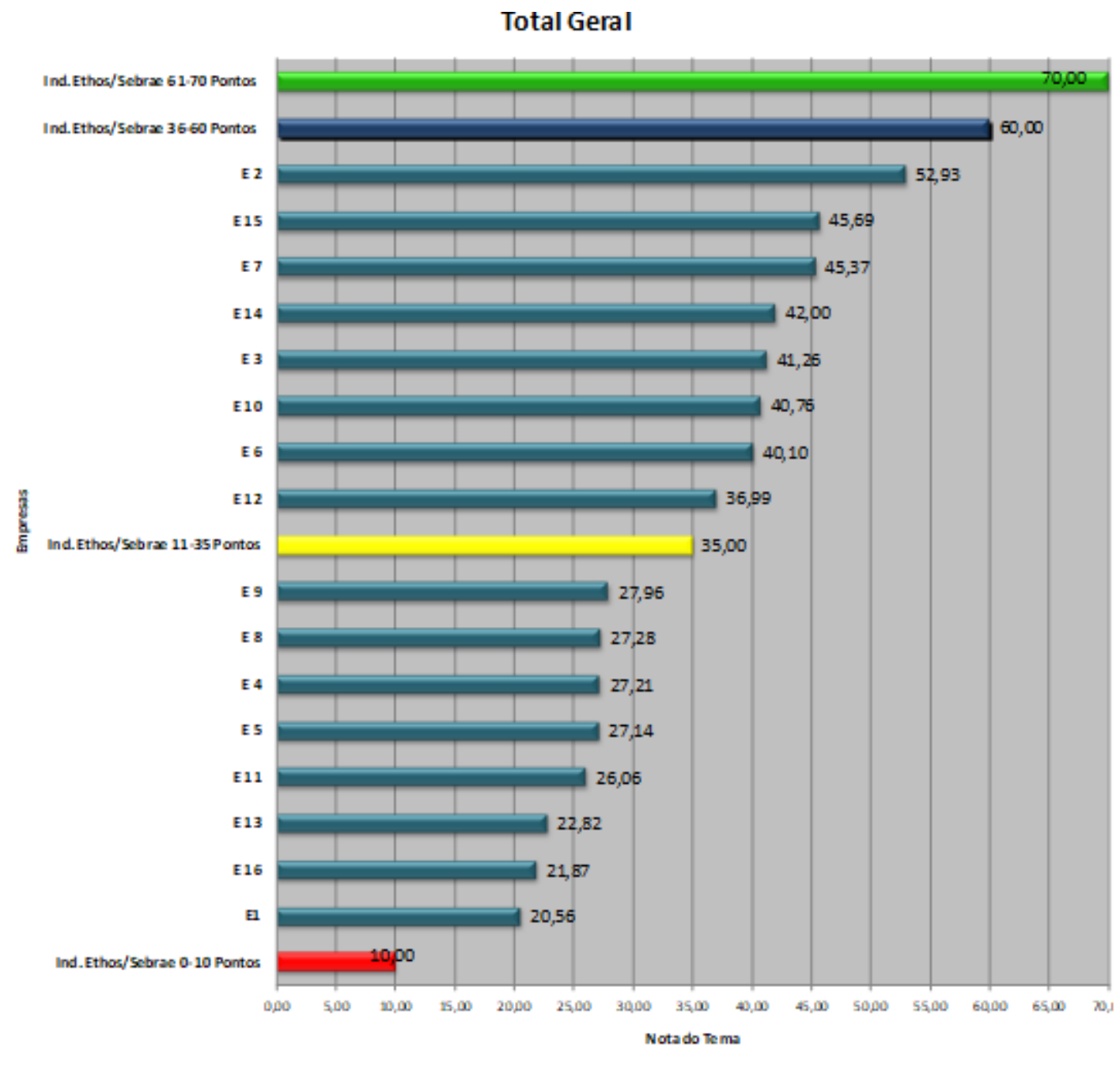

Fonte: Pesquisa de Campo, 2010.

De modo geral (figura 11) as empresas que fizeram parte da pesquisa sobre Responsabilidade Social Empresarial mantiveram-se com pontuação abaixo do índice que poderiam alcançar, não chegando ao índice acima de 61 pontos (de 61 a 70 pontos) que consideraria que a empresa está inteirada dos temas emergentes de gestão e utiliza a Responsabilidade Social Empresarial para atingir seus objetivos - nesse estágio, torna-se viável a busca de parcerias e de alianças intersetoriais como forma de potencializar a atuação da empresa e adquire importância a sistematização de conhecimentos como meio de colaborar com outras empresas.

Metade das empresas cotadas para a pesquisa ficou entre 36 e 60 pontos (E12, 36,99; E6, 40,10; E10, 40,76; E3, 41,26; E14, 42,00; E7, 45,37; E15, 45,69 e E2, 52,93) o que indica que as empresas já assimilaram os conceitos da RSE e tem clareza dos compromissos necessários para uma atuação socialmente responsável. Por meio destes compromissos devem-se esperar aspectos positivos para os 


\section{Administração: caminhos para o desenvolvimento sustentável}

negócios, por meio de um relacionamento mais próximo e produtivo com as partes envolvidas (governo e sociedade, comunidade, público interno, clientes, fornecedores). Nessa etapa, as empresas possuem maturidade para aprofundar alguns aspectos dessa atuação.

A outra metade das empresas ficou com pontuação que vai de 11 a 35 pontos (E1, 20,53; E16, 21,87; $E 13,22,82 ; E 11,26,06 ; E 5,27,15 ; E 4,27,21 ; E 8,27,28$ e E9, 27,96) o que indica que as empresas já realizam ações voltadas para a Responsabilidade Social Empresarial. Deve-se, então, fazer uma análise mais detalhada da ferramenta utilizada verificando em quais temas obteve pontuação mais alta e o que contribuiu para esse resultado. Nenhuma das empresas envolvidas na pesquisa ficou na faixa de pontuação que vai de 0 a 10 pontos, o que vale afirmar que nenhuma das empresas ainda não possui uma gestão voltada para a Responsabilidade Social Empresarial.

\section{CONSIDERAÇÕES FINAIS}

Ao concluir o estudo de caso fica clara a importância do envolvimento das empresas com a Responsabilidade Social Empresarial (RSE) - para o mundo que se apresenta: globalizado, competitivo e de rápidas mudanças, as empresas são obrigadas a buscar novas alternativas de gestão para adaptarse à nova realidade. Como resultado da pesquisa observou-se que as empresas envolvidas na pesquisa têm muito que melhorar no que se refere à RSE, porém, é importante salientar que todas demonstraram já conhecer o assunto e sua importância. Reforçando os achados nos estudos de SCHMIDT, F. C, et al., 2014; SCHMIDT, F. C. 2019.

Com tudo, a responsabilidade social acrescenta valor às organizações; ao desenvolver adequadamente suas atividades sociais a empresa passa ter uma imagem positiva, destacando-se na sociedade onde atua, e dentre o setor do qual faz parte. Importa ressaltar que, este estudo alavanque melhorias no entendimento da importância do tema proposto e que sirva como ponto de partida para futuras pesquisas.

\section{REFERÊNCIAS}

ASHLEY, P. A. (coord.). Ética e Responsabilidade Social nos Negócios. São Paulo: Saraiva, 2002.

CARRIERI, Alexandre de Pádua; BITTENCOURT, Epaminondas. Responsabilidade social: ideologia, poder e discurso na lógica empresarial. RAE Revista de Administração de Empresas, v.45, n.10, 2005.

CARVALHO NETO, Antônio. O estado concorrencial e as mudanças na natureza do trabalho no setor público. Rio de janeiro: ANPAD, 1997. 


\section{Administração: caminhos para o desenvolvimento sustentável}

COELHO, Helena Maria Queiroz. Gestão do público interno em duas empresas filiadas ao Instituto Ethos de Responsabilidade Social Empresarial: visão dos trabalhadores, dos gestores de pessoas e dos sindicalistas. XXIX Encontro Anual dos Programas de Pós-Graduação em Administração - ENANPAD. Brasília. Anais eletrônicos, 2005.

COUTINHO, Luciano; FERRAZ, João Carlos. Estudo da competitividade da indústria brasileira. Campinas: Papirus, 1995.

ETHOS, Instituto Ethos de Empresas e Responsabilidade Social. Indicadores Ethos de Responsabilidade Social Empresarial. São Paulo, 2005, Disponível

em: <http://www.ethos.org.br/docs/conceitos_praticas/indicadores/default.asp>. Acesso em: 18 jul. 2009.

Ferramenta de auto-avaliação e planejamento: Indicadores Ethos-Sebrae de Responsabilidade Social Empresarial para micro e pequenas empresas. Versão 2006. Disponível

em: http://www.uniethos.org.br/_Uniethos/Documents/indicadores_responsabilidade_micro_empr esas.pdf. Acesso em 01 out. 2009

FICAGNA, A.V.; et al. Manual de métodos e técnicas de pesquisa. Passo Fundo: Faplan; Méritos, 2007.

FRIEDMAN, M. Capitalismo e Liberdade. São Paulo, Abril Cultural, 1982.

SCHMIDT, Fabricio Carlos, et al. Evaluation of sustainability practices in small and medium-sized manufacturing enterprises in Southern Brazil. Sustainability, 10.7: 2460, 2018.

SCHMIDT, Fabricio Carlos. Sistema de Produção para Indústria de Autopeças com elementos da Indústria 4.0. Tese Doutorado, UNISINOS, 2019.

SCHMIDT, Fabricio Carlos; ZANINI, Roselaine Ruviaro. Mapeamento por processos e indicadores de desempenho de uma empresa metal-mecânica do setor automotivo. Revista ESPACIOS, 34 (№ 12), 2014.

SCHMIDT, Fabricio Carlos, et al. Estudo dos Principais Fatores Associados aos Acidentes de Trabalho em Uma Empresa de Grande Porte do Ramo Meta Mecânico. Dissertação, Universidade Federal de Santa Maria , 2014. 


\section{Administração: caminhos para o desenvolvimento sustentável}

\section{NOTAS}

\section{Notas 1}

O termo stakeholders pode ser definido como a representação dos acionistas, empregados, clientes, fornecedores, distribuidores, governo, sociedade, todos os públicos que de alguma forma se relacionam com a empresa e com seu processo produtivo.

\section{Notas 2}

O Instituto Ethos de Empresas e Responsabilidade Social é uma organização sem fins lucrativos, caracterizada como Oscip (organização da sociedade civil de interesse público). Sua missão é mobilizar, sensibilizar e ajudar as empresas a gerir seus negócios de forma socialmente responsável, tornandoas parceiras na construção de uma sociedade justa e sustentável. 


\section{Capítulo 12}

\section{O MICROCRÉDITO E O DESENVOLVIMENTO ECONÔMICO- FINANCEIRO DOS EMPREENDIMENTOS BENEFICIADOS PELO PROGRAMA BANCO SOCIAL.}

\section{DOI: $10.37423 / 200300385$}

Ana Paula Prestes Strassacapa (apprestes@hotmail.com)

\section{Eduardo Soares Westphalen (ewcoxa@gmail.com)}

Fernando Augusto Mazon (mazonfernando@hotmail.com)

Resumo: A crescente competitividade entre os pequenos empreendimentos exige que os mesmos possuam capacidąde financeira para continuarem ativos e contribuírem com seu papel social de-geração de emprego è renda. Alguns empreendimentos deparam-se com a insuficiência de capital para honrarem sẹus compromissos ou amptiarem sua capacidadede produção e buscam mecanismos para atender fais necessidades, dentre eles está o microcrédito. Neste aspecto buscou-se demonstrar a influência do programa de microcrédito denominado Banco Social nos empreendimentos por ele fomentados no estado do Paraná. A metodologia do trabalho baseou-se em uma pesquisa bibliográfica de caráter exploratório tendo sua análise elaborada de forma quantitativa considerando como base a análise dos créditos concedidos. 0 ganho alcánçado através da pesquisa forneceu meios para afirmar que o programa Banco/Social beneficia positivamente os empreendimentos por ele fomentados, driahdo/novos postos de trabalho e gerando ampliação de renda.

Palavras-chave: Emprego, renda, microcrédito, Banco Social.

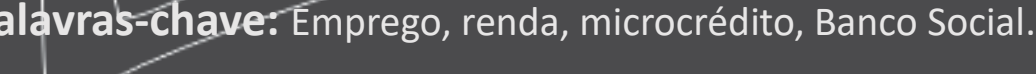




\section{Administração: caminhos para o desenvolvimento sustentável}

\section{INTRODUÇÃO}

A economia estuda dentre outras matérias a harmonia entre os fatores produtivos que são os recursos naturais, o trabalho e o capital. A escassez destes fatores leva a disparidades sociais, uma vez que o acesso não é a todos permitido.

O Estado tem papel fundamental para o bom funcionamento da economia, em especial na minimização das disparidades sociais, uma vez que dentre as diversas funções que exerce, uma é proporcionar condições dignas de sobrevivência a seus cidadãos, por meio de educação, trabalho e renda. No entanto, o Estado em geral, não tem desempenhado a contento esta sua função, fator que em meados do século $X X$, chamou a atenção da comunidade internacional nos países ricos, os quais iniciaram o desenvolvimento de programas internacionais de ajuda humanitária, onde os economistas participantes perceberam o alcance da economia informal como atividade de sobrevivência da população de baixa renda.

A informalidade é oriunda da falta de oportunidade, portanto, com o objetivo de minimizar tais discrepâncias o mundo vem aperfeiçoando técnicas, a muito usadas baseada na confiança existente entre participantes de uma mesma comunidade que permitiu a criação de programas de microcrédito.

O microcrédito por definição resume-se na concessão de crédito de pequena monta, por prazo curto e a juros baixos, atuando na promoção e no desenvolvimento regional através do fomento às pessoas físicas ou microempresas, tendo a finalidade de criar ou desenvolver empreendimentos de pequeno porte. A indústria microfinanceira surgiu para suprir um nicho de mercado formado por pessoas de baixa renda com acesso restrito ao crédito ofertado pelo sistema bancário convencional, principalmente por não possuírem bens para oferecer como garantias reais. No microcrédito normalmente as garantias são o aval solidário ou fiadores/avalistas individuais.

O Brasil demorou na implantação das políticas de microcrédito, quando comparado a outros países. Os primeiros relatos são do final da década de 70, porém atualmente há várias entidades promotoras deste tipo de crédito. $O$ processo de construção dessa política tem sido por meio de parcerias entre órgãos governamentais e a sociedade civil com o apoio de organizações nacionais e internacionais.

No estado do Paraná, o programa do microcrédito recebeu a denominação de Banco Social, sendo viabilizado através da Agência de Fomento do Estado do Paraná - AFPR. Desde a sua criação o programa vem evoluindo, beneficiando empreendedores excluídos do sistema financeiro tradicional, gerando oportunidades de emprego e renda. Partindo destas explicações, esta pesquisa procurou 


\section{Administração: caminhos para o desenvolvimento sustentável}

demonstrar a influência do programa de microcrédito Banco Social nos empreendimentos por ele fomentados no estado do Paraná.

\section{REFERENCIAL TEÓRICO}

\section{MICROECONOMIA}

A microeconomia sustenta o comportamento das unidades econômicas individuais, que consistem em consumidores, trabalhadores, investidores, proprietários de terra, empresas, qualquer indivíduo ou entidade que contribua para o funcionamento da economia. A teoria microeconômica explica como e porque essas unidades tomam decisões de compra e como suas ações refletem nas variações de preço e renda. Para tanto, a teoria microeconômica não deve ser confundida com economia de empresas, pois tem enfoque distinto. A Microeconomia estuda o funcionamento da oferta e da demanda na formação do preço no mercado, isto é, o preço sendo obtido pela interação do conjunto de consumidores com o conjunto de empresas que fabricam um dado bem ou serviço. Do ponto de vista da economia de empresas, se estuda uma empresa específica prevalecendo a visão contábilfinanceira, já na Microeconomia prevalece a visão do mercado (PINDYCK; RUBINFELD, 2005).

Outra vertente da microeconomia consiste em alocar da melhor maneira possível recursos escassos. Exemplo disso é como o consumidor pode dispender melhor sua renda limitada nos bens e serviços disponíveis para aquisição, em contrapartida elucida como as empresas podem alocar adequadamente seus recursos financeiros limitados na contratação de trabalhadores, aquisição de maquinário ou na produção de determinado bem no lugar de outro. A conceituação de empresa, do ponto de vista econômico, é a combinação, pelo empresário, dos fatores de produção (capital, trabalho, recursos naturais, tecnologia e capacidade empresarial), organizados para se obter o maior volume possível de produção ou de serviços, ao menor custo (Ibid).

\section{POLÍTICAS DE EMPREGO}

Políticas de emprego parece um conceito vasto se analisado pela teoria Keynesiana, que objetiva a elevação da oferta de emprego e mudanças na legislação trabalhista, se esta fosse um empecilho para a abertura de novas vagas. Mas na extremidade desta corrente haveria as políticas de redução real do salário mínimo, as políticas de formação profissional, literalmente toda a política cujo propósito seja a geração de novos empregos, é vista como uma política de emprego (RAMOS, 2003). Política de emprego está delimitada ao entendimento da forma direta ou indireta que contribui para a oferta 


\section{Administração: caminhos para o desenvolvimento sustentável}

e/ou demanda de trabalho. Sendo assim, descarta-se todas as políticas macroeconômicas e alterações legais que regulam o mercado de trabalho, bem como as medidas que podem afetar a demanda como o salário mínimo. Percebe-se que as políticas de emprego consistem em meios que atuam sobre a oferta ou demanda de trabalho, reduzindo ou alterando seu bem-estar de forma direta ou indireta (Ibid).

As políticas de emprego dividem-se em passivas e ativas. As políticas de emprego passivas consistem em suportar um desemprego ou redução da oferta de trabalho, baseadas na aposentadoria precoce, seguro-desemprego, extensão dos ciclos escolares e expulsão dos imigrantes. As políticas de emprego ativas vinculam ações que tendem a elevar o nível de emprego, basicamente atuando sobre o contingente dos trabalhadores, sendo elas: formação profissional, intermediação (agências de recrutamento), apoio aos micro empreendimentos, subsídios à contratação de uma determinada população alvo (RAMOS, 2003).

\section{RENDA}

Renda, baseado no Vademecum das Sociedadas Anônimas consiste em:

[...] moeda, ou valor em moeda, do objeto dos direitos. É comum, entretanto, designarmos o objeto do direito pela denominação deste. Assim, moeda e dinheiro são muitas vezes usados como sinônimos, e denominamos de propriedade o imóvel que é o objeto do domínio. Daí dizermos usualmente que renda financeira é dinheiro, ou valor em dinheiro de direitos patrimoniais. É expressão cômoda, que podemos usar sem incovenientes não é o direito, mas a moeda, ou o valor em moeda do objeto do direito (BULHÕES PEDREIRA ${ }^{1}, 1983$ apud MAUÉS 2004, p. 7).

A renda ainda pode ser definida em nacional, que consiste no somatório de remunerações (atividade econômica da sociedade) pagas aos fatores de produção; como o resultado líquido da atividade produtiva e real que é o resultado do ato de consumo (MAUES, 2004).

Dentre as possíveis conceituações de renda, enfatiza-se a que influencie o aumento patrimonial, pois renda é a parte do valor do produto total que resta ao indivíduo após o pagamento de todas as despesas de qualquer espécie, incluindo-se nestas despesas os lucros do capital empregado (Ibid).

\section{CONSUMO}

O conceito de renda econômica ajuda a explicar o funcionamento do efeito de consumo: "[..] é a diferença entre os pagamentos destinados a um fator de produção e o mínimo valor que teria de ser despendido para poder contratar o uso de tal fator" (PINDYCK; RUBINFELD, 2005, p.455). Sendo assim, 


\section{Administração: caminhos para o desenvolvimento sustentável}

consumo consiste na utilização direta de riquezas produzidas resultante de um aumento do poder de compra (Ibid).

\section{Fatores de produção}

Conforme Gregory Mankiw (2009) “os fatores de produção são os insumos usados para produzir bens e serviços". Assim, podemos definir como fatores de produção os recursos ou insumos produtivos utilizados para a geração de riquezas.

Dentro do conceito básico de fatores de produção, destacam-se três importantes categorias: terra, mão-de-obra e capital. A terra deve ser interpretada em um sentido mais amplo, abrangendo tanto as propriedades rurais e urbanas, como também todos os recursos naturais - o solo, florestas, rios, lagos, mar, depósitos minerais. Mão-de-obra corresponde à influência dos seres humanos no processo de geração de riqueza, com todas as suas capacidades físicas e intelectuais. Capital compreende os instrumentos de trabalho utilizados para a produção de outros bens, como as indústrias, os equipamentos, as instalações, dentre outros (Ibid).

Para exemplificar: "quando uma empresa de informática produz um novo programa para computador, usa o tempo dos programadores (mão-de-obra), o espaço físico em que estão seus escritórios (terra) e equipamentos de informática (capital). Da mesma forma, quando um posto de gasolina, usa o tempo dos frentistas (mão-de-obra), o espaço físico (terra) e os tanques de bombas de combustível (capital) (MANKIW, 2009). Há também quem considere a empresa como uma quarta categoria de fator de produção, sendo conceituada como a organizadora do processo produtivo. Contudo, essa lista (terra, trabalho, capital e empresa) não exaure, segundo alguns autores, todos aqueles elementos que participam direta ou indiretamente do processo produtivo ou pelo menos o asseguram. Eles consideram um outro fator: o Estado. Este, embora atue fora do âmbito da empresa, cria a elas condições indispensáveis para o tranqüilo e contínuo desenvolvimento do processo, ao assegurar a ordem, a propriedade, a exigibilidade das obrigações assumidas e a responsabilidade patrimonial correspondente. Embora não seja um fator de produção direto, pois parte da sua atividade destinase a toda a sociedade, criando as condições para o normal funcionamento do mercado (NUSDEO, 2001). 


\title{
Administração: caminhos para o desenvolvimento sustentável
}

\section{TAXA DE JUROS}

Juros são a remuneração cobrada pelo capital emprestado, pago pelo mutuário (tomador/beneficiário) ao mutuante (quem empresta) por determinado período de tempo. Podem ser cobrados por instituições financeiras (pessoa jurídica) ou pessoa física, devem ser ajustados caso a caso, em cada contrato ou acordo, e não se presumem. Quando um contrato não prevê juros, eles não podem ser exigidos, o que também ocorre quando não há uma determinação de seu valor percentual (MARTINS, 2002).

Por taxa de juros também se entende como o custo do dinheiro no mercado. O Banco Central do Brasil é o órgão regulador da política de juros. Quando a taxa de juros está alta é sinônimo de falta de dinheiro no mercado. Ao contrário, quando está baixa, é porque está sobrando dinheiro no mercado. A taxa de juros é um dos mais importantes indicadores de política monetária (Ibid).

A principal taxa de juros básica é a SELIC (Sistema Especial de Liquidação e de Custódia) foi criada em 1979 pelo Banco Central e a Andima (Associação Nacional das Instituições do Mercado Aberto), a fim de tornar mais segura a negociação de títulos. No Brasil a taxa de juros básica (taxa Selic meta) é definida pelo COPOM (Comitê de Política Monetária), através de reuniões periódicas para fins de políticas monetárias. O Banco Central do Brasil define a taxa SELIC como:

\begin{abstract}
A taxa apurada no Selic, obtida mediante o cálculo da taxa média ponderada e ajustada das operações de financiamento por um dia, lastreadas em títulos públicos federais e cursadas no referido sistema ou em câmaras de compensação e liquidação de ativos, na forma de operações compromissadas. Esclarecemos que, neste caso, as operações compromissadas são operações de venda de títulos com compromisso de recompra assumido pelo vendedor, concomitante com compromisso de revenda assumido pelo comprador, para liquidação no dia útil seguinte. Ressaltamos, ainda, que estão aptas a realizar operações compromissadas, por um dia útil, fundamentalmente as instituições financeiras habilitadas, tais como bancos, caixas econômicas, sociedades corretoras de títulos e valores mobiliários e sociedades distribuidoras de títulos e valores mobiliários (BANCO CENTRAL DO BRASIL, 2010).
\end{abstract}

Vale mencionar que a taxa Selic também é considerada como um mecanismo de balizamento para os juros que serão cobrados em empréstimos concedidos a empresas e pessoas físicas.

\section{EMPREENDEDORISMO}

Azevedo (1992) define o empreendedor como uma pessoa capaz de criar novos projetos e guiar um negócio próprio, de maneira satisfatória, rumo ao sucesso. 


\section{Administração: caminhos para o desenvolvimento sustentável}

O empreendedorismo intervém na falta de relações empregatícias e na informalidade do mercado de trabalho com o intuito de justificar a expansão da situação de desigualdade social e econômica, resultante das reformas neoliberais implantadas no Brasil a partir da década de 1990, que resultou no processo de transformação dos trabalhadores em indivíduos empreendedores (LIMA, 2008).

O empreendedorismo segundo Dolabela² (1999 apud LIMA, 2008) é abordado sob duas óticas distintas: a dos comportamentalistas e a dos economistas. Os economistas interligam o empreendedor à introdução de algo novo e ao desenvolvimento econômico e os comportamentalistas atrelam à criatividade e intuição as atitudes do empreendedor.

\footnotetext{
A função do empreendedor é reformar ou revolucionar o padrão de produção explorando uma invenção ou, de modo mais geral, um método tecnológico nãoexperimentado, para produzir um novo bem ou um bem antigo de uma maneira nova, abrindo uma nova fonte de suprimento de materiais, ou uma nova comercialização para produtos e organizando um novo setor (HISRICH; PETERS ${ }^{3}$ , 2004 apud LIMA 2008, p. 41).
}

Os empreendedores fazem as coisas acontecerem e conseguem resultados satisfatórios e aprimoram idéias novas ou inovadoras em operações comerciais reais (RESNIK, 1990).

A eficácia é o ponto fundamental de um bom gestor de pequena empresa, a capacidade de compreender, controlar a empresa e dirigi-la para mantê-la distante dos perigos inevitáveis do mundo dos pequenos negócios é a prova que direcionam a um crescimento firme e lucrativo da micro ou pequena empresa (RESNIK, 1990).

Face às discussões citadas anteriormente, montar um negócio é importante, mas para que seja criado um valor para a sociedade é preciso gerar empregos, satisfazer clientes, gerar lucro, entre outros. As micro e pequenas empresas representam uma parcela significativa de contribuição para a economia através da inovação em melhoria dos produtos e processos e são essas características que permitem o ciclo de renovação dos empreendedores.

\section{MICROCRÉDITO}

O microcrédito consiste em um financiamento concedido por instituições financeiras com ou sem fins lucrativos. Destinado a uma camada da população de baixa renda, principalmente os microempreendedores formais ou informais (PARENTE, 2002).

O primeiro relato sobre microcrédito que se tem conhecimento foi em 1846 na Alemanha, quando o pastor Raiffeinsen fundou a Associação do Pão com o intuito de fornecer farinha de trigo para que os fazendeiros locais pudessem obter capital de giro através da fabricação e comercialização de pães. 


\section{Administração: caminhos para o desenvolvimento sustentável}

Com o passar dos anos a associação prosperou e veio a se tornar uma cooperativa de crédito (BELTRÁN CASTAÑóN, 2004).

No entanto, a primeira experiência que deu origem ao programa de microcrédito foi vislumbrada pelo professor Muhamad Yunus em Bangladesh no ano de 1976, que observou os pequenos empreendedores da região vizinha a instituição de ensino em que lecionava reféns de agiotagem ${ }^{4}$, mas pagando tais quantias obtidas no prazo estipulado, foi então que Yunus começou a emprestar recursos próprios, cerca de 27 doláres a 42 pessoas em 1976, a juros mais baixos do que os cobrados por agiotas, tendo como garantia a confiança neles depositada (YUNUS, 2004). A proposta de Yunus cresceu de tal maneira que em 1978 foi criado o Banco Grameen, ampliando as linhas de crédito e de serviços financeiros, tais como: poupança popular, financiamento habitacional e educacional, seguros e cartão de crédito (PARENTE, 2002). Atualmente, o banco empresta um total de 2,4 bilhões de dólares de microcrédito para cerca de 2,3 milhões de pequenos empreendedores, que ampliam sua capacidade produtiva (SILVEIRA FILHO, 2005). Yunus defendia a crença na capacidade humana como o diferencial no acesso ao microcrédito, pregava "[...] que é mais importante ensinar a pescar do que dar peixe para as pessoas. Porém, ele acrescenta, deve- se também conceder o crédito para comprar a vara de pescar, sem a qual não se pesca" (ICCAPE, 2002). Partindo dos relatos sobre a origem do microcrédito o Banco Interamericano de Desenvolvimento (BID) conceituou em seu manual de princípios e práticas regulatórias a essência do microcrédito:

(...) Nesse sentido se define o microcrédito como um pequeno crédito concedido em larga escala por uma entidade financeira a pessoas físicas ou jurídicas cuja principal fonte de renda sejam as vendas provenientes da realização de atividades empresariais de produção de bens e serviços (ROSALES ${ }^{5}$, 2002 apud MARTINS, 2002, p. 59).

Neste contexto entende-se o microcrédito como um meio do empresário alavancar seu empreendimento através da concessão de empréstimos de valor e juros baixos e curto prazo, sendo uma oportunidade para gerar renda para a empresa e a comunidade ao redor desta organização. Neste contexto os processos para obtenção do microcrédito serão descritos a seguir (ICCAPE, 2002):

a) Público-alvo: famílias de baixa renda, micro e pequenos empreendedores formais e informais (Ibid);

b) Metodologia de crédito: os agentes de crédito dirigem-se ao cliente e analisam a capacidade financeira do empreendimento, o caráter do indivíduo e sua experiência no negócio. Os agentes tornam-se a ligação entre a Instituição Financeira e o cliente, sendo capacitado para 


\section{Administração: caminhos para o desenvolvimento sustentável}

realizar o levantamento socioeconômico e as necessidades do negócio, para então ocorrer à liberação do crédito (Ibid);

c) Valores: são compatíveis com a atividade da empresa e a capacidade de pagamento (Ibid);

d) Prazos: geralmente são curtos e flexíveis, variam de acordo com o recurso obtido (Ibid);

e) Garantias: alienação de bem ou do aval solidário, cuja garantia é oferecida por um grupo que mantém alguma interação ou afinidade, mas muitos casos justamente por não ter garantias reais a oferecer, tais como terrenos, carros, etc., uma das alternativas é o proponente apresentar um avalista (Ibid);

f) Taxas de juros: variam para cada instituição, mas os tomadores de microcrédito procupam-se mais com a liquidição do empréstimo mensalmente, do que a efetiva taxa de juros (Ibid);

g) Produtos e serviços: capital de Giro (mercadorias e matérias-primas para revenda) é o principal produto; investimento fixo (obras/reformas, aquisição de máquinas e equipamentos); ou investimento misto (combinação dos dois acima) (AFPR, 2010).

desemprego através das atividades desenvolvidas por empresas de micro e pequeno porte, contribuindo para o aumento da produtividade e cooperação, conseqüentemente desenvolvendo sua região de origem.

\section{AGÊNCIA DE FOMENTO}

As agências de fomento têm origem na Resolução do Conselho Monetário Nacional de no 2.574 de 17/12/1998 e na Resolução no 2828, de 30/03/2001. Conforme definição do Banco Central do Brasil (2010):

As agências de fomento têm como objeto social a concessão de financiamento de capital fixo e de giro associado a projetos na Unidade da Federação onde tenham sede. Devem ser constituídas sob a forma de sociedade anônima de capital fechado e estar sob o controle de Unidade da Federação, sendo que cada Unidade só pode constituir uma agência. Tais entidades têm status de instituição financeira, mas não podem captar recursos junto ao público, recorrer ao redesconto, ter conta de reserva no Banco Central, contratar depósitos interfinanceiros na qualidade de depositante ou de depositária e nem ter participação societária em outras instituições financeiras. De sua denominação social deve constar a expressão "Agência de Fomento" acrescida da indicação da Unidade da Federação Controladora. É vedada a sua transformação em qualquer outro tipo de instituição integrante do Sistema Financeiro Nacional. As agências de fomento devem constituir e manter, permanentemente, fundo de liquidez equivalente, no mínimo, a $10 \%$ do valor 


\section{Administração: caminhos para o desenvolvimento sustentável}

de suas obrigações, a ser integralmente aplicado em títulos públicos federais. (Resolução CMN 2.828, de 2001) ${ }^{6}$.

Podemos dizer que, de acordo com a definição do Banco Central do Brasil, as agências de fomento são instituições financeiras não bancárias, constituídas como sociedades anônimas de capital fechado, regulamentadas pelo BACEN, tendo por objeto social o financiamento de capitais fixo e de giro associado a projetos na Unidade da Federação onde tenham sede.

Importante destacar também outras características: são subordinadas à supervisão e fiscalização do BACEN; apenas podem praticar operações com recursos próprios e de repasses originários de fundos constitucionais; admitida a prestação de garantias, a utilização da alienação fiduciária em garantia e de cédulas de crédito industrial e comercial, e a cobrança de encargos nos padrões praticados pelas instituições financeiras.

A Agência de Fomento do Paraná S. A (AFPR) criada pela Lei 11741/97, tem como objetivo apoiar financeiramente os pequenos empreendedores (pessoas físicas ou jurídicas) na modernização e ampliação de suas atividades. Além dos financiamentos (atividades fim), a Agência de Fomento do Paraná também atua na gestão de fundos.

\subsection{BANCO SOCIAL}

O Banco Social é um programa de microcrédito com objetivo de geração de renda e emprego. Abrange pessoas físicas e jurídicas com negócio próprio e que necessitam de um financiamento para melhorar ou ampliar as suas atividades. O financiamento pode ser usado para capital de giro (mercadorias e matérias-primas industrializáveis), investimento fixo (máquinas e equipamentos) e investimento misto (combinação de investimento fixo e capital de giro ${ }^{7}$.

Desde 2001, o Programa Banco Social do Governo do Paraná já financiou mais de $\mathrm{R} \$ 120$ milhões em projetos de financiamentos a micro e pequenos empresários. O programa é uma parceria entre a Agência de Fomento do Paraná S.A, Secretaria de Estado do Trabalho e Promoção Social, Sebrae e prefeituras. Para adesão faz-se mister residir a mais de um ano no município (necessário endereço fixo), não possuir restrições cadastrais e ter faturamento bruto anual de até $\mathrm{R} \$ 360.000,00^{8}$.

\section{METODOLOGIA}

O desenvolvimento sócio-econômico gerado a partir dos empreendimentos financiados pelo Banco Social pode ser evidenciado por meio da análise dos resultados do programa, obtido junto aos Agentes de Crédito, que são os profissionais responsáveis pelo levantamento de informações sócio-econômicas 


\section{Administração: caminhos para o desenvolvimento sustentável}

e acompanhamento das operações de crédito e, por informações disponibilizadas por estudos realizados pelo SEBRAE/PR que participa como parceiro do programa.

O estudo em questão foi realizado por meio de análise, que tomou por base, 50 operações de microcrédito, selecionadas aleatoriamente, no universo dos microcréditos concedidos exclusivamente para fins de investimento e que tenham sido classificados como casos de sucesso do programa, a mensuração dos casos de insucesso está pautada em pesquisa realizada pelo Instituto Vox Populi (2005) em parceria com o SEBRAE/PR, que trata dos fatores condicionantes e da taxa de mortalidade das micro e pequenas empresas no Estado do Paraná.

A partir dos casos selecionados, foi solicitado aos Agentes de Crédito o levantamento das seguintes informações para análise:

a) Município e região pertencente;

b) Atividade e setor de atuação;

c) Início ou continuidade da atividade;

d) Quantidade e valor dos créditos;

e) Aumento de renda;

f) Geração de empregos.

Após a tabulação das informações obtidas através dos agentes de crédito foi realizada a análise dos dados coletados, possibilitando mensurar a geração de emprego e renda dos empreendimentos da amostra.

Finalmente, por meio de extrapolação dos resultados da amostra, e, de estudo realizado pelo Instituto Vox Populi a pedido do SEBRAE, foi estimada a geração média de emprego e renda nos investimentos financiados pelo programa Banco Social e seus impactos na economia do Estado do Paraná.

\section{APRESENTAÇÃO DO CASO}

O campo empírico deste estudo foi formado através do contato com o Diretor Administrativo Financeiro da Agência de Fomento do Paraná que forneceu ao grupo informações sobre os programas de microcrédito do Governo do Paraná. Entre as opções elencadas foi escolhido o programa nomeado de banco Social destinado a pessoas físicas ou jurídicas, dos setores de indústria, comércio e serviços, 


\section{Administração: caminhos para o desenvolvimento sustentável}

que desejam empreender ou que já possuam um empreendimento, sejam eles formais ou informais. Esta escolha foi baseada no intuito de verificar como os programas sociais do governo contribuem para a geração de emprego, renda e melhoria da condição de vida dos pequenos empreendedores.

Nesta análise serão apresentadas as informações obtidas a partir das amostras coletadas, demonstrando os impactos sócio-econômicos na geração de emprego e renda para o Estado do Paraná.

Gráfico 1 - Estabelecimentos em início de atividades e estabelecimentos já constituídos

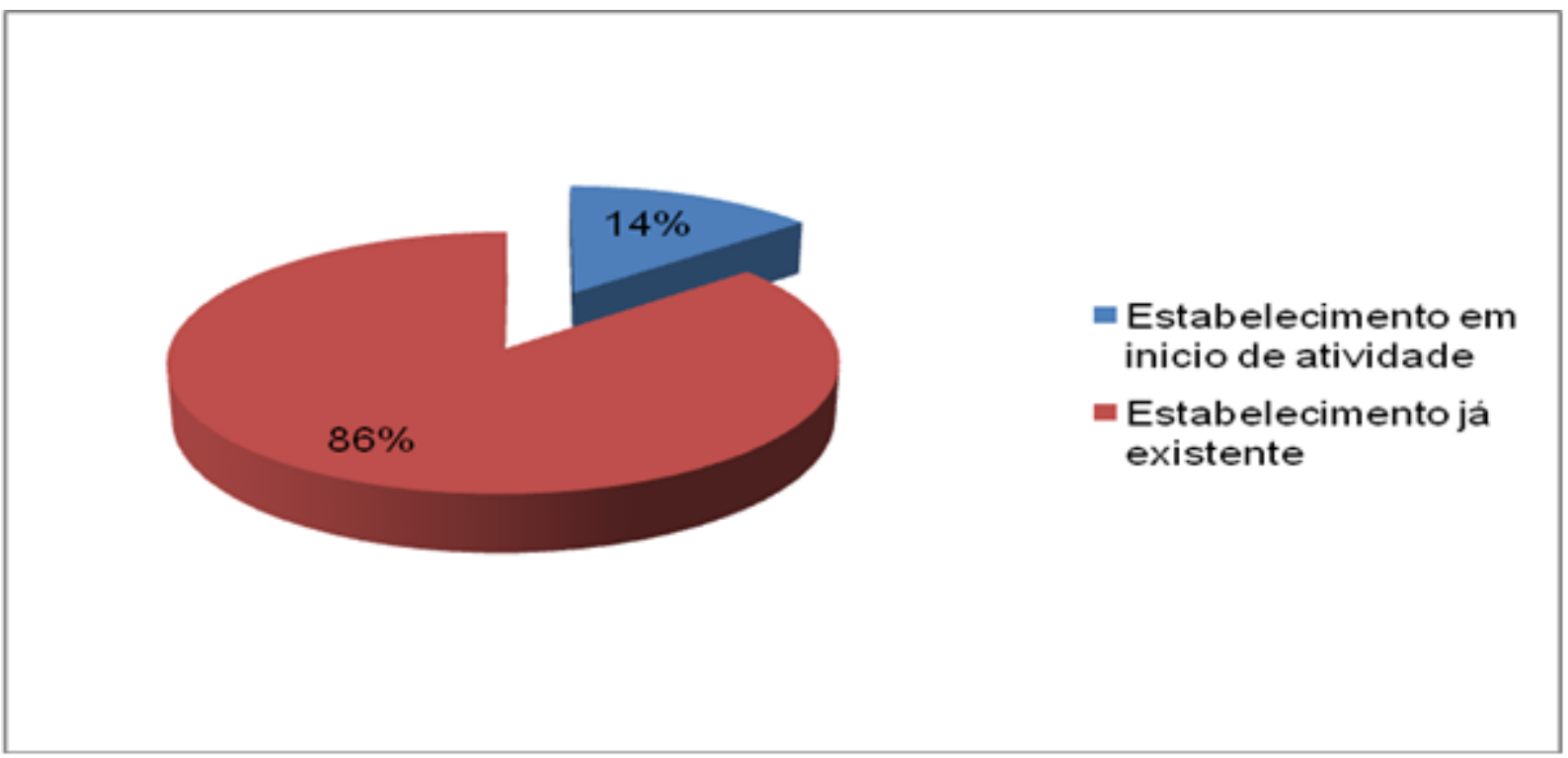

Por meio da amostra aleatória dos cinquenta casos estudados ficou evidenciado que o programa de microcrédito operado pela Agência de Fomento do Paraná apresenta concentração de $86 \%$ em créditos concedidos a estabelecimentos em atividade. Somente $14 \%$ dos casos o crédito é concedido a estabelecimentos em fase inicial de atividades. 


\section{Administração: caminhos para o desenvolvimento sustentável}

Gráfico 2 - Concessão de microcrédito por região do estado do Paraná

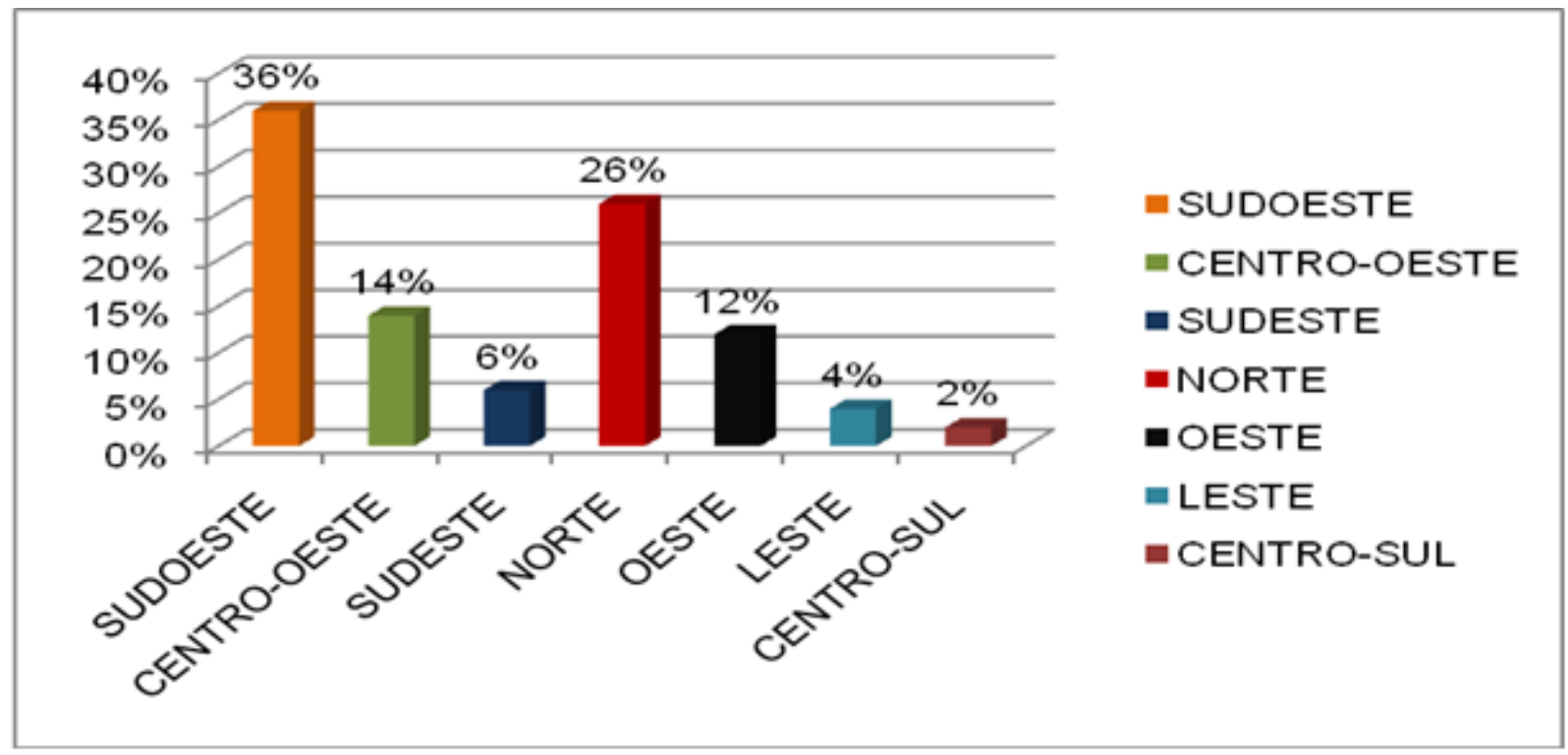

O gráfico demonstra que há concentração de concessões nas regiões sudoeste e norte do estado. A região sudoeste é bastante dependente economicamente da agricultura e da indústria que dela deriva. Já o norte conhecido nacionalmente como norte-pioneiro, é palco de uma agricultura forte, inserindose mais recentemente também nas indústrias madeireira e alimentícia.

Gráfico 3 - Concessão de microcrédito por segmento econômico

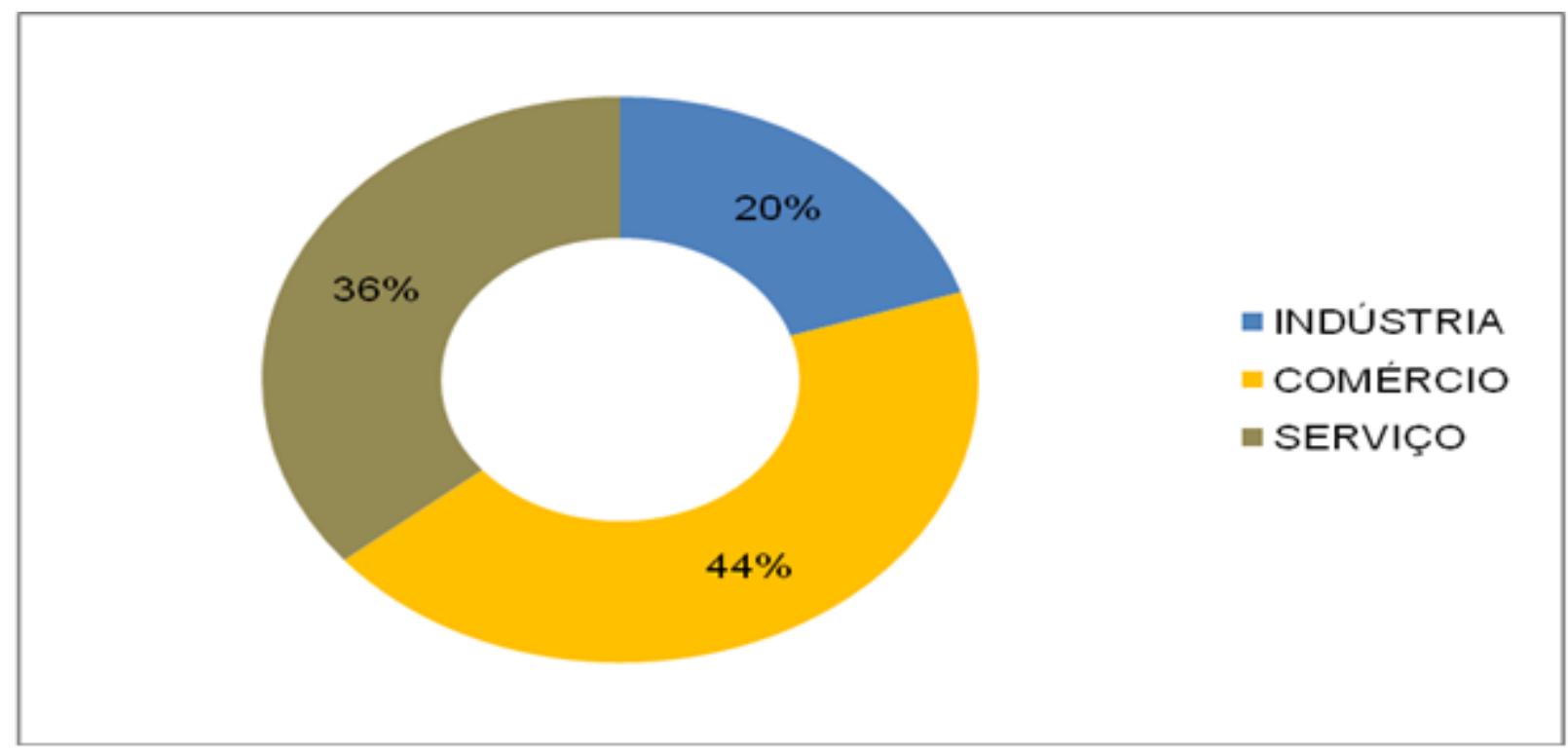

O microcrédito concentra-se nos segmentos de comércio e de serviços por tratar-se de créditos de pequena monta, sendo que a indústria em geral requer investimento maior, bem como habilidade e conhecimento mínimo para o seu desempenho. Em análise aos dados coletados, observa-se que $44 \%$ dos créditos concedidos foram para o setor comercial. 


\section{Administração: caminhos para o desenvolvimento sustentável}

Gráfico 4 - Faixa de valores de créditos concedidos

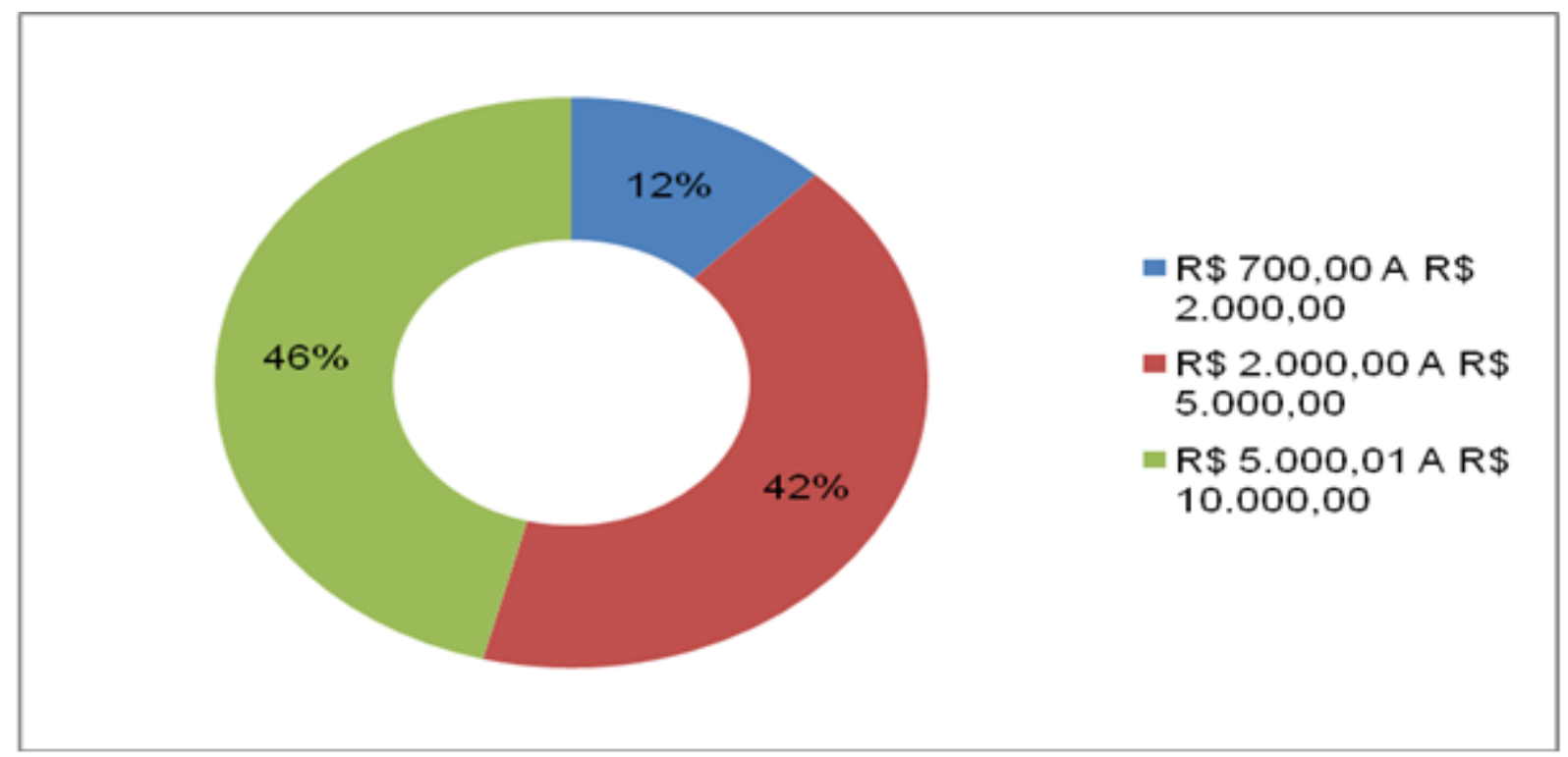

Dentre a amostra apresentada, é possível afirmar que as maiores parcelas de financiamentos concedidos ficam concentradas na faixa de valores de $\mathrm{R} \$ 5.000,00$ aproximadamente, visto que em $46 \%$ dos casos os montantes estão entre R\$ 5 mil e R\$ 10 mil e em 42\% entre R\$ 2 mil e R\$ 5 mil.

Gráfico 5 - Ampliação no número de empregos

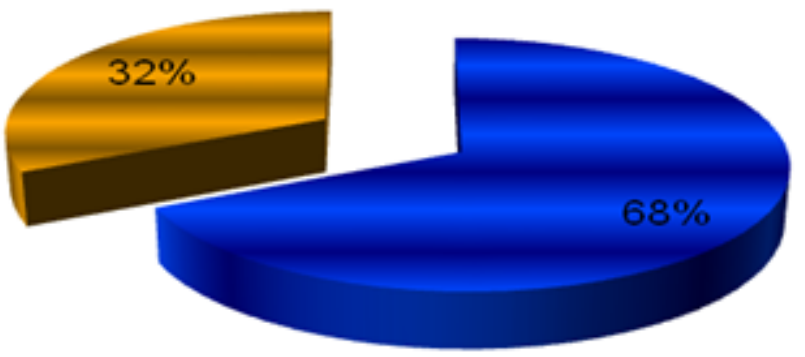

- HOUVE AMPLIAÇÃO DE EMPREGO

$=$ NÄO HOUVE AMPLIAÇÃO DE EMPREGO

Pelos dados coletados na amostra ficou evidenciada a criação de postos de trabalho que as micro e pequenas empresas vem criando ao longo dos anos no Estado. Em $68 \%$ dos empreendimentos que obtiveram crédito junto a Agência de Fomento do Paraná foi evidenciada a ampliação no número de empregos, alcançando um dos objetivos para o qual o programa foi criado. 


\section{Administração: caminhos para o desenvolvimento sustentável}

Gráfico 6 - Ampliação da renda

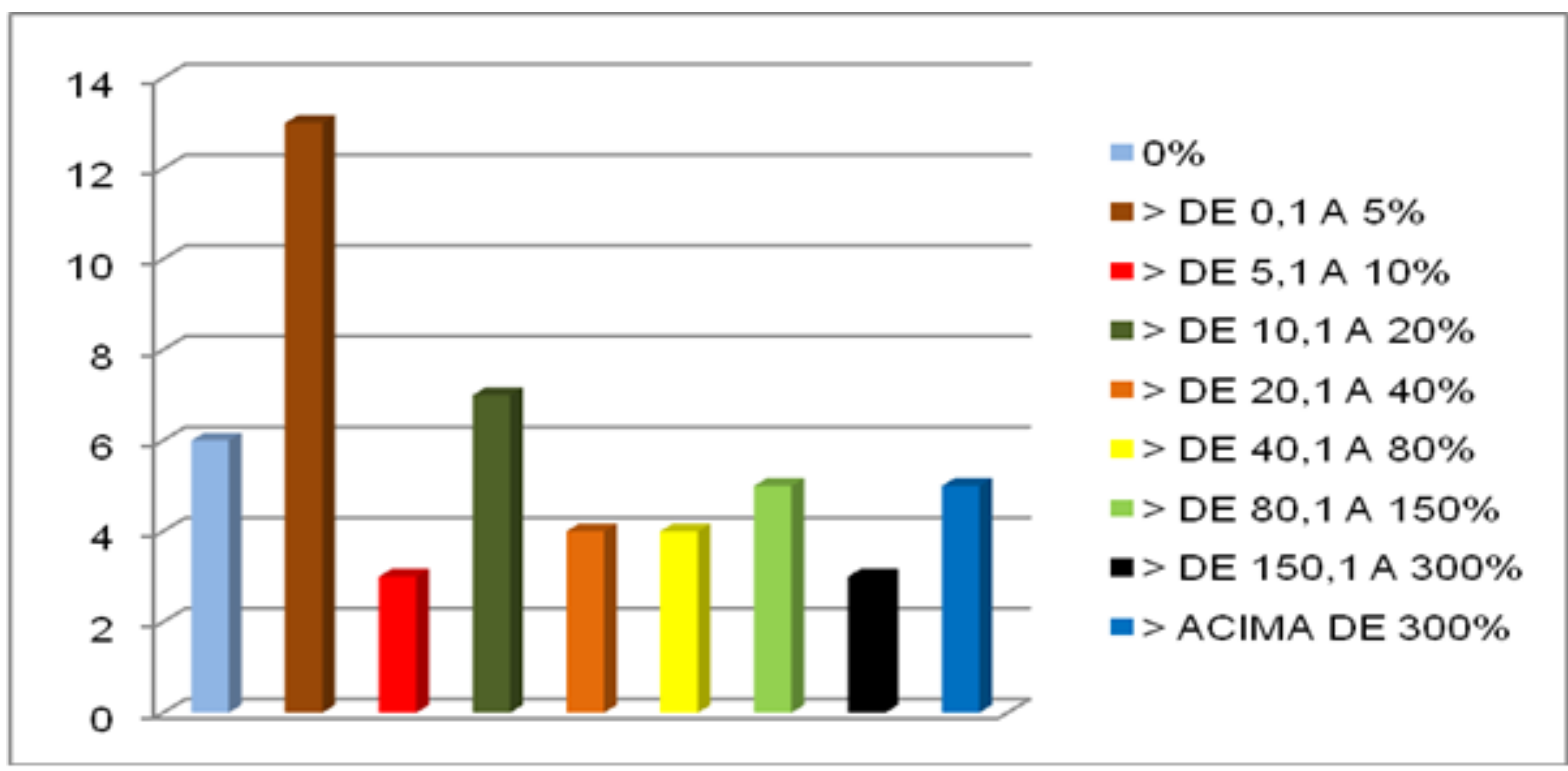

Os dados revelam que o segundo objetivo para o qual o programa de microcrédito foi criado também tem sido atingido. Em 13 empreendimentos dentre os 50 casos estudados houve acréscimo na renda entre 0,1 e $5 \%$ e em 7 empreendimentos, acréscimo de 10 a 20\%. Nos casos que não apresentaram aumento na renda verificou-se tratar de empreendimentos em início de atividade.

Gráfico 7 - Reincidência na obtenção de crédito por meio do programa de microcrédito

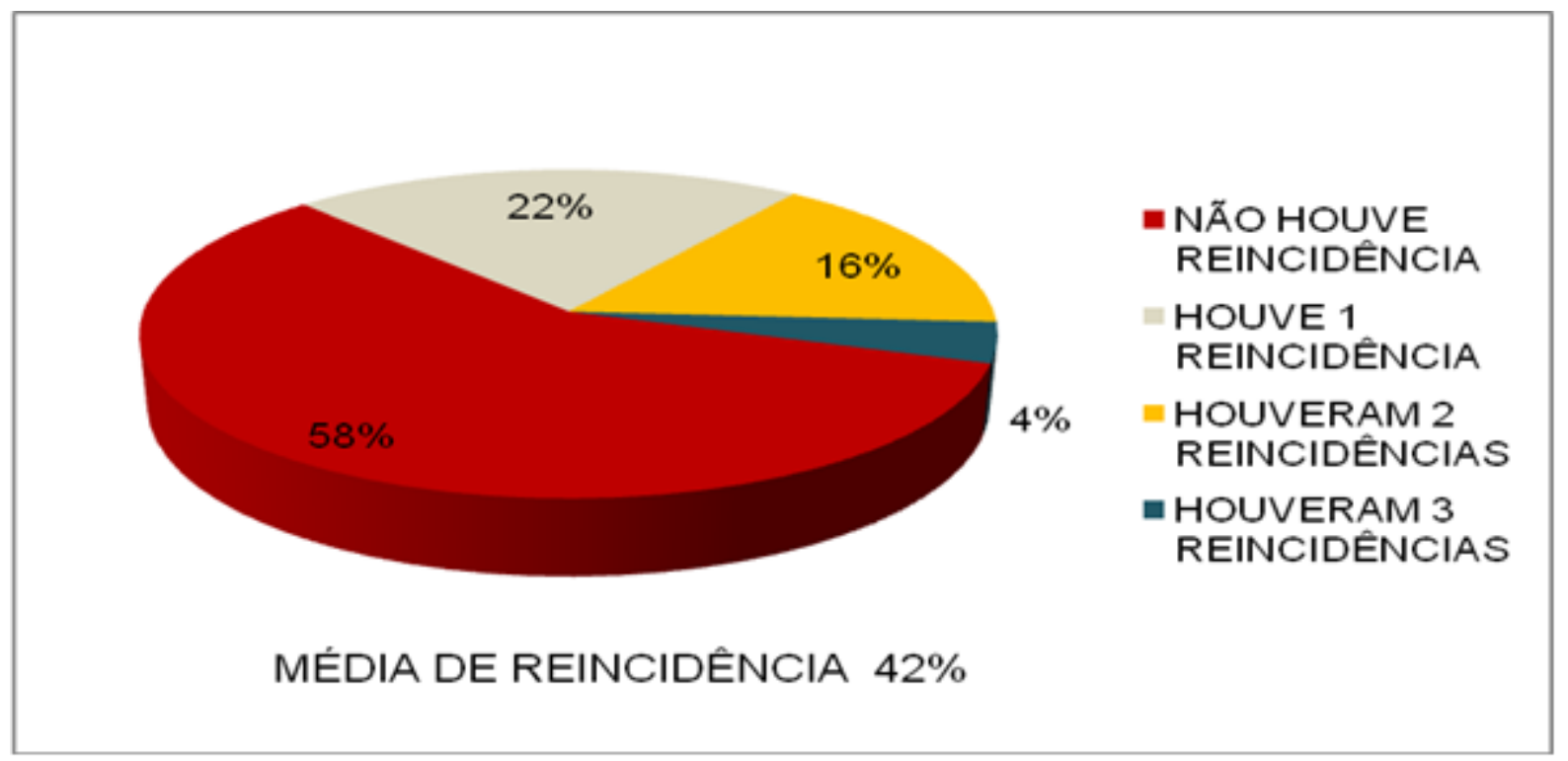

A amostra estudada revela que $58 \%$ dos casos não buscaram uma segundo crédito junto a instituição, isso se deve a dois motivos, primeiro pelo acesso ao crédito junto a outras instituições devido o montante necessário não mais ser atendido pelo programa Banco Social, o segundo pelo 


\section{Administração: caminhos para o desenvolvimento sustentável}

autofinanciamento proporcionado pelo empreendimento. A média de reincidência ficou em $42 \%$, sendo que alguns empreendimentos chegaram a buscar 3 novos financiamentos posteriores.

Gráfico 8 - Clientes que obtiveram crédito de outras fontes além do microcrédito operado pela Agência de Fomento do Paraná

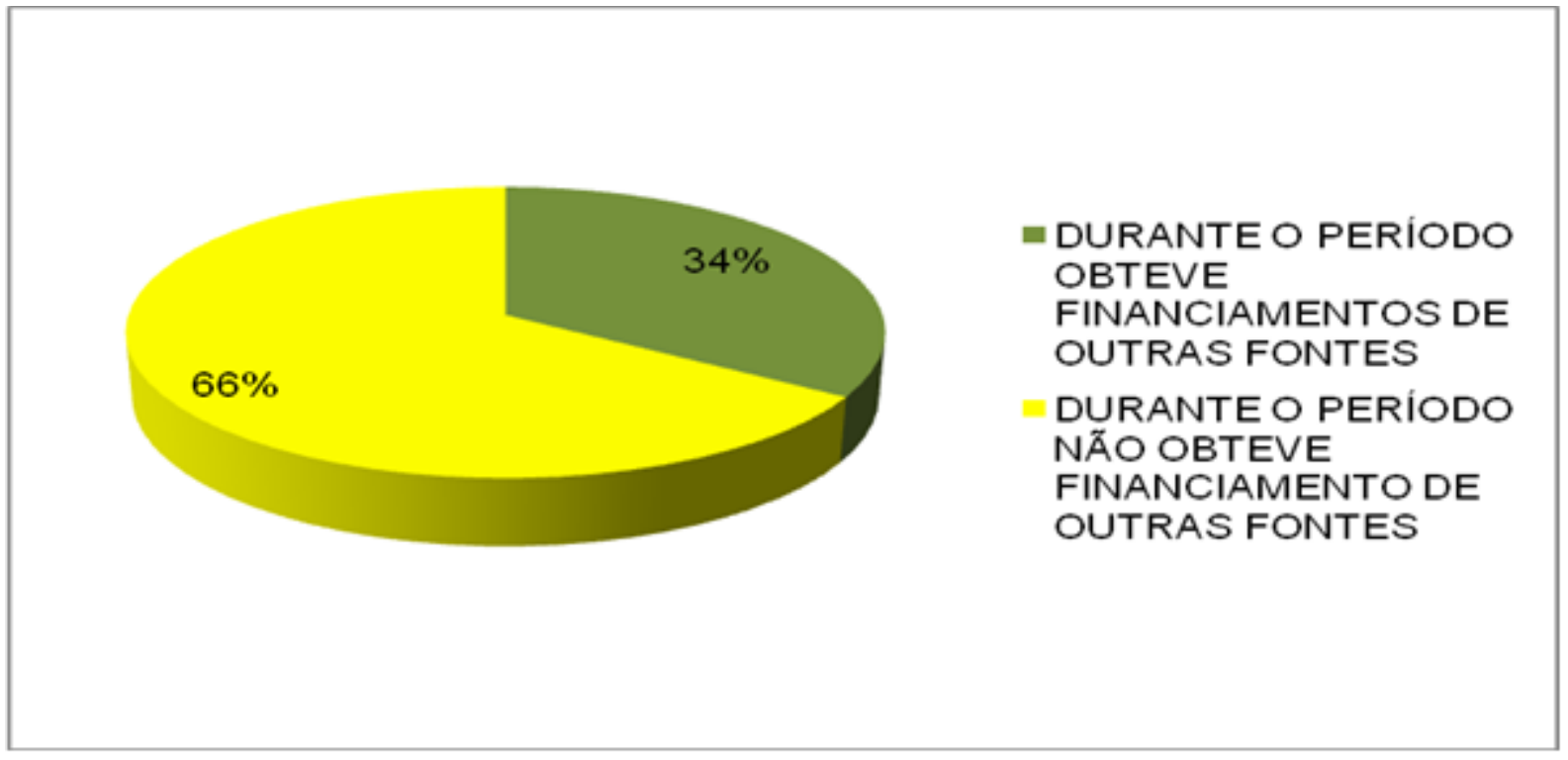

No caso em estudo, observa-se que somente $34 \%$ dos clientes do microcrédito foram buscar outras fontes de financiamento devido ao grande crescimento não proporcionar mais seu atendimento junto ao programa. A parcela de empreendedores que não buscaram outras fontes de financiamento obtiveram novo crédito junto ao programa para expandir o empreendimento, conforme análise demonstrada no gráfico 7.

\section{ANÁLISE DOS RESULTADOS}

A Agência de Fomento do Paraná S/A, juntamente com o Sebrae/PR e a Secretaria de Trabalho Emprego e Promoção Social, desde 2001 vem trabalhando para ampliar e melhorar o programa de microcrédito, o que proporcionou a formalização de mais de 33.300 contratos e o atendimento a aproximadamente 26.800 mutuários.

A meta para o programa é atingir até dezembro de 2010 a marca de 34.000 contratos, com R\$ 123 milhões de recursos liberados desde a sua criação. Para tanto, a rede de atendimento vem sendo ampliada, estando programados 3 novos cursos de formação para agentes de crédito até o fim do período. 


\section{Administração: caminhos para o desenvolvimento sustentável}

Ponto relevante a ser destacado no programa de microcrédito operado no estado do Paraná é a taxa de juros aplicada, considerada a menor do país, dentre as instituições financeiras oficiais. A taxa é fixa não tendo relação com a SELIC, no entanto, hoje ambas estão muito próximas. Uma taxa reduzida sobre um dos fatores de produção que é o capital produz impactos diversos junto aos demais fatores, como a possibilidade de geração de renda e sustento às famílias dependentes do empreendimento, a prática de preços compatíveis com os demais estabelecimentos do ramo, propiciando o desenvolvimento da comunidade a que pertence, devido à sobra de recurso para o consumo de outros bens ou para a poupança, e ao final a geração de novos empregos em função dos investimentos proporcionados pela poupança.

O Sebrae/PR, como parceiro do programa, realizou trabalho denominado "Fatores Condicionantes e Taxa de Mortalidade das Micro e Pequenas Empresas do Paraná 2005 - 2007 de suma importância para análise, com o levantamento de dados relevantes. Parte da pesquisa focou na taxa de mortalidade de empreendimentos no estado do Paraná, que revelou uma taxa de $25,2 \%$, isso demonstra que o empreendedorismo no Paraná e no Brasil ainda é incipiente, o seu desenvolvimento se dá por critérios ainda muito empíricos, necessitando um melhor embasamento teórico aos empreendedores, voltado à criação de rotinas de controles internos.

A partir dos dados coletados na amostra e dos contratos realizados até o mês de agosto de 2010, conforme citado anteriormente, conjugado com o trabalho desenvolvido pelo SEBRAE/PR em parceria com o Instituto Vox Populi, foram realizadas extrapolações para dimensionar os impactos que 0 programa de microcrédito da Agência de Fomento do Paraná S/A proporcionou à população paranaense, levando em consideração dois fatores aos quais o presente trabalho se propôs a explorar, que são a ampliação de postos de trabalho e da renda dos empreendimentos atendidos pelo programa.

Pela amostra foi possível verificar que houve ampliação na ordem de $29,34 \%$ no número de empregos nos estabelecimentos que obtiveram crédito junto ao programa de microcrédito, considerando que este atendeu aproximadamente 26.800 mutuários, mas que somente $74,8 \%$ deles permanecem ativos, é possível estimar que foram criadas aproximadamente 20.500 novas vagas de trabalho no Estado do Paraná, retirando estas pessoas da informalidade e proporcionando vida digna baseada no trabalho.

No que diz respeito à renda, verificou-se que nos empreendimentos estudados houve um crescimento médio de $35,69 \%$ na renda. Ao considerar que aproximadamente $25,2 \%$ dos empreendimentos no 


\section{Administração: caminhos para o desenvolvimento sustentável}

estado não sobrevivem, a taxa efetiva é de $26,77 \%$, levando-se em conta o número de empreendimentos atendidos pelo programa.

Este estudo demonstra que a economia paranaense foi impulsionada por estes novos consumidores de bens e serviços gerando o chamado ciclo virtuoso, trabalho gera renda, que gera consumo, que gera novo trabalho para satisfazer a demanda da população.

\section{RECOMENDAÇÕES E CONCLUSÃO}

O modelo do Banco Social operado pela Agência de Fomento do Paraná, atende vários requisitos de um programa de microcrédito, a concessão de empréstimos de pequenos valores, a não exigência de garantias reais, a baixa taxa de juros e, o agente de crédito ser alguém do município onde ocorre a demanda, esses fatores são essenciais para o sucesso do programa.

Em outros estados as agências de fomento tem modelos diversos do praticado no estado do Paraná, mas pelos estudos realizados, o resultado não é tão expressivo em especial pela falta do agente local, o que dificulta a elaboração de projetos que apontem a real necessidade do demandante.

Vislumbrando um desenvolvimento econômico sustentável do país, faz-se necessária a adoção de programas como este em todos os municípios do Brasil, que proporcione o desenvolvimento das regiões a partir de suas vocações locais e estimule o perfil empreendedor da população brasileira.

Ao sintetizar as informações obtidas com base no referencial teórico, observa-se que o microcrédito tem forte influência na economia, entrosando fortemente os fatores de produção e, portanto, capaz de gerar significativas mudanças sociais.

Tomando por base os dados coletados percebe-se que este instrumento é capaz de permear todo o estado, não ficando restrito a determinadas regiões, nem a um segmento econômico, tão pouco aqueles que podem apresentar garantias para a obtenção de um crédito e que estão incluídos no sistema tradicional de crédito. O modelo proporciona a inclusão de uma pequena parcela dos excluídos, que tem um ideal de trabalho para a busca de uma vida melhor.

Ao realizar a análise dos resultados é possível afirmar que o programa vem atingido o seu objetivo de influência efetiva nos empreendimentos por ele fomentados, criando novos postos de trabalho e gerando ampliação na renda das famílias. 


\section{Administração: caminhos para o desenvolvimento sustentável}

\section{REFERÊNCIAS}

AGÊNCIA DE FOMENTO DO PARANÁ - AFPR. Programa de microcrédito. Curitiba: AFPR, 2010. Disponível em: http://www.afpr.pr.gov.br/modules/conteudo/conteudo.php?conteudo=30 Acesso em 28/09/2010.

AZEVEDO, João Humberto. Como iniciar uma empresa de sucesso. Rio de Janeiro: Quality Mark, 1992.

${ }^{6}$ BANCO CENTRAL DO BRASIL. Disponível em: http://www.bcb.gov.br/?SELICDESCRICAO. Acesso em: $2 / 10 / 2010$.

BELTRÁN CASTAÑÓN, Aníbal Américo. O Microcrédito como instrumento de redução da pobreza: um estudo de caso da região de Puno - Peru. Dissertação de Mestrado. Faculdade de Economia, Administração e Contabilidade da Universidade de São Paulo. São Paulo, 2004.

${ }^{1}$ BULHÕES PEDREIRA in MAGALHÃES, Roberto Barcelos de. Vademecum das Sociedades Anônimas.

7,8Disponível:em:http://microcredito.blog.br/banco-social-atinge-marca-de-r-120-milhoes-emfinanciamentos . Acesso em: 2/10/2010.São Paulo: Gamma, 1983.

${ }^{2}$ DOLABELA, F. Oficina do empreendedor. São Paulo: Editora de Cultura, 1999.

${ }^{3}$ HISRICH, R. D.; PETERS, M. P. Empreendedorismo. 5a Ed. Porto Alegre: Bookman, 2004.

INSTITUTO CENTRO DE CAPACITAÇÃO E APOIO AO EMPREENDEDOR -ICCAPE. Guia de montagem: caminhos para montagem de uma instituição de microfinanças. Belo Horizonte: ICCAPPE, 2002.

INSTITUTO VOX POPULI. Fatores condicionantes e taxa de mortalidade das MPE. Paraná: 2005.

LIMA, Aguinaldo Luiz de. Os riscos do empreendedorismo: a proposta de educação e formação empreendedora. Dissertação de Mestrado em Educação. Faculdade de Educação da Universidade de São Paulo, São Paulo, 2008.

MANKIW, N. Gregory. Os Mercados de fatores de produção. In: Introdução à economia. São Paulo: Cengage Learning, 2009

MARTINS, Paulo Haus. Manual de Regulamentação das Microfinanças: Programa de Desenvolvimento Institucional. Rio de Janeiro: BNDES, 2002.

MAUES, Alcides da Costa. Capital e renda e suas influências no meio sócioesconômico e psíquico. Adcontar, Belém, v. 5, n.1. p. 15-34, junho, 2004

NUSDEO, Fábio. Microeconomia: a oferta. In: Curso de Economia: Introdução ao Direito Econômico. São Paulo: Ed. Revista dos Tribunais, 2001.

PARENTE, Silvana. Microfinanças: saiba o que é um banco do povo. Brasília: Agência de Educação para o desenvolvimento, 2002.

PINDYCK, Robert S.; RUBINFELD, Daniel L. Microeconomia. São Paulo: Pearson Prentice Hall, 2005. 


\section{Administração: caminhos para o desenvolvimento sustentável}

RAMOS, Carlos Alberto. Políticas de geração de emprego e renda, justificativas teóricas, contexto histórico e experiência brasileira. Texto para discussão. Universidade de Brasília. Brasília: 2003.

RESNIK, Paul. A bíblia da pequena empresa: como iniciar com segurança sua pequena empresa e ser muito bem-sucedido. São Paulo: Makron Books, 1990.

${ }^{5}$ ROSALES, Ramón. Manual de Princípios y Prácticas para La Regulación y Supervisión Del Microcrédito y de las Entidades Financeiras que Otorgan Microcrédito. BID, minuta de janeiro de 2002, pág. 35.

SILVEIRA FILHO, Jaime Albuquerque. Microcrédito na região metropolitana do Recife: experiência empreendedora do CEAPE. Dissertação de Mestrado. Universidade Federal de Pernambuco. Recife, 2005.

YUNUS, Muhammad. O banqueiro dos pobres. São Paulo: Ática, 2004. 


\section{Administração: caminhos para o desenvolvimento sustentável}

\section{NOTAS}

Notas 4

Agiotagem quer dizer especulação exagerada sobre títulos e mercadorias, em vista dos respectivos lucros. Empréstimo a juros muito altos. 


\section{Capítulo 13}

\section{ASPECTOS HISTÓRICOS E PEDAGÓGICOS DOS 10 ANOS DE IMPLEMENTAÇÃO DO PROGRAMA DE DESENVOLVIMENTO EDUCACIONAL NO ESTADO DO PARANÁ}

DOI: $10.37423 / 200300387$

Rodrigo Rodrigues da Silva, UTPFR, Brasil, rodrigorodrigues_97@hotmail.com

Elizangela Mara Carvalheiro, UTFPR, Brasil, elizangelam@utfpr.edu.br

Cássia Heloisa Ternus, Unochapecó, Brasil, chternus@gmail.com

Resumo: No ano de 2007 o Governo do Paraná implementou o Programa de Desenvolyimento Educacional (PDE), que oferece formação continuada aøs proferssores da rede estadual de ensino, para a implementação de projetos de intervenção pedagógica nas escolas. Neste sentido, este estudo visa evidenciar características/da implementaçãø do PDE no Estado do Paraná de 2007 a 2016. Para tanto, utilizou-se uma pesquisa descritiva de caráter qualitativo, com coleta de dados em documentos oficiais. Assim, a análise possibilitou o entendimento de que o PDE pode ser um facilitador para que os docentes sejam colocados como protagonistas das mudanças no ensino-aprendizagem no ambiente de sala de aula. O Estado é o súporte técnico e financeiro para que ocorra o desenvolvimento da formação de docentes e gestores escolares, e os projetos de intervenção podem contribuir para melhorias nas escolas. A rede de contato, gerado pela interação eñtre os profissionais por meio do Grupo de Trabalho Rede/(GTR), ainda que com certo percentual de desistências, pode apoiar essas melhokiàs.

Palavras-chave: Políticas públicas, Progranalde Desenvortvimento Educacional; Estado do Paralná.

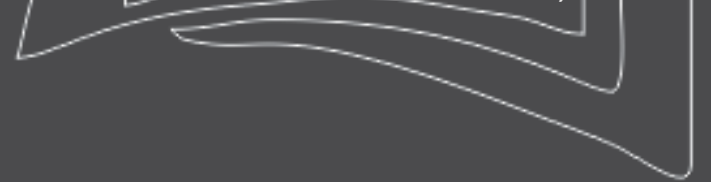




\section{Administração: caminhos para o desenvolvimento sustentável}

\section{INTRODUÇÃO}

Buscando atender as demandas, promover o bem-estar e interesse da sociedade, e atender as práticas de direito previstas na Constituição Federal, os governos criam as políticas públicas, com ações e/ou programas desenvolvidos e implementados para a área de interesse de atuação, dentre elas destacase a educação.

As políticas de educação são garantidas pela Constituição Federal e legislação específica como a Lei das Diretrizes e Bases da Educação Nacional (LDB) (Lei no 9.394/96) e Plano Nacional de Educação (Lei Federal $\mathrm{n}^{\circ}$ 13.005/14). Deste contexto, emergem questões significativas relacionadas à implementação de políticas públicas que buscam a melhoria da qualidade da educação básica em contextos brasileiros díspares em termos históricos e estruturais.

Tomando como base o PNE, este visa ser o elemento norteador de qualquer programa nacional, estadual ou municipal que aborde a educação em sua composição, estabelecendo as normas e diretrizes a serem seguidas. Aliado ao PNE, o Plano de Desenvolvimento da Educação se divide em mais de 40 programas que são organizados em quatro eixos, com projetos específicos para atender as necessidades regionais. Um desses programas é o Programa de Desenvolvimento Educacional (PDE) do Paraná, desenvolvido pelo Governo estadual para a profissionalização de professores.

O PDE do Paraná foi instituído pela Lei Complementar 103 de 15/03/2004, implementado por Decreto n. 4.482 de 14/03/2005, mas a regulamentação só ocorreu com a Lei Complementar 130 de 14 de julho de 2010. Este Programa tem como objetivo ofertar formação continuada aos docentes da rede estadual de ensino de formação básica, utilizando uma rede de contato com o quadro docente de Instituições de Ensino Superior (IES), buscando atualizar, preparar e capacitar o processo educacional para atender as constantes mudanças vivenciadas pelas pessoas no contexto da era digital.

É fato que velocidade com que as informações são observadas, disseminadas e construídas pelas pessoas da era digital - que estão constantemente conectados e interagindo em ambientes dinâmicos, faz com que o contexto de atuação dos docentes seja multifacetado e diversificado, gerando nestes uma busca constante de novas práticas de ensino-aprendizagem. Já que o método tradicional de escolarização não dá conta desta realidade, é necessária uma formação continuada para os docentes, para se manter atualizados com o ambiente no qual estão inseridos, e vivenciem novas práticas e metodologias de ensino, visando promover a autonomia e a criticidade dos estudantes. 


\section{Administração: caminhos para o desenvolvimento sustentável}

Neste contexto, o presente estudo visa evidenciar características da implementação do PDE no Estado do Paraná de 2007 a 2016. Para tanto, utilizou-se uma abordagem qualitativa, com objetivos descritivos, e procedimentos de coleta de dados em documentos oficiais do Programa.

\section{REFERENCIAL TEÓRICO}

Souza (2006) apresenta as políticas públicas como o campo de estudo que tem por objetivo colocar o governo em ação, sempre acompanhando e analisando-as, propondo melhorias no seu curso, se necessário. Uma das visões mais tradicionais na literatura, segundo autores como Dalfior, Lima e Andrade (2015), Frey (2009), Silva e Melo (2000) e Rua (2009), considera avaliar as políticas públicas utilizando o policy cycle. Nesse tipo de avaliação, a política é dividida em cinco fases: a formação da agenda, formulação das alternativas, tomada de decisão, implementação, e a avaliação.

Após a avaliação, a estratégia política envolve verificar as atividades sociais e políticas necessárias para tratar as possíveis desigualdades que possa ter gerado. Apesar da política buscar resolver um problema, ou lidar com dificuldades específicas verificadas em determinado ambiente socioeducacional, ela pode vir a gerar efeitos secundários que afetem a realidade de maneira não planejada.

Para Rua (2009), as políticas públicas são consequência das atividades políticas, onde, dentro de um conjunto de alternativas, são realizadas escolhas de programas e projetos que melhor atendem as necessidades. Não se pode pensar na política pública como desvinculada da atividade política em si, pois depende de um ambiente que seja favorável à tomada de decisões, e que ofereça possibilidade de aplicação real.

Além disso, as políticas públicas educacionais visam atender a Constituição Federal de 1988, que versa sobre os deveres do Estado, a manutenção da saúde, segurança, cultura e educação. O inciso V do Artigo 206 da Constituição trata sobre a valorização dos profissionais da educação, por meio de planos de carreira e concursos públicos para o ingresso na docência. No Artigo 214 fica disposta a elaboração decenal do PNE, de forma a alcançar os objetivos de erradicação do analfabetismo, universalização do atendimento escolar, melhoria do ensino, formação para o trabalho, promoção humanística e científica no país, e aplicação de recursos do Produto Interno Bruto (PIB) na educação (Constituição Federal, 1988).

Com reforma do aparelho do Estado, através do Plano Diretor de Reforma do Aparelho do Estado (PDRAE) (período de 1995 a 2003), houve a descentralização das ações governamentais na 


\section{Administração: caminhos para o desenvolvimento sustentável}

administração pública, propiciando que os estados se tornassem capazes de elaborar seus próprios planejamentos, sem a dependência federal (Oliveira, 2009). Neste contexto, inseriu-se as políticas educacionais. Com essa nova realidade, o Estado do Paraná, então implementou o PDE em 2007. O Programa buscou o alinhamento com o Artigo 2 ํ inciso VII da LDB, que dispõe sobre a valorização dos profissionais da educação escolar (Oliveira, 2009).

A gestão do programa em âmbito estadual é feita pela Secretaria de Estado da Educação (SEED), que fica encarregada coordenar a execução do programa; os Núcleos Regionais de Educação (NRE) são responsáveis por disponibilizar os professores participantes das escolas estaduais; e cada IES se compromete em oferecer estrutura e apoio metodológico/pedagógico aos ingressantes (Secretaria de Estado da Educação do Paraná [SEED], 2016).

Ao participar do Programa, cada docente deve ter como resultado o projeto pedagógico implementado em sua escola de origem. Para El Kadri, Campos e Souza (2012), a intervenção específica possibilitada quando o docente escolhe seu problema de pesquisa, oportunizando a heterogeneidade de ideias e metodologias a serem utilizadas no projeto, é um dos diferenciais do PDE. Isso dá aos pesquisadores a liberdade de criar soluções para os problemas que eles vivenciam no diaa-dia, sem que estejam engessados pela homogeneidade de métodos e ações, como ocorria com programas anteriores (SEED, 2016).

De acordo com Duarte e Viriato (2012) um dos motivos que levaram à criação do programa no estado do Paraná, foi a ineficácia identificada nos programas anteriores para a formação dos docentes. Cursos, palestras, entre outras atividades, faziam com que o educador adquirisse novas informações e conhecimentos, porém somente naqueles curtos períodos de tempo, sem que houvesse continuidade do aprendizado.

Entretanto, há que se considerar, conforme apresentaram El Kadri et al. (2012), o quanto a real continuidade dos estudos dos professores se efetiva, uma vez que um dos propósitos do programa é a "superação do modelo de formação continuada concebido de forma homogênea e descontínua" (SEED, 2016, p. 1). O argumento apresentado pelas autoras, sob a ótica de orientadoras do PDE em um dos polos de ensino, é de que os professores saem da formação e se sentem novamente sozinhos, não dando continuidade aos estudos.

Silva e Carvalheiro (2018) verificaram que o programa, apesar de algumas limitações, possibilita aos professores a geração inovações em metodologias ativas, por meio do projeto de intervenção. Entretanto, identificaram um baixo número de projetos que apresentaram continuidade após a 


\section{Administração: caminhos para o desenvolvimento sustentável}

conclusão do programa pelos docentes, o que indica que os professores acabam não levando os projetos adiante, tornando os efeitos do programa limitados ao público alvo escolhido.

Em se tratando dos custos que cada professor PDE gera durante o período de sua formação no programa, Hochuli (2011) analisou os valores totais aplicados nos anos de 2006 a 2010, rateando-os pelo total de professores participantes no Paraná. O resultado foi de, aproximadamente $\mathrm{R} \$ 30.000,00$, o que, segundo a autora, é quase o dobro do valor que o Ministério da Educação (MEC) informou que era gasto com um aluno de Instituições Federais de Ensino Superior, na faixa de $\mathrm{R} \$ 15.500,00$.

Para El Kadri et al. (2012), a partir do momento em que o PDE deixou de ser um programa de governo e passou para uma política de Estado, ele ganha um caráter mais forte e estruturado, e merece ser analisado de forma diferente, com mais criticidade. Silva e Ternus (2017) consideram que uma política de Estado como o PDE, após 10 anos de sua implementação, pode garantir sua continuidade ao longo dos anos, pois aponta uma potencialidade de melhorias no processo de ensino-aprendizagem, dinamizando e contribuindo com o desenvolvimento regional.

\section{METODOLOGIA}

Para se atender o objetivo deste estudo, utilizou-se uma abordagem descritiva de natureza qualitativa e procedimentos de execução classificados como documentais. A análise documental pautou-se nos registros institucionais de documentos oficiais do PDE disponibilizados pelo Ministério da Educação (MEC), acervo online do site Dia a Dia Educação, página dos cadernos PDE, Constituição Federal de 1988, Lei Complementar 103 de 15/03/2004, Decreto n. 4.482 de 14/03/2005, Lei Complementar 130 de 14 de julho de 2010. Sites institucionais estaduais da Casa Civil, Secretaria da Administração e da Previdência, Secretaria de Educação e federal do MEC.

Com as informações obtidas, realizou-se uma compreensão interpretativa dos textos (Análise Textual Discursiva), que possibilitaram realizar inferências válidas sobre as principais características que nortearam a implementação do PDE no Estado do Paraná.

\section{DISCUSSÃO E ANÁLISE DOS RESULTADOS}

PDE-PR foi instituído pela Lei Complementar 103 de 15/03/2004 - publicada no Diário Oficial do Estado sob n. 6.687 em 15/03/2004 -, cuja súmula dispõe sobre o Plano de Carreira do Professor da Rede Estadual de Educação Básica do Paraná; e implementado por Decreto n. 4.482 de 14/03/2005 - 


\section{Administração: caminhos para o desenvolvimento sustentável}

publicado no Diário Oficial do Estado sob n. 6.933 em 14/03/2005 e regulamentado pela Lei Complementar 130 de 14 de julho de 2010, publicada no Diário Oficial n. 8262 de 14 de julho de 2010. De acordo com a Lei Complementar 130, Art. 1‥, Parágrafo único

O PDE é um Programa de Capacitação Continuada implantado como uma política educacional de caráter permanente, que prevê o ingresso anual de professores da Rede Pública Estadual de Ensino para a participação em processo de formação continuada com duração de 2 (dois) anos, tendo como meta qualitativa a melhoria do processo de ensino e aprendizagem nas escolas públicas estaduais de Educação Básica. (p. 1)

O PDE é um Programa de responsabilidade da Secretaria de Estado da Educação (SEED), em parceria com a Secretaria de Estado da Ciência, Tecnologia e Ensino Superior (SETI), Escola de Música e Belas Artes do Paraná (EMBAP), Faculdade de Artes do Paraná (FAP), Faculdade Estadual de Ciências e Letras de Campo Mourão (FECILCAM), Faculdade Estadual de Educação, Ciências e Letras de Paranavaí (FAFIPA), Faculdade Estadual de Filosofia, Ciências e Letras de Paranaguá (FAFIPAR), Faculdade Estadual de Filosofia, Ciências e Letras de União da Vitória (FAFIUV), Universidade Estadual de Londrina (UEL), Universidade Estadual de Maringá (UEM), Universidade Estadual de Ponta Grossa (UEPG), Universidade Estadual do Centro-Oeste do Paraná (UNICENTRO), Universidade Estadual do Norte do Paraná (UENP), Universidade Estadual do Oeste do Paraná (UNIOESTE), Universidade Federal do Paraná (UFPR) e Universidade Tecnológica Federal do Paraná (UTFPR).

As cidades onde os cursos, palestras, seminários, e demais atividades inerentes aos Programa ocorrem, estão divididas em cinco polos: Curitiba, Guarapuava, Londrina, Maringá e Foz do Iguaçu (Silva, 2009).

Para dar condições a esses objetivos, a duração da capacitação é de dois anos. Os professores são afastados de $100 \%$ das atividades de docência no primeiro ano, e de $25 \%$ no segundo, para que possam implantar as atividades estabelecidas no projeto proposto. O primeiro ano de afastamento dos professores de suas atividades, acaba gerando custos diretos ao Estado, referentes a bolsa-auxílio para a estadia, locomoção e alimentação, valores estes custeados pela SEED/PR. Já o segundo, é dedicado ao desenvolvimento específico do material que será utilizado na implementação de um projeto, e o aprendizado em sala de aula, através do acompanhamento de professor orientador de cada uma das áreas específicas. 


\section{Administração: caminhos para o desenvolvimento sustentável}

A execução do Programa acompanha o Plano Integrado de Formação Continuada, o qual constitui-se de três grandes eixos de atividades, quais sejam: atividades de integração teórico-práticas, atividades de aprofundamento teórico e atividades didático pedagógicas com utilização de suporte tecnológico. No primeiro eixo, os docentes devem trabalhar o Projeto de Intervenção Pedagógica na Escola, a Produção Didático-Pedagógica, direcionada para a Implementação do Projeto na Escola e o Trabalho Final (de acordo com suas preferências individuais); tudo isso sob a supervisão direta da Orientação dos professores das Instituições de Ensino Superior (IES) parceiras. No segundo eixo, os professores PDE devem participar de cursos, seminários, encontros de área, eventos de inserção acadêmica e webconferências, nas Instituições de Ensino parceiras. No terceiro eixo, é realizado uma formação Tecnológica para o aprimoramento no uso de recursos tecnológicos para o desenvolvimento das atividades previstas no Programa, que são: acompanhamento do cronograma das atividades, postagem das produções realizadas e interação com o orientador no Sistema de Acompanhamento e Integração em Rede (SACIR); tutoria de um Grupo de Trabalho em Rede (GTR) que é realizado através do Ambiente Virtual de Aprendizagem da Secretaria de Estado da Educação (plataforma MOODLE) e uso de recursos de informática básica e internet (Lei Complementar no 130, 2010).

A atuação dos parceiros na execução dos eixos do Plano Integrado, pode ser observada na Figura 1. 


\section{Administração: caminhos para o desenvolvimento sustentável}

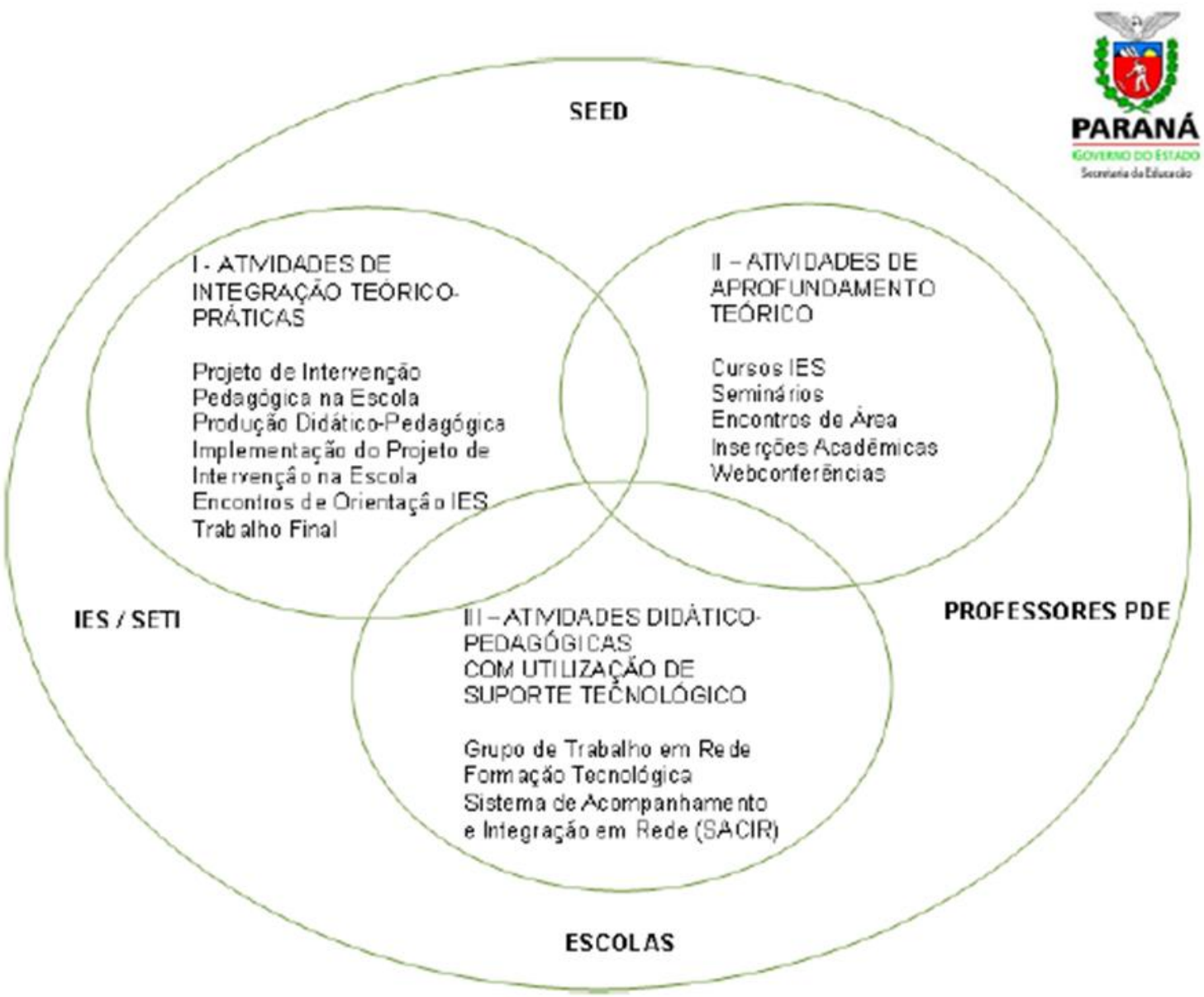

Figura 1 - Esquema do Plano Integrado de Formação Continuada PDE/PR

Fonte: Lei Complementar no 130, (2010)

Vale ressaltar que a organização deste Plano não pode ser considerada de forma estanque, já que se pressupõe que os conteúdos das atividades que compõe os eixos estejam articuladas, que as categorias que identificam cada um dos eixos estejam presentes em todas as atividades do Programa. Entretanto, é no terceiro semestre de do Programa que é aplicado o projeto (previsto no primeiro eixo), momento este em que o professor já retomou suas atividades docentes, e é afastado de apenas $25 \%$ de sua carga horária. No último semestre é produzido um artigo com os resultados obtidos, e com a utilização do embasamento teórico verificado no segundo período. Os professores fazem também uma apostila para distribuição aos demais colegas, sendo que esse valor é custeado com recursos próprios.

O gerenciamento e disponibilização de informações necessárias para a realização de cada atividade do professor PDE e dos diferentes envolvidos (Coordenação da SEED e da IES, Representante do PDE 


\section{Administração: caminhos para o desenvolvimento sustentável}

no NRE, além dos Professores Orientadores) é utilizado o SACIR. Assim, é possível acessar o histórico das atividades cumpridas, o material didático e projetos realizados.

O Programa possui 17 áreas de estudo ofertadas, sendo elas: arte, biologia, ciências, educação especial, educação física, educação profissional e formação de docentes, filosofia, física, geografia, gestão escolar, história, língua estrangeira moderna, língua portuguesa, matemática, pedagogia, química e sociologia. As áreas de gestão escolar e formação de docentes se destacam, por apresentarem linhas de estudo preocupadas com o desenvolvimento de ações que melhorem o desempenho dos docentes e gestores escolares. Essas linhas de estudo podem trazer novas perspectivas para a educação e para a gestão, pois abrem as portas para concepções de que há mudanças constantes na absorção de conhecimentos por parte dos discentes, havendo assim necessidade de se pensar formas de apresentar o conteúdo para os alunos.

Para o ingresso no PDE os professores devem estar, no mínimo, no nível ll classe 8 do Plano de Carreira do Professor da Rede Estadual de Educação Básica do Paraná (instituído pela lei complementar 103 de 2004). Esse critério foi definido Lei Complementar no 130 de 2010, que rege o PDE. Até a implementação da Lei, os critérios de seleção variaram para cada ano. Nos anos de 2007 e 2008 eram realizadas provas de cada área específica, onde o desempenho definia se o educador seria selecionado ou não.

Já em 2009, a proposta de intervenção na escola passou a ser o modelo avaliativo, logo, os projetos mais condizentes com as propostas pedagógicas do programa, e que apresentassem mais condições de melhorias locais, eram escolhidos. Para o ano de 2010, o currículo e/ou formação dos docentes se tornou o critério de seleção. Portanto, o tempo de docência, a ficha de estudos, especializações, possuir mestrado ou doutorado dava maiores chances de entrar para o programa. Como a Lei foi instituída em julho de 2010, a exigência de estar no nível II classe 8 ocorreu no processo seletivo para 2011, onde possuir mestrado (ou formação de nível acima) pontuava para ingresso.

Em 2018, a SEED e a SETI publicaram a Resolução no. 10.265 no Diário Oficial, onde ficou estabelecido o aproveitamento dos títulos stricto sensu (mestrado, doutorado ou pós-doutorado) para obtenção da certificação para o PDE. Para isso, a titulação não pode ter sido utilizada anteriormente para promoção ou progressão, e será considerado ainda o tempo de atuação na docência do Quadro Próprio do Magistério (QPM), na Educação Básica da Rede Pública Estadual ou em escolas conveniadas de Educação Básica na Modalidade Educação Especial (Resolução no. 10.265, 2018). 


\section{Administração: caminhos para o desenvolvimento sustentável}

Para cada Processo Seletivo Interno (PSI) foi publicado um edital para seleção dos professores, o qual teve as normas específicas. Ainda assim, os docentes deverão desenvolver um projeto de intervenção pedagógica, com os devidos procedimentos metodológicos. Tal qual os demais projetos já desenvolvidos até então, deve ter a Educação Básica como objeto de reflexão e investigação, pautada em uma problemática advinda da prática do professor, propondo intervenções para sua superação (Resolução no. 10.265, 2018).

O prazo para a conclusão do Programa, nessas condições, será de seis meses, e o professor deverá permanecer, no mínimo, 15 (quinze) meses em atuação na Rede Pública Estadual de Ensino ou em Escola Conveniada de Educação Básica na modalidade Educação Especial. O professor deverá desenvolver o projeto sem prejuízo às atividades laborais, sem ônus para o Estado e sem ampliação da carga horária Resolução no. 10.265, 2018). Assim sendo, o professor não gozará de período específico como os participantes em regime normal, e não serão custeados pelo Estado.

Com essa resolução, a lacuna que se apresentava até então, de que as titulações stricto sensu não tinham aproveitamento para crescimento para o Nível III do QPM, ganha um avanço, mesmo que os professores ainda precisem implementar uma intervenção nos moldes do PDE. De todo modo, os docentes não ficam condicionados a participar integralmente do programa para avançarem para o Nível III Classe I do QPM, tendo certa flexibilização nas promoções da carreira.

Desse modo, percebe-se que as instituições responsáveis necessitam estimular a continuidade de formação docente, em todas as modalidades, no intuito de proporcionar melhorias educacionais constantes. O documento síntese do PDE, publicado no ano de 2016, aponta a falta da relação teoriaprática dos programas instaurados tanto no Paraná quanto em outros estados brasileiros, como um dos geradores da ineficácia da formação dos educadores. As tentativas anteriores não consideravam modificações sofridas ao longo do tempo no processo educacional, e se tornavam homogêneas, ou seja, também acabavam não atendendo as necessidades específicas de cada região (SEED, 2016).

Percebe-se então, que o PDE veio com uma proposta de não ser superficial, buscando oferecer condições para os professores desenvolverem projetos de pesquisa em suas áreas de formação, que resultem em melhorias nas escolas onde lecionam. Isso visa gerar resultados mais perceptíveis no cotidiano pedagógico, e pode auxiliar no fechamento das lacunas específicas existentes em cada região.

O Grupo de Trabalho em Rede (GTR) proposto aos professores PDE também deve ser visto como um acréscimo, possibilitado pela proposta pedagógica desenvolvida. Consiste na construção, no terceiro 


\section{Administração: caminhos para o desenvolvimento sustentável}

período do programa, de grupos virtuais coordenados pelos professores PDE através dos sistemas da SEED, com cerca de vinte professores da rede de ensino cada, para a disseminação das ideias elaboradas durante o processo de estudo e da produção acadêmica. Além da interação com docentes de fora do programa, há a troca de ideias entre os que têm a mesma área de estudo e participam da capacitação, para que se utilizem tanto de embasamento teórico quanto de práticas de outras pesquisas, em suas produções.

Neste sentido, o PDE pode proporcionar condições aos docentes de se dedicarem ao estudo de novas metodologias de ensino, trocar informações com profissionais de outras regiões por meio de rede online e, capacitação, que resulta no desenvolvimento de um projeto de intervenção pedagógica na escola onde lecionam.

Entende-se que, não havendo um trabalho mais aprofundado que seja capaz de provocar a reflexão, a absorção plena das informações, e que traga mudanças reais para o processo de ensino, não há efetividade das ações, e os investimentos realizados pelo Governo não adquirem credibilidade. Além disso, pode-se dizer que o nível de intensidade e complexidade do Programa é alto, já que, além dos conteúdos teóricos aprendidos em sala, os professores têm que desenvolver um projeto de intervenção na escola que será aplicado no segundo ano, visando a prática dos estudos nos colégios.

Em 2018 foram publicados dados referentes aos 10 anos de implementação do PDE (2007-2016), disponíveis no site do Dia a Dia Educação. Além dos editais referentes a cada ano, resoluções específicas e documento síntese, foram disponibilizadas as relações entre professores ingressantes e concluintes, participantes dos GTR e publicações de artigos e produções didático-pedagógicas.

Em relação ao número de ingressantes (de acordo com o resultado de cada edital) e concluintes (certificados ao final do curso), os números demonstram que, dos 15.201 selecionados, receberam a certificação 12.800 professores (Secretaria de Estado da Educação do Paraná [SEED], \& Secretaria da Ciência, Tecnologia e Ensino Superior [SETI], 2018b). Essa diferença se deu em função do número de concluintes que iniciaram o programa em 2016 não estar disponível no relatório, portanto esses candidatos não estão inclusos nesta análise. Ainda hão de ser consideradas licenças, afastamentos, desistências e afins. Pode-se ponderar essa relação como positiva, tendo em vista que, dos 13.201 selecionados, quando desconsidera-se 2016, quase todos os que foram selecionados para a formação foram certificados. A Tabela 1 apresenta a relação entre ingressantes e concluintes. 


\section{Administração: caminhos para o desenvolvimento sustentável}

\begin{tabular}{l|l|l|l|l|l|l|l|l|l}
\hline SITUAÇÃO & \multicolumn{1}{|c|}{$\mathbf{2 0 0 7}$} & $\mathbf{2 0 0 8}$ & $\mathbf{2 0 0 9}$ & $\mathbf{2 0 1 0}$ & $\mathbf{2 0 1 2}$ & $\mathbf{2 0 1 3}$ & $\mathbf{2 0 1 4}$ & $\mathbf{2 0 1 6}$ & TOTAL \\
\hline Selecionados & 1.200 & 1.200 & 2.401 & 2.400 & 2.000 & 2.000 & 2.000 & 2.000 & 15.201 \\
\hline Certificados & 1.135 & 1.252 & 2.402 & 2.345 & 1.769 & 1.941 & 1.956 & 0 & 12.800 \\
\hline
\end{tabular}

Tabela 1 - Professores selecionados e concluintes 2007 a 2016

Fonte: SEED e SETI, 2018.

Para as produções dos participantes, seja a didático-pedagógica (intenção inicial de metodologia para implementação do projeto) ou para os artigos (produção científica elaborada ao final da capacitação), os dados revelam um total de 14.775 produções pedagógicas e 12.800 artigos publicados. Importante ressaltar que os 1.824 artigos apresentados em 2016 são uma previsão, portanto pode haver divergências dependendo do andamento dos projetos. A Tabela 2 apresenta os dados referentes às publicações.

\begin{tabular}{c|c|c|c}
\hline \multirow{2}{*}{ TURMA PDE } & PRODUÇÃO DIDÁTICO PEDAGOGICA & ARTIGO & TOTAL \\
\hline $\mathbf{2 0 0 7}$ & 1.151 & 1.135 & 2.286 \\
\hline $\mathbf{2 0 0 8}$ & 1.255 & 1.252 & 2.507 \\
\hline $\mathbf{2 0 0 9}$ & 2.407 & 2.402 & 4.809 \\
\hline $\mathbf{2 0 1 0}$ & 2.366 & 2.345 & 4.711 \\
\hline $\mathbf{2 0 1 2}$ & 1.804 & 1.769 & 3.573 \\
\hline $\mathbf{2 0 1 3}$ & 1.971 & 1.941 & 3.912 \\
\hline $\mathbf{2 0 1 4}$ & 1.994 & 1.956 & 3.950 \\
\hline $\mathbf{2 0 1 6}$ & 1.827 & $1.824 *$ & 3.651 \\
\hline Total & $\mathbf{1 4 . 7 7 5}$ & $\mathbf{1 4 . 6 2 4}$ & $\mathbf{2 9 . 3 9 9}$ \\
\hline
\end{tabular}

Tabela 2 - Produções dos professores participantes 2007 a 2016

Fonte: SEED e SETI, 2018.

* Quantidade de publicações previstas até a data de publicação do relatório.

Pode-se notar que há uma divergência entre os valores das Tabelas 1 e 2, no que tange ao número de professores que participaram da formação. Na Tabela 1 há 15.201 docentes selecionados, enquanto que na Tabela 2 há 14.775 produções relacionadas ao ingresso no PDE. Isso se justifica pelo fato de que, mesmo sendo selecionados, os professores podem não ter iniciado a formação em si, deixando de constar no número de publicações. Logo, conclui-se que $97 \%$ dos profissionais selecionados pelos editais iniciaram a formação, e destes, 99\% produziram os artigos obrigatórios para a conclusão.

Em relação aos dados disponíveis relacionados aos participantes dos Grupos de Trabalho em Rede (GTR), apresentam certo contraste se comparados aos participantes diretos da formação, devido ao percentual de ingressantes e concluintes. A Tabela 3 demonstra que $69 \%$ dos participantes dos GTRs 


\section{Administração: caminhos para o desenvolvimento sustentável}

acompanharam a interação a distância até a conclusão da intervenção. Entende-se isso como um ponto negativo para a formação desses professores, que deixam de aproveitar a oportunidade de contribuir com a implementação dos projetos nas suas localidades e, também, deixam de dar feedback sobre os resultados obtidos.

\begin{tabular}{c|c|c|c|c}
\hline TURMA PDE & GTR & $\begin{array}{c}\text { INSCRITOS DA } \\
\text { REDE }\end{array}$ & CONCLUINTES DA REDE & $\begin{array}{c}\text { \% DE } \\
\text { CONCLUINTES }\end{array}$ \\
\hline $\mathbf{2 0 0 7}$ & 1.051 & 22.706 & 8.915 & 39 \\
\hline $\mathbf{2 0 0 8}$ & 1.200 & 18.783 & 10.367 & 55 \\
\hline $\mathbf{2 0 0 9}$ & 2.401 & 30.056 & 17.377 & 58 \\
\hline $\mathbf{2 0 1 0}$ & 2.354 & 29.554 & 24.123 & 82 \\
\hline $\mathbf{2 0 1 2}$ & 1.773 & 26.611 & 22.688 & 81 \\
\hline $\mathbf{2 0 1 3}$ & 1.953 & 32.346 & 26.258 & 67 \\
\hline $\mathbf{2 0 1 4}$ & 1.951 & 34.286 & 23.049 & 72 \\
\hline $\mathbf{2 0 1 6}$ & 1.825 & 28.965 & 20.883 & 69 \\
\hline Total & 14.508 & 223.307 & 153.660 & \\
\hline
\end{tabular}

Tabela 3 - Produções dos professores participantes 2007 a 2016

Fonte: SEED e SETI, 2018.

Destaca-se que não houve turma de professores no PDE em 2015. De acordo a APP Sindicato, isso aconteceu devido a atrasos no pagamento das bolsas para os participantes de 2014, além da falta de repasse de valores para as IES parceiras. Para agravar o processo, em 2015 houveram greves dos professores, tanto estaduais quanto nas Universidades Federais, o que também prejudicou o início das atividades.

Percebe-se, portanto, que os professores que participam dos processos seletivos possuem real interesse em realizar a formação, a partir dos números apresentados. Quando analisada a relação entre professores certificados ao longo de 10 anos, e o total de 58.610 professores que fazem parte do QPM (tomando como referência o mês de junho de 2019), têm-se que foram certificados cerca de $25 \%$ dos profissionais.

Os Grupos de Trabalho em Rede, que constituem uma alternativa de trabalho conjunto, apresentam números mais baixos em relação à participação efetiva dos professores, tendo em vista que cerca de $31 \%$ dos que se dispõem a iniciar os trabalhos acabam não concluindo. Porém isso não afeta de forma direta a implementação dos projetos, apesar de limitar a sua disseminação para outras localidades. Além disso, o trabalho em rede não contribui diretamente para ampliação do número de concluintes. 


\section{Administração: caminhos para o desenvolvimento sustentável}

\section{CONSIDERAÇÕES FINAIS}

Entendendo a necessidade de a gestão pública elaborar políticas capazes de solucionar ou minimizar problemas na formação dos docentes e na forma como os repasses dos conhecimentos aos discentes são efetivados no meio educacional, o presente estudo buscou evidenciar características da implementação do PDE no Estado do Paraná de 2007 a 2016.

O programa apresenta-se como uma possibilidade para o desenvolvimento de ações diretas nas escolas, por parte dos próprios professores, que desenvolvem projetos de intervenção em suas disciplinas. Dessa forma, os docentes são colocados como protagonistas das mudanças educacionais, e recebem suporte por parte do Estado para concluírem a capacitação. Com isso, espera-se que as ações propostas pelo programa sejam continuadas independente de questões partidárias, mas sim como uma política de Estado efetiva.

Os dados apresentados na análise do período 2007 a 2016 trazem uma perspectiva positiva para as participações dos docentes, levando a entender que há interesse em participar da capacitação. A possibilidade de aproveitamento dos títulos stricto sensu também são tomadas como avanços, levando os professores a continuar buscando formar-se continuamente e trazer conteúdos e metodologias atualizadas aos alunos.

Aponta-se como limitações do programa a falta de continuidade das ações, citada por pesquisadores, que deve ser tratada para que os docentes levem a diante as ações e que os recursos públicos investidos possam trazer resultados efetivos para o longo prazo. Ainda, entende-se que o programa poderia ser aberto para outras faixas do plano de carreira, não limitando apenas aos docentes que já estão há vários anos, mas pensar uma forma de flexibilizar a entrada para profissionais em início de carreira.

Como sugestões para trabalhos futuros coloca-se a verificação da percepção dos diretores de escolas e/ou professores participantes, sobre o que mudou em relação a forma de ensino após a conclusão da capacitação. Ou ainda, acompanhar a evolução do desempenho acadêmico dos alunos das escolas que participam do programa, buscando analisar se escolas com mais professores participantes por aluno tem desempenho melhor.

\section{REFERÊNCIAS}

Constituição da República Federativa do Brasil de 1988. Recuperado de http://www.planalto.gov.br/ccivil_03/Constituicao/Constituicao.htm 


\section{Administração: caminhos para o desenvolvimento sustentável}

Dalfior, E. T., Lima, R. C. D., \& Andrade, M. A. C. (2015, março). Reflexões sobre análise de implementação de políticas de saúde. Saúde em Debate, 39(104), 210-225. Recuperado de http://www.redalyc.org/pdf/4063/406341749019.pdf

Decreto no 4482, de 14 de março de 2005. Implantado O Programa de Desenvolvimento Educacional - PDE, Que Disciplina A Promoção e Progressão do Professor no Nível III da Carreira. Recuperado de http://www.leisestaduais.com.br/pr/decreto-n-4482-2005-parana-implantado-o-programa-dedesenvolvimento-educacional-pde-que-disciplina-a-promocao-e-progressao-do-professor-no-niveliii-da-carreira

Duarte, L. F., \& Viriato, E. O. (2012, maio). Programa de desenvolvimento educacional no Paraná: questões históricas, políticas e pedagógicas. Seminário de Pesquisa do Programa de Pós-Graduação em Educação. Maringá, Paraná, Brasil, 11. Recuperado

de http://www.ppe.uem.br/publicacoes/seminario_ppe_2012/trabalhos/co_01/024.pdf

El Kadri, M. S., Campos, A. G., \& Souza, A. G. F. (2012, dezembro). Modelo de formação continuada do PDE-PR: o diálogo necessário entre escola básica e ensino superior? Entretextos, 11(2), 121-141. Recuperado de http://www.uel.br/revistas/uel/index.php/entretextos/article/view/8652.

doi: 10.5433/1519-5392.2011v11n2p

Frey, K. (2009, junho). Políticas públicas: um debate conceitual e reflexões referentes à prática da análise de políticas públicas no Brasil. Planejamento e políticas públicas, 21(158), 211-259. Recuperado de http://www.ipea.gov.br/ppp/index.php/PPP/article/viewFile/89/158

Hochuli, E. B. (2011). PDE - Programa de desenvolvimento educacional do Paraná (Especialização em Políticas e Gestão da Educação). Universidade Federal do Paraná, Curitiba, Paraná, Brasil. Recuperado dehttps://acervodigital.ufpr.br/bitstream/handle/1884/35194/HOCHULI,\%20ELISANGELA\%20BELNIA KI.pdf?sequence $=1 \&$ isAllowed $=y$

Lei Complementar no 130 de 14 de julho de 2010. Regulamenta o Programa de Desenvolvimento Educacional - PDE, instituído pela Lei Complementar no 103/2004, que tem como objetivo oferecer Formação Continuada para o Professor da Rede Pública de Ensino do Paraná. Recuperado de http://www.legislacao.pr.gov.br/legislacao/pesquisarAto.do?action=exibir\&codAto=5

Lei n. 9.394, de 23 de dezembro de 1996. Estabelece as diretrizes e bases da educação nacional. Recuperado de http://www.planalto.gov.br/ccivil_03/leis/L9394.htm

Lei no 103, de 15 de março de 2004. Institui e Dispõe sobre O Plano de Carreira do Professor da Rede Estadual de Educação Básica do Paraná e Adota Outras Providências. Disponível em http://www.legislacao.pr.gov.br/legislacao/pesquisarAto.do?action=exibir\&codAto=7470\&indice=1 \&totalRegistros $=1$

Lei № 13.005, de 25 de junho de 2014. Aprova o Plano Nacional de Educação - PNE e dá outras providências. Recuperado

de http://www.planalto.gov.br/ccivil_03/_ato2011-2014/2014/lei/l13005.htm 


\section{Administração: caminhos para o desenvolvimento sustentável}

Oliveira, D. A. As políticas educacionais no governo Lula: rupturas e permanências. (2009, agosto). Revista Brasileira de Política e Administração da Educação, 25(2), 197-209. Recuperado de http://www.seer.ufrgs.br/rbpae/article/view/19491. doi: 10.21573/vol25n22009.19491

Plano diretor da reforma do aparelho do Estado. Recuperado

de http://www.bresserpereira.org.br/documents/mare/planodiretor/planodiretor.pdf.

Resolução no 10265, de 31 de agosto de 2018. Normatiza a oferta do Programa de Desenvolvimento Educacional -PDE na Rede Pública Estadual de Ensino, no âmbito das Secretarias de Estado da Educação e da Ciência, Tecnologia e Ensino Superior, para aproveitamento de titulação obtida em cursos stricto sensu de professores do Quadro Próprio do Magistério. Recuperado de https://www.legislacao.pr.gov.br/legislacao/listarAtosAno.do?action=exibirlmpressao\&codAto=205

Rua, M. G. (2009). Políticas públicas. Florianópolis: Departamento de Ciências da Administração / UFSC. Recuperado

de<http://s3.amazonaws.com/academia.edu.documents/36102140/Apostila_GP_-

_Politicas_Publicas.pdf?AWSAccessKeyld=AKIAIWOWYYGZ2Y53UL3A\&Expires=1497933728\&Signatu

re=W6xwBx9HC\%2B59HAa3Vw0IZOPZ3t8\%3D\&response-content

disposition=inline\%3B\%20filename\%3DPOLITICAS_PUBLICAS.pdf

Secretaria de Estado da Educação do Paraná - SEED. (2016). Documento Síntese PDE. Recuperado de http://www.gestaoescolar.diaadia.pr.gov.br/arquivos/File/pde_roteiros/2016/documento_sintese_p de_2016.pdf

Secretaria de Estado da Educação do Paraná - SEED, \& Secretaria da Ciência, Tecnologia e Ensino Superior - SETI. (2018). Dados Estatísticos - PDE 10 anos. Recuperado de http://www.gestaoescolar.diaadia.pr.gov.br/modules/conteudo/conteudo.php?conteudo=1811

Silva, O. H. M. (2009, outubro). O Programa de Desenvolvimento Educacional do Paraná-PDE/PR. Congresso nacional de educação-EDUCERE. Curitiba, Paraná, Brasil, 9. Recuperado de http://www.pucpr.br/eventos/educere/educere2009/anais/pdf/2423_1687.pdf

Silva, P. L. B, \& MELO, M. A. B. (2000, maio). O processo de implementação de políticas públicas no Brasil: características e determinantes da avaliação de programas e projetos. NEEP-UNICAMP. Recuperado de https://governancaegestao.files.wordpress.com/2008/05/teresa-aula_22.pdf

Silva, R. R., \& Carvalheiro, E. M. (2018, outubro). A inovação na educação (metodologias ativas) dos projetos dos professores do Programa de Desenvolvimento Educacional do Paraná no Núcleo Regional da Educação de Pato Branco-PR. Congresso nacional de pesquisa em ciências sociais aplicadas. Francisco Beltrão, Paraná, Brasil, 7. Recuperado de http://www.unioeste.br/eventos/conape

Silva, R. R., \& Ternus, C. H. (2017, outubro). Gestão pública: O caso do Programa de Desenvolvimento Educacional do Paraná. Congresso nacional de pesquisa em ciências sociais aplicadas. Francisco Beltrão, Paraná, Brasil, 6. Recuperado de http://www.unioeste.br/eventos/conape 


\section{Administração: caminhos para o desenvolvimento sustentável}

Souza, C. (2006, dezembro) Políticas Públicas: uma revisão da literatura. Sociologias, 16(8), 20-45. Recuperado de http://www.scielo.br/pdf/soc/n16/a03n16 


\section{Capítulo 14}

\section{QUALIDADE DE VIDA DO TRABALHO DOCENTE: UM ESTUDO DE CASO COM OS DOCENTES DE UMA ESCOLA MUNICIPAL}

DOI: $10.37423 / 200300390$

Denise Fabiane Caobianco (UEM) denisecaobianco@hotmail.com

Deisy Cristina Corrêa Igarashi (UEM) deisyigarashi@gmail.com

Wagner Igarashi (UEM) wigarash@gmail.com

José Braz Hercos dúnior (UEM) jbhjunior@uem.br

Resum6: A escola donstitui um importante ambiente na cơnfiguração da realidade de vida do professor e dos áspectos relacionados às condições é organização do trabalho docente, os quais se repercutem sobre os processos de saúde/doença. Q objetivo do presente artigo é anališrar-aqualidade de vida do trabal ho em umá instituiçấo escolar e identifiear quais ações podem ser tomądas para minimizar suas consequências aos docentes. A metodologia utilizada foi uma pesquisa de caráter exploratório e descritivo, com a aplicação de questionários com perguntas fechadas. Como resultados, ostudo evidencia que, das 44 questões em análise, 15 geram impacto direto na qualidade de QVT. Além disso, no caso da escola em estudo, algumas ações poderiam ser tomada's para melhorar a QVT, tais como: cursos, palestras, campanhas de divulgą̧̧ão e conscientização.

Palavras chave: Qualidade de vida, Trabạlho doccente, Instituição escolar

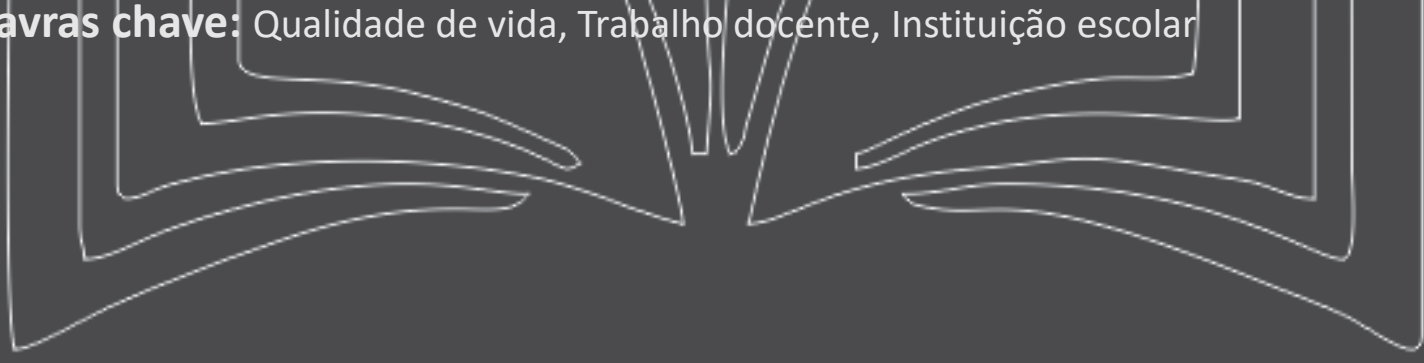




\section{Administração: caminhos para o desenvolvimento sustentável}

\section{INTRODUÇÃO}

Estudos realizados evidenciam que o relacionamento humano e a motivação são elementos essenciais presentes tanto nas organizações, como nas escolas, e agem no ambiente influenciando as pessoas (CODO, 1999; FERNANDES, 1996). Tal influência aumenta conforme aumenta o número de pessoas envolvidas na relação de trabalho.

Neste caso, em se tratando de professores, há diversos fatores envolvidos. Dentre eles se podem mencionar as interações sociais, tais como: de sala de aula; com os demais professores; com pais de alunos; e com as instâncias da própria instituição (níveis hierárquicos). Frente ao exposto, os professores, devido ao número de pessoas com as quais interagem, podem apresentar sinais de cansaço: dores musculares, problemas com voz, depressão e sintomas afins.

Observa-se que a qualidade de vida no trabalho depende de vários fatores, tais como: saúde física e mental, psicológica e social. Garcia (2011) considera que determinadas profissões, por requererem maior esforço físico, ou mental, e por serem realizadas em ambientes de pressão e tensão, produzem efeitos negativos para as pessoas (funcionários). Estes, por sua vez, sofrem estas ações e geram perdas para a instituição e, para a sociedade, em termos da qualidade dos serviços prestados. Em decorrência disso, muitas instituições investem na qualidade de vida no ambiente de trabalho.

Como a docência é uma atividade profissional essencial para o desenvolvimento da sociedade. É importante que o ambiente escolar ofereça condições adequadas ao desenvolvimento eficaz das atividades pedagógicas. Ressalta-se que fatores ambientais como: barulho, temperatura e iluminação podem ser decisivos para a consolidação de um ambiente não favorável a saúde do educador e ao rendimento das atividades de ensino-aprendizagem (MINAYO; HARTZ; BUSS, 2000).

Além disso, em se tratando de professores vinculados ao sistema público de ensino, a falta de qualidade de vida no trabalho pode representar encargos dispendiosos aos cofres públicos, pois em muitos casos os professores são afastados por problemas de saúde. A partir do exposto, justifica-se a escolha deste tema em função de ter-se ampliado as discussões referentes à qualidade de vida no trabalho, de maneira a se conceber um ambiente mais saudável ao professor, pois tal ambiente pode impactar em seu desempenho e em sua qualidade de vida.

Sendo assim, este estudo busca responder ao seguinte questionamento: Quais ações podem ser tomadas para minimizar os reflexos em decorrência da qualidade de vida no trabalho educativo dos docentes? Delineado o problema de pesquisa, foi possível estruturar o objetivo do estudo: analisar a 


\section{Administração: caminhos para o desenvolvimento sustentável}

qualidade de vida do trabalho em uma instituição escolar e identificar quais ações podem ser tomadas para minimizar suas consequências aos docentes.

Este estudo foi estruturado em mais 5 seções além da introdutória, a saber: a seção 2, de revisão teórica, apresenta os elementos teóricos que sustentam o desenvolvimento do estudo; a seção 3, de metodologia, enfoca os procedimentos metodológicos utilizados; a seção 4, de análise dos dados, apresenta os elementos observados e a correção teórica/empírica do estudo; a seção 5, de considerações finais, contempla os resultados do estudo, pontua o modo como o problema de pesquisa e o objetivo do estudo foram atendidos e apresenta recomendações para trabalhos futuros; por fim, a seção de referências contempla as fontes utilizadas para desenvolvimento da pesquisa.

\section{QUALIDADE DE VIDA NO TRABALHO}

A preocupação com a organização racional do trabalho está presente nas organizações desde o começo do século passado, porém, a atenção dada ao bem-estar físico e emocional dos trabalhadores é mais recente. Fernandes (1996, p. 17) observa que:

O termo "Qualidade de Vida no Trabalho" foi utilizado pela primeira vez por Eric Trist e outros pesquisadores do Tavistock Institute, em 1950. Eles desenvolveram uma abordagem sócio-técnica da organização do trabalho, agrupando o indivíduo, o trabalho e a organização, com base na análise e na reestruturação da tarefa, buscando melhorar a produtividade, reduzir os conflitos e tornar a vida dos trabalhadores menos penosa.

Entretanto, sabe-se que nem toda a insatisfação do empregado pode ser resolvida pela reformulação do cargo, pois a Qualidade de Vida no Trabalho (QVT) também é afetada por outros fatores, como: a supervisão, as condições de trabalho e a remuneração. (MARQUES, BORGEZ, ADORNO, 2008)

Um dos aspectos mais problemáticos dos programas de QVT é, justamente, relacionar os fatores que influenciam na qualidade de vida dos indivíduos em situação de trabalho, pois estes dependem das características da organização, do ambiente em que ela está inserida, da época em que o programa será desenvolvido e de sua amplitude. (BOWDITCH; BUONO,1992; FERNANDES, 1996; LIBÂNEO; 2006)

Devido aos inúmeros elementos vinculados a QVT, diversos trabalhos foram desenvolvidos sob óticas e enfoques distintos, e tais estudos resultam em ampla possibilidade de conceitos, vinculado ao tema, conforme quadro 1. 


\begin{tabular}{|c|c|}
\hline Autor & Conceito \\
\hline $\begin{array}{l}\text { Walton } \\
\text { (1973) }\end{array}$ & $\begin{array}{l}\text { Conceito de QVT envolve legislação trabalhista, segurança no trabalho, } \\
\text { oportunidades iguais de emprego, planos de enriquecimento de cargos e a relação } \\
\text { positiva, proposta por psicólogos, entre moral e produtividade }\end{array}$ \\
\hline $\begin{array}{c}\text { Dejours } \\
(1994, \text { p. } 29)\end{array}$ & $\begin{array}{l}\text { "O trabalhador não chega ao seu local de trabalho como uma folha em branco. Ele possui } \\
\text { uma história pessoal, que se caracteriza por certa qualidade de aspirações de seus desejos, } \\
\text { de suas motivações, de suas necessidades psicológicas, que integram sua história } \\
\text { passada". }\end{array}$ \\
\hline $\begin{array}{l}\text { Fernandes } \\
(1996, \text { p. 46) }\end{array}$ & $\begin{array}{l}\text { "Necessidades e aspirações humanas, tais como desejo por um empregador socialmente } \\
\text { responsável. Afirma, ainda, que faz parte da QVT a preocupação com valores } \\
\text { humanísticos e ambientais, esquecidos pela sociedade industrializada em favor de } \\
\text { inovações tecnológicas, produtividade e crescimento econômico". }\end{array}$ \\
\hline $\begin{array}{c}\text { Lipp } \\
(2002, \text { p. 32) }\end{array}$ & $\begin{array}{l}\text { Vista como um indicador da qualidade da experiência humana no ambiente de trabalho. } \\
\text { Trata-se de um conceito estreitamente relacionado à satisfação dos trabalhadores quanto a } \\
\text { sua capacidade produtiva em um ambiente de trabalho seguro, de respeito mútuo, com } \\
\text { oportunidades de treinamento e aprendizagem e com o equipamento e facilidades } \\
\text { adequadas para o desempenho de suas funções. }\end{array}$ \\
\hline $\begin{array}{c}\text { César } \\
(2001, \text { p. 24) }\end{array}$ & $\begin{array}{l}\text { Consideram que para a QVT atingir seus objetivos é preciso "estar atento a um conjunto } \\
\text { de expectativas por parte dos trabalhadores e que abrange vários aspectos ligados ao } \\
\text { indivíduo, sejam físicos, psicológicos ou sociais" }\end{array}$ \\
\hline $\begin{array}{l}\text { Borges e Marques } \\
\quad(2006, \text { p. 6) }\end{array}$ & $\begin{array}{l}\text { "A qualidade de vida no trabalho [...] possui sua importância bastante reconhecida há } \\
\text { várias décadas. Seu grande objetivo é melhorar o bem estar do trabalhador, aliado à } \\
\text { melhoria do desempenho organizacional. [...] A QVT pode ser vista como um indicador } \\
\text { de qualidade da experiência humana no ambiente de trabalho. Trata-se de um conceito } \\
\text { estreitamente relacionado à satisfação dos trabalhadores quanto à sua capacidade } \\
\text { produtiva em um ambiente de trabalho seguro, de respeito mútuo, com oportunidades } \\
\text { de treinamento e aprendizagem e, com o equipamento e facilidades adequadas para o } \\
\text { desempenho de suas funções }\end{array}$ \\
\hline
\end{tabular}

Quadro 1: Conceitos vinculados ao tema QVT

Como se observa no quadro 1, a qualidade de vida no trabalho interfere não somente no trabalho em

si. Ela tem implicações no campo familiar e social dos indivíduos, e vice-versa. Por isso, a busca constante por um ambiente humanizado é uma entre as tantas atribuições da QVT. A idéia básica consiste em aproveitar as habilidades mais refinadas dos trabalhadores, buscando um ajustamento entre tecnologia, tarefas e o bem-estar no desempenho das tarefas. Destaca-se que o quadro 1 evidencia que a QVT não se limita a prevenir acidentes de trabalho, uma vez que ela abrange todas as esferas da organização.

\subsection{QUALIDADE DE VIDA NO TRABALHO DOCENTE}

A atividade de professor é uma das profissões mais estressantes na atualidade (LIBÂNEO, 2006). Geralmente, as jornadas de trabalho dos professores são longas, com raras pausas de descanso e/ou refeições breves e em lugares desconfortáveis. O ritmo de trabalho é intenso e variável, com turno de trabalho iniciando muito cedo que pode se estender até a noite, em função de dupla ou tripla jornada de trabalho. Além disso, Libâneo (2006) observa que os docentes não têm horários respeitados; devido à rotina acelerada, perdem-se horas de sono, alimenta-se mal, e não há, ou há tempo insuficiente para o lazer. 


\section{Administração: caminhos para o desenvolvimento sustentável}

Lipp (2002, p 56) pontua que "o professor possui uma grande demanda de trabalho pedagógico a cumprir, o que acaba por sobrecarregá-lo, e estas situações especiais que tem que lidar, funciona como um ativador da quarta fase do estresse, que é a quase de exaustão". Observa-se, ainda, que o trabalho do professor não se limita as salas de aulas (lecionar e lidar com seus alunos). Há situações fora das salas de aula, como: esclarecimento de dúvidas dos alunos; questões pessoais de alunos que procuram o professor, por encontrarem neste mais segurança e compreensão, ao falarem de seus problemas; reuniões de pais e mestres; problemas com drogas na escola; gravidez precoce de alunas adolescentes; hostilidade e competição entre os professores (MACEDO, 2005).

Por interagir com todos estes problemas, o professor está sujeito ao estresse, o qual em certos momentos pode se manifestar de formas diferentes, de acordo com a estrutura psicológica e orgânica de cada um.

De acordo com Lipp (2002), ao se instalar, o estresse vai aumentando paulatinamente, e o professor, mesmo sem perceber, fica desmotivado, passa a perder a paciência com facilidade, não consegue desenvolver seu trabalho como deveria, não percebe significado no que faz, há casos em que ele falta constantemente ao trabalho, chora sem motivo, não se relaciona bem com os colegas e alunos e sentese fisicamente exausto.

Ou seja, vai se instalando o cansaço, o desânimo, o que gera um desgaste profissional. Tal quadro é denominado "Síndrome de Burnout" (VAQUEZ-MENEZES, 2002, p. 201). Esta síndrome atua como uma reação à tensão emocional crônica gerada a partir do contato direto e excessivo com outros seres humano vinculado a situações de trabalho, com um nível de estresse grande e permanente.

Por isso, a categoria de professores é apontada como uma das mais propensas ao estresse e burnout. O nome vem da expressão em inglês to burn out, ou seja, queimar completamente, consumir-se (VAQUEZ-MENEZES; 2002). O termo burnout é usado para definir um esgotamento físico e mental crônico causado pelo trabalho. Trata-se de um estresse ocupacional, caracterizado por exaustão emocional, apatia extrema, desinteresse pelo trabalho e lazer, depressão, alterações de memória e humor, fadiga, enxaqueca, dores musculares e distúrbios do sono (VAQUEZ-MENEZES; 2002).

Atualmente, a Síndrome de burnout é fundamentada na perspectiva sócio-psicológica e definida em três dimensões: exaustão emocional, despersonalização e baixa realização pessoal no trabalho. Exaustão emocional é caracterizada por uma falta ou carência de entusiasmo, de um sentimento de 


\section{Administração: caminhos para o desenvolvimento sustentável}

esgotamento de recursos; despersonalização caracteriza-se por tratar os clientes, colegas e a organização como objetos; e diminuição da realização pessoal no trabalho, tendência do trabalhador de se auto-avaliar de forma negativa. (VASQUEZ-MENEZES, 2002).

A enfermidade acomete principalmente profissionais que lidam com pessoas e, nesta categoria, estão incluídos os professores, expostos as situações de pressão, jornadas exaustivas, responsabilidade e frustração (VAQUEZ-MENEZES;2002). O burnout no docente se caracterizaria por uma exaustão dos recursos emocionais próprios, em que são comuns atitudes negativas e de distanciamento para com os alunos e a valorização negativa de seu papel profissional. Objetivamente manifesta-se conforme quadro 2.

Schaufeli e Enzmann (1998) observam que em muitos casos os professores, desgastados profissionalmente, sentem se insatisfeitos com seu trabalho, o que os leva a revelar sentimentos de ineficácia no desenvolvimento de suas atividades.

\begin{tabular}{|c|l|}
\hline Exaustão emocional & $\begin{array}{l}\text { Os professores, depois de uma interação intensiva com os alunos, denotam desgaste } \\
\text { de suas energias emocionais e advertem que não podem trabalhar com a mesma } \\
\text { dedicação e energia que apresentavam no princípio de suas carreiras. Esta dimensão } \\
\text { manifesta-se através do esgotamento de recursos emocionais próprios; o docente sente } \\
\text { que não pode dar mais de si mesmo em nível emocional }\end{array}$ \\
\hline Despersonalização & $\begin{array}{l}\text { Manifesta-se através de atitudes negativas como o tratamento depreciativo, atitudes } \\
\text { frias e distantes e/ou desconexão dos problemas dos estudantes. Esta dimensão pode } \\
\text { entender-se como um modo de enfrentamento à exaustão emocional que experimenta } \\
\text { o professor }\end{array}$ \\
\hline $\begin{array}{c}\text { Falta de realização } \\
\text { pessoal no trabalho: }\end{array}$ & Produz-se uma valoração negativa do próprio papel profissional \\
\hline
\end{tabular}

Fonte: Schaufeli e Enzmann (1998):

\section{Quadro 2: Sintomas de burnout}

Cabe mencionar que não há um consenso sobre a definição da síndrome, mas ela se refere a um processo de resposta ao stress crônico no trabalho. Ou seja, não é o próprio stress, mas, a forma de reação a ele com atitudes de desistência e alienação durante o exercício das atividades profissionais e frente às responsabilidades do cargo ou da função. Tais ações expressam um quadro de condutas negativas com relação ao usuário ou clientes e à organização do trabalho, que acarretam problemas de ordem prática e emocional ao trabalhador e ao local, afastamento ou rompimento com os compromissos e as responsabilidades da profissão.

Além dos elementos pontuados no quadro 3, são apresentadas outras questões que podem impactar na QVT. 


\begin{tabular}{|c|l|}
\hline $\begin{array}{c}\text { Codo } \\
(1999)\end{array}$ & $\begin{array}{l}\text { - Estresse do professor também pode ser determinado pelas más condições físicas do trabalho } \\
\text { - Em relação à saúde, os professores são mais suscetíveis a ter problemas de voz, por esta ser seu } \\
\text { principal instrumento de trabalho }\end{array}$ \\
\hline & $\begin{array}{l}\text { - Outros problemas ligados à prática docente são os problemas de postura, fadiga mental, alimentação } \\
\text { inadequada que oferecem riscos de desencadear uma diminuição no sistema imunológico, ocasionando } \\
\text { doenças de diversas naturezas }\end{array}$ \\
$\begin{array}{l}\text { Lemos } \\
(2005)\end{array}$ & $\begin{array}{l}\text { O professor brasileiro é cercado de um arsenal de burocracias, como: diários, planos de aula, fichas } \\
\text { leva para casa, tais como: plano de aula, elaboração de atividades, provas, trabalhos, correções, testes, } \\
\text { projetos etc. }\end{array}$ \\
$\begin{array}{l}\text { - O professor tem que enfrentar o problema da indisciplina escolar difundida na maioria das escolas } \\
\text { brasileiras, como o excesso de conversa, a bagunça, o uso indevido de aparelhos eletrônicos que } \\
\text { invadiram as escolas }\end{array}$ \\
\hline
\end{tabular}

Quadro 3: Situações cotidianas no contexto docente que pode gerar QVT

Os itens apresentados no quadro 3 contribuem para que o professor sinta-se desvalorizado pela instituição quanto à sua boa saúde, causando stress e, conseqüentemente, contribuindo para a baixa qualidade de vida. Estes aspectos, de forma isolada, não possuem grande peso. Entretanto, fazem parte de um conjunto de outros fatores que impactam no respeito ao profissional. Para minimizar tais ações, verifica-se alguns cuidados que devem ser colocados em prática para melhorar a qualidade de vida do professor e de seu ofício, conforme quadro 4.

\begin{tabular}{|c|l|}
\hline $\begin{array}{c}\text { Ribas e } \\
\text { Carvalho } \\
(1999)\end{array}$ & $\begin{array}{l}\text { Os gestores dos ambientes educativos poderiam estar atentos a oferecer situações motivadoras aos } \\
\text { seus educadores no contexto de trabalho, que oportunizem a realização de um trabalho desafiante, } \\
\text { o reconhecimento do desempenho, crescimento e desenvolvimento profissional e } \\
\text { consequentemente pessoal. }\end{array}$ \\
\hline $\begin{array}{c}\text { CURY, } \\
(2004)\end{array}$ & $\begin{array}{l}\text { Qualidade de vida, pressupõem-se cuidados com a saúde mental e física. Portanto, faz-se necessário } \\
\text { que o professor possa iniciar um trabalho consigo mesmo, resgatando sua história, seus medos, suas } \\
\text { frustrações, e podendo descobrir na profissão o desejo de viver feliz, com alegria e satisfação. }\end{array}$ \\
\hline $\begin{array}{c}\text { JARDIM } \\
\text { (2006) }\end{array}$ & $\begin{array}{l}\text { Ingerir várias vezes água durante a aula, ter cuidado com o pó do giz, evitar alimentos pesados nos } \\
\text { períodos de trabalho, ao despertar realizar alongamentos para relaxar, no banho deixar a água incidir } \\
\text { sobre os ombros para amenizar as tensões, exercícios de aquecimento para as cordas vocais. }\end{array}$ \\
\hline & $\begin{array}{l}\text { Organização do tempo: organizá-lo em torno de suas prioridades. } \\
\text { Exercícios físicos: praticar de cinco minutos a duas horas de exercício, seja na academia ou simples } \\
\text { alongamentos. }\end{array}$ \\
Beber água: ativar termostato e quebrar gordura. \\
GARCIA \\
(2011) \\
Arrumar a postura: má postura desencadeia várias doenças, desde as mais conhecidas, como cifose, \\
lordose e escoliose, até bronquite e pneumonia. \\
Qualidade de tempo: fazer o que gosta, se dedique a um hobby. \\
Sono: necessário para reorganizar tudo o que foi desorganizado durante o dia.
\end{tabular}

Quadro 4: Cuidados para melhorar a qualidade de vida do professor e de seu ofício

Além dos elementos apresentado no quadro 4, destaca-se que para o trabalho do professor ser estimado, e ter bases sólidas, o docente necessita trabalhar em conjunto com os demais integrantes da comunidade escolar. Assim, ele pode propor uma alternativa de colaboração em relação à atuação do gestor escolar, numa tentativa de contribuir para uma reflexão de gestão pedagógica inovadora, numa dinâmica que objetive um bom relacionamento entre professores, alunos e a comunidade escolar, proporcionando assim uma melhor qualidade de vida no trabalho docente. 


\section{Administração: caminhos para o desenvolvimento sustentável}

\section{METODOLOGIA}

Para responder o problema proposto, e atender ao objetivo da pesquisa, foram delineados alguns procedimentos metodológicos. A pesquisa apresenta caráter exploratório e descritivo. Uma pesquisa pode ser considerada exploratória e descritiva. Segundo Vergara (1988, p. 35), uma pesquisa nestes moldes "tem por objetivo conhecer e descrever os atores de um mercado específico bem como entender o seu comportamento para a formulação de estratégias".

De acordo com Gil (2008), as pesquisas descritivas possuem como objetivo a descrição das características de uma população, fenômeno ou de uma experiência. As pesquisas descritivas geralmente assumem a forma de levantamentos.

O estudo, para seu desenvolvimento, foi segmentado em dois momentos: teórico e empírico. A pesquisa teórica utilizou livros e artigos para se obter conhecimento sobre o tema 'qualidade de vida no trabalho docente'. A segunda etapa da pesquisa, parte empírica, a partir do conhecimento teórico adquirido foi estruturado um questionário com questões fechadas para explorar a percepção dos docentes da Escola Municipal Professora Ignez Corso Andreazza, quanto aos reflexos em decorrência da qualidade de vida no trabalho educativo. Nesta ótica, o enfoque empírico é considerado específico e assume a forma de um estudo de caso (GIL, 2008).

Cabe mencionar que as análises deste estudo foram realizadas segundo a ótica qualitativa. Segundo Gil (2008, p. 43) a pesquisas quantitativa faz "emergir aspectos subjetivos e atingem motivações não explícitas, ou mesmo conscientes, de maneira espontânea. São usadas quando se busca percepções e entendimento sobre a natureza geral de uma questão, abrindo espaço para a interpretação".

A escolha pela análise qualitativa se deve ao fato da pesquisa qualitativa ajudar a identificar questões e entender porque elas são importantes.

\section{ANÁLISE DE DADOS}

A Escola Municipal "Ignez Corso Andreazza", localizada na região norte da cidade de Londrina, abrange a Educação Infantil e Ensino Fundamental do 10 ao 50 ano. É normatizada e orientada pelo Conselho Municipal de Educação e Secretaria Municipal de Educação, a escola busca atingir sua plenitude enquanto Instituição de ensino, pautada no exercício da democracia. 


\section{Administração: caminhos para o desenvolvimento sustentável}

A escola tem um perfil acolhedor e não discriminatório. Possui característica de Escola Inclusiva, pois tanto alunos como professores agem de forma a não deixar que as diferenças físicas ou cognitivas sejam barreiras para a socialização e/ou aprendizagem. Os alunos deste estabelecimento de ensino pertencem a famílias que possuem um nível sócio-econômico considerado carente.

Na presente pesquisa, houve a coleta de informações a partir de um questionário com perguntas fechadas, a fim de conseguir ponderações de valor numérico relativo ao nível de amplitude de cada tópico analisado. A presente pesquisa se deu com os profissionais que lecionam na instituição de ensino Ignez Corso Andreazza, no período da tarde, perfazendo um total de 20 professores que responderam o questionário.

Verifica-se que $99 \%$ das pessoas que participaram dessa pesquisa são do sexo feminino e todas executam exclusivamente a função de docência nessa instituição. Em relação às instituições que trabalham, 97\% trabalha exclusivamente em instituições municipais, 2\% em instituições municipais e estaduais e $1 \%$ em instituições municipais, estadual e privada.

Além disso, a pesquisa evidencia quanto ao tempo de serviço como docente, e tempo serviço na escola, o cenário apresentado no gráfico 1
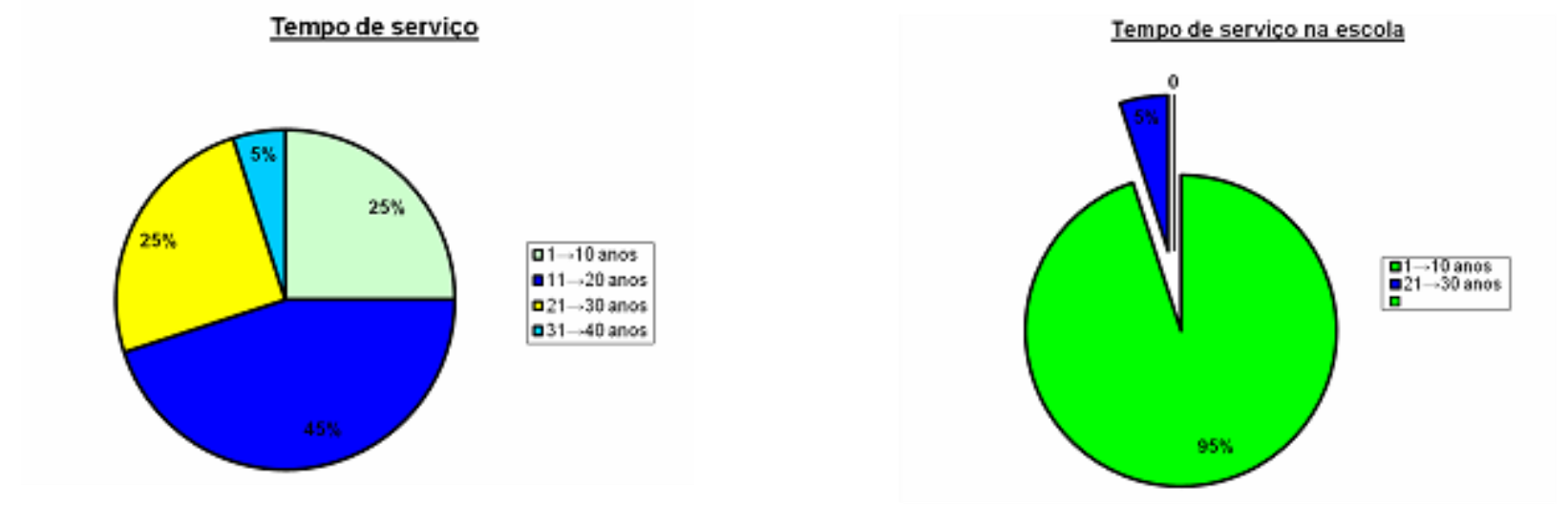

Gráfico 1: Tempo de serviço

Verifica-se que um quantitativo elevado dos participantes da pesquisa se enquadrou na faixa etária entre 20 e 40 anos de idade. Sendo que a maioria tem acima de 10 anos de tempo de serviço, logo, são profissionais já em uma faixa de idade amadurecida e com ampla experiência, vale ressaltar que essa faixa etária engloba a fase do indivíduo, na qual o ser humano se encontra em plena capacidade produtiva, e a fase de acomodação em que falta entusiasmo pela profissão. 
O questionário foi composto por 35 perguntas, as quais continham quatro opções de percepção, dos quais o respondente deveria escolher uma, conforme quadro 5.

\begin{tabular}{|c|c|c|c|c|}
\hline $\begin{array}{l}\text { Nas questões abaixo assinale " } X \text { " na alternativa que lhe } \\
\text { parecer mais adequada }\end{array}$ & Nunca & $\begin{array}{c}\text { Às } \\
\text { vezes }\end{array}$ & Regularmente & Sempre \\
\hline $\begin{array}{l}\text { 1) No último ano, houve algum episódio de agressão } \\
\text { ou ameaça na escola, praticado por pais de alunos / } \\
\text { responsáveis? }\end{array}$ & 9 & 11 & - & - \\
\hline $\begin{array}{l}\text { 2) No último ano, houve algum episódio de agressão } \\
\text { ou ameaça na escola, praticado por alunos? }\end{array}$ & 5 & 15 & - & - \\
\hline 3) Você utiliza TV/ vídeo durante as aulas? & & 13 & 6 & 1 \\
\hline $\begin{array}{l}\text { 4) A escola disponibiliza computador em número } \\
\text { suficiente para você realizar suas atividades com os } \\
\text { alunos? }\end{array}$ & - & 5 & 15 & - \\
\hline $\begin{array}{l}\text { 5) O acesso a internet disponibilizado é suficiente para } \\
\text { você realizar suas atividades com os alunos? }\end{array}$ & - & 5 & 15 & - \\
\hline 6) Em geral, você ingere água durante as aulas? & 2 & 12 & 1 & 5 \\
\hline 7) Você tem percebido piora na qualidade de sua voz? & 3 & 13 & 2 & 2 \\
\hline $\begin{array}{l}\text { 8) Há alguma instrução na escola sobre como manter a } \\
\text { saúde de sua voz? }\end{array}$ & 13 & 6 & 1 & - \\
\hline $\begin{array}{l}\text { 9) Você tem mantido a concentração nas atividades } \\
\text { que está fazendo? }\end{array}$ & - & 2 & 6 & 12 \\
\hline $\begin{array}{l}\text { 10) Você tem sofrido insônia por preocupação com suas } \\
\text { atividades enquanto docente? }\end{array}$ & 3 & 12 & 1 & 4 \\
\hline $\begin{array}{l}\text { 11) Você se considera útil, nas atividades profissionais } \\
\text { que desenvolve, como docente? }\end{array}$ & - & - & 1 & 19 \\
\hline $\begin{array}{l}\text { 12) Você se sente capaz de tomar decisões adequadas } \\
\text { em situações e conflito profissional? }\end{array}$ & - & 3 & 4 & 13 \\
\hline $\begin{array}{l}\text { 13) Você se sente agoniado (a) ou tenso (a) com relação } \\
\text { a suas atividades profissionais? }\end{array}$ & 3 & 15 & - & 2 \\
\hline $\begin{array}{l}\text { 14) Você tem superado suas dificuldades vinculadas às } \\
\text { relações de trabalho com facilidade? }\end{array}$ & - & 7 & 4 & 9 \\
\hline $\begin{array}{l}\text { 15) Você tem sido capaz de desfrutar atividades de lazer } \\
\text { no dia a dia, se desligando totalmente das atividades } \\
\text { profissionais? }\end{array}$ & 2 & 8 & 3 & 7 \\
\hline $\begin{array}{l}\text { 16) Você em momentos de reflexão se sente triste ou } \\
\text { deprimido, com suas atividades profissionais? }\end{array}$ & 5 & 9 & 5 & - \\
\hline $\begin{array}{l}\text { 17) Você tem se sentido confiante no que se refere às } \\
\text { atividades profissionais que executa no dia a dia? }\end{array}$ & - & - & 6 & 14 \\
\hline $\begin{array}{l}\text { 18) Você se sente satisfeito de modo geral com as } \\
\text { atividades profissionais que desenvolve? }\end{array}$ & - & - & 9 & 11 \\
\hline $\begin{array}{l}\text { 19) Com que frequiência você consome bebidas } \\
\text { alcoólicas? }\end{array}$ & 16 & 4 & - & - \\
\hline $\begin{array}{l}\text { 20) Você realiza alguma atividade física regular } \\
\text { (caminhadas, exercícios, prática de esportes, etc.)? }\end{array}$ & 9 & 6 & 4 & 1 \\
\hline 21) Você tem o hábito de fumar? & 17 & 1 & - & 2 \\
\hline $\begin{array}{l}\text { 22) A escola disponibiliza biblioteca com material } \\
\text { atualizado, que auxilia você a desenvolver suas } \\
\text { atividades com os alunos? }\end{array}$ & - & 6 & 2 & 12 \\
\hline $\begin{array}{l}\text { 23) Você já fez ou faz uso de medicamento prescrito } \\
\text { por médico em função de sua atividade de trabalho } \\
\text { impactar na sua saúde? }\end{array}$ & 10 & 2 & 1 & 7 \\
\hline $\begin{array}{l}\text { 24) Sua margem de autonomia no exercício do seu } \\
\text { trabalho é: }\end{array}$ & - & - & 7 & 13 \\
\hline $\begin{array}{l}\text { 25) Sua possibilidade de ser criativo no exercício do seu } \\
\text { trabalho é: }\end{array}$ & - & - & 5 & 15 \\
\hline $\begin{array}{l}\text { 26) A possibilidade de você sofrer situações de estresse } \\
\text { no exercício de seu trabalho é: }\end{array}$ & - & 3 & 7 & 10 \\
\hline
\end{tabular}




\section{Administração: caminhos para o desenvolvimento sustentável}

\begin{tabular}{|c|c|c|c|c|}
\hline $\begin{array}{l}\text { 27) Há oferta de treinamento para constante } \\
\text { aperfeiçoamento profissional, no exercício do seu } \\
\text { trabalho: }\end{array}$ & - & 2 & 15 & 3 \\
\hline $\begin{array}{l}\text { 28) No exercício do seu trabalho há segurança em suas } \\
\text { atitudes profissionais: }\end{array}$ & - & 2 & 10 & 8 \\
\hline $\begin{array}{l}\text { 29) No exercício do seu trabalho há respeito com as } \\
\text { questões relacionadas à sua vida pessoal: }\end{array}$ & - & 3 & 6 & 11 \\
\hline $\begin{array}{l}\text { 30) Seus direitos trabalhistas são respeitados no } \\
\text { exercício do seu trabalho }\end{array}$ & - & 2 & 17 & 1 \\
\hline 31) O ruído originado na sala de aula é alto: & - & 11 & 8 & 1 \\
\hline $\begin{array}{l}\text { 32) O ruído originado dentro da escola, mas fora da sala } \\
\text { de aula é alto: }\end{array}$ & - & 6 & 9 & 5 \\
\hline 33) A ventilação da sua sala de aula é adequada: & - & 2 & 16 & 2 \\
\hline 34) A iluminação em sua sala de aula é adequada: & - & 1 & 13 & 6 \\
\hline $\begin{array}{l}\text { 35) As condições das paredes e teto da sua sala de aula } \\
\text { são adequadas: }\end{array}$ & - & 1 & 15 & 4 \\
\hline
\end{tabular}

Quadro 5: Respostas obtidas na primeira etapa do questionário

Com as análises das respostas do quadro 5 , foi possível constatar que os professores às vezes presenciam agressões, sendo estas feitas por pais e alunos, sendo a frequência maior cometida por alunos. Além disso, observou-se que os docentes utilizam recursos tecnológicos em suas aulas, objetivando torná-las mais atraentes e motivadoras.

A maioria dos docentes pesquisados ingere água durante as aulas, contudo grande parte desses tem percebido piora na qualidade de sua voz. Insônia, tensão, depressão e tristeza também são sintomas decorrentes devido às preocupações docentes. No entanto, esses profissionais ainda se sentem no geral satisfeitos com as atividades profissionais que desenvolvem. A maior parte dos pesquisados não fuma e nem bebe, porém não realizam atividades físicas.

Outro ponto detectado foi que a autonomia e a criatividade são grandes em seu meio de trabalho, sendo oferecidos, também, treinamentos para aprimorar o conhecimento. No que tange as condições físicas, como estrutura e ruídos, relataram ser regulares.

O questionário evidencia que os pontos que mais geram baixa qualidade de vida no trabalho, no caso da escola em estudo, são: as tensões e depressões, cansaço mental e problemas de voz, que o contexto pode propiciar aos docentes. Além disso, o questionário também apresentou mais 9 questões, as quais continham cinco opções de percepção, destas o respondente deveria escolher uma, conforme quadro 6. 


\section{Administração: caminhos para o desenvolvimento sustentável}

\begin{tabular}{|c|c|c|c|c|c|}
\hline $\begin{array}{l}\text { Nas questões abaixo assinale " } X \text { " na alternativa que the } \\
\text { parecer mais adequada }\end{array}$ & $\begin{array}{l}\text { Defici } \\
\text { tário }\end{array}$ & Ruim & Regular & Bom & $\begin{array}{l}\text { Muito } \\
\text { bom }\end{array}$ \\
\hline 36) O tempo disponível para preparo das aulas é: & 2 & 2 & 9 & 6 & 1 \\
\hline 37) O tempo disponível para correção de trabalhos é: & 4 & 3 & 7 & 5 & 1 \\
\hline 38) O relacionamento com seus superiores? & - & - & - & 5 & 15 \\
\hline 39) O relacionamento com seus colegas? & - & - & - & 2 & 18 \\
\hline 40) O relacionamento com seus alunos? & - & - & - & 6 & 14 \\
\hline $\begin{array}{l}\text { 41) O relacionamento com os pais de seus alunos ou } \\
\text { responsáveis? }\end{array}$ & - & - & 1 & 5 & 14 \\
\hline $\begin{array}{l}\text { 42) Os cursos de capacitação que a escola oferece a } \\
\text { você são: }\end{array}$ & - & - & 1 & 16 & 3 \\
\hline $\begin{array}{l}\text { 43) Existem momentos de negociação de decisões e } \\
\text { troca de opiniões da escola com você? }\end{array}$ & 1 & - & 7 & 6 & 6 \\
\hline $\begin{array}{l}\text { 44) A qualidade de vida no trabalho que lhe é } \\
\text { oferecida na escola é: }\end{array}$ & - & - & 4 & 10 & 5 \\
\hline
\end{tabular}

Quadro 6: Respostas obtidas na 2ª etapa do questionário

Refletindo sobre as respostas apontadas no quadro 6, foi possível observar que os professores consideram regular o tempo que têm na escola para preparar aulas e corrigir trabalhos. Em relação ao relacionamento, a maioria julga ser muito bom, tanto com colegas, superiores, alunos e responsáveis pelos alunos.

No que tange a qualidade de vida no trabalho, houve um julgamento bom. Apesar disso, o questionário evidencia que o acúmulo de situações desconfortáveis faz com que haja o desgaste físico e psicológico. Algumas dessas situações são geradas por estímulos que são claramente perceptíveis, como um conflito expresso abertamente. Porém, muitas situações provêm de estímulos sutis que passam despercebidos, e esses são, em geral, os que geram maiores riscos, pois o indivíduo sente apenas as conseqüências que decorrem da exposição a eles.

\begin{tabular}{|c|l|}
\hline Questões & \multicolumn{1}{c|}{ Ação de melhoria } \\
\hline 1 & $\begin{array}{l}\text { Promover momentos de interação da família com a escola, otimizando assim o diálogo } \\
\text { e a troca de informações constantes entre todos os envolvidos no processo educativo. }\end{array}$ \\
\hline 2 & $\begin{array}{l}\text { Incentivar ações que estimulem o bom convívio entre professores e alunos, buscando dar } \\
\text { atendimento eficiente a casos de educandos com distúrbios de comportamento. }\end{array}$ \\
\hline 7 & $\begin{array}{l}\text { Instigar a ingestão de líquidos durante a aula e oferecer informações consistentes sobre } \\
\text { o tema. }\end{array}$ \\
\hline 8 & $\begin{array}{l}\text { Confecção de cartazes sobre como cuidar da voz e exposição permanente dos mesmos. } \\
\text { Trazer profissionais especializados para dar palestra sobre o assunto }\end{array}$ \\
\hline 10 & $\begin{array}{l}\text { Conscientização sobre a necessidade de "desligar-se" dos afazeres educativos fora do } \\
\text { ambiente escolar. }\end{array}$ \\
\hline 13 & $\begin{array}{l}\text { Dar mais confiança no trabalho que está desenvolvendo, buscando diminuir assim } \\
\text { tensões oriundas do trabalho. }\end{array}$ \\
\hline 15 & $\begin{array}{l}\text { Procurar aumentar as atividades de lazer, reservar pelo menos um dia do final de semana } \\
\text { para atividades que não envolvam afazeres escolares. }\end{array}$ \\
\hline 16 & $\begin{array}{l}\text { Refletir de forma objetiva sobre as atividades docentes, ressaltando os objetivos } \\
\text { atingidos em detrimento do que não deu certo, vendo todo o processo. }\end{array}$ \\
\hline 19 & Não fazer uso, ou para quem faz diminuir o uso de bebidas alcoólicas. \\
\hline 21 & Não fazer uso, ou para quem faz diminuir o uso do cigarro. \\
\hline 23 & $\begin{array}{l}\text { Procurar alternativas de relaxamento que não envolvam remédios, ou então que pelo } \\
\text { menos estes sejam naturais. }\end{array}$ \\
\hline
\end{tabular}




\section{Administração: caminhos para o desenvolvimento sustentável}

\begin{tabular}{|c|l|}
\hline 26 & $\begin{array}{l}\text { Tentar diminuir situações que possam causam estresse, ou em situações estressantes, } \\
\text { manter-se mais calmo. }\end{array}$ \\
\hline 31 & $\begin{array}{l}\text { Propor acordos com os alunos, almejando assim a diminuição do ruído dentro da sala de } \\
\text { aula e conscientizando-os que o ruído gerado também os prejudica. }\end{array}$ \\
\hline 36 & Otimizar o tempo destinado ao preparo de aulas. \\
\hline 37 & Buscar dividir o tempo, de maneira a não ficar sobrecarregado. \\
\hline
\end{tabular}

Quadro 7: Ações para melhoria do QVT na escola

De modo geral, o estudo evidencia que, das 44 questões em análise, 15 delas geram impacto direto na qualidade de QVT e, no caso da escola em estudo, algumas ações poderiam ser tomadas, tais como: cursos, palestras, campanhas de divulgação e conscientização de ações que poderiam ser tomadas direcionadas as 15 questões com impactos negativos, a fim de melhorar a QVT nestes pontos em específico.

\section{CONSIDERAÇÕES FINAIS}

A melhoria das condições de vida e da saúde tem sido um tema de crescente importância, já que impacta indireta ou diretamente a produtividade das pessoas, e os resultados obtidos pelas organizações.

Muitos são os fatores que interferem na QVT das pessoas, é verdade que a qualidade de vida não inclui somente os fatores diretamente relacionados à saúde, tais como: bem estar físico, funcional, emocional e bem estar mental, mas também, elementos como trabalho, amigos e outras circunstâncias de vida.

No caso deste estudo, conclui-se que é importante dar ao trabalhador condições básicas na melhoria do ambiente operacional, procurando proporcionar um nível de satisfação no trabalho através dos cuidados com a sua segurança e saúde. No caso em específico da escola em estudo, poderiam ser realizadas ações direcionadas as 15 questões com impactos negativos, a fim de melhorar a QVT nestes pontos de modo direto. Dentre tais ações, poderiam ser realizados: cursos, palestras, campanhas de divulgação e conscientização de ações que poderiam ser tomadas.

A partir da pesquisa realizada, o problema de pesquisa "Quais ações podem ser tomadas para minimizar os reflexos em decorrência da qualidade de vida no trabalho educativo dos docentes?" pode ser respondido, uma vez que ficou evidente a necessidade que os mesmos organizem melhor seu tempo, façam atividades físicas com regularidade, ingiram água com freqüência e busquem ter uma qualidade de tempo eficaz, bem como o papel que a própria instituição tem neste processo em termos de divulgar a importância da QVT e gerar ações de modo a incentivar a formação de um ambiente que 


\section{Administração: caminhos para o desenvolvimento sustentável}

atenda as questões identificadas como sendo de impacto negativo para a QVT. Além disso, o objetivo do estudo de: Analisar a qualidade de vida do trabalho em instituição escolar e quais ações podem ser tomadas para minimizar suas consequências aos docentes, foi atingido, pois ficou evidente a necessidade de que também se tenham políticas públicas que amparem os profissionais da educação, propiciando assim, condições satisfatórias de trabalho e de saúde física e mental no ambiente educativo, bem como a conscientização do próprio profissional sobre o tema.

Como trabalhos futuros, recomendam-se: (a) realizar a pesquisa em outras escolas, a fim de observar se o cenário identificado neste contexto se repete em outros contextos; (b) reaplicar a pesquisa na mesma escola decorrido um período de 12 meses, a fim de observar alterações no cenário vinculado a qualidade da QVT.

\section{REFERÊNCIAS}

BORGES, R. S.s G.s; MARQUES, A. L.; ADORNO, R. D. Investigando as relações entre políticas de RH, comprometimento organizacional e qualidade de vida no trabalho. In: Encontro Nacional da ANPAD, 29. 2005. Brasília: ANPAD 200.

BOWDITCH, J.; BUONO, A.. Elementos de Comportamento Organizacional. Traduzido por José Henrique Lamendorf. São Paulo: Pioneira, 1992. Tradução de A Primer on Organizational Behavior.

CESAR, A. M. R. V. C.. Qualidade de vida no trabalho: qualidade, vida e trabalho nas micro e pequenas empresas. In: SEMEAD - Seminário de Administração, 5, 2001, São Paulo. Anais eletrônicos.São Paulo: USP, 2001. Disponível

em: <http://www.ead.fea.usp.br/Semead/5semead/RH/QVT\%20peq\%20empresas.pdf>. Acesso em: 31 mai. 2011.

CODO, W. Indivíduo, trabalho e sofrimento: uma abordagem interdisciplinar. 4.ed. Petrópolis: Vozes, 1999.

CURY, A. Nunca desista dos seus sonhos. Rio de Janeiro: Sextante, 2004.

DEJOURS, C. Psicodinâmica do trabalho. São Paulo: Atlas, 1994.

FERNANDES, E. C. Qualidade de vida no trabalho: como medir para melhorar. Salvador: Casa da Qualidade, 1996.

GARCIA, D. A qualidade de vida do professor. Disponível em: <http://www.portaleducacao.com/>. Acesso em: 20 maio 2011.

GIL, A. C. Como elaborar projetos de pesquisa. 5. ed. São Paulo: Atlas, 2008.

HACKMAM, . R. Improving Life at Work: Bechavioral SCIENCE Approaches to Organizacional Change. Santa Monica: [s.n.], 1977. 


\section{Administração: caminhos para o desenvolvimento sustentável}

JARDIM, Renata.Voz, trabalho docente e qualidade de vida.Belo Horizonte, 2006.

LEMOS, J. C. Cargas psíquicas no trabalho e processos de saúde em professores universitários. Florianópolis: UFSC, 2005.

LIBÂNEO, J C.; OLIVEIRA, J. F.; TOSCHI, M. S.. Educação Escolar: políticas, estrutura e organização. 3. ed. São Paulo: Cortez, 2006.

LIPP, M.N., O estresse do professor. Campinas: Papirus, 2002.

MACEDO, L.. Ensaios pedagógicos. Como construir uma escola para todos. Porto Alegre: Artemed, 2005.

MARQUES, A. L..; BORGEZ, R. S. G. ADORNO, R. D.. A LDB/96 e a qualidade de vida no trabalho: com a palavra os docentes da rede pública de Belo Horizonte. Revista de Ciências da Administração, v. 10, n. 20, p. 72-94, jan./abr. 2008.

MINAYO, M. C. . S.; HARTZ, Z. M. A.; BUSS, P. M.. Qualidade de vida e saúde: um debate necessário. Ciência \& Saúde Coletiva, n. 5, p. 7-18, 2000.

RIBAS, M. H., CARVALHO, Ma. A.;.ALONSO, M. Formação continuada de Professores e mudança na prática pedagógica. In. O trabalho docente: teoria e prática. Ana Gracinda Queluz (Orientação) Myrtes Alonso (Org.) São Paulo: Pioneira, 1999.

SCHAUFELI, W., ENZMANN, D. The Burnout Companion to Study and Practice: a critical analysis, 1998.

VASQUEZ-MENEZES, I. Saúde mental e trabalho: Aplicações na prática clínica. In: M.G. Jacques \& W. Codo (Org.), Saúde mental \& trabalho: Leituras. Petrópolis: Vozes, 2002.

VERGARA, S. C. Projetos e relatórios de pesquisa em administração. São Paulo: Atlas Editora, 1998.

WALTON, R. E. Quality of working life: what is it? Slow Management Review. USA: v.15, n.1, p.11-21, 1973. 


\section{Capítulo 15}

\section{ESTUDO DA GOVERNANÇA CORPORATIVA EM INCUBADORAS DE BASE TECNOLÓGICA}

\section{DOI: $10.37423 / 200300392$}

Rúbia Carla Maier Biscaia, UEPG, Brasil , rubiacmaier@yahoo.com.br João Carlos Cunha,POSITIVO,Brasil, jccunhaisat@gmail.com Osvaldo Malta Callegari, UEPG, Brasil, osvaldo1264@hotmail.com

Resum6: As incubadoras de empresas trazem contribuições importantes para o processo de desenvolvimentø de negócios, estimulando os empreendedorés na criação de empresas. Este artigo tem por objetivo avaliar a governança corporativa em incubadoras de empresa de base teenológica. A sustentação teórica ocorreu/por meio do construto de governança corporativa em incubadoras. Em função dos objetivos está pesquisa é de natureza aplicada e descritivo-exploratória, nùma abordagem quantitativa. Foi realizada uma pesquisa survey aplicada aos gestores de incubądoras de empresas de base techológica do Brasil, obteve-se uma amostra de 65 incubadoras. Por meio dos resultados da pesquisa fo possível estabetecer um panorama inicial das incubadoras tecnológicas brasileiras e dessaforma, propor ações para melhoria.

Palavras-chave: Incubadoras de Empresas de Base Tecnológica; Governança Corpprativa; Moofelo de Gestão.

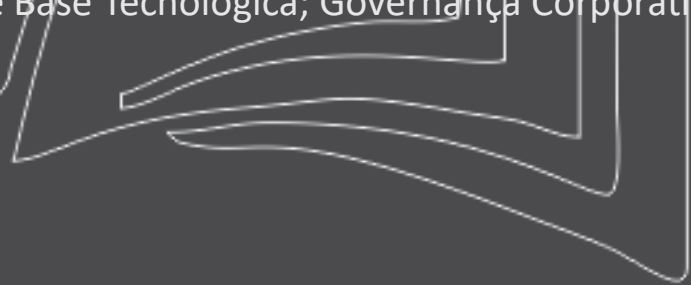




\section{Administração: caminhos para o desenvolvimento sustentável}

\section{INTRODUÇÃO}

A Governança Corporativa (GC) apresenta uma importância crescente, pois é vista como uma forma para melhorar a gestão e os processos em empresas com foco na inovação e no desenvolvimento constante, norteando os processos de tomada de decisão. Cada vez mais, as organizações no mundo, realizam alterações em sua estrutura para adotarem padrões de GC, pois além deste tema despertar o interesse de gestores, acionistas e investidores, também tem atraído a atenção de órgãos reguladores e da sociedade em geral, principalmente na observação se as organizações estão sendo gerenciadas de forma eficiente, eficaz e com ética.

A governança corporativa surge no contexto das incubadoras como um estudo de boas práticas, descrevendo modelos de interação entre os stakeholders, com uso do conhecimento e inovação para melhorar a aprendizagem e o desempenho das organizações. Esses ambientes são apropriados para desenvolver ideias e para fomentar empreendimentos de sucesso.

As incubadoras de empresa estão inseridas no ecossistema de inovação, com o objetivo de apoiar as novas empresas até que tenham condições para sobrevivência autônoma no mercado. Um tipo especializado de incubadoras são aquelas que apoiam empresas de base tecnológica - EBTs. Conforme afirmam BERGEK e NORRMAN (2008) e BRUNELL et al. (2012), as incubadoras foram estabelecidas em todo o mundo para estimular a criação de novas empresas de tecnologia tradicionais ou, quando especializadas em EBTs, colaborando para o surgimento de novas tecnologias e formas inovadoras de negócios. A popularidade das incubadoras sugere que eles são instrumentos eficazes para apoiar startups (WEELE; RIJNSOEVER; NAUTA, 2017). São apontadas como métodos importantes para uma política de desenvolvimento no Brasil e demais países e vistas como promotoras da inovação e do empreendedorismo.

Neste contexto, a governança surge como estudo de boas práticas, descrevendo modelos de interação entre os stakeholders, com uso do conhecimento e da inovação para melhorar a aprendizagem e o desempenho das organizações. Conforme aponta o IBGC (2015) as boas práticas de governança corporativa convertem os princípios em recomendações objetivas, alinhando interesses para preservar e otimizar o valor da organização, facilitando acesso a recursos e contribuindo para sua longevidade. Um sistema pelo qual os acionistas administram e defendem os seus interesses pelo monitoramento e fazem a avaliação das decisões da diretoria (ANDRADE; ROSSETTI, 2012). 


\section{Administração: caminhos para o desenvolvimento sustentável}

Esta pesquisa pretende contribuir na avaliação dos modelos de governança adotados pelas incubadoras de empresas de base tecnológica (IEBT) do país. Considerando que os métodos de governança têm papel relevante para o desempenho de incubadoras de empresas (PHAN; SIEGEL; WRIGHT, 2005). Sendo assim, o objetivo dessa pesquisa é avaliar a governança corporativa das IEBTs brasileiras.

\section{GOVERNANÇA NO CONTEXTO DA INCUBADORAS}

A GC é o campo da administração que trata do conjunto de relações entre a direção das empresas, seus conselhos de administração, seus acionistas e outros stakeholders (SHLEIFER; VISHNY, 1997). A GC também estabelece a estrutura por meio da qual são fixados os objetivos da companhia, são determinados os meios para alcançar esses objetivos e as formas de monitoramento de desempenho (OECD, 2004). Trata-se de um processo contínuo, por meio do qual, interesses conflitantes ou diversos podem ser acomodados e a ação cooperativa pode ser tomada (CLARKE, 2004). Estabelecendo as formas pelas quais os fornecedores de capital asseguram o retorno de seus investimentos, sua estrutura especifica a distribuição de direitos e responsabilidades entre os diferentes participantes na corporação e define as regras e procedimentos para a tomada de decisões de assuntos corporativos (SHLEIFER; VISHNY, 1997; CLARKE, 2004).

O termo governança está cada vez mais presente nos discursos das organizações sejam públicas, privada, com ou sem fins lucrativos. O conceito de governança é fundamental para o desenvolvimento da competitividade das empresas, e diz respeito ao desenvolvimento de uma sociedade atuante (CHIOCHETTA, 2010). A governança pode ser compreendida como um processo contínuo para acomodar os diferentes interesses em ações cooperativas, incluindo tanto relações formais, de hierarquia, poder e obediência, como acordos informais em relações não hierárquicas (STORPER; HARRISON, 1991).

As incubadoras de empresas são ambientes dotados de elementos como infraestrutura, capacidades tecnológicas e gerenciais para apoiar e amparar o empreendedor. No contexto das incubadoras, a GC tem o papel de caracterizar a sua constituição e condução, acompanhando o processo de gestão e a relação com as empresas incubadas e seus resultados.

No Brasil, existe um Modelo de Gestão de Incubadoras, conhecido como CERNE, já citado anteriormente, de modo que a implantação deste modelo recomenda que os processos da incubadora 


\section{Administração: caminhos para o desenvolvimento sustentável}

sejam definidos, testados e em contínuo desenvolvimento para atender suas atividades e funções. 0 modelo Cerne contribui para a GC, principalmente pela padronização de processos, de forma a facilitar o gerenciamento e avaliação de seus resultados, tornando a relação entre os stakeholders mais confiável A governança contribui para o fortalecimento das incubadoras, aumentando a confiança dos stakeholders. Gallon (2009) estudou os atores envolvidos e corresponsáveis no desempenho das incubadoras: o coordenador da incubadora; gestores e colaboradores das empresas incubadas; empresas incubadas e a sociedade que se beneficia de seus produtos e serviços.

De modo geral, os stakeholders são representados pelos atores que afetam a incubadora ou por ela são afetados em seus objetivos. Existem vários atores ao lado da incubadora, os quais exercem influências diversas no seu funcionamento e monitoramento. A governança da incubadora é constituída pela participação e coordenação entre esses diferentes atores, os quais tem interesse no seu desempenho. Na medida em que os princípios da boa GC, envolvendo questões sobre os arranjos e os processos do conselho, o equilíbrio da representação dos stakeholders, a gestão estratégica, os incentivos e o processo de estabelecimento de incentivos para gerentes de incubadoras, sejam formalizados e incorporados nas rotinas de gerenciamento dessas organizações, pode-se esperar um impacto mínimo do conflito principal (PHAN; SIEGEL; WRIGHT, 2005).

A National Business Incubation Association (NBIA), associação que congrega representantes de importantes incubadoras no mundo, ressalta que a incubadora deve observar aspectos estratégicos que irão resultar em uma efetiva estrutura de governança, contribuindo positivamente nos resultados das incubadoras. Esses aspectos devem ser relevados no modelo de governança adotado pelos gestores, envolvendo todos os stakeholders (NBIA, 2017). Entre as dimensões de um modelo de melhores práticas para incubadoras apresentada pelo MCTI (2015), apresenta-se a governança, que analisa o modelo de governança da incubadora, por meio da análise da participação da tríplice hélice, da transparência dos resultados e do reconhecimento da incubadora pela mantenedora. A governança nas incubadoras, assim como nos demais tipos de organizações, poderá permitir um melhor desempenho, em benefício dos stakeholders.

\section{METODOLOGIA}

Com uma metodologia quantitativa, este estudo permitiu avaliar as IEBTs brasileiras considerando seu modelo de governança. Para tanto, esta investigação teve um caráter descritivo-exploratório e conta com uma pesquisa bibliográfica que compõe o quadro teórico e o levantamento dos elementos de 


\section{Administração: caminhos para o desenvolvimento sustentável}

governança, importantes e necessários no contexto das incubadoras. Seguindo essa proposta foi realizada uma pesquisa survey.

A população deste estudo está constituída pelas IEBTs localizadas no Brasil. Foram encontradas 115 IEBTs ativas. Os dados foram obtidos por meio de envio de questionário endereçado aos gestores de todas as incubadoras apresentadas na tabela 1, sendo a amostra por adesão, onde foram considerados apenas os questionários válidos.

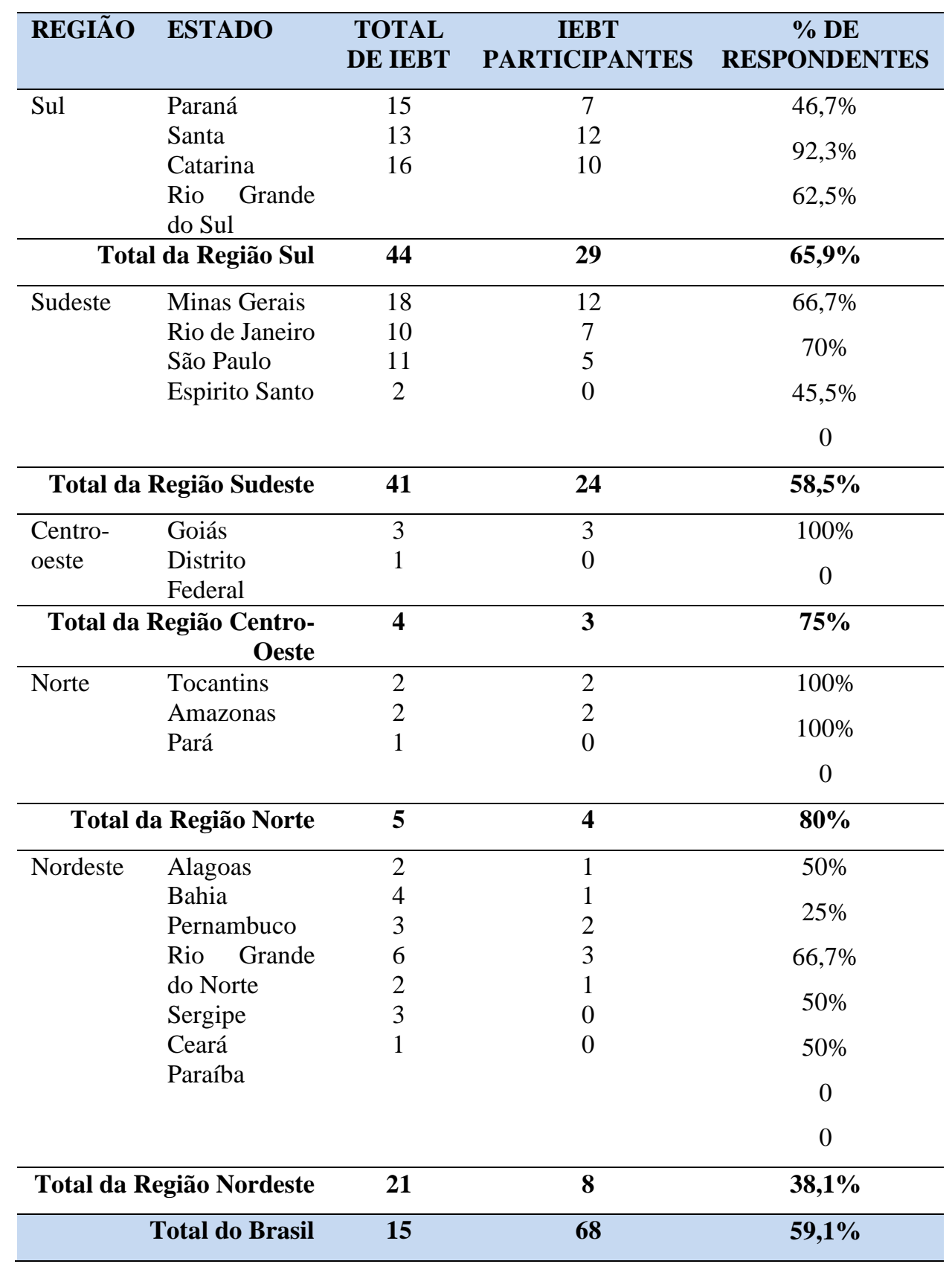

Tabela 1- IEBTs participantes na pesquisa

Fonte: Autores (2018). 


\section{Administração: caminhos para o desenvolvimento sustentável}

O respondente teve como opção de retorno por formulário eletrônico, na plataforma Google.Docs ou arquivo do Microsoft Word enviado por e-mail. Foram obtidos retornos de 68 incubadoras, e dessas, 65 questionários foram considerados válidos, o que corresponde a 56,5\% da população investigada.

Os questionários foram respondidos pelos coordenadores ou diretores de cada uma das incubadoras, indivíduos que apresentam conhecimentos suficientes para responder adequadamente essa pesquisa, fato que confere maior confiabilidade aos dados obtidos.

\section{ANÁLISE DOS RESULTADOS}

Com relação ao início das atividades das IEBTs, obteve-se a participação de incubadoras em diferentes níveis de maturidade. Os dados apontam os tempos de atuação das IEBTs pesquisadas, a adesão à pesquisa foi maior entre os anos de 2001 a 2010, um período considerado promissor no desenvolvimento de incubadoras no Brasil. Tratando de incubadoras com experiência nos processos de incubação, que pelo tempo que estão ativas já passaram pelo processo de graduação. As primeiras incubadoras de empresas surgiram no País na década de 1980, como iniciativa do governo federal, para fomentar o crescimento de pequenas e médias empresas e o desenvolvimento econômico (ETZKOWITZ; MELLO; ALMEIDA, 2005).

Segundo Vedovello, Puga e Felix (2001) no ano de 2000 haviam no Brasil 135 incubadoras (59 eram incubadoras de base tecnológica), sendo a maioria (82,97\%) nas regiões Sul e Sudeste. Esse foi um período muito promissor e de grandes investimentos nos processos de incubação. Em pesquisa divulgada pela ANPROTEC em 2016, já existiam no Brasil 369 incubadoras em operação, considerando os diferentes tipos de incubadoras (ANPROTEC, 2016). Nessa pesquisa concentrou-se nas incubadoras que recebem projetos de base tecnológica, onde foi possível localizar 115 incubadoras com esse perfil no Brasil.

Entre as características para o sucesso das incubadoras, ressalta-se o papel das universidades, segundo Ratinho e Henriques (2010) o vínculo com universidades apresenta impactos positivo no sucesso das incubadoras. Em relação à dependência institucional das IEBTs, verificou-se que a maioria das pesquisadas (70\%) estão vinculadas à universidade, conforme pode ser visualizado na figura 1. 


\section{Administração: caminhos para o desenvolvimento sustentável}

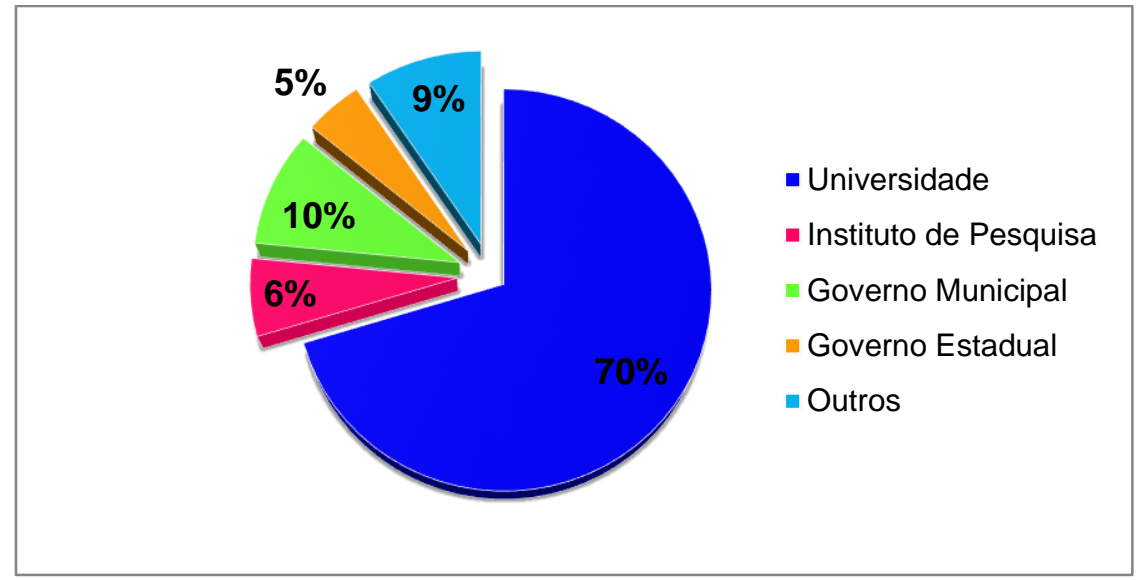

Figura 1 - Dependência institucional das incubadoras

Fonte: Autores (2018).

Conforme Zedtwitz (2003), o vínculo entre a universidade e os programas de incubação é essencial para garantir um melhor desempenho, funcionando como um elo entre o conhecimento acadêmico e o empreendedorismo, sendo um importante estimulo a projetos inovadores pelos acadêmicos. Assim, este vínculo é do interesse de ambas as instituições. Segundo Zouain e Silveira (2006) as universidades são chamadas para desempenhar um papel estratégico no desenvolvimento do setor produtivo, em busca de novos conhecimentos e tecnologias, assim como ao desenvolvimento de iniciativas que estimulem a transferência tecnológica dos centros de pesquisa para o mercado, sendo que muitas universidades brasileiras têm buscado fomentar o empreendedorismo por meio de programas como as incubadoras de empresas.

Incubadoras localizadas próximas das universidades trazem benefícios as empresas residentes, pois essas podem utilizar de suas instalações, laboratórios, compartilhar conhecimentos e transferência de tecnologia, gerando assim oportunidades de ensino, pesquisa e extensão (SERRA et al., 2011). O papel proativo das universidades, segundo Mian (1994), é geralmente motivado por seu desejo em participar dos esforços de desenvolvimento econômico regional e, encorajar a comercialização da própria pesquisa. Colombo e Delmastro (2002) realizaram uma pesquisa a fim de testar os efeitos da parceria entre Universidade e IEBT. Apontam que essas parcerias facilitam a transformação da pesquisa universitária em aplicações comerciais. Os resultados empíricos dessa pesquisa demonstram que as empresas italianas localizadas em IEBTs apresentaram taxas de crescimento mais elevadas do que as suas homólogas fora das IEBTs. Dessa maneira, entende-se a importância da IEBTs no crescimento das 


\section{Administração: caminhos para o desenvolvimento sustentável}

empresas e, as vantagens da proximidade com a universidade na transferência de conhecimentos e tecnologias.

As incubadoras ainda podem contar com apoio institucional de centros de pesquisa, do SEBRAE, de prefeituras municipais, instituições governamentais, entre outros. No Brasil a ANPROTEC e o SEBRAE são instituições que apoiam projetos inovadores em incubadoras, essas instituições trabalharam juntas na construção de um modelo de atuação e certificação, no ano de 2013 lançaram o Modelo Cerne. O modelo Cerne foi concebido para propor tanto os processos genéricos a serem implantados por uma incubadora de empresa, quanto às práticas que devem ser executadas para que a incubadora cumpra seu papel no ecossistema de inovação local (ANPROTEC, 2016). A figura 2 apresenta o percentual das incubadoras, entre as pesquisadas, que implantaram o Modelo Cerne no Brasil.

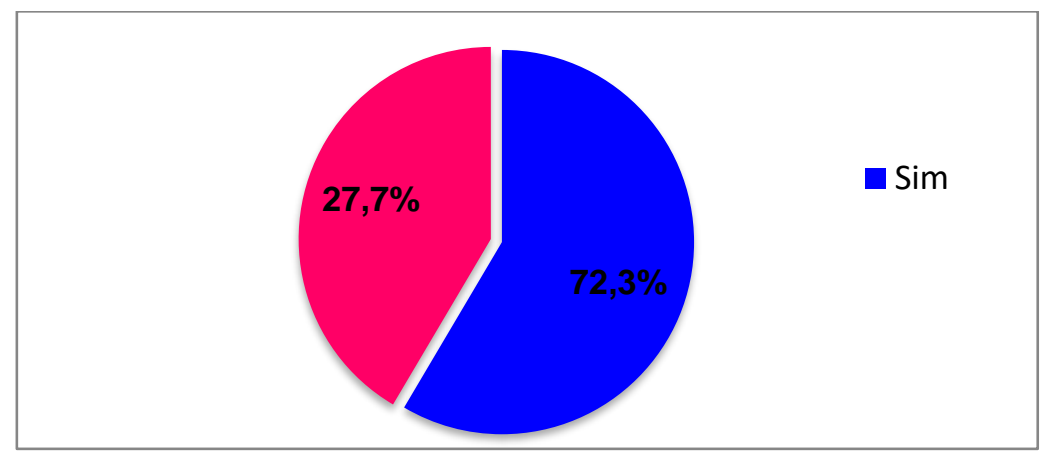

Figura 2 - Participantes do Modelo Cerne - ANPROTEC

Fonte: Autores (2018).

Conforme verificado na figura $2,72,3 \%$ das incubadoras pesquisadas implantaram o Modelo Cerne. Entre as incubadoras que ainda não implantaram, duas informaram que estão se preparando para o processo de implantação. Pode-se dizer que já existe uma adesão bastante representativa ao Cerne, o que, em breve, permitirá uma avaliação mais efetiva da eficácia das incubadoras, assim como do próprio modelo do Cerne.

O modelo Cerne contribui para a GC, principalmente pela padronização de processos, de forma a facilitar o gerenciamento e avaliação de seus resultados, tornando mais dinâmica a relação com os stakeholders. Esse modelo adota níveis crescentes de maturidade, na figura 10, verificou-se que $95 \%$ das incubadoras pesquisadas estão no nível 1 (de quatro níveis), o que é o estágio inicial do modelo. Há, portanto, um amplo campo aberto para o Modelo Cerne demonstrar sua efetividade nos próximos anos. 


\section{Administração: caminhos para o desenvolvimento sustentável}

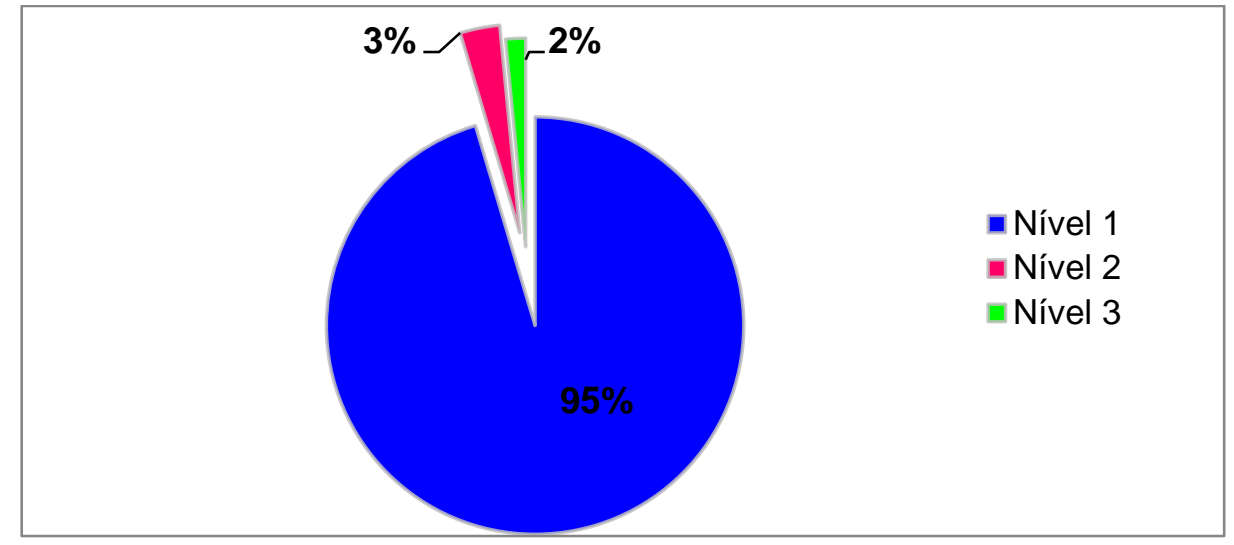

Figura 3- Nível de maturidade do modelo Cerne

Fonte: Autores (2018).

No nível 1, onde se encontra a maioria das incubadoras atualmente no Brasil, todos os sistemas implantados pelos processos-chave estão diretamente relacionados ao desenvolvimento dos empreendimentos, envolvendo aspectos relacionados à gestão da incubadora. Quando a incubadora atingir esse nível, "demonstra que tem capacidade para prospectar e selecionar boas ideais e transformá-las em negócios inovadores bem sucedidos, sistemática e repetidamente" (ANPROTEC, 2017). A capacidade de selecionar boas ideias a incubar pode ser verdade real, mas, a capacidade de transformá-las em negócios bem sucedidos ainda resta a provar. Entre as IEBTs pesquisadas nenhuma se encontra nesse nível de maturidade, uma vez que o modelo Cerne iniciou no ano de 2014. 0 propósito da certificação Cerne é contribuir na melhoria dos processos de incubação, possuindo um formato que atende aos requisitos de melhoria contínua, porém por se tratar de uma metodologia nova, suas contribuições ainda necessitam ser mais aprofundadas.

A GC traz inúmeros benefícios, principalmente na qualidade das decisões estratégicas, que se apresentam como elementos fundamentais para o sucesso do programa de incubação (ANPROTEC, 2016). Na estrutura de governança das incubadoras se ressalta a relevância do papel do Conselho de Administração, o qual exercerá funções estratégicas com mecanismos de governança eficazes para estabelecer, monitorar e implementar políticas efetivas, assim com as implicações relacionadas com o seu desempenho. A incubadora contará com um quadro de conselheiros composto por profissionais de mercado das áreas de atuação dos negócios incubados, empresários de empresas graduadas de sucesso, especialistas em transferência de tecnologias, representantes do governo e áreas correlatas 


\section{Administração: caminhos para o desenvolvimento sustentável}

à atuação da incubadora. O quadro de conselheiro representará a governança interna, permitindo monitorar e controlar os resultados e protegendo os interesses de todas as partes interessadas.

Buscou-se identificar as IEBTs que apresentam Conselho de Administração. Na figura 4 são apresentados os resultados quanto à existência ou não de Conselho de Administração nas incubadoras participantes.

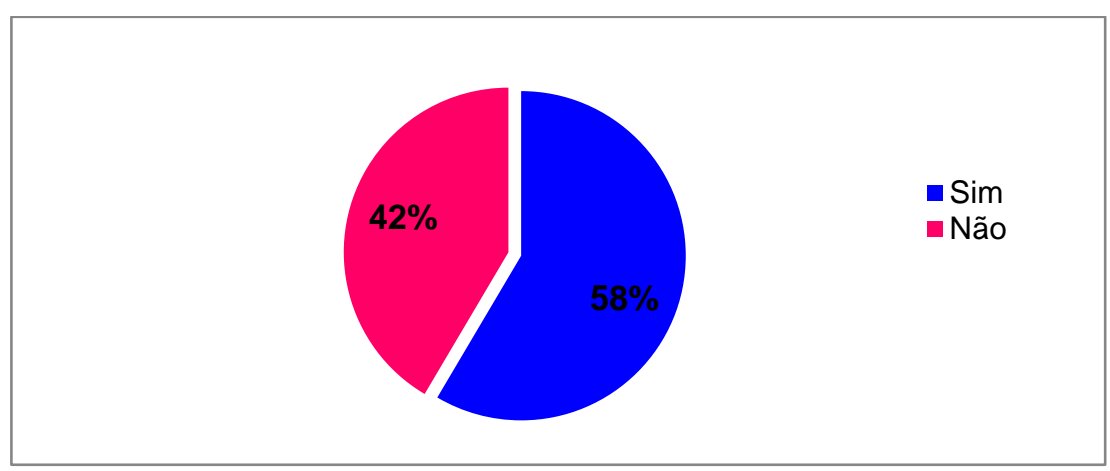

Figura 4- Conselho de Administração nas IEBTs

Fonte: Autores (2018).

A estrutura do Conselho de Administração é uma preocupação na pesquisa de GC, desde composição e tamanho. Verifica-se que $58 \%$ das IEBTs informaram possuir um conselho de administração instituído. Assim, um número significativo das incubadoras (42\%) não se beneficiam da capacidade dos conselhos no apoio de suas atividades.

As incubadoras que afirmaram possuir conselho de administração apresentam, em média, seis conselheiros, entre membros internos e externos. Para Andrade e Rosseti (2012) a eficácia do conselho de administração está relacionada à sua composição. Quanto à composição do conselho, essa dependerá de alguns fatores como os objetivos da organização, estágio de maturidade e expectativas em relação à sua atuação, é recomendado que o conselho de administração fosse constituído de cinco a onze conselheiros (IBGC, 2017). A média de seis conselheiros por IEBT é um número bom em tamanho, e na composição, a maioria das IEBT, apontou que esses conselheiros são escolhidos por indicação da própria incubadora ou de sua mantenedora, possuindo qualificações para tal função.

Buscaram-se também informações sobre a presença de um conselho consultivo, que possui papel importante à medida que emite pareceres sobre as decisões a serem tomadas, trazendo um olhar 


\section{Administração: caminhos para o desenvolvimento sustentável}

externo para a incubadora. Permite que os conselheiros contribuam e melhorem gradualmente sua governança (IBGC, 2015), podendo ser acatadas ou não pelo gestor da incubadora.

Em relação ao conselho consultivo, 38\% afirmaram possuir conselho consultivo, com média de seis membros por conselho. O conselho consultivo permite que seus membros contribuam, de forma isenta, com suas competências no direcionamento da estratégia da incubadora. Também contribui com a capacidade da incubadora em integrar-se com os segmentos públicos e privados, uma vez que seus membros, via de regra, são indivíduos influentes na região. Ou seja, a presença de um conselho consultivo poderá influenciar positivamente na gestão e nas boas práticas de GC.

Outra parte integrante do sistema de governança das organizações é a presença de um Conselho Fiscal. Em relação à presença de um conselho fiscal, uma minoria (15\%) apresentam conselho fiscal constituído. O conselho fiscal age como um órgão fiscalizador da administração, buscando por meio de princípios de transparência, equidade e prestação de contas, contribuir para um melhor desempenho (IBGC, 2015). Como se pode observar nos dados das incubadoras, não parece haver preocupação efetiva com um modelo de governança, isto pode explicar a não constituição de conselhos e de uma estrutura mais sofisticada de fiscalização.

\section{CONCLUSÃO}

Para avaliar a relação do modelo de governança corporativa das incubadoras de empresas de base tecnológica brasileiras e seus desempenhos, foi essencial recorrer aos gestores das incubadoras de base tecnológica do Brasil, , coletando as informações referentes a governança considerando os principais objetivos das IEBTs que são a criação e graduação de empresas de base tecnológicaadotar práticas baseadas em conceitos de governança corporativa se apresenta como positiva para o bom funcionamento das IEBTs, principalmente no alcance de seus objetivo.

Espera-se que um aprimoramento em termos de governança contribua no desenvolvimento do sistema de inovação local, regional e nacional. Dessa forma, sugere-se aos gestores das IEBTs que revejam o modelo de governança que trabalham, estabeleçam objetivos com foco neste modelo e que busquem sensibilizar todos os seus stakeholders da importância das incubadoras para o desenvolvimento regional. É importante prosseguir os estudos na IEBTs, como medida de criação e crescimento de empresas de tecnologia, fomentando o desenvolvimento regional e auxiliando na transferência de conhecimento e tecnologia. 


\section{Administração: caminhos para o desenvolvimento sustentável}

\section{REFERÊNCIAS}

ANDRADE, A.; ROSSETTI, J. P. Governança Corporativa: fundamentos, desenvolvimento e tendências. São Paulo: Atlas, 2012.

ANPROTEC. Estudo de impacto econômico: segmento de incubadoras de empresas do Brasil - Brasília, DF: ANPROTEC: SEBRAE, 2016. 26 p.

ANPROTEC. Centro de referência para apoio a novos empreendimentos - CERNE . 3. ed. Brasília: ANPROTEC, 2015.

ANPROTEC. Associação Nacional de Entidades Promotoras de Empreendimentos Inovadores. 2017. http://ANPROTEC.org.br/site/ (25 de abril, 2018).

ANPROTEC - Associação Nacional de Entidades Promotoras de Empreendimentos Inovadores. Estudo, análise e proposições sobre as incubadoras de empresas no Brasil - Relatório técnico. Brasília, 2012.

BERGEK A.; NORRMAN C. Incubator best practice: A framework. Technovation, v. 28(1-2):20-28. February, 2008.

BRUNEEL, J.; RATINHO, T.; CLARYSSE, B.; GROEN, A. The Evolution of Business Incubators: Comparing demand and supply of business incubation services across different incubator generations. Technovation, v. 32, n. 2, p.110-121, 2012.

CHIOCHETTA, J. C. Proposta de um modelo de governança para parques tecnológicos. Universidade Federal do Rio Grande do Sul, 2010. 208 f. Tese (Doutorado em Engenharia da Produção) - Programa de Pós Graduação em Engenharia de Produção -Universidade Federal do Rio Grande do Sula, 2010.

CLARKE. T. Theories of Corporate Governance. Nova York: Routledge, 2004.

COLOMBO, M. G., DELMASTRO, M. How effective are technology incubators? Evidence from Italy. Research Policy. V. 31, 1103-1122, 2002.

ETZKOWITZ, H., DE MELLO, J. M. C., ALMEIDA, M. Towards “meta-innovation” in Brazil: The Evolution of the Incubator and the Emergence of a Triple Helix. Research Policy, 34(4), 411-424, 2005.

GALLON, A. V. Metodologia multicritério para auto-avaliação do microdistrito industrial (MIDI) tecnológico com vistas a alavancar seu desempenho e de suas EBTs incubadas. 2009. 428 f. Tese (Doutorado) - Universidade Federal de Santa Catarina, Programa de Pós-Graduação em Engenharia de Produção, Florianópolis, 2009.

\section{INSTITUTO BRASILEIRO DE GOVERNANÇA CORPORATIVA}

(IBGC). http://www.ibgc.org.br/inter.php?id=18066 (03 de Março de 2018).

INSTITUTO BRASILEIRO DE GOVERNANÇA CORPORATIVA (IBGC). Guia de orientação para o conselho fiscal. São Paulo, SP: IBGC, 2a ed. 2007.

INSTITUTO BRASILEIRO DE GOVERNANÇA CORPORATIVA (IBGC). código das melhores práticas de governança corporativa. São Paulo, SP: IBGC, 2 ed. 2015. 


\section{Administração: caminhos para o desenvolvimento sustentável}

MIAN, S. A. US university-sponsored technology incubators: an overview of management, policies and performance. Technovation, 14(8), 515-526, 1994.

MINISTÉRIO DA CIÊNCIA E TECNOLOGIA (MCTI). Proposta de Políticas para Parques Tecnológicos e Incubadoras de Empresas. Brasília: 2015.

NATIONAL BUSINESS INCUBATION ASSOCIATION - NBIA. Resource library. http://www.nbia.org (20 de março 2018).

PHAN, P. H.; SIEGEL, D. S.; WRIGHT, M. Science parks and incubators: observations, synthesis and future research. Journal of business venturing, v. 20, n. 2, p. 165-182, 2005.

RATINHO, T.; HENRIQUES, E. The role of Science parks and business incubators in converging countries: The Portuguese case. Technovation. v.30. 2010. p.278-290

SERRA, B.; SERRA, F. R.; FERREIRA, M. P.; FIATES, G. G. Fatores fundamentais para o desempenho de incubadoras de base tecnológica. RAI: Revista de Administração e Inovação, v. 8, n. 1, p. 221-247, 2011.

SHLEIFER, A.; VISHNY, R. W. A survey of corporate governance. Journal of finance, v.52, 737-783, 1997.

STORPER, M.; HARRISON, B. Flexibility, hierarchy and regional developments: the changing structure of industrial production systems and their forms of governance in the 1990s. Research Policy, vol. 20, n. 5, pp. 407-422, 1991.

VEDOVELLO, C. PUGA, F. P. FELIX, M. Criação de Infraestruturas Tecnológicas: A Experiência Brasileira de Incubadoras de Empresas. Revista do BNDES, Rio de Janeiro, v. 8, n. 16, p. 183-214, Dez. 2001.

WEELE, M.; RIJNSOEVER, F. J.; NAUTA, F. You can't always get what you want: How entrepreneur's perceived resource needs affect the incubator's assertiveness. Technovation, v. 59, p.18-33, 2017.

ZEDTWITZ, M. Classification and management of incubators: aligning strategic objectives and competitive scope for new business facilitation. International Journal of Entrepreneurship and Innovation Management. v. 3, n. 1/2, 2003. 


\section{Capítulo 16}

\section{TESSITURAS SOBRE O MARKETING RELIGIOSO EM BOM JESUS DA LAPA, BAHIA.}

DOI: $10.37423 / 200300396$

Deyse Queiros Santos, Universidade do Estado da Bahia-UNEB, Brasil queirosdeyse@gmail.com

Neivande Dias dà Silva, Universidade do Estado da Bahia-UNEB Brasil, neivande@hotmail.com

Cassiaha Santos da Siva Farias, Universidade do Estado da Bąhia-UNEB, Brasil cassiassss@gmail.com

Restumo: Eficazes estratégias de marketing têm sido utilizadas por todos os segmentos empresariais. Este àrtigo tem por objetivo mostrar como o marketing tamabem está presente nas instituições retigiesas modernas, que despertaram para a importância de atender desejos e necessidades dos consumidores potenciais da religião cristã. Para isso, tais instituiçõe investem cada vez mạis em estratégias mercadológicas para obtenção do crescimento numérico dos fiéis, atendẹndo, de forma eficiente, uma considerável demanda do mercado religioso. Trata-se de uma pesquişa básica de natureza qualitativa. Foi contemplada a pesquisa descritiva e os prodcedimentos de coleta de dados foram a pesquisa bibliográfica e a documental, que permitiram/inferir sobre-o papel do marketing no desenvolvimento do turismo religioso do município de Bom Jesus da-tapa. A cidade investigada adquifiu importância na rede urbana regional em função da ôferta dè serviços e coméreios modernos, o que tem favorecido a expansão das atividades econômicas, muito influenciada pelo o incremento do numero de fiéis e a evolução do perfil dos romeiros. 


\section{Administração: caminhos para o desenvolvimento sustentável}

Palavras-chave: Turismo religioso; Marketing; Desenvolvimento regional. 


\section{Administração: caminhos para o desenvolvimento sustentável}

\section{INTRODUÇÃO}

A religião, que outrora possuía mera função espiritual e dogmática, atualmente tem um papel diferenciado na sociedade. Essa diferenciação ocorreu, sobretudo, após o crescimento e a internacionalização do protestantismo norte-americano e o surgimento de novos movimentos católicos em meados do século XX, como a teologia da libertação e a renovação carismática católica (MACHADO, 2015). Essa nova orientação religiosa transformou os templos religiosos em espaços que, além de agradecer a deuses, buscar o perdão dos pecados, ou realizar sacramentos tornam-se um lugar de entretenimento, de bem-estar afetivo e social.

Associados com frequência aos templos estão às novas formas de relacionar-se com os fiéis e também da prática dos cultos. Um dos possíveis caminhos atualmente é o turismo religioso. Locais onde há templos religiosos ou onde houve alguma manifestação de importância religiosa gera visitação. Nestes locais são criadas estruturas receptivas que podem gerar aspectos positivos como o aumento da arrecadação financeira, a geração de empregos, a qualificação da mão-de-obra e o desenvolvimento urbanístico, dentre outros. Entretanto, há também problemas sociais, econômicos e urbanísticos que o turismo proporciona, principalmente quando a localidade não possui planos e estratégias de gestão (SANTOS, 2010)

O Turismo Religioso tem um importante papel na economia, na cultura e na sociedade onde ocorrem. Os impactos políticos costumam ocorrer na gestão e divulgação da um determinado atrativo. Além disso, é papel do Estado garantir saúde, educação, transporte, saneamento básico e melhores condições de vida para os moradores de uma localidade, mesmo que seus atrativos não sejam geridos pela esfera pública (TEIXEIRA \& JUNIOR, 2003). Os impactos culturais abordam a mudança na estrutura da sociedade (MACHADO, 2015). Os impactos econômicos costumam se manifestar mais claramente e geralmente são os mais citados pelos administradores e autoridades locais para abordar um sucesso/ fracasso de um atrativo. Já os impactos sociais são consequência direta do processo de turistificação local, e costumam ser os mais difíceis de obter resultados positivos (RIBEIRO, 2010).

Outro fator relevante são as estratégias de marketing que, independente do setor de atuação visam estabelecer as melhores formas de propagação, aceitação e venda de um produto ou serviço em um mercado específico de forma a atender as necessidades e desejos de seus consumidores (SILVA, 2005). As religiões possuem um cenário atual de intensa competição mercadológica, disputando entre si a busca da aquisição, preservação e manutenção de novos e antigos seguidores (MARIANO, 2004). Um 


\section{Administração: caminhos para o desenvolvimento sustentável}

exemplo é o atual crescimento das religiões protestantes frente ao catolicismo, que tem mobilizado a Igreja Católica a encontrar uma forma para evitar a evasão de fiéis (Fernandes, 1996).

A abordagem da religião sob os enfoques estratégicos e mercadológicos vêm sendo efetuados nos últimos anos, destacando-se levantamento de opinião da Igreja sobre os meios de comunicação de massa (FADUL,1986), análise do processo de comunicação na Igreja (DELLACAVA \& MONTEIRO, 1991), princípios básicos de marketing religioso (KATER FILHO, 1993), análise das formas de comunicação das Religiões (GOMES, 1987), estratégias de marketing religioso (MATAYOSHI, 2000) e análise do comportamento do consumidor religioso (SALVI \& GIGLIO, 2003).

Neste sentido, este trabalho procura entender aspectos relacionados às estratégias de fidelização para o aumento do grau de envolvimento pessoal dos católicos com a religião, bem como avaliar as possíveis consequências do marketing religioso no desenvolvimento da cidade de Bom Jesus da LapaBa.

\section{MARKETING RELIGIOSO}

Hoje não causa mais espanto saber que as atividades humanas foram despertadas para a necessidade de persuasão e conquista. É assim no comércio, na indústria, nos serviços, na educação, na informação, na religião etc. Para as religiões que se encontram irremediavelmente submersas numa parafernália de símbolos e apelos, e mergulhadas na aberta permissão para a existência de uma “incômoda" pluralidade religiosa, o marketing passa a ser adotado nas diversas denominações religiosas com muita facilidade, e normalmente é visto como um instrumento eficaz no competitivo mercado religioso (CAMPÁ, 1998).

Num contexto de globalização, onde a oferta religiosa é cada vez mais diversificada, onde a informação se difunde a uma velocidade estonteante e onde cada pessoa se torna mais livre relativamente às escolhas que faz, o marketing surge como uma ferramenta útil para adequar a oferta que temos e para melhor definir aquela que é a nossa marca (KATTER FILHO, 1995). Estes consumidores da religião têm muitas necessidades de ordem espiritual, psíquica e emocional insatisfeitas, e podem perfeitamente satisfazê-las através da "compra de promessas religiosas" (PATRIOTA, 2003).

Pautando-se nessas oportunidades, alguns religiosos encontram o nicho, e compreendem a religião como um produto extremamente vendável na atual sociedade de consumo. Campos (1999) afirma que essa percepção: 


\section{Administração: caminhos para o desenvolvimento sustentável}

Propaga-se numa sociedade pluralista e com tendências à secularização, cujo campo sintonizadas com as necessidades e desejos de um público devidamente segmentado, religioso concorrencial e turbulento facilita o surgimento de instituições ágeis, formando assim seu próprio mercado, empregando para isso estratégias de marketing e de propaganda, as quais se exteriorizam em ritos, retórica, teologia, formas administrativas e organizacionais, adaptáveis aos interesses de uma sociedade capitalista em processo de globalização (CAMPOS, 1999, p 357).

O "nicho mercadológico" achado pelas igrejas cristãs que investem em marketing tem sido explorado de forma impressionante com a rapidez peculiar ao atual desenvolvimento tecnológico, e com os instrumentais da comunicação, elas desenvolveram um discurso próprio, uma teologia própria e uma linguagem padronizada e eficaz, invadindo sem cerimônia alguma, muitos lares através do rádio e da televisão (PATRIOTA, 2000).

O marketing é uma ciência social que tem por base uma teoria provinda da mais antiga ciência: a economia (BARNA, 1997). Desta forma, a par do que acontece na economia com o fenômeno da determinação do valor, em que existe uma estreita relação com a troca, também o marketing estuda as transações que remetem para a necessidade da troca de valores entre os intervenientes ("clientes" e organização).

O Marketing Religioso consiste na aplicação do marketing a um campo específico: a todas as organizações religiosas que têm como fundamento da sua existência a satisfação das necessidades espirituais e religiosas da pessoa (ABREU, 2004, BARNA, 1997). O seu objetivo prende-se com o desenvolvimento das organizações religiosas, procedendo-se para o efeito, à boa gestão das relações de troca que estabelece com os intervenientes, por forma a conseguir alcançar eficientemente a sua missão.

No marketing tradicional uma empresa oferece, ou torna disponível, produtos físicos, previamente guiados pela observação dos "anseios" do cliente. Nestes produtos, a empresa acrescenta "valores intangíveis", que se prontificam a satisfazer de imediato às necessidades latentes do consumidor (HOFFMAN \& BATESON, 2001). No entanto, mesmo que estas necessidades não sejam verdadeiramente latentes, o marketing, lançando mão da propaganda, se encarregará de convencer o possível cliente de que ele necessita realmente do produto oferecido.

Partindo dessa premissa, podemos analisar a materialidade de alguns discursos religiosos e ver que eles reproduzem integralmente o discurso publicitário no item persuasão. Nestes discursos, a 


\section{Administração: caminhos para o desenvolvimento sustentável}

argumentação religiosa parte de se dar aos "produtos da fé", uma vantagem competitiva sobre os oferecidos por outras igrejas que não têm a preocupação de trabalhar as suas embalagens.

Além disso, o marketing religioso, tal como outras concepções dentro do conceito de marketing remete-nos para a importância de bem servir as pessoas, havendo por isso que desvalorizar a associação depreciativa que ainda se faz do marketing às campanhas publicitárias, ou seja, ao comércio, aspecto menos bem avaliado (GRONROOS, 1997).

Com efeito, sendo de crucial importância conhecer os públicos para dessa forma melhor se poder agir sobre eles, torna-se imperativo iniciar as atividades de marketing estratégico que se podem sumariar nos seguintes procedimentos: segmentação, escolha do alvo, posicionamento.

\subsection{TURISMO RELIGIOSO NO BRASIL}

O Ministério do Turismo (MTur), órgão responsável por gerir e promover o turismo dentro do território brasileiro, traz na publicação Turismo Cultural: Orientações Básicas (2010) o seu próprio conceito para a atividade. De acordo com o MTur (2010), o turismo religioso:

[...] configura-se pelas atividades turísticas decorrentes da busca espiritual e da prática religiosa em espaços e eventos relacionados às religiões institucionalizadas, independentemente da origem étnica ou do credo [...] Está relacionado às religiões institucionalizadas, tais como as de origem oriental, afro-brasileiras, espíritas, protestantes, católica, composta de doutrinas, hierarquias, estruturas, templos, rituais e sacerdócio. (BRASIL, 2010, p. 19).

Os critérios utilizados para processar a segmentação podem incluir a idade, nível de renda, meio de transporte, duração da permanência, distância do mercado consumidor, tipo de grupo, sentido do fluxo turístico, condição geográfica da destinação turística, aspecto cultural, grau de urbanização da destinação turístico (IGNARRA, 2003).

$\mathrm{Na}$ atualidade a segmentação do mercado de turismo, uma vez que esta responde a demandas historicamente localizadas, se apresenta com os seguintes seguimentos: turismo científico, cultural, de estudos, de intercâmbio, pedagógico, de raízes, de eventos, de negócios, comercial, e no turismo, de golfe, espacial (Trigo et al, 2005). Despontam ainda como importantes seguimentos específicos do mercado turístico o turismo religioso e o turismo social.

O turismo religioso como fato social, gerador de deslocamento, que envolve públicos emissor e receptor, tem sua origem em tempos remotos, tendo em vista que peregrinações, romarias, festas 


\section{Administração: caminhos para o desenvolvimento sustentável}

religiosas desde muito antes do nascimento de Jesus Cristo já mobilizavam pessoas que viajavam motivados por suas crenças e por objetivos ligados ao transcendente. De acordo com dados preliminares do Departamento de Estudos e Pesquisas do MTur, em 2015, cerca de 17,7 milhões de brasileiros viajaram pelo país levados pela fé. Cerca de 10 milhões fizeram viagens sem pernoitar no destino (excursionistas) e outros 7,7 milhões permaneceram pelo menos uma noite no local.

Entre os destinos de turismo religioso consolidados no país também estão o Círio de Nazaré (Belém, PA), uma das maiores festas religiosas do mundo, que reúne cerca de um milhão e meio de pessoas em outubro; a Romaria à Juazeiro (Juazeiro do Norte, CE), que recebe cerca de dois milhões de devotos de Padre Cícero por ano; a Romaria de Bom Jesus da Lapa, com cerca de um milhão de peregrinos todo ano.

\subsection{Romaria de Bom Jesus da Lapa}

Caminhar, peregrinar, fazer romarias não é algo novo para o povo católico. Há séculos existem santuários nacionais, regionais e locais espalhados por todo o Brasil. Multidões continuam acorrendo a eles, apesar das grandes mudanças que se verificam no campo religioso brasileiro (AZZI, 1979). São tradições arraigadas em antigos costumes, repassados de geração a geração. Rosendal (2002) em suas pesquisas sobre três santuários populares, diz que as festas, procissões e romarias são as práticas mais sensacionais da religião popular, um tempo forte de imensa vivência religiosa, no qual ocorre visivelmente o encontro simbólico do santo com o povo, num controle direto, sem intermediários.

Romaria do Bom Jesus teve seu inicio no final do século XVII e tem seu ponto alto no dia 06 de agosto com a celebração da missa do romeiro na Esplanada do Santuário. É o evento religioso que reúne o maior número de fiéis na cidade e mobiliza todo espaço urbano da Hierópolis. As grutas, o morro e a água que brota das rochas são elementos naturais revestidos de sacralidade (MICEF, 2006).

Durante todo o ano a cidade de Bom Jesus da Lapa recebe romeiros e turistas no santuário do Bom Jesus, porém a visitação se intensifica no período do novenário ao santo padroeiro, com realização de celebrações todos os dias e nos três os turnos de forma a atender às demandas dos visitantes, que é grande. Celebrações são realizadas também na parte externa do templo religioso e seguem pelas ruas, agregando cada vez mais pessoas. O maior quantitativo de pessoas acontece, especialmente, em 06 de agosto, quando a procissão percorre as ruas com o andor com a imagem do Bom Jesus (SILVA, 2017). 


\section{Administração: caminhos para o desenvolvimento sustentável}

As tradições de culto aos santos vêm da Europa, mas são recriadas pelos crentes, que utilizam uma linguagem simbólica e litúrgica peculiar para cultuar os seus santos protetores nos lugares sagrados (SOUZA, 1991). A missa, a confissão e a eucaristia fazem parte da liturgia formal da Igreja, da qual o romeiro participa. Entretanto, práticas como a subida do morro, a via sacra, a promessa e vários cânticos, dos quais muitos são desconhecidos pelos párocos locais, fazem parte do amplo e diverso leque de atividades religiosas dos meios populares, muito utilizadas pelos peregrinos do Bom Jesus.

A vida econômica e social da cidade de Bom Jesus da Lapa está estruturada em torno da romaria do Bom Jesus, assim, os afluxos de romeiros ao longo de todo o ano trazem dividendos, influencia a forma de organizar a vida familiar, influencia também o calendário civil da cidade (escolar, semanas temática, atividades recreativas) e estabelece o ritmo cotidiano da vida das pessoas que ali residem (STEIL, 1996). Nos festejos do Bom Jesus, onde a participação popular aumenta exponencialmente o número de pessoas na cidade em relação ao número de habitantes, os moradores locais deixam as suas próprias casas a fim alugá-las aos romeiros e turistas e auferir algum lucro durante a peregrinação.

Embora o público que frequenta o santuário, na romaria-turismo do Bom Jesus, seja pobre e vítima de exclusão socioeconômica não deixa de influenciar no aporte financeiro que a cidade arrecada como também concorre para aquecer a economia do município e da região em seu entorno (MICEF, 2006). Durante seis meses um considerável número de comerciantes se coloca na expectativa da realização dos eventos tendo em vista os benefícios daí advindos, ou seja, a intensificação do consumo por parte dos visitantes e a consequente obtenção de lucros. Há uma tendência de se explorar ao máximo as atividades comerciais, na esperança de se ter assegurada a sobrevivência por mais um período, reproduzindo-se dessa forma o ciclo da "economia da romaria". Durante os outros seis meses, diante das limitações do mercado de trabalho, manifesta-se um aparente estado de apatia (SANTOS, 2010).

A romaria do Bom Jesus da Lapa, de 29 de julho a 06 de agosto, não é a única que acontece durante o ano para o Santuário, existem outras que reúnem um número expressivo de devotos e que vão de julho a janeiro de cada ano. Conforme o site do Santuário (www.bomjesusdalapa.org.br), são elas: Romaria da Terra e das Águas, sempre no primeiro semestre de cada ano; 28 de julho a 06 de agosto, novenário do Senhor Bom Jesus; 15 de agosto, Romaria Diocesana dos Coroinhas; 05 a 06 de setembro, Romaria da Pastoral da Criança; 08 a 15 de setembro, setenário de Nossa Senhora da Soledade; 18 a 20 de setembro, Romaria dos Agentes Comunitários de Saúde e Endemias; 04 de outubro, festa do fundador do Santuário, Francisco de Mendonça Mar; 12 de outubro, festa de Nossa Senhora 


\section{Administração: caminhos para o desenvolvimento sustentável}

Aparecida, com a visita da imagem (2009); 18 de outubro, Romaria da Renovação Carismática; 25 de outubro, Romaria da Legião de Maria; 08 de dezembro, Festa da Imaculada Conceição; 13 de dezembro, Festa de Santa Luzia; 31 de janeiro, festa de Bom Jesus dos Navegantes.

Dessas podemos destacar três como sendo as principais, por conta da quantidade de pessoas que participam - a romaria da Terra e das Águas, organizada pela CPT (Comissão Pastoral da Terra) do regional da CNBB (Conferência Nacional dos Bispos dos Brasil) da Bahia e de Sergipe e pelas CPTs diocesanas das Dioceses da Barra, Barreiras, Lapa, Irecê, Caetité e da arquidiocese de Vitória da Conquista; a Romaria do Bom Jesus da Lapa (em agosto) e a de Nossa Senhora da Soledade (em setembro).

O fluxo de peregrinos, com festas, rezas e todo um conjunto de atos rituais e devocionais, os números e estatísticas, teve início com um homem apenas, chamado Francisco Mendonça Mar, nascido em Portugal e que veio para o Brasil e desempenhou as funções de ourives e pintor e, em dado momento de sua história, foi o pivô da devoção ao Bom Jesus e Nossa Senhora da Soledade (SANTOS, 2010). Francisco de Mendonça Mar, nascido em Portugal, em 1657, era filho de um ourives, em Lisboa. Além de exercer a profissão do pai, era também pintor. Com vinte e poucos anos de idade, em 1679, chegou à Bahia, onde se instalou, tendo sua própria oficina e serventes - escravos. (MICEF, 2006 \& STEIL, 1996).

A presença desses religiosos na região e a devoção em torno das figuras de Jesus e Maria, representadas nas imagens do Crucificado e de Nossa Senhora, deram início à povoação do entorno da gruta e posteriormente à edificação da vila e da cidade. O município possui uma população de 68.609 habitantes de acordo com o Instituto Brasileiro de Geografia e Estatística IBGE, (2018) localizase no extremo Oeste do Estado, e distante 796 km de Salvador, no Território de Identidade do Velho Chico, e fica às margens do Rio São Francisco.

A festa do Bom Jesus da Lapa é, para os seus participantes, a vivência anual do extraordinário, do rompimento da rotina, da vivência de eventos simbólicos de capilaridade social que, pela extensão alcançada envolve diversas sociedades (oeste baiano, sul da Bahia, além de outros estados da federação), propiciando momentos extraordinários de interpretação, comunicação e transformação, produzindo condições de lançar um olhar diferenciado sobre a própria sociedade onde estes indivíduos estão inseridos, levando-os a refletir sobre as múltiplas realidades que os abarca (Mota, 2008). 


\section{Administração: caminhos para o desenvolvimento sustentável}

\section{ROMARIA DE BOM JESUS DA LAPA ASPECTOS ECONÔMICOS}

O turismo brasileiro apresenta, a cada ano, números mais expressivos em relação ao segmento religioso. De acordo com dados preliminares do Departamento de Estudos e Pesquisas do Ministério do Turismo (MTur), em 2014, cerca de 17,7 milhões de brasileiros viajaram pelo país levados pela fé (ABEOC, 2016).

Um levantamento realizado pelo MTur mostrou que mais de 344 municípios brasileiros promovem eventos que envolvem a fé, totalizando 96 eventos religiosos, entre eles pontos de peregrinação de fiéis e celebrações que atraem milhares de visitantes. Essas localidades se apropriaram de aspectos religiosos regionais e os transformaram em produtos turísticos, gerando uma fonte de desenvolvimento econômico e cultural para a comunidade local. O turismo religioso representa mais de 3\% de toda a movimentação do turismo nacional, movimentando em torno de 15 bilhões de reais anualmente, evidenciando sua importância para a economia nacional, sobretudo em tempos de crise (ABEOC, 2016).

Ainda de acordo com este levantamento, este segmento tem impulsionado economias locais e atraído pequenos negócios, além de movimentar setores da indústria, comércio, serviços e artesanato, gerando emprego e renda no país, e, tornando esse, um dos segmentos mais promissores do turismo nacional.

De acordo com cifras do Vaticano, o Brasil é o país com o maior número de católicos do mundo - mais de $12 \%$ da população católica mundial. Isso corresponde a 137 milhões de pessoas, quase a população da Rússia. Ainda segundo o Relatório de Tendências 2015 da WTM Latin America, apontou que 7,7 milhões de viagens domésticas feitas no Brasil em 2014 foram relacionadas à fé. Para efeito de comparação, essa cifra é equivalente ao número total de viagens domésticas realizadas no Uruguai em 2012.

O fluxo de romeiros, presente na cidade durante o ano todo, tem uma grande importância para as atividades econômicas, principalmente os serviços de hospedagem e de comércio (este será analisado posteriormente). Atualmente há aproximadamente 11 mil leitos distribuídos entre hotéis, pousadas, rancharias e dormitórios destinados ao aluguel diário (SANTOS, 2015). Com este total de leitos, Bom Jesus da Lapa ocupa o quarto lugar na Bahia, depois de Salvador, Porto Seguro e Feira de Santana, respectivamente. 


\section{Administração: caminhos para o desenvolvimento sustentável}

Há uma forte concentração dos hotéis e pousadas nas proximidades do Santuário, são os chamados "hotéis para romeiros". Uma característica típica desses hotéis é que a maioria é familiar, nos quais é comum a família, além de trabalhar, residir no próprio estabelecimento, compartilhando com o hóspede a sua sala de estar. Dividir o espaço da residência com o local de trabalho é uma das características do circuito inferior da economia urbana (SILVA, 2001).

Há alguns anos atrás foi criada a agência internacional do Vaticano, e esta agência de viagens oficial da igreja católica classificou algumas cidades do mundo para o seu roteiro turístico religioso internacional (SANTOS, 2015). No Brasil, foram classificadas as cidades de Aparecida (SP), Senhor do Bonfim e Bom Jesus da Lapa (BA). Isso quer dizer que essas cidades têm que passar por um padrão internacional de qualificação, principalmente em prestação de diversos tipos de serviços para receber essa "clientela" mais exigente e seleta.

Estas recentes transformações da romaria lapense favorecem o crescimento de atividades econômicas mais modernas. No entanto, vale destacar a importância das romarias como reduto do circuito inferior da economia urbana lapense, em função da proliferação de formas de trabalho e de geração de renda que ocorre apenas no período de maior fluxo. Neste sentido, a expansão de atividades típicas do circuito superior da economia urbana parece apontar para uma "invasão progressiva do mercado pobre pelas maiores empresas" (MONTENEGRO, 2011).

A cidade se destaca na rede urbana regional por oferecer diversos comércios e serviços modernos, especialmente os serviços públicos em função da presença de instituições tais como: Superintendência Regional da CODEVASF, Justiça do Trabalho, Promotoria Regional do Ministério Público, Juizado Especial, Justiça Federal, Inspetoria Fazendária, Unidade Avançada do INCRA, presença de instituições administradas pela Marinha, Aeronáutica e o Exército, Bancos (Banco do Brasil, Caixa Econômica Federal, Bradesco, Nordeste, Itaú, Bonsucesso e CredNordeste, etc.), Instituições de Ensino (UNEB, IFBAIANO, UBA, UNIP, UNISA e UNOPAR), serviços de saúde (SAMU, UPA, Maternidade), presença de grandes lojas como a Insinuante, Novo Mundo e Magazine Luiza e de algumas franquias como Microlins, FISK, Cacau Show, Subway, O Boticário, etc.

Atualmente, grande parte desses serviços e comércio é encontrada no oeste da Bahia apenas nas cidades de Bom Jesus da Lapa e Barreiras. Estes dados apontam a importante expansão do circuito superior (Santos, 2015) na cidade, especialmente a partir da década de 1990, mas, sobretudo na última década. 


\section{Administração: caminhos para o desenvolvimento sustentável}

Com a presença destas atividades econômicas anteriormente apresentadas, a cidade de Bom Jesus da Lapa além de se tornar relativamente conhecida no âmbito nacional por acolher o terceiro maior santuário do país (depois dos santuários de Aparecida/SP e Juazeiro do Norte/CE, respectivamente), também adquiriu uma importância significativa na rede urbana regional devido à sua oferta de serviços e de comércios modernos, bem como em função da sua rede de transportes que opera diariamente na região e no estado através de rodovias que ligam essa cidade aos centros urbanos mais importantes da rede urbana da Bahia. Essas recentes mudanças tiveram fortes implicações no espaço urbano de Bom Jesus da Lapa, a exemplo da expansão da mancha urbana do município (SILVA, 2001).

O tipo de economia e o fato do turismo religioso estar atrelado à história do desenvolvimento do município, além de outros fatores contemporâneos que levaram a diminuição das áreas rurais e ao aumento da urbanização, atingiram o município de Bom Jesus da Lapa (IBGE, 2010). Entretanto, o grau de urbanização deste município (68\%) é inferior a Juazeiro do Norte (96\%), Aparecida-SP (99\%) e do estado da Bahia (72\%). O Território de Cidadania Velho Chico, onde está localizado o município de Bom Jesus da Lapa, tem forte presença da agricultura familiar. Além disso, com a instalação do Perímetro Irrigado do Formoso nas ultimas décadas, situado a 30 quilômetros da cidade, houve uma expansão da agricultura no município. Nos anos de 2011 e 2012, Bom Jesus da Lapa foi o município que apresentou a maior produção de banana no Brasil, cujo valor bruto de comercialização foi de $R \$$ 112 milhões (quase um terço do PIB municipal) e também na geração de empregos, uma vez que, no perímetro irrigado são mantidos sete mil empregos diretos e 10,5 mil empregos indiretos, (CODEVASF, 2013).

Com relação aos domicílios permanentes, segundo dados do IBGE (2010), 78\% de agua encanada, 94\% de energia elétrica e $27 \%$ com esgotamento sanitário. Esses valores são inferiores aos observados em Juazeiro do Norte que dispõe de $93 \%$ de agua encanada, $100 \%$ de energia elétrica e $34 \%$ com esgotamento sanitário; Aparecida-SP com 98\% de agua encanada, 100\% de energia elétrica e 95\% com esgotamento sanitário; e o estado da Bahia com 80\% de agua encanada, 96\% de energia elétrica e $45 \%$ com esgotamento sanitário.

Em 2010, do total da população, 44\% foram consideradas economicamente ativas, sendo $77 \%$ desta ocupadas e $12 \%$ desocupadas. Estes dados são similares aos encontrados no Estado da Bahia, com $89 \%$ e $11 \%$, respectivamente e contrastantes com os regionais, que apresentaram $91 \%$ e $9 \%$, respectivamente, para os mesmos indicadores. Entre 2006 e 2014, o numero de pessoas ocupadas 


\section{Administração: caminhos para o desenvolvimento sustentável}

cresceu linearmente no município, com incremento de $51 \%$ neste período (IBGE, 2010). Esses resultados tiveram reflexos também no numero de pessoas assalariadas, com acréscimos de $61 \%$.

O salário médio mensal de todo município é composto de 1,9 salários mínimos e a renda per capta de $\mathrm{R} \$$ 443,16 (Figura 02). Comparando com a renda de Aparecida-SP e Juazeiro do Norte, pode-se

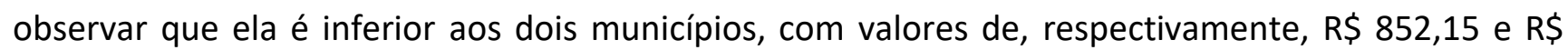
509,05, e menor que a do Estado $\mathrm{R} \$ 559,77$ (IPEA, 2016). Comparando-se com os anos de 2006 até 2014, percebe-se pouca variação em ganhos médios mensais. Desta forma, mesmo com bom índice de emprego, o salário dos moradores é mais baixo que o do estado e da região, caracterizando por empregos nas atividades de serviços voltadas ao turismo.

Assim, pode-se observar que na geração de emprego e renda para a população, o turismo como impacto é positivo quanto à empregabilidade, mas não quanto à remuneração destes empregos, que é baixo em relação à média do Estado. Também se considera alto o peso que o turismo religioso tem na economia do município e, por conseguinte, a sua dependência, não aparecendo muitas oportunidades de renda e geração de empregos em outros setores.

Figura 01 - Média de salário mensal dos municípios de Bom Jesus da Lapa- BA, Juazeiro do Norte-CE e Aparecida-SP.

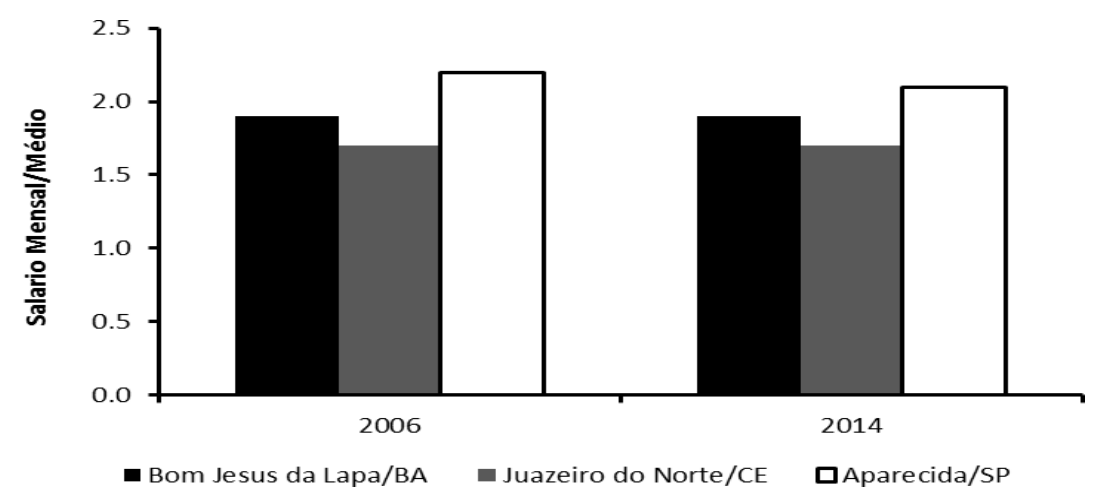

FONTE: IBGE, (2010).

Segundo o IBGE (2010) no município de Bom Jesus da Lapa 12\% das residências sobreviviam com até 1/2 de salário mínimo mensal por morador (1988 domicílios), 24\% sobreviviam com $1 / 2$ até um salário mínimo por pessoa (3878 domicílios), 28\% recebiam entre um a dois salários (4500 domicílios), 20\% 


\section{Administração: caminhos para o desenvolvimento sustentável}

tinham rendimento mensal entre 2 a 5 salários mínimos (3301 domicílios) e 9\% não tinham rendimento (1414 domicílios). Estes resultados contrastam com o Estado da Bahia, onde $41 \%$ das residências sobreviviam com menos de $1 / 2$ salário mínimo mensal por morador, $29 \%$ sobreviviam com $1 / 2$ até um salário mínimo para cada pessoa, $14 \%$ recebiam entre um a dois salários, $7 \%$ tinham rendimento mensal entre 2 a 5 salários mínimos e apenas 5\% não tinham rendimento. Na região do Nordeste, $38,1 \%$ das residências sobreviviam com menos de $1 / 2$ salário mínimo por morador, 29,9\% sobreviviam com $1 / 2$ até um salário mínimo por pessoa, $16 \%$ recebiam entre um a dois salários, 6,5\% tinham rendimento mensal entre 2 a 5 salários e apenas 2,9\% não tinham rendimento.

O PIB de Bom Jesus da Lapa, segundo o IBGE (2013) foi de $R \$ 348.399 .00$, sendo o setor de serviços responsável por 72\%, seguido por setor Agropecuário (20\%) e Industrial (8\%) (Figura 03). Em Juazeiro do Norte, o setor de serviços contribuiu com $84 \%$ ( $R \$ 2,284,884.0)$ do PIB, contra $16 \%(R \$ 423,994.0)$ da indústria e $1 \%$ do setor agropecuário ( $R \$ 18,953.0)$. Em Aparecida-SP, 88\% da produção interna esta associado ao setor de serviços ( $R \$ 606,905.0), 11,8 \%$ ao setor industrial ( $R \$ 81,057.0$ ) e apenas $0,2 \%(R \$ 1,480.00)$ ao setor agropecuário.

Figura 02 - Distribuição do Produto Interno Bruto do município de Bom Jesus da Lapa-Ba.

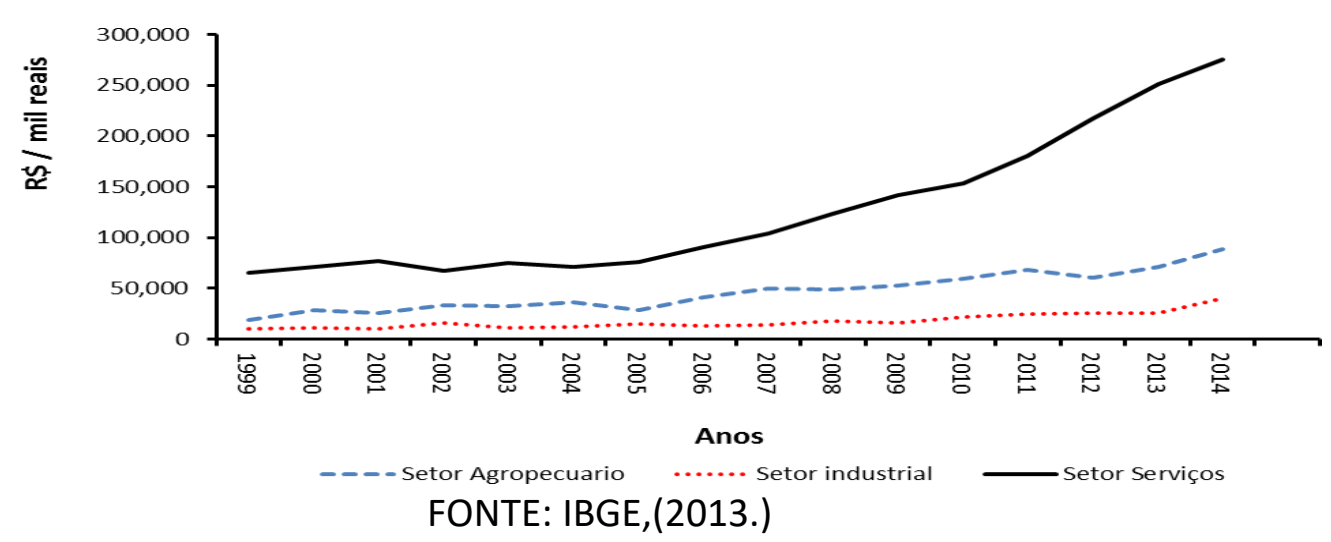

Entre 2006 e 2014, o numero de empresas atuantes cresceu de forma lenta no município de Bom Jesus da Lapa, com oscilações durante os anos e acréscimo não superior a $12 \%$. Esses resultados foram similares em Aparecida-SP e inferiores a Juazeiro do Norte, que em 2013 apresentou crescimento de $24 \%$ e 2014 valores chegaram a 14\% (IBGE, 2016).

O comércio e o setor hoteleiro e alimentício, associados ao turismo religioso gerido ao redor de Bom Jesus da Lapa, representaram as principais fontes de renda da cidade segundo dados do IBGE (2013), com $46 \%$ do total das fontes de renda per capita do município. Somam-se ainda a pecuária e a 


\section{Administração: caminhos para o desenvolvimento sustentável}

agricultura, que acrescentou $\mathrm{R} \$ 70.822$ mil reais na economia (13\%), Impostos, líquidos de subsídios, sobre produtos, a preços correntes (8\%), Administração, saúde e educação públicas e seguridade social, a preços correntes (29\%) e Indústria (5\%).

O circuito inferior em Bom Jesus da Lapa também tem papel importante na economia do município. Grande parte concentra-se na área central da cidade, onde existe maior fluxo de consumidores, a saber: principais avenidas, praças, mercado municipal, santuário, hospital, agências bancárias, etc. Dentre os pequenos comércios que pagam taxas ao poder público, consta no setor de tributos da Prefeitura Municipal um total de 395 estabelecimentos compostos por barracas ou bancas nas calçadas, ruas e praças para comercialização de qualquer produto; constam também 238 permissionários que atuam no mercado municipal, cujos produtos comercializados apresentam uma enorme diversidade (raízes medicinais, açougue, hortifrúti, peixaria, restaurante etc.). Estes dois tipos de estabelecimentos ocupam o segundo e o terceiro lugar, respectivamente, entre aqueles (sejam do circuito superior ou inferior) que pagam taxas à Prefeitura Municipal de Bom Jesus da Lapa (SANTOS, 2015).

Além destes pequenos negócios que são os mais representativos, pode-se observar ainda diversos tipos de pequenos estabelecimentos comerciais tanto na área central quanto nos bairros visitados. Nestes últimos, a economia popular encontra os seus consumidores na vizinhança, pois não conta com os mesmos fluxos de pessoas presentes na área central da cidade. Segundo Santos (2010), junto ao setor de tributação da Prefeitura Municipal de Bom Jesus da Lapa, para as romarias de 2014 foram emitidos 435 alvarás temporários distribuídos entre as atividades denominadas como: barracas ou pontos para comercialização de qualquer produto, tendas, vendedores de carrinho ambulante, carro de rapadura ou alho, diversões, parques de diversões, carro de rede, ambulante, etc.

Além dos agentes que atuam sazonalmente, nas romarias de Bom Jesus da Lapa também têm grande importância os trabalhadores do comércio de rua permanente, já os meses de julho a outubro, período em que ocorrem as grandes romarias, são considerados os meses de maiores vendas no comercio, o que demonstra a importância das romarias para o comércio sazonal, mas, sobretudo para a economia local.

De acordo com os estudos de Santos (2015) que traçou um perfil dos visitantes durante os eventos festivos de Bom Jesus da Lapa, 90,9\% dos turistas tiveram como principal motivo da viagem o próprio evento religioso, e apenas $9,1 \%$ visitaram as localidades por outros motivos. O próprio estado da Bahia foi o maior emissor de turistas domésticos aos municípios de pesquisa, com $78,8 \%$ do total de 


\section{Administração: caminhos para o desenvolvimento sustentável}

entrevistados. Observa- se também a incidência de turistas residentes em outros estados, como Minas Gerais (6,0\%) e São Paulo (4,6\%). A permanência média dos turistas entrevistados foi de 3,8 pernoites no estado da Bahia e 3,1 pernoites na localidade, fato explicado pela duração média dos festejos, que ocorriam ao longo de cinco dias a uma semana em ambas as cidades pesquisadas.

O gasto médio per capita efetivado somente dentro da localidade pesquisada pelos turistas que visitaram as cidades ao longo da etapa foi de $\mathrm{R} \$ \mathbf{6 2 5 , 0 5}$, sendo distribuídos entre hospedagem (31,0\%), alimentação $(13,8 \%)$, diversão noturna $(11,9 \%)$, compras de artigos religiosos $(11,7 \%)$, compras pessoais $(10,2 \%)$, atrativos e passeios $(10,0 \%)$, transporte local $(4,5 \%)$ e outros $(6,9 \%)$.

Os dados também apontam que mais da metade dos turistas $(72,0 \%)$ já tinha participado por outras vezes dos eventos religiosos pesquisados, um dado positivo, já que o retorno indica, muitas vezes, a satisfação do turista. Esse parecer ainda é reforçado com o dado de que $83,6 \%$ dos turistas tiveram suas expectativas superadas ou atendidas. A pesquisa mostra que cerca de $93,0 \%$ dos turistas entrevistados retornariam aos eventos pesquisados, e que mais de $98,0 \%$ os recomendariam a outras pessoas (IBGE, 2016).

Em relação à estrutura turística e de serviços das localidades, a maioria dos itens tiveram a avaliação positiva ("bom" ou "muito bom") de mais de $50,0 \%$ dos turistas, com exceção dos guias de turismo (avaliação negativa de 62,7\%), serviços de comunicação (avaliação negativa de 53,9\%), serviços médicos (avaliação negativa de 51,1\%) e sanitários públicos (avaliação negativa de 72,5\%). O destaque das avaliações positivas fica com a religiosidade $(99,7 \%)$, programação religiosa $(98,9 \%)$, patrimônio histórico/cultural (95,2\%), manifestações populares (95,7\%) e hospitalidade/povo (98,1\%).

Entre os aspectos que mais agradaram aos visitantes das localidades pesquisadas destacaram-se a programação religiosa, as missas, as procissões e a religiosidade e hospitalidade do povo.

\subsection{ASPECTOS SOCIAIS}

O turismo apresentou-se como um importante segmento para a dinâmica econômica de uma localidade. As teorias de desenvolvimento endógeno apresentaram- se como fortes aliadas do desenvolvimento local através do turismo, pois a oferta turística está em função não apenas dos atores locais, mas também da maneira como atuam conjuntamente, levando em consideração valores intangíveis: cultura local e identidade territorial (GUILLAUMON, 2011).

A população economicamente ativa no município gira em torno de $61,4 \%$, valor bem próximo ao observado em Juazeiro do Norte 62,8\%, entretanto inferior a Aparecida-SP 67\%. No estado da Bahia e 


\section{Administração: caminhos para o desenvolvimento sustentável}

na região do Nordeste, os valores são similares, $61,9 \%$ e $62,3 \%$, respectivamente. 0 Índice de Desenvolvimento Humano (IDH) aumentou entre os anos de 1991 a 2010, elevando o patamar de classificação de baixo (menos que 0,555) para médio (de 0,555 a 0,699) (Figura 04). Esses resultados também poderão ser observados em Juazeiro do Norte, de 0,42 para 0,69 (IBGE, 2016). Em AparecidaSP, os resultados foram ainda melhores, com o município evoluindo do IDH médio para o elevado.

Os países com IDH médio apresentam um grupo heterogêneo, e em geral vêm apresentando relativas melhoras em seus IDHs ao longo dos últimos anos, combatendo problemas sociais de saúde e educação, mas ainda estão muito longes de promover uma democrática distribuição de renda. Os países com baixo IDH são aqueles com graves problemas socioeconômicos, e muitos convivem com dificuldade no acesso a recursos básicos, como água e alimentos.

Figura 03 - Evolução do Índice de Desenvolvimento Humanos dos municípios de Bom Jesus da Lapa-

Ba, Juazeiro do Norte-CE e Aparecida-SP.

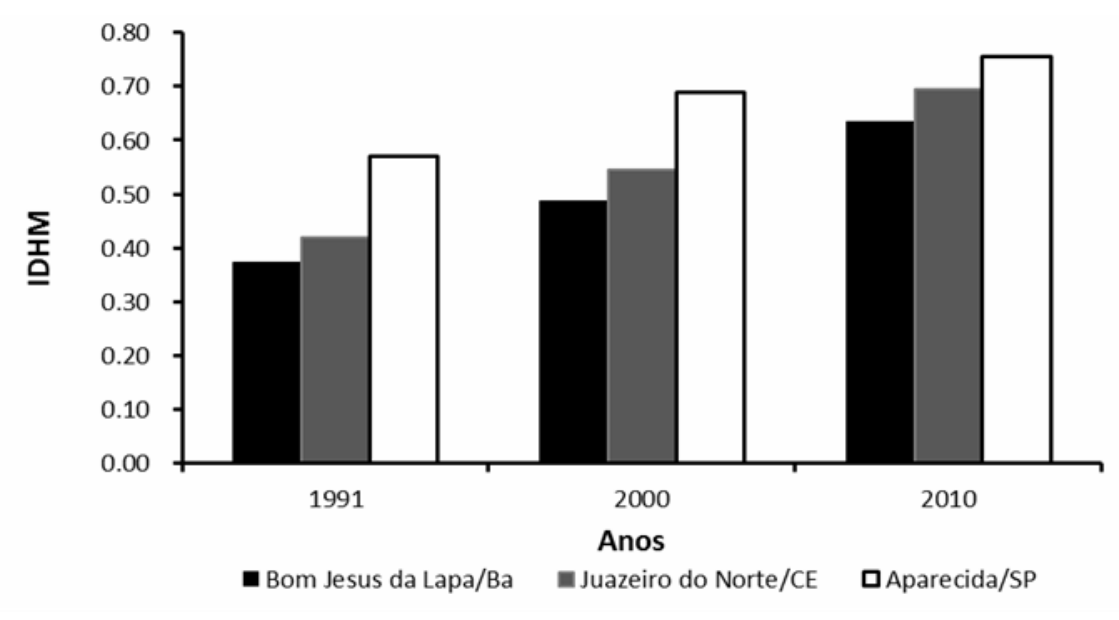

Fonte: IBGE, (2016.)

As taxas de analfabetismo em Bom Jesus da Lapa e Aparecida caíram entre os anos de 2000 e 2010, saindo de $25,4 \%$ para $19,2 \%(3,43 \%)$ e $5,5 \%$ para $3,4 \%$, respectivamente. Estes resultados foram ainda mais expressivos em Juazeiro do Norte- CE, 25,0\% para 16,2\%. No estado da Bahia, taxa de pessoas que não sabem ler e escrever é de $16,6 \%$ contra $16,9 \%$ no Nordeste. Outro indicador educacional positivo é a população alfabetizada corresponde $72,4 \%$, contra os $76,7 \%$ do Juazeiro do Norte e $89,9 \%$ de Aparecida-SP.

A expectativa de vida ao nascer era de 71,51 anos, a taxa de mortalidade infantil de 23,0 por mil nascimentos e a taxa de fecundidade de 2,4 filhos por mulher. Segundo dados do Ministério da Saúde, 


\section{Administração: caminhos para o desenvolvimento sustentável}

78 casos de AIDS foram registrados em Bom Jesus da Lapa entre 1990 e 2013 e, de 2001 a 2011, foram notificados 1582 casos de dengue, um caso de malária e 252 de leishmaniose (IBGE, 2010).

Segundo o Mapa da Violência de 2014, com dados relativos a 2012, divulgados pelo Instituto Sangari, dos municípios com mais de vinte mil habitantes, a taxa de homicídios no município foi de 20,1 para cada 100 mil habitantes, ficando na 1159a posição a nível nacional. O índice de suicídios para cada 100 mil habitantes foi de 0,0, com apenas três mortes confirmadas entre 2008 a 2012. Já em relação à taxa de óbitos por acidentes de trânsito, o índice foi de 21,6 para cada grupo de 100 mil habitantes, o $846^{\circ}$ a nível nacional. Em Aparecida-SP, no mesmo ano, foi registrada uma taxa de 37,1 homicídios para cada 100 mil habitantes, sendo o oitavo maior índice do estado de São Paulo e o 511으 maior do Brasil.

O índice de acidentes de trânsito neste mesmo ano foi de 25,7 ocorrências para cada 100 mil residentes, ocupando a 67ạ colocação a nível estadual e a 666ạ a nível nacional. Em relação à ocorrência de suicídios, a taxa foi de 2,9 ocorrências a cada 100 mil habitantes, sendo a 181a maior taxa a nível estadual e a 1117ạ a nível nacional.

A frota municipal de Bom Jesus da Lapa no ano de 2015 era de 11585 motocicletas, 4310 automóveis, 1631 caminhonetes, 964 motonetas, 484 caminhões, 183 camionetas, 166 ônibus, 79 micro-ônibus, 54 caminhões-trator, 59 utilitários, além de 313 em outras categorias, totalizando 19828 veículos. No transporte rodoviário, a cidade possui um terminal rodoviário de alcance interestadual. Bom Jesus da Lapa também conta com um aeroporto (IBGE, 2010).

Bom Jesus da Lapa, em termos rodoviários, é servida por quatro rodovias e desempenha importante função na área. A cidade é cortada pelas federais BR-349 e BR- 430. Com a construção da Ponte Gercino Coelho, em 1990, com a intenção de facilitar o escoamento da produção do Projeto Formoso, a cidade ganhou mais força no oeste baiano. Outra rodovia, a BA-161, liga Bom Jesus da Lapa à Sítio do Mato. Outra estrada, outrora de terra, foi criada. A BA-160 liga o município à Paratinga. Em contrapartida, em avaliações da Confederação Nacional do Transporte (CNT), recebeu o status de "péssima" durante vários anos consecutivos sendo que, em 2010, foi considerada a pior rodovia do Brasil.

\section{CONCLUSÃO}

Com base nos resultados alcançados nas pesquisas, verifica-se que o desenvolvimento do turismo religioso tem influência direta na economia do município de Bom Jesus da Lapa, revelando-se como 


\section{Administração: caminhos para o desenvolvimento sustentável}

uma das principais fontes de emprego e renda. O turismo ocasionou também benefícios à comunidade local com a valorização do patrimônio cultural e melhoria dos indicadores sociais.

A cidade investigada adquiriu uma importância na rede urbana regional em função da sua oferta de serviços e de comércios modernos. Isso possibilitou à presença de fluxos populacionais locais/regionais, além dos fluxos já existentes ligados a ocorrência de romarias, porém, estes têm aumentado significativamente graças aos novos meios de comunicação e à melhoria no acesso à cidade. Ambos os fluxos têm favorecido a expansão de atividades econômicas, atraindo grandes varejistas e principalmente o circuito inferior, características de grande parte dos romeiros que visitam a cidade, isto é, populações pobres e tipicamente consumidoras desse circuito.

Admitindo-se a aplicabilidade do conceito de marketing dentro das organizações religiosas, onde o fundamento da sua existência consiste na satisfação das necessidades espirituais e religiosas dos fiéis, percebe-se que as estratégias mercadológicas utilizadas pela Igreja ao longo dos anos tem possibilitado o incremento do numero de fiéis, com reflexo direto na evolução do perfil dos romeiros. A romaria, enquanto um movimento ou uma atividade oriunda do catolicismo popular valoriza a fé dos fiéis que encontram no santuário o espaço sagrado de sua devoção especial. Uma vez atingido pela palavra anunciada no santuário, o romeiro se encarrega de difundir sua fé para outras localidades, espalhando os conceitos e valores do catolicismo.

\section{REFERÊNCIAS}

ABEOC - Associação Brasileira de Empresa de Eventos. (2015) Turismo religioso em pauta na EMBRATUR. Recuperado de: http://www.abeoc.org.br/2015/04/turismo-religioso-em-pauta-naembratur/ ( 10 dez de dezembro de 2016)

ABREU, M., M. . O Uso do Marketing nas Organizações Religiosas. Departamento de Gestão e Economia da Universidade da Beira Interior. 30p. 2004

AZZI, R. As Romarias no Brasil. Petrópolis, n. 79, Revista Vozes p. 39-54,1979.

BARNA, G. O Marketing a Serviço da Igreja. São Paulo, Abba Press,2000 .

CAMPÁ, W . O empresário e a fé: "homens de negócio" e a expansão pentecostal - Trabalho apresentado no seminário temático ST01 "Os pentecostais". VIII Jornadas sobre Alternativas Religiosas na América Latina São Paulo. 1998

CAMPOS, L. (1999). A Igreja universal do reino de Deus, um empreendimento religioso atual e seus modos de expansão (Brasil, África e Europa). São Paulo, Lusotopie . p. 355-3671999

CODEVASF (Companhia de Desenvolvimento dos Vales do Rio São Francisco e do Parnaíba). (2012) Recuperado de: http://www.codevasf.gov.br/principal/publicacoes/publicacoes- atuais/producao- 


\section{Administração: caminhos para o desenvolvimento sustentável}

de-banana-cresce-17-no-perimetro-irrigado-de-formoso-ba-e-alcanca-r- 112-mi-em-2012>. (15 jan. 2017).

DELLACAVA, R. \& Monteiro, P. E o verbo se fez imagem: a igreja católica e os meios de comunicação no Brasil: 1962-1989. Petrópolis, Vozes. 1991

FADUL, A. Os meios de comunicação de massa: um desafio para a Igreja. Petrópolis, Vozes,1986

FERNANDES, R. C. Novo Nascimento: os evangélicos em casa, na igreja e na política. Rio de Janei-ro, Iser. 1996

GOMES, P G. Cultura, Meios de Comunicação e Igreja. São Paulo, Loyola,1987.

GRONROOS, C. (1997) Services marketing: the case of a missing product. Journal of Business and Industrial Marketing, v. 13, n. 4/5, p. 56-58.

GUILLAUMON, S. (2011). Turismo em Territórios de Grande Densidade Religiosa. In: Organizações \& Sociedade: O\&S. Salvador. UFBA: NPGA/EDUFBA, 2012, n. 63, p. $679-696$.

HOFFMAN, K; \& BATESON, D.( 2001). Princípios de Marketing de Serviços. Tradução de Bazán Tecnologia Linguística. São Paulo: Thomson.

IBGE, Instituto Brasileiro de Geografia e Estatística - Censo. (2010). Recuperado de: http://www.ibge.gov.br/home/estatistica/populacao/censo2010/tabelas_pdf/total_popula cao_ceara.pdf>. (10 dez. 2016).

IBGE, Instituto Brasileiro de Geografia e Estatística - Censo. (2016). Recuperado de: http://www.ibge.gov.br/home/estatistica/populacao/censo2010/tabelas_pdf/total_popula cao_ceara.pdf>. (03/03/2020.)

IBGE, Instituto Brasileiro de Geografia e Estatística - Produto Interno Bruto. ( 2010). Recuperado de: em:<http://www.ibge.gov.br/home/estatistica/populacao/censo2010/tabelas_pdf/total_popula cao_ceara.pdf>. (10 dez. 2016)

IGNARRA, L, R. Fundamentos do Turismo. São Paulo. Pionera Thompson Learning. 2003

IPEA. (2010). Recuperado de: < http://ipea.gov.br/>. (01 dez. 2016).

KATER Filho, A. O Marketing aplicado à Igreja Católica. São Paulo, Loyola. 1995

MACHADO, C. S. Impactos do turismo religioso nos moradores da estância turística de Aparecida/SP. 76p. Rio de Janeiro. Dissertação (Mestrado em Ciências Sociais Aplicadas) Universidade Federal Fluminense. 2015

MARIANO, R. Expansão pentecostal no Brasil: o caso da Igreja Universal. Estudos. Avançados. vol.18, no. 52, São Paulo Sept./Dec. 2004

MATAYOSHI, L. Y. Bem aventurados aqueles que se comunicam como marca: A igreja renascer em cristo. São Paulo. Dissertação de Mestrado - ECA-USP,. 120p. 2000

MICEF, F. Bom Jesus da Lapa. 2.ed. Bom Jesus da Lapa: Gráfica Bom Jesus. (2006 


\section{Administração: caminhos para o desenvolvimento sustentável}

Ministério do Turismo. (2010). Turismo Cultural: orientações básicas. / Ministério do Turismo, Secretaria Nacional de Políticas de Turismo, Departamento de Estruturação, Articulação e Ordenamento Turístico, Coordenação-Geral de Segmentação - 3ạ. ed. - Brasília: Ministério do Turismo.

MONTENEGRO. M.. Globalização, trabalho e pobreza no Brasil metropolitano. O circuito inferior da economia urbana em São Paulo, Brasília, Fortaleza e Belém. Tese (Doutorado em Geografia Humana) - Universidade de São Paulo, São Paulo. 2011

PATRIOTA, K. O. Fenômeno do Marketing Religioso: Análise do Discurso da Igreja Renascer em Cristo na Mídia. Dissertação de mestrado em Comunicação, UFPE, 145p. 2003

PATRIOTA, K. R. M. P. Fé na prateleira de vendas: A Sedução do Marketing Religioso.. 15p. 2000.

RIBEIRO, C. M. Turismo religioso: fé, consumo e mercado. E-Revista Facitec, v.5, n.1, Art.6, ago-dez. 2010.

ROSENDAL, Z. Hierópolis: O sagrado e o urbano. Rio de Janeiro: Editora UERJ. 2002

SALVI, R. D. \& Giglio, E. M. Aplicação dos modelos de comportamento do consumidor a católicos praticantes. Revista da ESPM, São Paulo, ano 9, n.4, p.58-72, jul./ago. 2003

SANTOS Filho, M. O processo de urbanização no Oeste-Baiano. SUDENE- DPG. PSU - URB. Recife. 1989.

SANTOS, J. R. A. Turismo, romaria e inclusão social no sul da Bahia. Dissertação (Mestrado em Cultura e Turismo), Universidade Estadual de Santa Cruz, Ilhéus.124p. 2010

SANTOS, S. A.. Circuito inferior da economia urbana na "capital baiana da fé. XIV Simpósio Nacional de Geografia Urbana: Perspectiva e Abordagens da Geografia Urbana no Século XXI. Fortaleza, CE. 2015. $20 p$.

SILVA A. M. B. (2). A contemporaneidade de São Paulo. Produção de informações e reorganização do território brasileiro. Tese de doutorado. Departamento de Geografia, Faculdade de Filosofia Ciência, Letras e Ciências Humanas, USP. São Paulo. 2001.

SILVA, J. C da. O Show da Fé: carisma e mídia na Igreja Internacional da Graça de Deus. 2005. Dissertação de Mestrado em Ciências Sociais, Universidade do Estado do Rio de Janeiro. Rio de Janeiro. $150 p$.

SILVA, N. D. Turismo em terra de romaria: um olhar sobre Bom Jesus da Lapa. Jundiaí, Paco Editorial, 2017.

SOUZA, J. E. . Catolicismo Popular e Evangelização na Diocese de Bom Jesus da Lapa - Bahia. Dissertação de Mestrado em Teologia, Instituto Santo Inácio - Centro de Estudos Superiores: Belo Horizonte: 140p. 1991

STEIL, C.A. O Sertão das Romarias: Um Estudo Antropológico Sobre o santuário de Bom Jesus da Lapa - Bahia. Vozes. Petrópolis. (1996).

TEIXEIRA, M. S. G. \& Junior, M. C. R.. Turismo religioso: Uma alternativa econômica para municípios do Seridó - RN. 20p. 2003. 


\section{Administração: caminhos para o desenvolvimento sustentável}

TRIGO, L. G. G. et al.. Análises regionais e globais do turismo brasileiro. Roca. São Paulo. 2005.

WAISELFSZ, J. J. Mapa da Violência: Homicídios por armas de fogo no Brasil. Recuperado: http://flacso.org.br/files/2016/08/Mapa2016_armas_web.pdf. (05 dez. 2016). 


\section{Capítulo 17}

\section{INTELIGÊNCIA COMPETITIVA E ANÁLISE DE PERFIL VISANDO O ENTENDIMENTO DO PROFISSIONAL DA INFORMAÇÃO}

DOI: $10.37423 / 200300398$

Jaqueline Rissá Franco (Universidade Estadual de Ponta Grossa) jaquerifr@gmail.com;

Taisa Trombini Carvalho(Universidade Estadual de Ponta Grossa) t_ais_a@hotmail.comp

Camila Lopes Ferreira (Universidade Estadual de Ponta Grossa) chitalf@gmail.com

Resumo: A utilizaçãa de protocolos de desenvolvimento de projetos de tecnologia da informação contribut para a seu sucesso, pqrém para que o sucesso do projeto seja atingido é importante que sejam feitas algumas verificações, principalmente em relação ąo perfil de cada membro da equipe. Este artiga tem por objetivo analisar dois métodos (Inteligência competitiva e analise de perfil de personalidade) que, quando utilizados em conjunto,podem contribuir significativamente para um produto final de qualidade. Para tanto, utilizou-\$e da técnica da pesquisa, sendo esta classificada como básica, exploratória, qualltativa e estudo de caso. O ponto analisado foi-a repasse de informações do analista de sistemas para os desenvolvedores do projeto, destacando que cada um possuiuma carga cultukal e psicologia que não deve sef-descartada pela metodologia aplicada.

Palavras chave: Inteligência Competitiva, Personalidade, Informação. 


\section{Administração: caminhos para o desenvolvimento sustentável}

\section{INTRODUÇÃO}

As mudanças ocorridas nos processos de desenvolvimento e projetos de software nos últimos anos, fez com que novos modelos surgissem nesta área. Uma maior organização dos projetos se tornou essencial, desde sua concepção até sua manutenção, para que assim, a gerencia dos imprevistos seja potencializada resultando em projetos altamente estruturados e de sucesso.

Um dos fatores que caracterizam um projeto de excelência é a comunicação bem sucedida entre todos os envolvidos no projeto. Protocolos de planejamento e desenvolvimento em constante evolução permitem que a informação do especialista seja corretamente receptada por todos.

O maior obstáculo encontrado pelos desenvolvedores não costuma ser os aspectos técnicos, como arquitetura e tecnologia, mas sim o domínio da informação necessário. Embora a maioria dos protocolos aborde o envolvimento dos desenvolvedores no processo de aquisição das informações, muitos, quando empregados isoladamente, não consideram o fator psicológico.

Ao finalizar um projeto e concluir que o mesmo foi mal sucedido é possível atribuir a este vários fatores causadores. Quando se conclui que a principal causa do insucesso foi uma execução falha do mesmo, pouco se analisa sobre a origem dos problemas durante o projeto e o motivo de os mesmos não terem sido abordados e tratados antes da conclusão do projeto, bem como o impacto em nível empresarial. Tais projetos acarretam problemas internos em diversos níveis, desde a diretoria, em que o foco principal não abrange os processos de desenvolvimento, até o gerenciamento de equipe, no qual a abrangência dos detalhes do procedimento adotado é essencial.

Um dos agentes de maior relevância é a falha da abordagem do fator psicológico da equipe envolvida no projeto. A psicologia e a personalidade devem ser fatores considerados, ao contrario da maioria dos modelos atuais, pois os principais membros da equipe, os desenvolvedores, como pessoas possuem cargas culturais e psicológicas. Assim a absorção da informação repassada pelo analista pode ser mais bem sucedida, diminuindo os problemas de comunicação. Wurman (1995, p.43) conceitua o termo informação como sendo "[...] aquilo que leva à compreensão [...] O que constitui informação para uma pessoa pode não passar de dados para outra".

A compreensão das informações por todos os envolvidos em um projeto é um ponto critico que varia de acordo com a percepção de cada um. Assim, este artigo tem por objetivo analisar dois métodos (Inteligência competitiva e analise de perfil de personalidade) que, quando utilizados em conjunto, 


\section{Administração: caminhos para o desenvolvimento sustentável}

podem contribuir significativamente para a redução dos problemas de comunicação, assim como no desenvolvimento de um produto final de qualidade.

\section{INTELIGÊNCIA COMPETITIVA}

A Inteligência Competitiva (IC) pode ser empregada como uma ferramenta de maneira a auxiliar o processamento das informações para que as mesmas possam ser absorvidas de maneira mais eficaz. A utilização da IC é de extrema importância nas organizações se as mesmas querem ser competitivas no mercado, pois analisa o ambiente em que a empresa está inserida, mostrando riscos e oportunidades que as mesmas têm neste mercado.

Para Valentim (2004), “[...] a utilização da IC é mais bem vista quando utilizada em equipes multidisciplinares, que atribui trocas de experiências, porém cada integrante da equipe deve saber exatamente sua função, pois a responsabilidade é determinada por sua especialização". Segundo Amaral (et. al. 2008), a consolidação da equipe de IC é essencial para que as atividades gerem melhores resultados, pois exige profissionais competentes, sendo que sua atuação deve ser basear em conhecimentos, habilidades e atitudes que condizem ao trabalho que realiza. Na Figura 1, pode-se visualizar as várias atividades envolvidas no trabalho de IC:

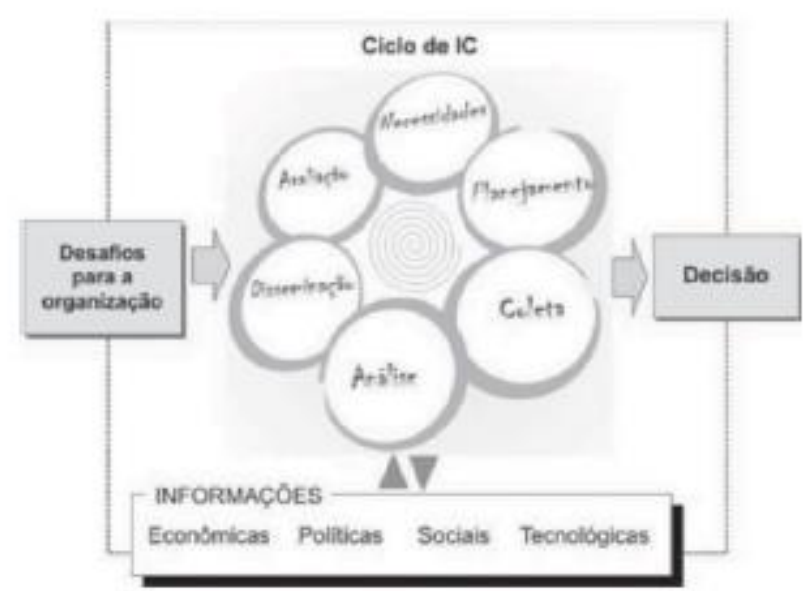

Fonte: Amaral (et. al. 2008)

Figura 1- Ciclo de IC

As informações que devem ser extraídas do meio são de múltiplas áreas e auxiliam na tomada da decisão que a empresa terá. As habilidades de cada integrante de uma equipe estão extremamente 


\section{Administração: caminhos para o desenvolvimento sustentável}

ligadas à personalidade e a cultura de cada um, assim como à linguagem utilizada. Para que possa criar-se uma adaptação das diferentes linguagens da equipe é necessário que se considere estes fatores, pois desconsiderá-los pode resultar em uma comunicação falha por parte da equipe, tanto para receber as informações externas quanto para repassá-las para os demais membros.

\section{ANÁLISE DE PERSONALIDADE}

O misto de cultura e personalidade pertencente às pessoas influencia tudo ao seu redor, como a maneira que interagem até o estilo de trabalho. Snedaker (2006) define que "[...] há alguns estilos que são mais apropriados ou úteis em certas posições". É possível dividir os estilos de trabalho em quatro estilos:

- Fazedor: pessoas que priorizam o fazer ao planejar; - Interativo: pessoas que preferem a conversação e costumam atrair os assuntos de reuniões de volta para elas;

- Jogador: pessoas desse perfil costumam levar mais em consideração a opinião do grupo do que a sua própria;

- Analista: o estilo de trabalho mais comum entre os profissionais de tecnologia da informação (TI) se caracteriza por necessitar do máximo de detalhes antes de iniciar a execução da tarefa. Existem diversas áreas a serem desenvolvidas pelos profissionais da $\mathrm{TI}$, as quais são interativas umas com as outras, sendo que se uma não sair de forma correta irá interferir na seguinte. É necessário que os integrantes das equipes tenham conhecimento em todas as áreas representadas na Figura 2, a saber:

De acordo com Gavioli (2009), profissionais dessa área devem especializar-se, não que isso signifique que os mesmos exercerão um único papel. Assim, o desenvolvimento interativo e multidisciplinar é necessário e requerido como forma de subsídio ao processo como um todo. 4 Metodologia Este artigo foi desenvolvido através da técnica da pesquisa, a qual se classifica como básica, exploratória, qualitativa e estudo de caso. 0 caso em questão diz respeito a 20 desenvolvedores de uma empresa prestadora de serviços na área da TI da cidade de Ponta Grossa, onde foi aplicado um questionário descrito na próxima sessão. 5 Estudo de Caso O questionário aplicado foi adaptado do Inspiira (2011) e continha 40 questões relacionadas ao perfil das pessoas. Este questionário é baseado no método de Mayers Briggs (MBTI) Segundo Santos (2010), "O indicador é frequentemente utilizado nas áreas de aconselhamento de carreira, pedagogia, dinâmicas de grupo, orientação profissional, treino de liderança, aconselhamento matrimonial e desenvolvimento pessoal, entre outros". O 


\section{Administração: caminhos para o desenvolvimento sustentável}

MBTI ${ }^{\circledR}$ postula a existência de quatro pares opostos de maneiras de pensar e agir, chamados

dicotomias (dimensões). As preferências são normalmente indicadas por letras maiúsculas que indicam cada uma destas quatro preferências (SANTOS, 2010). O Quadro 1 mostra as letras que irão definir a personalidade, a seguir:

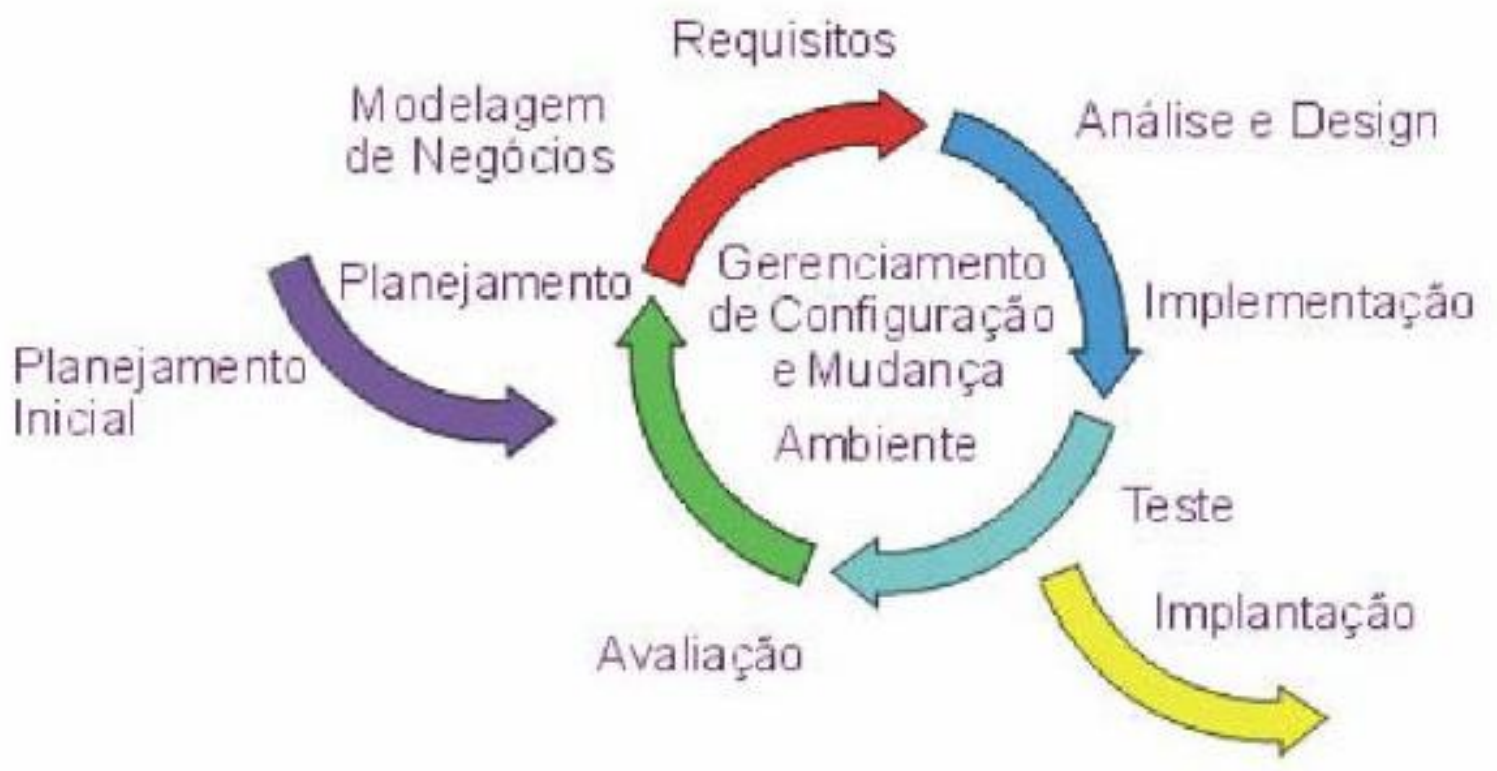

Fonte: Gavioli (2009)

Figura 2 - Processo interativo

De acordo com Gavioli (2009), profissionais dessa área devem especializar-se, não que isso signifique que os mesmos exercerão um único papel. Assim, o desenvolvimento interativo e multidisciplinar é necessário e requerido como forma de subsídio ao processo como um todo.

\section{METODOLOGIA}

Este artigo foi desenvolvido através da técnica da pesquisa, a qual se classifica como básica, exploratória, qualitativa e estudo de caso. 0 caso em questão diz respeito a 20 desenvolvedores de uma empresa prestadora de serviços na área da TI da cidade de Ponta Grossa, onde foi aplicado um questionário descrito na próxima sessão.

\section{ESTUDO DE CASO}

O questionário aplicado foi adaptado do Inspiira (2011) e continha 40 questões relacionadas ao perfil das pessoas. Este questionário é baseado no método de Mayers Briggs (MBTI) Segundo Santos (2010), "O indicador é frequentemente utilizado nas áreas de aconselhamento de carreira, pedagogia, 


\section{Administração: caminhos para o desenvolvimento sustentável}

dinâmicas de grupo, orientação profissional, treino de liderança, aconselhamento matrimonial e desenvolvimento pessoal, entre outros".

$\mathrm{O} \mathrm{MBTI}^{\circledR}$ postula a existência de quatro pares opostos de maneiras de pensar e agir, chamados dicotomias (dimensões). As preferências são normalmente indicadas por letras maiúsculas que indicam cada uma destas quatro preferências (SANTOS, 2010). O Quadro 1 mostra as letras que irão definir a personalidade, a seguir:

\begin{tabular}{|c|r|r|l|}
\hline Seu foco de atenção & Extroversão $(\mathrm{E})$ & $\ll$ ou $\gg$ & Introversão (I) \\
\hline $\begin{array}{c}\text { Sua maneira de processar } \\
\text { informações }\end{array}$ & Sensação $(\mathrm{S})$ & $\ll$ ou $\gg>$ & Intuição (N) \\
\hline $\begin{array}{c}\text { Sua maneira de tomar } \\
\text { decisões }\end{array}$ & Pensamento $(\mathrm{T})$ & $\ll$ ou $\gg>$ & Sentimento (F) \\
\hline $\begin{array}{c}\text { Como você lida com o } \\
\text { mundo exterior }\end{array}$ & Julgamento $(\mathrm{J})$ & $\ll$ ou $\gg>$ & Percepçăo (P) \\
\hline
\end{tabular}

Fonte: Santos (2010)

Quadro 1 - Definição Geral

A Tabela 1 abaixo apresenta os resultados de acordo com o teste MBTI:

\begin{tabular}{c|c|c|c|c}
\hline Tipologia & Guardião & Artista & Idealista & Racional \\
\hline $\begin{array}{c}\text { Porcentagem } \\
\text { relacionada a cada } \\
\text { tipo }\end{array}$ & $25 \%$ & $20 \%$ & $15 \%$ & $40 \%$ \\
\hline
\end{tabular}

Tabela 1 - Resultado da pesquisa

As tipologias são definidas por Pasquali (2000) da seguinte forma:

- SJ: Guardiães („Desconfiança" - Melancólico): Focalizam-se no dever, comércio e economia. São os guardiães das tradições, defendem a hierarquia, seu mote é o dever, sendo conservadores e tradicionalistas;

- SP: Artistas („Vamos beber vinho" - Sangüíneo): Focalizam-se na arte, estética e ventura. Procuram a diversão, a liberdade e a espontaneidade; 


\section{Administração: caminhos para o desenvolvimento sustentável}

- NT: Racionais („Previdência“ - Colérico): Focalizam-se na ciência, no teórico. Lutam pela competência, o saber, a objetividade; necessitam liderar e controlar;

- NF: Idealistas („Aspire pelo céu“ - Fleumático): Focalizam-se no espiritual, na ética. Lutam pela procura de si mesmos, da paz e da harmonia. Procuram os valores, a inspiração, a relevância na vida de si e dos outros.

\section{CONSIDERAÇÕES FINAIS}

Embora o estereótipo de que os profissionais em TI são racionais, a pesquisa mostrou que existe também profissionais que não dão importância suficiente a razão, sendo que os gerentes de TI, posições de coordenador e outros cargos superiores, precisam se especializar e se preocupar cada vez mais com esse fato, pois um idealista, por exemplo, não motivado por argumentos lógicos apenas, se não for capaz de seguir ou não concordar com a lógica tende a ficar desmotivado, com isso o mesmo realiza um produto final de baixa qualidade e fora dos prazos estipulados. Como em qualquer outra área, um resultado de baixa qualidade traz prejuízos a empresa, e como em qualquer equipe, membros desmotivados e de baixo rendimento colocam-na em desarmonia, muitas vezes sobrecarregando parte dela, sendo também extremamente prejudicial para a empresa tanto em curto prazo (no lucro),como a longo prazo (na fidelidade dos clientes).

\section{REFERÊNCIAS}

AMARAL, R. M.; et al. Modelo para o mapeamento de competências em equipes de inteligência competitiva, Brasília, Ci. Inf. vol.37, n. 2, mar./ago. 2008. Disponível

emhttp://www.scielo.br/scielo.php?script=sci_arttext\&pid=S010019652008000200001\&lng=pt\&nrm =iso. Acesso em: 24 mai. 2011.

GAVIOLI, E. S. Uma contribuição para o delineamento do perfil do profissional de TI frente aos papéis exercidos durante o processo de desenvolvimento de software. São Paulo, 2009. Disponível

em: http://www.centropaulasouza.sp.gov.br/Posgraduacao/Trabalhos/Dissertacoes/tecnologias-dainforma\%E7\%E3o-aplicadas/2009/eliana-de-souza-gavioli.pdf. Acesso em: 26 mai. 2011.

INSPIIRA. Disponível em: http://www.inspiira.org/view/pt-br/100. Acesso em: 26 mai. 2011.

LAUREANO, M. A. P. Informação, competitividade e estratégia. Gestão de Segurança da Informação, jun./2006. Disponível em < http://www.mlaureano.org/aulas_material/gst/apostila_versao_20.pdf > Acesso em: 24 mai. 2011.

PASQUALI, L. Os Tipos Humanos: A Teoria da Personalidade. Brasília: CopyMarket.com, 2000. Disponível 


\section{Administração: caminhos para o desenvolvimento sustentável}

em:http://www.veterinariosnodiva.com.br/books/Os\%20Tipos\%20Humanos\%20\%20A\%20Teoria\%2 0da\%20Personalidade.pdf. Acesso em: 26 mai. 2011.

SANTOS, J. R. Análise de Personalidade - MBTI ${ }^{\circledR}$. Life Coaching. Copyright, 2010. Disponível em http://coachingsp.files.wordpress.com/2010/08/modelo-mbti.pdf. Acesso em: 26 mai. 2011.

SNEDAKER, S. Como ter sucesso em Gestão de Projetos, São Paulo: Digerati Books, 2006.

VALENTIM, M. L.P. et al. O Processo de Inteligência Competitiva em Organizações. Revista de Ciência da Informação, v. 4, n. 3, jun./2003. Disponível em:

http://www.ipatinga.arquivar.com.br/espaco_profissional/sala_leitura/artigos/Processo_de_Intelige ncia_Competitiva_em_Organizacoes.pdf. Acesso em: 24 mai. 2011.WURMAN, R. S. Ansiedade de informação: como transformar informação em compreensão. 5.ed. São Paulo: Cultura Editores, 1995. 


\section{Administração: caminhos para o desenvolvimento sustentável}

\section{ANEXO A - QUESTIONÁRIO INSPIIRA (2011)}

Responda em termos de quem você é hoje, e não em termos de quem você gostaria de ser no futuro. Marque da esquerda para a direita de acordo com a intensidade que você considera que mais se adéqua ao seu perfil, sendo $1=$ NADA a ver comigo e $9=$ TUDO a ver comigo:

1- Tenho uma alta tolerância para surpresas; sinto-me confortável em lidar com as coisas conforme elas vão aparecendo, ajustando minhas atividades conforme a necessidade; geralmente sou descrito como uma pessoa "relax", "tranquila", ou "de boa". Não necessariamente valorizo fechamento na hora de tomar decisões, preferindo deixar minhas opções em aberto pela maior quantidade de tempo possível.

1-------2-------3-------4-------5------6--------7-------8-------9

2- Sinto-me confortável com rotina; para mim os métodos e as rotinas já testadas são as únicas maneiras confiáveis e eficientes de se conseguir fazer as coisas. A rotina me proporciona um grau importante de conforto e de segurança.

1-------2--------3--------4------5-------6-------7-------8-------9

3- Gosto de separar um tempo mais que suficiente para executar uma atividade de forma eficiente, sem irritações ou incômodos; sou mais eficaz quando posso fazer uma coisa por vez, e tento estruturar minha vida de acordo com esse preceito. Posso me tornar ineficiente sob o estresse de ter que trabalhar em algo até o último minuto de um prazo.

1-------2--------3--------4------5-------6-------7-------8-------9

4- Exibo uma postura informal e descontraída na hora de resolver problemas, avançando sem planos muito detalhados. Com isso posso acabar não lendo as instruções do kit de montagem antes de começar a montar algo. Tenho facilidade de trabalhar em projetos não-estruturados que requerem improvisação.

1-------2--------3--------4------5-------6-------7--------8-------9

5- Prefiro ser apresentado a alguém a ter que ir lá e me apresentar; quando estou no meio de um grupo grande de pessoas deixo que a conversa chegue até mim, ao invés de já ir me infiltrando, me apresentando, me misturando, e começando conversas com essas pessoas que não conheço bem.

1-------2--------3--------4------5-------6--------7-------8-------9

6- Prefiro trabalhar com e falar sobre coisas concretas e reais que podem ser sentidas com as mãos e enxergadas com os olhos (coisas concretas, palpáveis). Sou cuidadoso na hora de ir além dos fatos.

1-------2--------3--------4------5-------6-------7--------8-------9

7- Creio que as relações humanas são fonte de significado e de "verdade" em nossas vidas. A "verdade" é algo pessoal e ao mesmo tempo universal, e nunca existe isolada das pessoas em si. Os sentimentos e as relações humanas são mais importantes do os direitos.

1-------2--------3--------4------5-------6-------7--------8-------9 


\section{Administração: caminhos para o desenvolvimento sustentável}

8- Para mim a relevância de alguma coisa vai além de sua relação com as coisas palpáveis, estendendose às conexões em potencial com outros conceitos e ideias. Não tenho tanto interesse pelas coisas já descobertas ou bem conhecidas. Prefiro explorar o mundo procurando novas conexões entre conceitos e idéias abstratas. Gero soluções através de "sacadas" quando lido com situações novas.

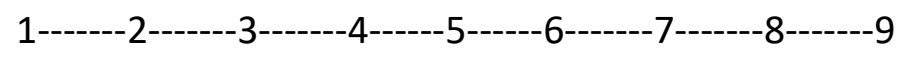

9- Gosto de fazer o papel de agente social, apresentando pessoas umas às outras. Me misturo, jogo conversa fora com estranhos (às vezes por horas), faço novas amizades, expando minha rede de contatos e me envolvo com outras pessoas com facilidade.

1-------2--------3-------4-------5-------6-------7--------8-------9

10- Encaro a crítica como uma forma válida de se chegar à verdade, e conto com a expectativa de que as outras pessoas não a levem para o lado pessoal. Creio que a crítica ajuda a resolver problemas de forma definitiva, aprimora ideias, situações, procedimentos, e evita as consequências de planos, decisões, e pontos de vista errôneos.

1-------2-------3--------4-------5------6--------7--------8-------9

11- Sinto-me confortável perante complexidade e me intrigo mais por significados insinuados ou deduzidos do que por significados explicitamente demonstrados, afirmados, ou apresentados. Dou mais valor a ideias e a possibilidades do que a detalhes palpáveis que consigo enxergar com meus olhos. Tendo a tirar notas altas. Estou mais disposto a me arriscar por grandes ganhos em potencial.

1-------2-------3--------4-------5------6--------7-------8-------9

12- Levo em consideração as necessidades únicas e individuais das outras pessoas; dou mais valor à misericórdia e ao perdão do que à justiça.

1-------2-------3--------4------5-------6--------7--------8-------9

13- Para mim desafiar e questionar são formas válidas e justificadas de compreender e de solucionar problemas, de descobrir pontos de comum acordo entre as pessoas, ou de expor falhas num ponto de vista contrário.

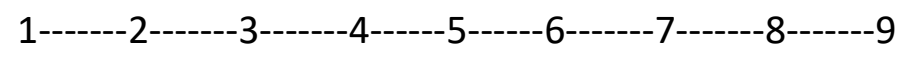

14- Prefiro que as coisas ofereçam benefícios práticos a mim e às outras pessoas. Valorizo o "bomsenso" porque é algo prático, realista, e, como já foi testado e aprovado pela experiência, funciona. Também valorizo altamente o conforto pessoal e a segurança familiar.

1-------2--------3-------4-------5-------6-------7--------8-------9

15- Prefiro me focar em conceitos, no significado abstrato das ideias, e nas relações entre estes. Tenho facilidade de interpretar as coisas de uma forma não literal.

1-------2--------3-------4-------5------6-------'-------8-------9 


\section{Administração: caminhos para o desenvolvimento sustentável}

16- Aparento ser uma pessoa mais reservada e quieta (até tímida), mas geralmente possuo uma abundância de reações internas ao que está se passando à minha volta. Pode ser difícil encontrar palavras para expressar meu mundo interior.

1--------2-------3--------4------5-------6-------7-------8-------9

17- Gosto de manter contato com círculos grandes e variados de amigos e conhecidos que por sua vez possuem interesses também variados. Sou habilidoso na hora de me comunicar com diferentes tipos de pessoas, e nas mais diversas situações. Gosto de me colocar em situações em que possa conhecer pessoas novas.

1-------2--------3--------4------5-------6-------7-------8-------9

18- Prefiro tomar decisões no calor do momento. Valorizo liberdade, "viver o momento", e gosto de deixar as coisas fluírem. Não gosto de ficar amarrado por conta de planos de longo prazo; quero que os planos sejam flexíveis.

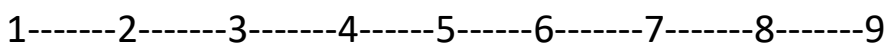

19- Mantenho um círculo bem mais limitado de amigos próximos e confiáveis; minha lista de interesses e atividades favoritas tende a ser igualmente menor, porém mais concentrada. Quando em meio a um grupo prefiro conversar no "um-a-um", e com pessoas que conheço bem; posso achar desconfortável jogar conversa fora com pessoas que tenha acabado de conhecer.

1-------2-------3--------4------5-------6-------7-------8-------9

20- Valorizo a originalidade como um meio de expressão pessoal e uma forma de incutir significado nas atividades do dia-a-dia; posso ser esperto, inventivo, aventureiro, e empreendedor. Tomo a iniciativa para expor minhas ideias originais. Para mim a variedade promove significado e progresso, enquanto a mesmice remove significado.

1-------2--------3--------4------5-------6-------7-------8-------9

21- Prefiro trabalhar com materiais e objetos que já conheço, através de métodos familiares e práticos. Me interesso por conforto físico que pode ser vivido aqui e agora. Prefiro construir a inovar, e me interesso mais por ganhos modestos palpáveis do que por oportunidades arriscadas de ganhos muito maiores.

1-------2-------3--------4------5-------6-------7--------8-------9

22- Tendo a estar disposto a compartilhar meus pensamentos, sentimentos, interesses e preocupações somente com pessoas em quem confio plenamente. Considero-me uma pessoa difícil de se conhecer; minhas reações emocionais são geralmente internas; pode ser difícil que eu me abra com outras pessoas já que quanto mais incomodado eu me torno, menos eu deixo esse incômodo transparecer.

1-------2--------3--------4------5-------6-------7--------8-------9 


\section{Administração: caminhos para o desenvolvimento sustentável}

23- Prefiro planejar e agendar horários para o lazer e para outras atividades com boa antecedência. Valorizo esse tipo de planejamento pois isso garante que eu esteja nos locais onde quero estar, fazendo as atividades que gosto.

1-------2-------3-------4-------5------6-------7-------8-------9

24- Prefiro tradições e convenções por estas promoverem continuidade, segurança, e validação ao meu meio social. Sinto-me desconfortável com modismos e práticas que fujam aos padrões tradicionais pois a estes falta a validação que somente o tempo, a experiência, e a aprovação de longoprazo da sociedade pode proporcionar.

1-------2-------3--------4------5------6--------7-------8-------9

25- Valorizo harmonia enormemente. Acredito que desafiar e confrontar é menos eficaz do que buscar acordos que incorporem os pontos de vista divergentes, visando assim satisfazer o maior número de pessoas possível.

1-------2-------3-------4------5------6-------7-------8-------9

26- Uso o carinho e a gentileza para conseguir o que quero ou preciso. Por trás de minha postura terna jaz a consciência de que há dois lados mutualmente contraditórios nas mais diversas questões, que acabam impossibilitando acordos puramente racionais.

1-------2-------3-------4-------5------6--------7-------8-------9

27- Para mim a lógica e a razão são as melhores ferramentas para se compreender o mundo e as pessoas à minha volta. Direitos, a equidade, e a razoabilidade são padrões altamente valorizados em meus relacionamentos, já que geralmente posso depender mais destes do que de sentimentos.

1-------2--------3-------4-------5------6--------7-------8-------9

28- Dou mais valor a possibilidades do que a coisas concretas. O poder ser me intriga mais do que o ser. "Me viro" na hora de lidar com experiências novas ou incomuns. Gosto de encontrar soluções novas para qualquer problema.

1-------2-------3--------4-------5------6--------7-------8-------9

29- Sou uma pessoa claramente racional ao tomar minhas decisões diárias; faço uso eficaz de raciocínio sequencial; raciocino com confiança e clareza.

1-------2--------3--------4------5-------6-------7--------8-------9

30- Aprendo muito melhor a partir de um formato visual, intelectual, ou mental, do que num formato que envolva um ambiente agitado em que eu tenha que ficar me expressando verbalmente. Aprende melhor em locais quietos que permitam uma reflexão prolongada.

1-------2-------3-------4-------5------6-------7--------8-------9

31- Trabalho melhor, mais criativamente, e com máximo vigor sob o estresse de um prazo iminente. Minha aparente procrastinação (procrastinar = "empurrar com a barriga") é frequentemente um 


\section{Administração: caminhos para o desenvolvimento sustentável}

período de gestação durante o qual gero as ideias e a inspiração para executar meu serviço da mais alta qualidade.

1-------2--------3-------4-------5------6-------7-------8-------9

32- Sou gentil e tolerante com relação às outras pessoas e também espero delas um tratamento idêntico. Para mim sempre é possível resolver problemas de tal forma que as duas partes saiam ganhando, e acredito que valha a pena batalhar por esse tipo de coisa.

1-------2--------3-------4-------5-------6-------7--------8-------9

33- Tendo a ser falante e amigável, obtendo grande prazer e animação só de conversar com outras pessoas. Gosto de ser o centro das atenções e adoro entreter outras pessoas e me divertir conversando numa roda de amigos (quanto mais amigos, melhor!). Gosto de ouvir e contar estórias como uma forma de compartilhar quem eu sou, e de aprender sobre outras pessoas.

1-------2--------3-------4------5-------6-------7-------8-------9

34- Prefiro ordem nas várias áreas da minha vida: desde o ambiente físico do trabalho e da casa, ao planejamento e agendamento de tarefas e atividades de lazer, aos métodos sistemáticos que utilizo para lidar com todas essas coisas.

1-------2-------3--------4------5-------6-------7-------8-------9

35- Gosta muito de organizar materiais, ferramentas, pessoas e sequencias de passos necessários para se terminar projetos complicados. Tem facilidade de seguir instruções envolvendo sequencias de ações passo-a-passo, e pode se sentir desconfortável se não há maneira alguma de se saber que coisas precisam ser feitas, e quando.

1-------2--------3-------4-------5-------6-------7-------8-------9

36- Trabalho melhor e com a maior quantidade de energia quando posso contar com variedade constante e quando tenho a liberdade de decidir quando executar minhas tarefas. Valorizo altamente a novidade e a variedade. Para mim o pior destino que uma pessoa pode ter é acabar num emprego ou viver num lar monótono, numa rotina que nunca muda.

1-------2-------3--------4------5-------6-------7--------8-------9

37- Após uma avaliação ponderada de situações, possibilidades, e das pessoas envolvidas, me mantenho firme sobre minhas decisões. Agir de outra forma seria rejeitar toda a lógica, o raciocínio, o questionamento, e a análise crítica utilizada quando a decisão inicial havia sido tomada.

1-------2--------3-------4-------5-------6-------7--------8-------9

38- Demonstro meus sentimentos e intenções com facilidade, ao ponto deles se tornarem óbvios. Sou uma pessoa animada, calorosa, engraçada, que tem uma certa facilidade de se abrir e contar meus segredos a outras pessoas, e que me descrevo como uma pessoa fácil de se conhecer.

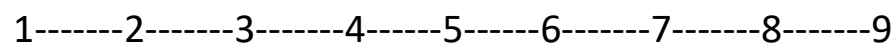




\section{Administração: caminhos para o desenvolvimento sustentável}

39- Prefiro me envolver diretamente em ambientes ativos e animados. Aprendo melhor fazendo, ouvindo, perguntando. Geralmente prefiro formas de diversão ativas (fazer esportes, conversar numa roda de amigos) às passivas (assistir televisão, ler, ouvir música).

1-------2--------3-------4-------5------6-------7-------8-------9

40- Utilizo a experiência como critério mais importante na hora de avaliar o que é verdadeiro e importante. Não vejo vantagem em substituir métodos que já comprovei por experiência própria. Prefiro o método da "tentativa-e-erro" na hora de executar tarefas para as quais não existam procedimentos estabelecidos, começando sempre com algo que já sei que funciona. (mãos-na-massa, aprende por observação e experiência).

1-------2--------3-------4-------5-------6-------7-------8-------9 


\section{Capítulo 18}

\section{APLICAÇÃO DE CONCEITOS DA LOGÍSTICA E DE PRODUÇÃO NA REALIZAÇÃO DE EVENTOS: ESTUDO DE CASO DE UM CASAMENTO.}

DOI: $10.37423 / 200300401$

Marillia Hamati, UEPG,marilliahamati@outlook.com

Patrícia Portes Dos Santos, UEPG, patyportes@hotmail.com

Cristina Gresełe,UEPG, cristinagresele@gmail.com

Resumo: O ramo de eventos tem uma presença bem evidente nos últimos tempos. Para uma perfeita organizaçầo de um evento é necessário um planejament coordenação dos sẹrviços realizados. Todavia, em certas ocasiőes alg̨uns acontecimentos podem não-sair como imàginado. Atualmente, divérsos evéntos são realizados sem o planejamento necessário e-causam diversos problemas e contratempos que poderiam ser evitados caso sejam identificadas e utilizadas algumas das ferramentas adequadas de produção de eventos a ferramentas Iogísticas de planejamento que auxiliam nessa organização. Este artigo tem por objetivo identificar conceitos de logística \& de produção que possam ser utilizados na realização de eventos plara aprimorar o planejamento, a organização e a execução do evento garantido unpaa adequada realização. Trata também da análise de um casamento realizado e suas inconsistências. Os resultádos mostrarão as vantagens e benefícios da utilização de uma gestão adequada das ferramenttas de logística e de produção em eventos.

Palavras-chaves: Produção de eventos; Loggistila em eventos; Planejamento e or

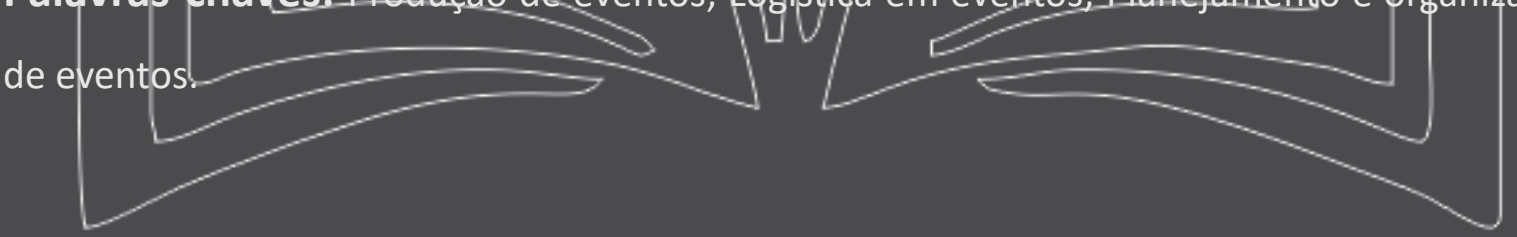




\section{Administração: caminhos para o desenvolvimento sustentável}

\section{1 - INTRODUÇÃO}

Atualmente com o crescimento do mercado de eventos pode-se verificar a ineficiência do planejamento e conseqüentemente como isso afeta a execução dos eventos. De acordo com Vieira (2015) os eventos são:

\footnotetext{
"acontecimentos efémeros promovidos por qualquer tipo de empresas, organismos e instituições, organizados para comemorar uma data, para divertimento dos participantes ou por qualquer outra razão relacionada com a sua vida, a vida das empresas, a vida das cidades ou a vida de uma comunidade local, regional ou nacional."
}

Para que um evento seja impecável, é primordial que os organizadores possuam conhecimentos de técnicas e métodos correspondentes a todos os processos necessários para a produção de um evento. Com os clientes cada vez mais exigentes, uma boa organização vai refletir em custos menores e numa geração de valor maior na realização pessoal de cada um.

Muitas são as atividades que compõe um evento, como: pensar e definir o conceito do evento; listar os recursos (financeiros e físicos), organizar e executar as tarefas; prever os resultados; e também o encerramento do evento.

São diversos erros e problemas que poderiam ser evitados ao utilizar alguns conceitos e ferramentas específicas, melhorando este setor.

O processo de planejamento e organização de um evento engloba diversas áreas da administração que podem e devem ser aplicadas para obter resultados mais eficazes.

A aplicação de instrumentos de produção e logística podem ser aplicadas a eventos para melhorar a eficácia e eficiência no planejamento, organização e execução de um evento social.

Em produção, o planejamento, a definição do local do evento e o layout bem aplicado são fundamentais.

Nichols (1989) relata que a definição do local é de extrema importância para se determinar tanto o sucesso do evento como o fracasso. É uma das primeiras coisas que se pensa ao definir um evento. Portanto, a escolha deve ser feita de maneira concreta com os objetivos esperados.

Concomitante com a Logística, Britto e Fontes (2004)nos diz que: 


\section{Administração: caminhos para o desenvolvimento sustentável}

"A supervisão da logística é o coração do evento, sem o qual o restante do processo não funciona. Esta supervisão planeja, gerencia os recursos físicos, materiais, de apoio e manutenção, de segurança e os recursos humanos necessários à realização do evento, dentro de cada etapa estabelecida".

Este artigo apresentará como os conceitos de logística e de produção podem ser utilizados na organização e execução de diversos tipos de eventos, diminuindo os erros cometidos e através do estudo de caso de um casamento identificar e solucionar as principais dificuldades no evento.

\section{2 - REFERENCIAL TEÓRICO}

Este artigo tem como referencial teórico conceitos e princípios de autores consagrados na área de eventos, bem como de Logística e Produção voltados para o planejamento, organização e execução de eventos.

Para a elaboração e desenvolvimento deste trabalho utilizaremos a experiência prática de uma das autoras que trabalha na área há mais de 5 anos e combinaremos este conhecimento com as bases doutrinarias da administração.

Diversos autores como Bahl (2004), Giacaglia (2006), 9) e Nakane (2000), entre outros conceituam o tema eventos de uma forma similar.Com base nesses autores evento é um acontecimento, uma ação profissional que exige pesquisa, planejamento, organização, coordenação, controle e implantação de um projeto visando atingir o publico alvo com medidas concretas e resultados projetados.

É o conjunto de ações profissionais com o objetivo de lançamento de produtos, apresentação de pessoas, empresas ou entidades, visando estabelecer o seu conceito ou recuperar a sua imagem. Visa atingir resultados qualificados e quantificados junto ao público alvo.

Para Giácomo (2007) o conceito de evento é um acontecimento previamente planejado, que ocorre num determinado lugar e tempo especifico, visando unir diversas pessoas a uma idéia ou ação determinada.

"Os eventos também devem estar orientados para atender as expectativas de quem os promove, organiza ou participa como expositor. Além disso, toda uma cadeia produtiva está associada na sua execução e também busca a obtenção de benefícios comerciais e econômicos quando das suas realizações". (BAHL, 2004, pg.38)

Para tanto deve-se levar em conta para esta pesquisa que evento é um acontecimento, previamente planejado através do desenvolvimento de um projeto objetivando a interação de diversas pessoas 


\section{Administração: caminhos para o desenvolvimento sustentável}

com objetivos em comum em lugar e tempo pré-determinados pela organização visando atender as necessidades e desejos do publico participante.

Um evento pode ser dividido em três etapas, cada uma delas com atividades específicas a serem realizadas para que se possa passar para a fase seguinte. Segundo Martin (2008) essas fases são: préevento, evento e pós-evento. Matias (2001,pg.97) estabeleceu que cada fase do evento deve seguir as seguintes etapas para sua organização: observação das necessidades do evento; desenvolvimento de alternativas para atender as necessidades; determinação dos objetivos específicos; obtenção de informações sobre os participante e patrocinadores; levantamento dos resultados almejados; estimativa da possibilidade econômica, técnica, de tempo e de recursos.

Um evento deve ser planejado e organizado, neste sentido as informações do evento como um todo devem ser levadas em consideração para que as ferramentas de logística e de produção possam ser aplicadas, como por exemplo o desenvolvimento de um projeto que contemple todas as etapas e cronogramas do desenvolvimento do evento, o layout do salão onde será realizado o evento, a logística de transporte e montagem dos itens contratados para o evento, entre outros.

Para definir as ferramentas de logística que podem ser aplicadas na realização de um evento utilizaremos como referência Allen et. al., 2008, que estabelece que as bases da logística e eventos são divididas em: suprimento; transporte; ligação; controle de fluxo; e rede de informações.

O suprimento pode se referir tanto ao consumidor quanto ao produto ou as instalações, incluindo a aquisição de bens e serviços necessários na organização de um evento. Um evento é composto por diversos bens e prestadores de serviço que requerem um transporte planejado e eficiente para evitar desperdício de tempo e recursos. A ligação se refere a logística em si que faz parte de um planejamento geral abrangendo todas as áreas correlatas do evento. O controle de fluxo faz-se durante a montagem e execução do evento e engloba todo o fluxo de produtos, serviços e consumidores necessários para que o evento aconteça.

Um planejamento eficaz da rede de informações faz com que o fluxo de informações durante o evento transcorra de forma clara e transparente e da forma mais eficiente possível.O planejamento e a organização de eventos relacionam-se com a produção em arranjo físico (layout) e o sistema produtivo. 


\title{
LAYOUT
}

O layout e sua correta utilização, têm consideráveis benefícios no que diz respeito a planta produtiva, fluxo de materiais, ao custo e ao lead time baixo. Cedarleaf (1994).

Correia (2013, p.407) diz que:

"O arranjo físico de uma operação é a maneira segundo a qual se encontram
dispostos fisicamente os recursos que ocupam espaço dentro da instalação de
uma operação."

A disposição dos elementos da produção, as instalações e consequentemente o serviço e o apoio prestados aos clientes são decisões pertencentes as decisões de layout. Monks (1987, p.89)

Fazer a adequação correta do arranjo físico com ferramentas, fluxo de pessoas e equipamentos visando a realização das tarefas de maneira mais eficaz, é uma preocupação das organizações que necessitam de um processo produtivo rápido e lucrativo.

O objetivo do arranjo físico é possibilitar um melhor desempenho dos colaboradores e das ferramentas de maneira que o arranjo físico flua mais fácil e mais simples. Krajewski e Ritzman (1999)

Correia (2013, p. 4017) salienta:

\begin{abstract}
"Dentro dos limites estabelecidos pela estratégia competitiva da operação, um bom projeto de arranjo físico pode visar tanto eliminar atividades que não agreguem valor, como enfatizar atividades que agreguem(...)"
\end{abstract}

Alguns objetivos podem ser associados ao planejamento de um evento, como mostra a tabela abaixo:

Utilizar o espaço físico disponível de forma eficiente;

Facilitar a comunicação entre as pessoas envolvidas na operação quando necessário

Facilitar a entrada, saída, e movimentação dos fluxos de pessoas e de materiais

Oferecer melhores condições de trabalho aos funcionários;

Facilitar a manutenção dos recursos garantindo fácil acesso

Reduzir ao mínimo as movimentações de materiais, produtos e pessoas

Minimizar os custos de manuseio e movimentação interna de materiais Evitar investimentos desnecessários 


\section{Administração: caminhos para o desenvolvimento sustentável}

\section{Permitir manutenção;}

\section{Possibilitar supervisão e obtenção de qualidade}

Fonte: Correia (2013); Rocha (1995)

Com a utilização de alguns desses mecanismos, haveria a minimização de erros e imprecisões que ocorrem muitas vezes por falta de um conhecimento mais específico e que interferem diretamente tanto na organização como no decorrer do evento.

O layout de um evento é organizado de acordo com o número de convidados, espaço disponível e especificações necessárias para atender os fornecedores que trabalharão no evento.Neste sentido, o Buffet deve ser montado de forma que os garçons tenham fácil acesso a cozinha, o DJ tenha acesso a tomadas e extensões de forma que isso não atrapalhe a movimentação do staff e dos convidados durante o evento, a mesa de doces tenha espaço para circulação entre outros.

\section{TIPOS DE LAYOUT}

- Por produto: Em uma mesma via, são dispostos em uma sequência de operações os materiais e o produto específico onde se movem pelos equipamentos.

- Funcional: São agrupadas as operações de ordem semelhante, independente do produto que se dirige em busca de processos diferentes. Geralmente utilizado para produtos com pouco volume.

- Posicional: Neste layout, o produto permanece parado (fixo) enquanto, os operadores e equipamentos trabalham e movimentam os materiais a sua volta, facilitando seu manuseio.

- Celular: Em uma mesma máquina, as operações são conectadas. Possuem estruturas mais estáveis e simples e as distancias são mais curtas. Agrega maior flexibilidade e aumenta a velocidade da produção.

O arranjo físico adequado a realização de um evento é o posicional. O local do evento é o produto definido e todos os recursos e materiais são trabalhados dentro ou envolta dele, conforme a necessidade do evento em questão a fim de atingir o seu objetivo.

O arranjo físico do casamento observado foi planejado e organizado visando atender essas especificações, o espaço disponível teve que ser aproveitado para atender todos os fornecedores e os recursos materiais foram alocados em locais específicos para atender as especificidades do evento, 


\section{Administração: caminhos para o desenvolvimento sustentável}

buscando deixar o ambiente agradável, com espaço a para circulação, espaço para a pista de dança e propiciando uma maior eficiência na circulação dos garçons e nos serviços prestados.

\section{SISTEMAS PRODUTIVOS}

Conhecer os sistemas produtivos, e identificar qual o melhor sistema para a administração de um evento pode interferir de maneira positiva.

Segundo Tubino (2009, p.1):

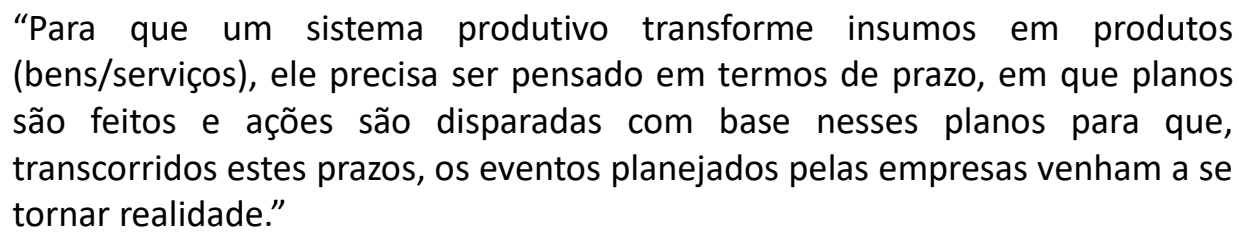

Os sistemas são divididos em 4 tipos e possuem as seguintes características:

- Sistema Contínuo $\rightarrow$ Os produtos são padronizados e trabalham com uma sequência linear de fluxo.

Características:

o Produtos e processos totalmente independentes;

o $\quad$ Custos menores de mão-de-obra;

o Lead Time baixo;

- Elevada demanda por produtos e serviços;

- Baixa flexibilidade para mudança do produto.

- Sistema em Massa $\rightarrow$ Sistema com elevada quantidade de produtos padronizados com grau de diferenciação pequeno, através das linhas de montagem.

Características:

- Variação entre produtos acabados somente na montagem final;

o $\quad$ Exige participação de mão-de-obra especializada;

o Lead Time baixo;

o Demanda por produtos e serviços é estável;

- Baixa Flexibilidade. 


\section{Administração: caminhos para o desenvolvimento sustentável}

- Sistema Repetitivo em lotes $\rightarrow$ Processo de maior variedade de produtos e tamanhos, onde após um lote de um determinado produto, ocupa o lugar do outro e equipamentos distribuídos com relação aos funcionários e as operações.

Características:

- Equipamentos agrupados em centros de trabalho;

- Mão-de-obra mais polivalente;

- Lead Time maior;

o Custos maiores;

o Relativa flexibilidade.

- Sistema por Encomenda/Projeto $\rightarrow$ Produção conforme pedido e necessidade do cliente, com projeto de prazo de início e término bem definidos.

\section{Características:}

o Demanda baixa;

- Alta flexibilidade dos recursos;

o $\quad$ Custo produtivos mais altos;

o Tendência a unidade

- Data específica para ser fabricado e entregue.

Observa- se que associando os sistemas produtivos com os eventos, este último sistema produtivo por encomenda ou projeto é o que se encaixa na produção e desenvolvimento dos eventos. Através de uma demanda ou necessidade de um cliente pela realização de uma festa ou evento, se produz de maneira específica o seu pedido.

Tubino (2009, p.12) descreve:

"Os sistemas sob encomenda organizam seus recursos produtivos por centros de trabalho ou departamentos com foco na função na função executada".

Um evento pode ter um prazo de evolução geralmente de médio a longo prazo, a depender do desejo do indivíduo. Tubino (2009, p.12) cita:

"Se inicia com a negociação de um projeto específico com o cliente eu necessita saber em que data o sistema produtivo consegue elaborar seu projeto." 


\section{Administração: caminhos para o desenvolvimento sustentável}

Muitas vezes, alguns descuidos e falhas acontecem pela falta de certos conhecimentos e de informações mais direcionadas sobre os procedimentos de eventos, prejudicando o seu andamento e da mesma forma no pós-evento.

\section{DISTRIBUIÇÃO FÍSICA}

De acordo com (BERTAGLIA, 2006), o processo de distribuição física está associado ao movimento de material de um ponto de produção ou armazenagem até a entrega ao consumidor final.

Segundo Bowersox e Closs (2001), a distribuição física tem uma ligação com o canal de marketing envolvendo a disponibilização para o abastecimento de um produto para consumo ou uso.

Para Ballou (2006), a gestão agregada de atividades como movimentação, transporte e armazenagem é realizada pela distribuição física dentro do composto da logística empresarial.

Ballou (2006) ainda salienta a segmentação da logística empresarial entre a distribuição física, e os canais físicos de suprimentos.

Complementando ainda esse conceito, alguns elementos compõem a distribuição física tais como:

- Os estoques de produtos

- Custos e pessoal

- Veículos para transporte

Além disso, sem deixar de citar as instalações físicas que são de extrema importância como os armazéns e os centros de distribuição, e os sistemas de hardware e software, que auxiliam principalmente no momento da expedição, onde se consulta os pedidos e faz a separação para a distribuição. Novaes (2007)

(BERTAGLIA, 2006) diz que o objetivo da distribuição é a fazer o produto chegar até o seu destino final, ou seja, o cliente, cumprindo o ciclo de venda saindo do vendedor até o consumidor, incluindo o pósvenda. Tudo isso de maneira confiável, rápida e segura, tanto para a empresa, quanto para o cliente.

Existem três elementos básicos que constituem a distribuição física:

- O recebimento $\rightarrow$ é iniciado quando o veículo é escolhido para transportar e descarregar a mercadoria, sempre respeitando a pesagem do produto e a conferência com o documento de transporte. 


\section{Administração: caminhos para o desenvolvimento sustentável}

- A armazenagem $\rightarrow$ quando os produtos são arrumados nos armazéns ou centros de distribuição em seus locais específicos, e organizados corretamente com protetores de umidade e verificando se são por exemplo perecíveis ou não.

- A expedição $\rightarrow$ momento onde é feita a separação dos itens que estão armazenados para fazer a entrega ao cliente. A expedição faz o carregamento e a pesagem dos veículos, assim como emite a documentação e libera os veículos para o transporte. (BERTAGLIA, 2006).

A Distribuição física preza por três utilidades essenciais:

- De tempo $\rightarrow$ quando o produto é entregue na hora desejada pelo cliente para sua utilização

- De lugar $\rightarrow$ quando é entregue no melhor local possível para o cliente, de forma que o acesso seja fácil ao produto

- De posse $\rightarrow$ quando é feita a transferência do produto do vendedor ao cliente, incluindo o tempo e o local desejado. (BERTAGLIA, 2006).

Para a realização de um evento, é necessário levar a distribuição física em conta. Ela vai organizar melhor a arrumação de um evento. Por exemplo, o recebimento dos itens da ornamentação de um casamento, como o que é necessário chegar antes e qual o horário adequado para sua utilização, sem que interfira no resultado final do evento.

Um item mal planejado, pode acarretar em um contratempo que pode afetar outros elementos que dão sequência a realização do evento.

\section{3 - PROCEDIMENTOS METODOLÓGICOS}

Utilizou -se como metodologia de pesquisa, a busca no portal Scielo, onde foi verificado pelas palavraschave e também pelos principais termos do artigo que se relacionavam, evidenciando o período entre 2000 e 2018, ao qual foram revisados por pares, e posteriormente classificando por ordem de relevância Com este critério foram localizados 4 artigos nos quais foram lidos os resumos, sendo selecionados 2 artigos relacionados com o objetivo do artigo.

Ainda foram selecionados outros 7 artigos como base através do Google e do Google Acadêmico. Elencou-se os principais pelos termos da palavra-chave e os assuntos relacionados. 
Foram verificados em todos os artigos, as principais relações com as aplicações de logística e produção no planejamento e organização dos eventos.

As revistas utilizadas e sua qualificação QUALIS estão elencadas no quadro I (Revista, ISN, QUALIS).

Nessas revistas foram utilizados, os seguintes termos de busca: gestão de eventos; produção de eventos; logística aplicada a eventos; produção aplicada a eventos.

Os autores consagrados na área de eventos foram considerados independente do recorte cronológico.

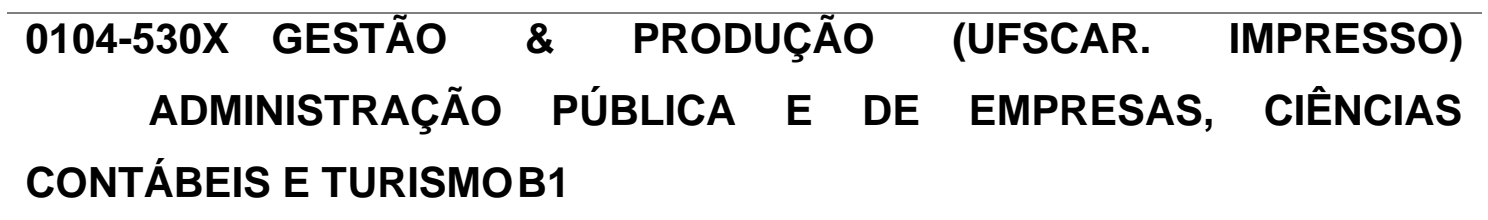
1806-9649 GESTÃO E PRODUÇÃO (UFSCAR) ADMINISTRAÇÃO
PÚBLICA E DE EMPRESAS, CIÊNCIAS CONTÁBEIS E TURISMO B1
2236-0972 GEP - - REVISTA DE GESTÃO E PROJETOS ADMINISTRAÇÃO PÚBLICA E DE EMPRESAS, CIÊNCIAS CONTÁBEIS E TURISMOB2

\section{8-8030 GESTAO E PLANEJAMENTO ADMINISTRAÇÃO PÚBLICA E DE EMPRESAS, CIÊNCIAS CONTÁBEIS E TURISMO B2}

Quadro 1, qualificação de revistas Qualis.

\section{4- ESTUDO DE CASO}

Este artigo tem por objetivo identificar conceitos de logística e de produção que possam ser utilizados na realização de eventos para aprimorar o planejamento, a organização e a execução do evento.

A organização de um casamento envolve diversos fornecedores que devem estar em sintonia para que a montagem seja realizada da forma mais efetiva possível. O problema da pesquisa foi observado na organização de um casamento, onde foi possível identificar diversas falhas de planejamento, layout e logística durante a montagem. As informações foram extraídas da empresa de organização e cerimonial Lillás Eventos. A proprietária Marillia Hamati através do seu relato, concedeu os dados importantes para o desenvolvimento deste estudo de caso.

O caso que iremos estudar será do casamento de A\&F, onde foi possível identificar diversas falhas que poderiam ser evitadas utilizando algumas ferramentas específicas de produção e de logística.O problema da pesquisa foi observado na organização de um casamento, onde foi possível do casamento 


\section{Administração: caminhos para o desenvolvimento sustentável}

de $A \& F$, Abaixo faremos um breve relato de como ocorreu a montagem do evento e quais foram as falhas identificadas.

O casamento de A\&F foi planejado em todos os detalhes, do ponto de vista do cliente, vamos trazer a visão de uma profissional da área que acompanhou o processo. A família da noiva reservou o salão de um restaurante da cidade de Ponta Grossa com capacidade para no máximo 160 pessoas, sem espaço para a pista de dança, somente depois disso as famílias dos noivos foram conversar com a organizadora do evento que solicitou a lista dos convidados, a lista final contava com 250 convidados, portanto o local do evento teve que ser mudado para um salão que comportasse o tamanho do evento. A noiva definiu como gostaria que fosse montada a decoração dentro do salão, o local da pista de dança, da mesa dos noivos, dos doces, do DJ e da cabine de fotos. Porém, ela não levou em consideração os aspectos técnicos, como por exemplo a estrutura elétrica necessária para atender a mesa de som do DJ e como funcionaria a logística do buffet, como: o local e momento em que ele seria servido; a entrada e saída dos garçons da cozinha; e o local onde ficaria localizado o bar.

Durante o planejamento do layout do evento, foram levadas em consideração alguns fatores primordiais. A cabine de fotos que foi contratada pela noiva utilizou energia elétrica e por isso foi montada estrategicamente num local que tivesse tomadas der fácil acesso e evitasse cruzar fios elétricos por locais de passagem de pessoas, tanto de convidados quanto de funcionários que trabalharam na montagem, no desenvolvimento e no fechamento do evento. O local onde seria montado e servido o buffet do jantar, foi determinado devido a facilidade de acesso a cozinha e aos convidados no momento de se servirem, bem como a logística de desmontar o buffet e abrir espaço para a pista de dança que seria aberta após o jantar. O bar ficou localizado em um lugar de fácil acesso devido a intensa movimentação durante a festa. A mesa de doces, fazendo parte da decoração ficou em um local de destaque sem atrapalhar a passagem e possibilitando a circulação dos convidados.

Levando em consideração as necessidades de circulação do evento, foi desenhado um layout do salão com cada coisa em seu devido lugar, conforme mostramos na figura acima abaixo: 


\section{Administração: caminhos para o desenvolvimento sustentável}

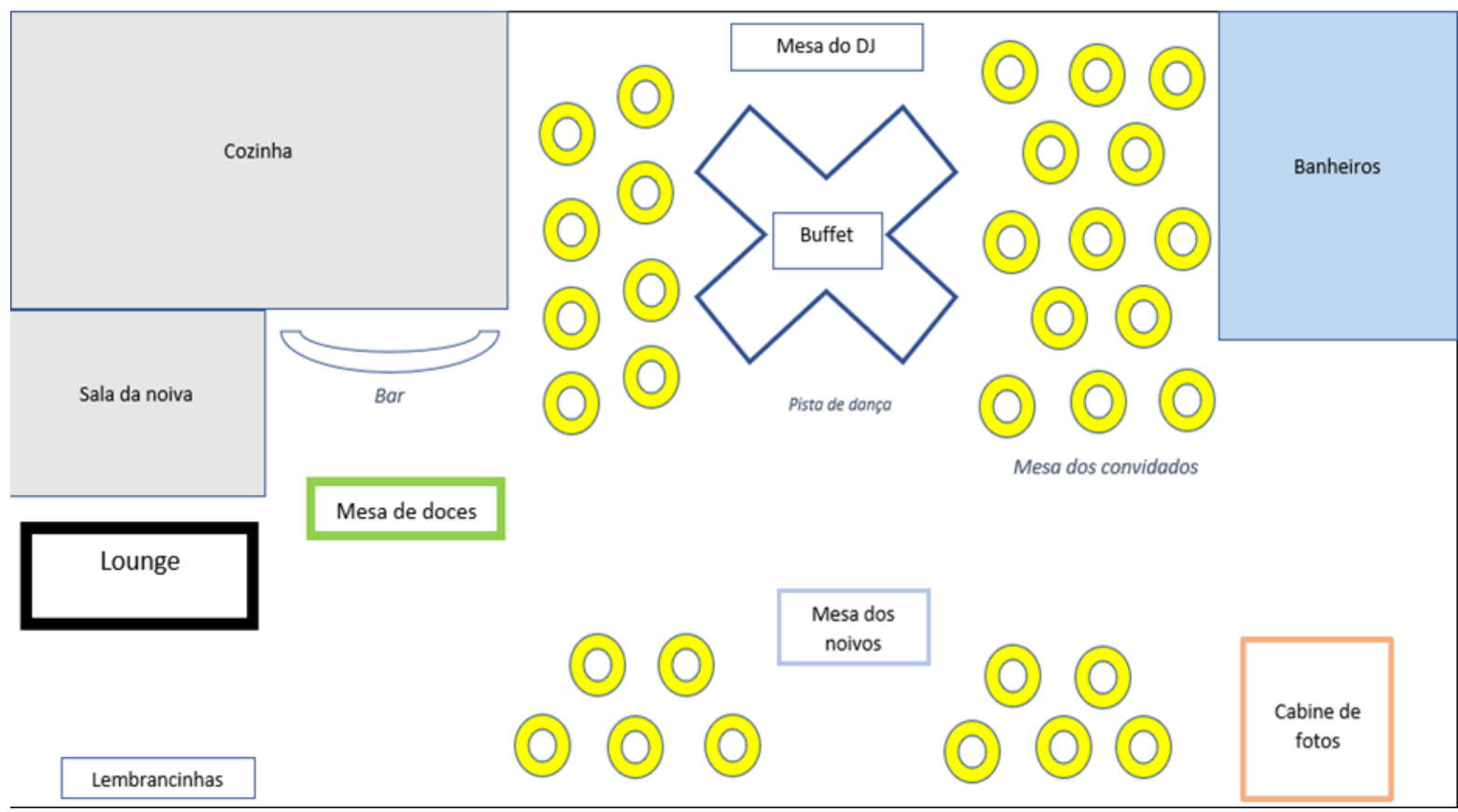

Esse layout serviu de base para a montagem do evento que foi organizada através de um cronograma para gerenciar todos os fornecedores durante a montagem de forma a não prejudicar o bom andamento da organização.

CRONOGRAMA DE MONTAGEM DO EVENTO

\section{Ordem de montagem Fornecedor Itens}

1.

DJ

Buffet

2.

3.
Decoração

Estrutura de metal da pista de dança e equipamentos de som e iluminação

5.

Buffet

Decoração

Montagem das mesas

Colocação dos móveis: mesa dos noivos, mesa de doces, lounge, aparador.

Colocação das toalhas de mesa

Colocação das peças dos arranjos de mesa

6.

DJ

Instalação do tapete da pista de dança

7.

Buffet

Montagem da estrutura do buffet

8.

Fotos
Montagem da Cabine de fotos 


\section{Administração: caminhos para o desenvolvimento sustentável}

9.

Decoração Outras peças de decoração: portaretratos, suportes para os doces etc.

10.

Decoração Colocação dos arranjos de flores

11.

Buffet

Montagem do misenplace (susplat, pratos, talheres e taças)

12.

Decoração Montagem da mesa de lembrancinhas e da decoração dos banheiros

13.

Doces

Montagem da dos doces na mesa

14.

Salão

Limpeza do salão

GRÁFICO DE GAUNT

\begin{tabular}{|c|c|c|c|c|c|c|c|c|c|c|c|c|c|}
\hline $\begin{array}{l}\text { Tempo/ hora } \\
\text { Atividade }\end{array}$ & $8 \mathrm{~h}$ & $9 \mathrm{~h}$ & $10 \mathrm{~h}$ & $11 \mathrm{~h}$ & $12 \mathrm{~h}$ & $13 \mathrm{~h}$ & $14 \mathrm{~h}$ & $15 \mathrm{~h}$ & $16 \mathrm{~h}$ & $17 \mathrm{~h}$ & $18 \mathrm{~h}$ & $19 \mathrm{~h}$ & $20 \mathrm{~h}$ \\
\hline 1 & & & & & & & & & & & & & \\
\hline 2 & & & & & & & & & & & & & \\
\hline 3 & & & & & & & & & & & & & \\
\hline 4 & & & & & & & & & & & & & \\
\hline 5 & & & & & & & & & & & & & \\
\hline 6 & & & & & & & & & & & & & \\
\hline 7 & & & & & & & & & & & & & \\
\hline 8 & & & & & & & & & & & & & \\
\hline 9 & & & & & & & & & & & & & \\
\hline 10 & & & & & & & & & & & & & \\
\hline 11 & & & & & & & & & & & & & \\
\hline 12 & & & & & & & & & & & & & \\
\hline 13 & & & & & & & & & & & & & \\
\hline 14 & & & & & & & & & & & & & \\
\hline
\end{tabular}




\section{Administração: caminhos para o desenvolvimento sustentável}

\section{5 -RESULTADOS}

Analisando o cronograma podemos perceber que as estruturas grandes e que podem deixar bagunça, sujeira ou atrapalhar outros processos de montagem são as primeiras a serem colocadas no salão e as estruturas delicadas como doces e flores são as últimas, levando em consideração a sua fragilidade evitando deixa-las em contato com qualquer processo que possa prejudicá-las.

Os profissionais da área de eventos, muitas vezes ordenam os processos baseados na experiência e na intuição, e algumas dificuldades que surgiram durante o processo de montagem. Um exemplo foi o tapete da pista de dança que era maior do que o espaço que o DJ deixou para a sua colocação, e também algumas louças das mesas tiveram que ser trocadas pois os garçons as colocaram antes da equipe da decoração terminar de posicionar os arranjos de flores, que soltaram algumas pétalas e folhas nos pratos que já estavam colocados. A equipe da limpeza também quis adiantar o serviço e acabou tendo que trabalhar dobrado, pois, fizeram a limpeza após a montagem da estrutura da pista de dança que faz bastante sujeira e posteriormente tiveram que limpar novamente depois da colocação das flores. Outro transtorno foi a doceira chegar com os doces para colocar na mesa antes da chegada dos suportes que a equipe de decoração é responsável por trazer, criando-se dessa forma uma situação complicada. Deve-se prestar atenção ao todo para evitar contratempos e não conformidades.

\section{6 - CONCLUSÃO}

Muitas são as atividades de elaboração de um evento. Muitos detalhes devem ser pensados antecipadamente para que eventuais contratempos não ocorram. Possuir experiência e um certo conhecimento sobre o assunto podem fazer toda a diferença. Compreender sobre layout é de extrema importância pois a alocação dos itens deve ser feita de maneira que se tenha acesso fácil a todo o espaço de maneira prática e objetiva. Deve ficar acessível tanto para os convidados na hora da circulação pelo salão e utilização dos itens, quanto para os funcionários, na hora da montagem e realização do evento, e igualmente na hora de desmontar a estrutura.

Os sistemas produtivos auxiliam no processo de produção e montagem do evento. Identificar o sistema produtivo sob encomenda ou projeto como o indicado para a questão, favorece no seu desenvolvimento, visto que, as características como: alta flexibilidade dos recursos, e data específica para ser fabricado e entregue, são determinantes no processo. 


\section{Administração: caminhos para o desenvolvimento sustentável}

Para um sistema produtivo funcionar de maneira efetiva é preciso que todas as partes estejam cientes de todo o processo além de saber qual é a sua obrigação e o tempo em que ela deve ser realizada. Quando o fornecedor tem uma visão global dos processos que envolvem a montagem de um evento é possível otimizar o trabalho e facilitar o desenvolvimento dos processos.

Um evento será bem-sucedido e realizado da forma mais eficiente e eficaz possível utilizando as ferramentas de logística e produção descritas neste artigo, evitando desperdício de tempo, mão-deobra e matéria-prima e levando em consideração todos os processos do planejamento, organização e execução do evento.

\section{7 - REFERÊNCIAS}

ABEPRO. Disponível

em <http://www.abepro.org.br/biblioteca/enegep2009_TN_STP_091_615_13136.pdf>Acesso em 25 de maio de 2019

Allen, J., O’Toole, W, McDonnel, I., \&Haris, R. (2003). Organização e gestão de eventos. (3a ed.) Rio de Janeiro: ELSEVIER

BAHL, Miguel (2004). Turismo e Eventos;Protexto

BARBOSA, Fabrício Silva. Turismo de Eventos na Serra Gaúcha: O Caso da Festa Nacional da Uva de Caxias do Sul, RS Disponível

em <http://www.ucs.br/etc/revistas/index.php/rosadosventos/article/view/2583> Acesso em 25 de maio de 2019

BASSI, Renata Elaine, et al. A logística de eventos da maior feira de artesanato da América Latina. Disponível em <http://www.revistarefas.com.br/index.php/RevFATECZS/article/view/92> Acesso em 25 de maio de 2019

CESCA, C. G. G. Organização de eventos. 9a edição São Paulo: Summus, 1997.

EBAH. Disponível

em <https://www.ebah.com.br/content/ABAAAg1GQAH/logistica-eventos?part=3>Acesso em 25 de maio de 2019

Ferramenta essencial na Produção de eventos. Disponível

em<https://www.cncp.org.br/UserFiles/File/LOGISTICA\%20ferramentaessencialnaproducaodeevent os.pdf

GRANT, David. Gestão de logística e cadeia de suprimentos. Disponível 


\section{Administração: caminhos para o desenvolvimento sustentável}

em<https://books.google.com.br/books?hl=ptBR\&lr=\&id=rjlnDwAAQBAJ\&oi=fnd\&pg=PT15\&dq=log \%C3\%ADstica+em+eventos\&ots=VhZrkaEi2g\&sig=6bYQ2dD5kqm6apmhk1DDx8ozOUI\#v=onepage\&q $=\log \%$ C3\%ADstica\%20em\%20eventos\&f=false> Acesso em 18 de maio de 2019

GIACAGLIA, M. C. Organização de eventos: teoria e prática. 1a edição. Ano: 2003.256 págs. São Paulo: Thomson Learning, 2006.

GIÁCOMO, C. Tudo acaba em festa. 1ạ edição. São Paulo: Summus, 2007.

HAMATI, Marillia. TEORIA E PRATICA DO PLANEJAMENTO E DA ORGANIZAÇÃO DE EVENTOS: UMA ANÁLISE DO XX ENCONTRO ANUAL DE INICIAÇÃO CIENTÍFICA - EAIC, 2011.

MARTIM, Vanessa. Manual prático e eventos. Disponível

em<https://books.google.com.br/books?hl=ptBR\&lr=\&id=QmHjBwAAQBAJ\&oi=fnd\&pg=PT5\&dq=log \%C3\%ADstica+em+eventos\&ots=qME9_Po53s\&sig=vYtcq_BmBFzzFvSuSrnnGl3KsA\#v=onepage\&q=lo g\%C3\%ADstica\%20em\%20eventos\&f=false> Acesso em 18 de maio de 2019.

Martin, V. (2008). Manual Prático de Eventos. São Paulo: Atlas. Matias, M. (2001). Organização de eventos: procedimentos e técnicas. São Paulo: Manole.

Matias, M. (2010). Organização de eventos: procedimentos e técnicas. (5a ed.) Barueri: Manole.

MEIRELLES, G. F. Tudo sobre eventos. 1ạ edição. São Paulo: Ed STS, 1999.

NAKANE, A. Técnicas de organização de eventos. 3a edição. Rio de Janeiro: Infobook, 2000.

Organização e execução de eventos. Disponível

em<http://proedu.rnp.br/bitstream/handle/123456789/1354/Organizacao\%20e\%20Execucao\%20de \%20Eventos\%202013.pdf?sequence=1> Acesso em 25 de maio de 2019.

SINGEP. Disponível em <https://singep.org.br/5singep/resultado/25.pdf> Acesso em 25 de maio de 2019.

SILABO. Disponível em <http://www.silabo.pt/Conteudos/7967_PDF.pdf>Acesso em 25 de maio de 2019.

UFPEL, Periódicos. Disponível

em <https://periodicos.ufpel.edu.br/ojs2/index.php/AT/article/view/10238> Acesso em 25 de maio de 2019

VIEIRA , João Martins. Eventos e Turismo. Eventos e Turismo - Planeamento e Organização - Da teoria à prática, Lisboa, Abril 2015. Disponível

em:file://C:/Users/patyp/OneDrive/Imagens/artigo\%20organiza\%C3\%A7\%C3\%A30\%20de\%20event os.pdf. Acesso em: 25 maio 2019.

ZANELLA, L. C. Manual de organização de eventos: planejamento e operacionalização.n.20, p.421-449, jun. 2005. ZANELLA, L. C.São Paulo: Atlas, 2006. 


\section{Capítulo 19}

\section{A VISÃO ESTRATÉGICA NAS ORGANIZAÇÕES DE PRODUTORES: A MATRIZ SWOT COMO INSTRUMENTO PARA A ELABORAÇÃO DAS ESTRATÉGIAS DA AMIGA EM IGARAPÉ-AÇU/PA}

DOI: $10.37423 / 200300402$

Alexandre Jorge Gaia Cardoso, (Universidade do Estado do Pará - UEPA) alexandregaia@yahoo.com.br

Wilza da Sikveira Pinto, (Universidade Federal Rural da Amazênia - UFRA) wilza.pinto@utra.edu.br

Rosa de Souza Oliveika, (Prefeitura Municipal de Igarape-Açu $-P M I A)$ rosa_inh@yahoo.com.br

Resumos Objetivo: o presente trabalho teve por objetivo definir estratéglas para a Assơciação de criadores e criaddoras de ąbelhas meliferas do municipio de Igarapé-Açu-Pärá AMIGA para que esta aumente o volume de produção de mel e atinja 0 mercado formal. Metodologia: quantoà-metodologia trata-se de una pesquisa qualitativa,especificamente um estudo de caso, no qual os dados foram colettadós por meio da metodologia GESPAR - gestão participativa e da matriz SWOT. Do confronto dos pontos fortes e fracos e ameaças e oportunidades foi elaborada uma matriz denominada de SWOT. Resultados: os resultados mostraram que a organização está em fáse de desenyo/vimento, portanto, foram estapelecidas as principais estratégias de desenvolvimẹnto que a associação deverá exequtar nos próximos ano\$. Ficou definido que-a planejamento deverá ser revisto anualmente ha tentativa de adequar as ações às mudanças ambièntais.

PALAVRAS-CHAVE: planejamento, gespar, swot.

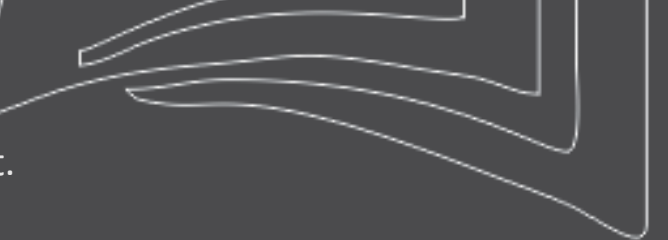




\section{Administração: caminhos para o desenvolvimento sustentável}

\section{INTRODUÇÃO}

Produzir alimentos nas condições sócio-econômicas vigentes no Brasil, não é tarefa simples, apesar de ser a produção agrícola, atividade econômica fundamental, sem a qual no rural não haverá reprodução social. Para os produtores, vender bem a produção é a etapa mais difícil é importante, pois na comercialização se fecha o ciclo produtivo. É o elo mais importante das cadeias produtivas do negócio agropecuário, onde ocorre o fluxo de capitais.

Para a agricultura familiar conseguir alcançar o mercado formal tem sido o grande gargalo da produção, uma vez, que individualmente a produção é pequena e muitas vezes sem a qualidade exigida pelo mercado, além de vender quase sempre sem agregação de valor, o que provoca baixos rendimentos a produção, desestimulando a continuidade no negócio.

Para amenizar satisfatoriamente esta etapa é que foram surgindo às organizações de produtores, seja na forma de cooperativas ou associações, estimulados pelo ideal cooperativista de que o fortalecimento se dá pela união e agregação das pessoas.

A finalidade destas organizações rurais familiares é aumentar o poder de barganha, a escala da produção, a diversificação e a estabilização das produções, viabilizar a agregação de valores aos produtos através do beneficiamento, com a instalação de pequenas agroindústrias, ampliar o mercado, a capitalização, e, com isso, incrementar as chances de melhores ganhos, de maneira mais lucrativa e sustentável das atividades produtivas.

Para Brum; Arastimunha \& Machado (2006) as associações de produtores rurais revelam-se como uma forma estratégica de geração e fortalecimento dos laços de relação e isto provavelmente permite avanços em processos associativos de negócios.

O ideal cooperativista de união das pessoas para desenvolvimento de atividades e negócios surgiu com o ideário de tecelões de Rochdale, na Inglaterra, que há mais de um século e meio atrás - em 1844 já percebiam a necessidade de se organizarem para superar as limitações e as injustiças da exploração a que eram submetidos no início da Revolução Industrial. Com isto surgiram no mundo várias organizações com o mesmo ideário de se unirem para se fortalecerem.

As diversas formas organizacionais têm sido desenvolvidas e experimentadas em diversas épocas e regiões, porém, muitas na maioria das vezes são instaladas, mas apresentam ciclo de vida curto. Quando permanecem, são altamente dependentes de iniciativas de agentes públicos. Incentivadas por políticas públicas algumas organizações são criadas, mas com o recuo da política a determinada 


\section{Administração: caminhos para o desenvolvimento sustentável}

atividade faz com que muitas famílias abandonem as associações, particularmente as que foram criadas na esteira de alguma atividade que foi estimulada.

Mesmo assim, alguns programas continuam ainda a exigir que para ser beneficiário o produtor deva estar associado a alguma entidade. Além disso, o acesso a determinados serviços de política pública ficam condicionados apenas aos integrantes das associações de produtores rurais.

Dentre os grandes problemas enfrentados por estas organizações está o quesito gestão, uma vez que, a maioria dos atores envolvidos no processo não está preparado para assumi-la. A falta de conhecimento sobre os elementos da gestão levou e ainda leva muitas organizações a não alcançarem êxito nas suas ações. Além disso, a falta de visão e planejamento nas organizações de produtores tem contribuído para o desarranjo organizacional e uma ameaça ao desenvolvimento das mesmas.

A Associação de criadores e criadoras de abelhas melíferas de Igarapé-Açu - AMIGA foi fundada em 17 de setembro de 2005, com um grupo de 25 apicultores e apicultoras interessados na produção e outras atividades relacionadas com a apicultura. A AMIGA surgiu a partir da necessidade que o grupo sentiu em organizar a produção e os apicultores para que juntos pudessem trabalhar volume de produção e atingir o mercado formal. A AMIGA foi registrada um ano após a sua fundação depois de passar por um período de amadurecimento do grupo e decidir por seu registro.

Tem como principal preocupação a produção sustentável e com responsabilidade ambiental a associação vem trabalhando para a garantia da produção e manutenção do negócio apícola em Igarapé-Açu. A produção é toda oriunda de flora silvestre e as abelhas africanizadas. Possui no seu quadro associativo 45 apicultores com uma produção anual de $5.000 \mathrm{~kg}$ de mel de Apis (Abelhas com ferrão) e entre seus associados 10 trabalham também com melíponas (Abelhas sem ferrão).

Apesar do amadurecimento inicial e de manter um grupo de associados motivados para a produção de mel viu-se a necessidade de estabelecer um grupo sistemático de ações que ressultassem em maior volume de produção e competividade da associação através do mapeamento do ambiente externo e interno da associação. Nesse processo uma ferramenta de gestão capaz de compatibilizar o ambiente externo e interno é a Matriz SWOT (forças, fraquezas, oportunidades e ameaças), que consiste em uma metodologia empregada para identificar forças e fraquezas em contraposição a oportunidades e ameaças, possibilitando a construção de cenários capazes de sintetizar a realidade e fundamentar estratégias. Essa ferramenta, desenvolvida pela Escola do Designer foi utilizada neste estudo aplicado na AMIGA. 


\section{Administração: caminhos para o desenvolvimento sustentável}

Estabelecida a proposta desde estudo, o objetivo principal deste trabalho foi propor estratégias que possam aumentar a volume de produção de mel da associação e atingir o mercado formal, respondendo ao problema de pesquisa: quais estratégias são capazes de fundamentar um conjunto sistemático de ações que possibilitem contribuir para o aumento do volume de produção de mel da AMIGA e permita atingir o mercado formal de mel?

O presente artigo foi estruturado em seis seções, incluindo esta. A Introdução apresenta em linhas gerais o tema, identifica o problema de pesquisa e os objetivos propostos pelo estudo. Na segunda e terceira seções será discutida a Revisão da Literatura, que discorrerá sobre a fundamentação teórica utilizada no estudo, pautada em temas como planejamento, processo de gestão e Escola do Designer, com uma de suas principais ferramentas de planejamento, a análise SWOT.

Na quarta seção, denominada Metodologia, serão reunidas e apresentadas as técnicas utilizadas no estudo, a classificação da pesquisa, a forma de tratamento dos dados e a interpretação dos resultados. A quinta seção, Apresentação dos Resultados, versará sobre os principais resultados do tratamento dos dados, e na sexta e última seção serão apresentadas as Considerações Finais do estudo.

\section{MARCO TEÓRICO}

\subsection{O PLANEJAMENTO E A GESTÃO ORGANIZACIONAL}

O gerenciamento das organizações contemporâneas exige, cada vez mais, o uso de técnicas e ferramentas capazes de contribuir para melhorar sua competitividade e longevidade. Assim, o processo de gestão consiste, a priori, na obtenção de resultados a partir de objetivos e das estratégias previamente estabelecidos pelo planejamento. As etapas seguintes do processo, ou seja, a organização, a direção e o controle são executadas dentro de uma determinada sequência lógica de maneira a viabilizar os planos organizacionais, decorrentes do planejamento, de maneira eficiente, ou seja, usando da melhor maneiro possível os recursos disponíveis.

Nesse contexto, emerge a importância do planejamento como técnica que será utilizada para "fazer funcionar" todas as demais etapas do processo e, conseqüentemente, a própria organização. Assim, Etzel, Walker e Stanton (2001, p.52) definem planejamento como "o ato de estabelecer metas e desenvolver estratégias e táticas para alcançar essas metas".

Robbins (2005) faz uma diferenciação nos termos utilizados para a definição do planejamento: metas e estratégias. Interpretando de forma mais exata a concepção do autor, nota-se que a organização 


\section{Administração: caminhos para o desenvolvimento sustentável}

alcança os estados futuros definidos em uma dimensão temporal (metas), por meio da aplicação e do direcionamento de recursos, sejam eles financeiros, humanos ou materiais (estratégias).

As metas ou objetivos são resultados, propósitos, intenções ou estados futuros que as organizações pretendem alcançar, para tanto devem ser quantificadas e aprazadas. Já os planos são guias que indicam o que deve ser feito, especificando os recursos e as ações necessárias para alcançar os objetivos.

A visão do planejamento como seleção de objetivos e planos também é defendida por Stoner e Freeman (1999). Para esses autores, o objetivo é pensar antecipadamente o que se quer, e os planos são as linhas-mestras pelas quais as organizações obtêm e aplicam os recursos necessários para o alcance de seus objetivos, desde que estes sejam escolhidos adequadamente, para que possam ser monitorados e alcançados, permitindo medidas corretivas caso não sejam satisfatórios ou ocorram mudanças ambientais não previstas.

Montana (2003) chama a atenção para o fato das organizações que não adotam o planejamento como uma prática gerencial e, portanto, passam a ter seu posicionamento à mercê das múltiplas forças do mercado, por isso, seja do ponto de vista empresarial ou profissional, faz-se necessário escolher um destino, avaliar as rotas alternativas e determinar o curso específico para alcançar o caminho escolhido. Este processo permite uma análise mais cuidadosa dos problemas existentes e das alternativas para superá-los.

Lacombe e Heilborn (2003) trabalham a idéia de decisão, portanto age-se no presente para colher resultados no futuro. Esta decisão antecipada envolve a definição do que fazer, de que maneira fazer, quando fazer e quem deve fazer. Essa abordagem também é apresentada por diversos autores (KOTLER, 2000; HOOLEY; SAUNDERS; PIERCY, 2001; HITT; IRELAND; HOKISSON, 2002).

O planejamento, portanto, é uma grande preparação para a ação. O plano, resultado do planejamento que estará contido em um documento, é uma forma de guia calculada do que deverá ser feito, representa um grande experimento que é feito antes de se colocar em prática, para que se evitem os riscos de se perder os poucos recursos que as organizações disponibilizam para fazer o que têm que ser feito.

O que fundamenta a ação do planejamento é um descontentamento contínuo em relação ao presente. Hitt, Ireland e Hokisson (2002) apresentam o planejamento a partir da análise e compreensão dos ambientes nos quais estão inseridas as organizações. Desta forma, o primeiro passo do planejamento 


\section{Administração: caminhos para o desenvolvimento sustentável}

consiste em procurar identificar as oportunidades e ameaças que surgirão no ambiente externo e confrontá-las com as forças e fraquezas do ambiente interno, de tal forma a possibilitar ações prévias que permitam tanto aproveitar as oportunidades, como defender-se das ameaças.

\subsection{A ESCOLA DO DESIGNER E MATRIZ SWOT}

A escola estratégica denominada como Escola do Designer foi provavelmente a escola mais influente na evolução do pensamento estratégico organizacional de todos os tempos. A concepção mais simples, parte da premissa que a estratégia emerge da habilidade em adequar as capacidades (internas) as possibilidades (externas). A Escola do Designer inicia-se no final da década de 1950 e tem como uma das principais ferramentas a análise SWOT (MINTZBERG; AHLSTRAND; LAMPEL, 2002).

Apesar das controvérsias quanto à autoria da técnica, acredita-se que análise SWOT foi proposta originalmente por Andrews em 1971 e resulta da combinação da análise do ambiente externo e interno (ROSSI;LUCE, 2002). Constitui-se de um instrumento de análise que poderá ser associado a uma oficina de planejamento ou workshop para possibilitar a avaliação, reflexão, capacitação, ou mesmo consultoria. Aplicada aos mais diversos contextos organizacionais, a sigla representa o acrônimo em inglês das palavras: forças (Strengths), fraquezas (Weaknesses), oportunidades (Opportunities) e ameaças (Threats).

Segundo Cordiolli (2001, p.5) o método SWOT:

[...] é uma abreviatura de quatro focos de análise, considerando os pontos fortes (objetivos alcançados, benefícios, satisfação); pontos fracos (dificuldades, fracassos, descontentamento); oportunidades (capacidade sem exploração, idéias de melhoramento) e ameaças (contexto adverso, oposição, resistências contra mudanças).

Os componentes da SWOT podem ser assim conceituados: oportunidade é uma situação externa, que dá à comunidade a possibilidade de facilitar o alcance dos objetivos e de melhorar sua situação econômica; ameaça é uma situação externa, que coloca a comunidade diante de dificuldades para o alcance dos objetivos ou a perda de renda; ponto forte corresponde a uma característica interna, ou um ativo que possibilita à comunidade uma vantagem sobre outros ou uma facilidade para o alcance dos objetivos (que podem incluir renda); ponto fraco é uma característica interna, ou uma limitação em um ativo, que coloca a comunidade em situação de desvantagem ou de dificuldade em relação a outras para o alcance dos objetivos (MANKTELOW; CARLSON, 2010).

A implementação da ferramenta ocorre a partir da constituição de uma matriz, na qual as linhas serão compostas pelas oportunidades e ameaças, e nas colunas forças e fraquezas (MANKTELOW; CARLSON, 


\section{Administração: caminhos para o desenvolvimento sustentável}

2010). Assim cada cruzamento (linha $X$ coluna) possibilita a elaboração de uma estratégia de aperfeiçoamento, nas situações de fraqueza ou de aproveitamento nas situações de oportunidade. Notoriamente o cruzamento das linhas e colunas ensejará inúmeras combinações e o estabelecimento de tantas estratégias quanto forem os cruzamentos de cada linha e coluna (Quadro 1).

Quadro 1 - Representação gráfica da SWOT

\begin{tabular}{l|c|c}
\hline & Forças & Fraquezas \\
\hline Oportunidades & Estratégia & Estratégia \\
Ameaças & Estratégia & Estratégia \\
\hline
\end{tabular}

Fonte: Manktelow (2011).

A identificação das oportunidades e ameaças, normalmente ocorre na forma de brainstorming. Essa técnica para solução de problemas envolve normalmente seis a 12 participantes, que são selecionados de forma a garantir ampla gama de conhecimentos. A seção inicia-se pela apresentação do problema e a partir desse momento registram-se todas as idéias que surgirem no grupo, independentemente de sua lógica ou pertinência, para depois serem refinadas e constituírem-se ao final em oportunidades e ameaças que representem o mais fielmente possível a opinião dos participantes (HISRICH; PETERS, 2002).

Estabelecidas as oportunidades e ameaças, a etapa seguinte consiste em identificar as forças e fraquezas e confrontá-las com as oportunidades e ameaças, possibilitando, assim, a escolhas das estratégias. Contudo, muitas vezes, observa-se grande número de células (local na matriz que resulta do cruzamento de uma linha com uma coluna), formados por situações remotas ou de baixo impacto, fato que leva o planejamento a um detalhamento cansativo e na maioria das vezes desnecessário.

A escolha das estratégias mais adequadas e pertinentes passa necessariamente pelo processo de seleção, tanto da estratégia em si, quanto do evento que será objeto do estabelecimento de estratégia. Ou seja, quando a Matriz resulta em muitas células, uma possibilidade de solução para a seleção delas é a classificação desses cruzamentos, por exemplo, a eventos com baixa probabilidade de ocorrência podem ser atribuídos valores baixos, como zero ou um; em eventos com alta probabilidade de ocorrência, ou de alto impacto, podem ser classificados com pesos elevados, como quatro ou cinco (Quadro 2). 


\section{Administração: caminhos para o desenvolvimento sustentável}

Quadro 2 - Redução das estratégias com a seleção dos cruzamentos da SWOT

\begin{tabular}{l|c|c}
\hline & Forças & Fraquezas \\
\hline Oportunidades & peso /probabilidade & peso /probabilidade \\
Ameaças & peso /probabilidade & peso/probabilidade \\
\hline
\end{tabular}

Fonte: Elaborado pelos autores

Os cruzamentos da SWOT possibilitam selecionar as células que serão objetos da elaboração de estratégias, com base na maior probabilidade de ocorrência, ou no impacto gerado, possibilitando atuar de forma mais direcionada nos reais problemas comunitários, tornando o planejamento efetivo e focado.

\section{METODOLOGIA}

Adotando a taxonomia proposta por Vergara (2009), o presente estudo classifica-se quanto aos fins como uma pesquisa aplicada, de caráter exploratório e descritivo. Uma vez que, pautada em problemas concretos, busca a compreensão inicial do fenômeno e sua descrição sem o compromisso preliminar de explicá-lo, apesar de a descrição contribuir sobremaneira para a explicação do fenômeno. Quanto aos meios, caracteriza-se como um estudo de campo, pois ocorreu no local onde se manifesta o fenômeno (CERVO; BERVIN; DA SILVA, 2007; VERGARA, 2009).

Quanto à forma de tratamento dos dados, observa-se o predomínio do qualitativo sob o quantitativo, uma vez que o estudo não foi baseado no tratamento estatístico de dados, e sim na procura por soluções para o problema proposto, a partir da compreensão da realidade, segundo a sistematização e interpretação da opinião dos atores envolvidos no processo participativo, expressa na construção da visão de futuro e do diagnóstico participativo que foram organizados e sistematizados pelos pesquisadores (SOARES, 2003; VERGARA, 2009).

O universo da pesquisa foi composto por associados da associação de criadores e criadoras de abelhas melíferas do município de Igarapé-Açu,- Estado do Pará. A amostra, classificada como não probabilística por acessibilidade, coletou dados primários dos grupos de discussão, utilizando a técnica de Diagnóstico Participativo-DP que é uma ferramenta da metodologia participativa - Gespar - Gestão Participativa. Trata-se de uma metodologia de capacitação que, promovendo a gestão participativa visa o desenvolvimento empresarial das organizações de pequenos produtores rurais e urbanos e a melhoria da qualidade de vida de suas famílias estimulando ao surgimento de novas institucionalidades que reflitam o empoderamento dos associados (PNUD, s/d). 


\section{Administração: caminhos para o desenvolvimento sustentável}

O diagnóstico participativo contribui para o conhecimento e a análise da realidade da organização de acordo com a percepção de cada associado e corresponde a um levantamento em um momento de reflexão. Desta forma, contribui para a descoberta de potencialidades, oportunidades, pontos de estrangulamentos e ameaças da organização, com intuito de provocar mudanças pela participação, com isso, contribui ao stat up das condições necessárias ao desenvolvimento organizacional (VERDEJO, 2006).

O trabalho de campo produziu relatórios que foram organizados e sistematizados, utilizando a Matriz SWOT como forma de possibilitar a proposição de um conjunto estratégico capaz de primeiro fortalecer as relações produtivas da organização de apicultores, superar os principais entraves econômicos e, principalmente, fundamentar um conjunto de planos de ação que, uma vez implementado, possibilite estruturar ações conjuntas e acompanhar os resultados obtidos de forma a corrigir planos de ação e ajustar novas proposições.

\section{RESULTADOS E DISCUSSÕES}

A apresentação dos resultados do estudo foi estruturada em seis subseções. A primeira (4.1) sumarizou os relatórios dos grupos de discussão do DP e proporcionou a representação da Matriz SWOT. A partir da interpretação da Matriz, as seções subseqüentes detalharam a análise em ameaças (4.2), oportunidades (4.3), pontos fracos (4.4), pontos fortes (4.5) e as (4.6) estratégias elaboradas com base nos aspectos mais relevantes da avaliação.

\subsection{REPRESENTAÇÃO DA MATRIZ SWOT}

A Matriz SWOT (Tabela 1) tem como função primordial possibilitar a escolha das estratégias mais adequadas, tomando com base na avaliação dos ambientes interno e externo. 0 cruzamento das variáveis que compuseram os diversos ambientes adotou como critério de hierarquização o impacto gerado pela confirmação do evento, seja ele favorável (oportunidade e força) ou desfavorável (ameaça e fraqueza). O método utilizado para tanto foi uma escala numérica seqüencial com qautro níveis: 0 (zero) quando não havia impacto; (1) qunado o impacto era muito baixo; 3 (três) para impacto intermediário; e 5 (cinco) para alto impacto. 
Tabela 1 - Matriz SWOT da AMIGA.

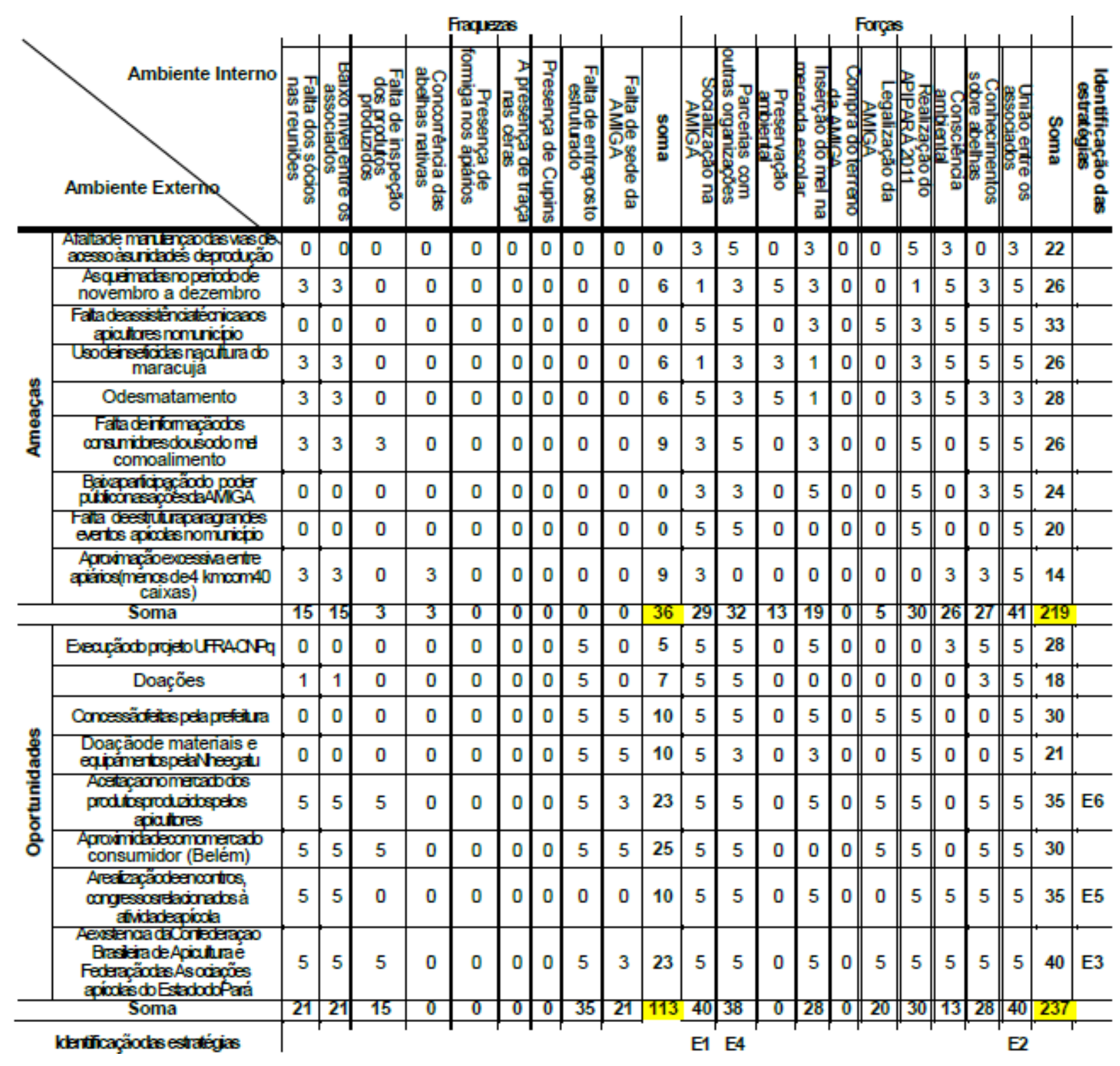

Fonte: pesquisa de campo

Após a soma dos cruzamentos entre ameaça e fraqueza, ameaça e força, oportunidade e fraqueza e oportunidade e força o quadrante que apresentou o maior número total foi o escolhido (237) indicando que o rumo que a associação deve buscar é o de desenvolvimento, uma vez, que prevaleceu oportunidades e forças na avaliação realizada. Após a escolha do quadrante (oportunidade $\mathrm{x}$ força) foram identificados os eventos com maior repercussão na organização, conforme a avaliação dos grupos de trabalho. E, desta forma, os mais importantes foram selecionados para o estabelecimento de estratégias de desenvolvimento. Resultou desta etapa a seleção de seis eventos mais relevantes que obtiveram a soma de seus impactos iguais ou superiores a 35 pontos no total do quadrante selecionado. 


\section{Administração: caminhos para o desenvolvimento sustentável}

\subsection{PONTOS FORTES:}

Pontos fortes, também denominados como forças, são potencialidades das organizações que correspondem a características positivas capazes de aumentar a competitividade, entre elas estão competências, ativos físicos e humanos, alianças e parcerias estratégicas, ativos intangíveis, como marcas, patentes, know-how, etc.. (SERRA; TORRES; TORRES, 2003).

Na associação "a socialização na AMIGA" se dá por meio das estratégias de integração do indivíduo à organização onde os valores e comportamentos vão sendo construidos de forma coletiva, transmitidos e incorporados pelos novos membros. A socialização é um processo educacional e a idéia principal é a persuasão das pessoas para adotarem atitudes e crenças, trabalhadas pelos membros da organização por meio de exemplos e pressões organizativas, além de reforço positivo sobre comportamentos adequados ou o reforço negativo sobre comportamentos inadequados a organização.

Nessa constante interação com o meio, os socios vão internalizando crenças e valores, construindo padrões de comportamento próprios para interação no grupo. Os valores vão se consolidando e determinando suas escolhas para um melhor padrão associativo. Ao ingressarem em um grupo, os atores precisam ser apresentados aos valores, crenças, normas e práticas da organização, passando por um processo de socialização, que Ihes permitirá articular-se com os processos de comunicação e de integração que permeiam o fazer coletivo (DURKHEIM,1987).

Uma alternativa potencialmente interessante é a "união entre os associasdos" neste aspecto a organização prima pela constante confraternização entre seus membros com a forte atuação de uma liderança servidora onde os propositos da organização são priorizados, sempre buscando o respeito mutuo, a troca de informações e a troca de experiencias entre seus membros.

Outra força capaz de contribuir para o aumento da produção de mel e o atingimento do mercado formal é a "parceria com outras organizações" que serve de proposito para o alcance de algumas metas. O sucesso de uma organização pode estar diretamente relacionado à sua capacidade de estabelecer e gerenciar parcerias estratégicas. Segundo os Conceitos Fundamentais da Excelência em Gestão da Fundação Nacional da Qualidade (FNQ), "o desenvolvimento de parcerias consiste no desenvolvimento de atividades em conjunto com outras organizações, a partir da plena utilização das competências essenciais de cada uma, objetivando benefícios para ambas as partes". Neste aspecto a AMIGA vem consolidando parcerias para um melhor desenvolvimento dos produtos produzidos por 


\section{Administração: caminhos para o desenvolvimento sustentável}

seus associados, mas especificamente mel de abelhas, melhorando a qualidade para atingir o mercado formal, para isso vem fechando parcerias com a Prefeitura Municipal de Igarapé-Açu, as Universidades instaladas no município, SEBRAE, Secretaria Estadual de Agricultura, Federação de Apicultura e Ministério da Agricultura.

\subsection{OPORTUNIDADES}

Caracterizadas também como eventos do ambiente externo, diferem das ameaças por representar situações positivas. As atividades da associação são eventos favoráveis, sua ocorrência contribui para a melhoria do desempenho da organização, reforçando a competitividade e resultando em maiores participações de mercado (SERRA; TORRES; TORRES, 2003; COSTA, 2006).

Uma das oportunidades potenciais identificadas pela pesquisa foi o "existência da Confederação Brasileira de Apicultura e a Federação das Associações Apícolas do Estado do Pará" organizações que fortalecem o trabalho associativista da cadeia produtiva e contribui para o fortalecimento da atividade ao mesmo tempo que cria um ambiente de agregação e identidade aos produtores.

Também obteve destaque a "realização de encontros e congressos relacionados a atividade apícola" que tem como objetivo melhorar a qualidade técnica da produção e fortalecer a cadeia produtiva. Os eventos contribuem para reunir e difundir tecnologias, capacitar mão-de- obra, gerar políticas públicas, discutir a preservação ambiental, marketing, mercado e comercialização.

Outra oportunidade identificada foi "a aceitação no mercado dos produtos produzidos pelos apicultores" . Segundo pesquisa realizada por Gomes (2009) o mercado brasileiro segue uma tendência mundial de adotar um novo conceito de consumo de alimentos de que os mesmos precisam contribuir para manter a saúde das pessoas e esta tendencia de consumo esta realcionada com o setor de produtos naturais e tem suas raízes no movimento mundial da sociedade na busca por melhor qualidade de vida, tendo relação com os temas, saúde e meio ambiente. O mundo está aberto a produtos mais saudáveis, mais seguros e mais sustentáveis ambientalmente. $E$ a tendência mundial hoje do consumidor é de que a compra de alimentos deve ser não pelo que eles fazem, e sim, pelo que significam (SOLOMON, 2008, p 34). 


\section{Administração: caminhos para o desenvolvimento sustentável}

\subsection{ESTRATÉGIAS DE DESENVOLVIMENTO DEFINIDAS PARA A AMIGA APÓS ANÁLISE DA MATRIZ}

\section{SWOT:}

Serra,Torres e Torres (2003, p.5) definem estratégia como "o conjunto de meios que uma organização utiliza para alcançar seus objetivos". Com esse propósito foram identificadas e sugeridas para definição de planos de ação, um conjunto estratégico apresentado a seguir:

Inicialmente, como forma de aproveitar o ponto forte representado pelo facilidade de socialização na AMIGA uma estratégia destacada seria a melhoria da infraestrutura para a reunião dos assciados além do estabelecimento de um calendário formal de encontros entre os mesmos durante o ano e as atividades a serem realizadas nestas reuniões.

A segunda estratégia proposta para potencializar a união entre os associados é incentivar o desenvolvimento de lideranças apoiadoras entre os associados, além do mais fortalecer a comunicação informal e de forma mais efetiva.

Outra alternativa estratégica para potencializar as parcerias da AMIGA com outras organizações foi elaboração de projetos para captar recursos necessários ao melhoramento da produção de mel e capacitação dos associados principalmente em técnicas de produção buscando a qualidade e melhoria da gestão na associação.

A estratégia, pleitear a carteira de apicultores, solicitar apoio junto aos órgãos de inspeção para registro no SIF e divulgação de eventos junto aos associados foi sugerida para aproveitar a existência Confederação Brasileira de Apicultura e a Federação das Associações Apícolas do Estado do Pará.

Para aporveitar a realização de encontros e congressos relacionados a atividade apícola sugere-se a seguinte estratégia: realizar troca de experiências, estabelecer uma comissão de apicultores para organizar a participação nos eventos e estabelecer parcerias nos eventos e encontros.

Finalmente aumentar a quantidade de mel produzido com qualidade nas propriedades apícolas, cumprir as exigências da vigilância sanitária para a produção do mel, criar campanhas de divulgação do mel produzido pela AMIGA para o mercado interno e externo, aumentar a participação dos associados da AMIGA em congressos e feiras do setor e realizar parcerias com outras organizações foi a estratégia escolhida para aproveitar a aceitação no mercado dos produtos produzidos pelos apicultores. 


\section{Administração: caminhos para o desenvolvimento sustentável}

\section{CONSIDERAÇÕES FINAIS}

O estudo possibilitou identificar as características da associação dos criadores e criadoras de abelhas melíferas do município de Igarapé-Açu de forma a construir a proposição de estratégias para a aumentar a produção de mel e atingir o mercado formal. A utilização da multiplicidade de ferramentas de diagnóstico oferecidas pela Gestão Participativa - GESPAR se mostrou efetiva, de fácil compreensão por parte dos associados, e eficiente na visão dos pesquisadores.

A análise SWOT como forma de sistematizar as informações e fundamentar as escolhas das estratégias, possibilitou sumarizar os resultados do estudo agrupando as informações de maneira a facilitar a compreensão da realidade da associação e, por conseguinte, a escolha das estratégias de desenvolvimento uma vez que na avaliação ambiente interno e externo pelos associados prevaleceu forças e oportunidades. Destaca-se o aspecto participativo na avaliação e elaboração das estratégias.

A utilização de ferramentas de gestão aliado a uma metodologia participativa se reveleram elementos essenciais no processo de aumento de competitividade necessário ao crescimento da organização e por conseguinte dos seus associados. Ao se definir uma visão de futuro para a associação esta provavelmente terá mais chance de sucesso, uma vez, que se fará uso de uma função fundamental da gestão, o planejamento.

\section{REFERÊNCIAS}

BRUM, C. C. L.; ARISTIMUNHA, J.; MACHADO, J. I. C. Associações de Produtores Rurais de São Sepé RS: averiguação das possíveis causas de sua continuidade ao longo de 15

anos. EMATER - RS. Out. 2006. Disponível em: http://www.emater.tche.br/site/br/arquivos/area. Acessado em Maio de 2011.

CERVO,A.L.; BERVIAN, P.A.; DA SILVA, R. Metodologia Cientifica. São Paulo: Pearson Prentice Hall. 2007.

CORDIOLI, S. Enfoque Participativo: um processo de mudança: conceitos, instrumentos e aplicação prática. Porto Alegre: Genesis, 2001.

DURKHEIM, E. As regras do método sociológico. 13 ed., São Paulo: Companhia Editora Nacional, 1987

ETZEL, M. J; WALKER, B.J; STANTON, W.J. Marketing. São Paulo: Makron Books, 2001.

GOMES. A. N. O Novo consumidor de produtos naturais: consumindo conceitos muito mais

do que produtos, mai. 2009. Disponível em http://www.espm.br/Publicacoes/CentralDeCases. Acessado em Maio de 2011. 


\section{Administração: caminhos para o desenvolvimento sustentável}

HISRICH, R. D.; Peters, M. P. Empreendedorismo. Porto Alegre: Bookman, 2004.

HITT, M.A.; IRELAND, R. D.; HOSKISSON, R. E. Administração Estratégica. São Paulo: Pioneira, 2002.

HOOLEY, G.J.; SAUDERS, J.A.; PIERCY, N.F. Estrategia de Marketing e Posicionamento Competitivo Sao Paulo: Prentice Hall, 2001.

KOTLER, P. Administração de marketing. São Paulo: Prentice Hall, 2000.

LACOMBE, F.; HEILBORN, G. Administração: princípios e tendências. São Paulo: Saraiva, 2003.

MANKTELOW, J.; CARLSON, M. SWOT Analysis Discover new Opportunities Manager

and Eliminate Threats. Disponível em: http://www.mindtools.com/pages/article/newTMC_05.htm . Acessado em Maio de 2011.

MINTZBERG, H.; AHLSTRAND, B.; LAMPEL, J. Safári de Estratégias. Porto Alegre: Bookman, 2000.

MONTANA, Patrick J. Administração. São Paulo: Saraiva, 2003.

PNUD - PROGRAMA DAS NAÇÕES UNIDAS PARA O DESENVOLVIMENTO. Gestão

participativa para o desenvolvimento local. Banco do Nordeste. Recife-PE. s/d.

ROBBINS, S. P. Administração: mudanças e perspectivas. São Paulo: Saraiva, 2005.

ROSSI, C.A.V.; LUCE, F. B. Construção e proposição de um modelo de planejamento estratégico baseado em 10 anos de experiência. In: Anais do XXIII ENCONTRO ANUAL DA ENANPAD - Encontro Anual dos Programas de Pós-Graduação em Administração. Salvador: ANPAD, CD ROM, 2002

SOLOMON, Michael R. O comportamento do consumidor: comprando, possuindo e sendo. Tradutor: Lene Belon Ribeiro. 7. ed. Porto Alegre: Bookman, 2008. 680 p.

SERRA. F.; TORRES, M.C.; TORRES, A. P. Administração Estratégica: conceitos, roteiro prático e estudos de casos. Florianópolis: Editora Insular, 2009.

SOARES; E. Metodologia Cientifica: lógica, epistemologia e normas. São Paulo: Atlas, 2003.

STONER, J. A. F.; FREEMAN, R. E. Administração. Rio de Janeiro: LTC, 1999.

VERDEJO, M. E. Diagnóstico Rural Participativo: um guia prático. Secretaria de Agricultura familiar. MDA. Brasilia. 2006.

VERGARA; S. C. Projetos e relatórios de pesquisa em administração. São Paulo: Atlas, 2009. 


\section{Capítulo 20}

\section{INTRAEMPREENDEDORISMO: PERSPECTIVAS E DESAFIOS NA ADMINISTRAÇÃO PÚBLICA}

\section{DOI: $10.37423 / 200300402$}

Elane de Souza Mafra, Instituto Federal do Amazonas - IFAM, mafra@ifam.edu.br

Tássia Patrícia Silva do Nascimento, Instituto Federal do Amazonas - IFAM, tassiapatricia.tp@gmail.com

Marcos Carneiro da Silvà, Institùto Federal do Amazonas - IFAM, marcos.carneiro@ifam.edu.br
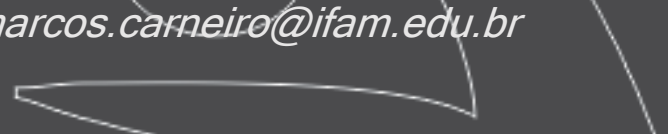

Jules Perelra Gomes, Exército Brasileiro - Ministério da Defesa, julespgomes@gmail.com

Resumo: Nos dias atuais, com o cenário empresarial cada vez mails competitivo, as organizações têm se mostrado cada vez mais receptivas para inovações que yenham agregar valor ao seu negócio e estabelecer ùm diferencial com relação à concorrência. Dentro dessa perspectiva, surge um novo concęito de empreendedorismo, proporcionando aos colaboradores das organizações, uma mạiọr autoṇømia de gestão e potenciфlização de suas habilidades dentro da empresa: o intraempreendedorismo. Este ensaio visa analisar o potencial e o aleance de aplicaçãò desśa ferramenta de gestão na-administração de organizações públieas. Por sua vez, ao aprofundar-se sobre o assunto, compreenđè-se que fazse necessário uma reflexão crítica acerca do processo de implantação desse modelo à realidade brasileira. 


\section{Administração: caminhos para o desenvolvimento sustentável}

A pesquisa precisou situar temporalmente marcos significativos, os quais serviram de pressupostos para sua legitimidade; procurou-se também dar visibilidade ao processo evolutivo das questões do empreendedorismo, amparados por tabelas e considerações, entre outros. A pesquisa, sob essa perspectiva, é um estudo exploratório preliminar cuja intencionalidade é contribuir substancialmente para a discussão já iniciada na atual sociedade brasileira acerca do tema em questão e a sua difusão na administração pública.

Palavras-chave: Gestão do Conhecimento e Inovação; Intraempreendedorismo; Administração Pública. 


\section{Administração: caminhos para o desenvolvimento sustentável}

\section{INTRODUÇÃO}

A Emenda Constitucional no 19, de 5 de junho de 1998, artigo 37, da Constituição Federal de 1988, fez constar no seu arcabouço, o Princípio da Eficiência como expressa exigência a ser observada no âmbito da Administração Pública Brasileira. Dessa forma, dentro do setor brasileiro público existem diversas lacunas que estão em constante processo de desenvolvimento, e com isso estão em busca de forte presença de estratégias para que haja uma maior eficiência de seus procedimentos, desde da perspectiva do próprio colaborador até as ferramentas de gestão.

Por outro lado, a concorrência no mundo empresarial tem aumentado a uma velocidade exponencial. Todos os dias entram no mercado centenas de novas empresas, boa parte delas cheias de novas ideias, empreendedores dedicados e muito dinheiro para investir. Uma combinação perigosa para empresas estagnadas, burocráticas e que não cultivam novas perspectivas.

Por isso, as organizações buscam colaboradores que possam oferecer um "algo mais", pessoas dedicadas que trabalhem como verdadeiros sócios do negócio. Que ofereçam opções diferenciadas de investimento, que observem o "desconhecido" com novos olhos e enxerguem o ninguém mais viu, tornando a empresa ainda mais competitiva à médio e longo prazo. Este modelo de colaborador é chamado de intraempreendedor. Essa mesma visão de negócio também é esperada dos novos servidores que adentram ao serviço público, sobretudo nas empresas públicas.

Nesse sentido, em suas duas últimas décadas a gestão pública brasileira, vem passando por reformas administrativas e estruturais em direção ao chamado modelo gerencialista, típica das organizações privadas. A ideia básica desse movimento é trazer maior eficiência e efetividade à administração pública, a partir do uso de modernas tecnologias gerenciais, já amplamente utilizadas pelo setor privado.

Quando se fala sobre organizações empreendedoras, quer-se referir ao empreendedorismo corporativo que, em linhas gerais, pode ser definido, segundo Antoncic e Hisrich (2001), como o empreendedorismo dentro das empresas já existentes. Trata-se de um processo de identificação de oportunidades e desenvolvimento delas para criar valor por meio da inovação.

Esse processo na organização pública é semelhante, porém existem processos burocráticos diferenciados e ineficientes. Parte-se da premissa de que o intraempreendedor constitui um modelo de empregado/trabalhador desejável dentro das organizações, uma vez que adota uma postura semelhante àquela do dono do negócio. Ou seja, um profissional inovador, alinhado aos objetivos da 


\section{Administração: caminhos para o desenvolvimento sustentável}

organização pública, que se preocupa constantemente em implementar melhorias nos processos assim como, na busca de novas oportunidades de negócios. Além disso, esse profissional possui automotivação, necessitando de menos supervisão à execução de suas atividades. Do exposto, o estudo tem como objetivo principal pesquisar o potencial e o alcance de aplicação da noção de empreendedorismo na administração de organizações públicas no Brasil.

\section{INICIANDO AS ESTRATÉGIAS: MODELO GERENCIALISTA ADOTADO PELO ESTADO BRASILEIRO.}

No processo de reforma da administração pública, destaca-se sua aproximação crescente com as teorias e métodos da administração privada, como uma tentativa de adquirir as estratégias de sucesso das empresas de mercado e aplicá-las à realidade governamental, cabendo neste contexto à aplicação da Gestão por Competência. O marco legal desse novo processo se materializa a partir da edição do Decreto no 5.707, de 23 de fevereiro de 2006 que Institui a Política e as Diretrizes para o Desenvolvimento de Pessoal da administração pública federal direta, autárquica e fundacional.

Segundo Paula (2005), "para alcançar seus objetivos, o novo modelo de gestão, que serve de referência para os três níveis governamentais - federal, estadual e municipal -, deveria enfatizar a profissionalização e o uso de práticas de gestão do setor privado".

Segundo Bergue (2008) "o atual cenário da administração pública brasileira revela forte inclinação para adição de práticas gerenciais usuais no campo gerencial". Sendo este movimento apresentado em forma de duas perspectivas:

a) oferta - esforços externos que promovem e estimulam a transferência, como as influências dos conceitos estrangeiros; e,

b) demanda - a busca das organizações públicas por inovações gerenciais, como recurso de legitimação e sobrevivência. No entanto, a apropriação de técnicas gerenciais no setor público apresenta algumas limitações significativas. Bergue (2011) observa que essa prática tem sido denotada de um caráter parcial, na qual a ênfase passa a ser no formato e não no conteúdo. Dessa forma, o reduzido esforço de reflexão crítica (em que os modelos são importados de casos de sucesso em outros países, ou, quando adaptado com propriedade e preservando seu formato original) poderá não favorecer a coexistência de elementos e práticas gerenciais tradicionais e inovadoras na administração pública. 


\section{Administração: caminhos para o desenvolvimento sustentável}

A Figura 1 mostra as características marcantes do modelo gerencial, no qual é propulsor inicial da pesquisa:

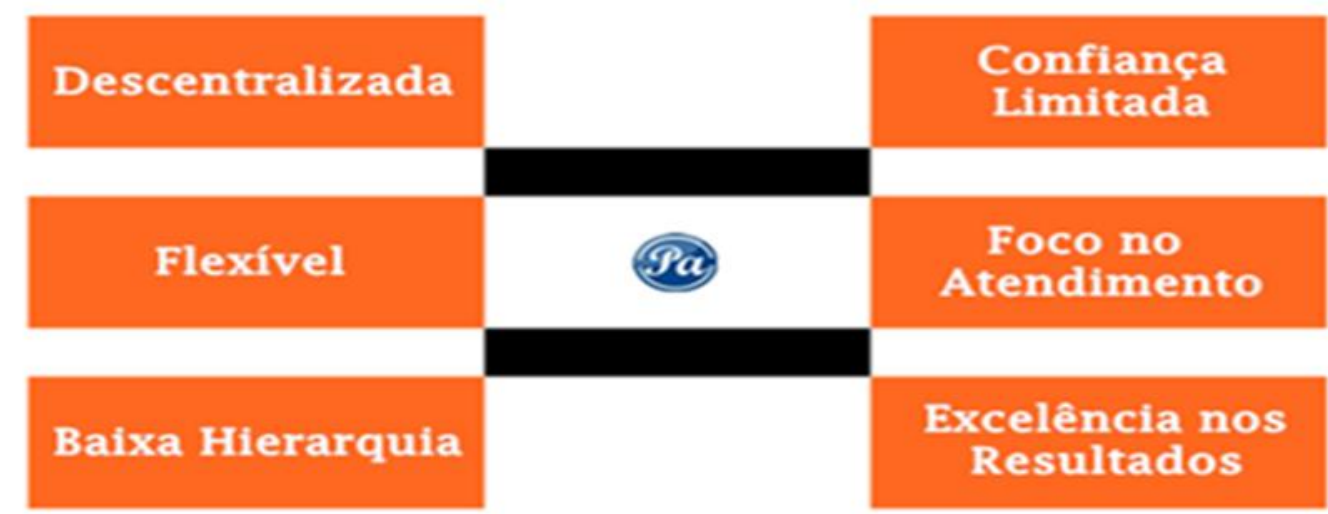

FIGURA 1: Características do modelo gerencial. Fonte: Portal Administrador.com

Portanto, estudar o intraempreendedorismo no setor público do Brasil torna-se uma oportunidade de pesquisa na área, a qual é movida por uma inquietação: Qual a aplicabilidade do resultado do modelo em termos de eficiência, ainda em construção na administração pública brasileira? Frente a este questionamento, este ensaio busca contribuir, de forma crítica, para a compreensão do intraempreendedorismo no setor público brasileiro, a partir das contribuições da literatura estrangeira e primordialmente da compreensão do conceito de empreendedorismo.

\section{EMPREENDEDORISMO}

A atividade de empreendedorismo é um marco de desenvolvimento econômico em muitos países, considerado como uma alternativa para problemas financeiros por muitos estudiosos. Chagas (2008) afirma que o empreendedorismo não é um tema novo ou um modismo, muito pelo contrário, existe desde sempre, desde a primeira ação humana inovadora com o objetivo de melhorar as relações do homem com os outros e com a natureza, portanto uma tendência mundial.

Dornelas (2001) descreve que "o empreendedor é aquele que faz as coisas acontecerem, se antecipa aos fatos e tem uma visão futura da organização". O espírito empreendedor, é uma característica distinta, seja de um indivíduo, ou de uma instituição. Não é um traço de personalidade, mas sim um comportamento e suas bases são o conceito e a teoria, e não a intuição. (DRUCKER, 2002).

Quando se ouve a palavra 'empreendedor', logo se imagina o indivíduo que abandona sua carreira para perseguir o sonho de ter um negócio próprio. Quando são bem sucedidos nesta trajetória, 


\section{Administração: caminhos para o desenvolvimento sustentável}

notamos alguns traços comuns em todos eles: Criativos, dinâmicos, auto motivados, cheios de energia, persistentes, bem relacionados, articulados, inteligentes, dotados de visão do futuro, perspicazes e mais uma série de qualidades. Se pensarmos bem, estas são características de um empreendedor, mas não necessariamente de alguém que tenha ou queira, um negócio próprio.

Sadler (2000) indica que o termo empreendedorismo deriva do verbo francês entreprendre, significa: iniciar ou realizar algum empreendimento. Os autores pioneiros dessa temática foram Cantillon (1755) e Say (1803) (FILION, 1997). Sadler (2000) indica que o conceito de Richard Cantillon buscou explicar a receptividade ao risco de comprar algo por um preço e vendê-lo em regime de incerteza. Jean-Baptiste Say (1803) sustentou que o empreendedor era capaz de alterar os recursos econômicos de uma área de baixa produtividade, transformando em uma área de produtividade e lucratividade elevadas, sendo que ele atuava como o catalisador do desenvolvimento econômico. Tanto na definição de Cantillon (1755) como na de Say (1803), o empreendedor é tido como um agente tomador de risco (SADLER, 2000).

Foi Joseph Schumpeter quem lançou o estudo contemporâneo de empreendedorismo ao alinha-lo com a inovação (SADLER, 2000). Para o referido autor, o empreendedor deveria ser tratado de forma peculiar por sua capacidade de criar, inovar e de agregar valor em produtos, processos e serviços, nos quais a inovação era a principal força para criação de nova demanda e riqueza. Em seus estudos, Schumpeter percebeu que o empreendedor conduzia, criava novas combinações de produção por meio do processo de destruição criativa.

\subsection{O EMPREENDEDORISMO CORPORATIVO}

Até a década de 1970, as pesquisas sobre empreendedorismo priorizavam as ações e características individuais dos empreendedores (DRUCKER, 1985; SADLER, 2000). No entanto, a partir de 1980, autores como Miller \& Freshmen (1982), Burgelmann (1983), Pinchot, (1985), Cornwall e Perlman (1990), Hashimoto (2009) e Diefenbach (2011) desenvolveram pesquisas que compreendessem a noção de empreendedorismo dentro das organizações. Surgiu, assim, o empreendedorismo corporativo ou intraempreendedorismo, ou seja, o estudo do comportamento empreendedor dentro das organizações (HASHIMOTO, 2009).

Sendo um processo pelo qual um indivíduo ou um grupo de indivíduos, associados a uma organização existente, criam uma nova organização ou instigam a renovação ou inovação dentro da organização existente, isto é, o empreendedorismo praticado dentro das organizações já estabelecidas recebe o 


\section{Administração: caminhos para o desenvolvimento sustentável}

nome de empreendedorismo corporativo, a inovação pode ser desenvolvida e os conceitos de empreendedorismo são aplicados internamente. Conciliando desafios atuais e futuros, permite e apoia seus colaboradores a pensar diferente, de certa forma estimula novas ideias, sem a perda de foco otimiza os recursos organizacionais e com isso surgem os novos produtos e serviços.

Burgelman (1984) define empreendedorismo corporativo como um processo de "extensão dos domínios de competência da organização e de oportunidade correspondente determinada pela combinação de novos recursos gerados internamente na organização". A prática do empreendedorismo nas organizações ocorre incentivando o potencial inovador dos seus colaboradores, e essa prática requer uma mudança comportamental que permita o surgimento dessas inovações e a agilidade para a implementação dos novos projetos. Essa mudança de comportamento se faz necessária para que a organização possa se adaptar ao novo ambiente.

\section{O INTRAEMPREENDEDORISMO}

Intraempreendedores podem ser entendidos como membros da organização que inovam, identificam e criam oportunidades de negócio, estruturam e coordenam novas combinações e arranjos de recursos para gerar e agregar valor por meio da exploração de necessidades não atendidas ou da melhoria da eficiência de algo que já é feito pela empresa (WUNDERER, 2001).

Esse profissional vai além das tarefas normalmente relacionadas aos administradores, em uma visão mais abrangente e não se contenta em apenas fazer o que deve ser feito. Ele quer mais e busca fazer mais. De acordo com Pinchot (1989), os intraempreendedores podem ser bem sucedidos rapidamente se aplicarem as dez táticas a seguir:

1. Pedir desculpas e não permissão, respeitando os limites;

2. Fazer tudo para transformar uma ideia em realidade;

3. Ir trabalhar todo o dia com o espírito de quem será demitido;

4. Ser leal e honesto com os patrocinadores;

5. Construir uma equipe de voluntários entusiastas, selecionando apenas os melhores;

6. Lograr qualquer regra que possa impedir a realização de uma ideia;

7. Criar uma rede de bons contatos capazes de prestar assistência; 


\section{Administração: caminhos para o desenvolvimento sustentável}

8. Aprender a ser mais modesto e trabalhar em silêncio tanto quanto possível para não ativar os mecanismos de defesa da organização;

9. Perseguir objetivos, mas de maneira realista em relação aos meios para atingi-los;

10. Manter o foco.

Para Pinchot (1989), a maior parte das peculiaridades da personalidade do intraempreendedor podem ser entendidas considerando-se as pressões de se combinar, em uma pessoa, um forte visionário e um executor insaciável, que não pode descansar até que sua visão esteja manifestada na terra assim como está em sua mente. São sonhadores que realizam e assumem a responsabilidade pela criação de inovações de qualquer espécie dentro de uma organização.

\section{O INTRAEMPREENDEDORISMO E A ADMINISTRAÇÃO PÚBLICA FEDERAL}

Nos tópicos anteriores foram abordados aspectos relativos a empreendedorismo, cultura corporativa e inovação sob várias óticas. Estas perspectivas foram condensadas para a elaboração de um modelo, o qual pode ser utilizado na verificação empírica destes pressupostos teóricos. Vamos apresentar agora os critérios utilizados para elaboração deste modelo.

As administrações públicas com culturas empreendedoras fortes estão aptas a adaptarem-se às modificações do ambiente de maneira integrada e rápida, já que seus valores culturais são capazes de criar um sistema aberto que envolve não apenas os membros da organização, mas também os constituintes externos aos processos e estratégias da organização. As normas destas organizações estão baseadas na participação e na inclusão de organizações que operam com princípios democráticos.

No lugar de uma estrutura hierárquica, uma atmosfera intraempreendedora possui uma estrutura organizacional plana, com várias redes, equipes, patrocinadores e mentores (HISRICH; PETERS, 2009). Contudo, o desenvolvimento de uma cultura na administração pública intraempreendedora madura e consolidada não é fácil e demanda tempo. 


\section{Administração: caminhos para o desenvolvimento sustentável}

A figura 2 mostra exatamente essa configuração positiva da administração gerencial que nos faz referências otimizadas da avaliação do intraempreendedorismo.

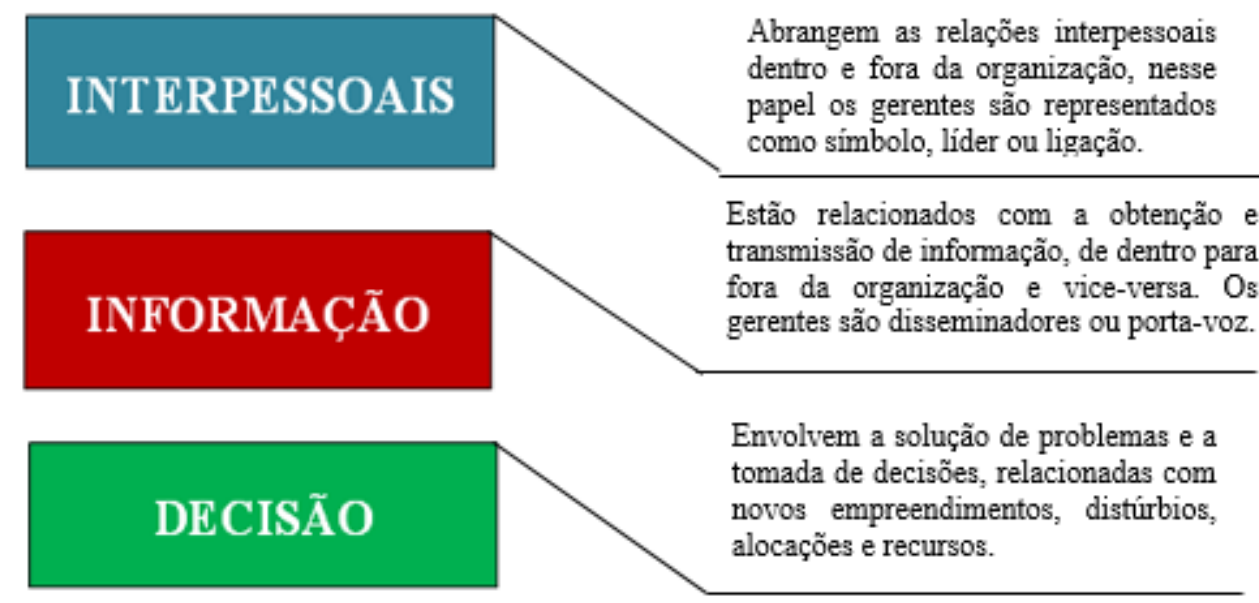

FIGURA 2: Papeis fundamentais do modelo gerencial. Fonte: Arquivo pessoal dos autores

\section{DISCUSSÃO E CONSIDERAÇÕES FINAIS}

Percebe-se que o tema, assim como o ramo do empreendedorismo de uma forma geral, carece de estudos mais profundos no Brasil, podendo-se aproveitar o conhecimento já desenvolvido por pesquisadores em outras partes do mundo. Os resultados deste trabalho trazem à luz a importância de reduzir o hiato existente entre o discurso acadêmico acerca do intraempreendedor e a realidade das organizações brasileiras públicas ou não. Promover uma cultura de inovação dentro das organizações tem sido o discurso de especialistas desde que o tema adquiriu massa crítica nas últimas décadas. Sendo ainda recente para os acadêmicos, o caminho para a prática, portanto, ainda é desconhecido pela maioria das empresas públicas ou privadas.

O empreendedorismo é a competência central da estratégia capaz de gerar vantagem competitiva para a organização. Os líderes devem ser capazes de: formular uma visão inspiradora exigindo respeito, honestidade e lealdade; introduzir novas ideias para ampliar os conhecimentos dos colaboradores e a sua percepção e habilidade para resolver problemas; e aumentar a motivação e autoconfiança nas habilidades pessoais (WUNDERER, 2001).

Organizações e/ou administrações públicas modernas são compostas de grupos que competem entre si e que têm, com frequência, interesses conflitantes e divergentes, e pode-se vê-las como estruturas pluralísticas nas quais questões políticas e administrativas surgem constantemente, uma em função da outra (HEYDEBRAND, 1973). Outros estudos e explicações, bem como um melhor desenvolvimento 


\section{Administração: caminhos para o desenvolvimento sustentável}

do modelo proposto, pode surgir em função do tamanho e da complexidade de diferentes Instituições e podem ser mais plausíveis em função de outras e novas teorias e pesquisas tanto em administração como nas demais áreas dos estudos sociais. Várias generalizações são possíveis a partir desta revisão bibliográfica sobre cultura intraempreendedora. Este trabalho não tem a pretensão de responder a nenhuma questão específica, mas desenvolver modelos para que outras organizações possam dar início à criação de suas próprias culturas intraempreendedoras e estimular novos estudos sobre este assunto de elevada importância para o sucesso organizacional. No caso do setor público brasileiro, ainda é cedo para identificar um impacto da implantação do modelo por várias razões, dentre elas pode-se destacar: o processo de aculturação do modelo nas organizações públicas; as condições desfavoráveis para um resultado positivo própria do setor público como estabilidade, hierarquização, salários, qualificação profissional, projetos consolidados de cargos e salários entre muitos outros. 0 que se pode afirmar é que o empreendedorismo no setor público brasileiro surge a partir do modelo neoliberal e da necessidade de resultados positivos reclamadas cada vez mais pela sociedade. Nesse contexto, fortalece a importância da discussão do tema, além do que o empreendedorismo e seus elementos desencadeadores, os chamados intraempreendedores, deixou de ser um modismo e se tornou uma tendência mundial, nas quais às organizações, sejam elas públicas ou privada, necessitam se adequar.

\section{REFERÊNCIAS}

ALVES, P. V. Gestão Pública Contemporânea. Rio de Janeiro, RJ: Alta Books, 2015.

BERGUE, S.T. A Redução Gerencial no Processo de Transposição de Tecnologias de Gestão para Organizações Públicas. In: ENCONTRO DA ANPAD, 32. Anais...Rio de Janeiro: EnANPAD/ANPAD, 2008. CD.

BURGELMAN, R. A. Designs for Corporate Entrepreneurship. California Management Review, vol. 26, 1984.

BURGELMAN, R. A.; SAYLES, L. R. Inside corporate innovation strategy, structure and managerial skills. New York: The Freepress, 1986.

CHAGAS, F. C. D. Oficina do empreendedor: a metodologia de ensino que ajuda a transformar conhecimento em riqueza. Rio de Janeiro: CULTURA, 2008.

CORNWALL, JR.; PERLMAN, B. Organisational Entrepreneurship. Irwin: Homewood, III, 1990.

DIEFENBACH, F. E. Entrepreneurship in the Public Sector: When Middle Managers Create Public Value, Gabler Verlag Wiesbaden, 2011. 


\section{Administração: caminhos para o desenvolvimento sustentável}

DORNELLAS, J. C. de A. Empreendedorismo: Transformando ideias em negócios. Rio de Janeiro: LTC, 2001.

DRUCKER, P. F. Innovation and Entrepreneurship: Practice and Principles. Londres: ButterworthHeinemann, 1985.

HASHIMOTO. M. Organizações Intra-empreendedoras: Construindo a ponte entre clima interno e desempenho superior. 363 f. (Tese de doutorado). EAESP/FGV, São Paulo, junho, 2009.

HEYDEBRAND, W. W. Comparative Organizations: the results of empirical research. Englewwod Cliffs, Prentice-Hall, 1973.

HISRICH, R. D.; PETERS, M. P., SHEPHERD, D. A. Empreendedorismo. 7. ed. Porto Alegre: Bookman, 2009. 662p.

LAPOLLI, É. M. e GOMES, R. K. Práticas intraempreendedoras na gestão pública: um estudo de caso na Embrapa. Programa de Pós-Graduação em Engenharia e Gestão do Conhecimento, Universidade Federal de Santa Catarina, Florianópolis, Santa Catarina Brasil, 2017.

MILLER, D.; FRIESEN, P. H. Strategy-making and environment: The third link. Strategic Management Journal, 4(3), p. 221-235, 1983.

PAULA, A. P. P. de. Por uma nova gestão pública: limites e potencialidades da experiência contemporânea. Rio de Janeiro: FGV, 2005.

PINCHOT III, G. Intrapreneuring: porque você não precisa deixar a empresa para tornar-se um empreendedor. São Paulo: Harbra, 1985.

SADLER, R. J. Corporate entrepreneurship in the public sector: the dance of the chameleon. Australian Journal of Public Administration, 59(2), p.25-43, 2000.

SCHUMPETER, J. A. History of Economic Analysis. Nova York: Oxford University Press, 1954.

SEQUEIRA, S.V. Intra-empreendedorismo e organizações não-governamentais: prática e discursos. 268 f. (Tese de doutorado). EAESP/FGV, São Paulo, 2005.

WUNDERER, R. Employees as "co-intrapreneurs" - a transformation concept. Leadership \& Organization Development Journal, v. 22, n. 5/6, p. 193, 2001.

VALE, G. M. V.; CORRÊA, V. S.; REIS, R. F. dos. Motivações para o Empreendedorismo: Necessidade Versus Oportunidade?. Disponível em http://www.anpad.org.br/rac, Rio de Janeiro, v. 18, n. 3, art. 4, pp. 311-327, Maio/Jun. 2014. Consultado em 16 de fevereiro de 2018. 


\section{Capítulo 21}

\section{CAPITAL HUMANO: UMA ABORDAGEM CONTEMPORÂNEA}

DOI: $10.37423 / 200300408$

leda maria zavatieri (Mestra em Ciências Contábeis pela Fundação Escola do Comércio Álvares Penteado - FECAP).

Resumo: o objetivo deste artigo foi introduzir uma abordagem/acerca do processo de construção da cultura de valorização do capital humano e a relação com o uso da tecnologia da informação em pequenas empręsas. O principalobjetivo foi promover a gestão da singularidade protagonizando os dilemas relacionados ao capitat humano delineander os aspectos que ènvolvem critérios como uso da tecnologia sob a óptica da gestão contemporânea. Nesse contexto tem-se à seguihte questão de presquisa: considerando a relevância da capital humano, como as empresas atuam na gestấo de pes\$oas no que tange os aspectos da singularidade?

A etnografia foi realizada por meio de interlocução cóm uma pequena empresa do terceiro setor, objeto do estudo, para o entendimento de/como é realizada a gestão de pessoas. Adicionalmente, teve o intuito de ampliar a visão dos pequenos empresários acerca da necessidade de evolução da-cultura emprésarial/em relação à gestão de pessoas e o uso adequado da teenotogia, através-de-uma combinaçã 6 de-práticas capazes-de promoyer o desenvolvimento de critérios que resulte na satisfação e consequente geração de-benefícios econômicos futuros.

Palavras-chave: Sustentabilidade Empresarial; Gestão de Pessoas; Recursos Humanos. 


\section{Administração: caminhos para o desenvolvimento sustentável}

\section{INTRODUÇÃO}

O Brasil encontra-se inserido na economia global, sendo esse ambiente altamente competitivo, onde os Países buscam suas riquezas por meio do desenvolvimento que abarca uma série de investimentos dentre eles: investimento em tecnologia e capital humano. Na atual realidade econômica impactada pela crise política, as pequenas empresas estão recorrendo à criatividade na inovação na sua forma de gestão global, considerando que se trata de uma era onde é preciso inovar para manter sua perenidade e desenvolvimento no mercado. Conscientes da necessidade de investimentos na era do conhecimento, as empresas se inclinam para as pessoas de forma a buscar profissionais talentosos, bem treinados, com o intuito de se tornarem um diferencial competitivo que contribui de forma relevante em termos de qualidade, produtividade, lucratividade e inovação. Nesta esteira, foi relevante o conhecimento da trajetória das empresas de menor porte, cuja relevância é inquestionável na economia do país. As dificuldades e desafios enfrentados pelas pequenas empresas, as estratégias, as ferramentas e as informações corroboram para os rumos das pequenas empresas.

Nesse cenário, o objetivo desse artigo foi o alcance do entendimento a respeito da demanda por profissionais qualificados, adequada identificação, desenvolvimento e retenção de talentos e sua efetiva contribuição em aspectos intrínsecos e extrínsecos em empresas de pequeno porte, bem como as melhores práticas aplicáveis à valorização do capital humano.

Vale comentar o entendimento de Kwasnicka (1981), a aplicação de recursos, apesar de envolver custo tipicamente econômico, espera-se que os benefícios contribuam para a eficácia organizacional. Do exposto, ressalta-se a relevância do capital humano. Como objetivo secundário, buscou-se a percepção dos aspectos negativos que devem ser mitigados, a fim de melhorar o desempenho global das empresas por meio do conhecimento humano e empresarial. A metodologia aplicável foi um estudo de caso, por meio de aplicação de questionário e interlocução com um empresário.

Considerando o cenário econômico atual, em que o desemprego encontra-se elevado, a carga tributária demasiadamente pesada para as pequenas empresas suportarem; o que impacta negativamente na promoção do desenvolvimento, nas contratações e garantia de perenidade no mercado. Desta forma, as empresas procuram inovar por meio da aplicação da tecnologia para o alcance de resultados geração de recursos, no entanto, não são poucas as empresas que ainda não assimilaram a cultura de valorização do capital humano e outras enfrentam dificuldades no gerenciamento desse capital. Por ser um dos capitais mais importantes dentro de um modelo de 


\section{Administração: caminhos para o desenvolvimento sustentável}

negócios, o capital humano é efetivamente responsável pela geração dos outros capitais, inclusive o capital intelectual.

A proposta foi compreender a atuação da sustentabilidade na gestão de pessoas e a relação tecnológica. Em última análise, esse trabalho visa contribuir socialmente em relação à percepção por parte das pequenas empresas que ainda estão em fase incipiente na valorização do capital humano e uso das tecnologias.

\section{REFERENCIAL TEÓRICO}

Este estudo foi desenvolvido levando-se em consideração as teorias que englobam a gestão empresarial em pequenas empresas no que se refere ao capital humano e uso tecnologia da informação sob o ponto de vista da autora.

\subsection{GESTÃO EMPRESARIAL CONTEMPORÂNEA}

No século XX já era possível à percepção do avanço tecnológico em longo prazo. Na visão de Drucker (1988) na época, inexistia uma grande dependência da tecnologia para o processamento de dados das informações, no entanto, previa que ao longo do tempo a dependência do computador e da tecnologia teria um grande impacto no processo decisório. De fato, o cenário preditivo do autor, são a garantia de sustentabilidade empresarial nos dias atuais, todo processo produtivo, retorno sobre investimentos e o planejamento estratégico.

Muito se fala em planejamento estratégico em pequenas empresas, pela perspectiva de associação do planejamento com melhorias. No tocante a esse raciocínio, Parnell (2015) defendeu a necessidade de focar no gerenciamento de crises no contexto empresarial e a exposição às vulnerabilidades em que a sociedade e economias estão expostas. Destarte, as pequenas empresas devem trabalhar numa perspectiva de prováveis eventos futuros que podem resultar em impacto no ambiente interno e externo, cujo impacto nas pequenas empresas pode ser sinônimo de mortalidade empresarial em face da limitada capacidade de solvência de ocorrências que não fazem parte das operações normais. Contemplando este, o planejamento estratégico deve levar em conta a premissa mencionada por Zavatieri (2016) de que a empresa deve ser vista como uma instituição mobilizada na criação de recursos para todas as partes interessadas. Neste laço, em verdade o planejamento estratégico deve ser delineado considerando como o principal fator - o capital humano -; a tecnologia gerencial pautada por princípios e práticas de gestão do conhecimento, é possível defender, elevada relação custo- 


\section{Administração: caminhos para o desenvolvimento sustentável}

benefício, além do alcance em diversos tipos de empresa. Entretanto, no caso das pequenas empresas, há que se trabalhar às especificidades e as condições dos contornos vigentes. Consequentemente, deve-se considerar a problemática que é a defasagem na formação educacional de boa parte da população brasileira. É inegável que os exemplos conhecidos de sucesso, atestam, por sua vez, que a superação dessa desvantagem passa, obrigatoriamente, por estratégias educacionais, gerenciais e empresariais inseridas no ambiente.

Os desafios relacionados à adoção das práticas e modelos associados à gestão do conhecimento não são, evidentemente, rotineiras. Em verdade, é preciso avaliar as pequenas empresas engajadas nos processos de mudanças. De modo geral, elas apontam, preliminarmente, para significativos esforços de conscientização, de comunicação e ativa participação das pessoas.

Indiscutivelmente, necessitam de suporte para as mudanças dos processos nos sistemas de informação. As mudanças precisam ser delineadas e associadas às melhores práticas de inovação e desempenho, que resultem na geração e difusão interna do conhecimento. De igual forma, ressaltase o esforço rumo aos avanços na tecnologia da informação aplicada na gestão da tecnologia que evolui para gestão do conhecimento. A Gestão do Conhecimento engloba os aspectos de aprendizado por meio da criatividade e esse aprendizado é tanto individual como empresarial. Em relação a tal aspecto, a aplicação de recursos constante que visa gerar, difundir e armazenar conhecimento resulta na agregação de valor.

\subsection{TECNOLOGIA X CAPITAL HUMANO}

É evidente que estamos inseridos em ambiente de grande turbulência, com busca constante pela vantagem competitiva. Especialmente, as pequenas empresas precisam ser reinventadas. A problemática é a baixa intensidade da aplicação de recursos em tecnologia da informação e capital humano resulta em perda da vantagem competitiva, também, inexoravelmente, afetam a participação econômica no mercado. Assim, é imenso o desafio para as pequenas empresas suplantarem os desafios de melhorar o portfólio de produtos e serviços, bem como seus processos.

Carcary e Doherty (2015) destacam a importância da tecnologia da informação e sua aplicação prática. Acreditam que é uma contribuição para base de conhecimento para um projeto relacionado à inovação e evolução na forma como as pequenas empresas gerenciam e usam a tecnologia da informação como investimentos para otimizar o valor do negócio. 


\section{Administração: caminhos para o desenvolvimento sustentável}

Os colaboradores, por sua vez, vêm elevando de maneira considerável seus patamares de educação, ao mesmo tempo em que a atividade profissional tem papel central em suas vidas. De fato, percebese que os colaboradores, em geral, se realizam com sua evolução profissional constante, na medida em que são valorizados.

Na concepção de Schultz (1961) a valorização dos colaboradores tem maior abordagem sob o ponto de vista de discurso, mas que a prática ainda não ocorre tal valorização. No entanto o autor menciona que já é uma introdução à mudança acerca da forma de valorização das pessoas. Desta forma a teoria do capital humano surgiu por intermédio da insatisfação relacionada à cultura empresarial, havia somente valorização dos aspectos relacionados ao processo de produção e do desenvolvimento econômico. Por conseguinte, paulatinamente, a evolução na forma de pensar o capital humano se deu em face da própria evolução do mercado que introduziu a escassez dos profissionais qualificados. Assim, emergiu a preocupação com o planejamento estratégico de pessoas, pautado pelos fatores que englobam a sustentabilidade tais como: atração, retenção e motivação.

\subsection{A ERA DO CONHECIMENTO X CAPITAL INTELECTUAL}

O capital humano é um dos componentes do capital intelectual das empresas e o desafio da mensuração da gestão do conhecimento é um ponto crucial para as empresas, considerando que o conhecimento é o que gera valor e riqueza. Atualmente, o aspecto de intangibilidade tem grande relevância no âmbito corporativo, em estágio incipiente, é uma preocupação relacionada à preparação das pessoas para utilização do conhecimento no exercício de suas funções. O conhecimento como fator mais importante para geração de ativos intangíveis abarca a importância da identificação do tipo de inteligência do indivíduo para alocação adequada do talento, que acarretará na aplicação correta de soluções inteligentes pelas empresas.

Incontestavelmente, o capital humano tem influência na geração do goodwill das empresas, que se refere à diferença entre ativos tangíveis e intangíveis. No entanto, vale ressaltar que os ativos tangíveis são de fácil mensuração e contabilização, já os ativos intangíveis carregam em seu bojo o aspecto de subjetividade exigindo dos profissionais de contabilidade maior cuidado nos critérios de mensuração. Os ativos intangíveis tem relação com inovação e tecnologia, é a inteligência, implicitamente, aplicada que repercute no mercado. 


\section{Administração: caminhos para o desenvolvimento sustentável}

É imperativo entendimento do conceito de ativos intangíveis (bens incorpóreos) para a compreensão da relevância do capital humano. Na definição dada por Hendriksen e Van Breda (2014) às vezes, os ativos são a diferença positiva entre o custo de uma empresa adquirida e a soma dos seus ativos tangíveis (bens corpóreos) e não deixam de ser ativos por não possuir substância. Essa definição abrangente ao goodwill. Todavia, a mensuração dos ativos é um grande desafio para a contabilidade.

No tocante a tecnologia, pode-se fazer referência à tecnologia da informação com a criação de novas ferramentas que permitiu uma velocidade na comunicação que introduziu uma abertura a interação e construção de uma economia global, o que resultou em competitividade e consequente aumento do goodwill das empresas. Destarte, o indivíduo que detém conhecimentos específicos interessantes para as empresas tem seu valor reconhecido. Não obstante, é relevante mencionar que a inovação por meio da tecnologia é dependente do capital humano porque é a habilidade deste importante capital que proporciona os efeitos almejados.

Hodiernamente, não são poucas as empresas que buscam um diferencial por meio das habilidades de criação e inovação, desta maneira dão enfoque ao conhecimento coletivo dos colaboradores se preocupando com motivação, valores, satisfação dos diversos stakeholders, especialmente, os clientes.

A construção do conhecimento é fundamentada por um conjunto de valores, experiências, ideias e informações existentes na empresa. Evidentemente, o capital humano tem papel fundamental no processo de transformação, de criação e inovação do próprio conhecimento. A empresa deve proporcionar um ambiente adequado, tanto individual como coletivo, para tanto é necessário que as condições de satisfação das necessidades dos colaboradores sejam atendidas; a manutenção da satisfação e motivação, sentindo-se valorizados e com possibilidades de participação nos processos de tomada de decisões, adequada liderança e inseridos em ambiente com parceiros com habilidades similares e acessibilidade ao conhecimento tornam o ambiente de trabalho adequado. Consequentemente, esse ambiente de conhecimento gera o capital intelectual.

Não se pode olvidar que o conhecimento nem sempre se apresenta formalmente por ser proveniente da experiência do colaborador, porém, é acessível entre o detentor do conhecimento e o interessado pelo conhecimento. No entendimento de Stehr (2017) A importância do conhecimento evolui englobando todas as esferas da vida e em todas as instituições sociais da sociedade contemporânea. 


\section{Administração: caminhos para o desenvolvimento sustentável}

Na sua perspectiva, à sociedade moderna é como uma sociedade do conhecimento, tão importante quanto à época que o enfoque era o trabalho por meio das máquinas.

Estrategicamente, as informações produzidas por meio do conhecimento são utilizadas para o desenvolvimento das atividades e processos de análise e gestão. O diferencial na gestão é a utilização da informação como forma de criação e ampliação de negócios. No tocante a esse aspecto, é importante a promoção da cultura de disseminação do processo ensino-aprendizagem dos colaboradores interessados na produção do conhecimento.

A ascensão dos ativos intangíveis na era da informação e do conhecimento é notória. No passado, o valor de uma empresa era pautado em seus ativos tangíveis, mas atualmente as empresas em face da era da globalização geram ativos intangíveis, muitas vezes, superiores aos tangíveis.

A grande subjetividade é a capacidade de avaliação dos ativos intangíveis relacionadas ao capital humano, a exemplo: as habilidades e competências dos colaboradores. Existe uma volatilidade, por vezes difícil de ser perceber, e é necessário tomar por base o valor de mercado. Indubitavelmente, existe um paradoxo acerca da inteligência sob a óptica de um ativo. Levando-se em conta a capacidade do indivíduo adquirir e aplicar sua inteligência nas atividades profissionais que resultam em benefícios econômicos para as empresas, torna-se vital o investimento na retenção desses talentos.

É sobremodo mencionar que o goodwill (mais valia) tem sua relação com o capital intelectual, uma vez que o capital intelectual seria um conglomerado de conhecimentos acumulado por uma empresa; é gerado por variados fatores e dentre eles: a satisfação dos colaboradores, tratamento adequado aos talentos, aprendizagem específica para o negócio e liderança que impacta, positivamente, no comportamento coletivo. Concernente a isto, fica evidente a relevância do capital humano que engloba os valores, as habilidades e experiências de um indivíduo.

\subsection{GESTÃO ESTRATÉGICA DE RECURSOS HUMANOS}

A gestão estratégica de recursos humanos emergiu como uma evolução da abordagem política da gestão de recursos humanos. Atualmente, procura-se o sentido entre gestão de recursos humanos e sustentabilidade. Apesar das dificuldades semânticas no sentido de conceituar essa relação intrínseca, pode-se analisar de forma bivariada as características que envolvem tal relação. Concernente a isto, é relevante frisar a importância dos resultados provenientes do capital humano e social. Considerando ainda, os impactos positivos e negativos para os stakeholders. Importa aos stakeholders os processos 


\section{Administração: caminhos para o desenvolvimento sustentável}

de implementação de políticas de gestão de recursos humanos. Embora, as dificuldades de equalização dos requisitos empresariais sejam perceptíveis. Tal abordagem tem o intuito de alcançar os resultados no curto e longo prazo.

No que diz respeito ao aspecto de sustentabilidade na gestão dos recursos humanos Wright e Snell (1991) afirmam que compreender que as influências das políticas implementadas como: emprego, comportamento, produtividade e outros resultados dos colaboradores são refletidos como contribuição para o desempenho empresarial.

A relação entre gestão de recursos humanos e resultados foi realizada sobre a relação entre gestão de recursos humanos resultados financeiros. Data, Guthrie e Wright (2005) acreditam que a gestão estratégica de recursos humanos tem contribuição para os resultados financeiros.

Na compreensão de Sikora e Ferris (2014) uma abordagem moderna da gestão de pessoas emergiu do reconhecimento explícito de que políticas de gestão de recursos humanos têm impacto no capital humano e financeiro.

No entender de Guthrie (2001) a gestão de recursos humanos sustentável reconhece explicitamente à legitimidade das práticas organizacionais no tocante, peculiarmente, as práticas de gestão de recursos humanos visam promover maior amplitude nos resultados. Em remate, tais resultados podem gerar impacto sobre os colaboradores ou grupos dentro das empresas.

De acordo com Wong (2009) é importante o reconhecimento do impacto da gestão de recursos humanos no aspecto ambiental. Adicionalmente, reconhecer o aspecto negativo, considerando a possibilidade de impactos negativos na saúde humana, social e ambiental. Levando em conta tais possibilidades reconhece-se a abordagem de uma gestão sustentável.

É inegável que a preocupação com gestão de recursos humanos surgiu com a globalização mundial, introduzindo a necessidade de evolução das tratativas relacionadas às pessoas como uma tentativa de lidar com as práticas que envolvem apenas resultados financeiros. Como se pode observar, é imperativo afirmar que a sustentabilidade na gestão de pessoas será sinônima de futuro sustentável para as empresas.

\section{METODOLOGIA DA PESQUISA}

A natureza da pesquisa é qualitativa, bibliográfica e etnográfica. Segundo Gil (2010) o uso da pesquisa etnográfica é utilizada no estudo de organizações e sociedades complexas e cada vez mais constantes 


\section{Administração: caminhos para o desenvolvimento sustentável}

no campo da administração. O propósito é o estudo de pessoas em seu ambiente utilizando procedimento de entrevista observando o participante com profundidade. Por conseguinte, envolve uma descrição detalhada do objeto de estudo, é adequada para investigação de um fenômeno contemporâneo.

O objetivo do artigo consistiu em analisar as práticas relacionadas à gestão de pessoas na empresa Actual Assessoria Condominial Ltda, segmento do terceiro setor, com base na interlocução com sócio administrador foram levantadas as práticas e desafios no que tange à gestão de pessoas e aplicação do uso da tecnologia da informação no cotidiano. E, alicerçada nas respostas obtidas na interlocução da empresa analisada, apresentam-se comentários e sugestões que visam evidenciar a importância na gestão de pessoas como forma de obtenção de vantagem competitiva.

Pautada na análise do conteúdo dos questionamentos, para identificação das melhores práticas de gestão de pessoas. Desta forma, contribuir com sugestões acerca das melhores práticas que possam ser aplicáveis em pequenas empresas.

Esta pesquisa justifica-se pelas dificuldades e desafios em relação às pessoas em empresas de pequeno porte, a aplicação, uso adequado da tecnologia e disseminação da cultura de valorização do capital humano, considerando a complexidade no tratamento desse importante capital e sua relevância nas empresas.

Desta forma, há que se considerar que existe uma intrínseca cultura que deveria ser, paulatinamente, modificada adicionando-se práticas que poderiam resultar em benefícios econômicos, por meio da obtenção de vantagem competitiva oriunda da valorização do capital humano.

\section{PESQUISA}

Preliminarmente, apresentaram-se os questionamentos envolvendo recursos humanos e tecnologia da informação para o levantamento das informações da gestão de recursos humanos.

\subsection{RECURSOS HUMANOS}

- A empresa possui colaboradores?

- A empresa se preocupa com o ambiente de trabalho?

- A empresa oferece benefícios?

- A empresa oferece autonomia para o trabalho? 


\section{Administração: caminhos para o desenvolvimento sustentável}

- O software é terceirizado?

- Os colaboradores estão preparados para a TI?

- Os colaboradores cumprem às normas da empresa?

- As falhas dos colaboradores são tratadas?

- As tratativas surtem efeitos positivos?

- Os colaboradores apresentam satisfação com as atividades?

- Os colaboradores são reciclados?

- Os colaboradores apresentam indícios de satisfação no trabalho?

\subsection{TECNOLOGIA DA INFORMAÇÃO}

- A empresa possui recursos de TI?

- A empresa planejou a aquisição dos recursos de TI?

- Os recursos tecnológicos são bem aproveitados

- O software é terceirizado?

- A empresa percebe os benefícios da TI?

- O sistema é integrado em rede?

- Qual a dependência da internet para uso do sistema?

- Utiliza o gerenciamento o banco de dados?

- Sistema é integrado?

\section{RESULTADOS DA PESQUISA}

Os resultados da pesquisa foram sintetizados em quatro perspectivas identificadas nas justificativas em resposta aos questionamentos da pesquisa, humana, estrutural, processos e ambiental.

\subsection{RECURSOS HUMANOS}

Iniciou-se com informações acerca da explanação dos trabalhos institucionais, contratação, capacitação, incentivos e recursos aplicados em pessoal. O conhecimento necessário é sistematizado e as habilidades do colaborador têm impacto direto na criação do valor da empresa. Apesar da 


\section{Administração: caminhos para o desenvolvimento sustentável}

formação e qualificação profissional dos colaboradores, as condições de trabalhos e capacitação oferecida, é um grande desafio conquistar o comprometimento profissional dos colaboradores. Em grande parte das contratações, além da verificação das habilidades profissionais, leva-se em conta o contexto da necessidade dos candidatos.

Relatou-se às dificuldades com a política de delegar as responsabilidades para manutenção do ambiente sem cobranças que pesam o ambiente de trabalho. Em relação a tal política, deve ser revista, em função da experiência de acomodação por parte dos colaboradores, ambiente tranquilo tem sido sinônimo de serviço realizado de modo ineficiente, bem como atrasos e faltas frequentes. A questão da insatisfação ocorre pelo tipo de atividade objeto da empresa, atividade cíclica e repetitiva.

\subsection{ESTRUTURAL}

Em relação ao espaço físico, é adequado e confortável para o desenvolvimento dos trabalhos, os equipamentos e aplicação de recursos em serviços de manutenção, busca constante por melhorias facilitando o desenvolvimento da atividade e atendimento aos clientes.

\subsection{PROCESSOS}

No que tange os processos, os investimentos em sistemas de informações resultam na agilização do fluxo de conhecimento. As competências são sistematizadas de forma a gerar um adequado processamento de dados das informações gerenciais. A dinâmica de sustentação da empresa é permeada pelas condições geradas ao atendimento. Adicionalmente, geram perspectivas e condições de crescimento.

\subsection{AMBIENTAL}

O ambiente em que a empresa está inserida, social, político e econômico, significa dizer que recebe constante e indiretamente interferência das empresas concorrentes. Nesse contexto, existem outros fatores que exercem impacto na empresa, como, moradores, prestadores de serviços e membros do corpo diretivo. Esses impactos podem ser positivos ou negativos dependendo das circunstancias envolvidas nos processos.

\section{CONSIDERAÇÕES FINAIS}

$\mathrm{O}$ artigo atingiu o objetivo que foi a abordagem prática e exemplificativa no elenco das dificuldades e desafios encontrados pelas pequenas empresas. Buscou-se um panorama comportamental da relação 


\section{Administração: caminhos para o desenvolvimento sustentável}

do capital humano e o uso da tecnologia. A pesquisa transpassou as fronteiras das expectativas em relação à obtenção das informações globais da empresa. Os resultados das informações obtidas foram divididos por quadrantes para melhor elucidação da temática, - recursos humanos, estrutural, processos e ambiental -. A pesquisa evidenciou que as empresas de pequeno porte com ferramentas e estratégias tão eficazes quanto às grandes empresas, considerando que o sistema de informações é um recurso acessível e democrático. No entanto, vale mencionar que as estratégias e ferramentas devem ser bem delineadas, com os rumos pré-estabelecidos pela empresa. A tecnologia da informação e o capital humano são recursos poderosos à disposição das pequenas empresas, dependendo da atividade, no caso da empresa objeto do estudo, trata-se de serviços de assessoria que envolve processamento de dados. Nesse tipo de atividade, tanto o capital humano como a tecnologia da informação são preponderantes para existência do modelo de negócio.

As pequenas empresas, independente da atividade, devem possuir sistema informatizado e recursos humanos capazes de buscar o melhor desempenho empresarial em relação aos seus concorrentes. Ademais, os colaboradores precisam ser capacitados o suficiente para lidar com as expectativas almejadas no planejamento estratégico.

Em última análise, as vantagens da capacitação e adequada gestão de pessoas, atreladas ao processo de informatização possibilita uma gestão eficaz e eficiente, o que resulta em aumento da lucratividade e competitividade. Entretanto, vale a consideração de cuidados nas relações de trabalho horizontalizadas no planejamento estratégico de recursos humanos.

\section{REFERÊNCIAS}

CARCARY, M.; DOHERTY, E. Development of a Small-To-Medium Sized Enterprise IT Management Framework - Leveraging Engaged Scholarship and Design Science Principles. Proceedings of the 14Th European Conference on Research Methodology for Business and Management Studies (Ecrm 2015), n. 2007, p. 96-103, 2015.

DATTA, Deepak K.; GUTHRIE, James P.; WRIGHT, Patrick M. Human resource management and labor productivity: does industry matter?Academy of management Journal, v. 48, n. 1, p. 135-145, 2005.

DRUCKER, Peter Ferdinand et al. The coming of the new organization. 1988.

FRIEDMAN, Milton. The social responsibility of business is to increase its profits. New York, p. 122-124, 1970.

HENDRIKSEN, Eldon S.; VAN BREDA, Michael F. Teoria da contabilidade; tradução de Antonio Zoratto Sanvicente. São Paulo: Atlas, p. 277-297, 214. 


\section{Administração: caminhos para o desenvolvimento sustentável}

GIL, Antonio C. Como elaborar projetos de pesquisa. 5. ed. São Paulo: Atlas, 2010.

GUTHRIE, James P. High-involvement work practices, turnover, and productivity: Evidence from New Zealand. Academy of management Journal, v. 44, n. 1, p. 180-190, 2001.

KAWASNICKA, Eunice Lacava. O impacto da utilização de um sistema de contabilização de RH na organização. 1981.

PARNELL, John A. Crisis Management and Strategic Orientation in Small and Medium-Sized Enterprises (SMEs) in Peru, Mexico and the United States. Journal of Contingencies and Crisis Management, v. 23, n. 4, p. 221-233, 2015.

SCHULTZ, Theodore W. Investment in human capital. The American economic review, v. 51, n. 1, p. 117, 1961.

SIKORA, David M.; FERRIS, Gerald R. Strategic human resource practice implementation: The critical role of line management. Human Resource Management Review, v. 24, n. 3, p. 271-281, 2014.

STEHR, Nico. Knowledge societies. In: Society and Knowledge. Routledge, 2017. p. 299-322.

WONG, Ling et al. Transforming organisations towards sustainable practices.International Journal of the Interdisciplinary Social Sciences, v. 4, n. 1, p. 397-408, 2009.

WRIGHT, Patrick M.; SNELL, Scott A. Toward an integrative view of strategic human resource management. Human resource management review, v. 1, n. 3, p. 203-225, 1991.

ZAVATIERI, leda Maria. Relato Integrado: um estudo de estruturas de divulgação do capital humano em relatórios bancários. 2016. 


\section{Capítulo 22}

O OUTRO LADO DA CIDADE SERRANA: INOVAÇÕES SUSTENTÁVEIS E EMPREENDEDORISMO NO LICOR DE GUAVIRA PRODUZIDO EM - BODOQUENA -MS

DOI: $10.37423 / 200300416$

Luan Caetano de Jesus (Bacharel em Administração pela Universidade Federal de Mato Grosso do Sul (UFMS) - Campus de Aquidauana (CPAQ). Foi aluno especial no Curso de Mestrado em Geografia (UFMS/CPAQ) Áreas de pesquisa: biotecnQlogia, serviços àmbientais, empreendedorimo e inovação sustentávell).
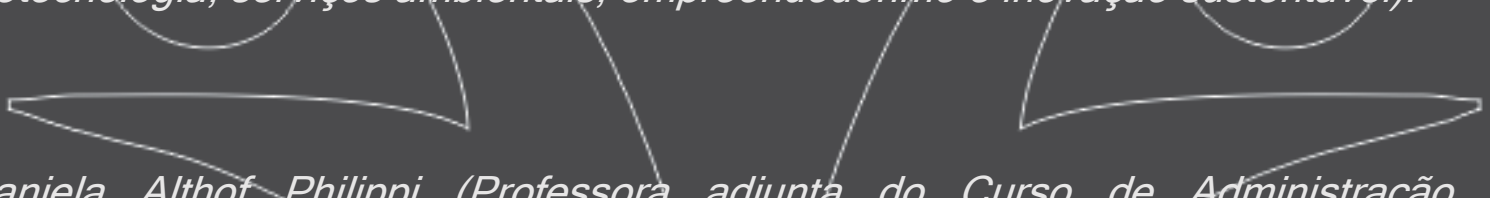

Daniela Althof Philippi (Professorá adjunta do Curso de Administração da Universidade Federal de Mato Grosso do Sul (UFMS) - Campus de Aquidauana (CPAQ). Doutora em Adrministração pela Universidade Nove de Jupho, com estágio doutoral na North Carolina State University. Mestre e Bacharel em Administração pela Universidade Federal de Santa Catarina (UFSC). Áreas de pesqutisa: inovação sustentável, cooperação tecno(ágica, logistica reversa).

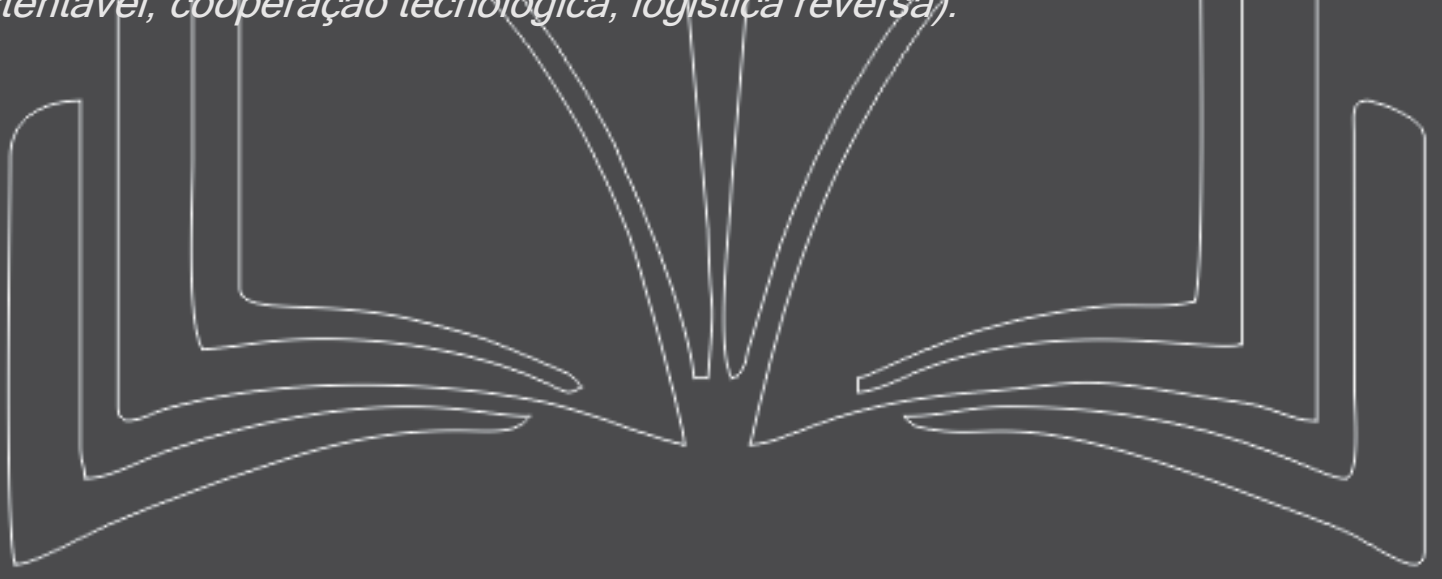




\section{Administração: caminhos para o desenvolvimento sustentável}

\section{INTRODUÇÃO}

A inovação não é um fenômeno novo. Incontestavelmente, é tão antigo quanto à própria humanidade. Mas, apesar de sua relevância, a inovação nem sempre tem a atenção acadêmica merece. Contudo, esse cenário recentemente tem-se transformado (Fagerberg, 2005). Cada vez mais estão surgindo discussões sobre a inovação sustentável e a sua relação com o empreendedorismo, pois, observa-se o debate sobre esses temas que promovem aproximação de administradores junto à realidade das empresas, além de representarem uma questão de sobrevivência da organização na atualidade, possibilitando o aumento da competitividade, aproximação da teoria com a prática e implantar cultura de inovação nos negócios.

No Brasil, o governo tem buscado incentivar por meio de políticas públicas o desenvolvimento da inovação, constatado a competitividade em nível nacional (Coral, Ogliari \& Abreu, 2009). Considerase ainda como um diferencial ações e processos sustentáveis nas organizações, sendo o Desenvolvimento Sustentável (DS) um meio para vantagem competitiva e oportunidade estratégica (Porter \& Van Der Linde, 1995; Rothenberg, 2007; Nidumolu, Prahalad \& Rangaswami, 2009).Surgem, assim, as Inovações Sustentáveis, buscando integra benefícios ambientais, sociais e econômicos (Barbieri,Vasconcelos, Andreassi \& Vasconcelos, 2010; Philippi, 2015).

Em Mato Grosso do Sul, são abundantes frutos nativos do Cerrado como a guavira (Campomanesia adamantium Camb, Myrtaceae), que possui potencial para exploração comercial, fonte de energia na alimentação e uso medicinal (Pelloso, 2011). Pesquisas sobre frutos nativos e abundantes do cerrado em Mato Grosso do Sul têm abordado a inovação sutentável como o de Alves e Philippi (2017), sobre a bocaiuva e da Silva e Philippi (2018), sobre a castanha de cumbaru.

A temática desenvolvida nesta pesquisa abrange Desenvolvimento Sustentável (DS), Inovação Sustentável (IS), Empreendedorismo e Tecnologia. Bignetti (2006) em sua pesquisa sobre gestão da tecnologia e inovação frisa a necessidade e relevância da inovação no sentido de discutir seu papel para a competitividade das organizações na atualidade. Estudiosos na América do Sul, América do Norte (principalmente Estados Unidos), Europa, Ásia que esenvolveram pesquisas ao longo dos últimos anos alegam que a inovação e empreendedorismosão os instrumentos para combater a crise em seus países, aliado a isso, sendo imprescindível investimento em educação. No Brasil em 2 de dezembro de 2004, pela Lei no 10.973, instituíram-se incentivos à inovação e à pesquisa científica e 


\section{Administração: caminhos para o desenvolvimento sustentável}

tecnológica no ambiente produtivo. Mais recentemente, em 2016, a Lei Federal n. 13.243 alterou e dispôs de estímulos quanto desenvolvimento científico e inovação no país (Brasil, 2004; Brasil, 2016).

O mapeamento das produções científicas apontam que nesse cenário que o país vivencia passa por estudos de inovação e desenvolvimento tenológico, principalmente quanto se referem ao emprego, produtividade, universidades e empresas. Incentivos à inovação em Mato Grosso do Sul (Santos, Da Silva, Vale, Gonzaga \& Ferreira, 2010, p. 6) "tem uma cadeia de agentes que direcionam seus trabalhos para a divulgação da necessidade de inovar, dando subsídios não só financeiros, mas também de caráter técnico, buscando por meio destes a dinamização do processo inovativo no Estado". Em Bodoquena - MS, a Prefeitura, por meio da Secretaria de Turismo, Meio Ambiente e Desenvolvimento Econômico, realizou a Semana do Meio Ambiente, de 5 a 7 de junho de 2019. O Serviço Brasileiro de Apoio às Micro e Pequenas Empresas [SEBRAE], em parceria com a Prefeitura do município, realizou nos dias 27 e 28 de junho, oficina voltada para negócios locais, visando ajudar os empresários do município a empreender e estruturar suas empresas.

Assim, o problema de pesquisa foi "Como ocorreu a inovação do licor de guavira produzido pela Rosa do Campo [RC] em Bodoquena - MS? Como se relaciona com DS e com o Empreendedorismo?"

Diante do exposto, a pesquisa descrita neste artigo debruçou-se a analisar como a inovação do licor de guavira produzido pela Rosa do Campo [RC] em Bodoquena - MS se relaciona com o Desenvolvimento Sustentável (Dimensão Econômica, Social e Ambiental). Para atender a essa finalidade foram nomeadas as etapas e mecanismos utilizados na produção do licor de guavira; identificar se ocorreram alterações no processo produtivo desde a sua criação e verificar se houve empreendedorismo a partir da Inovação Sustentável [IS] com Licor de guavira.

\section{FUNDAMENTAÇÃO TEÓRICA}

\subsection{INOVAÇÃO}

O Manual de Oslo, segundo a Organização para a Cooperação e Desenvolvimento Econômico [OECD] (OECD, 2006, p. 55) tece evidências que a inovação "é a implementação de um produto (bem ou serviço) novo ou significativamente melhorado, ou um processo, ou um novo método de marketing, ou um novo método organizacional nas práticas de negócios, na organização do local de trabalho ou nas relações externas." Schumpeter (1964) reforça que o conceito de inovação pautado em propor avanços e melhorias no produto e no processo, com efeito de mudanças e consequências criativas, 


\section{Administração: caminhos para o desenvolvimento sustentável}

não se restringindo a patente ou à invenção apenas. A inovação tem sido objetivo de diversas empresas, deste modo, em situações com características que precisam ser examinadas para estimular ou extinguir os impedimentos que podem interrompe-la (Bruno-Faria \& Fonseca, 2014). A Figura 1 apresenta a inovação na empresa, abordando suas atividades, sendo as bem-sucedidas (objetivo de implantação de produto/processo novo ou aprimorado), as atividades abortadas (fase de implantação do produto ou processo, com trocas de ideias e know-how, com compartilhamento entre empresas e observaao no mercado) e as atividades correntes (estão em fase de andamento e não chegam a implantação).

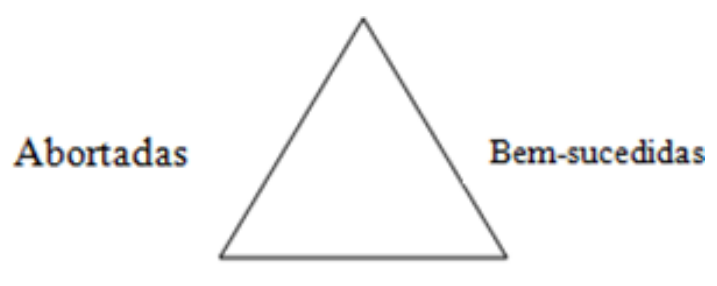

Correntes

Figura 1 - Atividades de inovação na empresa.

Fonte: Os Autores adaptado de Financiadora de Estudos e Projetos [FINEP] (FINEP, 2004, p. 23).

No entender de Dorneles (2013), o conceito de inovação relaciona-se com a criação de produtos/serviços que procuram resolução de problemas não resolvidos ou aperfeiçoamento, tendo em vista suas necessidades. Nesse contexto, OECD (2006) apresenta as quatro grandes categorias de inovação: de produto, de processos, organizacional e de marketing. Fagerberg $(2005$, p. 7) sustenta que, "a principal razão para isso tem que com uma fundamental característica da inovação: que toda nova inovação consiste em uma nova combinação de ideias, capacidades, habilidades, recursos, existentes etc.". A empresa inovadora é uma empresa que, durante o período analisado, implantou produto, processo, ou uma combinação de ambos, tecnologicamente novo ou significativamente aprimorado (FINEP, 2004, p. 24). É desta articulação que a inovação de produto é o início de um bem ou serviço novo ou significativamente melhorado no que concerne a suas características ou usos previstos. Nesse contexto, incluem-se melhoramentos significativos em especificações técnicas, componentes e materiais, softwares incorporados, facilidade de uso ou outras características funcionais (Manual de Oslo, OECD, 2006). Corroborando esse ponto, Barbieri (2011) afirma que a inovação, como instrumento de inserir ideias, princípios e soluções no contexto produtivo e social, seja em serviços ou produtos, contribui com processos e técnicas de administração novas, adaptadas 


\section{Administração: caminhos para o desenvolvimento sustentável}

ou alterada. No Manual de Oslo (OECD, 2006) frisa-se que a inovação de processo sugere um novo método de produção e/ou aprimoramento, compreendendo, assim, alterações em equipamentos e técnicas. O Quadro 1 apresenta conceitos sobre inovação, segundo alguns autores.

\begin{tabular}{|c|c|}
\hline Autores & Inovação \\
\hline Schumpeter (1964) & $\begin{array}{l}\text { Inovação que busca a interação entre o setor de } \\
\text { produção e áreas que desenvolvem pesquisa e } \\
\text { conhecimentos. }\end{array}$ \\
\hline $\begin{array}{l}\text { Zien e Buckler } \\
(1997)\end{array}$ & $\begin{array}{l}\text { Inovação compreende os níveis das organizações e } \\
\text { apresentam experiências. }\end{array}$ \\
\hline Dobni (2008) & $\begin{array}{l}\text { Inovação se traduz como uma ação com resultados } \\
\text { que são mensuráveis. }\end{array}$ \\
\hline $\begin{array}{l}\text { Bravo-Ibarra } \\
\text { Herrera (2009). }\end{array}$ & $\begin{array}{l}\text { Inovação pautada na capacidade de crescimento de, } \\
\text { reconfiguração, integração e absorção de } \\
\text { conhecimento compreendendo atores, liderança, } \\
\text { cultura, estrutura e sistemas. }\end{array}$ \\
\hline $\begin{array}{l}\text { Janiunaite e Petraite } \\
\text { (2010) }\end{array}$ & $\begin{array}{l}\text { Inovação relacionada a gestão do conhecimento, } \\
\text { sendo imprescinvível a inovação sustentável. }\end{array}$ \\
\hline & novação \\
\hline
\end{tabular}

Fonte: Os autores (2019) a partir do autores supra-citados.

A partir do quadro 2, verifica-se que a inovação compreende todos os níveis organizacionais, com ações que apresentam resultados mensuráveis, relacionadas ao conhecimento, que se orientam ao crescimento e contribuem com a inovação sustentável. Observa-se na Figura 2 que a inovação, de acordo com Bruno-Fari e Fonseca (2014), influencia na cultura organizacional, tendo em vista o desempenho e vantagem competitiva.

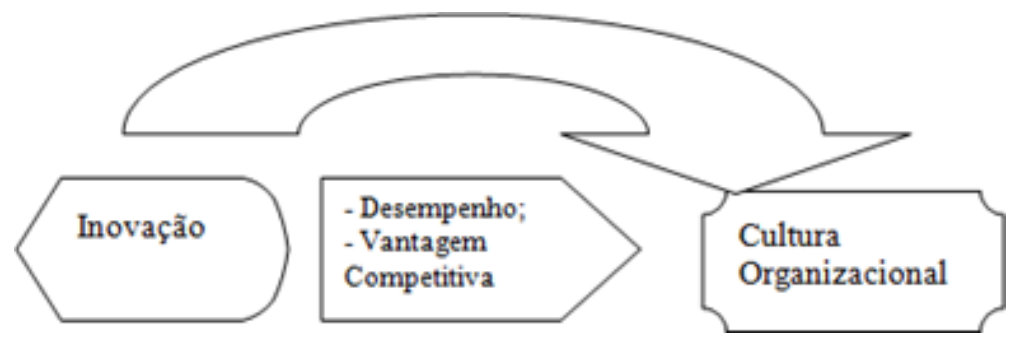

Figura 2 - Inovação e a sua influência na cultura organizacional.

Fonte: Os autores (2019) a partir de Bruno-Faria e Fonseca (2014).

Freeman (1995) esclarece que a inovação exige um perfil corporativo e econômico, relacionado aos fluxos de dados e informações essenciais que contribuem com o desempenho das empresas diante das demandas, interações sociais e concorrência de mercado. A Lei no 10.973 (Brasil, 2004) ressalta ambientes especializados e cooperativos, voltados a inovação, tendo em vista a participação das Instituições Científicas, Tecnológicas e de Inovação [ICTs] no processo, além disso, acrescentam-se 


\section{Administração: caminhos para o desenvolvimento sustentável}

estímulos de inovação nas empresas, com o desenvolvimento de novos processos, serviços ou produtos. A Figura 3 apresenta os tipos de inovação e a sua importância na competitividade.

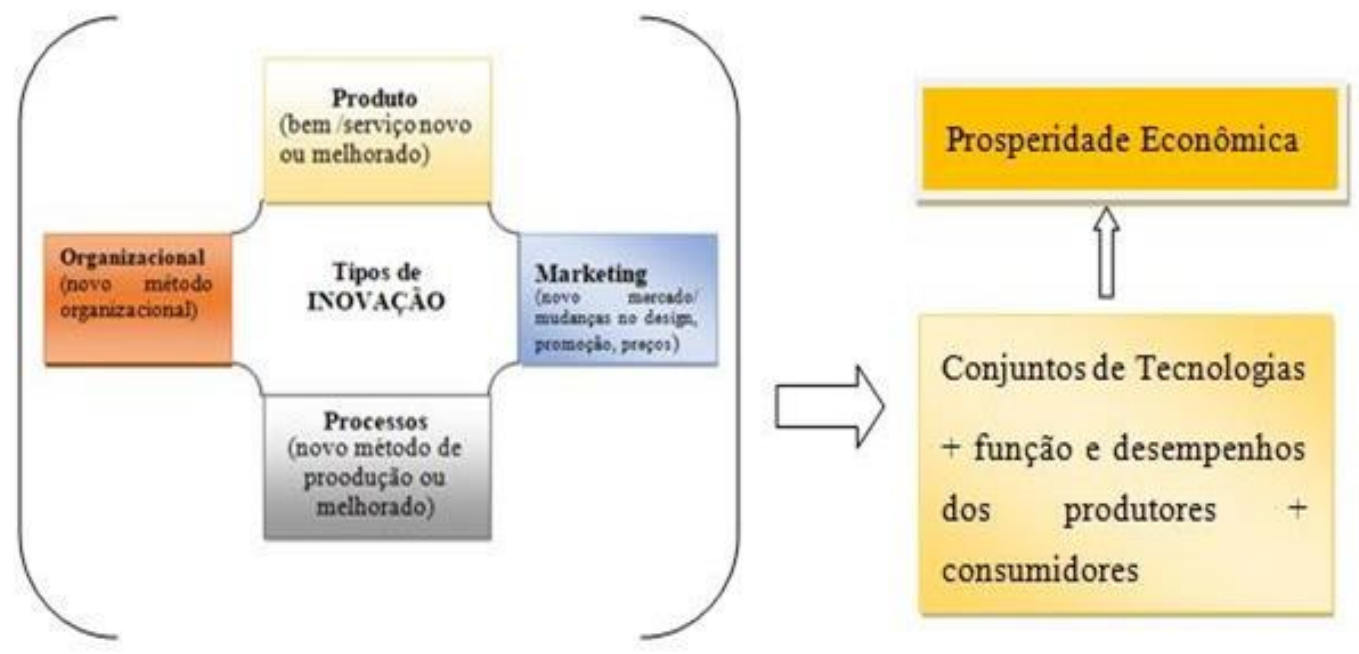

Figura 3 - Tipos de Inovação e sua importância na competitividade

Fonte: Os autores a partir de OECD (2005) e Haddad (2015).

Observa-se na Figura 3 que os tipos de inovações compreendem produto, área organizacional, marketing e processo, cooperando com conjunto de tecnologias e funções dos produtores e consumidorese, posteriormente, contribuindo com a prosperidade econômica. Fagerberger (2006) discute que a inovação constitui na primeira etapa de colocar em prática o conceito de inovação por meio de serviço e/ou produtos. Bessant e Tidd (2009) argumentam que a inovação possui inúmeras formas e contextos, no entanto, suas principais são produto (bem ou serviço), processo, organizacional e marketing. Enquanto que Dosi (1988) menciona que a inovação passa pelo desenvolvimento, experimentação, novos produtos e processos, além da descoberta.

\subsection{INOVAÇÃO SUSTENTÁVEL (IS)}

Por conseguinte, Barbieri et al. (2010) afirmam que a inovação sustentável (IS)compreende vantagens em aspectos ambientais, econômicos e sociais, visando possibilidades de inserir metodologias, produtos e processos no contexto empresarial.

Internamente, Silva et al. (2010) seriam responsáveis por explicar que a expressão IS como união de inovação e sustentabilidade, cooperando ao mencionar que as organizações na atualidade podem visualizar na sustentabilidade um meio para a inovação em consonância com sua estratégia e melhor seu desempenho competitivo. Somado a isto, Philippi; Maccari e Cirani (2015) salientam a ideia de criar soluções inovadoras sustentáveis, pensando no futuro do planeta e de futuras gerações, 


\section{Administração: caminhos para o desenvolvimento sustentável}

conforme o Relatório de Brundtland em 1987. Em consequência disso, é substancial junção de esforços coletivos, com ações, atividades e projetos, relacionados ao Desenvolvimento Sustentável (DS).

Avançando nas pesquisas, Silva e Souza-Lima (2010) propuseram que tem ocorrido um despertamento da humanidade quanto à preservação do meio ambiente, no entanto, é preciso ainda buscar produtos que não tenham maior impacto, promovendo maior consciência da população.

\subsection{DESENVOLVIMENTO SUSTENTÁVEL (DS) E SUAS DIMENSÕES}

A concepção de Dias (2011) acercado do Desenvolvimento Sustentável (DS) está pautada em uma economia contínua de forma racional com uso de tecnologias que causem menor impacto ao meio ambiente.

Barbieri (2011) acrescenta que nos últimos anos, houve maior preocupação no meio empresarial quanto a eficiência e eficácia da produção e principalmente, na perspectiva da produção mais limpa. Evidencia-se que o termo Desenvolvimento Sustentável começou a ser empregada por volta da década de 1970. Assim, a Comissão Brundtland - Nosso Futuro Comum, também chamada de Comissão Mundial sobre Meio Ambiente e Desenvolvimento foi realizada pela Assembleia Geral da Organização das Nações Unidas (ONU) em 1983, que iniciou pesquisas e estudos. Salienta-se que o conceito do DS precisa ser compreendido pelos líderes das organizações na atualidade, sendo um meio de produzir sem prejudicar/impactar ao meio ambiente, com compartilhamento e conhecimento de todos os colaboradores da empresa, com resultados em ações, projetos, atividades e rotinas que associe preservação ambiental com a produção, através de tecnologias limpas e/ou adaptas a realidade (Relatório de Brundtland, 1987). Alves e Philippi (2017, p. 85), por sua vez, compreendem o conceito de DS como "está assentado em dimensões, destacando-se a harmonia entre as dimensões social, ambiental e econômica, definidas como triple bottom line, o que compreende a busca por justiça social, equilíbrio ambiental e desenvolvimento econômico".

O DS relaciona-se com a sustentabilidade, desse modo, exige técnica e método de planejamento, tendo em vista oferecer vantagens e evitar ou produzir menor impacto (Afonso, 2006).Para um entendimento mais claro das dimensões do DS, apresenta-se uma análise dos autores descritos a seguir no Quadro 2. 


\begin{tabular}{|c|c|c|c|}
\hline $\begin{array}{c}\text { TIPOS DE } \\
\text { DIMENSÕES }\end{array}$ & $\begin{array}{r}\text { DIMENSÃO } \\
\text { ECONÔMICA }\end{array}$ & $\begin{array}{c}\text { DIMENSÃO } \\
\text { SOCIAL }\end{array}$ & $\begin{array}{r}\text { DIMENSÃO } \\
\text { AMBIENTAL }\end{array}$ \\
\hline $\begin{array}{l}\text { Conceitos para } \\
\text { os autores: } \\
\text { Bresser } \\
\text { Pereira (1962), } \\
\text { Stoffel e } \\
\text { Colognese } \\
(2015) \text { e } \\
\text { Souza (2012). }\end{array}$ & $\begin{array}{l}\text { Crescimento da } \\
\text { produção per capita, } \\
\text { tendo em vista os } \\
\text { elementos de produção } \\
\text { e desenvolvimento. } \\
\text { Transformação da } \\
\text { estrutura econômica, } \\
\text { relacionada a social } \\
\text { (Bresser Pereira, } \\
\text { 1962). }\end{array}$ & $\begin{array}{l}\text { Igualdade e isonomia } \\
\text { social, com geração de } \\
\text { emprego, acesso aos } \\
\text { serviços e qualidade de } \\
\text { vida } \\
\text { (Stoffel\&Colognese } \\
\text { 2015). }\end{array}$ & $\begin{array}{l}\text { Observação do } \\
\text { modelo de produção, } \\
\text { verificando } \\
\text { material e o consumo } \\
\text { que visualize a } \\
\text { economia, } \\
\text { introduzindo } \\
\text { principios } \\
\text { ecoeficiência } \\
\text { (Souza, 2012). }\end{array}$ \\
\hline $\begin{array}{l}\text { Conceitos para } \\
\text { autor: } \\
\text { Dias (2011) }\end{array}$ & $\begin{array}{l}\text { Organização seja } \\
\text { viável e enfase na } \\
\text { rentabilidade } \\
\text { Dias (2011). }\end{array}$ & $\begin{array}{l}\text { Ênfase nas condições } \\
\text { de trabalho das } \\
\text { organizações, } \\
\text { compreendendo a } \\
\text { diversidade, culturae } \\
\text { participação } \\
\text { (Dias, 2011). }\end{array}$ & $\begin{array}{l}\text { Introdução de } \\
\text { conceitos, ideias e } \\
\text { prática da produção } \\
\text { mais limpa, enfase na } \\
\text { cultura ambiental e } \\
\text { responsabilidade } \\
\text { ambiental } \\
\text { (Dias, 2011). }\end{array}$ \\
\hline $\begin{array}{l}\text { Conceitos para } \\
\text { os autores: } \\
\text { Amato (2015), } \\
\text { Dias }(2011) \text { e } \\
\text { Souza (2012). }\end{array}$ & $\begin{array}{l}\text { Atividade que } \\
\text { apresente viabilidade e } \\
\text { seja sustentável } \\
\text { (Amato, 2015). }\end{array}$ & $\begin{array}{l}\text { Compreensão da área de } \\
\text { atuação da empresa, } \\
\text { como seu entorno, } \\
\text { população ao redor } \\
\text { com acesso a }\end{array}$ & $\begin{array}{lr}\text { Ações } & \text { de } \\
\text { preservação do meio } \\
\text { ambiente } & \text { com } \\
\text { produção } & \text { que busque } \\
\text { impedir } & \text { a }\end{array}$ \\
\hline
\end{tabular}

oportunidades contaminação

(Dias, 2011). $\quad$ (Souza, 2012).

Quadro 2 - Triple Bottom Line (DS)

Fonte: Os autores (2019) a partir do autores supra-citados.

Oliveira et al. (2012) exploram o significado das três dimensões do DS, conhecido como Triple Bottom Line ou 3P (People, Planet, Profit), dessa forma, compreende: (A) Social, atividades aos colaboradores e população; (B) Ambiental, processos pautados na produção mais limpa e que não produzam impactos ao meio ambiente ou que seja de menor risco; (C) Econômico, rentabilidade dos negócios, com evidencias a prosperiedade econômica, criando novas oportunidades.

Nessa linha de raciocínio, Carvalho e Viana (1998) fomentam que o DS está configurado em equilíbrio ecológico, dimensão social e econômica. Martens, Kniess, De Carvalho e Martens (2013, p. 10) salientam outra questão: a necessidade da inserção dos conceitos de sustentabilidade com visão tridimensional Triple-Bottom Line nas práticas de gerenciamento de projetos com vistas a inovação sustentável. 


\section{Administração: caminhos para o desenvolvimento sustentável}

\subsection{EMPREENDEDORISMO: O PODER DA INICIATIVA E OPORTUNIDADES}

O empreendedorismo na visão de Leite (2000) está relacionado a ideias criativas, que possuem poder de transformação, por meio de criação de valores. Para Menezes (2003) o empreendedorismo pautase na mudança de contextos, ligado ao espírito empreendedor das pessoas que procuram atender as necessidades de realizar.

Descrevendo um contexto histórico e apresentando marco inicial do empreendedorismo, SEBRAE (2007) coloca a figura de Marco Polo como exemplo de uma iniciativa empreendedora em busca de rotas no Oriente. Dornelas (2008) evidencia que a palavra empreender era confundida com gerente, isso sob viés econômico. Somente, a partir do século XX relacionou-se a palavra empreender com conceitos de inovação. Desse modo, o termo empreender possui sua origem na palavra francesa entrepeneur, com o uso em 1725 por Richard Cantillon que admitia as circunstâncias de riscos (Leite, 2000; SEBRAE, 2007; Dornelas, 2008). Apesar das dificuldades, o Brasil apresenta algumas perspectivas positivas em relação ao empreendedorismo. Desde alguns anos atrás, foram criados órgãos e iniciativas de apoio ao empreendedor, como o SEBRAE, as fundações estaduais de apoio à pesquisa, as incubadoras de novos negócios e as escolas superiores, que tem oferecido cursos e outros tipos de programas sobre o empreendedorismo (Maximiano, 2006, p. 6).

Como bem definiu Drucker (2008), o empreendedorismo depende de esforços organizados e sistemáticos, sendo preciso observar as mudanças, necessidades da empresa e o ambiente em que está inserida, explorando oportunidades de empreender e inovar. Brittoe Wever (2003) argumentam que os empreendedores possuem esperança para vencer as necessidades e obstáculos, possuem planejamento e são adaptáveis as mudanças, enxergam nas dificuldades oportunidades para alcançar melhores resultados.

Em sua pesquisa, Longenecker, Moore e Petty (2004) descrevem a importância do empreendedorismo, ressaltando seu papel quanto a inovação e ao crescimento econômico. Drucker (1986) sintetiza que o empreendedor é uma pessoa que possui comportamento inovador, atende a satisfação dos clientes. Nesse sentido, identifica as oportunidades de negócios, os mercados, estabelece objetivos e metas diante de riscos calculados, sempre busca dados e informações e transforma em conhecimentos essenciais, além disso, desenvolve planejamento e controle de suas atividades. O empreendedorismo visa não somente oportunidades de negócios, define objetivos, há criação de planejamento e projeta estruturas organizacionais, permite a compreensão de contextos que envolve a empresa e suas oportunidades de atuação (Fillion, 2000; Dolabela, 2008). 


\section{Administração: caminhos para o desenvolvimento sustentável}

\subsection{ASSOCIAÇÃO DESENVOLVIMENTO SUSTENTÁVEL, INOVAÇÃO E EMPREENDEDORISMO}

O Empreendedorismo e a Inovação, principalmente em tempos de crise, são os principais pilares que sustentam o crescimento das economias em todos os países (Costa, Barbosa \& Silva, 2011, p. 2). Fialho et. al. (2008) revelam que o DS visa processos que desenvolvem atividades controladas, envolvendo competencias, conhecimentos e compreensão acerca do que é gestão socioambiental e sua função no contexto organizacional. O fio condutor permite reforçar que o empreendedorismo é composto de um conjunto de hábitos e práticas que podem executadas e/ou aperfeiçoada pelos colaboradores, por meio decompetências e conhecimentos como maneira de torná-los habilitados e instruídosa promover e desenvolver abertura de oportunidades, cooperando com novos processo, produtos e serviços (Drucker, 2008).

Drucker (2008) argumenta que o empreendedorismo é imprescindível para o desenvolvimento local e global, salientando a influência na economia, além dos impactos sociais. Com base no até então exposto, o Quadro 3, apresenta a Associação entre DS, Inovação e Empreendedorismo.

\begin{tabular}{|c|c|c|c|}
\hline ASSOCIAÇÃO & $\begin{array}{l}\text { DESENVOLVIMENTO } \\
\text { SUSTENTÁVEL (DS) }\end{array}$ & INOVAÇÃO & EMPREENDEDORISMO \\
\hline $\begin{array}{r}\text { DIMENSÃO } \\
\text { ECONÔMICA }\end{array}$ & $\begin{array}{l}\text { Uma das bases para o } \\
\text { desenvolvimento } \\
\text { estrutura econômica. }\end{array}$ & $\begin{array}{l}\text { Contribui para } \\
\text { economia do país. }\end{array}$ & $\begin{array}{l}\text { Coopera com crescimento } \\
\text { econômico. }\end{array}$ \\
\hline $\begin{array}{l}\text { DIMENSÃO } \\
\text { SOCIAL }\end{array}$ & 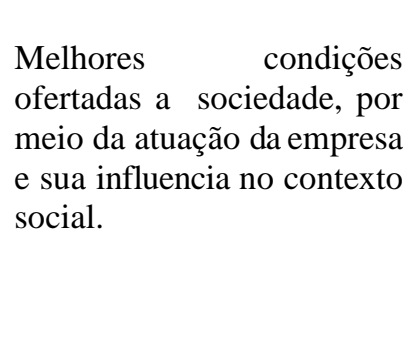 & $\begin{array}{l}\text { Contribui } \quad \text { com } \\
\text { desenvolvimento } \\
\text { novas atividades } \\
\text { conhecimentos. }\end{array}$ & 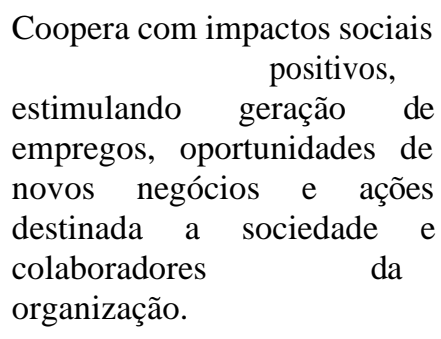 \\
\hline $\begin{array}{r}\text { DIMENSÃO } \\
\text { AMBIENTAL }\end{array}$ & $\begin{array}{l}\text { Modelo sustentável } \\
\text { quanto aos processos, com } \\
\text { ênfase nos processos e } \\
\text { produtos. }\end{array}$ & $\begin{array}{l}\text { Inovação por meio de } \\
\text { incentivo a produção } \\
\text { mais limpa e criação ou } \\
\text { adaptação com objetivo } \\
\text { de cooperar com o meio } \\
\text { ambiente. }\end{array}$ & $\begin{array}{l}\text { Atuação da empresa no } \\
\text { sentido de diminuir ou sanar } \\
\text { os impactos causados ao meio } \\
\text { ambiente por meio da criação } \\
\text { de ações, projetos.etc. }\end{array}$ \\
\hline
\end{tabular}

Quadro 3 - Associação entre DS, Inovação e Empreendedorismo

Fonte: Os autores (2019). 


\section{Administração: caminhos para o desenvolvimento sustentável}

\section{MÉTODOS E TÉCNICAS}

A pesquisa é classificada como estudo de caso de natureza qualitativa. Por ser considerada qualitativa, o estudo permitiu maior aprofundamento e análise em relação ao problema de pesquisa. Michel (2009) argumenta que a pesquisa qualitativa promove uma relação

contextual inserindo o pesquisador quanto ao tempo e seus fatos, assim como observação próxima do objeto. Gressler (2007) frisa que a abordagem qualitativa bsuca entender o problema descrevendo seus detalhes, possibilitando olhares do contexto em que está inserido o objetivo de pesquisa.

Acevedo (2013) defende o estudo de caso, como técnica de pesquisa, é um método que utiliza o planejamento por meio de coleta de dados, sendo que análise de dados se preocupa com questões do tipo, o que, como e porquê. Jung (2004) acrescenta queo estudo de caso possibilita o entendimento do objeto de pesquisa, especificadamente a sua realidade, seus limites, seu comportamento e local. Para Gil (2010) o estudo de caso pauta-se em aprofundar os conhecimentos acerca do objeto de pesquisa.

Para a coleta de dados, realizaram-se entrevistas nos meses de julho e agosto do ano de 2018 com os empresários RC. Após essa etapa, a pesquisa continuou sendo desenvolvida com análises. A empresa com produção de Licor de Guavira em Bodoquena - MS é uma forte representante para contribuir com a divulgação do produto reginal, contribuindo com o Turismo, Empreendedorismo e Inovação.

Além disso, realizou-se observação não participante que, para Marconi e Lakatos (2011) é aquela em que o pesquisador possui contanto com sua população de estudo, no entanto, não integra-se a mesma. A etapa exploratória da pesquisa possibilitou relacionar o problema de pesquisa com as possíveis hipóteses e referências bibliográficas. Destaca-se que os dados foram coletados em fontes primárias e secundárias. Sendo primárias, a observação e as entrevistas, como fontes secundárias foram extraídas da literatura acerca dos temas como: inovação sustentável, tecnologia, empreendedorismo e desenvolvimento sustentável. Salienta- se que os dados foram analisados e interpretados com objetivo de associar ao problema e objetivos desta pesquisa.

Os dados de fontes primárias (entrevistas e observações) e secundárias (literatura) foram triangulados (Yin, 2001) e a sua análise foi a de conteúdo, obedecendo a sequência indicada por Bardin (2011): a pré-análise, a descrição analítica e a interpretação referencial. 


\section{Administração: caminhos para o desenvolvimento sustentável}

\section{APRESENTAÇÃO E DISCUSSÃO DOS RESULTADOS}

Nestes sub-capítulos são abordados - com análise e discussão - os assuntos relacionados ao tema desse estudo. Apresentam-se os resultados sobre a empresa RC, descrevendo o Histórico e caracterização; Processo Produtivo do licor de guavira; Empreendedorismo a partir da Inovação Sustentável com Licor de guavira, e finaliza-se com a inovação do licor de guavira e sua relação com as dimensões do Desenvolvimento Sustentável.

\subsection{HISTÓRICO E CARACTERIZAÇÃO DA ROSA DO CAMPO (RC)}

A empresa foi aberta por iniciativa própria em 2014, assim, com o passar dos anos, criamos uma marca, conhecida como RC. Em 2019, a empresa completa 05 anos. Nesse sentido, a RC foi criada porque os proprietários foram colher guavira (fruta símbolo de Mato Grosso do Sul) para uso e colheram 80 quilos, pensando no que iria fazer com tanta quantidade da fruta, pensaram em produzir o licor. Na empresa trabalham somente os dois proprietários, não desenvolvem outros produtos e ainda não realizaram parcerias com outras instituições pensando em melhorar o licor de guavira, como Universidades, Institutos de Pesquisa, Agência de Desenvolvimento Agrário e Extensão Rural [AGRAER] OU SEBRAE.

\subsection{PROCESSO PRODUTIVO DO LICOR DE GUAVIRA DA RC}

A produção do licor de guavira para fins comerciais iniciou-se a partir de dezembro de 2014.Contudo, ainda não possui selo ou certificação do produto do licor de guavira, não houve alteração, com o passar do tempo (desde o início), no licor em sua forma final como produto, como embalagem, consistência, peso etc. Na Figura 4, apresenta-se amostra do produto.

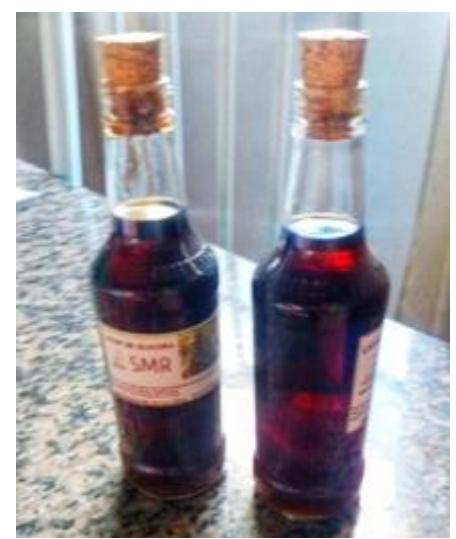

Figura 4 - Licor de guavira produzido em Bodoquena - MS.

Fonte: Dados primários (observação) (2019). 


\section{Administração: caminhos para o desenvolvimento sustentável}

Sobre a origem da guavira, ressalta-se que é uma planta nativa da região da Serra de Bodoquena, além de ser encontrada no Centro-Oeste, há disponibilidade em São Paulo, especialmente no Cerrado, sendo sua forma de extração por colheita manualmente pelos empresários e transportados pelos mesmos para a área de produção. A título de ressalva, a guavira possui o nome científico Campomonesia adamantium. Cabe ressaltar complementarmente que não houve nenhuma alteração nos meios de comercialização, nem de equipamentos e nem de modo de trabalho na produção do licor de guavira no decorrer do tempo (Rosa do Campo, 2018).

Verificou-se que não há alterações no processo produtivo relacionadas à redução de diferenças (desigualdade) social entre pessoas (produtores ou consumidores) e nem sobre a intensificação do uso dos potenciais naturais com o mínimo impacto negativo ao meio ambiente temporal. Observouse que sobre a geração de mais riquezas financeiras, considerou-se razoável. Apresenta-se o processo produtivo do licor de guavira, conforme Figura 5.

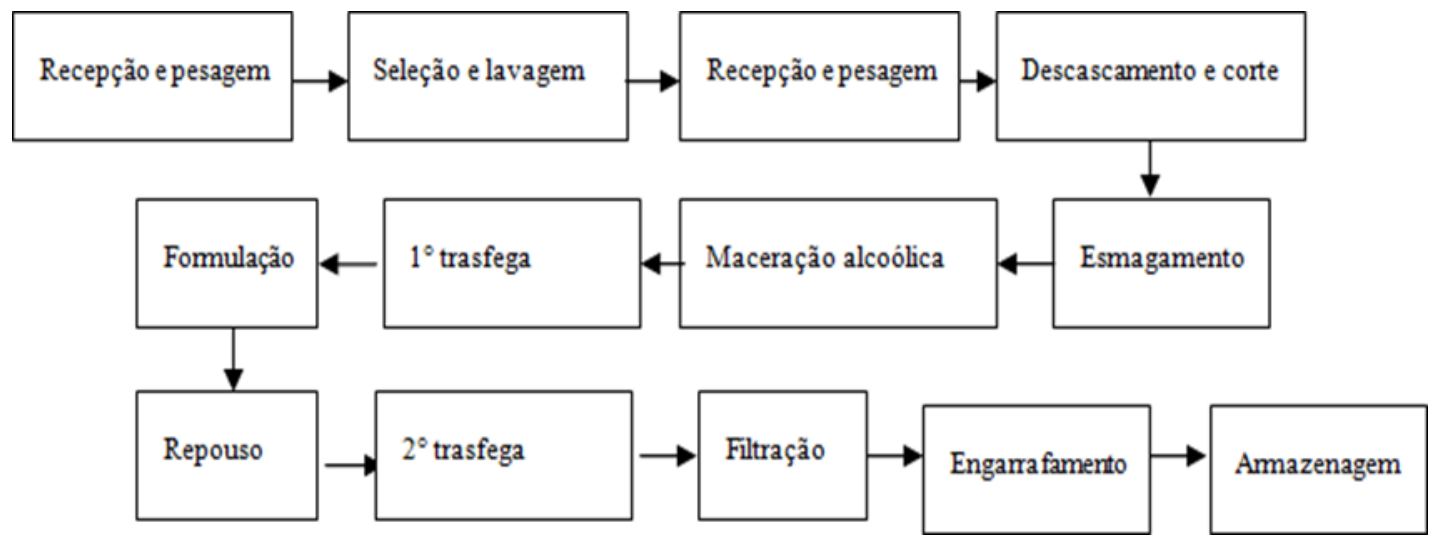

Figura 5 - Processo Produtivo do Licor de Guavira.

Fonte: Os autores a partir dos dados dados primários - entrevista (2019).

Os dados ilustrados na Figura 5 permitem contemplar que as etapas do processo produtivo do Licor de Guavira compreendem: I) recepção e pesagem, II) seleção e lavagem, III) recepção e pesagem, IV) descascamento e corte, V) formulação, VI) $1^{\circ}$ trasfega, VII) maceração alcoólica, VIII) esmagamento, IV) repouso, X) $2^{\circ}$ trasfega, XI) filtração, XII) engarrafamento,

XIII) armazenamento. Disto decorre, em análise dos resultados, especialmente sobre a maneira simples de realização em todos os processos para a obtenção do licor de guavira. Essencialmente, as etapas de produção partem de ações e atividades manuais e naturais além de se considerar que a guavira, principal matéria prima, é uma fruta extraída com potencial turístico do Pantanal Sul-MatoGrossense. 


\section{Administração: caminhos para o desenvolvimento sustentável}

\subsection{EMPREENDEDORISMO A PARTIR DA IS COM LICOR DE GUAVIRA}

Os resultos obtidos em relação ao empreendedorismo a partir da inovação sustentável de Licor de Guavira na empresa RC apresenta características de operacionalização da criatividade em processo do produto, observado a garantia de cooperação com o meio ambiente (onde realiza- se colheita da fruta) e no objetivo de criar relações, seja por meio de parcerias ou com os clientes (Hirschman, 1958).

A fim de contemplar esse pensamento, verificou-se que os empresários apresentam perfil que compreende as habilidades de empreendedores, isso confirma-se por através do sucesso com vendas do licor de guavira na região e em outros estados brasileiros, como São Paulo e outros. Aliado a isto, outro resultado analisado sustentado baseia-se em Leibenstein (1968), a empresa foi construída a partir das condições do mercado na região, nesse sentido, constatou- se vantagens obtidas à partida da inovação sustentável e do empreendedorismo pelo licor de guavira. É dentro do escopo do empreendedorismo e inovação sustentável com o licor de guavira que Kizner (1982), que vislumbra que os empresários são empreendedores, pois, contribuem com o sistema econômico a partir de colheita da fruta do meio ambiente. Para efeito de alinhamento conceitual e de resultados, esses autores entendem que a inovação e o empreendedorismo tem sido estudados com maior frequência, como visto an empresa RC apresentou associação a partir do crescimento economico com inovação a partir de recursos disponíveis, caracterizado por novas oportunidades, criando novas conexões, processos e adaptações ao licor de guavira (Rickards, 2000; Vale, 2007).

\subsection{A INOVAÇÃO DO LICOR DE GUAVIRA E RELAÇÃO COM AS DIMENSÕES DO DS}

Verificou-se que a inovação do Licor de Guavira possui relação com as dimensões do Desenvolvimento Sustentável. Nesse contexto, na dimensão econômica do licor de guavira verificou-se que houve preocupação em reduzir os custos de produção, com o passar do tempo e divulgação do produto, aumento da demanda, ou seja, uma maior procura mesmo que de maneira gradual. Posteriormente, necessidade de uma colheita objetivando aumentar o volume da produção.Com base nas análises, o Quadro 4, descreve a relação dos aspectos do Licor de Guavira e sua relação com as dimensões do DS. 


\section{Administração: caminhos para o desenvolvimento sustentável}

\begin{tabular}{|c|c|c|c|}
\hline $\begin{array}{c}\text { TIPOS DE } \\
\text { DIMENSÕES }\end{array}$ & $\begin{array}{r}\text { DIMENSÃO } \\
\text { ECONÔMICA }\end{array}$ & $\begin{array}{c}\text { DIMENSÃO } \\
\text { SOCIAL }\end{array}$ & $\begin{array}{l}\text { DIMENSÃO } \\
\text { AMBIENTAL }\end{array}$ \\
\hline $\begin{array}{l}\text { Aplicação de } \\
\text { conceitos e } \\
\text { análise da } \\
\text { prática da RC }\end{array}$ & $\begin{array}{l}\text { Houve transformação } \\
\text { da } \\
\text { econômica, procura e } \\
\text { aumento da demanda } \\
\text { pelo licor de guavira. }\end{array}$ & $\begin{array}{l}\text { Não houve geração de } \\
\text { emprego, no entanto, } \\
\text { acesso a mais serviços e } \\
\text { promoção da qualidade } \\
\text { de vida. }\end{array}$ & $\begin{array}{l}\text { Há aplicabilidade de } \\
\text { principios de } \\
\text { ecoeficiência, tendo } \\
\text { em vista uma } \\
\text { produção por meio de } \\
\text { colheita manual ecom } \\
\text { dependência do meio } \\
\text { ambiente } \\
\text { preservação do } \\
\text { mesmo dara } \\
\text { confecção do licor. }\end{array}$ \\
\hline
\end{tabular}

Quadro 4-RC - Rosa do Campo e relação com o Triple Bottom Line (DS)

Fonte: Os autores (2019).

Na dimensão social, há preocupação quanto a colheita e transporte, observando a qualidade do processo produtivo e o produto final.Na dimensão ambiental, constatou-se a necessidade de prevervação e consciência por parte dos empreendedores, pois, é uma fruta típica da região e para que sempre haja disponibilidade é imprescindível cuidados, assim como a forma correta dos resíduos da produção. Na dimensão ambiental, evidenciou-se a aplicação de princípios de ecoeficiência, preocupação e responsabilidade com preservação do meio ambiente, carcaterizando um processo produtivo sustentável quanto a essa dimensão.

\section{CONCLUSÃO}

Em todas as etapas deste estudo foi constatada a relevância do empreendedorismo e inovação sustentável e, se torna imprescindível que estes resultados sejam mais difundidos no Brasil e, devido a necessidade das organizações no contexto contemporâneo, a crise econômica, o avanço da tecnologia, as inovações no processo de produção tendo em vista a produção mais limpa, os novos desafios da administração, ambientes de oportunidades e ameças em que a empresa atua, portanto, há exigências de conhecimentos de gestão e atendimento das demandas, sejam de produtos ou serviços.

O pioneirismo do presente estudo está pautado em associar o produto licor de guavira a inovação, tecnologia e empreendedorismo, fortalecendo a gestão da inovação quanto ao desenvolvimento sustentável em meio as práticas de sustentabilidade, contribuindo com os negócios e mercado com modelos de que uma ideia e oportunidade podem transformar o ambiente, o município por meio de produtos sustentáveis no âmbito do turismo. Sobre esse ponto da articulação entre teoria e a prática 


\section{Administração: caminhos para o desenvolvimento sustentável}

na Administração, por meio desse trabalho aprofundou-se os conhecimentos sobre as funções, etapas com análise crítica voltado a inovação e ao empreendedorismo, tendo em vista contribuir e promover discussão sobre produtos naturais regionais. Além disso, incentivou-se a preservação dos recursos naturais, com ênfase na inovação de processos que causam mínimo impacto ao meio ambiente. Assim, conforme proposto por Gibb (1991) os empresários da RC possuem perfil de empreendedores, dado que, ao colher $80 \mathrm{~kg}$ de guavira, antes visto como problema, desenvolver uma solução, o licor de guavira, transformando-se oportunidade em negócio.

Em consonância com os autores com os quais se dialogou, analisou-se que a inovação do licor de guavira produzido pela RC no município de Bodoquena - MS relaciona-se com as dimensões do Desenvolvimento Sustentável (DS), em tais aspectos: Dimensão Econômica (organização da estrutura econômica da empresa e aumento da demanda pelo produto licor de guavira); Dimensão Social (não há geração de empregos, tendo em vista que somente os dois empresários realizam as atividades do processo produtivo, no entanto, percebeu-se contribuição para qualidade de vida); Dimensão Ambiental (aplicação de princípios de ecoeficiência, preocupação e responsabilidade com preservação do meio ambiente, processo produtivo sustentável). Os resultados do trabalho revelaram que as etapas e mecanismos utilizados na produção do licor de guavira compreendem processos manuais e sustentáveis, realizados pelos empresários. A organização dos dados nos permitiu identificar que não houve alterações no processo produtivo desde a sua criação, pois, o produto inicialmente desenvolvido faz sucesso, atende as demandas e atende as necessidades dos clientes e empresários. Nesse sentido, foi possível verificar que a RC apresentou características e habilidades que vão ao encontro do perfil do empreendedorismo, devido sua função incontestável na região que atua, sua maneira de desenvolver o produto e extraí-lo do meio ambiente, assim, principalmente a Dimensão Ambiental relaciona-se com a Inovação Sustentável (IS) com Licor de guavira. Destarte, as três dimensões foram observadas na RC, ao qual compõem o tripé do DS (Montibeller-Filho, 2001), contextualizado e inserido nas Teorias de Administração na atualidade a partir com discussão comparativas as inovações tecnológicas, permitindo ao administrador desempenhar funções que vão além de planejar, organizar, dirigir e controlar, ou seja, considerar as consequências das novas tecnologias e gerenciar as mudanças empresariais sejam em organizações privadas ou públicas, apoiadas em políticas públicas, contribuição ao turismo local e estadual, promovendo iniciativas de venture capital, fomentando parcerias entre governo-universidade-empresa, desenvolvimento de estudo com start-ups, além de estratégias, cooperativismo e incentivo a inovação sustentável para a base da pirâmide (BoP). Quanto às limitações e dificuldades para a realização desta pesquisa, 


\section{Administração: caminhos para o desenvolvimento sustentável}

ressaltam-se: número reduzido de estudos envolvendo empreendedorismo e inovação sustentável a partir de produtos sustentáveis, Teorias Administrativas que contemplem Inovação, Tecnologia e Empreendedorismo ao contexo de discutir as necessidades empresariais na atualidade e eixos fundamentais do Desenvolvimento Sustentável com maior aplicabilidades em empresas de pequeno porte e organizações públicas voltadas a inovação de seus serviços.

É praticamente unânime que esse sintagma apareça em trabalhos em que relacionam desenvolvimento sustentável e inovação. Encerra-se, com algumas recomendações para futuras pesquisas: realização de comparações em esfera pública a partir da inovação, realizar estudos que verifiquem o empreendedorismo em empresas multinacionais, além de trabalhos que incluem dados estatísticos em universidades do país, com olhar com o futuro em investigação de 'inovar' pela sustentabilidade com objetivo de fortalecer os caminhos para o desenvolvimento sustentável, inovação e empreendedorismo diante do fenômeno tecnológico no século XXI.

\section{REFERÊNCIAS}

Acevedo, C. R. (2013).Como fazer monografias, TCC, dissertações e teses. São Paulo: Atlas. Afonso, C. M.(2006). Sustentabilidade: caminho ou utopia? São Paulo: Annablume.

Alves, L. R.P., \& Philippi, D. A.(2017). A Inovação e Sustentabilidade da Farinha de Bocaiuva: estudo em Aquidauana/MS. Ateliê do Turismo, 1(1), 85-105.

Amato Neto, J. (2015), A era do ecobusiness: criando negócios sustentáveis. São Paulo: Monole. Barbieri, J. C. (2011). Gestão de ideias para inovação contínua. Porto Alegre: Bookman.

Barbieri, J. C., de Vasconcelos, I. F. G., Andreassi. T., \& de Vasconcelos, F. C. (2010). Inovação e sustentabilidade: novos modelos e proposições. Revista de Administração de Empresas, 50(2), 146154.

Bardin, L. (2011). Análise de conteúdo. São Paulo: Edições 70.

Bessant, J., \& Tidd, J. (2009).Inovação e empreendedorismo. Porto Alegre: Bookman, 2009.

Bignetti, L.P. (2006). Gestão de tecnologia e inovação: um análise de autores, vertentesteóricas e estratégiasmetodológicaspredominantesemtrabalhosapresentadosnosEncontros da Anpad. In: Encontro da ANPAD- EnANPAD, XXX, 2006. Anais...Salvador, ANPAD.

Brasil. (2004). Lei Federal n. 10.973, de 02 de dezembro de 2004. Dispõesobreincentivos à inovação e à pesquisacientífica e tecnológica no ambienteprodutivo e dáoutrasprovidências. Recuperadoem 05 abril, 2019, de http://www.planalto.gov.br/ccivil_03/_ato2004-2006/2004/lei/l10.973.htm.

Brasil. (2016). Lei Federal n. 13.243, de 11 de janeiro de 2016. Dispõe sobre estímulos ao desenvolvimento científico, à pesquisa, à capacitação científica e tecnológica e à inovação e altera a Lei $\mathrm{n}$ - 10.973, de 2 de dezembro de 2004. Recuperadoem 05 abril, 2019, 


\section{Administração: caminhos para o desenvolvimento sustentável}

de http://www.planalto.gov.br/CCIVIL_03/_Ato2015- 2018/2016/Lei/L13243.htm\#art2.

Bravo-lbarra, E. R., \& Herrera, L. (2009). Capacidad de innovación y configuración de recursosorganizativos.

Intagible Capital, 5(3), 301-320.

Bresser Pereira, L. C. (1962). DesenvolvimentoEconômico e o Empresário. Revista de Administração de Empresas, 2(4), 79-91.

Britto, F, \&Wever, L. (2003). Empreendedores brasileiros: vivendo e aprendendo com grandes nomes. Rio de Janeiro: Campus.

Brundtland, Relatório de. (1987). Nosso futuro comum. Recucuperado em: 10 de abril, 2019, de https://goo.gl/4frQ7T.

Bruno-Faria, M. de F.,\& Fonseca, M. V. de A.(2014). Culture of Innovation: Concepts and Theoretical Models.

Revista de AdministraçãoContemporânea, 18(4), 372-396.

Carvalho, O., \&Viana, O. (1998). Ecodesenvolvimento e equilíbrio ecológico: algumas considerações sobre o Estado do Ceará. Revista Econômica do Nordeste, 29(2), 1998.

Cezar, N, de A., \&Philippi, D. A. (2018). Gestão sustentável em uma organização militar no estado do Mato Grosso do Sul. Brazilian Journal of Develpment, 4(2), 365-383.

Coral, E. ; Ogliari, A. , \& Abreu, A. F. Gestão Integrada da Inovação. (2009). São Paulo, Editora Atlas.

Costa, D.de M.; Barbosa, F. V., \& Silva, C. H. P.da (2011). Empreendedorismo e inovação: o papel da educação superior nas economias mundiais. In: Colóquio Internacional sobre Gestão Universitária na América do Sul - XI,2011. Anais...Florianópolis: INPEAU.

Da Silva, H. D., \& Philippi, D. A. (2018).Características sustentáveis da inovação da castanha de cumbaru da Associação de Mulheres Agricultoras do Assentamento Monjolinho (AMAM) em Anastácio-MS. In: Simpósio de Administração da Produção. Logística e Operações Internacionais SIMPOI, XXI, 2018. Anais... São Paulo: FGV, EAESP.

Davis, G. (1974).Management Information Systems: Conceptual Foundations, Structure, and Development, McGraw-Hill.

Dias, R. (2011). Gestão ambiental: responsabilidade social e sustentabilidade. São Paulo, Atlas.

Dobni, C. B . (2008). Measuring innovation culture in organizations: the development of a generalized innovation culture construct using exploratory factor analysis. European Journal of Innovation Management, 11(4), 539-559.

Dolabela, F. (2008).O segredo de Luísa: umaideia, umapaixão e um plano de negócios: comonasce o empreendedor e se criaumaempresa. Rio de Janeiro: Sextante. 


\section{Administração: caminhos para o desenvolvimento sustentável}

Dornelas, J. C. A. (2008). Empreendedorismo: transformandoideiasemnegócios. Rio de Janeiro: Elsevier. Dosi, G. (1998). Technical change and economic theory. Londres: Pinter Publishers.

Drucker, P. F. (1986).Inovação e espírito empreendedor. São Paulo: Pioneira.

Drucker, P. (2008).Inovação e EspíritoEmpreendedor. Rio de Janeiro, Editora Campus.

Fagerberg, J. (2006). Innovation: a guide to the literature. In: Fagerberg, J.; Mowery, D. C.; Nelson R. R. The Oxford Handbook of Innovation, Oxford, Oxford University Press, Cap. 1.

Fagerberger, J. (2005). Innovation: a guide to the literature. In Fagerberger, Jan, Mowery, David \& Nelson, Richard, The Oxford handbook of Innovation. Oxford: Oxford Un Press, ( $p$ 1-26).

Falkenberg, E. W.; Hesse, P., Lindgreen, B.E.; Nilssen, J.L.H.; Oei, C.; Rolland, R.K., \&Stamper, F.J.M.V., Assche, A.A., Verrijn-Stuart, K., \& Voss, K. (1996). FRISCO: A Framework of Information Systems Concepts, IFIP WG 8.1 Task Group FRISCO.

Fialho, F. A. P.; Filho Montibeller, G.; Macedo, M.,\& Mitidieri, T. da C.(2008). Gestão da sustentabilidade na era do conhecimento: o desenvolvimento sustentável e a nova realidade da sociedade pós-industrial. Florianópolis: Visual Books.

Filion, L. (2000). Empreendedorismo e gerenciamento: processosdistintos, porémcomplementares. Revista de Administração de Empresas,7(3), 2-7.

Financiadora de Estudos e Projetos - FINEP. (2004). Manual de Oslo: Proposta de diretrizes para coleta e interpretação de dados sobre inovação tecnológica. Brasília: FINEP.

Freeman, C. (1995). The national system of innovation in historical perspective. Cambridge Journal of Economics, 1(19), 5-24

Gibb, A. (1991). Enterprise culture-its meaning and implications for education in training. Journal of European in Industrial Training, Monograph, 11(2), 2-38.

Gil, A. C.(2010). Como elaborar projeto de pesquisa. São Paulo: Atlas.

Gomes, L. de S. , \&Philippi, D. A. (2018). Características sustentáveis de inovações da carne e do couro de jacaré: estudo de caso na Caimasul. In: Congresso Internacional de Administração - 2018, 2018. Anais...Sucre - Bolívia: Universidad Mayor, Real e a Universidade Pontifícia de São Francisco Xavier de Chuquisaca.

Gressler, L. A. (2007).Introdução à pesquisa: projetos e relatórios. 3. ed. São Paulo: Loyola.

Haddad, P. R. (2015). Meio ambiente, planejamento e desenvolvimento sustentável. São Paulo: Saraiva. Hirschman, A. O. (1958). The strategy of economic development. Connecticut: Yale University Press.

Janiunaite, B., \&Petraite, M. (2010). The relationship between organizational innovative culture and knowledge sharing. in organization: The case of technological innovation implementation in a telecommunication organization, 3(69), 14-23. 


\section{Administração: caminhos para o desenvolvimento sustentável}

Jung, C. F. (2004).Metodologia para pesquisa e desenvolvimento: aplicada a novas tecnologias, produtos e processos. Rio de Janeiro: Axcel Books.

Kirzner, I. M. (1982). The theory of entrepreneurship in economic growth. p. 272-276. In: Kent, D. L.; Sexton,

D. L.; Vesper, K. H. (Ed.). Encyclopedia of entrepreneurship. New Jersey: Englewood cliffs.

Leibenstein, H. (1968). Entrepreneur and development. The American Economic Review, v. 58, n. 2, p. 72- 84. Leite, E. (2000). O Fenômeno do Empreendedorismo. Recife: Bagaço.

Longenenecker, J. G.; Moore, C. W., \& Petty,J.W. (2004). Administração de pequenas empresas: ênfase na gerência empresarial. São Paulo: Pearson.

Marconi, M. de A., \&Lakatos, E. M. (2011).Metodologia Científica. 6. ed. São Paulo: Atlas.

Martens. M., L;Kniess, C. T., De Carvalho, M. M., \& Martens, C. D. P. (2013). Avaliação de inovação sustentável em desenvolvimento de produtos. In: Encontro Nacional de Engenharia de Producão ENEGEP, XXXIII, 2013. Anais... Salvador: ABEPRO.

Maximiano, A. C. A. (2006). Administração para empreendedores: fundamentos da criação e da gestão de novos negócios. São Paulo: Pearson Prentice Hall.

Menezes, L.C.M. (2003). Gestão de Projetos. São Paulo: Atlas.

Michel, M. H. (2009). Metodologia e pesquisa científica em ciências sociais. 2. ed. São Paulo: Atlas.

Nidumolu, Ram; Prahalad, C. K., \& Rangaswami, M. R. (2009). Why sustainability is now the key driver of innovation. Harvard Business Review, 87(9), 56-94.

OECD - Organização para Cooperação e Desenvolvimento Econômico. (2006). Manual de Oslo: diretrizes para coleta e interpretação de dados sobre inovação. (Terceira edição, 2006). Recuperadoem02 de abril. 2019,

de http://www.finep.gov.br/images/apoio-e-financiamento/manualoslo.pdf

OECD. The Organisation for Economic Co-operation and Development. (2005). Oslo Manual: Guidelines for Collecting and Interpreting Innovation Data, 3rd Edition. Luxembourg: OECD, Statistical Office of the European Communities.

Oliveira, L. R. de; Medeiros, R. M.; Terra, P. de B, \&; Quelhas, O. L. G. (2012). Sustentabilidade: da evolução dos conceitos à implementação como estratégia nas organizações. Produção, 22(1), 70-82.

Pelloso, I. A. de O. (2011). Caracterização fenotípica de frutos e desenvolvimento inicial de plantas de Campomanesia adamantium (Cambess.) O. Berg, em Mato Grosso do Sul. Tese (Doutorado em Agronomia)

- Universidade Federal da Grande Dourados (UFGD). Dourados MS: UFGD, 2011. 


\section{Administração: caminhos para o desenvolvimento sustentável}

Philippi, D. A., Maccari, E. A., \& Cirani, C. B. S. (2015). Benefits of Universitylndustry Cooperation for Innovations of Sustainable Biological Control. Journal of Technology Management \& Innovation, 10(1), 17- 28.

Porter, M. E., \& Van der Linde, C. (1995). Green and competitive: ending the stalemate. Harvard Business Review, 73(5), 120-134.

Rickards, T. (2000). Creativity and innovation: state of art and trends. In: Encontro de estudos sobre empreendedorismo e gestão de empresas, 1, 2000. Anais... Maringá: UEM/UEL.

Rothenberg, S. Sustainability through servicizing. (2007). Mit Sloan Management Review, 48(2), 83-91.

Santos, M. J. de O.; Da Silva, A. K. M.; Vale, L. dos S.; Gonzaga, J. F., \& Ferreira, V. S. (2010). Incentivos à inovação: estudo de caso de Mato Grosso do Sul. In: Encontro Nacional de Engenharia de Produção - ENEGEP,XXX, 2010. Anais São Carlos-SP: ABEPRO.

Schumpeter, J. (1964). História da análiseeconômica. Rio de Janeiro: USAID.

Sebrae. (2007). Disciplina de empreendedorismo: manueal do aluno. São Paulo: SEBRAE.

Silva, C. E. L. da; Lima, G. B. A.; Cardoso, R., \& Narcizo, R. B. (2010). Inovação sustentável: uma revisão bibliográfica. In: Congresso Nacional de Excelência em Gestão, VI, 2010. Anais... Niterói - RJ: ABEPRO.

Silva, C. L. da, \& Souza-Lima, J. E. de. (2010). Políticas públicas e indicadores para o desenvolvimento sustentável. São Paulo: Saraiva.

Souza, C. L. de. (2012). Cidades sustentáveis: desenvolvimento num planeta urbano. Porto Alegre: Bookman.

Stoffel, J. A., \& Colognese, S. A. (2015.). O desenvolvimento sustentável sob a ótica da sustentabilidade multidimensional. Revista da FAE, 18(2), 18-37.

Tidd, J.; Bessant, J., \& Pavitt, K. (2008). Gestão da Inovação. 3. ed. Porto Alegre, Bookman.

Vale, G.M.V. (2007). Territórios vitoriosos: o papel das redes organizacionais. Rio de Janeiro: Garamond.

Van Bellen, H. M. (2002).Indicadores de Sustentabilidade: umaanálisecomparativa. Tese de Doutorado,Curso de Pós-GraduaçãoemEngenharia de Produção, Florianópolis: UFSC.

Yin, R. K. (2001). Estudo de caso. Planejamento e métodos. Porto Alegre: Bookman.

Zien, K. A., \& Buckler, S. A. (1997). From experience dreams to market: crafting a culture of innovation. Journal of Production Innovation Management, 14(4), 274-287. 


\section{Capítulo 23}

\section{A IMPORTÂNCIA DAS LIÇÕES APRENDIDAS COMO FERRAMENTA DA GESTÃO DO CONHECIMENTO NO SEGMENTO INDUSTRIAL OFFSHORE}

DOI: $10.37423 / 200300420$

Manoel Franklin de Sá, Msc. (UFF) mfranklin.sa@gmail.com Denise L. Bassanì, Msc. (UFF) denise.bassani@gmail.com João Alberto Neves dos Santos, Dsc. (UFF - UERJ) joaoalbertoneves@gmail.com

Resumo: Q compartilhamènto das Lições Aprendidas é uma das mais eficientes férramentas da LGestão do conhecimențo objetivando a transferência e-reuso do conhecimento experimentado e revalidado. No segmẹnto indystrial de construção de plataformas de petróleo e gás, a elaboraç̧ão e manutenção de um/repositório de liçø̃es aprendidas disponível para utilização em outros projetos adquire valor expressivo considerando-se que projetos deste gênẹro se constituem compo uma organização admínistrativa temporária já que a empresa construtora poderá ter qùe dissolver o time/dé trabalhadores capacitados se não houver projeto da mesma magnitude ém perspectiva após concluir o projeto em questão.

Palavras chave: Lições aprendidas, conhlecimentø, petróleo e gás.

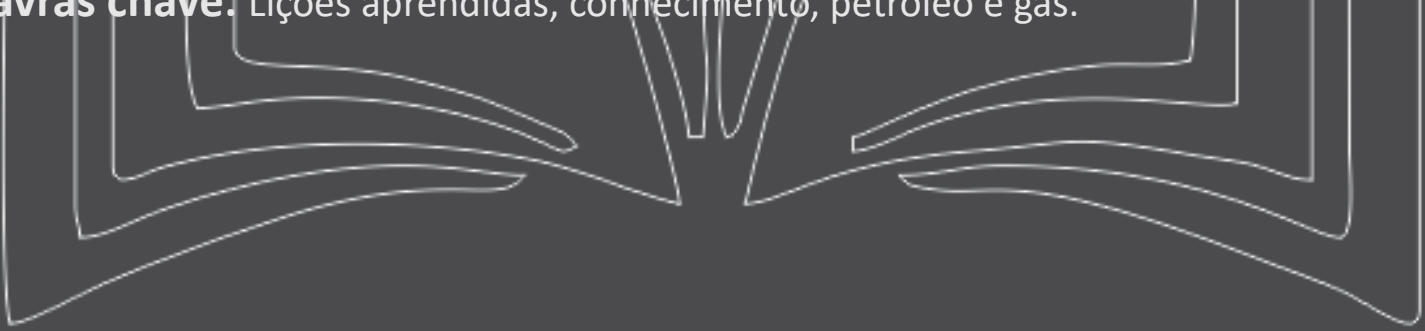




\section{Administração: caminhos para o desenvolvimento sustentável}

\section{INTRODUÇÃO}

As lições aprendidas são narrativas de experiências nas quais se registra o que aconteceu, o que se esperava de acontecimento, a análise das causas das diferenças entre ambas e o que foi aprendido durante o processo. Em síntese, as melhores práticas são aquelas que foram avaliadas e comparadas com outras práticas e são consideradas quase como um padrão a ser seguido. O compartilhamento das Lições Aprendidas constitui-se como uma das mais eficientes ferramentas da Gestão do Conhecimento objetivando transferir o conhecimento vivenciado que resulta em uma boa prática, assim como o conhecimento da mitigação do risco ao qual o processo poderia estar submetido.

A magnitude da indústria do Petróleo offshore em nosso país, por sua natureza, comporta e absorveria que toda Diretriz Contratual lançada no mercado destinado à contratação de empresas construtoras e montadoras de plataformas marítimas contivesse capítulos específicos à cobrança de exigências voltadas a disponibilidade de procedimentos específicos à gestão das Lições Aprendidas, em relação a contratos similares e que poderiam servir de base de dados a contratos futuros.

No Brasil, considerando-se as práticas adotadas pela maior empresa contratante deste segmento, esta iniciativa não é adotada em sua plenitude e no sentido amplo e sistêmico do processo. Tal fato propicia que cada empresa contratada neste segmento adote sua própria estruturação em relação ao processo das lições aprendidas, sem que as mesmas usufruam dos atributos da Gestão do Conhecimento (doravante denominada GC), que certamente prestariam relevantes serviços em nome da sistematização na transferência do conhecimento.

Dependendo do contexto e necessidade de utilização, a sistematização das Lições Aprendidas, pode ser considerada como um procedimento ou conjunto de procedimentos que se constitui como ferramenta a ser implantada mediante a compilação, organização e compartilhamento e transferência de informações, através da GC.

Em um aprofundamento mais detalhado quanto ao que, de fato, acontece no processar das lições aprendidas neste segmento, identificam-se ações individuais, dentre outras, baseadas no a seguir exposto:

a. Elaboração de Relatórios Técnicos e Análises Críticas de Resultados;

b. Emissão de Certificação de Fabricantes e Testes; 


\section{Administração: caminhos para o desenvolvimento sustentável}

c. Elaboração de Manuais de Operação, Data Book e As Built.

Estas iniciativas reconhecidamente constituem-se em ações pontuais, carecendo integralmente de uma orquestração sistêmica e tangente aos principais atributos da GC. Aliado a este fato, sem que haja uma ordenação e sistematização de como tratar todas estas informações destaca-se a dificuldade em identificar-se, de fato, o que se constitui em uma preciosa informação resgatável, diante de tantas informações e tópicos.

\subsection{SITUAÇÃO PROBLEMA}

Embora citado frequentemente na literatura acadêmica como uma eficiente ferramenta para disseminação do conhecimento, a utilização das Lições Aprendidas como tal (doravante com a denominação $L A$ ) de forma sistemática não se faz de forma simples. O desenvolvimento das atividades das pessoas na organização se faz de forma coletiva, entretanto, a aprendizagem é individual (Kleiner e Roth, 2000). Os resultados das LA podem ser capturados, classificados, mantidos e disponibilizados em um banco de dados, porém, para a sua utilização é necessário haver a intenção do usuário. Não há mecanismo que automatize a relação entre uma atividade em planejamento com uma lição aprendida na mesma disciplina que possa vir a alterar tal planejamento em decorrência de experimentos já vivenciados.

A utilização da prática das LA no segmento de construção de plataformas de petróleo e gás cresce em importância e gravidade, à medida que estes contratos agregam novas e desafiadoras condições e requisitos técnicos e mercadológicos. Considerando-se que projetos deste gênero se constituem como uma organização administrativa temporária, a empresa construtora poderá ter que dissolver o time de trabalhadores capacitados se, ao finalizar de um projeto, não possuir a encomenda de outro da mesma magnitude em sua carteira de negócios. Sendo assim, como construir um repositório de LA que possa permanecer para utilização em outros projetos, possivelmente formados por outras pessoas que não aquelas que passaram pela experiência, e traduziram-na como um fruto de aprendizagem?

Associado a condição do inevitável turn over da mão de obra que acontece não somente ao término do contrato, a indisponibilidade da ferramenta sistêmica consagrada contratualmente impede que os disponíveis profissionais possam fazer uso desta que poderia ser considerada uma preciosa ferramenta. 


\section{Administração: caminhos para o desenvolvimento sustentável}

\subsection{METODOLOGIA}

Face à natureza singular do problema exposto, ou seja, a enunciação de um recurso largamente utilizado através da GC que, contudo, poderá ser utilizado sob critérios específicos em uma ambiência pioneira, a pesquisa buscou amparo no espectro bibliográfico da GC, considerando-se experiências em outras áreas em paridade de importância no segmento industrial. A partir da analogia às situações particulares de aprendizagem organizacional encontradas na bibliografia e comparadas às situações concretas coletadas pelos pesquisadores em projetos recentes em ambiência offshore, a pesquisa segue o rumo do estudo exploratório.

Definida a situação problema, a metodologia utilizada foi a pesquisa exploratória, considerando a posse de conhecimento dos pesquisadores aquinhoados da vivência e experiência prática no campo onde ocorre a questão. Cooper e Schindler (2003) observam que a utilização da modalidade da pesquisa exploratória é cabível em situações como a acima descrita, onde os pesquisadores "não têm uma idéia clara dos problemas que vão enfrentar durante os estudos". Esta modalidade de pesquisa se insere na descrição do problema a ser estudado devido à escassez de literatura sobre o assunto em questão na ambiência do segmento offshore.

Os dados tratados na pesquisa enquadram-se nas definições de fontes primárias e secundárias. Prosseguindo conforme orientação metodológica de Cooper e Schindler (2003), como fontes primárias foram consultados os documentos que se configuram como repositório de LA conforme designados no item 3 deste trabalho. Como fonte secundária foi consultada a bibliografia existente sobre GC com enfoque na prática da utilização das LA. Cabe ressaltar a escassez de comentários divulgados oficialmente sobre a utilização da citada prática no ambiente industrial de petróleo e gás. Portanto, a pesquisa foi estendida na bibliografia sob este enfoque em outros segmentos industriais buscando relatos da utilização do recurso em atividades que pudessem ser comparadas às do segmento em foco.

E finalizando, é considerado que o enfoque das LA, pela sua natureza, também é suportado pela avaliação ex post facto pois não se pode avaliar uma lição aprendida antes da ciência do resultado. 


\section{REVISÃO DA LITERATURA}

\subsection{BREVE CONCEITUAÇÃO DA GESTÃO DO CONHECIMENTO}

Lições que são aprendidas fazem parte do processo natural de aprendizado observado no ser humano. A abordagem administrativa sobre o conhecimento organizacional subjacente às práticas da GC utilizase de várias ferramentas para o gerenciamento do conhecimento na empresa, entre elas a sistematização para o compartilhamento das LA como fonte de consulta e implementação de novas práticas.

Faz-se necessário definir sucintamente a abordagem conhecida como GC. Conforme Davenport, os tipos de projetos e as práticas da GC são compostas por: 1) captar e reutilizar o conhecimento estruturado; 2) captar e compartilhar LA com a prática; 3) identificar fontes e redes de expertise; 4) estruturar e mapear conhecimentos necessários para aumentar a performance; 5) mediar e controlar o valor econômico do conhecimento; 6) sintetizar e compartilhar conhecimento advindo de fontes externas. (DAVENPORT, apud BATISTA 2004, pg.15).

Assim sendo, o conhecimento organizacional para percorrer as etapas descritas acima deverá estar documentalmente estruturado de forma a prover o acesso aos colaboradores em atendimento às suas exigências. Como fundamento e transportando-se a valores atuais, foi considerada a clássica distinção publicada por Nonaka e Takeuchi (1997) sobre o conhecimento tácito, aquele iniciado na ação, no experimentar e na observação, porém ainda não comprovado como tal por não trazer a segurança dos movimentos e respostas; e o conhecimento explícito, aquele que é transmissível em linguagem formal e circula por toda a organização possibilitando a disseminação incessante do conhecimento. Exemplifica-se a conceituação acima através de concisa estrutura sistemática de GC adaptada do modelo em uso pelo Centro de Tecnologia Canavieira (CTC) exposto na Tabela 1.

\begin{tabular}{|l|l|l|l|}
\hline \multicolumn{4}{|c|}{ CONHECIMENTO } \\
\hline \multicolumn{1}{|c|}{$\begin{array}{c}\text { IDENTIFICAR } \\
\text { Mapear }\end{array}$} & \multicolumn{1}{|c|}{$\begin{array}{c}\text { CAPTURAR } \\
\text { Organizar }\end{array}$} & $\begin{array}{c}\text { ARMAZENAR } \\
\text { Proteger }\end{array}$ & $\begin{array}{c}\text { DISPONIBILIZAR } \\
\text { Compartilhar }\end{array}$ \\
\hline $\begin{array}{l}\text { Elaboração de lista de } \\
\text { conhecimentos; }\end{array}$ & $\begin{array}{l}\text { Padronizar a elaboração } \\
\text { de formulários e } \\
\text { entrevistas; }\end{array}$ & Banco de idéias; & $\begin{array}{l}\text { Criar ponto único de } \\
\text { acesso ao conhecimento; }\end{array}$ \\
\hline $\begin{array}{l}\text { Mapeamento de } \\
\text { competências; }\end{array}$ & $\begin{array}{l}\text { Padronizar e otimizar a } \\
\text { disponibilização de } \\
\text { documentos eletrônicos; }\end{array}$ & $\begin{array}{l}\text { Apoio aos programas de } \\
\text { retenção e valorização de } \\
\text { especialistas; }\end{array}$ & $\begin{array}{l}\text { Incentivar a criação de } \\
\text { eventos de transmissão de } \\
\text { conhecimento tácito; }\end{array}$ \\
\hline $\begin{array}{l}\text { Identificação e } \\
\text { mapeamento das fontes } \\
\text { externas de geração de } \\
\text { conhecimento; }\end{array}$ & $\begin{array}{l}\text { Padronizar a coleta de } \\
\text { fontes externas; }\end{array}$ & $\begin{array}{l}\text { Definição de políticas e } \\
\text { ferramentas para proteção } \\
\text { do conhecimento } \\
\text { armazenado; }\end{array}$ & $\begin{array}{l}\text { Promover a reutilização } \\
\text { do conhecimento } \\
\text { disponibilizado; }\end{array}$ \\
\hline
\end{tabular}




\section{Administração: caminhos para o desenvolvimento sustentável}

\begin{tabular}{|l|l|l|l|}
\hline $\begin{array}{l}\text { Mapeamento de } \\
\text { processos. }\end{array}$ & $\begin{array}{l}\text { Digitalização de } \\
\text { documentos em papel: do } \\
\text { passado e relevantes; }\end{array}$ & $\begin{array}{l}\text { Definição de mídias de } \\
\text { armazenagem; }\end{array}$ & $\begin{array}{l}\text { Selecionar ferramenta, } \\
\text { implantar, orientar e } \\
\text { acompanhar fóruns } \\
\text { virtuais de discussão; }\end{array}$ \\
\hline & $\begin{array}{l}\text { Organização do fluxo de } \\
\text { documentos; }\end{array}$ & $\begin{array}{l}\text { Definição de bancos de } \\
\text { dados e de estruturas de } \\
\text { diretórios. }\end{array}$ & \\
\hline & $\begin{array}{l}\text { Indicação de programas } \\
\text { de capacitação - captura } \\
\text { do conhecimento tácito. }\end{array}$ & \multicolumn{1}{|c|}{ MONITORAR } \\
\hline \multicolumn{2}{|l|}{} \\
\hline Monitoramento da utilização dos padrões de captura de conhecimento; \\
\hline Monitoramento da utilização dos meios de consulta; \\
\hline Sugestão de mudanças nos processos de captura, armazenagem e disponibilização; \\
\hline Acompanhamento dos eventos de transmissão do conhecimento; \\
\hline Acompanhamento de indicadores e desempenho e acompanhamento de tendências e tecnologias de mercado; \\
\hline Acompanhamento dos processos de novas aquisições e renovações dos periódicos pela biblioteca \\
\hline
\end{tabular}

Fonte: Adaptado do Escopo de Atuação da Gestão do conhecimento no CTC. (ALVARENGA 2008, pg.

Tabela 1: Estrutura sistematizada de Gestão do Conhecimento Organizacional

A preocupação em absorver o aprendizado contido nas lições provenientes de erros ou acertos é uma constante no exercício das atividades de gestão organizacional, pontualmente pela GC. Segundo Probst et al (2002), o conhecimento necessariamente deve ser compartilhado e distribuído dentro de uma organização de forma que as informações ou experiências beneficiem toda a empresa; porém, a pergunta-chave é: "Quem precisa saber (ou ser capaz de fazer), quanto do quê, e como podemos facilitar o compartilhamento de conhecimento?" (PROBST et al 2002, pg. 136). Os últimos citados autores recomendam sobre a distinção e hierarquização de informações a serem compartilhadas sugerindo que a organização deve pensar nas técnicas de segurança para a distribuição do conhecimento, sob a pena de o processo da disseminação do conhecimento acontecer de forma tão livre que possa ser levada ao conhecimento da concorrência sem dificuldades através da Internet. (PROBST et AL 2002, pg. 142).

Observando os componentes da ambiência da organização, faz-se necessário convocar os mecanismos da GC no sentido de oportunizar o momento de utilização das LA em condições em que a organização estava destinada a uma região de conflito e, na medida em que a ferramenta possa ser utilizada, passa a existir uma conversão daquilo que seria negativo e ameaçador como instrumento para instigar novos requisitos no processo interativo conforme relatado nos parágrafos seguintes, alinhados sob orientação de Sabbag (2007). 


\section{Administração: caminhos para o desenvolvimento sustentável}

A classe dos CLIENTES se constitui como a primeira na atenção da organização e principal fonte de conhecimento formador de LA com poder de alterar resultados. O objetivo da GC é fornecer elementos para tomada de decisões para que a organização seja capaz de sustentar a adaptação dinâmica, frente às flutuações do mercado (Sabbag, 2007).

A sempre preocupante classe dos CONCORRENTES: onde nenhuma organização fica imune às práticas de seus concorrentes; onde basta um deles estabelecer uma nova política comercial vitoriosa que todos tendem a segui-la (Sabbag, 2007).

Segundo Sabbag (2007) na classe dos FORNECEDORES é comum observar-se mútuo interesse no compartilhamento de saber e na redução dos custos de transação. A troca de saber ocorre para assegurar a produção de ambos.

A classe referente a UNIVERSIDADES, tal como a de CONSULTORES tem semelhanças, conforme identifica Sabbag (2007). Ambas desempenham os papéis de crítica, pesquisa e apoio ao aprendizado, legitimam experiências (casos registrados). Consultores fornecem o conhecimento criado e desenvolvido em outras organizações, legitimam outros conhecimentos, eliminam dúvidas, emprestam um "olhar" externo sobre a organização.

A classe das COMUNIDADES DE PRÁTICA é bastante curiosa: fornece perícia e apoio sem fronteiras; entretanto, devido ao caráter informal da maioria dos casos, permanece invisível aos olhos dos gestores (Sabbag, 2007).

Por último, a importante classe do GOVERNO promove mediação de interesses na sociedade e regulamentos; aprender com o Governo não é apenas sensato, é essencial (Sabbag, 2007).

\subsection{LIÇÕES APRENDIDAS: EFICIENTE FERRAMENTA DA GESTÃO DO CONHECIMENTO}

As LA configuram-se como uma eficiente ferramenta para a transferência de conhecimento dentro da organização uma vez que, havendo a percepção do gerenciamento sobre os fatos relatados e classificados, pode-se sedimentar inovações e melhorias nos processos e resultados. Segundo Xanthopoylos S. (2005, pg. 99-100), a utilização das LA aplica-se a:

a. Evitar desperdício de recursos;

b. Aumentar a segurança ocupacional, da saúde e do trabalho; 


\section{Administração: caminhos para o desenvolvimento sustentável}
c. Evitar retrabalhos;
d. Aumentar a excelência operacional;
e. Aumentar a qualidade do processo ou a percebida pelo cliente;
f. Adequar as características de produtos e serviços;
g. Conseguir tempo de resposta rápida às necessidades de mercado;
h. Tomar ações corretivas para novas diretrizes;
i. Prevenir recorrência de acidentes.

A gestão sobre as LA, utilizando sistemas computadorizados ou não, é análoga às etapas da GC uma vez que deve observar condições semelhantes de identificação, captura, retenção e disponibilização do conhecimento. Conforme relatado ainda por Xanthopoylos (2005, pg.89), observam-se os seguintes sub-processos:
a. conhecimento gerado: resultante de uma determinada experiência;
b. armazenado: o aprendizado é validado e apreendido para futuro reuso;
c. distribuído: disseminado para usufruto da organização em geral;
d. aplicado: reuso da informação.

Estes sub-processos da Gestão do Conhecimento aplicados ao trato das LA trazem algumas reflexões como as que seguem. (WEBER, AHA, BECERRA-FERNANDEZ, 2001, apud XANTHOPOYLOS, 2005 pg. 9192):

a. Processos de LA constituem-se como indispensáveis para alavancagem do conhecimento organizacional;

b. Existem ferramentas para recuperação, porém a organização não apresenta métodos efetivos de distribuição das LA para potenciais usuários. Os acima citados autores denominam o fenômeno como gap da distribuição; 


\section{Administração: caminhos para o desenvolvimento sustentável}

c. Organizações não costumam elaborar análise de custo / benefício quanto aos resultados da sistematização das LA;

d. A pesquisa dos acima citados autores constatou que menos de $10 \%$ das organizações utilizavam sistemas computacionais para gestão das LA.

e. A disseminação deficiente resulta da inexistência do uso de um sistema informatizado ou pelo fato de as LA se incorporarem rapidamente aos processos;

f. Metas de elevar o conhecimento organizacional não são atingidas. Xanthopoylos crê que isto acontece porque as LA são registradas em "campos de texto livre, quando existe o sistema" ou então pelo fato de os sistemas "não estarem integrados ao processo decisório da organização, fator crítico de sucesso para que um sistema possa contribuir com a GC da empresa." (XANTHOPOYLOS, 2005, pg.89).

\subsection{A UTILIZAÇÃO DAS LIÇÕES APRENDIDAS EM SEGMENTOS INDUSTRIAIS ANÁLOGOS AO OFFSHORE}

Nas últimas décadas o Brasil vivencia um notável crescimento, amadurecimento e reconhecimento internacional de segmentos que outrora não despontavam no cenário comercial globalizado. Dentre outros, destacam-se notórias participações e desenvolvimento de projetos no setor de mineração, metalurgia, indústria automotiva e aeronáutica; que hoje asseguram parcela significativa do nosso PIB.

Natural admitir-se que, em detrimento ao porte e ao natural agregar de capacitação e tecnologia em cada mencionada empresa, contaríamos com a disponibilidade de vasta literatura, trabalhos, artigos acervados, que retratassem em cada empresa, as melhores práticas relacionadas às LA. Ao consultarmos as principais fontes acadêmicas que pudessem dispor deste material descobre-se a inexistência, ou, em uma detalhada análise, reduzido número de trabalhos relacionados a esta temática, gozando de oficialidade corporativa e estruturação sistêmica.

O que acontece com este mercado que ainda não se organizou e se articulou em nome desta situação de tamanha importância? Será que não existe a clara percepção de tamanha importância em adotarse esta prática, em um segmento tão rico de valorosas informações?

Ao comparar-se a prática das LA em outros segmentos industriais de similar magnitude, analisou-se um estudo elaborado em 2002 sobre o repositório de conhecimentos de LA da corporação norte- 


\section{Administração: caminhos para o desenvolvimento sustentável}

americana NASA (sigla em inglês de National Aeronautics and Space Administration, Administração Nacional do Espaço e da Aeronáutica), e a eficácia destas lições. Em investigação elaborada pelo GAO (US General Accounting Office, Escritório de Investigações Gerais dos EUA) foi examinado se a NASA possuía mecanismos adequados para assegurar que as LA no passado, a partir de falhas, ocorridas nas missões estivessem sendo aplicadas. Especificamente nesta pesquisa, GAO buscou identificar (1) as políticas, procedimentos e sistemas que a NASA disponibiliza para as LA; (2) examinou o quanto estas políticas, procedimentos e sistemas efetivamente facilitam as LA e (3) determinou se serão necessários mais esforços para a melhoria do aprendizado.

A fonte principal estabelecida pela NASA para a organização e compartilhamento das LA é o LLIS (Lessons Learned Information System, Sistema de Informações de Lições Aprendidas), repositório de LA que alimenta uma base de dados on-line acessível aos colaboradores de toda a instituição. Além disso, a NASA utiliza em seus treinamentos, revisão de programas e revisões periódicas das políticas e diretrizes da instituição para comunicar as LA. A NASA desenvolveu melhorias na compilação e compartilhamento de informações através da GC, objetivando uma estratégia de gerenciamento para que a organização possa criar compilar e reutilizar conhecimento, para atingir aos seus objetivos.

A investigação apontou que, embora a NASA solicitasse aos gestores de programas e projetos a revisar e aplicar LA por todo um ciclo de vida dos programas e projeto onde aplicável, os gestores usualmente não identificavam, compilavam ou compartilhavam lições. Os respondentes fizeram objeções quanto à praticidade da base de informações LLIS: queixaram-se da dificuldade em achar alguma lição aplicável diante de tantos tópicos disponibilizados. Ao contrário, gestores identificaram as revisões de programas e discussões informais com seus pares como as principais fontes para LA.

Os respondentes também identificaram barreiras culturais para o compartilhamento de LA assim como áreas de melhoria. Gestores notaram que existia uma relutância para compartilhar lições negativas por medo que eles pudessem não ser vistos como bons gestores de projetos, e existe uma lacuna de tempo para que o aprendizado aconteça.

O estudo elaborado pelo GAO concluiu que foram identificadas fraquezas fundamentais no aprendizado das lições identificadas: resistência cultural ao compartilhamento de conhecimento e ausência de uma estrutura estratégica efetiva e a atenção de gestores para superar tal resistência. 


\section{Administração: caminhos para o desenvolvimento sustentável}

Embora a NASA tenha tomado sérias iniciativas quanto ao comprometimento da disseminação e compartilhamento do conhecimento por toda a instituição, estes esforços ainda não obtiveram o sucesso, pois a instituição não providenciou liderança, suporte e recursos necessários para que os mecanismos relacionados à GC pudessem estar presentes.

Do citado estudo sobre a NASA, dentre as recomendações para a melhoria do sistema de compartilhamento de conhecimento, destaca-se a valorização sobre a implementação de um eficiente sistema de GC, o desenvolvimento de métodos para implementar o mentoring e o relato de experiências entre funcionários e equipes tais como relacionar avaliações de desempenho e recompensas. Outra recomendação preciosa foi a de desenvolver o sistema LLIS através da indexação da informação, e desenvolver capacidade de busca mais amigável de modo a permitir ao usuário identificar lições relevantes, incluindo maior quantidade de lições positivas, fornecendo um meio para disseminar as lições fundamentais ao usuário e solicitar a este a alimentação do sistema rotineiramente.

No momento em que uma Agência Governamental como a NASA reconhece a importância de adotar em seus projetos as práticas de LA e, pelos motivos anteriormente expostos, não consegue a plenitude em sua implantação, natural que aumente nossas expectativas em conhecer e avaliar situação similar no Brasil, e particularmente no mercado de Petróleo e Gás.

Quanto à prática de mentoring, cabe ressaltar os esforços já empreendidos pela Petróleo Brasileiro, S.A (Petrobras) neste sentido. Em definição concisa, esta expressão significa o desenvolvimento humano fundamental. O mentor é o elemento da maior importância para um plano de GC, pois cabe a ele os esforços destinados a transferência do conhecimento, e ajuda no processo do crescimento profissional de outro colaborador. Conforme relatado por Fabio F. Batista à época do seu artigo elaborado em 2004, a prática do mentoring na Petrobras ainda está em estágio de planejamento, e a visão da empresa é desenvolvê-la na área técnica e na gerencial.

Prosseguindo o estudo elaborado pela NASA, esta pesquisa compila os processos de tratamento das LA conforme sugerido na citada obra.

Os mecanismos ou processos para capturar, compartilhar e disseminar LA pode variar, porém, em geral um processo compreende quatro elementos principais: compilação, verificação, armazenamento e disseminação. 


\section{Administração: caminhos para o desenvolvimento sustentável}

O processo de compilação envolve a captura da informação através de processos estruturados e não estruturados tais como relatórios de infortúnios ou acidentes, críticas de projeto, por escrito e reuniões. A compilação das lições pode acontecer de diversas maneiras, como uma organização pode solicitar. Lições aprendidas podem ser baseadas em experiências positivas que impediram acidentes ou economizaram recursos ou experiências negativas que provocaram resultados indesejados. Entretanto, se uma organização se concentrar apenas nas falhas, a eficácia do programa no geral será reduzida e haverá perda de oportunidades para melhoria em todos os processos.

A verificação de processos serve para constatar a correção e aplicabilidade das lições submetidas. Especialistas que dominam o assunto devem ser envolvidos na coordenação e revisões de procedimentos para determinar se uma lição é ou não relevante para os demais projetos, se é exclusiva a um departamento ou projeto em particular, ou se deve ser aplicada globalmente na organização como um todo.

As informações devem ser armazenadas de tal forma que permitam ao usuário identificar buscas aplicáveis de informação. Além disso, cada programa deve incluir palavra e categoria funcional chave para possibilitar a busca facilitando o resgate da informação. O elemento final e o mais importante é a disseminação das LA, uma vez que as lições são de pouco valor a não ser que sejam distribuídas e utilizadas pelas pessoas que serão beneficiadas por elas. A disseminação pode incluir a revisão de um procedimento de trabalho, treinamento e distribuição de rotinas através de uma variedade de mídias de comunicação. Lições podem ser "forçadas" ou automaticamente passadas para um usuário ou "resgatadas" em situações onde um usuário deva buscar manualmente por elas. Lições também podem ser disseminadas com caráter oficial de prioridade, o que denota o risco, imediatismo e urgência do conteúdo da lição aprendida. 


\section{Administração: caminhos para o desenvolvimento sustentável}

A Figura 1 é uma apresentação sintética do processo descrito acima.

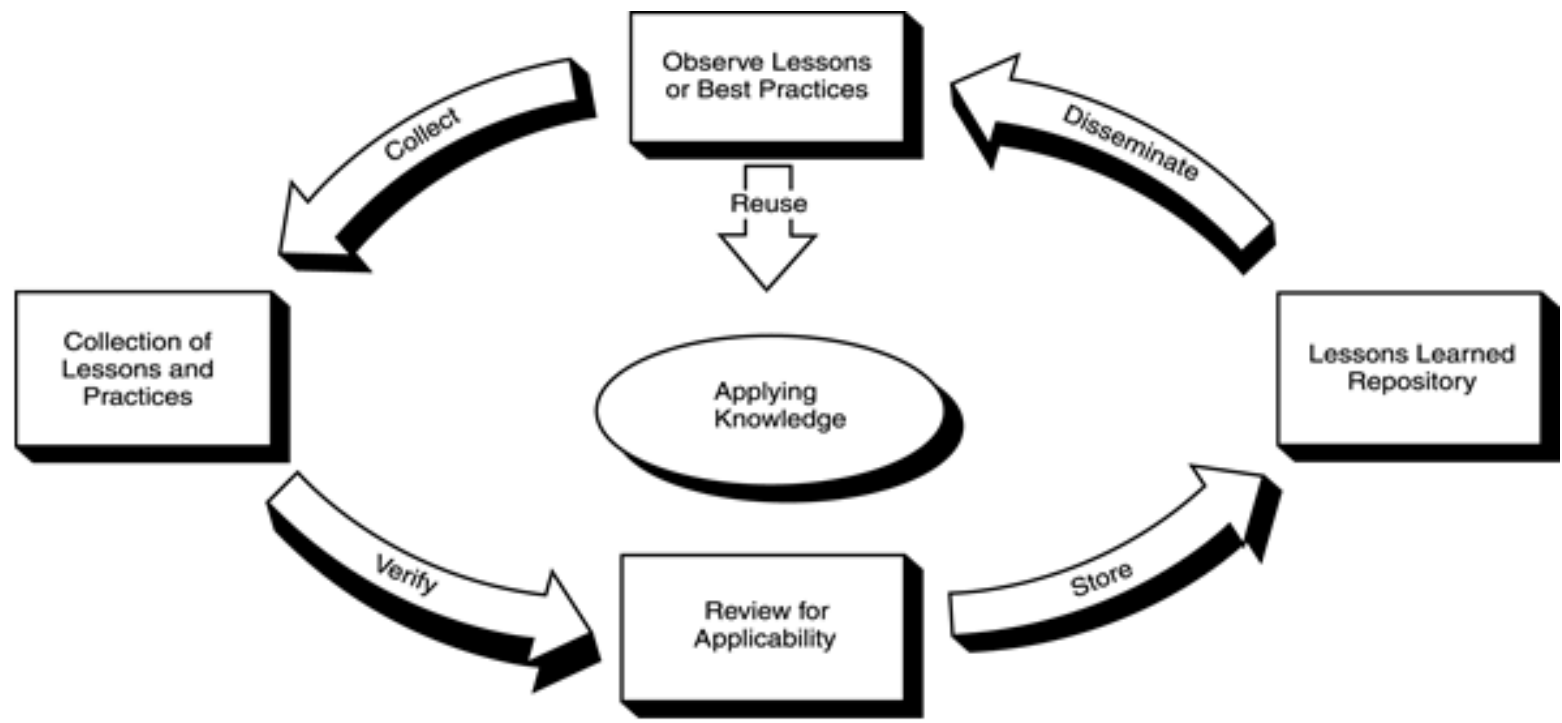

Fonte: Adaptado de Weber, R., Aha, D., e Becerra-Fernanadez, I. Categorizing Intelligent Lessons Learned Systems. Intelligent Lessons Learned Systems: Papers in AAAI Workshop (Technical Report AIC-00-005). Aha, D.W. e Weber, R. (Eds.) pg. 63-67. Washington, DC: Naval Research Laboratory, Navy Center for Applied Research in Artificial Intelligence, 2000, apud GAO, 2002.

Figura 1: Processo de Tratamento das Lições Aprendidas

No objetivo de facilitar o compartilhamento do conhecimento em suas dependências, a organização também percebe as barreiras do tempo e dos custos. Conceder um tempo para que os colaboradores "se afastem do trabalho "real" para contribuírem com know-how acaba por originar custo para a organização pois estes mesmos indivíduos não estão dedicando tempo para criar conhecimento novo" (BUKOWITZ e WILLIAMS 2002, pg. 180). Por outro lado, a manutenção de uma estrutura de recursos humanos para contribuir com conhecimento também é igualmente dispendioso (BUKOWITZ e WILLIAMS, op.). Segundo os autores citados, para o sucesso da contribuição do conhecimento, a organização deve analisar se os colabores dispensam seu tempo "gerando idéias mais inovadoras e mais úteis, em vez de recriar blocos de conhecimento básico" e também se é possível que os colaboradores sejam capazes de "utilizar o conhecimento que foi fruto da contribuição para criar algo novo e útil”. (BUKOWITZ e WILLIAMS 2002, pg. 180).

Além dos pontos abordados acima, há que se dar espaço ao valor da motivação quando se considera a questão da transferência de conhecimento em âmbito organizacional. É constatado que as pessoas usualmente compartilham conhecimento quando entendem que isto vá beneficiá-las de alguma sorte. 


\section{Administração: caminhos para o desenvolvimento sustentável}

Alguns autores privilegiam uma organização do sistema de recompensas para reforçar o valor da troca de conhecimentos de modo a envolver as pessoas nesta atividade. "A chave é assegurar que as recompensas não se tornem um recurso de curto prazo, que não pode ser sustentado" ( BUKOWITZ e WILLIAMS 2002, pg. 181).

\section{RESULTADOS}

Considerando-se que as Diretrizes Contratuais constantes dos processos licitatórios no segmento de Petróleo e Gás deveriam conter as exigências a serem aplicadas ao longo da execução do contrato, quer nas ambiências técnicas, administrativas como sistêmicas, o momento de sua elaboração constitui-se, em verdade, na oportunidade maior em inserirem-se no contrato as ferramentas e aplicativos relacionados às LA. A figura 2 abaixo é uma representação do citado processo de transferência e conversão do conhecimento com a finalidade em atingir-se as lições aprendidas, sendo estas consideradas como expressões de riqueza do conhecimento organizacional.

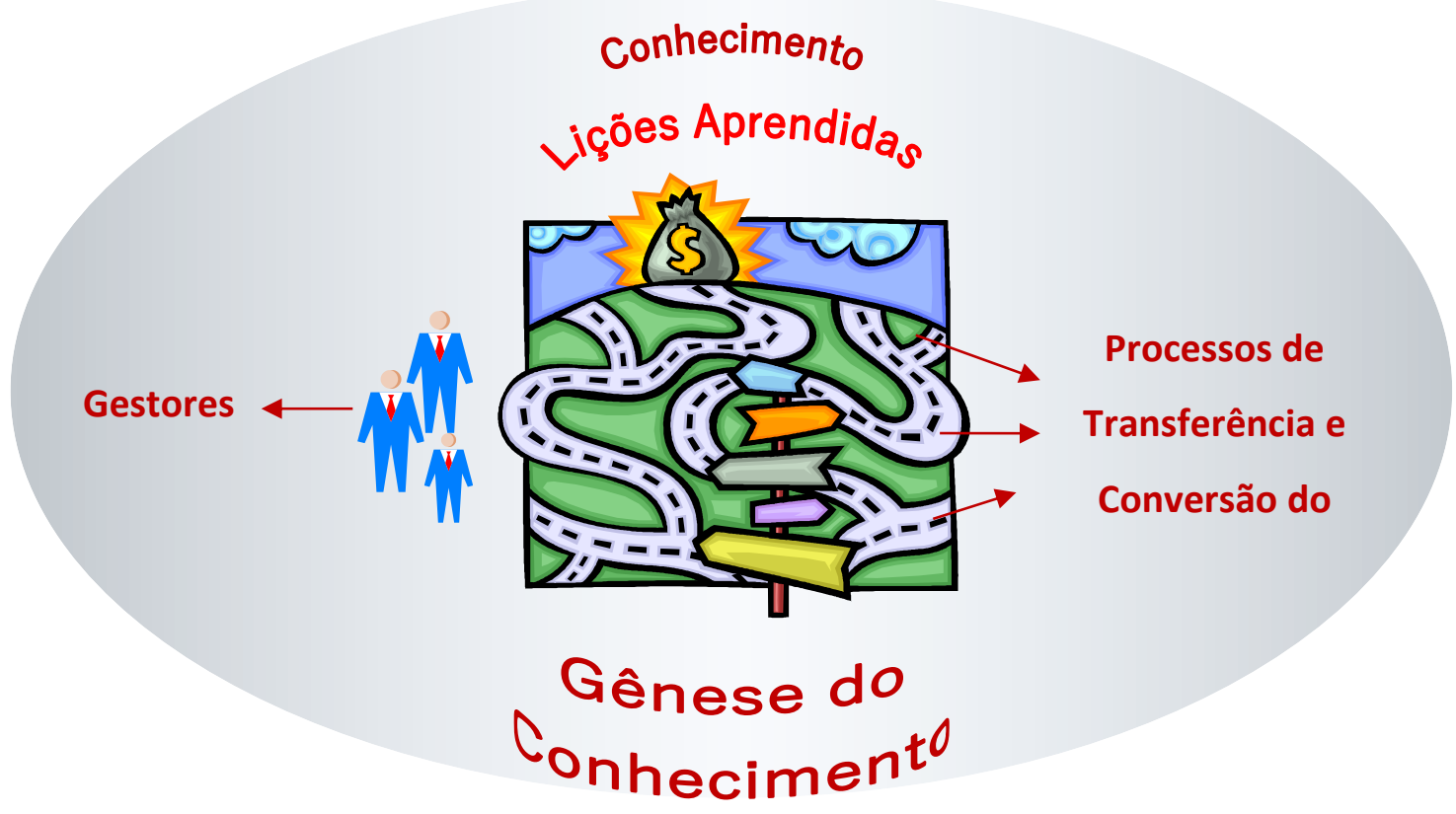

Figura 2 Representação da conversão do conhecimento no ambiente organizacional

Fonte: Os autores

Quanto à aplicabilidade, qual seria o momento ideal de se colocar em prática esta ferramenta? No deparar com dificuldades técnicas, administrativas, ou mesmo diante de toda necessidade em se resgatar informações que possam ser utilizadas no desenvolvimento do atual contrato? A experiência dos autores na gestão de contratos no segmento offshore fortalece a idéia que todos os instantes, sem exceção, são extremamente importantes, pois em toda a curva de acontecimentos do contrato 


\section{Administração: caminhos para o desenvolvimento sustentável}

verificam-se pontos estacionários e carentes da aplicação sistematizada desta ferramenta. De maneira a não fragilizar a consistência da ferramenta, há de se considerar momentos pontuais de exclusão, por conta de aspectos triviais do " dia a dia" da administração contratual que não careçam da aplicação desta ferramenta.

As ferramentas de LA deveriam ser maturadas e consolidadas na fase inicial de desenvolvimento orçamentário, visto que nesta fase as idéias ganham forma e contorno, em suas distintas ambiências técnica, administrativa, econômica e financeira. No momento em que se inicia o contrato, ainda que nesta fase aconteça o desenvolvimento do Projeto Conceitual; dever-se-ia dispor das diretrizes destinadas à aplicação das ferramentas de LA, seus recursos correlatos, hierarquias de aplicação, condicionantes ao resgate das informações, e por fim procedimento de como devolveríamos as informações após sua devida utilização.

Iniciar um contrato desta especificidade e magnitude, sem a efetiva definição de como se utilizar destas ferramentas de LA, pode e com certeza originará hiatos no processo de recuperação de informações, e a conseqüente melhor utilização das mesmas no atual contrato em diferentes situações e solicitações.

Ainda em relação ao momento do resgate destas informações, surge uma notável e importante particularidade neste cenário de mercado uma vez que a dinâmica imposta aos contratos, associada ao risco correlato que cada atividade contém intrinsecamente, nem sempre " a urgência dos fatos em dispor da informação pode aguardar que ela seja organizada e articulada à transferência, para pronta utilização". A urgência relacionada à expectativa e possibilidade de ocorrência de um sinistro não espera por esta articulação.

Difícil imaginar que um vazamento em alto mar que pode ser interrompido tenha que esperar uma organização de informações decorrentes de sinistros similares em outras plataformas, e que poderia representar uma fonte segura de informações reparadoras.

\section{CONCLUSÃO}

O primeiro e mais nobre recurso exigível e desejável que propicie a aplicação destas ferramentas, constitui-se na Decisão Corporativa por parte da Alta Administração em que estas práticas sejam adicionadas ao Contrato em todas as suas fases, como condicionantes exigíveis ao longo do desenvolvimento do mesmo. 


\section{Administração: caminhos para o desenvolvimento sustentável}

Na seqüência destaca-se a necessária disponibilidade no contrato de profissionais qualificados e ambientados na aplicação e utilização destas ferramentas. Além dos profissionais - usuário aponta-se a necessidade de que o contrato conte com rotinas procedimentalizadas contendo diretrizes e limites de aplicação destas ferramentas; bem como detalhamento permitindo a divulgação e permear por todos os setores.

A adoção de Rotinas e Procedimentos não pode e não deve ser associada ao cercear da criatividade por parte dos integrantes do contrato. Os limites definidos estabelecem tão somente cercanias que permitam o resgatar de informações, dados, e conhecimento - propiciando desta forma a utilização em outras requeridas fases contratuais. A depender da postura pessoal e criativa de cada gestor, podemos conviver com diferentes e surpreendentes inovações, a cada instante, de como gerenciar este processo de compartilhar idéias. Neste momento de luz e relampejo criativo, a procedimentalização e estruturação normativa cedem a vez ao novo, ao ágil e encantador mecanismo de transferência de informações personalizado. Este é o sentido em que não se deve, por conta dos limites, inibir a criatividade dos agentes e vetores do conhecimento.

A temporalidade desta ferramenta estende-se desde a concepção orçamentária a finalização do escopo contratual e encerramento do instrumento. Não existe tempo certo e mais conveniente, 0 contrato em toda sua magnitude deveria ser contemplado por estas ferramentas.

Contratos desta especificidade contam com uma estruturação multidisciplinar, envolvendo diferentes especialidades construtivas, requisitos administrativos, de segurança e meio ambiente; não menos importantes que os de caráter técnico, e por fim, condicionantes sistêmicas, que de igual sorte deveriam contar e dispor de estruturas próprias que disponibilizem as necessárias interfaces estruturantes - possibilitando a utilização da ferramenta em toda sua extensão.

Reconhecidamente o mercado não adota estas práticas de forma rotineira, ou mesmo sistematizada. Na medida e que estas praticas não integram a ambiência dos contratos, natural admitir-se que seus correlatos gestores tenham dificuldade em identificar o melhor momento, seguido de quais requisitos que poderiam integrá-las.

Na atualidade identificam-se no mercado de Petróleo ações isoladas sem nenhuma ordenação sistêmica, que atendem a pontuais necessidades, ou mesmo ações isoladas por parte destes gestores que na ausência de um credenciado repositório de informações se lançam em isoladas e intempestivas iniciativas, que em muitas das vezes, já refletem experiências pretéritas, que os mesmos por extrema necessidade recorreram a esta ferramenta no intuito de solucionar uma emergência. 


\section{Administração: caminhos para o desenvolvimento sustentável}

No momento em que se individualizam ações desta natureza, aumenta-se a certeza de que o mercado careça de parâmetros reguladores que possam nortear ações neste sentido. Desta forma reforçam-se os indícios que a não aplicação destas práticas abre uma considerável lacuna de oportunidades neste segmento de mercado que poderiam estar sendo aproveitadas de forma mais ampla em relação ao desenvolvimento dos contratos.

Na medida em que as ações relacionadas à aplicação das ferramentas de LA ganham contornos pessoais - imediatamente se afastam e fragilizam estruturações sistêmicas. Ausência de rotinas e procedimentos, em muitas das vezes propiciam uma acomodação e inércia em se desenvolverem ferramentas sistêmicas, a exemplo, das Lições Aprendidas.

\section{REFERÊNCIAS BIBLIOGRÁFICAS}

ALVARENGA NETO, Rivadávia C. Drummond de. Gestão do Conhecimento em organizações: proposta de mapeamento conceitual integrativo. São Paulo: Ed. Saraiva, 2008.

BATISTA, FÁBIO FERREIRA. Governo que aprende: gestão do conhecimento em organizações do executivo federal. IPEA (Instituto de Pesquisas Econômicas Aplicadas), Min. de Planejamento Orçamento e Gestão. Brasília, junho de 2004. http://www.inei.org.br/inovateca/estudos-e-pesquisasem-inovacao/GC\%20em\%200rganizacoes\%20do\%20Executivo\%20Federal\%20-

\%20Fabio\%20Batista.pdf Acesso em abril de 2010

BUKOWITZ, WENDI R; WILLIWAMS, RUTH L. Manual de Gestão do Conhecimento. Trad. Carlos Alberto Silveira Neto Soares. Porto Alegre, Bookman, 2002.

COOPER, DONALD R.; SCHINDLER, PAMELA S. Métodos de Pesquisa em Administração. Trad. Luciana de Oliveira da Rocha. 7.ed. Porto Alegre: Bookman, 2003.

GAO; UNITED STATES GENERAL ACCOUNTING OFFICE - NASA Better Mechanisms Needed for Sharing Lessons Learned. Report to the Subcommittee on Space and Aeronautics, Committee on Science, House of Representatives. Janeiro, 2002. http://www.gao.gov/new.items/d02195.pdf Acesso em abril, 2010.

NONAKA, IKUJIRO, TAKEUCHI, HIROTAKA. Criação de conhecimento na empresa. Tradução de Ana Beatriz Rodrigues, Priscilla Martins Celeste. Rio de Janeiro: Campus, 1997.

PROBST, G; RAUB, S; ROMHARDT, K. Gestão de Conhecimento: os elementos construtivos do sucesso. Tradução: Maria Adelaide Carpigiani. Porto Alegre: Bookman, 2002.

SABBAG, Paulo Yazigi. Espirais do Conhecimento - Ativando indivíduos, grupos e organizações. São Paulo: Saraiva, 2007.

XANTHOPOYLOS, Stavros. Um estudo exploratório sobre os mecanismos que permitem a capilarização das lições aprendidas na organização: um estudo de caso de empresas industriais competitivas. Tese 


\section{Administração: caminhos para o desenvolvimento sustentável}

(Doutorado em Administração de Empresas) Escola de Administração de Empresas de São Paulo da Fundação Getulio Vargas, São Paulo, 2005. 


\title{
Capítulo 24
}

\section{COMPORTAMENTO DE COMPRA DO CONSUMIDOR NO VAREJO SUPERMERCADISTA DE MATO GROSSO}

\author{
DOI: $10.37423 / 200300421$
}

Allyson Rodrigues Vargas

allysonvargas@gmail.com

Guilherme Angerames Rodrigues Vargas garvporto@gmaik.com

Resumo: Os estudos sobre Q comportamento do consúmidor sã̃o de grande-relevấncia para a definição de estratégias corporativas de sucesso. Entênder os fatores que levam o consumỉdor a escolher determinado produto ou marca em detrimento de outros é tum dos pilares das estratégias atuais de-marketing de qualquer empresa. A diversidade-e-a especificidade do impacto de fatores sociais, culturais e econômicos, no comportamento de consumo justificam a realização de estudos de caráter regional. Neste contexto, este trabalho ter como objetivo estudar o comportamento de compra do consumidor de/alimentos no varejo \$upermercadista de Mato Grosso como forma de subsieliar estratégias empresariais para o setor varejista de alimentos. A metodologia deste trabalho gompreẹndeu a realização de um survey junto aos consumidores mato-grossenses cujos resultados foram analisados por técnicas estatísticas multivariadas. Uma análise-multivariàda identificou sers grupos-distintos de consumidores: esclarecidos, econômicos, conveniência, hedônicos, novos compradoreśs e-exigenttes. 


\section{Administração: caminhos para o desenvolvimento sustentável}

O estudo aprofundado destes grupos revelou disparidades importantes no comportamento de consumo de seus integrantes Os resultados demonstram claramente que, por exemplo, alguns grupos buscam prazer na compra e consumo, independentemente do preço, enquanto outro grupo de consumidores procura por produtos com melhor custo-benefício. Ao quantificar e analisar o comportamento destes grupos de consumidores, este artigo traz importantes subsídios para todos aqueles que buscam atuar neste mercado. A metodologia e os resultados encontrados também podem ser utilizados para a condução de pesquisas análogas em outras regiões do país e/ou para a comparação com estudos semelhantes já realizados.

Palavras chave: comportamento do consumidor, varejo de alimentos, supermercado. 


\section{Administração: caminhos para o desenvolvimento sustentável}

\section{INTRODUÇÃO}

Os anos 90 trouxeram mudanças importantes no mercado consumidor brasileiro, dentre as quais destaca-se a abertura de mercado a produtos e empresas do mundo todo. Esta abertura estimulou as empresas brasileiras a buscarem melhorias nos seus sistemas de produção e gestão para manteremse no mercado. O mercado também foi impactado pela implementação do código de defesa do consumidor $(C D C)$ e a consequente expansão dos PROCONS. O CDC regulamentou a forma de relacionamento entre empresas e o consumidor. Outro acontecimento importante foi a estabilização econômica gerada pelo plano real de 1994. Esta estabilização gerou mudanças na condução da economia brasileira e levou a ganhos reais de renda pelo conjunto da população, aumento do consumo, mudança nos hábitos alimentares, entre outros. Outras mudanças sócio-demográficas vêm alternando o perfil do mercado consumidor brasileiro. O aumento da expectativa de vida e a consolidação da mulher no mercado de trabalho estão entre estes fatores de mudança.

Por outro lado, a tecnologia é outro fator que interfere diretamente no mercado, acirrando a concorrência e alterando o comportamento de consumo. As novas tecnologias de informação têm levado as empresas a criarem novas formas de comunicação e oferecimento de produtos aos seus clientes. Os clientes, por sua vez, valem-se deste acesso a informação para definirem e efetivarem seus processos de compra.

Neste novo cenário competitivo as empresas têm procurado aprimorar e intensificar seus contatos com os consumidores como forma de atender suas expectativas. Contemporaneamente, o segmento empresarial toma como fundamental que para conquistar a fidelidade do consumidor não basta apenas atender as necessidades da relação de consumo, é necessário fidelizá-lo pela superação das suas expectativas. Para tanto, é absolutamente vital conhecer o comportamento destes consumidores.

As investigações sobre comportamentos de consumo dos indivíduos constituem um dos objetos de estudo mais importantes no campo do marketing. O estudo do comportamento do consumidor representa para o marketing um meio de obter informações importantes para o desenvolvimento de novos produtos, para a precificação, para identificar as melhores opções quanto aos canais de distribuição e para o estabelecimento de políticas de promoção e publicidade. 


\section{Administração: caminhos para o desenvolvimento sustentável}

O estado do Mato Grosso não ficou imune a todo este processo de transformação ocorrido na economia e na sociedade brasileira e de suas inevitáveis repercussões no comportamento dos consumidores. Em Mato Grosso, o processo de desenvolvimento econômico mais importante iniciouse a partir da divisão territorial e administrativa, com a criação do estado de Mato Grosso do Sul em 1977. Tal divisão aconteceu tanto em função da necessidade de ocupação das regiões central e norte mato-grossense e da existência de programas federais de desenvolvimento regional que buscavam viabilizar iniciativas que levassem o Estado a se consolidar como importante produtor de commodities agropecuárias. Este quadro propiciou um importante processo migratório para o Estado. Assim, por ser um estado de colonização mais recente, o Mato Grosso ainda conta com poucos estudos relacionados ao comportamento dos seus consumidores. É importante que se possa conhecer qual seria o comportamento deste consumidor e investigar se ele se diferencia daquele encontrado em outros estados da União.

Assim, este artigo tem como objetivo apresentar estudo sobre o comportamento de compra do consumidor de alimentos no varejo supermercadista de Mato Grosso, como forma de subsidiar estratégias empresariais para o setor supermercadista.

\section{COMPORTAMENTO DO CONSUMIDOR}

O campo do comportamento do consumidor estuda a forma como as pessoas, grupos e organizações selecionam, compram, usam e descartam artigos, serviços, idéias ou experiências para satisfazer suas necessidades e desejos. (KOTLER, 2000, p. 182). No que se refere a conceituar o termo comportamento do consumidor, Sheth et al (1991, p. 29), o definem como sendo "as atividades físicas e mentais realizadas por clientes e bens de consumo e industriais que resultam em decisões e ações". Também Blackwell et al (2001, p. 6-7) definiram comportamento do consumidor como sendo as "atividades com as quais as pessoas se ocupam quando obtêm, consomem e dispõem de produtos e serviços" ou, de maneira mais ampla, "como um campo de estudo que foca nas atividades do consumidor".

Diferentes corpos de conhecimento podem ser utilizados para melhor compreender o comportamento do consumidor, áreas como economia, história, psicologia social, sociologia, antropologia, entre outras, são importantes para o estudo do comportamento do consumidor. Nesse sentido, Karsaklian (2004, p. 20) afirma que: 


\section{Administração: caminhos para o desenvolvimento sustentável}

O estudo do comportamento do consumidor é uma ciência aplicada, originária das ciências humanas e sociais, como a economia, a psicologia, a sociologia ou ainda a antropologia. Seu objetivo é compreender os comportamentos de consumo adotando uma perspectiva pluridisciplinar.

As primeiras concepções sobre o comportamento do consumidor foram baseadas na teoria econômica, mais especificamente na teoria da demanda por produtos e serviços. No início do século XX a ciência econômica era praticamente a única que se ocupava do comportamento do consumidor. Esta teoria considerava que o consumidor tinha informações completas sobre produtos e marcas que gostaria de adquirir e que usaria todas as informações disponíveis de forma racional nas suas decisões de compra.

Já os pesquisadores das Teorias Sociais e Antropológicas, consideram o consumo como um processo social. O consumo começou a gerar interesse sociológico a partir da década de 80 , conforme Barbosa; Campbell (2006 p.13-14):

Esse interesse originou-se em duas pressuposições teóricas que se tornaram disseminadas entre os cientistas sociais. A primeira delas é o reconhecimento de que o consumo é central no processo de reprodução social de qualquer sociedade, ou seja, todo e qualquer ato de consumo é essencialmente cultural. [...] A segunda pressuposição se baseia na caracterização da sociedade moderna contemporânea como uma sociedade de consumo.

Teorias da área da psicologia deram uma nova perspectiva ao estudo do comportamento do consumidor. Elas procuram aprofundar a compreensão do que acontece na mente do consumidor durante os processos de escolhas e decisões de compra, situação impensada na teoria econômica.

Para Kotler (2006, p. 182), quatro fatores psicológicos influenciam a reação do consumidor aos vários estímulos do marketing: motivação, percepção, aprendizagem e memória. Nesse processo de reação aos estímulos, três teorias são fundamentais: a Comportamental, a Psicanalítica e a Cognitiva. Observe a seguir:

- A Teoria Comportamental (Behavorista): o estudo da influência do ambiente bem como do papel do aprendizado no processo de compra permite maximizar a intenção de compra do consumidor. Porém, quando não se considera o que passa na mente deste, a teoria comportamental acaba deixando um vácuo entre a apresentação do estímulo de marketing e a decisão ou não do comportamento de compra.

- A Teoria Psicanalítica: fundada pelo neurologista austríaco Sigmund Freud, no final do século XIX foi com a utilização da psicanálise nas pesquisas de comportamento do 


\section{Administração: caminhos para o desenvolvimento sustentável}

consumidor que se iniciou o processo de se entender o que acontece na mente do consumidor no momento da compra. Segundo Karsaklian (2000, p. 24), para Freud, basicamente o comportamento humano se determina pela motivação e pelos impulsos instintivos. A mais forte tendência de comportamento não é necessariamente aquela que a pessoa decide que é a melhor para ela.

- A Teoria Cognitiva: esta é a teoria mais utilizada pelos estudiosos do comportamento do consumidor. Para esses estudiosos essa teoria permite estudar o comportamento do consumidor de forma ampla, a partir de um processo mental interno, ou seja, o que se "passa na cabeça" do consumidor e que permite que esse tome decisões. Esta teoria permite enxergar o consumo como resultante do processamento de informações não somente do indivíduo, mas também da cultura e do meio ambiente onde ele está inserido.

Conforme autores da área (SOLOMON, 2002; MOWEN \& MINOR, 2003; SAMARA \& MORSCH, 2005; BLACKELL et al, 2001; KOTLER; KELLER, 2006) o consumidor possui uma série de necessidades a serem satisfeitas, sejam elas pessoais ou profissionais, que o motivam a comportamentos distintos no ato da compra. A forma como estes consumidores se comportam antes, durante e depois do ato da compra é elemento primordial diante do processo de tomada de decisão pelas organizações que buscam identificar como e quais são as etapas mais freqüentes na decisão pela compra de um determinado produto ou serviço.

De maneira geral, percebe-se que os processos além de apresentarem quantidades de etapas bem parecidas, se aproximam também em sua nomenclatura. $\mathrm{O}$ quadro 1 apresenta de forma sintética as semelhanças dos processos de decisão de compra. 


\section{Administração: caminhos para o desenvolvimento sustentável}

\begin{tabular}{|c|c|c|c|c|}
\hline \multicolumn{5}{|c|}{ ETAPAS DO PROCESSO DE DECISÃO DE COMPRA } \\
\hline Solomon (2002) & Mowen e Minor (2003) & Samara e Morsch (2005) & Blackwell et al (2001) & Kotler e Keller (2006) \\
\hline $\begin{array}{c}\text { Reconhecimento do } \\
\text { problema }\end{array}$ & $\begin{array}{c}\text { Reconhecimento do } \\
\text { problema }\end{array}$ & $\begin{array}{c}\text { Reconhecimento da } \\
\text { necessidade }\end{array}$ & $\begin{array}{l}\text { Reconhecimento da } \\
\text { necessidade }\end{array}$ & $\begin{array}{c}\text { Reconhecimento do } \\
\text { problema }\end{array}$ \\
\hline Busca de informações & Busca das informações & Busca da informação & Busca da informação & Busca de informações \\
\hline $\begin{array}{c}\text { Avaliação das } \\
\text { altemativas }\end{array}$ & $\begin{array}{c}\text { Avalização das } \\
\text { altemativas }\end{array}$ & \begin{tabular}{|c|} 
Avaliação das \\
alternativas do produto
\end{tabular} & $\begin{array}{l}\text { Avalização das } \\
\text { altemativas pré }\end{array}$ & $\begin{array}{c}\text { Avalização de } \\
\text { altemativas }\end{array}$ \\
\hline Escolha do produto & Escolha & \begin{tabular}{|c|} 
Avaliação das \\
altemativas de compra
\end{tabular} & Compra & Decisão de compra \\
\hline \multirow[t]{3}{*}{ Resultados } & Avaliação pós compra & Decisão de compra & Consumo & $\begin{array}{c}\text { Comportamento pós } \\
\text { compra }\end{array}$ \\
\hline & & $\begin{array}{c}\text { Comportamento pós } \\
\text { compra }\end{array}$ & $\begin{array}{c}\text { Avaliação pós } \\
\text { consumo }\end{array}$ & \\
\hline & & & Descarte & \\
\hline
\end{tabular}

Quadro 1: Etapas do Processo de Decisão de Compra. Fonte: elaborado pelos autores

Através do estudo das etapas do processo de compra é que os pesquisadores começaram a criação de modelos de comportamento de compras.

\subsection{MODELOS DE COMPORTAMENTO DE COMPRA}

Um modelo é uma representação simplificada dos aspectos de uma situação real. Segundo Karsaklian (2000), uma pesquisa geralmente envolve uma sintetização daquilo que representa a realidade pesquisada, pelo fato da multiplicidade e complexidade dos inúmeros fatores estudados.

Os estudiosos do comportamento do consumidor identificaram as etapas que o consumidor segue para satisfazer suas necessidades. Baseados nestes processos e as variáveis que interferem sobre esses processos, diversos autores criaram modelos que procuraram definir parâmetros ou identificar como cada variável interfere nas etapas do processo de compra, podendo assim, através da aplicação destes modelos anteciparem a satisfação das necessidades dos consumidores.

Autores como Solomon (2002), Mowen e Minor (2003), Pinheiro et al. (2004), Engel et al (2000) e Samara e Morsch (2005), concordam que, ao perceber que deseja fazer uma compra (uma necessidade a ser satisfeita) o consumidor segue uma série de etapas que pode ajudar a entender seu comportamento.

\subsubsection{MODELO DE SHETH-NEWMAN-GROSS}

Para Costa (2007, p. 33). "a proposição básica de Sheth-Newman- Gross consistiu em ampliar o debate sobre as manifestações do valor, a partir da adoção de um conjunto de possibilidades de valor, que formariam dimensões a serem percebidas e julgadas pelos clientes na ocasião da escolha de compra". 


\section{Administração: caminhos para o desenvolvimento sustentável}

Ainda Costa (2007, p. 53) diz que os autores "mantêm concentração na análise da escolha de um cliente. Os autores adotam três postulados sobre valor e escolha: 1. a escolha do mercado é função de múltiplos valores; 2 . estes valores fazem contribuições diferenciadas em situações específicas de escolha; 3. os valores são interdependentes".

Segundo Goldstein e Almeida (2000, p. 19) "o modelo apresenta uma nova forma de abordar a modelagem do comportamento do consumidor: não se ocupa do processo, mas apenas dos fatores (valores independentes) que influenciam o comportamento".

Sheth et al (1991, p. 160-162), em seu artigo "Porque nós compramos, o que compramos: a teoria dos valores de consumo" apresentam os seguintes conceitos dentro de seu modelo de

- Valor funcional: a utilidade percebida adquirida a partir de uma capacidade alternativa para desempenho funcional, utilitarista ou físico. Uma alternativa ganha valor funcional através da posse de notáveis atributos funcionais, utilitaristas ou físicos. Valor funcional é medido considerando atributos de um perfil de escolha.

- Valor social: a utilidade percebida adquirida a partir de uma associação alternativa com um ou mais grupos sociais específicos. Como alternativa, ganha valor social através da associação com grupos positivamente estereotipados em termos demográficos, socioeconômicos e culturais. Valor social é medido considerando um perfil de escolha imaginário.

- Valor emocional: a utilidade percebida adquirida a partir de uma capacidade alternativa de despertar sentimentos de estados afetivos. Uma alternativa ganha valor emocional quando associada com sentimentos específicos ou quando precipita ou perpetua esses sentimentos. Valor emocional é medido considerando um perfil de sentimentos associados a uma alternativa.

- Valor epistêmico: a utilidade percebida adquirida a partir de uma capacidade alternativa para despertar curiosidade, proporcionar novidade, e/ou satisfazer um desejo por conhecimento. Uma alternativa ganha valor epistemológico pelo questionamento de itens referentes à curiosidade, novidade e conhecimento.

- Valor condicional: a utilidade percebida adquirida por uma alternativa como resultado de uma situação específica ou um conjunto de circunstâncias enfrentadas pelo decisor. Uma alternativa ganha valor condicional na presença de contingências antecedentes físicas ou sociais que potencializam seu valor funcional ou social. Valor condicional é medido considerando um perfil de escolhas contingenciais.

Segundo Costa (2007) as cinco categorias de valor quando associadas ao consumo são na realidade os objetivos finais que os consumidores buscam, sendo então as motivações para uma determinada escolha. 


\section{Administração: caminhos para o desenvolvimento sustentável}

Para Goldstein (1997), o modelo Sheth-Newman-Gross não analisa o consumidor como um solucionador de problemas, simplesmente procura responder à pergunta "porque o consumidor age de certa maneira?". Ainda Goldstein (1997) o modelo Sheth-Newman-Gross é o que mais atende aos critérios de análise do comportamento do consumidor. Algumas características diferenciam-no dos demais modelos:

- Não busca a explicação no processo de decisão do consumidor, apenas o acata como fato;

- Não foca apenas na reação do consumidor, mas também nos valores que influenciam essa reação (o foco do modelo é o porquê de tal reação);

- Não é um modelo pronto com as variáveis definidas, mas um conceito e uma metodologia de aplicação (identificação das variáveis e de sua importância relativa, que variam caso a caso).

\section{METODOLOGIA}

Este trabalho é o resultado de uma pesquisa bibliográfica e de um survey realizado no Estado do Mato Grosso. A pesquisa bibliográfica, visou identificar os principais trabalhos publicados nas áreas de estudo afins a este artigo.

A amostra utilizada na condução do survey foi determinada por técnica probabilística estratificada. A estratificação foi por perfil de compra (quem é o realizador da compra) e geográfica (cidade onde o consumidor reside e realiza as compras). O estudo selecionou para o estudo as quatro cidades do Mato Grosso com população (IBGE, 2007) acima de 100.000 habitantes, o que corresponde a 36,28\% da população do estado. O cálculo para definição da amostra utilizou o intervalo de confiança de $95 \%$ e erro amostral de 5\%, resultando em uma amostra de 385 entrevistados para as quatro cidades, sendo este o número de questionários aplicados. Os questionários foram aplicados proporcionalmente ao percentual populacional de cada cidade em relação ao conjunto da população estadual. Desta forma, a cidade de Cuiabá, que detêm 51\% da população pesquisada, ficou com 196 questionários ( $n=196$ ), em Várzea Grande (22\% da população) foram aplicados 86 questionários, em Rondonópolis foram entrevistados 64 consumidores e em Sinop foram abordados 39 consumidores.

A coleta de dados foi realizada por intermédio de um questionário estruturado e não disfarçado, sendo que suas questões foram baseadas no modelo de Sheth-Newman-Gross (1991). Utilizou-se a escala likert, variando de 1 a 5, solicitando aos entrevistados que apontassem o grau de concordância ou 


\section{Administração: caminhos para o desenvolvimento sustentável}

discordância para cada uma das afirmações, com as respostas variando de concordo totalmente (5) a discordo totalmente (1) (MALHOTRA, 2001). Foi realizado pré-teste do questionário com $5 \%$ do total da amostra (20 respondentes), onde pode-se realizar os ajustes deste instrumento de pesquisa. 0 método utilizado foi a entrevista pessoal com abordagem em locais públicos de grande fluxo. A coleta ocorreu durante os meses de Novembro e Dezembro de 2009.

O tratamento dos dados foi realizado através do pacote estatístico SPAD (Système Portable pour l'Analyse de Données), por intermédio da Análise Univariada (estatística descritiva), Análise Bivariada (cruzamento de variáveis), Análise Fatorial Multivatiada (clusters).

\section{ANÁLISE E RESULTADOS}

Nesta seção são apresentados os resultados em relação à forma como o consumidor investe seu dinheiro na compra de alimentos, a sua frequência de compra nos supermercados e em outros formatos de venda de alimentos, bem como quem interfere e realiza as compras nestes canais.

Em relação ao hábito de compra no mesmo supermercado, $68 \%$ dos entrevistados possuem o hábito de comprar no mesmo supermercado. O quadro 2 mostra que dentre estes entrevistados $30 \%$ compram diariamente ou até duas ou mais vezes por semana, $23 \%$ tem o hábito de comprar quinzenalmente e $47 \%$ ao menos uma vez por mês. Ao se comparar a frequência de compra com o estudo de Moura (2005), verificou-se que a média de frequência mensal dos brasileiros no formato hiper/supermercado é de $6 \%$, bem abaixo da média dos mato-grossenses.

\begin{tabular}{|c|r|r|r|r|r|r|r|}
\hline $\begin{array}{c}\% \text { Linha } \\
\% \text { Coluna }\end{array}$ & $\begin{array}{c}\text { Todos os } \\
\text { dias }\end{array}$ & $\begin{array}{c}\text { Uma vez na } \\
\text { semana }\end{array}$ & $\begin{array}{c}\text { Duas ou mais } \\
\text { vezes na } \\
\text { semana }\end{array}$ & $\begin{array}{c}\text { A cada } \\
\text { quinze dias }\end{array}$ & $\begin{array}{c}\text { Uma vez ao } \\
\text { mês }\end{array}$ & $\begin{array}{c}\text { Menos de } \\
\text { uma vez } \\
\text { ao mês }\end{array}$ & \multicolumn{1}{c|}{ Total } \\
\hline \multirow{2}{*}{$\operatorname{Sim}$} & $6 \%$ & $18 \%$ & $6 \%$ & $23 \%$ & $47 \%$ & $0 \%$ & $100 \%$ \\
\cline { 2 - 9 } & $100 \%$ & $100 \%$ & $100 \%$ & $100 \%$ & $100 \%$ & $0 \%$ & $100 \%$ \\
\hline
\end{tabular}

Quadro 2: Comparativo do Hábito de Compra de Alimentos no Mesmo Supermercado e Frequência de Compras de Alimentos no Supermercado. Fonte: Dados da pesquisa (2010)

Já em relação a frequência de compra de alimentos em supermercado e a faixa de renda mensal familiar, o quadro 3 mostra que 50\% dos pesquisados com renda entre menos de 1 a 4 salários mínimo (menos de $\mathrm{R} \$ 510,00$ a $\mathrm{R} \$ 2.040,00)$ realizam suas compras mensalmente. Este percentual cai para apenas $9 \%$ dos consumidores entrevistados com renda de 8 salários mínimo em diante $(R \$ 4.080,00)$. Pode-se pensar que isto ocorra pelo fato da limitação da renda destes consumidores, fazendo com 


\section{Administração: caminhos para o desenvolvimento sustentável}

que antecipem e priorizem os investimentos na compra de alimentos para que antes do final do mês não fiquem sem condições financeiras de adquiri-los.

\begin{tabular}{|c|c|c|c|c|c|c|c|}
\hline $\begin{array}{l}\% \text { Linha } \\
\quad \% \text { Coluna }\end{array}$ & Até RS510 & $\begin{array}{c}\text { RS511 } \\
\text { a } \\
\text { RS2.040 }\end{array}$ & $\begin{array}{c}\text { RS2.041 a } \\
\text { RS4.0S0 }\end{array}$ & $\begin{array}{c}\text { RS4.081 a } \\
\text { RS7.650 }\end{array}$ & $\begin{array}{c}\text { RS7.651 a } \\
\text { RS12.750 }\end{array}$ & $\begin{array}{l}\text { Acima de } \\
\text { RS12.750 }\end{array}$ & Total \\
\hline \multirow{2}{*}{$\begin{array}{l}\text { Todos os } \\
\text { dias }\end{array}$} & $0 \%$ & $48 \%$ & $29 \%$ & $14 \%$ & $10 \%$ & $0 \%$ & $100 \%$ \\
\hline & $0 \%$ & $6 \%$ & $4 \%$ & $9 \%$ & $25 \%$ & $0 \%$ & $6 \%$ \\
\hline \multirow{2}{*}{$\begin{array}{c}\text { Uma vez na } \\
\text { semana }\end{array}$} & $7 \%$ & $52 \%$ & $25 \%$ & $11 \%$ & $4 \%$ & $0 \%$ & $100 \%$ \\
\hline & $29 \%$ & $21 \%$ & $13 \%$ & $24 \%$ & $38 \%$ & $0 \%$ & $19 \%$ \\
\hline \multirow{2}{*}{$\begin{array}{c}\text { Duas ou mais } \\
\text { vezes na } \\
\text { semana } \\
\end{array}$} & $0 \%$ & $48 \%$ & $28 \%$ & $14 \%$ & $10 \%$ & $0 \%$ & $100 \%$ \\
\hline & $0 \%$ & $8 \%$ & $6 \%$ & $12 \%$ & $38 \%$ & $0 \%$ & $8 \%$ \\
\hline \multirow{2}{*}{$\begin{array}{c}\text { A cada } \\
\text { quinze dias }\end{array}$} & $3 \%$ & $47 \%$ & $46 \%$ & $4 \%$ & $0 \%$ & $0 \%$ & $100 \%$ \\
\hline & $18 \%$ & $26 \%$ & $31 \%$ & $12 \%$ & $0 \%$ & $0 \%$ & $26 \%$ \\
\hline \multirow{2}{*}{$\begin{array}{l}\text { Uma vez } \\
\text { ao mês }\end{array}$} & $6 \%$ & $44 \%$ & $41 \%$ & $9 \%$ & $0 \%$ & $0 \%$ & $100 \%$ \\
\hline & $53 \%$ & $39 \%$ & $46 \%$ & $44 \%$ & $0 \%$ & $0 \%$ & $42 \%$ \\
\hline \multirow{2}{*}{$\begin{array}{c}\text { Menos de } \\
\text { uma vez ao } \\
\text { mês }\end{array}$} & $0 \%$ & $100 \%$ & $0 \%$ & $0 \%$ & $0 \%$ & $0 \%$ & $100 \%$ \\
\hline & $0 \%$ & $1 \%$ & $0 \%$ & $0 \%$ & $0 \%$ & $0 \%$ & $0 \%$ \\
\hline \multirow{2}{*}{ Total } & $5 \%$ & $47 \%$ & $38 \%$ & $9 \%$ & $2 \%$ & $0 \%$ & $100 \%$ \\
\hline & $100 \%$ & $100 \%$ & $100 \%$ & $100 \%$ & $100 \%$ & $0 \%$ & $100 \%$ \\
\hline
\end{tabular}

Quadro 3: Comparativo de Frequência de Compra de Alimentos no Supermercado e Faixa de Renda

Mensal Familiar. Fonte: Dados da pesquisa (2010)

Assim como no caso da renda, o nível de formação (quadro 4) também interfere no aumento de frequência de compra dos consumidores entrevistados, sendo que consumidores de maior renda costumam comprar seus alimentos com frequência maior ou igual a semanal. Como a correlação entre a renda e nível de escolaridade é alta, em todos os estudos isto deve se repetir. 


\section{Administração: caminhos para o desenvolvimento sustentável}

\begin{tabular}{|c|c|c|c|c|c|c|c|c|c|}
\hline $\begin{array}{l}\% \text { Linha } \\
\% \text { Coluna }\end{array}$ & Analfabeto & \begin{tabular}{|c|} 
Ensino \\
fundamental \\
incompleto \\
\end{tabular} & \begin{tabular}{|c|}
$\begin{array}{c}\text { Ensino } \\
\text { fundamental } \\
\text { completo }\end{array}$ \\
\end{tabular} & $\begin{array}{c}\text { Ensnino } \\
\text { médio } \\
\text { incompleto }\end{array}$ & $\begin{array}{c}\text { Ensino médio } \\
\text { completo }\end{array}$ & $\begin{array}{c}\text { Ensino } \\
\text { superior } \\
\text { incompleto } \\
\end{array}$ & $\begin{array}{l}\text { Ensino } \\
\text { superior } \\
\text { completo }\end{array}$ & $\begin{array}{c}\text { Pós } \\
\text { graduação }\end{array}$ & Total \\
\hline \multirow{2}{*}{$\begin{array}{c}\text { Todos os } \\
\text { dias }\end{array}$} & $0 \%$ & $5 \%$ & $10 \%$ & $0 \%$ & $43 \%$ & $14 \%$ & $14 \%$ & $14 \%$ & $100 \%$ \\
\hline & $0 \%$ & $5 \%$ & $22 \%$ & $0 \%$ & $6 \%$ & $4 \%$ & $5 \%$ & $14 \%$ & $6 \%$ \\
\hline $\begin{array}{c}\text { Uma vez na } \\
\text { semana }\end{array}$ & $1 \%$ & $4 \%$ & $1 \%$ & $6 \%$ & $36 \%$ & $22 \%$ & $19 \%$ & $10 \%$ & $100 \%$ \\
\hline \multirow{2}{*}{$\begin{array}{c}\text { Duas ou mais } \\
\text { vezes na } \\
\text { semana }\end{array}$} & $0 \%$ & $3 \%$ & $0 \%$ & $7 \%$ & $21 \%$ & $45 \%$ & $17 \%$ & $7 \%$ & 1009 \\
\hline & $0 \%$ & $5 \%$ & $0 \%$ & $6 \%$ & $4 \%$ & $15 \%$ & $8 \%$ & $9 \%$ & $8 \%$ \\
\hline \multirow{2}{*}{$\begin{array}{c}\text { A cada } \\
\text { quinze dias }\end{array}$} & $0 \%$ & $4 \%$ & $2 \%$ & $9 \%$ & $36 \%$ & $28 \%$ & $16 \%$ & $4 \%$ & $100 \%$ \\
\hline & $0 \%$ & $18 \%$ & $22 \%$ & $28 \%$ & $25 \%$ & $32 \%$ & $27 \%$ & $18 \%$ & $26 \%$ \\
\hline \multirow{2}{*}{$\begin{array}{c}\text { Menos de } \\
\text { uma vez ao } \\
\text { mês }\end{array}$} & $0 \%$ & $0 \%$ & $0 \%$ & $100 \%$ & $0 \%$ & $0 \%$ & $0 \%$ & $0 \%$ & $100 \%$ \\
\hline & $0 \%$ & $0 \%$ & $0 \%$ & $3 \%$ & $0 \%$ & 096 & $0 \%$ & $0 \%$ & $0 \%$ \\
\hline \multirow{2}{*}{ Total } & $1 \%$ & $6 \%$ & $2 \%$ & $9 \%$ & $38 \%$ & $23 \%$ & $16 \%$ & $6 \%$ & $100 \%$ \\
\hline & $100 \%$ & $100 \%$ & $100 \%$ & $100 \%$ & $100 \%$ & $100 \%$ & $100 \%$ & $100 \%$ & $100 \%$ \\
\hline
\end{tabular}

Quadro 4: Comparativo de Frequência de Compra de Alimentos no Supermercado e Formação Fonte:

Dados da pesquisa (2010)

Por fim, o quadro 5 mostra uma situação interessante. $24 \%$ dos consumidores entrevistados que tem frequência diária de compra em supermercados, gastam acima de $\mathrm{R} \$ 1.000,00$ por mês. Isto mostra que as estratégias de merchandising utilizadas nestes pontos de venda (ambiente de loja, precificação, exposição de produtos, etc.) podem gerar bons resultados.

\begin{tabular}{|c|c|c|c|c|c|c|c|}
\hline $\begin{array}{l}\text { \% Linha } \\
\% \text { Coluna }\end{array}$ & Até 50,00 & $\underset{\text { RS } 50,01}{\mathrm{R} 200}$ & $\begin{array}{c}\text { RS } 200,01 \\
\text { RS500 }\end{array}$ & $\underset{\text { RSS } 500,01}{\text { RS }}$ & $\begin{array}{c}\text { RS } \$ 00,01 \text { a } \\
\text { RS1.000 }\end{array}$ & $\begin{array}{l}\text { Acima de } \\
\text { RS } 1.000\end{array}$ & Total \\
\hline \multirow{2}{*}{$\begin{array}{c}\text { Todos os } \\
\text { dias }\end{array}$} & $5 \%$ & $10 \%$ & $19 \%$ & $33 \%$ & $10 \%$ & $24 \%$ & $100 \%$ \\
\hline & $8 \%$ & $2 \%$ & $2 \%$ & $10 \%$ & $13 \%$ & $71 \%$ & $6 \%$ \\
\hline \multirow{2}{*}{$\begin{array}{l}\text { Uma vez na } \\
\text { semana }\end{array}$} & $11 \%$ & $43 \%$ & $28 \%$ & $12 \%$ & $5 \%$ & $0 \%$ & $100 \%$ \\
\hline & $62 \%$ & $31 \%$ & $12 \%$ & $13 \%$ & $25 \%$ & $0 \%$ & $20 \%$ \\
\hline \multirow{2}{*}{$\begin{array}{c}\text { Duas ou mais } \\
\text { vezes na } \\
\text { semana }\end{array}$} & $10 \%$ & $21 \%$ & $28 \%$ & $17 \%$ & $17 \%$ & $7 \%$ & $100 \%$ \\
\hline & $23 \%$ & $6 \%$ & $5 \%$ & $7 \%$ & $31 \%$ & $29 \%$ & $8 \%$ \\
\hline \multirow{2}{*}{$\begin{array}{c}\text { A cada } \\
\text { quinze dias }\end{array}$} & $0 \%$ & $29 \%$ & $56 \%$ & $13 \%$ & $2 \%$ & $0 \%$ & $100 \%$ \\
\hline & $0 \%$ & $27 \%$ & $31 \%$ & $18 \%$ & $13 \%$ & $0 \%$ & $25 \%$ \\
\hline \multirow{2}{*}{$\begin{array}{l}\text { Uma vez } \\
\text { ao mês }\end{array}$} & $1 \%$ & $23 \%$ & $53 \%$ & $22 \%$ & $2 \%$ & $0 \%$ & $100 \%$ \\
\hline & $8 \%$ & $35 \%$ & $49 \%$ & $51 \%$ & $19 \%$ & $0 \%$ & $42 \%$ \\
\hline \multirow{2}{*}{$\begin{array}{c}\text { Menos de } \\
\text { uma vez ao } \\
\text { mês }\end{array}$} & $0 \%$ & $0 \%$ & $100 \%$ & $0 \%$ & $0 \%$ & $0 \%$ & $100 \%$ \\
\hline & $0 \%$ & $0 \%$ & $1 \%$ & $0 \%$ & $0 \%$ & $0 \%$ & $0 \%$ \\
\hline \multirow{2}{*}{ Total } & $3 \%$ & $28 \%$ & $45 \%$ & $18 \%$ & $4 \%$ & $2 \%$ & $100 \%$ \\
\hline & $100 \%$ & $100 \%$ & $100 \%$ & $100 \%$ & $100 \%$ & $100 \%$ & $100 \%$ \\
\hline
\end{tabular}

Quadro 5: Comparativo de Frequência de Compra de Alimentos no Supermercado e Valor Mensal de Compra de Alimentos no Supermercado. Fonte: Dados da pesquisa (2010) 


\section{Administração: caminhos para o desenvolvimento sustentável}

Ao se comparar o valor gasto nas compras diárias com as compras realizadas quinzenalmente ou mensalmente, vê-se que os consumidores entrevistados gastam por mês até $R \$ 500,00$, ou seja, metade do valor gasto pelos consumidores que compram diariamente.

A seguir, o quadro 6 apresenta informações referente a relação renda média mensal familiar comparada com o gasto médio mensal na compra de alimentos, percebe-se que 53\% dos consumidores entrevistados que ganham entre $R \$ 4.080,00$ a $R \$ 7.650,00$ gastam com alimentos, mensalmente, entre $R \$ 500,00$ a $R \$ 1.000,00$. Entre os consumidores entrevistados que ganham entre $\mathrm{R} \$ 7.650,00$ a $\mathrm{R} \$ 12.750,00$ estes $88 \%$ gastam entre $\mathrm{R} \$ \mathbf{8 0 0 , 0 0}$ a mais de $\mathrm{R} \$ 1.000,00$. Ao contrário dos consumidores entrevistados de maior renda, os consumidores que ganham entre $\mathrm{R} \$ 511,00$ a $\mathrm{R} \$ 2.040,00,89 \%$ gastam na faixa de $\mathrm{R} \$ 50,00$ a $\mathrm{R} \$ 500,00$.

Ao se comparar o comprometimento da renda mensal dos entrevistados em relação aos gastos, levando em consideração a maior renda dentro da faixa salarial e o maior gasto dentro das faixas de consumo, percebe-se que quem ganha até $\mathrm{R} \$ 2.040,00$ gastando $\mathrm{R} \$ 500,00$ por mês na compra de alimentos, compromete $24,5 \%$ de seus ganhos, os consumidores entrevistados com renda mensal de até $\mathrm{R} \$ 7.650,00$ gastando até $\mathrm{R} \$ 1.000,00$ na compra de alimentos comprometem $13,1 \%$ de seus ganhos e os que ganham até $\mathrm{R} \$ 12.750,00$ gastando $\mathrm{R} \$ 1.000,00$ por mês, comprometem apenas $7,8 \%$ de seus ganhos.

\begin{tabular}{|c|c|c|c|c|c|c|c|}
\hline $\begin{array}{l}\% \text { Linha } \\
\qquad \% \text { Coluna }\end{array}$ & Até 50,00 & $\mid \begin{array}{cc}R S 50,01 & a \\
\text { RS } 200 & \end{array}$ & $\begin{array}{cc}R \$ 200,01 & a \\
R S 500 & \end{array}$ & $\begin{array}{c}\text { RS500,01 } \\
\text { RS\$00 }\end{array}$ & $\begin{array}{c}\text { RSS } 00,01 \\
\text { R } \$ 1.000\end{array}$ & $\begin{array}{l}\text { Acima de } \\
\text { RS } 1.000\end{array}$ & Total \\
\hline \multirow{2}{*}{ Até RS510 } & $13 \%$ & $\$ 1 \%$ & $6 \%$ & $0 \%$ & $0 \%$ & $0 \%$ & $100 \%$ \\
\hline & $17 \%$ & $13 \%$ & $1 \%$ & $0 \%$ & $0 \%$ & $0 \%$ & $4 \%$ \\
\hline \multirow{2}{*}{$\begin{array}{l}\text { RS511a } \\
\text { RS2.040 }\end{array}$} & $6 \%$ & $38 \%$ & $45 \%$ & $10 \%$ & $2 \%$ & $0 \%$ & $100 \%$ \\
\hline & $83 \%$ & $64 \%$ & $47 \%$ & $27 \%$ & $19 \%$ & $0 \%$ & $47 \%$ \\
\hline \multirow{2}{*}{$\begin{array}{c}\text { RS2.041 a } \\
\text { RS4.080 }\end{array}$} & $0 \%$ & $16 \%$ & $55 \%$ & $24 \%$ & $4 \%$ & $2 \%$ & $100 \%$ \\
\hline & $0 \%$ & $21 \%$ & $44 \%$ & $52 \%$ & $31 \%$ & $43 \%$ & $37 \%$ \\
\hline \multirow{2}{*}{$\begin{array}{c}\text { RS4.0\$1 a } \\
\text { RS7.650 }\end{array}$} & $0 \%$ & $3 \%$ & $41 \%$ & $41 \%$ & $12 \%$ & $3 \%$ & $100 \%$ \\
\hline & $0 \%$ & $1 \%$ & $8 \%$ & $22 \%$ & $25 \%$ & $14 \%$ & $9 \%$ \\
\hline \multirow{2}{*}{$\begin{array}{c}\text { RS7.651 a } \\
12.750 \\
\end{array}$} & $0 \%$ & $13 \%$ & $0 \%$ & $0 \%$ & $50 \%$ & $38 \%$ & $100 \%$ \\
\hline & $0 \%$ & $1 \%$ & $0 \%$ & $0 \%$ & $25 \%$ & $43 \%$ & $2 \%$ \\
\hline \multirow{2}{*}{$\begin{array}{l}\text { Acima de } \\
\text { RS12.750 }\end{array}$} & $0 \%$ & $0 \%$ & $0 \%$ & $0 \%$ & $0 \%$ & $0 \%$ & $0 \%$ \\
\hline & $0 \%$ & $0 \%$ & $0 \%$ & $0 \%$ & $0 \%$ & $0 \%$ & $0 \%$ \\
\hline \multirow{2}{*}{ Total } & $3 \%$ & $28 \%$ & $46 \%$ & $17 \%$ & $4 \%$ & $2 \%$ & $100 \%$ \\
\hline & $100 \%$ & $100 \%$ & $100 \%$ & $100 \%$ & $100 \%$ & $100 \%$ & $100 \%$ \\
\hline
\end{tabular}

Quadro 6: Comparativo de Faixa de Renda Mensal Familiar e Valor Mensal de Compra de Alimentos no Supermercado. Fonte: Dados da pesquisa (2010) 


\section{Administração: caminhos para o desenvolvimento sustentável}

Segundo o IBGE (2004), o item alimentação representa 17,1\% da despesas totais familiares, porém ao se analisar a proporção de gasto total por classe social, as famílias com menor renda (até $R \$ 400,00)$ comprometem $32,68 \%$ do ganho com alimentação, enquanto as famílias na maior faixa de renda (mais de $R \$ 6.000,00)$ comprometem apenas 9,04\% com alimentação.

Em relação a compra de alimentos em outros formatos de loja os entrevistados ao serem abordados, tinham a opção de marcar a frequência de compra em todos os formatos apresentados no questionário, sendo que do total dos 385 questionários aplicados a figura 1 mostra que, 30\% dos entrevistados além de comprarem em supermercados, compram também em hipermercados, $46 \%$ também realizam suas compras em mercearias/quitandas, $47 \%$ em feiras livre, $6 \%$ em sacolão, $72 \%$ em padarias, $25 \%$ em açougues e $12 \%$ em lojas de conveniência.

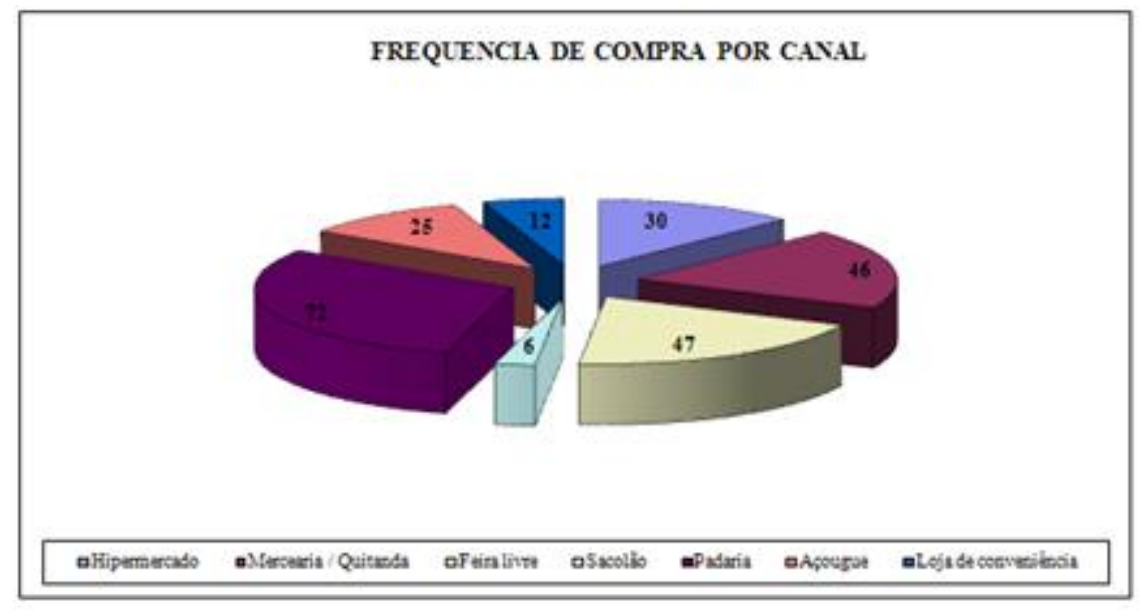

Figura 1: Opções de Compra de Alimentos em Outros Canais. Fonte: Dados da pesquisa (2010)

Nestes outros formatos, ao se analisar a frequência de compra, o quadro 7 mostra que os consumidores entrevistados que compram em hipermercado optam por comprar uma vez ao mês em sua maioria, os consumidores que compram em mercearia/quitanda compram duas ou mais vezes na semana, os consumidores de feira livre compram uma vez na semana assim como no formato açougue, já no formato padaria predomina a compra diária.

Isto deixa claro que o mix de produtos oferecido aos consumidores entrevistados está diretamente ligado à freqüência de compra. Por exemplo, os itens oferecidos pelos hipermercados podem ser comprados mensalmente por serem mais "duráveis", diferente dos itens oferecidos no formato mercearia/quitanda, que são em sua maioria frutas, legumes e verduras (FLV) considerados produtos extremamente perecíveis. Neste formato mercearia/quitanda, o consumidor para conseguir produtos mais frescos necessita de uma frequência de compras maior, mesmo acontece com o formato de 


\section{Administração: caminhos para o desenvolvimento sustentável}

padarias que oferece pães frescos diariamente bem como o café da manhã para os que não têm o hábito de tomá-lo em casa.

\begin{tabular}{|c|c|c|c|c|c|c|}
\hline $\begin{array}{c}\text { Periodicidade / } \\
\text { Estabelecimento }\end{array}$ & Todos os dias & $\begin{array}{c}\text { Uma vez na } \\
\text { semana }\end{array}$ & $\begin{array}{c}\text { Duas ou mais } \\
\text { vezes na semana }\end{array}$ & Quinzenalmente & $\begin{array}{c}\text { Uma vez por } \\
\text { mês }\end{array}$ & $\begin{array}{c}\text { Menos de uma } \\
\text { vez por mês }\end{array}$ \\
\hline Hipermercado & 1 & 5 & 2 & 3 & 13 & 6 \\
\hline Mercearia / Qvitanda & 3 & 13 & 21 & 4 & 3 & 1 \\
\hline Feira livse & 1 & 37 & 2 & 2 & 2 & 2 \\
\hline Sacolào & 0 & 4 & 0 & 0 & 1 & 1 \\
\hline Padaria & 42 & 3 & 24 & 1 & 1 & 1 \\
\hline Açougue & 4 & 9 & 5 & 4 & 2 & 1 \\
\hline Loja de conveniência & 1 & 1 & 4 & 1 & 3 & 2 \\
\hline
\end{tabular}

Quadro 7: Frequência de Compra de Alimentos em Outros Canais. Fonte: Dados da pesquisa (2010)

Para finalizar, o quadro 8 apresenta um comparativo em relação aos valores mensais de compra de alimentos gastos em supermercado e nos demais formatos.

Nos supermercados, $62 \%$ dos consumidores entrevistados gastam mensalmente uma média de $R \$ 200,01$ a $R \$ 800,00$. Nos outros formatos $84 \%$ dos consumidores gastam em media até $R \$ 200,00$ por mês. Este comparativo mostra que os consumidores ainda preferem os supermercados para realizar suas compras, independente da frequência de compra. Este fato reforça a tendência das redes supermercadistas em aumentar a variação dos formatos de lojas (supermercado de vizinhança, atacarejo, etc.) e dos serviços agregados (restaurantes, lanchonetes, farmácias) com o objetivo de atrair ainda mais consumidores para dentro de suas lojas.

\begin{tabular}{|l|c|l|c|}
\hline \multicolumn{2}{|c|}{ supermercado } & \multicolumn{1}{c|}{ Valor mensal compra alimentos outros } \\
\hline Valor compra & $\%$ & Valor compra & $\%$ \\
\hline Até RS50,00 & 3 & Até RS50,00 & 22 \\
\hline De RS50,01 a R $\$ 200,00$ & 27 & De RS50,01 a RS200,00 & 62 \\
\hline De RS200,01 a RS500,00 & 44 & De RS200,01 a RS500,00 & 12 \\
\hline De RS500,01 a RS $\$ 00,00$ & 18 & De RS500,01 a RS\$00,00 & 0 \\
\hline De RS\$00,01 a RS1.000,00 & 4 & De RS 800,01 a RS $1.000,00$ & 1 \\
\hline Acima de RS $1.000,00$ & 2 & Acima de RS $1.000,00$ & 0 \\
\hline
\end{tabular}

Quadro 8: Comparativo do Valor de Compra Mensal de Alimentos em Supermercados e o Valor de Compra Mensal de Alimentos em Outros Canais. Fonte: Dados da pesquisa (2010)

\subsection{ANÁLISE DOS AGRUPAMENTOS (CLUSTERS)}

A análise de cluster permite a formação de grupos com características homogêneas em relação ás variáveis mais relevantes na decisão de compra de alimentos em supermercados. Neste estudo optouse por analisar as variáveis ativas, sendo assim, os grupos não devem ser analisados considerando o 


\section{Administração: caminhos para o desenvolvimento sustentável}

seu posicionamento dentro dos eixos fatoriais (quadrantes positivos ou negativos), mas levando-se em consideração sua relevância.

Para se chegar aos agrupamentos, foi feita uma classificação hierárquica, onde os indivíduos foram divididos em grupos cada vez mais heterogêneos. Quanto mais se divide os grupos, maior será o número de clusters. Neste trabalho, com a utilização do SPAD, foram simulados 2 níveis de corte, com 4 e 6 grupos (clusters). Optou-se por trabalhar com 6 agrupamentos (clusters) para que houvesse maior "equilíbrio" (melhor representação percentual de cada grupo). Com quatro grupos, o maior cluster tem $66 \%$ e o menor cluster $3 \%$. Com seis grupos, o maior cluster tem $44 \%$ e o menor $3 \%$ do tamanho total da amostra.

\subsubsection{CLUSTER 1 - ESCLARECIDOS}

O cluster 1 é composto por 180 indivíduos denominados "consumidores esclarecidos", totalizando 46,39\% da amostra. Este grupo contém indivíduos na faixa etária entre 32 a 40 anos e com renda entre 4 a 8 salários mínimo, sendo que a esposa é quem decide sobre a compra de alimentos, embora não seja a principal responsável por realizar as compras.

Os consumidores entrevistados deste grupo realizam compras mensais no mesmo supermercado e quando precisam comprar poucos itens buscam o supermercado mais próximo. Os integrantes deste grupo normalmente realizam suas compras mensais em um mesmo supermercado preferido. Eles gastam em média entre $R \$ 200,00$ a $R \$ 500,00$ mensais nestas compras. Estes consumidores utilizamse também de outros formatos (canais) para comprar alimentos, como feiras-livres, mercearias/quitandas e padarias, para estes canais a frequência de compra é de uma a mais vezes na semana e gastam em média mensal $R \$ 50,00$ a $R \$ 200,00$ nestes canais.

Os consumidores entrevistados do cluster 1 entendem que o preço pago pelos produtos não é o mais adequado, porém não comparam preço em outros estabelecimentos. Estes consumidores interpretam que os produtos oferecidos em outros supermercados têm a mesma qualidade do supermercado onde compram, ficando evidente que, para esse consumidor, a interferência da marca do supermercado é mais relevante que o preço.

Estes consumidores acreditam que os serviços oferecidos pelo supermercado onde realizam suas compras são confiáveis, porém os serviços e demais benefícios oferecidos não são fatores de decisão na escolha ou compensatórios de preços mais elevados pela qualidade dos produtos. Além de comprarem os produtos mais expostos nas prateleiras, têm preferência por comprar produtos em 


\section{Administração: caminhos para o desenvolvimento sustentável}

promoção. Buscam freqüentemente experimentar novos produtos lançados no mercado, desde que não seja somente um modismo. Neste caso a marca dos produtos não se mostra tão importante como a marca do supermercado.

É importante dizer que durante a aplicação da fase de pré-teste do questionário, foram considerados "produtos de promoção" aqueles apregoados como estando sendo vendidos com desconto ou preço muito baixo.

Sobre a marca do supermercado, é importante ponderar que esta está diretamente ligada ao posicionamento da empresa, ou seja, as percepções e sentimentos dos consumidores sobre a empresa. Para os consumidores da pesquisa, qualidade, atendimento, higiene e limpeza interferem na escolha do supermercado. Estes consumidores não compreendem as vêem as formas de pagamento como fator decisivo na escolha do supermercado.

Os consumidores pertencentes a este cluster não tem o hábito de comprar em locais que seus amigos compram, assim como não socializam as informações referentes ao supermercado que costumam comprar no grupo que pertencem. Isto mostra que os fatores ligados aos grupos sociais não se mostraram relevantes na escolha do supermercado e nem na escolha dos produtos

Talvez por realizarem compras mensais, estocando alimentos para o mês todo e comprando apenas poucos itens complementares, as variáveis sociais (recepção de amigos em casa e períodos de festas) também são de pouca relevância na hora de comprar. Não costumam alterar a lista de compras com frequência.

Os consumidores que compõem o cluster 1, em maioria buscam comprar produtos ligados ao status, e ao estilo de vida que levam. Verificou-se que os consumidores deste grupo não possuem muita preocupação em adquirir produtos considerados saudáveis, pois não concordam nem discordam de que só devem comprar produtos considerados saudáveis para a família.

O momento econômico, independente se é bom ou ruim, é outra variável que não interfere na decisão de compra deste grupo de consumidores, pois, independente da sua situação econômica, estes consumidores não alteram a sua lista de compras. A faixa salarial destes consumidores poderia explicar este ponto. Como estes consumidores compram principalmente produtos básicos de alimentação, eles não podem abrir mão destes artigos. Assim, a única opção seria a de substituir marcas em busca de produtos mais baratos. 


\section{Administração: caminhos para o desenvolvimento sustentável}

\subsubsection{CLUSTER 2 - ECONÔMICOS}

O cluster 2 foi formado por 72 pessoas, as quais representam 18,56\% da amostra. Este grupo tem predominância de consumidores que possuem ensino fundamental incompleto. O grupo caracterizado por pessoas com este nível de instrução possui baixa renda.

Os consumidores deste grupo buscam alimentos mais baratos e para eles o preço é variável fundamental na escolha dos produtos e do ponto de venda. Independentemente da quantidade do produto a ser comprado, este grupo é fiel ao seu supermercado preferido, reconhecido por vender a preços mais baixos. Porém, como procuram fazer comparação de preço antes das compras, ao se depararem com um novo supermercado experimentam seus produtos e serviços em busca de melhor qualidade e menor preço.

A marca do supermercado não foi considerada como fator relevante na escolha do supermercado. A proximidade do supermercado também não se mostrou importante para este cluster.

Fatores como as instalações e a qualidade dos produtos não foram considerados como decisórios na escolha do supermercado, mas estes estabelecimentos devem possuir boa higiene e limpeza.

Para os consumidores deste cluster a variável econômica se mostrou muito relevante, pois procuram sempre consumir os produtos da mesma marca, porém, de acordo com a sua situação econômica, alteram a lista de produtos comprados. Estes consumidores buscam sempre produtos em promoção e os mais evidentes nas prateleiras. Eles não tem o hábito de experimentar novos produtos e nem de comprar qualquer produto que esteja fora de seu "padrão de preço".

Considerando as características do grupo do cluster 2, as questões econômicas interferem diretamente nas estratégias e mix de produtos dos supermercados. Talvez as marcas próprias sejam uma opção adequada para atender a este grupo de consumidores.

As pessoas com as características deste grupo buscam trocar informações entre si. Estes consumidores buscam comprar no mesmo supermercado onde encontram pessoas conhecidas.

Os componentes deste grupo buscam produtos ligados ao estilo de vida e ao hábito de consumo do grupo familiar, optando por comprar produtos que a família considera saudáveis.

\subsubsection{CLUSTER 3 - CONVENIÊNCIA}

O agrupamento do cluster 3 é formado por clientes que buscam "conveniência". Este grupo é formado por 21 indivíduos, representando 5,41\% da amostra. Os consumidores entrevistados que compõem 


\section{Administração: caminhos para o desenvolvimento sustentável}

este grupo não têm o hábito de comprar no mesmo supermercado. Compram em média uma vez ao mês no supermercado e uma vez na semana em mercearia/quitanda, gastando em média $\mathrm{R} \$ 50,00$ por mês nestas mercearias/quitandas.

Este agrupamento não apresentou características claras em relação a compra de alimentos em supermercados. Independentemente da quantidade a ser adquirida, eles buscam sempre o supermercado mais próximo, desde que apresente boa higiene e limpeza.

Variáveis como serviços oferecidos, promoção e status são relativamente importantes para este grupo.

Pelas características apresentadas, neste grupo poderiam estar pessoas que optam por comprarem alimentos prontos ou por realizar a maior parte de suas refeições fora de casa. Este grupo é mais numeroso em Cuiabá e tem preferência por comprar com maior frequência em mercearia/quitanda (frutas e verduras). Observa-se que este cluster possui um grande número de pessoas que moram sozinhas. Essas são características de habitantes de aglomerações mais urbanizadas, como é o caso de Cuiabá.

Estes consumidores mostraram-se indiferentes em relação às instalações, condições de pagamento e a marca de produtos.

Percebe-se neste cluster que questões ligadas a preço, situação econômica, atendimento, exposição de produtos e marca do supermercado, podem ser elementos secundários na estratégia de marketing dos supermercadistas. Uma forma dos supermercadistas atraírem os consumidores deste cluster é oferecer comida pronta e comida congelada, ou até mesmo colocando lojas que ofereçam produtos de conveniência para estes consumidores.

Em relação à conveniência, seria necessário oferecer não somente o formato tradicional de lojas, mas também novos formatos que atendam as necessidades destes consumidores (mercados de vizinhança e bairro, eletrônico, hipermercados, super centers, lojas de conveniência, entre outros).

\subsubsection{CLUSTER 4 - HEDÔNICOS}

O cluster 4 se caracteriza por questões ligadas ao consumo alimentar hedônico ${ }^{1} \cdot$. Estes consumidores que compram os produtos que têm vontade de comer, mesmo que não sejam considerados saudáveis, e produtos ligados a "modismos". Quando se sentem mais felizes costumam gastar mais no 


\section{Administração: caminhos para o desenvolvimento sustentável}

supermercado. É composto por apenas 10 indivíduos, os quais representam 2,58\% do total da amostra.

Lucchese (2007), ao analisar o comportamento alimentar de brasileiros urbanos, concluiu que os consumidores com este perfil acreditavam que comer bem estava associado com as expressões "comer o que gosta e alimenta", "tudo o que gosta", "comer o que gosta", "satisfação", "variedade, alimentação variada" e "dieta balanceada com alimentos que gosta". Os resultados retratados neste artigo também apontam nesta direção.

Percebeu-se ainda que os consumidores entrevistados não se preocupam em comprar produtos saudáveis para a família, dando mais importância a produtos indicados por amigos. Estes consumidores compram no mesmo supermercado onde seus amigos compram e onde encontram pessoas conhecidas, além de costumarem falar dos supermercados onde compram para pessoas próximas e parentes. Isto pode indicar que eles se preocupam mais com a questão de status ou convívio em grupos do que com aspectos econômicos ligados as compras.

A busca pelo status se reforça pelo fato dos consumidores deste cluster acreditarem que os produtos oferecidos pelo supermercado onde compram tem mais qualidade que de outros estabelecimentos, sempre levando em consideração o nome do supermercado para decidir onde comprar. Excepcionalmente eles compram alimentos no supermercado mais próximo, ou seja, ele não compram sempre no mesmo supermercado.

Variáveis como as instalações do supermercado, atendimento, higiene e limpeza, serviços oferecidos, promoção e fidelidade a determinados produtos e marcas não se mostraram relevantes para este grupo.

\subsubsection{CLUSTER 5 - NOVOS COMPRADORES}

Este cluster 5 é formado por 64 indivíduos, ou seja, 16,49\% da amostra. O cluster é caracterizado por consumidores jovens com idade entre 22 a 31 anos. São funcionários de empresas públicas com renda mensal familiar até um salário mínimo (provavelmente com baixa escolaridade e/ou início carreira). Eles realizam suas compras semanalmente em supermercados, gastando em média entre $\mathrm{R} \$ 50,00$ a $R \$ 200,00$ por mês. As compras são semanais em açougues e duas ou mais vezes na semana em lojas de conveniência. Nestes canais estes consumidores gastam mensalmente, em média, até $\mathrm{R} \$ 50,00$.

Pela frequência de compras e pelo valor gasto tanto nos supermercados como em outros canais supõese que estes consumidores devem fazer parte das suas principais refeições fora de casa, ou não são 


\section{Administração: caminhos para o desenvolvimento sustentável}

responsáveis pela compra de alimentos. Costumam consumir produtos que tem vontade, mesmo não os considerando saudáveis.

Devido à limitações de renda, o momento econômico interfere na lista de compra de alimentos. As condições de pagamento interferem na decisão de escolha do supermercado, por isso sempre procuram experimentar novos supermercados, sendo que eventualmente podem comprar em supermercados próximos.

A confiabilidade dos serviços oferecidos e os preços pagos nos supermercados nem sempre são considerados adequados por estes consumidores.

\subsubsection{CLUSTER 6 - EXIGENTES}

O cluster 6 é composto por 41 indivíduos (10,57\% da amostra). Este grupo é predominantemente composto principalmente por profissionais liberais. Neste grupo, a decisão sobre a compra de alimentos fica sob responsabilidade da esposa, marido e filhos, a empregada não decide sobre o que comprar. Estes consumidores vão ao supermercado muitas vezes na semana e gastam, em média, de $\mathrm{R} \$ 800,00$ a $\mathrm{R} \$ 1.000,00$ por mês em suas compras. Eles compram com grande frequência em açougues, diariamente em padarias e semanalmente em sacolões, gastando mensalmente nestes canais em torno de $\mathrm{R} \$ 200,00$ a $\mathrm{R} \$ 500,00$.

Os consumidores deste cluster levam em consideração as indicações de amigos e os produtos que a família consome, desde que os considerem saudáveis.

Para comprar alimentos os consumidores deste cluster buscam tanto o supermercado mais próximo como o supermercado preferido, porém sempre buscam experimentar novos supermercados. Quando se sentem mais felizes ou em períodos de datas comemorativas, estes consumidores sempre gastam mais na compra de alimentos.

Este grupo de consumidores considera importante o valor gasto na compra de alimentos, pois não estão totalmente satisfeitos com o preço, com as condições de pagamento, com a qualidade dos produtos oferecidos, assim como os serviços e benefícios oferecidos (atendimento e higiene e limpeza). Eles podem comparar os preços antes de comprar, procuram alimentos melhor expostos e em promoção, e podem mudar a lista de produtos dependendo do momento econômico. 


\section{Administração: caminhos para o desenvolvimento sustentável}

Os clientes deste agrupamento não são fiéis aos produtos e as marcas que compram. 0 termo fidelidade no mercado não tem como ser levado ao pé da letra e não pode ser visto como em um relacionamento pessoal, por exemplo.

\section{CONSIDERAÇÕES FINAIS}

As principais observações em relação a análise descritiva foram em relação ao gênero, pelo grande participação das mulheres no processo de compras, elas representaram $70 \%$ da amostra. A pesquisa mostrou que a mulher ainda tem maior participação tanto na decisão quanto na realização de compras em supermercados, muito embora a participação masculina venha crescendo. $O$ estudo mostra ainda que os filhos têm grande influência na decisão e pouca participação na realização das compras.

O estudo mostrou que a grande maioria dos consumidores ainda opta por comprar em seu supermercado preferido (68\%), com frequência de compra variando entre diária e quinzenal (53\%). Os valores gastos mensalmente nos supermercados ficaram entre $R \$ 200,01$ e $R \$ 800,00$

A pesquisa revelou que consumidores com renda mais elevada freqüentam mais assiduamente os supermercados. Outra situação observada na pesquisa é que quanto maior a frequência de compra, maiores são os gastos mensais nos supermercados. Porém, os consumidores de maior renda e conseqüentemente com maior frequência, comprometem, percentualmente, menos a renda que os consumidores de menor renda.

Sobre os outros formatos de varejo de alimentos, os consumidores utilizam com mais frequência as padarias, feiras livres, mercearias/quitandas e hipermercados. Açougues, lojas de conveniência e sacolões são os formatos utilizados com menor frequência.

Sobre a frequência de compra nestes canais, o estudo mostrou que nos hipermercados, predominam as compras mensais, nas mercearias/quitandas as compras são realizadas predominantemente duas ou mais vezes na semana, nas feiras livres, predominam as compras semanais e nas padarias a maior frequência de compra é diária. Nestes formatos o gasto médio mensal foi de até $R \$ 200,00$

Uma análise de cluster da amostra entrevistada revelou seis grupos distintos de consumidores. São eles:

Os esclarecidos (46,39\% da amostra): são consumidores casados, com renda familiar média (4 a 8) que estão na faixa de idade entre 32 a 40 anos, já conscientes do que querem, conseguindo distinguir muito bem sobre a qualidade da prestação de serviços, dos produtos oferecidos 


\section{Administração: caminhos para o desenvolvimento sustentável}

Os econômicos (18,56\% da amostra): Neste cluster há predominância de consumidores de baixa escolaridade e renda. Estes consumidores buscam sempre otimizar seus recursos disponíveis comprando nos estabelecimentos onde possam adquirir os "melhores" produtos com o menor preço possível. Uma das formas utilizadas para a obtenção de vantagens e a troca de informações dentro dos grupos de referência aos quais pertencem, assim quem conhecer onde estão as melhores promoções avisa a outros participantes do grupo

Os convenientes $\mathbf{( 5 , 4 1 \%}$ da amostra): Os consumidores deste grupo fazem boa parte das refeições fora de casa e quando realizam refeições em casa buscam refeições rápidas, cômodas e menos trabalhosas. Por comprarem alimentos mais específicos (prontos ou congelados) buscam sempre o supermercado mais fácil de encontrar (conveniência).

Os hedônicos (2,58\% da amostra): Para este grupo a alimentação é intimamente ligada ao prazer de consumi-la. Estes consumidores não estão preocupados com questões ligadas a saúde ou ao preço, ou seja, eles consomem o que lhes dá prazer. A influência do circulo de amigos a qual fazem parte tem maior influência que a decisão de consumo da família.

Os novos compradores (16,49\% da amostra): grupo formado por jovens casais que assumiram recentemente as responsabilidades de gestão da casa e ainda não tem a mesma clareza que o cluster 1 para poderem avaliar os melhores serviços e produtos oferecidos. Provavelmente realizam poucas refeições em casa e quando o fazem, optam por comida pronta ou lanches rápidos.

Os exigentes $(\mathbf{1 0 , 5 7 \%}$ da amostra): grupo formado por pessoas com alto poder aquisitivo e grande consumo. Sempre são muito críticos em relação a prestação de serviços e a qualidade dos produtos. Devido ao alto padrão de exigência, os consumidores deste grupo nunca estão totalmente satisfeitos. Estes consumidores sempre dão muito valor ao seu poder de compra e valorizam seu dinheiro.

O trabalho pôde trazer contribuições para o meio acadêmico, apresentando um panorama do perfil do consumidor de alimentos nos supermercado do Mato Grosso. Ele também pode servir de base para outros estudos ligados ao consumo dentro deste Estado. Para o meio empresarial, o objetivo principal deste trabalho foi o de apresentar informações que pudessem subsidiar estratégias empresariais.

Espera-se que estudos futuros possam servir de comparação ou crítica sobre os resultados obtidos neste estudo, ou até mesmo aprofundamentos em tópicos de relevância dentro do trabalho, como a interferência de grupos de influência e da cultura. Espera-se também que outros estudos possam auxiliar na implementação de estratégias sugeridas pelo artigo aos supermercadistas. 


\section{Administração: caminhos para o desenvolvimento sustentável}

\section{REFERÊNCIAS}

BABBIE, E. Métodos de Pesquisa de Survey. Belo Horizonte: Ed. UFMG, 1999. 519p.

BARBOSA, L.; CAMPBELL, C. Cultura, consumo e identidade. Rio de Janeiro: Editora FGV, 2006

BLACKWELL, R. D.; MINIARD, P. W.; ENGEL, J. F. Consumer behavior. 9th ed. Mason: South-Western, 2001.

BLESSA, R. Merchandising no ponto de venda. São Paulo: Atlas, 2001.

COSTA, F. J. A influência do valor percebido pelo cliente sobre os comportamentos de reclamação e boca a boca: uma investigação em cursos de pós-graduação lato sensu / Francisco José da Costa. 2007. $240 \mathrm{p}$.

ENGEL, J. F.; BLACKWELL, R. E.; MINIARD, P. W. Comportamento do consumidor. 8. ed. Rio de Janeiro: LTC, 2000.

GOLDSTEIN, M. Modelos integrativos de comportamento do consumidor: análise crítica e perspectivas. São Paulo, 1997. 151 p. Dissertação (Mestrado) - Escola Politécnica da Universidade de São Paulo. 1997

GOLDSTEIN, M.; ALMEIDA, H. S. Crítica dos modelos integrativos do comportamento do consumidor. Revista de Administração da USP, São Paulo v.35, n.1, p.14-22, janeiro/março 2000

HAIR JR, J. F.; ANDERSON, R. E.; TATHAM, R. L.; BLACK, W. C. Análise Multivariada de Dados. 5a ed. Porto Alegre: Bookman, 2005.

IBGE - Instituto Brasileiro de Geografia e Estatística. Disponível em: <www.ibge.gov.br>, Acesso em 15 dez. 2008.

IBGE. Estimativas das populações dos municípios em 2005. Disponível

em:<http://www.ibge.gov.br/home/presidencia/noticias/noticia_visualiza.php?id_noticia=429\&id_p agina=1>. Acesso em: 01 ago. 2008

IBGE. Pesquisa mensal de emprego. Disponível

em:<http://www.ibge.gov.br/home/estatistica/indicadores/trabalhoerendimento/pme/pmemet2.sh tm>. Acesso em: 01 ago. 2008

KARSAKLIAN, E. Comportamento do consumidor. São Paulo: Atlas, 2000

KARSAKLIAN, E.. Comportamento do Consumidor. 2a ed. São Paulo: Atlas, 2004.

KOTLER, P. Administração de Marketing. 12 ed. São Paulo: Prentice Hall, 2006.

KOTLER, P. Administração de marketing: a edição do novo milênio. São Paulo: Prentice Hall, 2000.

KOTLER, P.; KELLER, K.L. Administração de Marketing. A Bíblia do Marketing. 12 ed. São Paulo: Prentice Hall, 2006. 


\section{Administração: caminhos para o desenvolvimento sustentável}

LUCCHESE, T. Os comportamentos alimentares de brasileiros urbanos: identificação de uma tipologia de consumidores e análise das relações dos grupos com os alimentos. 2007. 247 p. Tese (doutorado) - Programa de Pós Graduação em Engenharia de Produção. Universidade Federal de São Carlos. São Carlos. 2007.

MALHOTRA, N. K. Pesquisa de Marketing: uma orientação aplicada. 3a edição. Porto Alegre: Bookman, 2001.

MOURA, T. L. Formatos de varejo de alimentos: um estudo sobre as preferências do consumidor. São Carlos : UFSCar, 2005. 210 p. Dissertação (Mestrado) - Universidade Federal de São Carlos, 2005.

MOWEN, J. C.; MINOR, M. S. Comportamento do Consumidor. São Paulo: Pearson Prentice-Hall, 2003.

NOVAES, A. L. Comportamento do consumo de carne bovina e hortaliças no Brasil: perfil dos consumidores. Campo Grande: Departamento de Economia e Administração, Universidade Federal de Mato Grosso do Sul, 2006, 200 p. Dissertação de Mestrado.

PINHEIRO, R. M. et al. Comportamento do consumidor e pesquisa de mercado. Rio de Janeiro: Editora FGV, 2004

ROJO, F. O comportamento do consumidor nos supermercados. Revista de administração de empresas - RAE. v. 38, n. 3, p. 16-24, Jul/set 1998.

SAMARA, B. S.; MORSCH, M. A. Comportamento do consumidor: conceitos e casos. São Paulo: Prentice Hall, 2005.

SHETH, J. N.; NEWMAN, B. I.; GROSS, B. L. Why we buy what we buy: a theory of consumption values. Journal of Business Research, v.22, p.159-170, 1991.

SHETH, J. N.; NEWMAN, B. I.; GROSS, B. L. Consumption values and predictions of market choices. Cincinnati, Southwestern, 1991.

SOLOMON, M. R. O Comportamento do Consumidor: comprando, possuindo, sendo. 5a ed. São Paulo: Bookman, 2002.

SOLOMON, M. R. O Comportamento do Consumidor: comprando, possuindo, sendo. 7ạ ed. Porto Alegre: Bookman, 2008. 


\section{Administração: caminhos para o desenvolvimento sustentável}

\section{NOTAS}

Nota 1

Ligadas ao prazer de consumir os alimentos 


\section{Capítulo 25}

\section{UTILIZAÇÃO DO MINICONTRATO DE DÓLAR FUTURO COMO FERRAMENTA PARA PROTEÇÃO DAS FLUTUAÇÕES CAMBIAIS EM EMPRESAS DE PEQUENO PORTE}

DOI: $10.37423 / 200300422$

Livio Marcel Queji, UEPG, Brasil, Iqueji@gmail.com

Gedeon Farias, UERG, Brasil,gedeon_gf@hotmail.com

Joselton José de Almejida Rocha, UEPG, Brasil, joseltonrocha@gmail.com

Carlos Ubiratan da Costa Schier, UEPG, Brasil, ubiratansqhier@hotmail.com

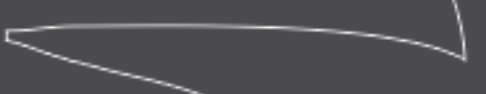

Cesar Eduardo Abud Limas, UEPG, Brasil, cesar.adm.uepg@gmail.com

Resumo: o objetivo principal deste estudo é avaliar se seria viável a utilização do minicontrato de dólar futuro como ferramenta para proteger 6 capital de gifa de pequenos empreendimentos locais, que estejàm sujeitos às flutuacóes do dólar comerc al. Para isso, foi desenvolvida pela equipe de pesquisa deste estudo, uma estratégia de hedge cambial, para atender as características específicas de pequenos empreendimentos, que pela natureza de suas atividades, sofrem com as flutuações da mbedá americana. A ideia também é validar uma estratégia de hedge cambial que-seja simpless e qué possa ser aprendida e implementada pelos próprios empreendederes. Consegtindo se proteger das flutuações cambials, esses empreendimentor estabelecem uma vantagem competitiva sustentávêt diante de seus concorrentes.

Palavras-chave: Mercados Futuros; Hedge Cambial; Minicontrato de Dólar Futuro. 


\section{Administração: caminhos para o desenvolvimento sustentável}

\section{INTRODUÇÃO}

A motivação para desenvolver esse artigo nasceu no decorrer das aulas da disciplina de Mercado de Capitais, ministrada na 4a série do Curso de Administração com Linha de Formação em Comércio Exterior da Universidade Estadual de Ponta Grossa. Durante o desenvolvimento dos conteúdos programáticos relacionados aos derivativos financeiros de câmbio, mas especificamente nos fundamentos e aplicações do derivativo de dólar futuro, surgiu entre alguns acadêmicos questionamentos sobre como aplicar na prática, mais especificamente em pequenos empreendimentos que as flutuações cambiais do dólar afetam a dinâmica de suas negociações.

Diante dos questionamentos da classe, foi proposto inicialmente uma reflexão sobre como o dólar afeta nossas vidas. Realizar o exercício mental simples de olhar a nosso redor e perceber o número de itens em nosso cotidiano que são importados ou possuem componentes importados, logo percebe-se que a globalização chegou definitivamente em sua vida. Deste raciocínio vem a problemática de perceber que, uma vez que sua vida está tão atrelada ao dólar, porque você trabalha e recebe seu salário em reais, que atualmente é uma moeda economicamente fraca, e se você está seguindo o raciocínio, vai notar que gasta boa parte de seus ganhos em produtos vinculados a uma moeda economicamente mais forte.

Agora vamos trazer essa problemática para os pequenos empreendimentos ao nosso redor. Uma pequena revenda de produtos de informática com abrangência local, uma farmácia de manipulação de medicamentos, uma revenda de suplementos esportivos. Esses exemplos entre outros, foram citados pelos alunos em sala de aula, como sendo empreendimentos locais afetados diretamente pelas flutuações cambiais da moeda americana.

Assim, esses três segmentos empresariais citados anteriormente, por terem seus empreendedores uma proximidade com alguns de nossos alunos, foram nosso laboratório para o desenvolvimento do presente estudo.

Desta forma, podemos formular a seguinte questão problema para balizar o desenvolvimento do estudo em tela: "Seria viável a utilização do minicontrato de dólar futuro como ferramenta para proteger o capital de giro destes pequenos empreendimentos locais que estão sujeitos às flutuações do dólar?" 


\section{Administração: caminhos para o desenvolvimento sustentável}

Para atingir a resposta para essa questão problema, iremos através dos procedimentos metodológicos descritos abaixo e norteados pelos conceitos de derivativos financeiros, mercados futuros, contrato de dólar futuro e hedge cambial, desenvolvidos no referencial teórico deste trabalho, verificar a viabilidade da utilização do minicontrato de dólar futuro como ferramenta capaz de minimizar os efeitos das flutuações cambiais do dólar no capital de giro dessas empresas.

\section{PROCEDIMENTOS METODOLÓGICOS}

Para pautar este estudo na cientificidade empregou-se os seguintes métodos de pesquisa.

Quanto a natureza a pesquisa é aplicada. Nessa perspectiva Silva (2001) comenta que a pesquisa aplicada tem como motivação básica a solução de problemas concretos ou de aplicação prática que é justamente o que busca o presente estudo.

Quanto aos objetivos a pesquisa é exploratória. Para Gil (2007) a pesquisa nessa modalidade deve explorar a realidade buscando conhecimento, para que em seguida possa descrevê-lo. O cunho exploratório balizou toda a pesquisa realizada no presente estudo.

Para Richardson (2007) classifica-se como qualitativa, do ponto de vista da forma de abordagem do problema, considerando que não podemos traduzir em números um vínculo entre o mundo objetivo e a subjetividade do sujeito, portanto não requer uso de métodos e técnicas estatísticas ou determinação de amostragens significativas.

Silva (2001) coloca que utilizando de material já publicado, os procedimentos técnicos assumirão a classificação de pesquisa bibliográfica. Também envolve aspecto de estudo de múltiplos casos, envolvendo o estudo aprofundado de um objeto que permitirá seu detalhado conhecimento.

\section{DERIVATIVOS}

Pode-se dizer que o mercado de derivativos é utilizado pelas instituições financeiras e empresas com diferentes finalidades, proteção e especulação são as principais. A importância dos derivativos é buscar equilíbrio e gerenciamento de risco das instituições financeiras e empresas. Neste contexto, para Molero e Mello (2018) possibilita as instituições financeiras e empresas a se proteger contra grandes variações nos preços. Fica evidente, diante desse quadro que é preciso manter o equilíbrio financeiro determinando uma estratégia para maximizar o gerenciamento de risco. 


\section{Administração: caminhos para o desenvolvimento sustentável}

Conforme verificado por Pina (2009), o valor do preço dos derivativos depende do valor do ativo origem. Fica claro que o papel fundamental dos derivativos é promover operações com pouco capital de forma alavancada em suas operações. O mais interessante, contudo, é constatar que existem diferentes agente que participam desse mercado como: hedgers, especuladores, arbitradores e os market makers. Sob essa ótima, os derivativos ganham particular relevância devido sua ampla utilização e aplicação, normalmente possuem elevada liquidez por serem muito negociados, fator esse que atraem diversos profissionais de mercado.

Como foi explicado acima é interessante, aliás, afirmar que os derivativos protegem as empresas que estão sujeita as variações no câmbio como as empresas importadoras e exportadoras de grandes oscilações, mas há um fato que se sobrepõe como a versatilidade dos derivativos. Mesmo assim não parece haver razão para discordar que esses fatores são aspectos essencial dos derivativos.

Para Neto (2000), os derivativos permitem passar o risco de um agente para outro. O autor deixa claro, a melhor maneira de compreender esse processo é considerar que os derivativos protegem contra grandes alterações nos preços dos ativos, possibilitando proteção a grandes variações e com isso garantindo um melhor gerenciamento de risco das instituições e empresas. Sob essa ótica, ganha particular relevância que o mercado de derivativos no Brasil é coordenado pela Bolsa de Mercadorias \& Futuros (BM\&F) que garante as operações estabelecendo a livre formação dos preços.

Ora em tese, mesmo sendo autores diferentes citados acima, percebemos as mesmas ideias. Caso contrário, teríamos divergência sobre o conceito de derivativos. Segundo Pina (2009, p.16), "os derivativos podem ser divididos em contratos futuros, contratos a termo, contratos de opções e contratos de swaps". Conforme mencionado pelo autor essa flexibilidade faz esse mercado ser utilizado amplamente em diferentes circunstâncias.

É interessante, observar o tamanho que o mercado de derivativos se tornou. Conforme esclarecido acima esse mercado é enorme devido a alavancagem e possui diferentes objetivos moldando-se a necessidade de seus participantes. Podemos falar, por exemplo, os hedgers, especuladores, arbitradores e os market makers. Essa, porém, é uma atividade usada pelas empresas e instituições financeiras.

Sanvicente (2003) explica que um derivativo está estreitamente relacionado ao ativo que Ihe deu origem, um exemplo seria um contrato futuro de câmbio (reais por dólares americanos) que é um 


\section{Administração: caminhos para o desenvolvimento sustentável}

derivativo porque o preço do contrato varia com a flutuação da taxa de câmbio entre o real e o dólar americano.

O autor deixa claro na citação que os derivativos se originam de um ativo origem. É o motivo pelo qual é importante frisar esse ponto, uma vez que, esses derivativos podem ser utilizados como proteção a variações cambiais, instituições financeiras e empresas. Portanto, uma característica dos derivativos é que sua oscilação depende do ativo ao qual está relacionado.

Diante desses fatos alguns questionamentos se evidenciam: Qual a função dos derivativos? Quais os agentes envolvidos nesse mercado? Por que as instituições e empresas utilizam os derivativos? A função dos derivativos é muito ampla e envolve basicamente quatro agentes, cada um com objetivo diferente. Os hedges utilizados como proteção a variações nos preços, especuladores buscando obter lucro com a variação dos preços, arbitradores buscando lucro em distorções nos preços em diferentes mercados, market makers disponibilizando liquidez para o mercado. As instituições financeiras e empresas utilizam como proteção otimizando seu gerenciamento de risco com pouco capital devido à grande alavancagem desse mercado.

\section{MERCADOS FUTUROS}

Os mercados futuros nasceram da necessidade dos produtores e comerciantes como uma forma de garantir os preços futuro de seus produtos. Segundo Neto (2000, p. 318) " uma operação de mercado futuro envolve basicamente um compromisso de compra ou venda de determinado ativo em certa data futura, sendo previamente fixado o preço objeto da negociação".

Como bem nos assegura Fonseca (2009), tem evidências que o mercado futuro nasceu na Idade Média pela necessidade de agricultores, produtores e comerciantes garantirem seus preços através do mercado futuro. O mais importante, contudo, é constatar que o mercado futuro possibilita a manutenção do risco com pouco capital, devido esse mercado ser bastante alavancado. Ora nesse sentido, o mercado futuro é mais volátil comparado ao mercado de ações.

Para muitos os mercados futuros é meramente uma palavra bonita e não relacionam com os resultados que podem obter com gerenciamento de risco. Geralmente é esquecido pelas pequenas e médias empresas, isso é um fator constituinte para a falência delas. A melhor maneira de entender o mercado futuro é considerar que ele é muito utilizado para o gerenciamento de risco. 


\section{Administração: caminhos para o desenvolvimento sustentável}

Cavalcante, Misumi e Rudge (2009) colocam que o mercado de futuros foi concebido para aqueles que procuram proteger sua produção ou produtos de baixas inesperadas no preço, assim como, consumidores também aproveitam para garantir preços na época da entressafra. $O$ autor ainda destaca uma terceira figura, que teria a função de unir e dar liquidez para o mercado, essa figura é o especulador.

Cavalcante, Misumi e Rudge (2009) explicam que a grande vantagem em operar o mercado futuros é justamente não necessitar de todo valor de referência de um contrato e sim uma fração desse, chamado de margem de garantia. Como é possível alavancagem de recursos o mercado de futuros atrai o interesse de especuladores.

Sendo assim, habitualmente, as empresas e instituições financeiras atuam no mercado futuro como uma forma de manutenção do gerenciamento de risco. Dessa forma, os mercados futuros contribuem de forma imprescindível para solução de problemas relacionada ao gerenciamento de risco. A vantagem desse mercado é alinhar proteção de grandes volumes financeiros com pouco capital de empresas e instituições financeiras.

\section{DÓLAR FUTURO}

O dólar futuro é um acordo de compra e venda de contratos futuros da moeda americana. Os contratos futuros de dólar são utilizados como proteção ou especulação, a respeito do preço da moeda em data futura. Nesse contexto, estão sujeitas as variações nos preços os importadores e exportadores.

Como bem nos assegura Junior (1995), pode-se dizer que o mercado de dólar futuro, possibilita transferir risco em relação a variação no câmbio. Não é exagero afirmar que os importadores e exportadores estão sujeitos as variações cambiais em suas atividades, e podem comprometer suas finanças com a variação do dólar. Desta maneira, é possível gerenciar o risco comprando/vendendo dólar fazendo hedge.

O dólar é influenciado tanto pelo mercado interno quanto externo, nesse sentido é caracterizado como difícil de prever sua direção, pois está associado a inúmeros fatores como a conjuntura economia e política. Conforme explicado acima, empresas com pagamentos ou recebimento em dólar estão expostos as variações, e por todas essas razões fazem hedge para minimizar os riscos. 


\section{Administração: caminhos para o desenvolvimento sustentável}

Fulgêncio (2006) argumenta que o dólar futuro se refere a cotação esperada pelo mercado financeiro do valor do dólar, no futuro. Ao comprar o dólar futuro o participante do mercado está garantindo o valor que pagará pelo dólar no futuro, desta forma minimizando seu risco e ficando a salvo das variações do mercado, pois passa a saber o valor que pagará no futuro pelo dólar.

Portanto, o dólar futuro possibilita investidores que fazem hedge a se proteger contra grandes variações nos preços. A vantagem desta abordagem é dar liberdade aos importadores e exportadores se protegerem contra variações do dólar com pouco capital, devido a alavancagem desse mercado, tornando desnecessário um grande comprometimento de elevado capital para o gerenciamento de risco.

\section{HEDGE CAMBIAL}

Hedge é um processo utilizado pelas instituições financeiras e empresas como forma de proteção e assegurar o equilíbrio financeiro. Segundo Pina (2009) a importância do hedge é buscar equilibrar os riscos associado a essas variáveis de modo a melhorar o gerenciamento de risco.

Corrêa e Raíces (2005) explicam que hedgear significa tomar uma posição oposta à sua exposição no mercado à vista. Ou seja, se você é um produtor, vai vender a mercadoria porque você é detentor da mercadoria física; diz-se que você está comprado naquela mercadoria. Se for um minerador, vai vender ouro. Já se for um ourives, vai comprar ouro. Seguindo o mesmo raciocínio, se você representar uma indústria de esmagamento de soja, vai comprar soja. Ao hedgear, tomando uma posição contrária à natural em sua origem, neutralizará as mudanças de preços da mercadoria de seu interesse no mercado à vista.

Os autores deixam claro que o hedge anula as possíveis perdas contra as oscilações das posições no mercado a vista. A melhor maneira de entender esse procedimento é compreender que os agentes procuram se defender das possíveis oscilações bruscas dos ativos, porque buscam um gerenciamento de risco que opere de forma eficiente no longo prazo.

A ausência desse conhecimento básico do significado do hedge e a sua aplicação adequada, pode ocasionar enormes perdas financeiras diante de grandes oscilações nos preços. Sendo assim, o hedge pode ser aplicado no mercado futuro como proteção. 


\section{Administração: caminhos para o desenvolvimento sustentável}

Hull (2016) explica que o objetivo é usar os mercados futuros para reduzir um risco específico que enfrentam. Esse risco pode estar relacionado a flutuações no preço do petróleo, uma taxa de câmbio, o nível da bolsa de valores ou alguma outra variável. Os hedges perfeitos são raros. Em sua maior parte, portanto, um estudo sobre o hedge usando contratos futuros é um estudo das maneiras de construir hedge de modo que seu desempenho se aproxime ao máximo da perfeição.

Ora, em tese, mesmo os autores citados acima serem em anos diferentes nas publicações, percebemos as mesmas ideais. Senão, aliás, teríamos discordância sobre hedge. Portanto esses autores convergem na definição de que o hedge se trata de operações financeiras realizadas por diferentes agentes com intuito de gerenciar o risco.

Segundo Yo (1984) o hedge limita os ganhos de operações comerciais, porém ao mesmo tempo protege contra prejuízos na comercialização e possibilita a concretização do empreendimento comercial. Pode-se dizer que, por exemplo, o hedge é vastamente utilizado pelos agentes, pois estes não querem estar exposto a variações nos preços, isso porque podem causar grandes prejuízos. Sob essa ótica, ganha particular relevância que as variações nos preços são frequentes em uma economia. Por isso, cabe aos agentes fazer hedge para gerenciar o risco.

O hedge constitui um método usado pelos agentes econômicos para proteger-se das variações nos preços as quais eles não podem prever. Fica evidente, diante desse processo que para uma operação bem-sucedida os agentes precisam saber executar o hedge.

São os agentes econômicos que procuram proteger-se dos riscos inerentes a suas operações financeiras ou transações econômicas. Atuam no mercado fixando (travando) os termos de troca (tomando determinada posição futura) e transferindo os riscos para terceiros, especuladores. Ishikawa (2003) reforça a ideia de proteção, como uma forma de proteger a saúde financeira dos negócios das flutuações de preço inesperadas. Em poucas palavras, visam à administração do risco.

O entendimento do mercado de hedge com relação ao gerenciamento de risco, possibilita as instituições financeiras e empresas a se protegerem contra grandes variações nos preços. $\mathrm{O}$ autor deixa claro que se trata da manutenção da saúde financeira possibilitando que os agentes envolvidos possam estar tranquilos que o preço do seu bem-estará garantido no futuro. Dito isso, hedge aplicado da maneira correta, proporciona a manutenção do sistema financeiro. Dessa forma, o hedge diminui os ganhos financeiros, porém garante um ótimo gerenciamento de risco. 


\section{Administração: caminhos para o desenvolvimento sustentável}

\section{ESTUDO DE MÚLTIPLOS CASOS}

Considerando o caso das empresas listadas na introdução deste estudo, dimensionou-se a quantidade de capital de giro de cada uma delas, exposto as flutuações do dólar. A revenda de Produtos de Informática levantou a necessidade de realizar proteção em $\mathrm{R} \$ 70.000,00$, a Farmácia de Manipulação em $\mathrm{R} \$ 110.000,00$ e a revenda de Suplementos Esportivos em $\mathrm{R} \$ 35.000,00$. Essa informação foi levantada diretamente com a direção de cada uma das empresas no final de novembro de 2018.

O passo seguinte foi determinar a data de início da aplicação da estratégia de hedge cambial para as empresas, que foi acordado para iniciar em janeiro de 2019. O mês de dezembro foi dedicado a atividade de cadastramento das empresas a uma sociedade corretora de valores ligada a Bolsa de Valores Brasileira a "B3". A corretora de valores é a instituição que intermedia as operações entre a Bolsa de Valores e os participantes do mercado de capitais. Fornecendo aos participantes as ferramentas necessárias para a realização das operações nos diversos produtos oferecidos pela Bolsa de Valores.

Com o valor a ser protegido determinado, cadastro em uma sociedade corretora realizado com sucesso, inclusive com a negociação de comissões e taxas condizentes a finalidade da contratação dos serviços, chega a hora de determinar a estratégia operacional a ser utilizada.

\subsection{ESTRATÉGIA UTILIZADA}

A determinação da estratégia em detalhes é fundamental para que se alcance o efeito desejado. Para as grandes instituições financeiras que atuam em nosso país, bem como para as grandes empresas importadoras e exportadoras, a estratégia de hedge cambial é realizada por profissionais altamente capacitados de grandes mesas de operações, tais como: Itaú, BTG Pactual, GP Morgan, UBS entre outras.

Mas a ideia aqui, é que a própria empresa possa executar as operações de hedge cambial e assim, proteger seu capital de giro das flutuações do dólar. Pois a contratação dos serviços de hedge cambial em uma grande instituição financeira, pelo elevado valor cobrado pelos serviços, tornaria inviável a operação para o montante de capital de giro desses pequenos empreendimentos. Nessa fase de elaboração da estratégia foi importante contar com o conhecimento e experiência profissional de toda a equipe que se debruçou sobre esse desafio. 


\section{Administração: caminhos para o desenvolvimento sustentável}

O produto que será o instrumento financeiro negociado para se atingir o objetivo proposto pelo trabalho é o minicontrato de dólar futuro. Um minicontrato de dólar futuro representa U\$10.000,00 e seu código de negociação é o WDO, seguido pela letra que representa o mês de vencimento do contrato e o ano vigente. Um exemplo seria o WDOG19 que representa o código do minicontrato de dólar futuro referente ao mês de fevereiro de 2019. A troca de contratos ocorre no último dia de cada mês, onde encerra-se um contrato e inicia-se o novo contrato, chamado pelos operadores de "dia de rolagem dos contratos".

A cotação do WDO utiliza a mesma forma do chamado "contrato padrão de dólar futuro" o DOL. Que em suma seria pegar a forma da cotação do Dólar Comercial e multiplicá-la por mil. Dito isso, o DOL e o WDO referentes ao valor do Dólar Comercial cotado em $\mathrm{R} \$ 3,70$ seriam de $\mathrm{R} \$ 3.700,00$. A mínima variação nesse modelo de cotação do dólar futuro ocorre de $R \$ 0,50$ em $R \$ 0,50$. Assim temos, uma sequência de cotações seguindo o seguinte formato: $R \$ 3.700,00-R \$ 3.700,50-R \$ 3.701,00$ e $R \$$ 3.701,50. A variação de $R \$ 0,50$ é a mínima variação desse derivativo e é conhecida como um tick, já a variação de $R \$ 1,00$ que equivale a dois ticks é conhecida como 1 ponto de dólar futuro.

A utilização de um exemplo tornará mais fácil o entendimento do funcionamento e da dinâmica do WDO. Supondo a compra de um contrato de WDO na cotação de $R \$ 3.703,00$ e a venda a $R \$ 3.703,50$ o ganho seria de um tick de WDO, que resultaria em um valor financeiro de $\mathrm{R} \$ 5,00$. Agora, se a operação fosse a compra de um WDO a R\$ 3.703,00 com venda a $\mathrm{R} \$ 3.705,00$ o ganho seria de quatro ticks ou dois pontos de dólar futuro, resultando em um ganho de $\mathrm{R} \$ 20,00$.

Cabe ressaltar nesse momento, que em virtude de as empresas objeto do estudo serem afetadas pela alta da moeda americana, foram realizadas operações basicamente de compra. Porém, se a queda no valor da moeda americana fosse a premissa a ser considerada, as operações não seriam de compra, mas sim de venda. Entendendo como operação de venda aquela que é iniciada com uma ordem de venda e que é encerrada através de uma ordem de compra e para que a operação gere um resultado positivo o mercado deve cair.

Então, vamos considerar o seguinte exemplo, a realização de uma venda do contrato de WDO em R\$ $3.705,00$ e a compra a $R \$ 3.703,00$, essa operação resultaria em um ganho de $R \$ 20,00$, referente aos 4 ticks. Resumindo, quando operamos comprados no WDO o mercado tem que subir para gerar ganhos e quando atuamos vendidos no WDO o mercado deve cair para gerar ganhos, ou seja, 


\section{Administração: caminhos para o desenvolvimento sustentável}

operações compradas visam a obtenção de ganhos com a alta do dólar futuro e as operações vendidas visam a obtenção de lucro com a baixa do dólar futuro.

A estratégia para a entrada nas operações de hedge cambial foi desenvolvida pela própria equipe de pesquisa do presente estudo, levando em consideração as necessidades e características específicas das empresas estudadas.

Primeiramente foi estabelecido as regiões de preços que quando ultrapassadas ou rompidas acionam a entrada na operação comprada no WDO, essas regiões são os números redondos, conhecido no mercado pelos operadores de mesa como "bola bola" por terminarem em dois zeros, tais como: 3.700, $3.800,3900$, assim por diante.

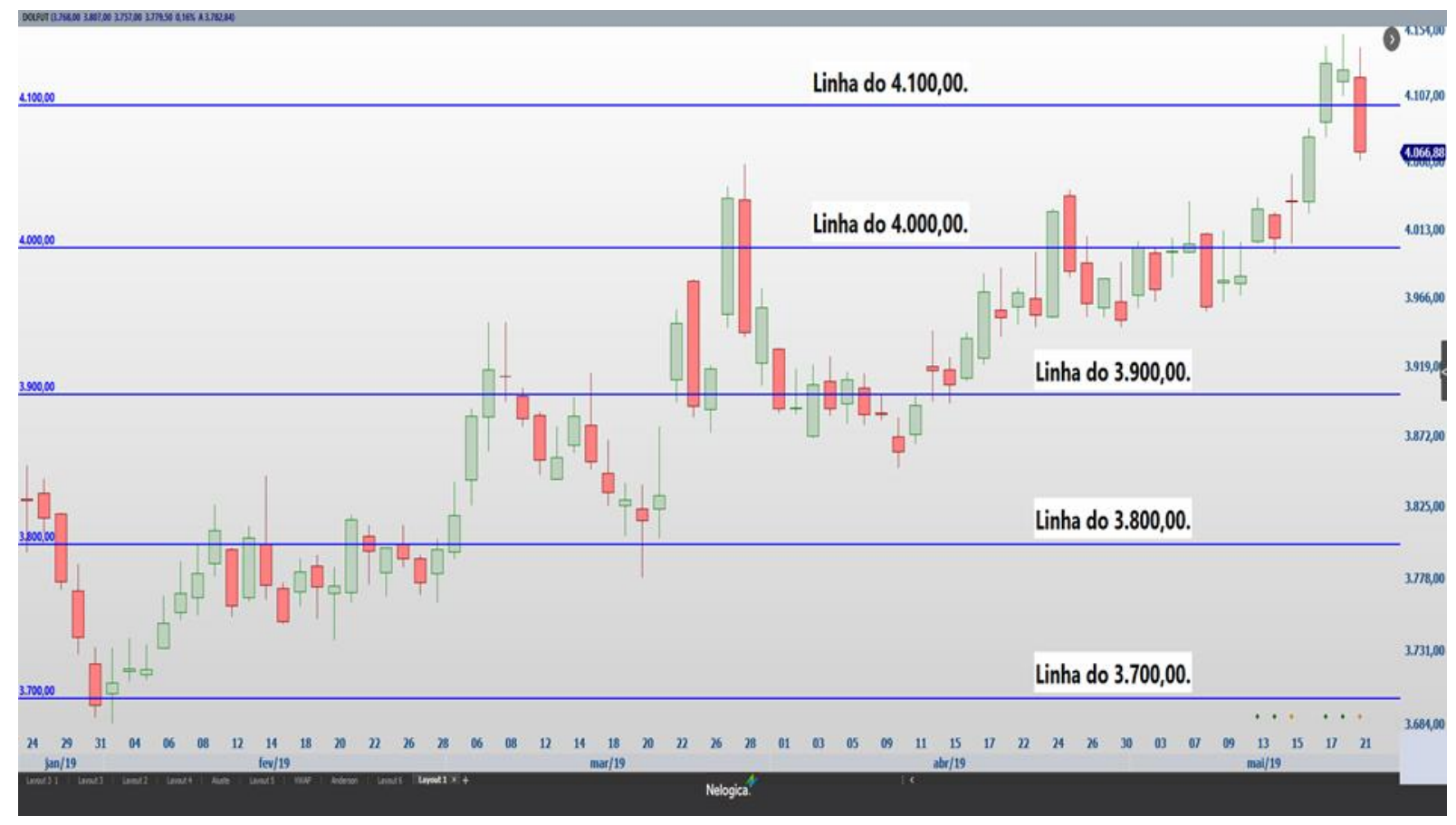

Figura 1 - Gráfico diário da flutuação do dólar futuro de janeiro a maio de 2019

O gráfico acima refere-se à variação do dólar futuro no período de janeiro a maio de 2019, período em que o estudo foi realizado, nele podemos observar as linhas marcando as regiões de preço que se rompidas de baixo para cima acionam a operação de hedge cambial. Como no mês de janeiro de 2019 o dólar futuro apenas caiu, não acionou nenhum sinal de compra.

A estratégia foi concebida com a intenção, de que cada vez que o dólar futuro apresentar um movimento de queda mais acentuado, irá gerar uma oportunidade de realizar uma operação de 


\section{Administração: caminhos para o desenvolvimento sustentável}

proteção em um patamar de preço mais baixo, o que seria mais vantajoso caso o dólar voltasse a apresentar movimentos de alta mais fortes.

Considera-se um exemplo em que uma empresa entra realizando a operação de hedge cambial na região de preço de $\mathrm{R} \$ 3.800,00$, porém passados alguns dias os preços caem abaixo da região de $\mathrm{R} \$$ 3.800,00. O limite para a manutenção da posição comprada em $R \$ 3.800,00$ e de $R \$ 3.780,00$, ou seja, 20 pontos de dólar futuro. Atingido o valor abaixo de $\mathrm{R} \$ 3.780,00$ a posição é encerrada. Assim, sempre que uma posição comprada não evolui, e volta 20 pontos de dólar futuro do seu ponto de entrada, ela é encerrada ou no jargão de mercado "estopada". Retomando o raciocínio, o dólar futuro realiza um movimento de queda e chega a $\mathrm{R} \$ 3.575,00$, onde entra pressão compradora e o dólar futuro retoma o movimento ascendente e ao ultrapassar a região do $\mathrm{R} \$ 3.600,00$ a posição de hedge cambial é retomada. Da mesma maneira, agora a posição de hedge cambial que estava em $\mathrm{R} \$ 3.800,00$ passa a estar no patamar de $\mathrm{R} \$ 3.600,00$, melhorando assim a posição comprada.

No andamento do estudo será descrito as operações realizadas pelas empresas participantes, no decorrer do período de observação de janeiro a maio de 2019.

\subsection{ANDAMENTO DAS OPERAÇÕES REALIZADAS}

No dia 31 de janeiro de 2019 o Dólar Futuro fecha o pregão em $R \$ 3.695,50$, fica assim a expectativa de que se o valor da cotação ultrapassar a região de preço do $\mathrm{R} \$ 3.700,00$ será acionada a operação de hedge cambial.

Em 1ㅇ de fevereiro de 2019 o dólar futuro abre em $\mathrm{R} \$ 3.700,00$ e rapidamente cai até $\mathrm{R} \$ 3.684,50$. Durante o pregão o preço retorna até a região do $\mathrm{R} \$ 3.700,00$ e aciona a entrada na operação de hedge para as três empresas. Realizada a entrada, o preço avança até $\mathrm{R} \$ 3.733,00$ onde marca a máxima do dia e na sequência retorna até $R \$ 3.710,50$ onde fecha as negociações do dia.

No dia 11 de fevereiro o dólar futuro rompe a região de preços do $\mathrm{R} \$ 3.800,00$ e chega a fazer máxima do dia em $R \$ 3.826,50$. Neste momento as empresas estavam ganhando $R \$ 1.260,00$ por minicontrato de dólar futuro comprado, dinheiro que após a realização do "ajuste diário", no final do dia, já se encontrava a disposição das empresas na conta da corretora.

Em 27 de março o dólar futuro ultrapassa a região do $\mathrm{R} \$ 4.000,00$, fazendo máxima neste mesmo dia a $R \$ 4.042,00$ e fechando o pregão a $R \$ 4.034,50$. Neste dia a operação de hedge cambial iniciada em 


\section{Administração: caminhos para o desenvolvimento sustentável}

10 de fevereiro de 2019 já acumulava um ganho de 334,50 pontos de dólar futuro por minicontrato, resultando em um financeiro de $\mathrm{R} \$ 3.345,00$ por contrato.

Já próximo ao fechamento do estudo, no dia 20 de maio de 2019 o dólar futuro faz a máxima do ano em $R \$ 4.151,00$ e quando fechamos o estudo em 27 de maio, o fechamento do dólar futuro ficou em $\mathrm{R} \$ 4.068,50$. Valor esse que será usado para a realização dos cálculos para avaliar a viabilidade da utilização da estratégia de hedge cambial com a utilização do minicontrato de dólar.

\subsection{RESULTADOS OBTIDOS}

A revenda de Produtos de Informática apontou a necessidade de proteção de $\mathrm{R} \$ \mathbf{7 0 . 0 0 0 , 0 0}$ do seu capital de giro, sugerimos assim, a época da realização da operação de hedge cambial, a compra de 2 mini contratos de dólar futuro no valor de $\mathrm{R} \$ 3.700,00$ o que permitiu a proteção efetiva de $\mathrm{R} \$$ 74.000,00, que obtém-se multiplicando o valor do dólar comercial de $\mathrm{R} \$ 3,70$ de 1 으 de fevereiro de 2019 por U\$ $10.000,00$ o que resulta em um hedge de $\mathrm{R} \$ 37.000,00$ por minicontrato de dólar. Neste caso, o valor do hedge para a empresa foi de $\mathrm{R} \$ 74.000,00$ efetivamente. Em resumo, na data de 27

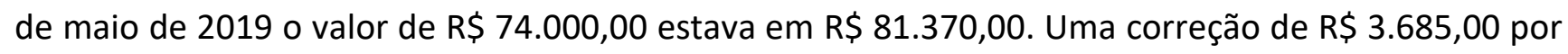
contrato, como foram 2 contratos a correção totalizou $\mathrm{R} \$ 7.370,00$.

A revenda de Suplementos Esportivos que gostaria de proteger $\mathrm{R} \$ 35.000,00$ do seu capital de giro, realizou a operação de hedge cambial com 1 minicontrato de dólar futuro. O que resultou no dia 27 de maio de 2019, em um capital de giro corrigido de $\mathrm{R} \$ 38.685,00$.

A Farmácia de Manipulação que possui o maior montante sujeito a perda de valor pela alta do dólar comercial, realizou a operação de hedge cambial com 3 minicontratos, resultando em uma correção de $\mathrm{R} \$ 3.685,00$ por contrato, passando assim de um total de $\mathrm{R} \$ 110.000,00$ inicial para $\mathrm{R} \$ 120.917,00$.

Para a realizar as operações acima descritas as empresas tiveram que depositar na sua conta operacional na corretora de valores escolhida uma margem de garantia de $\mathrm{R} \$ 1.750,00$ por contrato. Segundo Araújo (2017) a margem de garantia que representa apenas um pequeno percentual do valor do contrato futuro, no nosso caso seria de $\mathrm{R} \$ 1.750,00$ para um minicontrato de dólar futuro de U\$ $10.000,00$, que tem como objetivo de garantir o cumprimento do contrato futuro. Esse valor fica em custódia da bolsa de valores no período em que o cliente, comprado ou vendido, estiver com o contrato em aberto. Encerrada a posição o valor retorna a conta do cliente. 


\section{Administração: caminhos para o desenvolvimento sustentável}

Outro valor necessário para viabilidade das operações de hedge cambial é um depósito em conta para fazer frente a possíveis ajustes negativos, no caso, cada uma das empresas precisou deixar o valor de R\$ 1.200,00, valor sugerido pela equipe do estudo. Araújo (2017, pg. 82) explica que "o ajuste diário é pago pelos participantes do contrato futuro toda vez que houver uma diferença no preço de fechamento de um dia para o outro".

Considerando dois participantes, por exemplo, um abre uma posição comprada e o outro uma posição vendida em $\mathrm{R} \$ 3.750,00$ e o valor do ajuste de $\mathrm{R} \$ 3.753,00$. O participante comprado receberá um ajuste diário de 3 pontos de dólar futuro creditado em sua conta, ao passo que o participante vendido no mesmo valor, receberá em sua conta um débito de 3 pontos, por esse motivo o mercado de futuros é conhecido como mercado de soma zero, quem ganhou recebe de quem perdeu por esse mecanismo de ajuste.

A Figura 2 refere-se a uma nota de corretagem de compra e venda de um minicontrato de dólar futuro onde podemos observar os custos incorridos pela realização da operação. Essa única operação foi realizada por um dos membros da equipe de pesquisa, justamente para essa finalidade de observarmos os custos na negociação de um único minicontrato de dólar futuro.

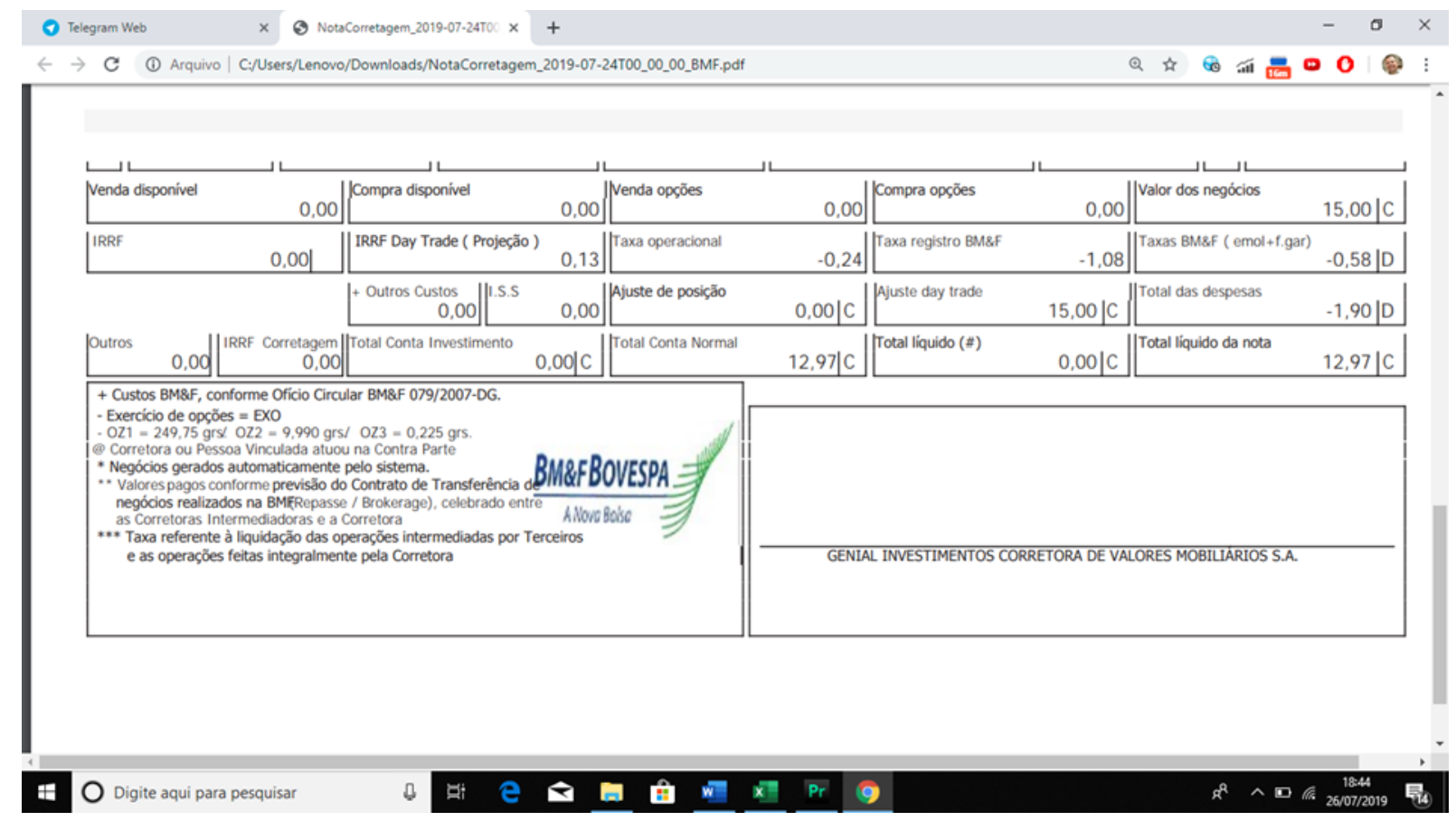

Figura 2 - Nota de corretagem de uma operação de compra e venda de WDO 


\section{Administração: caminhos para o desenvolvimento sustentável}

Nesta operação foi ganho 1,5 pontos de dólar, ou seja 3 ticks, o que resultou em um valor bruto de $\mathrm{R} \$$ 15,00, porém se fosse ganho 10 pontos de minicontrato de dólar futuro, fechando em ganho bruto de $R \$ 100,00$ e os custos pela operação de entrada e saída seriam os mesmos. Na nota temos $R \$ 0,24$ de taxa operacional, referente a $R \$ 0,12$ da corretagem de compra do WDO e R\$ 0,12 da corretagem da venda. A taxa de registro $B M \& F$ ficou em $R \$ 1,08, R \$ 0,54$ da compra e $R \$ 0,54$ da venda. Os emolumentos da BM\&F da operação realizada totalizaram $R \$ 0,58$. E o imposto de renda que aparece na nota de corretagem no valor projetado de $R \$ 0,13$, refere-se a operação "day trade" que não se aplica no caso do hedge cambial, por não se tratar de uma operação que será encerrada no mesmo dia. Para a realização da operação de hedge cambial com um minicontrato de dólar futuro o total dos custos são de R\$ 1,90, a Farmácia de Manipulação que utilizou três minicontratos de dólar futuro irá arcar com três vezes esse valor, ficando um custo de $\mathrm{R} \$ 5,70$ por operação.

\section{CONCLUSÃO}

Retornamos a questão problema inicial: "Seria viável a utilização do minicontrato de dólar futuro como ferramenta para proteger o capital de giro destes pequenos empreendimentos locais que estão sujeitos às flutuações do dólar?". Diante dos resultados obtidos, a equipe de pesquisa que realizou o estudo, bem como os empreendedores que disponibilizaram os dados de seus negócios para a realização do estudo, concordam que seria viável e estratégico para seus empreendimentos a utilização da estratégia de hedge cambial proposta.

Outro ponto que agradou os empreendedores, foi a possibilidade da execução da estratégia pela própria empresa, no caso dos três empreendimentos, foram treinados os próprios empresários para a realização das operações de hedge cambial, uma vez que o acompanhamento diário da cotação do valor do dólar comercial já se constituía em uma rotina diária, acompanhar o dólar futuro não gerou nenhum esforço adicional segundo eles.

No período de janeiro a maio de 2019, em que ocorreu o experimento, os empreendedores relataram que foi possível perceber o efeito positivo que o hedge cambial proporcionou na dinâmica das negociações, possibilitando manter o preço atrativo aos clientes e em muitos casos melhorar a margem de contribuição de alguns produtos.

Em avaliação final, os empreendedores relataram que a princípio acharam os valores destinados a "margem de garantia" e o valor destinado a possíveis "ajustes negativos" um pouco altos, porém ao 


\section{Administração: caminhos para o desenvolvimento sustentável}

entender que esses valores não são custos efetivos e sim valores que ao final da operação voltam a estar disponíveis em conta, como no caso da "margem de garantia". E que os custos efetivos são aqueles demostrados na nota de corretagem da Figura 2, lamentaram apenas não ter usado a estratégia a mais tempo.

\section{REFERÊNCIAS}

Araujo, Marcos (2017). O segredo do grão: o comércio de commodities agrícolas, Curitiba: Do Autor.

Cavalcante, F.J., Misumi, E.L., Rudje, E.F. (2009). Mercado de capitais: o que é, e como funciona, Rio de Janeiro: Elsevier Editora LTDA.

Corrêa, A., Raíces, C. L. (2005). Derivativos agrícolas, São Paulo: Globo S.A.

Fonseca, J. W.F. D. (2009). Mercado de Capitais, Curitiba: IESDE Brasil S.A.

Fulgêncio, P.C. (2006). Glossário Vade Mecum, Rio de Janeiro: Mauad Editora Ltda.

Gil, Antonio Carlos. (2007). Métodos e técnicas de pesquisa social, 5 ed. São Paulo: Atlas.

Hull, J. C. (2016). Ações, Futuros e outros Derivativos, São Paulo: Bookman Editora Ltda.

Ishikawa Filho, A. S. M. (2003). Mercado Financeiro e de Capitais, São Paulo: Atlas S.A.

Junior, A.A. Z. (1995). Taxa de Câmbio e Política Cambial no Brasil, São Paulo: Editora da USP.

Molero, L., Mello, E. E. (2018). Derivativos, Negociação e Precificação, São Paulo: Saint Paul Editora Ltda.

Neto, A. A. (2000). Mercado Financeiro, São Paulo; Editora Atlas.

Pina, M. (2009) Derivativos Financeiros, Curitiba: IESDE Brasil S.A.

Richardson, et al. (2007). Pesquisa social: métodos e técnicas, 3 ed. ver. ampl. São Paulo: Atlas S.A.

Sanvicente, A. Z. (2003). Derivativos, São Paulo: Geo-Gráfica e Editora Ltda.

Silva, Edna Lúcia da; Menezes, Estera Muskat.(2001). Metodologia da pesquisa e elaboração de dissertação, 3. ed. rev. e atual. Florianópolis: Laboratório de Ensino à Distância da UFSC.

Yo, G.T. (1984). Operadores a Termo de Mercadorias “Commodities”, São Paulo: Brasimex Ltda. 


\section{Capítulo 26}

\section{EDUCAÇÃO AMBIENTAL E COLETA SELETIVA: PERCEPÇÃO E CONSCIENTIZAÇÃO DOS DISCENTES DO CURSO DE ADMINISTRAÇÃO DA UNIVERSIDADE FEDERAL DO PIAUÍ - CAMPUS MINISTRO REIS VELLOSO}

DOI: $10.37423 / 200300426$

Elvis Rodrigutes dos Santos

Mara Águida Porfirio Moura

Kelsen Areângelo Ferreira e Silva

Resumo: Práticas Ecológicąs são mąneiras de agir visando à preservaçầ do meio/ambiente e a melhor utilização dos recursos dispọníveis, diminứndo assipn os impactos ambientais, em que a coleta seletiva de resíduos sólidos consiste ha separação de materiais-recicláveis na fonte geradora e o devido encaminhamento para reciclagem. Essa ação promove a educação ambiental, gera trabalho e renda e apresenta como consequência o hábito da separação do lixo para seur devido aproveitamento, contribuindo para a sustentabilidade urbana. Nesse sentido, of presente estudo questiona: os discentes/do Curso de Administração da Universidade Federal do Piauí - CMRY possuem entehdimento e consciência do procêssso de coleta seletiva qle lixo? Relacionado a essa questão, óbjetivo da pesquisa volta-se a identificar o níyel de entendimento e consciência dos lalunos do curso de Administraģão da UFPI- CMRV em relação à prática de coleta-sètetiva.
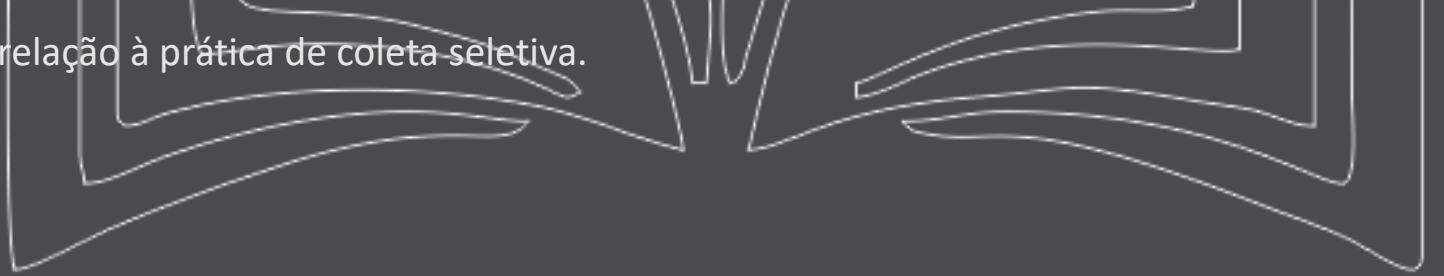


\section{Administração: caminhos para o desenvolvimento sustentável}

De acordo com a metodologia, trata-se de uma pesquisa de campo classificada como descritiva e exploratória em que foi aplicado um questionário para os acadêmicos de Administração. Concluiu-se que os interlocutores reconhecem a importância da prática da coleta seletiva para o meio ambiente e a reconhecem como um fator de diferencial a uma organização, porém, algumas vezes, falta um conhecimento mais aprofundado a respeito do assunto.

Palavras-chave: Gestão Ambiental. Educação Ambiental. Resíduos Sólidos. Coleta Seletiva. 


\section{Administração: caminhos para o desenvolvimento sustentável}

\section{INTRODUÇÃO}

Com o agravamento da problemática do lixo e seu poder de degradação do meio ambiente, viu-se a necessidade de trabalhar a conscientização da sociedade sobre os danos que o mesmo pode causar aos seres humanos, ao meio ambiente e aos animais. A coleta seletiva é definida como uma forma de separação prévia de possíveis materiais para o reaproveitamento (SANTOS, 1995).

Práticas Ecológicas são maneiras de agir visando à preservação do meio ambiente e a melhor utilização dos recursos disponíveis diminuindo assim os impactos ambientais. Dentre os problemas que agravam para a crise ambiental, notadamente em municípios de grande porte populacional, destaca-se a falta de gestão dos resíduos sólidos, a qual compromete os sistemas naturais, sociais e econômicos e a saúde do próprio homem. A implantação de um sistema de gestão de resíduos constitui uma importante estratégia para amenizar tal degradação ambiental. No entanto, na ausência de Educação Ambiental o alcance deste objetivo não será possível (SILVA, 2007). De acordo com a Lei 9.795/99,

entende-se por educação ambiental os processos por meio dos quais o indivíduo e a coletividade constroem valores sociais, conhecimentos, habilidades, atitudes e competências voltadas para a conservação do meio ambiente, bem de uso comum do povo, essencial à sadia qualidade de vida e sua sustentabilidade (LEI 9.795, 1999, art. 1ㅇ).

A inclusão da Educação Ambiental nas instituições de ensino tem o propósito de uma reestruturação da educação em direção à sustentabilidade, incentivo à gestão escolar dinâmica, estimulando a implantação dos projetos em Educação Ambiental (RUIZ, 2005).

Frente a esta problematização e tomando em vista que a consciência e colaboração do ser humano é fator primordial para a eficácia desse processo de coleta seletiva, surge a inquietação pautada no seguinte problema: Os discentes do Curso de Administração da Universidade Federal do Piauí - CMRV possuem entendimento e consciência do processo de coleta seletiva de lixo?

Para isso, o objetivo deste estudo se propõe a identificar o nível de entendimento e consciência dos alunos do curso de administração da UFPI- CMRV em relação à prática de coleta seletiva. O estudo trata-se de uma pesquisa exploratótia e descritiva com a realização de uma pesquisa de campo com a aplicação de um questionário para discentes do curso de administração da Universidade Federal do Piauí - CMRV. 


\section{Administração: caminhos para o desenvolvimento sustentável}

\section{GESTÃO AMBIENTAL}

Após a revolução industrial, os problemas como poluição das águas, do solo e do ar, a geração do lixo e outros problemas intensificaram-se. As consequências dessa poluição começaram a serem denunciadas de forma intensiva por meio de documentos oficiais, livros, reportagens e outros meios de comunicação. Com isso, os líderes políticos de diversos países iniciaram a discussão sobre como lidar e reverter os problemas ambientais (ANDRADE, 2010).

A primeira grande Conferência realizada no mundo relacionada às questões ambientais foi a Conferência de Estocolmo, na Suécia em 1972. Vinte anos após essa reunião de chefes de estado, em 1992 foi realizado no Rio de Janeiro a Conferência das Nações Unidas sobre o meio ambiente e desenvolvimento, também conhecida como Eco-92, momento em que se estabeleceram metas mundiais para a diminuição das emissões de carbono na atmosfera, além de alguns documentos como a Carta da Terra e a Agenda 21 destinadas a renovação e acompanhamento dos compromissos estabelecidos na Eco-92. No ano de 2012 foi realizada novamente no Rio de Janeiro, a Conferência Rio+20, cujos temas principais foram a economia verde e o desenvolvimento sustentável (ANDRADE, 2010).

Jabbour (2010) afirma que a adoção da gestão ambiental e o desenvolvimento de iniciativas verdes têm se tornado comum para muitas organizações, apesar dessas medidas serem frequentemente evitadas pela comunidade de negócios. Conforme Oliveira, Serra e Salgado (2010), a gestão ambiental é uma alternativa usada pelas empresas ao redor do mundo para melhorar e controlar suas atividades no sentido de poluir menos o meio ambiente, gerando economia e, consequentemente, um aumento de competitividade como resultado do processo de modernização, redução de desperdícios, emissões de resíduos e número de multas.

Ao invés de destinar o lixo para a coleta de lixo comum, pode-se iniciar um processo de reaproveitamento do papel para recados ou rascunhos, impressão de documentos nas duas páginas da folha e reciclagem. Esse tipo de modificação na utilização do papel gerará economia, pois, a empresa terá menores gastos nas compras de materiais de escritório, irá gerar menos lixo e ainda poderá vender o papel da coleta seletiva. Para o ambiente, os recursos água, energia elétrica e extração de madeira serão poupados, contribuindo com a sustentabilidade ambiental (ANDRADE, 2010). 


\section{Administração: caminhos para o desenvolvimento sustentável}

A Coleta seletiva deve ser vista como uma corrente de três elos: Destinação, Logística e Educação Ambiental. Caso um desses não seja planejado, a tendência é o programa de coleta seletiva não permanecer. O planejamento necessita ocorrer do fim para o começo da cadeia, ou seja, primeiro pensar em qual será a destinação, depois a logística e por fim o programa de educação ambiental cuja proposta resgata a necessidade de participação da sociedade para uma solução conjunta na solução dos problemas ambientais, harmonizando as ações humanas em relação à sua própria espécie e aos demais seres do planeta. A inclusão da Educação Ambiental nas instituições de ensino tem o propósito de uma reestruturação da educação em direção à sustentabilidade, incentivo à gestão escolar dinâmica, estimulando a implantação dos projetos em Educação Ambiental (RUIZ, 2005).

\subsection{COLETA SELETIVA}

A coleta seletiva é um sistema de recolhimento de materiais recicláveis: papéis, plásticos, vidros, metais e orgânicos, previamente separados na fonte geradora e que podem ser reutilizados ou reciclados. A coleta seletiva funciona, também, como um processo de educação ambiental na medida em que sensibiliza a comunidade sobre os problemas do desperdício de recursos naturais e da poluição causada pelo lixo. É o processo de transformação de um material, cuja primeira utilidade terminou, em outro produto. Por exemplo: transformar o plástico da garrafa PET em cerdas de vassoura ou fibras para moletom. Assim, gera economia de matérias-primas, água e energia, é menos poluente e alivia os aterros sanitários, cuja vida útil é aumentada, poupando espaços preciosos da cidade que poderiam ser usados para outros fins como parques, casas, hospitais, etc. (COELHO, 2013).

Segundo o IBGE (2014), a coleta seletiva destina-se promoção da educação ambiental, gera trabalho e renda e apresenta como consequência o hábito da separação do lixo para seu devido aproveitamento, contribuindo para a sustentabilidade urbana.

As vantagens proporcionadas pela implantação dos programas de coleta seletiva são: redução de custos com a disposição final do lixo em aterros sanitários ou incineradores trazendo como consequência o aumento da vida útil de aterros sanitários; diminuição de gastos com remediação de áreas ocupadas por lixões clandestinos; educação e conscientização ambiental da população, o que acarreta diminuição de gastos gerais com limpeza e melhoria das condições ambientais e de saúde (CEMPRE, 2014). Nesse sentido, em geral se adotada a filosofia comumente condensada sob a denominação três R's, que significa: Reduzir, Reutilizar e Reciclar. Os 3R's para controle do lixo são Reduzir, Reutilizar e Reciclar. Reduzindo e reutilizando se evitará que maiores quantidades de 


\section{Administração: caminhos para o desenvolvimento sustentável}

produtos se transformem em lixo. Reciclando se prolonga a utilidade de recursos naturais, além de reduzir o volume de lixo (BONELLI, 2005).

Em particular, as universidades são grandes geradoras de resíduos sólidos domésticos, químicos, de serviços de saúde, industriais, em quantidades e características variadas. Nos órgãos e entidades da administração pública federal direta e indireta do Brasil a publicação do Decreto no 5.940, em 2006, pelo governo federal instituiu a separação, na fonte geradora, dos resíduos recicláveis descartados e a sua destinação às associações e cooperativas dos catadores de materiais recicláveis. Em instituições de ensino públicas e privadas, segundo De Conto et al. (2010), as iniciativas partem dos professores e estudantes, concentrando-se a segregação inicialmente nos resíduos sólidos classificados como domésticos (papel, plásticos, metais e vidros).

Bispo (2011), analisando os resíduos coletados no Campus do IFET São Cristóvão - Sergipe constatou que os mesmos são depositados em local a céu aberto, dentro da área de abrangência da própria Instituição, sendo parcialmente enterrados, propiciando a contaminação do solo, do lençol freático e da atmosfera, como também a proliferação de vetores que comprometem a saúde da população e a sustentabilidade ambiental local. Evidenciou-se uma significativa quantidade de materiais recicláveis presentes na destinação final dos resíduos sólidos, o que representa além dos diversos impactos ambientais já citados, um risco à saúde da comunidade quando são queimados, enterrados ou descartados indiscriminadamente. Observou-se ainda, que a quantidade de lixeiras e coletores disponibilizados pelo Instituto era insuficiente para a demanda dos atores sociais, além de se encontrarem em péssimas condições de conservação, alguns totalmente inadequados para o armazenamento de resíduos.

Nas universidades a produção de resíduos sólidos é elevada e se os mesmos forem descartados de forma incorreta, poderão trazer sérios prejuízos ao meio ambiente e à saúde pública. No trabalho realizado na UFU por Eustáquio (2017), contatou-se que houve uma significativa melhora na qualidade de vida da comunidade acadêmica, dos catadores e da população, pois o descarte correto do lixo, bem como sua destinação correta, reduziu o índice de doenças relacionadas ao manejo e disposição incorreta dos resíduos. 


\section{Administração: caminhos para o desenvolvimento sustentável}

\subsection{COLETA SELETIVA NA UNIVERSIDADE FEDERAL DO PIAUÍ}

A Universidade Federal do Piauí (UFPI) é uma instituição federal de Ensino Superior sediada na cidade de Teresina - Estado do Piauí e com campi nas cidades de Parnaíba, Picos, Floriano e Bom Jesus. A Instituição é mantida pela Fundação Universidade Federal do Piauí - FUFPI (criada pela Lei no 5.528, de 12/11/1968) e é financiada com recursos do Governo Federal (UFPI, 2015).

A UFPI foi instalada em 01 de março de 1971 a partir da fusão de algumas faculdades isoladas que existiam no Estado - Faculdade de Direito, Faculdade Católica de Filosofia, Faculdade de Odontologia, Faculdade de Administração (Parnaíba) e Faculdade de Medicina. Sua missão é a de propiciar a elaboração, sistematização e socialização do conhecimento filosófico, científico, artístico e tecnológico adequado ao saber contemporâneo e à realidade social, formando recursos que contribuam para o desenvolvimento econômico, político, social e cultural local, regional e nacional (UFPI, 2015).

A origem do Campus de Parnaíba remonta à própria origem da UFPI, pois se originou da Faculdade de Administração do Piauí, uma das estruturas que foram agregadas para a formação da Universidade e que foi autorizada a funcionar pelos Pareceres números 57 e 900, datados de 07/02/1969 e 16/12/1970, respectivamente, ambos do então Conselho Federal de Educação. A Fundação Educacional de Parnaíba, criada em 04/06/1966, foi a entidade mantenedora da Faculdade de Administração. Sua instalação ocorreu em 03/03/1969. A incorporação da Faculdade de Administração à UFPI se deu em 01/03/1971, quando ela ainda funcionava do prédio do Ginásio São Luís Gonzaga. Dentre os desafios de então, estava o crescimento da infraestrutura e do número de cursos superiores no município (UFPI, 2017).

Inicialmente chamado de Campus Ministro Reis Velloso (CMRV), a construção da infraestrutura própria do campus foi iniciada no dia 11 de outubro de 1971, porém somente no dia 6 de setembro de 1975, o Curso de Administração de Empresas começou a funcionar em suas novas instalações, no endereço atual. Essas obras foram concluídas em 1978, permitindo o acréscimo de outros cursos de nível superior: Ciências Econômicas, Ciências Contábeis (1976) e Licenciatura Plena em PedagogiaMagistério (1984) (UFPI, 2017).

A Universidade Federal do Piauí deu início ao Plano de Gerenciamento de Resíduos Sólidos, sob a responsabilidade da Prefeitura Universitária (PREUNI). O trabalho começou com aplicação de questionários em todos os setores da Instituição e tabulação das informações coletadas. O próximo 


\section{Administração: caminhos para o desenvolvimento sustentável}

passo será a quantificação e qualificação dos tipos de lixo produzidos. A partir desses dados será criada a Unidade de triagem do lixo (UFPI, 2014).

Os materiais recicláveis serão doados para organizações que trabalham com reciclagem; os restos de construção civil passarão por um processo de beneficiamento e serão utilizados como aterro, pavimentação e outras aplicações na universidade; quanto aos resíduos químicos, passarão por um tratamento adequado para a destinação correta (UFPI, 2014).

Já foram distribuídos kits de coleta seletiva para o recolhimento de papel, plástico, metal, vidro e lixo orgânico separados. Foram distribuídos 56 kits, em diferentes pontos da Instituição. Ao todo, foram distribuídos mais de 80 kits nos campis de Teresina, Bom Jesus, Floriano, Parnaíba e Picos (UFPI, 2014).

De acordo com a chefia da Divisão de Orçamento da PREUNI, a ação obedece a um conjunto de medidas necessárias que apontam para a utilização racional dos materiais e recursos naturais, respeitando o meio ambiente. "Visa também adequar a Universidade para a devida obediência a determinação do Governo Federal, objetivando a preservação dos recursos naturais do planeta e sobrevivência das gerações futuras", esclareceu a chefia (UFPI, 2014).

\section{METODOLOGIA}

Este trabalho trata-se de uma pesquisa de campo, clas־sificada como exploratória. Gonçalves (2001) diz que a pesquisa de campo é o "tipo de pesquisa que pretende buscar a informação diretamente com a população pesquisada, exigindo do pesquisador um encontro mais direto". Compete, pois, ao pesquisador precisa dirigir-se ao local de ocorrência do fenômeno para a busca de evidências e informações a serem documentadas. E as pesquisas exploratórias têm como principal finalidade 0 desenvolvimento, esclarecimento e modificação de conceitos e ideias, tendo em vista a formulação de problemas mais precisos ou hipóteses pesquisáveis para estudos posteriores, ou seja, o estabelecmento de uma maior familiaridade com o problema (GIL, 1999).

Foi utilizada a abordagem quantitativa, a qual possibilitou a coleta, a análise de dados e a classificação das informações. Para Raupp e Beuren (2006, p 15) "a abordagem quantitativa caracteriza-se pelo emprego de instrumentos estatísticos, tanto na coleta quanto no tratamento dos dados". Essa demonstra em números as opiniões e informações a serem classificadas e analisadas. Esse tratamento de dados é o mais adequado aos propósitos dessa pesquisa, uma vez que quantifica opiniões, dados e outras formas de informações. A coleta dos dados ocorreu diretamente através dos estudantes, 


\section{Administração: caminhos para o desenvolvimento sustentável}

buscando dados sobre a postura discente mediante a sua conscientização e percepção da coleta seletiva na universidade.

O instrumento de coleta de dados foi na forma de questionário composto por 10 (dez) questões fechadas. Fez-se de 5 a 9 de novembro de 2018 a aplicação dos questionários aos alunos do curso de Administração da UFPI/CMRV, a partir de visitas as salas de aula e abordagens com conhecidos colegas de curso que circulavam pela universidade. Os dados obtidos pelos questionários respondidos foram demonstrados em gráficos e posteriormente analisados.

\section{RESULTADOS E DISCUSSÕES}

O questionário foi respondido por 97 acadêmicos de Administração do campus Ministro Reis Velloso dentre todos os períodos do curso. Dos respondentes, $88 \%$ são jovens entre 18 e 25 anos, $51 \%$ são do sexo masculino, e $49 \%$ do sexo feminino.

Primeiramente foi perguntado aos acadêmicos sobre o que fazem em relação ao lixo produzido na UFPI por eles mesmos. Do total, 56\% responderam que simplesmente jogam no lixo, 36\% guardam e procuram uma lixeira para jogar e apenas $8 \%$ selecionam e procuram a lixeira da coleta seletiva para despejar.

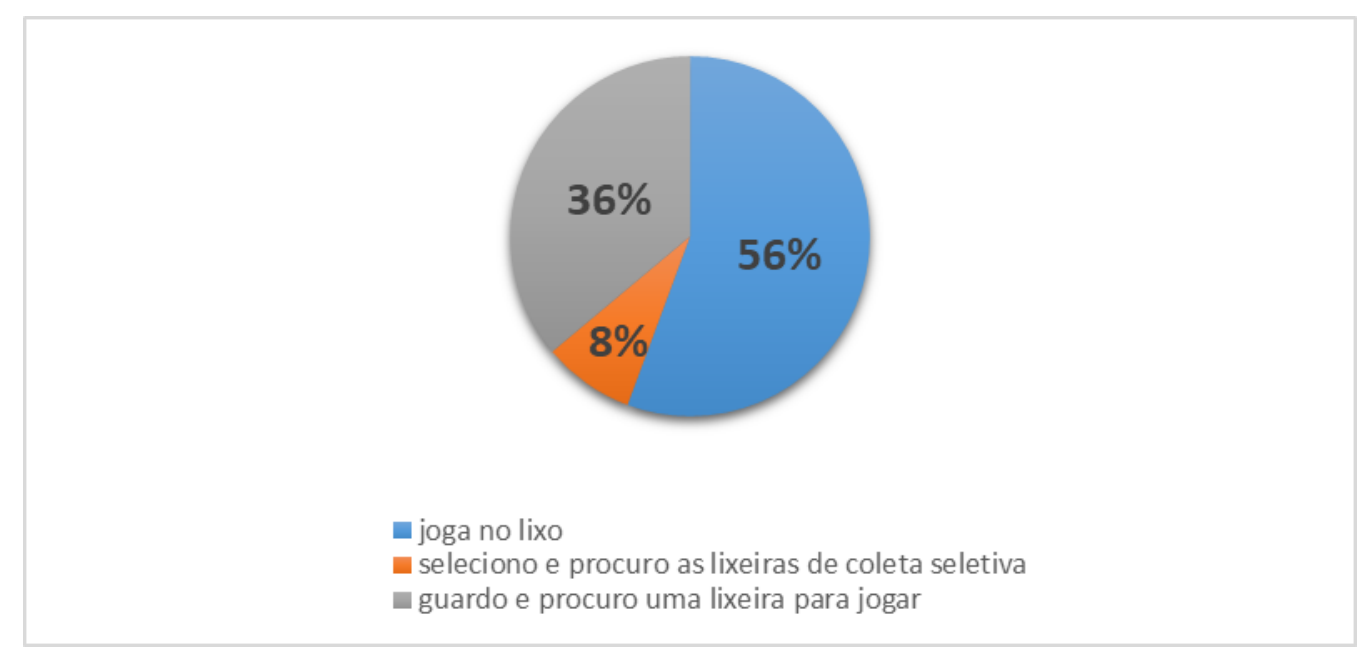

Gráfico 1 - O que você faz com o lixo que pessoalmente produz na UFPI?

Na segunda pergunta, questionou-se o conhecimento dos entre-vistados frente ao conceito de coleta seletiva e todos os entrevistados, ou seja, $100 \%$ sabem o que significa esta prática e conhecem a mesma. 


\section{Administração: caminhos para o desenvolvimento sustentável}

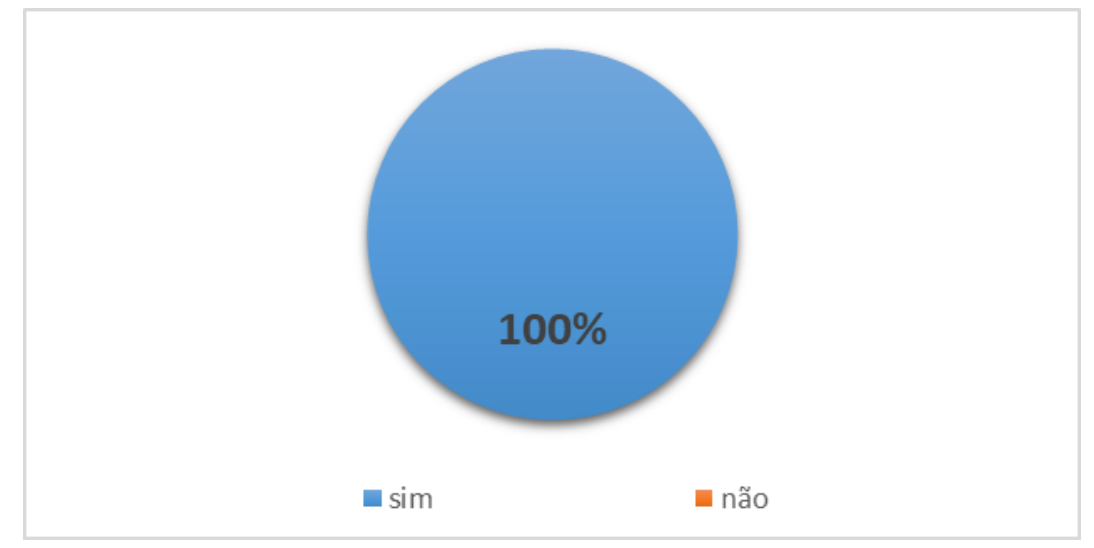

Gráfico 2 - Você sabe o que é coleta seletiva?

Quando questionados do conhecimento das lixeiras de coleta seletiva no campus, $97 \%$ dos entrevistados mostraram ter conhecimento das lixeiras, enquanto $3 \%$ não sabiam da presença das lixeiras.

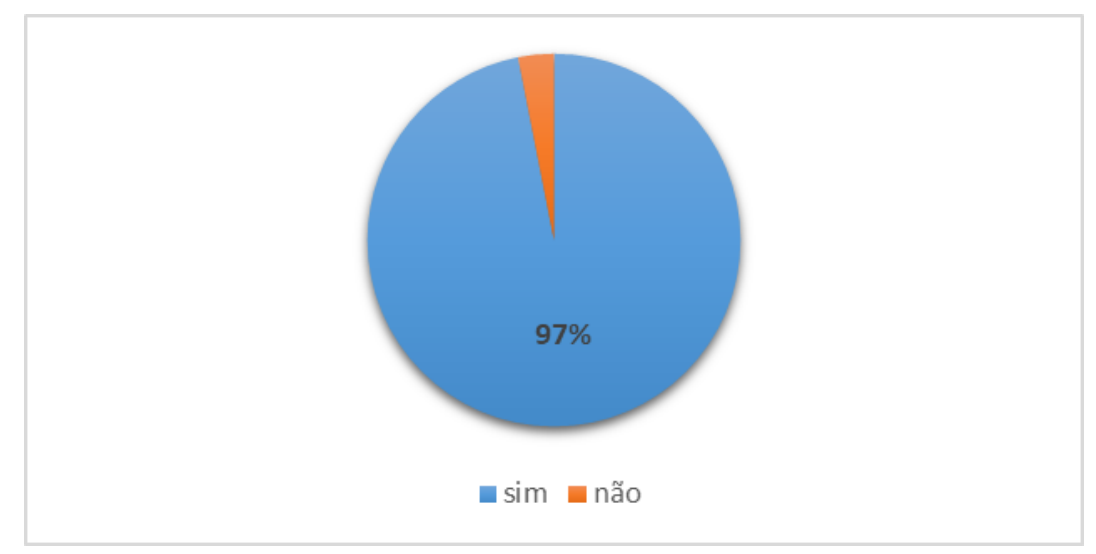

Gráfico 3 - Você sabia que em nosso campus temos lixeiras de coleta seletiva?

Acerca da localização das lixeiras dentro do campus, $86 \%$ responderam que sabem, enquanto $14 \%$ dos entrevistados responderam não saber onde as mesmas estão localizadas, mesmo tendo conhecimento delas no campus. 


\section{Administração: caminhos para o desenvolvimento sustentável}

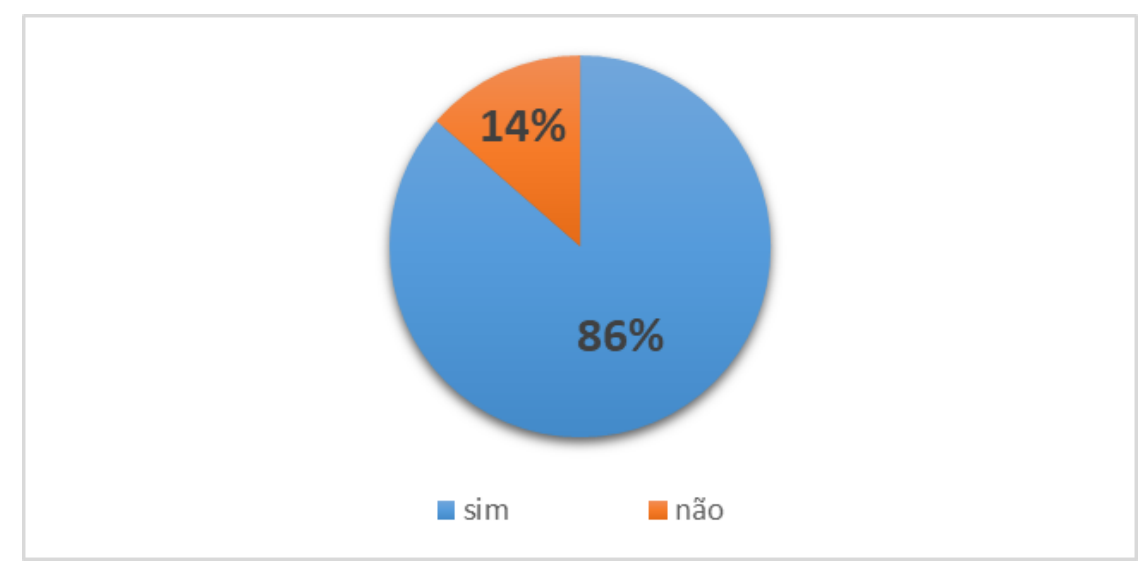

Gráfico 4 - Você sabe onde estão localizadas as lixeiras de coleta seletiva na UFPI?

Questionou-se aos entrevistados se os mesmos praticam a separação de resíduos sólidos no âmbito da UFPI. A maioria dos respondentes (57\%) responderam que não praticam, enquanto $43 \%$ dizem praticar a separação.

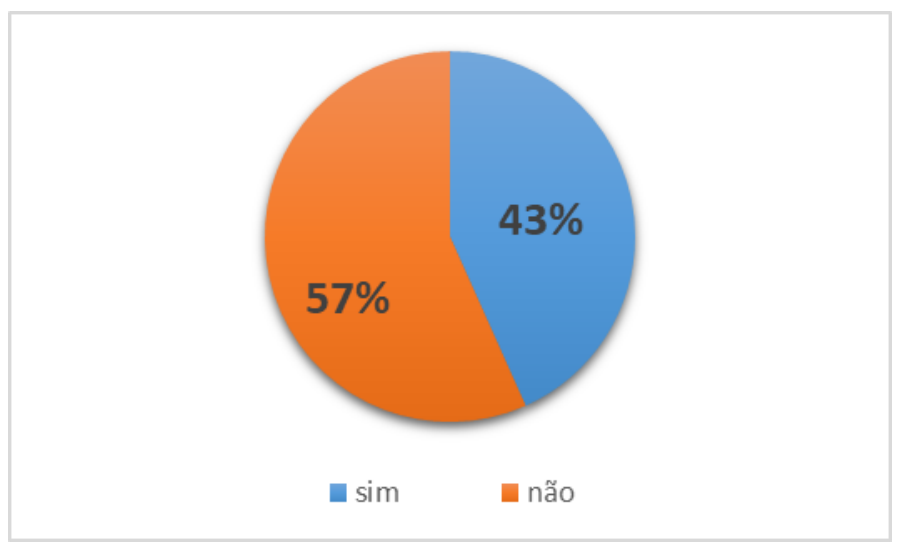

Gráfico 5 - Você pratica a separação de resíduos sólidos na UFPI?

Também foi questionado aos acadêmicos entrevistados se há conhecimento a respeito do significado das cores e símbolos das lixeiras. Dos respondentes, 58\% mostraram ter conhecimento, 29\% disseram saber, mas não perfeitamente e $13 \%$ responderam que não sabem os significados.

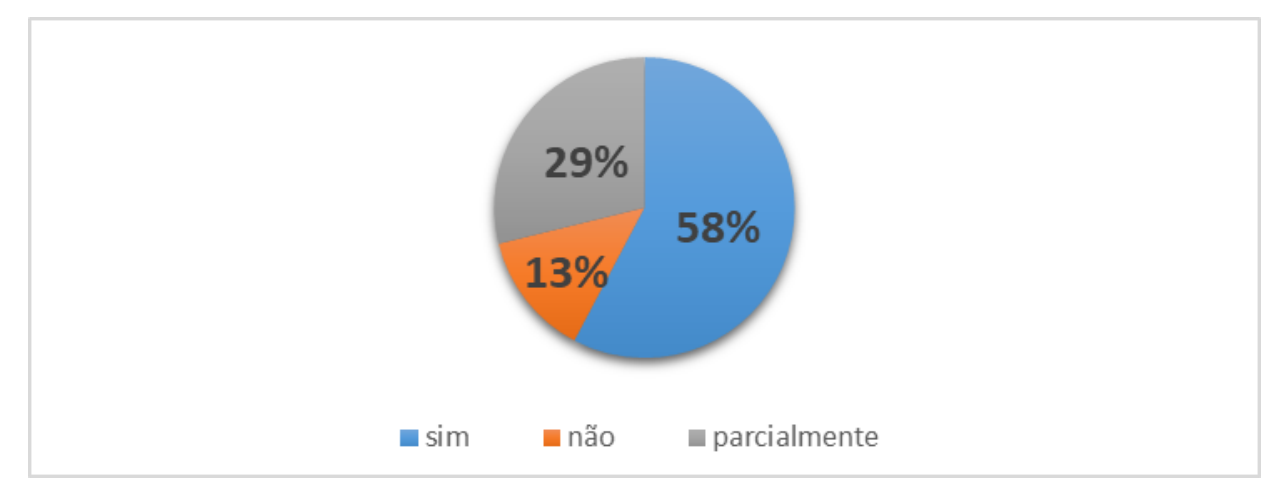

Gráfico 6 - Você sabe o significado das cores e símbolos das lixeiras? 


\section{Administração: caminhos para o desenvolvimento sustentável}

Verificou-se que, quanto à percepção dos entrevistados sobre a importância da prática da coleta seletiva, os mesmos consideram muito importante (66\%) ou importante (36\%) a prática desse tipo de programa. Logo, verifica--se que há uma demanda e necessidade do ensino da prática da coleta seletiva.

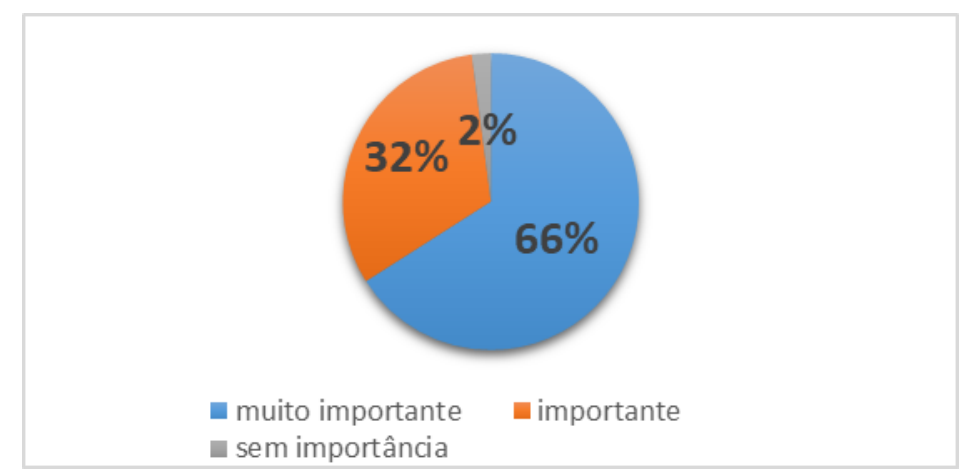

Gráfico 7 - Na sua opinião, qual a importância de realizar a coleta seletiva na UFPI?

Foi questionado aos entrevistados se esses se preocupam em diminuir a quantidade de resíduos sólidos (lixo) que é gerado pelos mesmos. Notou-se que $67 \%$ dos respondentes já pensaram em realizar essa minimização dos resíduos.

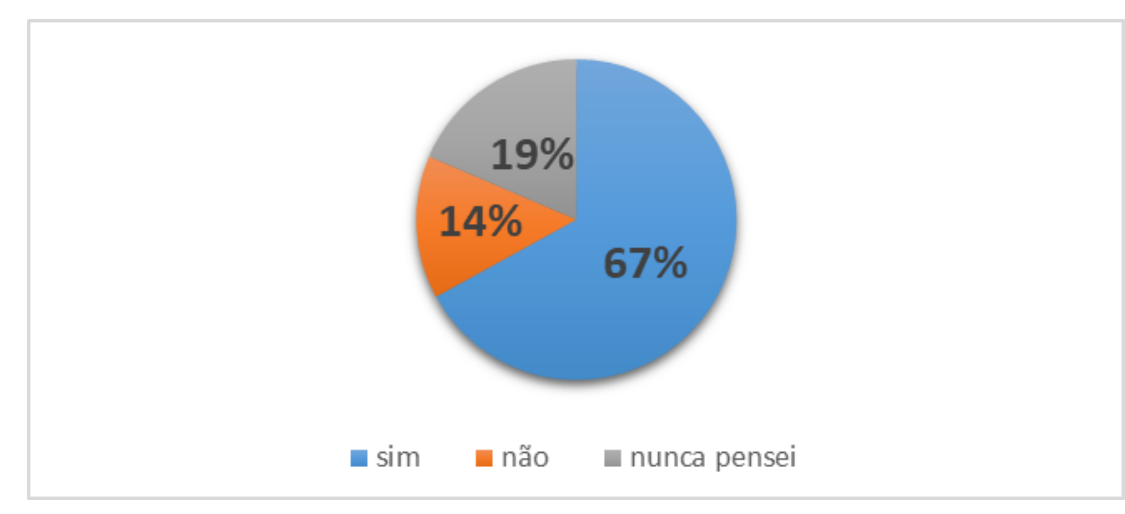

Gráfico 8 - Você se preocupa em diminuir a quantidade de resíduos sólidos produzidos?

Também foi questionado aos entrevistados, duas perguntas com a possibilidade de marcar mais de uma alternativa de resposta. Na primeira, perguntou-se a respeito das dificuldades encontradas na separação de materiais recicláveis no âmbito da UFPI. Percebeu-se pelos $26 \%$ das respostas, que a maior dificuldade para os acadêmicos de administração é a falta de interesse pelo tema. Seguida de outras dificuldades mais respondidas pelos discentes, como a falta de incentivo (20\%) e falta de coletores espalhados pelo campus (15\%). 


\section{Administração: caminhos para o desenvolvimento sustentável}

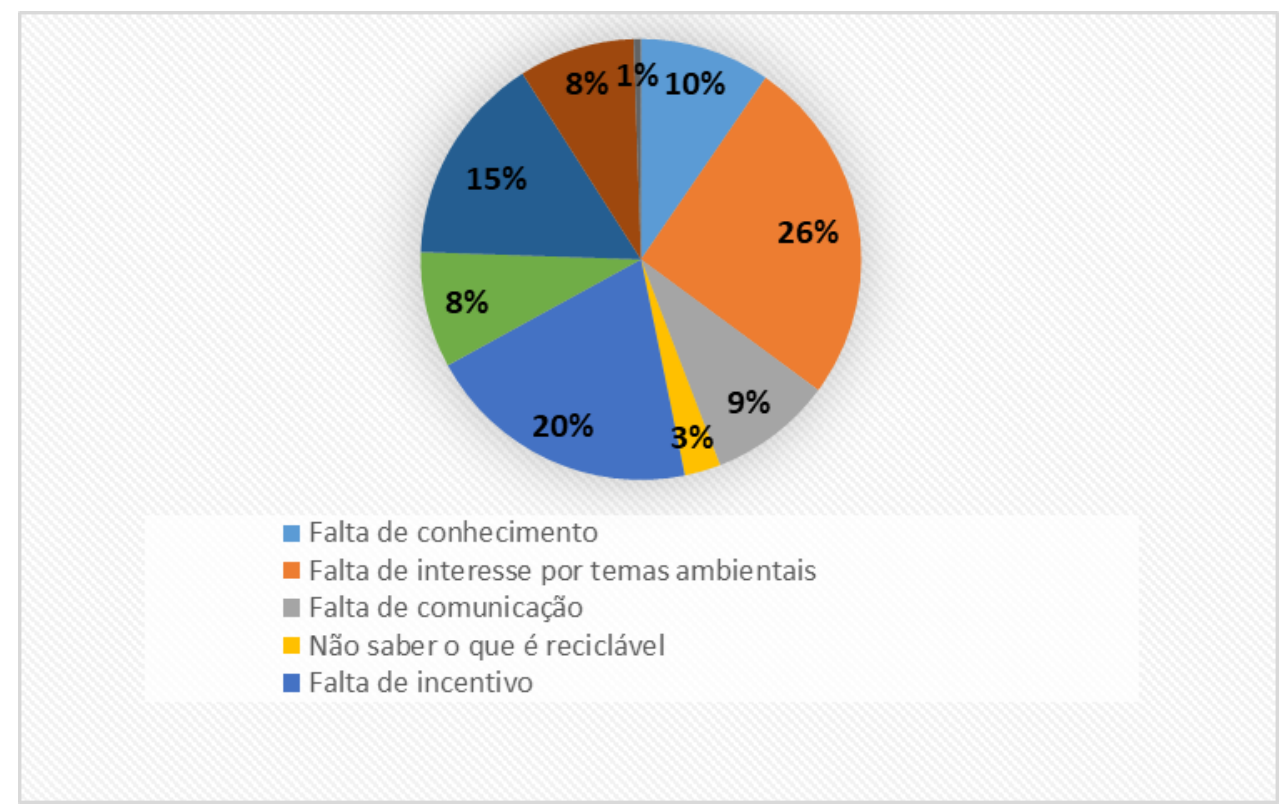

Gráfico 9 - Na sua opinião, quais as dificuldades encontradas na separação de materiais recicláveis, no âmbito da UFPI?

Na outra pergunta questionou-se sobre o que poderia ser feito para aperfeiçoar o diálogo entre a UFPI e a Comunidade Acadêmica visando a uma melhoria da coleta seletiva do campus. A maior indicação para o diálogo foi a colocação de placas indicativas pelo Campus (29\%) das respostas, seguida de cartazes alusivos ao tema (22\%) e de palestras sobre a temática pelos órgãos responsáveis (16\%). Nota-se que a comunidade acadêmica precisa saber sobre a política adotada na UFPI de coleta seletiva. 


\section{Administração: caminhos para o desenvolvimento sustentável}

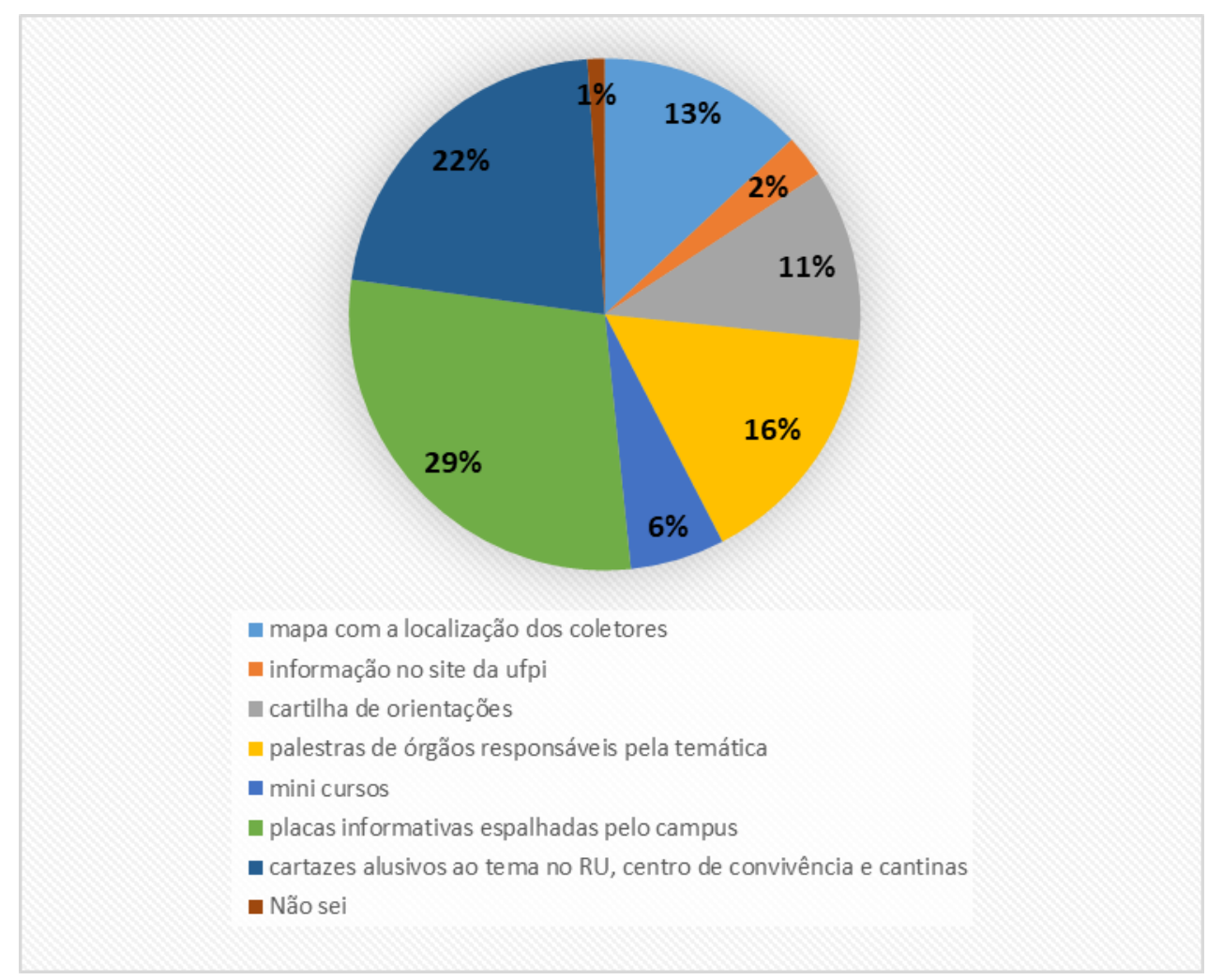

Gráfico 10 - Para você, o que pode ser feito para aperfeiçoar o diálogo UFPI-Comunidade Acadêmica, visando à melhoria da coleta seletiva?

Constatou-se que, o levantamento dos dados foi satisfatório, atingiu-se a amostragem mínima necessária para a realização e alcance do objetivo e da conclusão do estudo. Por meio das perguntas, os acadêmicos expessaram suas percepções e informações sobre a relevância da coleta setiva de lixo no CMRV.

\section{CONSIDERAÇÕES FINAIS}

Essa pesquisa teve como objetivo identificar o nível de entendimento e consciência dos alunos do Curso de Administração da UFPI/CMRV em relação à prática de coleta seletiva. Percebeu-se que os entrevistados têm conhecimento a respeito da prática da coleta seletiva e a sua importância para o meio ambiente, e a reconhecem como um fator de diferencial a uma organização. Porém, por vezes falta um conhecimento mais aprofundado a respeito do assunto. Ainda, é possível a verificação de que grande parte dos entrevistados acredita que a coleta seletiva é importante/muito importante e averiguou-se que grande parte dos respondentes possui uma preocupação com a redução dos resíduos sólidos produzidos pelos mesmos, embora a maioria não pratique a separação desses 


\section{Administração: caminhos para o desenvolvimento sustentável}

resíduos. O que apresenta certa contradição, mostrando que há a consciência da sua importância, mas que na prática não há esse interesse por parte dos acadêmicos em fazer valer esse conhecimento.

Conclui-se que devem ser desenvolvidas ações buscando a adesão aos programas de coleta seletiva pela comunidade acadêmica, constituída por alunos, professores e funcionários. Além disso, sugerese que a partir desse aprofundamento, sejam desenvolvidos materiais instrucionais a fim de despertar o interesse dos acadêmicos à temática, além da realização de atividades informativas continuadas para a comunidade universitária.

\section{REFERÊNCIAS}

BELTRAME, T.; LHAMBY, A. Coleta seletiva: percepção e conhecimento sobre o tema - uma pesquisa exploratória. Santa Maria - RS, 2013.

CEMPRE. Compromisso empresarial para reciclagem. São Paulo, 2014. Disponível

em: <http://cempre.org.br/ciclosoft/id/2>. Acesso em: 20 Out. 2018.

IBGE - Instituto Brasileiro de Geografia e Estatística. (2008). Plano Nacional de Saneamento Básico. Rio de Janeiro. Disponível

em:<http://www.ibge.gov.br/home/estatistica/populacao/condicaodevida/pnsb2008/PNSB_2008.p df. Rio de Janeiro, 2008>. Acesso em: 20 Out. 2018.

LEI 9.795/99. Educação ambiental e Política Nacional de Educação Ambiental. Disponível em: <http://www.planalto.gov.br/ccivil_03/LEIS/L9795.htm>. Acesso em: 17 Out. 2018.

MARQUES, E.; VASCONECELLOS, M.; GUIMARÃES, H.; BARBOSA, F. Gestão da coleta seletiva de resíduos sólidos no Campus Pampulha da UFMG: desafios e impactos sociais. Minas Gerais, 2017.

SOUZA, V.; LACERDA, C.; SILVA, N.; SILVA, L. Práticas ecológicas e coleta seletiva na Universidade Estadual da Paraíba. Paraíba, 2017.

UNIVERSIDADE FEDERAL DO PIAUÍ. Institucional. (2015). Disponível

em: <http://www.ufpi.br/institucional-ufpi>. Acesso em: 2 Nov. 2018.

UNIVERSIDADE FEDERAL DO PIAUÍ. História do CMRV. (2017). Disponível em: <http://ufpi.br/ocampus?id=19576:historia-do-cmrv>. Acesso em: 2 Nov. 2018.

VIEIRA, L. Limites e possibilidades da coleta seletiva na Universidade Federal de Uberlândia: um estudo de caso. Uberlândia - MG, 2017. 


\section{Capítulo 27}

\section{ESTRATÉGIAS DE MARKETING DIGITAL INFLUENCIAM OS CONSUMIDORES DA GERAÇÃO Z? UM ESTUDO COM ALUNOS DO IF FARROUPILHA CAMPUS SANTO AUGUSTO/RS}

\section{DOI: $10.37423 / 200300429$}

Khetlyn Günther, Instituto Federal de Educação Ciência e Tecnologia Farroupilha Campus Santo Augusto,Brasil).khetlyngunther@gmail.com

Luna Emanuelly Vieira, Instituto Federal de Educação Ciência e Tecnologia Farroupilha Campus Santo Augusto,Brasil0. IunaE5000@gmail.com

Simone Beatriz Nunes Ceretta, Instituto Federal de Educação Ciência e Tecnologia Farroupilha Campus Santo Augusto,Brasil).simone.ceretta@iffarkoupilha.edu.br

Valêria Bones Costa, Instituto Federà de Educąção Ciência e Tecnologia Farroupilha Campus Santo Augusto, Brasil).valeriabonescosta@gmail.com

Resumo: Constantes mudanças estão ocorrendo com ás empresas na atuàlidade e o marketing tradicional, vem migrand para o marketing digital, de modo que um canal acaba complementando o outro. Nesse contęxto, o estuldo tem o objetivo de identificar se as estratégias mercadológicas em meio a Era digital influenciam os consumidores da Geração Z, residentes em uma região-interiorana. A pesquisa foi aplicada a uma amostra de 260 discentes do If Farroupilha_campus Santo-Augusto/RS, com/faixa letaria_de 14 à 21-anos.

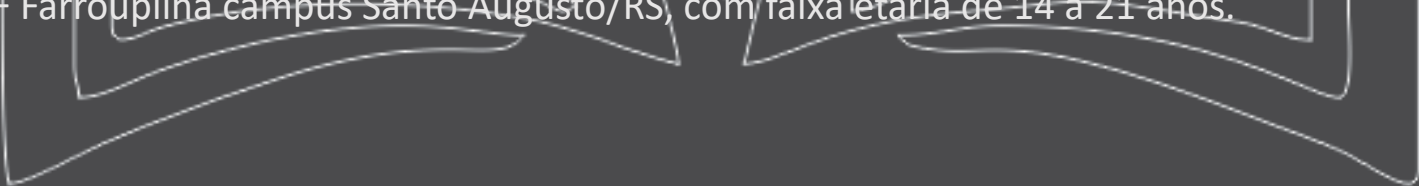




\section{Administração: caminhos para o desenvolvimento sustentável}

A metodologia abordada é de natureza aplicada, exploratória e descritiva. Caracteriza-se como um estudo qualitativo, de metodologia descritiva focus group, e da aplicação de questionários estruturados com questões abertas e fechadas, aplicados através do método survey. Os resultados apontam que a Geração Z, é hiperconectada, informada e exigente quanto a preços justos. Mesmo pertencente a uma região interiorana, mostra-se influenciada pelas estratégias de marketing digital e está atenta às redes sociais, na busca por informações, compras e interação. Cabe aos gestores planejar e implementar ações pontuais que possam atrair a atenção dos jovens e criar a predisposição de comprar via e-commerce ou a visitar a sua loja física. As mídias se tornaram cada vez mais expressivas e os jovens da Geração Z são os principais alvos e, simultaneamente, os divulgadores do conteúdo compartilhado pelas empresas. Daí a relevância dos administradores adaptarem estratégias do mundo off-line ao mundo on-line, ambos são complementares e não excludentes.

Palavras-chave: Consumo; Estratégias; Geração Z; Marketing digital. 


\section{Administração: caminhos para o desenvolvimento sustentável}

\section{INTRODUÇÃO}

A Era digital tem ocupado um espaço significativo no cotidiano das pessoas em todo o mundo. Através da internet, as pessoas tornaram-se mais conectadas, pela vantagem de se estabelecer uma relação na qual os indivíduos não necessitam estar próximos para serem capazes de comunicar-se. Com isso, determinadas gerações precisaram adaptar-se a tecnologia e ao modo de como utilizá-la, diferentemente da Geração Z, que nasceu em meio a tais transformações, e hoje vive hiperconectada nos estudos, em casa e no trabalho.

Neste cenário mutante, para que uma empresa permaneça no mercado, seja ela física ou on-line, torna-se necessário cada vez mais conhecer especificamente o perfil do cliente, como ele se comporta, e suas demandas de consumo (KOTLER; ARMSTRONG, 1999; ENGEL, BLACKWELL, MINIARD, 2000). É imprescindível compreender o que o satisfaz, os motivos e a forma com que este realiza suas compras, ainda mais, os jovens da Geração Z que possuem acesso a todo tipo de informações sobre produtos, marcas e serviços ao decidir o que, e de que empresa comprar. Destaca-se a partir disso, a relevância organizacional de planejar estratégias de marketing digital que possam influenciar a decisão de consumo.

À vista disso, objetivou-se identificar se as estratégias de marketing digital estão influenciando o comportamento de compra do consumidor da Geração Z, particularmente, os discentes do Instituto Federal Farroupilha, campus de Santo Augusto/RS. Esse público foi selecionado pela proximidade das autoras (professora e alunas da Instituição) e, por desejar identificar-se ainda, se em uma região interiorana, a influência de ações digitais estão sendo eficientes.

\section{REFERENCIAL TEÓRICO}

O presente capítulo tem como objetivo trazer uma breve abordagem das temáticas norteadoras da pesquisa, iniciando com a explanação da Era Digital, abordando o comportamento do consumidor da Geração Z e, por fim, as estratégias de Marketing Digital - Marketing 4.0.

\subsection{TEMPOS MODERNOS: A ERA DIGITAL}

Ao final do século XX falava-se sobre o boom que a Era digital traria ao cotidiano das pessoas, porém, não esperava-se que seria de forma tão acelerada. Vive-se hoje, tempos efêmeros e transitórios no qual em cerca de dez anos a tecnologia começou a estar presente na rotina diária de todos, seja nas atividades de lazer, trabalho, ou consumo. 


\section{Administração: caminhos para o desenvolvimento sustentável}

Pessoas encontram-se inteiramente conectadas minuto a minuto, em qualquer parte do mundo, seja para concretizar negócios, buscar conhecimentos ou apenas fazer contatos pessoais. São características dos tempos modernos: a Era Digital chegou para ficar, transformando a sociedade, seu jeito de pensar, comunicar, trabalhar e comprar.

Na concepção de Turchi (2017) quase metade da população brasileira está na web, o que em comparação ao resto do mundo, representa o grupo de internautas que mais tempo dedica a navegar na rede. Quanto mais tempo as pessoas permanecem navegando, maior a quantidade de tempo que ficam expostas aos anúncios, vídeos e redes sociais, aumentando dessa forma, a probabilidade de compras.

Com a expansão da internet, ou seja, desse ambiente virtual, a geração mais jovem, conhecida como Geração Z, apresenta mudanças comportamentais em termos de hábitos, atitudes, preferências e modo de pensar e agir. São esses os futuros clientes das empresas, tornando-se impraticáveis ações que desconsideram o digital e a forma com que o consumidor age em termos de comportamento pessoal e ou de consumo.

Devido esse revés da tecnologia, o meio corporativo foi impactado com a internet, concedendo espaço para diversas empresas entrarem no comércio eletrônico (TURCHI, 2017), o que acabou fazendo com que as organizações passassem a repensar suas estratégias perante seus concorrentes, necessitando constantes adaptações, em especial, quando se atende a nova Geração, que já nasceu em meio a toda essa tecnologia.

\subsection{COMPORTAMENTO DO CONSUMIDOR DA GERAÇÃO Z NA ERA DIGITAL}

O comportamento do consumidor vem ao longo dos anos passando por várias mudanças, muitas delas decorrentes ao acesso à tecnologia e ao maior volume de informações. Trata-se do estudo de "processos envolvidos quando indivíduos ou grupos, selecionam, compram, usam ou dispõem de produtos, serviços, ideias ou experiências para satisfazer necessidades e desejos" (SOLOMON, 2002, p. 24). Para Engel, Blackwell, Miniard (2000), o comportamento do consumidor são as atividades diretamente envolvidas em obter, consumir e dispor produtos e serviços, incluindo os processos decisórios que antecedem e sucedem tais ações.

Estudar o comportamento do consumidor gera resultado e, principalmente, vantagem competitiva (SOLOMON, 2002), daí a relevância de obter tais informações para subsidiar a tomada de decisão. 0 


\section{Administração: caminhos para o desenvolvimento sustentável}

consumidor contemporâneo, principalmente os jovens da Geração Z, tornaram-se mais exigentes e interconectados despertando o interesse dos gestores em estudos acerca de como eles pensam, quais seus hábitos, interesses, ou seja, como eles se comportam principalmente nas relações de consumo.

Torres (2009) menciona que o consumidor on-line no Brasil, representa as classes A, B e C e acaba utilizando pelo menos uma hora a internet toda a semana, buscando diversão, relacionamento e informação. Para isso, usa ferramentas de busca, participa de redes sociais e lê muito.

A Geração Z compreende pessoas nascidas em média entre 1998 a 2010, uma vez que cada autor traz uma data distinta, não havendo um consenso exato sobre o período. Tapscott (2010, p. 27) apresenta dados estatísticos de 301.621.157 habitantes em 2008 nos Estados Unidos da América, para caracterizar quatro gerações desde 1946:

\section{Geração Baby Boom}

Janeiro de 1946 a dezembro de 1964 - 19 anos, produzindo 77,2 milhões de crianças ou 23\% da população dos Estados Unidos.

\section{Geração X}

Janeiro de 1965 a dezembro de 1976 - 12 anos, produzindo 44,9 milhões de crianças ou $15 \%$ da população dos Estados Unidos. Também chamada de Baby Bust.

\section{Geração Internet}

Janeiro de 1977 a dezembro de 1997 - 21 anos, produzindo aproximadamente 81,1 milhões de crianças ou $27 \%$ da população dos Estados Unidos. Também chamada de Geração do Milênio ou Geração Y.

4. Geração Next Janeiro de 1998 até o presente - dez anos, produzindo aproximadamente 40,1 milhões de crianças ou $13,4 \%$ da população dos Estados Unidos. Também chamada de Geração Z.

Percebe-se que a Geração Z encontra-se de 1998 à 2010 conforme publicação de Tapscott (2010), a partir desta data, já encontram-se outras nomenclaturas para gerações futuras, como a Alpha. Na percepção de Souza e Gobbi (2014) a geração Z tem um perfil específico, com a tendência de assistir menos a televisão que seus pais, o que torna mais provável a atitude de ligar um computador, usar smartphones, ou seja, interagir e conectar-se para ficarem por dentro de tudo o que acontece ao seu redor simultaneamente. 
Hoje mais do que nunca, é necessário usar metodologias baseadas em avaliação de aspectos comportamentais, em hábitos culturais, entre outros. Isso significa que o grau de dificuldade aumentou e muito. Para se certificar disso, basta analisar de perto um exemplo, que é o público jovem ou adolescente, pois como se sabe, eles conseguem se conectar a diversas alternativas de mídia ao mesmo tempo, fazendo com que seja quase impossível saber qual é o tempo exato gasto em cada uma, quais, suas preferências, entre outros aspectos (TURCHI, 2017, p. 183).

A Era digital trouxe ao consumidor um novo meio de consumo através da internet capaz de suprir as carências e insuficiências do comércio tradicional. Torres (2009) destaca três necessidades básicas para compreendê-los melhor, criadas pelo próprio jovem consumidor: o entretenimento, a informação e os relacionamentos.

O entretenimento, uma vez que o indivíduo pesquisa por jogos, vídeos, e atualmente a Netflix, buscando por séries e filmes que incluem um preço mais baixo que a assinatura de canais pagos. Este, também, localiza diversos tipos de informações através da internet, em que, quando dispõe de alguma palavra ou frase na rede, abre-se uma diversidade de resultados, fazendo com que o indivíduo ache com agilidade o que procura (TORRES, 2009). Por exemplo, uma palavra lançada no Google (ferramenta de busca), abre uma infinidade de opções a serem pesquisadas.

Com a ampliação das redes sociais o diálogo rápido é um evento muito forte, ainda mais em meio às novas gerações. Isso porque, com a aplicação das redes sociais, através do Facebook, Whatsapp, Skype, Instagram, Twitter, entre outros meios, facilitou-se a interação entre as pessoas, passou-se a conhecer mais acerca da vida dos indivíduos pelo fato dos dados estarem expostos, bem como, pelo contato com as pessoas em qualquer parte do mundo (TAPSCOTT, 2010).

As redes sociais consistem em um fenômeno e, junto com os blogs e outros sites colaborativos, criam as chamadas mídias sociais. Elas integram perfis e comunidades, criando para o consumidor uma agradável sensação de proximidade com todos. Formam um fenômeno cultural em constante ascensão e, por serem colaborativas na essência, estão em constante transformação (TORRES, p. 31, 2009).

Os indivíduos não escutam mais noticiários ou rádios para obter informações, buscam no Google o que precisam e querem saber; a caminho da escola, faculdade e/ou trabalho optam por ouvir música a partir de um aplicativo pago de celular, com milhares de músicas disponíveis (TAPSCOTT, 2010). Percebe-se um jovem inteiramente conectado, que busca informações antes de tomar qualquer uma decisão acerca do que almeja, por haver uma gama de opções. 


\section{Administração: caminhos para o desenvolvimento sustentável}

Caracterizam-se ainda, por possuírem perfis mais ágeis, conseguindo realizar atividades simultaneamente, de modo que o fator geográfico não se limita, uma vez que utilizam a rede de computadores em dimensões internacionais (LOPES et. al., 2014). Isso faz com que o mercado tornese mais competitivo, varejo e e-commerce procurando conservar seu público, adequando suas estratégias de marketing tradicional para o digital.

\subsection{ESTRATÉGIAS DE MARKETING DIGITAL: O MARKETING 4.0}

O marketing na atualidade vem provocando discussões no sentido da sua transição, do tradicional para o digital. Na realidade o digital não substitui o tradicional, o que é necessário são estratégias que possam integrar o mundo off-line ao mundo on-line (KOTLER; KARTAJAYA; SETIAWAN, 2017). Pode-se considerar que o marketing digital é uma extensão do marketing tradicional, porém trabalhado e executado por meio das ferramentas digitais (via internet).

O mercado evoluiu nas últimas décadas influenciados pelo avanço tecnológico ao redor do mundo. Percebe-se que essa nova dinâmica mundial, ligada à Era digital, fez com que o foco do marketing mudasse com o passar do tempo, como demonstrado na Figura 01, na qual é exposta a transição do Marketing 1.0, 2.0 e, o 3.0.

\begin{tabular}{|c|c|c|c|}
\hline & $\begin{array}{l}\text { Marketing } 1.0 \\
\text { Marketing centrado } \\
\text { no produto }\end{array}$ & $\begin{array}{l}\text { Marketing } 2.0 \\
\text { Marketing voltado para } \\
\text { o consumidor }\end{array}$ & $\begin{array}{l}\text { Marketing } 3.0 \\
\text { Marketing voltado para } \\
\text { os valores }\end{array}$ \\
\hline Objetivo & Vender produtos & $\begin{array}{l}\text { Satisfazer e reter os } \\
\text { consumidores }\end{array}$ & $\begin{array}{l}\text { Fazer do mundo um lugar } \\
\text { melhor }\end{array}$ \\
\hline Forças propulsoras & Revoluçáo Industrial & Tecnologia da informaçẩo & Nova onda de tecnologia \\
\hline $\begin{array}{l}\text { Como as empresas veem } \\
\text { o mercado }\end{array}$ & $\begin{array}{l}\text { Compradores de massa, } \\
\text { com nccessidades físicas }\end{array}$ & $\begin{array}{l}\text { Consumidor inteligente, } \\
\text { dotado de coraçáo c mente }\end{array}$ & $\begin{array}{l}\text { Ser humano pleno, com } \\
\text { coraçäo, mente c cspírito }\end{array}$ \\
\hline Conceito de marketing & Desenvolvimento de produto & Diferenciaçäo & Valores \\
\hline $\begin{array}{l}\text { Diretrizes de marketing } \\
\text { da empresa }\end{array}$ & Especificaçẩo do produto & $\begin{array}{l}\text { Posicionamento do produto } \\
\text { e da empresa }\end{array}$ & $\begin{array}{l}\text { Missảo, visáo e valores } \\
\text { da empresa }\end{array}$ \\
\hline Proposiçáo de valor & Funcional & Funcional e emocional & $\begin{array}{l}\text { Funcional, emocional e } \\
\text { espiritual }\end{array}$ \\
\hline $\begin{array}{l}\text { Interaçâo com } \\
\text { consumidores }\end{array}$ & $\begin{array}{l}\text { Transaçâo do tipo } \\
\text { um-para-um }\end{array}$ & $\begin{array}{l}\text { Relacionamento } \\
\text { um-para-um }\end{array}$ & $\begin{array}{l}\text { Colaboraçáo } \\
\text { um-para-muitos }\end{array}$ \\
\hline
\end{tabular}

FIGURA 1: Evolução do Marketing 1.0 ao 3.0

FONTE: Kotler, Hartajaya e Setiawan (2012, p. 06) 


\section{Administração: caminhos para o desenvolvimento sustentável}

Ocorreu a passagem do marketing centrado no produto, para o foco no consumidor e, posteriormente, para a valorização do ser humano demandando estratégias de marketing mais colaborativas, culturais e espirituais (KOTLER; KARTAJAYA; SETIAWAN, 2017). O consumidor permanece o mesmo, a diferença está que na sua conduta e atitude diante do mundo virtual que é refletida de acordo com os desejos e preceitos trazidos das vivências em sociedade (TORRES, 2009). Hoje, emerge o marketing 4.0, voltado às informações, a tecnologia, à fusão do mundo físico com o digital. Uma Era caracterizada por exigir uma integração maior entre os canais de marketing, pois ocorre a explosão do consumo de conteúdo digital no mundo todo.

Em meio a isso, as organizações precisam planejar meios de adaptar-se ao mercado competitivo e a esse novo perfil de cliente, no caso deste estudo, a Geração Z, muito mais exigente, informada e sedenta por novidades. No marketing 4.0, o foco passa a ser justamente esse consumidor conectado. Conforme apontado por Kotler, Kartajaya e Setiawan (2017) e reiterado por Adolpho (2012), essas pessoas prezam pelo serviço instantâneo, pois estão sempre em movimento.

A economia digital intensificou algo que começou timidamente há muito tempo a necessidade do imediatismo da resposta. Já que tudo é tão rápido, não há mais tempo de esperar pelo que quer que seja [...] O mercado moldado pelas tecnologias muda profundamente o ser humano. Novos comportamentos surgem e novas oportunidades também (ADOLPHO, 2011, p. 75).

Diante desse cenário, Torres (2009) ressalta que é impossível fazer marketing sem a internet, ela é essencial nas estratégias mercadológicas. As organizações, sejam de porte pequeno, médio ou grande devem começar (já deveriam ter feito isso, na verdade) a procurar formas de destacarem-se nas plataformas de internet. Através da criação de sites institucionais, interação nas redes sociais, links patrocinados, entre outras opções. Conforme Turchi (2017), é nesse ambiente que os potenciais consumidores e as empresas concorrentes encontram-se atualmente.

Não basta conhecer apenas os conceitos já estabelecidos, mas também é necessário saber criar presença online da companhia de forma adequada, bem como sua estratégia de marketing digital para essa nova era, podendo vir a utilizar de várias ações tecnológicas (TURCHI, 2017, p. 65).

O marketing de conteúdo é uma das principais estratégias utilizadas no meio virtual, pois "o consumidor se acostumou a procurar um site em uma ferramenta de busca, e estas são baseadas na pesquisa por palavras-chave, o conteúdo dentro de um site é a primeira e mais importante forma de comunicação com o consumidor conectado" (TORRES, 2009, p. 72). Essa tática, faz com que se alcance 


\title{
Administração: caminhos para o desenvolvimento sustentável
}

um número mais abrangente de consumidores nas plataformas digitais, por trabalhar de um modo mais empático e familiarizado com este cliente que procura-se atrair.

\begin{abstract}
Vivemos em um mercado cada vez mais próximo da concorrência perfeita, ou seja, todos têm acesso à informação de preços, prazos, qualidade e outros atributos de produtos e serviços, podendo comparar de forma fácil todas as alternativas e se decidir qual a melhor. [...] A assimetria de informação, que faz com que todos enriqueçam, fica por conta da disponibilidade do consumidor procurá-la. Se ele se propuser a procurar o que precisa, ele encontrará. O papel dos buscadores e comparadores de preço é diminuir essa simetria, de modo a fazer com que os consumidores consigam ser o elo forte dessa corrente (ADOLPHO, 2011, p. 349-350).
\end{abstract}

Com isso, as mídias sociais ganham valor no momento de utilizar-se de ferramentas por permitirem, "a criação colaborativa de conteúdo, a interação social, e o compartilhamento de informações em diversos formatos" (TORRES, 2009, p.74). Turchi (2017) aponta que as mídias sociais vieram para ficar o que, consequentemente, fez com que as organizações adaptassem seus meios de divulgação para procurar maneiras de conquistar os consumidores nas redes. Ou seja, a partir das redes sociais os indivíduos relacionam-se, e isso faz com que a promoção dos produtos e serviços torne-se globalizada.

É possível classificar as redes sociais conforme sua aplicação:

[...] ferramentas de buscas (Google, Yahoo, Altavista), os sites de relacionamento (Orkut, Facebook, Linkedln, MySpace), os sites de compartilhamento de vídeos e fotos (YouTube, Flickr), os sites de blogs (Blogger, WordPress), os sites de comunicação instantânea (Skype, MSN), os sites de e-mail (Gmail, Hotmail), e muitos outros tipos de sites (TORRES, 2009, p. 63).

Um ponto importante, para obter resultados positivos com as estratégias de marketing digital é realizar um bom planejamento para atrair o consumidor. Turchi (2017) menciona que o marketing digital colaborou com algumas mudanças quanto aos meios de divulgação das organizações. "É preciso entender que é o cliente o motivo de a empresa existir, não o produto [...]" (ADOLPHO, 2011, p. 410). Em outras palavras, o marketing digital continua focando em atender os desejos dos consumidores, apenas mudou e adaptou as formas de divulgação, tornando-se necessário que as organizações encontrassem formas de inovar e se comunicar com eles através das redes.

Outras iniciativas realizadas pelas organizações, para conquistarem destaque no ambiente digital, são estratégias de marketing através do Mobile Marketing, E-commerce, M-Commerce, mídias sociais, 


\section{Administração: caminhos para o desenvolvimento sustentável}

como por exemplo, facebook, linkedin, Instagram, Twitter, entre outros (TURCHI, 2017). São ferramentas que permitirão uma maior proximidade entre as empresas e o mercado jovem.

\section{METODOLOGIA}

A presente pesquisa, quanto à natureza, classifica-se como aplicada, uma vez que os resultados poderão ter aplicabilidade prática. Em relação aos objetivos caracteriza-se como exploratória e descritiva (GIL, 2002; apud VERGARA, 2009), uma vez que buscou-se uma maior compreensão da influência das estratégias de marketing digital sob a decisão de compra de jovens da geração Z e, ao mesmo tempo, descreve características desse público. Trata-se de um estudo qualitativo para o qual utilizou-se como métodos de coleta de dados o focus group e o survey.

Uma metodologia bastante utilizada na pesquisa descritiva é o focus group, definido como "uma entrevista realizada por um moderador treinado, de uma forma não estruturada e natural, com um pequeno grupo de respondentes" (MALHOTRA, 2001, p. 156). Procura-se através dele, extrair-se respostas com um teor mais profundo de intenção (TEIXEIRA et. al., 2009).

Nesse estudo o focus group foi realizado com 8 pessoas na faixa etária entre 17 e 21 anos, de ambos os gêneros, previamente convidadas. O objetivo foi obter insights para a construção do questionário aplicado posteriormente. Foi realizado em 10 de Maio de 2019, com duração de uma hora, gerando um diálogo sobre as temáticas norteadoras do estudo.

O método survey é essencial, pois "se baseia no interrogatório dos participantes, aos quais se fazem várias perguntas sobre seu comportamento, intenções, atitudes, percepções, motivações e características demográficas e de estilo de vida" (MALHOTRA, 2001, p. 179). Como o cerne do estudo está no comportamento do consumidor da Geração Z optou-se pelo método survey de pesquisa, realizado através da aplicação de questionário estruturado, pré-testado, elaborado contendo questões abertas e fechadas, a uma amostra de 260 alunos do Instituto Federal Farroupilha, campus Santo Augusto/RS de um total populacional de 962 discentes. A amostragem abordada é por julgamento, visto que é focada em um grupo específico de indivíduos - a Geração Z (TEIXEIRA, et. al., 2009).

De acordo com Creswell (2007), os dados foram trabalhados com técnicas qualitativas. As questões fechadas foram tratadas através de análise de frequência tendo como instrumento adotado para 


\section{Administração: caminhos para o desenvolvimento sustentável}

compilar os dados o programa estatístico SPSS, enquanto as falas do focus group e as questões abertas do questionário foram sistematizadas e descritas ao longo do relato.

\section{RESULTADOS E DISCUSSÕES}

A vantagem competitiva das organizações está atrelada a sua capacidade de identificar como seu público-alvo se comporta, especialmente, no mundo digital - foco desta pesquisa. Planejar e executar estratégias de marketing voltadas aos jovens da Geração $Z$ requer pesquisar seu perfil, como e onde ele compra, bem como, identificar se realmente as mídias têm impacto de atração na decisão de Nesse cenário, realizou-se o presente estudo conduzido a 260 alunos do Instituto Federal Farroupilha campus Santo Augusto, com faixa etária de 14 a 21 anos, público característico da Geração Z. Caracterizando o perfil da amostra, identificou-se que $59 \%$ são do gênero feminino, 40 \% do gênero masculino e $1 \%$ declara-se como outros. Todos discentes da instituição, sendo $85 \%$ alunos dos cursos técnicos e $15 \%$ pertencentes aos cursos superiores. A maioria (87\%) não encontra-se empregado, o que pode ser justificado pelo fato de ainda estarem no ensino médio. São indivíduos classificados na classe social C (41\%), D (26\%) e E (22\%). Ou seja, a rentabilidade das famílias não é tão elevada, visto a economia atual em que o país encontra-se especificamente e pela região onde residem (Região Celeiro) ser interiorana.

Questionados acerca de qual canal costumam utilizar para efetuar suas compras, a maioria (57\%) menciona comprar tanto nas lojas físicas, quanto nas lojas virtuais. Outros $34 \%$ ainda optam pela compra em lojas físicas e apenas $9 \%$ apenas por lojas virtuais (Gráfico 1). Tais dados comprovam o que Kotler, Kartajaya e Setiawan (2017) apontam quando dizem que o marketing digital não substitui o tradicional, eles se complementam. São necessárias então, estratégias que possam integrar o mundo off-line ao on-line, pois mesmo o público sendo jovem e conectado ele aprecia e se sente atraído a frequentar lojas físicas também.compra. 


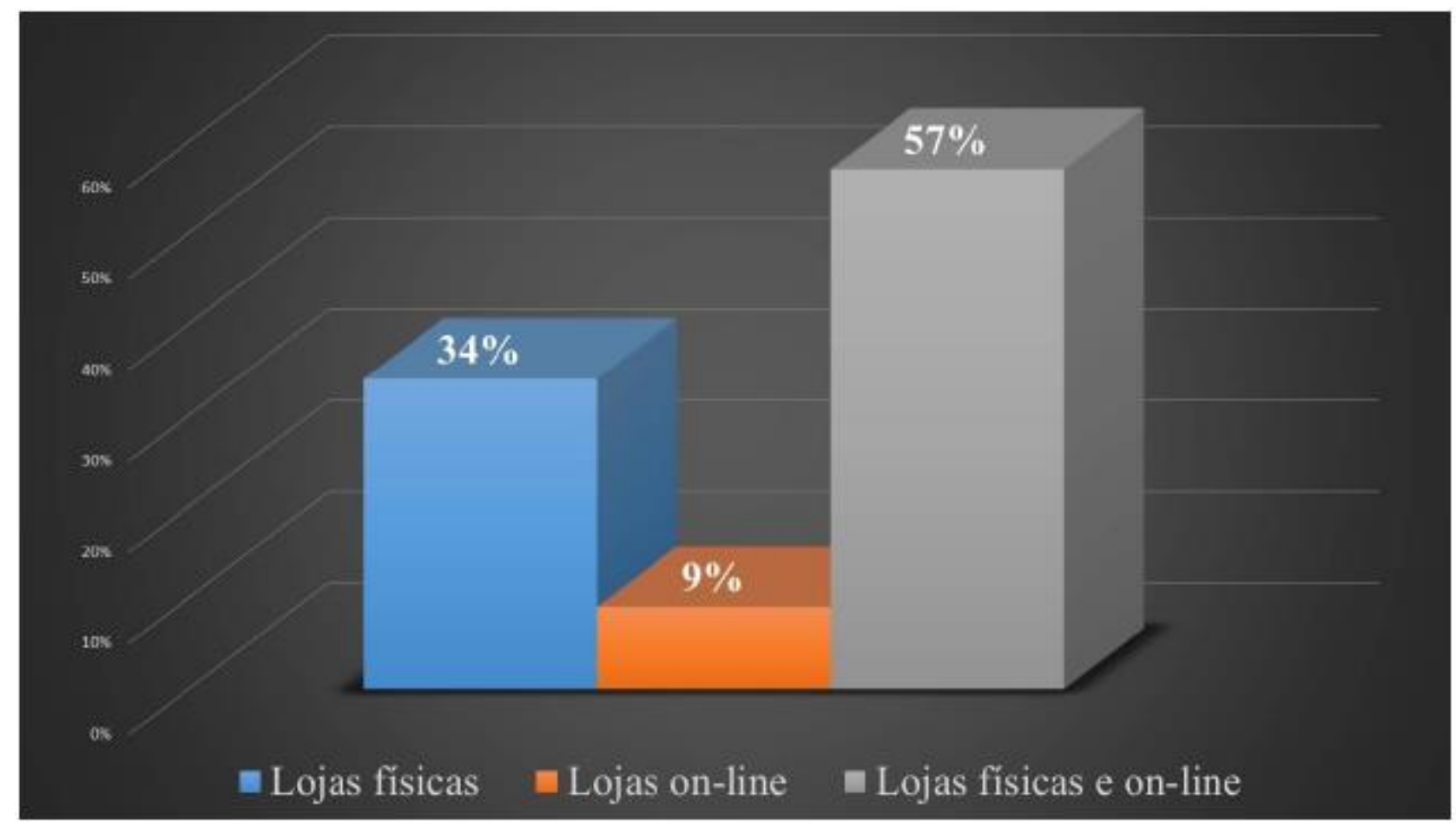

GRÁFICO 1: Meio mais utilizado de compras

\section{FONTE: Autoria própria}

Isso remete pensar o porquê da Geração Z estar procurando os meios digitais para realizar suas compras, ou seja, que atributos são valorizados por eles. Conforme pode-se observar no gráfico 2, o preço (57\%) é o atributo que mais se destaca na busca por produtos via on-line e que mais os motiva à decisão final de compra.

O segundo atributo, também está relacionado ao preço de certa forma: são as promoções de vendas (20\%), quando as lojas on-line apresentam propostas favoráveis aos consumidores, como forma de atrair sua atenção, como por exemplo as já conhecidas Liquidações Black Friday. E, em terceiro lugar (7\%) valorizam a economia de tempo que há em realizar as compras via e-commerce, sem precisar esperar em filas para realizar o pedido e/ou pagamento dos produtos.

A pesquisa demonstra que os jovens não são tão impulsivos e irracionais como apregoa a convicção popular. Pelo contrário, comprova que eles fazem uma relação custo versus benefícios e que o preço e as promoções são sim pertinentes. O que pode-se ser relacionado ainda, pela classe social que a amostra do estudo pertence (maioria C). Existem outros atributos citados em menor frequência, mas que podem ser visualizados no Gráfico 2. 


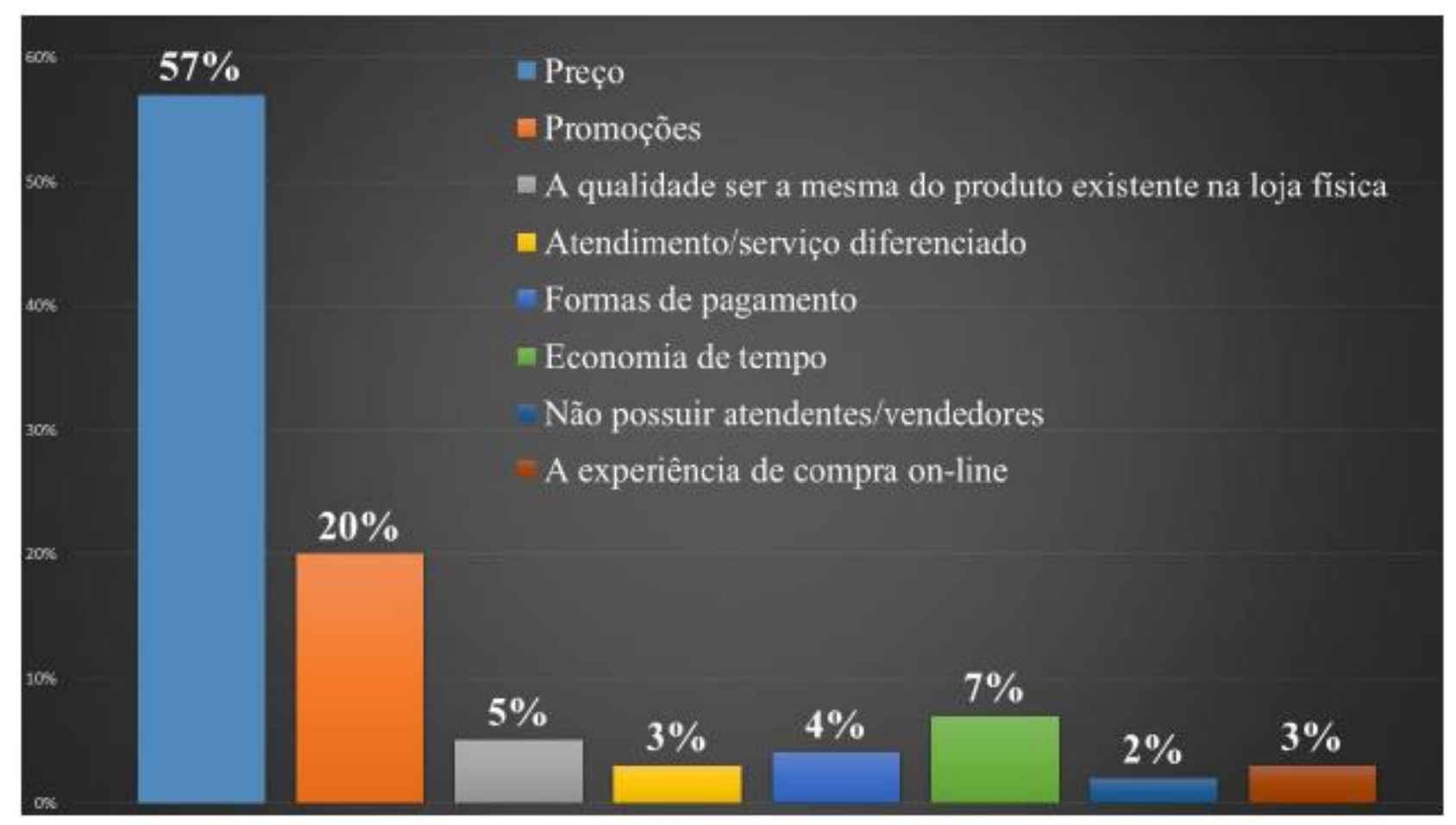

GRÁFICO 2: Atributos que atraem o consumidor nas compras on-line

FONTE: Autoria própria

Quando questionados acerca de qual tipo de produto que mais compram em lojas virtuais $30 \%$ mencionaram artigos de vestuário e acessórios, 26\% calçados e tênis, enquanto 19\% preferem comprar eletrônicos (Gráfico 3). A escolha de compra por tais produtos conferem quando observa-se a importância que a Geração $Z$ atribui ao preço, uma vez que a relação custo versus benefícios de vestuários, acessórios, calçados, tênis e livros, é mais benéfica em lojas virtuais quando comparadas as físicas. 


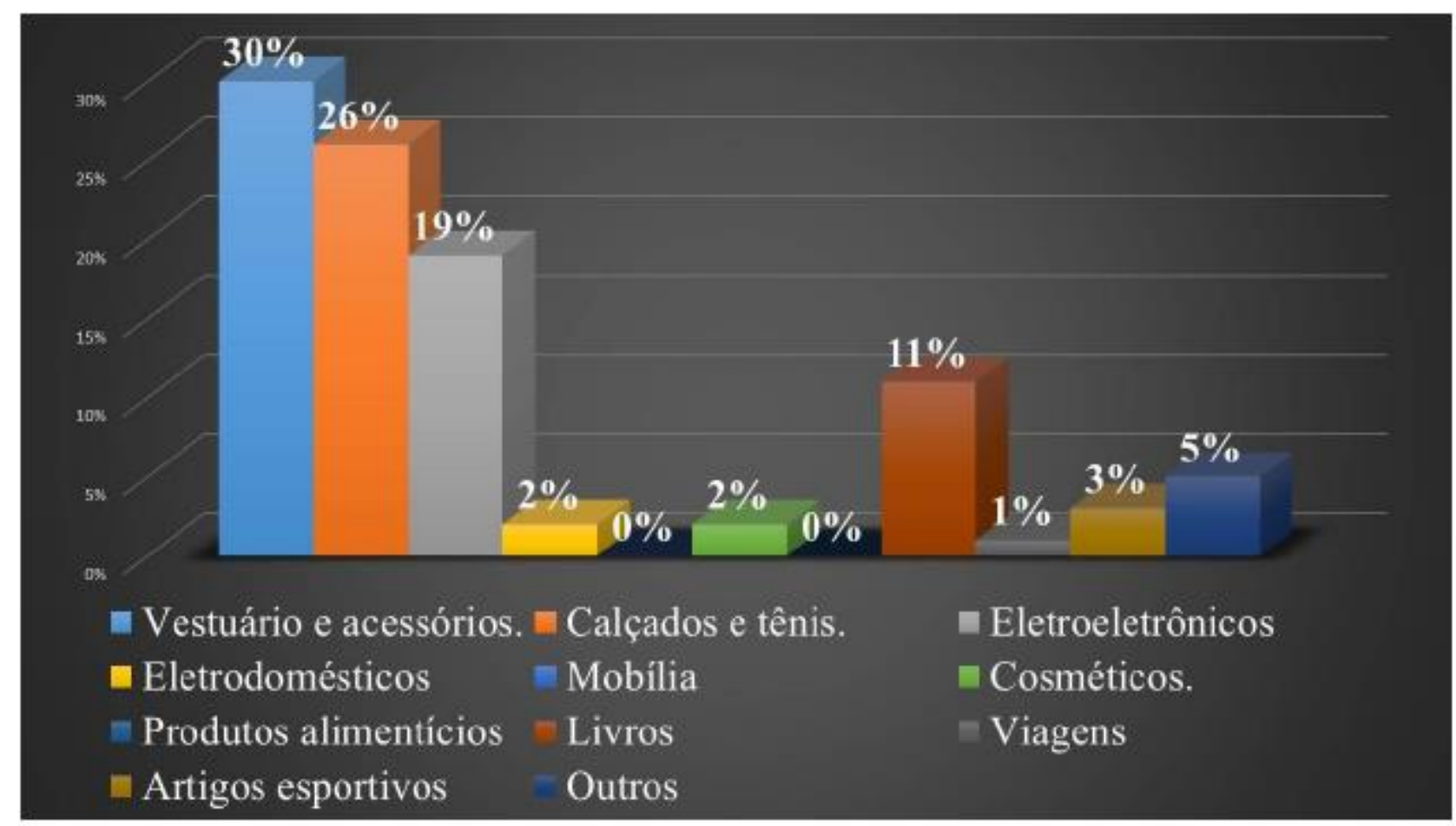

GRÁFICO 3: Artigos mais comprados on-line

FONTE: Autoria própria

estudo também demonstra uma correlação (Gráficos 3 e 4), observando-se que as empresas que os jovens mais buscam, são relacionadas com os artigos que mais procuram \compram. Como a Netshoes e Dafiti (28\%), lojas virtuais de vestuário, acessórios e calçados e; Mercado Livre e a Amazon (27\%), por serem grandes redes que apresentam uma infinidade de artigos ao consumidor, desde roupas a acessórios para veículos. Destaque para a Amazon que comercializa muitos livros, terceiro produto citado, a preços acessíveis e com grandes descontos.

As lojas Americanas, Magazine Luiza, Ponto Frio, Casas Bahia, Extra (19\%), inicialmente eram empresas de eletrodomésticos e eletroeletrônicos, e hoje adotam o novo canal e-commerce, procurando ofertar todos os tipos de produtos que estiverem ao alcance do consumidor. Perceberam que estavam perdendo mercado, e decidiram remodelar suas estratégias de canais. Valida-se assim, a afirmação de Kotler, Kartajaya e Setiawan (2017) de que as organizações necessitam buscar meios de adaptar-se ao novo perfil de consumidor: exigente, conectado e sedento por novidades. 


\section{Administração: caminhos para o desenvolvimento sustentável}

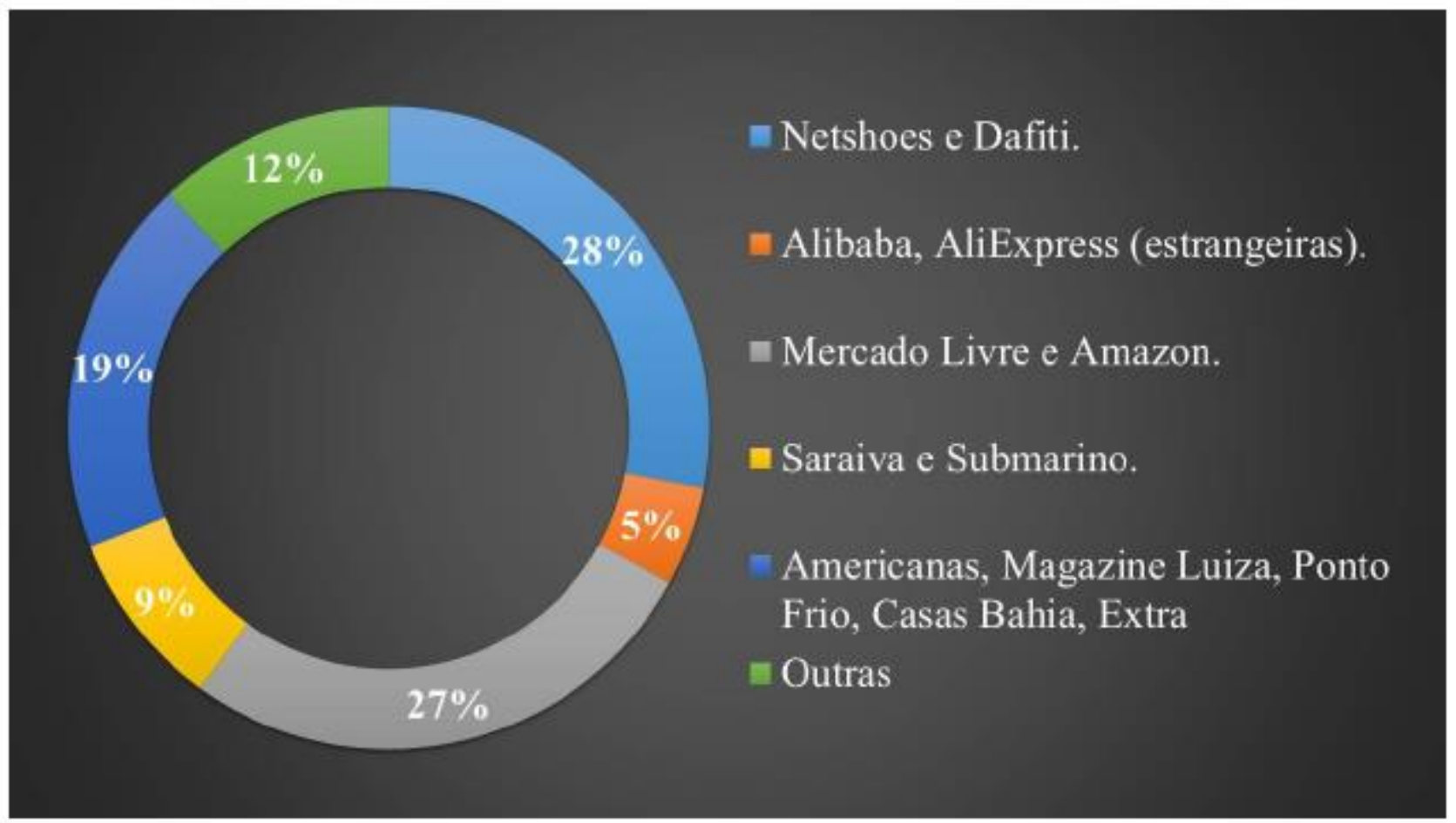

GRÁFICO 4: Lojas on-line que o jovem consumidor mais realiza compras

\section{FONTE: Autoria própria}

Da mesma forma que conhecer o que a Geração Z aprecia nas compra via internet é importante, conhecer os fatores que eles julgam negativos é primordial. Porque é exatamente sobre esses aspectos que as empresas devem estabelecer suas estratégias mercadológicas, procurando ofertar e agregar valor a sua empresa ou marca. Conforme a pesquisa 35\% dos entrevistados não gostam da cobrança de fretes exigida, fato esse apontado também, pode-se dizer, em função de que a amostra reside longe dos grandes centros, fazendo com que o valor do frete seja bem maior e, muitas vezes, exceda o valor da própria mercadoria, inviabilizando a compra virtual. Com isso, influenciam a decisão de compra da Geração Z, que pela disponibilidade de informações nas plataformas digitais, começam a procurar alternativas para comparar preço e prazos de entrega e optar por aquela que mais agrada, como destacado por Adolpho (2011).

Outro ponto negativo apresentado é a demora na entrega do produto, sendo que $33 \%$ se diz insatisfeito nesse quesito. Como a Geração Z, caracteriza-se pelo imediatismo (TAPSCOTT, 2010), querem ter o produto disponível o mais rápido possível, sem grandes esperas. É uma geração também desconfiada, 19\% mencionaram que não gostam de sites desconhecidos, preferem comprar de lojas e marcas já conceituadas. Outros fatores são apontados no Gráfico 5. 


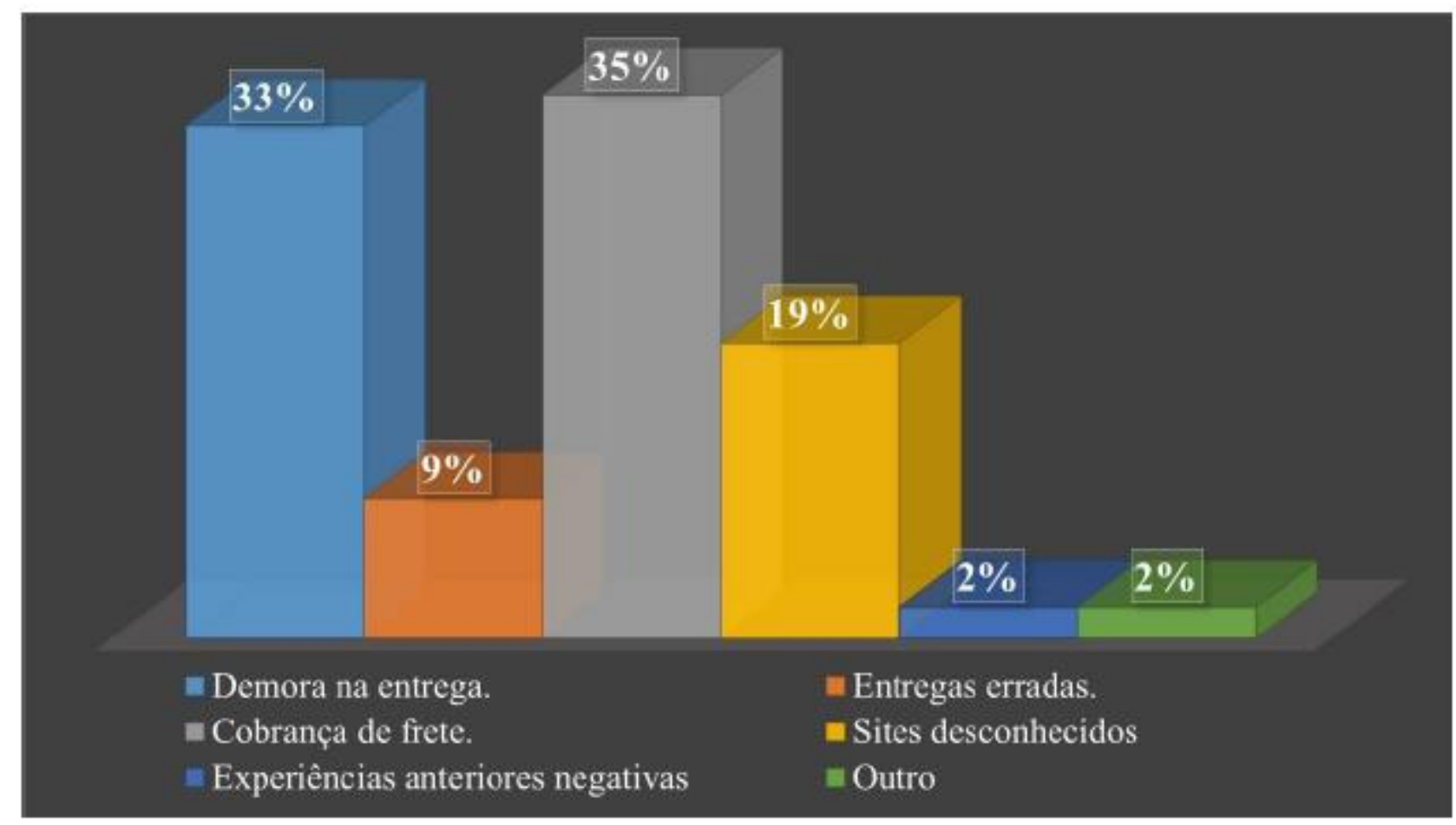

GRÁFICO 5: O que o consumidor não gosta nas compras on-line

FONTE: Autoria própria

A pesquisa aponta diferenças quanto à influência das redes sociais: $55 \%$ dos jovens não visualizam as propagandas no Facebook, diferentemente do Instagram (rede social que está em ascenção) que 46\% às vezes os influenciam e; $37 \%$ sentem influência das propagandas que surgem em meio ao feed de notícias (Gráfico 6). Pelo fato do Instagram ser uma rede social que está com muito potencial, diversas empresas estão utilizando desse meio para potencializar sua marca. Tais resultados servem como subsídio aos gestores, acerca de qual influencia as propagandas exercem e em qual rede social, assim como alerta Torres (2009) destacando o baixo investimento e o alto impacto do marketing digital. 


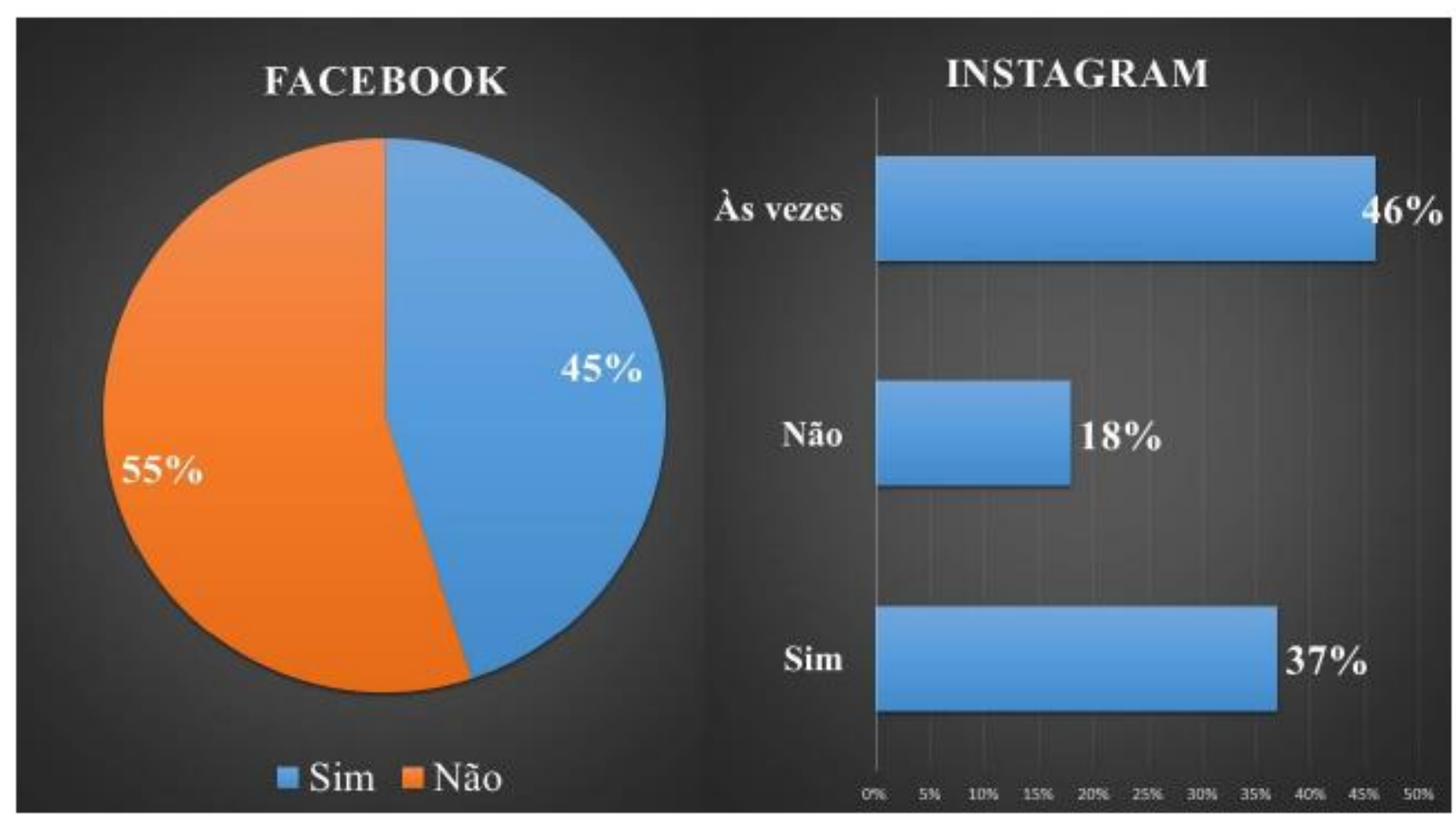

GRÁFICO 6: A influência das propagandas nas redes sociais

FONTE: Autoria própria

Com base no grupo focal realizado, foi ressaltado a importância da atualização das redes sociais para a atração dos clientes, bem como, a sugestão de que haja conteúdo no que está sendo ofertado. Torres (2009) ressalta o quão importante é realizar promoções que tenham argumentos sólidos para atrair o consumidor e como as redes sociais podem auxiliar na aproximação com o cliente. Nota-se que a interação via redes sociais tem sido uma ação estratégica muito eficiente na proximidade com o consumidor da Geração Z, afinal como mencionam Souza e Gobbi (2014) existe a tendência dos jovens assistirem menos a televisão e ter mais contato com computador, usar smartphones, ou seja, interagir e conectar-se.

Os componentes do grupo focal mencionaram ainda, que mesmo no trabalho ficam acessando a internet e, que, como nao possuem tempo de visitar as lojas, acabam tomando suas decisões de compra via on-line, seja uma compra efetiva pelo e-commerce, ou a predisposição de gostar de algum produto e ir, quando disponível até a loja. Os grupos de whatsApp das lojas também os estimulam, pois o contato faz com que solicitem amostras de mercadorias. 


\section{Administração: caminhos para o desenvolvimento sustentável}

Portanto, com base nos resultados obtidos percebe-se a relação do avanço tecnológico com a mudança do comportamento do consumidor atual. A Geração Z, público-alvo do estudo, apresenta um perfil diferente das outras gerações, é mais conectada buscando novidades no mercado, exigente quanto a preços justos, qualidade e prazos e procura comodidade por causa da rotina agitada. Por isso, a importância dos mercados conhecerem o perfil dessa geração, para utilizar essas informações na tomada de decisões da empresa, desenvolvendo-se estratégias de forma que atraia, encante e fidelize esse jovem consumidor.

\section{CONCLUSÕES}

Diante dos resultados apresentados, entende-se que a geração Z está inteiramente conectada e atenta às redes sociais e, também, pontua-se o quão as informações estão dissipando-se rapidamente em meio a sociedade. Nesse novo contexto, Kotler, Hermawan e Setiawan (2012) destacam que o futuro das comunicações de marketing estão no uso das mídias sociais.

A amostra é um público jovem interiorano, mesmo assim, estes demonstram estar sendo influenciados pelas estratégias de marketing digital por mais que haja preferência, também, em adquirir produtos em lojas físicas. Este jovem está exposto à tecnologia e são as redes sociais que criam a predisposição de ir até o estabelecimento físico.

As estratégias de marketing digital estão influenciando cada vez mais o comportamento de compra do consumidor da Geração Z, deve-se assim, planejar e implementar ações pontuais voltadas especificamente a atender as idiossincrasias desse público. O gestor necessita atrair a atenção do seu consumidor por meio das redes sociais como o Instagram, Facebook, WhatsApp, disponibilizando dicas acerca de como utilizar os produto/serviço por ele ofertados, postando como ou onde esse produto/serviço é melhor utilizado, apresentando o preço, as opções de pagamento que a empresa dispõe, se há entrega a domicílio, ou seja, estabelecer uma relação com seu público jovem. O que diferencia é o gestor aproximar-se do seu público consumidor, principalmente, daqueles que evitam o contato direto com os vendedores, devido a experiências de atendimento insatisfatórias.

As propagandas tradicionais irão ao longo do tempo, perder a influência em moldar o comportamento de compra, pois os jovens estão cada vez mais envolvidos em outras atividades virtuais e menos expostos a simples anúncios veiculados na televisão, rádio e jornais. As mídias sociais se tornarão cada vez mais expressivas como alertam Kotler, Hermawan e Setiawan (2012) e poderão fazer com que as 


\section{Administração: caminhos para o desenvolvimento sustentável}

pessoas influenciem outras com suas opiniões e experiências de compra. Será um ciclo vicioso: buscam informações, comparam empresas ou marcas, compram e, depois, emitem seus feedbacks aos outros, gerando novos estímulos de compra, ou não, no caso de insatisfação.

Cabe aos administradores contemporâneos compreender de forma ágil todas essas transformações geradas pelas novas tecnologias, co-criando, inovando e atendendo as demandas dos jovens da Geração Z. Eles estão "ligados", interconectados, são o futuro das empresas, nasceram em meio à inserção da internet, fica assim, um alerta aos gestores: mudem ou irão desaparecer do mercado (MENDES; BUENO, 2018).

\section{REFERÊNCIAS}

ADOLPHO, Conrado. Os 8Ps do Marketing Digital: O guia Estratégico de Marketing Digital. São Paulo: Novatec, 2011.

CRESWELL, J. Projeto de pesquisa: métodos qualitativo, quantitativo e misto. Porto Alegre: Artmed, 2007.

ENGEL, James F.; BLACKWELL, Roger D.; MINIARD, Paul W. Comportamento do consumidor. Rio de Janeiro: LTC, 2000.

GIL, Antonio Carlos. Como elaborar projetos de pesquisa. 4. ed. São Paulo: Atlas, 2002.

KOTLER, Philip. KARTAJAYA, Hermawan. SETIAWAN, Iwan. Marketing 3.0: As forças que estão definindo o novo marketing centrado no ser humano. Rio de Janeiro: Elsevier, 2012.

KOTLER, Philip. KARTAJAYA, Hermawan. SETIAWAN, Iwan. Marketing 4.0: do tradicional ao digital. Rio de Janeiro: Sextante, 2017.

KOTLER, Philip. KARTAJAYA Renato; BUENO, Roni Cunha. Mude ou Morra: tudo que você precisa saber para fazer crescer seu negócio e sua carreira na nova economia. São Paulo: Planeta do Brasil, 2018.

KOTLER, Philip; MARMSTRONG, Gary. Princípios de Marketing. Rio de Janeiro: LTC, 1999.

LOPES, M. A. et . al. Geração Internet: quem são e para que vieram. Revista CTS, Argentina, v. 9, n. 26, p. 39-54, mai., Buenos Aires, 2014.

MALHOTRA, Naresh K. Pesquisa de marketing: uma orientação aplicada. 3. ed. Porto Alegre: Bookman, 2001.

MENDES, Como elaborar projetos de pesquisa. 4. ed. São Paulo: Atlas, 2002.

SOLOMON, Michael R. O comportamento do consumidor: comprando, possuindo e sendo. 5. ed. Porto Alegre: Bookman, 2002. 


\section{Administração: caminhos para o desenvolvimento sustentável}

SOUZA; F. J.; GOBBI, C.M. Geração digital: uma reflexão sobre as relações da "juventude digital" e os campos da comunicação e da cultura. Revista Geminis, v. 2, n. 1, p. 129-145, 2014.

TAPSCOTT, Don. A hora da geração digital: como os jovens que cresceram usando a internet estão mudando tudo, das empresas aos governos. Rio de Janeiro: Agir Negócios, 2010.

TEIXEIRA, E.B; ZAMBERLAN, L.; RASIA, P.C. Pesquisa em administração. ljuí : Ed. Unijuí, 2009.

TORRES, Cláudio. A bíblia do marketing digital: tudo que você precisa saber sobre marketing e publicidade na internet e não tinha a quem perguntar. São Paulo: Novatec, 2009.

TURCHI, Sandra R. Estratégias de Marketing Digital e E-commerce. 1. ed. São Paulo.Atlas, 2012.

VERGARA, Sylvia Constant. Projetos e relatórios de pesquisa em administração. 10. ed. São Paulo: Atlas, 2009. 


\section{Capítulo 28}

\section{IMPLANTAÇÃO DA ESTRATÉGIA CRM EM PEQUENAS EMPRESAS}

DOI: $10.37423 / 200300430$

Walter Pereira de Freitas (Instituto Federal de Goiás - Campus Jataí (IFG)

Joslaine Cristina leske de Freitas (Universidade Federal de Jataí (UF. J)

Resumo: Customer Relationship Management (CRM) foi criado para definir toda uma classe de ferramentas que automatizam as funções de contato com $q$ cliente. Essas ferramentas incluem sistemas e, basicamente, umą mudança de átitude cơrporativa, qùe visa ajudar as empresas a criar e manter um bom relaçionamento com seus tiientes. Seu objetivo-principal é ajudar as organizzações a atrair e reter clientés e prospectos, fidełizar clientes atuais procurando atingir a stą satisfação total, para melhor compreender suas necessidades e expectativas de formação e uma visão geral dos ambientes de marketing. Com base neste princípio, este artigo tem como objetivo mostrar a eficácia da CRM em pequenas empresas.

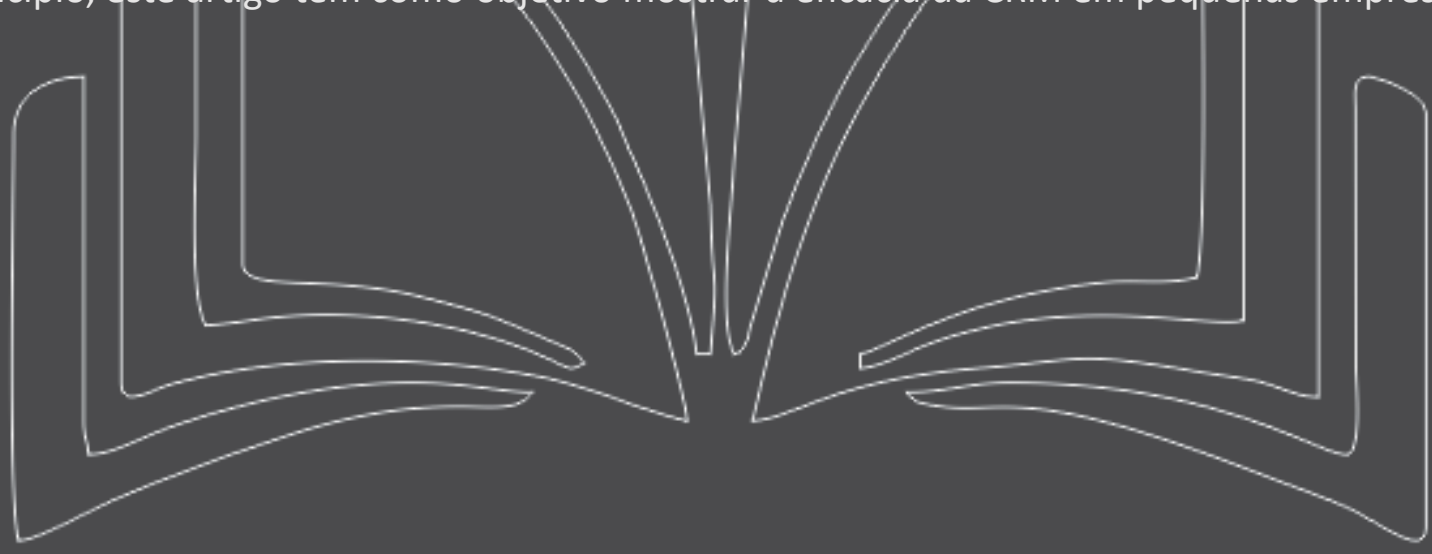




\section{Administração: caminhos para o desenvolvimento sustentável}

\section{INTRODUÇÃO}

Customer Relationship Management (CRM) é uma expressão em inglês que pode ser traduzida para a língua portuguesa como Gestão de Relacionamento com o cliente. Foi criada para definir toda uma classe de ferramentas que automatizam as funções de contato com o cliente, essas ferramentas compreendem sistemas informatizados e fundamentalmente uma mudança de atitude corporativa, que objetiva ajudar as companhias a criar e manter um bom relacionamento com seus clientes armazenando e inter-relacionando de forma inteligente, informações sobre suas atividades e interações com a empresa.

O seu objetivo principal é auxiliar as organizações a angariar e fidelizar clientes ou prospectos, fidelizar clientes atuais procurando atingir a sua satisfação total, através do melhor entendimento das suas necessidades e expectativas e formação de uma visão global dos ambientes de marketing.

O CRM abrange, na generalidade, três grandes áreas: automatização da gestão de marketing, automatização da gestão comercial, dos canais e da força de vendas e gestão dos serviços ao cliente.

Os processos e sistemas de gestão de relacionamento com o cliente permitem que se tenha controle e conhecimento das informações sobre os clientes de maneira integrada, principalmente através do acompanhamento e registro de todas as interações com o cliente, que podem ser consultadas e comunicadas a diversas partes da empresa que necessitem desta informação para guiar as tomadas de decisões.

Uma das atividades da Gestão do Relacionamento com o cliente implica registrar os contatos por si realizados, de forma centralizada. Os registros não dependem do canal de comunicação que o cliente utilizou (voz, fax, e-mail, chat, SMS, MMS etc.) e servem para que se tenham informações úteis e catalogáveis sobre os clientes. Qualquer informação relevante para a tomada de decisão pode ser registrada, analisada periodicamente, de forma a produzir relatórios de gestão.

\section{CRM}

Atualmente o mercado está cada vez mais competitivo e fazer um bom trabalho já não é a garantia de permanência no mercado, para que a empresa possa competir em tempo real é necessário que ela seja dotada de meios que possam reconhecer e relacionar com cada um de seus clientes. As integrações desses meios deram origem a um conceito chamado CRM. 


\section{Administração: caminhos para o desenvolvimento sustentável}

CRM é uma sigla derivada da palavra Customer Relationship Management (Gerenciamento de Relações com o Cliente). Segundo Bretzke (2000) surgiu pela necessidade das empresas possuírem meios que permitissem conhecer e relacionar-se de forma mais produtiva com os clientes. Os primeiros softwares de CRM surgiram no final dos anos 80 e se expandiram, no início dos anos 90, principalmente nos Estados Unidos. A expansão no Brasil ocorreu partir do final de 1998 e desde então, vem sendo cada vez mais adotado, devido à crescente conscientização de que, para manter a competitividade é fundamental conhecer profundamente o seu cliente e ter recursos para atender a demanda.

Segundo Peppers (2003) há bem pouco tempo, o planejamento estratégico das empresas baseava-se apenas no produto, marketing e gestão da organização. Com a globalização, o diferencial das empresas, passou a ser moldado com base na qualificação do atendimento aos clientes.

Gartner Group (2001) define CRM como uma estratégia de negócios voltada para otimizar a lucratividade, vendas e satisfação dos clientes, através da organização da empresa em torno de segmentos de clientes, da adoção de comportamentos voltados para satisfação dos clientes e da implementação de processos e tecnologias que suportem interações coordenadas com os clientes através de canais de relacionamento.

Silva (2001) descreve CRM como um sistema de gestão em marketing, composto de uma relação de processos de negócio que ajudam as empresas a conquistar novos clientes, mudando a cultura de funcionários com o objetivo de conhecer o cliente e atendê-lo melhor, fazê-lo comprar mais e comentar com outras pessoas sobre o atendimento da empresa. Partindo desse ponto, faz-se uma diferenciação no tratamento, com isso tem-se como resultado a garantia de fidelidade obtendo uma base sincera de consumidores.

\subsection{TIPOS DE CRM}

Como principal objetivo, o CRM apresenta a personalização de clientes, pois com a grande variedade de empresas oferecendo o mesmo tipo de produtos ou serviços, o diferencial competitivo encontrase na forma de como uma empresa atende seu cliente. Entender as necessidades e desejos individuais é de suma importância. O CRM é uma ferramenta de marketing, desta forma, está ligado diretamente ao processo de elaboração de estratégias da empresa. Existem estratégias que objetivam tornar a 


\section{Administração: caminhos para o desenvolvimento sustentável}

relação entre cliente e empresa, algo fácil, conveniente e satisfatório. O Gartner Group, propõe três tipos:

- CRM operacional: É a aplicação da Tecnologia de Informação (TI) para melhorar a eficiência do relacionamento entre os clientes e a empresa. Estão entre os produtos de CRM operacional as aplicações de automatização da força de vendas da automação de canais de venda, dos sistemas de comércio eletrônico e dos call centers (local em uma empresa onde se concentram as ligações telefônicas de clientes). O CRM operacional prevê a integração de todos os produtos de tecnologia para proporcionar o melhor atendimento ao cliente.

- CRM Colaborativo: Permite a automação e a integração entre todos os pontos de contato do cliente com a empresa. Esses pontos de contato devem estar preparados para interagir com o cliente e disseminar as informações levantadas para os sistemas do CRM Operacional.

- CRM analítico: Componente do CRM que permite identificar e acompanhar diferentes tipos de clientes como: cliente de maior valor, clientes de maior potencial e clientes de menor potencial dentro da carteira de clientes de uma empresa e, de posse dessas informações, determinar qual estratégia seguir para atender as diferentes necessidades dos clientes identificados.

\subsection{OBJETIVOS DE IMPLANTAR CRM}

Os processos e sistemas de CRM permitem que se tenha controle e conhecimento das informações sobre os clientes de maneira integrada, principalmente através do acompanhamento e registro de todas as interações com o cliente, que podem ser consultadas e comunicadas a diversas partes da empresa que necessitem desta informação para guiar e abrangem as decisões.

Uma das atividades do CRM envolve registrar os contatos por si executados, de forma centralizada. Os registros não dependem do canal de comunicação que o cliente utilizou (voz, fax, e-mail, Chat, SMS, MMS, etc.) e servem para que se tenham informações úteis e catalogadas sobre os clientes.

Qualquer informação relevante para a tomada de decisão pode ser registrada e analisada periodicamente, de forma a produzir relatórios gerenciais dos mais diversos interesses.

Segundo Brown, o CRM permite que uma empresa aborde todos os tipos de clientes que ela atendeu ou atende em momentos diferentes de seu ciclo de vida, que escolha o programa de marketing que 


\section{Administração: caminhos para o desenvolvimento sustentável}

melhor se enquadre com o ponto de vista de um cliente em relação à empresa e sua vontade de comprar os serviços e produtos oferecidos. (Brown, 2001, p.11).

Do ponto de vista tecnológico, CRM envolve capturar os dados do cliente ao longo de toda a empresa, consolidar todos os dados capturados internamente e externamente em um banco de dados central, analisar os dados consolidados, distribuir os resultados dessa análise aos vários pontos de contato com o cliente e usar essa informação ao interagir com o cliente através de qualquer ponto de contato com a empresa.

O CRM deve ser visto nas organizações como um processo contínuo, a empresa tem que estar munida de meios eficazes para o atendimento, obtendo, cuidados necessários com os seus clientes em tempo real, as quais a prioridade da empresa é possibilitar o tratamento de cada cliente de uma forma única e envolve todas as áreas e todas as funções, requerendo um trabalho periódico, composto por três fases:

- Conhecimento: nesta fase, após a compilação dos dados resultando em informações dos contatos com os clientes, decodifica as necessidades e conhece as peculiaridades, possibilitando a segmentação detalhada;

- Estratégia: a partir do conhecimento das informações, é possível determinar as melhores e corretas estratégias para atuação junto aos diferentes níveis de segmentação de mercado;

- Ações: fase da implementação das estratégias escolhidas, apuração e monitoração dos resultados e ampliação do conhecimento através da análise dos resultados das ações.

O intuito em implantar esse sistema se apóia em uma única razão, o desejo do empresariado em fechar o círculo do processo competitivo de sua empresa, ou seja, olhar mais profundo e detalhadamente a abordagem de pré-venda e da pós-venda, antes de decretar as táticas de marketing, de investimentos das posições desejadas dentro do mercado.

O CRM abrange, na qualidade, três grandes áreas no mercado:

- Automatização da gestão de marketing.

- Automatização da gestão comercial, dos canais e da força de vendas.

- Gestão dos serviços ao cliente. 


\section{Administração: caminhos para o desenvolvimento sustentável}

Automatização de Marketing (Marketing Automation), composto por aplicativos que otimizam o processo de marketing em uma empresa, com o objetivo de alocar recursos para mercados alvos com os maiores valores potenciais.

A segunda área refere-se à Automação da Força de Vendas (Sales Force Automation), cujo conjunto de softwares administra e otimiza o ciclo de vendas da empresa, aumentando sua produtividade, principalmente, por meio da otimização da realização dos contratos.

A última área trata do Suporte e Serviço ao Cliente (Customer Service \& Support), no qual são encontrados aplicativos desenvolvidos.

O desafio é trazer para o relacionamento com o cliente este conhecimento processual e ainda, encaixálo no atual paradigma do processo empresarial. A escolha por tipos de software, hardware e formatos de atendimento ao cliente, apropriado ao tamanho e aos objetivos das empresas no mercado, é a função do CRM, que atua exatamente no tão desejado diferencial competitivo.

Bretzke (2000) recomenda uma estratégia de implantação de 4 etapas de CRM:

- Definição e planejamento do modelo de relacionamento: envolve definições do modo como o cliente será tratado, quais eventos de relacionamento e plano de comunicação serão utilizados, e da coerência com o posicionamento, a segmentação e o plano de marketing da empresa.

- Redesenho dos processos de atendimento (entendido como conjunto de atividades que visam atender ao cliente).

- Seleção da solução: a partir da seleção do software, determina-se qual é o melhor hardware (incluindo computadores, equipamento de telefonia, etc.) para compor a solução.

- Implantação da tecnologia de CRM: envolve enfrentar obstáculos como à resistência organizada à mudança de cultura, a aprendizagem lenta e o esquecimento rápido (não consolidando a nova cultura).

\subsection{PROCESSO DE IMPLANTAÇÃO}

O processo de implantação do CRM passa pelas seguintes etapas: classificar e ordenar os clientes mais lucrativos e segmentar o mercado, tomando por base os fatores mais adequados para o tipo de produto/serviço oferecido. Kotler define segmentação como um esforço para aumentar a precisão da estratégia do marketing. (KOTLER, 2000, p.30)

O essencial para identificar os clientes mais lucrativos é entender quais características são mais relevantes ao mercado de cada empresa 


\section{Administração: caminhos para o desenvolvimento sustentável}

Após identificar os grupos mais interessantes, devem-se buscar características em comum para um deles, ou seja, segmentá-los, com o intuito de aumentar a previsibilidade de resposta para as ações adotadas. Contudo com as bases de consumidores cada vez maiores, as empresas são obrigadas a traçar estratégias para grupos com características similares, e oferecer no atendimento ou ponto de contato a personalização desejada pelos segmentos específicos de consumidores.

A partir destas informações elabora-se a segmentação tomando bases diferenciadas para isso, como comportamental (ciclo de vida, freqüência de utilização, comprometimento, estágio de prontidão, etc.), demográfica (idade, tamanho da família, sexo, rendimento, ocupação, religião, raça, etc.), geográfica (região, porte da cidade, densidade, área, etc.) e psicográfica (estilo de vida, personalidade, etc.).

Um passo importante para identificar clientes mais valiosos é entender por que eles compram os produtos ou utilizam os serviços da empresa. Um registro de CRM com recursos de gerenciamento de conta pode incluir um modelo personalizado, que permita que o representante de vendas categorize a venda, ou seja, defina se foi baseada em uma oferta especial ou uma ligação na proximidade geográfica

O sistema CRM deve também determinar se uma compra requer acompanhamento, talvez através de treinamento ou manutenção ou se requer um contato mínimo com o cliente, ou se provavelmente não irá ocorrer outra vez por um longo período. Esta informação é importante porque ajuda a empresa a avaliar a lucratividade do cliente através de um melhor conhecimento dos custos de aquisição e retenção.

\subsection{RELACIONAMENTO DE CRM E EMPRESA}

CRM também integra os módulos de automação, gerência, telemarketing e televendas, serviço de atendimento ao cliente, marketing, web e comércio eletrônico. Utiliza-se da Internet e de outras tecnologias de informação, comunicação e transporte para conectar-se diretamente com os clientes e modelar ofertas segundo suas necessidades.

Segundo Lobo se uma organização estiver procurando afinar todos os pontos de contato com a marca, integrando pessoas, processos e tecnologia do ponto de vista do cliente, resultando em valor de longo prazo para a marca, para a lealdade do cliente e rentabilidade, então pode-se ter certeza de que ela está entendendo o que significa CRM. (LOBO, 2002, p. 14). 


\section{Administração: caminhos para o desenvolvimento sustentável}

Numa empresa o software de gestão de relacionamento de clientes fornece informações sobre vendas, maiores lucros, identifica o potencial cliente de maior valor e maximizar os lucros por cliente mostrando como reduzir os custos das vendas a esse cliente. As pequenas empresas estão sempre ligadas às relações com os clientes uma vez que sabem os seus nomes, conhecem as preferências e proporcionam o tipo de serviço amigável que os leva a voltar sempre.

No entanto, à medida que uma empresa cresce essa capacidade de relacionamento a nível pessoal com cada cliente torna-se cada vez mais difícil, o proprietário pode estar mais envolvido nas operações e menos com os clientes e os gestores podem despender mais tempo a resolver problemas dos funcionários e menos a interagir com os clientes.

Por tudo o que foi mencionado acima consegue notar-se que o CRM é uma ferramenta altamente vantajosa para uma empresa, uma vez que possui um nível de desenvolvimento do qual faz sentido partilhar as informações sobre clientes entre equipes ou departamentos, e permite igualmente uma maior eficiência à medida que aumenta o número de registros de clientes.

Segundo Peppers a real vantagem competitiva de uma empresa consiste em ter informação sobre seus clientes que a concorrência não tem e ser capaz de transformar rapidamente esse conhecimento em ação. Ganha quem consegue estabelecer relacionamentos dominantes em seu mercado. (PEPPERS, 2004, p.15).

As ferramentas de CRM podem rastrear clientes de primeira linha, de modo que, quando clicarem no site, eles sejam automaticamente direcionados a uma página especial com ofertas relevantes. Em uma central de atendimento por telefone, os contatos com clientes de primeira linha podem até mesmo ser encaminhados a um representante de vendas ou atendimento de alto escalão para que estes clientes recebam o melhor atendimento. O mesmo tratamento pode ser oferecido aos clientes que ainda não produzem receita significativa, mas que se enquadram em um perfil que empresa busca.

\section{ESTUDO DA IMPLANTAÇÃO DE CRM EM PEQUENAS EMPRESAS}

É necessário saber que CRM é uma mudança cultural e organizacional, o que implica que todas as áreas da empresa têm influência na relação com os clientes, portanto toda a organização deve ser envolvida na iniciativa de CRM. 


\section{Administração: caminhos para o desenvolvimento sustentável}

O CRM significa maior lealdade do cliente e lucratividade. Mas este caminho implica em adesão integral, análise e redesenho dos processos existentes na empresa para acomodar novas e grandes quantidades de informações. Como sugestão para a implantação do CRM em pequenas empresas é o CRM vTirge, que é um software gratuito, multiplataforma muito eficiente. A opção de escolhê-lo foi à facilidade da utilização e instalação. Foi desenvolvido por um grupo de desenvolvedores de softwares livres. Encontra-se a versão em português para download, facilitando a utilização do software ao usuário.

O CRM vTiger inclui automação de força de vendas (contas, contatos e bem como cotações de vendas.), controle de suporte (proporciona a, base de conhecimento, auto-serviço do cliente.) automação de marketing (Gestão de campanhas, envio de e-mails.), gestão de inventário (permite a criação de um catálogo de produtos, livros de preços, gestão de vendas, ordens de encomendas, ordens de vendas e faturas.), suporte a múltiplas bases de dados (são conjuntos de registros dispostos em estrutura regular que possibilita a reorganização dos mesmos e produção de informação.), personalização de produto, (adaptar os produtos e processos ao gosto do cliente) calendário, integração com e-mail, entre outros variados recursos.

Serão necessários equipamentos como um computador, impressora caso queira imprimir algum dado do cliente, internet para que possa entrar em contato com esse cliente periodicamente e um telefone onde a secretaria poderá esta fazendo o trabalho de call center.

Em termos simples, o CRM pode ser entendido como uma estratégia que permite à empresa como um todo ter uma visão única de seu cliente e, a partir disto saber explorar as oportunidades de negócio. Para isso é necessário aproveitar todas as interações que a empresa tem com o cliente no sentido de captar dados e transformá-los em informações que possam ser disseminadas pela organização, permitindo que todos os departamentos call center, vendas, administrador vejam o cliente da mesma forma, ou seja, saibam quem ele é, seus gostos e preferências, quantas vezes ligou, reclamações que fez, sugestões que deu, quanto traz de valor para a empresa, entre outras.

Através do controle de suporte empresa deve ter o foco total no cliente e conquistá-lo para relacionamento mútuo e duradouro. A diferenciação dos clientes é outro ponto importante na estratégia de relacionamento em que a empresa deverá definir o grupo denominado bons, regulares e ruins e isto será feito pela automação de força de vendas. Clientes bons os que pagam corretamente, regulares os que atrasam e ruins os que não pagam, só assim é possível distingui-los, para manter os 


\section{Administração: caminhos para o desenvolvimento sustentável}

bons os clientes potenciais. Como tal a empresa deverá ter uma cultura comercial voltada para o cliente, que garanta que toda atividade da empresa está a serviço das necessidades do mesmo.

\subsection{PROCESSO DE MARKETING DA EMPRESA}

A empresa deverá ter a preocupação em adequar seus produtos e serviços a necessidades de seus clientes, isso é satisfatório para ambos, pois, a empresa conseguirá alcançar um patamar de vendas excelente e oferecerá um serviço de qualidade. Utilizando o CRM vTirge à empresa terá uma lista mostrando o início e o término de toda campanha de marketing, qual o produto que está na promoção, enviará e-mail a esse bom cliente informando sobre produtos novos.

Também se faz necessário adotar iniciativas de retenção dos clientes tradicionais e de conquista de novos, sendo acompanhadas de perto pela gerência e por toda a empresa. Para isso é preciso identificar quais são os clientes e especificamente, quais deles interessam mais para a empresa, por gerarem valor, e quais deles não interessam, porque seu atendimento gera alto custo e resulta em pouco valor para a empresa

Com o conhecimento sobre os hábitos e costumes sobre o cliente é, que se pode antever-se a qualquer ação, surpreendendo e fazendo-se presente em seu cotidiano. Com os dados em mãos, a empresa poderá oferecer ou até mesmo manter a compra de seu cliente, pois possuem as informações, históricos de grande valia que tornam sua comercialização mais personalizada, mais próxima e informal que é informado pelo suporte a múltipla base de dados. O cliente gosta de ser informado do problema tratado pelo mecânico em seu automóvel saber que esse profissional é capacitado com conhecimentos, experiência e especialização.

\subsection{MARKETING DE RELACIONAMENTO}

Com o software CRM vTirge desenvolvimento tecnológico, aos clientes têm uma grande facilidade para interagir com canais de contatos das empresas, o que tornara a mecânica Mania uma empresa capacitada na disputa empresarial, em geral todos os clientes querem um total atendimento quando precisam dos serviços.

A empresa contará com um serviço diferencial para os clientes que considerará ser de primeiro escalão, ou seja, aquele que paga em dia os seus débitos e freqüenta a empresa sempre que precisar 


\section{Administração: caminhos para o desenvolvimento sustentável}

de uma assistência o administrador e funcionários precisam conhece quem são esses os verdadeiros clientes.

A empresa deverá ter uma integração com o e-mail de cada cliente e estar apta a responder a eles em tempo real e em qual quer lugar e ainda possa atender seus pedidos imediatamente, conclui-se com isso que a empresa deve ter os recursos necessários para praticar o gerenciamento do relacionamento com os clientes e saber dialogar.

\section{CONSIDERAÇÕES FINAIS}

CRM é um meio abrangente para a empresa gerenciar o relacionamento com clientes inclusive com os de maior potencial para benefício mútuo e duradouro. A implantação de CRM vai ajudar a empresa a conhecer melhor os seus clientes de maior significado, ou seja, os que utilizam mais o serviço da mecânica e autopeças, assim quando o cliente utilizar os serviços da oficina, o funcionário saberá quais as suas preferências, o que está precisando, e qual é o preço melhor a oferecer para ele.

O CRM tem também a finalidade de resgatar a relação cliente-empresa que, em muitos negócios, anda extremamente desgastada, pois não adianta ter milhares de clientes se não se conhece nenhum deles profundamente.

A importância do CRM está intimamente ligada à importância do atendimento ao cliente, já que o atendimento comprovadamente é a principal razão da perda de clientes em uma empresa.

Com o uso adequado dos dados do cliente o empreendedor só tem a ganhar. Um dos primeiros benefícios obtidos é a melhoria contínua dos procedimentos internos sem perder o foco nos resultados junto ao cliente, com alta rentabilidade. Passar a entender sua clientela profundamente é fundamental para a administração eficiente, pois ajuda a estabelecer as ações estruturais.

O ideal para pequenas empresas é que se preservem a qualidade e o bom atendimento e que se apliquem esses conceitos diariamente. A compreensão e a prática dos conceitos de CRM são importantes para os lucros da empresa.

\section{REFERÊNCIAS}

BRETZKE, Miriam. Marketing de relacionamento e Competição em tempo real com CRM. São Paulo: Ed. Atlas. 


\section{Administração: caminhos para o desenvolvimento sustentável}

BROWN, Stanley A. CRM - Customer Relationship Management. São Paulo: Makron Books, 2001. p. 11.

GARTNER GROUP, CRM and E-commerce Summit Conference Presentation. São Paulo: March 2001.p.9-47

KOTLER, Philip. Administração de marketing: a edição do novo milênio. São Paulo: Prentice Hall, 2000. p.30.

LOBO, Alexandre. Marketing de relacionamento. São Paulo: Seminários SSJ, 2002. , p14.

PEPPERS, Don; ROGERS, Martha. CRM ganha força no país. HSM Management, v. 7, n. 38, p49-59, maio/jun. 2003.

PEPPERS \& ROGERS, Group. CRM Series - Marketing 1to1. 3.ed. São Paulo, 2004, p 15.

POSER, Denise von. In: ZENONE, L. C. CRM: conceitos e estratégias. São Paulo: Atlas, 2001. p. 25.

SILVA, Antonio Paulo de Andrade. O GED no CRM: Uma tecnologia que deve ser utilizada. No Mundo da Imagem, São Paulo, n 43, p. 2-8, jan/fev.2001. 


\section{Capítulo 29}

\section{A IMPORTÂNCIA DA TERCEIRIZAÇÃO EM USINA HIDRELÉTRICA: ESTUDO DE CASO SOBRE A GESTÃO DA MANUTENÇÃO}

\section{DOI: $10.37423 / 200300431$}

Tânia Helena Sobrinho Martins (UEMG, Brasil). taniahelenafrt@gmail.com Danilton Carlos da Sitvą (UNESP, Brasil).daniltoncarlos@gmail.com Jussara Goulart da Silva (UFU, Brasil). profadmjussara.ufl@gmail.com Leandro Divino Miranda de Oliveira (Brasil).leandro_miranda92@hotmail.com MarletteCassia Oliveira Ferreira) (IFSP,Brasil).marlettecassia@ginail.com
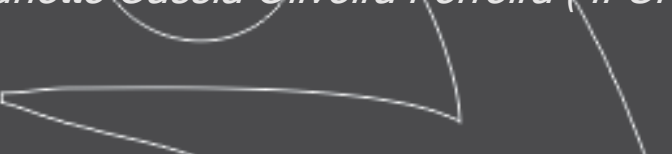

Resumo: O prèsente trabalho tem por objetivo evidenciar um modelo adotado na gestão de manutenção preventiva pela Usina Hidrelętrica Marimbondo-Furnas ressaltando o conceito de manutenção, as definiçồes de atuação das manutenções: Coyretiva; preventiva; preditiva; e a detectiva. A manutenção esstabelecida na Empresa é a corretiva sendo, serviço de terceirização contratada anualmente. Trata-se de uma pesquisa qualitativa, sథndo um estudo de cáso, baseado em uma entrevista dom um engenheiro da empresa. O ponto crítico nesse setor do comércio é a manutenção corregtiva, pois, se não realizada perjodicamente pode acarretar prejulzos-financeiros e morais.

Palavras-chave: Usina; Terceirizaçäo; Estudo de Caso; Qualitativa; Manutenção.

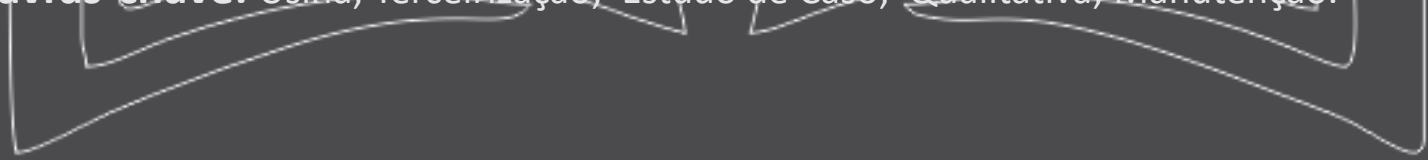




\section{Administração: caminhos para o desenvolvimento sustentável}

\section{INTRODUÇÃO}

Devido a globalização, estão ocorrendo várias transformações nas empresas, que devem ter que administrar seus recursos financeiros, tecnológicos e de gestão fazendo frente às ameaças do mercado, e com objetivo de diminuir os custos, sem prejudicar a qualidade. Diante disto, as ações de manutenção têm sofrido grandes avanços e mudanças ao longo do tempo.

Segundo a Associação Brasileira de Normas Técnicas (ABNT), a manutenção é um conjunto de todas as ações necessárias para que um item seja conservado ou restaurado de modo a poder permanecer de acordo com uma condição especificada. São medidas necessárias para a conservação ou a permanência de algum item ou de uma situação, ou ainda como cuidados técnicos indispensáveis ao funcionamento regular e permanente de motores e máquinas. Diante do estudo sobre a manutenção, observa-se que muitos acidentes e erros poderiam ser evitados se a adoção das estratégias especificas fossem priorizadas.

Para o presente estudo, definiu-se como objeto, a Usina Hidrelétrica Marimbondo-Furnas, e como objetivo geral definir o melhor modelo utilizado na gestão de manutenção preventiva adotado pela usina. O estudo visa contribuir para o aprimoramento de um modelo estratégico para a gestão da manutenção analisando as atividades desenvolvidas junto aos trabalhadores terceirizados que atuam no setor de manutenção.

Observa-se que o ponto crítico nesse setor é a manutenção corretiva, pois se não realizada periodicamente pode acarretar em futuros prejuízos financeiros e morais. A pesquisa traz como problema a seguinte pergunta: “Qual o melhor modelo de gestão de manutenção preventiva aplicável nas Usinas Hidrelétricas?

A pesquisa foi realizada no município de Fronteira, estado de Minas Gerais, na Usina Hidrelétrica de Marimbondo, construída entre 1971 e 1977, pertence a Furnas Centrais Elétricas, subsidiária da Centrais Elétricas Brasileiras, localizada no rio Grande, entre os municípios de Icém-SP e Fronteira-MG, e é considerada a segunda maior usina da empresa geradora de energia com oito unidades geradoras. 


\section{Administração: caminhos para o desenvolvimento sustentável}

\section{FUNDAMENTAÇÃO TEÓRICA}

\subsection{MANUTENÇÃO}

Nos últimos anos a atividade de manutenção tem passado por mais mudanças do que qualquer outra atividade. Essas alterações são consequências do aumento, acelerado, do número e da diversidade dos itens físicos (instalações, equipamentos e edificações) que devem ser mantidos; do aumento de instrumentação, automação e monitoramento "on line" dos equipamentos; dos projetos mais complexos; das novas técnicas de manutenção; dos novos enfoques sobre a organização da manutenção e suas responsabilidades; da importância da manutenção como função estratégica para melhoria dos resultados do negócio e aumento da competitividade das organizações e da introdução da gestão como fator indispensável para alcançar os melhores resultados para a manutenção e para a empresa como um todo (Kardec \& Nascif, 2012).

Júnior (2006) cita que o aumento dos registros de ocorrências de manutenção, bem como os altos gastos, que ficaram ainda mais evidentes com a prática da manutenção preventiva, impulsionaram as empresas a desenvolver o setor, aprimorando o planejamento e a gestão da manutenção.

O foco no controle e prevenção de falhas passou a fazer parte do cotidiano da equipe de manutenção e trouxe bons resultados em termos de aumento da confiabilidade e disponibilidade das máquinas e equipamentos, diminuição dos riscos de segurança e saúde do trabalhador, entre outros.

Formas simples de manutenção, como conservação de objetos e ferramentas de trabalho, estendendo-se até pequenas atividades de reparo, podem ser observadas desde os primórdios das civilizações. Apesar de existirem na indústria pessoas responsáveis pela manutenção, estes ainda eram subordinados à função operação e executavam manutenção corretiva emergencial, o que implicava em conserto após falha e eventual indisponibilidade de máquina (Filho, 2008).

\subsection{A IMPORTÂNCIA DA MANUTENÇÃO}

Este item descreve a importância da programação, pensar e agir estrategicamente, para que a atividade de manutenção se integre de maneira eficaz aos processos produtivos, contribuindo efetivamente, para que a empresa caminhe rumo à Excelência Empresarial.

"A Competitividade de uma organização depende de vários subsistemas que se interligam através de relações extremamente fortes e interdependentes" Como citados por Xenos (2004, p.35), a 


\section{Administração: caminhos para o desenvolvimento sustentável}

manutenção faz parte deste subsistema, com papel importantíssimo, cumprindo sua missão, de que por meio de suas ações atenda a todas as áreas dentro da organização, em especial seu cliente interno, que é a área de operação.

A manutenção é conceituada em restabelecer as condições originais dos equipamentos. "Garantir a disponibilidade, funcionamento e função dos equipamentos e instalações de modo a atender a um processo de produção ou de confiabilidade, segurança, preservação do meio ambiente e custo adequado (Kardec \& Nascif, 2012, p.52)".

No passado era comum um gerente de manutenção dizer que seu principal problema era o excesso da demanda de serviços, decorrente de uma confiabilidade não adequada ou da não adoção das melhores práticas na manutenção preventiva e ou corretiva.

A importância da manutenção se destaca desde o século passado, após a Segunda Guerra Mundial, com o forte avanço da mecanização e início da industrialização, fica em evidencia, como citado por Kardec e Nascif (2004, p. 2) "a ideia de que falhas dos equipamentos deveriam e poderiam ser evitadas".

Para a manutenção exercer um papel estratégico, a manutenção precisa estar voltada para os resultados empresariais da organização. É preciso, sobretudo, deixar de ser apenas eficiente para se tornar também eficaz; ou seja, não basta, apenas, reparar o equipamento ou a instalação tão rápida quanto possível, mas é preciso, principalmente, manter a função do equipamento disponível para a operação, reduzindo a probabilidade de uma parada de produção não planejada.

\subsection{TIPOS DE MANUTENÇÃO}

Os tipos de manutenção são caracterizados pela maneira como é realizada a intervenção no sistema. Neste item, serão descritas as práticas básicas de manutenção, consideradas como principais por diversos autores. São elas: manutenção corretiva planejada e não planejada, manutenção preventiva, manutenção preditiva, manutenção detectiva e engenharia de manutenção.

Basicamente a manutenção se apresenta de três formas possíveis, preventiva, corretiva (planejada e não planejada) e preditiva. E todas apresentam seus pontos positivos e negativos, a melhor opção é a que se adéqua a necessidade da organização, seja estrategicamente ou operacionalmente, conforme Figura 1: 


\section{Administração: caminhos para o desenvolvimento sustentável}

\section{ENGENHARIA DE MANUTENÇÃO}

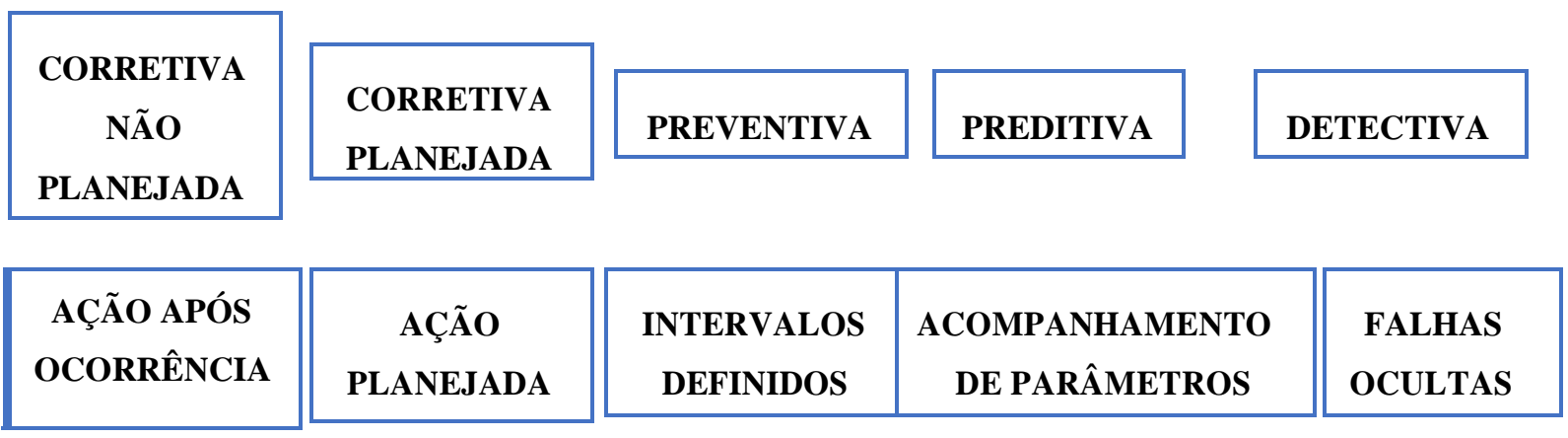

Figura 1: Tipos de Manutenção.

Existe uma grande variedade de denominações das formas de atuação da manutenção, as principais atividades ou metodologias de atuação de manutenção, estão explicitadas na NBR 5462, mostrados na Tabela 1.

\footnotetext{
Tipo/Método/Atividade Definição ou Conceituação

Manutenção Preventiva Manutenção efetuada em intervalos predeterminantes, ou de acordo com critérios prescritos, destinada a reduzir a probabilidade de falha ou a degradação do funcionamento de um item.

Manutenção Corretiva Manutenção efetuada após a ocorrência de uma pane, destinada a recolocar um item em condições de executar uma função requerida.

Manutenção Preditiva Manutenção Preditiva ou Manutenção Controlada- Manutenção que permite garantir Uma qualidade de serviço desejada, com base na aplicação sistemática de técnicas de análise, utilizando-se de meios de supervisão centralizados ou de amostragem, para reduzir ao mínimo a manutenção preventiva e diminuir a manutenção corretiva.

Tabela 1: Definições de Atuação de Manutenção.
}

É importante distinguir bem os resultados obtidos com a manutenção corretiva não planejada, enquanto na corretiva planejada, que ocorre a partir de uma demanda da preditiva ou da detectiva, a perda de produção é reduzida ou mesmo eliminada, além de o tempo de reparo e o custo serem minimizados, na manutenção corretiva não planejada ocorre justamente o oposto (Kardec \& Nascif, 2012).

\subsection{MANUTENÇÃO CORRETIVA}

A manutenção corretiva é efetuada após a ocorrência de uma pane ou de uma falha destinada a recolocar um item em condições de executar uma função requerida (NBR 5462). Ao atua em um equipamento que apresenta um defeito ou um desempenho diferente do esperado, estamos fazendo manutenção corretiva. 


\section{Administração: caminhos para o desenvolvimento sustentável}

Segundo Xenos (2004), a manutenção corretiva sempre é feita depois que ocorreu a falha. Em princípio, a opção por este método de manutenção deve ser levada em conta. Este método de manutenção, não planejada, tem a função de identificar onde ocorreu a falha e ou quebra do equipamento, máquina ou instalação, para que haja a recuperação, restauração ou até mesmo substituição de componentes, evitando a perca excessiva de tempo para que não gere a diminuição de capacidade produtiva. No entanto, este tipo de manutenção não deixa de ter seu custo, mantendo estoque de peças para reposição, ferramentas e mão de obra especializada.

\subsection{MANUTENÇÃO PREVENTIVA, PREDITIVA E DETECTIVA}

A manutenção preventiva é uma das atividades mais usada, por incluir tarefas rotineiras, tais como limpeza de equipamentos, lubrificações e inspeções das mais simples a mais detalhada, nas quais os gestores de manutenção planejam e as executam periodicamente com critérios preestabelecidos no objetivo de reduzir ou eliminar incidência de falhas e deterioração dos equipamentos (XENOS, 2004).

A manutenção preventiva, por se tratar de uma atividade executada periodicamente, se torna a principal atividade dentro da área de manutenção de qualquer empresa. Na realidade, a manutenção preventiva envolve algumas atividades sistemáticas, tais como, substituições de peças, recuperação e inspeções peroodicas.

Segundo Kardec e Nascif (2004) a manutenção preditiva é conceituada como: a atuação realizada com base na modificação de parâmetros de condições ou desempenho, cujo acompanhamento obedece a uma sistemática. Através de técnicas preditivas é feito o monitoramento da condição de correção, quando necessária, é realizada através de uma manutenção corretiva e planejada.

Xenos (2004) aborda que a manutenção preditiva permite aperfeiçoar a troca das peças e componentes, pois, permite prever quando a peça ou componente estarão próximo do seu limite de vida, estabelecidos previamente com base em parâmetro que podem ser acompanhados (vibrações, temperaturas) servindo como um complemento à manutenção preventiva.

A manutenção detectiva começou a ser mencionada na literatura a partir da década de 90 , sua denominação está ligada à palavra "Detectar" (em inglês Detective Maintenance, pode ser definida da seguinte forma: "atuação efetuada em sistemas de proteção, comando e controle, buscando detectar falhas ocultas ou não perceptíveis ao pessoal de operação e manutenção (KARDEC \& NACIF, 2012). 


\section{Administração: caminhos para o desenvolvimento sustentável}

\subsection{ENGENHARIA DE MANUTENÇÃO E A MELHOR MANUTENÇÃO}

É a segunda quebra de paradigma na Manutenção, e significa uma mudança cultural. A engenharia de Manutenção é o suporte técnico da manutenção que está dedicado a consolidar a rotina e implantar a melhoria.

De acordo com Kardec \& Nascif (2009) a Engenharia de Manutenção significa "perseguir benchmarks, aplicar técnicas modernas, estar nivelado com a manutenção do Primeiro Mundo". Com isso, visa, aumentar a confiabilidade, disponibilidade, segurança e manutenibilidade; eliminar problemas crônicos e solucionar problemas tecnológicos; melhorar gestão de pessoal, materiais e sobressalentes; participar de novos projetos e dar suporte à execução; fazer análise de falhas e estudos; elaborar planos de manutenção, fazer análise crítica e acompanhar indicadores, zelar sempre pela documentação técnica. As empresas que praticam a Engenharia de Manutenção estão alimentando sua estrutura de dados e informações sobre manutenção que irão lhe permitir realizar análises e estudos para proposição de melhorias no futuro.

Todos os tipos de manutenção (corretiva, preventiva e preditiva), apresentam seus pontos positivos e negativos. Sendo a manutenção corretiva o método primordial, desde o tempo dos homens da caverna estes usavam método de afiar suas flechas para pescar. E sendo a manutenção preventiva a mais moderna incluindo a manutenção preditiva, pois em um mesmo equipamento é possível a realização de duas ou mais manutenções simultaneamente. No exemplo de uma turbina geradora, é possível aplicar a manutenção corretiva em determinados componentes e em outros a manutenção preventiva, para aproveitamento de sua parada, porém esta combinação dependerá dos aspectos econômicos, ou seja, a organização deve sempre levar em consideração a relação entre os custos das perdas causadas pelas falhas e custos de uma manutenção (XENOS, 2004).

\subsection{TERCEIRIZAÇÃO}

Segundo Araújo (2007, p.138) "Terceirizar significa passar adiante (para terceiros e pagando) a responsabilidade pela execução de determinada atividade ou de conjunto de atividades". A terceirização quando bem empregada garante bons resultados, promovendo enxugamento da organização, geralmente encontra-se sufocada com as atividades do dia a dia, das estruturas e do pessoal. Com a terceirização é possível a que organização focar realmente no que é essencial, sua existência no mundo dos negócios, e transferir os serviços de apoio a empresa contratada. 


\section{Administração: caminhos para o desenvolvimento sustentável}

A tecnologia é um dos destaques feito pelo autor, como incentivo no surgimento de empresas de médio e pequeno porte e até mesmo os prestadores de serviços autônomos, assim, favorecendo a expansão da terceirização, que sem dúvida esse novo processo de gestão trouxe para o Brasil novas possibilidades de emprego.

Terceirizar não é abandonar as atividades, ou seja, funções de apoio, se essas não forem bem administradas, poderá trazer pontos negativos, influenciando o andamento das atividades fins. No entanto é fundamental que no processo de terceirização/outsourcing empresas contratantes busquem encontrar parceiros especializados que ofereçam uma qualidade inquestionável nos serviços prestados (Araújo, 2007).

Kardec e Nascif (2012, p.233) apresentam algumas das principais vantagens da terceirização, quando a terceirização está empregada de maneira correta e com parceiros certos, as vantagens são o aumento da qualidade; otimização de custos; transferência de processos suplementares a quem os tenham como atividade-fim; aumento da especialização; redução de estoques, quando se contrata com fornecimento de material; flexibilidade organizacional; melhor administração do tempo para a gestão do negócio; redução de áreas ocupadas; busca de especializações específicas. A grande vantagem de uma terceirização é que as empresas podem voltar-se inteiramente a seus negócios finais sem se preocupar com as inovações tecnológicas constantes, o que significa que tais empresas podem estar livres de altos investimentos, transferindo a terceiros especializados no assunto, que poderão, e decerto o farão, acompanhar as tendências tecnológicas e outras inovações, somando altos níveis de qualidade em suas atividades executadas (Araújo, 2007).

As principais desvantagens que podem ocorrer, quando se terceirizar sem uma adequada visão estratégica, são o aumento da dependência de terceiros; aumento de custos quando, simplesmente, se empreiteriza; aumento do risco empresarial pela possibilidade de queda na qualidade; redução da especialização própria; aumento do risco de acidentes pessoais; e aumento do risco de passivo trabalhista, dependendo da qualidade da contratação.

O processo de terceirização pode proporcionar resultados inesperados, devido a empresa escolhida, a terceirizada, se tornar uma concorrente após aprender toda a tecnologia de sua contratante. No entanto é necessário tomar cuidado na escolha dos parceiros e das atividades a serem terceirizadas, uma avaliação criteriosa e detalhada, consequentemente resultará em parceiros eficazes e confiáveis (Filho, 2008). 


\section{Administração: caminhos para o desenvolvimento sustentável}

Araújo (2007, p. 143-144) nos apresenta algumas características básicas que são perceptíveis em processos de contratação de empresas depois de termos definido o que ela, a terceirização, representa, sabe quais elementos a identificam, contudo, relacionadas para esclarecer as devidas proporções de seu uso nas empresas: o processo de interferência externa: como vimos tercerizar é buscar, em empresas especializadas externas, as soluções para os problemas de gestão organizacional; as funções de apoio: a terceirização, como também já vimos, age apenas sobre as denominadas funções de apoio da empresa, isto é, sobre funções que não influenciam diretamente o negócio central da empresa. As funções de apoio podem, e devem ser delegadas a terceiros.

A terceirização é uma tendência mundial, sendo uma ferramenta estratégica na busca da competitividade empresarial, alguns pontos devem ser observados, como a contratação ainda precisa evoluir, rapidamente, da empreiteirização para a terceirização. Para que isso ocorre são necessários esforços tanto das contratantes como das contratadas.

\section{PROCEDIMENTOS METODOLÓGICOS}

Nesta seção foi abordado sobre os procedimentos metodológicos adotados por esta pesquisa. Também foi apresentado uma breve contextualização e histórico da empresa.

\subsection{CONTEXTUALIZAÇÃO}

A pesquisa de campo procede à observação de fatos e fenômenos exatamente como ocorre no real, à coleta de dados referente ao mesmo e, finalmente, à análise e interpretação desses dados, com base numa fundamentação teórica consistente, objetivando compreender e explicar o problema pesquisado.

\subsection{SELEÇÃO DA EMPRESA}

A empresa selecionada é do segmento energético "Usina Marimbondo" foi fundada em 1975 para atender a necessidade de abastecimento de geração de energia elétrica, localizada no município de Fronteira-MG, considerada uma das 11 usinas Hidrelétrica pertencente a Eletrobrás.

\subsection{HISTÓRICO DA EMPRESA}

Há 60 anos, a Usina Hidrelétrica Marimbondo- Eletrobrás Furnas, vem desenvolvendo no Brasil a geração de energia. No dia 28 de fevereiro de 1957, o então presidente Juscelino Kubitschek lançava as bases de uma empresa que se tornaria paradigma de competência e orgulho de todos os brasileiros. 


\section{Administração: caminhos para o desenvolvimento sustentável}

Na época, o país iniciava um ciclo virtuoso de crescimento, com acelerado processo de urbanização, instalação de grandes indústrias, abertura de estradas e, alterando o foco do colonizador litorâneo, voltava suas energias para a ocupação e desenvolvimento das fronteiras agrícolas a Oeste. A cada dia reafirmando seu compromisso com o interesse nacional, a Empresa, nascida nas alterosas de Minas, atua hoje, nas áreas de geração, transmissão e comercialização de energia elétrica, garantindo o fornecimento em uma região onde estão concentrados $48 \%$ dos domicílios brasileiros, $65 \%$ do Produto Interno Bruto, englobando os estados de São Paulo, Rio de Janeiro, Minas Gerais, Espírito Santo, Goiás, Tocantins, Paraná, Mato Grosso e o Distrito Federal.

O sonho da geração dos idos dos anos 50 de uma grande empresa brasileira transformou-se, literalmente, em concreta realidade para as atuais e futuras gerações. E o que não falta é concretude. São onze usinas hidrelétricas, duas termelétricas, 46 subestações, mais de 19 mil km de linhas de transmissão, 9.919 MW de capacidade instalada - o que representa 12\% do total da geração de energia do país. Na área de Responsabilidade Social, as expectativas são igualmente animadoras. O projeto Jovens Aprendizes, que já formou cerca de 5 mil jovens, terá prosseguimento, assim como os de hortas comunitárias, promoção da cidadania, primeiro emprego, combate à fome, reciclagem, salas de leitura, Espaço Furnas Cultural, educação e saúde. Também merecem destaque os projetos de educação ambiental e musical Tom do Pantanal, já em andamento, e a implementação do Tom da Amazônia, além do projeto Furnas Geração Musical e a inauguração do Espaço Furnas Cultural.

O alto nível técnico de FURNAS, adquirido durante quatro décadas e aprimorado pelo talento de seus empregados, tem sido levado, através de parcerias, para países da América do Sul, África e Ásia. A expansão de negócios também é verificada no mercado brasileiro, consolidando a marca da Empresa como paradigma de excelência no setor energético nacional. A Gestão da Qualidade em FURNAS resultou em 39 certificações internacionais e 34 premiações em gestão (Arquivo interno da empresa Furnas).

\subsection{MISSÃO DA EMPRESA}

Atuar como empresa do ciclo de energia elétrica, ofertando produtos a preços razoáveis e serviços adequados para melhorar a condição humana. Além de gerar energia e controlar a possível ocorrência de enchentes, a Usina de Hidrelétrica também é fonte de renda para os municípios onde se localiza seu reservatório, $6,75 \%$ do valor de toda a energia produzida pela hidrelétrica são repassados anualmente como Compensação Financeira pela utilização de Recursos Hídricos (CFURH). 


\section{Administração: caminhos para o desenvolvimento sustentável}

Em 2009, o montante de benefícios gerados para os estados de Minas Gerais e São Paulo; os municípios de Fronteira, Frutal, Planura, Colômbia, Barretos, Guaíra, Olímpia, Guaraci e Icém; e entidades da União, atingiram quase R\$ 35 milhões (Arquivo interno da empresa Furnas).

\subsection{VISÃO DA EMPRESA}

Ser uma empresa de excelência no ciclo de energia elétrica, contribuindo para o bem-estar da sociedade, desenvolvimento tecnológico do país e a proteção do meio ambiente (Arquivo interno da empresa Furnas).

\subsection{PARQUE GERADOR}

A Eletrobrás Furnas conta com um complexo de doze usinas hidrelétricas e duas termelétricas, totalizando uma potência nominal de $10.050 \mathrm{MW}$, sendo 7.971 MW instalados em usinas próprias e 2.079 MW em parceria com a iniciativa privada ou em Sociedade de Propósito Específico (SPE). Entre os destaques está o primeiro projeto do Setor Elétrico Brasileiro desenvolvido em parceria com a iniciativa privada: a Usina de Serra da Mesa, localizada no Município de Minaçu, em Goiás.

Relação de usinas da Eletrobrás Furnas: Usina Baguari - 140 MW; Usina de Corumbá - 375 MW; Usina de Funil - 216 MW; Usina de Furnas - 1.216 MW; Usina de Itumbiara - 2.082 MW; Usina Foz do Chapecó - 855 MW; Usina Luiz C. B. Carvalho (Estreito) - 1.050 MW; Usina de Manso - 212 MW; Usina de Marimbondo - 1.440 MW; Usina Mascarenhas de Moraes (Peixoto) - 476 MW; Usina de Peixe Angical - 452 MW; Usina de Porto Colômbia - 320 MW; Usina de Serra da Mesa - 1.275 MW; Usina Serra do Facão - 212,58 MW; Usina Retiro Baixo - 82 MW; Usinas Termelétricas: Usina de Campos - 30 MW e Usina de Santa Cruz - 766 MW. A Tabela 2 mostra a ficha técnica utilizada na Usina Marimbondo como fonte de informações. 


\section{Administração: caminhos para o desenvolvimento sustentável}

\begin{tabular}{|c|c|c|c|c|c|c|}
\hline \multicolumn{7}{|l|}{ Barragem } \\
\hline Tipo & $\begin{array}{l}\text { Altura } \\
\text { máxima }\end{array}$ & \multicolumn{2}{|c|}{ Comprimento da barragem } & \multicolumn{3}{|c|}{ Queda nominal } \\
\hline $\begin{array}{l}\text { argila, seção } \\
\text { homogênea }\end{array}$ & $94 \mathrm{~m}$ & \multicolumn{2}{|l|}{$3.100 \mathrm{~m}$} & \multicolumn{3}{|l|}{$60,30 \mathrm{~m}$} \\
\hline $\begin{array}{l}\text { Largura da } \\
\text { crista }\end{array}$ & $\begin{array}{l}\text { Cota na } \\
\text { crista }\end{array}$ & \multicolumn{5}{|l|}{ Volume total } \\
\hline $10 \mathrm{~m}$ & $450,5 \mathrm{~m}$ & \multicolumn{5}{|l|}{$14.400 .000 \mathrm{~m}^{3}$} \\
\hline \multicolumn{7}{|l|}{ Reservatório } \\
\hline $\begin{array}{l}\text { Nível máximo de } \\
\text { operação }\end{array}$ & $\begin{array}{l}\text { Nivel de } \\
\text { cheia }\end{array}$ & $\begin{array}{l}\text { Nível mínimo de } \\
\text { operação }\end{array}$ & $\begin{array}{l}\text { Área } \\
\text { inundada }\end{array}$ & \multicolumn{2}{|c|}{ Volume total } & Volume útil \\
\hline $446,3 \mathrm{~m}$ & $447,36 \mathrm{~m}$ & $426 \mathrm{~m}$ & $438 \mathrm{~km}^{2}$ & \multicolumn{2}{|c|}{6,150 bilhões $\mathrm{m}^{3}$} & 5,26 bilhões $\mathrm{m}^{3}$ \\
\hline \multicolumn{7}{|c|}{ Estrutura de concreto } \\
\hline \multicolumn{7}{|l|}{ Tomada d'água } \\
\hline \multicolumn{3}{|l|}{ Comportas } & \multicolumn{4}{|l|}{ Dimensões } \\
\hline Tipo & Quantidade & $\begin{array}{l}\text { Altura d'água } \\
\text { sobre a soleira }\end{array}$ & Largura & Altura & & Fabricante \\
\hline lagarta & 08 & $37,3 \mathrm{~m}$ & $7,859 \mathrm{~m}$ & $12,067 \mathrm{~m}$ & & $\begin{array}{l}\text { Bardella (Brasil) e Sorefame } \\
\text { (Portugal) }\end{array}$ \\
\hline \multicolumn{7}{|l|}{ Vertedouro } \\
\hline \multirow[t]{2}{*}{$\begin{array}{l}\text { Descarga } \\
\text { máxima }\end{array}$} & \multicolumn{2}{|l|}{ Comportas } & \multicolumn{4}{|l|}{ Dimensões } \\
\hline & Tipo & Quantidade & Largura & Altura & Raio & Fabricante \\
\hline $21.400 \mathrm{~m}^{3} / \mathrm{s}$ & Segmento & 09 & $15 \mathrm{~m}$ & $18,85 \mathrm{~m}$ & $19 \mathrm{~m}$ & ATB (Brasil e Itália) \\
\hline \multicolumn{7}{|l|}{ Casa de Força } \\
\hline Tipo & & & Dimensões & & & \\
\hline Coberta & & & $250,2 \mathrm{~m} \times 2$ &, $3 \mathrm{~m}$ & & \\
\hline
\end{tabular}




\section{Administração: caminhos para o desenvolvimento sustentável}

\begin{tabular}{|l|l|l|l|l|}
\hline \multicolumn{2}{|l|}{ Unidades Geradoras } & Rotação & Potência nominal \\
\hline 08 & $100 \mathrm{rpm}$ & $180 \mathrm{MW}$ \\
\hline Turbinas & Diâmetro do Rotor & Fabricante \\
\hline Tipo & $6.500 \mathrm{~m}$ & Consórcio Voith (Brasil e Alemanha), Neyrpic \\
\hline Francis de eixo vertical & & França), Creusoti-Loire (França) e MEP (Brasil) \\
\hline Geradores & Tensão nos Terminais & Fabricante \\
\hline Frequência & 13.8 KV & Asea (Brasil e Suécia ) \\
\hline 60 Hz & Monofásico & 63,333 MVA & $13,8 / 525$ KV \\
\hline Transformadores & Capacidade & Relação de Transformação & Fabricante \\
\hline Quantidade & Tipo & Tusa (Brasil) \\
\hline
\end{tabular}

Tabela 2: Ficha técnica- Usina Marimbondo.

\subsection{FUNCIONAMENO DE UMA HIDRELÉTRICA E SUPORTE TÉCNICO}

Uma usina hidrelétrica pode ser definida como um conjunto de obras e equipamentos cuja finalidade é a geração de energia elétrica, através de aproveitamento do potencial hidráulico existente em um rio.

O potencial hidráulico é proporcionado pela vazão hidráulica e pela concentração dos desníveis existentes ao longo do curso de um rio. Isto pode se dar de forma natural, quando o desnível está concentrado numa cachoeira; através de uma barragem, quando pequenos desníveis são concentrados na altura da barragem; através de desvio do rio de seu leito natural, concentrando-se os pequenos desníveis nesse desvio (Arquivo interno da empresa Furnas).

Basicamente, uma usina hidrelétrica compõe-se das seguintes partes: barragem; sistemas de captação e adução de água; casa de força; sistema de restituição de água ao leito natural do rio. Esta empresa domina modernas tecnologias associadas à transmissão, sistemas de supervisão e controle digital, centrais telefônicas computadorizadas e complexo sistema de microondas para transmissão de dados. 


\section{Administração: caminhos para o desenvolvimento sustentável}

A Empresa tem excelência e pioneirismo nos Centros de Treinamento e Laboratórios de solos, concreto e hidráulica experimental. Furnas, como uma grande empresa de energia elétrica, vem consolidando e ampliando sua atuação na área internacional, através de contratos de assessoria, consultoria, serviços e convênios de cooperação técnica com diversos países.

A experiência e a competência técnica da empresa, fazem com que as vantagens competitivas sejam transmitidas aos clientes de uma forma objetiva. Tudo isso somado a imagem e a marca de uma grande empresa, são a garantia de uma prestação de serviços de altíssima qualidade, o que viabiliza ótimas oportunidades de negócios no cenário internacional.Um exemplo disso é a presença da empresa em países como Angola - Assessoria e consultoria na implantação da Usina Hidrelétrica de Capanda com capacidade de 520 MW; Botswana - Assessoria técnica na execução do tratamento das fundações rochosas da barragem de Letsibogo; Moçambique - Capacitação de Recursos Humanos da Empresa Eletricidade de Moçambique; Argentina - Assessoria à LITSA, na operação e manutenção da Linha de Transmissão de 500 KV, que interliga Yaciretá a Salto Grande; Paraguai - Elaboração do programa de expansão do Sistema Elétrico para a ANDE (Administración Nacional de Eletricidad); Colômbia Consultoria Técnica para ISA e ISAGEN no projeto da Linha de Transmissão Compacta de 500 KV César El Copey; China - Assessoria para a Empresa China Three Gorges Project Development Corporation;

Além da prestação de serviços, a empresa mantém Convênios de Cooperação Técnica comNamíbia, Costa do Marfim, Moçambique, Paraguai, Colômbia e El Salvador.

\section{ENTREVISTA}

O roteiro da entrevista foi elaborado com base no referencial teórico estudado e respondido pelo Engenheiro C. A. M, responsável pela área de manutenção da empresa Usina de Hidrelétrica de Furnas. O mesmo é Engenheiro Eletricista, especialista em Manutenções Corretivas, Preventivas e Preditivas.

A gestão de manutenção da Empresa: Usina Marimbondo é realizada com planos de Manutenção Centrados na Confiabilidade ( $M C C)$, sendo que é probabilidade de um equipamento, célula de produção, planta ou qualquer sistema que funcione em condições de projeto, por um determinado período de tempo preestabelecido, onde por experiências adquiridas ao longo dos anos, utilizamos programações periódicas preventivas e corretivas. Deixando as preditivas para melhorias de processos e equipamentos, instalações e maquinários em geral. 


\section{Administração: caminhos para o desenvolvimento sustentável}

As técnicas de manutenção utilizadas pela empresa, são através do MCC, norteia nossas manutenções, onde pela programação, existem tempos pré-definidos para inspeção, verificação, troca ou mesmo conservação dos equipamentos, máquinas, componentes e acessórios da Usina.

Na empresa onde atuo, a terceirização está relacionada ao apoio nas diversas áreas de trabalho, devido os problemas de redução de pessoal efetivo, tornou-se indispensável esta modalidade de trabalho.

Em minha posição, do gerente fazer parte da equipe que determina as necessidades operacionais de cada atividade, considerando a utilização dos HHTs (Homens Horas Trabalhados), nas diversas atuações, coordenando assim o número de pessoal a ser contratado para suprir a deficiência de funcionários efetivos e ao bom andamento das manutenções.

Nos aspectos positivos da terceirização da empresa, o gerente ressalta o apoio incondicional dos funcionários terceirizados, que não medem esforços em cumprir suas tarefas e ajudar os funcionários efetivos em suas tarefas rotineiras, diárias, programadas ou de emergência. Já negativamente, há a gestão do fator humano, que por força de contrato ou conjunturas político-econômicas, achata as remunerações recebidas, provocando arrochos e nivelamentos mínimos, mesmo nos casos de contratados mais experientes.

Também tem a falta de conscientização de alguns efetivos, em não considerar o contratado como mais um a ajudar no processo, mas isto é cultural de cada indivíduo, podendo ser sanado de forma motivacional e psicológica.

Como mudanças, sugere serem alcançadas em um degrau mais amplo, para que os contratos contemplem as qualidades e especificidades de cada cargo, não gerando assim desigualdades entre contratados e efetivos, possibilitando uma melhora financeira, motivacional e de equiparação de cargo e função. Pois fica complicado gerenciar pessoas da mesma capacidade técnica, com desníveis salariais gritantes. Feito isto, tenho certeza de que o clima motivacional será bem melhor!

\section{ANÁLISE DOS RESULTADOS}

A gestão da manutenção corretiva proposto neste trabalho está dividido em classificação dos equipamentos; identificação das falhas mais recorrentes nos equipamentos; associação da tarefa de reparo; associação do código falha-decisão; representação de casos e construção e atualização de 


\section{Administração: caminhos para o desenvolvimento sustentável}

casos. As tarefas da manutenção corretiva aplicada na Usina Hidrelétrica, é verificar estado do selo mecânico; corrigir anormalidades no selo mecânico, substituir o selo mecânico se é necessário; verificar estado dos rolamentos, lubrificar os rolamentos, e substituir os rolamentos se for necessário. Este tipo de manutenção tem como função organizar os dispositivos segundo sua funcionalidade, localização, importância ou criticidade. Permite gerar níveis hierárquicos ou taxonomias de equipamentos, segundo o critério definido, facilitando sua identificação, a definição de tarefas de manutenção preventiva, a definição de uma equipe de trabalho que irá monitorar o ativo, a identificação de falhas mais comuns que acontecem neste e outras vantagens.

Com esta manutenção, o objetivo é identificar as famílias de equipamentos que existem em um domínio industrial complexo, como o de usinas hidrelétricas, e classificar cada um dos ativos presentes de acordo a máquina identificada. Quanto a identificação de falhas nos equipamentos o objetivo é identificar as falhas ou eventos anormais que, com mais frequência, acontecem nos equipamentos. $O$ intuito é estabelecer um padrão de falhas sobre a máquina. Este padrão de falhas pode ser determinado a partir da análise da informação histórica identificado nos equipamentos e sao baseados em modelos ou metodologias de identificação de falhas. Uma vez estabelecido o padrão de falhas, uma tarefa de manutenção deve ser associada na tarefa de reparo pelos técnicos em manutenção.

\subsection{SAÚDE, SEGURANÇA E MEIO AMBIENTE}

Como empresa de geração e transmissão de energia elétrica, insumo básico para o desenvolvimento econômico e social, Furnas reconhece que suas atividades podem levar à interferência ambiental, sendo seu compromisso conduzir as ações da Empresa respeitando o meio ambiente, com base nos seguintes princípios: integração da Política Ambiental às demais políticas da Empresa; incorporação da componente ambiental às etapas do planejamento, projeto, construção e operação de seus empreendimentos; atendimento à legislação ambiental e aos compromissos ambientais assumidos; tornar pública as informações ambientais associadas a seus empreendimentos; conscientização dos empregados, comunidades e demais partes interessadas, tendo em vista a troca de informações e a busca de soluções participativas; promoções de treinamento e participação em ações de educação ambiental, no que se refere às atividades da Empresa; aperfeiçoamento de processos e incorporação de novas tecnologias visando a melhoria contínua do desempenho ambiental; racionalização do uso de recursos naturais e o combate ao desperdício de energia elétrica. 


\section{Administração: caminhos para o desenvolvimento sustentável}

O cuidado com o meio ambiente e a racionalização de recursos humanos e financeiros no exercício de ações concretas resultaram na soma de esforços de outras instituições comprometidas com a conservação do meio ambiente e a melhoria da qualidade de vida. Hoje, especialmente Universidades e Centros de Pesquisa dão respaldo técnico e político aos projetos desenvolvidos ou em fase de desenvolvimento.

Criada com um desafio, a empresa vem, gradativamente, ampliando sua missão. Investe tanto no desenvolvimento energético quanto na conservação da natureza. Nas áreas de influência das Usinas Hidrelétricas de Corumbá e Serra da Mesa destacam-se os seguintes projetos:

- Consolidação e implantação de Unidades de Conservação, em parceria com o Ibama e a Femago, garantindo a conservação da fauna e da flora do cerrado;

- Recuperação do patrimônio arqueológico histórico-cultural e pré-histórico, em parceria com as Universidades Federal de Minas Gerais e Federal Católica de Goiás, reconstituindo a história regional e conservando testemunhos pré-históricos;

- Conservação da flora e da fauna silvestre, através de convênios com a Embrapa/Cenargen, a Universidade Católica de Goiás e a Fundação Pró-Natureza;

- Gestão da questão indígena: conservação do grupo indígena Avá-Canoeiro do Tocantins, através de convênios com a FUNAI.

Furnas realiza ainda programas de monitoramento hidrotermal, sismológico, climatológico, limnológico e da ictiofauna, estendendo alguns destes programas às Usinas Hidrelétricas de Furnas, Porto Colômbia, Itumbiara, Funil e Marimbondo.

\section{CONSIDERAÇÕES FINAIS}

Este estudo fez uma abordagem teórica e metodológica, apresentando também um estudo de caso, realizado dentro da Empresa Usina Hidrelétrica relacionada a manutenção corretiva.

Após ter consultado a literatura referente à manutenção preventiva, estudando a sua história, as formas de implantação, as vantagens e desvantagens, relatando os principais conceitos de manutenção preventiva, como falha, defeito, e ter confrontando seus conceitos com as demais formas 


\section{Administração: caminhos para o desenvolvimento sustentável}

de manutenção, foi possível entender melhor os princípios da manutenção preventiva e dos demais métodos de manutenção.

A terceirização das atividades de manutenção é uma maneira de responder de forma eficiente e rápida às especificidades pesquisadas neste estudo. Não seria interessante para a Usina Hidrelétrica ter a sua mão de obra própria, especifica e qualificada para fazer a manutenção, pois, é mais vantajoso para empresa a contratação de emresas terceirizadas que prestam esses serviços de forma mais economica e vantajosa para usina, inclusiva no processo de recrutamento uma vez que o mercado de trabalho não possui demanda suficientemente ja qualificada para atender as necessidades da empresa. $E$ as empresas terceirizadas são as que melhor atendem à demanda e conseguem solucionar os problemas de forma mais pontiais.

Foi realizada uma entrevista com o engenheiro C.A.M, responsável pela área e manutenção da Empresa Usina de Marimbondo. O roteiro da entrevista foi elaborado com base no referencial teórico estudado e respondido. Citou que a Empresa trabalha com planos de Manutenção Centrados na Confiabilidade (MCC), norteando a manutenção por tempo pré-definidos para inspeção, verificação, troca ou mesmo conservação dos equipamentos, máquinas, componentes e acessórios da Usina. Por ter sido uma pesquisa limitada em só uma entrevista, pode-se num futuro próximo aprimorar este estudo com novas pesquisas.

A realização deste estudo possibilitou o cumprimento dos objetivos traçados, pois aprofundou o conhecimento sobre as formas de manutenção, das quais foram expostos na revisão da literatura vários conceitos e princípios. Realizando o estudo de caso, foi possível observar na prática o que foi relatado na teoria sobre o assunto pesquisado, sendo assim, pode-se concluir que na Usina Hidrelétrica citada, a utilização de manutenção preventiva é muito vantajosa, pois a empresa conta com o apoio de mão de obra qualificada por funcionários terceirizados, como citado pelo engenheiro C.A.M, assim resultando num bom andamento da empresa em seus aspectos financeiros. $O$ estudo de caso aqui apresentado deixa uma lacuna, para futuro aprofundamento, talvez com uma pesquisa quantitativa com funcionários terceirizados, para que haja mais conhecimentos sobre a realidade do assunto.

\section{REFERÊNCIAS}

Araújo, A, M, C. (2007). Terceirização no Brasil: do discurso da inovação à precarização do trabalho,atualização do debate e perspectivas. São Paulo: Annablume, CUT. 


\section{Administração: caminhos para o desenvolvimento sustentável}

Filho, R. A.(2008). Introdução à manutenção centrada na confiabilidade - MCC. Programa de atualização técnica 2008 - Sistema FIRJAN - SESI/SENAI - Rio de Janeiro. Disponível em < http://manutencao.net/v2/uploads/article/file/Artigo24AGO2008.pdf> Acesso em 15 dez. 2017.

Júnior, N. (2006). Gerência de Manutenção. UFPB- Universidade Federal da Paraíba. Cidade Universitária, Campus I, João Pessoa.

Kardec, A \& Nascif, J. (2012). Manutenção: função estratégica. 4ạ ed. Rio de Janeiro: Editora Qualitymark.

Xenos, H, G. (2004). Gerenciamento a Manutenção Produtiva: o caminho para eliminar falhas nos Equipamentos e Aumentar a Produtividade. Nova Lima: Editora Falconi. 


\section{Capítulo 30}

\section{ABORDAGEM VIVENCIAL E COOPERATIVA DOS JOGOS DE EMPRESA}

DOI: $10.37423 / 200300432$

Álvaro José Periotto UEM/UEL

Carolina Martins Fernandes Messinetti UEMIUEL

Fabrizio Meller da Silva UEMIUEL

Resumo: O presènte ensaío teórico resulta de um estudo exploratório desenvolvido por

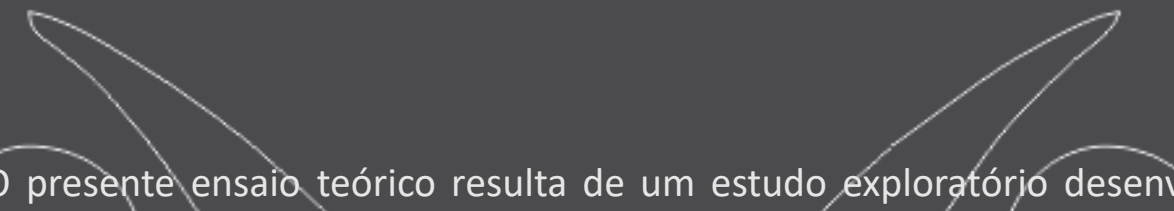

meio de pesquisa bibliogrăfica com o propósito de resgatar/as questóes centrais que envolvem as vertentes da pesquisa sobre os jogos de empresa. Tratando p tema sob uma perspectiva crítiea, procurou-se discutir a proposta sob o ponto gle vista histórico, a tipologia de joges, e os aspectos diferenciais entre os jogos de empresa competitivos e cooperativos como um método de ensino-aprendizagem no contexto do ensino superior, apontando seus benefícios e riscos. Optou-se por indicarr um processo de aprendizagem variado e dinâmico, concluindose que o modo vivencial e cooperativo dos jog $\phi$ s, quando atrelado a uma b professor, acaba resultando em um contexto eficiente efacilitador de aprendizagem.

Palavras-chave: Estratégia empresarial. Jogos/de empresa. Abordagem vivehcial. Cooperação. Formação do administrador.

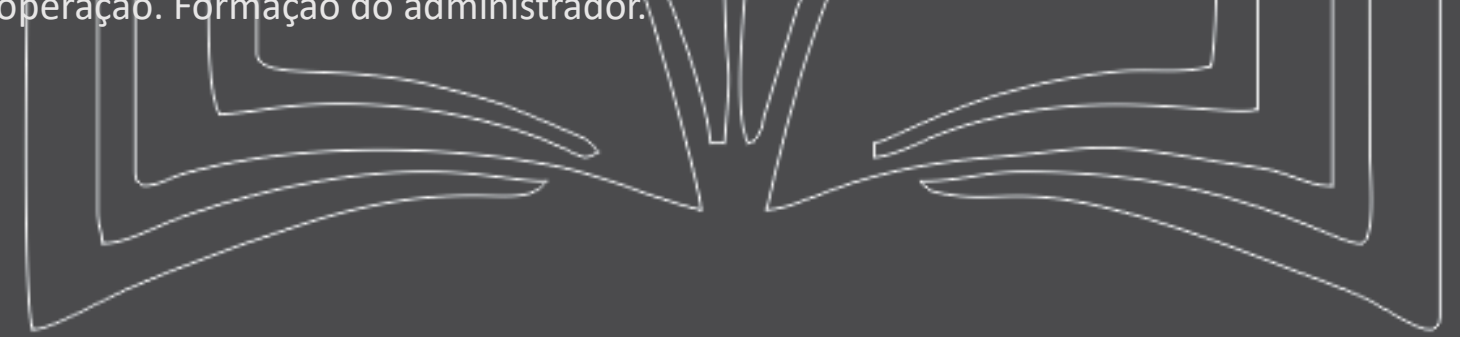




\section{Administração: caminhos para o desenvolvimento sustentável}

\section{INTRODUÇÃO}

As tendências atuais na formação do administrador, almejado pelas instituições de ensino e desejado pelos empresários, são orientadas pelo pensamento sistêmico e complexo, visto que a realidade atual não comporta mais a forma linear-cartesiana do curso como um conjunto de matérias e disciplinas, mas, sim, como campos de conhecimentos cujos conteúdos se inter-relacionam. Conforme aponta Lopes (2001), o dinamismo econômico e as rápidas mudanças no ambiente de negócios exigem mais do que a simples utilização de técnicas gerenciais, subdivididos, em suas aplicações, por áreas específicas da organização e aplicáveis em contextos decisórios pré-definidos na formação do administrador.

Esta realidade é demonstrada na Pesquisa Nacional Sobre o Perfil, Formação, Atuação e Oportunidades de Trabalho (ANDRADE e ABREU, 2006), realizada em 2006, que aponta, em seus resultados sobre os itens identidade, competências e habilidades necessárias a um administrador, uma convergência para a necessidade de se possuir uma visão sistêmica da organização que o permita articular as diversas áreas da organização, ter uma visão do todo e que consiga identificar problemas, formular e implantar soluções. Segundo os três segmentos pesquisados (administradores, professores e empresários), a característica predominante no administrador é a articulação, o que demonstra a importância da ênfase na formação holística.

Outro fator que demonstra preocupação com a formação do administrador é a própria mudança das diretrizes curriculares que conferiu maior liberdade na implementação dos projetos pedagógicos, priorizando o atendimento de competências e habilidades. Segundo Andrade e Amboni (2004, p. 91), a Lei de Diretrizes e Bases da Educação Nacional "[...] procura assegurar maior flexibilidade na organização de cursos e carreiras para atender à crescente heterogeneidade da formação prévia e às expectativas de todos os interessados nesse nível de ensino".

Essas constatações e mudanças geram novas oportunidades e desafios a serem aproveitados pelos gestores de cursos para inovarem e buscarem novos processos de ensino-aprendizagem que complementem o método tradicional de ensino, centrado no professor, e possibilitem ao aluno o desenvolvimento de suas habilidades, competências, conhecimentos e atitudes, por outros métodos.

Neste sentido, os jogos de negócios correspondem a um método de ensino baseado na aprendizagem vivencial, que possibilita a ativa participação do aluno, tornando-o o foco da aprendizagem dentro de 


\section{Administração: caminhos para o desenvolvimento sustentável}

um ambiente simulado (BARÇANTE e PINTO, 2003). Além disso, a utilização dos jogos de negócios propicia uma abordagem das dimensões afetiva e cognitiva, o que confere uma formação mais completa e dentro de uma visão sistêmica. Entretanto, conforme observado por Gabardo (2006), o método ainda vem sendo utilizado de maneira muito tímida. Talvez pelo despreparo dos professores em utilizarem corretamente esta ferramenta, ou, também, pelas dúvidas quanto a real efetividade do aprendizado, por parte dos alunos.

Mediante tais fatores, objetiva-se discutir a possibilidade de aprendizado por meio de um jogo de empresa, enfatizando sua utilização com um enfoque cooperativo e não competitivo, apresentando seus benefícios e cuidados como método de ensino. Para tanto, o trabalho assume as características de estudo exploratório desenvolvido por meio de pesquisa bibliográfica.

Conforme considera Gil (1999), o planejamento da pesquisa exploratória é bastante flexível e, na maioria dos casos, assume a forma de pesquisa bibliográfica ou de estudo de caso, corroborando a opção metodológica. Quanto ao mecanismo de desenvolvimento, conforme Vergara (2004, p.48), a pesquisa bibliográfica corresponde ao "[...]estudo sistematizado desenvolvido com base em material publicado em livros, revistas, jornais, redes eletrônicas, isto é, material acessível ao público em geral”.

\section{ORIGENS E TIPOLOGIA DOS JOGOS DE EMPRESA}

Como instrumento de treinamento de executivos, os jogos foram usados pela primeira vez em 1956 por um grupo de pesquisadores da American Management Association - AMA, proporcionando a adaptação da filosofia e dos procedimentos empregados nos jogos de guerra para os negócios. Foi lançado o Top Management Decision Game (Fries apud Orlandeli, 2001), um jogo de empresas muito elementar se comparado aos atualmente disponíveis, mas que, dadas as características, provavelmente pode ser considerado um dos primeiros jogos empresariais. Em 1957, este jogo foi levado para a Universidade de Washington, a fim de ser incorporado ao método de ensino empregado em sala de aula (ORLANDELI, 2001).

No Brasil, os jogos chegaram com força total na década de 80. A princípio, os jogos eram traduzidos e, com o passar dos anos, profissionais e pesquisadores do tema criaram seu próprio modelo. Hoje, observa-se uma variedade razoável de jogos cuja característica é a "adaptação à nossa cultura e às nossas necessidades específicas" (GRAMIGNA, 1997, p.16). 


\section{Administração: caminhos para o desenvolvimento sustentável}

As simulações empresariais são consideradas importantes instrumentos de desenvolvimento gerencial e de aprendizagem, sendo que, na década de 60, foram incorporados como recursos metodológicos nas universidades, em especial nos cursos de administração (SAUAIA apud FREITAS, 2007). Atualmente, os jogos desempenham importante papel social e psicológico: eles representam uma das maneiras que a humanidade encontrou para transmitir conhecimentos, valores culturais e éticos às gerações futuras, sendo um poderoso instrumento de ensino e aprendizagem. Os jogos vêm sendo cada vez mais utilizados na área de Treinamento e Desenvolvimento, auxiliando na aquisição e no desenvolvimento de habilidades mentais, emocionais e físicas. (MAGDA e FALCÃO, 2002).

Tanabe (1977), um dos pioneiros a conceituar jogos de empresas no Brasil, afirma que o jogo de empresa é uma seqüência de tomadas de decisões que influenciam o estado patrimonial e reditual das empresas fictícias, à luz das quais os participantes tomam novas decisões, e assim sucessivamente. Desta forma, é enfatizada a contribuição dos jogos no processo de tomada de decisão, característica essencial ao gestor de qualquer organização, que a realiza de forma constante no exercício de sua profissão (FREITAS, 2007).

São várias as formas de classificação dos jogos de empresa (ou de negócios), algumas das quais são apresentadas no quadro 1.

Para estabelecer uma perspectiva sobre a utilização de jogos como método de aprendizado, cabe considerar as vivências nesse contexto. Recorrendo a Gramigna (1997), tem-se que as vivências correspondem aos momentos vividos pelo grupo em atividades simuladas, semelhantes à sua realidade, permitindo ampla participação e forte comprometimento com o aqui e agora. Portanto, todo jogo implica em vivência, mas nem toda vivência é um jogo. 


\section{Administração: caminhos para o desenvolvimento sustentável}

\begin{tabular}{|c|c|c|}
\hline $\begin{array}{c}\text { Autor } \\
\text { Motomura }\end{array}$ & $\begin{array}{c}\text { Classificação } \\
\text { Natureza do jogo }\end{array}$ & \begin{tabular}{l}
\multicolumn{1}{c}{ Agrupamento dos Jogos } \\
sistêmicos (ênfase no funcionamento do sistema) \\
humanos (ênfase nas variáveis humanas presentes nas negociações) \\
mistos (intervêm componentes sistêmicos c humanos)
\end{tabular} \\
\hline Kopittke & $\begin{array}{l}\text { Meio de apuração } \\
\text { dos resultados }\end{array}$ & $\begin{array}{l}\text { gerais (conjunto de empresas industriais oligopolistas) } \\
\text { específicos (modelação de uma empresa particular) } \\
\text { setoriais (empresas de um setor da economia) } \\
\text { funcionais (área especifica dentro da empresa) } \\
\text { computadorizados (cálculos e relatórios via computador) } \\
\text { manuais (cálculos e relatórios manuais }\end{array}$ \\
\hline Gramigna & $\begin{array}{l}\text { Interaçào entre } \\
\text { equipes } \\
\text { Habilidades } \\
\text { envolvidas }\end{array}$ & $\begin{array}{l}\text { interativos (as decisões de uma empresa interferem nas demais) } \\
\text { não-interativos (as decisões de uma empresa não afetam os resultados } \\
\text { das demais) } \\
\text { de comportamento (enfatizam habilidades comportamentais) } \\
\text { de processo (enfatizam habilidades técnicas) } \\
\text { de mercado (enfatizam habilidades técnicas e de mercado) }\end{array}$ \\
\hline
\end{tabular}

Fonte: Adaptado de Mendes (2001).

Quadro 1 - Classificação dos jogos de negócios

Para a a autora, a diferença entre jogo e vivência é determinada pelas regras: quando estas contêm pontuação que permite definir vencedores e perdedores, colocando a competição às claras, trata-se de um jogo; do contrário, a atividade é uma vivência. Desta forma, torna-se necessário mesclar as atividades vivenciais e os jogos, evitando sobrecarregar o grupo com muitas atividades competitivas, o que poderia levar a um clima desfavorável à aprendizagem, uma vez que, apesar de simuladas, as atividades têm um grande poder de mobilização das emoções (GRAMIGNA, 1997).

\section{ABORDAGEM COOPERATIVA DOS JOGOS DE EMPRESA}

Embora a imagem dominante sobre os jogos de empresa remetam ao caráter competitivo, reforçando posições antagônicas, mesmo dentro de uma mesma empresa, cabe destacar também o aspecto cooperativo de sua utilização no ensino, considerando a importância de pensar a estratégia empresarial não somente como destaque em meio à competição mas vislumbrando também a cooperação como uma estratégia de sobrevivência.

Confirmando esse aspecto, Magda e Falcão (2002) consideram que, na prática, o jogo cooperativo promove maior comunicação e intercâmbio entre os participantes e que as pessoas se expõem e se arriscam mais quando não se sentem ameaçadas pelo peso da derrota. Para as autoras, o desafio existe dentro de um jogo competitivo, considerado fator motivacional da interação, continuando presente no jogo cooperativo, aliado a um aumento da auto-estima e da confiança mútua gerada num ambiente propício a um aprendizado mais rápido e efetivo, que tem como premissas básicas: 


\section{Administração: caminhos para o desenvolvimento sustentável}

- jogar com os outros e não contra eles;

- jogar para superar desafios ou vencer obstáculos, e não para vencer alguém;

- atingir objetivos com a contribuição de todos e valorizar metas coletivas e não individuais; - eliminar agressão e desconfiança;

- desenvolver atitudes de empatia, cooperação, estima e boa comunicação;

- compartilhar sucessos, melhorar o clima organizacional e desenvolver equipes fortes, uma vez que o outro passa a ser visto como parceiro e não como adversário;

A rigor, um jogador pode fazer dois movimentos no momento de jogar: aproximação com os outros jogadores (Processo Associativo) ou afastamento dos demais (Processo Dissociativo). Esses dois processos são apresentados de maneira comparativa no quadro 2.

\begin{tabular}{|c|c|}
\hline Processo Dissociativo & Processo Associativo \\
\hline Competitivo & Cooperativo \\
Individualista & Coletivo \\
Participação limitada & Participação de todos \\
Desorganizado & Organizado \\
Gera ganhadores e perdedores & Todos ganham \\
Desune & Agrega \\
Frustante & Reconfortante \\
Limitante & Amplo \\
Repudiante & Acolhedor e confiante \\
Conformista & Desafiador \\
"O jogo sou eu" & "O jogo somos nós" \\
\hline
\end{tabular}

Fonte: Adaptado de Magda e Falcão (2002).

Quadro 2 - Processos Dissociativo e Associativo

A adoção de jogos cooperativos em treinamento estimula a participação de todos, agrega os participantes e proporciona um ambiente acolhedor e confiante, predispondo os treinandos ao aprendizado, melhorando o clima organizacional e reforçando os vínculos fora e dentro da empresa. O quadro 3 permite, de forma sintética, a comparação entre essas situações. 


\section{Administração: caminhos para o desenvolvimento sustentável}

\begin{tabular}{|c|c|}
\hline Situação Cooperativa & Situação Competitiva \\
\hline $\begin{array}{l}\text { Percebem que o atingimento de seus } \\
\text { objetivos ê, em parte, consequếncia da ação } \\
\text { dos outros membros. }\end{array}$ & $\begin{array}{l}\text { Percebem que o atingimento de seus } \\
\text { objetivos ê incompativel com a obtenção dos } \\
\text { objetivos dos demais. }\end{array}$ \\
\hline $\begin{array}{l}\text { São mais sensiveis às solicitaçōes dos } \\
\text { outros. }\end{array}$ & $\begin{array}{l}\text { Sào menos sensiveis às solicitaçōes dos } \\
\text { outros. }\end{array}$ \\
\hline Ajudam-se mutuamente com frequê̌ncia. & $\begin{array}{l}\text { Ajudam-se mutuamente com menor } \\
\text { freqüčncia. }\end{array}$ \\
\hline $\begin{array}{l}\text { Há maior homogeneidade na quantidade de } \\
\text { contribuiçôes e participações. }\end{array}$ & $\begin{array}{l}\text { Há menor homogeneidade na quantidade de } \\
\text { contribuicốes e participacốes. }\end{array}$ \\
\hline $\begin{array}{l}\text { A produtividade em termos qualitativos ê } \\
\text { maior. }\end{array}$ & $\begin{array}{l}\text { A produtividade em termos qualitativos é } \\
\text { menor. }\end{array}$ \\
\hline A especialização de atividades é maior. & A especialização de atividades é menor. \\
\hline
\end{tabular}

Fonte: Adaptado de Brotto (1997, p 45).

Quadro 3 - Diferenças entre situações cooperativas e competitivas

Embora em ambas as situações das atividades simuladas o aprendizado seja possível, conforme apontado por Gramigna (1997), uma análise das diferenças entre jogos competitivos e cooperativos leva a considerar que esses últimos permitem um envolvimento maior dos participantes e benefícios condizentes com a utilização dos jogos de empresa no ensino superior, ao formar um aluno com características adequadas para enfrentar o mercado de trabalho e as situações empresariais (ver quadro 4).

\begin{tabular}{|c|c|}
\hline Jogos Competitivos & Jogos Cooperativos \\
\hline São divertidos apenas para alguns. & São divertidos para todos. \\
\hline A maioria tem um sentimento de derrota. & Todos têm um sentimento de vitória. \\
\hline $\begin{array}{l}\text { Alguns sào excluidos por sua falta de } \\
\text { habilidade. }\end{array}$ & $\begin{array}{l}\text { Há mistura de grupos que brincam juntos, } \\
\text { criando alto nivel de aceitaçào mútua. }\end{array}$ \\
\hline Aprende-se a ser desconfiado. & $\begin{array}{l}\text { Todos participam e ninguém é rejeitado ou } \\
\text { excluido. }\end{array}$ \\
\hline $\begin{array}{l}\text { Os perdedores ficam de fora do jogo e } \\
\text { simplesmente se tornam observadores. }\end{array}$ & $\begin{array}{l}\text { Os jogadores aprendem a ter um senso de } \\
\text { unidade e a compartilhar o sucesso. }\end{array}$ \\
\hline $\begin{array}{l}\text { Os jogadores não se solidarizam e ficam } \\
\text { felizes quando alguma coisa de "ruim" } \\
\text { acontece aos outros. }\end{array}$ & $\begin{array}{l}\text { Desenvolvem auto-confiança porque todos } \\
\text { são bem aceitos. }\end{array}$ \\
\hline $\begin{array}{l}\text { Pouca tolerâneia à derrota desenvolve em } \\
\text { alguns jogadores um sentimento de } \\
\text { desistência face a dificuldades. }\end{array}$ & $\begin{array}{l}\text { A habilidade de perseverar face às } \\
\text { dificuldades é fortalecida. }\end{array}$ \\
\hline Poucos se tornam bem sucedidos. & $\begin{array}{l}\text { Para cada um o jogo é um caminho de co- } \\
\text { evoluçầ. }\end{array}$ \\
\hline
\end{tabular}

Fonte: Adaptado de Orlick, 1978 (apud Brotto, 1997, p. 65).

Quadro 4 - Diferença entre jogos competitivos e cooperativos 


\section{Administração: caminhos para o desenvolvimento sustentável}

\section{JOGOS DE EMPRESA COMO MÉTODO DE ENSINO-APRENDIZAGEM: BENEFÍCIOS E RISCOS}

O ambiente organizacional encontra-se, hoje, cada vez mais complexo, mediante o aumento do número de variáveis envolvidas, tais como pressões do ambiente externo, interferências internacionais, políticas e ambientais, além de competitividade organizacional. Tal contexto leva a uma constante demanda por adaptação, inovação e criação dentro das empresas, provocando a quebra de paradigmas.

No passado, as organizações necessitavam de profissionais técnicos e processos eficientes que elevassem a produtividade, mas isso já não representa um diferencial para as empresas nos dias atuais. Em novo cenário, os profissionais precisam ter conhecimento e serem capazes de transformar. Portanto, o profissional deve ter uma aprendizagem multidimensional pois, assim, os jogos de empresa podem se tornar uma alternativa metodológica para alcançar este objetivo, uma vez que envolvem três dimensões formativas: conhecimento, habilidades gerenciais e atitudes da competência dos profissionais (Freitas, 2007).

As novas exigências do mercado exigem que se repense, inclusive, os métodos de ensino e de aprendizagem. Os primeiros, conforme Orlandeli (2001, p. 17), correspondem aos "meios e recursos organizados que o professor faz uso como base, para criar condições favoráveis à assimilação do assunto em discussão". Por sua vez, a aprendizagem envolve a assimilação do conhecimento pelo indivíduo e, conforme Johnsson (2006, p. 60), trata-se de "um processo através do qual é possível desenvolver mudanças duradouras nas pessoas".

Apesar de existirem diversos enfoques metodológicos, os métodos de ensino podem ser agrupados em (Rocha, apud Johnsson, 2006; Orlandeli, 2001):

Método prático (aprender fazendo). A premissa básica é a de que o ambiente onde se realiza o aprendizado deve ser semelhante ao que os participantes irão encontrar quando vierem a executar tal atividade em situações reais, como, por exemplo, os escritórios jurídicos modelos, as empresas juniores, entre outros.

Método conceitual (aprender pela teoria). É o principal método utilizado nas instituições de ensino. Privilegiam o foco no docente como transmissor da conceituação teórica; os exercícios e atividades buscam consolidar esses conhecimentos, devendo ser defrontados com aplicações concretas. 


\section{Administração: caminhos para o desenvolvimento sustentável}

Método simulado (aprender pela realidade imitada). Nesta situação, o professor deve criar um ambiente próximo da realidade para que os alunos respondam às situações que ocorrem no ambiente, como, por exemplo, o júri simulado nos cursos de Direito; utilização de animais em aulas práticas; e a utilização de simuladores, tais quais os jogos de empresa, para simular o ambiente empresarial.

Método comportamental (aprender com o crescimento psicológico). Tenta-se criar condições passíveis de se tornarem reais na vida profissional para que os participantes reajam e possam analisar suas atitudes, podendo alterá-las e adequá-las às situações. Neste caso, ao assumirem posições hierárquicas nas organizações do método simulado, há a possibilidade de constatarem de que maneira devem reagir aos fatos e concluir a respeito de suas atitudes e mudanças necessárias.

Os jogos de empresa são enquadrados no método simulado, por compreenderem a criação do ambiente empresarial para que os alunos desenvolvam suas habilidades em situações próximas da realidade; porém, como veremos a seguir, a utilização do jogo de empresa como método de ensinoaprendizagem envolve, também, a utilização de métodos conceituais e comportamentais, por desenvolver um processo de ensino-aprendizagem baseado na vivência.

A concepção predominante é que a aprendizagem está associada ao professor, à sala de aula e ao livro texto, não cabendo ao aluno uma participação ativa. Contudo, no caso jogos de empresa, as bases pedagógicas fundamentamse, principalmente, na aprendizagem vivencial de David A. Kolb (Lopes, 2001; Gabardo, 2004; Barçante e Pinto, 2003; Johnsson, 2006; Orlandeli, 2001).

A aprendizagem vivencial é a conseqüência do envolvimento das pessoas em uma situação na qual, além de vivenciá-la, terão a oportunidade de analisar o processo de forma crítica, extraindo algum insight útil desta análise, podendo aplicar o aprendizado, percebido como significativo, em seu dia-a-dia (Johnson, 2006, p. 73).

A aprendizagem vivencial apresenta uma visão holística do processo de ensino-aprendizagem, levando em consideração a aprendizagem, a percepção, a cognição e o comportamento. Considerando que Abreu e Masseto (apud Freitas, 2007) classificam a aprendizagem em três categorias - cognitiva ou conhecimento (aprender a aprender); modificação de valores e atitudes (aprender a ser); e de habilidades (aprender a fazer) - verifica-se que a utilização de jogos de empresa, na perspectiva da aprendizagem vivencial, torna-se interessante para a formação do administrador. Segundo Bowen 


\section{Administração: caminhos para o desenvolvimento sustentável}

(apud Orlandeli, 2001), um jogo, avaliado segundo a teoria de aprendizado experimental, apresenta um grande impacto neste processo, uma vez que pode ser estruturado, principalmente, de modo a: promover um grande estímulo emocional; permitir uma resposta imediata das conseqüências das ações propostas; ocorrer em um ambiente de total segurança; permitir uma visão holística da empresa, mostrando as inter-relações existentes; e, explorar uma característica da personalidade humana.

Os jogos de empresa, na perspectiva da aprendizagem vivencial, colocam os alunos como atores principais do aprendizado, o que não quer dizer que, para oferecer um curso de qualidade, basta focar o aprendizado no aluno, pois, conforme apontado por Lowman (apud Lopes, 2001), o professor - com suas habilidades, domínio de conteúdo e motivação - e o curso - com base em seus objetivos e organização - também interferem na qualidade da aprendizagem.

Feitas essas considerações, é importante enfocar o ciclo da abordagem vivencial de forma a obter o melhor aproveitamento na utilização dos jogos de empresa como ferramenta didática-pedagógica. Segundo Wolfe e Byrne (apud Barçante e Pinto, 2003), essas fases são:

- Projeto: momento em que se definem os objetivos educacionais, produção e atividades a serem desenvolvidas pelos participantes, incluindo a base teórica a ser discutida. Condução: atividades projetadas e as modificações para assegurar um adequado envolvimento com a aprendizagem. Relaciona-se, aqui, a importância de um instrutor qualificado e com experiência.

- Avaliação: atividade realizada durante todo o processo. Deve-se permitir a expressão por parte dos alunos dos aspectos de aprendizagem adquirida a partir da condução da vivência. Inclui-se, aqui, a avaliação do jogo.

- Retro-alimentação: para a aprendizagem vivencial, os erros também ensinam. Para isso, é importante ter o retorno das atividades, com seus erros e acertos, para conclusão do aprendizado e possibilidades de utilização da aprendizagem em novas situações no dia-a-dia.

A utilização dos jogos de empresa como ferramenta de ensino-aprendizagem é compatível com a proposta didática das instituições de ensino e das exigências da formação do profissional de administração, devendo-se ter maior atenção com alguns aspectos: promover a participação e 


\section{Administração: caminhos para o desenvolvimento sustentável}

interação dos alunos; compreender o aluno como um todo; criar situações de interação com o ambiente; incluir situações de variabilidade e incerteza; propor o exercício de forma estruturada e orientada; proporcionar avaliação da vivência e incluir comentário de retroalimentação pelo professor (Barçante e Pinto, 2003).

Ferreira (apud Freitas, 2007) aponta, nos estudos sobre jogos de empresas, benefícios que podem resultar aos participantes:

- Permitem o desenvolvimento das capacidades gerenciais dos participantes através da elaboração de estratégias frente a fatores controláveis e incontroláveis, e a resposta do mercado simulado em relação a estas estratégias; - Estimula o intercâmbio de experiência entre os participantes, os quais, dentro do processo de decisão, estarão externando e colocando à discussão e apreciação do grupo conceitos como autoridade, responsabilidade e valores pessoais;

- Permite o aprendizado através dos erros sem o custo que os mesmos acarretam no mundo real, mostrando aos participantes as conseqüências de suas decisões;

- Permite que sejam apresentados aos participantes, num curto espaço de tempo, vários anos de vivência empresarial.

Neste sentido, a adesão aos jogos, pelos diversos profissionais, deveu-se, em grande parte, às vantagens e aos resultados obtidos, que segundo Gramigna (1997) são:

- melhor compreensão de conceitos antes considerados abstratos;

- conscientização da necessidade de um realinhamento atitudinal e comportamental no atual momento de mudanças; - redução do tempo dos programas, sem prejuízo da qualidade; - maior possibilidade de comprometimento do grupo com resultados;

- reconhecimento do próprio potencial e das dificuldades individuais;

- maior aproximação e integração entre facilitador e grupocliente; - mudanças atitudinais e comportamentais favoráveis ao desempenho profissional;

- clima grupal favorável à participação ampla nas diversas etapas do processo; 


\section{Administração: caminhos para o desenvolvimento sustentável}

- resgate do lúdico, essência do ser humano;

- possibilidade de mensuração de resultados durante os jogos simulados, facilitando avaliações comparativas com a realidade empresarial;

- maiores chances de desenvolvimento de habilidades técnicas, conceituais e interpessoais.

Considerando como objetivo dos jogos de negócios aumentar o conhecimento, desenvolver habilidades gerenciais e fixar atitudes adequadas às situações envolvidas na profissão, os autores citados identificam vários benefícios que são agrupados dentro desses objetivos.

No entanto, é importante destacar alguns riscos inerentes à sua utilização, tais como: as possíveis relações criadas pelos alunos de que um bom jogador é um bom administrador e o inverso, rotulando ou bloqueando o aluno para a atividade; a idéia de que sempre existirá uma única forma correta de se responder às situações impostas pela simulação, criando resistência para outros tipos de enfoque; internalização de conceitos errados (para isso os conceitos devem ser abordados para evitar precipitações futuras); não deixar os jogos serem vistos como o grande método de ensino, pois na verdade ele deve ser integrado à outras ferramentas.

\section{CONSIDERAÇÕES FINAIS}

Despertando interesses, usados experimentalmente e, finalmente, integrados às práticas de ensinoaprendizagem sob cenários de competitividade e suporte tecnológico, os jogos de empresa evidenciam suas contribuições na formação do profissional de gestão.

Como outros recursos da tecnologia educacional, a utilização dos jogos requer que seja mesclado com a leitura, conceituações e vivências, para possibilitar o aprendizado completo, envolvendo a cognição e o comportamento.

Ao se considerar, entretanto, os vários aspectos levantados neste estudo, cabe destacar que, embora a primeira imagem associada aos jogos de empresa seja a de competição, a ênfase à abordagem cooperativa, além de desenvolver as dimensões básicas para a formação do profissional, oportuniza o desenvolvimento de um comportamento mais participativo e solidário, simulando o que caberia ser praticado sob os princípios que se tornaram clichês e passaram a ser banalizados na sociedade atual. 


\section{REFERÊNCIAS}

ANDRADE, Rui Otávio B. de; AMBONI, Nério. Gestão de cursos de administração: metodologias e diretrizes curriculares. São Paulo: Prentice Hall, 2004.

ANDRADE, Rui Otávio B. de; ABREU, José Augusto R. de. Pesquisa nacional sobre o perfil, formação, atuação e oportunidades de trabalho do administrador. Brasília: CFA, 2006. 48p.

AZRIEL, Jay A.; ERTHAL, Margaret; STARR, Ervin. Answers, questions and deceptions: what is the role of games in business education?. Journal of education for business, sep/oct, 2005.

BARÇANTE, Luiz César; PINTO, Fernando Costa. Jogos de negócios: revolucionando o aprendizado nas empresas. Rio de Janeiro: Impetus, 2003.

BROTTO, Fábio Otuzi. Jogos Cooperativos: se o importante é competir, o fundamental é cooperar! Santos: Projeto Cooperação, 1997.

GRAMIGNA, Maria Rita Miranda. Jogos de Empresa e Técnicas Vivenciais. São Paulo: Makron Books, 1997. FREITAS, Carlos César Garcia. Aprendizagem experiencial e jogos de empresas no estudo do mercado de capitais: uma aplicação. Dissertação (Mestrado em Administração). Londrina: PPA UEM/UEL, 2007.

GABARDO, Luiz Omar S. Jogos de empresas: uma metodologia de utilização. In: OLIVEIRA, Marilisa do R.; et al. (org.). Gestão estratégica para a competitividade. Ponta Grossa: Editora UEPG, 2006.

GIL, Antônio Carlos. Métodos e Técnicas de Pesquisa Social. São Paulo: Atlas, 1999.

JOHNSSON, Marcelo Evandro. Jogos de empresa: modelo para identificação e análise de percepções da prática de habilidades gerenciais. Tese (doutorado em Engenharia de Produção). Florianópolis: UFSC, 2006.

LOPES, Paulo da Costa. Formação de administradores: uma abordagem estrutural e técnico-didática. Tese (doutorado em Engenharia de Produção). Florianópolis: Universidade Federal de Santa Catarina, 2001.

MAGDA, Vila; FALCÃO, Paula. Focalização de Jogos em T\&D. Rio de Janeiro: Qualitymark, 2002.

MENDES, M. L. M. S. O modelo GS-RH: uma integração de Jogos de Empresas para treinamento e desenvolvimento gerencial. Dissertação (Mestrado em Engenharia de Produção. Florianópolis: UFSC, 2001.

ORLANDELI, Rogério. Um Jogo de Empresas envolvendo cadeia logística: GameF61. Dissertação (Mestrado em Engenharia de Produção).Florianópolis: Universidade Federal de Santa Catarina, 2001.

TANABE, M. Jogos de empresas. Dissertação (Mestrado em Administração). São Paulo: FEA/USP, 1977.

VERGARA, Sylvia Constant. Projetos e relatórios de pesquisa em administração. São Paulo: Atlas, 2004. 


\section{Capítulo 31}

\section{ANÁLISE DA VIABILIDADE ECONÔMICA E AMBIENTAL DO PLANTIO DE TECA (TECTONA GRANDIS LINN F.) NO MUNICÍPIO DE ALTA FLORESTA D'OESTE - RO.}

DOI: $10.37423 / 200300433$

Rosimeire do Carmo Ferreira Rover (Administradora pela Universidade Federal de Rondônia - empresária do setor de matéria-prima moveleira).

Juliano Avelar Moura (Rrofessor da Universidade Federal de Goiás - Doutor em Engenharia de Rrodução).

Simone Marçal Quintino YProfessora da Universidade Federal de Rondônia-Doutora em Ciências Ambientais).

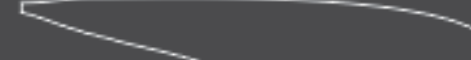

Resumo: Ò tema apresentado aborda a questấo ambiental em torno da supressão da floresta amazônica no èstado de Rondônjia. Apresenta, como alternativa, uma análise da viabilidade econômica e ambjental do plantio de Teca no município de Alta Floresta D'Oeste RO. A necessidade deste estudo se estabeleceu devido a uso desordenado das florestas nativas no estado de Rondônia, apontando o plantio de/feca como alternativa para diminuição da exploração das mesmas. Apresentamos com os s/estudos um levantamento de dados referentes à cultura da Teca, desde têchnicas de/plantio, obtenção de mudas, ytilização, comercialização elos custos e receitas do plantío. O estudo de caso foi desenvolvido nas Fazendas Matagal, Santa Júlia, Ourinhbos e Carob,a, locatizađas no município de Alta Floresta D'Oeste, num-total de-198 hectares cobertos com a cultura de Teca.

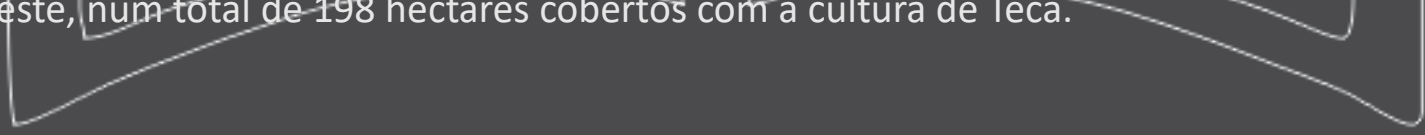




\section{Administração: caminhos para o desenvolvimento sustentável}

Após o estudo sobre a análise da viabilidade econômica e ambiental do plantio de Teca, e mediante comparativo com a bovinocultura de corte, conclui-se que a rentabilidade do plantio de Teca é mais vantajosa e ajudará na diminuição da exploração das florestas nativas e no aumento da biodiversidade da região do plantio. A pesquisa apontou que o Estado de Rondônia possui características climáticas favoráveis para a implantação do plantio de Teca, porém, um dos potenciais problemas identificados é com a comercialização das toras dos primeiros desbastes, em função da escassez de compradores desta bitola de madeira. Para a região onde foi feito o estudo, município de Pimenta Bueno - RO, que conta com algumas movelarias, é o principal destino da matéria prima.

Palavras-chave: Viabilidade Econômica e Ambiental; Cultura da Teca; Florestas; Silvicultura. 


\section{Administração: caminhos para o desenvolvimento sustentável}

\section{INTRODUÇÃO}

O presente trabalho apresenta estudos sobre a análise da viabilidade econômica e ambiental do plantio de Teca no município de Alta Floresta D'Oeste - RO através dos aspectos econômicos e ambientais, além dos estudos pertinentes aos dados gerais referentes à cultura da Teca, seu mercado global, técnicas de obtenção de mudas, técnicas de implantação do plantio, utilização, comercialização da mesma e sua aplicação efetiva. A necessidade desta investigação se estabeleceu em função do uso desordenado e ilegal das florestas nativas, onde a partir da década de 80 passou a ser umas das principais fontes econômicas do Estado de Rondônia.

Algumas questões devem ser tratadas com maior preocupação, como por exemplo, as extrações desordenadas nas últimas décadas da Floresta Amazônica no Estado de Rondônia e as atuais normas ambientais, que a cada ano ficam mais exigentes, se tornam fatores primordiais para análises de âmbito econômico e ambiental voltados para o reflorestamento da região em questão. Diante disto, questionamos: o estudo da viabilidade econômica da cultura do plantio de Teca no município de Alta Floresta D’Oeste - RO proporcionará melhoria na remuneração agrícola e em contra partida contribuirá ambientalmente com a redução das áreas desmatadas?

O estudo desenvolvido é um assunto de relevância, pois além de ser importante economicamente, também proporciona benefícios ambientais, como a proteção ao meio ambiente, podendo andar lado a lado. Para possível solução uma das alternativas que vem ganhando destaque no Brasil são as florestas plantadas, principalmente as espécies exóticas, seu crescimento é mais rápido do que as espécies nativas. São meios encontrados para preservar as florestas existentes e para a obtenção de matéria-prima madeireira, como também para outros fins extrativistas, tendo como intuito aumentar a remuneração dos produtores rurais através da implantação da silvicultura.

No Brasil a região Norte tem condições climáticas favoráveis para o desenvolvimento da Teca (Tectona Grandis Linn F.) semelhantes ao do país de origem da mesma, originária do Subcontinente Índico e do Sudeste Asiático, sendo uma vantagem a mais para os investidores que desejam diversificar sua renda.

A Teca (Tectona Grandis Linn F.) é uma das espécies tropicais de alto valor comercial, devido às características da sua madeira (durabilidade e resistência), chegando a superar valores de outras espécies nobres como o mogno (Swietenia macrophylla King). 


\section{Administração: caminhos para o desenvolvimento sustentável}

\section{A GESTÃO AMBIENTAL}

Para que as empresas possam cumprir com suas atividades comercias e industriais, os recursos necessários são provenientes da natureza, consequentemente esses recursos tornam-se mais escassos conforme o seu uso. Nos séculos anteriores os recursos naturais eram utilizados pelas empresas sem grandes preocupações com a degradação dos mesmos, somente nas últimas décadas é que as empresas e a sociedade começaram a preocupar-se com a preservação dos recursos provenientes da natureza, levando-as a voltarem seus pensamentos para um crescimento econômico em harmonia com o equilíbrio ecológico, como por exemplo, a adoção dos chamados programas de gestão ambiental.

A Gestão Ambiental envolve a ordenação das atividades humanas para que se cause o menor impacto possível ao meio em que vivem, assim como práticas que garantam a conservação e preservação da biodiversidade, a reciclagem das matérias-primas e a redução do impacto ambiental aos recursos naturais. $O$ conceito de gestão é definido como um conjunto de medidas administrativas que engloba os recursos humanos, como a preocupação com o bem-estar das futuras gerações; os recursos financeiros, através do crescimento econômico introduzindo a sustentabilidade como critério fundamental e os recursos físicos no sentido de programar determinada política para desenvolver, projeto, programa, ou plano, como por exemplo, o plano de manejo sustentável, de forma orgânica e controlada, a fim de atingir os seus objetivos mediante resultados avaliáveis (MILARÉ, 2005).

As empresas vêm adotando uma nova consciência ambiental, as despesas com proteção ambiental passaram a ser vistas pelas empresas como investimentos nas gerações futuras e como vantagens competitivas, onde os administradores e executivos incluíram a gestão ambiental como ferramenta indispensável numa organização. Um dos principais objetivos dos gestores ambientais é conciliar a administração dos recursos naturais utilizados em seus projetos, procurando encontrar as melhores opções para alcançar a qualidade ambiental do mesmo, ou seja, garantindo um bom funcionamento do projeto e seu melhor rendimento, assim seguindo com o propósito de continuidade e desenvolvimento dos projetos em andamento. (BACHA; ROCHA, 2000).

O Conselho Nacional do Meio Ambiente (CONAMA) no uso de suas atribuições e considerando a necessidade de revisão em relação aos critérios e procedimentos utilizados no Licenciamento Ambiental, criou a Resolução no 237/97 com o objetivo de utilizar o Licenciamento Ambiental como forma de gestão ambiental, visando o desenvolvimento sustentável, a melhoria contínua do 


\title{
Administração: caminhos para o desenvolvimento sustentável
}

empreendimento ambiental e conciliando o desenvolvimento econômico com a conservação do meio ambiente. Nessa resolução o Licenciamento Ambiental é definido como:

\begin{abstract}
Licenciamento Ambiental: procedimento administrativo pelo qual o órgão ambiental competente licencia a localização, instalação, ampliação e a operação de empreendimentos e atividades utilizadoras de recursos ambientais, consideradas efetiva ou potencialmente poluidoras ou daquelas que, sob qualquer forma, possam causar degradação ambiental, considerando as disposições legais e regulamentares e as normas técnicas aplicáveis ao caso. (MMA - MINISTÉRIO DO MEIO AMBIENTE, 1997, p. 01).
\end{abstract}

O Licenciamento Ambiental é de suma importância para a conservação ambiental e segurança quanto à viabilidade dos empreendimentos, visto que, quando ocorre a liberação da Licença Ambiental pelo órgão competente, o empreendimento se torna responsável pela manutenção da qualidade ambiental no local onde a empresa será instalada, assim o poder público tem um instrumento que pode controlar a instalação e operação dessas empresas, visando a conservação e preservação do meio ambiente para as gerações futuras. A Gestão Ambiental é um instrumento utilizado no empreendimento ambiental para trabalhar em conformidade com o órgão ambiental, sendo uma série de medidas administrativas para conseguir conciliar a utilização dos recursos naturais causando o menor impacto possível ao meio ambiente.

\section{O ESTADO DE RONDÔNIA E O USO DOS RECURSOS NATURAIS: A FLORESTA}

Num contexto mais amplo as ações do homem sobre o meio ambiente são tão antigas quanto à própria história da civilização humana, pois desde que surgiu o mundo surgiu a exploração dos recursos naturais disponíveis, sendo que, as florestas eram fontes dos recursos para diversas atividades e necessidades do homem. Com o passar dos anos, o homem passou a substituir a floresta por áreas cultiváveis para a construção das cidades, começando assim o ciclo de exploração das florestas nativas. (PERLIN apud RESENDE, 1992, p. 11).

As florestas brasileiras vêm sofrendo com o desmatamento desordenado desde o início da sua colonização. O primeiro bioma a sofrer com o desmatamento foi a Floresta de Mata Atlântica, que além da extração das madeiras nobres utilizadas naquela época, como o Pau-Brasil, sofreu com os ciclos do cultivo da cana-de-açúcar, a extração do ouro e com o plantio de café. Em meados da década de 60, com a política de desenvolvimento do Governo Militar para a ocupação da região Norte e desafogamento das demais regiões brasileiras, o desmatamento é intensificado e passa a ser direcionado para a Floresta Amazônica, a maior floresta tropical do mundo, representando cerca de 


\section{Administração: caminhos para o desenvolvimento sustentável}

$2 / 5$ do território sul-americano e metade do brasileiro. Possui aproximadamente $1 / 5$ do reservatório de água doce do planeta, além do maior banco genético da Terra (WALLACE, 2007).

O Estado de Rondônia a partir da década de 70 passou a receber um grande fluxo migratório populacional com o intuito de desenvolver o Estado, ocasionando consequências, como a devastação da floresta nativa, causando impactos ambientais, sociais e econômicos. Os migrantes foram atraídos pelos incentivos do governo para colonizar o Estado, como por exemplo, as aberturas das estradas ligando à Região Norte as demais regiões, o potencial econômico, como as florestas e terras ainda inexploradas. Contudo, o desenvolvimento não seria possível sem impactos e conflitos, ocorrendo a devastação das florestas existentes, desavenças entre os colonos por áreas de terras, pois o governo não conseguiu atender a grande demanda que chegava do Sul e das demais regiões do Brasil em busca de terras com preços baixos (BACHA; ROCHA, 2000).

Hoje, existe uma atenção voltada para a Floresta Amazônica, sobretudo em função do trabalho árduo de muitos ambientalista. A fiscalização intensificou, em comparação ao início da colonização do estado, pressupomos que em mais alguns anos os setores madeireiros serão levados a novas alternativas devido a execução da política ambiental, o que levará o reflorestamento e os plantios de árvores exóticas a melhor alternativa para quem pretender continuar nesse setor, além disso, outros fatores tornam o reflorestamento importante tanto para a sociedade como para o meio ambiente, traz como vantagem a captura de carbono pelas árvores em fase ativa de crescimento que absorvem uma maior quantidade de $\mathrm{CO}^{2}$ da atmosfera (POGGIANI, 1996).

\section{O DESENVOLVIMENTO SUSTENTÁVEL}

A sociedade e o poder público tem buscado formas e se adequando às novas tendências de preservação ao meio ambiente, onde o crescimento econômico é necessário, mas em conformidade com o desenvolvimento sustentável que pode ser caracterizado como a conciliação entre a preservação do meio ambiente, junto com a melhoria da qualidade de vida da população local, na Constituição da República do Brasil, o princípio do desenvolvimento sustentável encontra-se descrito no artigo 225, caput, segundo o qual:

Artigo 225. Todos têm direito ao meio ambiente ecologicamente equilibrado, bem de uso comum do povo e essencial à sadia qualidade de vida, impondo-se ao Poder Público e à coletividade o dever de defendê-lo e preservá-lo para as presentes e futuras gerações. (BRASIL, 2005, p.142). 


\section{Administração: caminhos para o desenvolvimento sustentável}

A preocupação com o meio ambiente há muito tempo vem sendo tratada como um problema mundial, visto que a ONU (Organização das Nações Unidas) em suas assembleias vem tomando decisões para que todos os países membros busquem formas para tornarem possível o desenvolvimento sustentável que é definido pela Comissão Mundial sobre Meio Ambiente e Desenvolvimento apud Milaré (2005, p. 57) como “...aquele que atende às necessidades do presente sem comprometer a possibilidade de as gerações futuras atenderem a suas próprias necessidades...".

O desenvolvimento sustentável pode ser adotado por diversos setores, um deles é o florestal, as florestas se tornam fontes econômicas através de uma exploração com base na sustentabilidade. Mas, a sustentabilidade do empreendimento florestal depende do equilíbrio entre os aspectos econômicos, ambientais e sociais, os três princípios têm que andar em conformidade um com o outro, buscando sua integração ampla. Toma-se como exemplo, a atividade florestal que pode ser economicamente viável e socialmente justa, mas se não atingir o aspecto ambiental, não será considerada como uma atividade sustentável, uma das opções que se tem disponível para alcançar esse objetivo é o uso do manejo sustentável de uso múltiplo que permite um melhor aproveitamento dos recursos florestais atuando dentro dos três princípios. (MILARÉ, 2005, p. 1085):

Administração da floresta para a obtenção de benefícios econômicos, sociais e ambientais, respeitando-se os mecanismos de sustentação do ecossistema objeto do manejo, e considerando-se, cumulativa ou alternativamente, a utilização de múltiplas espécies madeireiras, de múltiplos produtos e subprodutos não madeireiros, bem como a utilização de outros bens e serviços de natureza florestal (Dec. 2.788, de 28.09.1988).

Com a criação da Lei no 6.938/81, o Brasil passou a ter formalmente uma Lei destinada à Política Nacional do Meio Ambiente, integrando as demais legislações relacionadas ao meio ambiente existente até o momento, anteriormente cada Estado detinha leis próprias sobre o assunto, a partir da criação desta lei ocorreu a integração e harmonização das mesmas, com objetivos e diretrizes comuns à União (FARIAS, 2006). A integração desta Lei é considerada por muitos como um marco importante para o Brasil e o Meio Ambiente, visto que, o Governo Federal passou a ter uma preocupação de fato pelo desenvolvimento sustentável integrado com a preservação dos recursos naturais brasileiros.

A Política Nacional do Meio Ambiente segundo Resende (2006, p. 100) foi instituída com o "objetivo de preservar, melhorar e recuperar a qualidade ambiental propícia à vida, visando o desenvolvimento socieconômico e protegendo a dignidade da vida humana". A finalidade maior desta Lei é promover o desenvolvimento sustentável juntamente com a garantia da dignidade da vida humana, pois são 


\section{Administração: caminhos para o desenvolvimento sustentável}

valores importantes para a nação brasileira, tornando todos responsáveis pela preservação dos recursos naturais para garantir que as nações futuras também desfrutem dos recursos que hoje podemos utilizar.

Outro fato importante foi à criação do Sistema Nacional do Meio Ambiente (SISNAMA) e o Conselho Nacional do Meio Ambiente (CONAMA) órgãos administrativos responsáveis pela coordenação das Leis da Política Nacional do Meio Ambiente. (FARIAS, 2006). Estes órgãos são responsáveis pela efetiva aplicabilidade da Lei no 6.938 por meio da coordenação dos órgãos e entidades públicas da União, do Distrito Federal, dos Estados, dos Municípios, que têm o objetivo de proteger o meio ambiente e a qualidade de vida da sociedade.

\section{A ECONOMIA AMBIENTAL}

A Economia Ambiental é o campo da economia que aplica a teoria econômica às questões ligadas ao manejo dos recursos naturais e à preservação do meio ambiente. Nos últimos anos vêm crescendo a preocupação e o interesse da sociedade voltada para assuntos relacionados ao meio ambiente.

Até aproximadamente o final da década de 1960, a teoria econômica neoclássica não reconhecia a problemática ambiental, que a mesma não pudesse causar falhas substanciais em economias de mercado. Até então, acreditava-se que o sistema econômico funcionaria como se existissem fontes inesgotáveis de insumos e de energia para alimentar o processo econômico, no processo de produção não ficaria sobras de resíduos, no consumo dos produtos finais os mesmos desapareceriam inteiramente. Esse pensamento em relação ao meio ambiente se justificava enquanto se acreditava que eram limitadas as emissões de resíduos ao mesmo. (MUELLER, 1996). Esse pensamento sobre a economia neoclássica necessitou de revisão quando se detectou as externalidades causadas pela transformação dos recursos naturais em produtos finais e pela detecção da diminuição desses recursos, ocorrendo com o tempo a escassez dos mesmos.

Segundo Mankiw (1999, pg. 206) “...uma externalidade é o impacto das ações de uma pessoa sobre o bem-estar de outras que não participam da ação...", as externalidades podem ser classificadas como negativa, se o impacto for ruim e positiva, se for benéfica. A teoria neoclássica admitiu que na transformação dos materiais e no seu consumo final, os resíduos e rejeitos voltam ao ecossistema, podemos chamar de externalidades negativas, assim a economia ambiental propõe como principal discussão o desenvolvimento de mecanismos que objetive a alocação eficiente dos recursos naturais (MUELLER, 1996). 


\section{Administração: caminhos para o desenvolvimento sustentável}

Antes da implantação de um projeto é recomendável que se proceda todo um estudo de viabilidade econômica que forneça informações mínimas, porém as mesmas têm que ser consistentes, para verificar se o projeto é viável economicamente. A cultura florestal pode ser considerada como uma poupança a longo prazo, seu ciclo de produção é longo, próximo dos vinte anos, o projeto para alcançar a viabilidade econômica tem que apresentar lucro, tendo em vista que o capital investido está crescendo em forma de madeira, este produto geralmente é de qualidade, plantado de forma adequada, e o mercado consumidor da madeira garantido (MIRANDA, SILVA, CORDEIRO, 2001).

\section{ANÁLISE DA LEGISLAÇÃO SOBRE O REFLORESTAMENTO}

O Código Florestal Brasileiro foi instituído pela Lei no 4.771/65 de suma importância para disciplinar à utilização e preservação das florestas e outras formas de vegetação, nesse código no artigo 12, tratase da exploração das florestas plantadas, que assim dita:

Artigo 12. Nas florestas plantadas, não consideradas de preservação permanente, é livre a extração de lenha e demais produtos florestais ou a fabricação de carvão. Nas demais florestas dependerá de norma estabelecida em ato de Poder federal ou estadual, em obediência a prescrição ditadas pelas técnicas e peculiaridades locais. (BRASIL, 2005, p. 574).

$\mathrm{O}$ artigo 12 vem tratando do plantio de árvores para uso comercial para qualquer finalidade, desde que o plantio não esteja em área protegida por Lei, como Área de Preservação Permanente e Reserva Legal, tornando uma vantagem para quem pretende investir no plantio de árvores, trata também das florestas nativas onde sua exploração se dá mediante autorização dos órgãos ambientais competentes por meio de Plano de Manejo Florestal Sustentável.

O Programa Nacional de Florestas (PNF) criado em 20 de Abril de 2000, pelo decreto presidencial no 3.420/00, os principais objetivos pretendidos pelo Governo Federal ao criar este decreto foram “...estimular o uso sustentável de florestas nativas e plantadas e fomentar as atividades de reflorestamento, notadamente em pequenas propriedades rurais..." (SCARPINELLA, 2002, p. 60). 0 programa procura incentivar o uso sustentável das florestas nativas e plantadas, incentivar os pequenos proprietários de terras a investir em reflorestamento, visto que geralmente são as grandes empresas e proprietários de grandes latifúndios que adotam a silvicultura.

A Instrução Normativa no 01 de 10 de Maio de 2001, trata de normas relacionadas à silvicultura, cuja redação, trás que os proprietários de reflorestamento em áreas permitidas e, que seja para corte, não precisam elaborar projetos e nem passarem por vistoria dos órgãos ambientais. Contudo, o Instituto Brasileiro do Meio Ambiente e dos Recursos Naturais Renováveis (IBAMA) ou órgão conveniado 


\section{Administração: caminhos para o desenvolvimento sustentável}

poderá a qualquer momento, desde que conveniente, fazer vistoria nos plantios. Na época do corte para comércio, o proprietário do plantio deverá entrar em contato com o órgão ambiental para a legalização das árvores para comercialização.

Artigo 1․ A execução e condução de plantios florestais de espécies nativas ou exóticas, com a finalidade de produção e corte, em áreas de cultivos agrícola e pecuária, alteradas, subutilizadas ou abandonadas, localizadas fora das Áreas de Preservação Permanente e de Reserva Legal, estão isentas de apresentação de projeto e de vistoria técnica.

Parágrafo Único: O Instituto Brasileiro do Meio Ambiente e dos Recursos Naturais Renováveis - IBAMA - ou órgão conveniado, em qualquer tempo, poderá realizar vistoria técnica nesses plantios.

Artigo 2‥ Os proprietários de florestas plantadas, quando da colheita e comercialização dos produtos delas oriundos, deverão prestar informações ao IBAMA ou órgão conveniado sobre as espécies, quantidade e destinatários, com vistas à legalização desses produtos. (BRASIL, 2001, p. 04).

\section{SILVICULTURA NO BRASIL}

A silvicultura é a ciência que se ocupa das atividades ligadas à implantação e regeneração de florestas. Tem como objetivo o manejo científico adequado para produzir de forma contínua bens e serviços florestais. Pode ser dividida em duas formas diversificadas de florestas, a pura, que é composta de uma única espécie de árvore num mesmo espaço ou a mista, que são áreas que contem mais de uma espécie no mesmo espaço (INOUE et. al., 1983; YARED, 1996 apud MMA , 2006).

As florestas plantadas no Brasil oferecem importantes contribuições nos aspectos econômicos, sociais e ambientais. Como benefícios econômicos um dos mais significativos é o fornecimento de matéria-prima para o setor industrial florestal, na área social a geração de empregos, só em 2009 foram de 3,9 milhões de empregos, 535 mil diretos e 1,26 milhão indiretos. Do ponto de vista ambiental, as florestas plantadas favorecem para a redução da pressão sobre o bioma, reduz os efeitos negativos referentes ao desmatamento já consolidado, pode melhorar a fertilidade do solo e consequentemente aumentar a produtividade por área, favorece a ciclagem dos nutrientes, a proteção de bacias hidrográficas e da biodiversidade (ABRAF, 2010).

No Brasil os números são favoráveis aos investimentos em plantios de espécies tropicais, pois o país é o líder de produção mundial e consumo nesse setor. A produção de madeiras em toras é de 25 milhões de $\mathrm{m}^{3}$ por ano, sendo o consumo no país de 13 milhões de $\mathrm{m}^{3}$ por ano de madeira serrada, são dados importantes para os interessados na implantação de plantios e serve de incentivo para investidores do setor (ALMEIDA, 2010).

No Brasil as espécies que detém maior área de florestas plantadas é o eucalipto e o pinus, os estados onde ocorreu um maior crescimento do cultivo de eucalipto foi na Bahia, seguido por São Paulo, Maranhão, Mato 


\section{Administração: caminhos para o desenvolvimento sustentável}

Grosso do Sul e Minas Gerais. A cultura de pinus teve uma redução, sendo maior no Paraná, seguido por Minas Gerais, São Paulo e Bahia. Ocorreu uma redução nas áreas de florestas plantadas em decorrência da crise mundial que afetou a economia de todos os países, incluindo o setor florestal, visto que em 2009 a área de florestas plantadas de eucalipto e pinus atingiram 6.310 .450 hectares, crescimento de 2,5\% em relação ao ano de 2008, mas no período de 2005 a 2008 esse crescimento foi de 5,5\% demonstrando assim o impacto da crise econômica. (ABRAF, 2010).

\section{A TECTONA GRANDIS LINN L.}

A Tectona Grandis Linn L. no Brasil é chamada popularmente como Teca, uma das espécies de madeira conhecida mundialmente, em cada região e país possui um nome diferenciado, segundo Wagenfuhr apud Drescher (2004, p. 07) pode ser conhecida pelos seguintes nomes:

[...] na Alemanha, Inglaterra, Índia, Grã Bretanha, Siam, Birmânia, Tailândia, Java, Burma, Indonésia e na maioria dos países do mundo, a teca é conhecida como Teak. Na França e Itália, ela é chamada de teck. Em Java, de ojati. Em Laos, Camarões e Tanzânia, de May sak. Em Burma, chama-se Kyum. Na Indonésia, é conhecida por tadi, Tek e Sâgwam. Na Malásia e Gabun, é Djati. No Vietnam, é Giathi. No sul da Indonésia, é Kembal ou Semarang. A teca é chamada no sul da Indonésia e na Tailândia de Jat ou Sak." O nome científico Tectona grandis Linn F. significa "o maior orgulho dos carpinteiros

Considerada como uma das espécies de madeiras comercializadas mais antigas do mundo, desde 4.000 a.C. Nessa época era utilizada em construções de navios, palácios reais e templos religiosos é originária do Subcontinente Índico e do Sudeste Asiático. (DRESCHER, 2004).

A teca, espécie amplamente empregada em reflorestamentos em várias partes do mundo, tem como objetivo principal a produção de madeira para serraria. O cultivo da espécie começou a ganhar importância no século 18, quando os britânicos demandavam grandes quantidades de madeira para construir as embarcações, iniciando-se neste período os plantios na Índia. (FIGUEIREDO, 2001, p. 08).

No Brasil as primeiras árvores plantadas de Teca foram no Jardim Botânico do Rio de Janeiro em 1930, já o primeiro plantio (em escala) registrado é de 1959, na Escola Superior de Agricultura Luiz de Queiroz, em Piracicaba-SP, pelo professor de silvicultura Helladio do Amaral Mello, podendo ser considerado pioneiro no plantio de Teca no Brasil (DRESCHER, 2004).

A utilização da madeira de Teca é bem diversificada, devido as suas características próprias, como beleza, leveza, resistência e durabilidade. São utilizadas tanto no Brasil como em outros países, para construções de navios em geral, de vários portes e qualidades, nesse setor é praticamente insubstituível, devido a sua resistência à exposição ao sol, ao calor excessivo, ao frio, às águas das chuvas e do mar. As indústrias madeireiras usam na produção de portas, janelas e pisos, os carpinteiros 


\section{Administração: caminhos para o desenvolvimento sustentável}

e marceneiros a utilizam na produção de móveis finos e artesanais, utensílios domésticos, como tábuas de carne, colheres, entre outros (TSUKAMOTO FILHO, 2002; DRESCHER, 2004).

“...No sudeste asiático, a teca leva de 60 a 80 anos para atingir dimensões de corte, enquanto no Brasil o seu ciclo de corte é de 25 anos...", (FERNANDES, FARIA, FLORÊNCIO, 2009, p. 306). O clima é um dos principais fatores para esse crescimento rápido, considerando-se ideal o de tropical úmido, com temperatura média mínima de $220 \mathrm{o}$ e com máxima de $460 \mathrm{C}$, sendo a região Norte a que mais se enquadra nessas características, são números significantes, tanto para a região Norte como também para as pessoas e empresas que pretendem investir em empreendimentos florestais voltados para o cultivo de Teca, visto que, seu crescimento é rápido, consequentemente, mais rápido o retorno financeiro (ARAUJO, 2008; DRESCHER, 2004; SALGADO, 2003).

A partir do plantio comercial da Teca, em conjunto foi aprimorado um conjunto de técnicas modernas para o cultivo e produção da madeira. Hoje já se trabalha com o espaçamento de $3 \times 2 \mathrm{~m}$ no plantio, o que possibilita maior crescimento para as árvores. A obtenção de mudas varia, as mais utilizadas são a de mudas de toco de raiz nua. (ARAUJO, 2008; DRESCHER, 2004; SALGADO, 2003).

Dados da EMBRAPA (2010, p. 01):

O Mato Grosso é, atualmente, o estado que mais planta teca, uma alternativa às espécies tradicionalmente cultivadas, como pínus e eucalipto. Mas o Brasil conta ainda com diversas regiões geográficas com condições de clima e solo para a espécie. Atualmente, segundo dados da Abraf, as áreas de plantios comerciais de teca ultrapassam 65 mil hectares. A teca poderia ser plantada nas grandes áreas desmatadas ou descaracterizadas como alternativa para as indústrias madeireiras.

De acordo com Araújo (2008) nas semelhanças entre a Teca e o Mogno identificam-se algumas características, como sua rusticidade, rápido crescimento e excelente forma (tronco retilíneo e pouco sujeito a bifurcação). No Brasil, a Teca tem se expandido principalmente nas regiões Centro-Oeste e Norte, sendo produzida a madeira de alta qualidade que é utilizada principalmente para fabricação de móveis finos e na construção naval.

A produção de Teca no Brasil atingiu em 2009 aproximadamente 65.240 ha, enquanto em 2008 o total foi de 58.810 ha, representando assim um crescimento de 10,9\% na área plantada dessa espécie no Brasil, demonstrando assim um interesse nessa cultura devido ao retorno financeiro em projetos com a mesma (ABRAF, 2010). 


\section{Administração: caminhos para o desenvolvimento sustentável}

\section{ASPECTOS GEOGRÁFICOS DO MUNICÍPIO DE ALTA FLORESTA D’OESTE-RO}

O município de Alta Floresta D’Oeste está localizado nas coordenadas geográficas 11ํ56’37' Latitude, de Longitude 6154'24" e altitude de 350 metros. De acordo com a classificação Köppen (1931), a região do município se caracteriza pelas estações de clima tropical, quente e úmido, com períodos bem definidos durante o ano: os meses que vão de maio a setembro é o período seco, a partir dos meses de outubro a abril é o período chuvoso. Por causa dos meses chuvosos, observa-se um alto índice de umidade relativa do ar, aproximadamente $85 \%$, a temperatura média anual varia de $22^{\circ} \mathrm{C}$ a 35ํㅡ, com precipitação anual de 2.000 mm. (MOREIRA, 2008).

\section{LOCALIZAÇÃO E CARACTERÍSTICAS DO PLANTIO}

O estudo foi realizado no município de Alta Floresta D'Oeste - RO, em quatro propriedades: Fazenda Matagal, área total 333 hectares; Fazenda Santa Júlia, 199 hectares; Fazenda Ourinhos, 101 hectares; e, Fazenda Caroba, 97 hectares. A área total das quatro fazendas corresponde a 730 hectares, sendo a soma das áreas cobertas com Teca de 198 hectares. Na Fazenda Matagal tem uma área de pastagem, de aproximadamente 90 hectares que o proprietário trabalha com bovinocultura, não entrando em detalhes sobre a quantidade de bois que possui nesta propriedade. Os restantes das fazendas são cobertas com florestas nativas e floresta de Teca.

De acordo com o informado pelos proprietários, as fazendas estão em conformidade com a legislação. Os espaçamentos variam de $2 \mathrm{~m} \times 2 \mathrm{~m}$ e $3 \mathrm{~m} \times 2 \mathrm{~m}, 2500$ e 1666 plantas por hectare respectivamente.

Quanto ao manejo predominante, os talhões no espaçamento $2 \mathrm{~m} \times 2 \mathrm{~m}$ necessitaram de mais desbastes do que os plantados no espaçamento $3 \times 2 \mathrm{~m}$, isto, devido ao número final de árvores que devem ficar por hectare, que são aproximadamente 350 árvores. Este é o número mais adequado para um maior crescimento e desenvolvimento das árvores até o corte final. Com isso ocorre um aumento dos custos totais do plantio, um dos proprietários relatou que não obteve receita dos desbastes feitos nos talhões com espaçamento $2 \mathrm{~m} \times 2 \mathrm{~m}$, devido o baixo valor comercial do diâmetro da madeira no estágio inicial. Isso tem levado a uma preferência pelo espaçamento $3 \mathrm{~m} \times 2 \mathrm{~m}$, que apresenta menor custo de produção.

No estado, a madeira proveniente de árvores com até 14 anos (madeira de desbaste) não apresentou atratividade comercial. $\mathrm{O}$ que contradiz estudos que apresentaram receitas de desbastes com 4 anos de idade de $\mathrm{R} \$ 3.250,00$ por hectare, com 8 anos uma receita $\mathrm{R} \$ 7.816,80 /$ ha e com 12 anos o equivalente à R\$ 14.233,95/ha (TSUKAMOTO FILHO, et al, 2003). 


\section{Administração: caminhos para o desenvolvimento sustentável}

\section{ASPECTOS TÉCNICOS E ASPECTOS ECONÔMICOS DO PLANTIO}

Os custos de aquisição de mudas, preparo do solo, plantio, controle das ervas daninhas e demais despesas até a colheita, foram calculados em valores para 1 hectare, são valores levantados nas propriedades mencionadas:

TABELA 1: Custos para implantação de 1 hectare de Teca (em dólar/ média no ano de 2009/ $\mathrm{R} \$ 1.99)$

\begin{tabular}{lll}
\hline Especificações & Ano de Ocorrência & Custo Total (dólar/ha) \\
Produção de Mudas & 0 & 184,32 \\
Preparo da Terra & 0 & 145,72 \\
Plantio & 0 & 149,87 \\
Manutenção $1^{\text {o }}$ Ano & 1 & 108,29 \\
Manutenção $2^{\text {o }}$ ao $4^{\text {o }}$ Ano & 2 a 4 & 78,39 \\
Manutenção (adubação) & 6 a 10 & 9,49 \\
Manutenção do $5^{\circ}$ em diante & 5 a 25 & 66.58 \\
Desrama $2^{\circ}$ ao $8^{\text {o }}$ ano & 2 a 8 & 199.98 \\
Desbaste & 3 a 5 & 169.46 \\
Desbaste & 10 a 12 & 227.13 \\
Colheita $\left(\mathrm{R} \$ / \mathrm{m}^{3}\right)\left(120 \mathrm{~m}^{3} / \mathrm{ha}\right)$ & 25 & 1380 \\
Transporte $\left(\mathrm{R} \$ / \mathrm{m}^{3}\right)\left(120 \mathrm{~m}^{3} / \mathrm{ha}\right)$ & 25 & 343.2 \\
\hline Total dos Custos & & $\mathbf{2 9 9 5 , 8 5}$ \\
\hline
\end{tabular}

Para efeitos de custos na produção das mudas, considerou-se coleta de mudas, arranque, preparo dos tocos e manutenção necessária. As mudas produzidas desta forma são conhecidas como "toco de raiz nua". Para o plantio de 1 hectare de Teca no espaçamento $3 \times 2$ m, são necessárias 1.834 mudas (considerando o replantio de $10 \%$ ), cada muda custa US\$0,10 o que corresponde a um custo total/ha de US\$183,40 em relação às mudas. Os cuidados referentes à produção das mudas e o espaçamento utilizado para a plantação das mudas são descritos por TSUKAMOTO FILHO, et al (2003).

No preparo do terreno foram consideradas as atividades necessárias para implantar o povoamento de Teca numa área de pastagem, considerou-se como custos gradagem e combate à formiga, esses custos foram calculados em hora/máquina. Para o plantio, foram considerados os custos com o replantio, a adubação, a aplicação de calcário e o transporte, além dos custos com o próprio plantio das mudas.

Para o manejo do plantio, no primeiro ano de manutenção considerou-se o combate intensivo à formiga, o controle das ervas daninhas (capina), o transporte de mudas e a eliminação de brotações. Do segundo ao quarto ano, consideraram-se as atividades de combate à formiga, controle das ervas daninhas (roçadas) e transporte de mão de obra. O controle das ervas daninhas é realizado somente 


\section{Administração: caminhos para o desenvolvimento sustentável}

até o terceiro ano, sendo feita no quarto se considerada necessária, o combate à formiga após o quarto ano é realizado também somente conforme a necessidade.

Para a produção de madeira de boa qualidade e livre de nós, a Teca exige a desrama dos galhos laterais. As desramas foram consideradas a partir do segundo ano, até as árvores atingirem altura comercial de oito metros. A desrama deve ser feita até o oitavo ano do povoamento, a mesma deve ser feita até a proporção de $2 / 3$ da copa, sem prejuízos para o desempenho da árvore, em anos intercalados (TSUKAMOTO FILHO, et al, 2003).

Com o crescimento das árvores aumenta a competição por luz, água e nutrientes, necessitando-se desbaste de algumas árvores, aumentando o espaço para o crescimento das árvores restantes, esses desbastes servem também como seleção do povoamento, assim o desbaste é feito principalmente nas árvores que estão com defeitos, tortas e fracas. O primeiro desbaste ocorre após o 3ำ ano do plantio, os próximos são no 5 ano, no $10^{\circ}$ ano e no $12^{\circ}$ ano, para o corte final restará aproximadamente 350 árvores por hectare. Os próximos desbastes devem realizar-se quando a copa de uma árvore encontrar-se com a copa da outra árvore.

Conforme informações levantadas no local, um grande problema é quanto ao destino das árvores desbastadas, visto que, em Alta Floresta D’Oeste não há comercialização da madeira de Teca no estágio intermediário, tendo com isso um desperdício de madeira, o que aumenta o custo de produção. Para o caso específico, o retorno do investimento só acontece no último corte.

Para analisar a viabilidade econômica do plantio de Teca no Município de Alta Floresta D’Oeste - RO utilizou-se o comparativo entre a bovinocultura de corte e o plantio de Teca para verificar qual dos dois é mais rentável. No Estado de Rondônia o rebanho bovino representa um total de 11.119.946 cabeças de boi, é o quinto Estado exportador de carne do Brasil, essa atividade representa uma receita de $60 \%$ para o Estado. Para o produtor rural que adota a criação dos animais soltos na propriedade, que é denominado sistema extensivo, o tempo que leva para o bezerro chegar ao peso ideal de aproximadamente 15 arrobas para o abate chega a 3 anos, considerando uma capacidade de suporte de 2 animais por hectare(TILP, 2009).

Para efeito de comparação de receita entre a cultura da Teca e a bovinocultura de corte, considerouse a rotatividade da Teca de 25 anos para o corte final. O produtor rural que tiver como fonte de renda a bovinocultura terá abatido 8 vezes a quantidade de 2 bois por hectare que representa um total de 16 bois no final do ciclo de 25 anos. Segundo TILP (2009) o custo para manter um boi é de US\$92,08 ao ano, sendo o custo total de US\$4419,85 para manter e engordar os 16 bois durante os 25 anos. 


\section{Administração: caminhos para o desenvolvimento sustentável}

Para calcular as receitas considera-se que cada boi apresenta um peso de 15 arrobas, há um preço de US\$ 40,20 a arroba para venda diretamente ao frigorífico, esse produtor terá uma receita de US\$603,01 por cabeça, que representa no total de 25 anos uma receita bruta de US\$9648,24 por hectare, retirando os custos o produtor terá uma receita líquida de US\$5228,39 por hectare.

O custo para implantar um hectare de Teca e para a manutenção necessária em todos os anos de cultivo é de US\$2995,85, parece pouco, mas temos que ressaltar que o sistema de cultivo investigado não é intensivo e a aplicação do capital é para 25 anos. O povoamento no final de 25 anos contará com um número próximo de 350 árvores por hectare, com estimativa de venda ao preço de U\$150,00 por árvore, no corte final representa uma receita bruta de aproximadamente US\$52500,00. Ressaltamos que os valores estão em dólares (valor médio do dólar para o ano de 2009 de $\mathrm{R} \$ 1.99$ ), portanto, uma receita bruta de US\$52500,00/ha e líquida de US\$49504,15/ha.

Após todo o estudo sobre a análise da viabilidade econômica e ambiental do plantio de Teca no município de Alta Floresta D'Oeste - RO e após o comparativo com a bovinocultura de corte, concluise que a rentabilidade do plantio de Teca é vantajosa em relação a bovinocultura de corte, lembrando, diferentemente da bovinocultura, o retorno do capital só acontecerá a longo prazo. Para um bom retorno financeiro e também para assegurar as vantagens ambientais que o plantio proporciona para a região de sua implantação, o mesmo necessitará de cuidados de cultivo como qualquer cultura, desde a obtenção das mudas até o corte final no $25^{\circ}$ ano; para assim garantir um produto final de alta qualidade.

\section{ASPECTOS AMBIENTAIS DO PLANTIO DE TECA}

Os proprietários relataram que a silvicultura tráz vantagens ambientais para a biodiversidade da região, pois o plantio de Teca diminui a necessidade crescente da utilização da floresta nativa. Quando substitui a pastagem, a floresta de Teca facilita o fluxo de animais e sementes nas áreas de reserva legal e de preservação permanente, aumentando assim a biodiversidade e a troca genética entre eles, várias espécies de animais se beneficiam da situação favorável na fazenda.

Os possíveis impactos ambientais que o plantio de Teca apresenta para o solo são riscos de degradação que pode ocorrer em qualquer cultura agrícola ou florestal, sempre que essas culturas são mal conduzidas, seja ela qual for. Um plantio bem manejado, com utilização correta de fertilizantes, desrama e desbastes apresentam riscos de degradação ambientais menores que as principais culturas agrícolas e pecuárias. Os sistemas florestais proporcionam uma vantagem a mais do que as culturas 


\section{Administração: caminhos para o desenvolvimento sustentável}

agrícolas tradicionais que é o sequestro de carbono. Outra, na medida que acontece o desbaste da área plantada e ao longo dos 25 anos, a área fica apta ao consórcio com outras culturas, o que sinaliza a possibilidade do desenvolvimento de sistemas agroflorestais.

Segundo Figueiredo (2001, p. 08) os problemas de impactos ambientais identificados aparecem quando os plantios de Teca são efetuados em locais inapropriados e ambientes diferentes daquele característico dessa cultura, como também a falta de cuidados silviculturais com o plantio, principalmente pela falta dos desbastes nas épocas adequadas.

\section{CONSIDERAÇÕES FINAIS}

Devido aos incentivos fiscais concedidos pelo Governo Militar e a abertura das malhas rodoviárias federais a partir da década de 1960, no intuito de desenvolver a região, ocorreu uma exploração desordenada da Floresta Amazônica que trouxe consequências negativas para o meio ambiente, como a devastação da fauna e flora nativa do bioma.

Após a exploração das florestas nativas de forma desordenada e ocorrendo a diminuição das mesmas, foi disparado as primeiras iniciativas em direção da implantação de florestas plantadas. A partir de então, no município de Alta Floresta D’Oeste e nos demais municípios do Estado, foi dado início, quase que experimental, do cultivo da Teca. O que hoje, tem proporcionado uma renda extra para o produtor rural, como também beneficiado o meio ambiente, diminuindo a exploração das florestas nativas e aumentando a biodiversidade da localidade de implantação do reflorestamento.

A proteção ao meio ambiente e sua utilização econômica, porém de forma sustentável, é tratada na Constituição Federal de 1988, onde determina que é dever de todos proteger o meio ambiente para as presentes e futuras gerações, e que as atividades econômicas devem ter como base a proteção do meio ambiente. As leis referentes às florestas plantadas são bem específicas, no caso da Floresta Amazônica 80\% da propriedade deverá ser destinada à reserva legal, percentual que é contestado em todo estado e que tráz conflitos políticos em torno do assunto. Grandes pecuaristas alegam que a lei "não deixa Rondônia crescer", fazendo referência aos $80 \%$ exigidos na legislação. Aí fica a seguinte pergunta: a criação da bovinocultura de corte é o único caminho possível para o desenvolvimento do estado? Podemos estender a pergunta para todos os estados que compõem a Amazônia e Amazônia Legal.

A região norte, tem potencialidade para o plantio de Teca, visto que, toda região reproduz um clima favorável para o melhor desenvolvimento e rápido crescimento da Teca. O principal destino da 


\section{Administração: caminhos para o desenvolvimento sustentável}

madeira da Teca no Estado de Rondônia é como matéria-prima para movelarias do próprio estado, do centro oeste e sudeste.

\section{REFERÊNCIAS}

ABRAF (Associação Brasileira de Florestas). Anuário Estatístico da ABRAF 2010. Disponível em: http://www.abraflor.org.br/estatisticas/ABRAF10-BR/controle.html. Acesso em 22 de set. 2010.

ALMEIDA, A. N. et al. Mercado de Madeiras Tropicais: Substituição na Demanda de Exportação. Disponível em: http://www.scielo.br/pdf/aa/v40n1/v40n1a15.pdf. Acesso em: 29 mai. 2010.

ARAUJO, H. B., DELGADO, L. G. M., GOMES, J. E. Análise do Sistema de Produção de Teca (Tectona grandis L. F) no Brasil.

Disponível em:http://www.revista.inf.br/florestal11/pages/artigos/ARTIG002.pdf. Acesso em: 17 mar. 2010.

BACHA, C. J. C., ROCHA, D. P. A Preocupação das Politicas Públicas com a Sustentabilidade dos Recursos Florestais em Rondônia. Disponível

em: http://www2.fgv.br/ibre-cea/publicacoes/arq/art_am_legal_01.pdf. Acesso em: 16 de jun. 2010.

BRASIL, Constituição Federal, Coletânea de Legislação de Direito Ambiental. Organizadora Odete Medauar. Ed. Revista dos Tribunais. 4a Ed., São Paulo, 2005.

Instrução Normativa no 01 de 10 de Maio de 2001. Estabelece a necessidade de estabelecer procedimentos relativos a silvicultura sustentável e o atendimento aos preceitos contidos no Código Florestal. Ministério do Meio Ambiente. Disponível em: mma.gov.br. Acesso em: 12 de set. 2010.

DRESCHER, Ronaldo. Crescimento e Produção de Tectona grandis Linn. F., Em Povoamentos Jovens de Duas Regiões do Estado de Mato Grosso - Brasil. Disponível

em:http://cascavel.cpd.ufsm.br/tede/tde_arquivos/10/TDE-2006-12-01T142839Z-

255/Publico/RONALDODRESCHER.pdf. Acesso em: 27 abr. 2010.

EMBRAPA - EMPRESA BRASILEIRA DE PESQUISA AGROPECUÁRIA. Teca Pode Ser Alternativa Para Plantios Florestais No Brasil. Disponível

em:http://www.embrapa.br/embrapa/imprensa/noticias/2010/maio/3a-semana/teca-pode-seralternativa-para-plantios-florestais-no-brasil. Acesso em: 12 de jun. 2010.

FERNANDES, A. L. T., FARIA, M. F., FLORÊNCIO, T. M. Análise da Biometria das Espécies Florestais Teca e Mogno Submetidas a Diferentes Tratamentos de Irrigação e Nutrição Mineral. Disponível em: http://www.ipabhi.org/serhidro/anais/anais2009/doc/pdfs/p24.pdf. Acesso em: 04 fev. 2010.

FIGUEIREDO, E. O. Reflorestamento com Teca (Tectona grandis L.F.) no Estado do Acre. Disponível em: http://www.cpafac.embrapa.br/pdf/doc65.pdf. Acesso em: 17 jan. 2010. 


\section{Administração: caminhos para o desenvolvimento sustentável}

MANKIW, N. G. Introdução à Economia: Princípios de Micro e Macroeconomia. Rio de Janeiro: Editora Campus, 1999.

MILARÉ, É. Direito do Ambiente: Doutrina, Jurisprudência, glossário. 4ạ Ed. - São Paulo: Editora Revista dos Tribunais, 2005.

MIRANDA, G. DE M., SILVA, M. L.,CORDEIRO, S. A. Benefícios da Atividade Florestal Para o Produtor Rural. Disponível em: http://www.ciflorestas.com.br/arquivos/doc_beneficios_rural_29856.pdf. Acesso em 18 de jun. 2010.

MMA - MINISTÉRIO DO MEIO AMBIENTE. Plano Nacional de Silvicultura com Espécies Nativas e Sistemas Agroflorestais - PENSAF. Disponível em: http://www.rebraf.org.br/media/PENSAF\%20VF.pdf. Acesso em 23 de jun. 2010.

. Resolução CONAMA 237/97. Disponível

em: http://www.mma.gov.br/port/conama/res/res97/res23797.html. Acesso em 03 de out. de 2010.

MOREIRA. K. F. A.Diagnóstico Local do Município de Alta Floresta D’Oeste-RO. Disponível em: http://portal.saude.gov.br/portal/arquivos/pdf/Diagnostico_Local_Alta-Floresta-Doeste-RO.pdf.

Acesso em 22 de out. 2010.

MUELLER. C. C. Economia e Meio Ambiente na Perspectiva do Mundo Industrializado: Uma Avaliação da Economia Ambiental Neoclássica. Disponível

em: http://www.usp.br/estecon/index.php/estecon/article/view/585/294. Acesso em 22 de set. de 2010.

POGGIANI, F. Monitoramento Ambiental de Plantações Florestais e Áreas Naturais Adjacentes. Disponível em: http://www.ipef.br/publicacoes/stecnica/nr29/cap04.pdf. Acesso em 14 de jun. 2010.

RESENDE, K. M. Legislação Florestal Brasileira: uma reconstituição histórica. Dissertação de Mestrado. Universidade Federal de Lavras, Minas Gerais, 2006.

FARIAS, T. Q. Aspectos Gerais da Política Nacional do Meio Ambiente - Comentários sobre a Lei no 6.938/81. Disponível em: http://www.ambito-juridico.com.br/pdfsGerados/artigos/1544.pdf. Acesso em 19 de set. 2010.

21. SALGADO, B. G. et al. Desenvolvimento Inicial de Tectona grandis L.f. (Teca) em Diferentes Espaçamentos no Município de Paracatu, MG. Disponível

em:http://www.dcf.ufla.br/cerne/Revistav11n1-2005/07\%20artigo\%20009\%20Editorado.pdf. Acesso em: 05 jun. 2010.

SCARPINELLA, G. A. Reflorestamento no Brasil e o Protocolo de Quioto. Disponível em: http://www.iee.usp.br/biblioteca/producao/2002/Teses/Disserta\%E7\%E3o_Scarpinella.pdf. Acesso em: 30 jul. 2010. 


\section{Administração: caminhos para o desenvolvimento sustentável}

TILP. A. M. S. A Importância da Gestão de Custos na Bovinocultura de Corte do Estado de Rondônia: Estudo de Caso na Fazenda Brasil Fronteira. Trabalho de Conclusão de Curso (Graduação em Administração)-Universidade Federal de Rondônia, Cacoal, 2009.

TSUKAMOTO FILHO, A. A. et al. Análise Econômica de um Plantio de Teca Submetido a Desbastes. Disponível em: http://www.scielo.br/pdf/rarv/v27n4/a09v27n4.pdf. Acesso em: 15 jan. 2010.

WALLACE, S. Amazônia Ilegal, Revista National Geographic Brasil, p.21 - 51 Jan/2007. 


\section{Capítulo 32}

\section{MULTICOLINEARIDADE EM ANÁLISE DE REGRESSÃO.}

DOI: $10.37423 / 200300435$

Luís Fernando Moreira (Doutor em Administração - PPGA - USP, Mestre em Administração [Finanças]-PPGA - UFRGS, Professor da UNIOESTE - Foz do Iguaçu -PR).
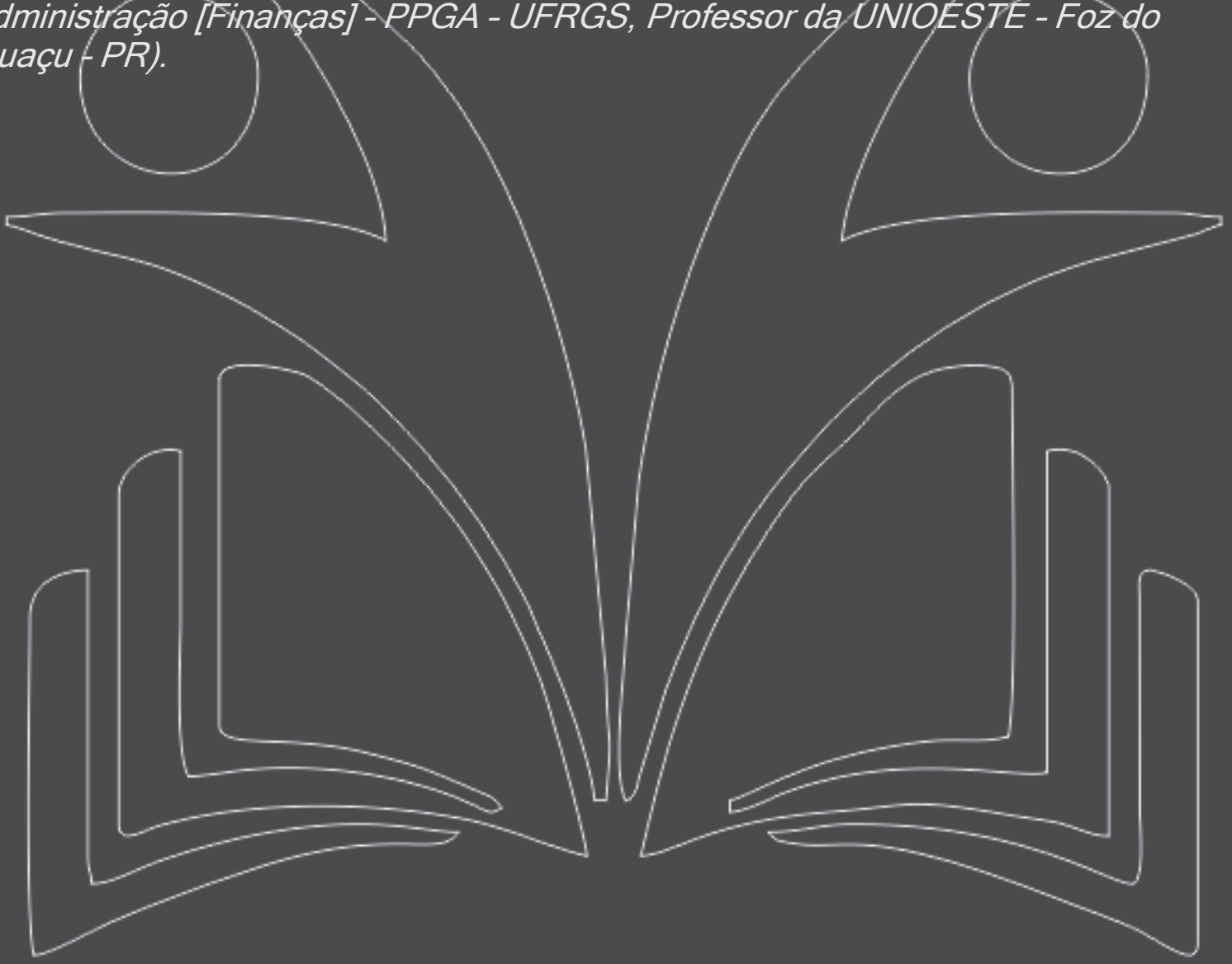


\section{Administração: caminhos para o desenvolvimento sustentável}

\section{INTRODUÇÃO}

Nos modelos de regressão múltipla de primeira ordem, quando as variáveis preditoras não estão correlacionadas, o efeito atribuído a cada uma delas é o mesmo, não importa quais variáveis estejam inclusas no modelo. Ainda nesse contexto, a contribuição marginal para a redução da soma dos quadrados da regressão de uma das preditoras quando a outra está no modelo é a mesma de quando ela aparece sozinha no modelo (Kutner et al., 2004). Mais formalmente:

$\operatorname{SSR}(x 1)=\operatorname{SSR}(x 1 / x 2)(1)$

Em modelos de regressão com duas ou mais variáveis explicativas é usual que tais variáveis apresentem algum tipo de interdependência. A essa relação de interdependência chamamos multicolinearidade (Fonseca, 2003). A presença de multicolinearidade independe da existência de relação de dependência entre a variável dependente e os termos independentes (Ferrar \& Glauber, 1967).

De acordo com Kutner et al. (2004) a regressão múltipla visa entre outras coisas estabelecer a importância relativa e a magnitude do efeito das variáveis preditoras sobre a variável dependente, identificar preditores que deveriam ser eliminados do modelo e apontar a necessidade de inclusão de variáveis preditoras ainda não participantes do modelo. Na ausência de multicolinearidade esses objetivos podem ser facilmente alcançados. Infelizmente, nas ciências sociais, em função dos experimentos não serem controlados, a existência de multicolinearidade é a regra.

A relação de interdependência quase sempre presente pode ser facilmente identificada; medi-la, entretanto, não é tarefa tão simples. De modo bastante pragmático identificar a presença de multicolinearidade em pouco contribui no sentido de saber se isso representa um problema ou não para o modelo. É preciso aquilatar a magnitude da multicolinearidade para saber se ela é severa - caso em que exige tratamento - ou não; surge então o problema de saber qual a medida adequada a ser utilizada (Gujarati, 2000).

\section{O QUE A MULTICOLINEARIDADE CAUSA}

Mas afinal o que ocorre se houver multicolinearidade severa? Primeiramente conforme observado por Ferrar e Glauber (1967) em um artigo seminal sobre o assunto, se o conjunto de variáveis independentes for totalmente interdependente os coeficientes da regressão não poderão ser estimados uma vez que a matriz resultante da multiplicação da matriz transposta das variáveis independentes pela matriz das variáveis independentes será singular e não será possível a inversão 


\section{Administração: caminhos para o desenvolvimento sustentável}

dessa matriz necessária para cálculo dos coeficientes da regressão, ou seja, não existe $(X T X)-1$. Nesse caso a multicolinearidade é, obviamente, severa e o modelo deve ser revisto.

O problema é mais sutil quando a matriz $X T X$ não é singular. Nesse caso os coeficientes serão estimados normalmente. Uma vez que a multicolinearidade implica que as variáveis preditoras estão linearmente relacionadas, o problema usualmente implica em alta correlação entre as variáveis preditoras, mas nem sempre isso ocorre (Tamhane \& Dunlop, 2000).

A presença de multicolinearidade severa faz com que os coeficientes não reflitam nenhum efeito particular da variável explicativa na regressora, pois o coeficiente estará contaminado pelo efeito de outras variáveis e apenas um efeito parcial lhe poderá ser atribuído. Em outros termos isso equivale a dizer que os coeficientes terão valores que vão depender da existência ou não de outras variáveis explicativas no modelo. Além disso, a variabilidade amostral dos coeficientes é grande gerandes mudanças na magnitude de $\hat{\beta}_{j}$ por conta de pequenas alterações nos dados, $s^{2}\left\{\hat{\beta}_{j}\right\}$ terá valores elevados e crescerá na medida em que novos preditores forem incluídos (Kutner et al., 2004; Tamhane \& Dunlop, 2000).

Quanto à soma dos quadrados da regressão (SSR), como a informação de um coeficiente já está contida em outro, a redução por conta da adição da variável explicativa é modesto e, como no caso dos coeficientes, seu valor vai depender de quais outras variáveis estão no modelo não podendo ser atribuído a nenhuma delas em particular. Em casos especiais, em que as variáveis preditoras estão correlacionadas entre si, mas uma delas não tem correlação com a variável dependente; pode até ocorrer aumento na SSR (Kutner et al., 2004). Os coeficientes de determinação parcial também serão afetados uma vez que a SSR é utilizada em seu cálculo.

Pode ocorrer também de haver uma relação de regressão - estatística $\mathrm{F}$ da regressão apontando que pelo menos um $\hat{\beta}_{j}$ é diferente de zero - e ainda assim os coeficientes não serem estatisticamente significantes (Kutner et al., 2004; Tamhane \& Dunlop, 2000).

Por outro lado, se o objetivo for tão somente prever a variável dependente o problema da multicolinearidade é menos relevante haja vista sua presença, em geral, não impedir que um ajuste seja obtido e tampouco afetar as inferências sobre novas observações ou sobre a resposta média da variável dependente. Mais tecnicamente, o MSE é reduzido na medida em que novas variáveis explicativas são adicionadas e a $s^{2}\left\{\hat{Y}_{h}\right\}$ é reduzida (Kutner et al., 2004). 


\section{Administração: caminhos para o desenvolvimento sustentável}

\section{UM COMENTÁRIO ADICIONAL A RESPEITO DOS COEFICIENTES $\left(\hat{\beta}_{j}\right)$}

É muito comum em se tratando de regressão múltipla o desejo de interpretar ocoeficiente $\hat{\beta}_{j}$ observando diretamente seu valor e atribuindo maior magnitude de seu efeito sobre a variável dependente em função disso. Cabe frisar em primeiro lugar que as magnitudes das estimativas de ${ }^{\beta_{j}}$ não podem ser comparadas diretamente, uma vez que guardam relação com as unidades das variáveis preditoras. É importante ter em mente que a unidade de $\hat{\beta}_{j}$ é dada pela divisão da unidade de y pela unidade de ${ }^{x_{j}}$, como as variáveis preditoras não costumam ter a mesma unidade de medida a comparação direta é incoerente. A solução consiste em padronizar as variáveis antes da regressão, o que permite que os coeficientes obtidos sejam comparados entre si (Tamhane \& Dunlop, 2000).

Outro deslize usual diz respeito ao exame da estatística a seguir:

$$
t^{*}=\frac{\hat{\beta}_{j}}{s\left\{\hat{\beta}_{j}\right\}}
$$

para decidir se $\hat{\beta}_{j}$ é igual a zero para um k qualquer. Nesse caso, conforme observam Kutner et al. (2004), o nível de significância deve ser controlado no nível global da regressão, isto é levando em conta o número de variáveis preditoras. Porém, mesmo com um procedimento de inferência simultânea, há problemas quando as variáveis dependentes estão fortemente correlacionadas, uma vez que cada teste $t^{*}$ é um teste de significância marginal (Kutner et al., 2004).

\section{DIAGNOSTICANDO A MULTICOLINEARIDADE}

Há alguns indicadores da presença de multicolinearidade que são calculados pela maioria dos softwares que fazem regressão múltipla. Um indicador da provável presença de multicolinearidade ocorre quando como um conjunto as variáveis preditoras são significantes, ao passo que individualmente não (Newbold, 1994). Isso reflete o caso em que a estatística F da regressão é altamente significante, mas o valor da estatística $t^{*}$ não aponta algum ${ }^{\hat{\beta}_{j}}$ significante. Isso ocorre porque $\mathrm{F}$ mede a relação de regressão do conjunto de preditores contra a variável dependente, ao passo que $t^{*}$ mede a contribuição de uma única variável explicativa (McClave \& Sincich, 2000). Somese a isso um $\mathrm{R}^{2}$ alto e a sintomatologia está completa (Gujarati, 2000). 


\section{Administração: caminhos para o desenvolvimento sustentável}

Outro indicador é a matriz de correlação de ordem zero das variáveis explicativas, embora deva ser enfatizado que alta correlação simples entre as variáveis é condição suficiente, mas não necessária para que exista multicolinearidade, portanto sua presença não é indício infalível de multicolinearidade salvo no caso de apenas duas variáveis preditoras (Fonseca, 2003; Gujarati, 2000). O exame das correlações parciais pode também ser útil (Gujarati, 2000).

Ainda de acordo com Gujarati (2000) como a multicolinearidade se manifesta em função dos vetores das variáveis explicativas serem linearmente dependentes, um meio de descobrir qual variável $x$ se relaciona com outras é regredir $X_{k}$ sobre as demais e calcular o $R^{2}$ para cada regressão. Calcular a seguinte estatística $\mathrm{F}$, onde $\mathrm{N}$ é o tamanho da amostra e $\mathrm{k}$ o número de variáveis explicativas incluindo o intercepto:

$$
F=\frac{\frac{R_{x_{1} x_{2} \ldots x_{k}}^{2}}{(k-2)}}{\frac{\left(1-R_{x_{1} x_{2} \ldots x_{k}}^{2}\right)}{(n-k+1)}}
$$

Se o $\mathrm{F}$ calculado é significante há multicolinearidade. Porém se a multicolinearidade envolver associações lineares complexas esse processo de identificação pode ser infrutífero. Há ainda uma regra prática que estabelece que o $\mathrm{R}^{2}$ obtido na regressão auxiliar só é preocupante se for maior que o $\mathrm{R}^{2}$ global, isso evita o teste de cada regressão auxiliar.

Outra abordagem para diagnosticar e medir a multicolinearidade é através da análise dos autovalores (eigenvalues) e de seu derivado índice de condição (IC). Autovalores muito próximos de zero podem indicar multicolinearidade. O índice de condição é dado por:

$$
I C=\sqrt{\frac{A_{\mathrm{Max}}}{A_{\mathrm{Min}}}}
$$

Onde $A_{\text {Max }}$ é o valor do maior autovalor e Min A é o valor do menor autovalor. Entre 10 e 30 há multicolinearidade moderada, valores acima de 30 implicam multicolinearidade severa (Gujarati, 2000). 


\section{Administração: caminhos para o desenvolvimento sustentável}

O fator de inflação da variância (VIF) também é utilizado para medir a multicolinearidade, tal fator é calculado conforme demonstrado no quadro 1.

Quadro 1 - Como é calculado o VIF

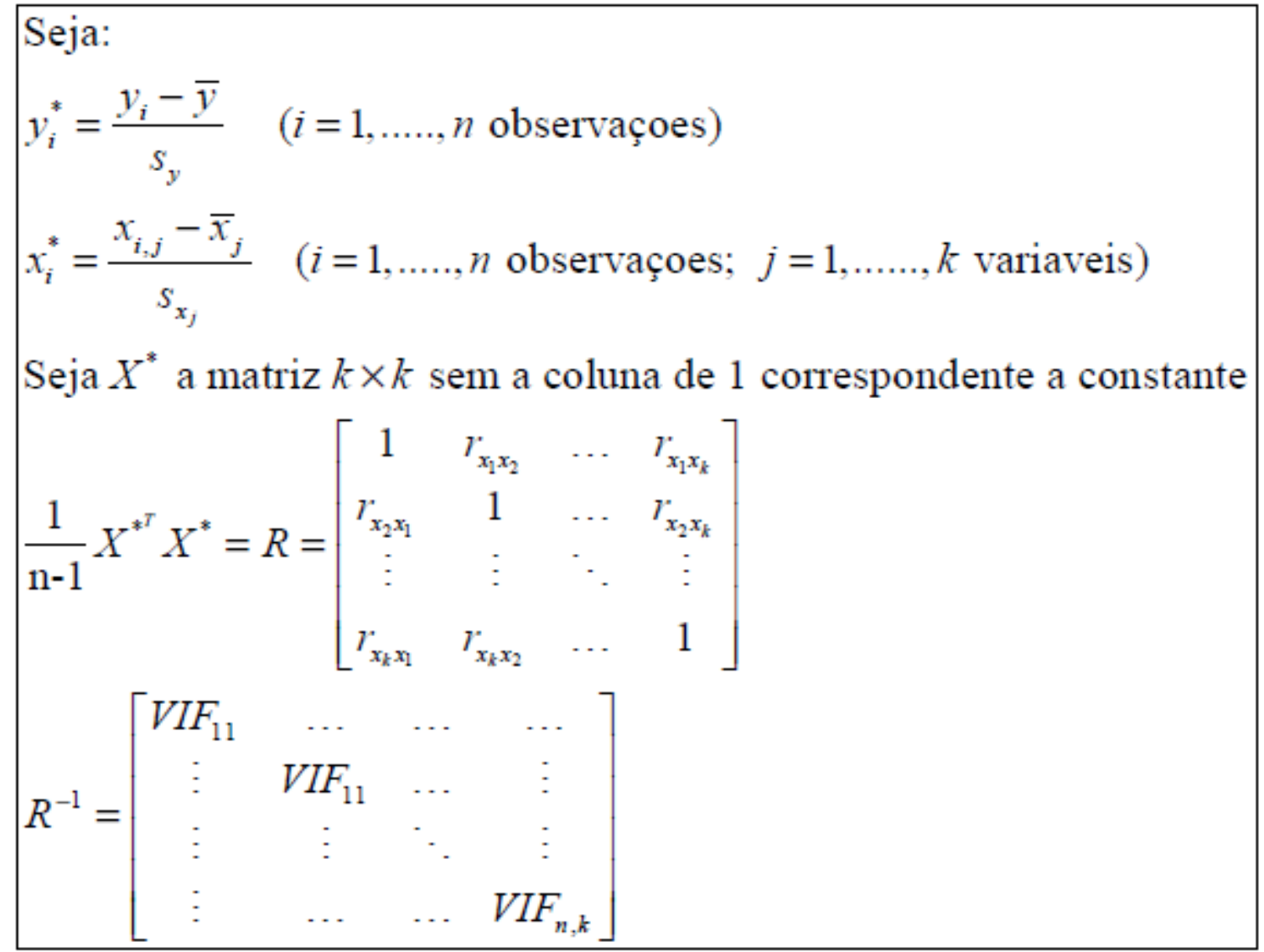

Pode ser demonstrado que o VIF é igual a:

$$
V I F_{j}=\frac{1}{1-r_{j}^{2}} \quad(j=1,2 \ldots \ldots k)
$$

Quando as variáveis estão linearmente relacionadas o coeficiente de determinação múltipla ${ }^{r_{j}^{2}}$ será próximo de 1,0 e o VIF será alto; esse coeficiente de determinação é obtido quando se faz a regressão de $X_{j}$ sobre as variáveis k-1 remanescentes. Quanto maior o VIF maior a variância do $\hat{\beta}_{j}$, valores maiores que 10 correspondem a um coeficiente de determinação múltipla 2 0,90 j r > e são considerados inaceitáveis. (Kutner et al., 2004; Tamhane \& Dunlop, 2000).

Finalmente Ferrar e Glauber (1967) indicam um índice, aqui chamado de FG, que, segundo os autores, gera uma medida objetiva para a multicolinearidade. A fórmula de Ferrar e Glauber é a seguinte: 


\section{Administração: caminhos para o desenvolvimento sustentável}

$$
F G=-\left[N-1-\frac{1}{6}(2 n+5)\right] \ln |R|
$$

Nessa fórmula $N$ é o tamanho da amostra, $n$ é o número de variáveis e ln $\mid R /$ é o logaritmo natural do determinante da matriz $\mathrm{R}$ que aparece no quadro 1. Essa estatística tem distribuição aproximadamente qui-quadrado com $v=1 / 2 n(n-1)$ graus de liberdade. Como a distribuição $\mathrm{X}^{2}$ segue uma escala conhecida essa seria uma estatística das mais úteis para detectar e quantificar de modo realmente objetivo a multicolinearidade; estranhamente até onde foi possível constatar nenhum pacote estatístico trás em seu bojo essa estatística. No exemplo apresentado na próxima seção ela será calculada.

\section{UM EXEMPLO ILUSTRATIVO}

O problema a seguir visa ilustrar os aspectos tratados nas seções anteriores, além de alguns outros ainda não contemplados e não necessariamente relacionados a multicolinearidade, mas usuais na análise de regressão. Os dados para análise foram obtidos de McClave \& Sincich (2000), a amostra original continha 129 dados, foram eliminados 16 deles por falta de alguma variável explicativa ou por possuírem algum valor padronizado superior a 2,5, portanto, a análise inicial parte de uma base com 113 informações a respeito de carros de marcas e modelos variados. As variáveis que entrarão inicialmente no modelo são as seguintes: $y=$ Preço; $1 x=$ Aceleração em segundos de 0-60 milhas por hora; $X_{2}=$ Aceleração em segundos para percorrer $1 / 4$ de milha; $X_{3}=$ Velocidade máxima em milhas por hora; $X_{4}=$ Distância de frenagem em pés a 70 milhas por hora; $X_{5}=$ Consumo em milhas por galão; $X_{6}$ = Aderência em g's durante a curva. A idéia inicial é optar por um modelo de primeira ordem linear nos parâmetros no seguinte formato:

$$
y=\beta_{0}+\beta_{1} x_{1}+\beta_{2} x_{2}+\beta_{3} x_{3}+\beta_{4} x_{4}+\beta_{5} x_{5}+\beta_{6} x_{6} \quad \text { (VII) }
$$

Os dados que serviram de base para a análise estão disponíveis no anexo 1. Sempre que se inicia a análise de um conjunto de dados é recomendável explorá-los através de algumas estatísticas descritivas a tabela 1 apresenta algumas dessas estatísticas. 


\section{Administração: caminhos para o desenvolvimento sustentável}

Tabela 1 - Estatísticas Descritivas

\begin{tabular}{|c|c|c|c|c|c|c|c|c|}
\hline & & $y$ & $\mathrm{x}_{1}$ & $x_{2}$ & $\mathrm{x}_{3}$ & $\mathrm{x}_{4}$ & $x_{5}$ & $x_{6}$ \\
\hline \multirow[t]{2}{*}{$\bar{N}$} & Valid & 113 & 113 & 113 & 113 & 113 & 113 & 113 \\
\hline & Missing & 362 & 362 & 362 & 362 & 362 & 362 & 362 \\
\hline \multicolumn{2}{|c|}{ Mean } & 33695,86 & 8,02 & 16,148 & 126,78 & 184,65 & 18,89 & ,7951 \\
\hline \multicolumn{2}{|c|}{ Std. Deviation } & 18021,771 & 1,679 & 1,2636 & 17,263 & 12,258 & 3,363 &, 06239 \\
\hline \multicolumn{2}{|c|}{ Skewness } & 1,606 &,- 050 &,- 451 &, 517 &, 222 & 474 & 200 \\
\hline \multicolumn{2}{|c|}{ Std. Error of Skewness } & ,227 & ,227 & ,227 & ,227 & ,227 & ,227 &, 227 \\
\hline \multicolumn{2}{|c|}{ Kurtosis } & 2,752 &,- 443 &,- 143 &,- 697 &,- 266 &, 254 & 231 \\
\hline \multicolumn{2}{|c|}{ Std. Error of Kurtosis } & 451 & 451 & 451 & 451 & 451 & 451 & 451 \\
\hline
\end{tabular}

Um Scatter Plot desses dados já padronizados está na figura 1, é clara a forte associação entre $x 1$ e $x 2$.

Figura 1 - Box Plot das variáveis explicativas.

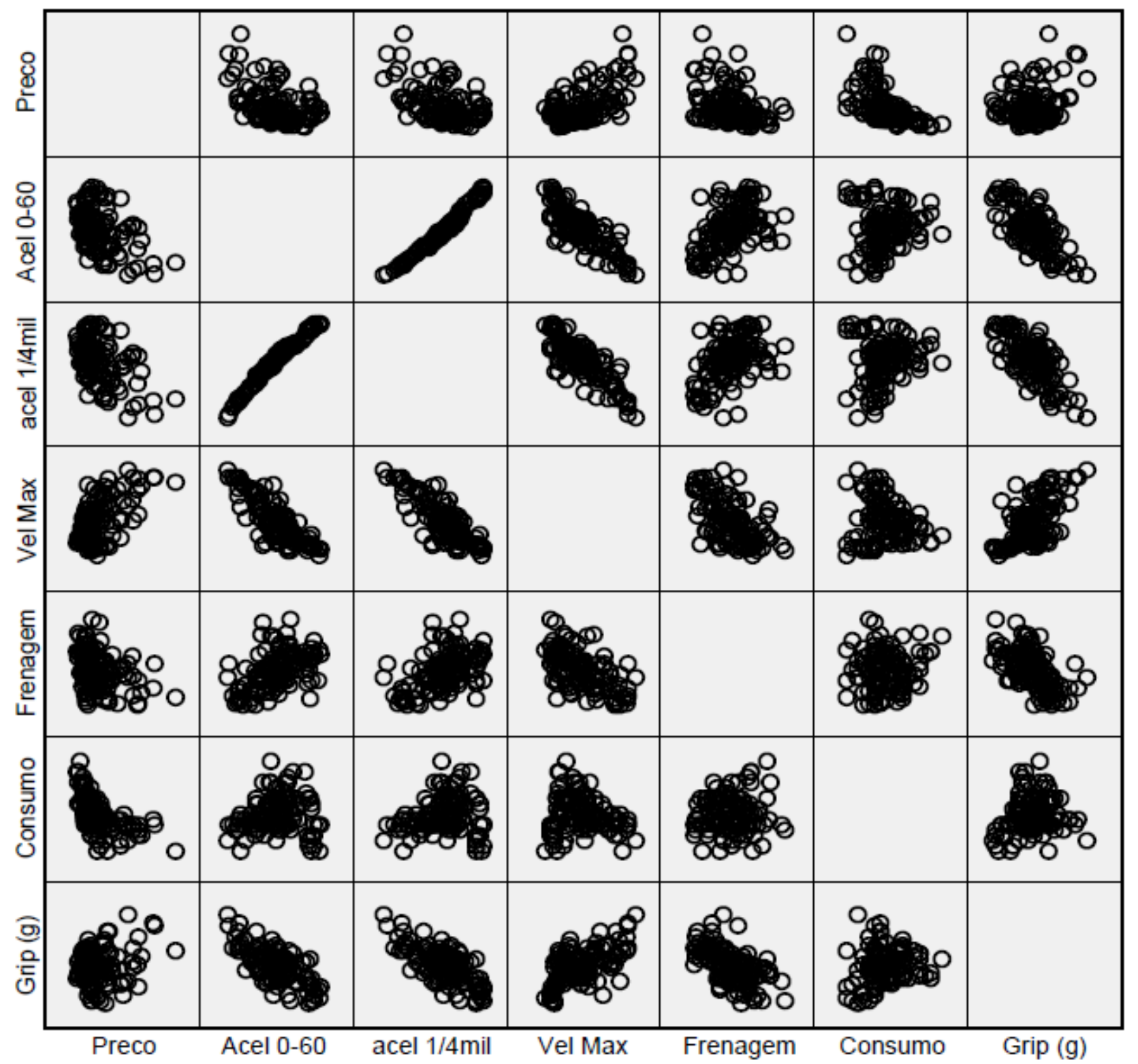




\section{Administração: caminhos para o desenvolvimento sustentável}

Em seguida, com os dados padronizados, uma primeira regressão incluindo todas as variáveis e dados disponíveis foi realizada e os resultados são apresentados abaixo:

\section{Tabela 2 - Regressão com MINITAB}

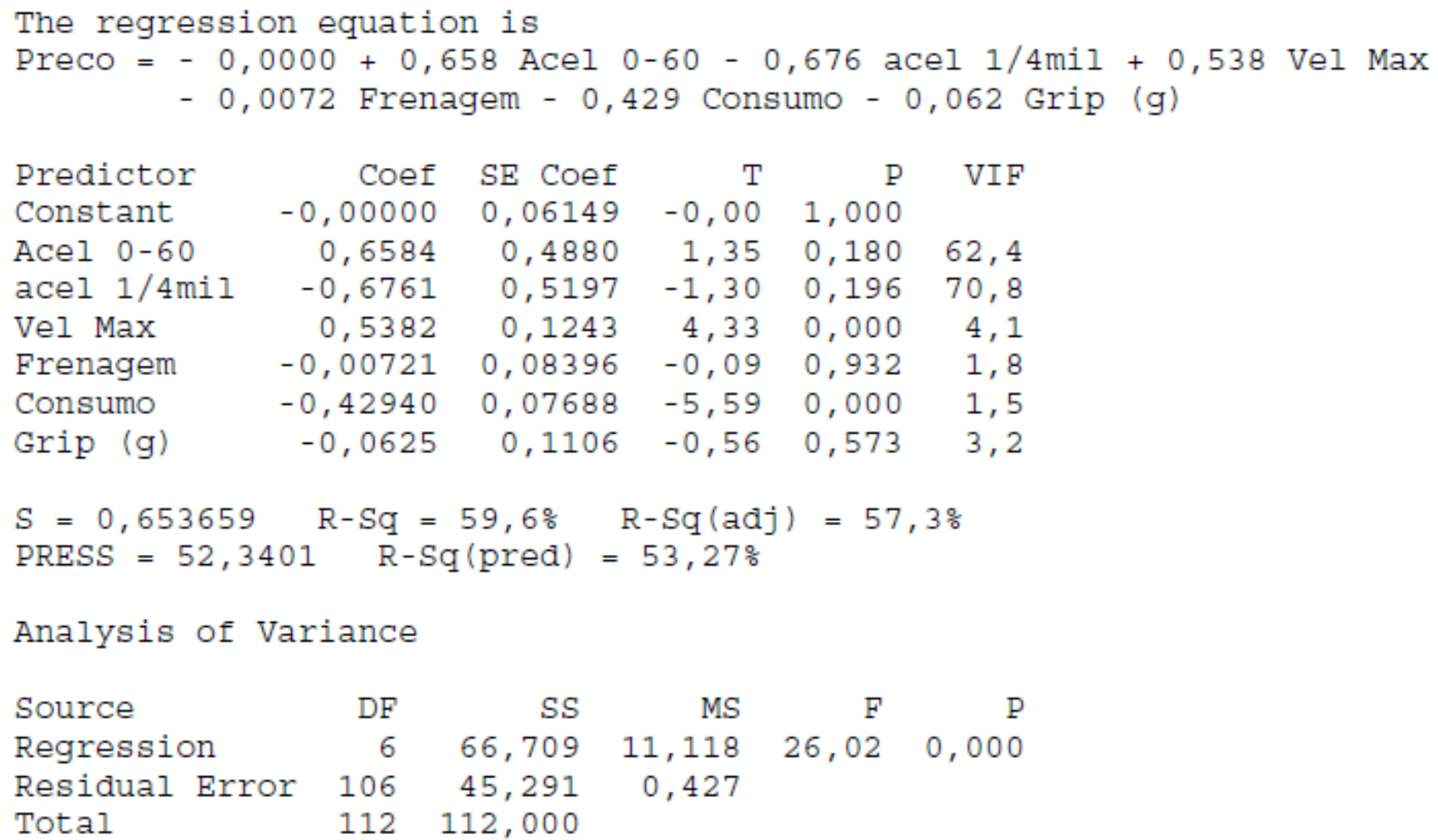

Aqui a atenção deve se voltar primeiramente para o fato de haver uma relação de regressão entre as variáveis, a estatística $\mathrm{F}$ na análise da variância é significante, porém nem todas as variáveis no modelo são relevantes conforme denota o valor $\mathrm{p}$ do teste $\mathrm{t}$ para os. ${ }^{\hat{\beta}_{j}}$ O fator de inflação da variância VIF confirma claramente que as variáveis x 1 e x2 apresentam colinearidade o valor da tolerância calculado pelo SPSS aponta no mesmo sentido com valores de 0,016 e 0,014 respectivamente para $\times 1$ e $\times 2$. A estatística de Ferrar e Glauber (FG) foi calculada conforme demonstrado no quadro 2. 


\section{Administração: caminhos para o desenvolvimento sustentável}

Quadro 2 - Estatística de Ferrar e Glauber

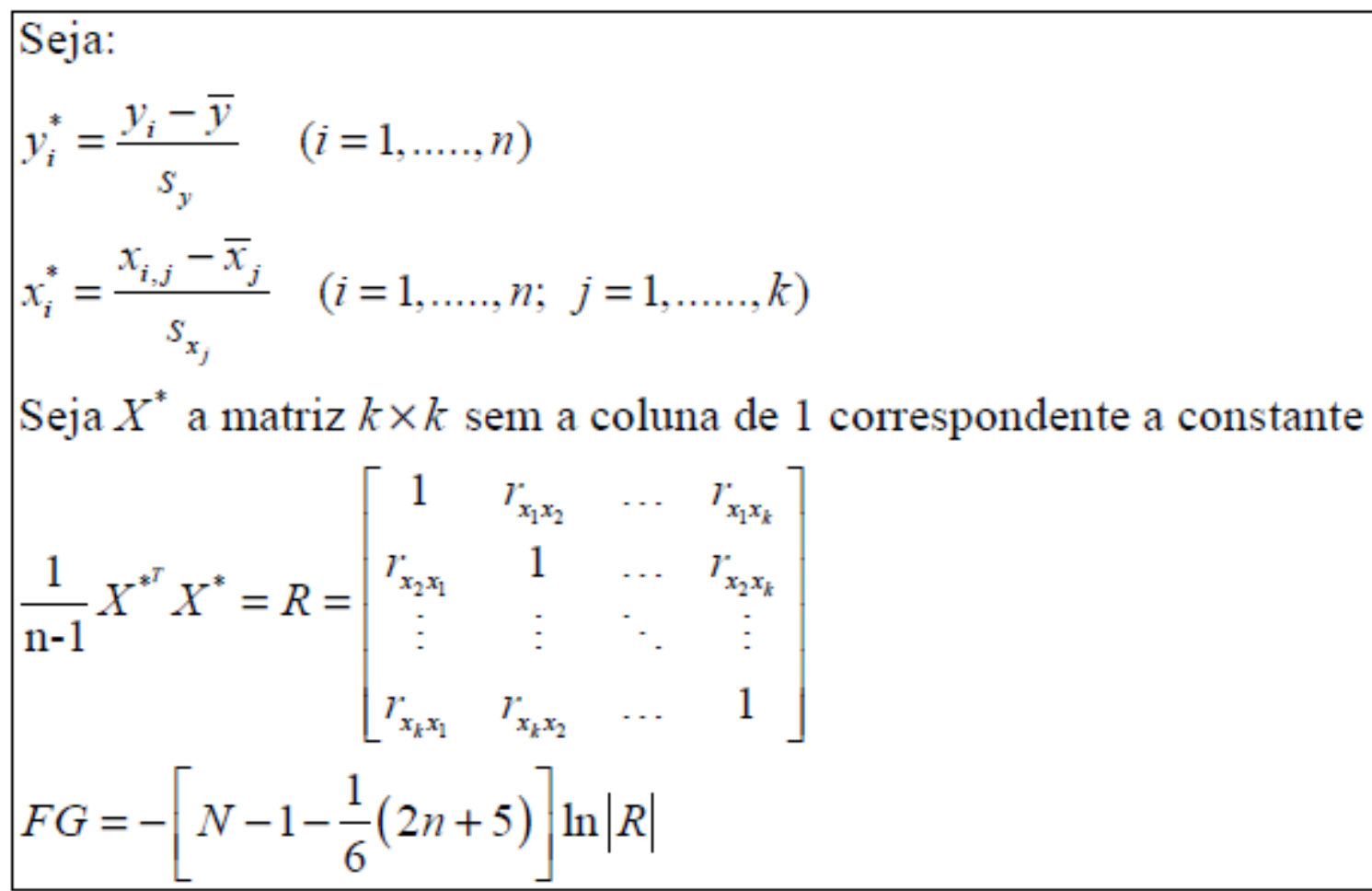

Essa estatística produziu um valor de 758 contra um valor crítico de 12,6 também indicando forte presença de multicolinearidade.

Por outro lado, as variáveis velocidade máxima e consumo são as únicas que produziram estimativas significantes. O passo seguinte foi realizar uma regressão utilizando o algoritmo best subsets do MINITAB que produziu a saída da tabela 3 . O resultado indica que $58 \%$ da variância da variável dependente na amostra é explicada pelas variáveis $3 \mathrm{x}=$ Velocidade máxima em milhas por hora e $5 \mathrm{x}$ = Consumo em milhas por galão. A tabela apresenta também o CP de Mallows igual a 1,0 o que implica um erro quadrático médio total pequeno. 


\section{Administração: caminhos para o desenvolvimento sustentável}

Tabela 3 - Regressão usando o algoritmo "best subsets" do MINITAB

\begin{tabular}{|c|c|c|c|c|c|c|c|c|c|}
\hline & & & 110ws & & & & $\mathrm{x}$ & & \\
\hline Vars & $\mathrm{R}-\mathrm{Sq}$ & $R-S q(a d j)$ & $C-p$ & S & 1 & 2 & 3 & 45 & 56 \\
\hline 1 & 36,3 & 35,7 & 58,0 & 0,80177 & & & $\mathrm{X}$ & & \\
\hline 1 & 32,9 & 32,3 & 66,9 & 0,82290 & & & & & $\mathrm{X}$ \\
\hline 1 & 24,9 & 24,2 & 87,9 & 0,87052 & & $\mathrm{X}$ & & & \\
\hline 1 & 20,9 & 20,2 & 98,2 & 0,89315 & $\mathrm{X}$ & & & & \\
\hline 1 & 11,7 & 10,9 & 122,6 & 0,94415 & & & & $\mathrm{X}$ & \\
\hline 2 & 58,8 & 58,0 & 1,0 & 0,64774 & & & $\mathrm{X}$ & & $\mathrm{X}$ \\
\hline 2 & 50,4 & 49,5 & 23,1 & 0,71093 & & $\mathrm{X}$ & & & $\mathrm{X}$ \\
\hline 2 & 49,2 & 48,3 & 26,2 & 0,71925 & $\mathrm{X}$ & & & & $\mathrm{X}$ \\
\hline 2 & 43,2 & 42,2 & 41,8 & 0,76022 & & & & & $\mathrm{X} X$ \\
\hline 2 & 41,2 & 40,1 & 47,2 & 0,77393 & & & & X $Y$ & $\mathrm{X}$ \\
\hline 3 & 58,9 & 57,8 & 2,7 & 0,64988 & $\mathrm{X}$ & & $\mathrm{X}$ & & $\mathrm{X}$ \\
\hline 3 & 58,9 & 57,7 & 2,8 & 0,65012 & & & $\mathrm{X}$ & & $\mathrm{X} X$ \\
\hline 3 & 58,8 & 57,7 & 3,0 & 0,65053 & & $\mathrm{X}$ & $\mathrm{X}$ & & $\mathrm{X}$ \\
\hline 3 & 58,8 & 57,7 & 3,0 & 0,65066 & & & $\mathrm{X}$ & X & $\mathrm{X}$ \\
\hline 3 & 51,4 & 50,1 & 22,4 & 0,70669 & & $\mathrm{X}$ & & X $Y$ & $\mathrm{X}$ \\
\hline 4 & 59,4 & 57,9 & 3,3 & 0,64864 & $\mathrm{X}$ & $\mathrm{X}$ & $\mathrm{X}$ & & $\mathrm{X}$ \\
\hline
\end{tabular}

Com base nessas novas informações uma nova regressão agora incluindo apenas a velocidade máxima e o consumo foi conduzida e as estatísticas recalculadas. Os resultados da regressão aparecem na tabela 4.

A estatística de Ferrar e Glauber para esses dados resultou em um valor calculado de 3,52 contra um valor crítico de 5,99; o valor da estatística de tolerância calculada no SPSS foi de 0,969. Com essas duas variáveis no modelo os números da regressão melhoraram substancialmente e foi eliminado o problema da multicolinearidade. 


\section{Administração: caminhos para o desenvolvimento sustentável}

Tabela 4 - Regressão com $X_{3}$ e $X_{5}$ resultado do MINITAB.

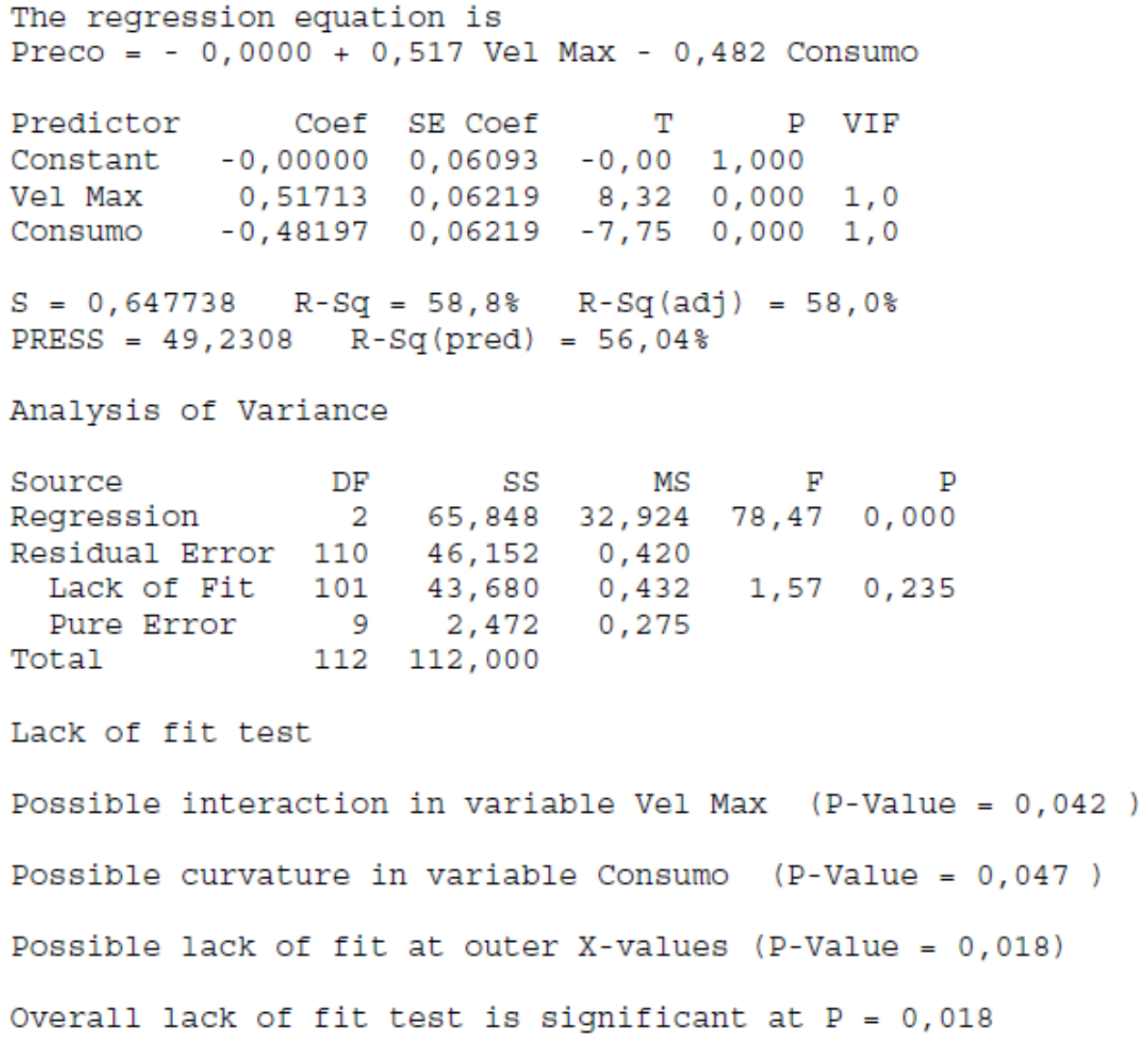

Porém a natureza das coisas é tal que basta resolver um problema para nos deparamos com outro, os resultados parecem indicar uma relação não linear e interação em certas variáveis. As figuras 2 e 3 a seguir mostram scatter plot do preço contra a velocidade máxima e consumo respectivamente.

Figura 2 - Scatter plot preço versus velocidade máxima

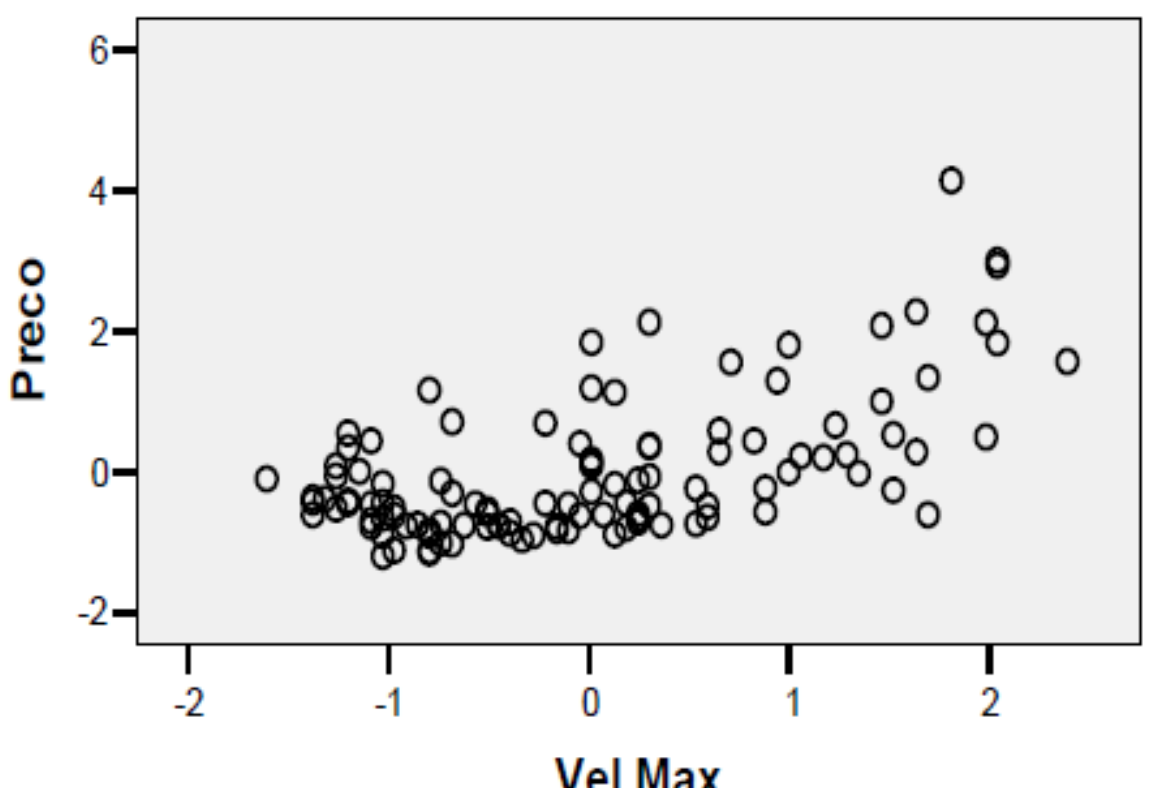




\section{Administração: caminhos para o desenvolvimento sustentável}

Figura 3 - Scatter plot preço versus consumo

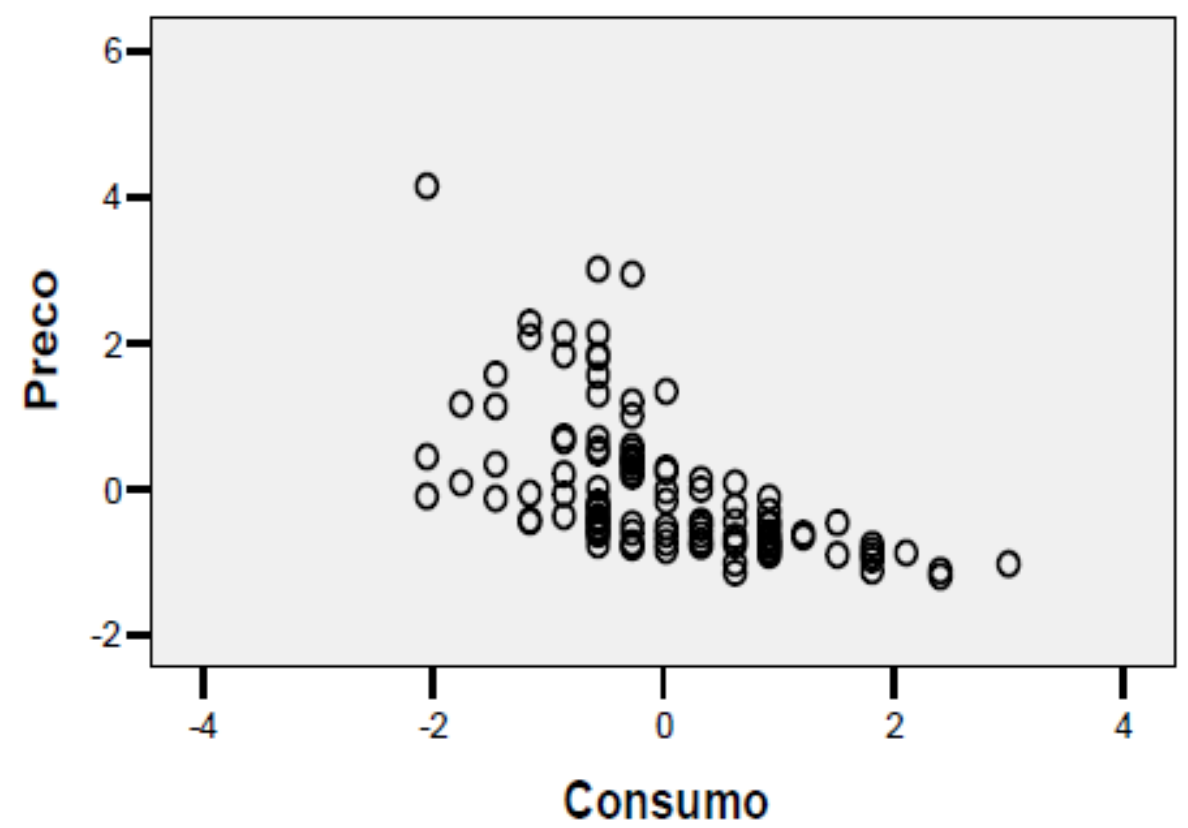

Com base nas figuras 2 e 3 e na informação da regressão anterior foram criadas as seguintes variáveis transformadas assim definidas $y^{\prime}=$ ey $=$ Exponencial do preço; $x_{7}=e_{x 3}=$ Velocidade máxima em milhas por hora; $\mathrm{X}_{8}=\mathrm{X}_{3}=$ Exponencial do consumo em milhas por galão; $x_{9}=e^{x_{3}} e^{x_{5}}=$ : Produto das variáveis $e^{x_{3}}$ e $e^{x_{5}} ; x_{10}=x_{3} x_{5}=$ Produto da velocidade pelo consumo; $x_{9}=e^{x_{3}} e^{x_{5}}=$ Produto das variáveis $e^{x_{3}} \mathrm{e} e^{x_{5}} ; x_{10}=x_{2} x_{5}=$ Produto da velocidade pelo consumo; $x_{11}=x_{3}^{2}={ }_{\text {Quadrado da velocidade; }} x_{12}=x_{5}^{2}={ }_{\text {Quadrado do consumo; }} x_{13}=x_{3}^{2} x_{5}^{2}=$ Produto do quadrado da velocidade pelo quadrado do consumo. Com essas variáveis explicativas e todas as anteriores foi conduzida uma regressão usando o algoritmo best subset do MINITAB alguns resultados parciais aparecem na tabela 5. 


\section{Administração: caminhos para o desenvolvimento sustentável}

Tabela 5 - Resultado parcial da egressão usando o algoritmo "best subsets" do MINITAB Response is Preco

\begin{tabular}{|c|c|c|c|c|c|c|c|c|c|c|c|c|c|c|c|}
\hline & & & OWS & & & & & & & $x$ & $x$ & & & & \\
\hline Vars & R-Sq & $R-S q(a d j)$ & $C-p$ & S & 12 & 34 & \pm 5 & 6 & 7 & 8 & 9 & 10 & 111 & 12 & 13 \\
\hline 4 & 65,6 & 64,3 & 1,6 & 0,59761 & & & & & $\mathrm{X}$ & $\mathrm{X}$ & & $\mathrm{X}$ & & & $\mathrm{X}$ \\
\hline 4 & 64,9 & 63,6 & 3,7 & 0,60362 & & $\mathrm{X}$ & $\mathrm{X}$ & & & $\mathrm{X}$ & & $\mathrm{X}$ & & & \\
\hline 4 & 64,8 & 63,5 & 4,0 & 0,60445 & & $\mathrm{X}$ & $\mathrm{X}$ & & & & & $\mathrm{X}$ & & $\mathrm{X}$ & \\
\hline 4 & 64,3 & 63,0 & 5,4 & 0,60836 & & $\mathrm{X}$ & & & & & $\mathrm{X}$ & & & & \\
\hline 4 & 64,2 & 62,9 & 5,8 & 0,60946 & & $\mathrm{X}$ & & & & $\mathrm{X}$ & & $\mathrm{X}$ & & & \\
\hline 5 & 66,3 & 64,8 & 1,2 & 0,59364 & & & & & $\mathrm{X}$ & $\mathrm{X}$ & & $\mathrm{X}$ & & & \\
\hline 5 & 65,9 & 64,3 & 2,6 & 0,59752 & & $\mathrm{X}$ & & & $\mathrm{X}$ & $\mathrm{X}$ & & $\mathrm{X}$ & & & $\mathrm{X}$ \\
\hline 5 & 65,8 & 64,2 & 2,9 & 0,59830 & & & & & $\mathrm{X}$ & $\mathrm{X}$ & $\mathrm{X}$ & $\mathrm{X}$ & & & $\mathrm{X}$ \\
\hline 5 & 65,8 & 64,2 & 3,0 & 0,59857 & & $\mathrm{X}$ & & & & $\mathrm{X}$ & & $\mathrm{X}$ & $\mathrm{X}$ & & \\
\hline 5 & 65,8 & 64,2 & 3,0 & 0,59864 & & & & & $\mathrm{x}$ & $\mathrm{X}$ & & $\mathrm{X}$ & $\mathrm{X}$ & & \\
\hline 6 & 66,8 & 64,9 & 1,8 & 0,59229 & & $\mathrm{X}$ & & $\mathrm{X}$ & $\mathrm{X}$ & $\mathrm{X}$ & & $\mathrm{X}$ & & & \\
\hline 6 & 66,7 & 64,9 & 2,0 & 0,59275 & & & & $\mathrm{X}$ & $\mathrm{X}$ & $\mathrm{X}$ & & $\mathrm{X}$ & $\mathrm{X}$ & & \\
\hline 6 & 66,6 & 64,8 & 2,3 & 0,59367 & & & & $\mathrm{X}$ & $\mathrm{X}$ & $\mathrm{X}$ & $\mathrm{X}$ & $\mathrm{X}$ & & & \\
\hline 6 & 66,5 & 64,6 & 2,9 & 0,59533 & & $\mathrm{X}$ & & $\mathrm{X}$ & & $\mathrm{X}$ & & $\mathrm{X}$ & $\mathrm{X}$ & & \\
\hline 6 & 66,4 & 64,5 & 2,9 & 0,59552 & & & & $\mathrm{X}$ & $\mathrm{X}$ & $\mathrm{X}$ & & $\mathrm{X}$ & & $\mathrm{X}$ & \\
\hline
\end{tabular}

Os demais resultados apresentavam resultados superiores a 2,0 para o CP de Mallows e não foram reportados por essa razão. Foram testados os três modelos destacados na tabela 5 e o melhor ajuste foi obtido com a regressão com CP de Mallows de 1,6 cuja saída do MINITAB é apresentada na tabela 6. Esse modelo parece ser o melhor por combinar as seguintes características: (1) Estatística F com valor 51,40 a maior dos três modelos, (2) todos os valores $\mathrm{p}$ das estimativas de $\hat{\beta}_{k}$ altamente significantes; (3) Valor do $R_{\text {ajustado }}^{2} 0,643$ apenas 0,006 inferior ao valor máximo obtido em outras regressões,(4) não há indicação de lack of fit $(p>0,10)$, (5) com intervalo de confiança de 95\%, nenhum dos $\hat{\beta}_{j}$ tem valor nulo, (6) o $\mathrm{Cp}$ de Mallows é de apenas 1,6 implicando um erro quadrático médio pequeno e um modelo parcimonioso, (7) índice de condição com valor máximo de 5,814, (8) índice de inflação da variância com valor máximo de 3,2, (9) tolerância com valor mínimo de 0,31, e (10) correlações zero order e parciais aceitáveis entre os regressores.

O único indicador que parece apresentar valores preocupantes é a estatística de Ferrar e Glauber que retornou um valor FG de 172,12 contra um valor crítico de 9,49 apontando que ainda existe multicolinearidade. Tal resultado para essa estatística parece contra intuitivo em função de todas as características positivas e mais especificamente dos valores aceitáveis dos demais indicadores da presença e intensidade da multicolinearidade. 


\section{Administração: caminhos para o desenvolvimento sustentável}

Tabela 6 - Resultado da regressão do modelo final.

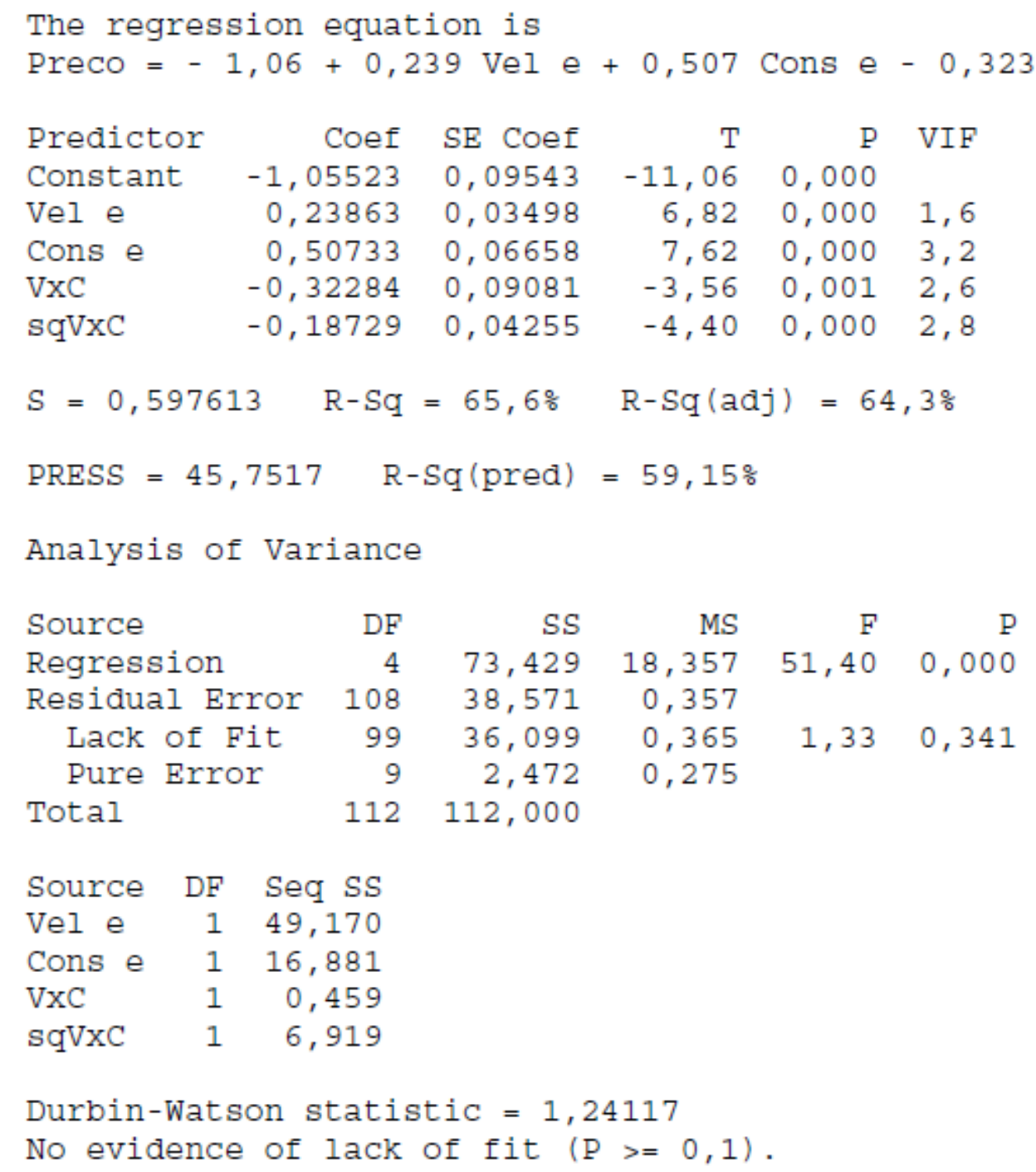

$\begin{array}{lrrrrr}\text { Source } & \text { DF } & \text { SS } & \text { MS } & \text { F } & \text { P } \\ \text { Regression } & 4 & 73,429 & 18,357 & 51,40 & 0,000 \\ \text { Residual Error } & 108 & 38,571 & 0,357 & & \\ \quad \text { Lack of Fit } & 99 & 36,099 & 0,365 & 1,33 & 0,341 \\ \quad \text { Pure Error } & 9 & 2,472 & 0,275 & & \\ \text { Total } & 112 & 112,000 & & & \end{array}$

$\begin{array}{lrr}\text { Source } & \text { DF } & \text { Seq SS } \\ \text { Vel e } & 1 & 49,170 \\ \text { Cons e } & 1 & 16,881 \\ \text { VxC } & 1 & 0,459 \\ \text { sqVxC } & 1 & 6,919\end{array}$

Durbin-Watson statistic $=1,24117$

No evidence of lack of fit $(P>=0,1)$.

Tais resultados levam a duas possibilidades (1) o teste de Ferrar e Glauber não é eficaz. Gujarati (2000) chama a atenção para essa possibilidade ao mencionar três estudos ${ }^{1}$ que lançam dúvidas sobre a capacidade do teste; (2) o teste de Ferrar e Glauber é eficiente e todos os demais indicadores obtidos estão viesados e as respectivas regras de bolso são falaciosas. Tal resultado seria pelo menos surpreendente e colocaria em cheque um bom número de contribuições científicas em diversas áreas do conhecimento que tenham utilizado esses indicadores.

O modelo final considerando as variáveis iniciais na forma normalizada é o da equação II que aparece a seguir:

$$
y=\beta_{0}+\beta_{1} \exp x_{3}+\beta_{2} \exp x_{5}+\beta_{3} x_{3} x_{5}+\beta_{4}\left(x_{3} x_{5}\right)^{2}
$$




\section{Administração: caminhos para o desenvolvimento sustentável}

O modelo obtido é de primeira ordem linear nos parâmetros. O modelo poderia ainda ser melhorado uma vez que há leve heteroscedasticidade remanescente.

\section{REFERÊNCIAS BIBLIOGRÁFICAS}

FERRAR D. E. \& GLAUBER, R. R. Multicollinearity in regression Analysis - the problem revisited. The Review of Economics and Statistics, v. 49, n. 1, Feb. 1967.

FONSECA, M. A. R. Álgebra linear aplicada a finanças, economia e econometria.Barueri: Manole, 2003.

GUJARATI, D. N. Econometria básica. 3 ed. São Paulo: Makron Books, 2000.

KUTNER, M. H. et al. Applied linear models. 5th ed. New York: McGraw-Hill Irwin,2005.

${ }^{2}$ KUMAR, T. K. Multicollinearity in regression analysis. Review of Economics and Statistics, v. 57, 1975. O'HOGAN, J. \& McCABE, Tests for the severity of multicollinearity in regression Analysis: a comment. Review of Economics and Statistics, v. 57, 1975.

McCLAVE, J. T. \& SINCICH, T. Statistics. Upper Saddle River: Prentice-Hall, 2000.

NEWBOLD, P. Statistics for business and economics. 4 ed. Upper Saddle River:Prentice-Hall, 1994.

TAMHANE, A. C. \& Dunlop D. D. Statistics and Data Analysis - from elementary tointermediate. Upper Saddle River: Prentice-Hall, 2000.

${ }^{1}$ WICHERS, C. R. The detection of multicollinearity: a comment. Review of Economics and Statistics, v.57, 1975. 
DADOS UTILIZADOS NO EXEMPLO. 


\begin{tabular}{|c|c|c|c|c|c|c|c|c|c|c|c|c|c|c|c|c|c|}
\hline $\mathrm{n}$ & Fabricante/Modelo & $\mathrm{y}$ & $\mathrm{x} 1$ & $\mathrm{x} 2$ & $\mathrm{X} 3$ & $\mathrm{X} 4$ & $\mathrm{x} 5$ & $\mathrm{X} 6$ & $\mathrm{n}$ & FAbricante/Modelo & $\mathrm{y}$ & $\mathrm{x} 1$ & $\mathrm{X} 2$ & $\mathrm{X} 3$ & $\mathrm{X} 4$ & $\mathrm{X} 5$ & $\mathrm{x} 6$ \\
\hline 1 & Acura Integra GS-R & 20015 & 7.0 & 15.6 & 133 & 185 & 25 & 0.84 & 64 & Lexus LS400 & 57828 & 7.8 & 15.8 & 156 & 182 & 19 & 0.74 \\
\hline 2 & Acura Integra LS & 18560 & 7.5 & 15.9 & 125 & 189 & 25 & 0.82 & 65 & Lexus SC300 & 44225 & 6.8 & 15.4 & 138 & 178 & 18 & 0.84 \\
\hline 3 & Acura NSX-T & 86642 & 5.2 & 13.8 & 162 & 173 & 18 & 0.95 & 66 & Lincoln Continental & 46152 & 7.6 & 15.7 & 123 & 178 & 17 & 0.78 \\
\hline 4 & AM General Hummer & 71760 & 181 & 21.2 & 83 & 253 & 10 & 0.62 & 67 & Lincoln Town Car & 43627 & 90 & 169 & 106 & 186 & 17 & 0.79 \\
\hline 5 & Audi A6 Quattro & 36802 & 8.3 & 16.5 & 127 & 191 & 18 & 0.79 & 68 & Lingenfelter Firebird 383 & 34958 & 4.1 & 12.6 & 183 & 150 & 15 & 0.95 \\
\hline 6 & Audi Cabriolet & 40960 & 9.7 & 17.2 & 126 & 189 & 18 & 0.73 & 69 & Lotus Esprit S4S & 87904 & 4.4 & 13.0 & 162 & 189 & 17 & 0.94 \\
\hline 7 & BMW M3 & 38782 & 5.3 & 14.0 & 138 & 165 & 19 & 0.88 & 70 & Mazda Miata R Edition & 19905 & 8.2 & 16.4 & 119 & 169 & 22 & 0.86 \\
\hline 8 & BMW 325i & 36015 & 7.7 & 16.0 & 127 & 182 & 20 & 0.82 & 71 & Mazda Millenia S & 33595 & 7.7 & 16.0 & 144 & 189 & 20 & 0.81 \\
\hline 9 & BMW 540i Six-speed & 54044 & 5.7 & 14.3 & 129 & 186 & 14 & 0.78 & 72 & Mazda Protege ES & 17870 & 8.9 & 17.0 & 120 & 195 & 26 & 0.76 \\
\hline 10 & BMW 740i & 66837 & 8.4 & 16.6 & 127 & 181 & 16 & 0.79 & 73 & Mazda RX-7 & 35252 & 5.3 & 14.0 & \begin{tabular}{|l|}
157 \\
\end{tabular} & 156 & 17 & 0.99 \\
\hline 11 & BMW $840 \mathrm{Ci}$ & 74790 & 7.1 & 15.5 & 155 & 170 & 15 & 0.83 & 74 & Mazda 626ES & 24015 & 8.4 & 16.8 & 118 & 189 & 20 & 0.80 \\
\hline 12 & BMW $850 \mathrm{CSi}$ & $1 \mathrm{E}+05$ & 5.3 & 13.9 & 158 & 167 & 12 & 0.85 & 75 & Mercedes-Benz C 36 & 51750 & 6.0 & 14.6 & \begin{tabular}{|l|}
152 \\
\end{tabular} & 163 & 18 & 0.83 \\
\hline 13 & Buick Park Avenue Ultra & 33797 & 7.0 & 15.5 & 107 & 216 & 17 & 0.74 & 76 & Mercedes-Benz C220 & 31500 & 8.8 & 16.9 & 131 & 178 & 22 & 0.80 \\
\hline 14 & Buick Regal Gran Sport & 24305 & 8.3 & 16.5 & 110 & 202 & 19 & 0.79 & 77 & Mercedes-Benz E420 & 55130 & 7.3 & 15.7 & \begin{tabular}{|l|}
127 \\
\end{tabular} & 185 & 18 & 0.73 \\
\hline 15 & Buick Riviera & 30643 & 8.2 & 16.3 & 109 & 199 & 19 & 0.75 & 78 & Mercedes-Benz S320 & 72037 & 8.1 & 16.4 & \begin{tabular}{|l|}
132 \\
\end{tabular} & 178 & 17 & 0.72 \\
\hline 16 & $\begin{array}{l}\text { Cadillac Eldorado } \\
\text { Touring Coupe }\end{array}$ & 45626 & 6.4 & 14.8 & 148 & 184 & 16 & 0.80 & 79 & Mitsubihhi Eclipse GS & 18668 & 8.6 & 16.7 & 124 & 189 & 22 & 0.82 \\
\hline 17 & Cadillac SLS & 46501 & 6.7 & 15.0 & 115 & 195 & 16 & \begin{tabular}{|l|}
0.77 \\
\end{tabular} & 80 & Mitsubishi Galant GS & 21838 & 7.8 & 16.1 & 131 & 207 & 22 & 0.77 \\
\hline 18 & Chevrolet Blazer LT & 26969 & 9.1 & 17.0 & 103 & 218 & 16 & 0.67 & 81 & Mitsubishi Montero SR & 39796 & 10.5 & 17.9 & 106 & 191 & 14 & 0.66 \\
\hline 19 & Chevrolet Camaro & 20509 & 7.7 & 15.9 & 114 & 192 & 19 & 0.83 & 82 & Mitsubishi 3000GT VR4 & 43190 & 5.1 & 13.9 & 153 & 164 & 18 & 0.92 \\
\hline 20 & \begin{tabular}{|l|} 
Cherrolet Camaro \\
Convertible
\end{tabular} & 22484 & 9.3 & 17.0 & 110 & 195 & 19 & 0.84 & 83 & Nissan Maxima SE & 25586 & 7.3 & 15.9 & 123 & 187 & 21 & 0.75 \\
\hline 21 & Cheurolet Camaro Z28 & 22686 & 5.5 & 14.1 & 156 & 162 & 17 & 0.86 & 84 & Nissan Quest GXE & 24219 & 11.2 & 18.3 & 105 & 178 & 17 & 0.71 \\
\hline 22 & \begin{tabular}{|l} 
Cherrolet Cavalier \\
\end{tabular} & 13417 & 8.8 & 16.7 & 113 & 209 & 25 & 0.76 & 85 & Nissan Sentra GXE & 13914 & 8.5 & 16.7 & 109 & 208 & 30 & 0.78 \\
\hline 23 & \begin{tabular}{|l|} 
Cherrolet Corvette \\
\end{tabular} & 42614 & 5.1 & 13.7 & 161 & 166 & 17 & 0.85 & 86 & Nissan 200SX SE-R & 17400 & 8.0 & 16.1 & \begin{tabular}{|l|}
109 \\
\end{tabular} & 182 & 24 & 0.85 \\
\hline 24 & Cherrolet Impala SS & 23355 & 6.5 & 15.0 & 142 & 179 & 17 & 0.86 & 87 & Nissan 240SX SE & 23000 & 7.7 & 16.0 & 118 & 170 & 22 & 0.89 \\
\hline 25 & \begin{tabular}{|l|} 
Chevy Suburban \\
Turbodiesel
\end{tabular} & 35242 & 13.6 & 19.2 & 96 & 218 & 15 & 0.69 & 88 & Nissan 300ZX Tubbo & 38806 & 5.6 & 14.2 & 155 & 175 & 18 & 0.89 \\
\hline 26 & Cheurolet Lumina LS & 19900 & 8.0 & 16.3 & 119 & 205 & 17 & \begin{tabular}{|l|}
0.79 \\
\end{tabular} & 89 & Nissan $300 \mathrm{ZX} 2+2$ & 37688 & 6.8 & 15.3 & \begin{tabular}{|l|l|}
145 \\
\end{tabular} & 177 & 18 & 0.87 \\
\hline 27 & \begin{tabular}{|l} 
Cherrolet Monte Carlo \\
LS
\end{tabular} & 18530 & 8.7 & 16.7 & 113 & 197 & 19 & 0.80 & 90 & Oldsmobile Aurora & 32390 & 8.2 & 16.4 & 132 & 185 & 16 & 0.78 \\
\hline 28 & Chevrolet Tahoe LT & 31877 & 11.3 & 18.2 & 99 & 198 & 12 & 0.68 & 91 & $\begin{array}{l}\text { Oldsmobile Eighty Eight } \\
\text { LSS }\end{array}$ & 25817 & 7.2 & 15.5 & 109 & 198 & 17 & 0.80 \\
\hline 29 & Chrysler Curus LXi & 19600 & 9.0 & 17.0 & 124 & 202 & 20 & \begin{tabular}{|l|}
0.76 \\
\end{tabular} & 92 & Pontiac Bonneville SE & 28662 & 7.0 & 15.5 & \begin{tabular}{l|l}
127 \\
\end{tabular} & 186 & 17 & 0.81 \\
\hline 30 & $=\pi \mathrm{Y}$ & & 89 & 61 & إ & 101 t & 1 & & 93 & Pontiac Grand Am GT & 7414 & & & & & & \\
\hline 31 & \begin{tabular}{|l} 
Chryys1 \\
Chrys
\end{tabular} & $1 / 000$ & 8.2 & 10.4 & 129 & 191 & 22 & 0.10 & 94 & & $1 / 414$ & 9.5 & 17.0 & 119 & 85 & 22 & 0.79 \\
\hline & Count & 26160 & 10.9 & 18.1 & 106 & 196 & 17 & 0.71 & & ire GT & 15400 & 8.9 & 16.9 & 114 & 183 & 21 & 0.79 \\
\hline 32 & Dodge Avenger ES & 20800 & 9.1 & 17.0 & 120 & 190 & 20 & 0.80 & 95 & $\begin{array}{l}\text { Pontiac Trans Am 25th } \\
\text { Anniversary }\end{array}$ & 28965 & 6.1 & 14.6 & 153 & 166 & 17 & 0.84 \\
\hline 33 & Dodge Intrepid & \begin{tabular}{|l|}
19837 \\
\end{tabular} & 9.5 & 17.2 & 111 & 195 & 20 & \begin{tabular}{|l|}
0.74 \\
\end{tabular} & 96 & Porsche Canrera 4 & 71973 & 4.9 & 13.6 & 161 & 163 & 16 & 0.90 \\
\hline 34 & \begin{tabular}{|l|} 
Dodge I \\
Coupe
\end{tabular} & 15155 & 7.6 & 160 & 115 & 207 & 29 & 0.82 & 97 & Porsche 911 Carrera & 66775 & 4.7 & 13.4 & 162 & 168 & 17 & 0.86 \\
\hline 35 & \begin{tabular}{|l|} 
Coupe \\
Dodge Stratus ES \\
\end{tabular} & 16195 & 8.9 & 16.8 & 121 & 197 & 25 & 0.78 & 98 & Porsche 911 Turbo & $1 E+05$ & 3.7 & 12.3 & \begin{tabular}{l|l}
176 \\
\end{tabular} & 162 & 13 & 0.95 \\
\hline 36 & Dodge V Ver RT/10 & 61975 & 4.3 & 12.8 & 168 & 180 & 14 & 0.98 & 99 & Range Rover 4.0 SE & 54625 & 10.5 & 17.9 & 113 & 185 & 13 & 0.73 \\
\hline 37 & & & & & & & & & 100 & ce Silver Sp & & & & & & & \\
\hline & Eagle Talon TSi AWD & 22000 & 6.6 & 15.3 & 137 & 169 & 21 & 0.85 & & III & $2 \mathrm{E}+05$ & 9.3 & 17.0 & 130 & 191 & 10 & 0.70 \\
\hline 38 & Ferrari F355 & $1 \mathrm{E}+05$ & 4.5 & 13.0 & 179 & 165 & 10 & 1.02 & 101 & Saab $900 \mathrm{~S}$ & 22430 & 7.6 & 16.1 & 126 & 188 & 20 & 0.75 \\
\hline 39 & Ford Contour SE & 20140 & 8.8 & 16.9 & 112 & 183 & 22 & 0.82 & 102 & Saab 900SE Convertible & 40377 & 8.6 & 16.7 & 132 & 184 & 18 & 0.77 \\
\hline 40 & Ford Crown Victoria LX & 25900 & 8.8 & 16.8 & 106 & 190 & 17 & 0.81 & 103 & Saab 900SE Tubo & 29460 & 6.5 & 15.3 & 142 & 171 & 21 & 0.82 \\
\hline 41 & Ford Explorer XIT & 25625 & 10.7 & 17.9 & 106 & 199 & 15 & \begin{tabular}{|l|}
0.67 \\
\end{tabular} & 104 & Saab 9000CDE & 40157 & 8.3 & 16.3 & 132 & 178 & 18 & 0.75 \\
\hline 42 & Ford Probe GT & 20815 & 7.4 & 15.9 & 131 & 164 & 21 & 0.86 & 105 & Saleen Mustange S351 & 37319 & 5.1 & 13.9 & 147 & \begin{tabular}{|l|}
171 \\
\end{tabular} & 16 & 0.87 \\
\hline 43 & Ford Windstar LX & 26700 & 11.4 & 18.3 & 104 & 195 & 17 & 0.72 & 106 & Satum $\mathrm{SC2}$ & 17340 & 7.6 & 16.0 & 122 & 174 & 25 & 0.84 \\
\hline 44 & \begin{tabular}{|l|} 
Guldstrand GS90 \\
\end{tabular} & $1 \mathrm{E}+05$ & 4.6 & 12.9 & 176 & 172 & 17 & 0.95 & 107 & Subaru Legacy L & 19584 & 10.4 & 17.9 & 108 & \begin{tabular}{|l|}
176 \\
\end{tabular} & 22 & 0.75 \\
\hline 45 & HIV & 60 & & & & & & & 108 & Subaru Legacy Outba & & & & & & & \\
\hline 46 & \begin{tabular}{|l} 
Honda \\
Honda \\
\end{tabular} & \begin{tabular}{|l|}
22030 \\
13210
\end{tabular} & \begin{tabular}{|l|}
8.8 \\
8.7
\end{tabular} & 16.7 & $\begin{array}{l}128 \\
110\end{array}$ & \begin{tabular}{|l|}
182 \\
198
\end{tabular} & 235 & \begin{tabular}{|l|}
0.75 \\
0.72
\end{tabular} & 109 & $\frac{\mathrm{Wa}}{\text { Sut }}$ & 29420 & \begin{tabular}{|l|}
10.0 \\
7.6
\end{tabular} & \begin{tabular}{|l|}
17.9 \\
15.9
\end{tabular} & $\frac{108}{136}$ & $\frac{166}{174}$ & $\frac{22}{17}$ & $\frac{0.82}{0.83}$ \\
\hline 47 & \begin{tabular}{|l} 
Honda Odyssey EX \\
\end{tabular} & 25390 & \begin{tabular}{|l|}
10.7 \\
\end{tabular} & 18.1 & 108 & 192 & 20 & 0.73 & \begin{tabular}{|l|}
110 \\
\end{tabular} & Toyota Avalon XI & 25689 & 7.5 & \begin{tabular}{|l|}
15.7 \\
\end{tabular} & 130 & 175 & 20 & 0.81 \\
\hline 48 & Honda Passport EX & 25975 & 10.4 & 18.0 & 103 & 189 & 15 & 0.70 & 111 & Toyota Camry DX & 19978 & 10.7 & 18.1 & 116 & \begin{tabular}{|l|l|}
196 & \\
\end{tabular} & 21 & 0.75 \\
\hline 49 & \begin{tabular}{|l} 
Honda Prelude VTEC \\
\end{tabular} & 24942 & 6.5 & 15.1 & 137 & 181 & 22 & 0.86 & 112 & Toyota Camny SE & 24984 & 7.9 & 16.2 & 132 & 177 & 18 & 0.78 \\
\hline 50 & Hyundai Elantra GLS & 12965 & 10.0 & 17.3 & 113 & 193 & 21 & 0.81 & 113 & & 25459 & 8.0 & 16.5 & 117 & 173 & 22 & 0.87 \\
\hline 51 & & & & & & & & & 114 & To & & & & & & & \\
\hline & Hyundai Sonata GLS & 19516 & 9.3 & 17.1 & 118 & 189 & 18 & 0.77 & & & 28120 & 9.0 & 16.9 & 115 & 175 & 22 & 0.85 \\
\hline 52 & Infiniti G20t & 25325 & 8.3 & 16.5 & 125 & 176 & 24 & 0.83 & 115 & Toyota Corolla DX & 13498 & 9.3 & 17.1 & 110 & 197 & 27 & 0.77 \\
\hline 53 & \begin{tabular}{|l|} 
Infiniti $\mathrm{I} 30 \mathrm{t}$ \\
\end{tabular} & 35200 & 7.7 & 16.1 & 127 & 189 & 21 & 0.78 & 116 & Toyota Land Cruiser & 41631 & 10.7 & 17.9 & 108 & 178 & 12 & 0.72 \\
\hline 54 & \begin{tabular}{|l|} 
Infiniti Q45 \\
\end{tabular} & 57025 & 7.8 & 16.1 & 143 & 187 & 17 & \begin{tabular}{|l|}
0.69 \\
\end{tabular} & \begin{tabular}{|l|}
117 \\
\end{tabular} & Toyota Supra & 41642 & 6.5 & 15.0 & 141 & 173 & 18 & 0.92 \\
\hline 55 & Isuzu Trooper LS & 32580 & 10.9 & 18.1 & 105 & 193 & 15 & \begin{tabular}{|l|}
0.69 \\
\end{tabular} & 118 & Toyota Tercel & 12595 & 9.2 & 17.0 & 110 & 195 & 33 & 0.75 \\
\hline 56 & \begin{tabular}{|l|l|} 
Jaguar \\
\end{tabular} & 71193 & 6.4 & 14.8 & 152 & 162 & 15 & 0.80 & 119 & Toyota T100 & 22634 & 8.9 & 16.8 & 103 & 201 & 17 & 0.69 \\
\hline 57 & \begin{tabular}{|l|l|l} 
Jaguar \\
\end{tabular} & & & & & & & & 120 & & & & & & & & \\
\hline & Converti & 66210 & \begin{tabular}{|l|l}
8.3 \\
0.5
\end{tabular} & 16.4 & 144 & 194 & 17 & 0.81 & & Volkswagen Cabrio & 21800 & 10.3 & \begin{tabular}{|l|}
77.6 \\
152
\end{tabular} & 109 & 182 & 23 & 0.81 \\
\hline 58 & Jaguar XJ6 & 61788 & 8.1 & 16.3 & 139 & 189 & 17 & 0.74 & \begin{tabular}{|l|}
121 \\
\end{tabular} & Volkswagen GII VR6 & 19265 & 6.6 & 15.2 & 130 & 179 & 18 & 0.78 \\
\hline 59 & $\begin{array}{l}\text { Jeep Grand Cherokee } \\
\text { Limited }\end{array}$ & 31332 & 8.0 & 16.3 & 114 & 180 & 14 & 0.75 & 122 & $\begin{array}{l}\text { Volkswagen Jetta III } \\
\text { GLX }\end{array}$ & 20365 & 6.9 & 15.5 & 136 & 208 & 18 & 0.78 \\
\hline 60 & Kia Sephia GS & 12065 & 10.2 & 17.6 & 109 & 197 & 27 & 0.75 & 123 & Volswagen Passat GLX & 22930 & 8.6 & 16.5 & \begin{tabular}{|l|}
131 \\
\end{tabular} & 178 & 18 & 0.81 \\
\hline 61 & Lamborghimi Diablo VT & $3 \mathrm{E}+05$ & 5.9 & 14.0 & 185 & 164 & 9 & 0.89 & \begin{tabular}{|l|l|}
124 \\
\end{tabular} & Volvo 850 Turbo & 33266 & 6.1 & 14.6 & 150 & 172 & 19 & 0.81 \\
\hline 62 & Land Rover Discovery & 35192 & 10.9 & 18.3 & 105 & 204 & 13 & 0.67 & 125 & Volvo $850 \mathrm{~T}-5 \mathrm{R}$ & 38056 & 6.7 & 15.2 & 149 & 181 & 19 & 0.79 \\
\hline 63 & Lexus LS400 & 57828 & 7.8 & 15.8 & 156 & 182 & 19 & 0.74 & 126 & Volvo 960 & 30360 & 8.6 & \begin{tabular}{|l|l} 
\\
\end{tabular} & 129 & 190 & 17 & 0.80 \\
\hline
\end{tabular}




\section{Capítulo 33}

\section{REDES COLABORATIVAS INTRAORGANIZACIONAIS: ESTUDO DAS RELAÇÕES INTERNAS EM UMA PREFEITURA MUNICIPAL}

DOI: $10.37423 / 200300437$

Fernando Zatt Schardosin

RESUMO: Este capítulo tem como objetivo estudar a importância das redeş colaborativas, estudando as relaçães ìnternas em uma prefeitura municipal no estado dø Paraná, utilizandose do método observacional entrevista, com um formulário de pesquisa estruturado, sendo composto de cinco grupos, de questões, em que o primeiro procurava saber as informações do entrevistado, o segundo buscava dados sobre as tarefas do/cargo ocupado, o terceiro procurava saber sobre quais gs processós, informaçõ ds ou docúmentos o cargo precisava dos outros quatorze cargos, o quarto grupo de questões perguntava sobre a cooperação entre os cargos e a frequência com que ocorriam, por fim q/quinto questionaya sobre quais processos, informações ou documentos, o cargo precisava repassar para os demais. Verificou-se entre outros fatores, que a colaboraçąo interdepartamental se encontra abaixo do [ideal, por vezes não existem relações com setores fụndamentais para a eficiência organizacional. Entre outras sugestôes, foi proposta uma melhor ligação entre os departamentos públicos para sañanestes problemas.

Palavras-chave:-Redes_colaborativas, intraorgahizacional, eficiência-organizacional, setor

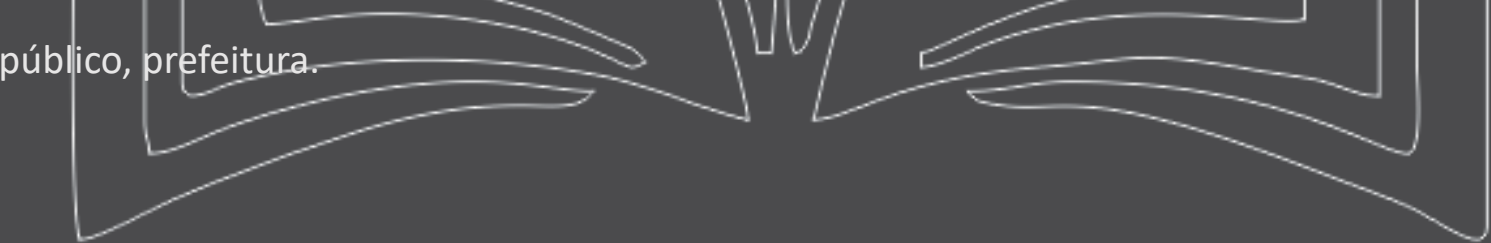




\section{Administração: caminhos para o desenvolvimento sustentável}

\section{INTRODUÇÃO}

A administração possui como alicerces fundamentais as atividades de planejar, organizar, dirigir e controlar, sendo instrumento essencial aos negócios públicos, por suas características, ela dispõe de pessoal permanente e transitório, submetido a uma disciplina hierárquica, tendo normas próprias para o recrutamento e seleção de pessoal.

É responsabilidade de a Administração Pública proporcionar os meios e ferramentas para que uma lei, diretriz ou norma emanada pelo poder competente se torne efetiva. Deve empregar, dentro de regras preestabelecidas, o patrimônio coletivo (ANDRADE, 1982).

De acordo com o artigo 37 da Constituição Federal do Brasil "a administração pública direta e indireta de qualquer dos Poderes da União, dos Estados, do Distrito Federal e dos Municípios obedecerá aos princípios de legalidade, impessoalidade, moralidade, publicidade e eficiência..."

O princípio da eficiência, assim como os demais, é de grande importância, pois para o atendimento da coletividade (população) foi sempre necessário o dever de boa administração, realizando com presteza, perfeição e rendimento funcional, com economicidade de tempo, trabalho (MADEIRA, 2000), utilizando os recursos disponíveis, possibilitando os melhores resultados.

Para o atendimento deste princípio as relações internas na organização devem estar sincronizadas a partir do estabelecimento de uma rede de colaboração que possibilite o fluxo correto de informações, o que viabiliza o trabalho de todos os setores, por meio da qualidade da informação e equalização do tempo necessário para execução das tarefas, uma vez que evita o retrabalho, por exemplo.

O objetivo deste capítulo é analisar a importância das redes colaborativas intraorganizacionais, estudando as secretarias municipais em um município do estado do Paraná.

\section{REFERENCIAL TEÓRICO}

\subsection{REDES COLABORATIVAS}

As redes colaborativas podem ser arquitetadas em vários níveis, interindividuais, se referem as redes entre indivíduos, intraorganizacionais são as redes presentes dentro de organizações, interorganizacionais são aquelas que ligam diferentes organizações, inter-regionais, ocorrem entre regiões diferentes com representação política, e assim por diante. 


\section{Administração: caminhos para o desenvolvimento sustentável}

Estas redes pressupõem a existência de cooperação entre os participes com a finalidade de consecução de objetivos comuns. O IAD - Instituto Alemão para o Desenvolvimento ao expor sobre cooperação salienta que a cooperação não representa a união de todos atrás de uma liderança, ou então uma ação totalmente sincronizada em conjunto, ou ainda a negação de interesses divergentes, nem mesmo significa a ausência de conflitos entre parceiros.

A cooperação precisa da troca de informações, do estabelecimento de um intercâmbio de idéias, desenvolvimento de visão estratégica coerente, definição de áreas de atuação, análise conjunta dos problemas e solução em comum e definição das contribuições dos parceiros. Predispõe abandonar o individualismo e saber tolerar, ceder (CASAROTTO FILHO e PIRES, 2001).

A eficiência de um sistema, de acordo com Chester Barnard (1938) é sua capacidade de satisfazer aos motivos dos indivíduos, incentivando-os a cooperar, em outras palavras é a capacidade de atender aos objetivos das pessoas, as organizações são por natureza essencialmente sistemas cooperativos e a cooperação é alcançada quando há equilíbrio entre os benefícios que a organização oferece para o indivíduo e o esforço que o indivíduo dá para a organização.

A disposição para cooperar depende do que o indivíduo percebe entre o esforço que dedica à organização e os benefícios que dela recebe. Estes benefícios são incentivos financeiros e recompensas não materiais e persuasão ou doutrinação (MAXIMIANO, 2010).

Neste intento a Fundacion Cotec (1999) salienta que o trabalho intelectual ou profissional é baseado essencialmente em conhecimento, pelo qual se deve avaliar o que se sabe e como se pode aplicar este conhecimento (DEITOS, 2002). Sendo que não é só individuo quem molda o seu trabalho a sua maneira mais o inverso também ocorre, o profissional é colocado em um cargo que possua características parecidas com suas habilidades para que a partir daí esta pessoa comece a exercer a sua própria influência.

Fernandez et al. (2014) enfatizam a natureza multinível das tensões na coopetição em sua discussão. Além do nível interorganizacional, eles discernem os níveis intraorganizacional e interindividual e propõem que as limitações de recursos possam influenciar a prioridade dada às atividades realizadas pelos parceiros e que os funcionários podem enfrentar tensão quando um concorrente atual se tornar um parceiro ou quando um parceiro atual se torna um concorrente. 


\section{Administração: caminhos para o desenvolvimento sustentável}

\subsection{ATRIBUIÇÕES DAS SECRETARIAS MUNICIPAIS}

As organizações formais são grupos de indivíduos formados com base em objetivos comuns, as empresas, tanto privadas, quanto públicas se encontram nesta definição e são compostas de normas racionais, atribuindo o que se pode ou não fazer, estas normas são leis, regulamentos, circulares, entre outros tipos (MAXIMIANO, 2010), se faz necessário a existência de organizações bem estruturadas em termos de regulamentos e procedimentos (AMATO NETO, 2000).

A Prefeitura Municipal objeto deste estudo não dispõe sobre as atribuições de cada cargo das secretarias municipais, entretanto em seu sítio na internet se pode verificar algumas características sobre as secretarias, sendo que a Lei municipal 072 de 23 de dezembro de 2008 atribui aos cargos a denominação de natureza substantiva, alterada pela Lei municipal 006 de 13 de março de 2012, são eles:

- Secretaria Municipal de Administração e Planejamento - têm as atribuições de Planejar, delegar, coordenar, normatizar e executar os sistemas de administração da prefeitura.

- Secretaria Municipal de Agricultura, Abastecimento e Meio Ambiente - são atribuições desta secretaria municipal, contribuir para a promoção do desenvolvimento rural, desenvolver projetos em conjunto com as organizações representativas dos diversos setores agropecuários e orientar quanto a recuperação e o uso adequado do solo agrícola e dos recursos naturais como um todo.

- Secretaria Municipal de Assistência Social e Segurança da Família - garantir os direitos e o acesso dos cidadãos e grupos em situação de vulnerabilidade social e pessoal a bens e serviços, por meio da formulação, coordenação e avaliação da política de Assistência e Desenvolvimento Social e da realização de parcerias, transferência e geração de renda.

- Secretaria Municipal de Assuntos Comunitários - atender à população, dirimir dúvidas e sanar os problemas sociais da comunidade. Auxiliar o cidadão enquanto consumidor já que absorve as atribuições do Procon (Fundação de Proteção e Defesa do Consumidor).

- Secretaria Municipal de Educação e Cultura - é o órgão administrativo municipal responsável por organizar, difundir, administrar, orientar, acompanhar, controlar e avaliar o desempenho da rede educacional municipal, em consonância com os sistemas 


\section{Administração: caminhos para o desenvolvimento sustentável}

estadual e federal de Educação. Avaliar as ações setoriais a cargo do Município relativas à garantia e à promoção da Educação, com a participação da sociedade.

- Secretaria Municipal de Esportes, Lazer e Turismo - oferecer instruções aos atletas nas categorias de base, treinamento aos atletas amadores, organizar competições municipais nas mais diversas modalidades e oferecer suporte às equipes que representam o município em competições regionais e estaduais. Apoiar qualquer tipo de atividade coletiva de recreação ou de lazer.

- Secretaria Municipal de Finanças e Orçamento - promover o equilíbrio das finanças públicas entre receitas e despesas com a finalidade de garantir o desenvolvimento ordenado do município, proporcionando às demais secretarias, condições de trabalho.

- Secretaria Municipal de Governo e Gestão - tem como finalidade assessorar o Executivo Municipal como um todo, articulando as ações governamentais e acompanhando os trâmites dos projetos de governo. Representar o Município junto às autoridades, em todas as esferas, além de acolher e acompanhar as reivindicações da comunidade e de seus representantes. É um elo entre o Executivo e o Legislativo.

- Secretaria Municipal de Saúde - promover a saúde da população mediante a integração e a construção de parcerias com os órgãos estaduais e federais, bem como com a iniciativa privada e a sociedade, contribuindo para a melhoria da qualidade de vida e para o exercício da cidadania.

- Controladoria interna - proporcionar economicidade, eficiência, eficácia e efetividade à Gestão Governamental, avaliando o cumprimento das metas, comprovando a legalidade e a legitimidade dos atos, pautando pela ética e transparência, com o objetivo de garantir a otimização dos gastos públicos. De acordo com Peixe (2002) a controladoria serve como coordenação e controle da cúpula administrativa, fornecendo informações que planeja e pesquisa por toda a organização.

- Secretaria Municipal de Obras e Urbanismo - atender aos anseios da comunidade, através da execução de obras públicas, tais como saneamento, urbanização, proporcionando infraestrutura adequada. Executar serviços de topografia; manter atualizada a planta cadastral do município; promover a elaboração de projetos e obras públicas. Fiscalizar e ordenar a execução de obras particulares através de concessão de 


\section{Administração: caminhos para o desenvolvimento sustentável}

alvarás e vigilância do Código de Obras e Código de Posturas. Promover a aplicação do Plano de Desenvolvimento Habitacional de Interesse Social, proporcionando moradia digna para as pessoas situadas na linha de pobreza. Orientar, fiscalizar e fixar diretrizes para a elaboração e aprovação de novos loteamentos urbanos, obedecendo o Plano Diretor. Zelar pelas áreas de preservação ambiental, incentivando a criação de reservas legais.

- Secretaria Municipal de Viação - executar, orientar, conservar as vias públicas não pavimentadas, a conservação de estradas e caminhos municipais, a abertura de vias e logradouros públicos, organizar e controlar as máquinas e equipamentos rodoviários do município, executar os serviços de limpeza pública, como coleta de lixo e retirada de entulhos.

- Secretaria Municipal de Comunicação Social - oferecer ao cidadão, informações relacionadas às ações do governo municipal, por meio de veículos de comunicação de massa como rádio e jornal. Oferecer subsídios jornalísticos relacionados aos fatos ligados ao governo municipal aos profissionais da imprensa por meio de releases, fotos e entrevistas, afim de assegurar o direito à informação. Gerenciamento logístico necessário para atos públicos oficiais, solenidades cívicas e eventos festivos promovidos pelo poder público municipal.

A secretaria municipal de indústria e comércio não possui ocupantes no cargo e não há atribuições desta secretaria no sítio da Prefeitura na internet, ocorrendo o mesmo para a procuradoria geral apesar de estarem constando na Lei 072/2008.

As tarefas apresentadas de cada secretaria municipal foram veiculadas com caráter informativo pela secretaria de comunicação da Prefeitura Municipal, no entanto devem representar o que cada secretaria deve desempenhar para não incorrer em atividades que não correspondem as suas atribuições e/ou deixar de fazer aquilo que lhe coubera.

Outrossim necessita-se identificar o método de pesquisa, tendo em vista a necessidade de identificação do publico alvo, tipo de entrevista, e método de tabulação dos dados, tais informações são tratadas na próxima seção.

\section{METODOLOGIA E PROCEDIMENTOS}




\section{Administração: caminhos para o desenvolvimento sustentável}

Para realização do presente trabalho foram utilizados dois métodos. Observacional, que é a técnica utilizada para obtenção de alguns aspectos da realidade, examinando fatos ou fenômenos, e entrevista estruturada, sendo a pesquisa com perguntas predeterminadas (LAKATOS e MARCONI, 2008), apresentadas a todos os entrevistados. Se caracterizando como método de observação direta intensiva, com o qual através do método indutivo se busca aceitar ou refutar a hipótese de pesquisa. Inicialmente foram identificados os possíveis entrevistados dentro do município, sendo o universo de pesquisa os popularmente conhecidos como "secretários municipais". O formulário de pesquisa foi elaborado pelo autor através de estudo sobre os principais pontos que deveriam ser questionados, levando em consideração o referencial teórico do trabalho, este formulário foi direcionado aos titulares dos cargos descritos, aos quais foi dado um tempo para resposta. Eventuais dúvidas eram solucionadas pelo pesquisador que efetuava visitas pessoais aos pesquisados.

O formulário de pesquisa foi composto de cinco grupos de questões, em que o primeiro procurava saber as caracteristicas do entrevistado, como estado civil, filhos, idade e escolaridade.

O segundo buscava dados sobre as atibuições do cargo ocupado. O terceiro procurava saber sobre quais os processos, informações ou documentos o cargo precisava dos outros quatorze cargos. 0 quarto grupo de questões perguntava sobre a colaboração entre os cargos e a frequência com que ocorriam. Por fim o quinto questionava sobre quais processos, informações ou documentos, o cargo precisava repassar para os demais.

A pesquisa obteve o retorno de treze formulários tendo em vista que a secretaria municipal de indústria e comércio não possuia ocupantes na época em que foi realizada a pesquisa e a secretaria municipal de comunicação social, apesar de possuir ocupante no cargo, não foi obtido resposta até o fechamento da pesquisa.

Esta pesquisa foi tabulada em arquivo de planilha eletrônica, pelo qual foi possível verificar as interligações indicadas pelos entrevistados das relações de interdependencias de informações existentes entre as secretarias.

\section{ANÁLISE DOS RESULTADOS}

Verificando-se as características individuais dos secretários municipais, que responderam a pesquisa, denota-se que a grande maioria é formada por pessoas casadas, havendo apenas um solteiro, com as idades variando entre 35 a 57 anos. 


\section{Administração: caminhos para o desenvolvimento sustentável}

Com relação a escolaridade constatou-se que das 13 Secretarias analisadas, 8 Secretarios possuem Curso Superior Completo, 01 possui Curso Superior Incompleto (Assistência social e segurança da família), 03 possuem Ensino Médio Completo (Administração e planejamento; Assuntos comunitários; Esportes, lazer e turismo), 1 possui Ensino Fundamental Incompleto (Agricultura, abastecimento e meio ambiente).

Constou-se que a maioria dos secretários possui uma visão apenas genérica dos cargos que ocupam, o que pode ser prejudicial no sentido de realizar uma correta administração da secretaria, acreditando que algumas situações de sua competência são de outra secretaria e vice-versa, ocasionando uma falta de solução para o problema.

Fazendo-se uma análise do que realmente é atribuição do cargo de cada secretário, poderá chegar-se a valiosas conclusões de que alguns estão sobrecarregados por estarem agindo em tarefas que seriam de outra secretaria, expondo claramente sobre as reais atribuições de cada secretaria tenderá a tornar-se a administração municipal mais eficiente e ágil.

Com base na pesquisa se verificou que as as secretarias não possuem condições para selecionar corretamente as informações que serão relevantes para as outras secretarias e o que realmente precisam das demais.

As secretarias com atribuições correlatas, tais como Assuntos comunitários com Assistência social e segurança da familia; Administração e planejamento com Governo e Gestão; Obras e urbanismo com Viação; Educação e cultura com Esporte, lazer e turismo; procuram elaborar projetos coletivamente, visando dimensionar e otimizar recursos, entrando diretamente em contato uma com a outra, sem intermediação de outro órgão ou pessoa.

Constatou-se que as secretarias realizam alguns trabalhos que já estavam prontos em outra secretaria, ocasionando em um problema de duplo trabalho, retardando a conclusão dos projetos e causando perda de tempo, trabalho e recursos das secretarias envolvidas. Já que em torno de $80 \%$ a $90 \%$ da informação necessária para desenvolver qualquer projeto já existe e está disponível (MORIN e SEURAT, 1998).

Como exemplo pode-se citar as secretarias de Assistência Social com Assuntos Comunitários e ainda com Agricultura, abastecimento e meio ambiente, visando atendimento a famílias carentes no interior, entre outros projetos. Os trabalhos desenvolvidos por um podem servir de base para a continuidade dos trabalhos do outro. 


\section{Administração: caminhos para o desenvolvimento sustentável}

A Secretaria municipal de Comunicação Social é de grande importância pois deve proporcionar o fluxo de informações com as secretarias entre si e entre as secretarias e o público em geral, entretanto nenhum envolvimento entre secretarias foi constatado neste sentido, apenas a necessidade da comunicação social para divulgar ao público as atividades das secretarias.

Algumas Secretarias afirmaram que não tem cooperação com a secretaria de Controle Interno e Procuradoria Geral, o que é preocupante, pois estas duas secretarias são as que dão suporte legal sobre os procedimentos, obedecendo-se a todos os preceitos necessários e exigidos pela legislação. Quanto as frequências de cooperação varia de acordo com a necessidade de cada secretaria com intensidades baixa, média ou alta, conforme a percepção do entrevistado, estas informações são salientadas na figura 1 segundo a frequência da cooperação que a secretaria de Administração e Planejamento tem com as demais.

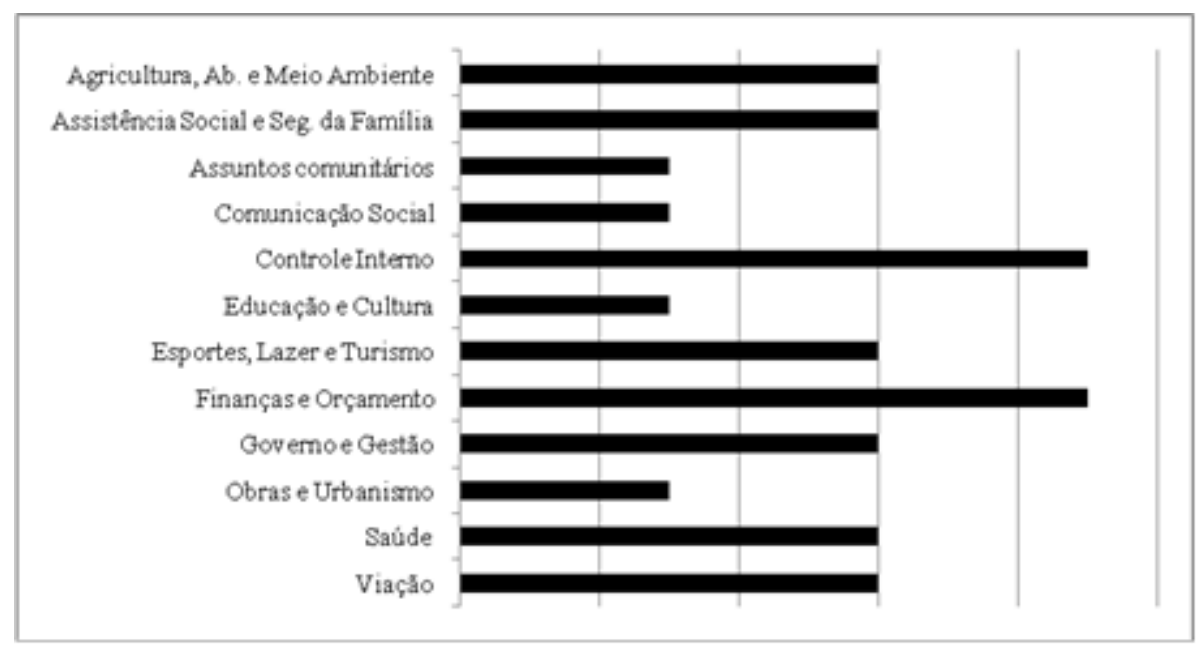

Figura 1.Frequência de cooperação de Administração e Planejamento

Observam-se que não há cooperação com a procuradoria geral, quanto as freqüências, elas são altas apenas com o sistema de Controle Interno e com Finanças e Orçamento, áreas muito importantes para Administração e Planejamento, entretanto existem frequências baixas com Assuntos Comunitários, Comunicação Social, Educação e Cultura e Obras e Urbanismo, que também devem estreitar os laços. 


\section{Administração: caminhos para o desenvolvimento sustentável}

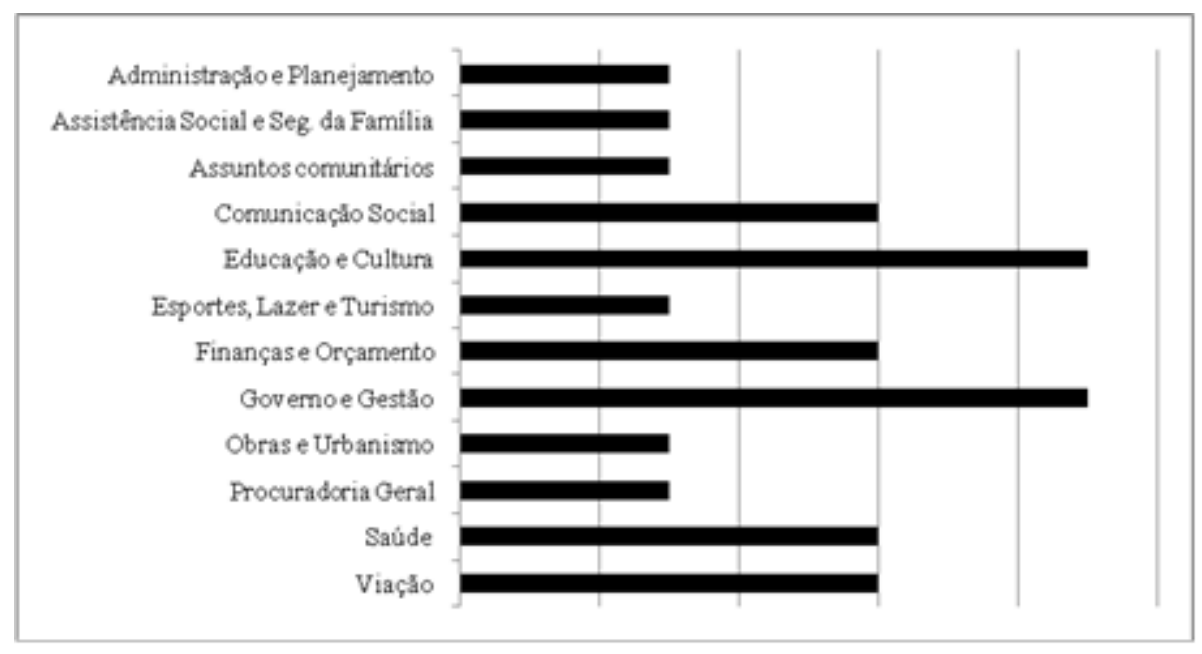

Figura 2.Frequência de cooperação de Agricultura, abastecimento e meio ambiente

Na figura 2 o respondente salienta não existir cooperação com o sistema de controle interno, existir frequências consideradas altas apenas com Educação e Cultura e com Governo e Gestão.

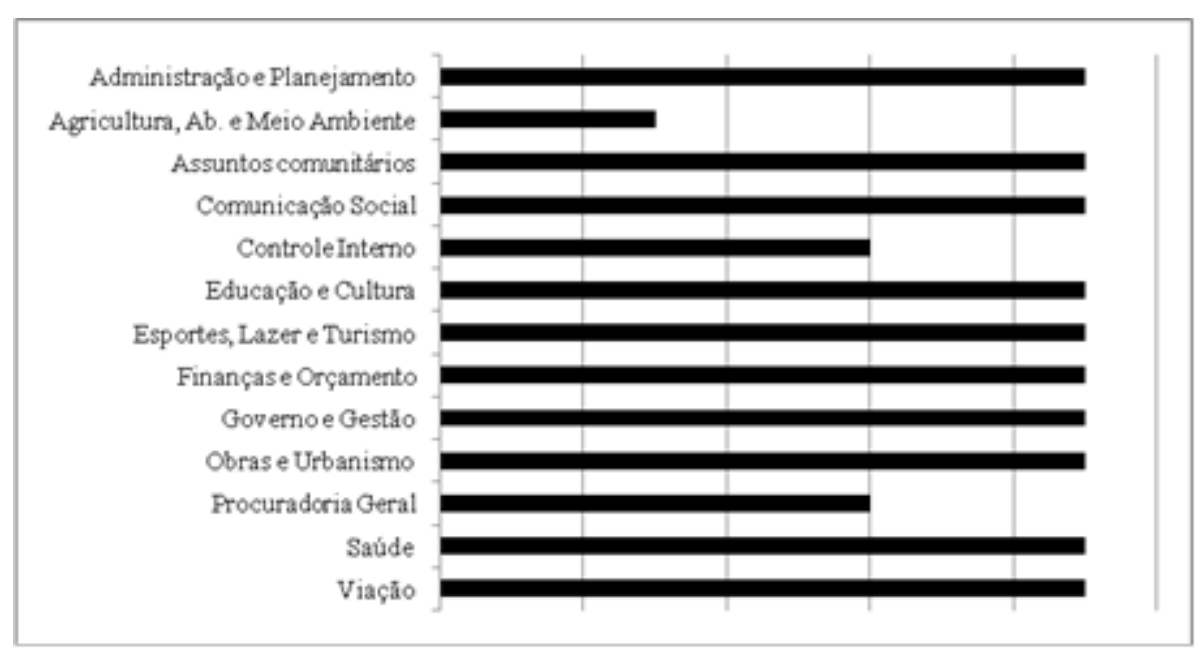

Figura 3.Frequência de cooperação de Assistência Social e Segurança da Família

De acordo com a secretaria de Assistência Social e Segurança da Família há um relacionamento com todas as outras secretarias, entretanto com nível baixo de freqüência com Agricultura, abastecimento e meio ambiente e níveis médios de freqüência com Controle interno e procuradoria geral. 


\section{Administração: caminhos para o desenvolvimento sustentável}

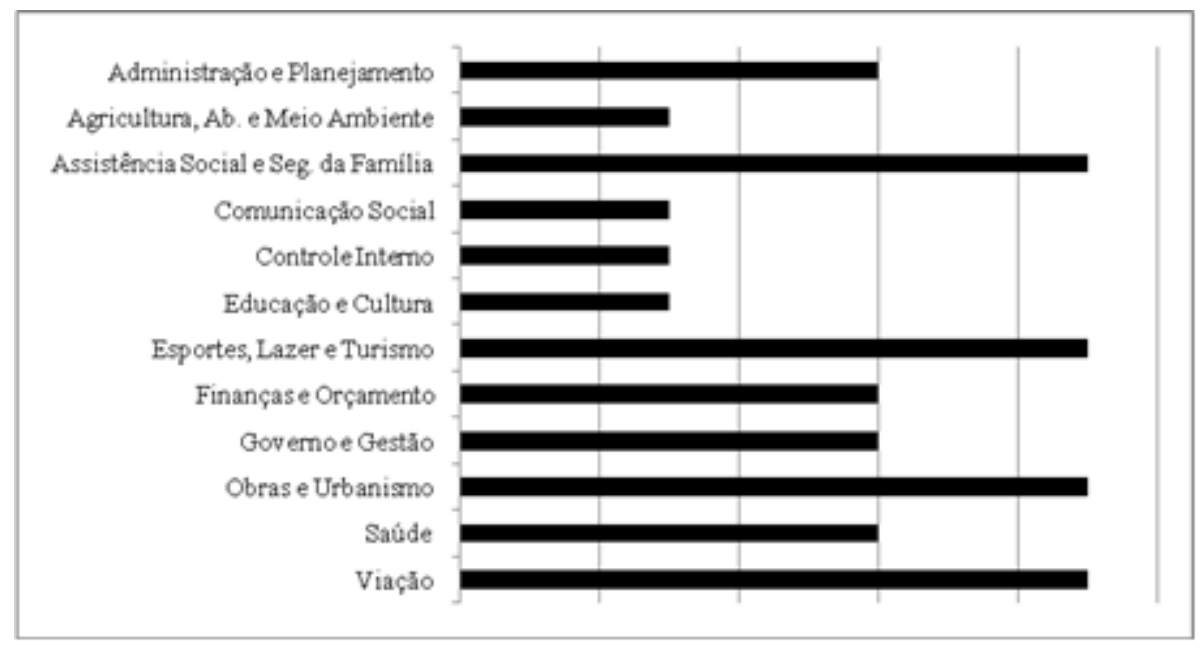

Figura 4.Frequência de cooperação de Assuntos Comunitários

Na figura 4 o entrevistado frisou não haver cooperação com a procuradoria geral, os níveis altos de frequência foram atribuídos apenas para Assistência Social e Segurança da Família; Esportes, Lazer e Turismo; Obras e Urbanismo; e Viação.

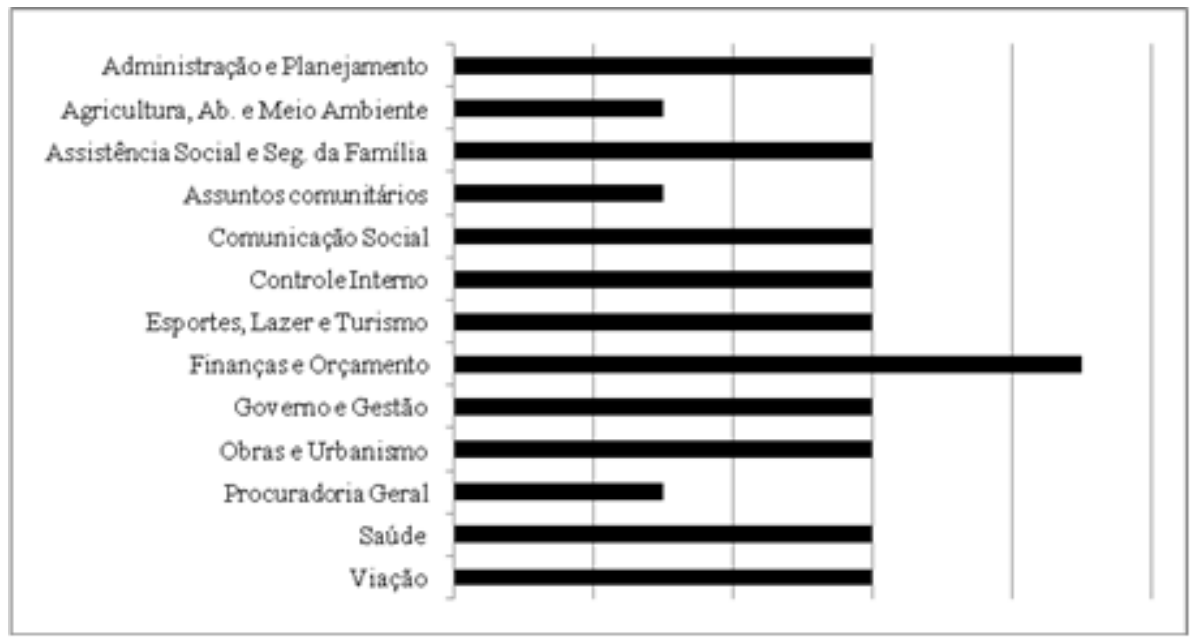

Na secretaria de Educação e Cultura, o entrevistado salientou haver cooperação com todas as secretarias, mas somente Finanças e Orçamento foi considerada uma frequência alta. 


\section{Administração: caminhos para o desenvolvimento sustentável}

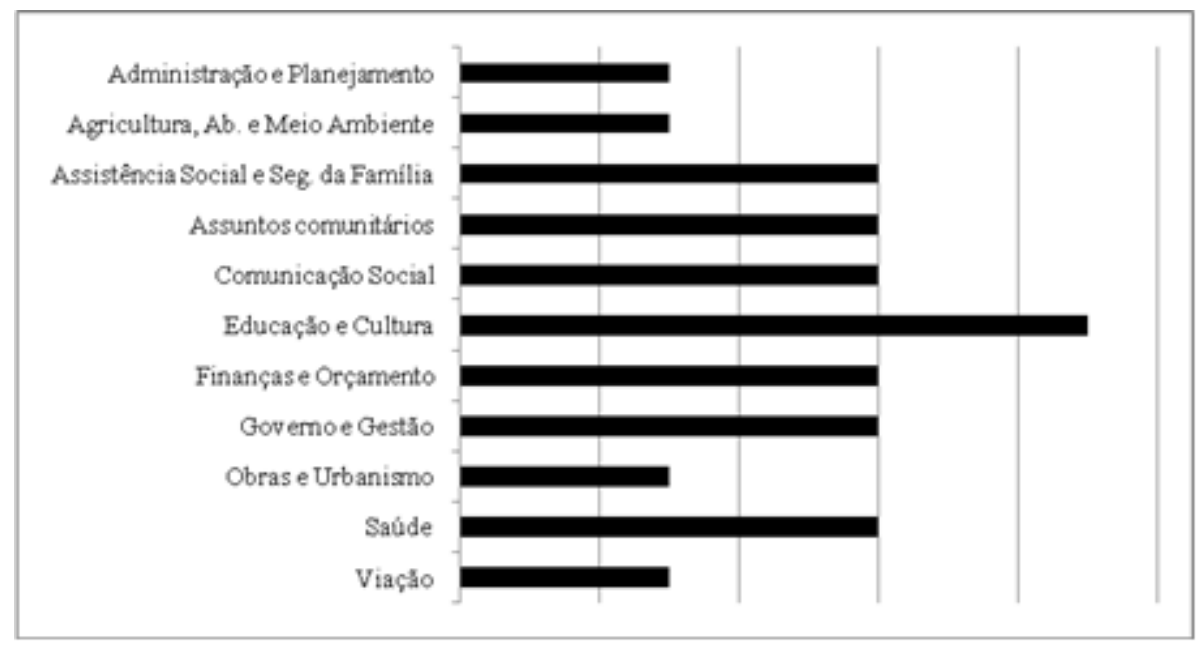

Figura 6.Frequência de cooperação de Esportes, lazer e turismo

Com base na figura 6 o entrevistado salientou não haver cooperação com o sistema de controle interno e com Procuradoria Geral, sendo considerado com uma frequência alta apenas Educação e Cultura.

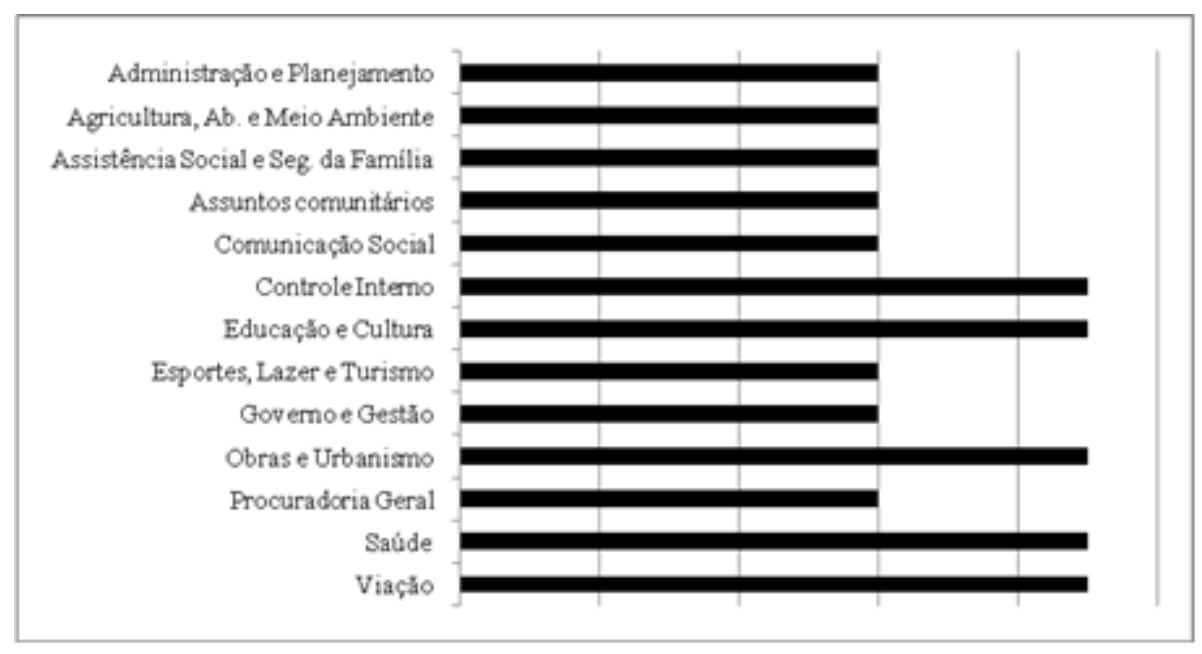

Figura 7.Frequência de cooperação de Finanças e Orçamento

Na figura 7 o entrevistado salientou existir cooperação com todas as demais secretarias, entretanto com níveis altos de frequência foram 5: Controle Interno; Educação e Cultura; Obras e Urbanismo; Saúde e Viação. Todas as demais foram consideradas cooperação de média frequência. 


\section{Administração: caminhos para o desenvolvimento sustentável}

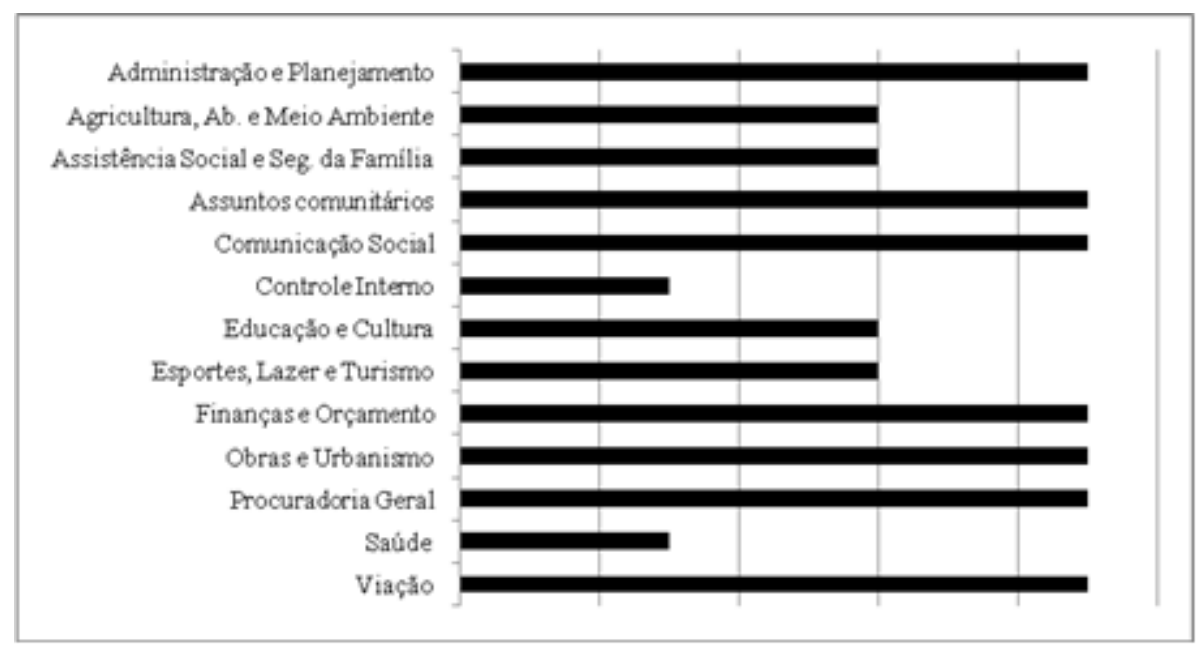

Figura 8.Frequência de cooperação de Governo e Gestão

Na figura 9 o entrevistado entende haver cooperação com todas as demais secretarias, entretanto 2 possuem frequências baixas (Controle Interno e Saúde), 4 possuem frequências médias (Agricultura, Abastecimento e Meio Ambiente; Assistência Social e Segurança da Família; Educação e Cultura e com Esportes, Lazer e Turismo), todas as demais 7 foram consideradas frequências altas.

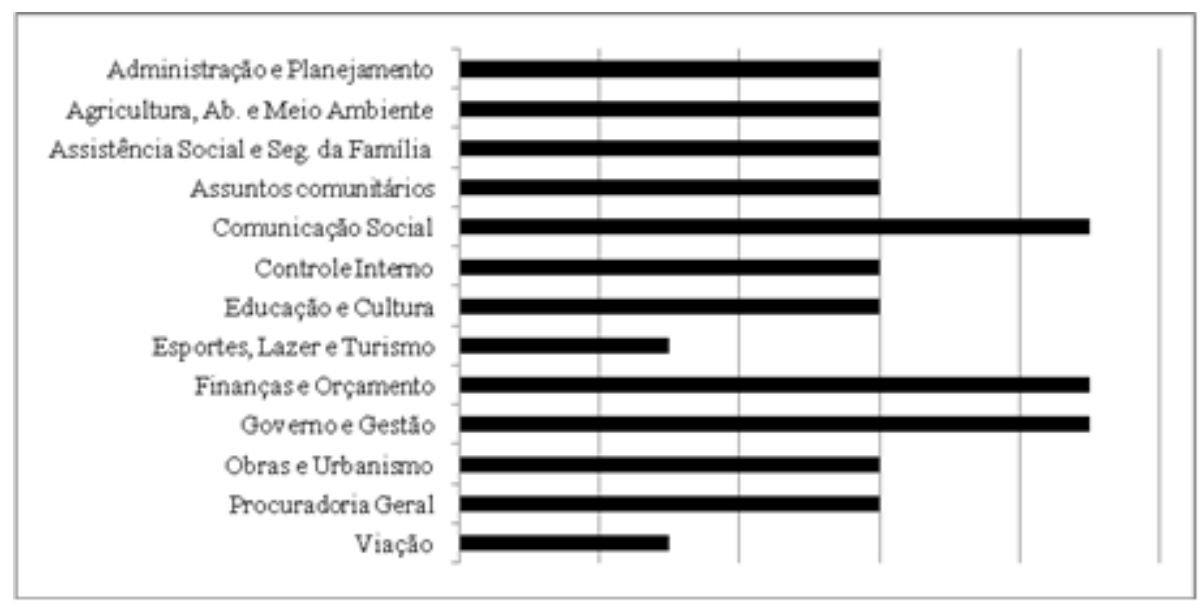

Figura 9.Frequência de cooperação de Saúde

Analisando a figura 9, o entrevistado salientou haver cooperação com todas as demais secretarias, entretanto os níveis mais altos de cooperação ficam em Comunicação Social; Finanças e Orçamento e Governo e Gestão. 


\section{Administração: caminhos para o desenvolvimento sustentável}

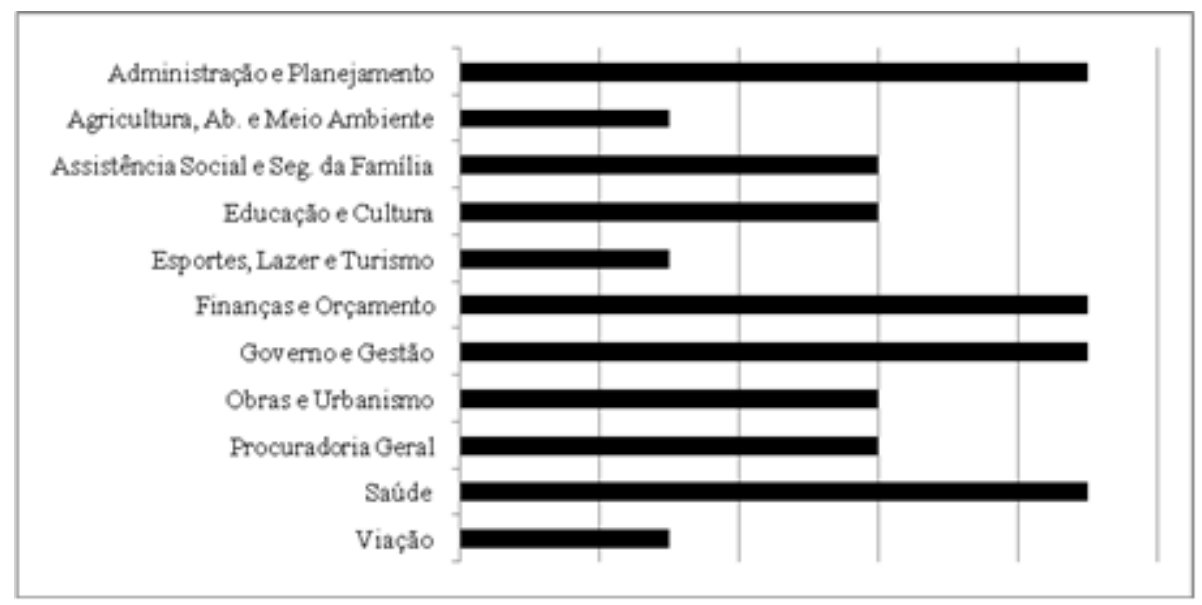

Figura 10.Frequência de cooperação do Sistema de controle interno

Na figura 10, o entrevistado declarou não haver cooperação com Assuntos Comunitários, nem mesmo com Comunicação Social, níveis altos de frequência apenas com Administração e Planejamento; Finanças e Orçamento; Governo e Gestão e Saúde.

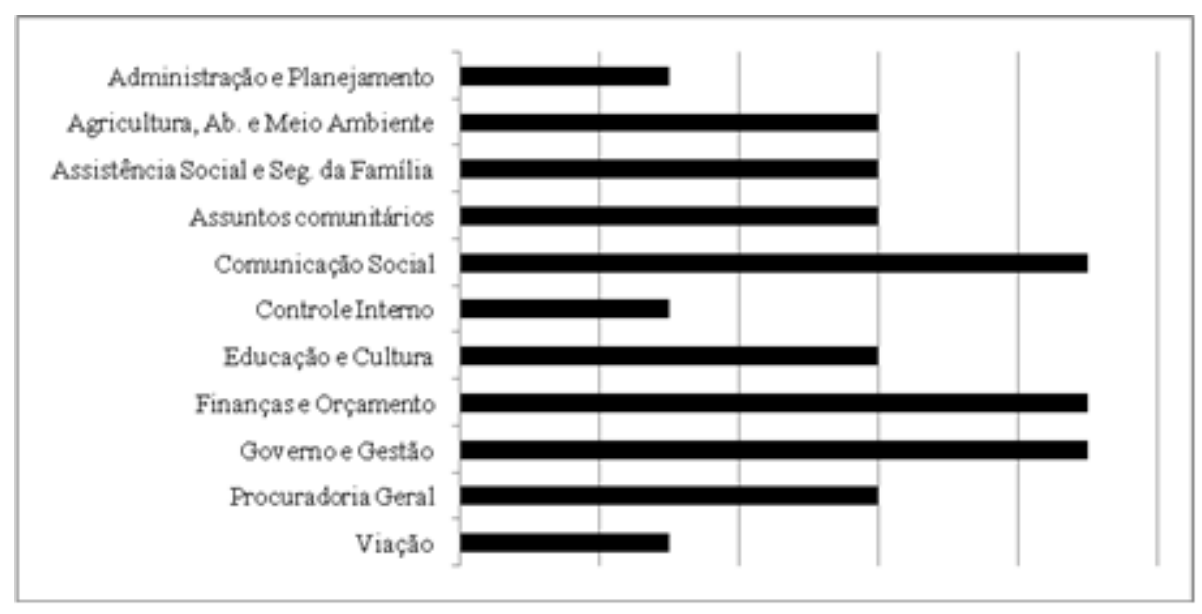

Figura 11.Frequência de cooperação de Obras e urbanismo

Na figura 11, o entrevistado declarou não haver cooperação com Esportes, Lazer e Turismo e com Saúde, níveis altos de frequência apenas para Comunicação Social, Finanças e Orçamento e Governo e Gestão. 


\section{Administração: caminhos para o desenvolvimento sustentável}

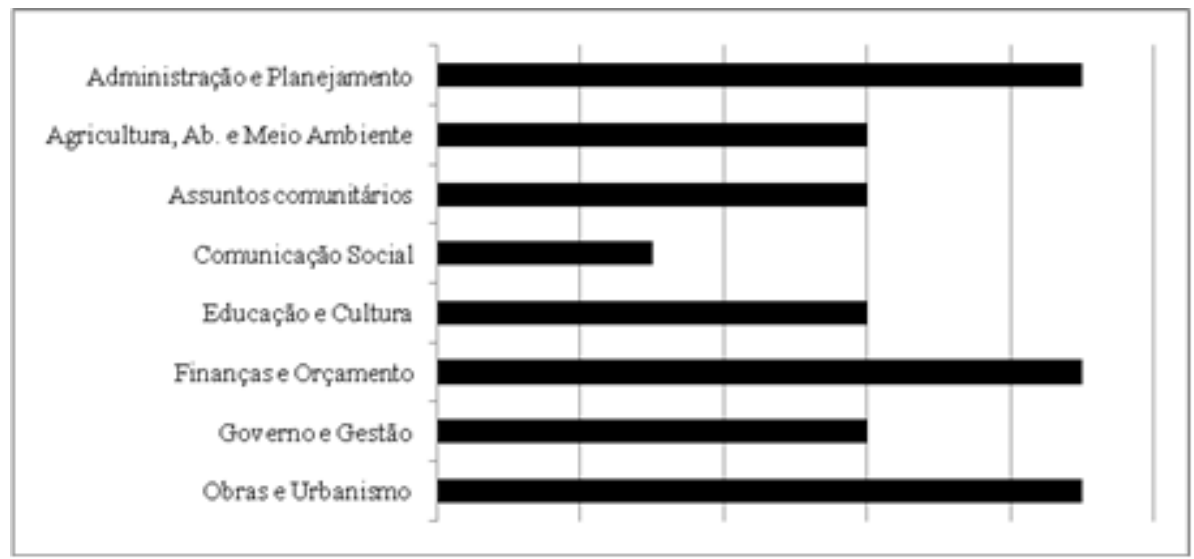

Figura 12.Frequência de cooperação de Viação

A entrevista representada na figura 12 revela não haver cooperação com Assistência Social e Segurança da Família, com Esportes, Lazer e Turismo, com Saúde, com Controle Interno e com Procuradoria Geral, frequências altas de cooperação apenas para Administração e Planejamento, Finanças e Orçamento e Obras e Urbanismo.

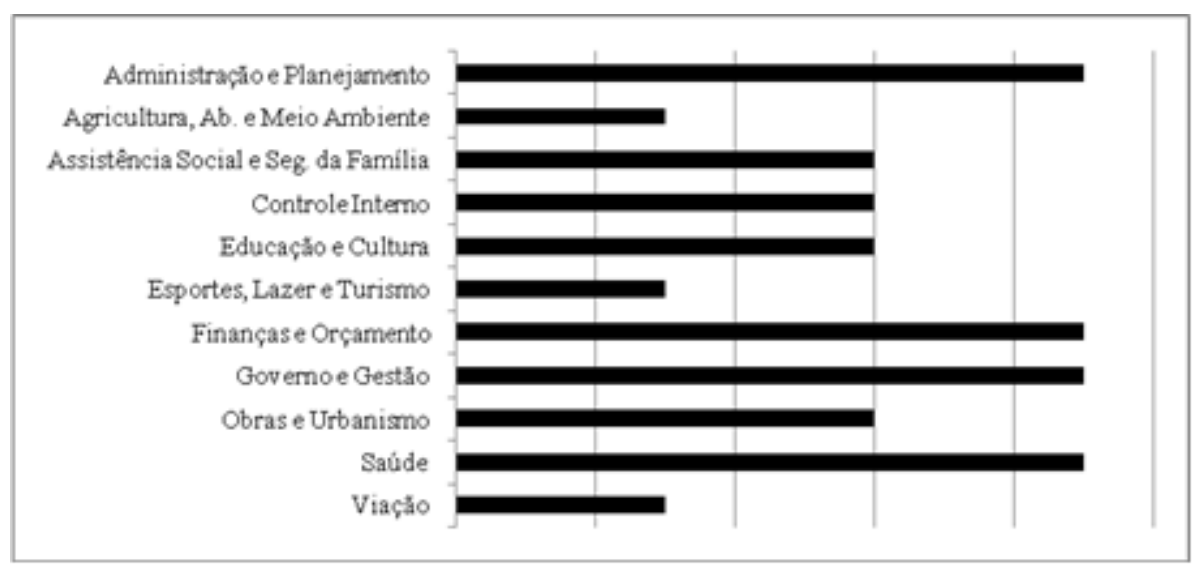

Figura 13.Frequência de cooperação da Procuradoria Geral

Analisando a figura 13, o entrevistado diz não haver cooperação com Assuntos Comunitários e com Comunicação Social, níveis altos de frequência foram considerados para Administração e Planejamento, Finanças e Orçamento, Governo e Gestão e Saúde.

Contudo, das 169 respostas possíveis neste quesito frequência, 62 respostas foram iguais na comparação dos gráficos, aproximadamente $40 \%$ do total como é o caso de Assistência Social e Segurança da Família com Assuntos Comunitários que afirmaram ter uma frequência alta de cooperação. Entretanto foram percebidos alguns detalhes durante o levantamento dos dados:

1 - A cooperação, em alguns casos, foi interpretada como a dependência que o entrevistado possui das informações de outro órgão e não como uma troca de informações; 


\section{Administração: caminhos para o desenvolvimento sustentável}

2 - Os aspectos relativos à frequência eram analisados sobre o ponto de vista de proximidades de relacionamentos interpessoais e não relativos a necessidades de informações para o trabalho.

\section{CONCLUSÕES}

O objetivo deste capítulo era analisar a importância das redes colaborativas intraorganizacionais, estudando as secretarias municipais em um município do estado do Paraná.

Depois de efetuada a pesquisa verificou-se que os agentes públicos municipais precisam se interar melhor dos processos que envolvem os seus próprios trabalhos e necessita reavaliar as suas necessidades para saber quais informações realmente precisam receber e quais precisam direcionar aos demais, para poupar tempo e trabalho. Os projetos realizados conjuntamente são uma forma para conhecer melhor o outro departamento e interar-se das realizações de outro órgão.

A secretaria de Comunicação Social deveria prover as demais secretarias com informações sobre a realização dos planejamentos e o que está sendo realizado, para que todos saibam dos projetos e trabalhos, multiplicando-se as informações e interando a todos do processo de gestão municipal.

A Secretaria de Governo e Gestão, que centraliza e canaliza as informações com o Prefeito, deveria promover reuniões, para realizar um maior entrosamento entre as divisões e passar de forma geral as orientações, evitando-se assim a repetição de informações separadamente para cada agente público.

O Controle Interno deve operar com maior independência e autoridade para realizar seu trabalho com as demais secretarias, a fim de orientar sobre os procedimentos legais e mais eficientes, conjuntamente com a Procuradoria Geral.

A maneira ideal é a de que todos os departamentos, órgãos e divisões de uma organização possuam uma cooperação com alta frequência entre si, para alcançar a máxima eficiência organizacional. Recomenda-se trabalhos futuros nesta área, para contribuir com a discussão sobre a eficiência organizacional no setor público.

\section{REFERÊNCIAS}

AMATO NETO, João. Redes de cooperação produtiva e clusters regionais: oportunidades para pequenas e médias empresas. São Paulo: Atlas, 2000.

ANDRADE, Cândido Teobaldo de Sousa. Administração de relações públicas no governo. São Paulo: Loyola, 1982.

CASAROTTO FILHO, Nelson; PIRES, Luis Henrique. Redes de pequenas e médias empresas e desenvolvimento local. 2a ed. São Paulo: Atlas, 2001. 


\section{Administração: caminhos para o desenvolvimento sustentável}

BRASIL. Constituição da República Federativa do Brasil: promulgada em 5 de outubro de 1988. 29a ed. atual. e ampl. São Paulo: Saraiva, 2002.

DEITOS, Maria Lucia de Melo de Souza. A gestão da tecnologia em pequenas e médias empresas: Fatores limitantes e formas de superação. Cascavel: Edunioeste, 2002.

FERNANDEZ, A. S.; LE ROY, F.; GNYAWALI, D. R. Sources and management of tension in co-opetition case evidence from telecommunications satellites manufacturing in Europe. . Ind. Mark. Manag., v. 43, p. 222-235, 2014.

LAKATOS, Eva Maria; MARCONI, Marina de Andrade. Metodologia científica. 5a ed. 5a reimp. São Paulo: Atlas, 2008.

MADEIRA, José Maria Pinheiro. Administração pública centralizada e descentralizada. Rio de Janeiro: América Jurídica, 2000.

MAXIMIANO, Antonio Cesar Amaru. Teoria Geral da Administração: da Revolução Urbana à Revolução Digital. 6ạ ed. 6a reimp. São Paulo: Atlas, 2010.

MORIN, Jacques; SEURAT, Richard. Gestión de los recursos tecnológicos. Madrid: Cotec, 1998.

PEIXE, Blênio César Severo. Finanças Públicas: Controladoria Governamental. Curitiba: Juruá, 2002. 


\section{Capítulo 34}

\section{LIDERANÇA: SUA IMPORTÂNCIA NA GESTÃO DE PESSOAS}

DOI: $10.37423 / 200300440$

Natalie Evelin Casanova Correia (Faculdade Zumbi dos Palmares) natalie_evelin@yahoo.com.br

Antônio Carlos Estęndek(Faculdade Zumbi dos Palmares) estender@uol.com.br

Marcio de Cassio Juliano (Faculdade Zumbi dos Palmares) prof.mcj@hotmail.com

RESUMO: Os pilares e conceitos de liderança vêm sofrendo mudanças nas últimas décadas em todo o mudo administrativo e o cenário da liderança dentro das organizações ganha, a cada dia, mais importância para a evolucacão da empresa no mercado competitivo. op presente artigo tem como objetivo explanar sobre a liderança, suas competências e tipos, as habilidades que um liøer necessita para envolver um grùpo, equipe o,lorganização, bem comp fazer com que todos envolvidos sintam-se satisfeitos e motivadoß para a conclusão das metas e alcance de resultados. Ganhará foco também o incentivo a colláboração e o envolvimento das pessoas em prol do objetivo do Tider. O problema de pesquijsa questiona:- Como a empresa pode utilizar a liderança como ferramenta na gestão de pessoas? -0 estudo dos atuais conceitos e diretrizes de liderança-permitirá elaborar a resposta para a questão. 


\section{Administração: caminhos para o desenvolvimento sustentável}

A metodologia adotada neste estudo foi de pesquisa bibliográfica com revisão de literatura disponível sobre o tema em questão. O estudo apresentado neste artigo sugere a necessidade do líder em sempre buscar conhecimento atualizado para manter-se alinhado com os objetivos da organização e com seus colaboradores ou equipe. O benefício de um profissional bem preparado para liderar um grupo ou organização é a motivação e satisfação desse grupo e em consequência o sucesso da organização no cumprimento de seus planos estratégicos e metas, alavancando seu desempenho em relação as suas concorrentes de mercado.

Palavras-chave: líder, liderança, gestão de pessoas, competências, habilidades. 


\section{Administração: caminhos para o desenvolvimento sustentável}

\section{INTRODUÇÃO}

A pessoa que comanda uma organização deve ter uma qualidade em especial, a liderança. Liderar é, em suma, a habilidade que um indivíduo possui de reunir pessoas em torno de um objetivo com o intuito de concretizá-lo da melhor maneira possível. Nos nossos dias, o perfil de liderança mudou, é mais participativo, sensitivo e exige dedicação do líder para com os colaboradores promovendo a ideia de divisão de poder.

Dentro da esfera desse tema será abordado o problema da falta de liderança na gestão de pessoas dentro de uma organização. A questão é: Como a empresa pode utilizar a liderança como ferramenta na gestão de pessoas?

O objetivo do estudo é elucidar aos gestores das organizações as competências e habilidades que um líder deve ter para que as pessoas lideradas sintam-se motivadas e satisfeitas e acima de tudo queiram trabalhar em torno do mesmo objetivo do líder e da organização.

A metodologia usada para a realização deste artigo foi a pesquisa bibliográfica onde foram feitas revisões de literatura do tema proposto pelo artigo.

Foi escolhida essa abordagem de tema, pois a liderança é parte principal no que diz respeito ao capital humano, do que viabiliza ou não o sucesso de uma organização. O método de pesquisa utilizado foi escolhido devido à vasta e rica literatura disponível sobre o tema liderança.

Este artigo está estruturado em cinco partes, além da introdução. Na primeira seção é apresentado o problema de pesquisa, logo após é discutida a questão da base da liderança, seus tipos e suas competências, como envolver as pessoas e o incentivo a colaboração. Em seguida é apresentado o estudo de caso com a empresa Pisom Comércio de Materiais Fotográficos Ltda. Após, foi elaborada uma proposta e na última seção são apresentadas as considerações finais.

Problema de Pesquisa: Como a empresa pode utilizar a liderança como ferramenta na gestão de pessoas? A partir desse questionamento e do estudo realizado com diversas revisões bibliográficas será possível identificar os conceitos atuais da liderança e como eles podem ser aplicados no cotidiano organizacional. 


\section{Administração: caminhos para o desenvolvimento sustentável}

\section{REFERENCIAL TEÓRICO}

\subsection{A BASE DA LIDERANÇA}

Drucker (2001) nos diz que a "verdadeira liderança só pode ser definida de forma significativa em um contexto social, ou seja, visões socialmente significativas e outros valores de liderança devem ser construídos com base em padrões que beneficiem a sociedade".

Afirma, ainda, que "a liderança, como a conhecemos, resulta diretamente da inteligência, talvez do poder e do carisma pessoal do desejo e do compromisso e de uma disposição para fazer coisas que os demais estão menos propensos a fazer". Cabe dizer que o autor chama a atenção para o fato de que a verdadeira liderança só ganha significado num contexto social e que alguns atributos são precisos para que o indivíduo exerça a liderança.

Para Deming (1990) a definição de líder é precisa: "Liderar consiste em ajudar as pessoas a fazer um trabalho melhor e perceber quais delas necessitam de uma ajuda individual. $O$ trabalho de um gerente não é dizer às pessoas o que elas devem fazer ou puni-las quando cometem erros, mas sim liderá-las". Observa-se muito clara a definição de que os líderes devem apoiar seus seguidores com suas habilidades procurando um relacionamento positivo e honesto com eles. Na empresa estudada observou-se a falta dessa sensibilidade em perceber qual funcionário precisa de ajuda para uma melhor execução do trabalho proposto.

Para Kouzes; Posner (2003) a liderança é um conjunto reconhecível de habilidades e práticas que estão disponíveis para todos, e não apenas para alguns homens e mulheres carismáticos. A teoria de que o líder é um grande homem ou uma grande mulher está totalmente errada. À medida que observamos mais a fundo o processo dinâmico da liderança descobrimos cinco regras básicas comuns às experiências que permitem aos líderes fazer coisas extraordinárias:

- - Apontar o caminho.

- - Inspirar uma visão compartilhada.

- - Desafiar o estabelecido.

- - Permitir que os outros ajam.

- - Encorajar o coração.

Essas regras são princípios básicos para que o líder tenha sucesso em sua empreitada, como bem observou Kouzes; Posner. O cumprimento dessas cinco regras desenvolverá um novo cenário na empresa Pisom, fará com que seus líderes trabalhem seguindo um padrão pra obter êxito. 


\section{Administração: caminhos para o desenvolvimento sustentável}

Segundo Caruso; Salovey, (2007) Uma variedade de taxonomias para as funções administrativas e de liderança foi proposta ao longo dos anos. Uma maneira de as pessoas diferenciarem esses dois papéis é ver a função do administrador como consistindo no planejamento e na implementação de atividades, ao passo que a função dos líderes é vista mais globalmente como a de influenciar outras pessoas na concretização de metas. Os autores aqui diferenciam claramente o papel do administrador e do líder justificando porque uma empresa necessita dos dois para que sua rotina funcione bem.

Ainda segundo os autores Caruso; Salovey, (2007) estas analises funcionais proporcionam uma ideia do que um administrador ou líder eficiente deve fazer, mas fazer tais coisas não significa necessariamente que terá sucesso. Os administradores enfrentam um grande número de obstáculos potenciais, como a dificuldade de formar uma equipe, a dificuldade de se adaptar e problemas com as relações interpessoais. Distribuímos as várias funções de administradores e líderes com seus potenciais obstáculos em seis áreas principais:

- Criar equipes eficientes.

- Planejar e decidir com eficiência.

- Motivar as pessoas.

- Comunicar uma visão.

- Promover mudanças.

- Gerar relacionamentos interpessoais efetivos. 


\section{Administração: caminhos para o desenvolvimento sustentável}

Figura 10 que fazem administradores e Líderes

\begin{tabular}{|ll|}
\hline Função Geral & Exemplos \\
\hline Criar equipes eficientes & Dificuldade de criar e liderar uma equipe \\
& Como liderar \\
& Modelar o caminho \\
\hline $\begin{array}{l}\text { Planejar e decidir com } \\
\text { eficiência }\end{array}$ & Agendar projetos \\
& Planejar orçamentos e recursos \\
& Logística \\
& A não-concretização de objetivos de negócios \\
\hline Motivas as pessoas & Motivar os funcionários \\
& Gerar entusiasmo \\
& Motivar uma equipe \\
& Permitir que os outros ajam \\
\hline Comunicar uma visão & Criar um senso de importância e significado \\
& Criar uma identidade organizacional \\
& Desenvolver metas coletivas \\
& Inspirar uma visão compartilhada \\
\hline Promover mudanças & Promover os pensamentos flexível e decisório \\
& Facilitar o pensamento criativo \\
& Dificultar a mudança ou a adaptação \\
& Orientação funcional muito estreita \\
& Desafiar o processo \\
\hline interpessoais efetivos & Resolução de conflitos entre subordinados \\
& $\begin{array}{l}\text { Lidar com a demissão de alguém } \\
\text { Problemas com relacionamentos interpessoais }\end{array}$ \\
\hline & Incentivar a emoção \\
& \\
&
\end{tabular}

Fonte: elaborado pelos autores

Essa abordagem contribui para a compreensão de como administradores e líderes desempenham essas difíceis tarefas (CARUSO; SALOVEY, 2007). Existe uma grande variedade de tarefas e ações que um líder precisa exercer para que sua equipe esteja alinhada com o mesmo, os autores citam as 


\section{Administração: caminhos para o desenvolvimento sustentável}

principais e percebe-se a dificuldade de encontrar um indivíduo com o perfil de liderança. Na Pisom a liderança é dividida entre os proprietários e alguns funcionários e isso dificulta o desenvolvimento das ações, pois nenhum deles tem perfil de líder e os funcionários acabam ficando confusos quanto aos objetivos da empresa.

\subsubsection{ESTILOS DE LIDERANÇA}

Baseando-se na Teoria de Estilos, Bergamini (2002) cita três tipos de líderes que são:

Autocrata: regime autoritário, o líder baseia-se na autoridade com seus subordinados, apenas ele tem a decisão, não permitindo nenhuma expressão de ideia ou vontade do grupo.

Democrata: neste regime existe a participação do grupo, o líder faz questão de ouvir as vontades e ideias, fazendo assim o grupo se tornar o centro das atenções.

Liberal: neste tipo de liderança o líder apenas aconselha e faz sugestões, é o grupo que decide nas tomadas de decisões.

O autor coloca que os três tipos são distintos entre si e cada qual tem uma definição bem diferente do outro. O líder autocrata geralmente não é bem aceito por seus colaboradores e sua postura prejudica o desempenho do trabalho de todos, o democrata é o perfil ideal para um bom líder, pois ele valoriza o grupo, já o liberal corre o risco de perder a liderança, pois é pouco ativo.

Pode-se considerar como pioneiro no estudo dos estilos de liderança Max Weber (1992), que diferenciou em três tipologias o comportamento do líder: liderança autoritária, liberal e democrática. Weber (1992) delimita a diferença entre esses três estilos, dizendo que a liderança autocrática possui sua ênfase centrada no líder, sendo ele quem fixa as diretrizes a serem seguidas e determina as técnicas a serem utilizadas, sem qualquer participação do grupo. Já a liderança democrática coloca sua ênfase tanto no líder como nos subordinados, sendo as diretrizes debatidas e as técnicas e processos escolhidos pelo grupo assistidos pelo líder. Por sua vez, a liderança liberal coloca todo seu foco nos subordinados. Segundo Weber, neste caso, há liberdade completa, por parte dos colaboradores, para a tomada de decisões.

Para concluir sobre estilos de liderança, cada indivíduo que atue como líder deve reconhecer seu estilo de liderar e buscar aprimorar suas fraquezas e acentuar ainda mais suas qualidades, trazendo o sucesso para perto de si, de seu grupo e da organização que está inserido. 


\section{Administração: caminhos para o desenvolvimento sustentável}

\subsubsection{COMPETÊNCIAS DA LIDERANÇA}

Partindo de um estudo sobre a conceituação de competências nas organizações Júlio; Neto (2002) diferenciam dois tipos de competências a seguir:

- - Práticas: o que as pessoas fazem, exercendo suas funções, para obter resultados. Por exemplo, um líder pode "orientar a visão e o direcionamento", "colocar o foco no cliente" e "tomar decisões".

- - Atributos: conhecimentos, técnicas e outras características que as pessoas trazem para a função, que Ihes permitem exercer as tarefas de liderança. Um líder pode, por exemplo, demonstrar capacidade de "pensamento estratégico", "iniciativa" e "grande energia" como atributos pessoais.

Observa-se que os atributos são essenciais pra o desempenho, são as habilidades do indivíduo para a função. A partir dos atributos vem a tomada de decisão, a atitude, que nada mais é que as competências práticas.

Segundo Oliveira; Marinho (2006) no geral são atribuídas diversas competências a liderança, como se observa abaixo:

$\mathrm{Na}$ área pessoal e educacional, ser líder é adotar uma atitude baseada em princípios éticos que norteiam os relacionamentos e decisões pessoais, além de estar sempre aprendendo e ensinando, num processo contínuo de crescimento.

$\mathrm{Na}$ área interpessoal, ser líder é valorizar as pessoas e estar comprometido com o desenvolvimento do potencial humano em todos os níveis, mantendo boas relações humanas, um elevado nível de comunicação interpessoal e a sensibilidade para interagir na diversidade de um mundo globalizado, com um clima de integração constante.

Na área organizacional, ser líder é não se conformar com o status quo e sempre procurar criar e inovar para desenvolver novas ideias, estratégias e processos, e encontrar novos caminhos, o que influencia toda a estrutura organizacional, tanto na geração de recursos materiais quanto no desenvolvimento de pessoas.

Na área cognitiva, ser líder é estar sempre em busca do conhecimento e da informação, pesquisando, analisando e interpretando dados de diferentes fontes, em busca de um domínio cada vez maior dos princípios e teorias de liderança. 


\section{Administração: caminhos para o desenvolvimento sustentável}

$\mathrm{Na}$ área profissional, ser líder é ser uma pessoa e um profissional diferente, utilizando as competências de liderança no exercício da profissão e desenvolvendo o potencial da equipe em busca de melhores decisões e soluções, da realização de grandes empreendimentos, bem como do planejamento, da administração e da execução de projetos em diferentes áreas e níveis (OLIVEIRA; MARINHO, 2006). Como se observou todas as competências são importantes para que um líder seja eficiente e completo, cada habilidade tem seu peso no resultado final do relacionamento entre líder e seguidor. Está aí um dos pontos fracos da liderança na Pisom, os gestores não se preocupam em buscar conhecimento e novas maneiras de trabalhar para um melhor aproveitamento de seus funcionários.

\subsection{ENVOLVA AS PESSOAS}

Para Kouzes; Posner (2003) a liderança não envolve impor o sonho do líder, envolve um senso de destino compartilhado. Envolve envolver os outros para que eles possam ver como seus interesses e aspirações pessoais estão alinhadas com a visão e, portanto, podem se mobilizar para dedicar suas energias individuais à sua concretização. A visão inclui as aspirações dos seguidores; ela é uma imagem ideal e singular do futuro para o bem comum. Quando os líderes comunicam a visão com eficácia seja para uma pessoa, um pequeno grupo ou uma organização -, essa visão tem um efeito poderoso. Descobrimos que quando os líderes articulam sua visão com clareza para a organização, os seguidores relatam aumentos significativos em diversas reações positivas, como por exemplo:

- Satisfação com o emprego.

- Motivação.

- Compromisso.

- Lealdade.

- Esprit de corps.

- Compreensão clara dos valores da organização.

- Orgulho da organização.

- Produtividade.

Pode-se, assim, observar com clareza que o ensino da visão produz resultados poderosos (KOUZES; POSNER, 2003). Envolver as pessoas para um mesmo propósito depende de o líder passar clara e honestamente a sua visão para os liderados, fazer com que eles entendam que seus interesses e aspirações estão intimamente ligados ao da organização. Se eles obtiverem sucesso em suas tarefas diárias isso construirá o sucesso da organização também. 


\section{Administração: caminhos para o desenvolvimento sustentável}

Segundo Kouzes; Posner (2003) "ao aprender como alcançar as pessoas, tocar sua alma e levantar seu espírito - e o nosso - nos voltamos para um mestre da arte: o reverendo Martin Luther King Jr. Que, no dia 28 de agosto de 1963, nas escadas do Lincoln Memorial em Washington, D.C., diante de uma multidão de 250.000 pessoas, proclamou seu sonho ao mundo. Enquanto falava - e milhares de pessoas aplaudiam e gritavam -, a nação se comovia. Aquele discurso constitui uma das peças mais instrutivas de apresentação pública inspiradora, tanto pela habilidade de King, quanto pela sua capacidade de comover os ouvintes. Ilustra também como a capacidade de exercer uma influência estimulante tem raízes nos valores fundamentais, nas tradições culturais e na convicção pessoal". Percebe-se que a convicção do que está falando aliada a outros fatores é o que torna o discurso comovente, a partir daí as pessoas tendem a sentir e entender melhor a mensagem que estão recebendo. Na empresa Pisom os funcionários não tem interesses pelos discursos pois os líderes não mostraram claramente a visão dos objetivos.

Para Oliveira; Marinho (2006) inúmeros fatores influenciam no relacionamento entre duas ou mais pessoas. Entre esses, podem se mencionar semelhanças e diferenças individuais, temperamento, a "química" que ocorre entre duas pessoas, interesses particulares, habilidades e competências pessoais e assim por diante. Como uma equipe é formada de pessoas, é inevitável que esses fatores influam no relacionamento do líder com os membros da equipe, fazendo com que o líder tenha melhor relacionamento com uns do que com outros. Isso é um fato em toda equipe, e cabe ao líder administrálo para que não se torne um obstáculo sério na equipe. O autor explica que a capacidade de tocar uma pessoa com seu discurso é algo deveras importante para o líder, ele precisa comover e persuadir sua equipe ou grupo como um todo precisa ser eficaz ao passar uma visão para que ela seja aceita e compreendida.

\subsection{INCENTIVE A COLABORAÇÃO}

Segundo Oliveira; Marinho (2006) as organizações procuram processos de mudanças estruturais e comportamentais, no intuito de melhorar a prestação de serviços e a produção de bens, e atender às exigências do mercado consumidor. $\mathrm{O}$ autor explica que as mudanças são fundamentais para os processos de evolução das organizações. A empresa Pisom sofre essas mudanças, porém, de maneira desorganizada e sem saber lidar com elas.

Nesse sentido, os perfis dos líderes atuais também mudaram:

Esses líderes devem ser pessoas flexíveis, inovadoras, criadoras, pois as ações e práticas por eles executadas caracterizam sua figura como a de "espelho" do processo (OLIVEIRA; MARINHO 2006). 


\section{Administração: caminhos para o desenvolvimento sustentável}

líder é a figura de referência dos colaboradores e ele deve ser o exemplo para a postura dos mesmos. Na empresa estudada, o líder precisa se alinhar as novas habilidades necessárias a sua função, pois ele é o "espelho" do processo dentro da organização e só assim os colaboradores também se alinharam a ele.

Para Kouzes; Posner (2003) a colaboração é a competência mais importante para se alcançar e sustentar o alto desempenho - sobretudo na era da internet. O que definirá o sucesso não será a capacidade de competir acirradamente, mas sim a capacidade de cooperar de bom grado. Observa-se que a globalização está presente em todas as áreas profissionais e isso demanda gestores antenados e criativos para ter sua equipe no mesmo objetivo. A Pisom tem gestores com alguns pensamentos ultrapassados que necessitam se renovar e criar um vínculo de colaboração mútua com seus funcionários.

Para incentivar a colaboração, é essencial ter líderes capazes de:

- Criar um clima de confiança.

- Facilitar a interdependência positiva.

- Apoiar as interações face a face.

Para os líderes a mensagem está clara: colaboração é sinônimo de sucesso!

A confiança encontra-se no cerne do processo de incentivo à colaboração. Ela constitui o ponto central dos relacionamentos humanos dentro e fora da organização. A confiança é também um elemento essencial da eficácia organizacional. Os indivíduos que não confiam nas outras pessoas não conseguem ser líderes. Por não suportarem depender da palavra ou do trabalho dos outros, eles acabam fazendo todo o trabalho sozinhos, ou controlando-o de maneira excessiva. A falta de confiança que demonstram em relação aos outros faz com que estes também não confiem neles (KOUZES; POSNER, 2003). Um ponto extremamente importante no trato do líder com seus seguidores é a confiança, como bem colocou o autor. Ela quem criará o vínculo do líder com os liderados e o fortalecerá cada vez mais. Esse ponto deve ser revisto na Pisom já que na relação de gestores e funcionários a confiança está ausente nas duas partes.

Na visão de Caruso; Salovey (2007) "os processos mediante os quais administradores ou líderes cultivam uma visão comum, motivam as outras pessoas e incentivam seus subordinados estão alicerçados no uso inteligente das emoções e na integração entre sensações e pensamentos". Observa-se novamente o quanto é importante estar claro para os funcionários a visão da organização e o líder precisa de inteligência e "feeling" para saber como deverá reproduzir essa visão. 


\section{Administração: caminhos para o desenvolvimento sustentável}

As equipes não nascem elas se formam. Como observa Steve Zaccaro, um bom líder de equipes gera confiança entre indivíduos e, portanto, utiliza os elos de confiança do grupo para formar uma equipe coesa. Antes que o líder consiga modelar as ações desejadas, ele deve deixar seus valores claros e alinhar com eles suas ações (CARUSO; SALOVEY, 2007). Conclui-se que para que a liderança tenha bons resultados é primordial que exista a colaboração do líder com toda sua equipe. O líder deve promover a confianças em todos os membros do grupo, incentivar suas ideias e estar sempre se reunindo com eles para manter esses elos firmes.

\section{ASPECTOS METODOLÓGICOS}

O método de pesquisa utilizado neste artigo científico foi o de Pesquisa bibliográfica. A pesquisa bibliográfica é uma técnica de coleta de materiais imprescindível em um estudo de caráter acadêmico, pois o relatório de pesquisa pressupõe uma revisão da literatura disponível sobre o tema tratado. Assim, foi realizado um fichamento em arquivos de Word do material bibliográfico selecionado, permitindo a evolução das ideias do grupo, a inserção de comentários a partir de conclusões "pósleitura", com eventuais adaptações ou comparações entre os conceitos. O conteúdo, conforme citado por Lima (2004) indica que o pesquisador, após fazer a análise literária, seja capaz de reconhecer e sintetizar partes importantes da obra lida, reconhecer e extrair citações que possam traduzir os conceitos-chave do assunto tratado e fundamentar exercícios de reflexão e análise em que o pesquisador possa estabelecer relações com outras obras consultadas sendo estas de outras fontes ou não e até inferir no momento de redação do relatório final da pesquisa.

Para a efetiva realização da pesquisa documental, foram feitos resumos e fichas, com exatidão e cuidado, já que muitos materiais, tidos como importantes e muitas vezes sigilosos para as unidades de estudo, também foram utilizadas e feitas também cópias destes. Em seguida, foi feita interpretação e análise dos materiais selecionados, para desenvolver a redação da pesquisa documental, no contexto do artigo realizado. Esses materiais são de suma importância, pois são as provas do que está sendo afirmado pelo pesquisador e que muitas vezes podem não ser interpretadas à luz de referenciais teóricos compatíveis com as

exigências do tema/problemas norteadores de investigação (LIMA, 2004).

Nesta etapa, com a explanação dos conceitos gerais de lideranças, suas principais competências e habilidades que o indivíduo necessita para exercer função de líder, o trabalho alcança outras dimensões, que permitem entender os conflitos e divergências no campo humano e elucidar as soluções para estes conflitos. Após a coleta, tratamento e análise dos dados, foi feita uma conclusão 


\section{Administração: caminhos para o desenvolvimento sustentável}

mais detalhada e aprofundada, descrita ao final do artigo. A conclusão propriamente dita possui explicações e inferências realizadas pelo autor deste artigo.

\section{ESTUDO DE CASO}

A Pisom Comércio de Materiais Fotográficos Ltda. é uma empresa de capital fechado que surgiu da vontade do fotógrafo Jonas Chun em inovar os serviços oferecidos no campo fotográfico. É uma empresa de pequeno porte relativamente jovem, já que iniciou suas atividades em 2004. A Pisom atua no ramo fotográfico comercializando materiais e serviços agregados a fotografia em geral, sua gama de serviços é extensa e vai de simples ampliações até impressões em grandes formatos e em papéis nobres. Apesar do pouco tempo de vida a empresa tem uma cartela de clientes fiéis que apreciam muito o serviço prestado, dentre esses clientes muitos fotógrafos profissionais, estudantes de fotografias, fotógrafos internacionais, grandes empresas que trabalham com imagem e prefeituras. Trata-se de organização com um número baixo de funcionários, somam-se 15 (quinze). Por ser uma empresa de cultura familiar convive desde sua fundação com problemas relacionados à gestão de pessoas, diversos conflitos foram percebidos na relação líder $X$ colaboradores. A Pisom tem ampla comunicação entre os seus diferentes setores (laboratório fotográfico; área digital; acabamento; atendimento e administração), como não tem variados cargos gerenciais a comunicação com seus colaboradores é direta, o que propicia uma proximidade dos mesmos com o seu gestor. Os colaboradores têm fácil acesso aos gestores, porém, existe uma dificuldade de entendimento entre eles causada pelo despreparo de quem exerce o cargo de líder. Por ser uma empresa familiar os líderes são subordinados aos donos e estes diversas vezes interferem nas decisões dos mesmos deixando-os sem autoridade.

O grande desafio da empresa está em preparar melhor as pessoas que exercem cargo de liderança, fazendo com que esse funcionário siga os atuais critérios e conceitos da gestão de pessoas, desenvolva as competências e habilidades inerentes ao cargo, mesmo tendo como obstáculo a relação líder $\mathrm{X}$ colaborador tão próxima e familiar.

\section{PROPOSTA}

Como demonstrado neste artigo, há diversos estilos de lideranças, competências variadas e habilidades que o indivíduo precisa ter para liderar uma equipe, grupo de pessoas ou organização. 0 líder deve ter perspicácia para saber quando cada habilidade precisa ser colocada em prática, para dosar suas ações de acordo com as circunstâncias apresentadas e identificar o modo que deve 


\section{Administração: caminhos para o desenvolvimento sustentável}

relacionar-se com cada colaborador, já que precisa ser honesto e justo com todos sem deixar de ser flexível e maleável, pois cada ser humano é diferente e em consequência disto necessita de tratamento único. Para construir uma relação de confiança com seus colaboradores o líder deve passar para os mesmos uma visão clara dos objetivos da organização e promover que o êxito pessoal de cada funcionário construirá o sucesso no resultado final do trabalho. Dessa forma, uma organização que tenha um líder com essas características certamente desenvolverá uma relação firme e proveitosa para ambas as partes

- com seus colaboradores, utilizando de maneira positiva a ferramenta excepcional na gestão de pessoas que é a liderança.

Numa análise da empresa Pisom, observamos que a causa da divergência e dos conflitos entre chefia e funcionários está no mau preparo desses gestores para liderar um grupo de pessoas. Os mesmos não possuem habilidades para incentivar suficientemente os funcionários e motivá-los para que trabalhem em prol dos objetivos da organização com a consciência de que a produtividade trará benefícios para ambos os lados. O efeito disso é a solução momentânea dos conflitos, grande rotatividade de pessoas e funcionários desalinhados com os objetivos e metas da organização, que trabalham somente para suas aspirações pessoais.

Algumas estratégias e providências precisam ser traçadas e colocadas em prática para que a gestão de pessoas na organização não seja um fardo pesado que acarrete insucessos e prejuízos para a mesma. Primeiramente a empresa deve fazer um estudo para determinar se as pessoas que hoje estão exercendo função de líder são competentes e habilitadas para tal. Num segundo passo, decidir se manterá os líderes atuais ou se contratará novos funcionários para gerir as equipes. Independente de qual seja a escolha, o perfil dessa pessoa deve estar em sintonia com os atuais conceitos e competências de liderança. A empresa deve apoiar e subsidiar meios para que essa pessoa mantenhase atualizada e sempre buscando conhecimentos para melhorar sua comunicação com os funcionários, os proprietários devem confiar no líder, dar autoridade e espaço para que ele mostre suas habilidades, participando de todo o processo de mudança, desta forma se firmará uma relação transparente que pode ser o início de uma nova era na gestão com pessoas na empresa.

\section{CONSIDERAÇÕES FINAIS}

A gestão de pessoas, em especial a liderança, exerce papel de suma importância dentro da organização, considerando que o capital humano é parte imprescindível do que determina o sucesso ou não de uma empresa. 


\section{Administração: caminhos para o desenvolvimento sustentável}

Para Kouzes; Posner (2003) "não faltam oportunidades desafiadoras atualmente. Nessa época extraordinária em que vivemos, os desafios parecem estar aumentando e, através de nossas reações temos a possibilidade de modificar o mundo em que vivemos e trabalhamos".

Acredita-se que as organizações sofrem constantes mudanças que são relevantes para a sua sobrevivência e ter um profissional bem preparado ocupando a posição de líder é imprescindível na atual conjuntura.

O objetivo desse estudo foi alcançado, se identificou que diagnosticar onde estão as fraquezas e as qualidades do líder é o passo inicial para a construção da melhoria da gestão de pessoas dentro de uma organização. Um líder deve estar sempre em busca de novos conhecimentos e habilidades, aprimorando suas competências e reciclando-se constantemente para manter um relacionamento positivo com seus colaboradores. É importante que o líder incentive seus seguidores e construa uma relação de colaboração e confiança com a equipe. Um líder influencia positiva ou negativamente seus seguidores, a forma como o grupo se comporta está em suas mãos, ele é o espelho. Portanto, o líder deve ser honesto e motivar as pessoas mostrando uma visão clara dos objetivos e apoiando seu grupo para que todos trabalhem satisfeitos em prol da meta a ser alcançada.

Para concluir, um pensamento de Kouzes; Posner (2003) que resume bem o que é ser um líder: "de todas as coisas que sustentam um líder ao longo do tempo, o amor é a mais duradoura (KOUZES; POSNER (2003)". Realmente é difícil conceber a ideia de que uma pessoa trabalhe duro todos os dias, enfrente desafios, desânimos e tantos outros obstáculos

para realizar coisas maravilhosas sem estar de coração, corpo e alma dedicada a tal. E Kouzes; Posner (2003) completa" o segredo mais bem guardado dos líderes bem-sucedidos é o amor: amor pela liderança, pelas pessoas que executam o trabalho, pelo que suas organizações produzem e pelos que homenageiam a organização usando seu trabalho".

\section{REFERENCIAS BIBLIOGRÁFICAS}

BERGAMINI, Cecília Whitaker. O Líder Eficaz. São Paulo: Atlas, 2002.

CARUSO, David R.; SALOVEY, Peter. Liderança com Inteligência Emocional. São Paulo: M. Books, 2007. DEMING, William E. Qualidade: A Revolução da Administração. Rio de Janeiro: Marques-Saraiva, 1990. DRUKER, Peter Ferdnand. O Líder do Futuro. São Paulo: Futura, 2001.

JÚLIO, Carlos Alberto; NETO José Salibi (orgs.). Liderança e gestão de pessoas: autores e conceitos imprescindíveis. São Paulo: Publifolha, 2002. 


\section{Administração: caminhos para o desenvolvimento sustentável}

KOUZES, James M.; POSNER, Barry Z. O Desafio da Liderança. 3ạ ed., Rio de Janeiro: Elsevier, 2003.

LIMA, Manolita Correia. Monografia: A engenharia da produção acadêmica. São Paulo: Saraiva, 2004. $210 p$.

OLIVEIRA, Jair Figueiredo de MARINHO, Robson M. (orgs.). Liderança: uma questão de competência. São Paulo: Saraiva, 2006.

WEBER, M. Economia y sociedad. México, Fondo de Cultura Económica, 1992. 


\section{Capítulo 35}

\section{EXPECTATIVAS DOS ACADÊMICOS DE CIÊNCIAS CONTÁBEIS AO INICIAR O CURSO: A PERCEPÇÃO DOS CALOUROS INGRESSANTES EM 2008 NA UEPG.}

DOI: $10.37423 / 200300445$

Enelis Michelli Ruppel (UEPG) michelli_contabeis@hotmail.com

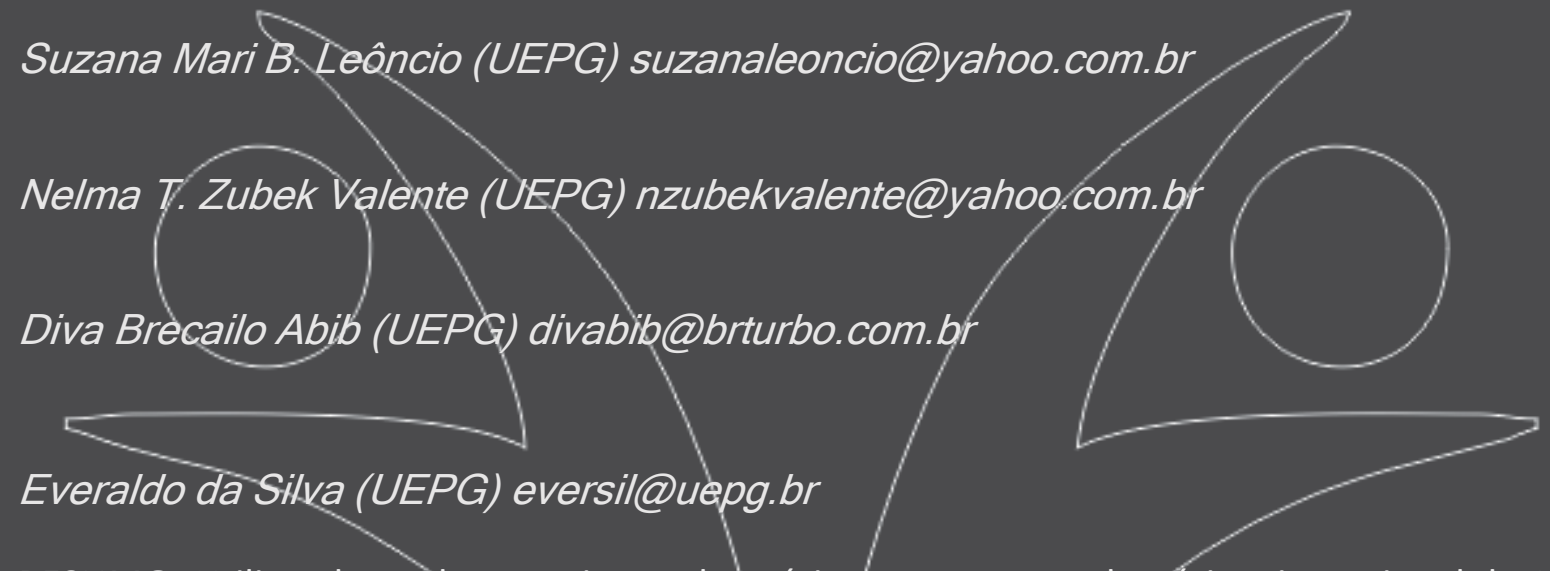

RESUMO: Utilizando-se de pesquisa exploratória com amostra aleatoria e intencional de 108 alunos de $1^{\circ}$ anos do curso de Ciências Contábejs da Universidade Estaduąl de Ponta Grossa (UEPG), ingressantes em 2008, este artigo objetivou: identificar os fatores que os levaram à escolha do curso, verificar as expectativas destes acadếmicos ao iniciar o referido curso e investigar se essas expectativas estạa sendo correspondidas. Os resultados Coletados permitiram concluir que, na amostra analisada, a escolha pelo curso de Ciências Contábeis foi motivada pelo promissor mercado de trabalho \& que a maior expectativa dos alunos ao ingressarem no curso refere-se à bòa preplakaçáp que-oferece para_o mercado de trabalho. Constatqu-se-ainda que, apesar da insatisfação đos acadềmicos pesquisados em relaçấo ao laboratório, qualificação de professores e também à falta de cursos e palestras, grande parte dos acadêmicos está considerando o curso proveitoso, apontando aspectos concretos nos quais percebem que o curso escolhido atende às suas expectativas. 


\section{Administração: caminhos para o desenvolvimento sustentável}

Palavras-chave: curso ciências contábeis, expectativas, razões escolha do curso. 


\section{Administração: caminhos para o desenvolvimento sustentável}

\section{INTRODUÇÃO}

Entrar em uma boa universidade está cada vez mais difícil. De acordo com Monteiro, (2000, p.33-34) o Ensino Superior se apresenta como uma forma de competição onde só entram os melhores, “[...] privilegiando poucos dentro do sistema de ensino". No entanto, muitas vezes quando isso acontece começam novos desafios, objetivos e uma enorme expectativa sobre o tão sonhado curso. Aí vai entrar a boa vontade do estudante em prosperar na vida, almejando tornar-se um grande profissional, lutando contra várias dificuldades, especialmente para os alunos do curso noturno como: saudades da família, problemas financeiros, divisão do tempo entre estudar e trabalhar, entre outros, fazem com que o aluno tenha menos disposição e dedicação aos estudos (OLIVEIRA, 2003, p.03). Pitela (2000, p.29) comenta ainda que muitas vezes, a opção pelo curso não corresponde aos interesses do candidato, mas apenas pela grande disponibilidade de vagas oferecidas na hora do vestibular. Tudo isso pode levar a que o curso escolhido passe a não corresponder com as expectativas do aluno após seu ingresso na universidade. Há situações em que o acadêmico tem uma idéia totalmente contrária à realidade oferecida pelo curso; procurando algo que muitas vezes o curso não proporciona e isso acaba por desmotivá-lo. Procurando verificar as expectativas que envolvem os acadêmicos dos 1ㅇanos do curso de Ciências Contábeis da Universidade Estadual de Ponta Grossa, estas pesquisadoras decidiram investigar: Quais os fatores que motivam a escolha pelo curso? Quais as expectativas dos acadêmicos de Ciências Contábeis ao iniciar o curso? O curso está correspondendo à essas expectativas? O estudo, originado de um projeto de pesquisa elaborado para a disciplina Métodos e Técnicas de Pesquisa em Contabilidade, gerou uma ampla pesquisa desenvolvida através de um projeto de iniciação científica do Programa de Iniciação Científica da UEPG onde duas autoras deste artigo atuaram como voluntárias do Programa PIBIC- Programa de Incentivo à Bolsa de Iniciação Científica do CNPQ. Assim, o presente estudo, por representar apenas uma parte da ampla pesquisa desenvolvida sobre assunto, utiliza-se da mesma base teórica que fundamenta a pesquisa global e os demais estudos parciais desenvolvidos sobre o tema em questão, devidamente mencionados na lista de referências. 


\section{Administração: caminhos para o desenvolvimento sustentável}

\section{REVISÃO DA LITERATURA}

\subsection{ACESSO. À UNIVERSIDADE}

Entrar em uma boa universidade está cada vez mais difícil. De acordo com Monteiro, (2000, p.33-34) o Ensino Superior se apresenta como uma forma de competição onde só entram os melhores, “[...] privilegiando poucos dentro do sistema de ensino".

Monteiro (2000, p.33) expõe ainda que esta competição teve início nos anos setenta, após o denominado "milagre brasileiro", enfatizando que nesse período, "[...] se pode observar a mudança de comportamento da sociedade de maneira geral, em especial dos jovens que incorporam, em seus desejos e sonhos, as formas de antecipar resultados, imediatistas e milagrosos."

No entanto, muitas vezes quando isso acontece começam novos desafios, objetivos e uma enorme expectativa sobre o tão sonhado curso.

Aí vai entrar a boa vontade do estudante em prosperar na vida, almejando tornar-se um grande profissional, lutando contra várias dificuldades, especialmente para os alunos do curso noturno como: saudades da família, problemas financeiros, divisão do tempo entre estudar e trabalhar, entre outros, fazem com que o aluno tenha menos disposição e dedicação aos estudos (OLIVEIRA, 2003, p.03).

Pitela (2000, p.29) comenta ainda que muitas vezes, a opção pelo curso não corresponde aos interesses do candidato, mas apenas pela grande disponibilidade de vagas oferecidas na hora do vestibular.

Tudo isso pode levar a que o curso escolhido passe a não corresponder com as expectativas do aluno após seu ingresso na universidade. Como afirma Schwez (1995, p.15):

Grande parte das dificuldades dos alunos reside no problema da motivação; nos conflitos entre o que eles desejam aprender e o que decorre do sistema de educação; na compreensão de seus interesses e necessidades; na descoberta dos verdadeiros motivos que determinam seu comportamento; na seleção de procedimentos que promovam desempenhos desejados. (SCHWEZ, 1995, p.15)

Há situações em que o acadêmico tem uma idéia totalmente contrária a realidade oferecida pelo curso; procurando algo que muitas vezes o curso não proporciona e isso acaba por desmotivá-lo. Neste mesmo sentido Laffin $(2005$, p. 22) complementa argumentando que as universidades na atual sociedade, "[...] não promovem um processo de ensino e de formação para atender às demandas da sociedade e de novos conhecimentos com a mesma intensidade e rapidez das mudanças do mundo moderno e objetivo." 


\section{Administração: caminhos para o desenvolvimento sustentável}

\subsection{O ENSINO DA CONTABILIDADE}

Comentando a respeito das evoluções contínuas pelas quais a profissão contábil vem passando, Rolo e Pereira (2003, p.50), afirmam que, em razão disso a profissão hoje vem se tornando um instrumental indispensável no gerenciamento das empresas. E enfatizam ainda a necessidade da transmissão dessa evolução também ao ensino da contabilidade, para permitir que os acadêmicos se tornem no futuro, excelentes profissionais.

Isto tudo é alcançado, de acordo com o autor através de pesquisas e estímulos ao questionamento "[...] tendo por meta o fortalecimento do senso critico" do aluno de ciências contábeis.

No entanto, Koliver (1999, p.27) ressalta que o curso de Ciências Contábeis deve suprir os futuros contadores:

[...] de conhecimento, habilidades e valores profissionais, bem como de capacidade de análise crítica, suficientes para o exercício profissional nos primeiros anos e ao aprendizado contínuo, com a conseqüente adaptação às mudanças que venham a ocorrer durante suas vidas profissionais. (KOLIVER, 1999, p.27)

O autor enfatiza também, que o curso de contabilidade não estimula a análise crítica do acadêmico, fazendo-o aceitar todos os procedimentos contábeis, sem impor objeções às interferências oriundas das normas e legislação.

Rollo e Pereira $(2003$, p.50) ressaltam que, para se alcançar eficácia no processo do ensino, deve-se observar a metodologia utilizada e o perfil do corpo docente e do corpo discente.

\subsection{CORPO DOCENTE}

A qualidade do ensino está intimamente ligada ao nível dos professores que lecionam. Como ressalta Rollo e Pereira (2003, p.51) :

Os professores não podem se limitar a ser meros reprodutores do conhecimento alheio na transmissão para os alunos. No processo educacional, o simples conhecimento do assunto não é suficiente, é necessário que a forma de transmissão atinja os objetivos do processo ensino-aprendizagem. (ROLLO;PEREIRA, 2003, p.51)

No entanto, Monteiro (2000, p.35) enfatiza que muitos professores são excelentes profissionais nas suas áreas específicas, mas quando entram em uma sala de aula não conseguem transmitir o conteúdo de forma clara a ser absorvida pelos alunos.

Por essa razão os professores, segundo Monteiro (2000,p.36), devem conhecer e saber bem o conteúdo da matéria que vão ministrar para ser capaz de, didaticamente, garantir que seus alunos transformem os seus ensinamentos em saber.

Nesse sentido, Laffin $(2005$, p. 21$)$ observa que: 


\section{Administração: caminhos para o desenvolvimento sustentável}

A compreensão do conhecimento, de como ele é produzido, a quem se destina e a maneira como é socializado, bem como as mudanças que provoca na vida das pessoas devem constituir procedimentos de análise critica nas ações do professor de contabilidade, pois a concepção que ele tem do conhecimento ultrapassa o âmbito da aula e dos conteúdos contábeis específicos e vai inferir na constituição de sujeitos e de subjetividades humanas. (LAFFIN, 2005, p. 21)

Assim, cabe ao educador não apenas transmitir informações, como ressalta Favarin (2000, p.2), mas principalmente desenvolver no acadêmico a capacidade de aprender a aprender, pois é dessa maneira que "[...] ele será capaz de manter-se atualizado com o seu tempo e estará apto ao pleno exercício de sua profissão."

Com respeito à formação e ao preparo do professor universitário da área contábil para o exercício de sua função de ensino, Rollo e Pereira (2003, p.52) destacam que "[...] valoriza-se muito mais a sua formação acadêmica enquanto especialista do que a sua formação educacional e pedagógica, ocasionando deficiência do conhecimento didático do corpo docente."

Segundo Monteiro (2000, p.37), a conseqüência da falta de qualificação dos professores, e a ênfase dada às aulas teóricas, deixando de lado as práticas, que são mais importantes, afeta diretamente o acadêmico, que ao se deparar com o mercado de trabalho encontra várias dificuldades em desenvolver o que aprendeu, pelo fato de ter sido adestrado para uma realidade não condizente com a apresentada em sala de aula.

Nesse mesmo sentido Pitela (2000, p.31), ressalta que o professor deve juntar o conteúdo teórico com a parte prática, para que o aluno possa perceber a interdependência entre as duas, e possam, assim, colocar em prática o conteúdo aprendido na realidade empresarial. Favarin (2000, p. 215) aponta esse distanciamento da realidade como instrumento de decepção dos alunos em relação à disciplina Contabilidade Geral considerada, segundo o autor, como "[...] espinha dorsal do Curso de Ciências Contábeis, e disciplina de fundamental importância para os cursos de Administração e Economia, além de importante disciplina para outros cursos da área empresarial." Para o autor a utilidade desta disciplina não é mostrada como deveria em razão do distanciamento entre a teoria e sua prática.

O autor apresenta como uma das soluções para motivação e aprendizagem dos alunos, os Simuladores de Transações, que no seu entender proporcionam “[...] uma ampla visão da disciplina como instrumento de informação para a tomada de decisões, sem prejuízo do aprendizado de habilidades necessárias ao desempenho das funções contábeis exigidas dos contadores." (FAVARIN, 2000, p.216) 


\section{Administração: caminhos para o desenvolvimento sustentável}

Pitela (2000, p. 32) ainda comenta que o professor é quem vai moldando, durante o curso, o perfil do futuro profissional, destacando-se que o "[...] indicador mais evidente do grau de participação dos professores no processo ensino-aprendizagem é a competência dos profissionais por eles formados." Em consonância com essa posição, Favarin (2000, p.31) observa que a responsabilidade do professor é de extrema importância, pois é dele o dever de preparar "[...] o contador em condições de atender às expectativas da sociedade a respeito da sua competência profissional e da sua qualidade como homem."

O autor ainda complementa ressaltando que as mudanças cada vez mais constantes na sociedade exigem a capacidade do profissional para se ajustar ao seu ambiente mediante melhoria de sua qualificação profissional para exercer competentemente a sua profissão e assim atender às exigências do mercado. (FAVARIN, 2000, p.31).

$\mathrm{Na}$ área contábil, as mudanças são constantes, demandada, portanto, atualização permanente dos professores, através da participação em palestras, cursos, simpósios, congressos dentre outros, conforme destacam Rollo e Pereira (2003, p.50).

\subsection{CORPO DISCENTE}

Em pesquisa realizada constatou-se que o aluno de Ciências Contábeis tem um perfil de quem estuda a noite, e uma grande parcela deles não trabalha na área relacionada à contabilidade. $O$ tempo que dedicam aos estudos e as pesquisas são mínimos. (ROLLO; PEREIRA, 2003, p.55).

Um aspecto importante a ser considerado visto que, em pesquisa realizada por Pitela (2000, p.29) nas principais instituições do Paraná, constatou-se que "[...] o acadêmico do curso de Ciências Contábeis caracteriza-se como um cidadão de classe média baixa que trabalha para se sustentar e auxiliar a família e que, portanto, estuda no período noturno, preferencialmente, em escolas públicas."

Ainda segundo esse autor, o acadêmico carrega diversos vícios trazidos de ensino de primeiro e segundo graus, como "[...] falta de hábito de leitura e ausência de objetivos definidos".

Por essa razão, Pitela (2000, p.29) enfatiza que a queda de qualidade dos cursos de ciência contábeis é decorrente das deficiências do corpo discente.

Os professores devem ter noção da capacidade de aprendizagem dos alunos, considerando que cada um tem características individuais. Salientando a importância do conhecimento das diferenças individuais os autores Rollo e Pereira (2003, p.54) afirmam que: “[...] é fundamental que os professores reconheçam os diferentes estilos de aprendizagem dos estudantes e tenham uma maior sensibilidade perante as diferenças e as experiências pessoais que os alunos trazem a sala de aula." 


\section{Administração: caminhos para o desenvolvimento sustentável}

Isso porque, segundo os autores, nem todos os estudantes ingressam no curso com o mesmo nível de aprendizagem, alguns têm maior facilidade em certas matérias e outros em outras.

Por essa razão, Rolo e Pereira (2003, p.54) sustentam que a sala de aula deve ser um ambiente motivador, para encorajar o aluno "[...] em termos de aquisição e compreensão ativa do conhecimento".

Considerando que normalmente determinadas matérias atraem maior atenção dos alunos, os autores enfatizam que nesses casos, os professores devem colocar um esforço maior para que os alunos se interessem pelo conteúdo dessas disciplinas, buscando demonstrar a sua importância em termos profissionais. (ROLLO; PEREIRA, 2003, p.56)

\section{APRESENTAÇÃO E ANÁLISE DOS RESULTADOS}

Os resultados obtidos com 108 (cento e oito) questionários válidos dos 157 (cento e cinquenta e sete) alunos regularmente matriculados nas turmas de 10 ano do curso de graduação em Ciências Contábeis da UEPG, no ano de 2008 , que representam $68,8 \%$ da população pesquisada, permitiram as constatações que serão apresentadas e analisadas a seguir.

Em relação ao perfil dos entrevistados, $51 \%$ são do sexo masculino e $49 \%$ do sexo feminino. Esta situação comprova que o curso não é essencialmente masculino, e que a mulher está em posição similar ao homem na profissão contábil. Quanto à faixa etária, observou-se que 56\% dos entrevistados têm idades que variam de 17 a 20 anos, vindo em segunda posição os alunos com idades entre 21 a 24 anos. A faixa entre 29 e 34 anos ou mais representa apenas $9 \%$ da população pesquisada, indicando que o curso não é necessariamente jovem e mostra muitos alunos voltando aos estudos após algum tempo.

Dentre os fatores que levaram à escolha do curso de Ciências Contábeis (Figura 1), 51\% dos acadêmicos destacaram o fator mercado de trabalho como o principal motivo de escolha do curso, aparecendo em segundo lugar, com 16\%, a opção "trabalho na área", e apenas 2\% motivados pela menor concorrência. Isso demonstra que o curso de Ciências Contábeis é um curso desejado, bastante valorizado e portanto, também bastante concorrido, e não somente uma segunda opção de curso pela baixa concorrência como comumente se falava no meio estudantil. Foram também mencionados outros fatores motivadores para a escolha do curso tais como: afinidade, trabalhar na área, por já ser técnico em contabilidade, por querer prestar concurso público, entre outros. 


\section{Administração: caminhos para o desenvolvimento sustentável}

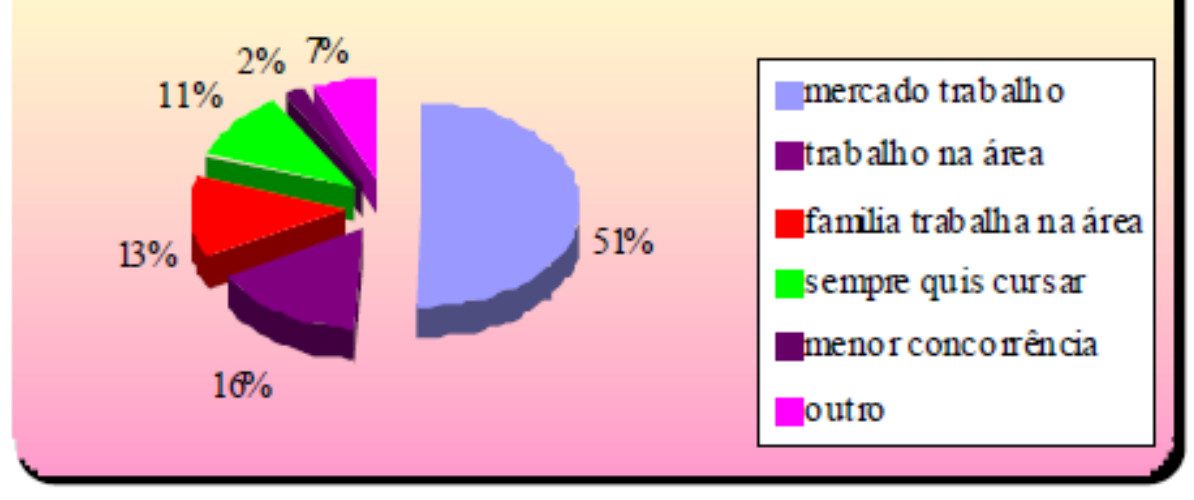

Figura 1 - Por que escolheu o curso de Ciências Contábeis?

No tocante às expectativas dos acadêmicos em relação ao curso (Figura 2), para 48\% dos pesquisados o curso de Ciências Contábeis proporciona uma boa preparação para o mercado de trabalho destacando-se esta como a principal expectativa para o ingresso no curso. Apesar disso e de também considerarem a profissão rentável que a formação do curso pode proporcionar, a opção "prestar concurso público" como expectativa para o ingresso no curso, ficou com a segunda maior concentração de respostas. $E$ ainda, $4 \%$ dos acadêmicos têm por expectativa concluir o curso apenas pelo diploma. Percebe-se assim que, a maioria dos pesquisados não ingressa na universidade apenas pelo diploma, mas sim com o intuito de adquirir técnicas e conhecimento para um bom desempenho profissional.

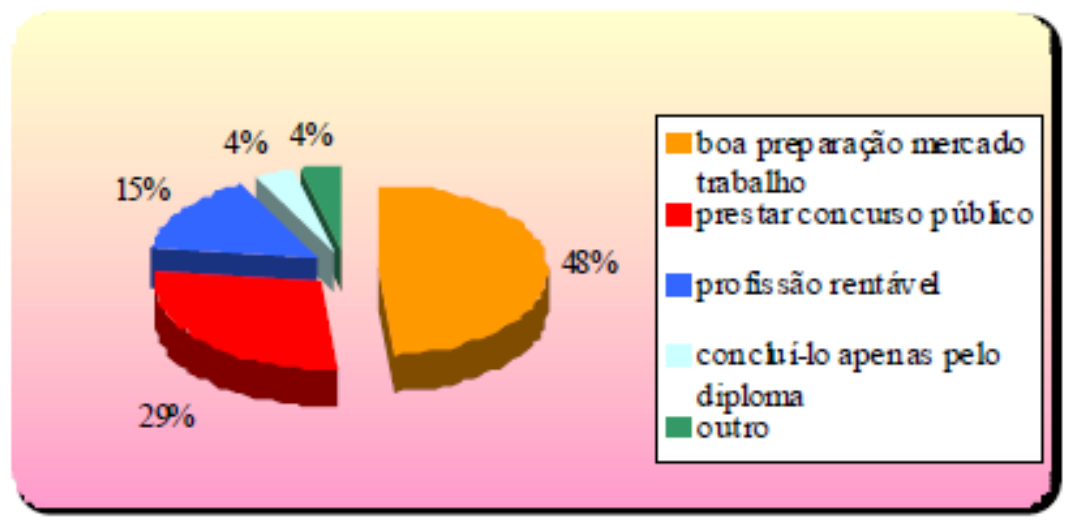

Figura 2 - Qual sua expectativa perante o curso?

Apesar de o ano letivo ter apenas começado, comentando sobre o que o curso oferece em relação às suas expectativas ao ingressar na Universidade, expondo o que sentiram ou sentem falta no curso, 73\% dos alunos pesquisados, apontaram a inexistência de um laboratório de informática como o aspecto que mais faz falta no curso. Ressaltaram também outros aspectos como a falta de mais 


\section{Administração: caminhos para o desenvolvimento sustentável}

palestras e cursos extracurriculares, a deficiência/insuficiência de livros na biblioteca, a falta de estágios e ainda a falta de professores mais qualificados.

Logo no início do curso, apesar de todas as dificuldades encontradas, $87 \%$ dos acadêmicos consideram o curso proveitoso. $13 \%$ afirmaram ainda não saber e nenhum dos pesquisados considerou o curso não proveitoso.

Em relação aos aspectos nos quais percebem que o curso de Ciências Contábeis está sendo proveitoso 29\% dos acadêmicos apontaram como fator preponderante aprender coisas novas, novos conhecimentos, em segundo lugar com $17 \%$ abertura para o mercado de trabalho e ascensão profissional. Com $15 \%$ foi apontada a aplicação da teoria na prática.

Além disso, foram também mencionados outros fatores como: o diploma no final do curso, possibilidade de prestar concursos públicos, preparo para a vida, entre outros, conforme mostra a Figura 3, a seguir.

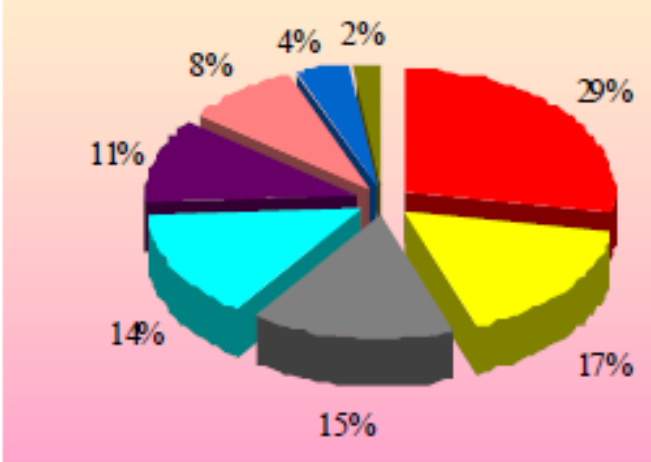

aprender coisas novas/novos conhecimentos abertura para o mercado

trabalho/ascens ão profissional aplicação da teoria na prática

aulas práticas / conhecimento útil contab ilidade

na qualidade do ensino

outios

discip hnas de legis lação comercial

não po ss o av aliar ainda

Figura 3 - Em quais aspectos considera que o curso está sendo proveitoso?

Para $72 \%$ dos pesquisados o curso está correspondendo às expectativas. Para $20 \%$ dos acadêmicos o curso está correspondendo parcialmente, e somente $8 \%$ dos pesquisados dizem que o curso não está correspondendo às suas expectativas iniciais.

Entre as razões apontadas pelos $8 \%$ de respondentes que consideram que o curso não está correspondendo às suas expectativas, foram mencionadas: a falta de professores, o despreparo de alguns professores e a falta de prática da contabilidade no curso. Parte dos pesquisados não quis opinar pelo pouco tempo decorrido de aula, não tendo por isso ainda uma opinião formada em relação ao curso. 


\section{Administração: caminhos para o desenvolvimento sustentável}

\section{CONCLUSÕES}

A análise dos resultados obtidos com base na amostra de acadêmicos pesquisados embasa e permite as considerações e conclusões, a seguir apresentadas.

No que se refere aos fatores que levaram à escolha do curso de Ciências Contábeis, os resultados obtidos com a amostra pesquisada, permitiram concluir que o fator que mais influenciou os acadêmicos na escolha do curso de Ciências Contábeis da UEPG foi o promissor mercado de trabalho, e que, em função disso, a escolha está sendo embasada em firme decisão pelo curso.

No tocante a expectativa dos acadêmicos ao ingressar no curso de Ciências Contábeis observou-se que diz respeito ao fato do curso propiciar uma boa preparação para o mercado de trabalho, que a maioria julga rentável. E também em conseqüência dessa boa preparação oferecida pelo curso, um grande número de acadêmicos ingressou no curso com a expectativa de "prestar concurso público".

Investigando se as expectativas dos acadêmicos ao ingressar no curso estão sendo correspondidas, constatou-se que para a maioria dos acadêmicos pesquisados o curso está correspondendo às expectativas, apesar de praticamente todos terem mencionado deficiências infra-estruturais, pedagógicas e curriculares.

Embora as considerações e conclusões aqui apresentadas sejam respaldadas apenas na amostra de alunos analisada, não podendo, portanto, ser generalizadas, espera-se que os resultados da presente pesquisa possam contribuir para a reflexão de todas as instâncias da UEPG, especialmente as envolvidas com o curso de Ciências Contábeis, no sentido de buscar a implementação das melhorias necessárias para que o curso venha a corresponder plenamente às expectativas dos alunos que o escolhem.

\section{REFERÊNCIAS}

FAVARIN, A. M. Uma contribuição à modelagem de simulador de transações aplicado ao ensino da contabilidade geral. São Paulo, 2000. Tese de Doutorado. FEA/USP. Universidade de São Paulo, 2000.

KOLIVER, O. As diretrizes curriculares e a formação dos contadores. Revista Brasileira de Contabilidade. AnoXXXII, n. 142, p.23-35, set/out 1999.

LAFFIN, M. De contador a professor: a trajetória da docência no ensino superior de contabilidade.

Florianópolis: Imprensa Universitária, 2005.

MONTEIRO, F. Repensando a realidade do ensino superior: projetos pedagógicos despojados. FACEP Pesquisa, V.3, p.31-43, 2000. 


\section{Administração: caminhos para o desenvolvimento sustentável}

NETO, J. D. de O.; JUNIOR, J. M.; MORAIS, L. T. Os cursos de Ciências Contábeis no Brasil e o conteúdo das disciplinas de sistemas de informação: a visão acadêmica versus a necessidade prática. Revista Contabilidade \& Finanças. FIPECAFI-FEA-USP, São Paulo, v. 16, № 27, p.59-65, set/dez, 2001.

NOSSA, V. Ensino de contabilidade no Brasil: uma análise crítica da formação do corpo docente. São Paulo, 1999. Dissertação de Mestrado. FEA/USP. Universidade de São Paulo, 1999.

OLIVEIRA, E. Ensino, aprendizagem e avaliação do conhecimento. Portal da Classe Contábil. Ano III, n. 1051, 2003, ISSN 1679-8732. Disponível

em: http://www.classecontabil.com.br/servlet_art.php?id=142 Acesso em: 09. out. 2005

PASSOS, I. C. A interdisciplinaridade no ensino e na pesquisa contábil: um estudo do município de São Paulo. Ano 2004. Dissertação de Mestrado - FEA/USP Universidade de São Paulo, 2004. Disponível em:http://www.teses.usp.br/disponiveis/12/12136/tde-03032005-144822/ Acesso em 04 nov. 2005. PEREIRA, D. M. V. G. et. al. A formação e a qualificação do contador face ao programa mundial de estudos em contabilidade proposto pelo ISAR: Uma abordagem no processo ensino-aprendizagem. Anais do 20 Congresso USP de Iniciação Científica em Contabilidade. Ano 2005, p.1-16. Disponível em: http://www.congressoeac.locaweb.com.br/artigos22005/an_resumo.asp?cod_trabalho. Acesso em: 15. dez. 2005.

PITELA, A. C. O perfil do corpo docente dos cursos de Ciências Contábeis. In: Revista do CRC-PR. Ano $25, \mathrm{n}$ ㅇ 128, dez/2000.

QUAGLIATO, J. D. Por um novo ensino da contabilidade. In: Revista do CRC-PR. Ano 25, no 128, dez/ 2000.

ROLLO, L. F.; PEREIRA, A. C. Análise do processo educacional contábil sob o prisma de seus elementos de maior relevância. In: Revista Brasileira de Contabilidade. Ano XXXII, no 142, p. 49-57, jul/ago. 2003. RUPPEL, E. M.; VALENTE, N. T. Z. Fatores considerados na escolha do curso de ciências contábeis e as expectativas em relação ao curso: estudo exploratório com os acadêmicos do curso de graduação em ciências contábeis da Universidade Estadual de Ponta Grossa (UEPG). Anais do XV EAIC e VI EUEPG, 22 a 25 de agosto de 2006, Ponta Grossa, Paraná, ISSN: 1676-0018.

RUPPEL, E. M.; LEÔNCIO, S. M. B.; VALENTE, N. T. Z.; ABIB, D. B. Expectativas dos acadêmicos de ciências contábeis ao iniciar o curso e dificuldades encontradas para concluí-lo: estudo de caso na UEPG. Anais do III ENPPEX - Encontro Paranaense de Pesquisa e Extensão em Ciências Sociais Aplicadas. 18 a 20 de junho de 2007, Ponta Grossa, Paraná.

SCHWEZ, N. Reflexão sobre o papel do professor na área contábil. In: Revista Brasileira de Contabilidade. Ano XXXIV, no.91, p.13-15, jan/fev 1995. 


\section{Administração: caminhos para o desenvolvimento sustentável}

VASCONCELOS, Y. L. A Universidade frente ao problema da formação intelectual no curso de Ciências Contábeis. Revista Brasileira de Contabilidade. Ano XXX, nำ127, p. 67-68, 2001 


\section{Capítulo 36}

\section{GESTÃO DE DOCUMENTOS E O GERENCIAMENTO DA INFORMAÇÃO DOCUMENTAL: ESPECIFICAÇÃO DE UMA SOLUÇÃO PARA UMA UNIDADE ADMINISTRATIVA DE UMA UNIVERSIDADE PÚBLICA}

\section{DOI: $10.37423 / 200300446$}

\section{Dorival José Batista (UEM)}

Álvaro José Reriotto (UEM)

Tania Regina Corredato Periotto (Unicesumar)

RESUMO: Os novos paradigmas tecnológicos propõe a/releitura das técnicas vigentes e determina maior atenção àos processos geradores de produtøs e serviços nos diferentes segmentos e organizações. Na Administração Pública/essencial Imente formal e conservadora, os processos de Gestão de Documentos ainda observam padrões em descompasso com a realidade. O gerenciamento da informaçãd documental, vital para a fotina administrativa nas ações inerentes ao planejamento, controle e subsídio às consultas, tramitação de processos, estruturação de relatos e produção de novas/peças, dentre outros, emb bra assíduo nas discussões sobre otimização dos processos, parece resignado e inerte diante da falta de soluçôes próprias. Esse parece ser o cenárib típico/da organização pública com pequenas variações em suas costumeiras dificuldades operacionais para recuperar as informações releyantes e necessárias em tempo hábil. Ao donsjiderarmos o valor que os documentos são capazes de agregar ao contexta des processos administrattivos, os ganhos em eficiência e eficấcia nas ações administrativas, proporcionados pelo gêrenciamento efetivo da informação documental e as perspectivas estratégicas que se estabelecem com a gestão de uma "inteligência institucional", temos argumentos e motivações suficientes para a intensificação da pesquisa aplicada nesse contexto. 


\section{Administração: caminhos para o desenvolvimento sustentável}

Com o desenvolvimento do presente trabalho e os resultados parcimoniosamente alcançados, estabeleceu-se uma solução exemplar para um dos departamentos acadêmicos da Universidade Estadual de Maringá, uma universidade pública, que ganhou especial importância e respeito na pesquisa nacional e tornou-se igualmente exitosa no ensino e formação de profissionais nas diferentes áreas do conhecimento humano. Entretanto, mesmo contando com um aparato tecnológico de suporte à rotina universitária, questões rotineiras como as dificuldades para localização e recuperação de documentos, decorrentes da falta de informação sobre os mesmos - vigência ou indicações de relacionamentos com outros, por exemplo - ganharam significativas proporções e se transformaram em problemas gerados pela gestão de documentos arquivados em consonância com as normas que orientam os processos públicos, especialmente relacionadas com as necessidades de armazenamento e recuperação de documentos: parâmetros de normatização definidos pelo Conselho Nacional de Arquivos (CONARQ) e pelo Departamento Estadual de Arquivo Público (DEAP) para o Código de Classificação de Documentos, Tabela de Temporalidade e Destinação. Assim, o presente trabalho expõe detalhadamente os elementos de contexto para expor e, ao final, discutir os resultados da pesquisa aplicada: o trabalho de análise de requisitos essenciais de gestão documental para uma unidade administrativa da Universidade seguida da especificação de uma solução de software para ambiente Web, replicável e customizável para outras unidades, visando atender ao gerenciamento de suas informações documentais e abarcando o armazenamento e a recuperação de documentos gerados pelos diferentes órgãos na Instituição. A eliminação de redundâncias, a criação de interrelacionamentos entre documentos e as múltiplas formas de pesquisa e recuperação, sustentam a solução resultante e estabelecem boas perspectivas para a administração gerencial, de suporte e nos níveis estratégicos.

Palavras-chave:Gestão documental. Sistemas de Informações Corporativos. Inteligência Organizacional. Gestão do Conhecimento. Administração Pública. 


\section{Administração: caminhos para o desenvolvimento sustentável}

\section{INTRODUÇÃO}

Muito diferente dos dias atuais, os primeiros computadores não se mostravam atraentes, chegando às grandes instituições públicas e privadas dos países desenvolvidos apenas nas décadas de 60 e 70 . Analogamente, a vertente dos PC's ingressou no mercado com algumas fragilidades, exigindo espera por um padrão tal que o colocasse como viável para a adoção de empresas de menor porte e usuários domésticos. O mesmo fenômeno se repetiu com a Internet, que aguardou até o advento da Web para se tornar um ícone de nossa sociedade.

Tais mudanças impactaram diretamente nas organizações com a descentralização de atividades informatizadas, emprego de sistemas transacionais e gerenciais operados com extrema facilidade e a geração de uma demanda informacional customizada, refletindo na necessidade de soluções próprias de sua disseminação nas redes corporativas ou abertas.

Juntamente com esse processo de intensa adoção de recursos tecnológicos, os documentos, até então gerados em papel através de processos manuais ou mecânicos convencionais, passaram a ser gerados em meio eletrônico, armazenados em suporte magnético e ótico em substituição ao suporte físico. Desta forma surge o documento digital.

Assim, juntamente com os documentos digitais, passou-se a explorar as vantagens dos processos inerentes a eles, no que diz respeito à produção, armazenamento, distribuição e acesso. A massificação desses processos introduziu, em contrapartida, algumas desvantagens, dentre as qua is a informalidade dos registros e emprego de linguagem apropriada, flexibilização ou distorção nos procedimentos administrativos, acesso não autorizado. Nos casos mais graves, a exploração criminosa da tecnologia digital, introduziu na sociedade os ataques às bases documentais, fraudes e crimes.

A nova tecnologia trouxe também novas preocupações e apenas para ilustrar algo que se torna corriqueiro, duas dessas preocupações atingem em especial os setores da Administração Pública no que diz respeito à preservação dos documentos digitais à longo prazo: a obsolescência - tanto do hardware como do software - e a degradação das mídias digitais. Contudo, as diversificações de aplicações introduzem maior complexidade ao gerenciamento dos processos dado que já se incorporou uma cultura de geração de documentos oriundos de editores de textos, planilhas, mensagens de correio eletrônico, bases de dados, imagens fixas, imagens em movimento, gravações sonoras, página da Web, etc.

Para garantir acesso contínuo e sistematizado às bases documentais faz-se necessário a implantação de um Programa de Gestão de Documentos. 


\section{Administração: caminhos para o desenvolvimento sustentável}

Os cuidados com a guarda e o acesso aos documentos públicos são antigos, porém só recentemente esta preocupação começou a ser regulamentada. Os órgãos públicos produzem e manipulam inúmeros documentos diariamente. Estes documentos advêm de suas próprias repartições ou de órgãos externos de diferentes esferas executivas, legislativas e judiciárias.

A Universidade Estadual de Maringá é uma autarquia do Governo do Estado do Paraná e, sendo classificada como um Órgão Secundário é integrante da Organização de Arquivos do Poder Executivo enquadrando-se no disposto no art. 3ㅇ da resolução № 3.107, de 25 de setembro de 1995 em seu inciso II que tem o seguinte teor: "Órgãos Secundários: arquivos setoriais e gerais da Secretaria de Estado e demais órgãos da Administração Direta e Indireta", desta forma cabe a ela cumprir o disposto no art. 50 da referida resolução que trata da "Competência dos Órgãos Secundários".

Atualmente na Universidade Estadual de Maringá a publicação na Web ocorre apenas para o tipo documental resolução, produzidos pelos conselhos superiores: Conselho de Administração - CAD, Conselho de Ensino, Pesquisa e Extensão - CEP e o Conselho Universitário - COU através do site www.scs.uem.br. De forma simples, organizada por ano, e em ordem numérica decrescente. Os documentos estão disponíveis para usuários internos e externos à instituição.

Considerando, por exemplo, o Departamento de Engenharia Química, enquanto unidade administrativa, suas publicações contemplam vários tipos documentais emitidos e recebidos. Os diferentes tipos de documentos emitidos são gerados através de editor de texto, onde a informação ganha o formato digital e são convertidos em formato de arquivo PDF - Portable Document Format, desenvolvido para representar documentos de maneira independente do aplicativo, do hardware e do sistema operacional usados para criá-los. Adicionalmente, os documentos recebidos passam pelo scanner para gerarem uma imagem digital em formato PDF. Tanto os documentos emitidos como os recebidos são disponibilizados em páginas da intranet do departamento, organizados por ano, por tipo documental e número do documento. Cabe ressaltar que o acesso é restrito a professores e funcionários lotados no departamento.

Como resultado de um estudo prévio das dimensões do contexto considerado, organizou-se a Tabela 1, que apresenta o volume de documentos, do tipo "resolução" produzidos nos conselhos superiores da Universidade e na unidade administrativa acima considerada no período de pesquisa compreendendo os anos de 2005 à 2008, que foram submetidos ao tratamento digital descrito. 


\section{Administração: caminhos para o desenvolvimento sustentável}

Tabela 1 - Volume de documentos emitidos

\begin{tabular}{l|l|l|l|l|l}
\hline Emissor & 2005 & 2006 & 2007 & $2008^{*}$ & Total \\
\hline COU & 29 & 31 & 25 & 8 & 93 \\
\hline CEP & 220 & 226 & 178 & 39 & 663 \\
\hline CAD & 602 & 601 & 546 & 413 & 2162 \\
\hline DEQ & 162 & 208 & 334 & 223 & 927 \\
\hline Total & 1013 & 1066 & 1083 & 683 & 3845 \\
\hline Média & 253,25 & 266,5 & 270,75 & 170,75 & 961,25 \\
\hline Mínimo & 29 & 31 & 25 & 8 & 93 \\
\hline Máximo & $602 \quad *$ & 601 & 546 & 413 & 2162 \\
\hline
\end{tabular}

Fonte: dados da pesquisa

As fontes de geração destes documentos são, portanto, diversas e decorrentes de vários níveis da administração. Ressalta-se ainda que geralmente um documento emitido relaciona-se com outros documentos como fontes de referência, sendo que cada um desses documentos tem um prazo específico de validade.

A complexidade na gestão de documentos e informações aumenta significativamente ao considerarmos a diversidade de tipos documentais emitidos pelos vários órgãos da instituição, conforme exemplificado no Quadro 1.

\begin{tabular}{l}
\hline Edital 023/2008-SCS (Secretaria dos Colegiados Superiores) \\
Fica convocado, o CONSELHO DE ENSINO, PESQUISA E EXTENSÃO, para a reunião a realizar-se no \\
dia 25/06/2008, quarta-feira, às 14h, no Auditório dos Conselhos Superiores - Reitoria \\
\hline Ofício Circular 005/2008-DCF (Diretoria de Contabilidade e Finanças) \\
Ref. Mudança de Instituição bancária responsável pelo processo de Arrecadação da UEM. De: Banco Itaú Para: \\
Caixa Econômica Federal \\
\hline Ofício 041/2008-UNI (Núcleo/Incubadora Unitrabalho) \\
A Fundação Unitrabalho convida para Seminário de Economia Solidária, Soberania Alimentar e Agroenergia. \\
\hline Portaria 336/2008-GRE (Reitoria) \\
Art $1^{\circ}$ O resultado final do Concurso Público para a Carreira do Magistério Público do Ensino Superior do Estado \\
do Paraná para suprir vagas da Universidade Estadual de Maringá, aberto por meio do Edital 14/2008-PRH, para \\
as áreas de conhecimento abaixo. \\
\hline Resolução 023/2008-CTC (Centro de Tecnologia) \\
Ementa: Aprovar o novo Regulamento para edição da Revista Tecnológica do Centro de Tecnologia \\
\hline
\end{tabular}

Quadro 1 - Diversidade de tipos documentais (Fonte: dados da pesquisa)

No mesmo levantamento procedeu-se à seleção aleatória de diversos documentos relacionados a um tipo documental específico, tomando-se por base uma "Resolução" expedida pelo CEP, Conselho de Ensino, Pesquisa e Extensão. A título de ilustração foi construída a figura 1 que exemplifica o fato de que uma única Resolução pode referenciar documentos de diversos níveis dentro da própria Instituição, bem como de órgãos externos. 


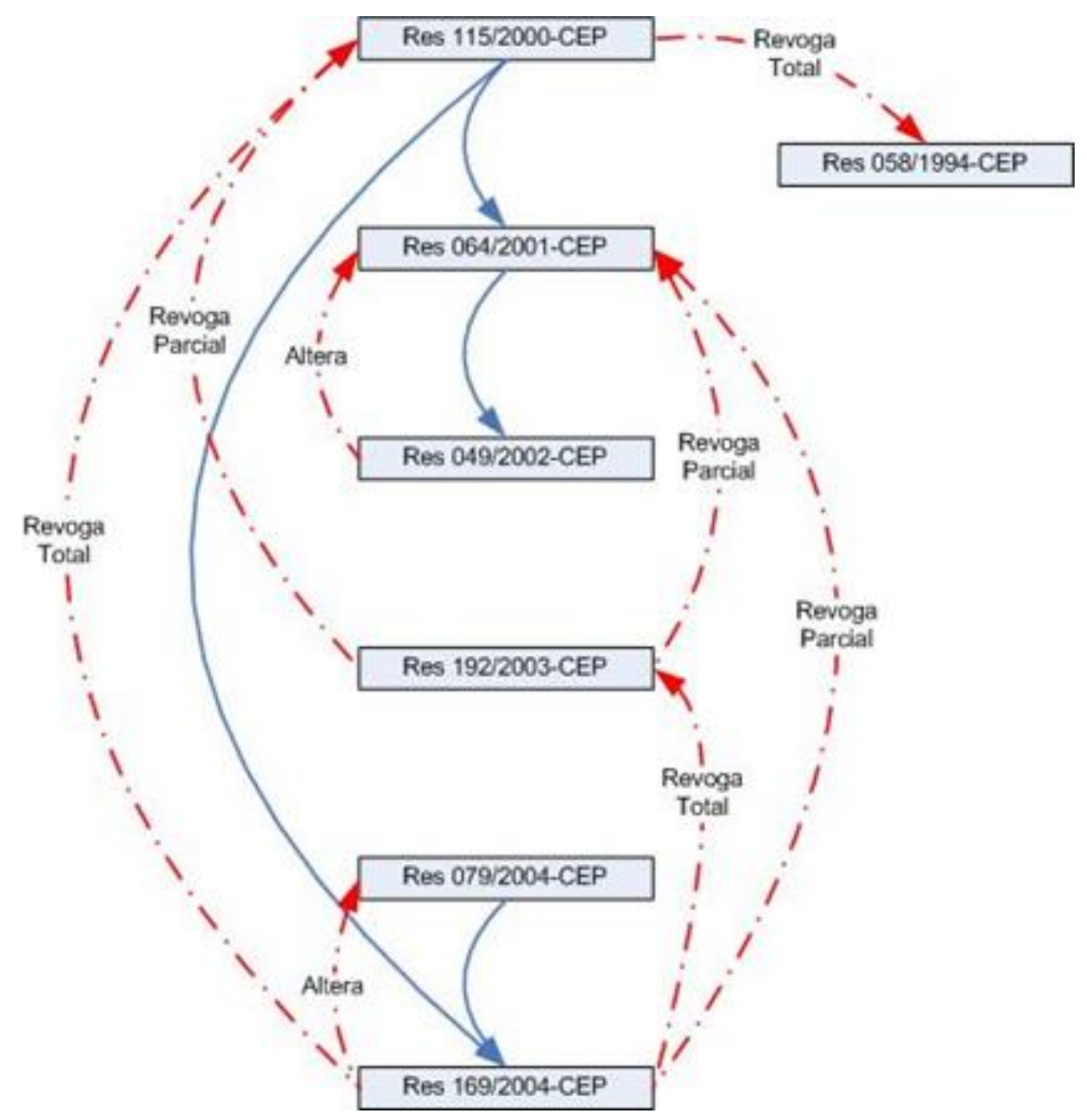

Figura 1 - Fluxo dos Relacionamentos dos Documentos (Fonte: dados da pesquisa)

Em processos semelhantes ao ilustrado pela Figura 1, os relacionamentos são classificados como "Referência" e "Interferência". O primeiro caso ocorre quando um novo documento usa um ou mais documentos anteriores como fonte de referência. A "Interferência" ocorre quando um novo documento altera, revoga parcial ou total um ou mais documentos anteriores.

Estes documentos são arquivados nas unidades administrativas geradoras e as demais unidades administrativas que os recebem também procedem ao arquivamento, porém podendo adotar uma metodologia própria. Além dos problemas de redundância, outras dificuldades aparecem quando há necessidade de recuperação destas informações. Para ilustrar, durante a realização do um levantamento prévio, foi encontrado um ofício convidando uma autoridade para cerimônia de um evento em outubro de 2006, armazenado desnecessariamente ainda em 2008, uma vez que já cumpriu a sua função e não há nenhuma obrigação legal que exija a sua manutenção. Em outro caso, uma resolução que já foi revogada, entretanto ao consultá-la não há indicação que isto tenha ocorrido, agravando situações de análise que remetem a documentos correlatos de maneira inócua. 


\section{Administração: caminhos para o desenvolvimento sustentável}

Assim, além de aspectos de classificação e temporalidade, o uso de documentos na Administração Pública leva aqueles que os manipulam a averiguar documentos correlatos ao assunto, questionar a validade dos mesmos, suas modificações, revogações, necessidade de armazenamento e possibilidade de eliminação, entre outros.

Em função disso, formulou-se a seguinte questão de pesquisa:

Como uma solução tecnológica apropriada pode atender às necessidades de armazenamento e recuperação de documentos oficiais em uma unidade administrativa?

Para viabilização do desenvolvimento de um estudo de especialização, decidiu-se reduzir seu escopo, pela formulação do seguinte objetivo geral:

Desenvolver estudo sobre as características específicas da Universidade Estadual de Maringá em relação aos requisitos essenciais para a Gestão Arquivística de Documentos e especificar um modelo, para operação ambiente Web, capaz de atender às necessidades de armazenamento e recuperação de documentos oficiais em uma unidade administrativa da Instituição.

Na sequência dessa introdução o presente trabalho traz uma revisão teórica sobre Gestão de Documentos seguida de uma descrição do processo que culmina no modelo proposto: Sistema Informatizado de Gestão Arquivística de Documentos (SIGAD). Em sua apresentação verifica-se que o modelo de requisitos sintetiza as propostas elaboradas pelo CONARQ (ARQUIVO NACIONAL, 2006). Finalmente, junto a uma breve discussão acerca da da proposta especificada, são apresentadas considerações sobre o modelo proposto frente aos parâmetros pontuados para sua avaliação, bem com considerações acerca dos objetivos do presente estudo.

\section{GESTÃO DOCUMENTACIONAL - LEGISLAÇÃO E NORMATIZAÇÃO}

A Constituição Federal de 1988, em seu artigo 216, parágrafo $2^{\circ}$ define que: "cabem à administração pública, na forma da lei, a gestão da documentação governamental e as providencias para franquear sua consulta a quantos dela necessitem" (BRASIL, 1988).

Posteriormente com a promulgação da Lei no 8.159, de 8 de janeiro de 1991, se estabelece uma política nacional de arquivos públicos e privados, juntamente com a criação de programas de gestão de documentos, que reúnem procedimentos e operações técnicas referentes à produção, tramitação, uso, avaliação e arquivamento de documentos (BRASIL, 1991). Essa Lei estabelece a responsabilidade do Poder Público sobre a gestão documental, estabelece a criação do Conselho Nacional de Arquivos 


\section{Administração: caminhos para o desenvolvimento sustentável}

- CONARQ como órgão responsável pela política nacional de arquivos e, em seu segundo artigo qualifica "arquivos"

Art. 2o - Consideram-se arquivos, para os fins desta Lei, os conjuntos de documentos produzidos e recebidos por órgãos públicos, instituições de caráter público e entidades privadas, em decorrência do exercício de atividades específicas, bem como por pessoa física, qualquer que seja o suporte da informação ou a natureza dos documentos. (BRASIL, Lei no 8.159, de 8 de janeiro de 1991).

Complementarmente, a mesma Lei estabelece as responsabilidades na organização dos arquivos Estados, do Distrito Federal e dos Municípios e define garantias de acesso aos arquivos públicos:

Art. 21ㅇ - Legislação Estadual, do Distrito Federal e municipal definirá os critérios de organização e vinculação dos arquivos estaduais e municipais, bem como a gestão e o acesso aos documentos, observado o disposto na Constituição Federal, e nesta Lei.

Art. $22^{\circ}$ - É assegurado o direito de acesso pleno aos documentos públicos. (BRASIL, Lei no 8.159 , de 8 de janeiro de 1991).

Seguindo determinação da Constituição Federal e da Lei Federal 8.159, o Estado do Paraná, criou o "Departamento Estadual de Arquivo Público - DEAP" como o órgão central da organização de arquivos do Estado do Paraná através da Resolução no 3.107, de 25 de Setembro de 1995, e define competências para elaborar normas sobre arquivo de documentos, elaboração de tabela de temporalidade, acompanhamento e orientação de atividades arquivísticas, conforme estabelece seu Artigo 5:

Art. 50 - É de competência dos Órgãos Secundários:

I - elaborar conjunto de normas disciplinares internas de recepção, produção, tramitação e arquivamento de documentos gerados e recebidos em seus respectivos âmbitos de atuação;

II - participar do processo de avaliação de documentos e elaborar Plano de Destinação e Tabela de Temporalidade de Documentos, no âmbito dos Órgãos da Administração Direta e Indireta do Poder Executivo, por meio das Comissões Setoriais de Avaliação;

III - acompanhar e orientar a execução das atividades arquivísticas de acordo com as rotinas estabelecidas;

IV - prestar ao Órgão Central informações sobre as suas atividades e apresentar sugestões para o aprimoramento da Organização de Arquivos. (PARANÁ, Resolução no 3.107, de 25 de Setembro de 1995).

Em conformidade com o CONARQ, os documentos arquivísticos conferem aos órgãos e entidades a capacidade de conduzir as atividades de forma transparente, possibilitando a governança e o controle social das informações, bem como apoiar e documentar a elaboração de políticas e o processo de tomada de decisão. Nesta perspectiva, são considerados requisitos dos documentos arquivísticos: ser 


\section{Administração: caminhos para o desenvolvimento sustentável}

confiáveis, autênticos, acessíveis, compreensíveis e possa ser preservado, o que só é possível por meio da implantação de um programa de Gestão Arquivística de Documentos (ARQUIVO NACIONAL, 2006). Para aprofundar no conceito de Gestão Arquivística de Documentos, é necessário inicialmente conceituar as três idades, que são: Idade Corrente, Idade Intermediária e Idade Permanente. Idade Corrente - refere-se a documentos em curso, que embora arquivados, são objetos de consultas freqüentes e devem ser conservados sob a guarda do órgão produtor; Idade Intermediária - trata-se de documentos fora de uso que aguardam o cumprimento do prazo estabelecido pela tabela de temporalidade e destinação para serem eliminados ou recolhidos ao arquivo permanente; Idade Permanente - documentos que devem ser definitivamente preservados devido ao seu valor histórico, probatório ou informativo.

A transição entre as idades é feita através do processo de avaliação que leva em conta a freqüência de uso do documento e a identificação de seus valores primários e secundários.

O Valor Primário refere-se ao valor do documento para atender aos fins pelo qual foi produzido, sejam esses fins de caráter administrativo, legal ou fiscal. Os documentos apenas com valor primário podem ser eliminados após o cumprimento do prazo de arquivamento estabelecido na Tabela de Temporalidade.

Valor Secundário refere-se ao valor do documento para atender outros fins que não são, necessariamente, aqueles pelos quais foi criado. Os documentos com valor secundário apresentam interesse cultural, científico, tecnológico ou histórico. Devem ser preservados em caráter permanente, mesmo já tendo cumprido suas finalidades primárias.

Enquanto todos os documentos têm um valor primário que dura mais ou menos tempo conforme os casos, nem todos têm ou adquirem necessariamente um valor secundário (ARQUIVO NACIONAL, 2001). Documentos que cumpriram o seu valor primário, mas não apresentam valor secundário deverão ser eliminados, entretanto os que já atenderam o valor primário e apresentam valor secundário deverão ser preservados permanentemente.

Desta form, percebe-se a necessidade de uma série de instrumentos de apoio aos procedimentos e operações técnicas de Gestão Arquivística de Documentos como o Plano de Classificação baseado nas funções e atividades do órgão ou entidade e da Tabela de Temporalidade e Destinação de Documentos. 


\section{Administração: caminhos para o desenvolvimento sustentável}

Um Plano de Classificação constitui-se de um esquema de distribuição de documentos em classes, de acordo com os métodos de arquivamento específicos, elaborado a partir do estudo das estruturas e funções de uma instituição e da análise do arquivo por ela produzido (ARQUIVO NACIONAL, 2005). A Tabela de Temporalidade e Distribuição é o instrumento de apoio que determina os prazos de guarda, recolhimento e eliminação e deverá contemplar atividades-meio - que dão apoio à execução do objetivo precípuo de uma instituição - e atividades-fim, ou seja, aquelas para as quais a instituição foi criada.

No Paraná, o DEAP elaborou um Plano de Classificação e uma Tabela de Temporalidade e Distribuição de Documentos para atividades-meio que todos os órgãos do Poder Executivo. No que diz respeito ao Plano e Tabela para atividades-fim, estes deverão ser elaborados pela comissão setorial de avaliação de cada órgão conforme previsto na Resolução 3.107.

Um programa de gestão arquivística de documentos deverá cumprir uma série de requisitos, tais como, o ciclo de vida dos documentos, garantir a acessibilidade dos documentos, manterem os documentos em ambiente seguro, reter os documentos somente pelo período estabelecido na tabela de temporalidade e destinação, implementar estratégias de preservação dos documentos desde a sua produção pelo tempo que for necessário, garantir as seguintes qualidades de um documento arquivístico: organicidade, unicidade, confiabilidade, autenticidade e acessibilidade.

Como ilustração, pode-se verificar que uma vez aplicadas as codificações do Plano de Classificação de Documentos e Tabela de Temporalidade e Destinação de Documentos para atividades-meio, decorrido o prazo de um ano da publicação uma Portaria de convocação de um Colegiado Superior da UEM, o documento seria eliminado desobstruindo o armazenamento; ao passo que uma Portaria da Reitoria da UEM de divulgação dos resultados de um concurso público, após dezesseis anos de sua publicação, deverá ser transferido para o Arquivo Permanente do DEAP e não poderá ser eliminado em tempo algum (ver Quadro 2). 


\begin{tabular}{|c|c|c|c|c|c|}
\hline \multicolumn{6}{|c|}{ Portaria 336/2008-GRE (Reitoria) } \\
\hline \multicolumn{6}{|c|}{$\begin{array}{l}\text { Art } 1^{\circ} \mathrm{O} \text { resultado final do Concurso Público para a Carreira do Magistério Público do Ensino Superior do } \\
\text { Estado do Paraná para suprir vagas da Universidade Estadual de Maringá, aberto por meio do Edital 14/2008- } \\
\text { PRH, para as áreas de conhecimento abaixo. }\end{array}$} \\
\hline \multirow{5}{*}{$\begin{array}{l}\text { Código de } \\
\text { Classificação }\end{array}$} & \\
\hline & \multicolumn{5}{|c|}{\begin{tabular}{|l|l|}
$0-2-4-2$ & (Atividade-meio) \\
Classe & ADMINISTRAÇ̃̃O GERAL
\end{tabular}} \\
\hline & Subclasse & \multicolumn{4}{|c|}{ Recursos Humanos } \\
\hline & Grupo & \multicolumn{4}{|c|}{ Recrutamento. Seleção } \\
\hline & Subgrupo & \multicolumn{4}{|c|}{ Processo de Seleção } \\
\hline \multirow[t]{3}{*}{ Temporalidade } & \multicolumn{4}{|c|}{ Prazos de Arquivamento } & \multirow{2}{*}{ Eliminação } \\
\hline & Setor & Geral & DEAP - AI & DEAP - AP & \\
\hline & 2 anos & 14 anos & -- & Sim & Não \\
\hline
\end{tabular}

\section{Quadro 2 - Elementos da publicação de um documento de acordo com o Plano de Classificação e}

Temporalidade (Fonte: dados da pesquisa)

A despeito das conseqüências operacionais, percebe-se, através do quadro 2, a sistematização clara da classificação e da temporalidade do documento, agregando valor ao documento, enquanto, peça de conteúdo informacional.

\section{PROPOSTA DE UM SISTEMA INFORMATIZADO DE GESTÃO ARQUIVÍSTICA DE DOCUMENTOS}

O CONARQ estabelece no documento o Modelo de Requisitos para Sistemas Informatizados de Gestão Arquivística de Documento - e-ARQ Brasil - os requisitos mínimos para um Sistema Informatizado de Gestão Arquivística de Documentos - SIGAD - independente da plataforma tecnológica em que for desenvolvido e/ou implantado (ARQUIVO NACIONAL, 2006).

O SIGAD reúne um conjunto de procedimentos e operações técnicas, característico do sistema de gestão arquivística de documentos, processado por computador. Pode compreender um software particular, um determinado número de softwares integrados, adquiridos ou desenvolvidos por encomenda, ou uma combinação desses.

O SIGAD inclui operações como: captura de documentos, aplicação do plano de classificação, controle sobre os prazos de guarda e destinação, armazenamento seguro e procedimentos que garantam o acesso e a preservação a médio e longo prazo de documentos arquivísticos digitais e não digitais confiáveis e autênticos. Tratando-se de documentos digitais, deve abranger todos os tipos de documentos arquivísticos digitais, tais como: textos, imagens fixas, imagens em movimento, gravações sonoras, mensagens de correio eletrônico, páginas Web, bases de dados entre outras possibilidades. O modelo de software proposto neste estudo, destinado à gestão documentacional na UEM, se estabelece sob a tecnologia de ambiente Web, que permite o registro, armazenamento e a recuperação sem dependência da plataforma de hardware ou software que o usuário utiliza. 


\section{Administração: caminhos para o desenvolvimento sustentável}

Apresenta três formulários de cadastros que permitem o suporte ao cadastro de documentos, representados na Figura 2. A finalidade destes formulários é obter melhor eficiência e garantir padronização dos dados no momento da captura do documento.

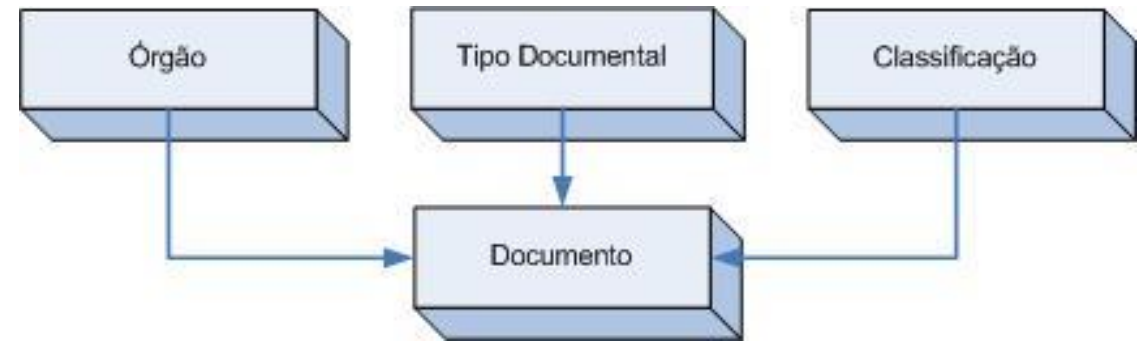

Figura 2 - Relacionamento entre os Formulários do SIGAD (Fonte: elaboração própria)

O formulário Cadastro de Órgãos e o formulário Cadastro de Tipo Documental têm como objetivo a padronização dos nomes de órgãos e tipos documentais da instituição e garantir a inserção de novas instâncias.

Um dos pontos fortes na Gestão Arquivística de Documentos é a Classificação de Documentos e a tabela de Temporalidade e Destinação aqui representada pelo formulário Cadastro de Classificação conforme Figura 3.

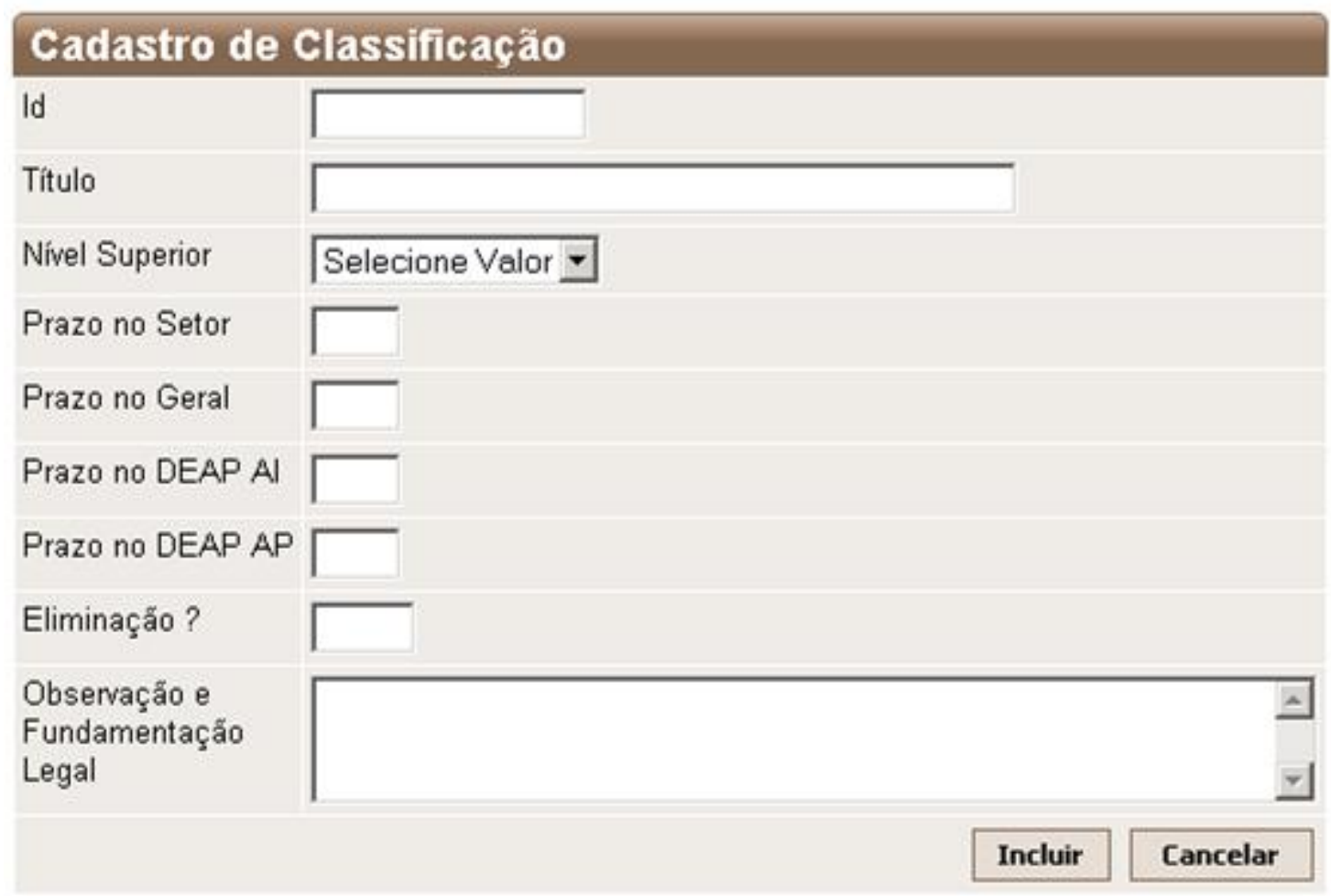

Figura 3 - Formulário de Cadastro de Classificação

Com base nos requisitos essenciais, os atributos são: código de classificação pelo método de codificação do DEAP; o nome da classe, subclasse, grupo ou subgrupo conforme o nível hierárquico; 


\section{Administração: caminhos para o desenvolvimento sustentável}

os prazos de guarda no setor e no arquivo geral do órgão; prazos de guarda no DEAP para: arquivo intermediário e arquivo permanente; permissão de eliminação; observações e fundamentação legal relacionadas ao documento.

O ponto de captura de um documento em um SIGAD é o momento que o sistema é alimentado com dados do documento que foi gerado, quer seja documento digital ou documento convencional.

O formulário Cadastro de Documento Oficial tem esta finalidade onde o responsável pela geração do documento fará o preenchimento dos dados e no mesmo formulário executará a carga do documento digital ou o link para o documento no site do órgão gerador para que esteja a disposição para pesquisa, localização e apresentação (ver Figura 4).

Os dados deste formulário são baseados nos requisitos essenciais e são eles: sigla do órgão emissor; tipo documental; número do documento; ano do exercício da geração do documento; texto com a ementa do documento; texto com o conteúdo do artigo 1ㅇ da resolução; data da emissão do documento; data da publicação do documento; número de folhas; data do registro no SIGAD; nome da autoridade signatária (completo); cargo da autoridade signatária; o código de classificação e de temporalidade (previamente cadastrado através do formulário Cadastro de Classificação); localização da pasta onde se encontra o documento digital a ser publicado para carga ou o link do documento no site do órgão gerador. Entende-se por carga do documento, a transferência de uma cópia do documento para determinada pasta dentro da estrutura do SIGAD elaborada a partir da tabela de classificação. 


\section{Administração: caminhos para o desenvolvimento sustentável}

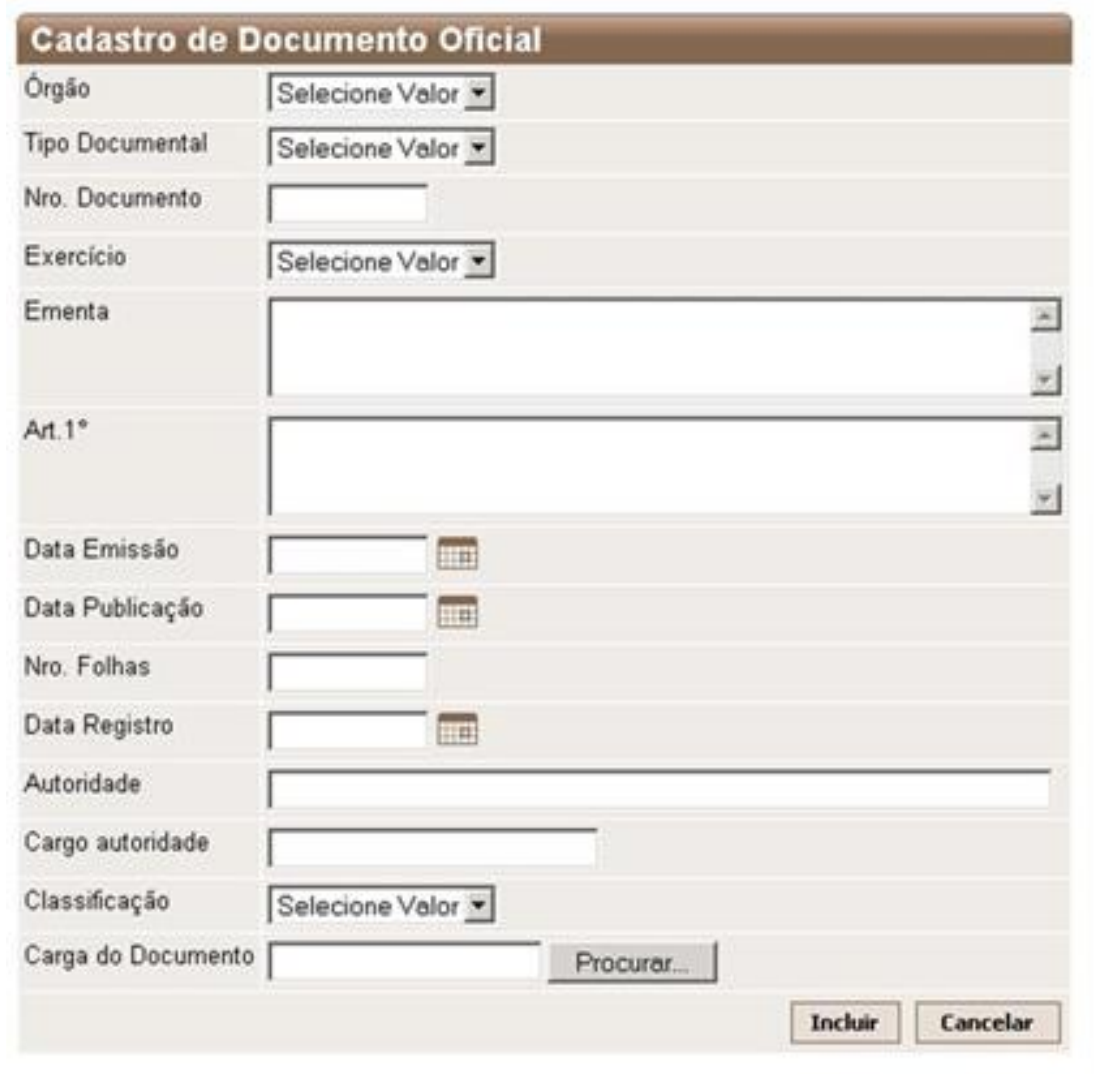

Figura 4 - Formulário de Cadastro de Documento Oficial

A Figura 4 representa a fase de captura do documento, concluída esta fase a base de dados e o documento já estão à disposição para pesquisa, localização e apresentação que poderá ser realizada através do formulário Pesquisa Documento Oficial onde é permitido até seis opções de dados para pesquisa que poderão ser combinados entre si (ver Figura 5).

No caso dos campos "Órgão", "Tipo Documental" e "Ementa” o usuário não precisa digitar o termo completo, ou seja, apenas partes do termo. No campo “Código Classificação" o usuário poderá selecionar em qualquer um dos níveis de classificação. Nos campos "Exercício" e "Nro Documento" os valores deverão exatos para obtenção dos resultados.

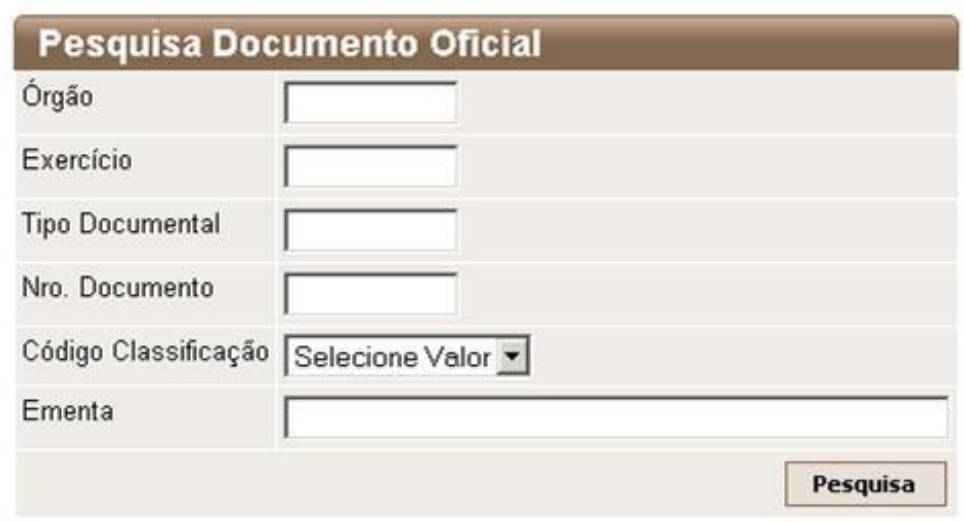

Figura 5 - Formulário de Pesquisa a Documento Oficial 


\section{Administração: caminhos para o desenvolvimento sustentável}

O resultado do preenchimento do formulário Pesquisa Documento Oficial é o formulário Lista de Documento Oficial que apresenta uma lista com os documentos pesquisados, conforme exposto na Figura 6.

Neste formulário são apresentados atributos do documento baseado no código de classificação, os prazos de arquivamento no Arquivo do Setor e no Arquivo Geral da instituição são mostrados. $\mathrm{Na}$ coluna mais a direita apresenta um atributo com o valor "Doc" que representa o link para o documento digital. Uma vez acionado este link será apresentada nova página com o documento arquivado. Documentos com prazos de guarda expirados serão identificados neste formulário através de um ícone na cor vermelha.

\begin{tabular}{|c|c|c|c|c|c|c|c|c|c|c|c|c|}
\hline \multicolumn{13}{|c|}{ Lista de Documento Oficial } \\
\hline Id & Órgăo & Exer. & Tipo Documental & Nro & Ementa & Publicaçào & Folhas & Registro & Classificacdo & Setor & Geral & \\
\hline Editar & CTC & 2008 & Resoluçăo & 22 & $\begin{array}{l}\text { Aprovar o Regulamento de } \\
\text { Eleiçấo do Representante } \\
\text { Técnico. Universitário no } \\
\text { Conselho Interdepantamental do } \\
\text { Centro de Tecnologia }\end{array}$ & $23 / 12 / 2006$ & 12 & $23 / 12 / 2008$ & 0.5 & & & Des \\
\hline Editar & $\operatorname{cou}$ & 2008 & Resoluçấo & 123 & asdsadsadsadsa & $17 / 01 / 2009$ & 1 & $17 / 01 / 2009$ & $0-1-10$ & & & Dec \\
\hline Editar & $\operatorname{cou}$ & 2006 & Resoluçáo & 479 & $\begin{array}{l}\text { Autoriza prorrogaçáo de contrato } \\
\text { de professores temporários }\end{array}$ & $19 / 11 / 2006$ & 6 & $23 / 12 / 2006$ & $0.1-06-2$ & 02 & & - Des \\
\hline Editar & $C A D$ & 2008 & Resoluçăo & 12 & dsads & & & & $0.1-05$ & & & Des \\
\hline Editar & $C A D$ & 2008 & Resoluçăo & 479 & $\begin{array}{l}\text { Autoriza promogaçáo de contrato } \\
\text { de professores temporários }\end{array}$ & $19 / 11 / 2008$ & 6 & $23 / 12 / 2006$ & $0-1.06-1$ & 05 & 12 & 2 Dec \\
\hline Editar & CEP & 2008 & Edital & 54 & Comunica & $29 / 01 / 2009$ & 3 & $29,01 / 2009$ & $0-1.06-2$ & 02 & & - Dos \\
\hline
\end{tabular}

Figura 6 - Formulário Lista de Documento Oficial

\section{DISCUSSÃO E CONSIDERAÇÕES FINAIS}

Mesmo uma breve observação da sistemática atual de arquivamento de documentos atual nos diversos órgãos da UEM, percebe-se que a mesma propicia redundâncias prejudiciais à autenticidade do conteúdo informacional dos documentos, a falta de informações sobre a vigência do documento é prejudicial à confiabilidade do documento e a dificuldade de localização do documento torna-se impraticável qualquer pesquisa na documentação existente. Outro fator importante é a preservação de documentos que já cumpriram a sua função e continuam arquivados, fazendo volumes e dificultando as pesquisa.

Uma solução desenvolvida orientada por requisitos essenciais tem a garantia do armazenamento com organicidade, unicidade e autenticidade e como conseqüência desta tríade a confiabilidade. Organicidade decorrente da aplicação da classificação de documentos, estrutura estabelecida pelo CONARQ e definida pelo DEAP para órgãos do poder executivo do Estado do Paraná que propõe o 


\section{Administração: caminhos para o desenvolvimento sustentável}

arquivamento dos documentos por assuntos correlatos. Unicidade relacionada a documentos externos à unidade administrativa que serão apenas registrados e o documento será acessado diretamente ao site do órgão gerador. Autenticidade pelo fato de acessar o documento diretamente do site do órgão gerador. A confiabilidade decorre da aplicação da organicidade, unicidade e autenticidade e da tabela de temporalidade que estabelece a validade do documento. A acessibilidade é garantida através de mecanismos computacionais tais como múltiplas opções de parâmetros de busca que permite ao usuário encontrar respostas às suas necessidades na recuperação de documentos.

Para a consecução deste estudo, o escopo foi centrado em uma unidade administrativa da UEM, especificamente no Departamento de Engenharia Química e exclusivamente o tipo documental "Resolução", que demonstrado na Tabela 1, gera em média 230/ano documentos deste tipo documental (pesquisa realizada nos anos de 2005, 2006, 2007 e 2008).

A seleção de requisitos essenciais para a Gestão Arquivística de Documentos seguiu as orientações do CONARQ em seu Modelo de Requisitos para Sistema Informatizado de Gestão Arquivistica de Documentos (CONARQ, 2006) e Manual de Gestão de Documentos do Estado do Paraná (DEAP, 2007).

Seguindo experiências com gestão documental adquiridas no Departamento de Engenharia Química, observações in-loco durante o desenvolvimento das atividades dos funcionários da secretaria do departamento e consultas ao site da Secretaria dos Conselhos Superiores proporcionaram a base para o estudo. Estudo este que permitiu posicionar os tipos de relacionamentos de um determinado documento com outros documentos do próprio órgão bem como de outros órgãos. Fica também documentada na Figura 1 a interferência de um documento em outro ou outros quando se trata de alteração, revogação parcial ou revogação total.

O Estudo seguiu orientações de normas do CONARQ e do DEAP relacionadas à classificação de documentos e tabela de temporalidade e com uma proposta especificada para o ambiente Web, que não há restrição quanto a hardware ou software, foi possível implementar um protótipo experimental, submetido à análise.

Em relação aos requisitos essenciais, destacamos o plano de classificação, captura de documentos, avaliação de destinação, pesquisa, localização e apresentação de documentos.

A especificação do Modelo Proposto com interface amigável e com estrutura de armazenamento organizado de conformidade com o Código de Classificação favorece a recuperação pelo fato de ser o 


\section{Administração: caminhos para o desenvolvimento sustentável}

código elaborado por assuntos correlatos e aliado a mecanismos computacionais que permite a múltiplas combinações de parâmetros para a formulação pesquisa pelo usuário. A tabela de temporalidade dá a certeza da validade dos documentos recuperados uma vez que informa ao usuário no momento da recuperação, isto comprova a confiabilidade. Tratando da unicidade, os documentos externos a esta unidade administrativa serão ligadas diretamente ao site do órgão gerador, eliminando assim a duplicidade de fonte de origem. A captura do documento deverá ser efetuada após a geração do document oe, consequentemente, o documento já estará disponível aos usuários.

O inter-relacionamento de documentos será efetuado no momento da captura do documento, para isto os documentos de referência deverão estar capturados previamente, desta forma haverá condições de cruzamentos entre documentos referência e documentos referenciados, facilitando a navegação dos documentos através de pesquisas por assunto proporcionado pela classificação de documentos e a validade dos documentos garantidos pela temporalidade.

Vale lembrar que o Programa de Gestão Arquivistica deverá contemplar o Código de Classificação de Documentos e Tabela de Temporalidade e Destinação para atividades-meio e atividades-fim. O DEAP elaborou tais instrumentos para atividades-meio e deverá ser utilizado por todos os órgãos do Poder Executivo do Estado do Paraná. Já para atividades-fim aguarda-se, da UEM, a constituição da Comissão Setorial de Avaliação.

Diante de tais considerações, cumpre registrar a disponibilidade de uma solução tecnológica pautada pela normatização própria do armazenamento e recuperação de documentos oficiais. É bem verdade que nasceu sob o contexto de uma unidade administrativa, mas com potencial para tornar-se uma solução institucional.

Estabeleceu-se a fronteira do paradigma posto para a gestão documentacional da mesma forma que outras tantas inovações, próprias do momento tecnológico em que vivemos.

Cumpre, então, estabelecer expectativas que, como ocorre em outras aplicações, a Instituição Pública reaja eficientemente à implementação da solução, superando obstáculos burocráticos, lugar comum para as organizações do setor.

Não fosse apenas os apelos de uma comunidade por qualidade e acesso digital aos documentos institucionais, demandas próprias de uma sociedade que está por encerrar a primeira década de um novo milênio de novos valores, também A Lei e as Normas requerem resposta. 


\section{Administração: caminhos para o desenvolvimento sustentável}

Por fim também cabe considerar que o SIGAD, aqui apresentado, se constitui em uma ferramenta e contribuição para a gestão de informações e documentos para a Universidade Pública, uma vez que se reveste de uma produção técnica parametrizável.

Para a área de conhecimento, a Administração de Informações, se estabelece um novo laboratório, aberto a estudos dos impactos da solução na organização, à própria governança da Tecnologia da Informação e ao alinhamento estratégico de soluções integradas a essa com o Planejamento Organizacional.

\section{REFERÊNCIAS}

ARQUIVO NACIONAL (Brasil). Conselho Nacional de Arquivos. Classificação, temporalidade e destinação de documentos de arquivo relativos às atividade-meio da administração pública. Rio de Janeiro: Arquivo Nacional, 2001. 156p.

ARQUIVO NACIONAL (Brasil). Dicionário Brasileiro de Terminologia Arquivística. Rio de Janeiro: Arquivo Nacional, 2005.

ARQUIVO NACIONAL (Brasil). Conselho Nacional de Arquivos. Modelo de Requisitos para Sistemas Informatizados de Gestão Arquivística de Documentos - e-ARQ Brasil. Rio de Janeiro: Arquivo Nacional, 2006. 132p.

Bernardes. IP, Delatorre H, de Souza CB, Martinelli E, Breganhola MCC. Manual de Elaboração de Planos de Classificação e Tabelas de Temporalidade de Documentos da Administração Pública do Estado de São Paulo: Atividades-Fim. São Paulo: Arquivo Público do Estado de São Paulo, 2008. 107p.

BRASIL. Lei no 8.159, de 08 de janeiro de 1991. Dispõe sobre a política nacional de arquivos públicos e privados e dá outras providências. Brasília: Diário Oficial, 1991.

PARANÁ. Resolução no 3.107 de 25 de setembro de 1995. Define a competência da organização de arquivos no âmbito do Poder Executivo Estadual.

CONSELHO NACIONAL DE ARQUIVOS. Resolução n. 1 de 18 de outubro 1995. Dispõe sobre a necessidade da adoção de planos e ou códigos de classificação de documentos nos arquivos correntes, que considerem a natureza dos assuntos resultantes de suas atividades e funções. Brasília: Diário Oficial, 1995.

CONSELHO NACIONAL DE ARQUIVOS. Resolução n .4 de 28 de maio de 1996. Dispõe sobre o Código de Classificação de Documentos de Arquivo para a Administração Pública: Atividades-Meio, a ser adotado como um modelo para os arquivos correntes dos órgãos e entidades integrantes do Sistema Nacional de Arquivos _ SINAR., e aprova os prazos de guarda e a destinação de documentos estabelecidos na Tabela Básica de Temporalidade e Destinação de Documentos de Arquivo Relativos às Atividades-Meio da Administração Pública. Brasília: Diário Oficial, 1996.

CONSELHO NACIONAL DE ARQUIVOS. Diretrizes gerais para a construção de websites de instituições arquivísticas. Rio de Janeiro: CONARQ, 2000. 11p. 


\section{Administração: caminhos para o desenvolvimento sustentável}

CONSELHO NACIONAL DE ARQUIVOS. Legislação arquivística. Disponível em Acesso digital www.arquivonacional/conarq. Acesso em 01/12/2008.

Departamento Estadual de Arquivo Público - DEAP (PR). Manual de Comunicação Escrita Oficial do Estado do Paraná. Curitiba: Imprensa Oficial, 2005. 124p.

Departamento Estadual de Arquivo Público - DEAP (PR). Manual de Gestão de Documentos do Estado do Paraná. Curitiba: O Arquivo, 2007. 115p.

RONDINELLI RC. Gerenciamento arquivístico de documentos eletrônicos. Rio de Janeiro: FGV, 2005. $157 p$. 


\section{Capítulo 37}

NOVAS PRÁTICAS SOBRE A DEPRECIAÇÃO DO ATIVO IMOBILIZADO, CONFORME AS NORMAS BRASILEIRAS DE CONTABILIDADE APLICADAS AO SETOR PÚBLICO (NBCASP)

DOI: $10.37423 / 200300447$

Rosaly Machado (UEPG) rosalymachado@uepg.br

Ephrain Talmud Leite de Oliveira Cruz (UEPG) ephraincruz@hotmail.com

Rafaela Fatima Urban (UEPG) rafa_rfu@hotmail.com

RESUMO: Esta sìntese foi elaborada pelo viés das modificações que/incide à contabilidade aplicada ao setor público, e que se estende às significativas inovações, seguidas pela têndência de harmọnização internaciọnal das normas contábeis. A pesquísa qualitativa tem como o intuito sobrepor à seriedade da aproximação das normas de Contabilidade Pública no Brasil às Normàs taternacionais de Contabilidade Aplicadás ao Setor Público (IPSAS = International Public Accounting Standards). Assim sendo, o ativo imobilizado, especificamente para este contexto de depreciaçã̊ de bens do patrimônio público, recebe alterações em seu delineamento-de registro e męnsuração e controle contábil/Apresenta como-imperativa a necessidade da existência de um sistema de controle físico, para que possibilite a implantação dos procedimentos propostos pelas hormas internacionnais à padronização contábilaplicado ao setor público.

Palavras-chave.Contabilidade, Setor Público, Attivo Imobilizado, Depreciaçẩo.

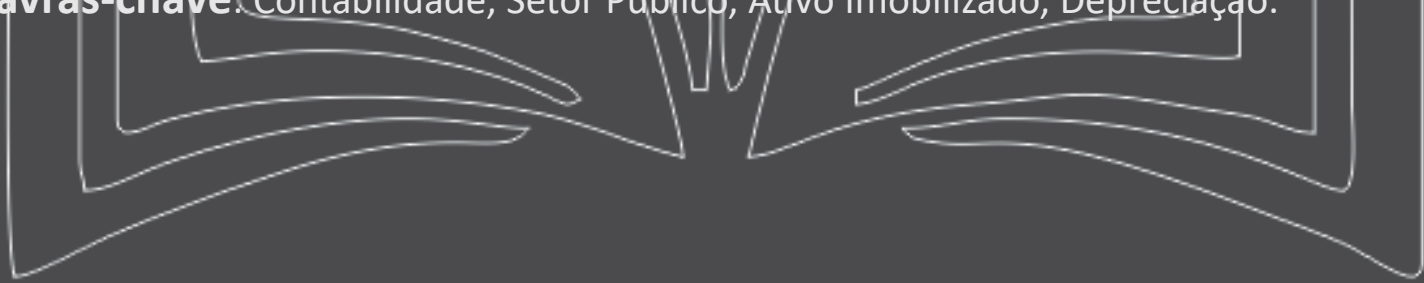




\section{Administração: caminhos para o desenvolvimento sustentável}

\section{INTRODUÇÃO}

A Contabilidade Aplicada ao Setor Público (CASP) tem suas diversas regras em origem constitucional, destacando-se entre elas os princípios da Administração Pública da legalidade, impessoalidade, da moralidade, da publicidade e da eficiência, devendo seguir, portanto, um arcabouço de atos administrativos, como Leis, Decretos, Portarias e Instruções Normativas.

Nesta esteira, é oportuno trazer à tona a Lei $\mathrm{n}$ - 4.320/64, onde são estabelecidos diversos procedimentos contábeis gerais, envolvendo as funções de registro, evidenciação, mensuração de ativos e passivos, entre outras. A citada Lei estatui normas gerais de Direito Financeiro para elaboração e controle dos orçamentos e balanços da União, dos Estados, dos Municípios e do Distrito Federal.

Seguindo a busca da melhor adaptação das informações contábeis dos entes públicos, o Decreto-Lei no 200/67, que dispõe sobre a organização da Administração Federal, estabelece diretrizes para Reforma Administrativa e abrange expressivas mudanças. Dentre elas, a adoção de um plano de contas único e de normas gerais de contabilidade pelos órgãos da administração direta, apuração dos custos dos serviços pela contabilidade, de forma a evidenciar os resultados da gestão e contabilização dos fatos administrativos da gestão pública.

Mais tarde, o Decreto-Lei no 93.872/86, regulamentou algumas regras existentes na Lei n 4.320/64 e o Decreto-Lei 200/67, principalmente nos aspectos atinentes à execução da despesa pública e da prestação e tomada de contas. Neste momento, fica claro que a Contabilidade Pública tinha seu foco voltado para execução da despesa, sendo implantado o Sistema Integrado de Administração Financeira do Governo Federal (SIAFI), naquele mesmo ano, voltado inicialmente para acompanhamento e execução do Orçamento Público.

Com o advento da Lei no 101/00, ou Lei de Responsabilidade Fiscal (LRF), novos procedimentos contábeis foram adicionados à Lei no 4.320/64, estabelecendo assim, normas de finanças públicas voltadas para a responsabilidade na gestão fiscal, no sentido de oferecer maior transparência dos atos e fatos administrativos emanados pela administração pública.

No aperfeiçoamento da Contabilidade Pública Brasileira, a Lei no 10.180/01 organizou e disciplinou o Sistema de Contabilidade Federal (SFC). Dentre as finalidades do SFC pode ser destacada "a evidenciação da situação patrimonial do ente público e suas variações" (MOTA, 2009, p. 238).

Assim sendo, o Ministério da Fazenda publicou a Portaria MF no 184/08, ponto inicial para conduzir as disposições sobre as diretrizes de convergências a padronização contábil a serem observadas no Setor 


\section{Administração: caminhos para o desenvolvimento sustentável}

Público quanto aos procedimentos, práticas, elaboração e divulgação das demonstrações contábeis, de forma a torná-los convergentes com as International Public Sector Accounting Standards (IPSAS). É oportuno citar que a resolução do Conselho Federal de Contabilidade (CFC) no 1.111/07 que trata da aplicação dos princípios contábeis aplicados ao setor público adverte para que estes sejam observados, que são:

- Princípio da Entidade: destinação social do patrimônio do ente público, que por ele é responsável e é obrigada a prestação de contas dos agentes pertencentes àquela entidade;

- Princípio da Continuidade: este princípio está vinculado ao estrito cumprimento da destinação social do patrimônio, ou seja, a continuidade da entidade pública se dá enquanto perdurar sua finalidade.

- Princípio da Oportunidade: é base indispensável à integridade e à fidedignidade dos registros contábeis dos atos e fatos que afetam ou possam afetar o patrimônio da entidade pública, visando ao completo atendimento da essência sobre a forma;

- Princípio do Registro pelo Valor Original: nos atos e fatos contábeis será considerado o valor original dos componentes patrimoniais;

- Princípio da Atualização Monetária: consiste na necessidade de atualizar valores de mensuração de elementos patrimoniais, quando a taxa acumulada de inflação, no triênio, for igual ou superior a $100 \%$.

- Princípio da Competência: Os atos e fatos que afetam o patrimônio público devem ser contabilizados por competência, e os seus efeitos devem ser evidenciados nas Demonstrações Contábeis do exercício financeiro com o qual se relacionam complementarmente ao registro orçamentário das receitas e das despesas públicas; e

- Princípio da Prudência: visa constituir garantia de inexistência de valores fictícios, de interesses de grupos ou pessoas, especialmente gestores, ordenadores e controladores, sem manipulação do resultado, ocultação de passivos e super, ou subavaliação de ativos.

Portanto, os princípios contábeis definem o norte para o bom desempenho das entidades, e configuram um conjunto de comandos que no âmbito contábil deve ser acatado e praticado. Como visto no decorrer das transições, a contabilidade aplicada ao setor público retoma como forma de orientação os princípios contábeis. Além disso, o CFC criou o comitê gestor de convergência, com o objetivo de desenvolver ações para promover a harmonização das Normas Brasileiras de Contabilidade. 


\section{Administração: caminhos para o desenvolvimento sustentável}

O processo de convergência ganhou força em 2008, com a publicação das Resoluções CFC no 1.128 a 1.137, consolidando as NBC T 16, a seguir relacionadas:

- - Resolução no 1.128/08: Conceituação, objeto e campo de aplicação;

- - Resolução no 1.129/08: Patrimônio de sistemas contábeis;

- - Resolução no 1.130/08: Planejamento e seus instrumentos sob enfoque contábil;

- - Resolução no 1.131/08: Transações no setor público;

- - Resolução no 1.132/08: Registro contábil;

- - Resolução no 1.133/08: Demonstrações contábeis;

- - Resolução no 1.134/08: Consolidação das demonstrações contábeis;

- - Resolução no 1.135/08: Controle interno;

- - Resolução no 1.136/08: Depreciação, amortização e exaustão; e

- - Resolução no 1.137/08: Avaliação e mensuração de ativos e passivos em entidades do setor público.

Assim, uma das principais mudanças na CASP é a mudança do enfoque contábil, outrora centrado eminentemente no orçamento, para uma Contabilidade Pública patrimonial. Nesse sentido, o objetivo do trabalho é verificar a implantação do procedimento da depreciação sobre o ativo imobilizado e seus reflexos na administração pública.

O desígnio desta síntese é motivado pelo ineditismo de tal procedimento na CASP, sendo os conceitos abordados pelas Resoluções no 1.136 e 1.137/08 intrínsecas ao início e continuidade da depreciação. O tema é, portanto, relevante, carecendo de estudos, principalmente no âmbito acadêmico, onde a discussão deste escopo é pouco explorada. Ressalta-se ainda, a carência de bibliografias e trabalhos, o que limita a expansão da pesquisa.

\section{EMBASAMENTO TEÓRICO}

Com a edição das Normas Brasileiras de Contabilidade Aplicadas ao Setor Público, surge a NBC T 16, que aborda aspectos contábeis voltados à contabilidade pública brasileira. Deste modo o foco no patrimônio do setor público, objetiva encontrar em seu ativo imobilizado itens referentes a bens móveis e imóveis registrados, em seus sistemas patrimoniais, no valor de R\$ 0,01 (um centavo) em função dos cortes de "zeros" decorrentes dos diversos planos econômicos. Entretanto, o valor de mercado destes bens necessita de levantamentos que conduzam a informações a valores presente. 


\section{Administração: caminhos para o desenvolvimento sustentável}

Por outro lado, também pode ocorrer de bens móveis serem evidenciados nos demonstrativos contábeis por valor superior ao valor de mercado, porque não há aplicação da prática contábil da depreciação acumulada.

Portanto, é possível inferir que as informações contábeis das entidades do setor público não possuíam, até então, critérios capazes de representar com fidedignidade os valores reais do seu patrimônio, não fornecendo qualidade, relevância e credibilidade à informação contábil.

\subsection{DEFINIÇÕES IMPORTANTES DAS NBC T 16.9 E 16.10}

Para o perfeito entendimento do foco desta pesquisa, é necessária a exposição de algumas definições aludidas nas NBC T 16.9 e 16.10 (2008):

a. Depreciação: a redução do valor dos bens tangíveis pelo desgaste ou perda de utilidade por uso, ação da natureza ou obsolescência;

b. Valor bruto contábil: o valor do bem registrado na contabilidade, em uma determinada data, sem a dedução da correspondente depreciação, amortização ou exaustão acumulada;

c. Valor depreciável, amortizável e exaurível: o valor original de um ativo deduzido do seu valor residual;

d. Valor líquido contábil: o valor do bem registrado na Contabilidade, em determinada data, deduzido da correspondente depreciação, amortização ou exaustão acumulada;

e. Valor residual: o montante líquido que a entidade espera, com razoável segurança, obter por um ativo no fim de sua vida útil econômica deduzida os gastos esperados para sua alienação;

f. Vida útil econômica: o período de tempo definido ou estimado tecnicamente, durante o qual se espera obter fluxos de benefícios futuros de um ativo;

g. Mensuração: a constatação de valor monetário para itens do ativo e do passivo decorrente da aplicação de procedimentos técnicos suportados em análises qualitativas e quantitativas;

h. Reavaliação: a adoção do valor de mercado ou de consenso entre as partes para bens do ativo, quando esse for superior ao valor líquido contábil; 


\section{Administração: caminhos para o desenvolvimento sustentável}

i. Valor de mercado ou valor justo (fair value): o valor pelo qual um ativo pode ser intercambiado ou um passivo pode ser liquidado entre partes interessadas que atuam em condições independentes e isentas ou conhecedoras do mercado;

j. Redução ao valor recuperável (impairment): o ajuste ao valor de mercado ou de consenso entre as partes para bens do ativo, quando esse for inferior ao valor líquido contábil;

k. Valor recuperável: o valor de mercado de um ativo menos o custo para sua alienação, ou o valor que a entidade do setor público espera recuperar pelo uso futuro desse ativo nas suas operações, o que for maior.

\subsection{ASPECTOS DA DEPRECIAÇÃO}

Com a edição da Resolução CFC no 1.136/08 que aprovou a NBC T 16.9 - Depreciação, Amortização e Exaustão, "tornou-se obrigatória, a partir do exercício contábil de 2010, o registro de depreciação acumulada sobre os itens do ativo imobilizado" (MANUAL SIAFI, p. 4, 2011).

Segundo o Manual de Contabilidade Aplicada ao Setor Público (MCASP), Parte II Procedimentos Contábeis Patrimoniais (2010, p.67) "a depreciação se inicia a partir do momento em que o item do ativo se tornar disponível para uso". Para tanto, é necessário formar uma base de cálculo inicial.

Assim, "ao valor de aquisição, produção ou construção inclui-se os gastos adicionais ou complementares para que o ativo esteja no local e nas condições operacionais pretendidas pela administração" (MOTA, 2009, p. 244). Deste valor (valor original) subtrai-se o valor residual do ativo, obtendo-se o valor depreciável, conforme letra c do item 2.1, supracitado.

O valor residual, por sua vez, tem como base, valor percentual conforme Manual SIAFI (2011, p. 1316), onde os bens que integram cada conta contábil possuem uma vida útil e valor residual padronizados. Quanto aos bens imóveis, a depreciação deve ser calculada com base, exclusivamente, no custo de construção, deduzido o valor dos terrenos (NBC T 16.9/08).

O item 6 da NBC T 16.9/08, prevê que a depreciação deve ser reconhecida até que o valor líquido contábil seja igual ao valor residual. Então, mesmo que o bem seja retirado temporariamente de operação ou torne-se obsoleto, a depreciação não cessará (MOTA, 2009, p. 245).

No entanto, nem todos os ativos imobilizados são depreciáveis. O Manual SIAFI (2011, p. 18) estabelece os seguintes bens não depreciáveis:

a. Terrenos rurais e urbanos; 


\section{Administração: caminhos para o desenvolvimento sustentável}

b. Prédios ou construções não alugados e não utilizados pelo proprietário na produção dos seus rendimentos ou destinados a revenda;

b) Bens móveis de natureza cultural, tais como obras de artes, antiguidades, documentos, bens com interesse histórico, bens integrados em coleções, entre outros os quais normalmente aumentam de valor com o tempo;

c) Bens de uso comum que absorveram ou absorvem recursos públicos, considerados tecnicamente de vida útil indeterminada;

d) Animais que se destinam à exposição e à preservação.

Conforme o item 14 da NBC T 16.9 (2008), podem ser adotados os seguintes métodos de cálculo dos encargos de depreciação:
a) Método das quotas constantes;
b) Método das somas dos dígitos; e
c) Método das unidades produzidas.

Neste foco, conforme Manual SIAFI (2011, p. 22) "o método de cálculo de depreciação a ser utilizado para toda a administração direta, autárquica e fundacional, será o das quotas constantes, já que a informação deve ser consistente e comparável".

Além disso, é pertinente frisar que, "o administrador deverá iniciar o procedimento de depreciação pelos bens adquiridos, incorporados e/ou colocados em utilização a partir de janeiro de 2010" (MANUAL SIAFI, 2011, p. 8).

É oportuno elucidar que "a apuração da depreciação deve ser feita mensalmente" (MCASP, 2010, p. 61), sendo que, a partir do exercício de 2011, serão utilizados os códigos de restrição contábil referentes à falta da informação da rotina de depreciação, tudo com a finalidade de que a Contabilidade Pública demonstre a adequada situação patrimonial dos seus órgãos e entidades (MANUAL SIAFI, 2011, p. 10).

Prosseguindo o assunto, diversas Unidades Gestoras (UG) da Administração Pública deverão desenvolver e adaptar seus sistemas de controle patrimonial, haja vista que o SIAFI aplica a depreciação sobre o valor da conta contábil como um todo. Assim, por exemplo, ao depreciar a conta de Mobiliário em Geral, todos os bens que compõem esta conta têm seu valor reduzido.

Por conseguinte, o MCASP (2010, p. 107) propõe, como sugestão, o seguinte modelo de Relatório Mensal de Bens (RMB), por cada item componente das contas contábeis: 


\section{Administração: caminhos para o desenvolvimento sustentável}

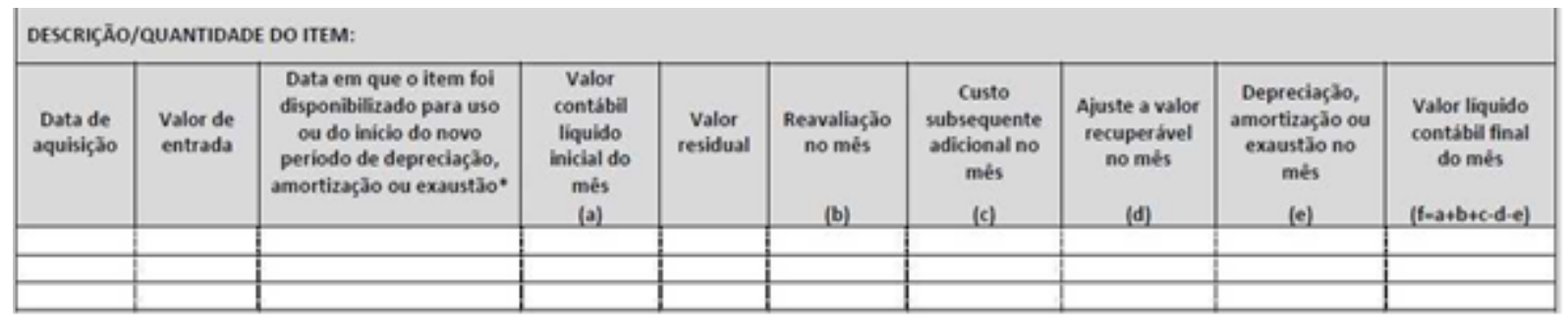

Fonte: Adaptado de MCASP (2010, p. 107).

Figura 1 - Relatório Mensal de Bens (RMB).

Finalmente, ressalta-se a necessidade do reconhecimento do valor depreciado como "decréscimo patrimonial nas contas de resultado do exercício, e, no balanço patrimonial como conta redutora do respectivo ativo" (NBC T 16.9, 2008).

\subsection{REAVALIAÇÃO}

Com a obrigatoriedade da aplicação da boa prática da depreciação, conforme o item anterior, alguns fatores podem contribuir para que o valor contábil de um ativo não corresponda ao seu valor justo. Em conseqüência disso, foi editada a NBT C 16.10/08, que trata da avaliação e mensuração de ativos e passivos em entidades do setor público.

Conforme Lemes e Carvalho (2010, p. 69) "após o reconhecimento inicial, a empresa pode mensurar o imobilizado usando o modelo de custo ou modelo de reavaliação". Segundo os autores, o modelo de custo consiste em manter o valor do ativo deduzido da depreciação e das perdas por impairment reconhecidas. Já o modelo de reavaliação, o ativo é mantido ao valor reavaliado deduzido da depreciação e das perdas de impairment reconhecidas.

Colaborando com o assunto, Mota (2009, p. 244), afirma que "a mensuração do ativo imobilizado tem como método o valor de aquisição, produção ou construção, incluído dos gastos adicionais ou complementares (custo original do bem)".

Para Mota (2009, p. 240) "após a inclusão inicial do ativo no patrimônio, começa a ser aplicada a depreciação. Com o passar do tempo, é necessário realizar reavaliações dos itens do ativo, pois o valor justo do bem pode ser superior ao valor líquido contábil constante no sistema patrimonial".

Para elucidar este aspecto, o MCASP (2010, p. 81) alinhado com o item 36 da NBC T 16.10/08, estabelece a seguinte consideração:

A freqüência com que as reavaliações são realizadas depende das mudanças dos valores justos dos itens do ativo que serão reavaliados. Quando o valor justo de um ativo difere materialmente de seu valor contábil registrado, exigese nova reavaliação. Os itens do ativo que sofrerem mudanças significativas no valor justo necessitam de reavaliação anual. Tais reavaliações freqüentes são desnecessárias para itens do ativo que não sofrem mudanças significativas no 


\section{Administração: caminhos para o desenvolvimento sustentável}

valor justo. Em vez disso, pode ser necessário reavaliar o item apenas quatro anos.

Em decorrência da primeira reavaliação, a mensuração do ativo imobilizado, bem como o cálculo de seu valor residual e depreciável, tem como base o valor reavaliado. Para Mota (2009, p. 242), "na impossibilidade de se estabelecer o valor de mercado, o valor do ativo pode ser definido com base em parâmetros de referência que considerem características, circunstâncias e localizações assemelhadas". Em relação aos bens imóveis, o valor justo pode ser estimado utilizando o valor de reposição do bem com as mesmas características e no mesmo estado físico (MANUAL SIAFI, 2011, p. 27).

É importante salientar que "se um item do ativo imobilizado for reavaliado, é necessário que todo o grupo/classe do ativo imobilizado à qual pertence esse ativo seja reavaliado" (MCASP, 2010, p. 81). Esse procedimento é pertinente para que seja evitada a reavaliação seletiva de ativos e divulgação de montantes nas demonstrações contábeis que sejam uma combinação de valores em datas diferentes (MCASP, 2010, p. 82).

Para que seja procedida a reavaliação, deve ser formada uma comissão, de no mínimo três servidores que deverão elaborar o "laudo de avaliação" que deve conter, ao menos, as seguintes informações, conforme Manual SIAFI (2011, p. 26-27):

a) Documentação com descrição detalhada de cada bem avaliado;

b) Identificação contábil do bem;

c) Critérios utilizados para avaliação e sua respectiva fundamentação;

d) Vida útil remanescente do bem; e

e) A data da avaliação.

O MCASP (2010, p. 82) também prevê que a reavaliação pode ser realizada através da elaboração de um laudo técnico por perito ou entidade especializada. Conforme explicitado no item 2.2, a depreciação, inicialmente, é aplicada apenas aos bens adquiridos ou postos em funcionamento no ano de 2010, tendo em vista que estes itens do ativo possuem uma base confiável para a implantação de tal procedimento.

O material adquirido ou posto em funcionamento anterior a 2010 necessita, portanto, passar pelo procedimento de reavaliação. Isso, com intuito de que as informações contábeis de bens registrados a valores abaixo do mercado, como, por exemplo, itens do ativo registrados a $\mathrm{R} \$ \mathbf{0 , 0 1}$ (um centavo), possam espelhar seu valor justo. 


\section{Administração: caminhos para o desenvolvimento sustentável}

Finalmente, é oportuno destacar que os acréscimos do valor do ativo em decorrência de sua avaliação devem ser registrados em contas de resultado (MANUAL SIAFI, 2011, p. 26).

\subsection{REDUÇÃO AO VALOR RECUPERÁVEL}

É percebível que com o passar do tempo, o valor contábil de itens do ativo pode não espelhar o seu valor justo. Todavia, no item supracitado, foi comentado o aspecto do valor líquido contábil ser menor que o valor justo. Neste momento, é necessário comentar a situação do valor líquido contábil ser maior que o valor recuperável, que tem como base de cálculo o valor justo ou de mercado.

Neste aspecto, os bens do ativo imobilizado adquiridos e/ou postos em funcionamento anteriores ao ano de 2010, devem ser submetidos ao teste de imparidade (impairment) para que se tenha uma base de valor confiável para aplicação do procedimento depreciatório (MANUAL SIAFI, 2011, p. 8).

Cabe ressaltar que um teste de imparidade não deve considerar como parâmetro único o valor de mercado, mas também o valor em uso do ativo, pois no Setor Público, a maioria dos ativos é mantida para fornecer serviços ou bens públicos. Sendo assim, seu valor em uso, provavelmente, é maior do que seu valor justo menos os custos de alienação (MCASP, 2010, p. 84).

A redução ao valor recuperável não deve ser confundida com a depreciação, consoante ao item 2 da NBC T 16.9/08 "a depreciação é entendida como declínio gradual do potencial de geração de serviços motivada pelo desgaste, uso, ação da natureza ou obsolescência. Já o impairment é a desvalorização de um ativo quando o seu valor contábil excede o valor recuperável, podendo ser entendida como uma perda dos futuros benefícios econômicos ou do potencial de serviços de um ativo, além da depreciação.

Para melhor elucidar o conceito em epígrafe, o MCASP (2010, p. 84) descreve:

Quando o valor contábil for superior ao valor recuperável, ocorrerá uma perda por redução ao valor recuperável do ativo que reflete, portanto, um declínio da utilidade de um ativo para a entidade que o controla. Por exemplo, uma entidade pode ter uma instalação de armazenamento para fins militares que já não é mais utilizada. Além disso, devido à natureza especializada desta instalação e de sua localização, em provável que possa ser arrendada ou vendida e, portanto, a entidade é incapaz de gerar fluxos de caixa por meio de arrendamento ou de venda do ativo. $O$ ativo é considerado como tendo sofrido perda por irrecuperabilidade porque não é mais capaz de prover à entidade com potencial de serviços, pois tem pouca ou nenhuma utilidade na contribuição para que ela atinja seus objetivos.

Segundo o Manual SIAFI (2011, p. 29) um bem deve ser reduzido ao valor recuperável se alguma das situações abaixo for verdadeira: 


\section{Administração: caminhos para o desenvolvimento sustentável}

a) Cessação total ou parcial das demandas ou necessidade dos serviços fornecidos pelo bem;

b) Diminuição significativa, de longo prazo, das demandas ou necessidade dos serviços fornecidos pelo bem;

c) Dano físico do bem;

d) Mudanças significativas, de longo prazo, com efeito adverso na entidade ocorreram ou estão para ocorrer no ambiente tecnológico, legal ou de política de governo no qual a entidade opera;

e) Mudanças significantes, de longo prazo, com efeito adverso na entidade correram ou estão para ocorrer na extensão ou maneira da utilização do bem. Essas modificações incluem a ociosidade do bem, planos para descontinuar ou reestruturar a operação no qual ele é utilizado, ou planos de se desfazer do bem antes da data previamente estimada;

f) É decidido interromper a construção de um bem antes que o mesmo esteja em condições de uso;

g) Há indicação de que a performance de serviço do bem está ou estará significativamente pior do que esperado; e

h) Durante o período, o valor de mercado de um bem caiu significativamente, mais do que seria esperado pela passagem do tempo ou uso normal.

Para que seja procedida a redução a valor recuperável, deve ser formada uma comissão, de no mínimo três servidores que deverão elaborar o "laudo de avaliação" que deve conter, ao menos, as seguintes informações, conforme Manual SIAFI (2011, p. 30):

a) Documentação com descrição detalhada de cada bem avaliado;

b) Identificação contábil do bem;

c) Critérios utilizados para avaliação e sua respectiva fundamentação;

d) Vida útil remanescente do bem; e

e) A data da avaliação.

Da mesma forma como ocorre no procedimento da reavaliação, o MCASP (2010, p. 89) também prevê que a reavaliação pode ser realizada através da elaboração de um laudo técnico por perito ou entidade especializada.

Após a devida publicação do laudo evidenciando a necessidade de redução a valor recuperável, os decréscimos do valor do ativo em decorrência do ajuste ao valor recuperável devem ser registrados em contas de resultado. Caso o respectivo laudo indique que o valor estimado do bem, subtraído de eventuais custos para a venda ou descarte for inferior a zero, seu valor contábil deve ser reduzido à zero. Destarte, aplicação da perda por irrecuperabilidade pode indicar que a vida útil remanescente, o método de depreciação ou o valor residual do ativo necessitem ser revisados (MCASP, 2010, p. 88). 


\section{Administração: caminhos para o desenvolvimento sustentável}

\section{METODOLOGIA}

Trata-se de uma pesquisa exploratória, com abordagem qualitativa, pois ocorreu a preocupação de clarificar o fenômeno e a capacidade de ser observado, ou seja, ação de estudo para conhecer algo que está acontecendo na realidade.

Segundo (Gil 2002) a pesquisa exploratória tem suas características e entre estas, se valida o levantamento bibliográfico, observações da realidade e entrevistas com pessoas experientes no problema pesquisado.

Portanto, explica Triviños (1987, p. 129), que "a pesquisa qualitativa tem enfoque indutivo, pois no seu campo de investigação, o fenômeno tem sua própria realidade fora da consciência.

Ele é real, concreto e como tal é estudado".

Ao mesmo tempo, a pesquisa pode ser classificada como qualitativa, "não empregando instrumento estatístico de medição, buscando uma análise mais profunda do fenômeno que está sendo estudado" (BEUREN, 2009, p. 92). Foi utilizada, portanto, as técnicas da observação e entrevista, buscando explorar os conceitos constantes nas NBCASP e salientar o impacto das inovações impostas por elas.

\section{RESULTADO DOS DADOS COLETADOS EM ÓRGÃOS PÚBLICOS}

Tendo em vista a edição das NBCASP, os órgãos públicos da administração dos níveis Federal, Estadual e Municipal, buscam para auxílio no desenvolvimento às novas rotinas contábeis voltadas para as normas internacionais.

Neste escopo, destaca-se que a convergência às Normas Internacionais de Contabilidade ainda está sendo implementada.

Esta pesquisa teve como abrangência a amostra dois órgãos administração pública, sendo um a nível Federal e outro a nível Estadual. Não se objetivou conhecer as rotinas dos lançamentos contábeis em si, mas como estas instituições estão se adaptando à implantação da depreciação sobre o ativo imobilizado.

Como resultado da coleta de dados, inicialmente, percebe-se a imperativa necessidade da existência de um sistema de controle físico, para que possibilite a implantação dosprocedimentos do escopo desta pesquisa. Foi possível verificar que, na Instituição do nível Estadual, ainda não houve a plena adequação às exigências das novas normas. Isso pode ser evidenciado, pelo fato de seus 


\section{Administração: caminhos para o desenvolvimento sustentável}

administradores ainda estarem realizando o inventário de seus bens móveis, haja vista, que não préexistia um sistema de controle patrimonial paralelo ao SIAFI.

Por outro lado, a Instituição de nível Federal já está aplicando o procedimento da depreciação sobre os ativos imobilizados adquiridos ou postos em funcionamento a partir do ano de 2010.

Isso, graças à pré-existência de um sistema de controle físico, pelo qual a administração pode ter a informação de qual, quanto e onde está cada item do ativo imobilizado.

Foi possível observar ainda que, nem todas as contas contábeis previstas para sofrerem a depreciação estão passando por este procedimento, devido à particularidade apresentada pelos itens componentes destas contas, como por exemplo, aeronaves e embarcações, conforme Manual SIAFI (2011, p. 17). Ainda nesta esteira, a aplicação da reavaliação e da redução ao valor recuperável dos ativos adquiridos e/ou postos em funcionamento, anteriores ao ano de 2010, estão carecendo de maiores esclarecimentos dos órgãos normativos do Sistema de Contabilidade Federal.

Alguns aspectos interessantes foram elencados, pela Instituição Federal. Normalmente, acontece a transferência patrimonial de uma UG para outra, sendo necessária a observância da depreciação do respectivo material. Conforme prevê o item 29 da NBC T 16.9/08, ratificado pelo MCASP (2010, p. 64), no caso de transferência de ativos, o valor atribuído deve ser o valor contábil líquido constante dos registros da entidade de origem.

Ainda como forma de complemento, existe a recomendação da Secretaria do Tesouro Nacional (STN), conforme mensagem SIAFI 2011/0170943, de 13 de janeiro de 2011, que no momento da transferência do material, seja confeccionado documento que conste do valor de aquisição do material, o período previsto de depreciação, o período efetivamente depreciado na unidade de origem e o seu valor líquido contábil.

\section{CONSIDERAÇÕES FINAIS}

A Contabilidade Brasileira está passando por significativas mudanças. A Legislação Societária foi modificada pelas Leis $11.638 / 07$ e a 11.941/09. Nesta evolução, a Contabilidade Aplicada ao Setor Público também passa por profundas alterações em suas rotinas, convergindo seus procedimentos às Normas Internacionais de Contabilidade Aplicadas ao Setor Público, através das NBCASP.

Neste viés, destaca-se a mudança do enfoque orçamentário para o patrimonial, fornecendo qualidade, relevância e credibilidade à informação contábil. Destarte, ainda favorece a implantação de um 


\section{Administração: caminhos para o desenvolvimento sustentável}

sistema de custos, que permitirá a avaliação e o acompanhamento da gestão orçamentária financeira e patrimonial conforme exigência do art. 50 da LRF.

Entretanto, há ainda, a escassez de material para pesquisa a respeito do assunto em estudo, sendo limitado apenas ao aspecto normativo em si, algumas orientações da STN, Manual SIAFI e MCASP.

Foi possível concluir que, apesar dos procedimentos elencados na normatização vigente, muitos estudos serão necessários a respeito da efetiva implantação de mecanismos, para completa operacionalização, em todas as esferas da administração pública.

\section{REFERÊNCIAS}

BEUREN, I. M. Como elaborar trabalhos monográficos em contabilidade. 3. ed. São Paulo: Atlas, 2009.

BRASIL. Lei Complementar Federal $n^{\circ} 101$, de 4 de maio de 2000. Estabelece normas de finanças públicas voltadas para a responsabilidade na gestão fiscal e dá outras providências. Brasília, DF. Disponível em:

<http://www.planalto.gov.br/ccivil_03/Leis/LCP/Lcp101.htm>. Acesso em 23 mar. 2011.

. Lei Federal $n^{\circ} 4.320$, de 17 de março de 1964. Estatui Normas Gerais de Direito Financeiro para elaboração e controle dos orçamentos e balanços da União, dos Estados, dos Municípios e do Distrito Federal.

Brasília, DF. Disponível em: <http://www.planalto.gov.br/ccivil_03/Leis/L4320.htm>. Acesso em 23 mar. 2011.

. Portaria Ministério da Fazenda $\mathrm{n}^{\circ}$ 184, de 25 de agosto de 2008. Dispõe sobre as diretrizes a serem observadas no setor público (pelos entes públicos) quanto aos procedimentos, práticas, laboração e divulgação das demonstrações contábeis, de forma a torná-los convergentes com as Normas Internacionais de Contabilidade Aplicadas ao Setor Público.

. Lei № 10.180, de 6 de fevereiro de 2001. Organiza e disciplina os sistemas de Planejamento e Orçamento Federal, de Contabilidade Federal e de Controle Interno do Poder Executivo Federal, e dá outras providências. Brasília, DF. Disponível em:

<http://www.planalto.gov.br/ccivil_03/Leis/LEIS_2001/L10180.htm>. Acesso em 23 mar. 2011.

- Decreto-lei no 200 de 25 de fevereiro de 1967. Dispõe sobre a organização da Administração Federal, estabelece diretrizes para Reforma Administrativa e dá outras providências. Brasília, DF. Disponível

em: <http://www.planalto.gov.br/ccivil/Decreto-Lei/Del0200,htm>. Acesso em 23 mar. 2011.

. Manual de contabilidade aplicada ao setor público: aplicado à União, aos Estados, ao Distrito Federal e Municípios. Válido para o exercício de 2011. Portaria STN no 664, de 30 de novembro de 2010. Parte II - Procedimentos Contábeis Patrimoniais - 3. ed. - Brasília, 2010. 


\section{Administração: caminhos para o desenvolvimento sustentável}

CARVALHO, L. N.;LEMES, S. Contabilidade Internacional para Graduação: texto, estudos de caso e questões de múltipla escolha. São Paulo: Atlas, 2010.

CONSELHO FEDERAL DE CONTABILIDADE. Resolução CFC no 750, de 29 de dezembro de 1993.

Dispõe sobre os Princípios Fundamentais de Contabilidade (PFC). Disponível

em: <http://www.cfc.org.br>.Acesso em 23 mar. 2011.

. Resolução CFC no 1.103, de 28 de setembro de 2007. Cria o Comitê Gestor da Convergência no Brasil, e dá outras providências.

. Resolução CFC no 1.111, de 29 de novembro de 2007. Aprova o Apêndice II da Resolução CFC no. 750/93 sobre os Princípios Fundamentais de Contabilidade.

. Resolução CFC no 1.121, de 28 de março de 2008. Aprova a NBC T 1 - Estrutura Conceitual para a Elaboração e Apresentação das Demonstrações Contábeis.

. Resolução CFC no 1.128, de 21 de novembro de 2008. Aprova a NBC T 16.1 - Conceituação,

Objeto e Campo de Aplicação.

. Resolução CFC no 1.129, de 21 de novembro de 2008. Aprova a NBC T 16.2 - Patrimônio e

Sistemas Contábeis.

. Resolução CFC no 1.130, de 21 de novembro de 2008. Aprova a NBC T 16.3 - Planejamento e seus Instrumentos sob o Enfoque Contábil.

Setor Público.

. Resolução CFC no 1.131, de 21 de novembro de 2008. Aprova a NBC T 16.4 - Transações no

. Resolução CFC no 1.132, de 21 de novembro de 2008. Aprova a NBC T 16.5 - Registro

Contábil.

. Resolução CFC no 1.133, de 21 de novembro de 2008. Aprova a NBC T 16.6 - Demonstrações

Contábeis.

. Resolução CFC no 1.134, de 21 de novembro de 2008. Aprova a NBC T 16.7 - Consolidação das Demonstrações Contábeis.

. Resolução CFC no 1.135, de 21 de novembro de 2008. Aprova a NBC T 16.8 - Controle Interno.

. Resolução CFC no 1.136, de 21 de novembro de 2008. Aprova a NBC T 16.9 - Depreciação, Amortização e Exaustão.

. Resolução CFC no 1.137, de 21 de novembro de 2008. Aprova a NBC T 16.10 - Avaliação e 


\section{Administração: caminhos para o desenvolvimento sustentável}

Mensuração de Ativos e Passivos em Entidades do Setor Público.

GIL, A. C. Como elaborar projetos de pesquisa. 4. ed. São Paulo: Atlas, 2002.

MOTA, F. G. L. Contabilidade Aplicada ao Setor Público. 1. ed. Brasília: Gestão Pública, 2009.

PORTAL SIAFI. Manual SIAFI. Disponível em:<http://www. tesouro.fazenda.gov.br >. Acesso em 23 mar. 2011.

TRIVIÑOS, A. N. S. Introdução à pesquisa em ciências sociais: a pesquisa qualitativa em educação. São Paulo: Atlas , 1987. 


\section{Capítulo 38}

\section{ANÁLISE DO PROCESSO DA CRIAÇÃO DO CONHECIMENTO ORGANIZACIONAL EM UMA INDÚSTRIA DO VESTUÁRIO: UM ESTUDO DE CASO}

DOI: $10.37423 / 200300454$

Nagamatsu, Rosimeiri Naomi, Dra UTFPR naomi@utfpr.edu.br

Dias, Marcelade Capre,DrUTFPR capre@utfpr.edu.br

Oenning, Josiany, Dra UTFPR josianyo@utfpr.edu.br

Rezende, Juliana,Ribeiro, UTFPR julianarezende17@hotmail.com

RESUMO: 0 presente artigo fem como objetivo analisar o conhecimento organizacional do departamenta de modelagem em uma indústria de confecção de calças jeans. A análise e descrição do procesşo produtivo de uma empresa de vestuárjo, especificamente do departamento de modelagem do vestuárip, unidas à revisão de literaturas demonstrou a importância do conhecimento organizacional no processo produtivo do departamento de modelagem da empresa. A metodoliagia utilizada foi estúdo de caso por meio de observação in locoee entrevistas. Para que o setor de vestuário seja.competitivo, é necessário trañsformar os vários conhecimentos em conhecimento organizacional para melhprar além das características \& funcionalidade do produto o seu/processo de produção.

Palavras chave: Conhecimento, thdústria dowe stuário, eonhecimento organizacional.

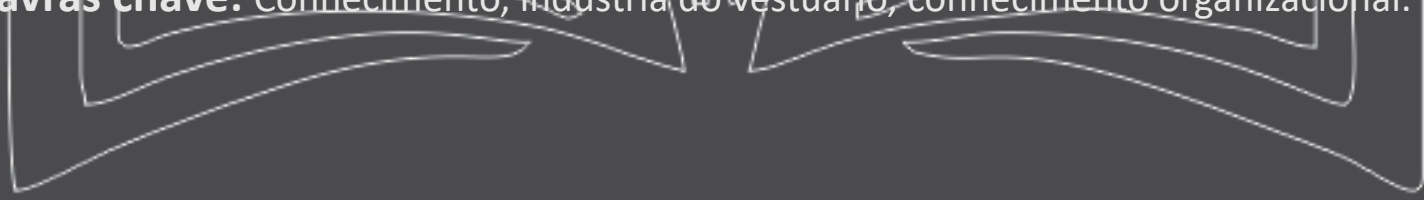




\section{Administração: caminhos para o desenvolvimento sustentável}

\section{INTRODUÇÃO}

Com a estruturação da economia global, o mercado de produtos de consumo vem sofrendo transformações e com isso o setor produtivo em nível mundial tem que se adequar frequentemente ao perfil mutante e diversificado do mercado através de novas estratégias competitivas. Um dos segmentos de produtos de consumo que vem sofrendo com essa onda de invasão de produtos globalizados são empresas da cadeia têxtil, mais precisamente o setor de confecção. Segundo a Associação Brasileira da Industria Têxtil (ABIT) o setor em 2017 foi considerado o 5o maior produtor mundial têxtil, o 2 을 maior produtor e 30 maior consumidor mundial de Denin e o 4 으 maior produtor de roupas do mundo, empregando 1,48 milhão de pessoas.

Segundo dados do SEBRAE (2006), dentre os diversos segmentos produtivos das MPEs, o setor de confecção é o segundo maior empregador de trabalhadores, perdendo apenas para a construção civil. Essa grande absorção de mão de obra pelo setor de confecção se deve ao processo de produção muito flexível, exigência da sazonalidade do mercado fashion de produtos bastante diferenciados.

A customização e a diversificação do produto de moda e consequentemente do processo de produção são necessárias para a sobrevivência das empresas, no entanto, isso está exigindo do mercado de trabalho profissionais mais competentes e capazes de promover a integração entre mercado, produto e processo produtivo.

Em 2006, nas indústrias do vestuário de Apucarana 1\% dos empregados possuíam o Ensino Técnico e $2 \%$ o Ensino Superior (IPARDES, 2006). Desse modo, pode-se concluir que a pesquisa mostra que a maioria do conhecimento acumulado na indústria do vestuário é de conhecimento tácito, adquirido através da experiência diária. Nesse caso, provenientes de anos de atuação na área, onde executam a tarefa sem nenhum embasamento teórico, eles aplicam o conhecimento na prática de trabalho.

Os setores de produção de uma indústria de vestuário em sua maioria são: desenvolvimento de produto; modelagem; estudo de encaixe; corte; serigrafia; bordado; costura; acabamento; embalagem e expedição, sendo a costura o setor que mais concentra a mão de obra e tempo de produção, são responsáveis por cerca de $80 \%$ do trabalho produtivo (Mello Jr. e Másculo, 2006).

Neste sentido o presente artigo tem como objetivo analisar a criação do conhecimento organizacional em uma indústria de confecção de porte médio, mais precisamente, do departamento de modelagem 


\section{Administração: caminhos para o desenvolvimento sustentável}

\section{CONHECIMENTO}

O investimento tecnológico sempre foi constante, e hoje se percebe a necessidade em investir mais em capital humano, seja em qualificação, quanto em ferramentas que facilitem o desenvolvimento do trabalho.

Em muitos casos, para as micros e pequenas empresas, investir em melhoramento produtivo ocorre de forma intuitiva. A falta de conhecimento explícito e o alto custo do investimento em inovação e tecnologia fazem com que esses empresários criem alternativas de melhoramento nos processos e produtos, em sua maioria através de conhecimentos tácitos.

Terra (2005, p.68) exemplifica Senge onde menciona que a criação é resultado "a tendência natural dos indivíduos em buscar uma solução para as tensões encontradas, que surgem em função da discrepância entre a realidade percebida e a realidade desejada".

Neste sentido, Nonaka e Takeuchi (1997, p. 64) definem que os conhecimentos "são específicos ao contexto e relacionais na medida em que dependem da situação e são criados de forma dinâmica na interação social entre as pessoas", podendo ocorrer através de discussões, compartilhamento de experiências e observação. Quando esse conhecimento passa para os trabalhadores em caráter tácito possibilita a eficiência coletiva.

Souza e Alvarenga Neto (2004) citam o modelo de CHOO (1998) onde o objetivo é compreender a gestão do conhecimento passam por três etapas, primeiro a criação da construção do entendimento compartilhado do que é a organização e o que ela faz; em seguida, a criação do conhecimento é o momento em que as organizações adquirem, organizam e processam informação com o propósito de gerar novo conhecimento através da aprendizagem organizacional; e por último a empresa deve escolher a melhor opção dentre todas com base na estratégia empresarial

Nonaka e Takeuchi (1997) entendem o conhecimento como sendo Tácito e Explícito. O conhecimento tácito é dificilmente visível exprimível, é altamente pessoal e difícil de formalizar, o que dificulta a sua transmissão e compartilhamento com outros e está enraizado nas ações e experiências de um indivíduo, bem como suas emoções, valores ou ideais. O conhecimento Explícito é facilmente processado, pois para ser comunicado e compartilhado dentro da organização, ele terá que ser convertido em palavras ou números para que qualquer pessoa possa entender. 


\section{Administração: caminhos para o desenvolvimento sustentável}

É durante a conversão de Conhecimento Tácito em Conhecimento Explícito, e depois em Conhecimento Tácito que o conhecimento Organizacional é criado.

\subsection{CONHECIMENTO ORGANIZACIONAL}

A organização não pode criar conhecimento por si mesmo, sem a iniciativa do indivíduo e a interação que ocorre dentro do grupo. O conhecimento Organizacional é a capacidade de uma empresa criar um novo conhecimento, difundi-lo na organização como um todo e incorporá-lo a produtos, serviços e sistemas. A criação desse conhecimento é a chave para os modos característicos com que as empresas inovam, de forma contínua, incremental e em espiral (NONAKA E TAKEUCHI 1997).

Como um novo conhecimento sempre começa com um indivíduo e como o conhecimento pessoal de um indivíduo se transforma em conhecimento Organizacional valioso para a empresa com um todo, isso pode gerar uma nova patente, ou a experiência de anos de um funcionário, resultando em processo de inovação. O conhecimento pode ser amplificado ou cristalizado em nível de grupo através de discussões, compartilhamento de experiências e observação. (NONAKA E TAKEUCHI 1997)

Desse modo, a experiência e os conhecimentos tácitos de cada indivíduo podem contribuir para o bom desempenho do setor, além disso promover o diálogo entre o grupo pode fazer com que todos compreendam as necessidades que cada indivíduo possui para o bom desempenho do trabalho.

\section{DEPARTAMENTO DE MODELAGEM}

Para entender melhor como o conhecimento organizacional pode melhorar o processo de produção em uma indústria de vestuários é necessário entender o setor ao qual foi aplicado este estudo: o setor de modelagem.

O setor de modelagem faz parte do departamento de desenvolvimento de produto, é responsável em transformar em peças do vestuário coleções idealizadas pelos designers de moda a partir de um desenho plano, croquis ou figurino tendo como objetivo transformar moldes básicos em outros modelos mais elaborados. Para tanto, é usada uma tabela com medidas padronizadas, ou seja, medidas que se assemelham ao padrão médio do corpo de acordo com o perfil consumidor pretendido. Através de uma numeração pré-estabelecida, são executados os moldes bases (blocos de moldes) que servirão como matrizes para a produção em série do produto. 


\section{Administração: caminhos para o desenvolvimento sustentável}

É, também, no setor de modelagem que são definidos o processo de produção, em relação a sequência operacional, ou seja, a sequência hierárquica de máquinas que serão usadas no processo de montagem do vestuário.

Segundo SABRÁ (2009), a modelagem dentro do processo de confecção é um ponto essencial no processo de transformação têxtil em vestuário, que influencia e sofre influência direta do mercado, já que é tido como peça fundamental na motivação de compra do consumidor de produtos de vestuário.

De acordo com SILVEIRA (2003), as indústrias do vestuário buscam novas tecnologias com o intuito de aumentar a produtividade, qualidade e variedade de artigos. O investimento em novas tecnologia permite maior flexibilidade, favorecendo produzir uma maior gama de itens do vestuário, com enfoque em moda, estilo e design. Foi em setores como criação, modelagem e corte de vestuários, onde a tecnologia mais avançou. Um exemplo é o uso dos sistemas CAD/CAM, que trouxe rapidez e precisão do desenvolvimento de modelagens e economia de tempo e tecido no processo de corte.

Assim, pode-se compreender que o setor de modelagem em uma indústria do vestuário é o responsável pela padronização do processo de produção e da qualidade do produto. É nele onde está centralizada as informações em relação as medidas corpóreas dos consumidores alvo de cada marca, além das informações necessárias para alterar a forma e estrutura do produto.

\section{METODOLOGIA}

É de fundamental relevância o conhecimento do processo produtivo do vestuário, para a melhor compreensão do resultado final: o produto. Dessa forma, essa pesquisa faz uma análise do processo produtivo de uma empresa de confecção de calças jeans de porte médio, focando o departamento de modelagem.

Inicialmente, a metodologia desse estudo de caso (YIN, 2001) foi desenvolvida fundamentando-se na gestão do conhecimento, que se divide em:

- explícito: conhecimento teórico catalogado em livros, artigos, de modo geral:

- tácito: que se aplica na empresa de maneira mais prática de acordo com a experiência do indivíduo. 


\section{Administração: caminhos para o desenvolvimento sustentável}

E em seguida, analisou o fluxograma de trabalho do departamento de Modelagem. Além disso, observou a rotina de trabalho baseado no processo de produção do departamento de Modelagem, onde inicia-se a experimentação das formas dos protótipos, que juntamente com os artigos têxteis irão definir o modelo e caimento, fatores primordiais no processo de escolha pelo consumidor. (JONES, 2005)

As decisões tomadas no desenvolvimento da modelagem que norteiam todo o trabalho do processo produtivo da empresa

\section{A EMPRESA}

A empresa estudada para o desenvolvimento desta pesquisa atua no ramo de confecção do vestuário, mais precisamente de calças jeans. Está localizada no município de Londrina - PR. Possui um quadro de 200 funcionários dos quais cinco atuam no departamento de modelagem.

A empresa confecciona artigos em jeans e tecidos PT (Pronto para Tingir), em um processo de confecção industrial, onde é feito para carda peça de vestuário uma ficha técnica, modelagem, separação de aviamentos, corte das peças, bordado, preparação e montagem em máquinas industriais, revisão do produto, processo de acabamento têxtil como lavanderia e estamparia (terceirizado) e acabamento final (aplicação de botões, rebites e etiquetas das marcas). Atualmente possui uma capacidade produtiva mensal de 50.000 peças.

O alto grau de diversificação do produto de moda, da matéria-prima e o fato do tecido ter característica maleável fazem com que não haja muita automação no processo produtivo, exigindo do profissional muita habilidade para execução dos modelos diferenciados propostos pelas tendências estéticas mundiais. (NAGAMATSU, 2008)

O departamento de modelagem da empresa é responsável em transformar um desenho (em forma bidimensional) em uma peça do vestuário (em forma tridimensional). Para tanto utiliza de ferramentas CAD/CAM e informações de um banco de dados da empresa que é o foco desse estudo de caso.

\subsection{HISTÓRICO DA CRIAÇÃO DO CONHECIMENTO ORGANIZACIONAL NO DEPARTAMENTO DE MODELAGEM}

A empresa possuía um histórico de produtos sem padronização em relação as lavagens dos jeans e tamanhos dos manequins. Isso ocorre pois em cada tipo de Beneficiamento Têxtil cada lote de tecido 


\section{Administração: caminhos para o desenvolvimento sustentável}

encolhe em uma determinada porcentagem interferindo no molde desenvolvido, e consequentemente, nas medidas finais do produto.

Muitas vezes os produto possuíam uma estética agradável aos olhos dos consumidores, no entanto, essa falta de padronização no tamanho do produto resultava em não fidelidade do consumidor em relação a marca, ocorrendo assim, a reclamação ou até mesmo a devolução dos produtos por parte de grandes lojistas clientes.

No departamento de modelagem da empresa já existia uma tentativa em organizar as informações por meio de fichas técnicas, no entanto a falta organização do arquivo tornava moroso o trabalho o que acarretou na desmotivação para codificação das informações de modo mais completo.

Além disso, apesar de a empresa organizar-se com documentos padronizados com algumas informações necessárias para o desenvolvimento do produto, perdia-se muito tempo com testes de lavagens e confecção de peças pilotos dos modelos das coleções desenhados pelas estilistas.

Nesta fase, toda a tomada de decisão concentrava-se no proprietário da empresa apesar da modelista possuir todo o conhecimento tácito em relação ao desenvolvimento da modelagem e encolhimento do produto. Isso ocorria pela falta de padronização de um modelo para as tomadas de decisões, onde os outros colaboradores do departamento dependiam das informações e conhecimentos da modelista para executarem a rotina do setor.

Assim, para iniciar o processo de criação do conhecimento organizacional da empresa, os cinco funcionários do departamento de modelagem passaram a conhecer todos os processos do departamento. Todos, de um modo geral, passaram por um rodízio de atividades do departamento.

Desse modo, conhecendo as atividades dos colegas de trabalho, entenderiam as informações e processos necessários para a otimização do trabalho e consequentemente a melhor forma de codificála nos documentos da empresa.

Para sanar o problema de falta de organização das informações obtidas durante o processo, o departamento contou com a colaboração de uma arquivologista que trouxe a rotina de organização das informações. 


\section{Administração: caminhos para o desenvolvimento sustentável}

Além dessa rotina, foi criado um fluxograma do departamento de modelagem para que os funcionários do departamento compreendessem o curso das informações obtidas no departamento de modelagem (figura 1).

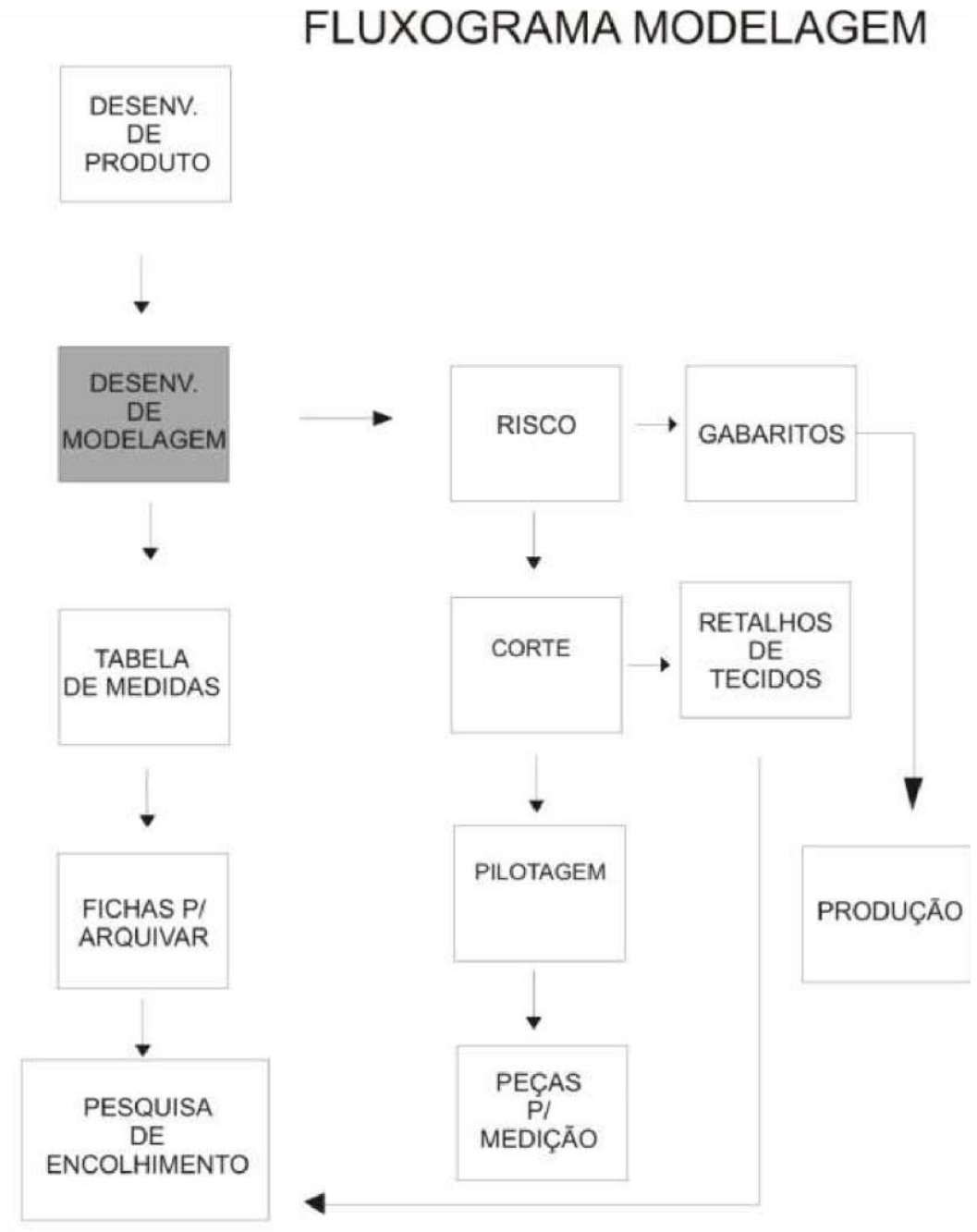

Figura 1: Fluxograma do departamento de modelagem.

Fonte: os autores.

O Fluxograma do departamento de modelagem funciona da seguinte maneira:

1. As Fichas Técnicas de peças Piloto e de Produção são repassadas pelo Desenvolvimento de Produto para o desenvolvimento da modelagem, no sistema CAD/CAM;

2. Tabelas de medidas: desenvolvidas em planilhas computacionais atendendo as especificações de cada produto, são feitas pelas Modelistas, que com o 


\section{Administração: caminhos para o desenvolvimento sustentável}

auxílio das assistentes realizam um levantamento de encolhimento dos tecidos (jeans ou PT) em lavagens específicas, anteriormente realizadas para aplicarem ao desenvolvimento da nova modelagem;

3. Arquivamentos: o arquivamento das fichas técnicas e tabelas de medidas com as informações obtidas nestes processos facilitam a aprovação de novos modelos, além de ser utilizado posteriormente para detectar possíveis falhas no processo de produção de cada modelo;

4. Em seguida, a modelagem é transferida para o riscador fazer o encaixe dos moldes, que se resume em encaixar todas as partes que compõem a modelagem e em tamanhos seguindo a grade de pedido, otimizando o consumo do tecido que depois é impresso na Ploter;

5. Gabaritos: feito o recorte dos gabaritos que são repassados para a Pilotagem e/ou Produção.

6. Junto com os gabaritos é impresso o risco e levado para o setor de Corte, que encaminha as peças cortadas, dependendo das informações contida na Ficha Técnica, para a Pilotagem ou Produção.

As peças-piloto depois de confeccionadas são medidas antes e depois que passam pelo processo de lavanderia, para verificação do encolhimento dos tecidos que servirá de base para a liberação da Produção como também para o desenvolvimento de outros modelos que utilizaram o mesmo processo de lavagem e lote de tecido.

Todas as informações desse processo passaram a ser documentados e arquivados para serem utilizados como parâmetro para verificação de falhas no processo de produção ou para servirem de partida para o desenvolvimento de outros modelos.

\subsection{ANÁLISE DOS RESULTADOS}

Os pontos relevantes no departamento de Modelagem é o gerenciamento por parte da Líder, possuidora do conhecimento tácito, que orienta a organização das etapas de trabalho e o treinamento dado aos funcionários, facilitando a aprovação das fichas técnicas de peças que irão para a Produção ou Pilotagem, evitando atrasos para as próximas etapas do processo produtivo da empresa. 


\section{Administração: caminhos para o desenvolvimento sustentável}

O sistema CAD/ CAM, facilita e muito o processo de desenvolvimento da modelagem, função já predeterminada pelos equipamentos tecnológicos, porém a empresa quando inicia com um novo sistema recebe um treinamento por parte da empresa prestadora do serviço. No entanto, cabe ao funcionário personalizar e otimizar a utilização da ferramenta durante o processo de trabalho para que se torne mais ágil, que só se dá com a experiência dia-a-dia do manuseio do programa.

Mesmo com a documentação das informações de todo o processo, um problema que acontece na empresa, é a falha no controle do encolhimento do artigo têxtil. Ainda que, com a realização de testes em retalhos nos lotes novos de tecidos, quando é feito a verificação das medidas antes e depois do processo de lavanderia, acontecem variações no porcentual de encolhimento de lotes de tecidos diferentes, mas de mesmo fornecedor.

Essas variações podem ser referentes ao fornecedor do lote de tecido, modo de estocagem do tecido e a não conformidade no processo de lavanderia. Esses fatores podem interferir no resultado final do produto.

\section{CONSIDERAÇÕES FINAIS}

Enfim, na transferência do conhecimento Explícito em Tácito, surge o conhecimento Organizacional que é a capacidade da empresa criar um novo conhecimento, difundi-lo na organização e incorporálo aos seus produtos de modo geral.

O Conhecimento Explícito (conhecimento teórico catalogado em livros, artigos, em geral) e Tácito (se aplica na empresa de maneira mais prática de acordo com a experiência do indivíduo), são aplicados no dia-a-dia da empresa tanto por profissionais graduados em área de design de moda, arquitetura, design gráfico, design de interiores, entre outros, quanto por profissionais sem formação acadêmica, porém com experiência de trabalho no ramo, que contribuem para a melhoria contínua do processo de produção do produto.

O Departamento de Modelagem é organizado de uma maneira para que todos os funcionários sejam treinados, com o objetivo de aprender todo o procedimento de trabalho. E, esse treinamento faz com que o fluxo seja ágil facilitando a aprovação de peças Piloto e consequentemente da liberação para a Produção em grande escala do modelo desenvolvido, já que o setor é um dos principais responsáveis por garantir o andamento da Produção e da Pilotagem. 


\section{Administração: caminhos para o desenvolvimento sustentável}

Assim, a criação do conhecimento organizacional na empresa de calças jeans estudada proporcionou ao responsável pelo departamento de modelagem, mais autonomia para tomada de decisão, para liderar as tarefas da maneira mais conveniente a todos.

No entanto, apesar de todo o esforço da equipe ainda ocorrem falhas na padronização do produto, principalmente em decorrência da não conformidade no processo de produção do setor de lavanderia.

Portanto, produzir não é apenas utilizar conhecimentos tácito ou explicito, é necessário equacionar fatores de natureza variadas, atendendo aos critérios de qualidade e produtividade.

Para que o setor de vestuário seja competitivo, é necessário transformar os vários conhecimentos em conhecimento organizacional para melhorar as características e funcionalidade do produto.

\section{REFERÊNCIAS}

ARAUJO, Mário de. Tecnologia do vestuário. Lisboa: Fundação Calouste Gulbenkian, 1996.

GIL, Antonio Carlos. Como elaborar projetos de pesquisa, 5 ed. São Paulo: Atlas, 2010.

IPARDES Censo industrial do arranjo produtivo local de confecções de bonés de Apucarana o Estado do Paraná. Curitiba: Ipardes: ACIA, 2006.

JONES, Sue Jenkyn. Fashion design - manual do estilista: Sue Jenkyn Jones. 1.ed. São Paulo: Cosac Naify, 2005.

MELLO JR., Abelardo da Silva; MÁSCULO, Francisco Soares. Analise comparativa das atividades de costurar calcinhas e blusas, sob a ótica da análise ergonômica do trabalho: estudo de caso numa indústria de confecções. In: 14을 CONGRESSO BRASILEIRO ERGONOMIA, 40 FORUM BRASILEIRO DE ERGONOMIA, 2 ABERGO JOVEM e II CONGRESSO BRASILEIRO DE INICIAÇÃO EM ERGONOMIA, 2006, Curitiba. Anais... Curitiba: ABERGO-BR, 2006. 1 CD-Rom.

NAGAMATSU. Rosimeiri Naomi; HATAKEYAMA,Kazuo. MARÇAL, Rui.F.M.. Implantação de cadeira ergonômica: estudo de caso numa indústria de confecção de bonés. In: 15을 CONGRESSO BRASILEIRO ERGONOMIA, 6 FORUM BRASILEIRO DE ERGONOMIA, 3o ABERGO JOVEM e 3 CONGRESSO BRASILEIRO DE INICIAÇÃO EM ERGONOMIA, 2008, Porto Seguro. Anais... Porto Seguro: ABERGO-BR, 2008. 1 CD-Rom.

NONAKA, Ikujiro. TAKEUCHI, Hirotaka. Criação de conhecimento na empresa. Rio de Janeiro: Elsevier, 1997.

SABRÁ, Flávio org. Modelagem: tecnologia em produção de vestuário.1. ed. São Paulo: Estação das Letras e Cores, 2009.

SEBRAE - Onde estão as Micro e Pequenas Empresas no Brasil. 1a ed. - São Paulo :Editora SEBRAE, 2006. 


\section{Administração: caminhos para o desenvolvimento sustentável}

SILVEIRA, Icléia et al. Análise da implantação do sistema CAD, na indústria do vestuário. Moda palavra 2: Reflexões em moda / Universidade do Estado de Santa Catarina, Florianópolis, v. 2, no 2, p. 1730, 2003.

SOUZA, R.R.; ALVARENGA NETO, R.C.D. A construção do conceito de gestão do conhecimento: práticas organizacionais garantias literárias e o fenômeno social. REUNA vol 9, no2 , 2004.

TERRA, José Cláudio Cyrineu. Gestão do conhecimento: o grande desafio empresarial. Rio de Janeiro: Elsevier, 2005.

YIN, Robert K. Estudo de caso: planejamento e métodos - 2ª Ed. Porto Alegre: editora Bookman, 2001. 


\section{Capítulo 39}

\section{ÉTICA PROFISSIONAL: A PERCEPÇÃO DOS EGRESSOS DO CURSO DE CIÊNCIAS CONTÁBEIS DA UFMS}

DOI: $10.37423 / 200300456$

Cleston Alexandre dos Santos (UFMS-CPTL) cleston.alexandre@hotmail.com Maria Saleti Carvalho Brcko (UFMS-CPAN) saleticbrcko@yahoo.com.br Leandro Assad Benevides (UFMS-CPAN) leandro_assad@hotmail.com Luciann de Aquino Evangelista (UFMS-CPAN) luciann.aquing@hotmail.com

RESUMQ: O profissjonal contábil destaca-se na sociedade por seu papel de profeção ao patrimônio da empresa e pela capaciedade de produzir/informaçóes necesśárias-à tomada de decisão. A prática contábitpróporcia benefícios recíprocos a quem pratica e a quem recébe o fruto do trabalho, sendo primordial uma postura ética nas atividades exercidas. O presente estudo tem como objetive geral evidenciar a percepção dos egressos do curso de Ciências Contábeis da Universidade Federal de Mato Grosșo do Sul, Campus do Pantanal, quanto à Ética Profissionar.Trata-se de um estudo descritivo, ex post facto, em condiçpós de campo, transversal, utilizando-se de coleta de dados com questionário previamente formulado, aplicado aos egressos do Curso de Ciên çás Contábeis. No resultado da pesquisa foi constàtado que 58,82\% dos egressos apresentam conhecimęhto em relação ao Código de Ética do Prof ssional Contader. Os alunos destacaram os pais como sendo os que predominam no fator de atuação ética das pessoas, mas Q profes sof e $\phi$ patrão também tem um papel importante. A maioria des respondentes discordam dà prática da concorrência-desleât-na oferta de serviços e đa realização de serviços que não apresentem a realidade da empresa.

Palavras-chave: Percepção, Egressos, Ética contábil. 


\section{Administração: caminhos para o desenvolvimento sustentável}

\section{INTRODUÇÃO}

A escolha por uma profissão é optativa, mas ao escolhê-la, o conjunto de normas de conduta e deveres profissionais passa a ser obrigatório. Toda a fase de formação profissional, o aprendizado das competências e habilidades referentes à prática específica numa determinada área, deve incluir a reflexão. Ao completar a formação em nível superior, a pessoa faz um juramento, que significa sua adesão e comprometimento com a categoria profissional onde formalmente ingressa. Isto caracteriza o aspecto moral da chamada Ética Profissional, uma adesão voluntária a um conjunto de regras estabelecidas como sendo as mais adequadas para o seu exercício.

Conforme Lisboa $(1997$, p.23) a ética e moral "[...] pode ser definido como sendo um ramo da filosofia que lida com o que é moralmente bom ou mau, certo ou errado". Baseado nesta definição, a fase da escolha profissional, ainda durante a adolescência muitas vezes, já deve ser permeada por esta reflexão.

Nos diversos tipos de atividades, faz se necessário uma postura compatível com os bons costumes e as normas que regem o convívio em comunidade. O contador, por exemplo, tem que estar em constante aperfeiçoamento para conseguir atender as necessidade de evolução do mercado e estar pronto para verificar as causas que estão ajudando no crescimento da empresa, bem como evitar futuros problemas que possam surgir decorrentes da deficiência do uso de recursos pela administração.

A gestão contábil organizacional ocorre por meio do embasamento dos princípios, postulados e convenções contábeis, ficando o Contador incumbido da orientação correta e eficaz às empresas, respeitando o Código de Ética Profissional do Contador e a legislação vigente. É de se esperar que o profissional da contabilidade na orientação ao seu cliente, mostre segurança, conhecimento e domínio das regras estabelecidas, possuindo habilidades para comprovar ações irregulares e ilegais, fazendo do cliente um aliado no cumprimento das normas e deveres.

Qual é a percepção dos egressos do curso de Ciências Contábeis da Universidade Federal de Mato Grosso do Sul, Campus do Pantanal, quanto à Ética Profissional? É a questão norteadora do presente trabalho cujo objetivo geral é evidenciar a percepção dos egressos do curso de Ciências Contábeis da Universidade Federal de Mato Grosso do Sul, Campus do Pantanal, quanto à Ética Profissional. 


\section{Administração: caminhos para o desenvolvimento sustentável}

Quando se fala de grupos profissionais ou de categoria profissional, há valores que podem ser estruturados e sistematizados por meio dos códigos de ética profissional, indicando limites em relação aos quais o profissional pode medir as suas possibilidades e as limitações a que deverá se submeter. Segundo Camargo (1999, p. 34) "os códigos de ética por si não tornam melhores os profissionais, mas representam uma luz e uma pista para seu comportamento; mais do que ater-se àquilo que é prescrito literalmente, é necessário compreender e viver a razão básica das determinações."

O Código de Ética do Profissional Contábil tem a finalidade de regulamentar o exercício da profissão, dá consciência de visão do certo e do errado e é fundamental para que o profissional siga os princípios, as normas e os deveres ao exercer as suas atividades. Desta maneira, muitas vezes é possível evitar a prática incorreta ou atos ilícitos observando e aplicando o Código de Ética pertinente ao Profissional Contábil.

O presente trabalho está estruturado em mais quatro tópicos. No segundo tópico é abordada a revisão de literatura, no terceiro o design da pesquisa de campo. No quarto os resultados da pesquisa e na sequência as considerações finais.

\section{REVISÃO DA LITERATURA}

A revisão da literatura do presente trabalho contemplará a ética geral aplicada, a ética do profissional contador brasileiro e por fim, as penalidades aplicadas ao profissional contador.

\section{1 ÉTICA GERAL APLICADA}

A palavra ética vem do grego ethos que quer dizer "modo de ser", ou "caráter", enquanto maneira de vida que o homem adquire ou conquista. Mais objetivamente, pode-se definir ética como sendo um conjunto sistemático de conhecimentos racionais e objetivos a respeito do comportamento humano, moral, tal como colocado por Vásquez (1982). Entrementes, a ética se advém dos conhecimentos racionais e objetivos, contudo, a própria coisa ser racional e objetiva deve ter um ponto de partida, isto significa dizer, o racional e objetivo vão servir a quem? Quem está dizendo o que é certo ou errado?

Portanto a ética significa a teoria ou ciência do comportamento moral dos homens em sociedade. A ética é o aspecto científico da moral, pois tanto a ética como a moral, envolve a filosofia, a história, a psicologia, a religião, a política, o direito, e toda uma estrutura que cerca o ser humano. Isto faz com 


\section{Administração: caminhos para o desenvolvimento sustentável}

que o termo ética necessite ter, em verdade, uma maneira correta para ser empregado, quer dizer, ser imparcial, a tal ponto a ser um conjunto de princípios que norteia uma maneira de viver bem, consigo próprio, e com os outros.

Segundo Bittar (2009, p. 104 - 105):

os pilares de uma sociedade podem ser os próprios valores por ela construídos, capazes de sustentá-la em períodos de crise, em momentos de conflito, em épocas de cortesia. Quais são esses pilares, senão os sólidos valores de preservação do indivíduo e da coletividade, construídos por processos históricos pela cultura de uma sociedade.

O comportamento ético do homem se tornará realidade quando ele conseguir compreender as heranças culturais que foram agregadas na sua formação individual, tomando como parâmetro básico o respeito aos seus semelhantes. O fato de os seres humanos serem os únicos a "construir culturas" que possuem um certo número de características, que embora universais, também variam de uma sociedade para outra. Esta evolução cultural traz consigo as tradições e as transformações, o que significa que os conceitos e os valores, de uma comunidade ou sociedade podem ter conotações diferentes, e portanto, os valores éticos e morais também. De qualquer modo, a história presenciou civilizações onde o senso de coletividade e sociedade era muito arraigado, porque valores de preservação do indivíduo e da coletividade eram mais cultivados.

De acordo com Mansur (2007): [...] "ética é o comportar-se de forma individual ou coletiva por ações justas e para o bem, no propósito de ajudar o ser humano a conquistar seu apogeu". Hoje, no mundo contemporâneo, o consumidor exigente busca relacionar-se com empresas que contribuem para a construção de um mundo atual e justo; que praticam ações dignas de uma empresa responsável, ou seja, empresas com atitudes às claras e com relacionamentos eficazes junto à sua clientela.

Portanto, a ética, é o julgamento do que é certo ou errado, bom ou ruim. A ética tem como objetivo o estudo da conduta humana e tem como objetivo também a padronização das condutas com fins de diminuir os conflitos que possam surgir da convivência em sociedade e no desenvolvimento profissional. Desta forma, nascem os códigos de ética profissionais, para tentar padronizar procedimentos diante de determinadas situações cotidianas, cujo objetivo será divulgar o senso de justiça que todo profissional deve ser possuidor, sempre lutando por uma sociedade mais justa.

Segundo Sá (1998, p. 100), 


\section{Administração: caminhos para o desenvolvimento sustentável}

que dentre todas as profissões a do Contabilista é uma das que mais exija do profissional, a todo instante, um apelo ao comportamento ético, pois: É a atividade contábil aquela que através de seus relatórios, registros, demonstrativos e principalmente pela assinatura da responsabilidade técnica pelo serviço prestado, que expõe aos dependentes e usuários da contabilidade tais informações.

O contabilista apresenta a terceiros, que são os usuários de suas informações, o resultado de seu trabalho, que deve ser feito com credibilidade. Caso essas informações não sejam fornecidas com base no conhecimento técnico e na ética, poderão trazer sérios problemas, como:

a) ao empresário contratante dos trabalhos, informações que poderão levá-lo a tomar decisões prejudiciais à empresa;

b) aos sócios, acionistas ou proprietários, prejuízos na avaliação de seus patrimônios;

c) aos credores ou fornecedores de créditos, prejuízos pelo eventual não-recebimento de seus direitos;

d) ao País, pelo não-recebimento de impostos, o que causará danos a todos de maneira geral.

Alcançar a devida valorização da profissão requer competência e dedicação de cada profissional envolvido e, atualmente, mais do que nunca, exige atitudes comportamentais éticas para com a sociedade, o que pode ser o diferencial do sucesso ou do fracasso, principalmente, naquelas profissões que protegem, direta ou indiretamente, os interesses da sociedade, como, por exemplo, a profissão contábil.

Segundo Franco (1991, p. 273),

Uma das marcas distintivas da profissão contábil é a sua responsabilidade para com o público. É salutar lembrar que os contadores são mais notados por serem honestos do que por serem confiáveis. Como contadores, precisamos reconhecer que nosso comportamento ético é envolvido não apenas pelo que vemos como ético, mas pelo que é visto por terceiros que nos observam.

Há algumas décadas, algumas características evidenciavam o bom profissional: iniciativa, liderança, criatividade, auto desenvolvimento, habilidade para lidar com pessoas etc., porém, diante de um mercado muito exigente e competitivo tais características mudaram muito. Hoje o mercado exige um profissional capaz de avançar junto com a tecnologia, solucionar problemas, interpretar relatórios gerenciais. A necessidade que se tem não é mais apenas de ser um mero guardião de números e 


\section{Administração: caminhos para o desenvolvimento sustentável}

valores, mas sim um parceiro eficiente, e que age dentro dos preceitos que reza o código de ética, altamente qualificado, capaz de prestar informações corretas e atualizadas, contribuindo assim com os gestores na tomada de decisões.

\section{2 ÉTICA PROFISSIONAL DO CONTADOR BRASILEIRO}

A importância do profissional contábil na sociedade destaca-se por seu papel de proteção ao patrimônio da empresa e pela capacidade de produzir informações necessárias à tomada de decisão. A prática contábil traz benefícios recíprocos a quem pratica e a quem recebe o fruto do trabalho. $A$ partir daí tem-se a necessidade de se obter postura ética nas atividades exercidas pelo profissional da contabilidade.

É importante destacar o que diz Sá (1998, p.127): “a profissão que pode enobrecer pelas atitudes corretas e competentes, pode também ensejar a desmoralização, através da conduta inconveniente, com a quebra de princípios éticos". A Contabilidade é uma das profissões mais antigas da humanidade. Ainda segundo Sá (1998, p.130) "há provas de exercício profissional da Contabilidade na civilização sumero-babilônica, há mais de 6.000 anos. Os registros contábeis datam de mais de 20.000 anos, encontrados no Paleolítico Superior."

O homem primitivo possuía alguns conceitos rudimentares ao inventariar instrumentos de caça e pesca, rebanhos e ânforas de bebidas. O ser que se dedica à contabilidade possui deveres para com a regularidade do emprego racional das riquezas nas empresas, nas instituições diversas, assim como perante o ensino, a pesquisa, a difusão cultural e educacional, o mercado, a sociedade e também na produção de provas e opiniões sobre comportamentos do patrimônio. (SÁ, 1998).

A ética profissional, ou moral profissional, conforme Lisboa (1997, p.29), denomina-se, também, deontologia, a qual compreende o estudo dos conceitos básicos o direito e do dever na profissão. Segundo Andrade (1999, p.57):

Ética profissional é o conjunto de princípios que regem a conduta funcional e de comportamento daqueles que compõem determinada profissão. Assim, a ética profissional aplicada ao exercício da contabilidade, é a parte da moral que trata das regras de conduta do contabilista. Entende-se, pois, que Ética Profissional é o conjunto de regras de comportamento do contabilista, no exercício de suas atividades profissionais.

O respaldo da ética na profissão contábil é fundamental para perenidade da atividade profissional. 0 argumento mais relevante, de acordo com Lisboa (1997), que pode ser utilizado, no meio profissional, 


\section{Administração: caminhos para o desenvolvimento sustentável}

para que todos compreendam a importância da ética, válido para qualquer profissão, é o de que, caso a sociedade em geral não perceba a disposição dos profissionais em proteger os valores éticos, certamente ela passará a não acreditar mais na profissão.

Marion e Santos (2000) destacam que a profissão contábil, assim como qualquer outra, é exercida na combinação da competência com a ética. Ou melhor, é o exercício da competência conduzido pela ética. A competência é fazer aquilo que é certo. A ética exige que seja feito de forma correta, consistente com boa reputação da profissão.

O exercício de uma profissão pressupõe o pleno conhecimento e o domínio de toda a sua amplitude, não apenas quanto aos aspectos técnicos, mas também quanto às regras de conduta moral. Não é admissível, sob o ponto de vista ético, que um indivíduo aceite um encargo sem ter a competência profissional para exercê-lo; ou que o profissional adote ou forneça deliberadamente uma solução técnica para determinado problema, sabendo não se tratar da melhor opção; ou ainda que, por falta de zelo, o profissional adote uma solução que traga efeitos danosos no futuro (SILVA et al, 2004).

De acordo com o código de ética da classe, é dever do profissional contábil, entre outros, exercer a profissão com zelo, diligência, honestidade e capacidade técnica, observada toda a legislação vigente, em especial aos Princípios de Contabilidade e as Normas Brasileiras de Contabilidade, e resguardados os interesses de seus clientes e/ou empregadores, sem prejuízo da dignidade e independência profissionais. Ao passo que, no desempenho de suas funções é vedado, entre outras coisas, exercer atividade ou ligar o seu nome a empreendimentos com finalidades ilícitas, assim como, receber do cliente ou empregador qualquer vantagem que saiba para aplicação ilícita.

É importante ressaltar que o profissional contábil é o que mais está sujeito a partilhar de esquemas espúrios já que sua atividade está intimamente ligada com repórter de dados, cifras, apuração de resultados, e, conseqüentemente, exibe dados que geram montantes referentes a impostos, taxas, dividendos, encargos, valor patrimonial da ação, lucro, etc. Logo, é de extrema importância a existência de mecanismos que busquem preservar a conduta ética na classe contábil.

\subsection{PENALIDADES APLICADAS AO PROFISSIONAL CONTADOR}

É dever do contador apresentar aos sócios as contas justificadas de seu trabalho e apresentar-lhes, anualmente, o inventário, bem como o balanço patrimonial e o de resultado. Destaca-se que, de acordo com o novo código civil, o contador é tido como preposto responsável pela escrituração 


\section{Administração: caminhos para o desenvolvimento sustentável}

contábil das sociedades empresárias ou dos empresários. Logo, as atividades do contador são tratadas com mais rigor.

Franco e Cardoso (2009) deixam claro que a responsabilidade civil é a obrigação que o autor tem de responder legal ou moralmente por seus próprios atos ou por atos de outrem, ressarcir ou reparar danos ou prejuízos causados, através de uma indenização.

De acordo com o art. 186 da lei 10.406 de 11/01/2002, código civil brasileiro, aquele que, por ação ou omissão voluntária, negligência ou imprudência, violar direito e causar dano a outrem, ainda que exclusivamente moral, comete ato ilícito. Trata-se da responsabilização resultante da prática de uma infração a um dever, legal ou contratual, e do qual resulta dano a terceiro. Com isso fica seu causador na obrigação de reparar o prejuízo causado. Essa referência aplica-se perfeitamente nos casos de trabalhos elaborados com erros técnicos, os quais resultem em prejuízo para o cliente.

Conforme Oliveira (2005), a responsabilidade civil abrange tanto a obrigação de reparar danos decorrentes de inadimplência, de má execução ou de atraso no cumprimento de obrigações e violação de outros direitos alheios. Na responsabilidade civil, o interesse é diretamente do prejudicado em recompor seu patrimônio privado lesado.

Ressaltam-se também as penalidades imputadas ao profissional contábil, de acordo com o código de ética do profissional contador. $\mathrm{O}$ artigo 12 deixa claro que a transgressão de preceito do código de ética do profissional contador constitui infração ética, sancionada, segundo a gravidade, com aplicação das penalidades de advertência reservada, censura reservada e censura pública.

De acordo com o parágrafo primeiro do artigo 12 do código de ética do profissional contador, na aplicação das sanções éticas, podem ser consideradas como atenuantes a falta cometida em defesa de prerrogativa profissional, a ausência de punição ética anterior e a prestação de relevantes serviços à contabilidade. Ao passo que o parágrafo segundo deixa claro que na aplicação das sanções éticas, podem ser consideradas como agravantes a ação cometida que resulte em ato que denigra publicamente a imagem do profissional da contabilidade e a punição ética anterior transitada em julgado.

A fiscalização do exercício da profissão contábil, assim entendendo os profissionais habilitados como contadores e técnicos em contabilidade, é exercida pelo conselho federal de contabilidade e pelos conselhos regionais de contabilidade. Compete, entre outras coisas, ao conselho regional de 


\section{Administração: caminhos para o desenvolvimento sustentável}

contabilidade fiscalizar o exercício das profissões de contador e técnico em contabilidade, impedindo e punindo as infrações, e, bem assim, enviando às autoridades competentes minuciosos e documentados relatórios sobre fatos que apurarem, e cuja solução ou repressão não seja de sua alçada; ao passo que é de incumbência do Conselho Federal de Contabilidade decidir, em última instância, os recursos de penalidade imposta pelos Conselhos Regionais. (BRASIL, 1946).

Comumente à aplicação do código de ética do profissional contador e do código civil, destacam-se algumas legislações a serem analisadas acerca da responsabilidade penal do contador: código penal; lei 8.137/90, no que tange aos crimes contra a ordem tributária; lei 11.101/2005, casos de falências, e lei 7.492, crimes contra o sistema financeiro nacional.

A responsabilidade penal do contador, de acordo com Oliveira (2005), busca a reparação do dano causado ao conjunto social, sem a repercussão patrimonial direta a sociedade, agindo contra a liberdade do agente reprimindo-o. A responsabilidade penal é pessoal e intransmissível, a pena imposta consiste na privação de liberdade do réu.

De acordo com o art. 1ㅇ da lei 8.137/90, constitui crime contra a ordem tributária suprimir ou reduzir tributo, ou contribuição social e qualquer acessório, mediante o ato de:

I - omitir informação, ou prestar declaração falsa às autoridades fazendárias;

II - fraudar a fiscalização tributária;

III - falsificar ou alterar a nota fiscal, fatura, duplicata, nota de venda, ou qualquer outro documento relativo à operação tributável;

IV - elaborar, distribuir, fornecer, emitir ou utilizar documento que saiba ou deva saber falso ou inexato;

V - Assim como, negar ou deixar de fornecer, quando obrigatório, nota fiscal ou documento equivalente, relativa à venda de mercadoria ou prestação de serviço, efetivamente realizada, ou fornecê-la em desacordo com a legislação. A pena para essa infração é de reclusão de 2 (dois) a 5 (cinco) anos e multa. A falta de atendimento da exigência da autoridade, no prazo de 10 (dez) dias, poderá ser convertida em horas em razão da maior ou menor complexidade da matéria ou da dificuldade quanto ao atendimento da exigência. 


\section{Administração: caminhos para o desenvolvimento sustentável}

A sonegação de contribuição previdenciária, regulamentada pelo artigo 37-A do código penal e acrescentado pela lei 9.983/2000, se perfaz com a ação de suprimir ou reduzir contribuição social previdenciária e qualquer acessório, mediante as seguintes condutas: I - omitir de folha de pagamento da empresa ou de documento de informações previsto pela legislação previdenciária de segurado empregado, empresário, trabalhador avulso ou trabalhador autônomo ou a este equiparado que lhe prestem serviços; II - deixar de lançar mensalmente nos títulos próprios da contabilidade da empresa as quantias descontadas dos segurados ou as devidas pelo empregador ou pelo tomador de serviços; III - omitir, total ou parcialmente, receitas ou lucros auferidos, remunerações pagas ou creditadas e demais fatos geradores de contribuições sociais previdenciárias. A pena é reclusão, de 2 (dois) a 5 (cinco) anos, e multa.

No caso de sonegação de contribuição previdenciária, é extinta a punibilidade se o agente, espontaneamente, declara e confessa as contribuições, importâncias ou valores e presta as informações devidas à previdência social, na forma definida em lei ou regulamento, antes do início da ação fiscal. Destaca-se também a lei № 11.101/2005 que regula a recuperação judicial, a extrajudicial e a falência do empresário e da sociedade empresária. A legislação em questão amplia a responsabilidade do profissional contábil no que tange aos crimes em espécie fraude a credores, colocando em evidencia sua responsabilidade solidária. Em seu artigo 168, deixa claro que o contador ao praticar, antes ou depois da sentença que decretar a falência, conceder a recuperação judicial ou homologar a recuperação extrajudicial, ato fraudulento que resulte ou possa resultar em prejuízo aos credores, com o fim de obter ou assegurar vantagem indevida para si ou para outrem é passível de pena de reclusão de 3 a 6 anos e multa.

\section{DESIGN DA PESQUISA DE CAMPO}

Na realização da presente pesquisa, é necessário selecionar um planejamento específico para usar. Existem vários modelos diferentes, mas nenhum sistema único define todas as variações que devem ser consideradas. Segundo Cooper e Schindler (2003), o presente estudo envolve procedimentos de interrogação/comunicação, através de questionário. Trata-se de um estudo ex post facto, transversal e em condições de campo. Com relação ao objetivo do estudo, é uma pesquisa descritiva e causal.

Como instrumento de pesquisa foi utilizado o questionário fechado, dividido em 2 partes e contendo no total 15 perguntas. Quanto às perguntas abordadas nos questionários, segundo Cooper \& Schindler 


\section{Administração: caminhos para o desenvolvimento sustentável}

(2003, p. 278), "as decisões de estratégia de resposta (o tipo de pergunta usada) dependem do conteúdo e dos objetivos das perguntas específicas".

A população foi os egressos do Curso de Ciências Contábeis da Universidade Federal de Mato Grosso do Sul, Campus do Pantanal. O período de coleta e análise de dados ocorreu de 26 de abril de 2011 a 20 de maio de 2011, sendo entregue um questionário ao potencial respondente.

\section{DISCUSSÃO E ANÁLISE DOS DADOS}

Do total de 24 (vinte e quatro) egressos do curso, 17 (dezessete) participaram da pesquisa, ou seja, 70,83\% dos egressos. O questionário foi dividido em duas partes: na primeira foram abordadas as características dos respondentes e na segunda a percepção da Ética Profissional do Contador por parte dos egressos.

Na primeira parte do questionário em que foi abordado as caracteristicas do respondente, foi constatado que $70,59 \%$ dos egressos são do gênero masculino e $29,41 \%$ do gênero feminino. Verificou-se o predomínio de respondentes entre 26 e 30 anos de idade, representado por 6 acadêmicos, ou seja, 35,29\% do total; em seguida, com idade entre 22 e 25 anos, representada por 5 acadêmicos, ou seja, $29,41 \%$ do total. Apenas $11,76 \%$ possuem idade até 21 anos e 23,53\% possuem idade superior a 30 anos.

Dos 17 alunos entrevistados, 76,47\% tem o curso de Ciências Contábeis como o primeiro em graduação e $23,53 \%$, apresentam outro tipo de graduação em seu currículo acadêmico.Os resultados também revelam que entre os acadêmicos, apenas 6 atuam na área contábil, e desses 6 egressos, 4 $(66,67 \%)$ trabalham pelo menos a 5 anos na área e os outros $2(33,33 \%)$, trabalham em um período superior a 6 anos, revelando menor convivência quanto o mercado de trabalho. Do total de 17 entrevistados, todos possuem algum tipo de experiência profissional, onde a vivência em um ambiente de trabalho pode influenciar as percepções quanto à ética.

Na segunda parte do questionário foi abordado a percepção da Ética Profissional do Contador por parte dos egressos. 


\section{Administração: caminhos para o desenvolvimento sustentável}

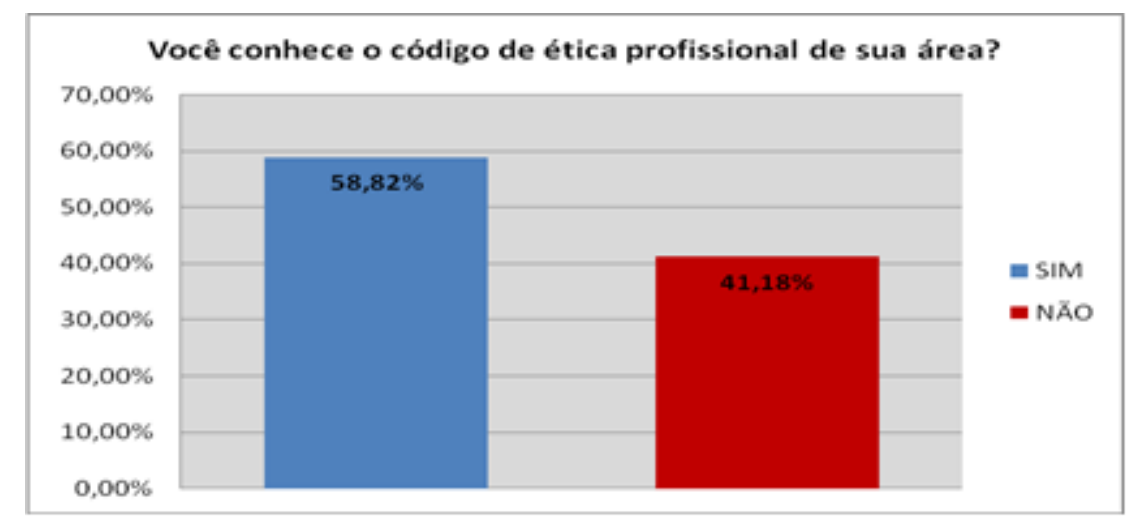

Fonte: Dados da pesquisa

Gráfico 1: Conhecimento quanto a ética profissional contábil.

Analisando os dados obtidos no Gráfico 1, pode-se perceber que cerca de 58,82\% dos entrevistados admitem ter um conhecimento em relação ao Código de Ética do Profissional do Contador. Mesmo tendo um percentual relevante de egressos que conhecem o código de ética de sua área, 41,18\% dos entrevistados confirmaram que não possuem conhecimento.

Dos $58,82 \%$ que possuem conhecimento do código de ética, representado por 10 entrevistados, $60 \%$ deles afirmam ter realizado a leitura completa do código de ética da classe e que também o mesmo é suficiente para uma boa conduta profissional.

Como forma de minimizar o índice de descumprimento das normas éticas que de certa forma limita o comportamento do profissional contábil, surgem as sanções. Portanto na análise do Gráfico 2, podese verificar que 11 dos 17 respondentes, ou seja 64,71\%, afirmam que as sanções promovem sim as ações éticas, $23,53 \%$ responderam as ações não promovem éticas e $11,76 \%$ não souberam opinar sobre o assunto. 


\section{Administração: caminhos para o desenvolvimento sustentável}

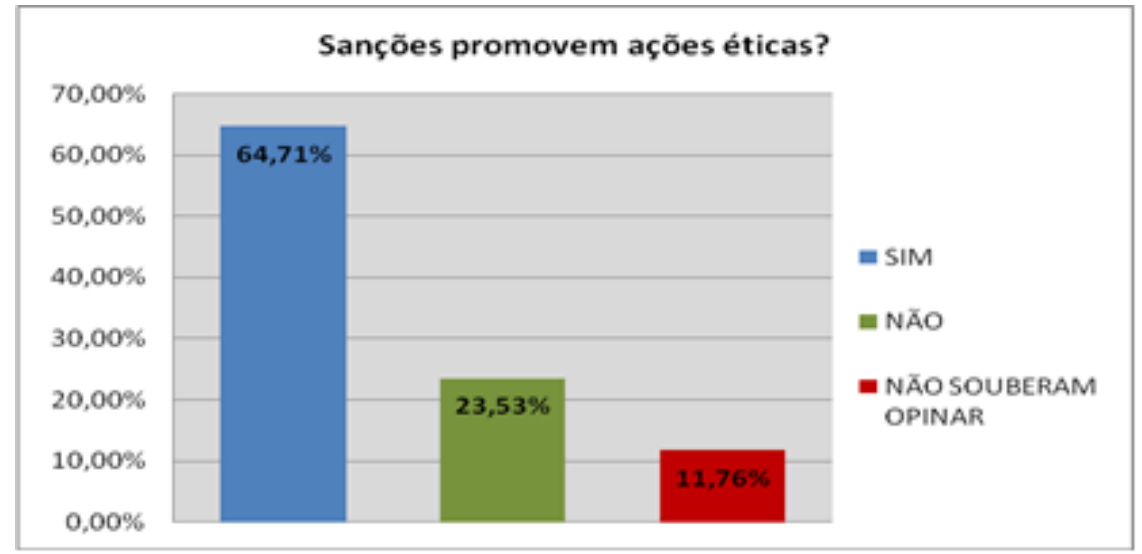

Fonte: Dados da pesquisa

Gráfico 2: Sanções e ética.

De acordo com gráfico 3, quando questionados sobre o entendimento sobre o que é ser ético, os egressos alternaram suas respostas.

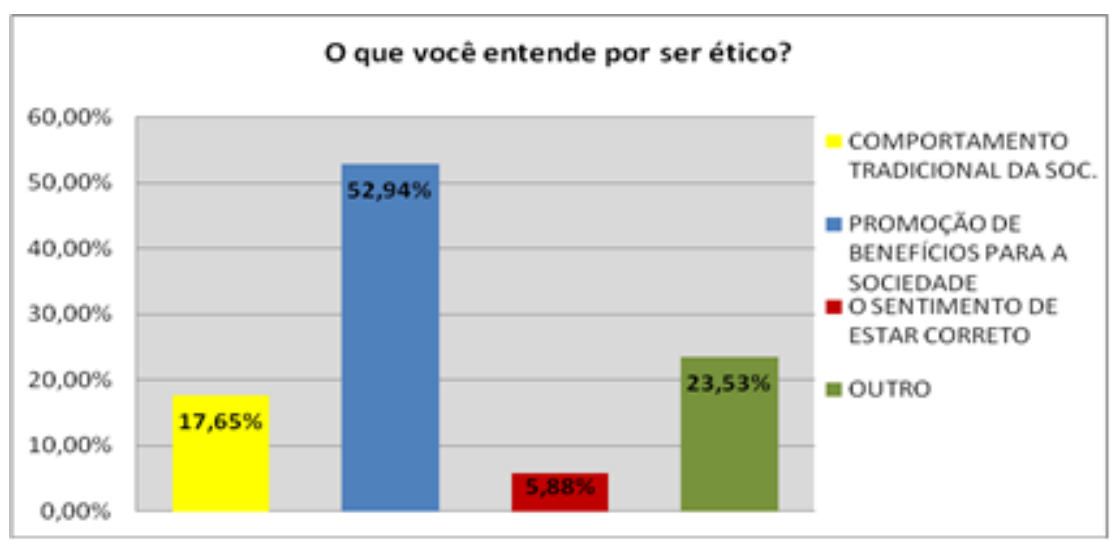

Fonte: Dados da pesquisa

De acordo com o gráfico acima, pode-se confirmar que para mais da metade dos acadêmicos, cerca de $52,94 \%$, afirmam que a ética promove melhores benefícios para a maioria da sociedade, dos 17 , 23,53\% afirmam outros motivos para o entendimento do que é ser ético. Lembrando que a ética é o controle do certo ou errado e para que uma sociedade viva em harmonia e ordem, é preciso que essas regras sejam cumpridas. Ainda de acordo com as respostas, $17,65 \%$ dos egressos tem a ética como comportamento tradicional da sociedade e apenas $5,88 \%$ revelaram a ética como uma indução do sentimento de estar correto. 


\section{Administração: caminhos para o desenvolvimento sustentável}

No Gráfico 4, quando perguntados sobre qual seria o motivo mais relevante para a atuação ética na sociedade, tem-se quase uma unanimidade nas respostas, sendo que dos 17 alunos concluintes do curso, 14 respondem como sendo os princípios morais o principal motivo, ou seja $82,35 \%$. E de igual percentual, no quantitativo de 5,88\% cada, revela como fatores relevantes as convenções sociais, o medo de sanções e algum outro motivo não especificado pelo respondente.Gráfico 3: Ser ético.

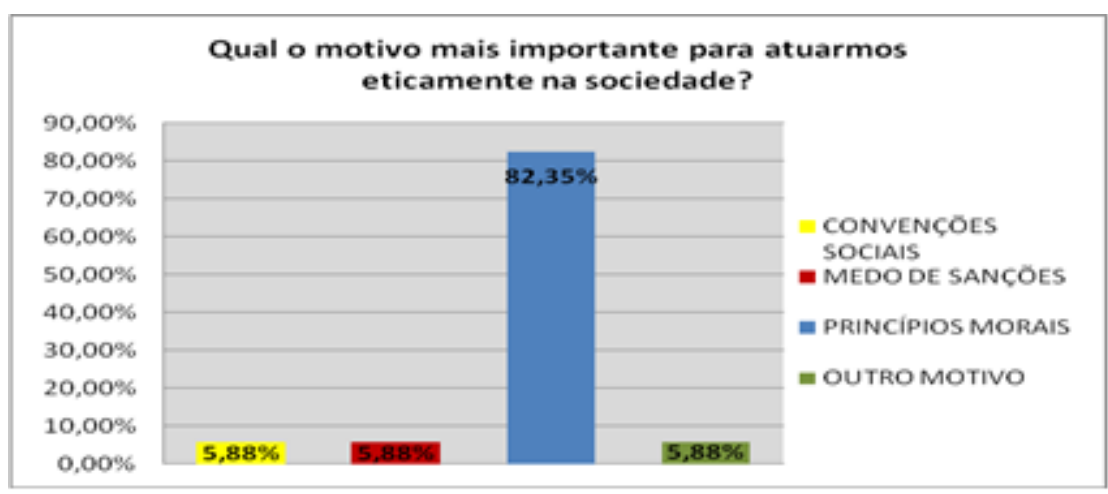

Fonte: Dados da pesquisa

Gráfico 4: Motivos para atuação ética na sociedade.

Quanto a influência no fato de atuar éticamente, os dados demonstram que o pai/ e ou mãe são apresentados com $64,71 \%$, como sendo os que predominam no fator de atuação ética das pessoas, de igual porcentagem tem-se 11,76\%, como professor e patrão; e também com índices igualados tem-se a influencia religiosa e não souberam opinar, com $5,88 \%$ dos respondentes.

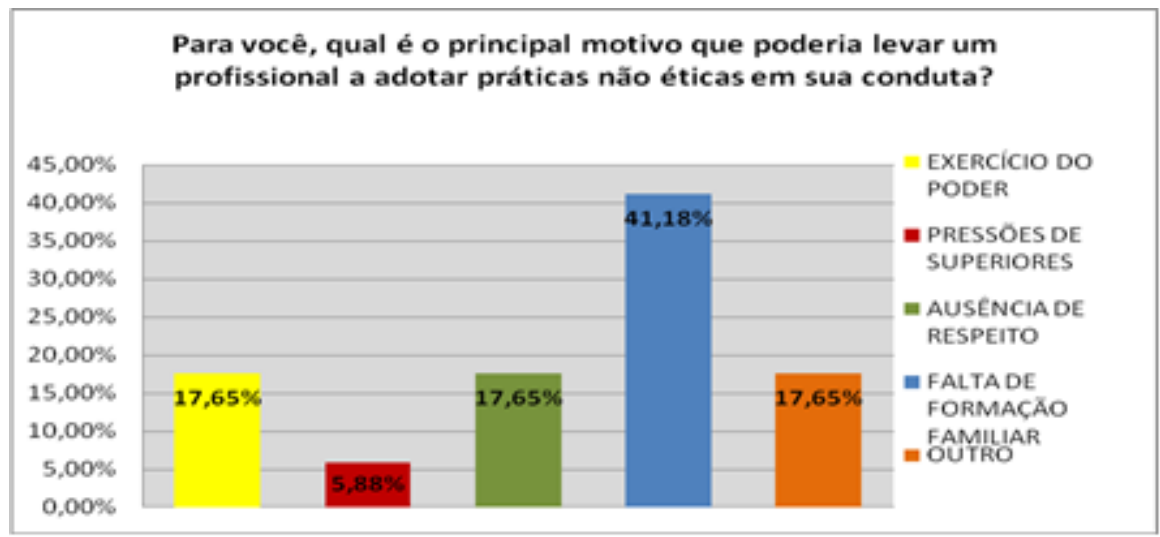

Fonte: Dados da pesquisa

Gráfico 5: Adoção de práticas não éticas. 


\section{Administração: caminhos para o desenvolvimento sustentável}

No gráfico 5, quando questionados para apontarem o principal motivo que poderia levar um profissional a adotar práticas não éticas em sua conduta, pode-se notar que as opiniões foram bem divididas, porém houve a predominância de $41,18 \%$ dos acadêmicos que destacaram o quesito falta de formação familiar. Dos 17 respondentes, de igual porcentagem tem-se que 17,65\% apontam a necessidade de exercer o poder, a ausência de respeito e algum outro motivo, como sendo o que causa a adoção de práticas não éticas na conduta dos profissionais. E por fim, tem-se que 5,88\% aderem as pressões de superiores como agente motivador.

De acordo com o gráfico 6, foi questionado aos 17 respondentes a seguinte situação: supondo que o contador A receba de um cliente pela prestação de serviços o valor de $R \$ 1.000,00$, e que esse cliente seja abordado pelo contador B, o qual the oferece os mesmos serviços por $\mathrm{R} \$ 700,00$. Você, como futuro profissional da contabilidade, acha correta a atitude do contador B?

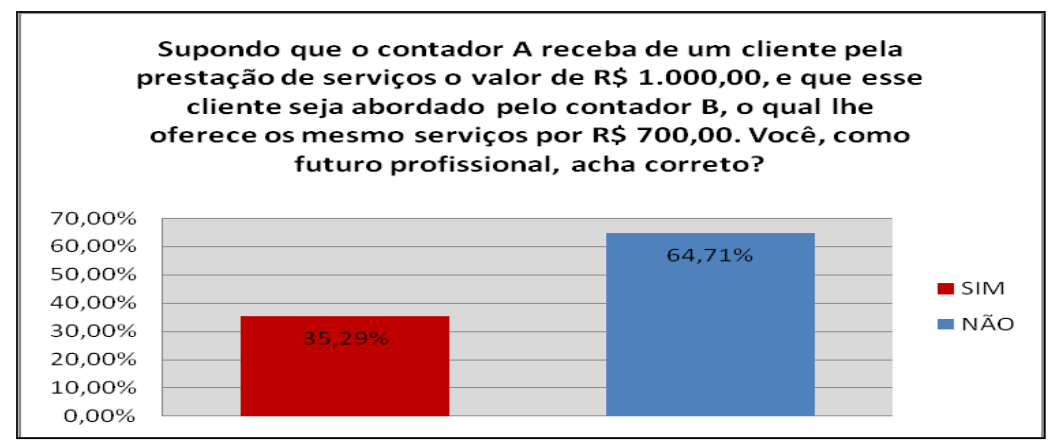

Fonte: Dados da pesquisa

Gráfico 6: Ética e conduta profissional.

Observou-se que os acadêmicos, em sua maioria, 64,71\%, correspondete a 11 alunos, responderam que não, sendo proibido ao contabilista oferecer ou até mesmo disputar serviços profissionais mediante descrádito de honorários ou por concorrência desleal. No segunto ponto observado, 35,29\% das respostas, representado por 6 alunos, afirmaram não ver como uma atitude incorreta por parte do contador $\mathrm{B}$, oferecer o valor $\mathrm{R} \$ \mathrm{700,00}$, pois a oferta de um valor menor para ele não significa concorrência desleal, podendo ser uma estratégia de agrado ao cliente, como forma de buscar sua fidelidade.

Quando foram questionados se diante a uma excelente oferta de serviço, como profissionais contadores, percebessem que não foram solicitados seus conhecimentos contábeis, mas sim uma 


\section{Administração: caminhos para o desenvolvimento sustentável}

maquiagem de demonstrações contábeis para que seu cliente obtivesse benefícios, 100\% dos entrevistados responderam que não aceitariam o serviço.

O fato de sua totalidade ser contra a essas práticas demonstra o conhecimento dos futuros profissionais perante o assunto ética profissional, onde as conseqüências de sua utilização afetam de forma direta todos os interessados nas informações fornecidas pela contabilidade, ocasionando distorções significativas na interpretação dos dados, podendo trazer consequencias para quem as aplicaram.

\section{CONSIDERAÇÕES FINAIS}

O presente estudo teve como objetivo geral evidenciar a percepção dos egressos do curso de Ciências Contábeis da Universidade Federal de Mato Grosso do Sul, Campus do Pantanal, quanto à ética profissional.

Ao realizar a análise da percepção dos egressos com relação a ética profissional, constatou-se que 58,82\% apresentam conhecimento em relação ao Código de Ética do Profissional do Contador. Mesmo sendo um percuntual relevante, o resultado poderia ser melhor. Percebe-se o bom conhecimento do Código de Ética pelos egressos, como também a predominancia de jovens de 26 à 30 anos, sendo que todos já possuem uma vivência em um ambiente de trabalho, mesmo não sendo especificamente na área contábil.

Os egressos destacaram os pais como sendo os que predominam no fator de atuação ética das pessoas, mas o professor e o patrão também tem um papel importante, conforme destacado nos resultados da pesquisa. Outros fatores que também apontaram a predominancia da boa conduta dos egressos, foram quando a maioria discordaram da prática da concorrência desleal na oferta de serviços e da realização de serviços que não apresentem a realidade da empresa.

Portanto, o profissional de contabilidade frente a execução de sua profissão deve-se guiar sempre pelos princípios éticos, assim como conhecer as práticas e normas estabelecidas pelo Código de Ética do Profissional do Contador. Caso o profissional escolha o caminho das possibilidades de benefícios e ganhos por meio de atividades não éticas, estará sujeito a penalidades determinadas por esse mesmo Código e pela própria ordem pública, prejudicando além da empresa, a sociedade e também infamando sua imagem e de todos pertencentes a classe. 


\section{Administração: caminhos para o desenvolvimento sustentável}

\section{REFERÊNCIAS}

ANDRADE, A. Ética profissional: comentários, reflexões e orientação (comentários e orientação de aulas sobre ética profissional do contabilista).São Paulo: FECAP, 1999.

BRASIL. Decreto-Lei № 2.848, de 7 de dezembro de 1940. Código penal.

.Decreto-Lei no 9.295, de 27 de maio de 1946. Cria o conselho federal de contabilidade, define as atribuições do contador e do guarda-livos e dá outras providências.

.Lei no 7.492, de 16 de junho de 1986. Define os crimes contra o sistema financeiro nacional, e dá outras providências.

.Lei no 8.137, de 27 de dezembro de 2009. Define crimes contra a ordem tributária, econômica e contra as relações de consumo, e dá outras providências.

.Lei no 9.249, de 26 de dezembro de 1995. Altera a legislação do imposto de renda das pessoas jurídicas, bem como da contribuição social sobre o lucro líquido, e dá outras providências.

.Lei $\mathrm{n}$ 0 9.983, de 14 de julho de 2000. Altera o Decreto-Lei no 2.848 , de 7 de dezembro de 1940 - Código Penal e dá outras providências.

.Lei no 10.406, de 10 de janeiro de 2002. Institui o Código Civil brasileiro.

. Lei № 11.101, de 9 de fevereiro de 2005. Regula a recuperação judicial, a extrajudicial e a falência do empresário e da sociedade empresária.

BITTAR, Eduardo C.B. Curso de ética jurídica: ética geral e profissional. 6a ed. São Paulo: Saraiva, 2009.

CAMARGO, Marculino. Fundamentos da ética geral e profissional. Rio de Janeiro: Vozes, 1999.

CONSELHO FEDERAL DE CONTABILIDADE. Resolução nํ 803, de 10 de outubro de 1996. Aprova o código de ética do profissional contador.

COOPER, Donald R.; SCHINDLER, Pamela S.. Métodos de pesquisa em administração. 7. ed. Porto Alegre, Bookman, 2003.

FRANCO, Hilário. Auditoria Contábil. 2. ed. São Paulo: Atlas, 1991.

HOLLANDA, Aurélio Buarque de. Pequeno Dicionário Brasileiro da Língua Portuguesa. Rio de Janeiro, Nacional, 1976.

HORNGREN,Charlester ; FOSTER, George; DATAR, Srikant M. Contabilidade de custos. 9a. ed. Rio de Janeiro, 1997.

LEONARDO, Boff . Ética e Moral. Publicado no jornal O POVO, dia 04 de julho de 2003.

LISBOA, Lázaro Plácido . Ética geral e profissional em contabilidade. São Paulo: Atlas, 1997.

MANSUR, Beto. Ética nas empresas do século XXI. 2007. Disponível 


\section{Administração: caminhos para o desenvolvimento sustentável}

em: <http://www.empreenderparatodos.com.br/etica/mat_04.htm>, Acesso em: 14 mai. 2011.

MARION, José Carlos; SANTOS, Márcia Carvalho. Os dois lados de uma profissão. Belo Horizonte: Contab. Vista e Revista, 2000.

NUNES, Ruam R.B; LEITE, Tiago R.T.; SOUZA, Erica X.. Ética contábil: a percepção dos alunos do curso de ciências contábeis da universidade federal de alagoas. IN: XIII SEMEAD, 2010, São Paulo. ANAIS do XIII Seminários em Administração, 2010.

OLIVEIRA, C. M. Responsabilidade civil e penal do profissional de contabilidade. São Paulo: IOBThomson, 2005.

SÁ, Antonio Lopes de. Ética profissional . 2a Ed. São Paulo: Atlas, 1998.

SILVA, Solange et al. A ética e o profissional de contabilidade no novo milênio In: XXXIX Asamblea Anual. del Consejo Latinoamericano de Escuelas de Administración (CLADEA), 2004, Puerto Plata. CLADEA: 2004.

VÁSQUES, Adolfo Sánches. Ética. Rio de Janeiro: Civilização, 1982. 


\section{Capítulo 40}

\section{PLANEJAMENTO ESTRATÉGICO, BALANCED SCORECARD (BSC) E VISÃO SISTÊMICA: UM PROCESSO DE GESTÃO ESTRATÉGICA}

DOI: $10.37423 / 200300457$

Kellerman Augusto Lemes Godarth (IFPR Capanema) kgodarth@gmail.com

André Felipe Muller (Faculdade Iguaçu) crusader_erdan@hotmail.com

Tiago Rodrigo Canzi (Faculdade Iguaçu) trcanzi@hotmail.con

RESUMO: O artigo tem como objetivo demonstrar que /um bom planejamento estratégico juntamente-ao sistema de Gestão Estratégica, o Balannced Scorecard e a Visão Sistêmica, pođem desenvolver métodos. para organizar a emprésa, podehdo observá-la como um todo facilitando a criação de uma estrutura organizacional adequada para melhor realizar os objetivos financeiros, dos clientes, dos recursos internos e da aprendizagem e crescimento dos colaboradores, deste modo fazendo com que a/empresa possa atingir com facilidade seus objetivos maiores, que são a Missão e a Visão da organizaçáo.

Palavras chave: Planejamento estratégico, Balanced Scorecard, Vantagem competitiva, Visão Sistêmica, Organização.

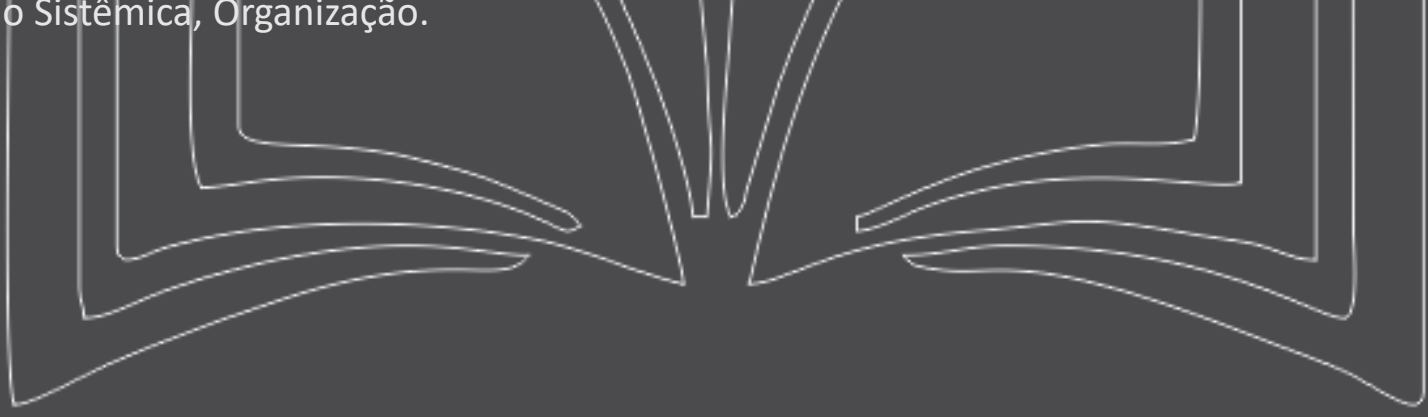




\section{Administração: caminhos para o desenvolvimento sustentável}

\section{Introdução}

Devido à competição global e a grande oferta de produtos e serviços, pessoas e empresas estão muito mais exigentes e mais conscientes sobre preços, prazos, qualidade e serviços pós-venda.

Através de um planejamento estratégico adequado, administradores podem formar um grande diferencial competitivo, o planejamento procura considerar todas as possibilidades para maximizar o uso dos recursos materiais e humanos, reduzindo os custos tangíveis e intangíveis, inovando e se antecipando às necessidades atuais e futuras dos clientes, assim definindo estratégias e sistemas de gestão para assegurar a competitividade, a rentabilidade, agregando valor ao negócio e satisfazendo, não só os acionistas, mas todos os demais "stakeholders", que, segundo Raskin (2003), são as partes interessadas e motivadas para participarem da organização, e podem ser divididos entre:

- Stakeholders internos, que são as pessoas internas a organização, como os acionistas, os gerentes e os trabalhadores. Os acionistas são os donos da organização e sua contribuição é o investimento em suas ações pela perspectiva de retorno. Os gerentes são os responsáveis pelos negócios da organização, coordenando os recursos e assegurando o alcance dos objetivos. Os trabalhadores são todos os outros colaboradores que possuem obrigações e responsabilidades.

- Stakeholders externos, que são pessoas que possuem algum interesse na organização, como clientes, fornecedores, governo, comunidades locais e públicos em geral.

\section{INTERAÇÃO DOS PROCESSOS DE GESTÃO ESTRATÉGICA}

O Planejamento Estratégico é uma seqüência de passos encadeados que organiza e coordena as atividades estratégicas, visando elevar o grau de interações com o ambiente interno e externo, em busca de atingir objetivos previamente estabelecidos.

Para Maximiano, (2004), organizar é o processo de dispor qualquer conjunto de recursos em uma estrutura que facilite a realização de objetivos.

O processo de organização é um processo decisório que através dos dados de entrada, são originados pelo processo de planejamento e o resultado é uma estrutura organizacional, onde Maximiano (2004) a descreve, como sendo, aquela que define autoridades e responsabilidades das pessoas, como indivíduos e como integrantes do grupo, e estas responsabilidades são representadas pelo organograma, que se podem encontrar as seguintes informações: 


\section{Administração: caminhos para o desenvolvimento sustentável}

- Divisão de trabalhos, que consiste em dividir uma tarefa em tarefas menores, e estas atribuídas a pessoas ou grupos diferentes, podem ser denominados cargos;

- Autoridade e hierarquia são o direito legal que gerentes têm de influenciar o comportamento de seus subordinados, autoridade pode ser descrita como aquela que garante a coordenação e execução das tarefas;

- A comunicação, é o ato de expressar sentimentos, através da fala ou gestos, é o principal meio de encontrar e resolver problemas dentro de uma organização, mas ela deve ser de forma clara para que todos possam entender o que está sendo levantado.

Alem de dividir tarefas e definir uma estrutura organizacional adequada é necessário, segundo Clemente e Fernandes (1998), desenvolver um projeto estratégico, no qual consiste em definir:

- Missão, motivo pelo qual a empresa existe;

- Visão, cenário ideal a atingir a médio ou longo prazo;

- Objetivos, passos que são necessários para que a visão se concretize;

- Metas, são objetivos menores, os quais em conjunto buscar realizar o objetivo proposto;

- Estratégias, são meios utilizados para se alcançar as metas ou objetivos;

- Ações, delegado o que cada pessoas deve fazer para se alcançar o objetivo;

- Controle, monitorar o que esta sendo executado buscando a melhoria, e;

- Prêmios, lucro para a empresa, retorno para o empresário ou acionista, e formas de incentivo aos colaboradores.

As metas e os objetivos impulsionam as organizações a obterem o resultado planejado, mas para que isso aconteça deve existir em conjunto com pessoas de ação que acreditam que o resultado previsto possa ser concretizado, e através do controle sobre as tarefas que estão sendo realizadas, buscarem as melhorias dos processos ou mesmo a reengenharia caso estiver algo errado. Quando as organizações conseguirem estabelecer estas políticas estratégicas poderá aumentar suas chances de 


\section{Administração: caminhos para o desenvolvimento sustentável}

sobreviver e crescer, neste mercado competitivo, alem de criar novos diferenciais em relação aos seus concorrentes.

Mintzberg (2001) argumenta que não existe uma melhor estratégia e nenhuma receita funciona da mesma forma para todas as organizações. Mesmo quando uma receita parece ser eficiente em um determinado contexto (situação ou ambiente competitivo), ela requer uma compreensão completa do que é exatamente o contexto em questão e como este funciona. Aparentemente poucas são as empresas que tem cultura, estrutura e liderança necessárias para transformar seus recursos internos em vantagem competitiva relevante.

Mintzberg (2001) complementa que a estratégia lida com a continuidade, não com a mudança. A estratégia preocupa-se em impor padrões estruturais de comportamento em uma organização. Porém, hoje, administrar a estratégia é administrar a mudança, reconhecendo quando uma alteração de natureza estratégica é possível, desejável ou necessária e, quando é a hora certa para agir.

Um diferencial competitivo pode ser definido por alguns critérios qualificadores, segundo Hill (1989) e Slack (2001), estes critérios são aqueles aspectos da competitividade nos quais o desempenho da manufatura deve estar acima de um nível determinado, considerado pelo cliente. Podem não ser os principais determinantes do sucesso competitivo, mas são importantes para manter a empresa em paridade com os concorrentes. Os exemplos de critérios qualificadores mais conhecidos podem ser a certificações dos sistemas da qualidade conforme as normas ISO 9000, ISO 14000 e/ou outras certificações específicas.

Aumentar o desempenho em um critério ganhador de pedidos melhora a probabilidade de ganharem mais pedidos. Estes critérios ganhadores de pedidos podem ser o custo do produto ou mesmo a flexibilidade ou prazo de entregas.

Aos critérios qualificadores e ganhadores de pedido de Hill e Slack (2001), acrescentam os critérios menos importantes, os quais não influenciam os clientes de forma significativa e direta, mas podem influenciar a produtividade e também os custos. Eles fazem um alerta em relação ao gerenciamento da qualidade total (TQM) e ressaltam que o custo associado ao esforço de melhoria da qualidade é pequeno, se comparado ao custo de não ter qualidade, mas existe um ponto além do qual os custos da melhoria tornam-se maiores que os benefícios gerados. 


\section{Administração: caminhos para o desenvolvimento sustentável}

Algumas empresas utilizam sistemas de medição de indicadores para se situar no mercado competitivo e decidir através de dados mais concretos. O sistema mais usado pelas organizações é o Balanced Scorecard (BSC), segundo Kaplan e Norton (1997), o BSC é uma ferramenta que traduz a visão e a estratégia da empresa num conjunto de medidas de desempenho e objetivos estratégicos específicos, organizados segundo quatro perspectivas diferentes: financeira, do cliente, dos processos internos e do aprendizado e crescimento. O equilíbrio dessas perspectivas permite estabelecer objetivos organizacionais e realimentar o processo continuo da empresa, quando as empresas criarem o BSC, deve ser escolhido um conjunto de indicadores que reflita precisamente os fatores críticos dos quais depende do sucesso da estratégia, que mostrem uma relação de causa e efeito entre os indicadores individuais e proporcionem uma visão abrangente e atualizada sobre a organização.

O BSC trata-se de um sistema de gestão baseada em indicadores de ocorrência, que mostram o que já aconteceu, e direcionadores ou indicadores de tendências, que mostram o progresso de áreas-chaves para implementação da estratégia, onde estes impulsionam o desempenho, propicia a organização uma visão atual e futura do negocio, e seu objetivo principal é o alinhamento do planejamento estratégico com as ações que levarão ao alcance dos objetivos estratégicos. As quatro perspectivas se relacionam umas com as outras numa relação de causa e efeito e podem ser visualizadas através de um mapa estratégico, demonstrado na figura 1.1 a baixo.

\begin{tabular}{|c|c|c|c|c|}
\hline Estratégia & Financeira & Clientes & $\begin{array}{c}\text { Processo } \\
\text { Intemo }\end{array}$ & $\begin{array}{c}\text { Crescimento e } \\
\text { Aprendizado }\end{array}$ \\
\hline $\begin{array}{c}\text { Objetivos } \\
\text { Estratégicos }\end{array}$ & $\begin{array}{c}\text { Receita e } \\
\text { Lucro }\end{array}$ & $\begin{array}{l}\text { Quais os } \\
\text { segmentos no } \\
\text { mercado? }\end{array}$ & $\begin{array}{l}\text { Quais são os } \\
\text { processos } \\
\text { críticos para } \\
\text { oucesso? }\end{array}$ & $\begin{array}{c}\text { Investimento } \\
\text { Capacitação } \\
\text { Sistemas }\end{array}$ \\
\hline
\end{tabular}

Fonte: Kaplan e Norton (1997)

Figura 1.1 As Perspectivas do BSC, Causa e Efeito

A perspectiva financeira descreve os resultados tangíveis da estratégia em termos financeiros e indicam se as estratégias e sua implementação, estão contribuindo para a saúde financeira da empresa e para o alcance dos objetivos financeiros, que estes também servem de meta principal para todos os outros indicadores. 


\section{Administração: caminhos para o desenvolvimento sustentável}

Esta perspectiva é importante para a continuidade dos negócios, a satisfação dos acionistas e os recursos financeiros para investimentos e crescimento. Porém, estes mesmos indicadores quando analisados de maneira isolada, são inadequados para analisar o potencial de crescimento, avaliar a trajetória e direcionar o desempenho das empresas no novo contexto global.

Nos mercados altamente globalizados, competitivos e em constantes mudanças as organizações alcançam o sucesso através dos investimentos e do gerenciamento das suas capacidades e dos ativos intangíveis. As funções especializadas devem ser integradas em processos de negócios baseado no cliente. A inovação em produtos, processos e serviços devem ser criados por funcionários altamente treinados e capacitados, tecnologia de informação de ponta e por processos organizacionais alinhados. Conforme as organizações investem na aquisição destas novas capacidades e ativos intangíveis, o sucesso não pode ser motivado e controlado somente pelos tradicionais indicadores financeiros. (SIMONS, 2000, p. 203).

A perspectiva do cliente define os direcionadores do crescimento da receita como a satisfação dos clientes, retenção e conquista de novos clientes bem como a proposição de valor para o cliente, as preocupações com os clientes normalmente recaem em outras perspectivas, tais como qualidade, custo, atendimento, moral e segurança.

A perspectiva dos processos internos mostra como as operações, gerenciamento da relação com os clientes, processos de inovação, gerenciamento das leis e regulamentos relativos ao negócio, qualidade e produtividade assegura a proposição de valor para o cliente e gera impacto nos objetivos financeiros, na satisfação de todos os "stakeholders". Nesta perspectiva pode levar a organização a excelência.

A perspectiva do aprendizado e crescimento identifica os ativos intangíveis mais importantes da estratégia e envolve as competências e infra-estruturas necessárias para o desenvolvimento de um clima que propicia a mudança, inovação, excelência operacional e crescimento no médio e longo prazo.

O aprendizado deve ser uma intenção estratégica nas organizações e estar internalizado na cultura organizacional, tornando-se parte do trabalho diário em quaisquer de suas atividades, em todos os níveis...dissemina suas melhores práticas, pratica o "benchmarking" interno e externo, compartilha informação e conhecimento, desenvolve soluções e implementa melhorias e inovações de forma sustentada. A organização que avalia periodicamente seu sistema de gestão e implementa melhorias ou inovações em suas práticas gerenciais se adapta mais facilmente às mudanças e tem mais condições de atingir e manter a excelência no desempenho. (FPNQ, 2005). 


\section{Administração: caminhos para o desenvolvimento sustentável}

O planejamento estratégico demonstra em que patamar que a empresa quer chegar, define sua missão, suas metas e seus objetivos, o BSC o complementa o planejamento demonstrando através de uma forma de controle de indicadores, em qual situação que a empresa se encontra e a visão sistêmica tem como principal objetivo ver estas ações de uma forma totalmente complexa.

De acordo com Senge (2006), o pensamento sistêmico é a quinta disciplina que permite integrar e compreender o domínio pessoal, modelos mentais, visão compartilhada e aprendizagem em equipe. É de conhecimento coletivo que as empresas são, em suma, um sistema composto por inúmeras partes e que estas, de certa forma, estão conectadas umas às outras. Essa conexão entre as partes impõe, segundo a teoria de A Quinta Disciplina, que toda organização alcance um patamar de educação, em que cada um e todos tenham condições de ver o todo.

Nesse sentido, o processo de formação de estratégias para o desenvolvimento local, nada é simples; ao contrário, de acordo com Maximiano (2002) “Tudo depende de tudo. Tudo é complexo”. Entender e lidar com a complexidade são as bases do pensamento sistêmico, uma das importantes ferramentas intelectuais que o administrador possui.

Desta forma, as questões que envolvem o tema, o qual propõe a reflexão sobre o desenvolvimento local, apresentam problemas de natureza complexa, causados pelas interações de diferentes fatores sociais. Assim, a abordagem sistêmica parece ser a mais indicada para abordá-la, já que o enfoque sistêmico permite a necessária reorientação do pensamento e da visão do mundo a partir da introdução dos sistemas como novo paradigma científico, que contrasta com o paradigma analítico, mecanístico e linear de causa e efeito da ciência clássica (PASSADOR, 2005).

Entretanto, mais importante do que a própria definição, são os princípios que o conceito de sistemas enfatiza, dentre os quais destacam-se os seguintes (CAPRA, 1996):

- Visão do todo: A abordagem sistêmica visa o estudo do desempenho total de sistemas, ao invés de se concentrar isoladamente nas partes.

- Interação e autonomia: Sistemas são sensíveis ao meio ambiente com o qual eles interagem, o qual é geralmente variável dinâmico e imprevisível. A fronteira do sistema estabelece os limites da autonomia interna, a interação entre os componentes do sistema e a relação deste com o ambiente. 


\section{Administração: caminhos para o desenvolvimento sustentável}

- Organização e objetivos: Em um sistema imperfeitamente organizado, mesmo que cada parte opere o melhor possível em relação aos seus objetivos específicos, os objetivos do sistema como um todo, dificilmente serão satisfeitos.

- Complexidade: Este enfoque parte do princípio de que, devido a interações entre os componentes e entre o meio ambiente e o sistema como um todo, este é bem mais complexo e mais compreensivo do que a soma das partes individuais.

- Níveis: Entender cada setor da organização, os processos (caminhos percorridos pela matéria prima e pelos recursos humanos).

Sendo assim, o desenvolvimento local não pode ser abordado de maneira separada, levando em conta apenas aspectos econômicos e/ou sociais; deve levar em consideração diversos atores locais e não locais para a formação de uma extensa rede, isto é, o desenvolvimento local tem que ser abordado a partir de um enfoque sistêmico.

\section{CONSIDERAÇÕES FINAIS}

A base para uma empresa se desenvolver e conseguir atingir seus objetivos depende de um ótimo planejamento estratégico, e de pessoas que acreditem na Missão e Visão da empresa. Criar uma cultura voltada para a implementação, execução e controle das estratégias, apoiada por sistemas adequados de medição de desempenho, fortalece o ambiente interno das organizações e as mudanças no ambiente de negócios são mais facilmente detectadas, favorecendo tomadas de decisões baseadas em fatos e dados.

O desempenho organizacional é o resultado de todos os esforços, atividades e ações realizadas todos os dias dentro de uma organização, a chave para a melhoria é assegurar um ambiente organizacional comprometido com os resultados e que incentive um processo decisório alinhado com os objetivos estratégicos da organização.

\section{REFERÊNCIAS}

CAPRA, F. O ponto de mutação. São Paulo: Cultrix, 1996.

CLEMENTE, Ademir; FERNANDES Elton. "Planejamento e projetos". Projetos Empresariais e Públicos Editora Atlas, São Paulo, 1998. 


\section{Administração: caminhos para o desenvolvimento sustentável}

FPNQ - Fundação para o prêmio nacional da qualidade. Rumo à Excelência: Critérios para a avaliação do desempenho e diagnostico organizacional, 2005.

HILL, Terry. Manufacturing Strategy: Text and Cases; Richard D. IRWIN, INC; 1989.

KAPLAN, Robert. S.; NORTON, David P. A estratégia em ação: Balanced Scorecard. Rio de Janeiro: Campus, 1997.

MINTZBERG, Henry; QUINN, James B. O processo da estratégia, Bookman companhia editora, 2001.

MAXIMIANO, Antonio Cezar Amaru. Teoria Geral da Administração, da Revolução Urbana a Revolução Digital. São Paulo, Ed Atlas, 2004.

PASSADOR, Claudia Souza, Um estudo do projeto Escola do Campo - Casas Familiar Rural (1990-2002) do Estadodo Paraná: a pedagogia da alternância como referencial de permanência, 2003, 194 f. Tese de Doutorado (Doutorado em Educação), Universidade de São Paulo, São Paulo, Brasil. site: http://www.simpep.feb.unesp.br/upload/93.pdf

RASKIN, Sara Fichman, As Organizações e a Teoria

Organizacional, http://www.pr.gov.br/batebyte/edicoes/2002/bb121/organizacoes.htm, acesso 17/06/2008.

SENGE, Peter Michael, A Quinta Disciplina, Brochura, editora Best Seller, 2006.

SLACK, Nigel. Administração da produção; São Paulo, Editora Atlas, 2ª edição -2001

SIMONS, Robert; Performance measurement and control systems for implementing strategy: Text and Cases. New Jersey: Prentice-Hall. Inc, 2000. 


\section{Capítulo 41}

\section{ECOEFICIÊNCIA: OS BENÉFICIOS DA EMPRESA CENTROFLORA SER ECOEFICIENTE NA CIDADE DE PARNAÍBA-PI}

DOI: $10.37423 / 200300464$

Mara Águida Porfírio Moura, UFPI, Brasil, maraguida@hotmail.com

Liz Tâmara Pinto Lopes, UFPI, Brasil,liztamarapl18@gmai.com

Izabella Costa UFPI, Brasil,izabellacostaa@gmail.com

Renata Cristiną Santos Galeno UFPI, Brasil, renatasantosgaleno@gmail.com Kelsen ArcângeldFerreira e Silva, UFPI, Brasil,kelsen@ufpi.edu.br

RESUMO: Esse artigo tem como objetivo principal investigar asferramentas utilizadas pela empresa Centroflora para alçançar a ècoeficiência e $q$ desenvolvimento da organização e da sociedade, demonstrando que a empresa Centroflora, na uniđade III de Parnaíba-Pte uma organização que produz a Pilocarpina parà o mercado com maior responsabilidade ambiental e ecoeficiência, trazendo a melhor qualidade ole vida às pessoar, e a sustentabilidade. A metodologia desse estudo for à pesquisa de campo que compreende a coleta de dados e a análise do\$ mesmos, utilizando perguntas em forma de entrevista com os funcionários da organização estudada. Diante da anấlise desses dados concluiu-se que asspciando os oito elementos da ecoeficiência com a maneiria na qual a empresa Centroflora realiza sua produção industrial e suas atividades em geral , a empresa e traz beneficios para a cidade de ParnaíbaPI, produzindo com menos-recursos näp rengyáveis e com-mais produtos com maior durabilidade, rastreabilidade e cofianç̧a para o mercad b de consumidores:

Palavras-chave: Ecoeficiencia; Gestão Ambiental; Responsabilidade Social. 


\section{Administração: caminhos para o desenvolvimento sustentável}

\section{INTRODUÇÃO}

As empresas procuram cada vez mais vantagens competitivas no mercado e uma delas está relacionada à sociedade e o ambiente em que estão inseridas. Os fatores externos são de suma importância, assim como os internos, representando que as empresas são moldadas por esses dois fatores. Quando se citae os fatores externos, não se pode deixar de citar os recursos naturais, biodiversidade e ecossistema, os quais quando não estão alinhados influenciam direta ou indiretamente na organização. Gerir uma organização de maneira mais produtiva com menos recursos naturais, minimizando custos de produção e satisfazendo as necessidades humanas, trazendo qualidade de vida, remete diretamente ao conceito a ecoeficiência. Além do conceito, o presente artigo apresenta os benefícios de uma empresa ecoeficiente em Parnaíba-PI, uma vez que quando a organização associa sua produção aos eixos sustentáveis e socioambientais, demonstram cada vez mais ganhos para todas as cadeias inseridas.

Esse artigo tem como objetivo principal investigar as ferramentas utilizadas pela empresa Centroflora para alcaçar a ecoeficiência e o desenvolvimento da organização e da sociedade, demostrando que a empresa Centroflora, na unidade III de Parnaíba-PI é uma organização que produz a Pilocarpina para o mercado com maior responsabilidade ambiental e ecoeficiencia, trazendo a melhor qualidade de vida às pessoas, e a sustentabilidade. Com a dedicação a empresa acaba sendo aprimorada para a redução de suas fontes naturais atingindo assim o objetivo de não impactar o ambiente, consequentemente o desperdício nos custos de produção. O desenvolvimento da metodologia foi realizado com um levantamento bibliográfico e de campo, com questionário direcionado ao Grupo Centroflora, procurando responder as indagações sobre seus métodos sustentáveis e ecoeficientes. Já no que diz respeito à pesquisa em livros, esses foram utilizados como base para a pesquisa de conceitos e contextualizações referentes ao tema abordado e por fim pesquisas eletrônicas, em artigos e dissertações. Partindo desses ideais o estudo propos a resposta do seguinte questionamento:

Quais as ferramentas utilizadas pela empresa Centroflora para alcançar a ecoeficiência e o desenvolvimento da organização e da sociedade?

\section{GESTÃO AMBIENTAL}

A geração de poluentes no ambiente vem se agravando cada vez se agravando gerando lixo no mundo, e os países começaram a se preocupar com o rumo dessa poluição. Diante disso se iniciou as denuncias por meio de documentos oficiais, livros, mídias, etc. E os políticos iniciaram o processo para reverter 


\section{Administração: caminhos para o desenvolvimento sustentável}

este quadro. Dessa forma pode-se conceituar Gestão Ambiental como uma área de conhecimento que visa resolver problemas em empresas e diversas organizações seguindo normas e especificações ambientais, bem como a legislação vigente.

Para Zanatta (2017) "As empresas adeptas a adoção Empresas adeptas a adoção de medidas ambientais mais cautelosas tendem a receber um retorno benéfico. Podem diminuir custos de produção, agregar valor à produtos, produzir novos materiais a base de reciclagem, aproveitamento de resíduos e melhoria da imagem institucional, sem mencionar os benefícios para saúde do meio ambiente e da população". A autora Zanatta(2017, p 302) apresenta que para VALLE (1995) a "gestão ambiental consiste de um conjunto de medidas e procedimentos bem definidos e adequadamente aplicados que visam a reduzir e controlar os impactos introduzidos por um empreendimento sobre o meio ambiente". Por sua vez, Meyer (2000, p.38) apresenta a gestão ambiental da seguinte forma:

\footnotetext{
Objeto: manter o meio ambiente saudável (à medida do possível), para atender as necessidades humanas atuais, sem comprometer o atendimento das necessidades das gerações futuras;
}

Meios: atuar sobre as modificações causadas no meio ambiente pelo uso e/ou descarte dos bens e detritos gerados pelas atividades humanas, a partir de um plano de ação viável técnica e economicamente, com prioridades perfeitamente definidas;

Instrumentos: monitoramentos, controles, taxações, imposições, subsídios, divulgação, obras e ações mitigadoras, além de treinamento e conscientização;

Base de atuação: diagnósticos (cenários) ambientais da área de atuação, a partir de estudos e pesquisas dirigidos em busca de soluções para os problemas que forem detectados.

Neste contexto, as empresas que tem como objetivo ser vista com credibilidade no mercado que a cada dia é mas competitivo, deverão acrescentar no seu planejamento a questão sustentável a questão ambiental nas suas atividades. Para Martins e Silva (2014) esta mudança é "uma questão de manutenção da competitividade, uma vez que o mercado está, a cada dia, mais aberto e competitivo, fazendo com que as empresas tenham que se preocupar com o controle dos impactos ambientais".

\subsection{ECOEFICIÊNCIA}

Introduzido em 1992 pelo World Business Council for SustainableDevelopment (WBCSD) - Conselho Mundial de Negócios para o Desenvolvimento Sustentável, através da publicação do livro Changing Course em 1993, a ecoeficiência veio se tornando a filosofia de gerenciamento que leva a 


\section{Administração: caminhos para o desenvolvimento sustentável}

sustentabilidade. Onde durante anos, e ainda num passado recente, as empresas consideravam as questões de relacionados a sustentabilidade associados a uma série de fatores de riscos e custos acrescidos (CANTRELL, 1993).

Considera-se ecoeficiência como a dedicação de atividades que uma organização desenvolve para aperfeiçoar os processos com a redução na fonte da utilização dos recursos naturais, tendo como finalidade restringir o impacto ambiental, resultando em benefícios ecológicos e também econômicos (Almeida, 2005 apud Petrow e Almeida, 2005). Isso significa produzir menos utilizando menos recursos naturais e energias, reduzindo assim, o desperdício e os custos de produção e operação.

Segundo a World Business Council for Sustainable Development ( 2013) a ecoeficiência é alcançada através de entregas de bens e serviços com preços competitivos que satisfaçam as necessidades humanas e tragam qualidade de vida, reduzindo assim, progressivamente os impactos ambientais da produção dos bens e serviços, através de todo o ciclo de vida, equivalente a capacidade de suporte estimada da Terra . A ecoeficiência é umas das principais medidas para um futuro sustentável, seus princípios refletem diretamente na natureza, pois os recursos são utilizados de uma maneira mais inteligente - visando e beneficiando a competitividade de mercado, buscando a satisfação das necessidades humanas de forma sustentável, além de uma qualidade de vida mediante a diminuição dos impactos ambientas e suas degradações.

Segundo Manual do Formando "Ecoeficiência na Vida das Empresas" (2013) a ecoeficiência não vem a se limita simplesmente a melhorar as práticas e hábitos existentes, ela estimula também a criatividade e inovação na procura de novas formas de produção. Buscando não se restringe a áreas concretas dentro da empresa, como a produção ou a gestão, sendo válida para outras atividades a montante e a jusante, envolvendo toda a cadeia de valor do produto e serviço. Na qual, podem emergir em qualquer ponto do ciclo de vida de um produto ou serviço.

Para sua identificação todos os colaboradores deverão entender o que é a Ecoeficiência, reconhecendo o valor acrescentado que pode trazer para a empresa e como concretizá-lo. Tal requer competências e conhecimentos, de forma a integrar a Ecoeficiência nas operações de produção, negócios e sectores de atividade, permitindo espaço para a inovação e criatividade. 


\section{Administração: caminhos para o desenvolvimento sustentável}

\subsection{RESPONSABILIDADES SOCIAIS, AS ORGANIZAÇÕES E A SOCIEDADE}

A responsabilidade social é um conceito bem simples de ser discutido onde as empresas decidem tem como vista ser um trabalho voluntário, contribuir por uma sociedade, mas justa e por um ambiente saudável e mais limpo.

Dias, faz uma ligação entre responsabilidade ambiental e responsabilidade social empresarial. Segundo Dias (2006, p.52) responsabilidade ambiental é um conjunto de ações realizadas além das exigências legais, e responsabilidade ambiental empresarial é constituída de ações que extrapolam a obrigação, que assumem um conteúdo voluntário onde o objetivo seja manter o meio ambiente natural livre de contaminação e saudável para ser usufruído pelas gerações futuras. Segundo Wikipédia (2010) o livro Verde da Comissão Européia/2001, responsabilidade social é um conceito segundo o qual, as empresas decidem, numa base voluntária, contribuir para uma sociedade mais justa e para um ambiente mais limpo.

Percebe-se que as mídias sociais: TVS, internet, mídia visuais, entre outros estão realizando muitos trabalhos focados sobre a responsabilidade ambiental, que empresas estão investido nessa área para ser uma empresa sustentável gerando assim valor a mesma. Levando em consideração as inúmeras vantagens competitivas que a empresa ganha em relação a sua responsabilidade social e ambiental, muitos autores identificam vantagens, como as vantagens competitivas: As vantagens competitivas identificadas, segundo Dias (2006, p. 52) são as seguintes:

Há melhora no desempenho ambiental de uma empresa quando são cumpridas as exigências normativas, possibilitando-se maior inserção num mercado cada vez mais exigente em termos ecológicos, melhorando a imagem da empresa junto aos seus stakeholders e a comunidade; Adotando um design do produto de acordo com as exigências ambientais, é possível torná-lo mais flexível do ponto de vista de instalação e operação, com um custo menor e uma vida útil longa; Ocorre melhoria na gestão ambiental, quando reduz o consumo de recursos energéticos e consequentemente redução nos custos de produção; Há redução dos custos de matéria-prima e do consumo de recursos quando se reduz a quantidade de material utilizado ao mínimo por produto; Há melhoria na imagem da organização quando se utiliza materiais renováveis, pois emprega-se menos energia pela facilidade de reciclagem;

Ressalta-se assim a importância de como as empresas podem obter um retorno positivo adotando medidas mais sustentáveis e que estimulem a diminuição do consumo de materiais e recursos não renováveis em seus processos produtivo. Dessa maneira , a vantagem competitiva é um diferencial no mercado para uma organização que quer se destacar diante seus concorrentes e além de buscar por 


\section{Administração: caminhos para o desenvolvimento sustentável}

se beneficiar, irá esta beneficando a sociedade como um todo e despertando o interesse do seu consumidor.

\subsection{A CENTROFLORA COMO EMPRESA ECOEFICIENTE EM PARNAÍBA - PI}

O Grupo Centroflora completou 61 anos em 2018 e tem como visão, ser reconhecida globalmente na fabricação de ativos naturais rastreáveis de alto valor agregado com responsabilidade socioambiental. De acordo com o Relatório de sustentabilidade (2017) “O Grupo tem trajetória de constante evolução e adaptação às mudanças nas esferas econômica, ambiental e social. Diante da visão estratégica para o crescimento do Grupo nos próximos anos e levando em conta as especificidades de cada indústria em que atuam, principalmente do ponto de vista regulatório, foi decidido pelos gestores, focar os negócios da organização na área farmacêutica".

De acordo com o relatório de sustentabilidade (2017) Nos anos de 2016 e 2017 a organização manteve o foco em monitorar o consumo de energia, água, resíduos e emissão de gases, sempre com o objetivo de minimizar os impactos ambientais de suas atividades.

A sustentabilidade busca atender as necessidades das gerações atuais sem que comprometa as gerações futuras. Por esse motivo essa artigo julga-se importante entender o conceito e compreender mais ainda os benefícios que aplicação de métodos mais sustentáveis pode trazer tanto para o ambiente externo e interno da organização. Dentro desta definição, outro conceito de suma importância é o de ecoeficiência, que nada mais é uma característica de produtos e serviços que podem produzir mais e melhor, com menos recursos, conseguintemente evitando maiores desperdícios, como já colocado no presente trabalho.

Lapa (2016) cita que existem sete elementos essenciais para ecoeficiência. São eles, a minimização do uso de materiais dos bens e serviços, minimizar o uso de energia na produção de bens e serviços, redução a dispersão de resíduos tóxicos, fomentar a reciclabilidade dos materiais, maximização da utilização sustentável de recursos renováveis, estender a durabilidade dos produtos, promover a educação dos consumidores para um uso mais racional dos recursos naturais e energéticos.

O autor cita ainda alguns exemplos de medidas ecoeficiente para a organização, dentre elas encontram-se a minimização da escassez da água ao trocar equipamentos convencionais por aqueles com fechamento automático, reduzir gastos supérfluos de luz através de sistemas de iluminação automáticos, procurar por formas alternativas de geração de energia, reparar os resíduos, além de 


\section{Administração: caminhos para o desenvolvimento sustentável}

reduzir, reciclar e reutilizar os resíduos sólidos, realizar a compostagem de resíduos orgânicos, substituir lâmpadas convencionais por opções de baixo consumo.

O Grupo Centroflora tem a inovação e a sustentabilidade como elementos centrais na condução de seus negócios, buscando crescer e se manter competitivo, valorizando a biodiversidade e a sua conservação e se mantendo sempre conectado com o avanço da ciência e da tecnologia. Para continuar crescendo de forma competitiva foram identificados pilares estratégicos para o desenvolvimento tecnológico sustentável do Grupo Centroflora, fomentando a inovação no estabelecimento de cadeias produtivas, modernização do parque fabril, visando eficiência de processo e agregação de valor na criação de extratos vegetais diferenciados, com qualidade, segurança e eficácia atestados.

Associando os conceitos ecoeficiencia com a maneira que a empresa leva sua produção industrial, foi observado em pesquisa com os funcionários a existência de processos ecoeficientes que agregam valor ao produto, a empresa e ao meio ambiente. A empresa trabalha com a folha do jaborandi e no processo de extração da pilocarpina, que é o alcaloide (C11 H18 N2 O2) retirado da folha, nesse processo foi descrito que há o reaproveitamento da matéria, intitulada por puro cristal e que e a partir da 4으 fase de produção já passa a ser chamada de cru, vale ressaltar que é um processo que acontece em cinco fases. Além do ciclo descrito, os resíduos sólidos são disponibilizados para serem usados como adubo, envolvendo um processo de movimentação entre doze meses para então serem colocados como composto para plantas, hortaliças entre outros.

A dispersão dos resíduos tóxicos é feita em tanques e por serem solventes voláteis, os tanques tem um processo de baixa temperatura que agem para a condensação dos solventes, desta forma, quando os gases sobem há condensação, reduzindo assim o nível de dispersão para o meio ambiente. Os solventes são o metanol e acetona de acordo com que foi relatado em entrevista, existem empresas que compram esses solventes.

Além dos processos de produção e fazendo referência a um dos elementos da ecoeficiência citados pelo autor (LAPA, 2016) sobre intensificar a reciclagem de matérias, foi observado que a empresa disponibiliza materiais para confecção de bolsas, arranjos decorativos voltados para trabalhos de conscientização ambiental e geração de renda. Tendo como exemplo para confeç̧ão de bolsas a reutilização dos sacos de jutas que embalam a folha do Jaborandi. As bolsas por sua vez, podem ser utilizadas nos supermercados, feiras e mercadinhos, assim diminuindo o consumo de plástico. 


\section{Administração: caminhos para o desenvolvimento sustentável}

\section{METODOLOGIA}

Segundo Lakatos e Marconi (2011, p. 46) método é o "conjunto de atividades sistemáticas e racionais que, com maior segurança e economia, permite alcançar o objetivo, traçando o caminho a ser seguido detectando erros e auxiliando as decisões do cientista". Dessa forma como ocorreu o desenvolvimento do conhecimento, se desenvolveu também o método, o processo de sistematização das atividades. Segundo Oliveira (1991), um "método é um conjunto de processos pelos quais se torna possível conhecer uma determinada realidade, produzir determinado objeto ou desenvolver certos procedimentos ou comportamentos.

Quanto ao estudo foi escolhido estudo de caso e estudo bibliográfico como direcionador da pesquisa para obtenção de resultados. Segundo Gil (2010, p.117), "diferentemente do que ocorre com outros delineamentos, como o experimento e o levantamento, as etapas do estudo de caso não se dão numa sequência rígida".

A pesquisa bibliográfica é fundamental no que diz respeito ao fornecimento de informações relativas ao estudo que foi feito, auxiliando no embasamento científico da pesquisa. Segundo Medeiros (2006, p.51) "a pesquisa bibliográfica é passo decisivo em qualquer pesquisa científica, uma vez que elimina a possibilidade de se trabalhar em vão, de se despender tempo com o que já foi solucionado".

O ser humano vivência todos os dias, as mais diversas formas de conhecimento, constrói seu próprio senso crítico, e sua maneira de ver o mundo e a realidade ao seu redor, seja na sua forma popular ou na sua forma científica. O estudo realizado em setembro de 2018, na empresa Centroflora se deu por meio de perguntas estruturadas e baseadas nos oito elementos da ecoeficiencia, em entrevista aplicada com dois colaboradores da organização, caracterizando assim um estudo de campo .

A pesquisa de campo, é um passo importante no processo de execução da pesquisa, compreende a coleta de dados e a análise desses dados que são utilizados para se chegar à conclusão da pesquisa. Através da entrevista com a empresa em estudo, pode-se obter uma maior interação com os informantes, proporcionando à pesquisa, um quadro mais fiel da realidade.

\section{RESULTADOS}

Como já citado nesse estudo, foi utilizada uma metodologia de coleta de dados através da entrevista com a Empresa Centroflora, as perguntas usadas para busca de resultados desta pesquisa foram 


\section{Administração: caminhos para o desenvolvimento sustentável}

baseadas nos oito elementos da ecoeficiencia propostos por Lapa (2016) em que o grupo de pesquisa separou os elementos que se alinhavam com a proposta de produto/serviço que a empresa promove.

Primeiramente foi explanado se no processo industrial da empresa Centroflora, na Unidade III da cidade de Parnaíba há a minimização do uso de materiais dos bens e serviços e como resposta o Coordenador de Produção, relatou que, para obter o produto final existe um ciclo que o material retirado da folha do jaborandi é reutilizado nas etapas do ciclo descrito por ele, no qual foi segmentado em cinco fases. Caracterizando o procedimento mais ecoeficiente e sustentável para a empresa.

Sobre a minimização do uso de energia na produção de bens e serviços, o processo de produção acontece de acordo com a demanda, a minimização do produto vária de acordo com a meta a se alcançar por lote, no mais existem outros tipos de minimização, como por exemplo, torneiras automáticas que se encontram na empresa e colaboram de forma direta e indireta para a diminuição não apenas de energia, mas evitando desperdícios prejudiciais.

Logo após responder sobre a minimização o uso de energia, o coordenador foi questionado sobre a dispersão de resíduos tóxicos e então ele relatou sobre como se dava os solventes que por sua vez podem causar impactos ambientais. Os solventes citados foram o metanol e a acetona e os mesmos são colocados em tanques, mesmos sendo voláteis existe um método de condensação que impossibilita a saída dos solventes. Ainda foi dito que existem empresas que compram o metanol e a acetona e dessa maneira a empresa se assegura que não estão sendo dispersos no meio ambiente de forma qualquer.

Em seguida, no que se relaciona a fomentar a reciclabilidade dos materiais foi respondido que até mesmo os resíduos que poderiam ser descartados tem seu papel ressaltado, exemplo que foi descrito, foi o uso da "borra" do jaborandi que é utilizado como adubo em um processo após doze meses sendo revirado para dai então ser usado como composto. Além da borra a empresa doa materiais como sacos de jutas que fomentam oficinas de customização, reforçando a idéia de sustentabilidade na redução de lixos plásticos. Uma das Instituições que recebem esses materiais é o Instituto Floravida, que também foi idealizado pelo Grupo Centroflora, a partir desses materiais, o Instituto desenvolve diversas atividades com a comunidade em torno da fábrica, especialmente nos bairros Igaraçu, Lagoa da Prata e Dom Rufino. 


\section{Administração: caminhos para o desenvolvimento sustentável}

Prosseguindo com as indagações, surgiu o questionamento sobre a maximização da utilização sustentável de recursos renováveis, porém essa pergunta foi direcionada a outro colaborador, Domingos Vidal responsável pelos processos de tratamento da água dentro da empresa. Ele conta que a empresa faz o tratamento de efluentes de acordo com a Legislação Federal da CONAMA que é necessário um padrão de lançamentos no qual tem que atender um ph final de 5 a 9 . 0 tratamento de efluentes industrial é feito em duas fases, a primeira é a separação do material em suspensão, método de gradeamento, já a segunda fase, titulada por tratamento biológico, funciona com o controle por meio de bactérias, a matéria orgânica. $O$ terceiro processo seria o efluente para reuso, porém a empresa ainda não trabalha com esse sistema. A água da empresa é despejada em uma lagoa próxima a fábrica e atende aos critérios que a CONAMA estabelece. Os efluentes contam com o controle por meio de análise externa, laboratórios externos que fiscalizam e garantem a qualidade desse recurso.

Ainda partindo dos elementos ecoeficiente apresentados por Lapa (2016), foi perguntado no que diz respeito a estender a durabilidade dos produtos, o Gerente de produção por sua vez conta que há cerca de alguns anos a empresa passou a substituir uma substância no seu produto e obteve sete anos de durabilidade ao invés de cinco, tendo assim a preocupação de estender para mais dois anos a utilização no mercado, marco importante para a cidade de Parnaíba, que também conta como um diferencial positivo para a empresa Centroflora.

Finalizando a entrevista foi discutido se a empresa promove a educação dos consumidores para um uso mais racional dos recursos naturais e energéticos e de acordo com Relatório de sustentabilidade (2017) disponibilizado pela empresa, é observado que a Empresa tem essa preocupação, como já citado no presente trabalho, o Grupo Centroflora desenvolveu durante sua trajetória a conscientização sobre uso ponderado de recursos naturais e continua atuando na educação ambiental principalmente no processo de extrativismo de sua matéria-prima, a folha de jaborandi.

\section{CONCLUSÃO}

A ecoeficiência está vinculada a atender as todas as atividades que visam transformação do meio ambiente. Por esse motivo, julgou-se necessário neste artigo entender seu conceito e compreender mais ainda seus benefícios, através dos estudos de conceitos da ecoeficiência, gestão ambiental e responsabilidade social, onde buscou-se entender o quanto é importante manter o uso dos recursos naturais de forma inteligente para assegurar que eles se mantenham no futuro. Neste sentido, o presente artigo objetivou a analisar os processos produtivos ecoeficientes do Grupo Centroflora, no 


\section{Administração: caminhos para o desenvolvimento sustentável}

qual pode-se perceber que a ideia da ecoeficiência sugere uma maior e melhor qualidade ambiental na produção, com a finalidade de minimizar o consumo de recursos naturais e os impactos ambientais.

De acordo com as informações levantadas acerca do processo de extrativismo da matéria prima folha de jaborandi, observou-se que o Grupo Centroflora possui um processo estruturado, seguindo etapas interligadas, visando buscar um processo produtivo seguindo os elementos ecoeficientes trazidos por Lapa (2016), obtendo-se assim o produto final com etapas estruturadas e interligadas umas com as outras, desde extração com a minimização do uso de energia até a dispersão dos resíduos sólidos e reciclabilidade dos materiais.

Conclui-se que, gerir uma organização de maneira mais produtiva com menos recursos naturais, minimizando custos de produção e satisfazendo as necessidades humanas, trazendo uma melhor gestão ambiental para gerações futuras, remete diretamente ao conceito a ecoeficiência. Além do conceito o presente artigo consta os benefícios de ser uma empresa ecoeficiente em Parnaíba-PI, caso do Grupo Centroflora, pois quando a organização associa sua produção aos eixos sustentáveis e socioambientais, demonstram cada vez mais ganhos para todas as cadeias inseridas.

Com isso, percebe-se que o Grupo Centroflora tem a inovação e a sustentabilidade como elementos centrais na condução de seus negócios, buscando crescer e se manter competitivo, valorizando a biodiversidade e a sua conservação e se mantendo sempre conectado com o avanço da ciência e da tecnologia, fomentando a inovação no estabelecimento de cadeias produtivas, modernização do parque fabril, visando eficiência de processo e agregação de valor na criação de extratos vegetais diferenciados, com qualidade, segurança e eficácia atestados.

\section{REFERÊNCIAS}

Anderson, P. (2017). Relatório de sustentabilidade: Grupo Centroflora 2016/2017. 2017. Disponível em:<http://www.centroflora.com.br/wp-content/uploads/pdf/RelatorioSustentabilidade.pdf $>$. Acesso em: 5 Out. 2018. BCSD Portugal - Business Council For Sustainable Development Portugal. (2013). Ecoeficiência na Vida das Empresas. [S. I.: s. n.], Maio/2013. Disponível em: http://www.bcsdportugal.org/wp-content/uploads/2013/10/BEE-Manual-do-Formando.pdf. Acesso em: 5 out. 2018.

BCSD Portugal - Business Council For Sustainable Development Portugal. (2012). Young Managers Team 2012. Manual do Formando: A ecoeficiência na vida das empresas. ed. [S.I.: s.n.], 2012. 49 p. v. 1. Disponível em: <http://www.bcsdportugal.org/wp-content/uploads/2013/10/BEE-Manual-doFormando.pdf>. Acesso em: 7 Set. 2018. Comissão Europeia - CE. (2001). Promover um quadro europeu para a responsabilidade social das empresas. Livro Verde. Bruxelas. Recuperado em 07 nov. ,2008. http://europa.eu.int/comm/employment_social/soc-dial/csr/greenpaper_pt.pdf. CEBDS - 


\section{Administração: caminhos para o desenvolvimento sustentável}

Conselho Empresarial Brasileiros para o Desenvolvimento Sustentável. A história do termo ecoeficiência. Disponível em: <http://www.ecoeficientes.com.br/a-historia-do-termoecoeficiencia/>. Acesso em: 7 Set. 2018. Gil, A. C. (2008). Métodos e técnicas de pesquisa social. 6. ed. Atlas, São Paulo.

Lapa, R. P. (2016). Ecoeficiência: o que é e por que as pessoas devem investir. Disponível em: <http://segurancatemfuturo.com.br/index.php/2016/09/15/o-que-e-e-por-que-as-empresas-deveminvestir-na-ecoeficiencia/>. Acesso em: 8 Set.2018.

Marconi, M. A.; Lakatos, E. M. (2009). Técnicas de pesquisa: planejamento e execução de pesquisas, amostragens e técnicas de pesquisa, elaboração, análise e interpretação de dados. 7. ed. Atlas, São Paulo. Martins, M. R. S.; Silva, J. G. F. (2015). O sistema de gestão ambiental baseado na ISO 14000: Importância do instrumento no caminho da sustentabilidade ambiental. Revista Eletrônica em Gestão, Educação e Tecnologia Ambiental, e-ISSN 22361170 - V. 18 n. 4 Dez 2014, p.1460-1466.

Petkow, M.; Almeida, V. (2005). Ecoeficiência e o desenvolvimento sustentável: um estudo de caso em um hotel certificado pela ISO 14001. XXV Encontro Nacional de Engenharia de Produção. 2005. Disponível em: <http://www.abepro.org.br/biblioteca/enegep2005_enegep1002_0605.pdf>. Acesso em: 7 Set. 2018.

Santiago, A. L. F. (2018). Licença social para operar relacionamento da empresa com a comunidade local critérios de influência para a concessão da LSO, um estudo de caso na mineração. Disponível em: <https://rua.ua.es/dspace/bitstream/10045/69591/1/tesis_ana_lucia_frezzatti_santiago.pdf >. Acesso em: 9 Out. 2018.

Valle, C. E. (1995). Qualidade ambiental: O desafio de ser competitivo protegendo o meio ambiente. Ed. Pioneira, São Paulo. Zanatta, P. (2017).Gestão ambiental e o desenvolvimento sustentável. Revista Gestão e Sustentabilidade Ambiental , Florianópolis,. Disponível

em:http://www.portaldeperiodicos.unisul.br/index.php/gestao_ambiental/article/view/5567. Acesso em: 6 out. 2018. 


\section{Capítulo 42}

\section{COOPERATIVISMO: UMA ALTERNATIVA EMPREENDEDORA SUSTENTÁVEL}

DOI: $10.37423 / 200300471$

\section{Eliane Noviski Nadal}

elianenovi@gmail.com

Juraci Maria Batista de Macedo (Centro Universitário Uninter)

jumacedo01@yànod.com.br
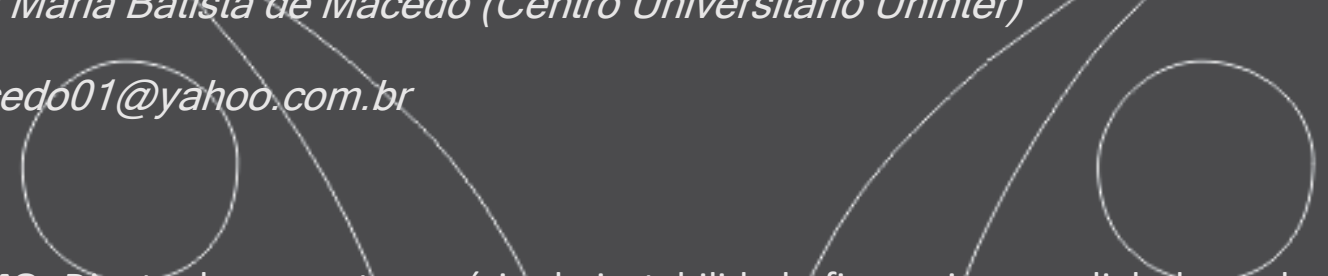

RESUMO: Dìante do presente cenário de instabilidade financeira mundial, đesaceleração da indû́stria e da economia nacional, desemprego crescente e métodos de globalização em constante evoluçầ, indaga-se qual a importânciá do cooperativismo no processo de (re) organização e de sustentabilidade da comunidade/atual, consubstanciadaem uma nova forma de empreendedorismo que explore novas possibilidades quie participe do processo de transforma ção, de geração de valores, serviços e renda. Assim, a partir de um modelo de funcionamento ajustado ao contexto e ao ideário søcial, econômico e juridico atual e às perspectivas do desenvolvimento susstentávęl, através do exercício de novas prâticas desenvolvidas para este fim, o cooperativismo torna-se uma alternativa de empreendedorismo sustentável, contribuinglo/para uma melhor qualidade de vida e possibilitando uma-nova forma de atuação em prol da Eoletividade.

Palavras-chave: Cooperativismo, Desenvolvimento Sustentável, Sustentabilidade, Empreendedorismo. 


\section{Administração: caminhos para o desenvolvimento sustentável}

\section{INTRODUÇÃO}

"Cooperativas constroem um mundo melhor" Com esse slogan a ONU (Organização das Nações Unidas) declarou 2012 como o Ano Internacional das Cooperativas, a fim de chamar a atenção dos governantes para este empreendimento.

Atualmente o Cooperativismo tem seu empenho na produção e distribuição de mercadorias nos diferentes setores da economia: agropecuária, consumo, crédito, transporte, educação, bancos, seguros, habitação, pesca e toda ordem de serviços. Aceito por todos os governos, sem encontrar nenhum obstáculo ideológico, pois inegavelmente concorre para o desenvolvimento de todos os países. Assim encontramos cooperativas no Brasil, na Rússia, no Japão, nos Estados Unidos... Enfim no mundo todo.

O objetivo deste trabalho é mostrar os impasses e desafios que os empreendimentos cooperativos enfrentam. Para tanto, de forma contextualizada, faremos um estudo sobre a história e sobre os princípios norteadores do sistema cooperativo.

Posteriormente analisaremos as principais espécies de cooperativas e o tratamento constitucional e legal dispensado às mesmas no atual contexto nacional.

Redefinido, a partir de uma visão de empreendedorismo sustentável e orientado, agora, por novos paradigmas sociais de produção e consumo, de equilíbrio entre desenvolvimento econômico, bem estar social e proteção ambiental, surge como alternativa para a geração e manutenção do emprego e da renda e como meio de proporcionar maior inclusão social.

Enfim, uma abordagem que, amparada na história, nos ideais e princípios que cercavam a ladeira dos "Probos de Rochedalle", visa resgatar a importância do cooperativismo.

\section{DOUTRINA COOPERATIVISTA E SUAS ORIGENS}

Primeiramente, para compreender melhor a especificidade do empreendimento cooperativo faz-se necessário saber alguns dos principais conceitos, definição de cooperação, de cooperativa e de cooperativismo.

Cooperação, etimologicamente, vem do verbo latino, cooperari, de cum e operari. Tem seu significado como produzir junto, produzir em conjunto. 
Cooperativismo é a doutrina econômica estruturada para a geração de riquezas por meio do livre associativismo entre pessoas que, espontaneamente, concordam em criar uma cooperativa em qualquer segmento produtivo permitido pela legislação e, unidas pelos mesmos ideais e tendo objetivos, buscam a satisfazer suas necessidades financeiras e de realização pessoal/profissional por meio da produtividade e da valorização humana, e não da exploração do homem pelo homem. O cooperativismo é a "alma" da cooperativa, assim como, grosso modo, o mercantilismo é a "alma" do capitalismo (RIOS, 1998).

Segundo Pinho (1961, p.58) "Cooperativas são sociedades de pessoas organizadas em bases democráticas, que visam não só suprir seus membros de bens e serviços, como também a realizar determinados programas educativos e sociais".

A história do cooperativismo é de suma importância para a sua multiplicação e difusão. 0 cooperativismo não surgiu de repente. Ele surgiu como forma de adequação do homem às transformações criadas pelo capitalismo industrial, implantado pela Revolução industrial.

A Revolução Industrial surgiu no século XVIII, principalmente na Inglaterra, até o século XX. Com ela instala-se o Capitalismo Industrial, trazendo consigo mudanças implantadas na sociedade e na economia da época. Contudo essas mudanças trouxeram várias consequências: boas e más.

As boas mudanças foram: aproveitamento da mão de obra nas indústrias para produção em larga escala, a fim aumentar o lucro; urbanização das cidades e consequente utilização dos meios implantados pela Revolução Industrial na preparação da estruturação das cidades, que explodiam em número de população em poucos anos. São construídas ruas pavimentadas; o gás passa a iluminar as ruas; o carvão é usado para aquecimento das casas.

As más: crescimento dos problemas sociais e econômicos. O desemprego era frequente, como consequência da superprodução fabril; o êxodo rural como procura de trabalho nas cidades e os baixíssimos salários pagos às crianças e aos trabalhadores. Não existiam direitos dos trabalhadores e a superoferta de mão de obra deixava o proletariado a mercê dos empresários. Qualquer reclamação era seguida de dispensa.

Em decorrência destas mudanças surgem homens que, além de teóricos, eram verdadeiros empreendedores. Homens de coragem, bravura e elevado espírito de humanidade, face à nova realidade. 


\section{Administração: caminhos para o desenvolvimento sustentável}

John Bellers (1654- 1725). Nascido na Inglaterra, que sugere criar as casas "comunais" e indústrias associadas.

Robert Owen (1771-1858). Também nascido na Inglaterra, é considerado o pai do Cooperativismo por dedicar sua vida e investir seus recursos na criação de uma forma de substituir a competição e a ganância, pela cooperação.

William King (1786-1865), em 1827, ordena em Brighton, Inglaterra, a primeira pré-cooperativa de consumo. No ano de 1835, nasce na cidade de Lyon, na França, uma sociedade semelhante àquelas já existentes na Inglaterra: a Associação Lionesa, nomeada Au Commerce Véridique.

Felipe Buchez (1796-1865) nascido na Bélgica. Procurou criar um cooperativismo autogestionado, com autonomia política e ajuda externa. Tentou empreender na França as "associações operárias de produção".

Louis Blanc (1812-1882). Espanhol, viveu na França e mostrou-se um notável político. Preocupou-se com o direito ao trabalho, defendia a liberdade fundamentada na instrução geral e na constituição moral da sociedade.

Contudo em Rochdale, na Inglaterra deu-se o surgimento do Cooperativismo como empreendimento sócio econômico.

A associação constituída pelos pioneiros teve origem em uma greve fracassada de tecelões de flanela. Pelos fins de 1843, 28 trabalhadores pobres e necessitados. Grande parte pertencente à classe dos referidos tecelões, começaram a promover reuniões com o fim de buscarem uma maneira de aliviar a situação de penúria em que viviam. Decidiram organizar-se em sociedade cooperativa e passaram a reunir parcas economias que the permitissem constituir um modestíssimo capital. MAUER JÚNIOR (1966, p. 28)

O ideal cooperativista se espalhou pelo mundo, bem como por todos os setores da economia. Atualmente o cooperativismo tem reconhecimento e aceitação em todos os países como fórmula mais adequada no atendimento às necessidades e interesses específicos das pessoas.

No Brasil, após a libertação dos escravos, e ao mesmo tempo com a chegada dos imigrantes europeus que trouxeram consigo juntamente com sua cultura os ideais associativistas. 


\section{Administração: caminhos para o desenvolvimento sustentável}

Em 1891, na cidade de Limeira, estado de São Paulo surge a Associação Cooperativa dos Empregados da Companhia Telefônica. A Cooperativa Militar de Consumo no Rio de Janeiro e no ano de 1895 a Cooperativa do Proletariado Industrial de Camaragibe (Pernambuco).

Somente em 1902, Teodoro Amstad inicia um movimento de caráter mais genuíno com as caixas rurais do tipo Raiffeisen, surgidas no Rio Grande do Sul, das quais a primeira se organizou em Nova Petrópolis. Assim foram surgindo novas cooperativas.

“Em 1913 surgiram no Rio Grande do Sul quatro cooperativas do setor de consumo. Duas em Santa Catarina e uma em Rio Pardinho e uma na Linha Santa Cruz". (LIMBERGER, 1996).

Em 1895, na Inglaterra, foi criada a ACl- Aliança Cooperativa Internacional, atualmente é sediada em Genebra, na Suíça. Associação não governamental e independente agrupa, representa e ampara às cooperativas e suas organizações correspondentes. Conta com mais de 900 milhões de pessoas, mais de 230 organizações nacionais e internacionais, distribuídas por mais de 100 países. Filiada a esta, a OCB, Organização das Cooperativas Brasileiras, criada juridicamente pela Lei 5.764/71, tem atuação técnica-consultiva do governo, congrega as demais Organizações Cooperativas Estaduais (OCEs), estando também afiliada à Organização das Cooperativas das Américas (OCA).

Sabemos que mudanças são inevitáveis e fazem parte da natureza humana e de suas relações. Esta é uma certeza! Como também, é sabido que o ser humano só sobrevive a elas através da adaptação. Foi assim que o Cooperativismo deu condições ao homem para sobreviver aos aspectos selvagens do capitalismo industrial, facilitando a adequação do homem a estas mudanças.

\section{TIPOS DE COOPERATIVAS}

Ao se considerar a numerosa diversidade de tipos de cooperativas surge uma dificuldade em decidirse por uma norma de classificação que compreenda todas. Comumente os autores estabelecem normas focadas nas análises cooperativistas as quais se apresentam.

Bernard Lavergne (1959) citado por Júnior (1966, p.113) classifica-as, segundo o sistema econômico a que se filiam, em cooperativas distribuidoras (de consumidores), em que os benefícios da atividade econômica pertencem ao consumidor; cooperativas "corporativas" obreiras, nas quais o benefício da empresa cabe aos que nela trabalham; cooperativas profissionais ou patronais (de compra, de suprimento, de seguro, de produção, etc., mas sempre com o fim de dar maiores lucros ao capital). 


\section{Administração: caminhos para o desenvolvimento sustentável}

Pinho (1965) define a forma de atividade exercida pelas cooperativas agrupando-as: a) Cooperativas de primeiro grau; b) Cooperativas de segundo grau; c) Cooperativas de terceiro grau.

As sociedades cooperativas singulares ou de 1 o grau objetivam prestar serviços diretos ao sócio. Constituída de no mínimo 20 pessoas físicas, não é aceito o ingresso de pessoas jurídicas iguais ou atividades econômicas correlatas das pessoas físicas que a integram.

O objetivo de sociedades cooperativas centrais e federação ou de 2ำ grau é organizar em comum e em escala maior as atividades das filiadas, favorecendo o uso recíproco das atividades. A constituição dá-se de no mínimo três cooperativas de 10 grau.

As sociedades cooperativas confederações ou de 3ำ grau objetivam definir em comum e em escala maior as atividades das filiadas. Para constituir uma federação é necessário de no mínimo três cooperativas centrais e ou federação de qualquer ramo.

Algumas diferenças essenciais entre a representação de uma sociedade cooperativa e a sociedade econômica empresária aparecem no quadro que segue:

\begin{tabular}{|l|l|}
\hline Sociedade cooperativa pura & Sociedade econômica \\
\hline O principal é o homem & O principal é o capital \\
\hline O cooperado é sempre dono e usuário da sociedade. & $\begin{array}{l}\text { Os sócios vendem seus produtos e serviços a uma } \\
\text { massa de consumidores. }\end{array}$ \\
\hline Cada pessoa conta com um voto na assembleia. & Cada ação ou quota com um voto na assembleia. \\
\hline O controle é democrático. & O controle é financeiro. \\
\hline $\begin{array}{l}\text { É uma sociedade de pessoas que funciona } \\
\text { democraticamente. }\end{array}$ & $\begin{array}{l}\text { É uma sociedade de capital que funciona } \\
\text { hierarquicamente. }\end{array}$ \\
\hline
\end{tabular}

Fonte: CAVALCANTI, 2008, p.15.

Tabela 1: Tipos de sociedade empreendedora

Cumprindo sua função de entidade representativa, a OCB determinou os ramos do cooperativismo que se baseiam nas diversas áreas em que a entidade atua. As denominações dos ramos foram aprovadas pelo Conselho Diretor da OCB, em 4 de maio de 1993. A divisão facilita a organização vertical das cooperativas em confederações, federações e centrais.

O Sistema OCB congrega no Brasil 6.652 cooperativas, que reúnem mais de 9 milhões de associados e geram 300 mil empregos diretos. Em todo o país, cerca de 30 milhões de pessoas estão ligadas ao movimento cooperativista. O setor contribui diretamente para o desenvolvimento sustentável do país, 


\section{Administração: caminhos para o desenvolvimento sustentável}

tem participação expressiva na economia brasileira, e ainda atuam em outros mercados, levando produtos a outros países. Suas vendas ao exterior devem fechar 2011 em praticamente US\$6 bilhões.

\begin{tabular}{|c|c|c|c|}
\hline \multirow{2}{*}{ Ramo de Atividade } & Cooperativas & Associados & Empregados \\
\cline { 2 - 4 } & 6 mil cooperativas & 9 milhões de associados & 300 mil empregados \\
\hline Agropecuário & 1.548 & 943.054 & 146.011 \\
\hline & & & 9.892 \\
\hline Consumo & 123 & 2.297 .218 & 56.178 \\
\hline Crédito & 1.064 & 4.019 .528 & 3.349 \\
\hline Educacional & 302 & 57.547 & 14 \\
\hline Especial & 12 & 397 & 1.676 \\
\hline Habitacional & 242 & 101.071 & 144 \\
\hline Infraestrutura & 141 & 778.813 & 3.669 \\
\hline Mineral & 63 & 20.792 & 56.776 \\
\hline Produção & 235 & 11.454 & 3.879 \\
\hline Saúde & 852 & 246.265 & 10.787 \\
\hline Trabalho & 1.024 & 217.127 & 32 \\
\hline Transporte & 1.015 & 321.893 & $\mathbf{2 9 8 . 1 8 2}$ \\
\hline Turismo e Lazer & 31 & 1.368 & $\mathbf{9 . 0 1 6 . 5 2 7}$ \\
\hline Totais & $\mathbf{6 . 6 5 2}$ & & \\
\hline
\end{tabular}

Fonte: Organização de Cooperativas Brasileiras

Tabela 2: números de 2010

Assim a gestão das cooperativas conforme os ramos diferem-se de acordo com alguns fatores como: área de atuação, educação cooperativista, estrutura administrativa e organizacional, conhecimento, experiência, habilidade e atitudes de seus gestores. (OCB, 2012).

\section{DOUTRINA COOPERATIVISTA E SUA RELAÇÃO COM O DESENVOLVIMENTO SUSTENTÁVEL}

De acordo com os estatutos de Rochdale, base doutrinária do cooperativismo adotada pela Aliança Cooperativa Internacional $(\mathrm{ACl})$, um grupo de tecelões ingleses foram os fundadores da sociedade cooperativa de consumo Rochdale Society of Equitable Pioneers, no ano de 1844. Responsáveis pela iniciativa da constituição dos princípios que até agora determinam uma sociedade cooperativa. 


\section{Administração: caminhos para o desenvolvimento sustentável}

\begin{tabular}{|l|l|}
\hline Princípios doutrinários & Estatutos de Rochdale \\
\hline Solidariedade & Associativismo \\
Igualdade & Retorno pro rata \\
Liberadade & Gestão democrática \\
Fraternidade & Neutralidade política e religiosa \\
& Cooperação voluntária \\
& Livre entrada e saída \\
& Educação cooperativa \\
\hline
\end{tabular}

Fonte: Lambert. Op. cit. apud BATALHA, M. O.

Tabela 3: Princípios doutrinários do cooperativismo expressos nos estatutos da cooperativa de

Rochdale.

A harmonização democrática com as exigências técnicas e econômicas da dimensão da empresa, para as cooperativas são um grande desafio, onde às vezes podem depositar-se demasiadas atribuições e poderes a executivos e profissionais na tomada de decisões essenciais. Para que a democracia seja real é importante impedir que o poder seja apropriado pelos executivos e técnicos contratados e não eleitos. Assim o cooperado há de ser capacitado para realizar as obrigações dos gestores contratados (SHNEIDER, 1994).

Elaborada pelos velhos pioneiros, a doutrina cooperativista, é entendida como tendo dois polos, e sem os mesmos é impossível compor uma economia cooperativista: "a economia a serviço do consumo" e “a humanização e a justa remuneração do trabalho”. (MAUER JÚNIOR, 1966).

Esse cooperativismo não pode ser uma solução parcial, destinada a minorar um pouco os efeitos perniciosos de um sistema cruel e desumano, como aquele que domina no mundo moderno. Antes, ele deve constituir um vasto programa social e cultural, todo ele alicerçado na afirmação da primazia do homem, de seus direitos e necessidades, porque é isto o que significa, em última análise, a primazia do consumidor e o justo tratamento dispensado no trabalho. Nem capitalismo, nem comunismo, mas cooperativismo genuíno e integral, eis o alvo por que devem lutar aqueles que desejam uma reforma profunda e duradoura da nossa civilização desorientada (MAUER JÚNIOR, 1966, p.19).

1ํ Princípio: Adesão voluntária e livre: as cooperativas são organizações voluntárias, abertas a todas as pessoas aptas a utilizar os seus serviços e assumir as responsabilidades como membros, sem discriminação de sexo, sociais, raciais, políticas e religiosas. (OCB, 2011)

A constituição de um modelo de negócios pautado pela sustentabilidade perpassa o desenvolvimento de uma dinâmica com os stakeholders, por meio da criação de ambientes propícios nos quais os públicos afetados pelos 


\section{Administração: caminhos para o desenvolvimento sustentável}

negócios da empresa possam manifestar suas opiniões e visões de mundo, participar de negociações e até de tomada de decisões. (PEREIRA, 2011).

2 Princípio: Gestão democrática e livre: as cooperativas são organizações democráticas, controladas pelos seus membros, que participam ativamente na formulação das suas políticas e na tomada de decisões. Eleitos representantes dos demais são responsáveis perante estes (OCB, 2011).

3o Princípio: Participação econômica dos membros que contribuem equitativamente para o capital das suas cooperativas controlando-o democraticamente. Parte desse capital normalmente é uma remuneração limitada ao capital integralizado condicionado a sua adesão (OCB, 2011).

Quanto a participação econômica, Ocb (2011) complementa: "Os membros destinam os excedentes para o desenvolvimento de suas cooperativas, benefícios aos membros na proporção das suas transações com a cooperativa ou apoio a outras atividades $[. . .]^{\prime \prime}$.

4ํ Princípio: Autonomia e independência; as cooperativas são autônomas, de ajuda mútua, controladas pelos seus membros. Firmando acordos com outras organizações, devem fazê-lo de forma segura ao controle democrático mantendo a autonomia da cooperativa (OCB, 2011).

Segundo Rodrigues (1999, p.12), fusões e incorporações são indispensáveis, como já acontece em todos os países desenvolvidos: é preciso aumentar a força cooperativa, e, sem dúvida, isto se dará com o desaparecimento de muitas delas, incorporadas por outras, antes que morram.

Contudo, com a competitividade no âmbito empresarial também deve ser levada em conta no contexto do desenvolvimento sustentável. Afinal, de nada adianta a organização ser ambientalmente correta e socialmente justa, se não se mantiver competitiva no mercado. (PEREIRA, 2011).

5o Princípio: Educação, formação e informação; as cooperativas promovem a educação e a formação de seus membros, dos representantes eleitos e dos trabalhadores, de forma que estes possam contribuir, eficazmente, para o desenvolvimento das suas cooperativas (OCB, 2011).

Pereira (2011) ressalta: "Os indivíduos e grupos aprendem através da experiência, de programas de treinamento e suporte contínuo, a capacidade de gestão e inovação se fortalece e se amplia. As redes sociais se expandem e se fortalecem, tornando-se capazes de suportar a estabilidade social contínua e o desenvolvimento econômico". 


\section{Administração: caminhos para o desenvolvimento sustentável}

É preciso investir muito na formação de recursos humanos, sobretudo tendo em vista a criação de lideranças comprometidas com esta nova realidade, em que a agilidade de decisões precisa ser compatibilizada com o princípio de democracia. (RODRIGUES, 1999).

60 Princípio: Intercooperação: as cooperativas servem de forma eficaz os seus membros e dão mais força ao movimento cooperativo, trabalhando em conjunto, através das estruturas locais, regionais, nacionais e internacionais. (OCB, 2011)

70 Princípio: Interesse pela comunidade: as cooperativas trabalham para o desenvolvimento das suas comunidades através de políticas aprovadas pelos membros.

"Doravante, as cooperativas, passam a assumir um papel que transcende a prestação de serviços a seus associados: passam ser organizações muito importantes na preservação e na defesa da democracia!" (RODRIGUES, 1999, p.13).

As regras tem uma fonte, uma lógica e um papel a desempenhar no curso de um processo histórico em permanente mudança e adaptação a novas circunstâncias, no qual também as regras cooperativas acompanham o seu curso. Portanto, devem ser concebidas numa perspectiva dinâmica, evolutiva, flexível. (LASSERRE apud SCHNEIDER, 1999, p. 71).

"Rochdale não se criou a fim de beneficiar um grupo de trabalhadores, capacitando-os para, arregimentados, melhor explorarem os benefícios do seu trabalho; criou-se, sim, para constituir uma organização comercial e depois industrial a serviço dos consumidores." (MAUER JÚNIOR, 1966, p.79).

Embora os princípios do cooperativismo vêm sendo modificados ao longo do tempo, tendo em vista os objetivos organizacionais e a busca pela eficácia administrativa, para acompanhar a evolução e competitividade do mercado, o objetivo primordial continua o mesmo: buscar através da união de um grupo de pessoas com interesses comuns, atuar de forma independente contra as injustiças existentes no setor privado e amenizar a incapacidade do setor público em promover condições igualitárias. (ALBARELLO, 2006, p.51).

Nas análises de Peter Drucker (2001), referem-se ao compromisso das empresas com o melhoramento no modo de vida da população de baixa renda. Para ele reduzir os problemas sociais é um encargo social necessário das empresas bem sucedidas.

Partindo do pressuposto de que o desenvolvimento sustentável visa [...] integrar e harmonizar as ideias e conceitos relacionados ao crescimento econômico, a justiça e ao bem estar social, a conservação ambiental e a utilização racional dos recursos naturais. (IBGE, 2004, p. 101). 


\section{Administração: caminhos para o desenvolvimento sustentável}

Pode- se afirmar que as cooperativas podem se transformar em organizações sustentáveis, colaborando no combate à crise financeira e impulsionando o crescimento e o desenvolvimento econômico local e nacional.

Uma pesquisa realizada em 1998, já apontava o cooperativismo brasileiro como responsável por:

$75 \%$ do trigo, $40 \%$ do açúcar, $32 \%$ do álcool, $37 \%$ da soja e $41 \%$ da cevada produzidos no país; $43 \%$ das exportações brasileiras de lã e derivados; $52 \%$ do leite inspecionado, $25 \%$ do leite em pó integral, $42 \%$ do leite desnatado, $50 \%$ da manteiga, $35 \%$ do queijo e $40 \%$ do iogurte são produzidos por cooperativas; $23 \%$ da capacidade nacional de armazenamento de grãos pertence a sociedades cooperativas. (SECRETARIA DO EMPREGO E RELAÇÕES DO TRABALHO, 1998, p. 9).

Por outro lado, o cooperativismo atua, também, sobre o desenvolvimento local, pois garante uma melhor distribuição de renda, promove a organização e a inclusão social, gera empregos e impostos e movimenta a economia.

A satisfação das necessidades e aspirações humanas é o principal objetivo do desenvolvimento. As necessidades essenciais de um grande número de pessoas nos países em desenvolvimento por comida, roupas, habitação e emprego não tem sido atendidas e, mais do que necessidades básicas, essas pessoas têm aspirações legítimas pela melhoria da qualidade de vida. Um mundo onde a pobreza e a iniquidade são endêmicas sempre estará sujeito a crises ecológicas e a crises de outra natureza. O desenvolvimento sustentável requer o atendimento das necessidades básicas de todos e a extensão a todos das oportunidades de satisfazer suas aspirações de uma vida melhor. (BRUNDTLAND, 1987 apud PEREIRA; SILVA; CARBONARI, 2011, p. 71).

\section{ALGUNS ASPECTOS DO DESENVOLVIMENTO SUSTENTÁVEL - DEFINIÇÃO E SEUS PILARES}

O conceito de desenvolvimento sustentável surgiu durante a Comissão de Brundtland, na década de 1980.

"É a forma com as atuais gerações satisfazem as suas necessidades sem, no entanto, comprometer a capacidade de gerações futuras satisfazerem as suas próprias necessidades" (BRUNDTLAND APUD SCHARF, 2004, p.19).B

Promovida no Rio de Janeiro, a "Conferência das Nações Unidas sobre Meio Ambiente e Desenvolvimento" (mais conhecida por "Rio 92") promoveu a discussão sobre desenvolvimento sócio econômico e suas consequências na natureza. Assim, através da Agenda 21, criou-se o plano de 


\section{Administração: caminhos para o desenvolvimento sustentável}

sustentabilidade que condicionava o crescimento sustentável ao desenvolvimento simultâneo dos três pilares: social, econômico e ambiental.

Para que a empresa seja sustentável, é preciso minimizar seus riscos, criando condições para um futuro mais estável, garantindo a continuidade do negócio e o relacionamento amigável com a sociedade. Identifica onze indicadores de sustentabilidade (FIJIHARA, apud SCHARF, 2004, p.24):

a) Mantém uma perspectiva de rentabilidade econômica no médio e longo prazo.

b) Opera dentro da lei, sem passivos que possam gerar prejuízos inesperados.

c) Minimiza sua dependência de recursos esgotáveis ou sujeito a escassez.

d) Minimiza seus impactos sobre os recursos naturais e a paisagem.

e) Desenvolve produtos ou serviços que contribuem para o que é percebido pela sociedade como um benefício social e ambiental.

f) Estabelecer uma relação de respeito e minimiza o conflito com seus funcionários, fornecedores, clientes, acionistas, e outros stakeholders - ou seja, os diversos atores que têm interesses diretos ou indiretos no empreendimento.

g) Cultiva a eficiência no uso dos recursos renováveis e não renováveis - com investimentos em tecnologia avançada e soluções de longo prazo - assim como se preocupa com os impactos de seus bens e serviços ao longo de todo o seu ciclo de vida.

h) Reduz os resíduos e recicla os materiais que descarta.

i) Tem transparência na gestão independente de possuir capital aberto, promovendo assim a confiança dos acionistas, investidores, fornecedores, clientes, etc.

j) Evita o uso de formas de propaganda maliciosa que induzam o publico a confundir a verdadeira atuação da empresa com ações beneficentes que não influenciam sua atuação.

k) Relaciona-se com demandas de ordem global (o aquecimento do planeta ou o surgimento de consumidores engajados em outros continentes) e local (a comunidade que a sua atuação afeta). 


\section{Administração: caminhos para o desenvolvimento sustentável}

Para a autora, o desenvolvimento sustentável se tornou imprescindível para a sobrevivência das empresas e do próprio planeta Terra. No seu entendimento, uma empresa que visa sustentabilidade deve ser transparente, e capaz de avaliar seu desempenho sócio ambiental. A melhor maneira de se fazer isso é através do relatório anual de sustentabilidade.

"Esse relatório aponta diversos indicadores sociais, econômicos e ambientais, referente ao desempenho da empresa além de ressaltar seus valores." (FIJIHARA, apud SCHARF, 2004, p.24).

Scharf (2004, p.22) ressalta três tipos de balanço sócio ambiental, utilizados no Brasil:

1. O balanço proposto pelo Ibase - Instituto Brasileiro de Análises Sociais e Econômicas é o mais antigo deles, que através de uma planilha apresenta detalhadamente dos números relacionados à responsabilidade social da empresa.

2. O Guia de Elaboração de Relatórios e Balanço Anual de Responsabilidade Social Empresarial, elaborado pelo Instituto Ethos, utiliza a planilha do Ibase, porém apresenta de forma mais detalhada as ações e princípios desenvolvidos pela empresa. Ele apresenta indicadores sociais, econômicos e ambientais, onde se esclarece os objetivos em relação à produtividade, investimentos, bem estar da força de trabalho e seus direitos e impactos sobre o meio ambiente, como poluição, desmatamento entre outros.

3. GRI - Global Reporting Initiative, lançado em 1997, utilizado mundialmente, tem por objetivo tornar o balanço sócio ambiental cada vez mais popular e é um dos melhores relatórios para se comparar o desempenho das empresas.

No relatório que produziram em 2005, os bancos cooperativos europeus (European Associoation of Cooperative Banks) enfatizam que estão ativamente engajados nas metas que envolvem a responsabilidade social das empresas (RSE), devido à identidade própria de seus empreendimentos, à sua gestão transparente democrática e participativa, à sua colaboração para o desenvolvimento local sustentável (DS) através de investimentos socialmente responsáveis, de projetos como Finança Verde, de oferta de microcrédito, de reinclusão social, de cooperação através de conhecimentos especificados, da disponibilização de produtos e insumos adequados e, por último, com o apoio à cidadania responsável, às instituições de caridade e ao patrimônio cultural.

Para Moura (2006), citado por Araújo (2008, p.112):

“Uma empresa socialmente responsável poderia assim ser considerada como aquela capaz de contribuir para que os valores da comunidade onde se insere em nível local, nacional e internacional em todos os domínios da vida humana a saber, trabalho, ambiente, relações humanas, aproximem as sociedades e as pessoas num sentido e caminho comuns, pautados por mais justiça e equidade 


\title{
Administração: caminhos para o desenvolvimento sustentável
}

social, promovendo o equilíbrio necessário à elaboração e assegurando uma legitimação social capaz de ultrapassar a relação de conflito típica da sociedade industria".

\section{FUNDAMENTOS JURÍDICOS E COMENTÁRIOS}

A Lei no 5.764, de 1971 definiu a Política Nacional de Cooperativismo e instituiu o regime jurídico das cooperativas.

Acerca da publicação da lei, Rech tece o seguinte comentário:

\begin{abstract}
"verifica-se uma tendência intervencionista e conservadora nos sucessivos diplomas legais editados, culminando com a Lei 5.764/71 que, impôs uma estrutura muito rígida na organização das cooperativas. Ou seja, ao invés de auxiliar em seu desenvolvimento, acabou por tornar difícil a sua constituição e funcionamento (RECH, 2000, p.20)".
\end{abstract}

Todavia, mais tarde, com a promulgação da Constituição Federal de 1988, alguns artigos desta lei foram, então, revogados, como a exigência de autorização para o funcionamento das cooperativas e a obrigatoriedade de filiação à OCB.

A nova Constituição Federal (CF) em seu artigo 174, parágrafo 2.ำ, prescreve que: “a lei apoiará e estimulará o cooperativismo e outras formas de associativismo" e em seu artigo 146 estabelece que "caberá á lei complementar disciplinar acerca do tratamento tributário atribuído ao ato cooperativo".

O Novo Código Civil - lei no 10.406, de 10 de janeiro de 2002, em seu artigo 982, enquadra as cooperativas como "entidades civis" no Regime das Sociedades Simples, podendo assim, ser constituídas com ou sem fins lucrativos, sendo tributáveis apenas as operações tidas como atos não cooperativos, ou seja, aqueles qualificados como atos de mercancia (SARAIVA, 2010).

Por outro lado, o entendimento majoritário da doutrina e da jurisprudência pátria é de que o art. 146, III, "c", não estabeleceu nenhuma imunidade para as sociedades cooperativas e que: "cabe à lei complementar disciplinar a matéria tributária que dispense adequado tratamento tributário ao ato cooperativo praticado pelas sociedades cooperativas" (CF, art. 146, inc. III, "c").

Vale citar aqui a decisão, proferida à unanimidade pela 2a Turma do Superior Tribunal de Justiça (Superior Tribunal de Justiça. Rep.211.236/RS):

A decisão agravada, fundada em jurisprudência dominante deste Tribunal, negou seguimento ao recurso consignando o entendimento de que a prática de atos cooperativos, [...], na dicção do art. 79, caput, da Lei 5.764/71, não está sujeita à tributação. 


\section{Administração: caminhos para o desenvolvimento sustentável}

O entendimento está em perfeita consonância com o tratamento constitucional dispensado às cooperativas e com a legislação aplicável à espécie, não merecendo o menor ajuste.

A Constituição Federal de 1988 dispensou tratamento especial às cooperativas, de modo a incentivar sua criação e desenvolvimento, em virtude de sua singular natureza.

Quanto à matéria tributária, a Constituição Federal de 1988 fez expressa previsão de que o tratamento tributário das atividades das cooperativas (ato cooperativo) se dê por lei complementar que dispense "adequado tratamento tributário ao ato cooperativo praticado pelas sociedades cooperativas (CF, art. 146 , inc. III, "c")".

Tem-se, dessa forma, que a Constituição Federal erigiu como princípio tributário, o tratamento adequado às cooperativas, que, na autorizada lição de Roque Antônio Carraza significa "reconhecer as peculiaridades do ato cooperativo e, ao fazê-lo, eximi-lo, o quanto possível, de tributação".

Na esteira destes entendimentos e motivado pela desatualização da Lei no 5.764/1971, o Governo Federal enviou ao Congresso Nacional os Projetos de Lei (PL) no 386/2008 e 3.723/2008 que tratam da questão tributária, um que irá definir o Ato Cooperativo e a isenção de tributos nas operações efetuadas pelas cooperativas (PL Complementar no 386/2008), e outro que regulará a base de incidência de cada um dos tributos federais sobre o Ato Cooperativo (PL no 3.723/2008). Dentre os pontos encaminhados conforme Agenda Legislativa da Agricultura Familiar Ate 2011, p. 17 destacamse:

- Regulação da sociedade cooperativa como ente que atua no âmbito econômico e social;

- Liberdade de representação;

- Fortalecimento da assembleia como espaço de tomada de decisão;

- Redução do número mínimo de sócios;

Possibilidade de utilização do Fundo de Assistência Técnica e Social como incentivo para que as cooperativas criem mecanismos de capitalização entre elas no que se refere ao PL no 3.723/2008, ressaltam-se:

- A redução de tributos não é motivo para constituição de cooperativas;

- A relação entre a cooperativa e o mercado deve ter o mesmo tratamento tributário que o associado, pessoa física ou jurídica, teria sem a intervenção da cooperativa; 


\section{Administração: caminhos para o desenvolvimento sustentável}

- As cooperativas podem praticar atos não cooperativos e estes serão tributados

como se fossem pessoa jurídica tradicional;

- Manter a carga tributária média do segmento.

Ao PL no 3.723, de 2008, do Poder Executivo, segue em apenso o PL no 5.770/2009, cuja proposta é a não incidência do Imposto de Renda sobre o lucro realizado quando os Atos Cooperativos praticados não tiverem natureza mercantil, portanto não geram receita para a cooperativa.

Assim sendo, estes Projetos sinalizam com o instituto jurídico da isenção tributária evitando que atos da sociedade cooperativa se submetam à incidência de tributos quando permitirem identificar o cooperado como o beneficiário do resultado jurídico, econômico ou financeiro, isenção esta, que se fundamenta nos princípios e ideais cooperativistas (solidariedade, cooperação, administração democrática, gestão participativa de seus associados...).

\section{CONSIDERAÇÕES FINAIS}

O sistema cooperativo, em toda sua existência no Brasil, suportou crises importantes, mesmo assim construiu seu crescimento com as incorreções do passado. Podemos concluir que, apesar de tanto experimentar, esse empreendimento, alicerçado pelos velhos Pioneiros de Rochdale é viável em confronto ao sistema capitalista.

Contudo, é relevante salientar este empreendimento a favor da democracia. Cooperativas contribuem na redução das desigualdades sociais, criam empregos, movimentam a economia, amenizam a responsabilidade política do estado e ainda conseguem competir com grandes corporações.

Todo governo sério tem propostas coincidentes com as do cooperativismo: direitos e oportunidades iguais para todos. Assim, as relações do movimento cooperativista com os governos devem ser de parceria, de fraternidade: companheiros de caminhada, de mãos dadas em busca da melhoria do social através do econômico. (RODRIGUES, 1998, p. 11).

Assim sendo é de extrema urgência a adoção de medidas de incentivo e proteção ao setor cooperativo no país, eis que vários são os problemas enfrentados, tais como dificuldades de acesso ao crédito e ausência de leis que estimulem e favoreçam o sistema cooperativo.

\section{REFERÊNCIAS}




\section{Administração: caminhos para o desenvolvimento sustentável}

em <http://www.marcomaia.com.br/dirarq/arq_publicacoes/1256671379_cartilhaalterada>. Acesso em: 20 mai 2012.

ALBARELLO, C. B. Estratégias capazes de contribuir no processo de promoção do desenvolvimento sustentável na esfera local e regional. Revista de Administração, Frederico Westphalen, v.5, n.8, p. 39-63, dez. 2006.

ARAUJO, G. F de. Estratégias de Sustentabilidade: Aspectos científicos, Sociais e Legais: contexto global: Visão comparativa. São Paulo: Letras Jurídicas, 2008.

BATALHA, M. O. Gestão Agroindustrial. 2. ed. São Paulo: Editora Atlas S.A, 2001.

BRASIL. Constituição (1988). Constituição da República Federativa do Brasil: promulgada em 5 de outubro de 1988. 4. ed. São Paulo: Saraiva, 1990. 168p. ( Série Legislação Brasileira).

BRASIL. Instituto Brasileiro de Geografia e Estatística. Vocabulário Básico de Recursos Naturais e Meio Ambiente. 2. ed. Rio de Janeiro, 2004. ISBN: 85-240-3766-0 (meio impresso).

BRASIL. Secretaria do Emprego e Relações de Trabalho. Cooperativismo de Trabalho, Cooperativismo e a Cooperativa de Trabalho: Origens, Princípios, Conceitos, Estrutura e Funcionamento, ago. 1998.

BRASIL. Superior Tribunal de Justiça. Recurso Especial 211.236/RS. Relator Min. Paulo Medina DJU de 10.03.2003. Disponível em <http://wwwstj.jus.br/SCON/jurisprudencia. Acesso em: 13 mai. 2012.

BRUNDTLAND, Gro Harlem. Nosso futuro comum: Comissão Mundial sobre Meio Ambiente e Desenvolvimento. 2. ed. Rio de Janeiro: FGV,1991.

BRUNDTLAND, Gro. (Ed.) Our common future. Oxford: Oxford Press, 1987.

CAVALCANTI, M. (Org.).Gestão social, estratégias e parcerias: redescobrindo a essência da administração brasileira de comunidades para o Terceiro setor. 2. ed. São Paulo: Saraiva, 2008.

DRUCKER, P. Sociedade pós-capitalisa. São Paulo: Pioneira, 2001.

EUROPEAN ASSOCIATION OF CO-OPERATIVE BANKS. La responsabilité sociale des enterprises. Les activités des banques cooperatives, Groupement européen des banques cooperatives (document disponible: www.eurocoopbanks.coop), 2005. Acesso em 11 abr. 2012.

LIMBERGER, E. Cooperativa: empresa socializante. Porto Alegre: Imprensa Livre, 1996. 267p.

MAUER JÚNIOR, T. H. O cooperativismo: uma economia humana. São Paulo: Imprensa Metodista, 1966.

MENEGÁRIO, A. H. Emprego de indicadores sócio-econômicos na avaliação financeira de cooperativas agropecuárias. Dissertação (Mestrado em Economia Agrícola) - Escola Superior de Agricultura Luiz de Queiroz. Universidade de São Paulo. Piracicaba: ESALO/USP, 2000.

ORGANIZAÇÃO DAS COOPERATIVAS BRASILEIRAS (OCB). Principais números/ações. Disponível em HTTP: $<w w w . a n o 2012 . c o o p . b r>$. Acesso em: 05 mai. 2012.

PEREIRA, A. C.; SILVA, G. Z. da; CARBONARI, M. E. E. Sustentabilidade, responsabilidade social e meio ambiente. São Paulo: Saraiva, 2011. 216p.

PINHO, D. B. A Doutrina Cooperativa nos Regimes Capitalista e Socialista. 2. ed. São Paulo: Livraria Pioneira Editora, 1965. 


\section{Administração: caminhos para o desenvolvimento sustentável}

D. B. Dicionário de cooperativismo. São Paulo: Dotto Garcia, 1961.

RECH, D. Cooperativa: uma alternativa de organização popular. Rio de Janeiro: DP\&A, 2000.

RIOS, L. O. Cooperativas brasileiras: manual de sobrevivência sustentável. São Paulo: STS, 1998.

RODRIGUES, R. Cooperativismo: A segunda onda. Preços Agrícolas, ESALQ, Piracicaba ESP, p. 12 e 13, abril de 1999.

SARAIVA. Vade Mecum. Novo Código Civil. 9 ed .atual. e ampl. São Paulo, 2010.

SCHARF, R. Manual de Negócios Sustentáveis. São Paulo, Amigos da Terra, 2004.

SCHNEIDER, J. O. Democracia, participação e autonomia cooperativa. Porto Alegre: UNISSINOS, 1999. $496 p$.

SCHNEIDER, J. A Doutrina do Cooperativismo nos Tempos Modernos. In Cedope-série Cooperativismo e Desenvolvimento Rural e Urbano, ano 6, n.12, p. 7-23, 1994. 


\section{Capítulo 43}

\section{INOVAÇÃO E PEQUENAS EMPRESAS: ANÁLISE NO ARRANJO PRODUTIVO LOCAL DO BREJO PARAIBANO}

DOI: $10.37423 / 200300473$

Leisianny Mayara Costa Silva, Universidade Federal Rural de Pernambuco, Brasil). leisianny@hotmail.com

Alexandra Kelly de Moraes, Universidade Federal Rural de Pernambuco, Brasil). akmoraes.an@gmail.com

Ana Regina Bezerca Ribeiro, Universidade Federal Rural de Pernambuco, Brasil). arbr2008@hotmail.com

Luana (Vanessa Silveira Rodrigues, Universidade Federal Rujal de Pernambuco). Brasil, luh_vsr@hotmail.com

RESUMO: No que se refere às pequenas empresás frente lao dínamismo econômié, o fenômeno da inovação tem surgido como forma de manutenção, crescimento e destaque no mercado. Considerando os meios contributivos para o desenvolvimento de inovações, os Arranjos Produtivos Locais (ARLs) têm surgido com forte papel Impulsionador da inovação, principalmente nas pequenas empresas. Desse modo, esta pesquisa tem por objetivo analisar a atuação da inovação nas pequenas empresas inserjdas no Arranjo Produtivo Local de turismo do Brejo Paraibano, a partir das inovações/desenvolvidas com base no grau de inovação das dimensões inovadoras. Este trabalh 0 foi consolidado frente a uma proposta metpdológica de abordagem mista com método/de estudo de caso baseado em um APL, considerando como unidades de anàlise sete pequenas empresas inseridas no programa ALI no estado da Paraíba, edição 2014/2016. Ö instrumento para coleta de-dados foi o Radar de Inovação bem como a observação sistemática intensiva e extensiva, que deram suporte a análise dos dados. 


\section{Administração: caminhos para o desenvolvimento sustentável}

Os resultados desta pesquisa revelaram que as dimensões mais inovadoras foram Processos, Rede, Relacionamento e Clientes, com inovações desenvolvidas de forma incremental. Também foram destacados aspectos que contribuíram para o desenvolvimento de inovações nas pequenas empresas do APL, relacionados ao conceito amplo de inovação e aprendizagem no processo inovativo. As contribuições desta pesquisa assinalam para a relevância dos estudos voltados para inovação nas empresas de menor porte dentro da perspectiva de formação de arranjos.

Palavras-chave: Inovação; Pequenas empresas; APLs; Radar de Inovação. 


\section{Administração: caminhos para o desenvolvimento sustentável}

\section{INTRODUÇÃO}

As pequenas empresas têm se mostrado bastante atuantes no cenário econômico brasileiro. Correspondendo a $99 \%$ das empresas do país, mais da metade dos empregos formais e $27 \%$ do Produto Interno Bruto (PIB), estas empresas desempenham um elemento importante para o desenvolvimento do país nos mais diversos setores e localidades (FGV, 2016).

A inovação se configura como importante ferramenta de crescimento e competitividade das empresas (Scuotto, Del Giudice, \& Carayannis, 2017; Nagano, Stefanovitz, \& Vick, 2014; Tigre, 2006; OCDE, 2005; Gopalakrishnan \& Damanpour, 1997); e, quando se refere à empresa de menor porte, o processo inovativo tem representatividade significativa para o seu desenvolvimento (Ošenieksa \& Babauska, 2014; Bhaskaran, 2006; Audretsch, 2003; Hoffman, Parejo, \& Bessant, 1998; Roper, 1997).

Em vista disto, é importante citar que o processo de inovação não ocorre de forma isolada, mas dentro de uma perspectiva de coletividade (Van de Ven, 1986) que envolve fortes interações de aspectos econômicos, técnicos e também sociais dentro da empresa, ou entre ela e o ambiente externo (Rothwell, 1977).

Dessa forma, diante do destaque da dimensão regional e local ocasionada pelo avanço da globalização, os Arranjos Produtivos Locais (APLs) têm surgido com forte papel de impulsionar à inovação e à competitividade nas empresas (Tigre, 2006). Além do mais, o aproveitamento da composição de forças coletivas geradas pela participação em APLs contribui para a sobrevivência e crescimento no mercado, principalmente das pequenas empresas, gerando vantagens competitivas duradouras (Lastres, Cassiolato, \& Maciel, 2003).

Diante dessa conjuntura, é importante compreender que o desenvolvimento da inovação em empresas de menor porte dentro de uma lógica coletiva são desafios a serem vencidos, tendo em vista que a inovação também se caracteriza como variável relevante para compreensão da dinâmica de evolução dos APLs e das potencialidades para caminhos futuros (Matos, Borin, \& Cassiolato, 2015).

Com base nessas informações, este estudo foi estimulado por meio do seguinte questionamento: Como a inovação é desenvolvida nas pequenas empresas participantes de um APL, no que diz respeito ao seu grau de inovação? 


\section{Administração: caminhos para o desenvolvimento sustentável}

Dessa forma, esta pesquisa tem por objetivo analisar a atuação da inovação nas pequenas empresas inseridas do Arranjo Produtivo Local de turismo do Brejo Paraibano. Tal propósito consolida-se por meio do diagnostico do grau de inovação das empresas que compõem o APL, dentro de uma perspectiva detalhada das inovações desenvolvidas ao longo de um determinado período.

O artigo está organizado da seguinte forma: Na Seção 2, é apresentado brevemente o conceito de inovação e suas principais características; Inovação nas pequenas empresas; e a definição dos Arranjos Produtivos Locais e o processo de inovação. A Seção 3 expõe os procedimentos metodológicos no que concerne à caracterização da pesquisa, sujeito de pesquisa e as estratégias para coleta e análise dos dados. A Seção 4, por sua vez, elucida o desdobramento das inovações nas empresas do APL referente a cada ciclo, conforme os resultados do radar de inovação e suas respectivas dimensões. Por fim, a seção 5 aponta as conclusões e limitações do estudo, além das propostas para pesquisas futuras.

\section{REFERENCIAL TEÓRICO}

\subsection{CONCEITO DE INOVAÇÃO E SUAS PRINCIPAIS CARACTERÍSTICAS}

O marco teórico sobre inovação na esfera empresarial foi desencadeado pelos estudos de Joseph Alois Schumpeter (Schumpeter, 1934) a respeito da inovação frente ao viés econômico. Em seu livro "Teoria do desenvolvimento econômico", buscando adaptar toda empresa capitalista para a sobrevivência no mercado, foi abordada a ideia de que a estrutura econômica deveria ser revolucionada pelo processo de "destruição criadora".

Segundo o autor supracitado é através da inovação sob um processo dinâmico de substituição de antigas tecnologias por novas, que é regido o desenvolvimento econômico. A inovação pode relacionar-se a um novo produto (ou melhoramento de um já existente), novo método de produção, novo mercado, nova fonte de fornecimento de insumos ou nova forma de organização (Schumpeter, 1934). Corroborando com essa ideia e de forma mais delimitada no que diz respeito à inovação empresarial, a Organização para Cooperação e Desenvolvimento Econômico define a inovação como a inserção de novos elementos no negócio, nas suas relações tanto interna quanto externa. Esses elementos podem ser: um produto (bem ou serviço) novo ou significativamente melhorado; processo; novo método de marketing; ou um novo método organizacional (OCDE, 2005). 


\section{Administração: caminhos para o desenvolvimento sustentável}

Assim, conforme essas abordagens percebe-se que falar da inovação na esfera empresarial abrange os componentes principais do negócio e não se limita apenas ao produto ou a inovação tecnológica (Sawhney, Wolcott, \& Arroniz, 2006).

Nesse entendimento, Carvalho (2011) aponta a existência de três elementos internos das empresas que contribuem no processo de inovação: ambiente propício à inovação; pessoas criativas preparadas e estimuladas para inovar; e processo (ou método) sistemático e contínuo. Conforme o autor, tais elementos viabilizam o aproveitamento das oportunidades para inovar e dentre eles as pessoas (empresários, colaboradores, etc.) são o elemento fundamental (Carvalho, 2011).

Quanto à prática da inovação, esta pode ser caracterizada através de quatro tipos: inovação de produto (inserção de um bem ou serviço novo ou significativamente melhorado); processo (implementação de um método de produção ou distribuição novo ou significativamente melhorado); marketing (introdução de um novo método de marketing com mudanças significativas); ou organizacional (implementação de um novo método organizacional nas atividades da empresa) (OCDE, 2005). De forma complementar, Tidd, Bessant e Pavitt (2008) apontam o s "4Ps" de inovação que categorizam mudanças com base em quatro tipos de inovação: produto, processos, posição e paradigma.

Os tipos de inovação também podem ser classificados considerando seu impacto, podendo ser: Inovação radical, que se refere ao desenvolvimento de algo novo por completo ou Inovação incremental que pode ser qualquer tipo de melhorias em algo já existente (Kim, Kumar, \& Kumar, 2012; Tidd, Bessant, \& Pavitt, 2008; Tigre, 2006; Lastres \& Cassiolato, 2005; Schumpeter, 1934). No entanto, muitos estudos sobre inovação têm ignorado a figura das inovações incrementais ou menores e focado apenas nas radicais (Rothwell, 1977).

Quanto à estratégia, as inovações podem ser classificadas como inovação fechada ou inovação aberta. O modelo fechado corresponde à forma isolada e sigilosa que as organizações desenvolvem suas inovações baseada em recursos e fonte de conhecimento prórias. Já na inovação aberta refere-se à ideia do uso de fontes externas na geração de inovação pelas empresas, de modo que as ideias surgidas possam advir de canais externos, fora dos negócios formais da organização (Chesbrough, 2003). 


\section{Administração: caminhos para o desenvolvimento sustentável}

Sendo assim, considerando essas terminologias a respeito da inovação nas empresas e seus feitos, devem-se levar em conta as características de cada empresa, tendo em vista que a natureza das atividades de inovação varia muito dependendo do tipo de empresa (OCDE, 2005).

\subsection{Inovação nas pequenas empresas}

A inovação nas pequenas empresas pode ser vista como importante elemento de contribuição para competitividade e de fortalecimento (Ošenieksa \& Babauska, 2014; Nagano, Stefanovitz, \& Vick, 2014; Bhaskaran, 2006; Roper, 1997). No entanto, para compreender como se configura o processo de inovação dessas empresas é necessário se atentar as características próprias das empresas de menor porte.

De acordo com Romero e Martínez-Román (2012) há três níveis de fatores que afetam a inovação nas pequenas empresas: (1) as características pessoais ligadas as vertentes motivacional, educacional e profissional; (2) As características da organização, relacionadas ao setor, número de colaboradores, fornecedores ou clientes e a forma da gestão; e (3) As características do ambiente externo.

Nesse contexto, De Jong e Marsili (2005) procurando classificar as pequenas empresas inovadoras, examinaram o comportamento inovador e classificaram empiricamente os tipos de pequenas empresas inovadoras tanto na indústria quanto em serviços, dividindo-se em quatro grupos, como mostra o Quadro 1 a seguir: 


\section{Administração: caminhos para o desenvolvimento sustentável}

\begin{tabular}{|c|c|c|}
\hline $\begin{array}{l}\text { TIPOS DE } \\
\text { EMPRESAS }\end{array}$ & $\begin{array}{l}\text { FOCO DAS } \\
\text { INOVAÇÕES }\end{array}$ & CARACTERÍSTICAS \\
\hline $\begin{array}{l}\text { Empresas } \\
\text { dominadas pelos } \\
\text { fornecedores }\end{array}$ & $\begin{array}{lr}\text { Inovação de processos } \\
\text { ligado as novas } \\
\text { aplicações } \\
\text { fornecedores }\end{array}$ & $\begin{array}{l}\text { As empresas são relativamente "abertas", pois, em média, } \\
\text { consultam mais de três partes externas. }\end{array}$ \\
\hline $\begin{array}{l}\text { Fornecedores } \\
\text { especializados }\end{array}$ & $\begin{array}{l}\text { Uso mais difuso da } \\
\text { mão-de-obra } \\
\text { especializada. }\end{array}$ & $\begin{array}{l}\text { As empresas são orientadas para o cliente, uma vez que } \\
\text { dependem fortemente da compreensão das necessidades dos } \\
\text { clientes como fonte de inovação. }\end{array}$ \\
\hline $\begin{array}{l}\text { Empresas baseadas } \\
\text { em ciência. }\end{array}$ & $\begin{array}{l}\text { A inovação alta, tanto } \\
\text { em produtos como em } \\
\text { processos, com atuação } \\
\text { de especialistas em } \\
\text { inovação. }\end{array}$ & $\begin{array}{l}\text { As empresas são distinguidas por usar o conhecimento de } \\
\text { universidades e institutos de pesquisa como fonte de } \\
\text { inovação, mas também se baseiam fortemente nas } \\
\text { necessidades dos clientes (o último é uma caracteristica } \\
\text { comum com fornecedores especializados). Os gerentes têm } \\
\text { uma forte atitude positiva em relação à inovação, que é mais } \\
\text { frequentemente acompanhada por um plano escrito. As } \\
\text { empresas baseadas na ciência também são as mais "abertas"; }\end{array}$ \\
\hline $\begin{array}{l}\text { Empresas com uso } \\
\text { intensivo de } \\
\text { recursos. }\end{array}$ & $\begin{array}{l}\text { Inovação de processos, } \\
\text { assemelhando-se com } \\
\text { algumas características } \\
\text { das empresas do } \\
\text { fornecedor, mas com } \\
\text { grau de inovação } \\
\text { relativamente maior. }\end{array}$ & $\begin{array}{l}\text { A característica mais distintiva consiste nas altas ações das } \\
\text { empresas que reservam orçamentos e tempo para atividades } \\
\text { inovadoras, Essas empresas parecem, portanto, alocar } \\
\text { recursos financeiros e de tempo para a inovação, embora } \\
\text { com uso limitado de pessoal dedicado e redes externas. }\end{array}$ \\
\hline
\end{tabular}

Quadro 1: Taxonomia das Pequenas Empresas Inovadoras.

Fonte: Elaborado a partir de De Jong e Marsili (2005, p. 10).

Com base nessas definições e no tocante a forma como as pequenas empresas inovam, nota-se que o gerenciamento, planejamento e orientação externa que as empresas usam para alcançar a inovação, faz com que elas se diferenciem não apenas por suas atividades inovadoras, mas por suas práticas e estratégias de negócio (De Jong \& Marsili, 2005).

Dentro dessa perspectiva, Bhaskaran (2006) salienta que mesmo sob a existência de um ambiente altamente competitivo, dependendo das estratégias inovadoras adotadas, as pequenas empresas podem obter lucros significativos.

Por outro lado, o processo de inovação não se limita ao contexto interno, uma vez que o ambiente externo pode desenvolver um papel importante de interferência na inovação em pequenas empresas (Romero \& Martínez-Román, 2012). Em vista disso, Carvalho (2011) registra alguns elementos externos que contribuem para a capacidade de inovação nas pequenas empresas como o envolvimento entre associações e federações de empresas. 


\section{Administração: caminhos para o desenvolvimento sustentável}

Corroborando com esse entendimento, Tidd, Bessant e Pavitt (2008) ressaltam o trabalho em rede como contribuinte significativo para a inovação nas pequenas empresas. Pois, tendo em vista que a inovação envolve assumir riscos, a formação de conglomerados de empresas pode contribuir como dissipador do risco nessas empresas onde existe escassez dos recursos.

\subsection{ARRANJOS PRODUTIVOS LOCAIS E O PROCESSO DE INOVAÇÃO}

O aproveitamento da composição de forças coletivas geradas pela participação em APLs contribui para a sobrevivência e crescimento no mercado, principalmente das empresas de menor porte, gerando vantagens competitivas duradouras (Olivares \& Dalcol, 2010; Lastres, Cassiolato, \& Maciel, 2003; Cassiolato \& Lastre, 2003).

Com vínculos teóricos também baseados na "destruição criativa" de Schumpeter (1934), o conceito de Arranjo Produtivo Local (APL) surgiu no Brasil no final dos anos 90 por meio dos estudos da Redesist (Rede de Pesquisa em Sistemas e Arranjos Produtivos e Inovativos Locais). Essa modalidade de desenvolvimento, que ocorre em diferentes setores da economia, pode ser definida por Lastres, Cassiolato e Maciel (2003) como:

\footnotetext{
Aglomerações territoriais de agentes econômicos, políticos e sociais - com foco em um conjunto específico de atividades econômicas - que apresentam vínculos mesmo que incipientes. Geralmente envolvem a participação e a interação de empresas - que podem ser desde produtoras de bens e serviços finais até fornecedoras de insumos e equipamentos, prestadoras de consultoria e serviços, comercializadoras, clientes, entre outros - e suas variadas formas de representação e associação. Incluem também diversas outras organizações públicas e privadas voltadas para: formação e capacitação de recursos humanos, como escolas técnicas e universidades; pesquisa, desenvolvimento e engenharia; política, promoção e financiamento. (Lastres, Cassiolato, \& Maciel, 2003, p. 27).
}

Ratificando essa compreensão e de forma sucinta, conforme Simonetti et al. (2013) os APLs são aglomerações de empresas (complementares, fornecedoras de insumos ou equipamentos, prestadoras de consultorias e serviços, dentre outras) que atuam em torno de uma mesma atividade produtiva e em um mesmo espaço geográfico. A formação dessas aglomerações está intimamente relacionada às trajetórias históricas através de vínculos regionais ou locais fundamentados em um contexto social, cultural, político e econômico comum (Stallivieri, Campos, \& Britto, 2009).

Para Olivares e Dalcol (2010) a articulação de empresas entre si e com demais instituições por meio de agrupamentos locais, pode interferir positivamente no desenvolvimento econômico e na qualidade 


\section{Administração: caminhos para o desenvolvimento sustentável}

de vida dos indivíduos da região, sobretudo nos ganhos de produtividade individual e coletiva, com fortes incrementos na competitividade sistêmica.

Por outro lado, para compreender o funcionamento de um APL é preciso conhecer as particularidades de cada arranjo, no que tange ao: grau de desenvolvimento - os arranjos podem ser classificados como Incipientes (desarticulação, carência de lideranças e falta de integração e cooperação das empresas, do poder público e da iniciativa privada); em Desenvolvimento (lideranças legitimadas e capacitadas e se organizam em entidades de classe para defender os interesses da região); Desenvolvidos ou Sistemas Produtivos e Inovativos Locais (interação, cooperação e aprendizagem que possibilitem inovações de produtos, processos e formatos organizacionais e gerem maior competitividade empresarial e capacitação social) (SEBRAE, 2009); principais características- Dimensão territorial; Diversidade de atividades e atores econômicos, políticos e sociais; Conhecimento tácito; Inovação e aprendizado interativos; Grau de enraizamento; e Governança (Cassiolato \& Lastre, 2003).

Tendo em vista que a inovação constitui-se como uma variável central para compreensão da dinâmica de evolução dos APLs e discussão de perspectivas futuras (Matos, Borin, \& Cassiolato, 2015), os APLs por sua vez, também têm o papel de promover e possibilitar o desenvolvimento de inovações por meio do melhoramento no padrão da qualidade dos produtos (bens e/ou serviços).

Nesse sentido, levando em consideração os meios de mensurar o desempenho dos APLs, Stallivieri (2012) por meio da Redesist, apresenta a inovação como um dos indicadores de desempenho nos APLs. O Quadro 2 destaca as categorias de análise desse indicador:

\begin{tabular}{|c|l|}
\hline INDICADOR & \multicolumn{1}{c|}{ OBJETIVO } \\
\hline $\begin{array}{c}\text { Inovação Radical em } \\
\text { Produtos }\end{array}$ & $\begin{array}{l}\text { Busca identificar se as empresas do APL introduziram algum produto novo para o } \\
\text { mercado nacional e/ ou para o mercado internacional. }\end{array}$ \\
\hline $\begin{array}{c}\text { Inovação Radical em } \\
\text { Processos }\end{array}$ & $\begin{array}{l}\text { Busca identificar inovações de caráter mais complexo, refere-se à introdução de } \\
\text { processos novos para o setor de atuação do APL. }\end{array}$ \\
\hline $\begin{array}{c}\text { Inovação Incremental } \\
\text { em Produtos }\end{array}$ & $\begin{array}{l}\text { Busca identificar a capacidade de imitação de produtos no APL, identificando a } \\
\text { introdução de produto novo para a empresa, mas já existente no mercado. }\end{array}$ \\
\hline $\begin{array}{c}\text { Inovação Incremental } \\
\text { em Processos }\end{array}$ & $\begin{array}{l}\text { Verifica a capacidade de imitação de processos do APL, ou seja, se as empresas do } \\
\text { arranjo introduziram processos novos, mas já existentes em seus setores de } \\
\text { atuação. }\end{array}$ \\
\hline $\begin{array}{c}\text { Inovações } \\
\text { Organizacionais }\end{array}$ & $\begin{array}{l}\text { Identifica a capacidade das empresas do APL em introduzirem inovações } \\
\text { organizacionais. }\end{array}$ \\
\hline
\end{tabular}

Quadro 2: Indicadores de Desempenho Inovativo nos APLs.

Fonte: Elaborado a partir de Stallivieri (2012, p. 39). 


\section{Administração: caminhos para o desenvolvimento sustentável}

Assim, no tocante aos indicadores que correspondem à mensuração do desempenho inovativo em APLs, é importante também refletir as peculiaridades de do APL a ser investigado. Pois, o processo de inovação em APLs varia conforme seus diversos agentes, quanto ao tipo, setor, estágio de capacitação tecnológica, país ou localidade que está inserido (Costa, 2011).

\section{PROCEDIMENTOS METODOLÓGICOS}

A presente pesquisa caracteriza-se como um estudo de caso aplicado com enfoque exploratório e descritivo, que visa proporcionar dentro do estágio cognitivo de conhecimento, um ato ou efeito de conhecer o objeto em empírico (Creswell, 2010).

Quanto à abordagem, este estudo consolida-se a partir de abordagem mista sendo qualitativa, devido a sua finalidade de revelar a complexidade de determinado problema, por meio da compreensão e classificação dos processos dinâmicos pelo qual os grupos interagem, proporcionando a concepção das mais variadas particularidades dos indivíduos (Diehl \& Tatim, 2004), fundamentada em um contexto quantitativo, tendo em vista que esta se utiliza da quantificação perante a análise realizada por meio dos modelos estatísticos, buscando a objetividade e sistematização dos dados (Creswell, 2010).

Por se tratar de uma investigação de determinado fenômeno atual dentro da conjuntura de realidade, a escolha para o estudo de caso foi desencadeada pelo estudo empírico, na busca pela compreensão das fronteiras existentes entre o fenômeno e o contexto (Yin, 2005). O estudo se caracteriza também como pesquisa de campo, pois pressupõe a observação dos fatos exatamente onde, quando e como ocorrem (Creswell, 2010), uma vez que houve contato in loco junto ao objeto de estudo.

Tendo em vista adotar um método de estudo de caso, no que se refere ao sujeito da pesquisa, considerou-se o APL de turismo do Brejo Paraibano e como unidades de análise sete (07) pequenas empresas, participantes do Programa Agentes Locais de Inovação (ALI) da edição 2014/2016 no estado da Paraíba, polo Guarabira. A escolha dessas empresas se deve ao alcance dos seguintes critérios estabelecidos por este estudo: 1) Atuação no segmento de Turismo (hotéis, bares e restaurantes); 2) participação do Arranjo Produtivo Local do Brejo Paraibano; 3) empresas que avançaram de ciclos no programa. 


\section{Administração: caminhos para o desenvolvimento sustentável}

Quanto às estratégias para coleta e análise dos dados, aplicou-se o instrumento Radar de Inovação (RI) que corresponde ao questionário utilizado na metodologia do programa ALI, bem como o uso da observação direta intensiva e extensiva.

Desse modo, com ajuda dos resultados alcançados mediante as dimensões do instrumento RI, foram definidas pelos pesquisadores as categorias de análise que irão nortear a observação de forma sistematizada, que registra, interpreta e relaciona os fatos sem nenhuma manipulação da realidade (Lima, 1997).

Assim, as categorias de análises deste estudo foram as 13 dimensões do Radar de Inovação (RI), com base nas 12 dimensões dos autores Sawhney, Wolcott, \& Arroniz (2006), e a dimensão ambiência inovadora complementada pelos autores Bachmann \& Destefani (2008): Oferta, Plataforma, Marca, Clientes, Soluções, Relacionamento, Agregação de Valor, Processos, Organização, Cadeia de Fornecimento, Presença, Rede e Ambiência Inovadora. O Quadro 3 a seguir apresenta as 13 dimensões e suas definições.

\begin{tabular}{|c|l|}
\hline DIMENSÃO & \multicolumn{1}{|c|}{ DEFINIÇÃO } \\
\hline Oferta & As ofertas são produtos e serviços de uma empresa. \\
\hline Plataforma & $\begin{array}{l}\text { Uma plataforma é um conjunto de componentes comuns, métodos de } \\
\text { montagem ou tecnologias que servem como blocos de construção para um } \\
\text { portfólio de produtos ou serviços. }\end{array}$ \\
\hline Marca & $\begin{array}{l}\text { São símbolos, palavras ou marcas através das quais uma empresa comunica } \\
\text { uma promessa aos clientes. }\end{array}$ \\
\hline Cliente & $\begin{array}{l}\text { São os indivíduos ou organizações que usam ou consomem ofertas de uma } \\
\text { empresa para satisfazer certas necessidades. }\end{array}$ \\
\hline Soluções & $\begin{array}{l}\text { Uma solução é uma combinação personalizada e integrada de produtos, } \\
\text { serviços e informações que soluciona o problema de um cliente. }\end{array}$ \\
\hline Relacionamento & $\begin{array}{l}\text { Esta dimensão considera tudo o que um cliente vê, ouve, sente e de outra } \\
\text { forma experimenta ao interagir com uma empresa em todos os momentos. }\end{array}$ \\
\hline Agregação de Valor & Refere-se ao mecanismo que uma empresa usa para recuperar o valor que cria. \\
\hline Processos & $\begin{array}{l}\text { As configurações das atividades comerciais são utilizadas para realizar } \\
\text { operações internas. }\end{array}$ \\
\hline Organização & $\begin{array}{l}\text { E a forma como uma empresa se estrutura, suas parcerias e seus papéis e } \\
\text { responsabilidades dos funcionários. }\end{array}$ \\
\hline Cadeia de Fornecimento & $\begin{array}{l}\text { Uma cadeia de suprimentos é a sequência de atividades e agentes que movem } \\
\text { mercadorias, serviços e informações de origem para entrega de produtos e } \\
\text { serviços. }\end{array}$ \\
\hline Presença & $\begin{array}{l}\text { Os pontos de presença são os canais de distribuição que uma empresa emprega } \\
\text { para oferecer ofertas ao mercado e os locais onde suas ofertas podem ser } \\
\text { compradas ou usadas pelos clientes. }\end{array}$ \\
\hline
\end{tabular}




\section{Administração: caminhos para o desenvolvimento sustentável}

\begin{tabular}{|c|l|}
\hline Rede & $\begin{array}{l}\text { Uma empresa e seus produtos e serviços estão conectados aos clientes através } \\
\text { de uma rede que às vezes pode tornar-se parte da vantagem competitiva da } \\
\text { empresa. }\end{array}$ \\
\hline Ambiência Inovadora & $\begin{array}{l}\text { Uma forma de avaliar o ambiente propício à inovação é medir a fração da } \\
\text { equipe que é composta por profissionais que tem formação voltada } \\
\text { para a pesquisa. }\end{array}$ \\
\hline
\end{tabular}

Quadro 3. Definição das Dimensões do Radar de Inovação.

Fonte: Adaptado de Bachmann e Destefani (2008) e Sawhney, Wolcott e Arroniz (2006).

O questionário RI é composto por 32 questões, com perguntas relacionadas a cada uma das 13 dimensões do Quadro 3, mediante formulário eletrônico. A tabulação dos dados coletados concretizou-se por meio do Sistema Operacional do Ali - SISTEMALI, cuja finalidade foi de obter a geração do radar a partir dos escores de cada dimensão.

Conforme os resultados das dimensões, o radar gerado pode variar entre 1,0 e 5,0, classificados como: 1,0 (empresa pouco ou nada inovadora); 3,0 (inovadora ocasional); ou 5,0 (inovadora sistêmica) (Bachmann \& Destefani, 2008), como se observa na Figura 1 abaixo:

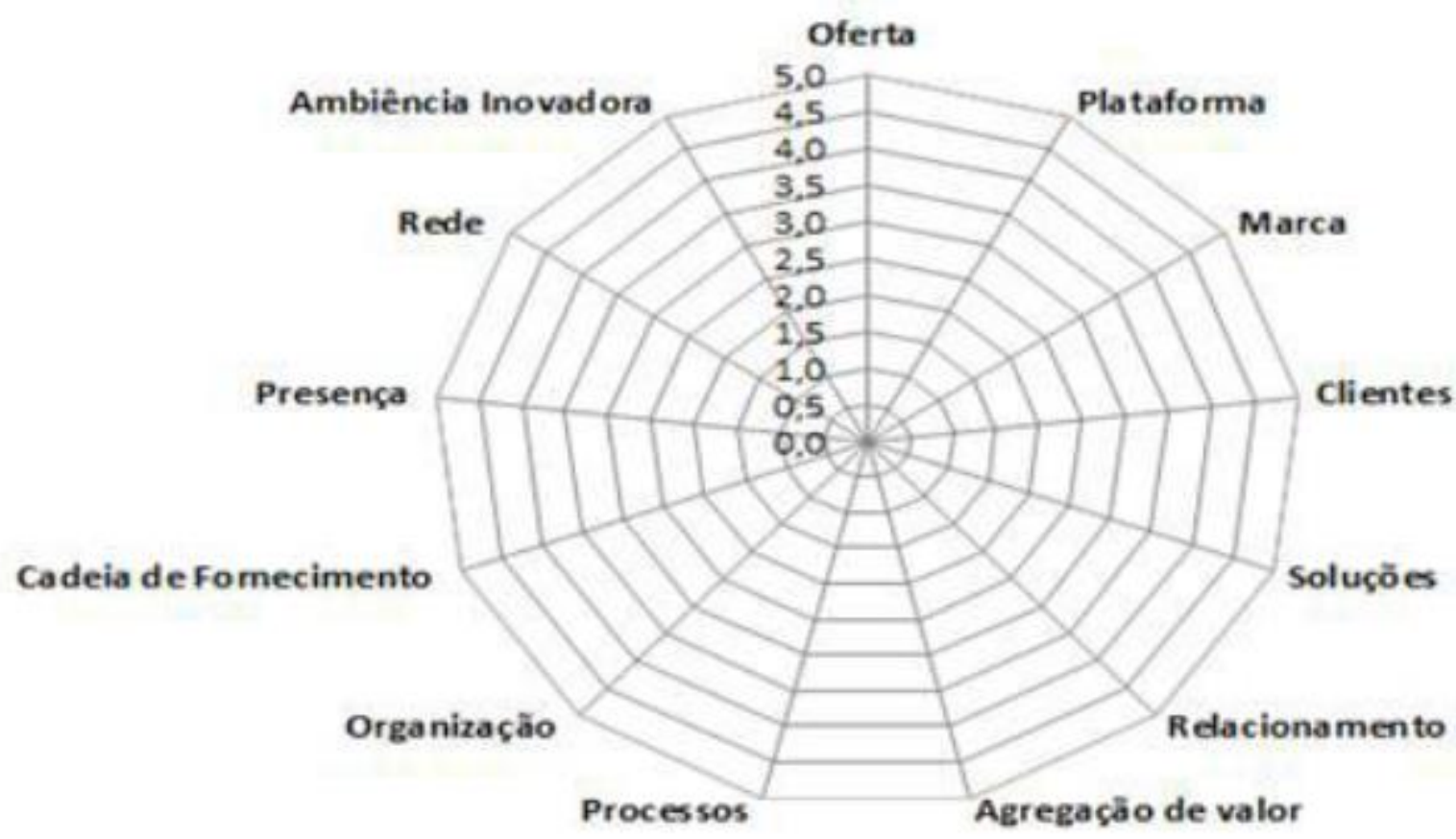

Figura 1- Radar de Inovação (RI).

Fonte: Adaptado de Bachmann e Destefani (2008); Sawhney, Wolcott e Arroniz (2006). 


\section{Administração: caminhos para o desenvolvimento sustentável}

Os dados foram coletados por meio da aplicação do RI durante a vigência do programa, no período de 2014 a 2016, correspondentes a três ciclos, o Ro (Ciclo 0) - avaliou o grau de inovação inicial de cada empresa, o R1 (Ciclo 1) - avaliou o nível de inovação após ações executadas, dentro da metodologia do programa ALI, e o R2 (Ciclo 2) - o último momento, avaliou o nível de inovação após as inovações sucessivas executadas. Os resultados deste estudo estão dispostos sob a conjuntura do APL referente ao somatório das empresas investigadas, ou seja, cada empresa foi analisada de forma individual e logo depois foi feita a compilação dos dados de todas as empresas investigadas.

\section{RESULTADOS E ANÁLISES}

Ao longo da vigência do programa as empresas do APL conseguiram avançar de ciclos e alcançar o Ciclo 2, onde cada ciclo foi caracterizado por momentos diferentes. O Ciclo 0 representa o contato inicial com as empresas, perante a realização do primeiro diagnóstico com base nas inovações realizadas nos três últimos anos, os demais ciclos por sua vez, foram desencadeados já após o primeiro contato com as empresas. Desse modo, a seguir será disposta a evolução do grau de inovação das empresas do APL mediante as dimensões do RI, considerando os três ciclos $(0,1$ e 2$)$ perpassados pelas empresas.

\subsection{ANÁLISE DAS EMPRESAS DO APL: CICLO 0}

O Ciclo 0 foi marcado pela aplicação do primeiro diagnóstico RI (R0) nas empresas, com base nas inovações realizadas por elas nos três últimos anos. A utilização da ferramenta promoveu benefícios iniciais importantes, por um lado provocou a primeira impressão das empresas no que diz respeito à inserção da inovação em suas práticas. Pois, para muitos gestores, o conceito de inovação ainda estava atrelado às tecnologias de ponta relacionadas exclusivamente a produtos ou processos e de fato, os questionamentos do RI permitiram aos gestores ampliar a visão do conceito de inovação. Por outro lado, o resultado do RO quanto à situação atual da inovação nas empresas trouxe um impacto motivador nos gestores em querer mudar aquela realidade.

Sendo assim, a Tabela 1 apresenta o resultado do Ciclo 0 (R0) tomando por base a média dos escores das dimensões e o escore geral das empresas investigadas do APL, como mostra a seguir. 


\begin{tabular}{|l|l|}
\hline \multicolumn{1}{|c|}{ DIMENSÕES } & R0 \\
\hline 1 Oferta & 2,15 \\
\hline 2 Plataforma & 4,85 \\
\hline 3 Marca & 3,85 \\
\hline 4 Clientes & 2,62 \\
\hline 5 Soluções & 3,57 \\
\hline 6 Relacionamento & 3,85 \\
\hline 7 Agregação de valor & 2,14 \\
\hline 8 Processos & 2,00 \\
\hline 9 Organização & 3,10 \\
\hline 10 Cadeia de fornecimento & 2,42 \\
\hline 11 Presença & 1,14 \\
\hline 12 Rede & 1,28 \\
\hline 13 Ambiência inovadora & 1,75 \\
\hline Geral & 2,67 \\
\hline
\end{tabular}

Tabela 1. Escores das Dimensões do Ciclo 0.

Fonte: Dados da Pesquisa (2016).

Como se observa na Tabela 1, a média do escore geral das empresas foi representada por 2,67, ou seja, a situação inicial das empresas do APL classificou-as como "pouco inovadoras".

No entanto, cabe destacar algumas dimensões que as empresas desenvolviam inovações com escores acima da média $(3,0)$ do $\mathrm{RI}$, como as dimensões Plataforma $(4,85)$, Marca $(3,85)$, Relacionamento $(3,85)$ e Soluções $(3,75)$. Diante desses resultados, nota-se que as empresas investigadas introduziam inovações voltadas para ampliação do portfólio de produtos (Plataforma) com combinações personalizadas e integradas (Soluções) e melhoramento a comunicação (Marca) e experiência do cliente (Relacionamento). Dentro da perspectiva de APLs, apenas as dimensões Soluções e Marca apresentaram inovações de forma conjunta com outras empresas, a exemplo da integralização de serviços e da divulgação da marca em canais de massa. 


\section{Administração: caminhos para o desenvolvimento sustentável}

\subsection{ANÁLISE DAS EMPRESAS DO APL: CICLO 1}

Após o primeiro diagnóstico e de acordo com a metodologia do programa ALI, cada empresa, perante um plano de ação e com base nos resultados das dimensões do R0, escolhia as inovações mais viáveis de serem implantadas.

Dessa forma, o Ciclo 1 teve destaque quanto a inserção de inovações de maneira mais direcionada e focada na estratégia de cada empresa, de modo que os resultados do R0 orientou os gestores em qual área as empresas necessitavam de inovações. Logo, conforme as inovações realizadas no Ciclo 1, a Tabela 2, mostra os resultados do R1 com os escores por dimensão das empresas e a evolução do Ciclo 0 ao Ciclo 1.

\begin{tabular}{|l|c|c|c|}
\hline \multicolumn{1}{|c|}{ DIMENSÕES } & R0 & R1 & $\begin{array}{c}\text { Var } \\
\text { R0 e R3 }\end{array}$ \\
\hline 1 Oferta & 2,15 & 2,34 & $+0,19$ \\
\hline 2 Plataforma & 4,85 & 4,85 & - \\
\hline 3 Marca & 3,85 & 4,00 & $+0,15$ \\
\hline 4 Clientes & 2,62 & 2,81 & $+0,19$ \\
\hline 5 Soluções & 3,57 & 3,71 & $+0,14$ \\
\hline 6 Relacionamento & 3,85 & 4,14 & $+0,29$ \\
\hline 7 Agregação de valor & 2,14 & 2,28 & $+0,14$ \\
\hline 8 Processos & 2,00 & 2,22 & $+0,22$ \\
\hline 9 Organização & 3,10 & 3,10 & - \\
\hline 10 Cadeia de fornecimento & 2,42 & 2,42 & - \\
\hline 11 Presença & 1,14 & 1,14 & - \\
\hline 12 Rede & 1,28 & 1,57 & $+0,29$ \\
\hline 13 Ambiência inovadora & 1,75 & 1,81 & $+0,06$ \\
\hline Geral & 2,67 & 2,80 & $+0,13$ \\
\hline
\end{tabular}

Tabela 2. Escores das Dimensões do Ciclo 0 ao Ciclo 1.

Fonte: Dados da Pesquisa (2016).

De acordo com a Tabela 2, nota-se que de modo geral as empresas obtiveram um pequeno avanço de 0,13 do Ciclo 0 ao Ciclo 1. Apesar de o avanço ter sido bem baixo, tal resultado representou bastante 


\section{Administração: caminhos para o desenvolvimento sustentável}

para as empresas quanto à inovação sistêmica, tendo em vista que foram desenvolvidas inovações em quase todas as dimensões.

Em vista dos resultados do Ciclo 1, cabe evidenciar as dimensões que obtiveram avanço significativo perante as demais e que não eram foco principal das empresas no Ciclo 0 , que compreendem: Rede $(0,29)$, Processos $(0,22)$, Clientes $(0,19)$ e Oferta $(0,19)$. O ponto central das inovações nestas dimensões foi voltado para o melhoramento nas configurações de atividades operacionais (Processos), novos meios de se conectar com os clientes por meio de canais virtuais (Rede), novas formas de identificar as necessidades dos clientes através da pesquisa de satisfação (Clientes) e a inserção de novos serviços ao mercado como a implantação de novos pratos (Oferta).

O desdobramento de inovações nestas dimensões foi importante por permitir que muitos gestores visualizassem a inovação em todas as áreas da empresa. Pois, ainda que haja incerteza associada à inovação como aponta Gopalakrishnan e Damanpour (1997), cabe ao gestor responsável se atentar em todas as áreas de competências que o processo de inovação (Rothwell, 1977).

\subsection{ANÁLISE DAS EMPRESAS DO APL: CICLO 2 E A EVOLUÇÃO AO LONGO DOS CICLOS}

O Ciclo 2 indicou de forma nítida o processo inovativo das empresas ao longo do período investigado. Observou-se no ciclo supracitado que as empresas representadas por seus gestores, passaram a alcançar um nível inicial de independência com relação às práticas inovadoras. Ou seja, enquanto no Ciclo 1 a participação do agente local de inovação foi crucial no incentivo e monitoramento de inovações, no Ciclo 2 muitas inovações foram implementadas pelos gestores de forma espontânea e autônoma.

Nesse contexto, tal característica pode estar ligada ao processo de aprendizagem ao longo do tempo/ciclos, uma vez que os gestores desenvolveram habilidades e aptidões no Ciclo 2 que não estavam presentes nos ciclos anteriores. Essa característica reforça a citação de Tigre (2006) quanto à participação da aprendizagem nas etapas do processo da gestão da inovação.

No que concerne aos escores das dimensões referentes ao Ciclo 2, a Tabela 3 por sua vez, apresenta além dos resultados do R2 e o escore geral, o avanço das empresas do APL do Ciclo 0 ao Ciclo 2. 


\section{Administração: caminhos para o desenvolvimento sustentável}

\begin{tabular}{|l|l|l|l|c|}
\hline \multicolumn{1}{|c|}{ DIMENSÕES } & R0 & R1 & R2 & $\begin{array}{c}\text { Var } \\
\text { R0 e R3 }\end{array}$ \\
\hline 1 Oferta & 2,15 & 2,34 & 2,34 & $+0,19$ \\
\hline 2 Plataforma & 4,85 & 4,85 & 4,85 & - \\
\hline 3 Marca & 3,85 & 4,00 & 4,14 & $+0,29$ \\
\hline 4 Clientes & 2,62 & 2,81 & 3,00 & $+0,38$ \\
\hline 5 Soluções & 3,57 & 3,71 & 3,71 & $+0,14$ \\
\hline 6 Relacionamento & 3,85 & 4,14 & 4,28 & $+0,43$ \\
\hline 7 Agregação de valor & 2,14 & 2,28 & 2,28 & $+0,14$ \\
\hline 8 Processos & 2,00 & 2,22 & 2,70 & $+0,70$ \\
\hline 9 Organização & 3,10 & 3,10 & 3,10 & - \\
\hline 10 Cadeia de fornecimento & 2,42 & 2,42 & 2,42 & - \\
\hline 11 Presença & 1,14 & 1,14 & 1,14 & - \\
\hline 12 Rede & 1,28 & 1,57 & 1,85 & $+0,57$ \\
\hline 13 Ambiência inovadora & 1,75 & 1,81 & 2,10 & $+0,35$ \\
\hline Geral & 2,67 & 2,80 & 2,92 & $+0,25$ \\
\hline
\end{tabular}

Tabela 3. Escores das Dimensões do Ciclo 0 ao Ciclo 2.

Fonte: Dados da Pesquisa (2016).

Como se observa na Tabela 3, o último ciclo analisado é marcado pelo avanço geral condizente a 0,25 das empresas do APL, chegando a um escore final de 2,92, sendo consideradas ainda como "pouco inovadoras", mas quase classificadas como "inovadoras ocasionais".

No que tange às dimensões, verificou-se que no R2 as inovações foram desenvolvidas nas mesmas dimensões trabalhadas no R1, uma vez que as empresas permaneceram com os mesmos escores nas dimensões Plataforma $(4,85)$, Organização $(3,10)$, Cadeira de Fornecimento $(2,42)$ e Presença $(1,14)$ desde o R0. Esses resultados apontam para as seguintes reflexões: Plataforma - por já se apresentar de modo consolidado, obtendo desde o R0 escore quase máximo, não demandava tanta atenção quanto às demais dimensões; Organização - manteve seu escore mediano sendo um valor preocupante diante da ligação desta dimensão com a gestão da empresa e as estratégias do negócio; Cadeia de fornecimento - segundo alguns gestores, por se tratar de um segmento com forte contato com o cliente: uma pequena mudança poderia colocar em risco o serviço, e por isso preferiram 


\section{Administração: caminhos para o desenvolvimento sustentável}

conservar as atividades que já executavam nesta dimensão; Presença - de acordo com os gestores, essas inovações demandavam maior capital de investimento.

Sob outra perspectiva, as dimensões que se destacaram ao longo dos ciclos e obtiveram maiores avanços na variação do R0 ao R2, foram Processos $(0,70)$, Rede $(0,57)$, Relacionamento $(0,43)$ e Clientes $(0,38)$. A dimensão Processos, a mais inovadora ao longo dos ciclos, destacou-se pela implantação de inovações de automação dos processos adquirido por meio do subsídio SEBRAETEC Programa SEBRAE de Consultorias Tecnológicas. As dimensões Rede, Relacionamento e Clientes por sua vez, se destacaram pelo forte interesse dos gestores em atrair, fidelizar e manter sua demanda, e de fato, as inovações desenvolvidas nestas dimensões resultaram na melhoria da relação, conexão e atendimento à clientela.

Diante destes resultados e procurando ilustrar a atuação das empresas do APL durante o período investigado no que compreende os Ciclos 0, 1 e 2 perpassados pelas empresas, a Figura 2 elucida por meio do radar o desempenho inovativo do APL.

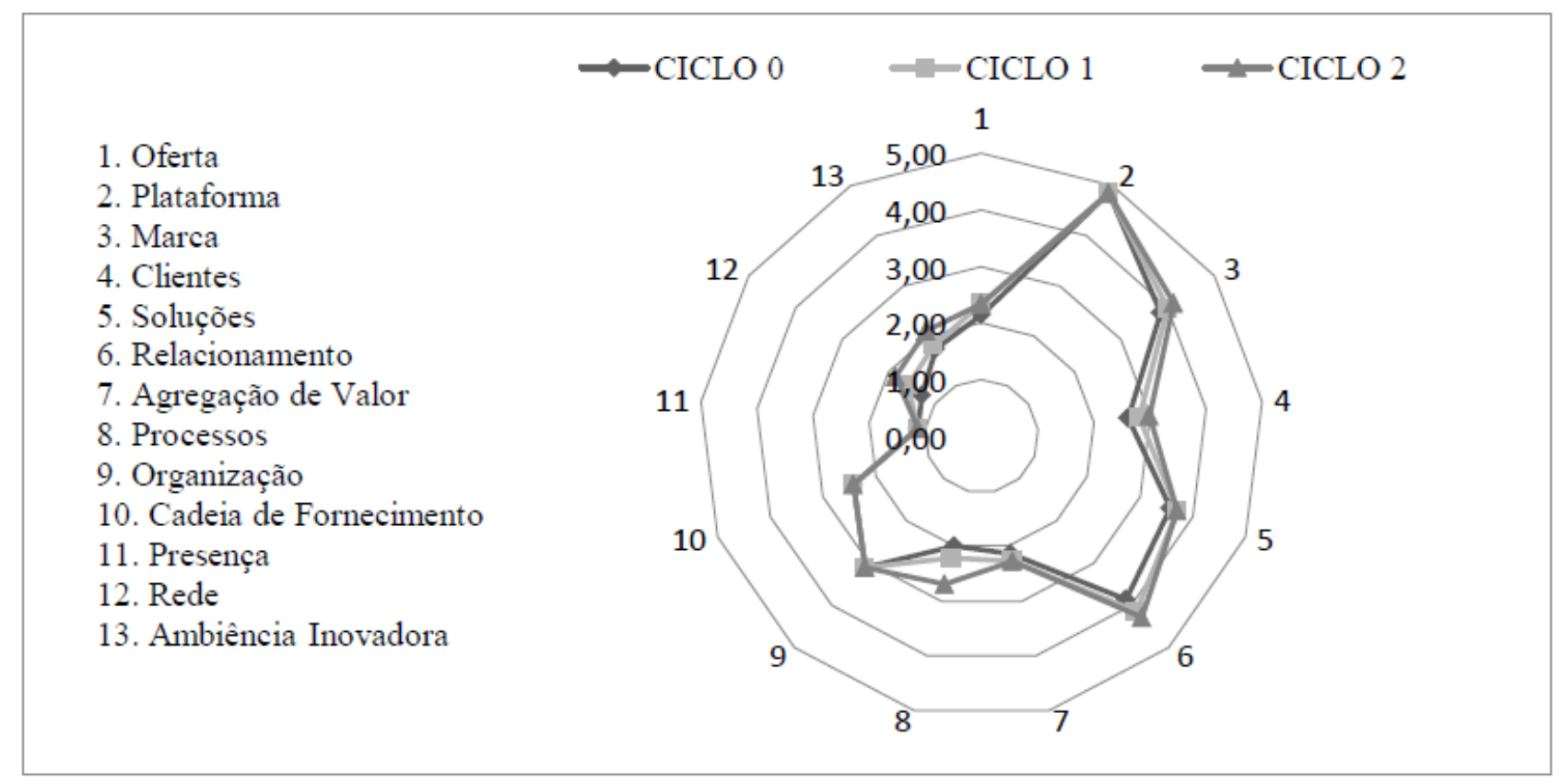

Figura 2. Radar de Inovação dos Ciclos 0, 1 e 2.

Fonte: Dados da Pesquisa (2016).

Como mostra a Figura 2, as empresas do APL obtiveram um avanço não tanto expressivo ao longo dos ciclos. No entanto, apesar desse calculo ter sido feito com base nas médias das dimensões de todas as 


\section{Administração: caminhos para o desenvolvimento sustentável}

empresas investigadas, nota-se que algumas delas avançaram consideravelmente, tendo como resultado uma não tão linearidade das inovações desenvolvidas no APL.

Partindo para concepção do conceito do APL quanto às práticas em rede, cabe ressaltar que muitas das inovações desenvolvidas pelas empresas tiveram participação de algum apoio externo principalmente no campo de conhecimento, informação e subsídio financeiro. A dimensão com maior destaque dessas ações conjuntas foi a Ambiência Inovadora, a qual se destacou: o compartilhamento de ideias em reuniões com demais gestores do setor, treinamentos conjuntos dos colaboradores das empresas, organização de evento voltado para o turismo envolvendo gestores e demais agentes como associações, serviços de apoio, etc.

Além disso, levando em consideração a conjuntura de inovação em APLs (Quadro 2) abordada neste estudo, notaram-se algumas características importantes ao longo do período analisado:

- Percebeu-se que nenhuma inovação radical de produto ou processos, foi desenvolvida nas empresas do APL, tendo em vista que todas as inovações foram incrementais, pautadas no melhoramento em produtos, processos já existentes. E quanto às inovações organizacionais percebe-se que ao longo dos dois anos nenhuma empresa apresentou inovações voltadas para esta dimensão.

Diante desses resultados e com base na realidade das empresas de menor porte quanto às inovações incrementais, observa-se que essas características podem ser explicadas pelo fato das inovações incrementais serem mais acessíveis e mais rápidas de operacionalizar do que as inovações radicais (Bhaskaran, 2006).

- Levando em consideração as dimensões Processos, Rede, Relacionamento e Clientes como as mais inovadoras, focalizando as três ultimas, há uma clara atuação das empresas do APL com foco em inovações de marketing, devido à preocupação significativa das empresas para com seus clientes.

Desse modo, há uma divergência existente quanto à teoria abordada por Stallivieri (2012) no que diz respeito à mensuração do desempenho inovativo em APLs, tendo em vista que apenas inovações dos tipos produto, processo e organizacionais são utilizadas como indicadores. Portanto, este entendimento remete a inserção das inovações do tipo marketing como importante indicador de desempenho inovativo em APLs.

\section{CONCLUSÃO}




\section{Administração: caminhos para o desenvolvimento sustentável}

A inovação tem se configurado como papel importante no processo de desenvolvimento econômico devido a sua contribuição para competitividade das empresas, sobretudo as que se constituem de menor porte. No entanto, essas empresas têm enfrentado grandes desafios quando se trata do quesito inovar, devido à escassez dos recursos necessários.

Não obstante, as pequenas empresas têm adotado estratégias significativas para inovar, como a vinculação em Arranjos Produtivos Locais, onde por meio do trabalho em rede passam a desenvolver inovações de forma mais expressivas.

Logo, esta pesquisa teve o objetivo analisar a atuação da inovação nas pequenas empresas inseridas do Arranjo Produtivo Local de turismo do Brejo Paraibano. Tal propósito consolidou-se por meio do diagnostico do grau de inovação das empresas que compõem o APL, dentro de uma perspectiva detalhada das inovações desenvolvidas ao longo de um determinado período.

Os resultados desta pesquisa destacaram quanto ao desenvolvimento de inovações que as empresas do APL avançaram, ainda que de maneira tímida, ao longo dos ciclos e que as dimensões mais inovadoras foram Processos, Rede, Relacionamento e Clientes, sendo a dimensão Processos a mais inovadora, marcada por inovações realizadas com aquisição de subsídio financeiro. A dimensão Ambiência Inovadora, apesar de não ter tido escores tão expressivos, ganhou notoriedade pela realização de inovações de forma conjunta com demais empresas e agentes.

Por outro lado, nenhuma inovação referente às dimensões Plataforma, Organização, Cadeira de Fornecimento e Presença foi realizada do Ciclo 0 ao Ciclo 2. Além do mais, todas as inovações desenvolvidas foram incrementais, o que se percebe que ao longo do período investigado não houve ruptura significativa no APL quanto à inovação radical.

Os apontamentos deste estudo também revelaram a importância do conceito de inovação para os gestores e a aprendizagem no processo inovativo das pequenas empresas. Por outro lado, tendo em vista a representatividade das inovações do tipo marketing no APL ao longo do período analisado, esta pesquisa também identificou na literatura a necessidade de revisão dos indicadores de mensuração de inovação em APLs.

As contribuições desta pesquisa apontam para a consolidação da relevância dos estudos voltados para inovação nas pequenas empresas, sobretudo dentro da concepção de formação de arranjos de 


\section{Administração: caminhos para o desenvolvimento sustentável}

empresas; além de fortalecer a literatura quanto ao conceito de APL, uma vez que compreende um termo genuinamente brasileiro.

Portanto, as limitações desta investigação se pautam na análise de um APL correspondente a um setor específico. Logo, as futuras pesquisas poderiam explorar outros APLs ou outros setores e regiões, bem como investigar por meio de um estudo comparativo, empresas participantes e não participantes de $A P L$, verificando se a formação em arranjos interfere no processo de inovação das pequenas empresas.

\section{REFERÊNCIAS}

Audretsch, D. B. (2003). Standing on the Shoulders of Midgets: The U.S. Small Business Innovation Research Program (SBIR). Small Business Economics 20, pp. 129-135.

Bachmann, D. L., \& Destefani, J. H. (2008). Metodologia para estimar o grau de inovação nas MPE. Cultura do Empreendedorismo e Inovação. Curitiba, PR.

Bhaskaran, S. (2006). Incremental Innovation and Business Performance: Small and Medium-Size Food Enterprises in a Concentrated Industry Environment. Journal of Small Business Management, 44 (1), pp. 64-80.

Carvalho, H. G. (2011). Gestão da Inovação. Curitiba: Aymará.

Cassiolato, J. E., \& Lastre, H. M. (2003). O foco em arranjos produtivos e inovativos locais de micro e pequenas empresas. Obtido em 20 de 12 de 2017, de Grupo

Redesist: http://www.ie.ufrj.br/redesist/P3/NTF2/Cassiolato\%20e\%20Lastres.pdf

Chesbrough, H. W. (2003). Open innovation. Boston, MA: Harvard Business School Press.

Costa, O. M. (2011). Arranjos Produtivos Locais. APL's como estratégia de desenvolvimento:uma abordagem teórica 75 p. Fortaleza: Instituto de Pesquisa e Estratégia Econômica do Ceará-IPECE.

Creswell, J. W. (2010). Projeto de Pesquisa: métodos qualitativos, quantitativo e misto. Porto Alegre: Artmed.

De Jong, J. P., \& Marsili, O. (2005). The Fruit Flies of Innovation: A Taxonomy of Innovative Small Firms. Dynamics of Industry and Innovation: Organizations, Networks and Systems.

Diehl, A. A., \& Tatim, D. C. (2004). Pesquisa em Ciênciais Sociais Aplicadas: métodos e técnicas. São Paulo: Pearson Prentice Hall.

FGV, P. (2016). 10 Anos do Simples Nacional. Cadernos FGV Projetos, 96.

Gopalakrishnan, S., \& Damanpour, F. (1997). A Review Economics, of Innovation Research in Sociology and Technology Management. Omega, International Journal Management Science Vol. 25, No. I, pp. 15-28. 


\section{Administração: caminhos para o desenvolvimento sustentável}

Hoffman, K., Parejo, M., \& Bessant, J. (1998). Small firms, R\&D, technology and innovation in the UK: a literature review. Published in Technovation, 18.

Kim, D., Kumar, V., \& Kumar, U. (2012). Relationship between quality management practices and innovation. Journal of Operations Management, v. 30, pp. 295-315.

Lastres, H. M., \& Cassiolato, J. E. ( 2005). "Innovation systems and local productive arrangements: new strategies to promote the generation, acquisition and diffusion of knowledge". Innovation: Management, Policy \& Practice, 7, (2), pp. 172-187.

Lastres, H. M., Cassiolato, J. E., \& Maciel, M. L. (2003). Pequena empresa: cooperação e desenvolvimento local. Rio de Janeiro: RelumeDumará Editora.

Lima, M. C. (1997). A Engenharia da Produção Academica. São Paulo: Unidas.

Matos, M. G., Borin, E., \& Cassiolato. (2015). Políticas estratégicas de inovação e mudança estrutural: uma década de evolução dos arranjos produtivos locais. Rio de Janeiro: E-papers.

Nagano, M. S., Stefanovitz, J. P., \& Vick, T. E. (2014). Innovation management processes, their internal organizational elements and contextual factors: An investigation in Brazil. Journal of Engineering and Technology Management v. 33, 63-92.

OCDE, O. p. (2005). Manual de Oslo: Diretrizes para coleta e interpretação de dados sobre inovação, 3a ed. FINEP.

Olivares, G. L., \& Dalcol, P. R. (2010). Proposta de um sistema de indicadores para medir o grau de contribuição dos aglomerados produtivos para o desenvolvimento local e regional. Revista Brasileira de Gestão e Desenvolvimento Regional v. 6, n. 2, 188-218.

Ošenieksa, J., \& Babauska, S. (2014). The relevance of innovation management as prerequisite for durable existence of small and medium enterprises. Procedia - Social and Behavioral Sciences, Vol 110, pp. 82-92.

Romero, I., \& Martínez-Román, J. A. (2012). Self-employment and Innovation. Exploring the determinants of innovative behavior in small businesses. Research Policy, 41, 178-189.

Roper, S. (1997). Product Innovation and Small Business Growth: A Comparison of the Strategies of German, U.K. and Irish Companies. Small Business Economics 9, pp. 523-537.

Rothwell, R. (1977). The characteristics of successful innovators and technically progressive firms (with some comments on innovation research). R \& D Management 7,3, pp. 191-206.

Sawhney, M., Wolcott, R. C., \& Arroniz, I. (2006). The 12 different ways for companies to innovate. MIT Sloan Management Review Vol. 47, No.3, pp. 75-81.

Schumpeter, J. A. (1934). The Theory of Economic Development. Cambridge: Harvard University Press.

Scuotto, V., Del Giudice, M., \& Carayannis, E. G. (2017). The effect of social networking sites and absorptive capacity on SMES' innovation performance. The Journal of Technology Transfer, 42 (2), 409-424. 


\section{Administração: caminhos para o desenvolvimento sustentável}

SEBRAE, S. B. (2009). Arranjo produtivo local. Brasília: Sebrae.

Simonetti, E. R., Carniello, M. F., Rodrigues, M. S., \& Oliveira, E. A. ( 2013). Diagnóstico do arranjo produtivo local das indústrias têxteis do município de Imperatriz-MA. Revista Brasileira de Gestão e Desenvolvimento Regional v. 9, n. 3, 250-278.

Stallivieri, F. (2012). Indicadores para Arranjos Produtivos Locais- REDESIST. Obtido em 07 de Janeiro de 2018, de Site do Portal

APL: http://portalapl.ibict.br/export/sites/apl/galerias/biblioteca/Nota_Txcnica_5_VF.pdf

Stallivieri, F., Campos, R. R., \& Britto, J. N. (2009). Indicadores para a análise da dinâmica inovativa em arranjos produtivos locais: uma análise exploratória aplicada ao arranjo eletrometal-mecânico de Joinville/SC. Estudos Econômicos (São Paulo) v. 39, n. 1, 185-219.

Tidd, J., Bessant, J. R., \& Pavitt, K. (2008). Gestão da Inovação 3ạ ed. Porto Alegr: Bookman.

Tigre, P. B. (2006). Gestão da Inovação: A Economia da Tecnologia no Brasil. Rio de Janeiro: Elsevier.

Van de Ven, A. H. (May de 1986). Central Problems in the Management of Innovation. Management Science, Vol. 32, No. 5, pp. 590-607.

Yin, R. K. (2005). Estudo de Caso: planejamento e métodos. Porto Alegre: Bookman. 


\section{Capitulo 44}

\section{POLÍTICAS PÚBLICAS E AGRICULTURA FAMILIAR: UMA ANÁLISE DOS AGRICULTORES QUE BUSCAM FINANCIAMENTO NO PRONAF}

DOI: $10.37423 / 200300475$

Sonia Aparecida Beato Ximenes de Melo, UNEMAT, Brasil). msc.soniaximenes@gmail.com

Geazi Dias da Silva, UNEMAT, Brasil).geazidias@hotmail.com André Ximenes de Melo, USCS).Brasil, andre.melo@uscs.edu.br Amauri da Silva Salvador, UNEMAT).Brasil, amauri_salvador@hotmail.com Sandro Benedito Sguarezi, UNEMAT, Brasil).sandrosguarezi@gmall.com

RESUMO: A agricuítura familiar tem ganhado destaque na economia brasileira, nas políticas sociaाis e econômicas e-está diretamente ligada à redução da pobreza. Nesse sentido, o Programa Naciơnal de Fortalecimento da Agriculfura Familiar - PRONAE VIsa estimular a geração de renda e melherar o uso da mäjo de obra familiar, por maeio do financiamento de atividades e serviços rüaìs agropecuários e não agropecuários, desenvolvidos em estabelecimento rural ou em áreass comunitárias próximas. $\varnothing$ acesso a esse t po de crédito é um fator determinante para a produção agrícola. Assim,objetivou responder a pergunta: quais os fatores que dificultam o acesso dos Agricultores Familiares à Política de crédito Rural do Pronaf? o presente estudo, caracterizou-se comb/uma pesquisa empírica de abordagem qualitativa e de natureza descritiva. Utiliz

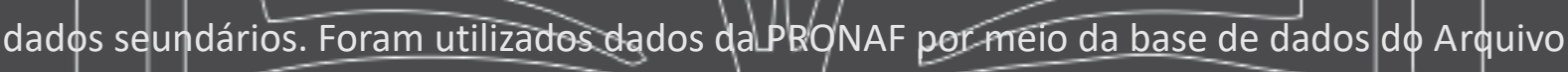
Nacional nos anos de-2015 e 2016, composta por uma populaçãa de 104 famílias que buscaram eredito Rural do Programa PRONAF, nas cidades de Tangara da Serran Barra do Bugres e Nova Olímpia, no estado de Mato Gosso. 


\section{Administração: caminhos para o desenvolvimento sustentável}

As principais entraves encontradas para obtenção de credito pelos agricultores foram: Matrícula do Imóvel irregular, Imposto Territorial Rural (ITR) em atraso, e CCIR (Certificado de Cadastro do Imóvel Rural), entre outros. Muitos agricultores ainda não conseguem acessar o programa, principalmente pela burocracia ou falta de informação.

Palavras-chave: Produção Rural; Financiamento; Agricultura familiar. 


\section{Administração: caminhos para o desenvolvimento sustentável}

\section{INTRODUÇÃO}

A agricultura familiar é um tema em ascensão no Brasil, vem ganhando importância política, social e econômica. Em meados de 80 devido a crise financeira vivida no Brasil, a agricultura familiar passou a ser vista como oportunidade de abastecimento de alimentos como emprego rural e autoemprego, uma parcela substancial da população foi absorvida com rápido crescimento em pequenas propriedades como solução para amenizar o quadro de miséria que assolava o país.

Até o início da década de 90 não havia políticas públicas voltadas para a agricultura familiar no âmbito nacional. Em 1994, em consequência da pobreza no campo e das reivindicações dos agricultores familiares, bem como estudos realizados conjuntamente pela FAO/INCRA, definindo precisamente a agricultura familiar e estabelecendo diretrizes para formulação de políticas voltadas a esses agricultores, o governo implementou o programa de Valorização de Pequena Produção Rural (PROVAP), tendo como fonte de recursos do Banco nacional de Desenvolvimento Econômico e Social (BNDES.

A criação deste programa representa o reconhecimento e a legitimação do Estado, em relação às especificidades de uma nova categoria social - os agricultores familiares - que até então era designada por termos como pequenos produtores, produtores familiares, produtores de baixa renda ou agricultores de subsistência. O PRONAF busca estimular a gerar renda e melhorar o uso da mão de obra familiar, por meio do financiamento de atividades e serviços rurais agropecuários e não agropecuários desenvolvidos em estabelecimento rural ou em áreas comunitárias próximas

Partindo desse pressuposto pode-se fazer a seguinte questão problema: Quais os fatores que dificultam o acesso dos Agricultores Familiares à Política de Crédito Rural do Pronaf? Assim, esse estudo objetivou estudar agricultores familiares que solicitaram crédito rural por meio do PRONAF. Mais especificamente, a) Traçar o perfil dos agricultores que buscaram créditos pelo PRONAF; b) Verificar os fatores que dificultam o acesso do crédito rural para os pequenos agricultores.

A agricultura familiar é aquela em que a propriedade pertence a uma família e é administrada pelos seus componentes, tendo ainda suas principais atividades desenvolvidas por eles mesmos.Ter acesso a esse tipo de crédito é um fator que possibilita o desenvolvimento da produção agrícola das pequenas propriedades. 


\section{Administração: caminhos para o desenvolvimento sustentável}

\section{PROGRAMA NACIONAL DE FORTALECIMENTO DA AGRICULTURA FAMILIAR}

As diretrizes do PRONAF têm como referência experiências europeias, principalmente a da França, no pós-guerra, na qual a produção da agricultura familiar foi modernizada a fim de contribuir para a competitividade da economia nacional e, em consequência, na melhoria da qualidade de vida da população rural. A "revolução agrícola" foi realizada com grandes contribuições de vários setores da sociedade que tinha interesse em transformar o campesinato em um setor produtivo dinâmico de produção e consumo (Lamarche, 1993). A política foi implementada quando o chamado "Estadoprevidência" se afirmava (Servolin, 1989; Abramovay, 1992), com recursos previstos em orçamento do governo, também apoiado por outras fonte de financiamento como o fundo perdido foram disponibilizados para o produtor a fim de garantir sua produção (Carneiro, 1997.

No Brasil desde a segunda metade da década de 1990, foi um programa diferenciado por causa da classificação do grupo de produtores. O programa combina, no seu funcionamento, quatro instrumentos básicos: (i) oferta de linhas de crédito especiais, a taxas de juros preferenciais, e com menores exigências de garantias do que as que se encontram no mercado; (ii) financiamento, a fundo perdido, de investimentos em infra-estrutura econômica de suporte aos pequenos produtores; (iii) oferta de assistência técnica aos beneficiários do programa; (iv) oferta de oportunidades de capacitação profissional (Dias, Magalhães, Silveira Neto \& Barros, 2004).

Em 1996 o Programa de Valorização da Pequena Produção Rural - PROVAP foi reformulado e deu origem ao (Programa Nacional de Fortalecimento da Agricultura Familiar - PRONAF, (Schneider et al., 2004). Atualmente o PRONAF está na esfera do Ministério do Desenvolvimento Agrário (MDA). Foi por intermédio do PRONAF que o governo atribuiu à agricultura um papel central na promoção do desenvolvimento econômico nacional e na melhoria das condições de vida da população. Assim determinando que o papel da agricultura é o de contribuir para a redução das desigualdades espaciais e sociais. A fim de gerar renda de forma desconcentrada, criando ocupações produtivas nos setores situados antes, dentro e depois da porteira (Carneiro, 1997).

Com a intenção de proporcionar a redução da migração campo-cidade, gerando divisas e, contribuindo para uma maior competitividade da economia nacional. Dessa forma, outras políticas criadas a partir do PRONAF destacam-se a criação do Programa de Aquisição de Alimentos (PAA), a Lei da Agricultura Familiar, o Seguro Rural, a nova Assistência Técnica e Extensão Rural (Ater) e, mais recentemente, o 


\section{Administração: caminhos para o desenvolvimento sustentável}

Programa Nacional de Alimentação Escolar (PNAE), que já existia desde os anos 1950, mas foi reestruturado visando atender a compra de alimentos dos agricultores (Gazolla \& Schneider, 2013).

Uma das principais finalidades do PRONAF é a de "promover o desenvolvimento sustentável do segmento rural constituído pelos agricultores familiares, de modo a lhes propiciar o aumento da capacidade produtiva, a geração de empregos e melhoria da renda" (Lei Federal no 11.326/ 2006, Art. 1ㅇ). Com a criação e implantação do PRONAF, o ambiente institucional em que estava inserida a política nacional de crédito ao produtor rural, assim como a dimensão do papel da agricultura familiar no processo de desenvolvimento rural, foi significativamente modificado (Pereira \& Nascimento, 2014).

Tais mudanças nas regras permitiram diretamente que a agricultura familiar tenha maior inserção no mercado de crédito, e por outro lado, a inserção política e a interação social, contribuiu para ampliar a compreensão sobre a importância da agricultura familiar tanto no âmbito dos governos quanto da sociedade em geral, incentivando a comercialização dos produtos e dando condições aos produtores de produzir com mais qualidade (Oliveira \& Baccarin, 2016).

O crédito rural possui a função de simplificar as negociações, favorecendo a sua execução, e a substituição do valor por um documento que represente essa troca financeira. No artigo 2ㅇ da lei 4.829 de 5 de novembro de 1965, o empréstimo agrário é definido como uma provisão de fundos de finanças por estabelecimentos públicos e organizações financeiras. Ofertado a agricultores ou a grupos cooperados para a utilização em suas incumbências. Destaca-se, dois aspectos importantes: o empréstimo é para atender imprevistose carências e o por esse tipo de serviço ser específico para o agricultor.

A liberação dos empréstimos se dá em três fases: a primeira é uma realização de verificação retroativa, que avaliará o comportamento do possível cliente, encontrando as maiores dificuldades em relação à tarefa desenvolvida pelo mesmo. A próxima fase é a verificação de vertentes, onde se realizará a prospecção da situação das finanças do provável cliente, e se este possui condição de suster alguma espécie de financiamento dispendioso e parte advém das primeiras fases, onde se alcança um fechamento em relação à eficácia do crédito do cliente, e em contrapartida à formulação de uma sugestão de crédito. 


\section{Administração: caminhos para o desenvolvimento sustentável}

A possibilidade de ingressar no programa de financiamento é de suma relevância para o desenvolvimento da agricultura, impreterivelmente para os micros regiões. O que dificulta esse processo é o impedimento de aquisição aos esclarecimentos por parte dos agricultores em relação à permissão ao empréstimo e a forma do meio agropecuário, em que os perigos envolvidos são grandes e, dificultam a liberação creditícia a uma parte concebível de agricultores.

Segundo a Fundação Paulo Bonavides - FPB (2011), uma das mais importantes justificativas da restrição do meio agrário ao direito do financiamento é a dificuldade da oposição do informe. A burocratização do processo e a ausência de informes para o produtor rural tanto em como conseguir o empréstimo, como em passar comunicados sobre a região agrária são outras dificuldades existentes. Aquino e Teixeira (2005) bem como os autores Cazella, Capellesco, Stropasolas e Búrigo (2009), discutem sobre a dificuldade na liberação de crédito por parte dos bancos e segundo eles a lista de exigências para se obter o crédito do programa Pronaf não condiz com o dia a dia do agricultor, pois é necessário elaboração de projetos para que seus investimentos sejam aprovados.

Fatos esses que ocorrem principalmente por que o sistema bancário tem que responder pelos riscos dos contratos firmados, fato esse que atrapalha a permissão do financiamento principalmente por que a maioria dos agropecuários não possuem garantias patrimoniais exigidas por essas instituições.

\section{METODOLOGIA}

O presente estudo, com o propósito de responder ao objetivo da pesquisa, caracterizou-se como uma pesquisa empírica de abordagem qualitativa (Gil, 2008) e de natureza descritiva (Triviños, 1987). Quanto aos procedimentos, utilizou-se inicialmente de pesquisa bibliográfica em periódicos afim de contextualizar a temática, e posteriormente estudo documental por meio de banco de dados seundários. Foram utilizados dados da PRONAF por meio da base de dados do Arquivo Nacional nos anos de 2015 e 2016, composta por uma população de 104 famílias que buscaram crédito Rural do Programa PRONAF, nas cidades de Tangara da Serra, Barra do Bugres e Nova Olímpia, no estado de Mato Gosso. A partir da produção dos dados, os mesmos foram tabulados e analisados utilizando-se de estatística descritiva.

\section{RESULTADOS E DISCUSSÃO}

O perfil dos agricultores que buscaram financiamento agropecuário, apesar de atuarem no mesmo ramo da economia, a produção agropecuária, os produtores rurais têm perfis muito diferentes. As 


\section{Administração: caminhos para o desenvolvimento sustentável}

estratificações mais usuais levam em conta o tamanho da fazenda, região geográfica e o cultivo principal. Os agricultores pesquisados são compostos majoritariamente por homens em um percentual (74\%).

Em relação à faixa etária, pode-se dizer que o envelhecimento é uma realidade na maioria das sociedades desenvolvidas e em desenvolvimento, como também na zona rural esse número vem aumentando. Quando separados por faixa etária e por genero (Tabela 1), demonstra que a variação do perfil, não há uma regra a ser seguida nesse seguimento. A maioria são do gênero masculino, no entanto, nota-se que as mulheres vem aumentando cada vez mais a sua participação no meio rural, com isso nos leva a crer que as mulheres têm mais longevidade e ao longo dos anos passou a cuidar dos negócios da família.

\begin{tabular}{lllll}
\hline & Idade & \% Produtores & Mas & Fem \\
\hline 30 a 40 & $17 \%$ & $83 \%$ & $17 \%$ \\
41 a 50 & $36 \%$ & $71 \%$ & $29 \%$ \\
51 a 60 & $36 \%$ & $73 \%$ & $27 \%$ \\
61 a 71 & $11 \%$ & $73 \%$ & $27 \%$ \\
Total & $100 \%$ & & \\
\hline
\end{tabular}

Tabela 1 - Idade dos agricultores

Uma das preocupações no meio rural é a sucessão familiar, nesse sentido foi observado que os agricultores têm em média 3 filhos cada família. Segundo Leite (2002, p. 22), no Brasil, o velho ditado "pai rico, filho nobre e neto pobre ou neto sem empresa" é o que mais se acredita nos dias atuais segundo o que pensam os empreendedores, pois eles constroem seu império, mas não sabem planejar sua sucessão.

Segundo Gassen (2013), na Europa da mesma maneira como nos Estados Unidos, na Austrália e nos países de grande importância econômica, a idade média do agricultor no campo aumenta quase um ano a cada ano que se passa, ou seja, o trabalho está sendo desempenhado cada vez mais por pessoas idosas, e os jovens não fazem a sucessão.

Quanto à escolaridade, pode-se notar na Tabela 2 que 17\% dos agricultores não são alfabetizados e outros $30 \%$ só possuem ensino fundamental completo ou incompleto. Sendo que, $6 \%$ dos agricultores possuem formação acadêmica. 


\section{Administração: caminhos para o desenvolvimento sustentável}

\begin{tabular}{lllllll}
\hline \multicolumn{1}{c}{ Escolaridade } & Mas & $\mathbf{\%}$ & Fem & $\mathbf{\%}$ & Total & \% \\
\hline Não alfabetizado & 13 & $17 \%$ & 5 & $19 \%$ & 18 & $17 \%$ \\
Fundamental incompleto & 11 & $14 \%$ & 3 & $11 \%$ & 14 & $13 \%$ \\
Fundamental completo & 13 & $17 \%$ & 5 & $19 \%$ & 18 & $17 \%$ \\
Ensino Médio incompleto & 7 & $9 \%$ & 7 & $26 \%$ & 14 & $13 \%$ \\
Ensino Médio Completo & 12 & $16 \%$ & 3 & $11 \%$ & 15 & $14 \%$ \\
Ensino superior & 4 & $5 \%$ & 2 & $7 \%$ & 6 & $6 \%$ \\
Não informado & 17 & $22 \%$ & 2 & $7 \%$ & 19 & $18 \%$ \\
Total & 77 & $100 \%$ & 27 & $100 \%$ & 104 & $100 \%$ \\
\hline
\end{tabular}

Tabela 2 - Escolaridade dos agricultores, por gênero.

Em relação à formação escolar por sexo, o grupo de homens contém $16 \%$ não alfabetizado. A escolaridade de $44 \%$ das mulheres são de nivel médio e superior. Nota-se que esses seguem a tendência nacional, de acordo com o Censo Agropecuário (2017) 15,44 nunca frequentou escola, 38\% dos agricultores são alfabetizados, ou estudou até o ensino fundamental, somente $5,5 \%$ tem o ensino superior. O que pôde perceber é que os agricultores mesmo que seja lentamente, vem buscando uma maior qualificação fazendo esse quadro de não alfabetizados gradualmente ir diminuindo, pprincipalmentes as mulheres.

Pode-se observar que dos agricultores familiar não aprovados no crédito rural do PRONAF 63\% tem formação escolar até o ensino fundamental (Tabela 3).

Tabela 3 - Grau de aprovação do crédito Pronaf por escolaridade dos agricultores

\begin{tabular}{l|l|l|l|l|l|l}
\hline \multicolumn{3}{c}{ Aprovados } & \multicolumn{2}{c}{ Não aprovados } & \multicolumn{2}{c}{ Total } \\
\hline Escolaridade & Quantidade & $\%$ & Quantidade & $\%$ & Quantidade & $\%$ \\
\hline Não alfabetizado & 4 & $11 \%$ & 17 & $25 \%$ & 21 & $20 \%$ \\
\hline Fundamental incompleto & 1 & $3 \%$ & 13 & $19 \%$ & 14 & $13 \%$ \\
\hline Fundamental completo & 5 & $14 \%$ & 13 & $19 \%$ & 18 & $17 \%$ \\
\hline Ensino médio incompleto & 4 & $11 \%$ & 9 & $13 \%$ & 13 & $13 \%$ \\
\hline Ensino médio completo & 16 & $44 \%$ & 0 & $0 \%$ & 16 & $15 \%$ \\
\hline Ensino superior & 6 & $17 \%$ & 0 & $0 \%$ & 6 & $6 \%$ \\
\hline Não informado & 0 & $0 \%$ & 16 & $24 \%$ & 16 & $15 \%$ \\
\hline Total & 36 & $100 \%$ & 68 & $100 \%$ & 104 & $100 \%$ \\
\hline
\end{tabular}

Alguns dos maiores problemas encontrados por produtores é se adequarem à organização do trabalho, pois sofrem com a descapitalização, falta de recursos e a pouca formação escolar, ou seja, a desinformação sobre vários assuntos, como impactos ambientais, organização social da propriedade e o alto índice de analfabetismo (Fonseca, 2001). 


\section{Administração: caminhos para o desenvolvimento sustentável}

Na Tabela 4, nota-se que $100 \%$ dos agricultores que têm nível superior e ensino médio completo conseguiram que seus créditos fossem aprovados. Isso mostra que quanto maior é o nível de qualificação, maior pode ser a agilidade das aprovações e acesso das informações do programa, sendo um fator relevante o conhecimento, indo ao encontro do expressado por Fonseca (2001).

Tabela 4 - Grau de escolaridade dos aprovação do crédito e valor aprovado.

\begin{tabular}{lllllllc}
\hline \multirow{2}{*}{\multicolumn{1}{c}{ Escolaridade }} & \multicolumn{3}{c}{ Pedidos } & \multicolumn{4}{c}{ Aprovados } \\
\cline { 2 - 9 } & RS Média & Área Média & Qt & RS Média & Área Média & Qt & \% \\
\hline 1- Não Alfabetizado & $50.035,71$ & 166 & 21 & $52.490,35$ & 199 & 4 & $19 \%$ \\
\hline 2- Fundamental Completo & $47.097,02$ & 185,3 & 18 & $47.735,20$ & 246 & 5 & $7 \%$ \\
\hline 3- Ensino Fundam. Incompleto & $46.402,66$ & 201,4 & 14 & $143.000,00$ & 143 & 1 & $28 \%$ \\
\hline 4- Ensino Médio Completo & $49.888,03$ & 201,8 & 16 & $53.062,01$ & 201,8 & 16 & $31 \%$ \\
\hline 5- Ensino Médio Incompleto & $51.147,93$ & 178,7 & 13 & $48.799,16$ & 208,8 & 4 & $100 \%$ \\
\hline 6- Ensino Superior Completo & $46.781,12$ & 207,3 & 6 & $46.781,12$ & 207,3 & 6 & $100 \%$ \\
\hline Não Informado & $51.082,03$ & 143,3 & 16 & & & & $0 \%$ \\
\hline TOTAL & $48.919,20$ & 183,4 & 104 & $65.311,30$ & 201 & 36 & \\
\hline
\end{tabular}

Dos pesquisados com resultado positivo no financiamento, os homens conseguiram em média R\$ $52.155,00$ e as mulheres $R \$ 44.810,00$, o que se constata $25 \%$ a mais de volume financeiro adquirido pelos homens e $\mathrm{R} \$ 33.403,00$ para os que detinham nivel superior.

Um dos itens analisados foi o tamanho da propriedade, sendo constatado que $11 \%$ dos agricultores têm propriedades até 100 hectares, desses todos foram provados (Figura 1).

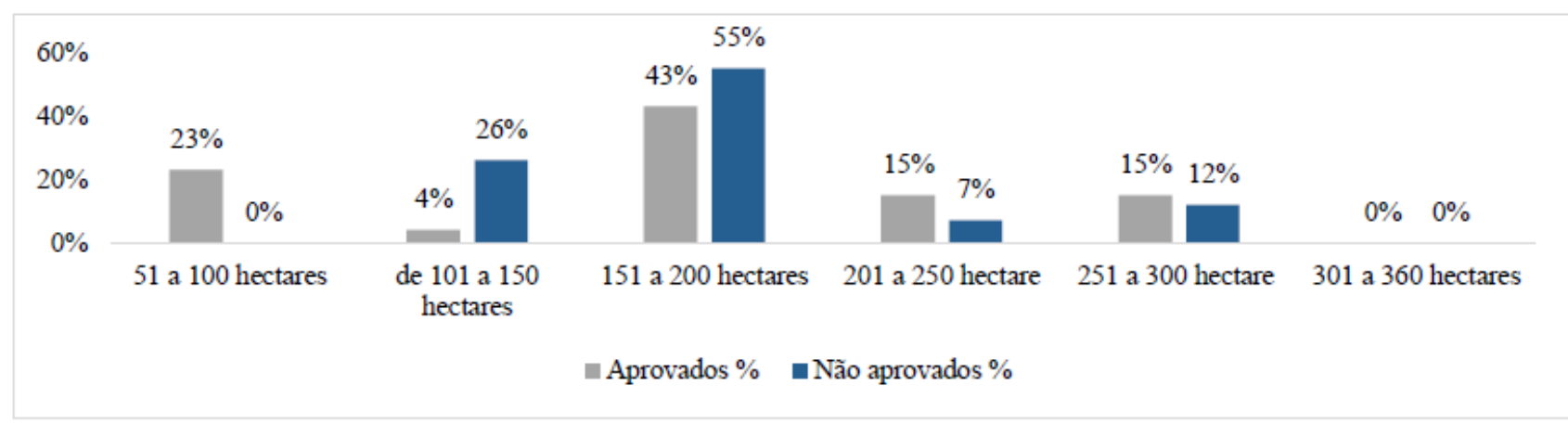

Figura 1 - Tamanho das propriedades dos agricultores aprovados e não aprovados para o crédito PRONAF. 


\section{Administração: caminhos para o desenvolvimento sustentável}

Isso demonstra que não é a quantidade de terra que faz o agricultor ser ou não ser aprovado. Nota-se que os o maior número que produtores, 49\% possuem área de 151 a 200 hectares, desses, 43\% tiveram os créditos aprovados e 55\% foram reprovados em suas análises de créditos.

\subsection{ENTRAVES ENCONTRADOS NO ACESSO DO CRÉDITO RURAL}

Dentre todos os produtores rurais que buscaram crédito para suas propriedades, $32 \%$ foram reprovados por conta do Certificado de Cadastro de Imóvel Rural (CCIR), isto porque, sem que o CCIR regular não se pode vender, hipotecar ou prometer seu imóvel em venda, além desses 19\% tiveram seu crédito negado porque a matrícula do imóvel estava irregular, portanto não poderia hipotecar a área para obter o crédito. Ainda tiveram $14 \%$ dos produtores que não conseguiram o crédito pois o Imposto sobre a propriedade territorial Rural (ITR) não estava devidamente pago. Assim, 35\% dos agricultores conseguiram aprovação por possuirem toda documentação necessária exigida para obtenção do PORONAF. Nesse sentido, um dos motivos pelos quais os agricultores têm sua solicitação de crédito negada acontece mais pela falta de informação de como regularizar sua propriedade.

Portanto, o PRONAF é considerado um avanço sem precedentes no país. Anualmente, a cada plano safra, o PRONAF se consolida como instrumento transformador dessa categoria, a exemplo, pode-se verificar o crescimento acelerado de recursos disponibilizados e dos beneficiários que continuamente firmam novos contratos, como exemplo de crescimento podemos citar a disponibilidade de crédito que no ano safra 2002/2003 foi de $R \$ 2,3$ Bilhões de reais e no ano safra de 2015/2016 foram liberados $\mathrm{R} \$$ 28,9 Bilhões de reais para a modalidade de Crédito rural PRONAF.

Nesse seguimento, o financiamento agropecuário é de suma importância para o agricultor, devido ao fato de apresentar uma das menores taxas de juros do sistema de financiamento brasileiro. Este tipo de empréstimo tem aumentado ultimamente, do mesmo modo como os recursos disponíveis pelos programas governamentais e pelas instituições bancárias.

\section{CONCLUSÃO}

Mesmo o PRONAF sendo um avanço na agricultura familiar, as dificuldades são maiores para com aqueles que detem menos tempo de estudo, logo, o programa é muito criticado, principalmente por beneficiar determinados produtores. 


\section{Administração: caminhos para o desenvolvimento sustentável}

O governo tem reformulado o programa à cada ano, isso se dá pela discrepancia entre o que se exige e a capacidade de documentar do agricultor, tais mudanças apontam aumento do número de agricultores atendidos a cada ano. Consequentemente, os problemas ainda permeiam, pois dos 104 agricultores que tentaram o financiamento, apenas 24 conseguiram resultados positivos, sendo seis deles que possuem nivel superior completo e em média de 46 anos de idade e com as compras de bens no valor médio de $\mathrm{R} \$ 33.402,50$. Porém muitos agricultores ainda não conseguem acessar o programa, principalmente pela burocracia ou falta de informação, mas ainda existe a questão de acessibilidade, pois faltam agências de créditos nas proximidades de onde o agricultor mora.

Importante salientar que o perfil dos agricultores que buscaram créditos pelo PRONAF foi composto majoritariamente por homens (em 74\%), com idade média de 48 anos e 5 meses, em média 180 hectares de área. 59\% dos que tentaram o financiamento haviam estudado menos que 12 anos (ensino médio).

As mulheres representaram $26 \%$ da amostra. Em se abstraindo os que não informaram o grau de educação, o tempo de estudo das mulheres tem sido maior, sendo que os homens estudam menos, assim as mulheres com ensino médio (incompleto ou completo) são $37 \%$ e os homens $24,7 \%$, no nivel superior as mulheres são $7,4 \%$ e os homens $5,2 \%$.

Dos pesquisados com resultado positivo no financiamento, os homens conseguiram em média $\mathrm{R} \$$ $52.155,00$ e as mulheres $R \$ 44.810,00$, o que se constata $25 \%$ a mais de volume financeiro adquirido pelos homens e $\mathrm{R} \$ 33.403,00$ para os que detinham nivel superior.

Em relação a área dos pesquisados, a área média foi de 183 hectares, se dividirmos entre as maiores e menores teremos: nas áreas entre 100 e 200 hectares foi de 178 hectares em média, e os que estavam entre 200 e 300 hectares foi de 253 hectares. Os adquirentes que possuiam nível superior, a média percebida foi de 207,3 hectares. Para os que foram aprovados a área média é semelhante a dos de nível superior, sendo de 207,66 hectares. Quanto ao número de aprovados pode-se observar que todos os produtores que solicitaram crédito por meio do PRONAF com propriedades entre 51 e 100 hectares obtiveram 100\% de aprovação, já os produtores entre 101 a 150 hectares obtiveram taxa de aprovação de apenas $4 \%$.

O Agricultor deve ter cuidado com a documentação, tanto pessoal quanto de sua propriedade, não ter restrições bancárias e não ter restrições cadastrais em sua propriedade (Copetti, 2008), apurar 


\section{Administração: caminhos para o desenvolvimento sustentável}

entraves encontrados no momento da solicitação do crédito, tais como Matrícula do Imóvel irregular, Imposto Territorial Rural (ITR) em atraso, e CCIR (Certificado de Cadastro do Imóvel Rural), que comprova que o imóvel está cadastrado no INCRA com pendências. Dessa forma, com documentação regular, independente de qual nivel de estudo, o financiamento terá maior probabilidade de ser aprovado. Nesse ponto, apesar de que quanto mais estudado, mais provavel que consiga a aprovação, a qualificação de nível superior faz com que o adquirente peça menos volume financeiro e a facilidade de comunicação é maior. Não obstante lembrar que os mais humildes perdem a nocão de tempo, e imaginam que documentos não vencem, o que prejudica o andamento do processo.

\section{REFERÊNCIAS}

Abramovay, R. (1997). Uma extensão para a agricultura Familiar-Anais. Brasília: PNUD (Programa das Nações Unidas para o Desenvolvimento), 222, p.3.

Aquino, J. R. \& Teixeira, O. A. (2005). Agricultura familiar, crédito e mediação institucional: a experiência do Pronaf em São Miguel no Nordeste Brasileiro, Cadernos de Desarrollo Rural, 2, 54, 6185.

Carneiro, M. J. (1997). Política pública e agricultura familiar: uma leitura do PRONAF. Estudos Sociedades e Agricultura, 8, 70-82.

Cazella, A. A., Capellesco, A. J., Stropasolas, V. L. \& Búrigo, A. J. (2009). Políticas públicas: o rural é mais que produzir! Anais do Congresso da Sociedade , Brasileira de Economia, Administração e Sociologia Rural, Porto Alegre, RS, Brasil, 47.

Copetti, L. D. (2008). Fatores que dificultam o acesso dos agricultores familiares às políticas de crédito rural: O caso do Pronaf-Crédito no município de Alegria RS. Dissertação de mestrado em Desenvolvimento Rural, Faculdade de Ciências Econômicas, Universidade Federal do Rio Grande do Sul, Porto Alegre.

Dias, F. M., Magalhães, A., Silveira Neto, R., \& Barros, A. (2004). A experiência recente do PRONAF em Pernambuco: uma análise através de propensity score. Anais do Encontro Nacional de Economia, XXXII, João Pessoa/PB. Paraíba.

Fonseca, D.M. (2001). Desenvolvimento rural: algumas considerações. Trabalho e Cidadania, Rio de Janeiro.

Fundação Paulo Bonavides. (2011). Instituto para o desenvolvimento de estudos econômicos, sociais e políticas públicas (IDESPP). Microcrédito e desenvolvimento regional. Fortaleza: Premius.

Gassen, D. (2009). O Brasil entre os principais produtores de grãos. Revista Plantio Direto, Passo Fundo, ed. 109, jan./fev. 


\section{Administração: caminhos para o desenvolvimento sustentável}

Gazolla, M. \& Schneider, S. (2013). Qual "fortalecimento" da agricultura familiar? uma análise do PRONAF crédito de custeio e investimento no Rio Grande do Sul. Revista de Economia e Sociologia Rural, 51, 1, 45-68.

Gil, Antônio Carlos. (010). Como elaborar projetos de pesquisa. 5a ed. São Paulo: Atlas.

Instituto Brasileiro de Geografia - IBGE. (2017). Censo agropecuário 2017: resultados preliminares. IBGE.

Lei Federal no 11.326 de 24 de julho de 2006. (2006). Estabelece as diretrizes para a formulação da Política Nacional da Agricultura Familiar e Empreendimentos Familiares Rurais. http://www.jusbrasil.com.br/legislacao/95601/lei-11326-06 (21 de maio de 2019.

Lei Federal no 4.829 de 05 de novembro de 1965. (1965). Institucionaliza o crédito rural. http://www.planalto.gov.br/ccivil_03/leis/L4829.htm (21 de maio de 2019.

Leite, R. C. (2002). As técnicas modernas de gestão de empresas familiares. In: GRZYBOVSKY, D.; TEDESCO, J. C. Empresa familiar: tendências e racionalidades em conflito. 3. ed. Passo Fundo: UPF. p. $17-62$

Oliveira, J. A \& Baccarin, J. G. (2016). Organização espacial e execução do programa de aquisição de alimentos da agricultura familiar entre 2001-2012. Revista Equador (UFPI), 5, 2, 120 - 138 (Janeiro/Junho)

Pereira, E. L. \& Nascimento, J. S. (2014). Efeitos do Pronaf sobre a produção agrícola familiar dos municípios tocantinenses. Revista de Economia e Sociologia Rural, 52, 1, 139-156.

Schneider, S., Silva, M. K. \& Marques, P. E. M. (Org.). (2004). Políticas públicas e participação social no Brasil rural. Porto Alegre: Ed. da UFRGS, p. 21-49.

Schneider, S. (2007). A importância da pluriatividade para as políticas públicas no Brasil. Revista de política Agrícola, 16, 3, 14-33.

Triviños, A. N. S. (1987). Introdução à pesquisa em Ciências Sociais: a pesquisa qualitativa em educação. São Paulo: Atlas. 


\section{Capítulo 45}

\section{DISCUSSÃO SOBRE O USO DA CONTROLADORIA NO APOIO AO PLANEJAMENTO OPERACIONAL}

DOI: $10.37423 / 200300475$

Elias Garcia, Unioeste, elias.garcia@unioeste.br

Andreia A. Pimenta, Unioeste, apimentaandreia@gmail.com

João Daniel dos S. Mendonça, Unioeste, jdsmespanhol@gmail.com

RESUMO: A função da controladoria pode ser entendida em diferentes níveis de abirangência, a depender, entre outros fatores, do tamanho da empresa é da necéssidạde de seus diretores. Algumas empresas podem restringi-la a elaborar e controlar/o plano orçamentário, em conjunto-com os gestores das áreas detentoras do orçamento Qutras, podem preferir colocála como uma área de assessoria da diretoria na eláboração de relatórios gerenciais. Com o objetivo de discutir a ùtilização da controlądoria no apoio ao planejamento operacional, que foi desenvolvido este artigo, que é parte de uma pesquisa descrítiva, apoiada em uma survey aplicada nas milcro e pequenas empresas sediadals no Paraná. $\sigma$ trabalho faz urîa breve revisão inerente as decisões de investimentas de capital, descreye os aspectos do custo de capital e alavancagem financeira, sem contudd, esgotar o/assunto, mostrando allguns exemplos hipotéticos para melhor fixação do contẹưdo.

Palavras-chave. Controladoria; Investimentos, Alavancagem Einanceira, Informação.

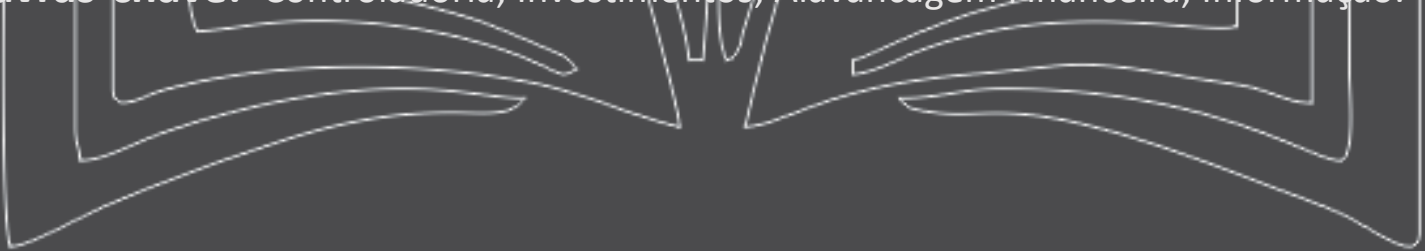




\section{Administração: caminhos para o desenvolvimento sustentável}

\section{INTRODUÇÃO}

Em tempos de mudanças aceleradas e de alta competitividade, a gestão de todo o processo econômico é chave para a otimização de desempenho e de controle empresarial, visando que a empresa se mantenha viva e atuante no mercado, garantindo resultados positivos aos seus investidores. Nesse contexto, a controladoria tem um importante papel no ciclo do processo de gestão, chamando para si a responsabilidade de respaldar os gestores com informações úteis, a fim de que tomem decisões assertivas e levem a empresa a uma maior eficácia, que é medida pelo lucro obtido.

O processo de gestão é composto das etapas de planejamento (estratégico, operacional e programação), execução e controle. Neste trabalho apresentamos a função da controladoria no planejamento operacional, enfatizando temas como decisão de investimento de capital, custo de capital e alavancagem financeira. A fim de adentrarmos nesse tema, é importante apresentarmos, também, um breve contexto sobre a controladoria e o processo de gestão, visando ter em mente onde o planejamento operacional se encontra dentro do referido processo.

O objetivo principal do trabalho é discutir o papel da controladoria em todo o processo de gestão estratégica da empresa, enfocando a área do planejamento operacional.

\section{O CONTEXTO DA CONTROLADORIA E O PROCESSO DE GESTÃO}

A função da controladoria pode ser entendida em diferentes níveis de abrangência, a depender, entre outros fatores, do tamanho da empresa e da necessidade de seus diretores. Algumas empresas podem restringi-la a elaborar e controlar o plano orçamentário, em conjunto com os gestores das áreas detentoras do orçamento, outras podem preferir colocá-la como uma área de assessoria da diretoria na elaboração de relatórios gerenciais. Contudo, há aquelas que conseguem destacar a controladoria como a responsável pela gestão econômica da empresa. Assim, podemos dizer que a controladoria é responsável por criar valor ao acionista, tendo como meta assegurar o alcance do resultado planejado e mensurar adequadamente os resultados empresariais, conduzindo a empresa a uma maior eficácia. É com base nesta visão de controladoria que enfocaremos o presente trabalho.

Padoveze (2011) sintetiza a função da controladoria nos seguintes aspectos:

a) Responsável pela gestão econômica da empresa; portanto com foco em resultados. 


\section{Administração: caminhos para o desenvolvimento sustentável}

b) Apoio a todos os gestores das diversas atividades empresariais.

c) Construção de um sistema de informação que auxilie os gestores em todo o processo de gestão.

O ciclo de um processo de gestão é composto pelo planejamento, execução e controle. O primeiro subdivide-se em planejamento estratégico (longo prazo); planejamento operacional (médio e curto prazos) e programação (curto prazo). A seguir destacamos uma breve descrição das etapas deste ciclo:

\subsection{Planejamento Estratégico}

De forma sucinta, pode-se dizer que o planejamento estratégico é o ato de, com base na missão, crenças e valores da empresa, definir as estratégias para alcançar os objetivos almejados. Esse planejamento deve ser elaborado levando em consideração a análise de fatores internos e externos à empresa (pontos fracos e fortes, ameaças e oportunidades), pois tem como finalidade preparar a empresa para o futuro.

Nessa etapa a empresa define políticas, diretrizes e objetivos estratégicos dentro de uma visão específica do futuro.

\subsection{Planejamento Operacional}

O planejamento operacional dá curso às estratégias definidas. Sua missão é quantificar os objetivos qualitativos, para depois transformar em metas, as quais estão relacionadas a um padrão de consumo de recursos para a obtenção de um determinado nível de resultado desejado. As metas se tornam um norte para os gestores no sentido de indicar, de forma clara, as expectativas que a alta administração tem quanto às contribuições que deles se esperam para aprimorar o resultado econômico da organização, criando novos parâmetros que servirão de base para suas próprias avaliações de desempenho.

\subsection{Programação}




\section{Administração: caminhos para o desenvolvimento sustentável}

Atua na ordenação da definição dos meios, recursos e ações necessárias para executar o plano operacional adotado.

Segundo Padoveze (2011), a programação compreende o planejamento das necessidades e ações para o próximo exercício, sendo representada basicamente pelo processo orçamentário (plano orçamentário, orçamentos de vendas, produção, materiais, estoques, despesas gerais, investimentos, financiamentos e controle orçamentário).

\subsection{Execução}

A execução é o processo de gestão operacional em que os gestores decidem sobre as atividades que estão sob sua área de atuação, executando o que foi planejado e programado. Padoveze (2011) caracteriza a gestão operacional pelo ciclo de comprar, produzir, vender ou revender produtos e serviços.

\subsection{Controle}

O controle, além de avaliar o quanto há de aderência entre os planos e sua execução, procurando identificar as causas dos desvios que podem ter ocorrido e direcionar ações para correção, também deve observar as variáveis que podem ocorrer no cenário futuro e causar impacto no seu planejamento estratégico.

Controlar adequadamente o planejamento pode significar que a empresa está mais bem preparada para lidar com novas variáveis ambientais que possam surgir e, assim, tomar decisões oportunas, pois, a depender da complexidade de tais variáveis, os rumos e resultados da organização podem ser alterados e, até mesmo, ocorrer risco à sua continuidade.

\section{O PLANEJAMENTO OPERACIONAL}

A situação futura almejada para a empresa procura ser estabelecida no planejamento, assim como os possíveis meios para alcançá-la. Por isso o planejamento é considerado um valioso instrumento de 


\section{Administração: caminhos para o desenvolvimento sustentável}

gestão. Segundo Beuren et al. (2002) o planejamento "pode ser comparado a uma espécie de ponte que liga os estágios "onde estamos" e "onde pretendemos estar" numa perspectiva temporal futura de médio ou longo prazo".

Drucker (1998) afirma que "o planejamento começa pelos objetivos da empresa" e menciona que "em cada área desses objetivos, é preciso formular a pergunta: Que temos que fazer agora para alcançar amanhã os nossos objetivos?". Para obter a resposta desta pergunta é necessário um contínuo esforço de cooperação e integração entre profissionais de diversas áreas do conhecimento da empresa. 0 papel da controladoria é coordenar essa integração.

Dentro do contexto geral de planejamento, encontramos o planejamento operacional, que, após a elaboração do planejamento estratégico, consiste, segundo Catelli (2010), "na identificação, integração e avaliação das alternativas de ação e na escolha de um plano de ação a ser implementado". Segundo Catelli et al. (1999), o processo de planejamento operacional compreende as seguintes etapas:

1. Estabelecimento dos objetivos operacionais;

2. Definição dos meios e recursos;

3. Identificação das alternativas de ação;

4. Simulação das alternativas identificadas;

5. Escolha das alternativas e incorporação ao plano;

6. Estruturação e quantificação do plano e

7. Aprovação e divulgação do plano.

No planejamento operacional a controladoria deve disponibilizar sistemas de informações que contenham modelos de decisão e mensuração adequados, com base na realidade operacional da empresa, de modo que, com base em dados oportunos, corretos e confiáveis, viabilizem a tomada eficaz de decisões por parte dos gestores da organização.

Dentre os sistemas de informações que permitam simulações e projeções sobre eventos econômicos no processo de tomada de decisão, na visão de Almeida et al. (2001) destacam-se:

- Orçamento e projeções; 
- Análise e investimentos;

- Contabilidade de custo;

- Contabilidade por responsabilidade;

- Acompanhamento dos negócios;

- Projeções financeiras;

- Credibilidade, persuasão e direção.

Roehl (1996) ressalta que os gestores buscarão na controladoria as informações consistentes para a tomada de decisão em relação à direção a ser seguida:

Através da controladoria a direção de uma empresa tem a possibilidade de conduzir a que seus esforços sejam produtivos. É junto a essa área que a alta direção e os gestores da organização buscarão informações consistentes a fim de definir os rumos a serem seguidos pela organização. (ROEHL, 1996, p. 85)

Nesse ponto, é importante destacar que a controladoria não tem como função se responsabilizar pelos resultados obtidos pelos gestores. Os autores Almeida, Parisi e Pereira expõe que:

A Controladoria é por excelência uma área coordenadora das informações sobre gestão econômica; no entanto, ela não substitui a responsabilidade dos gestores por seus resultados obtidos, mas busca induzi-los à otimização do resultado econômico. (in Catelli, 1999, p. 372).

Por esse lado, concluimos que, a função da controladoria está adstrita ao processo de geração e disseminação das informações que servirão para apoiar o gestor no momento da tomada de decisão.

\subsection{ATRIBUIÇÕES DO CONTROLLER NO PLANEJAMENTO OPERACIONAL}

Segundo Gonçalves (2019), as organizações com fins lucrativos "reconhecem que o planejamento operacional é um dos instrumentos mais úteis na controladoria, pois este serve de parâmetro fundamental para o controle e análise do comportamento futuro da empresa". 


\section{Administração: caminhos para o desenvolvimento sustentável}

A Controladoria no planejamento operacional também é um recurso imprescindível para a elaboração das diretrizes orçamentárias, que visa respaldar as organizações na tomada de decisões e ajudá-las a alcançarem o rendimento máximo dos recursos disponibilizados na atividade operacional.

Para Tung (1993) o papel do controller é, entre outras funções, verificar as possibilidades da empresa na fixação de objetivos, no estabelecimento de políticas básicas, na definição das responsabilidades de cada área na organização, no estabelecimento de padrões de controle, no desenvolvimento de métodos eficientes de comunicação e na manutenção de um sistema adequado de informações.

Esclarece ainda Tung (1993), que não compete ao controller o comando do navio, tarefa que cabe ao principal executivo. O controller representa na empresa o navegador que cuida dos mapas de navegação. Sua função é manter informado o comandante quanto a distância percorrida pela embarcação, ao local em que se encontra, a sua velocidade, a resistência que encontra, aos desvios da rota, aos recifes perigosos e aos caminhos traçados nos mapas, para que todos cheguem ao destino final.

Para Bianch (2006), a função do controller não se limita a administrar o sistema contábil da empresa, pois os conhecimentos de contabilidade e finanças não são mais suficientes para o desempenho organizacional. O autor aponta algumas funções primordiais da controladoria, das quais se destacam a direção e implantação dos sistemas de informação, coordenação, avaliação, planejamento e acompanhamento do negócio.

Quando se trata de planejamento operacional, o autor Padoveze (2011) entende que duas grandes áreas estão ligadas: as do Balanço Patrimonial - Ativo e Passivo. O Ativo está relacionado com a decisão de investimentos da empresa, onde será alocado capital dentre as propostas de investimentos que trarão benefícios no futuro. O Passivo se relaciona com a decisão de financiamento, tendo em vista que qualquer projeto de investimento requer a definição de quais serão as fontes de recursos para sua realização.

Apesar de praticamente todos os autores de finanças definirem que as decisões de investimento e de financiamento são funções fundamentais do administrador financeiro, elas fazem parte do escopo de responsabilidade do controller, uma vez que ele, segundo Padoveze (2011), "tem por fim apoiar a empresa em todo o processo de gestão, que inclui o planejamento operacional", cabendo à 


\section{Administração: caminhos para o desenvolvimento sustentável}

controladoria, determinar estrategicamente as possíveis estruturas de ativos e passivos necessárias para atender ao planejamento estratégico e operacional da empresa.

\subsection{DECISÃO DE INVESTIMENTO DE CAPITAL}

Ligado ao planejamento operacional está o plano financeiro, que é uma ferramenta no desenvolvimento, análise e comparação de cenários, permitindo que a empresa decida questões relativas às linhas futuras de investimento de capital e os melhores esquemas de financiamento.

Padoveze (2011) explica que, sob a ótica da literatura financeira, a decisão de investimento é tomada em cima das opções de investimentos que são apresentadas no contexto de fluxo de caixa. Assim, a apreciação utilizada para tal decisão, é com base no valor do dinheiro no tempo, retorno e riscos esperados, escolhendo aquele que apresentar melhor retorno com menor risco. Dentre os critérios mais utilizados estão o Valor Presente Líquido (VPL) e a Taxa Interna de Retorno (TIR).

Ainda, na opinião do autor, é de que os modelos financeiros não evidenciam os meios, os critérios nem os conceitos para se chegar aos valores estimados que utilizam como base. Afirma que "não tem sido explorado nem desenvolvido um modelo de decisão que evidencie os critérios e conceitos para se chegar ao valor que deverá ser investido em cada uma das opções" (Padozeve, 2011).

Utilizando-se da visão de Gitman, Padoveze conclui que o aspecto ainda não explorado, é uma etapa do planejamento operacional:

... as decisões de investimento determinam a combinação e o tipo de ativos constantes do balanço patrimonial da empresa (...) a combinação refere-se ao montante de recursos aplicados em ativos circulantes e ativos permanentes. (Gitman, 1997, p.14).

Assim, no enfoque da decisão de investimento no planejamento operacional, se atribui à Controladoria a criação de modelos de decisão, mensuração e informação a partir da determinação de estruturas do ativo das unidades de negócio e da determinação de estruturas do passivo relativas aos meios de financiamento dos investimentos do ativo.

Com base nas duas visões, financeira e modelos de decisão preparadas pela controladoria, destacaremos nos próximos tópicos os conceitos de orçamento de capital e a estruturação de ativos e passivos. 


\section{Administração: caminhos para o desenvolvimento sustentável}

\section{a) Orçamento de Capital}

Sob a ótica da literatura financeira, a decisão de investimento está relacionada ao orçamento de capital. Segundo Hoji (2010) “O orçamento de capital é um programa de longo prazo vinculado ao plano estratégico e trata de investimentos permanentes". Importante mencionar que investimentos temporários de natureza financeira não fazem parte do orçamento de capital. Hoji (2010) classifica investimentos temporários como os de natureza financeira, aplicados normalmente no mercado financeiro, que podem ser de curto ou longo prazo. No Ativo, tais investimentos, são classificados como Aplicações de liquidez imediata e Títulos e valores mobiliários.

Segundo a especialista Camargo (2018), o orçamento de capital é um processo no qual as empresas identificam, avaliam e selecionam investimentos significativos de longo prazo e que envolvem grande volume de capital (como por exemplo, compra de uma nova planta, mais máquinas, investimento em nova tecnologia etc.). Considera o orçamento de capital como uma ferramenta extremamente importante devido a mensurar todos os riscos envolvidos em um investimento de projeto. O objetivo de estimar um investimento de capital é determinar a lucratividade real de um projeto.

Antes de tomar qualquer decisão sobre investimento de capital, assevera Camargo (2018), é imperativo a empresa fazer uma análise, baseada em SWOT, para dimensionar seu crescimento. Para tanto entende como ponto chave a elaboração das seguintes perguntas para análise:

1. O que diferencia o seu negócio dos seus concorrentes? Invista em ferramentas e tecnologias que possam destacar ainda mais sua empresa.

2. Quais são os pontos fracos da sua empresa que precisam ser trabalhados? Investir em sistemas, máquinas ou processos podem ajudar a transformar fraquezas em forças. Aqui vale uma análise SWOT para identificar fraquezas, ameaças forças e oportunidade.

3. Quais ameaças e oportunidades externas devem ser controladas/maximizadas? Uma dica é aplicar a Análise Pest ${ }^{1}$ para detectar quais investimentos podem ser realizados a fim de eliminar ameaças ou maximizar oportunidades. 


\section{Administração: caminhos para o desenvolvimento sustentável}

4. Em que pontos da sua empresa pode haver redução de custos? A fim de ter capital para investir, reduza os gastos em áreas que terão um impacto mínimo no resultado.

Após listar os investimentos que a empresa será capaz de executar, deve avaliar aqueles que trarão retorno. Para tal pode-se utilizar os seguintes indicadores, corrobora Camargo:

- Valor Presente Líquido (VPL) - um dos métodos para calcular o Goodwill, ou Patrimônio de Marca. Este nada mais é do que os elementos não materiais de uma empresa que valorizam sua reputação.

- Taxa Interna de Retorno TIR - A TIR calcula a taxa de desconto que deve ter um fluxo de caixa para que seu Valor Presente Líquido (VPL) iguale-se a zero.

- Fluxo de Caixa Descontado - Fluxo de Caixa Descontado possui aplicações financeiras e comerciais. Para exemplificar, o FCD é um método utilizado por investidores antes de comprarem ações de uma empresa

- Payback -É um indicador de desempenho.

Para realizar esse tipo de investimento, segundo os especialistas, é preciso considerar aspectos-chave do planejamento financeiro: o planejamento de caixa e de lucros. O primeiro envolve o planejamento do orçamento de caixa da empresa; já o planejamento de lucros é normalmente realizado por meio de demonstrativos financeiros projetados, os quais são úteis para fins de planejamento financeiro interno, como também comumente exigidos pelos credores atuais e futuros. $\mathrm{O}$ objetivo de um bom planejamento financeiro é o de evitar surpresas e desenvolver planos alternativos.

Segundo Weston $(2000$,$) O planejamento financeiro envolve a realização de projeções de vendas,$ renda e ativos baseados em estratégias alternativas de produção e de marketing, seguidas pela decisão de como atender às necessidades financeiras previstas.

\section{b) Determinação das estruturas de Ativo e Passivo}

Como mencionado no tópico anterior, o orçamento de capital é de longo prazo, portanto vinculado ao planejamento estratégico da empresa. Com base na análise deste planejamento, nascerão as 


\section{Administração: caminhos para o desenvolvimento sustentável}

diretrizes e pontos de referência que determinam a estrutura do ativo do investimento e, posteriormente, os planos operacionais.

Para se determinar a estrutura do ativo, deve-se considerar como premissa que os investimentos da empresa são classificados no Balanço Patrimonial em duas principais classes: Capital de Giro, que acompanha o ciclo de operações da empresa (estoque, contas a receber, contas a pagar) e Ativos Fixos (imóveis, equipamentos, intangíveis - marcas, patentes, etc.).

Segundo Padoveze (2011), existem quatro grandes principais tipos de investimentos. Dois deles aquisição de uma empresa já existente e aquisição de ativos específicos - caracterizam-se por se basearem em um único valor: o de aquisição. Os outros dois - investimentos em uma nova empresa ou em uma nova unidade de negócio - caracterizam-se por combinarem duas classes de investimentos: Ativos fixos e capital de giro, que requerem um estudo diferenciado, o qual denomina de determinação da estrutura do ativo.

Padoveze conceitua a determinação da estrutura do ativo e seu propósito como: ... a decisão de investimento que é tomada na obtenção da combinação ideal de ativos em relação ao negócio proposto, objetivando a menor estrutura de capital. O propósito desta combinação é determinar a parcela ideal de investimentos em Ativos Fixos e Capital de Giro para o negócio ou empresa a ser constituída. (Padoveze, 2011, p. 146).

Considera ainda que, talvez a decisão da estrutura do ativo "seja uma das decisões mais difíceis de serem modeladas na gestão econômica das empresas", pois envolve muitas variáveis, tais como estrutura do produto a ser explorado no negócio da empresa, cadeia produtiva ou comercial, volume de produção, tempo, tecnologias (do produto, de produção, de informação, comercial, administrativa), processos de fabricação, atividades, preços de venda, mercados em que o produto será ofertado. Para avaliar a necessidade de investimentos, todas essas variáveis precisam ser definidas com antecedência e se ordenarem dentro de uma estrutura lógica de geração e interrelacionamentos. Por isso é necessária a construção de um modelo de decisão orientador que possibilite determinar a estrutura do ativo para o investimento proposto e sirva de modelo para análise dos custos envolvidos e, também modelar as decisões que deverão ser tomadas após a implantação do projeto de investimento. 


\section{Administração: caminhos para o desenvolvimento sustentável}

A seguir apresentamos um exemplo de cadeia produtiva de confecção e suas opções de estrutura de ativo:

Fiação $\rightarrow$ Tecelagem $\rightarrow$ Acabamento $\rightarrow \quad \begin{aligned} & \text { Grife } \\ & \text { Etiqueta }\end{aligned} \rightarrow \quad$ Varejo

Figura 01 Exemplo de cadeia produtiva

Fonte: Padoveze (2010).

Na cadeia produtiva acima apresentada, se a empresa optar por participar desde seu início, demandara mais ativos fixos. Se optar por trabalhar apenas no varejo, por exemplo, demandará uma quantidade menor de ativo fixo e maior capital de giro em estoque.

Para melhor entendimento, apresentamos, com base em Padoveze (2010), um exemplo de uma estrutura de ativo no setor de confecção de vestuário, que mostra duas opções de investimentos para o decisor. Na opção 1 apresenta uma empresa fabricante que vende, com vendedores próprios. $\mathrm{Na}$ opção 2 uma empresa que coloca a sua marca e vende por meio de vendedores terceirizados, conforme quadro a seguir: 


\section{Administração: caminhos para o desenvolvimento sustentável}

\begin{tabular}{|c|c|c|c|c|}
\hline & \multicolumn{2}{|l|}{ Opção 1} & \multicolumn{2}{|l|}{ Opção 2} \\
\hline & Valor & $\%$ & Valor & $\%$ \\
\hline \multicolumn{5}{|l|}{ GIRO } \\
\hline \multicolumn{5}{|l|}{ Estoque de } \\
\hline Materiais & $24.000,00$ & $9,56 \%$ & - & $0,00 \%$ \\
\hline$(-)$ & - & & - & \\
\hline Fornecedores & $8.000,00$ & $-3,19 \%$ & $16.266,67$ & $-13,96 \%$ \\
\hline \multicolumn{5}{|l|}{$\begin{array}{l}\text { Estoque de } \\
\text { produtos }\end{array}$} \\
\hline acabados & $43.000,00$ & $17,13 \%$ & $48.800,00$ & $41,88 \%$ \\
\hline Clientes & $60.000,00$ & $23,90 \%$ & $60.000,00$ & $51,49 \%$ \\
\hline Total & $119.000,00$ & $47,41 \%$ & $92.533,33$ & $79,41 \%$ \\
\hline \multicolumn{5}{|l|}{ ATIVO FIXO } \\
\hline Imóveis & & & & \\
\hline Fábrica & $48.000,00$ & $19,12 \%$ & - & $0,00 \%$ \\
\hline \multicolumn{5}{|l|}{ Equipamentos } \\
\hline - Fábrica & $60.000,00$ & $23,90 \%$ & - & $0,00 \%$ \\
\hline \multicolumn{5}{|l|}{ Equipamentos } \\
\hline \multicolumn{5}{|l|}{-} \\
\hline \multicolumn{5}{|l|}{ Administração } \\
\hline / Vendas & $24.000,00$ & $9,56 \%$ & $24.000,00$ & $20,59 \%$ \\
\hline Total & $132.000,00$ & $52,59 \%$ & $24.000,00$ & $20,59 \%$ \\
\hline TOTAL GERAL & $251.000,00$ & $100,00 \%$ & $116.533,33$ & $100,00 \%$ \\
\hline
\end{tabular}

Figura 02: Estrutura do Ativo (investimentos)

Fonte: Padoveze (2010)

A opção 1, por ter mais processos, necessita consequentemente de mais ativos fixos (52,59\%) e estoque de materiais $(9,56 \%)$, os quais compreendem no total $62,15 \%$ do ativo. A opção 2 , necessita maior participação no capital de giro $(79,41 \%)$.

Há que se levar em consideração, que cada opção trará diferentes resultados, que poderão ser tanto de lucro quanto de prejuízo. Portanto, também caberá a análise de cenário da demonstração de resultados, assim como feito para a estrutura de ativo, e a partir disso calcular o retorno sobre o investimento (lucro operacional versus ativo).

Ainda em relação ao exemplo de estrutura de ativo, nota-se que fornecedores está deduzindo o total do capital de giro. Isso acontece pelo fato de, no estudo da estrutura de ativo e passivo, ser classificado como um passivo de funcionamento, decorrente dos custos de operação da empresa, assim como 


\section{Administração: caminhos para o desenvolvimento sustentável}

impostos, salários e contas a pagar, por exemplo. Estes passivos não são explicitamente remunerados com juros, por isso devem ser colocados no ativo com sinal negativo.

Em relação à determinação da estrutura do passivo, devem ser alocadas as fontes de recursos utilizadas para financiar os investimentos do ativo, que são efetivamente remuneradas. Essas fontes são denominadas passivos de financiamento e basicamente representadas por financiamentos, debêntures, cotas ou ações preferenciais e ordinárias.

Quando a decisão de financiamento é para um projeto específico, por exemplo, comprar máquinas, fica determinado uma estrutura específica de passivo (fonte(s) de recurso originária para a aquisição). Contudo, pela operacionalidade contínua da empresa, essa decisão específica se juntará a outras decisões de financiamento de projetos anteriormente realizadas, formando esse conjunto a estrutura de passivo da empresa.

A administração da estrutura de passivo deve ser realizada de maneira contínua. Essa tarefa é originariamente ligada à área financeira, porém, segundo Padoveze, também cabe à Controladoria, tendo em vista agregar valor à empresa e fazer parte do processo de planejamento orçamentário da empresa:

Essa estrutura de passivo tem que ser administrada continuamente. Apesar de ser uma atividade ligada à Tesouraria, cabe também à Controladoria seu monitoramento, pois a estrutura de passivo adequada gera resultados econômicos mensuráveis que causam impacto no valor da empresa, e é componente fundamental do processo de planejamento orçamentário. (Padoveze, 2010, p.110)

Quanto mais a empresa se valer de fontes externas, menor aversão ao risco ela tem.

\section{c) Decisão de financiamento e o custo de capital}

Segundo Hoji (2010) “O capital de uma empresa está todo investido no Ativo, com o objetivo de gerar retornos adequados. Esse capital é fornecido por terceiros e pelos acionistas ou sócios. A parte dos acionistas ou sócios é representada pelo Capital próprio (Patrimônio Líquido)". Por meio dos ativos, que são financiados pelo capital próprio e de terceiros, é gerado o retorno do investimento.

Contudo, é necessário manter o equilíbrio entre o capital próprio e o de terceiros. O custo do capital de terceiros pode tornar-se excessivamente alto, até podendo inviabilizar sua captação, a depender do grau de alavancagem financeira. 


\section{Administração: caminhos para o desenvolvimento sustentável}

Para o cálculo do custo do capital próprio, Hoji afirma que:

... há que considerar os custos das ações e dos lucros retidos, levando-se em consideração os dividendos esperados pelos acionistas, pois, além da maximização do valor de mercado da companhia, eles esperaram que os lucros sejam distribuídos periodicamente. (Hoji, 2010, p.195)

De forma sucinta, significa dizer, os dividendos são os custos a serem pagos pelas ações dos investidores na empresa.

Em relação ao custo do capital de terceiros, Hoji (2010) o considera como sendo "a taxa de retorno pela qual o investidor (emprestador) deseja ser remunerado pelo risco que estará correndo temporariamente, ao ceder seu capital ao tomador". Além disso, em caso de empréstimos ou financiamentos em moeda estrangeira, haverá o risco de câmbio, podendo incorrer despesas ou receitas financeiras (ameaça versus oportunidade).

Dentre as principais fontes de capital de terceiro, estão os empréstimos para capital de giro, recursos do BNDS, financiamento de importação, leasing e debêntures.

O custo de capital de terceiros é determinado pelas taxas de juros, as quais flutuam muito a longo prazo, dificultando a estimativa das taxas futuras. A despesa financeira com variação cambial, também difícil de ser mensurada, pode causar um custo adicional ao capital de terceiro. Em contrapartida, para empresas tributadas pelo lucro real, tanto as despesas com juros quanto as com a variação cambial são dedutíveis no cálculo do imposto de renda e contribuição sobre o lucro líquido, o que reduz o custo de capital de terceiros devido ao impacto tributário.

Ainda se tratando de juros, cabe mencionar que caso a empresa opte por remunerar o capital de seus sócios ou acionistas por meio do pagamento de Juros sobre o Capital Próprio, poderá deduzi-lo no cálculo dos tributos acima mencionados, reduzindo assim o custo do capital próprio, caso calculado nos moldes do art. 75 da Instrução Normativa RFB no 1700 de 14/03/2017, utilizando como índice a TJLP (Taxa de Juros de Longo Prazo). Segundo Padoveze (2011), “...essa figura é muito interessante, pois permite maior distribuição de resultados, ao mesmo tempo que encoraja as empresas a se capitalizarem com lucros retidos, evitando maior endividamento financeiro".

É necessário que o custo de capital seja o mais realista possível, considerando que é com base nele que importantes decisões estratégicas são tomadas. 


\section{Administração: caminhos para o desenvolvimento sustentável}

\section{d) Alavancagem financeira}

De acordo com Padoveze (2011) a alavancagem financeira significa a possibilidade dos acionistas obterem maiores lucros para as suas ações com o uso mais intenso de capital de terceiros. No caso, empréstimos. Ele esclarece que o fundamento da Alavancagem financeira é que os juros são custos fixos e, portanto, permitem o fenômeno da alavancagem.

Hoji aborda a questão da alavancagem combinada. O uso combinado de uma determinada estrutura do ativo com uma determinada estrutura do ativo. O que dá a origem a alavancagem combinada. Segundo o autor, o grau de alavancagem combinada é obtido pela multiplicação do grau de alavancagem operacional pelo grau de alavancagem financeira. Por conseguinte, o grau de alavancagem combinada determina o grau de risco do empreendimento dentro daquela combinação de alavancagem escolhida. (Hoji 2010)

Segundo Martins e Assaf Neto (1986), alavancagem financeira atribui à relação entre capital próprio e créditos empregados em uma operação financeira. É a utilização de ativos ou recursos com encargos financeiros fixos, para expandir os efeitos de variações do lucro antes de juros e imposto de renda com relação ao lucro por ação. Assim, a empresa usa recursos de terceiros, empréstimos, debêntures, ações preferenciais, dentre outros, para elevar os resultados da alteração do lucro operacional (LAJIR) sobre os lucros por ação.

Alavancagem financeira é isso, a "alavanca" que esta absorção produz no rendimento dos acionistas. Ocorre quando os recursos de terceiros originam resultados sobre o patrimônio líquido, é como se o capital de terceiros usando uma alavanca, gerasse efeitos positivos ou negativos sobre o patrimônio líquido.

Segundo Par Mais (2016), “Alavancagem Financeira como a capacidade de aumentar expressivamente os ganhos sem aumentar os gastos ou investimentos na mesma proporção. Uma forma de alavancar é trabalhar com recursos financeiros de terceiros, não próprios, para conseguir realizar operações com maiores volumes no mercado financeiro.

Ainda de acordo com Par Mais (2016), fazendo uma analogia, a alavancagem financeira traz consigo a mesma ideia do exemplo da criança e da gangorra, em que, com pouca força, uma criança consegue levantar amigos até mesmo mais pesados do que ela mesma. 


\section{Administração: caminhos para o desenvolvimento sustentável}

O conceito é muito utilizado no meio empresarial, em análises contábeis e financeiras, ressaltam. Mas a alavancagem financeira também é muito comentada em outros contextos, como no mercado de capitais, sempre indicando a possibilidade de aumento de ganhos sem o mesmo nível de aumento de esforços. Porém, segundo os especialistas da Par Mais (2016), a alavancagem financeira pode se tornar uma operação perigosa se realizada sem acompanhamento. Sem o uso de estratégias bem definidas, operações alavancadas podem comprometer todo o patrimônio conquistado ao longo de anos.

\section{CONCLUSÃO}

Diante dos desafios do mundo empresarial, é essencial a elaboração e consolidação de um adequado planejamento estratégico e seus planos decorrentes, para que as empresas possam tomar decisões adequadas no presente, que apoiem os resultados esperados para o futuro. Neste processo, a função da controladoria se torna imprescindível na estratégica para o crescimento da empresa.

Como vimos, o trabalho da controladoria transcende o de somente fornecer relatórios, e vai além do controle financeiro. Ela ocupa lugar de destaque em todo o processo de gestão, pois serve de base de informações e projeções consistentes que auxiliam os gestores em suas decisões imediatas e planejamentos. Além disso, ela serve de apoio aos gestores na busca de sinergia entre eles.

No contexto do planejamento operacional, a controladoria se torna peça chave, pois dela provém os modelos de estrutura de ativos e passivos que respaldarão a administração na tomada de decisão de investimentos de capital e expansão dos negócios. Também auxiliará os gestores a, dentre os vários planos operacionais alternativos, escolherem aqueles que tragam maior resultado econômico.

Por tudo isso, entendemos fundamental a existência da controladoria, que foca em agir com rapidez na disponibilização de modelos de decisão e projeções que garantam corretas opções de escolha aos administradores, a fim de se ter a continuidade dos negócios da empresa e o alcance dos resultados esperados.

\section{REFERÊNCIAS}

ASSAF NETO, Alexandre. (2005) Finanças corporativas e calor. 2. ed. São Paulo: Atlas

BIANCHI, M.; BACKES, R. G.; GIONGO, J A (2006). Participação da Controladoria no Processo Organizacional, - Contexto. Porto Alegre, RS. Vol. 6 - lume.ufrgs.br

BEUREN, Ilse Maria, et al., (2002) A controladoria como unidade administrativa de suporte ao processo de gestão na perspectiva da gestão econômica. Paraná: Revista CRC - 113a Edição. 


\section{Administração: caminhos para o desenvolvimento sustentável}

CATELLI, Armando (coordenador). (1999) Controladoria: uma abordagem da gestão econômica GECON. São Paulo: Atlas.

A. et al. (2001). Sistema de Gestão Econômica - GECON. In: CATELLI, A. (Coord.). Controladoria: uma abordagem da gestão econômica - GECON. São Paulo: Atlas.

CAMARGO, Renata Freitas de. O Que é e Como Elaborar um Orçamento de Capital. Disponível em: <https://www.treasy.com.br/blog/orcamento-de-capital/> Acessado 11.05.2019

DRUCKER, Peter F.(1998) Introdução à administração. São Paulo: Pioneira.

GONÇALVES, Claudio, Controladoria no Planejamento Operacional, 2019. Disponível em: $<$ https://www.academia.edu/23051005>. Acessado 13.05.2019

GITMAN, Lawrence J. (1997). Princípios de administração financeira - 7ạ edição. São Paulo, Harbra.

HOJI, Masakazu. (2010). Administração Financeira e Orçamentária - 9o edição. São Paulo: Atlas.

PADOVEZE, Clóvis Luís. (2010). Controladoria Básica - 2o edição. São Paulo: CENGAGE Learning.

Clóvis Luís.(2011) Controladoria Estratégica e Operacional - 2o edição. São Paulo: CENGAGE Learning.

Clóvis Luís; BENEDICTO, Gideon Carvalho de. (2003). Cultura Organizacional: análise e impactos dos instrumentos no processo de gestão. Encontro Nacional de Pós-Graduação e Pesquisa em Administração - ENANPAD. Atibaia.

ROEHL, Anderson; BRAGG, Steven M. (1996). Manual del Controler: Funciones, Procedimientos y Responsabilidades. Tradução: Gloria Hillers de Luque. Bilbao: Deustro.

TUNG, Nguyen H. (1993). Controladoria Financeira das Empresas: uma abordagem prática. 8a . ed. São Paulo, Edições Universidade-Empresa Ltda.

PAR MAIS, você sabe o que é alavancagem financeira? 2019. Disponível

em: <https://www.parmais.com.br/blog/alavancagem-financeira/>. Acessado 08.05.2019

WESTON, J. Fred; Brigham, Eugene F. (2000). Fundamentos da administração financeira. São Paulo: Makron Books. 


\section{Capítulo 46}

\section{A FORMAÇÃO DE COMPETÊNCIAS GERENCIAIS NO MODELO QUINN: UM ESTUDO DE CASO DA CONTRIBUIÇÃO DO CURSO DE ADMINISTRAÇÃO}

DOI: $10.37423 / 200300514$

Gislaine Martinelli Baniski (UEPG) gmbaniski@uepg.br Silas G. Moro (UERG) smoro@uepg.br Marilisa Rocio Oliveira (UEPG) marilisa2@bol.com.br Carolina S.T. F.Sh/umbergè(UEPG) carolstfs@terra.com.br Osvaldo M. Callegari (UEPG) dsvaldo1264@hotmail/com RESUMO: O presente artigo-demonstra o perfil do acadêmicoldo curso de administração no que tange à formação de competências gerenciais. Para fins deste estudo consideraram-se competências gerenciajs as descritas no modelo définido por Quinn que elenca oito elementos de referência para um conjunto de atitudes comportamentais consideradas essenciais ao gestor. São elas, inovador, monitor, negociador, produtor, mentor, facilitaddr, cóordenador, diretor. A base do artigo foi a realização de uma pesquisa onde se buscou verificar o atendimento aos requisitos definidos pelip autor, a cohtribuição do curso para formação destas competências \& a auto percepção do aluṇp em re/ação a estas. Utilizou-se um levantamento por questionário, aplicado aos formandos do/curso de Administração gerand $\phi$ análise quantitativa das respostas dos acadêmicos. Percebeu-se uma contribuição bastante abrangente diante des perfis de Quinn e uma tendência ao perfil Produtor na autopercepção dos alunos.

Palavras chave: competências gerenciais, formação acadêmica, administração. 


\section{Administração: caminhos para o desenvolvimento sustentável}

\section{INTRODUÇÃO}

Entender o caráter complexo e dinâmico do mundo organizacional e agir de modo a direcionar os rumos para horizontes desejados, concentra-se aí a atuação gerencial. Compreender as competências gerenciais faz com que se consiga melhorar e explorar a ação do gestor permitindo atuação estratégica e específica.

Um curso de graduação visa colocar no mercado, profissionais em consonância com a expectativa deste, assim, para o curso de Administração, formar acadêmicos num perfil de atuação de acordo com os interesses da sociedade a qual serve, é mais que uma obrigação, é uma missão.

Pensando desta forma, este estudo objetiva o melhor entendimento dos pontos de vista dos futuros egressos do curso acerca das contribuições que eles percebem em sua formação. De posse destas percepções docentes, colegiados de curso e demais envolvidos podem direcionar esforços para a adoção de um estilo próprio do curso, sua vocação na formação e suas diretrizes estratégicas.

Para fins deste estudo, foram utilizados os papéis gerenciais desenvolvidos por Quinn (2003), que adota oito papéis gerenciais com caracteristicas distintas, pontuando o papel do líder como mentor, facilitador, monitor, coordenador, produtor, diretor, negociador, inovador.

\section{COMPETÊNCIAS GERENCIAIS}

Uma competência constitui um repertório de comportamentos capazes de integrar, mobilizar, transferir conhecimentos, habilidades, julgamentos e atitudes que agregam valor econômico a organização e valor social a pessoa. (CHIAVENATO, 2008)

As competências, segundo Chiavenato, 2008 podem ser hierarquizadas da seguinte maneira:

- Competências Essenciais (core competences): são as competências que distinguem uma organização, caracterizando vantagem competitiva;

- Competências Funcionais: são as competências de cada unidade organizacional que irão servir de base para as competências essenciais. Por exemplo, competências em finanças, marketing, etc.

- competências Gerenciais: são as competências que cada gerente ou executivo precisa construir e possuir para atuar como gestor.

- competências individuais: cada pessoa deve construir para pode atuar na organização. (CHIAVENATO, 2008). 


\section{Administração: caminhos para o desenvolvimento sustentável}

O termo competência tem sido utilizado desde a idade média, sendo na época vinculado à linguagem jurídica, indicando a faculdade atribuída a alguém para julgar questões. Desde então, esse termo é utilizado para referendar socialmente a pessoa que é capaz de se pronunciar sobre determinado assunto. Com a revolução industrial e a concepção taylorista, esse termo passa a ser utilizado indicando pessoas capazes de desempenhar determinado papel ou atividade operacionalmente definida. A partir da década de 1970, muitos autores foram se especializando no tema e propondo definições próprias (CARDOSO, 2009).

A competência é materializada pelo "desempenho expresso pela pessoa em determinado contexto, em termos de comportamentos e realizações decorrentes da mobilização e aplicação de conhecimentos, habilidades e atitudes no trabalho". O autor propõe entender competências humanas como combinações sinérgicas, de conhecimentos, habilidades e atitudes, expressas pelo desempenho profissional dentro de determinado contexto organizacional e que agregam valor a pessoas e organizações. (CARBONE, 2006, p. 43 apud CARDOSO, 2009)

De acordo com Perrenoud (1999 apud Plebiani, 2008), competência é a capacidade de agir de forma eficaz, em determinadas situações, colocando em ação diversos recursos cognitivos, dentre eles o conhecimento. O desenvolvimento das competências transcende a transmissão dos conhecimentos, estando totalmente relacionado com a forma com que o aluno se relaciona, apropria e consegue aplicá-lo.

O conceito de competência organizacional incorpora o conceito de competência individual, colocando em destaque a noção de competência gerencial. Por exemplo, para exercer a competência funcional da área de Recursos Humanos "desenvolver a análise crítica dos funcionários", deve-se mobilizar certas competências individuais (e gerenciais) no âmbito da área de recursos humanos, tais como a orientação estratégica, competência fundamental à concepção de processos de desenvolvimento alinhadas as intenções estratégicas da empresa. Entre as competências individuais, as competências gerenciais devem ser mobilizadas pelo lideres de equipes, responsáveis pela mobilização das competências dos demais indivíduos. (MASCARENHAS, 2008 p. 191).

Para que a competência organizacional possa ser atingida, uma série de fatores é requerida, entre eles as aptidões individuais e coletivas. Para Zarifian, 2001 citado por Lopes, 2010, a competência é assumida por um coletivo, mas depende de cada pessoa individualmente. $O$ trabalho em equipe, em rede ou por projeto fornece um quadro e um referencial para a ação de cada pessoa e formaliza a 


\section{Administração: caminhos para o desenvolvimento sustentável}

convergência necessária das ações profissionais, mas cada pessoa singular torna-se importante em si mesma.

Compreendendo o que é competência, devemos caracterizar especificamente as competências gerenciais. Pretende-se revisar algumas vertentes que causaram impacto na formulação do que se entende hoje por competências gerenciais.

Inicialmente têm-se os modelos de metas racionais e processos internos que viam nos princípios gerenciais de Taylor uma diretriz importante.

Ao emergir o modelo das relações humanas, com destaques para o trabalho de Fayol, Max Webber e Mayo, começou a ficar claro que o modelo de metas racionais e processos internos não eram inteiramente apropriados para as demandas apresentadas (QUINN, 2003). Neste modelo a ênfase central era no compromisso, coesão e moral. A premissa quanto aos meios e fins em questão é que o envolvimento resulta em compromisso e os valores centrais são participação, resolução de conflitos e construção de consenso. Porém, colocar este modelo em prática muitas vezes recaía numa benevolência autoritária.

Em sua tese, que se tomou um livro clássico para o estudo da administração, Mintzberg questiona a idéia de Fayol de que os administradores apenas planejam, organizam, dirigem e controlam. Essas funções dizem respeito ao processo administrativo, mas os gerentes têm muitas outras funções. Ou seja, os gerentes têm outras responsabilidades gerenciais além do desempenho das funções do processo administrativo. Mintzberg estudou um pequeno grupo de altos executivos, por meio da técnica da observação direta e registro exaustivo de suas atividades em diários. Ele concentrou-se nas atividades que os gerentes realizam: o que eles fazem, com quem conversam, como se comunicam, quanto tempo trabalham sozinhos e assim por diante. Essa pesquisa deu-lhe a base para fazer a proposição de que as atividades dos gerentes classificam-se em dez papéis. Mintzberg definiu um papel como um conjunto organizado de comportamentos que pertencem a uma função ou posição identificável e agrupou os dez papéis gerenciais em três famílias: papéis interpessoais, papéis de informação e papéis de decisão (MAXIMIANO, 2000).

Outros pontos de vista sobre a atuação do gerente podem ser citados, segundo Gil, o gerente deve exercer os seguintes papeis: comunicador, selecionador, treinador, avaliador de desempenho, analista de cargos, motivador, líder, negociador, gestor da qualidade, coach. (GIL, 2008 p.66) 


\section{Administração: caminhos para o desenvolvimento sustentável}

$\mathrm{Na}$ década de 70 a força de trabalho começou a apresentar uma orientação mais individualista e conservadora. O vocabulário gerencial estava repleto de termos da administração racional, tais como Administração por Objetivos (APO) e sistemas de informação Gerencial (SIG). O modelo dos sistemas abertos traz a necessidade de competir num ambiente ambíguo e competitivo. (QUINN, 2003)

Da confrontação dos modelos de metas racionais, processos internos, relações humanas e modelos de sistemas abertos, Quinn (200)3, desenhou um quadro com critérios de eficácia, que moldariam as atuações gerenciais.

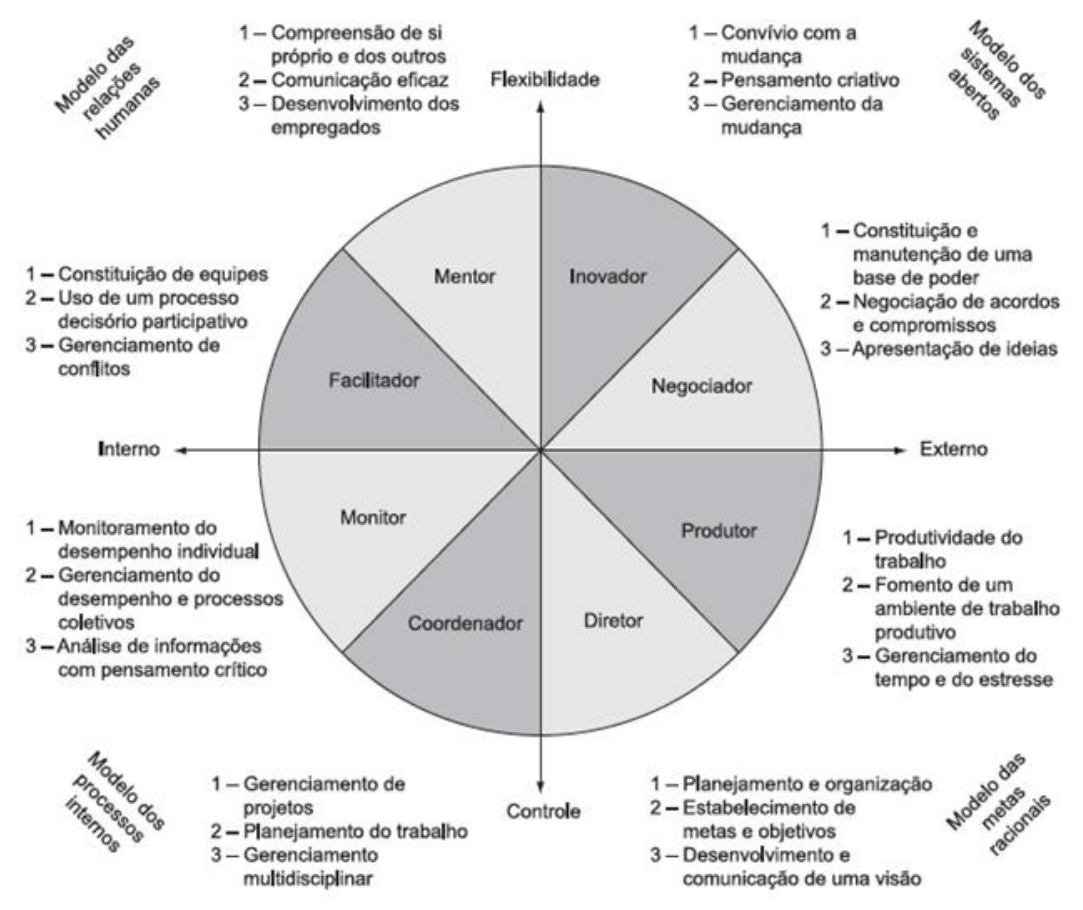

Figura 1: quadro de valores competitivos e competências gerenciais, Quinn, 2003 p.13.

Segundo Quinn (2003), os quatro modelos do arcabouço representam os valores invisíveis pelos quais pessoas, programas, políticas e organizações vivem e morrem. Como resultado, nossas escolhas e o potencial de efetividade são reduzidos. Mas obter efetividade organizacional, o gerente deve entender as vantagens e desvantagens destes modelos, utilizar as competências de cada um e integrar de maneira dinâmica as competências de cada um dos modelos às situações gerenciais.

O modelo de competências gerenciais de Quinn (2003) é um dos mais adotados em pesquisas relacionadas, de acordo com levantamento conduzido por Freitas e Odelius (2018) "seu uso e robustez provavelmente se dão por conta da amplitude (agregando MC privilegiadas pelas teorias afetas às metas racionais, relações humanas, processos internos, e perspectiva sistêmico-situacional) e por 


\section{Administração: caminhos para o desenvolvimento sustentável}

abranger as relações vivenciadas pelos gestores, a depender da ênfase no ambiente e em características do contexto e de seu próprio perfil (FREITAS E ODELIUS, 2018 p. 46).

Os professores acostumados com uma atuação baseada no modelo tradicional, ou seja, aquele baseado na exposição oral, tendo o professor como o centro do processo, na memorização dos conhecimentos e na disciplina do aluno tem dificuldade em compreender a abordagem educacional de formação de competências. A formação de competências exige uma pequena revolução cultural para passar de uma lógica do ensino para uma lógica do treinamento (coaching), baseada em um postulado relativamente simples: constroem-se as competências exercitando-se em situações complexas (PERRENOUD, 1999 apud PLEBIANI e DOMINGUES, 2009).

Quanto à eficácia atribuída aos métodos de ensino pelos professores, a tradicional aula expositiva ganha destaque em conjunto com métodos inovadores como o estudo de caso e os jogos de empresas. Todavia, ficou evidente que os professores tem conhecimento e aplicam métodos de ensino, bem como compreendem a sua importância. Os métodos de estudo de caso e jogos de empresa são considerados por Marion (2007) aqueles que mais contribuem para a formação das competências gerenciais, deste modo, a pesquisa mostra um cenário favorável a melhor formação de competências com a utilização destes métodos (PLEBIANI e DOMINGUES, 2009).

Alguns estudos demonstram empiricamente (PINCHAI, 2008; BARROS et al. 2013; PAIVA E FERREIRA, 2013) que as competências gerencias podem ampliar as entregas desejadas por uma organização e sua compreensão permite planejar e conduzir de forma mais acertada este processo.

\section{METODOLOGIA}

Com o ojetivo de verificar qual a percepção dos alunos com relação aos aspectos apontados no modelo de Quinn (2003), obtendo-se um feedback relativo à formação proporcionada pelo curso, foi desenvolvida uma ferrametna de coleta, na forma de questionário impresso, que foi respondido por egressos do curso.

Tratou-se de uma pesquisa aplicada (GIL, 2008) adotando-se a análise quantitativa dos dados, com coleta sendo realizada meio de questionários aplicados aos formandos do curso de Administração de uma universidade estadual. O formulário compreendeu a investigação dos três aspectos inerentes à cada um dos perfis de Quinn (2003), somando-se 24 questões respondidas em escala de contribuição 


\section{Administração: caminhos para o desenvolvimento sustentável}

que variava de Muito Alta contribuição a Nada contribuiu. Dos 75 alunos pertencentes à turma obtevese o retorno de 63 formulários.

Desta forma caracterizou-se o método não probabilístico, com amostragem por conveniência. Os cuidados para evitar a tendenciosidade envolveram a aplicação por pessoa não participante da pesquisa bem como cuidados para garantir anonimato no recolhimento dos formulários.

Quanto ao tratamento dos dados, foram tabulados e avaliados por membros da equipe de pesquisa, procecendo-se à posterior análise dos resultados.

A tabulação dos dados demonstrou maior ou menor incidência em um dos oito perfis do autor. Para enquadramento num dos perfis foi desenvolvido um algoritmo que relacionava as três questões de cada perfil a um índice próprio para cada perfil de competência gerencial.

\section{ANÁLISE DOS RESULTADOS}

A aplicação dos questionários junto aos formandos do curso de Administração permitiu uma análise sobre o perfil julgado pelos estudantes acerca de sua formação. Inicialmente buscou-se colher dados sobre a opinião dos respondentes sobre a contribuição do curso em cada uma das competências do modelo Quinn de tal forma que as opiniões ficaram condensadas em cada um dos oito perfis. $\mathrm{Na}$ seqüência o acadêmico deveria optar por um dos perfis, conforme sua autopercepção.

$\mathrm{Na}$ figura 2, abaixo, está demonstrado o resultado desta pesquisa. Nota-se certa homogeneidade na contribuição do curso para a formação dos diversos perfis.

O menor índice é percebido no perfil Coordenador, 3,67. Isto se reflete devido à opinião de baixa contribuição das disciplinas do curso na condução de projetos, questão levantada neste perfil. Num sentido positivo pode-se entender que uma formação mais homogênea das diferentes capacitações permitiria uma formação mais adaptável ao novo gestor, sendo este tanto negociador como coordenador, alterando situacionalmente as atuações, por outro lado, esta formação careceria de um posicionamento mais claro para obter-se maior profundidade na formação. 


\section{Administração: caminhos para o desenvolvimento sustentável}

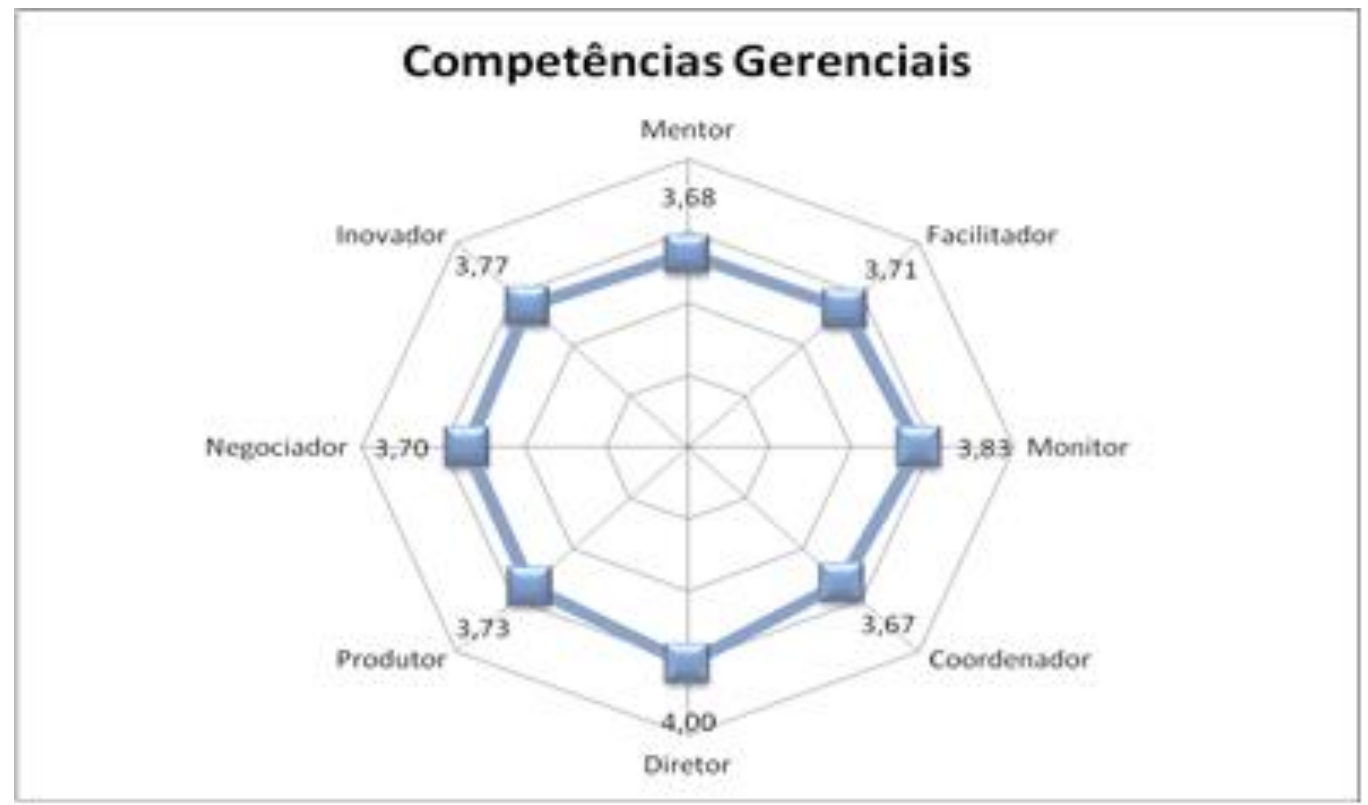

Figura 2: classificação das incidências nos perfis de competência

Também por solicitar um gerenciamento multidisciplinar, o perfil Coordenador traz a reflexão sobre a necessidade de atuação mais forte na formação de liderança. Fica evidente esta carência ao observarmos a segunda menor concordância que foi no perfil de Mentor. Ou seja, as contribuições do curso não estão gerando uma atuação de líder, merecendo reforço.

Ainda na Figura 2, percebe-se na posição Diretor, a maior concordância dentre os perfis. O Diretor, na visão de Quinn (2003) é descrito em práticas de estabelecimento de missão e visão, metas e objetivos, planejamento e organização. Fica evidente realmente que o acadêmico identifica contribuição neste sentido, uma vez que muitas disciplinas do curso reforçam tais características, porém, ao ser inquirido sobre qual perfil o acadêmico mais se via, ele não nota no Diretor o seu sinal de identidade. Acreditase haver aí uma divergência conceitual com o termo Diretor que, na interpretação do acadêmico traz um sentido mais distante.

Visando uma análise mais detalhada das intensidades das opiniões dos respondentes, o gráfico abaixo traz as dimensões de contribuição de baixa à muito alta de cada uma das competências gerenciais. 


\section{Administração: caminhos para o desenvolvimento sustentável}

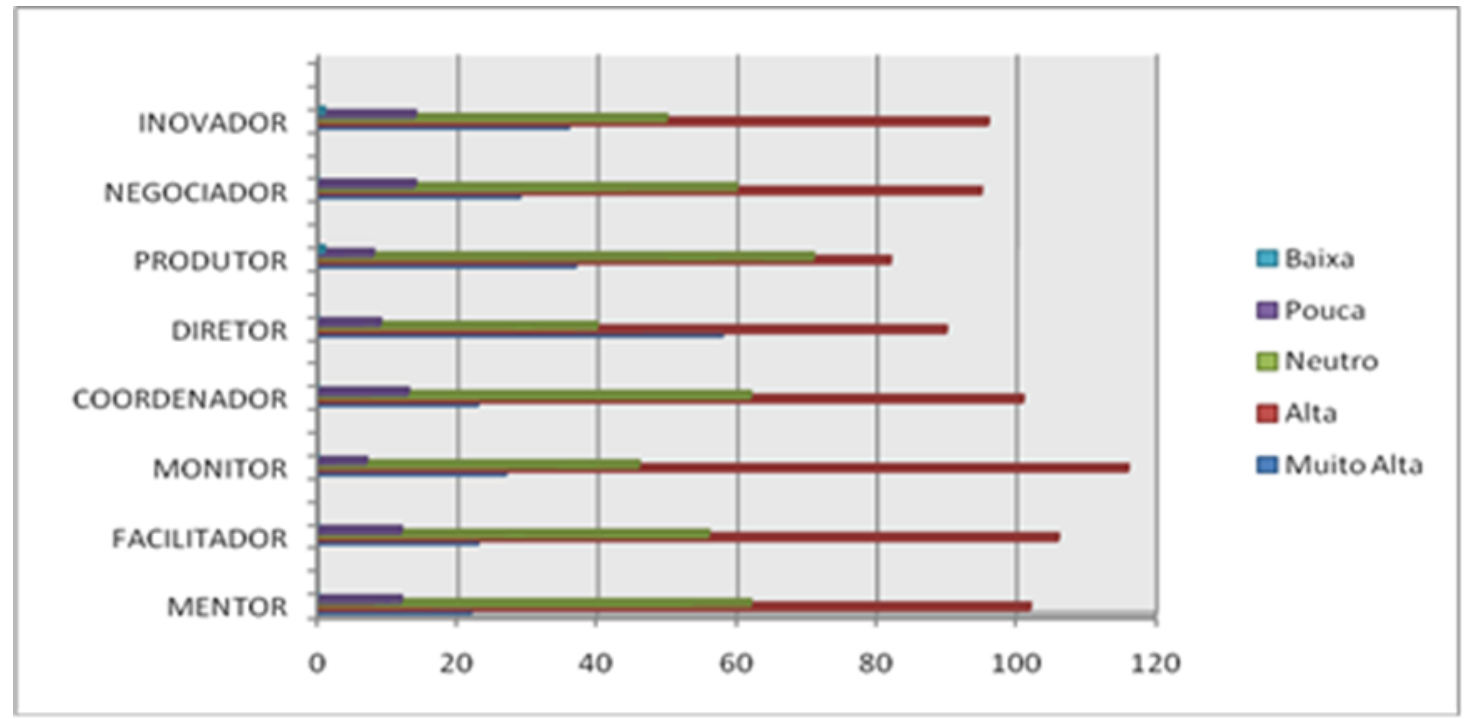

Figura 3: intensidades das contribuições em cada perfil de competência

Percebemos com clareza que a incidência que mais se destaca é o Monitor, com alta concordância, nas questões que formam o perfil. A análise que se faz é que realmente muitas disciplinas abordam temáticas sobre monitoramento de metas e desempenho de processos. Ao mesmo tempo que é importante para a atuação de um gestor, requer atenção para não tender a uma formação de niveis hieráquicos operacionais e táticos, em detrimento dos estratégicos.

A informação mais desejada, sem dúvidas, é saber-se qual a maior ocorrência de contribuição Muito Alta. Fica claro que o perfil Diretor obteve a maior incidência de respostas como contribuição muito alta do curso de Administração. Este fator é positivo mas deve sempre ser reforçado com características interpessoais e de condução de equipes.

Outro elemento que atrai o olhar é a verificação das maiores discordâncias, ou seja, qual o perfil que obteve menos contribuição no curso. Isto foi percebido no perfil Inovador. Realmente ao observarmos as disciplinas do curso, a atuação mais clara sobre a gestão da mudança e preparo para atuar com a inovação requer melhorias. Mesmo que seja um discurso muito atual, a gestão de mudanças, abordada no perfil do Inovador, não ficou devidamente clara para os alunos e estes não demonstraram que sentiram contribuição neste sentido. Não sentiram-se devidamente preparados para o tema de modo mais efetivo.

Outro fator que chama muito a atenção foi a grande incidência de opções "Neutro" em todos os perfis (visível na cor verde no gráfico 3). Optar por neutro, pode se entendido como uma falta de entendimento do acadêmico em julgar seu próprio preparo profissional. Certamente despertar no 


\section{Administração: caminhos para o desenvolvimento sustentável}

acadêmico o espírito crítico para julgar e exigir contribuição clara em sua formação é uma das grandes colaborações dos colegiados de curso e mesmo dos docentes.

Cabe porém salientar que a maior ocorrência da opção neutro, ao observarmos as questões individuais, foi marcada na questão que aborda gerenciamento do tempo e do estresse, no perfil Produtor. Muito embora este tema seja extremamente atual e muito abordado de modo transversal, o acadêmico não soube julgar se o curso o preparou para atuar efetivamente neste campo. Certamente nota-se aí uma possibilidade de destaque e até mesmo de um diferencial do curso, explorar mais esta competência, preparando o aluno para agir no ambiente empresarial de modo a mudar a realidade onde estiver inserido.

Ao olharmos também questões individuais, as maiores concordâncias (42 opções) foram nas questões de planejamento do trabalho e monitoramento do desempenho individual. É possível perceber uma tendência a uma atuação eficiente, porém pouco estratégica. Requer reflexão sobre o real interesse no curso em tal formação.

\begin{tabular}{|c|c|c|c|c|c|c|}
\hline & & |Muito Alta|A & & Neutro & Pouca & Baixa \\
\hline ID & Questāo / Tema & 5 & 4 & 3 & 2 & 1 \\
\hline W & quanto à compreensăo de mim mesmo e dos outros & 8 & 33 & 22 & 3 & 0 \\
\hline \multirow{5}{*}{ 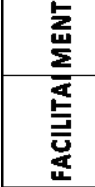 } & quanto à comunicar -me eficarmente & 8 & 34 & 19 & 5 & 0 \\
\hline & quanto a minha capadidade em desenvolver meus possiveis subordinados & 6 & 35 & 21 & 4 & $\mathbf{0}$ \\
\hline & quanto a minha capadidade de formar equipes & 9 & 36 & 17 & 3 & $\mathbf{0}$ \\
\hline & quanto ao uso de um processo decisório participativo & 7 & 36 & 18 & 5 & $\mathbf{0}$ \\
\hline & quanto ao gerendiamento de confilitos & 7 & 34 & 21 & 4 & $\mathbf{0}$ \\
\hline \multirow{6}{*}{ 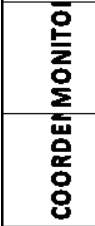 } & quanto ao monitoramento do desempenho individual & 5 & 42 & 17 & 1 & 0 \\
\hline & quanto ao gerenciamento de processos coletivos & 6 & $\mathbf{3 6}$ & 20 & 3 & $\mathbf{0}$ \\
\hline & quanto à análise de informaçỏes com pensamento critico & 16 & 38 & 9 & 3 & 0 \\
\hline & quanto ao gerenciamento de projetos & 4 & 30 & 25 & 7 & $\mathbf{0}$ \\
\hline & quanto ao planejamento do trabalho & 12 & 42 & 10 & 2 & $\mathbf{0}$ \\
\hline & quanto ao gerendiamento multidisciplinar & 7 & 29 & 25 & 4 & $\mathbf{0}$ \\
\hline \multirow{6}{*}{ 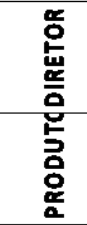 } & quanto ao desenvolvimento e comunicaçăo de uma visăo/missăo & 17 & $\mathbf{2 6}$ & 19 & 4 & 0 \\
\hline & quanto ao estabelecimento de metas e objetivos & 21 & $\mathbf{2 9}$ & 12 & 4 & $\mathbf{0}$ \\
\hline & quanto ao planejamento e organtzaçáo & 20 & 35 & 9 & 1 & 0 \\
\hline & quanto a produtividade do trabalho & 15 & 32 & 19 & & $\mathbf{0}$ \\
\hline & quanto ao fomento de um ambiente de trabalho produtivo & 15 & 31 & 19 & 1 & $\mathbf{0}$ \\
\hline & quanto ao gerenciamento do tempo e do estresse & 7 & 19 & 32 & 7 & 1 \\
\hline \multirow{6}{*}{ 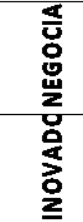 } & quanto a negociar com differentes bases de poder & 8 & 28 & 22 & 8 & $\mathbf{0}$ \\
\hline & quanto a negociar acordos e compromissos & 9 & 30 & 24 & 3 & $\mathbf{0}$ \\
\hline & quanto a apresentar idéias & 12 & 37 & 14 & 3 & 0 \\
\hline & quanto ao convivio com a mudança & 16 & 30 & 15 & 4 & 1 \\
\hline & quanto ao pensamento criativo & 11 & 34 & 15 & 6 & $\mathbf{0}$ \\
\hline & quanto ao gerenciamento e conduçăo de mudanças & 9 & 32 & 20 & 4 & $\mathbf{0}$ \\
\hline
\end{tabular}

Tabela 1: dados da pesquisa 


\section{Administração: caminhos para o desenvolvimento sustentável}

Com o intuito de confrontar as opções dos acadêmicos nas questões advindas do modelo de Quinn, com sua própria visão de estilo gerencial, foi aplicada uma questão onde o acadêmico precisou posicionar-se em um dos perfis. 0 resultado pode ser avaliado na figura 4, abaixo.

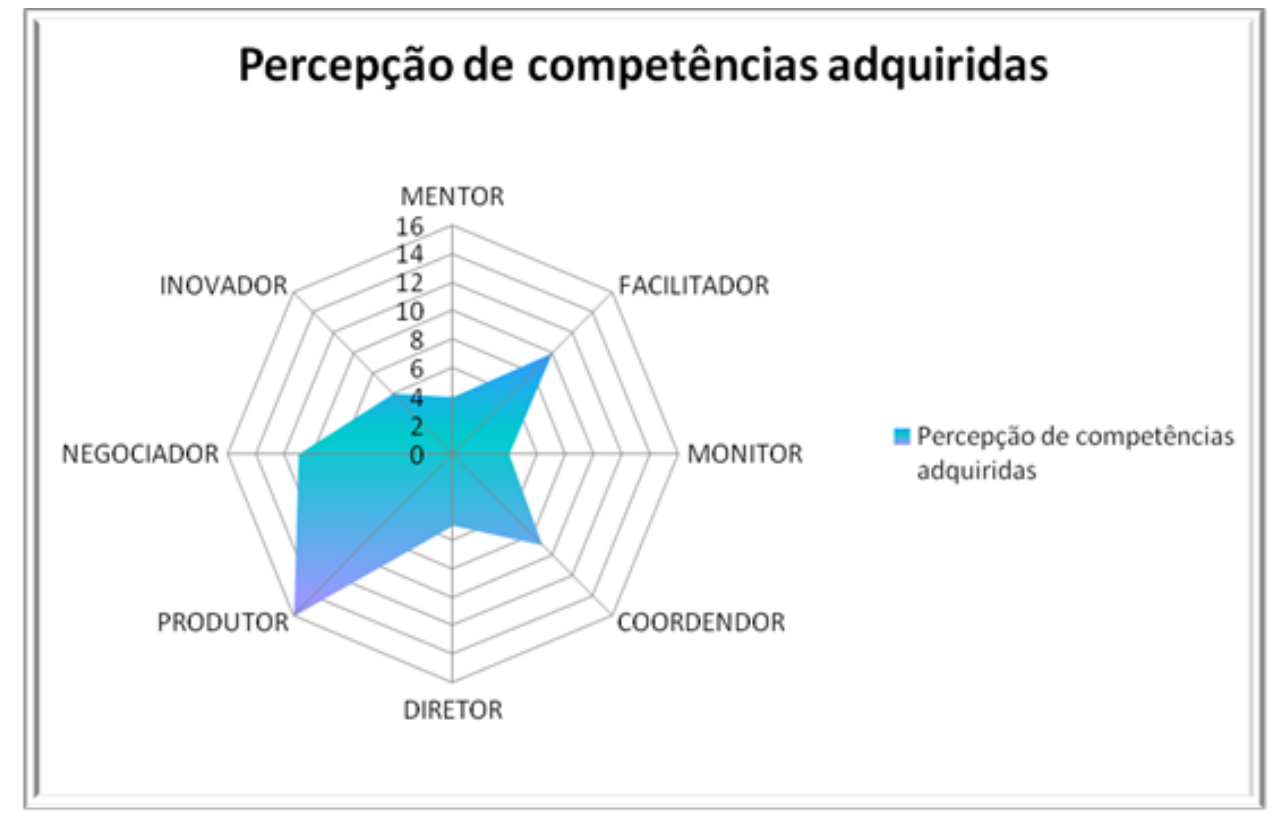

Figura 4: percepção de competências adquiridas

O perfil de competência gerencial Produtor obteve maior opção pelos acadêmicos. As conclusões possíveis certamente reforçam um perfil mais operacional. Se comparado com o Mentor, que obteve menor marcação, fica uma nuance que caracteriza um conjunto atitudinal ligado ao trabalhador assalariado, funcionário público ou outras opções profissionais mais ligadas à estabilidade.

A atuação profissional empreendedora, de profissional liberal e até mesmo de executivo de alto escalão tem demonstrações ainda tímidas, podendo ser trabalhadas em todas as dimensões do curso.

Positivamente notamos que os perfis Diretor, Coordenador e Facilitador obtiveram boas colocações e são perfis bastante solicitados pelo mercado de trabalho, com contribuição efetiva no ambiente organizacional.

De um modo geral, a autopercepção do aluno em ver-se mais como Produtor e menos como Mentor pode ser ligada ao momento de vida pelo qual estes passam. Como a grande maioria da turma é composta por jovens, ingressando no mercado de trabalho, buscando adequar-se ao máximo aos requisitos de competência exigidos pelas empresas, visando adotar posturas de produtividade, eficiência e bons resultados; entendemos o porquê desta característica. 


\section{Administração: caminhos para o desenvolvimento sustentável}

\section{CONCLUSÕES}

Com o levantamento realizado junto aos acadêmicos do curso de Administração sobre o perfil de Competências Gerenciais formadas pelo curso, percebe-se homogeneidade dentre os oito perfis (mentor, facilitador, monitor, coordenador, produtor, diretor, negociador, inovador) . Isto é possitivo se levarmos em consideração uma formação abrangente e flexível. Deixa para a reflexão se o curso não deveria ter uma identidade mais clara ou um diferencial que o destaque dentre outros cursos.

Alguns perfis, dos oito elencados por Quinn (2003) como os que agregam competências gerenciais, obtiveram destaque. O Diretor, Facilitador e Coordenador obtiveram elevados indices de contribuição percebida. Isto reflete um conjunto de caracteristicas em conformidade com os desejos atuais de atuação gerencial.

O perfil Mentor merece atenção, recomenda-se enfase no desenvolvimento de atitudes de liderança. Já o perfil Inovador requisita mais destaque das práticas que podem ser atendidas neste perfil, pois ambos obtiveram baixa contribuição na visão dos acadêmicos.

Ao serem convidados a optar por um dos modelos o Produtor elevou-se dos demais. Pode-se refletir sobre uma tendência ao jovem, formando, visualizar-se desta forma produtiva, desejando enquadrarse. Traz também a reflexão sobre a necessidade de incrementos em perfis empreendedores e inovadores.

O conhecimento acerca do perfil de formação disponibilizado é fundamental para qualquer curso que vise qualificar pessoas e alinhar-se ao feedback direcionando-o para o mercado e às novas demandas é primordial. O modelo Quinn (2003) demonstrou-se adequado tanto às demandas requeridas pelo mercado, bem como à muitas formações dispostas nos curriculos dos cursos de graduação ou mesmo profissionalizantes, assim, pode ser adotado periodicamente como uma forma de realinhamento e realimentação dos conteúdos e ações direcionadas aos estudantes.

No cenário atual, que vislumbra mais contribuição empreendeora e inovadora, os cursos podem valerse de instrumentos como este para readequarem suas abordagens e desenvolverem sua contribução de modo mais efetivo com sua realidade regional. 


\section{Administração: caminhos para o desenvolvimento sustentável}

\section{REFERÊNCIAS}

CARDOSO, AL. J. Percepções de gestores sobre competências gerenciais em diferentes contextos: estabilidade e mudança organizacional REBRAE. Revista Brasileira de Estratégia, Curitiba, v. 2, n. 2, p. 147-169, maio/ago. 2009

CHIAVENATO, Idalberto Gestão de Pessoas: o novo papel dos Recursos Humanos na Organização 3.ed. Rio de Janeiro: Elsevier, 2008.

BARROS, Conceição de Maria Pinheiro; SILVA, Joelma Soares da; LIMA, Geovana Alves de; SILVA BRITO, Daniela Graciela As Competências Gerenciais Desenvolvidas Pelos Secretáriosexecutivos. Revista de Gestão e Secretariado, vol. 4, núm. 2, julio-diciembre, 2013, pp. 25-47.

FREITAS, Pablo Fernando Pessoa de; ODELIUS, Catarina Cecília Competências gerenciais: uma análise de classificações em estudos empíricos Cad. EBAPE.BR, v. 16, no 1, Rio de Janeiro, Jan./Mar. 2018

GIL, Antonio Carlos Gestão de Pessoas: enfoque nos papéis profissionais, São Paulo: Atlas, 2008.

LOPES, Mauricio C. Análise da relação entre aptidões cerebrais e competências gerenciais: o caso de uma empresa têxtil. Gest. Prod., São Carlos, v. 17, n. 1, p. 123-136, 2010

MASCARENHAS, André O Gestão Estratégica de Pessoas São Paulo: Cengage Learning, 2008.

MAXIMIANO, Antônio Amaru Teoria Geral da Administração São Paulo: Atlas, 2000.

QUINN, R. E. et al. Competências gerenciais: princípios e aplicações. Rio de Janeiro: Elsevier, 2003.

PICCHIAI, D. Competências gerenciais: estudo de caso de um hospital público.Cadernos Gestão Pública e Cidadania, v. 13, n. 52, 2008.

PAIVA, K. C. M. \& FERREIRA, L. S. Competências Gerenciais na área de Tecnologia de Informação: um estudo com gestores de empresas localizadas no Triângulo Mineiro. Revista Gestão \& Tecnologia, 13(1), 205-229, 2013.

PLEBIANI, S. e DOMINGUES, M.J.C.S A utilização dos métodos de ensino e a formação de Competências gerenciais: uma análise no curso de Administração Anais XIX ENANGRAD, Curitiba, 2008. 


\section{Capítulo 47}

\section{UMA ANÁLISE SOBRE O ENVELHECIMENTO: A PERCEPÇÃO DOS GESTORES E DOS SUJEITOS DA TERCEIRA IDADE}

DOI: $10.37423 / 200300516$

Sthéfany Rhodes Cicarini, Centro Universitário Unifacig, Brasil). sthefanyrhoci@hotmail.com Rita de Cássia Martins de Oliveira Ventura, Centro Universitário Unifácig, Brasil). ritakmartins@hotmail.com Lilian Beatriz Ferreira< Longo, Centro Universitário Unifacig, Brasil). lilianfacig@hotmail.com Reginaldo Adriano de Souza, Centro Universitário Unifacig/Brasil). reginaldoberbert@hotmail.com
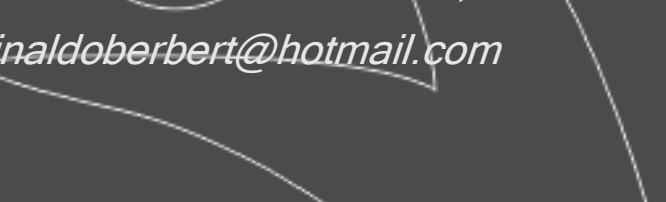

RESUMO: O envelhecimento populacional tem sido um importante reflexo do aumento da expectativa de vida, definindo novas mudanças ho perfil demográfico brasileiro. Diante dos diversos cenários a serem repensagdos com essa nova realídade, este artigo buscou analisar como esse fator influencia o mercado de trabalho na regiáo de Manhuaçu - MG, com o objetivo de compreender as percepções dos próprios sujeitos $\mathrm{e}$ dos gestores da área de recrutamento e seleção de diferentes empresas. A colleta dos dados realizada se deu por meio de uma entrevista com um roteiro semiestruturadb com gestores e, para os sujeitos da terceira idade, utilizou-se a técnica da história oral como proposta para-obter novos campos de investigação por meio de depoimentos pessoals e histöriàs de-vida.
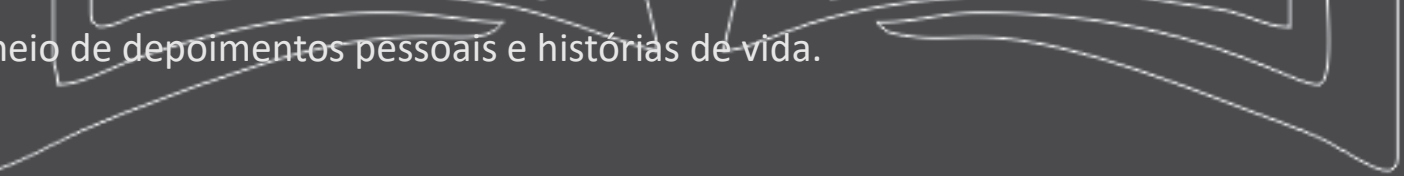


\section{Administração: caminhos para o desenvolvimento sustentável}

Entre as principais constatações obtidas verificou-se que os idosos ainda possuem capacidade laborativa, sendo muitas vezes mais ativos e saudáveis do que os jovens e possuindo atributos desejados pelo mercado. Ainda assim, mostrou-se que a idade não é um fator limitador, mas que variáveis como cultura, época vivida e histórias de vida são capazes de interferir nesse processo.

Palavras-chave: Aposentadoria; Envelhecimento; Mercado de Trabalho; Percepção; Reinserção. 


\section{Administração: caminhos para o desenvolvimento sustentável}

\section{INTRODUÇÃO}

A população brasileira está em trajetória de envelhecimento. Segundo uma projeção divulgada pelo Instituto Brasileiro de Geografia e Estatística (IBGE, 2018), o percentual de pessoas com mais de 65 anos passará dos atuais 9,2\% para 25,5\% até 2060. O motivo, segundo o IBGE (2018), pode estar presente no desacelerado crescimento populacional, sendo a redução da taxa de fecundidade uma de suas principais causas.

Diante disto, e com o aumento da expectativa de vida, a população mais madura tende a permanecer e almejar um lugar no mercado de trabalho. Entretanto, de acordo com Ximenes e Concone (2009), ainda há um estereótipo e uma cultura de valorização por pessoas jovens, vistas como mais vigorosas e produtivas, o que torna cada vez mais difícil inserir a chamada "terceira idade" dentro das organizações.

Estudos como os realizados por Kim e Moen (2001) revelam que aposentados que retornam ao mercado de trabalho são mais felizes e satisfeitos ao trabalharem por livre escolha. Por outro lado, é perceptível que existem reais dificuldades na empregabilidade dos trabalhadores mais velhos, aposentados ou não, no mercado de trabalho formal. Além disto, França e Stepansky (2016) questionam a natureza do envelhecimento e da aposentadoria, ressaltando a necessidade de avaliar estes conceitos no cenário atual do nosso país.

Sendo assim, considerando esse atual processo de envelhecimento, este estudo buscou analisar essa mesma realidade na região de Manhuaçu, pertencente a Zona da Mata de Minas Gerais que, consoantes projeções apontadas pelo IBGE (2018) e de acordo com Thuany do Jornal O Tempo (2018), será o Estado com maior número de idosos em todo o país, concentrando-se em uma média de $28,7 \%$ dessa população na região contra $25,5 \%$ no Brasil.

Desta forma, o objetivo da pesquisa é apresentar quais são os fatores que os gestores da região analisam ao contratar pessoas mais maduras ou o porquê não, e também, por meio da mesma perspectiva, buscar compreender como são os desafios enfrentados pela maior idade ao procurar se reinserir ou manter-se no mercado de trabalho formal ou informal, assim como as dificuldades encontradas por aqueles que estão trabalhando.

Usou-se o Artigo 1으 da Lei do Estatuto do Idoso como meio de selecionar os sujeitos de pesquisa. Desta forma, optou-se por uma pesquisa de campo, por meio do uso da técnica da história oral, com sujeitos 


\section{Administração: caminhos para o desenvolvimento sustentável}

com idade igual ou superior a 58 anos de idade. Quanto aos gestores, a pesquisa se deu por meio da acessibilidade dos mesmos, na qual os dados foram alcançados por meio de entrevistas semiestruturadas.

\section{REFERENCIAL TEÓRICO}

\subsection{ASPECTOS GERAIS DO ENVELHECIMENTO DA POPULAÇÃO BRASILEIRA}

O envelhecimento populacional é um proeminente fenômeno mundial e um acontecimento recente na população brasileira. Foi a partir de 1970 que o país teve seu perfil demográfico transformado de uma sociedade majoritariamente rural para a urbana (Leone, Maia \& Baltar, 2010) resultando em uma mudança gradativa do cenário demográfico de uma população jovem para um contingente maior de pessoas acima dos 60 anos, fenômeno que, conforme Berquó e Cavenaghi (2006) é explicado pela redução das taxas de mortalidade e fecundidade. "Quando as taxas de fertilidade e mortalidade se mantém baixas, há um progressivo aumento na proporção de adultos, na população, incluindo, naturalmente, os mais idosos" (Kalache, 1987).

A evolução da medicina, a ampliação dos programas de saneamento básico e o avanço tecnológico, além do advento dos métodos anticoncepcionais juntamente com a revolução feminina e sua inserção no mercado de trabalho, são fatores, segundo Carvalho (2009), determinantes no planejamento familiar e na alteração da formação da família, onde a média atual é de 1,77 filhos por mulher (IBGE, 2018).

Esse expressivo aumento da longevidade indica a necessidade de se compreender a velhice e suas consequências. Segundo dados do IBGE (2018), estima-se que a evoluçao do índice de Idosos no Brasil entre a faixa etária de 60 e 90 anos, no período de 2018-2060, passará do total de 28.025.302 milhões em 2018, para 73.460.946 milhões em 2060, totalizando mais que o dobro da nossa população idosa atual. Só em 2020, estima-se uma projeção média total de 30.197 .077 milhões de idosos compreendidos na mesma faixa etária.

No entanto, a questão econômica é um dos desafios que a longevidade brasileira enfrenta que a diferencia dos países em desenvolvimento (Kalache, 1987). De acordo com Almeida (2010) e Sampaio (2012), os valores pagos atualmente pelo setor previdenciário brasileiro são baixos, e muitas vezes não suprem as reais necessidades da população idosa no país, principalmente os que possuem altos gastos com medicamentos e com a saúde. Junto a isto, Miranda, Mendes e Da Silva (2016), ressaltam 


\section{Administração: caminhos para o desenvolvimento sustentável}

que o envelhecimento populacional traz consigo problemas estruturais que desafiam os sistemas de saúde e previdência social.

Sendo assim, tem-se como consequência uma alteração da estrutura social, onde o envelhecimento exerce impacto direto na economia de um país e, no que concerne a relação com a aposentadoria, gera um impacto duplo onde de um lado o Estado passa a assumir o pagamento do benefício aos aposentados e, do outro lado, deixa de receber a contribuição, já que eles saem do mercado de trabalho mesmo que outros ainda permaneçam (Carvalho, 2009).

Desta forma, um dos caminhos possíveis do Brasil é seguir a tendência de outros países em aumentar a idade mínima de aposentadoria, fato importante para que o indivíduo não saia do mercado de trabalho. Esse envelhecimento populacional juntamente com as pressões no sistema previdenciário, de acordo com o Instituto de Pesquisa Econômica Aplicada - IPEA - (2010) acarretará na necessidade de manter o trabalhador em atividade por mais tempo, requerendo uma maior capacitação quanto às mudanças tecnológicas e políticas para a redução de preconceitos com a idade.

\subsection{INSERÇÃO DO IDOSO NO MERCADO DE TRABALHO FORMAL E INFORMAL}

Por muito tempo, o Brasil foi caracterizado como um país em que os jovens eram predominantes, onde as políticas de emprego direcionavam-se principalmente a este público. Ainda hoje, grande parcela de trabalhadores são formados pelos mais jovens. Porém, o envelhecimento é um fenômeno real e muitos idosos continuam trabalhando por diferentes motivos. Conforme Derroso e Oliveira (2018), em uma sociedade cuja percepção de um bom desempenho organizacional se baseia na produtividade, a relação entre o trabalho e o envelhecimento pode parecer complicada, e a valorização de mão de obra tende a ser mais robusta e jovem.

Todavia, há muitas pessoas idosas que ainda manifestam a vontade de permanecerem trabalhando ou de iniciarem novas atividades laborais. Além disso, consoante a Política Nacional do Idoso na Lei n. 8.842/94 e no Estatuto do Idoso n. 8.842/2003, é direito do idoso permanecer ou voltar ao mercado de trabalho, mesmo já aposentado, desde que as condições próprias da idade sejam respeitadas.

Segundo Camarano, Kanso e Mellho (2004), a importância do trabalho para a pessoa idosa está relacionada a uma renda mais elevada, ao indicador de autonomia física e mental e a maior integração social. O trabalho alcança dimensões significativas para os idosos, além de contribuir financeiramente 


\section{Administração: caminhos para o desenvolvimento sustentável}

ou como forma de auxiliar no orçamento familiar, visto que na medida que podem se sustentar também adquirem a possibilidade de garantir sua liberdade e autonomia (Carvalho, 2009).

Argimon, Lopes e Nascimento (2006), por exemplo, alegam que a importância do trabalho é comprovada para uma melhor qualidade de vida dos idosos, já que influencia no desenvolvimento físico, cognitivo e emocional destes. Por sua vez, Souza, Matias e Brêtas (2010) argumentam que além da proporção financeira como forma de satisfazer as necessidades humanas, o trabalho funciona como um elemento central da manutenção da autoestima.

Cabe também pontuar que a aposentadoria não mais representa o desligamento da esfera do trabalho. Segundo Alcântara, Camarano e Giacomin (2016), embora o recebimento da aposentadoria tenha o propósito de atender aos trabalhadores que estiveram em situação de risco - como a aposentadoria por invalidez - ou daqueles que chegaram à idade - aposentadoria por idade, ela passou a ser uma fonte de renda aos idosos.

A. M. Oliveira, E. L. Oliveira e Wajnman (2004) destacam que os idosos que possuem maior probabilidade de se manterem ocupados com idades mais avançadas são os que possuem maior nível de escolaridade. Corroborando com esta reflexão, Ladeira, D. V. F. Costa, Ferreira, Nascimento e M. P. C. Costa (2017) salientam que a baixa escolaridade, o alto nível de exigência e a qualificação criteriosa também podem contribuir para que o número de pessoas mais velhas inseridas no mercado de trabalho formal seja menor do que daqueles que gostariam de compor esse grupo, o que faz com que muitos idosos acabam se inserindo no mercado de trabalho informal ou o subemprego.

De Almeida, De Andrade Carmo e Da Silva (2013) também afirmam isto ao salientar que a elevação dos índices de desemprego e as dificuldades de se ter um emprego formal, devido as exigências feitas pelo empregador, faz com que o número de trabalhadores informais aumente. $\mathrm{O}$ indivíduo, segundo os mesmos autores, vivendo em um momento de necessidade e em busca de alguma renda, vê na atividade informal uma opção, fato presente no cotidiano dos idosos.

A esse respeito, Cockell e Perticarrari (2011) explicam também que o atual modelo de aposentadoria por idade ou por tempo de contribuição apresenta uma série de obstáculos para os trabalhadores informais. Isto porque muitos deles apresentam trajetórias ocupacionais instáveis e encontram dificuldades para computar o tempo de serviço concomitante às atividades rurais e urbanas. 


\section{Administração: caminhos para o desenvolvimento sustentável}

Sendo assim, esse aumento do envelhecimento da população brasileira vem gerando uma eventual mudança no comportamento desse grupo no que tange a seus estilos de vida e decisões, mas principalmente em sua participação no mercado de trabalho. Segundo dados do IPEA (2018), do total de trabalhadores ocupados com mais de 60 anos no Brasil, $46 \%$ trabalham por conta própria no trabalho informal e $27 \%$ no trabalho formal.

Tendo em vista que na sociedade capitalista atual o valor está intimamente ligado ao fato do indivíduo ser um participante produtivo da economia formal, ainda há uma associação do envelhecimento com características negativas, em que os mais velhos são tratados como cidadãos que nada mais têm a oferecer à sociedade, onde a discriminação tende a se apresentar no cotidiano dessas pessoas (Silva, 2014).

\subsection{ESTERIÓTIPOS AO PROFISSIONAL MADURO}

Envelhecer é um processo que ocorre de maneira singular para cada indivíduo. Conforme Beauvoir (1990) a velhice possui uma dimensão além dos aspectos biológicos e psicológicos que modificam a relação do indivíduo com o tempo. Todavia, o envelhecimento não representa um estado somente natural, sendo que, como em qualquer idade, ela também é fruto de um estatuto imposto pelo fator cultural da sociedade à qual pertence.

Ampliando estes conceitos, Debert (1997) aponta que apesar do envelhecimento biológico ter ligação com a idade dos indivíduos, todas as demais variáveis relacionadas ao envelhecimento devem ser consideradas, tais como a cultura, época vivida e também as histórias de vida que se variam, não sendo possível, assim, traçar um determinante preciso sobre este conceito e pensar a questão do envelhecimento como uma homogeneidade.

No aspecto do mercado de trabalho, pela percepção capitalista - pautada pela busca de produção e lucro -, a fase da velhice é vista também como uma fase de incapacidade e improdutividade, onde o trabalhador mais velho acaba por internalizar esse conceito, muitas vezes assumindo uma postura passiva de substituição pelos mais novos, além de se inserir na ideia que não é mais adaptável ao contexto do trabalho (Derroso \& Oliveira, 2018).

Essa cultura de valorização da juventude e da ideologia preconceituosa sobre a idade interfere na maneira como se olha o envelhecimento, e o mercado de trabalho ainda não compreende como 


\section{Administração: caminhos para o desenvolvimento sustentável}

utilizar as competências dessas pessoas que ainda desejam permanecer ativos e produtivos (Júnior et al., 2009).

Conforme Derroso e Oliveira (2018), muitos gestores ainda possuem uma perspectiva distorcida quanto ao desempenho e qualidade do trabalho desse público. Porém, Loretto e White (2006) abordam que há empregadores que mostram possuir preferência pelos mais velhos por conta das experiências e o comprometimento com o trabalho.

Junto a isto, muito se engana quem ainda vê o idoso por trás dos estereótipos. Ladeira et al. (2017) destacam as mudanças acerca das variáveis relacionadas ao trabalho, tais como a criatividade e o crescimento intelectual. Sendo assim, segundo o mesmo autor, as sociedades passaram a se deparar com um grande número de idosos que vem apresentando um perfil bastante diferente de alguns anos atrás. "São pessoas mais ativas, saudáveis e principalmente, ainda produtivas" (Ladeira et al., 2017, p.6).

Ademais, D'Alencar e Campos (2006) afirmam que independente do setor, as pessoas mais velhas que procuram um novo emprego, ganham em qualidade de vida, pois além de ganharem uma renda extra, previnem a ociosidade e aumentam a autoestima por sentirem-se ativas e úteis. Júnior et al. (2009), também afirmam que a ocupação do mais velho depois da aposentadoria denota melhores condições de saúde, maior autonomia e mobilidade física, menor dificuldade em exercer tarefas domésticas diárias e maior possibilidade de aumentar a escolaridade.

Posto isto, Posthuma e Campion (2009) apontam atitudes positivas ao contratarem essas pessoas nas organizações, sendo eles a maior confiabilidade, flexibilidade, compromisso, lealdade, pontualidade, respeito pela autoridade, ética experiência, baixo absenteísmo, qualidade do trabalho, facilidade em disseminação da cultura organizacional para os profissionais mais jovens e estabilidade no emprego.

Desta forma, é possível perceber que hoje, o índice de desemprego dos adultos mais velhos se dá mais devido à falta de oportunidades educacionais, do treinamento em serviços e dos preconceitos do que o envelhecimento em si (Néri, 2002). 


\section{Administração: caminhos para o desenvolvimento sustentável}

\section{DELINIAMENTO METODOLÓGICO}

A fim de atingir os objetivos propostos neste estudo, foi realizada uma pesquisa do tipo descritiva com uma abordagem qualitativa utilizando-se para a coleta dos dados as técnicas da história oral, com os sujeitos de pesquisa, e da entrevista semiestruturada com os gestores.

Conforme Gil (2002), uma pesquisa descritiva tem como objetivo primordial descrever as características de determinada população ou fenômeno ou uma relação entre as variáveis. Segundo o mesmo, essa forma de pesquisa visa proporcionar novas visões sobre uma realidade podendo ir além da descoberta da relação entre as variáveis, servindo para proporcionar uma nova visão do problema (Gil, 2002).

Uma abordagem qualitativa possibilita o emprego de diferentes estratégias de investigação, métodos de coleta, análise e interpretação de dados (Creswell, 2010). É uma abordagem mais flexível, tornando-se mais adaptável as múltiplas realidades além de expor com mais clareza a natureza da troca entre o investigador e o entrevistado.

Já a técnica da história oral caracteriza-se por ser um recurso que, segundo Da Cw Menegolo; Cardoso e Menelogo (2006) possibilita a percepção de acontecimentos do passado do depoente como algo que tem continuidade e sequência histórica, permitindo alterar o enfoque da própria história e revelar novos campos de investigação, podendo derrubar barreiras entre gerações, instituições e percepções.

Outro instrumento de coleta de dados foi a entrevista semiestruturada caracterizada pela realização de questionamentos básicos apoiados em teorias e hipóteses que se relacionam ao tema da pesquisa (Triviños, 1987). Para Manzini (1990) esse tipo de entrevista pode fazer emergir informações de forma mais livre com elaboração de perguntas básicas e principais para atingir o objetivo da pesquisa, semelhante a uma conversa informal.

Como cenário de pesquisa, tem-se a cidade de Manhuaçu-MG, pertencente a Zona da Mata de Minas, como campo de análise. Com uma população média de 89.200 habitantes (IBGE, 2018) e tendo como base de sua economia a produção, distribuição e comercialização do café, a cidade conta com uma boa prestação de serviços, tornando-se um grande polo comercial da região.

Para a formação do grupo pesquisado, foram definidos cinco critérios para a participação no estudo: I) Aposentados que não trabalham; II) Aposentados que trabalham como autônomos; III) Aposentados 


\section{Administração: caminhos para o desenvolvimento sustentável}

funcionários de empresas; IV) Não aposentados funcionários de empresas e V) Não aposentados autônomos. Já para os gestores, o critério necessário para o estudo foi apenas um: ser gestor responsável pelo setor de recrutamento e seleção de uma organização.

Ambas as escolhas dos sujeitos de pesquisa se deu pela acessibilidade e, quanto à quantidade de sujeitos aposentados que ainda trabalham (autônomos e funcionários de empresas), as entrevistas se deram por meio do método de saturação, quando o pesquisador cogita a ocorrência de uma espécie de descarte dos dados porque houve uma repetição dos mesmos gerando uma redundância de informações (Barcellos Fontanella \& Magdaleno Júnior, 2012). Desta forma, foram entrevistados dois gestores e doze sujeitos com 58 anos de idade ou mais, sendo o conteúdo do relato gravado e transcrito na íntegra para a análise de dados.

\section{ANÁLISE DE RESULTADOS}

Para entender a percepção dos indivíduos que se encontram no grupo da terceira idade, buscou-se com este estudo identificar o ponto de vista dos mesmos sobre diferentes contextos que dificultam ou corroboram com o processo de inserção deste público no mercado de trabalho, abrangendo aspectos biológicos e fisiológicos assim como os socioeconômicos e culturais.

O grupo pertencente a esta categoria deu-se por doze indivíduos acima de 58 anos, sendo eles de áreas urbanas e rurais. Dentre eles, 9 são aposentados e 3 ainda estão para se aposentar. Quanto à ocupação profissional, 6 são autônomos, 4 são funcionários de empresas e 2 não exercem nenhuma atividade laborativa.

Quanto a categoria de gestão, o grupo ficou composto por dois gestores de empresas de grande porte da região, onde jovens e idosos compõe seu quadro de funcionários. Tornando este um ponto relevante na pesquisa para melhor compreensão de suas percepções e fatores de influência quanto à contratação de novos colaboradores. 


\section{Administração: caminhos para o desenvolvimento sustentável}

\begin{tabular}{|c|c|c|c|c|c|}
\hline ENTREVISTADOS & IDADE & APOSENTADO & $\begin{array}{c}\text { GRAU DE } \\
\text { ESCOLARIDADE }\end{array}$ & $\begin{array}{c}\text { CATEGORIA } \\
\text { PROFISSIONAL }\end{array}$ & PROFISSÃO \\
\hline E1 & 59 & Não & Sup. Completo & Empregado & $\begin{array}{c}\text { Assistente De } \\
\text { Secretaria }\end{array}$ \\
\hline E2 & 58 & Sim & Pós Graduação & Empregado & $\begin{array}{c}\text { Coordenador De } \\
\text { Curso Ead }\end{array}$ \\
\hline E3 & 65 & Sim & Mestrado & Empregado & $\begin{array}{c}\text { Professor De Ensino } \\
\text { Superior }\end{array}$ \\
\hline E4 & 83 & Sim & $2^{\circ}$ Grau Completo & Autônomo & Comerciante \\
\hline E5 & 61 & Sim & $2^{\circ}$ Grau Completo & Autônomo & Comerciante \\
\hline E6 & 58 & Não & Sup. Completo & Empregado & $\begin{array}{c}\text { Gerente Adm. } \\
\text { Financeiro }\end{array}$ \\
\hline E7 & 70 & Sim & $2^{\circ}$ Grau Completo & Aposentado & Não Exerce \\
\hline E8 & 58 & Sim & $2^{\circ}$ Grau Completo & Autônomo & Trabalhadora Rural \\
\hline E9 & 72 & Sim & $1^{\circ}$ Grau Incompleto & Aposentado & Não Exerce \\
\hline E10 & 58 & Não & $1^{\circ}$ Grau Incompleto & Autônomo & Trabalhador Rural \\
\hline E11 & 91 & Sim & Pós Graduação & Autônomo & Médico \\
\hline E12 & 58 & Sim & Pós Graduação & Autônomo & Dentista \\
\hline
\end{tabular}

QUADRO 1 - Perfil da Amostra Pesquisada

\subsection{ANÁLISE DESCRITIVA DOS GESTORES}

Para este grupo, selecionou-se questões relacionados aos i) desafios e benefícios encontrados em ter esses funcionários na organização; ii) os critérios que são analisados no processo de contratação; iii) as diferenças percebidas entre as gerações quanto ao trabalho; iv) percepção quanto ao futuro da terceira idade e o mercado de trabalho; e v) sobre os estereótipos que são atribuídos a eles.

Começando com os desafios e os benefícios, ambos gestores reconhecem os pontos positivos que essa classe trabalhadora pode oferecer à organização ao relatarem unanimidade em suas respostas, onde dizem que "o trabalho que eles fazem são de mais qualidade" (G1, G2); passam mais confiança ao realizar com mais resultado o mesmo serviço realizado pelo mais jovem além de possuírem mais preocupação e dedicação na execução das tarefas (G2), são mais comprometidos (G1, G2), não faltam ao serviço por qualquer motivo e costumam ser mais tranquilos e sábios (G1). Confirmando as análises de Derroso e Oliveira (2018) quando dizem que um dos pontos positivos desse público é o baixo absenteísmo, a qualidade no trabalho, a lealdade e experiência.

Tais fatores também podem ser confirmados pelas percepções dos gestores ao compará-los com os mais jovens, no qual relatam que os mais velhos são mais proativos, conseguindo realizar além de suas atribuições (G1), possuem mais compromisso com o horário e com suas obrigações (G2), possuem mais experiência $(G 1, G 2)$ e estão se tornando muito mais ativos, produtivos e saudáveis do que os 


\section{Administração: caminhos para o desenvolvimento sustentável}

mais novos (G1). Enquanto isso, os mais novos não possuem compromisso com o trabalho e acham que a qualquer momento irão sair da empresa (G2), faltam por qualquer motivo e sempre alegam que estão doentes (G2), e que "eles não aceitam receber a tarefa que the é proposta, estão sempre querendo mais, o que as vezes até ajuda, mas nem sempre. " (G1).

Porém, houve também alguns pontos positivos a se considerar quanto aos mais jovens, principalmente em relação às suas condições fisiológicas, que os tornam vantajosos para a organização, além de fatores como a agilidade, o estudo, a capacitação e maior acesso à tecnologia (G1, G2).

Quanto aos desafios analisados sobre esses trabalhadores mais maduros, observou-se como percepção as questões naturais advindas com a idade, mas também os estereótipos que são formados que podem interferir na forma como eles se vêm e se comportam. Por meio disso, os gestores alegam que muitos, mesmo sendo ativos fisicamente, possuem uma certa dificuldade quando precisam pensar muito (G1), outros já possuem dificuldades físicas na execução das tarefas, em que a capacidade diminui um pouco (G1), e há aqueles que se acomodam, por saberem que possuem experiência e por estarem há mais tempo na empresa (G2). Além disso, percebem também que:

às vezes eu vejo que é a própria pessoa mais velha que coloca obstáculo sobre sua própria idade. Eles acham que tudo que acontecem é porque são mais velhos, criando suas próprias barreiras. Percebo que são inseguros em perder o espaço que conquistaram pelos mais jovens. (G1)

Tal afirmativa do gestor confirma as análises de Derroso e Oliveira (2018) sobre a percepção da velhice e a interiorização desses estereótipos sobre o mais velho.

Em relação aos jovens, ao ser ressaltado sobre uma de suas principais características, a agilidade, ambos gestores afirmam que tal fator nem sempre pode ser considerado algo vantajoso para essa classe trabalhadora e para a organização: "[...] porque nem sempre o mais rápido será o ideal, ele pode ser o mais demorado, pois o mais novo pode fazer mais rápido, mas as vezes da retrabalho. E o do mais velho pode ser mais lento, mas é um serviço que faz uma vez só." (G1). "[...] eu vejo muitos ai que são acelerados demais e faz o dobro do que o outro colaborador mais velho, mas só que o retrabalho as vezes é também o dobro daquele que faria de forma mais devagar." (G2)

Entretanto, tais percepções contradizem as de Derroso e Oliveira (2018) ao alegarem que o mercado de trabalho olha a velhice como uma fase de incapacidade e improdutividade, sendo que os gestores conseguem perceber a produtividade dos mais velhos em detrimento da agilidade dos jovens. Além 


\section{Administração: caminhos para o desenvolvimento sustentável}

disto, no processo de recrutamento e seleção, ambos entrevistados possuem critérios unânimes em suas organizações, ao afirmarem que muitas vezes preferem pessoas experientes às mais novas (G1, G2), concordando com as afirmações de Loretto e White (2006). Os mais velhos possuem muito mais sabedoria e conhecimentos para agregar nas empresas (G1); e que o principal critério a se analisar é a qualificação para o serviço, independentemente da idade, possuindo um equilíbrio em saber usar o trabalhador correto no setor correto (G1, G2). "Alguns são mais sábios, e tem muito a nos ensinar. Realizam o serviço bem feito e se hoje eu precisar contratar uma pessoa igual a essa eu não botaria nenhum obstáculo, nem mesmo quanto a idade." (G1).

Tal análise contradiz as afirmações de Júnior et al (2009) ao dizerem que o mercado de trabalho não compreende como utilizar e não reconhece a capacidade dessas pessoas, sendo que, no cenário desta pesquisa, ambos gestores reconheceram as características que valorizam esse público e sabem como e quando utilizarem da melhor forma para a sua organização.

Quanto ao futuro, um deles percebe que a questão é que muitos idosos estão voltando para o mercado muito mais ativos e com mais vontade do que os jovens, além da sabedoria, paciência, comprometimento, responsabilidade e honestidade, fatores que tem atraído as empresas (G2). Porém, ressaltam algumas inseguranças e divergências quanto a inserção da terceira idade no mercado de trabalho em que, enquanto um crê na necessidade de criar meios de adaptação como programas de inserção (G1), outro pensa que não haverá essa mesma necessidade, até porque "o próprio mercado já vem se ajustando para esses novos trabalhadores, então eles que necessitam se ajustar ao mercado também" (G2). Junto a isto, pensam que, com essa nova tendência, é provável que no futuro sejam criadas outras ordens legais para que as empresas se adequem a esta nova oferta e tenham que se adaptar, como aos programas do jovem aprendiz (G1).

Sendo assim, observa-se que as percepções dos gestores possuem certas similaridades quanto aos aspectos contratuais, valorização e reconhecimento dessa força de trabalho, não indo de encontro a alguns aspectos analisados por Derroso e Oliveira (2018) sobre uma maior valorização por parte dos gestores pelo trabalhador jovem. Além disto, quanto aos estereótipos, também nota-se uma divergência quanto as afirmações dos mesmos autores, pois ambos gestores analisam pontos positivos e características valorosas a estes trabalhadores, concordando assim com preceitos de Beauvior (1990) e Debert (1997) em não definir o conceito de envelhecimento como uma homogeneidade, mas pensar que há infinitos fatores que influenciam esta percepção dos sujeitos da terceira idade. 


\section{Administração: caminhos para o desenvolvimento sustentável}

\subsection{ANÁLISE DESCRITIVA DOS NÃO APOSENTADOS}

Dentre os entrevistados da terceira idade, três indivíduos compõem esta categoria: E1, E6 e E10. Sendo o E10 pertencente à zona rural como trabalhador autônomo, e os demais como funcionários de empresas na zona urbana.

Para o delineamento deste relato, foram abordadas questões relacionados aos i) motivos que os levam a quererem ou não continuar a trabalhar depois da aposentadoria; ii) quais os desafios enfrentados em relação ao trabalho, incluindo os estereótipos e os aspectos fisiológicos da idade; e iii) quais as percepções que possuem quanto ao futuro, abordando os medos e inseguranças, principalmente quanto ao mercado de trabalho e aos trabalhadores jovens.

No que se refere a continuarem trabalhando depois da aposentadoria, os três entrevistados afirmam que um dos motivos é porque ainda se sentem ativos e hábeis para continuar a trabalhar por mais tempo, não vendo a idade como um limitador inicial. "Em relação a minha pessoa, eu ainda me sinto jovem. Sinto que aguentaria trabalhar por uns 20 anos" (E6). Junto a isto, eles vêm o trabalho como sinônimo de motivação e de uma melhora na saúde (E10), e também como algo belo, de valor e digno de honra (E1, E6).

Quanto ao segmento de trabalho, E1 e E10 dizem que desejam continuar a realizar a atividade atual, enquanto o E6 pensa em montar seu próprio negócio depois da aposentadoria. Quanto a isso, E1 diz que um dos motivos de querer continuar na empresa é que “(...) se eu sair daqui, pela minha idade, eu penso que eu não encontre outro lugar. Eu estou bem onde estou hoje, e começar tudo de novo em uma outra empresa será difícil, porque eu descobri aqui que eu sei fazer de melhor". Já para E6, montar um próprio negócio é um desejo de aprender além do segmento de mercado no qual trabalha há anos e descobrir novas habilidades, onde a aposentadoria entraria como uma fonte de renda extra.

Porém, um ponto relevante a se considerar foi explanado por E10, em que, ao ser questionado sobre o porquê continuar a trabalhar na zona rural, esclarece que:

Para eu arrumar um emprego, eu acho que pela minha idade eu não consigo, porque eu só tenho até a 4a série, eu não consegui estudar. Então eu sei que pra mim é muito difícil por conta disso, então eu tenho que continuar a trabalhar na roça. [E10]

Tal postura aponta dois aspectos: o estereótipo internalizado no indivíduo sobre como o mercado capitalista o vê, confirmando as reflexões de Derroso e Oliveira (2018) e o reconhecimento de que o 


\section{Administração: caminhos para o desenvolvimento sustentável}

maior nível de escolaridade abre mais portas no mercado, fator afirmado por A. M. Oliveira, E. L. Oliveira e Wajnman (2004). Nesta mesma linha de raciocínio, confirma-se as ideias de Ladeira et al (2017) sobre a atividade informal se tornar uma opção devido à baixa escolaridade e o alto nível de exigência e qualificação do mercado.

Ainda sobre os estereótipos, os sujeitos E1 e E6 apontam que não se sentem, diretamente, atingidos por isso, mas reconhecem que devido à idade, encontrarão dificuldades em se reinserirem no mercado. "Um vez uma chefe já havia me dito que se eu saísse da empresa, com o meu jeito e a minha idade, seria difícil eu me empregar novamente." (E1).

Além destes aspectos, os três sujeitos também abordam que a escolha em continuar a trabalhar depois da aposentadoria seria como uma forma de aumentar a renda, uma vez que reconhecem que o valor não é suficiente, concordando com Almeida (2010) e Sampaio (2012) sobre o setor previdenciário brasileiro.

Quanto aos desafios enfrentados, os três apresentam respostas unânimes, boa parte relacionado as questões fisiológicas, como a oscilação de energia ao longo do dia e a diminuição do raciocínio rápido (E1, E6 e E10). Porém, também abordam com uniformidade que nenhum desses fatores é capaz de limitá-los e que, ao contrário dos estereótipos criados sobre suas capacidades produtivas, eles possuem muito mais saúde, devido ao avanço da medicina (E6); a idade não é um limitador (E10); e que é a personalidade de um indivíduo, como o comprometimento e a vontade de trabalhar, que devem ser usados como "medida" para defini-los, e não a idade (E6).

No que se refere ao futuro, houve relatos de insegurança e medo em relação a aposentadoria e as mudanças das leis previdenciárias, tal como as doenças e limitações que são mais propícias com a maior idade: "Eu sinto que devido a minha limitação e forma de trabalhar, vai chegar um tempo que as vezes eu não vou conseguir acompanhar o crescimento da empresa. " (E1). "[...] daqui a dois anos eu vou me aposentar, mas eu não sei como vai ser até lá, porque as leis estão mudando muito, e não temos como confiar. O meu medo então é de não conseguir me aposentar." (E10)

Ainda assim, quanto as opiniões em relação aos jovens e as tecnologias, E1 diz que as questões tecnológicas são complicadas, onde as transformações acontecem muito rápido em que fica difícil acompanhar. Já para E6, a tecnologia é vista como mais vantajosa para os mais jovens, pois possuem mais facilidade por terem nascido no auge do seu desenvolvimento. 


\section{Administração: caminhos para o desenvolvimento sustentável}

Aprofundando a questão dos jovens, como pares no local de trabalho, os três se sentem seguros, não os vendo como uma ameaça e reconhecendo que a experiência e o valor que possuem pelo trabalho são seus principais diferenciais. "Nós valorizados o trabalho e trabalhamos porque gostamos, e isso é diferente do que os que estão entrando agora". (E6).

Desta forma, depreende-se que os sujeitos apresentam inseguranças quanto as alterações previdenciárias, reconhecendo também suas limitações físicas naturais e os possíveis preconceitos enfrentados quanto a idade. Junto a isto, constatou-se, pela análise de E10, a afirmação de Ladeira et al (2017) sobre os trabalhadores mais escolarizados possuírem maiores oportunidades no mercado de trabalho e, por meio de E6, sobre as novas possibilidades que surgem depois da aposentadoria, podendo ter na atividade informal uma nova opção de renda e de trabalho, aperfeiçoando suas habilidades e mantendo sua autoestima, como afirmam Argimon, Lopes e Nascimento (2006).

\subsection{ANÁLISE DESCRITIVA DOS APOSENTADOS}

Sobre os aposentados, o grupo compõe-se por 9 indivíduos, sendo 7 (E2, E3, E4, E5, E8, E11, E12) que ainda exercem atividade laborativa e 2 (E7, E9) que não exercem nenhuma atividade remunerada. Dos sujeitos que ainda trabalham, E4, E5, E8, E11, E12 são autônomos, e E2, E3 são funcionários de empresas.

Nesta categoria, buscou-se compreender as perspectivas dos sujeitos sobre as mesmas temáticas abordadas anteriormente, no grupo dos não aposentados. Desta forma, percebeu-se uma familiaridade com as respostas dos sujeitos anteriores, mesmo sendo indivíduos de contextos sociais diferentes quanto à aposentadoria.

No tocante a continuarem a trabalhar, alguns alegam que, por terem começado a trabalhar muito cedo, ainda se sentem ativos para continuarem (E3, E12), outros já decidiram continuar para não ficarem ociosos dentro de casa (E11), e que trabalhar traz uma mudança de vida e outros bons hábitos para a saúde (E4). Além disso, é uma forma de não envelhecer a cabeça (E11), e que os auxiliam a passar as fases da maior idade com mais entusiasmo, com maior interação social e mais autoestima (E2), além de manter contato com as pessoas e de estabelecer a troca de experiências que fazem bem para a mente, não os fazendo se sentir tão "velhos" (E12). Tais fatores apontam que o trabalho para estes indivíduos está atrelado a outros valores, que não só financeiros, mas de bem estar pessoal e 


\section{Administração: caminhos para o desenvolvimento sustentável}

até mesmo pela saúde mental e física, além da autoestima, confirmando com Argimon, Lopes e Nascimento (2006).

Porém, há também aqueles que trabalham como uma forma de complementar a aposentadoria, alegando que, como a aposentadoria vai defasando com o passar do tempo, e que seu valor não é suficiente para sobreviver (E9), torna-se necessário procurar uma forma de inteirá-la, “(...) de forma que a gente consiga alguma coisa a mais na vida." (E5). "Além da aposentadoria, eu também vendo legumes e verduras, que me ajuda a ter uma renda extra, porque se for pra manter a gente em um padrão regular de vida, o salário não é suficiente." (E8). “Hoje eu trabalho mais tranquila porque já estou aposentada, e claro que também olhamos a parte financeira, porque não trabalhamos atoa." (E12). Assim, tais preceitos corroboram com Camarano, Kanso e Mellho (2004) sobre o trabalho também ser visto como uma forma de contribuir financeiramente no orçamento familiar dos idosos, assim como afirmam as análises de Almeida (2010) e Sampaio (2012) sobre o valor pago pela aposentadoria ser insuficiente.

No que concerne aos sujeitos E7 e E9 sobre escolherem não continuarem a trabalhar depois da aposentadoria, E9 diz que trabalhou por mais 10 anos depois de se aposentar, mas que decidiu parar porque viu que não sentia mais necessidade e nem condições físicas para tal, já que trabalhava como produtora rural. Já E7, alega que o fato de não trabalhar era porque não via outra opção de serviço, pois se sentia limitado por não ter estudo e por ter trabalhado somente com um mesmo tipo de função por muitos anos. Junto a isto, E9 também salienta sobre o trabalho, ao dizer que se precisasse continuar, veria oportunidade no meio rural, já que também não possui estudos.

\footnotetext{
Devido a minha falta de experiência em outras coisas, eu optei a não continuar a trabalhar depois da minha aposentadoria, porque eu não tinha outra opção de trabalho, eu só entendia de banco, então eu era limitado só a isso, não sabia fazer outra coisa. (...) e também eu vejo que os jovens possuem muito mais oportunidade na vida por causa dos estudos, e como eu não tive, fica mais difícil pra mim. (E7) Pra mim eu preferiria trabalhar na roça do que na cidade, porque eu tenho pouco estudo então só me resta a roça. Pra dentro da cidade eu acho que precisa de gente mais novo e gente que tem um pouco de estudo. (E9)
}

Pode-se perceber que tais pontos apresentam similaridade com as percepções dos sujeitos não aposentados sobre o assunto e também concordam com as afirmações de A. M. Oliveira, E. L. Oliveira e Wajnman (2004) sobre a relação da escolaridade com a ocupação. 


\section{Administração: caminhos para o desenvolvimento sustentável}

Em relação aos estereótipos, E11 e E5 alegam que não percebem isso no dia a dia do trabalho, por outro lado E2 diz que as vezes há uma falta de respeito com o outro devido até mesmo as questões da experiência e dificuldades naturais da idade, enquanto E3 pensa que se sair do emprego atual, achará dificuldade em se empregar em outro lugar devido à idade. Em relação a isto, e as limitações atribuídas, E11 e E12 confirmam possuírem limitações na coluna mais que isto não é um fator que os atrapalham em realizarem suas atividades, ao passo que E3 não sente nenhuma limitação e E2 percebe que não consegue realizar muitas atividades em um ritmo intenso que exige muito raciocínio.

Quanto aos medos e inseguranças em relação ao futuro e aos jovens, E2, E5 E9 e E12 esclarecem que decidiram se aposentar, mesmo podendo esperar por mais alguns anos, porque se sentiam inseguros quanto as mudanças da previdência. No que se refere aos jovens, E3 mostra que, ao contrário deles, ele possui muita insegurança quanto as mudanças e se sente resistente e E5 afirma que se sente em um ambiente de competição. Em contrapartida, E2 e E12 notam uma troca de conhecimentos e experiências interessantes entre as gerações; E3 afirma sobre a importância do equilíbrio entre ambos, pois tanto um quanto o outro podem oferecer algo para uma organização e E11 salienta que os jovens hoje possuem muito mais acesso às mudanças e atualizações de informações sobre o mundo, o que os tornam muito úteis para o serviço. Além disso, demonstram que a tecnologia não é um desafio como muitos pensam, pois ela pode ser ensinada e facilmente adaptada (E5), assim como as empresas podem oferecer cursos e os colegas de serviço podem auxiliá-los quando necessário (E2).

Ainda sobre o futuro, buscou-se dos entrevistados soluções e sugestões sobre os desafios enfrentados onde salientam sobre a importância da melhora da política pública do país (E3, E11), do valor da aposentadoria (E7) e de prolongar o tempo de trabalho das pessoas, pois "se você tem uma população econômica ativa cada vez mais envelhecida, e ela continuar aposentando muito nova, daqui um pouco de tempo os governos não aguentam mais como pagar a conta [sic]." (E3). Fator semelhante a análise de Carvalho (2009) sobre o impacto do envelhecimento na economia de um país.

\section{CONSIDERAÇÕES FINAIS}

O objetivo deste artigo foi analisar como o mercado na cidade de Manhuaçu - MG vê e oferece espaço aos trabalhadores da "terceira idade" e como esses sujeitos se percebem neste ambiente, apontando quais os fatores que os gestores da região analisam no processo de contratação e quais as dificuldades enfrentadas pelos sujeitos da maior idade. 


\section{Administração: caminhos para o desenvolvimento sustentável}

Deste modo, pelas análises dos gestores, foi possível desmistificar muitos conceitos sobre como o mercado analisa estes profissionais, sejam pelos estereótipos ou pela valorização dos jovens. No campo deste estudo, tornou-se evidente o reconhecimento das qualificações dos mais idosos, a importância que ainda possuem para o trabalho e o quanto ainda estão preparados para continuarem a atividade laborativa por mais tempo. Quanto aos estereótipos, percebeu-se que muitas vezes são os próprios sujeitos que se sentem vítimas destes conceitos, uma vez que não houve relatos relativos entre a incapacidade para o trabalho e a idade, comprovando que a idade não é um limitador e que o trabalho nesta fase está atrelado a uma melhor saúde e qualidade de vida.

Concernente a isto, comprovou-se também que um dos motivos para os idosos voltarem ao mercado está vinculado ao valor insuficiente da aposentadoria e, quanto ao trabalho informal, boa parte dos entrevistados afirmam que viram neste segmento uma forma mais atrativa para continuarem a atividade laboral, seja pela realidade vivida no país, assim como pelas suas condições ou devido à baixa escolaridade, como afirmam Oliveira et al (2004).

Sendo assim, conclui-se que alguns fatores predominantes do campo de análise podem ter contribuído para a obtenção do resultado deste estudo, como a cultura local, baseada na gestão familiar e da valorização da experiência, e pela pequena formação do grupo de gestores. Desse modo, foi possível observar algumas discrepâncias quanto aos autores de estudos anteriores, tornando possível perceber a predominância da valorização dos idosos sobre o trabalho e poucos relatos abrangentes sobre o preconceito com esses trabalhadores.

Mesmo assim, abordou-se aspectos de grande relevância, como a escolaridade, assunto este que merece atenção pois vem mostrando ser uma nova tendência quanto ao futuro do trabalho, principalmente nas grandes capitais do Brasil.

Desta forma, tendo como base as reflexões de Ladeira et al (2017), a sociedade atual passará a se deparar com um grande número de idosos com perfis bastante diferentes de alguns anos atrás e, de alguma forma, terá que se adaptar a elas e desconsiderar muitos conceitos generalizados. Por isto, sugere-se um maior acompanhamento e estudos sobre esta atual temática pois, diferente do que foi constatado neste estudo, é possível encontrar outras realidades em diferentes campos que merecem ser repensadas e reavaliadas. 


\section{Administração: caminhos para o desenvolvimento sustentável}

\section{REFERÊNCIAS}

ALCÂNTARA, A. de O.; CAMARANO, A. A.; GIACOMIN, K. C. (Orgs.). Política Nacional do Idoso: velhas e novas questões. Rio de Janeiro: Ipea, 2016. Disponível

em:<http://www.ipea.gov.br/portal/images/stories/PDFs/livros/livros/161006_livro_politica_nacion al_idosos.PDF>

ALMEIDA, M. Geografia Global 2. São Paulo: Escala Educacional, 2010.

ARGIMON, I. I. L.; LOPES, R. M. F; NASCIMENTO, R. F. L. Atualidades sobre o idoso no mercado de trabalho. Portal dos psicólogos. 2006. Disponível

em: <http://www.psicologia.pt/artigos/textos/A0300.pdf>

BARCELLOS FONTANELLA, B. J.; MAGDALENO JÚNIOR, R. Saturação teórica em pesquisas qualitativas: contribuições psicanalíticas. Psicologia em Estudo, v. 17, n. 1, 2012. Disponível

em: < http://www.redalyc.org/html/2871/287123554008/>

BEAUVOIR, S. A velhice. 5. ed. Rio de Janeiro: Nova Fronteira, 1990.

BERQUÓ, E.; CAVENAGHI, S. Fecundidade em declínio: breve nota sobre a redução no número médio de filhos por mulher no Brasil. Novos Estudos-CEBRAP, n. 74, p. 11-15, 2006. Disponível em: <http://www.scielo.br/scielo.php?pid=S0101-33002006000100001 \&script=sci_arttext>

BRASIL. Lei n. 10.741, de $1^{\circ}$ de outubro de 2003. Dispõe sobre o Estatuto do Idoso e dá outras providências. Brasília, 3 out. 2003. Disponível

em: <http://www.planalto.gov.br/ccivil_03/leis/2003/L10.741.htm>

BRASIL. Lei n. 8.842, de 4 de janeiro de 1994. Dispõe sobre a política nacional do idoso, cria o Conselho Nacional do Idoso e dá outras providências. Brasília, 4 de janeiro de 1994. Disponível em: <http://www.planalto.gov.br/CCivil_03/Leis/L8842.htm >

CAMARANO, A. A.; KANSO, S.; MELLHO J. L. e. Como vive o Idoso brasileiro? In: CAMARANO, Ana Amélia. Os novos idosos brasileiros: muito além dos 60? Rio de Janeiro: Ipea, 2004. Disponível em: < http://www.ipea.gov.br/portal/images/stories /PDFs/livros/Arq_29_Livro_Completo.pdf>

CARVALHO, A. S. Gestão de pessoas e envelhecimento: sentido do trabalho para o idoso. [Anais... São Paulo, SP, Brasil], v. 33, 2009. Disponível em: < http://www.anpad.org.br/admin/pdf/GPR3213.pdf>

COCKELL, F. F.; PERTICARRARI, D. Retratos da informalidade: a fragilidade dos sistemas de proteção social em momentos de infortúnio. Ciência \% Sáude coletiva, 16 (3), 1709 - 1718. 2011. Disponível em: < https://www.scielosp.org/pdf/csc/2011.v16n3/1709-1718/pt>.

CRESWELL, J. W. Projeto de pesquisa: métodos qualitativo, quantitativo e misto. Porto Alegre: Artmed. 2010. Disponível em: < http://periodicos.unb.br/index.php/les/article/view /7145/5645> 


\section{Administração: caminhos para o desenvolvimento sustentável}

D'ALENCAR, R.S.; CAMPOS, J.B. Velhice e trabalho: a informalidade como (re) aproveitamento do descartado. Estudos interdisciplinares sobre o envelhecimento, v. 10, 2006. Disponível em: < https://seer.ufrgs.br/RevEnve Ihecer/article/view/4794/2700>

DA CW MENEGOLO, E. D.; CARDOSO, C. J.; MENEGOLO, L. W. O uso da história oral como instrumento de pesquisa sobre o ensino da produção textual. Ciências \& Cognição, v. 9, p.3-5, 2006. Disponível em: < http://www.cienciasecognicao.org/revista /index.php/cec/article/view/596>

DE ALMEIDA, M. G.; DE ANDRADE CARMO, L.; DA SILVA, S. R. R. O trabalho informal como alternativa no mundo de trabalho atual. IV Seminário CETROS. Fortaleza - CE. 2013. Disponível em: <http://www.uece.br/eventos/seminariocetros/anais/ trabalhos_completos/69-12758-08072013174708.pdf>

DEBERT, G.G. A Invenção da Terceira Idade e a Rearticulação de Formas de Consumo e Demandas Políticas. RBCS - Revista Brasileira de Ciências Sociais. No. 34, jan 1997. Disponível em: <http://www.anpocs.com/images/stories/RBCS/34/rbcs34_03.pdf>

DERROSO, G.; OLIVEIRA, M. A inserção de Idosos no mercado de Trabalho de Foz do Iguaçu. UNITAU - Revista de Ciências Humanas - Educação e Desenvolvimento Humano, Taubaté/SP - Brasil, v. 11, $\mathrm{n}$ 1, edição 20, p. 47 - 61, Junho 2018. Disponível

em: < https://www.rchunitau.com.br/index.php/rch/article/view/428/249>

FRANÇA, L.H., STEPANSKY, D. V. Educação Permanente para Trabalhadores Idosos - O Retorno à Rede Social. Boletim Técnico do Senac. 2016. Disponível

em: <http://www.bts.senac.br/index.php/bts/article/view/337/320>

GIL, A. C. Como elaborar Projetos de Pesquisa. 4. Ed. São Paulo: Atlas, 2002. Disponível em: < https://professores.faccat.br/moodle/pluginfile.php/13410/mod_resource/content

/1/como_elaborar_projeto_de_pesquisa_-_antonio_carlos_gil.pdf >

INSTITUTO BRASILEIRO DE GEOGRAFIA E ESTATíSTICA - IBGE. Censo Demográfico 2018: Projeções da população 2010-2060. Minas Gerais: IBGE, 2018. Disponível

em: <https://www.ibge.gov.br/apps/populacao/projecao/>

INSTITUTO DE PESQUISA ECONÔMICA APLICADA - IPEA. Carta de Conjuntura - Mercado de Trabalho, s. X, n. 39, p. 4-8, 2018. Disponível

em: <http://www.ipea. gov.br/cartadeconjuntura/index.php/category/mercado-de-trabalho/>

- Comunicados do IPEA: Tendências Demográficas. n. 64, 2010. Disponível em: $<$ http://www.ipea.gov.br/portal/index.php?option=com_content\&view=article\&id=5339>

JÚNIOR, E. G. et al. Considerações sobre a terceira idade e o mercado de trabalho: questionamentos e possibilidades. Revista Brasileira de Ciências do Envelhecimento Humano, v. 6, n. 3, 2009. Disponível em: <http://www.seer.upf.br/ index.php/rbceh/article/view/250/824> 


\section{Administração: caminhos para o desenvolvimento sustentável}

KALACHE, A. Envelhecimento populacional no Brasil: uma realidade nova. Caderno de Saúde Pública Rio de Janeiro, 1987. Disponível em: < https://www.scielosp.org/pdf/ csp/1987.v3n3/217-220/pt>

KIM, J. E.; MOEN, P. Is retirement good or bad for subjective well-being?. Current directions in psychological science, v. 10, n. 3, p. 83-86, 2001. Disponível

em: < https://journals.sagepub.com/doi/abs/10.1111/1467-8721.00121>

LADEIRA, M. M. et al. Significado do trabalho para o idoso. Revista Vianna Sapiens, v. 8, n. 1, p. 6-8, 2017. Disponível em: < file:///C:/Users/user/Downloads/216-Texto\%20do\%20 artigo-394-1-1020171124.pdf>

LEONE ET, MAIA AG, BALTAR PE. Mudanças na composição das famílias e impactos sobre a redução da pobreza no Brasil. EconSoc 2010;19(1):59-77. Disponível

em: http://www.scielo.br/pdf/ecos/v19n1/a03v19n1

LORETTO, W.; WHITE P. Employers' atitudes, practices and policies toward older workers. Management School and Economics. University of Endiburgh. Human Resource Management Journal, v. 16, n. 3, p. 313-30, 2006. Disponível em: < https:// onlinelibrary.wiley.com/doi/full/10.1111/j.17488583.2006.00013.x>.

MANZINI, E. J. A entrevista na pesquisa social. Didática, São Paulo, v. 26/27, p. 149-158, 1990. Disponível

em:<https://edisciplinas.usp.br/pluginfile.php/3145622/mod_resource/content/1/Entrevista\%20se mi\%20estruturada\%20estudo\%20UNESP\%20Mari\%CC\%81lia.pdf>

MIRANDA, G. M. D.; MENDES, A. C. G.; DA SILVA, A. L. A. O envelhecimento populacional brasileiro: desafios e consequências sociais atuais e futuras. Revista Brasileira de Geriatria e Gerontologia, v. 19, n. 3, p. 507-519, 2016. Disponível em: < http://www.redalyc.org/pdf/4038/403846785012.pdf>

NÉRI, A. L. Envelhecer bem no trabalho: possibilidades individuaus, organizacionais e sociais. In: Revista Terceira Idade. SESC São Paulo, v.13 n.24. 2002. 7-27 Disponível em: < https://www.sescsp.org.br/files/edicao_revista/7417fe99-464d-462b-9b15-db35ece4c52e.pdf>

OLIVEIRA, A. M.; OLIVEIRA, E. L.; WAJNMAN, S. Os idosos no mercado de trabalho: tendências e conseqüências. In: CAMARANO, A. A. (Org.). Os novos idosos brasileiros: muito além dos 60 ? Rio de Janeiro: Ipea, 2004. Disponível

em: <www.ipea.gov.br/sites/000/2/livros/idososalem60/Arq_23_Cap_14.pdf.>.

POSTHUMA, R. A.; CAMPION, M. A. Age stereotypes in the workplace: common stereotypes, moderators, and future research directions? Journal of Management. v. 35, n. 1, Jan. 2009. Disponível em: < https://journals.sagepub.com/doi/abs/10.1177/0149206308 318617>

SAMPAIO, F. S. Para viver juntos: geografia 70 ano - 3. Ed. São Paulo: Edições SM, 2012.

SOUZA, R. F.; MATIAS, H. A.; BRÊTAS, A. C. P. Reflexões sobre envelhecimento e trabalho. Ciência \& Saúde Coletiva, v. 15, p. 2835-2843, 2010. Disponível 


\section{Administração: caminhos para o desenvolvimento sustentável}

em: < https://www.scielosp.org/pdf/csc/2010.v15n6/2835-2843/pt>

THUANY, M. Minas terá a maior população idosa do país até 2060, diz IBGE. Belo Horizonte, O tempo, 2018. Disponível em: <https://www.otempo.com.br/capa/brasil/minas-terá-a-maiorpopulação-idosado-país-até-2060-diz-ibge-1.2005327>

TRIVIÑOS, A. N. S. Introdução à pesquisa em ciências sociais: a pesquisa qualitativa em educação. São Paulo: Editora Atlas, 1987. Disponível em: <http://www.hugoribeiro.com.br/bibliotecadigital/Trivinos-Introducao-Pesquisa-em_Ciencias-Sociais.pdf>

XIMENES, Maria Amélia; CONCONE, Maria Helena Villas Bôas. Velhice e trabalho, uma relação possível?. Revista Kairós: Gerontologia, v. 12, 2009. Disponível

em: <https://revistas.pucsp.br/index.php/kairos/article/view/2681/1726> 


\section{Capítulo 48}

\section{CADEIA TÊXTIL E A MANUFATURA DO VESTUÁRIO DE MODA - UMA ESTRATÉGIA DE NEGÓCIOS}

DOI: $10.37423 / 200300536$

Profa. Ms. Francisca Dantas Mendes (UNIP) 5light5@uol.com.br

Profa. Maria Aparecida de Almeida Santos (UNIP) hktreina@uol.com.br

Prof. Dr. José Bentedito Sacomano (UNIP) sacomano@terra.com.br

Prof. Dr. José Paùlo Alves Fusco (UNIP) jpafusco@uol.com.br

RESUMO: Este trabalho tem como objetivo relatar a dinâmica da Cadeia Produtiva Têxtil com foco nos negócios da Mąnufatura do Vestuário de/Moda f MVM e suas principais características, acompanhado por um estudo de caso. Com $/ 0$ mundo globalizado e sem frontềras, os limites da criaçăo alcançàm território,s longínqưos, porém a resposta-positiva para o retorno desse.investimento somente virá sê for acompanhado de. Planos Estratégicos adequados à Produção, Gesțão da Qualida@e na produção de produtos e serviços, Gestão da Cadeia de Suprimentos, Dessenvolvimento de um Relacíonamento adequado com Fornecedores (nacionais e internacienais) e, por conseguinte, a Gestão de Outsourcing.

Palavras chave: Cadeia, Têxtil, Estratéggia, Vestuáriø, Outsourcing.

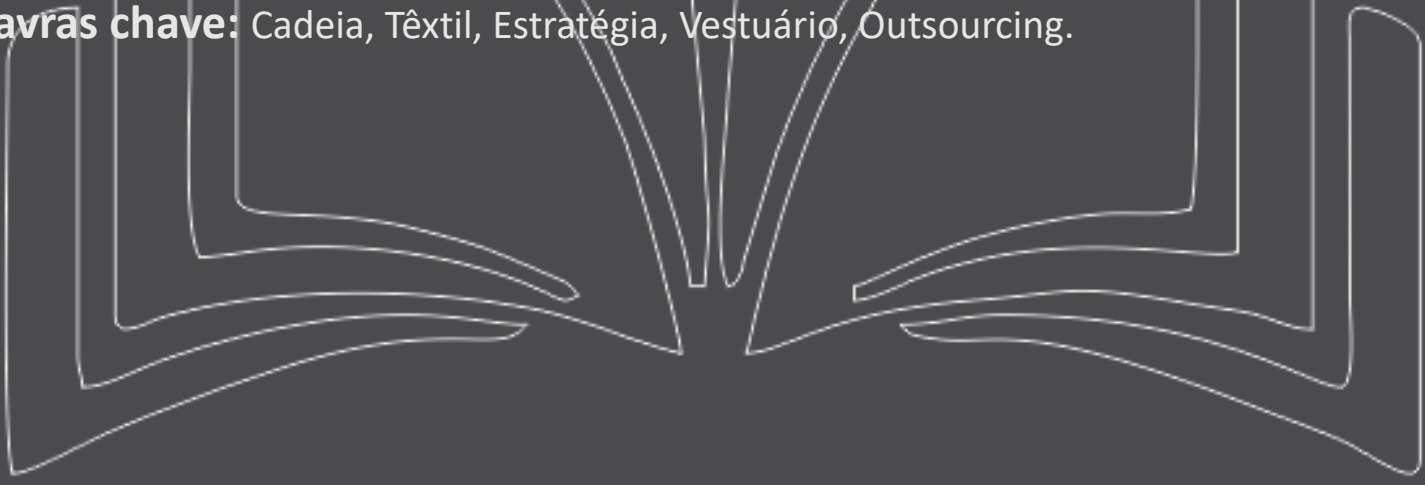




\section{Administração: caminhos para o desenvolvimento sustentável}

\section{INTRODUÇÃO}

O vestuário de moda, neste trabalho denominado produto de moda, é altamente diferenciado em suas formas, volumes e insumos. Para sua produção, exigem-se tecnologias e processos produtivos adaptados aos materiais utilizados. O produto possui curto ciclo de vida e produção em lotes com reduzidas quantidades que precisam ser distribuídas ao mercado em tempos cada vez mais curtos.

A moda movimenta uma engrenagem contínua e em constante alteração. Seus movimentos podem ser considerados espiralados, uma vez que sempre há retorno de formas, cores e texturas de tempos em tempos, porém com uma aparência renovada e aplicação de modernas tecnologias nos materiais e nos processos de produção.

A inovação tecnológica compreende novos materiais através de misturas de fios e filamentos ou novas tecnologias em maquinários e/ou beneficiamentos têxteis mecânicos ou químicos, implementando formas, volumes e texturas inéditas.

Os fios, tecidos e produtos de moda recebem tratamentos que alteram o toque e o visual dos materiais resultando em novas estéticas e conforto para o consumidor final.

O vestuário de moda mobiliza uma cadeia que tem a participação de diversos atores com foco em um público consumidor ávido por inovações constantes, criações exclusivas ou estéticas que distinguirão o consumidor dentre as demais pessoas (MENDES, 2006b).

Araújo (1996) afirma que, por produto têxtil, considera-se todo o produto que, no estado bruto, semiaberto, aberto, semi-manufaturado, manufaturado, semi-confeccionado ou confeccionado, se apresenta exclusivamente constituído por fibras têxteis de qualquer natureza, independentemente da técnica de mistura ou da união utilizada.

2 Importância econômica do setor têxtil

Este trabalho se justifica também pela importância econômica do setor nos cenários mundial e brasileiro.

Em termos de produção em toneladas, o IEMI (2009) descreve: "a produção mundial de têxteis foi de cerca de [...] 75 milhões de toneladas para o ano de 2007, calculada com base no consumo total de 


\section{Administração: caminhos para o desenvolvimento sustentável}

fibras e filamentos daquele ano, considerada, nesse volume, a produção de artigos de vestuário estimada em 42,3 milhões de toneladas".

É notável a participação dos países emergentes da Ásia e, mais recentemente, do Leste Europeu, Norte da África e Caribe, fator que altera substancialmente o mapa da produção mundial.

"Atualmente, mais de $44 \%$ da produção mundial de têxteis e quase $47 \%$ da produção mundial de vestuário é realizada na China. Os Estados Unidos ainda resistem como produtores de manufaturas têxteis, mas em vestuário sua produção atual é pequena, representando apenas cerca de $5 \%$ do seu consumo interno." (IEMI, 2009)

É importante esclarecer que as manufaturas têxteis produzidas pelos Estados Unidos compreendem filamentos, fibras e tecidos (plano e malha),

Em 2007, no mercado mundial, o Brasil ocupou a 7ạ posição entre os maiores produtores de manufaturados têxteis e a 6a como produtor de vestuário. Muito pouco dessa produção foi exportada.

Em termos financeiros, o IEMI (2009) afirma que a produção têxtil mundial cresceu 97\% entre 1990 e 2007 e o comércio internacional de têxteis e vestuário teve incremento de $175 \%$, atingindo a soma de US \$ 583 bilhões em 2007. Ao considerar somente o vestuário, o crescimento foi ainda maior, ou seja, $220 \%$ no mesmo período.

"A indústria têxtil e confeccionista brasileira participou com 5,4\% do valor da produção total da indústria de transformação de 2008. Em termos de pessoal ocupado, sua participação foi também altamente significativa, pois contribuiu com $16,5 \%$ do emprego total da indústria de transformação nacional" (IEMI, 2009)

Embora o Brasil seja o sexto maior produtor mundial de têxteis e vestuário, sua participação no comércio exterior ainda é muito pequena, uma vez que ocupa a 26ạ. colocação entre os países exportadores de têxteis e a 69a. dentre os maiores exportadores de vestuário (IEMI, 2009). 


\section{Administração: caminhos para o desenvolvimento sustentável}

\begin{tabular}{|l|r|r|r|r|} 
& $\begin{array}{c}\text { No. } \\
\text { Empresas }\end{array}$ & Mão-de-obra & $\begin{array}{c}\text { Produção em } \\
\text { tons. (mil/ano) }\end{array}$ & $\begin{array}{c}\text { Produção em } \\
\text { US\$. (bilhões) }\end{array}$ \\
\hline Fiação (fios e filamentos) & 419 & 75889 & 1.390 .927 & 5,198 \\
\hline Tecelagem & 601 & 101.870 & 1.393 .356 & 9,234 \\
\hline Malharia & 2.421 & 121.753 & 679.055 & 6,005 \\
\hline Beneficiamento, especialidades & 1.056 & 41.205 & 71.920 &,-- * \\
\hline Confecção em geral & 24.338 & 1.286 .867 & $9.243 .276 * *$ & 43.242 .935 \\
\hline Confecção do vestuário & 21.044 & 1.090 .115 & $5.142 .013 * *$ & 35.635 .898 \\
\hline * valor não fornecido & & & & \\
** em 1.000 peças & & & & \\
\hline
\end{tabular}

Tabela 1 - Dados comparativos do setor têxtil - Fonte: tabela elaborada pelos autores

A Tabela 1 demonstra a importância do segmento do vestuário em cada item de análise (número de empresas, mão-de-obra, produção em toneladas de fibras e tecidos, número de peças confeccionadas e valores em dólares americanos). De fato, $74 \%$ do número de empresas são do segmento de vestuário que absorve $70 \%$ da mão-de-obra e gera $82 \%$ do faturamento total do setor têxtil no ano de 2008 (IEMI, 2009).

\section{ATORES ENVOLVIDOS NA CADEIA TÊXTIL}

A Cadeia têxtil que envolve produtos de moda abrange uma rede heterogênea de setores industriais com estruturas diversas quanto ao tamanho e número de empresas, intensidade de mão-de-obra, capital e complexidade tecnológica.

São empresas que, estimuladas pelo ciclo da moda, procuram lançar no mercado uma maior quantidade de produtos inovadores e tecnológicos com tempos de produção cada vez mais curtos.

A Figura 1 demonstra o fluxo de forma detalhada, sendo que o eixo principal compõe-se de empresas produtoras de:

a) Fibras: aqui participam a agropecuária, agroindústria, petroquímica, química;

b) Fiação: produção de fios e linhas;

c) Tecelagem, malharia e não tecido: produção de matérias primas para os confeccionados;

d) Confecção: produto final da indústria de transformação da cadeia têxtil;

e) Varejo: comércio, serviços e rede de distribuição para o consumidor final. 


\section{Administração: caminhos para o desenvolvimento sustentável}

No entorno dessa cadeia produtiva encontram-se empresas que, como clientes e fornecedores, atendem à demanda do mercado por produtos têxteis, do vestuário em geral e do vestuário de moda. Essas empresas são:

a) Tinturarias: indústria de transformação para tratamento dos insumos e produtos da cadeia;

b) Lavanderias industriais: indústria de transformação para tratamento dos insumos e produtos finais;

c) Bordados: "corridos", quando aplicados em tecidos ou "localizados", quando aplicados em tecidos ou peças em determinados locais isolados;

d) Estamparias: corridas e localizadas, da mesma forma que os bordados;

e) Aviamentos: são produtos destinado ao embelezamento, fechamento, estrutura de peças, responsável por atender a legislação com a aplicação de etiquetas obrigatórias e normatizadas por leis globais;

f) Componentes para distribuição: produção de petrechos para o varejo como cabides e materiais para embalagens.

g) Distribuição: serviços que incluem logística de distribuição.

Atendendo a todos os elos da cadeia encontram-se também as indústrias de maquinários e de produtos químicos. 


\section{Administração: caminhos para o desenvolvimento sustentável}

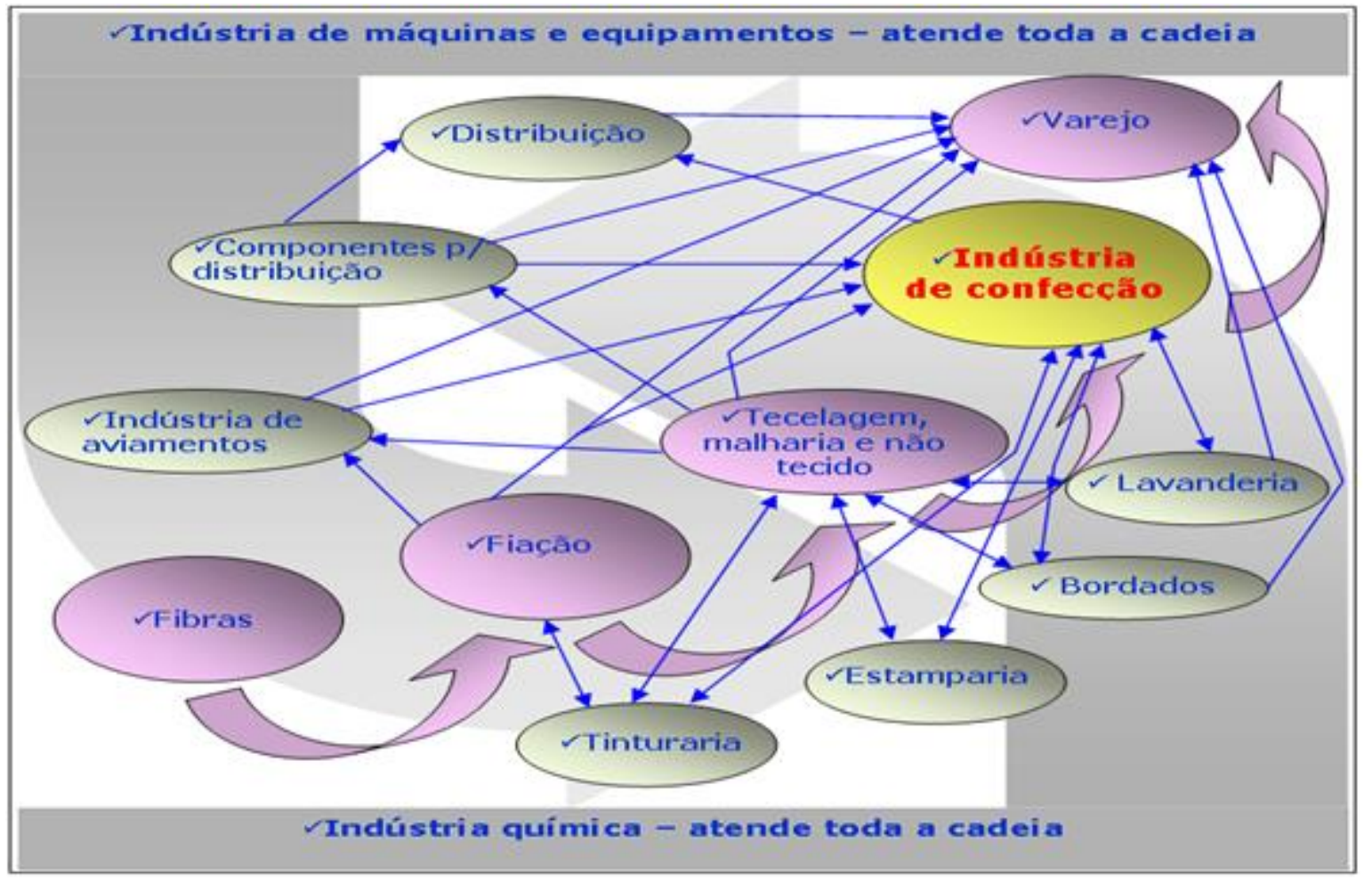

Figura 1 - Cadeia Têxtil e sua rede de negócios - Fonte: Mendes (2006a)

\section{SEGMENTO DO VESTUÁRIO DE MODA}

A manufatura do vestuário de moda, também denominada confecção, até meados do século XX, era verticalizada, uma vez que cada empresa realizava todas as atividades da cadeia produtiva desde a compra dos tecidos, desenho dos modelos, definição da modelagem, do corte, da costura, arremate, alisamento das peças, até as vendas em suas próprias lojas, denominadas "butiques". Logo após o advento do prêt à porter (pronto para vestir), surgiram as confecções especializadas em seguir as tendências da moda parisiense. Pequenos estilistas passaram a desenvolver suas criações e contratar profissionais especializados para controlar e executar sua produção. (MENDES, 2005).

Cruz-Moreira (2003) argumenta que “... a fragmentação das etapas do seu processo produtivo permite, ao mesmo tempo, a dispersão geográfica e a mobilidade das atividades produtivas. Possibilita, ainda, a divisão do trabalho e dos lucros em forma desigual. A existência de etapas da produção intensiva em mão-de-obra e o baixo custo do posto de trabalho na etapa de costura (que continua basicamente constituído por um operador e uma máquina de costura), favorece a geração de emprego e, por isso, muitos governos nacionais vêem essas indústrias como estratégias para seu desenvolvimento industrial." 


\section{Administração: caminhos para o desenvolvimento sustentável}

\section{O PRODUTO DE MODA}

O produto de moda é distribuído ao público consumidor a partir de um mix de peças conjugadas entre si. Esse mix, denominado coleção, compreende produtos fashion e commodities distribuídos conforme o seu público alvo (Figura 2). Os produtos de uma coleção são desenvolvidos a partir de diferentes aviamentos e tecidos.

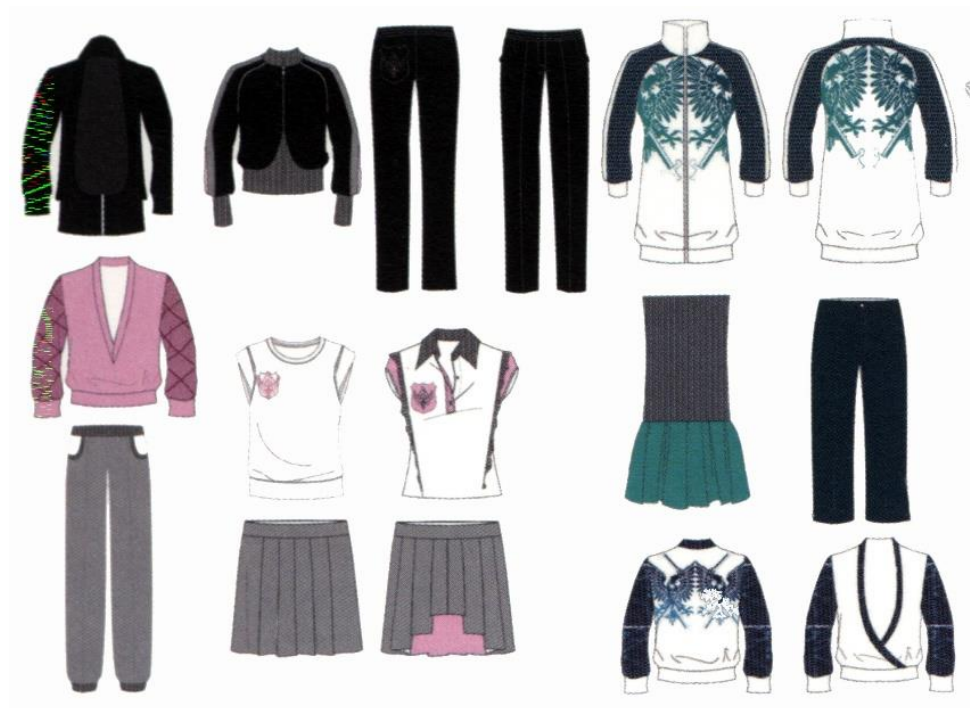

Figura 2 - Coleção de moda - Fonte: IFM (2004)

Commodities são os produtos que se distinguem por apresentar um grande volume de produção por modelo com pequenas diferenças que não alteram as etapas do processo. As peças se diferenciam apenas pelas cores e estampas. Na figura 3 as camisetas são um bom exemplo, pois um só corte ou modelagem dá origem a diversos visuais com cores e estampas aplicadas pela técnica do silk screen (aplicação de imagens com tintas especiais nos tecidos de malha).

Fashions são produtos diversificados possuem características que atendem completamente as tendências de moda. São concebidos com modelagens, tecidos, aviamentos e costuras exclusivas e buscam a exclusividade dos produtos. Mesmo que sejam influenciados por outros modelos que já existiram no mercado, tais produtos são desenvolvidos com um estudo bastante específico para a criação de um novo produto, de forma que cada peça se apresenta de acordo com a expectativa do cliente consumidor (Figura 4). 


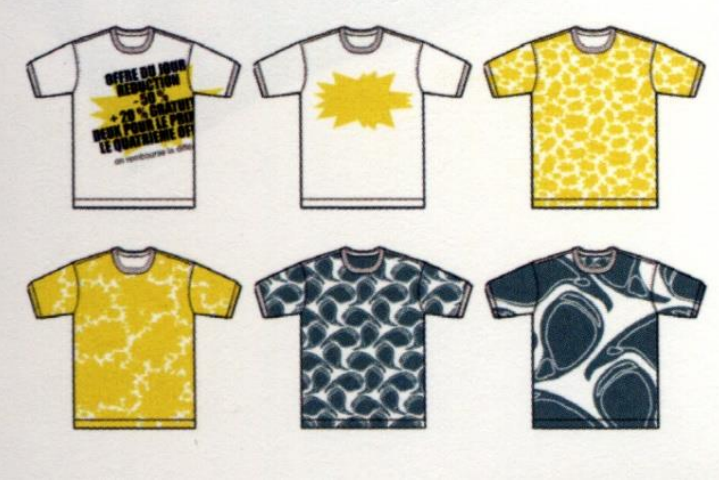

Figura 3 - Commodities - Fonte: Mendes (2006c)

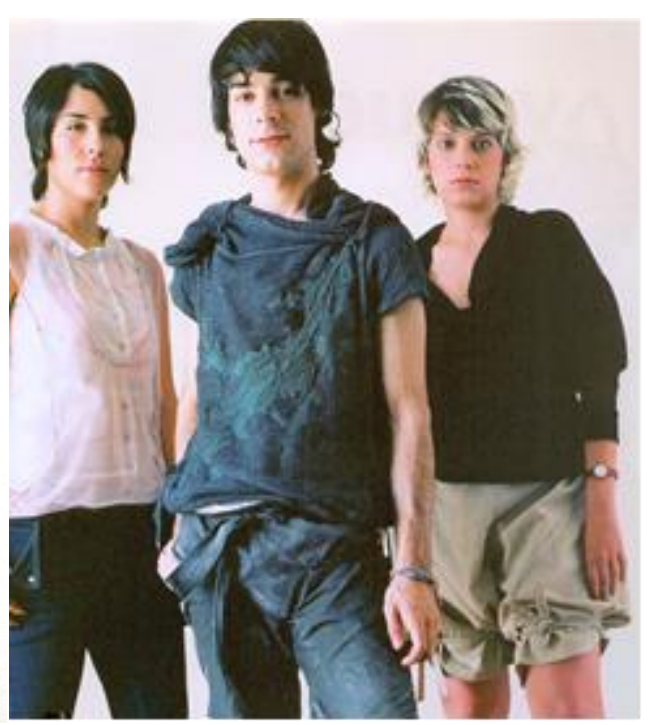

Figura 4 - Fashion - Fonte: Mendes (2006c)

A moda evolui e modifica os aspectos do produto e os desejos dos consumidores. Sobre o tema, Lipovetsky (1989) afirma que "Torrentes de 'pequenos nadas' e pequenas diferenças que fazem toda a moda, que desclassificam ou classificam imediatamente a pessoas que os adota ou que deles se mantém afastada, que tornam imediatamente obsoleto aquilo que os precede."

Uma das características principais do produto de moda é a sua rápida obsolescência visual e o seu reduzido ciclo de vida. Para o público da faixa "inovadores" e "formadores de opinião", a exigência quanto á renovação é imediata, na medida em que cada produto passa a ser disseminado para a massa geral de consumidores com a exposição nas vitrines das lojas e magazines.

O ciclo de vida do produto visa também atender a expectativa de diferentes públicos consumidores: aqueles mais arrojados que buscam destaque de moda e estilo, os "clássicos" que procuram produtos discretos nos detalhes e o público massificado que consome produtos conhecidos como "modinha", ou seja, trajes que despertam atenção para o que significa "estar na moda".

A Figura 3 apresenta os ciclos de vida do produto de moda no ponto de venda. É uma relação entre o volume de venda e o tempo de obsolescência. Os quadros ao lado descrevem as características de cada grupo de produto. 


\section{Administração: caminhos para o desenvolvimento sustentável}

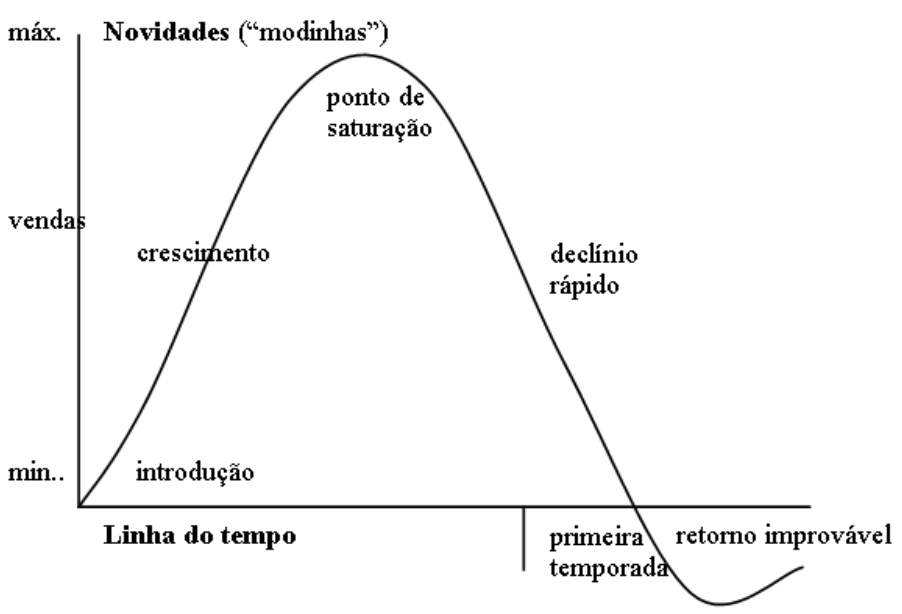

“Modinha”

Exemplos: blusas

tipo

cigana,

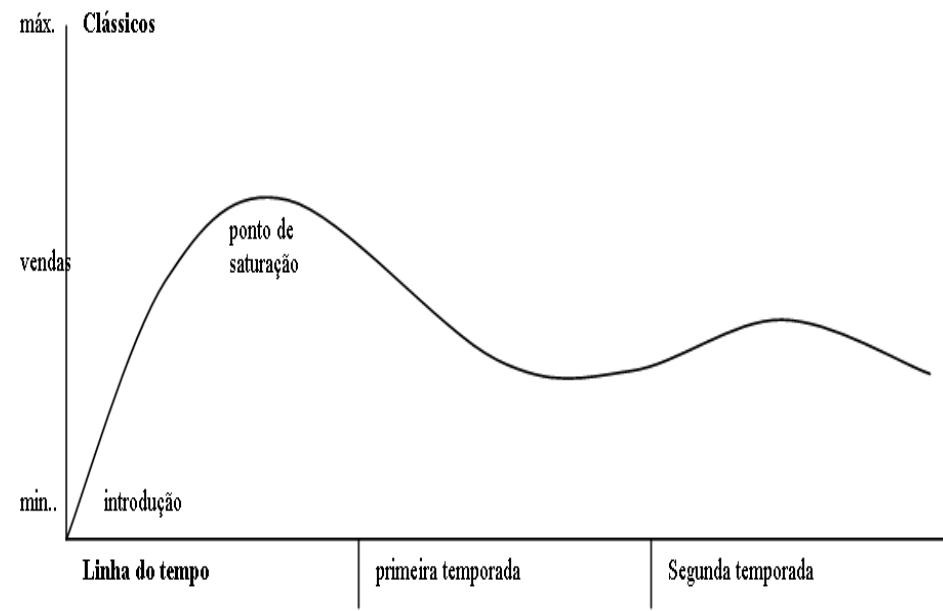

Clássicos

Exemplos:

blazer

azul-

marinho, paletó

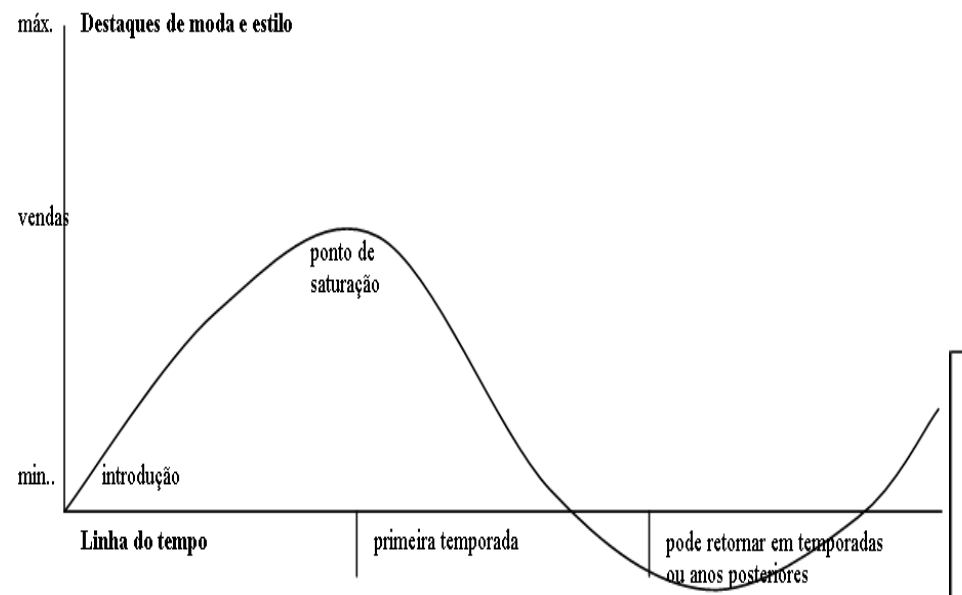

Fashion/inovad

ores

Exemplos: as

bainhas das

Figura 3 - Ciclo de vida do produto - Fonte: Jones (2005) 


\section{Administração: caminhos para o desenvolvimento sustentável}

\section{EMPRESAS PRESTADORAS DE SERVIÇOS: SEUS PROCESSOS E TECNOLOGIA}

A matéria prima consumida na Manufatura do Vestuário de Moda é composta basicamente por tecido plano e malha. O tecido plano é produzido em teares e utiliza fios na vertical, denominados "urdume" e, no entrelaçamento horizontal, o fio denominado "trama". Já a malha normalmente é trançada com um único fio lembrando o tricô e normalmente possui bastante elasticidade como característica principal. Para a sua produção, são necessários diferentes maquinários e processos produtivos. Esta é a razão pela qual há empresas especializadas em diferentes segmentos (por materiais e produtos).

Para Cunha (2002), “...dentro da indústria de confecção existem segmentos bastante diferenciados no que diz respeito às matérias-primas e aos processos produtivos utilizados, bem como aos padrões de concorrência e às estratégias empresariais."

Cruz Moreira (2003), escreve sobre a evolução da produção mundial na indústria do vestuário no século XX. Na década de 50 e começo dos anos 60 ocorreu uma migração da produção dos países industrializados para o Japão. Em seguida, na década de 70 e 80, do Japão para os tigres asiáticos e, em meados da década de 80, outra grande movimentação aconteceu, desta vez partindo principalmente dos tigres asiáticos para outros países em desenvolvimento, principalmente China e sudoeste asiático. Já na década de 90, novos fornecedores surgiram em razão da consolidação dos blocos comerciais dos Estados Unidos para a América Central e o Caribe e principalmente México.

As empresas que processam tecidos de malha possuem máquinas especiais para manter a elasticidade dos tecidos. Seu maquinário é composto de overloques, interloques, galoneiras, elastiqueiras, e outras, que atendem os segmentos underwear, beachwear, sportswear, sleepwear, além do casualwear confeccionado em tecido de malha, ao passo que as confecções especializadas em tecidos planos possuem máquinas como: máquinas de ponto fixo, ponto corrente, interloque, barra invisível e overloque que realizam acabamentos nas partes internas do produto destinadas aos segmentos workwear, socialwear, galadress (Tabela 2). 


\section{Administração: caminhos para o desenvolvimento sustentável}

\begin{tabular}{|c|c|c|c|}
\hline Segmentos & & Produtos & Tecidos mais utilizados \\
\hline Underwear & Roupa íntima & Calcinha, sutiã, cueca, meia & Fios e tecidos de malha \\
\hline Beachwear & Roupa de praia e piscina & $\begin{array}{l}\text { Maiô, biquíni, sunga de } \\
\text { banho }\end{array}$ & Tecidos de malha \\
\hline Sportswear & $\begin{array}{l}\text { Roupa para práticas } \\
\text { esportivas }\end{array}$ & $\begin{array}{l}\text { Artigos para prática de } \\
\text { esportes }\end{array}$ & Tecidos de malha \\
\hline Sleepwear & Roupa para dormir & $\begin{array}{l}\text { Pijama, camisola, robe de } \\
\text { chambre, penhoar }\end{array}$ & $\begin{array}{l}\text { Tecidos planos e de } \\
\text { malha }\end{array}$ \\
\hline Casualwear & Roupa do cotidiano & $\begin{array}{l}\text { Blusa, camisa, camiseta, } \\
\text { calça, bermuda, shorts, saia, } \\
\text { vestido, casacos }\end{array}$ & Tecidos planos e malha \\
\hline Workwear & Roupa para trabalho & $\begin{array}{l}\text { Blusa, camisa, calça, } \\
\text { macacão, avental, jaleco }\end{array}$ & Tecidos planos \\
\hline Socialwear & Roupa social & $\begin{array}{l}\text { Paletó, calça, colete, saia, } \\
\text { vestido }\end{array}$ & Tecidos planos \\
\hline Galadress & $\begin{array}{l}\text { Roupa para eventos } \\
\text { formais }\end{array}$ & Vestido longo, smoking & Tecidos planos \\
\hline
\end{tabular}

Tabela 2 - Segmentos por produtos e materiais - Fonte: tabela elaborada pelos autores

O segmento de tecido plano também está subdividido em manufaturas que trabalham com tecidos planos pesados (possuem maior espessura) e manufaturas de tecidos finos (menor espessura, mais delicados e sofisticados), que exigem maquinários especiais (MENDES, 2006d).

\section{METODOLOGIA}

Na presente investigação, as fontes teóricas de metodologia e pesquisa demonstraram que não há uma única teoria que apresente um conjunto de ações de forma a possibilitar a coleta de dados e de informações de uma empresa que participa de um cenário empírico pouco estudado e documentado.

\begin{tabular}{|l|l|}
\multicolumn{1}{|c|}{ Descrição } & \multicolumn{1}{c|}{ Especificações } \\
\hline Caráter do estudo & Exploratório ou descritivo \\
\hline Método de abordagem mais amplo & Hipotético-dedutivo \\
\hline Abordagem & Qualitativa \\
\hline Métodos de pesquisa & - estudo de caso \\
& - pesquisa-ação \\
\hline
\end{tabular}

Tabela 3 - Quadro-resumo das opções metodológicas. - Fonte: tabela elaborada pelos autores

A tabela 3 apresenta um quadro dos vários métodos a serem utilizados para a realização da pesquisa. A escolha do tipo de método recai na necessidade de procurar percepções (insights) sobre um determinado assunto, descrever comportamentos ou classificar fatos e variáveis. As observações são feitas in loco e com entrevistas semi-estruturadas. O objetivo do investigador é expandir teorias e não enumerar freqüências, descrever e explorar situações nas quais perguntas "como" e "por que" sejam a base da investigação, de forma a engendrar características e ligações de importância teórica. Pesquisa-ação, para efeito deste trabalho, é de grande importância ao se considerar a experiência 


\section{Administração: caminhos para o desenvolvimento sustentável}

profissional dos autores no campo da moda e o seu relacionamento profissional com a empresa envolvida na pesquisa.

\section{ESTRATÉGIA CORPORATIVA}

Segundo Slack (2002), Porter (1986), Zaccarelli (2000), Contador (1996) e Horte et al (1987), a estratégia de negócios ou estratégia competitiva consiste na definição de sua missão e objetivos individuais, tendo como foco a maneira como a empresa pretende competir em seus mercados. A estratégia deve ser elaborada em cada área de negócios da empresa estabelecendo parâmetros de relacionamento com seus consumidores, mercados, concorrentes e a própria empresa da qual faz parte.

De acordo com Porter (1986), Liderança de Diferenciação pressupõe a oferta de produtos ou serviços com determinadas características únicas no mercado. O diferencial pode estar situado na imagem da marca, no projeto, na tecnologia, em peculiaridades ou serviços sob encomenda, como na rede de fornecedores, por exemplo. A Liderança de Enfoque refere-se a um determinado grupo de consumidores, a um segmento da linha de produtos, ou a um determinado mercado geográfico. Liderança de Custo Total refere-se à capacidade de a organização atingir o máximo de desempenho em relação aos seus concorrentes.

Prioridade Competitiva é um conjunto consistente de metas e atitudes que a empresa deve adotar para competir no mercado. São elas: Qualidade, Flexibilidade, Desempenho das Entregas e Custos (HORTE et al, 1987).

Sob esse aspecto, Contador (1996) distinguiu campos de competição e armas da competição. Campo da competição refere-se a atributos de interesse do comprador, tais como qualidade e preço do produto. Já arma da competição é o meio através do qual a empresa alcança vantagens competitivas nas áreas de produtividade, qualidade no processo e domínio de tecnologia.

Na era da competitividade global, Zaccarelli (1995) ressalta que o grande desafio das organizações está centrado na capacidade de buscar novas tecnologias, novos mercados e novos métodos de gerenciamento, ou do redesenho dos processos de negócio e de integração total das cadeias de valor da empresa, clientes e fornecedores.

Segundo Prochnik (1989) e Haguenauer (2001), as cadeias produtivas resultam, por um lado, do crescente processo de desintegração vertical e da divisão do trabalho e, por outro, da maior 


\section{Administração: caminhos para o desenvolvimento sustentável}

interdependência originada por pressões competitivas entre os agentes econômicos. Uma cadeia produtiva pode ser então definida como o conjunto de etapas consecutivas pelas quais passam e vão sendo transformados e transferidos os diversos insumos.

Em termos específicos, os potenciais benefícios para ambas as partes do relacionamento (empresa cliente e fornecedora) são: redução e controle de custos operacionais, ganhos de produtividade, melhoria no foco da empresa, acesso às capacidades de classe mundial, liberação de recursos internos e economias de investimento, obtenção de recursos que não estão disponíveis internamente, ganhos de capacitação para fornecedor, disponibilização de capitais, compartilhamento de riscos e aumento na eficiência administrativa. (MARINHO \& AMATO NETO, 1997; AMATO NETO, 1993).

Araújo (2001), define o conceito de Outsourcing como sinônimo de terceirização, caracterizado pela prática de "passar adiante a responsabilidade" pela execução de determinada tarefa ou de um conjunto de atividades, tornando-se um processo permanente. Isso permite à empresa, ficar mais focalizada em sua atividade-fim (Core Business).

Cadeias de produção industrial sempre existiram. A diferença é que atualmente as etapas de produção localizam-se de forma dispersa, em diferentes partes do globo. As organizações que delas participam mudaram também as hierarquias e as formas de se estruturar o fluxo de produção. CRUZ-MOREIRA, 2003

\section{ESTUDO DE CASO}

Quanto ao estudo de caso, YIN (1989) comenta, “... estudos de caso, assim como experimentos, são generalizáveis em termos de proposições teóricas e não para populações ou universos. Nesse sentido, o estudo de caso não representa uma 'amostra' e o objetivo do investigador é expandir teorias (generalização analítica) e não enumerar freqüências (generalização estatística)." Ainda acrescenta "que estudos de caso são especialmente indicados para explicar, descrever e explorar situações nas quais perguntas de 'como' e 'por que' sejam a base da investigação, assim como para situações onde se tenha pouco ou nenhum controle sobre o evento."

A empresa LITS, há 20 anos no mercado de moda, possui como prioridade competitiva atender um mercado que demanda produtos inovadores, considerados fashion e quase exclusivos, razão pela qual possui, por coleção, 350 novos produtos manufaturados em pequenos lotes (por modelo) e altamente diversificados em estética de modelagem, estampas e tecidos. 


\section{Administração: caminhos para o desenvolvimento sustentável}

A proposta é atender um mercado que demanda produtos inovadores considerados fashion e quase exclusivos, razão pela qual desenvolve, por coleção, cerca de 350 novos produtos a serem produzidos em pequenos lotes (por modelo) e altamente diferenciados em estética de modelagem, tecidos e aviamentos.

A característica principal das coleções é a inovação. A LITS utiliza 80 tipos de tecidos (malha e plano) distribuídos entre diferentes estampas e cores. Algumas estampas são corridas ou localizadas e a modelagem é bastante diversificada com aplicações de aviamentos inovadores.

A LITS, em parceria com as empresas fornecedoras de estampas e aviamentos, desenvolve constantemente novos produtos, com a finalidade de agregar inovação aos seus produtos. O serviço de costura é realizado por empresas externas que possuem novas tecnologias para a execução das tarefas de costura em tecidos plano e tecidos de malha.

Recentemente iniciou a contratação de uma empresa na China que aceitou a produção de jaquetas e calças jeans em pequenos lotes.

A gestão de fornecedores de insumos e serviços é realizada por dois funcionários que distribuem os lotes de peças cortadas entre as empresas prestadoras de serviços de costura previamente cadastradas. As produções dessas empresas são acompanhadas periodicamente por funcionários da LITS responsáveis pela empresas terceirizadas.

\section{ANÁLISE E CONCLUSÃO}

De acordo com os modelos de estratégia descritos pelos autores, observa-se que, para o segmento de vestuário de moda, destaca-se o modelo de estratégia descrito por Porter (1986) nesta ordem de importância quanto ao mercado: Liderança de Diferenciação, seguida pela Liderança de Enfoque e Diferenciação dos Produtos. Observa-se que foram focadas as exigências e características do público consumidor, sem perder de vista o custo do produto, não havendo, porém, a busca por essa Liderança. As principais prioridades competitivas do produto de moda são Qualidade Percebida pelo cliente através do visual do produto, a Flexibilidade para o Desenvolvimento e a Produção de novos produtos atendendo ao desempenho de entrega a espaços de tempo cada vez mais curtos.

Quanto aos campos de competição descritos, as armas de competição da MVM encontram-se nas áreas produtivas através das empresas parceiras que atendem com diferentes tecnologias e lay out de fábrica e de processos produtivos, possibilitando, dessa forma, maior flexibilidade e agilidade. 


\section{Administração: caminhos para o desenvolvimento sustentável}

Nas decisões estratégicas para a produção do vestuário, os pontos fortes encontram-se nas áreas estruturais em função do mix de produto e do grau de especialização dos processos produtivos por matérias-primas e produtos com o emprego das empresas parceiras (facções).

O ponto fraco dessa área encontra-se na tecnologia primitiva utilizada por algumas facções. O processo produtivo ainda é executado em máquinas simples e sem automação. Somente empresas de grande porte e que produzem em grande escala possuem acesso às altas tecnologias. Pequenas e micro-empresas não possuem condição financeira para investir em maquinários com alto nível de tecnologia.

Percebe-se a crescente demanda por vestuário com incremento de 220\% no período de 1990 a 2007. O fato revela-se como uma grande oportunidade para países em desenvolvimento como a Índia, Brasil e outros, que podem aprimorar suas tecnologias e design, assumindo melhores posições no ranking de exportações.

Destaca-se a importância do PCP na organização de uma empresa de vestuário de moda. Uma coleção de moda apresenta, geralmente, um alto volume de produtos diversificados e diferenciados, construindo, desta forma, uma rede de empresas prestadoras de serviços, o que caracteriza uma gestão de Outosourcing.

As empresas integrantes da Cadeia Têxtil, da mídia especializada e todas as demais envolvidas com eventos de moda têm interesse pelo curto ciclo de vida dos produtos, uma vez o rápido giro gera efeitos positivos em todas as atividades representadas pela realização de lucros, novos empregos, novos investimentos, etc. Da parte dos consumidores, por sua vez, observa-se um comportamento condicionado, hoje já consagrado pelo hábito do consumo de massa, que impulsiona o mercado com a exigência de novidades.

\section{REFERÊNCIAS}

AMATO NETO, J. Desintegração Vertical / "Verticalização" e o novo padrão de relacionamento entre empresas: o caso do complexo automobilístico brasileiro. Escola Politécnica, 236 p. Tese (Doutorado em Engenharia de Produção) - Universidade de São Paulo, São Paulo:1993.

ARAÚJO, M. de. Tecnologia do Vestuário. Lisboa: F.C.Gulbenkian, 1996.

ARAÚJO, L. C. G. de. Tecnologias de gestão organizacional. São Paulo: Atlas, 2001.

CONTADOR, T. C. Modelo para aumentar a competitividade industrial. São Paulo: Edgar Bhicher, 1996. 


\section{Administração: caminhos para o desenvolvimento sustentável}

CRUZ-MOREIRA, J. R. Industrial upgrading nas cadeias produtivas globais: reflexões a partir das indústrias têxteis e do vestuário de Honduras e do Brasil. Tese (Doutorado em Engenharia de Produção) Escola Politécnica Universidade de São Paulo, São Paulo: 2003.

CUNHA, D.C. Avaliação dos Resultados da Aplicação de Postponement em uma Grande Malharia e Confecção de Santa Catarina, Dissertação (Mestrado em Engenharia de Produção) - Universidade Federal de Santa Catarina, Santa Catarina: 2002.

HAGUENAUER, Lia; BAHIA, Luiz D.; CASTRO, Paulo F.; RIBEIRO, Márcio B. Evolução das Cadeias Produtivas Brasileiras na Década de 90, Texto para discussão no.786, IPEA. Brasília: 2001.

HORTE, S. A.; LINDBERG, P.; TUNALV, C.- Conference paper : Manufacturing strategies in Sweden.

International Journal of Production Research, v 25, n 11, 1987.

IEMI, Instituto de Estudos e Marketing Industrial. Brasil Têxtil 2009 Relatório Setorial da Indústria Têxtil Brasileira. São Paulo: Free Press, 2009.

IFM, Designer de mode Institut Français de la Mode, Paris: 2004.

JONES, S. J. Fashion Design: Manual do Estilista. São Paulo: Cosac Naify, 2005.

LIPOVETSKY, G. O Império do Efêmero: a moda e seu destino nas sociedades modernas, São Paulo: Schwarcz, 1989.

MARINHO, B. L.; AMATO NETO, J. O movimento da desverticalização, terceirização \& parceriais. São Paulo: Educond DT\&P USP, 1997.

MENDES, F. D.; FUSCO, J. P. A.; SACOMANO. J. B. Relações do Trabalho nos Processos de Manufatura da Indústria do Vestuário, Bauru: XII Simpósio de Engenharia de Produção, Anais, São Paulo: 2005.

MENDES, F. D.; FUSCO, J. P. A.; SACOMANO. J. B. Manufatura do Vestuário de Moda - O PCP como Estratégia Competitiva, Fortaleza Abepro, XXVI Encontro Nacional de Engenharia de Produção, Anais, São Paulo: 2006a.

MENDES, F. D.; FUSCO, J. P. A.; SACOMANO. J. B. Processo Produtivo da Manufatura do Vestuário como Estratégia Competitiva, Recife, XXII Congresso Nacional de Técnicos Têxteis, Anais eletrônicos, São Paulo: 2006b.

MENDES, F.D. Cadeia Têxtil e as Estratégias de Manufatura na Indústria do Vestuário de Moda. Dissertação (Mestrado em Engenharia de Produção) Universidade Paulista - São Paulo: 2006c.

MENDES, F. D.; FUSCO, J. P. A.; SACOMANO. J. B. Planejamento e Controle da Produtividade na Manufatura do Vestuário de Moda, São Paulo FGV-EAESP, IX Simpósio de Administração da Produção, Logística e Operações Internacionais, Anais, São Paulo: 2006d.

PORTER, M.E. Estratégia Competitiva. Rio de Janeiro: Campus, 1986.

PROCHNIK, V. Cadenas y Etapas en el Complejo de la Construcción Civil, El Trimestre Econômico, Vol. LVI (4), n. 224, out./dez. 1989, Ed. Fondo de Cultura Econômica, México: 1989. 


\section{Administração: caminhos para o desenvolvimento sustentável}

YIN, R. Case Study Reserch, London, Sage, 1989.

ZACCARELLI, S. B. A nova ideologia da competição. Revista de Administração de Empresas, São Paulo: 1995.

ZACCARELLI, S. B. Estratégia e sucesso nas empresas. São Paulo: Saraiva, 2000. 